РОССИЙСКАЯ АКАДЕМИЯ НАУК

Институт лингвистических исследований

RUSSIAN ACADEMY OF SCIENCES

Institute for Linguistic Studies 


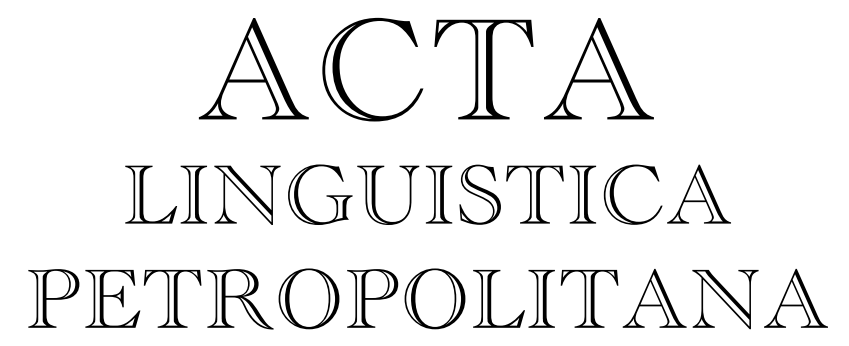

TRANSACTIONS

OF THE INSTITUTE FOR LINGUISTIC STUDIES

Vol. XVI, part 3

Editor-in-chief Evgeny V. Golovko 


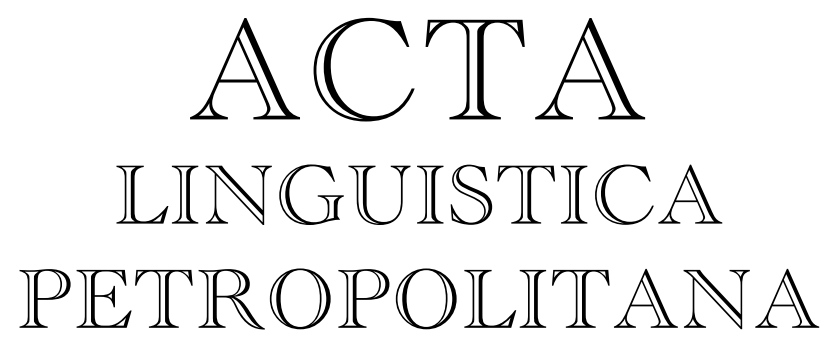

ТРУДЫ

ИНСТИТУТА ЛИНГВИСТИЧЕСКИХ ИССЛЕДОВАНИЙ

Том XVI, часть 3

Главный редактор Е. В. Головко 


\section{УДК 81}

ББК 81.2

A 38

Acta Linguistica Petropolitana. Труды Института лингвистических исследований. 2020. — T. XVI. Ч. 3. — 912 с.

Acta Linguistica Petropolitana. Transactions of the Institute for Linguistic Studies. 2020. — Vol. XVI. Pt. 3. - 912 p.

Редакторы тематической части

Н. В. Кузнецова, Л. Лейсиё, А. Ю. Урманчиева

Ответственные за выпуск от редколлегии

Г. А. Мольков, С. С. Сай

Статьи отбираются редколлегией журнала на основе анонимного независимого рецензирования

Материалы выпуска доступны в электронном виде по ссылке:

https://alp.iling.spb.ru/ru/issues.html

Адрес журнала: 199004, Санкт-Петербург, Тучков пер., д. 9, Институт лингвистических исследований РАН, редакция журнала «Acta Linguistica Petropolitana. Труды Института лингвистических исследований»

$$
\text { Телефон: + } 7812 \text { 328-16-11 }
$$

E-mail: acta_linguistica@iling.spb.ru

Сайт: https://alp.iling.spb.ru/

Свидетельство Роскомнадзора ПИ № ФС 77-60965 от 05.03.2015

ISSN 2306-5737

DOI 10.30842/alp23065737163 (c) ИЛИ РАН, 2020

(C) Составление. Редколлегия журнала, 2020

(C) Авторы, 2020 


\section{РЕДКОЛЛЕГИЯ}

член-корр. РАН, д. филол. н. Е. В. Головко, главный редактор (ИЛИ РАН); д. истор. н. А. К. Байбурин (Музей антропологии и этнографии им. Петра Великого (Кунсткамера) PAH, Санкт-Петербург); PhD, Assoc. Prof. A. Barentsen / А. Барентсен (Амстердамский ун-т, Нидерланды); д. истор. н. Ю. Е. Березкин (Музей антропологии и этнографии им. Петра Великого (Кунсткамера) РАН, Санкт-Петербург); член-корр. РАН, д. филол. н., проф. Е. Л. Березович (Уральский университет, Екатеринбург); д. филол. н. П. Е. Бухаркин (СПбГУ); член-корр. РАН, д. филол. н., проф. Н. Б. Вахтин (Европейский университет в Санкт-Петербурге); д. филол. н. М. Д. Воейкова (ИЛИ РАН); PhD, Prof. L. Grenoble / Л. Гренобль (Ун-т Чикаго, США); к. филол. н. С. Ю. Дмитренко (ИЛИ $\mathrm{PAH}) ; \mathrm{PhD}$, к. филол. н. Н. М. Заика (ИЛИ РАН, СПбГУ); д. филол. н., проф. В. Б. Касевич (СПбГУ); к. филол. н. А. Ю. Кожевников (ИЛИ РАН); член-корр. РАН, д. филол. н. Н. В. Корниенко (Институт мировой литературы РАН, Москва); д. филол. н., проф. Н. Б. Кошкарева (Институт филологии СО РАН, Новосибирск); д. филол. н. М. А. Кронгауз (Высшая школа экономики, Москва); к. филол. н. Г. А. Мольков (ИЛИ РАН); членкорр. РАН, д. филол. н. И. И. Муллонен (Институт языка, литературы и истории Карельского научного центра РАН, Петрозаводск); членкорр. РАН, д. филол. н. С. А. Мызников (Институт славяноведения РАН); акад. РАН, д. филол. н. С. И. Николаев (Институт русской литературы РАН (Пушкинский Дом), Санкт-Петербург); д. филол. н., проф. В. И. Подлесская (РГГУ, Москва) д. филол. н. К. И. Поздняков (Национальный институт восточных языков и цивилизаций, Париж, Франция); PhD, Prof. J. Russell / Дж. Рассел (Ун-т Калифорнии во Фресно, США); к. филол. н. Е. А. Руднева, секретарь редколлегии (ИЛИ РАН); д. филол. н. А. Ю. Русаков (ИЛИ РАН); к. филол. н. С. С. Сай (ИЛИ РАН); д. филол. н., проф. А. Н. Соболев, заместитель главного редактора (ИЛИ РАН); д. филол. н. С. Г. Татевосов (МГУ); к. филол. н. А. Ю. Урманчиева (ИЛИ РАН); PhD, Prof. А. Ю. Фильченко (Nazarbaev University, Астана, Казахстан); д. истор. н., проф. Д. А. Функ (Институт этнологии и антропологии им. Н. Н. Миклухо-Маклая РАН, Москва); д. филол. н., проф. В. С. Храковский (ИЛИ РАН); Dr. habil., Prof. J. A. Janhunen / Ю. А. Янхунен (Хельсинкский ун-т, Финляндия) 


\section{EDITORIAL BOARD}

Evgeny V. Golovko, editor-in-chief (Institute for Linguistic Studies, Russian Academy of Sciences); Albert K. Baiburin (Peter the Great Museum of Anthropology and Ethnography (Kunstkamera), Russian Academy of Sciences); Adriaan Barentsen (University of Amsterdam); Yuri E. Berezkin (Peter the Great Museum of Anthropology and Ethnography (Kunstkamera), Russian Academy of Sciences); Elena L. Berezovich (Ural Federal University); Petr E. Bukharkin (St. Petersburg State University); Sergey Yu. Dmitrenko (Institute for Linguistic Studies, Russian Academy of Sciences); Andrey Yu. Filchenko (Nazarbaev University, Kazakhstan); Dmitry A. Funk (Miklukho-Maklai Institute of Ethnology and Anthropology, Russian Academy of Sciences); Lenore Grenoble (University of Chicago); Juha A. Janhunen (University of Helsinki); Vadim B. Kasevich (St. Petersburg State University); Viktor S. Khrakovsky (Institute for Linguistic Studies, Russian Academy of Sciences); Natalia V. Kornienko (Institute of World Literature, Russian Academy of Sciences); Natalia B. Koshkareva (Institute of Philology of the Siberian Branch of the Russian Academy of Sciences); Aleksandr Yu. Kozhevnikov (Institute for Linguistic Studies, Russian Academy of Sciences); Maksim A. Krongauz (Higher School of Economics, Moscow); Georgy A. Molkov (Institute for Linguistic Studies, Russian Academy of Sciences); Irma I. Mullonen (Institute of Linguistics, Literature and History Karelian Research Centre, Russian Academy of Sciences); Sergei A. Myznikov (Institute of Slavic Studies, Russian Academy of Sciences); Sergei I. Nikolaev (Institute of Russian Literature, Russian Academy of Sciences); Vera I. Podlesskaya (Russian State University for the Humanities); Konstantin I. Pozdniakov (INALCO, Paris); Ekaterina A. Rudneva, board secretary (Institute for Linguistic Studies, Russian Academy of Sciences); Aleksandr Yu. Rusakov (Institute for Linguistic Studies, Russian Academy of Sciences); James Russell (California State University, Fresno); Sergey S. Say (Institute for Linguistic Studies, Russian Academy of Sciences); Andrey N. Sobolev, deputy editor-in-chief (Institute for Linguistic Studies, Russian Academy of Sciences); Sergei G. Tatevosov (Moscow State University); Anna Yu. Urmanchieva (Institute for Linguistic Studies, Russian Academy of Sciences); Nikolai B. Vakhtin (European University at St. Petersburg); Maria D. Voeikova (Institute for Linguistic Studies, Russian Academy of Sciences); Natalia M. Zaika (Institute for Linguistic Studies, Russian Academy of Sciences; St. Petersburg State University) 


\section{URALISTICA}

\section{PETROPOLITANA}





\section{Карело-вепсский диалог на карте южной Карелии*}

\section{А. А. Афанасьева}

Петрозаводский государственный университет, Петрозаводск; anastasia20085@mail.ru

\section{И. И. Муллонен}

Институт языка, литературы и истории, Карельский научный центр РАН, г. Петрозаводск; mullonen@sampo.ru

Аннотация. В статье развиваются идеи Д. В. Бубриха о диалектном членении карельского языка, обусловленном участием вепсского языкового компонента в формировании ливвиковского и людиковского наречий. Через ареальный и этимологический анализ конкретных лексических и топонимических основ устанавливается характер вепсско-карельского контактирования на территории Онежско-Ладожского перешейка: вепсские субстратные явления в карельском и, соответственно, карельские включения в вепсские диалекты. В целях реконструкции исторических границ вепсской и карельской территории на перешейке привлечен топонимический материал. Показано также, что граница, разделяющая ливвиковский и людиковский ареалы, проходит по древнему транзитному водно-волоковому пути с р. Свирь на р. Шуя, который на протяжении длительного времени использовался вепсами и препятствовал в определенной степени карельскому продвижению на восток вдоль р. Шуя.

Ключевые слова: ареальная лингвистика, языковой ареал, субстрат, вепсский и карельский языки, языковые контакты, прибалтийско-финская топонимия.

\footnotetext{
* Статья подготовлена в рамках выполнения госзадания КарНЦ РАН.
} 


\title{
A Karelian-Veps dialogue on the map of southern Karelia
}

\section{A. A. Afanasjeva}

Petrozavodsk State University, Petrozavodsk; anastasia20085@mail.ru

\section{I. Mullonen}

Institute of Language, Literature and History, Karelian Scientific Center, Russian Academy of Sciences, Petrozavodsk; mullonen@sampo.ru

\begin{abstract}
The paper elaborates on D. V. Bubrikh's ideas about the dialectal division of the Karelian language associated with the impact of the Veps linguistic component on the formation of the Livvi and Ludic variants. An areal analysis of specific lexical and toponymic stems was employed to identify the nature of Veps-Karelian contacts in the Onego-Ladoga isthmus, i.e, the Veps substrate in Karelian and, correspondingly, Karelian inclusions in the Veps language. The toponymic material made it possible to reconstruct the historical distribution of the terms addressed (the Veps purde 'spring (wellhead)' and the Karelian kiidžin 'moss growing underwater on the bottom') and, building on this, the historical boundaries of the Veps and Karelian territories in the isthmus. It is also demonstrated that the dividing line between the Livvi and the Ludic areas runs along the ancient boating and portage route from the Svir River to the Shuja River that had for a long time been in Vepsian use, impeding, in a way, Karelian advancement eastwards along the Shuja. Its markers are several Veps toponymic patterns (e.g., the metaphoric name for hills Kukoinharj, literally 'Cockscomb'). Along with the areal method, the paper applied an etymological study to prove that the Veps. purde 'spring' is derived from the Baltic-Finnish verb stem puurta- 'dig, form a stream bed'. The paper also discusses approaches to reveal the etymology of the Karelian kiidžin.
\end{abstract}

Keywords: areal linguistics, linguistic area, substrate, Veps and Karelian languages, language contacts, Finnic toponymy.

\section{1. Введение}

Южная Карелия, расположенная между Ладожским и Онежским озерами, была в свое время зоной активного вепсско-карельского контактирования, в ходе которого сформировалась языковая карта этой относительно компактной территории. На западе и в центральной части 
Онежско-Ладожского перешейка сложились два карельских ареала ливвиковский и людиковский, а на востоке - северновепсский, отделенный от карельской территории «русским коридором», протянувшимся вдоль реки Ивина.

Происходивший здесь карело-вепсский диалог не раз становился предметом научного обсуждения. В нем принял участие и Д. В. Бубрих, предложивший свою модель генезиса ливвиковского и людиковского наречий карельского языка. Его теория исходила из существования вепсского субстрата [Бубрих 1947], в то время как предшествующие исследования не сформулировали четкого механизма взаимоотношений между языками и описывали их как «вепсское влияние», «вепсское отражение», «вепсское наследие» (см., например, обзор гипотез формирования ливвиковского наречия в [Itkonen 1971: 153-154]). Субстратная гипотеза подтвердилась в ходе дальнейшего исследования. Наиболее убедительное подтверждение наличия вепсского субстрата в олонецком (а также косвенным образом и в людиковском) наречии предложил в свое время Терхо Итконен. Он связал с субстратом особенности в системе чередования ступеней согласных, а также появление конечного гласного $u$ / $\ddot{u}$ на месте исторических $a$ / $\ddot{a}$ [Itkonen 1971].

Несмотря на целый ряд исследований, тема карело-вепсского диалога не исчерпана полностью. В центр внимания настоящей статьи вынесен ареальный аспект этого диалога: выявляются и анализируются границы ареалов отдельных лексем и топооснов, показательных с точки зрения контактов, реконструируются пути их проникновения на искомую территорию, обсуждается относительная хронология формирования ареалов. Предлагаются также подходы к этимологической интерпретации ряда лексических и топонимических основ.

Карело-вепсский диалог получил отражение на всех языковых уровнях. В данной статье проблема контактирования рассматривается на материале лексики как самого проницаемого для иноязычного воздействия уровня языка и топонимии. Топонимические модели носят ареальный характер и хронологически обусловлены, и поэтому они способны конкретизировать наше понимание этого диалога, уточнить его ареальные и временные рамки. Кроме того, в связи со значительной консервативностью географических названий, топонимические ареалы нередко оказываются шире лексических и позволяют реконструировать исторический ареал бытования лексемы. 


\section{2. Вепсское наследие на Олонецком перешейке: вепс. purde 'родник'}

Для обозначения родника в вепсских говорах бытует несколько терминов: purde, lähte, uhring, urting и позднее русское заимствование rodnik. Из них исконно вепсская лексема purde purte < *purdeg, не имеющая аналогов в других прибалтийско-финских языках, была, очевидно, основным термином для выражения понятия 'родник, ключ'. При этом ее современный ареал (Рисунок 1 ) должен характеризоваться как остаточный. На более широкое распространение термина purde

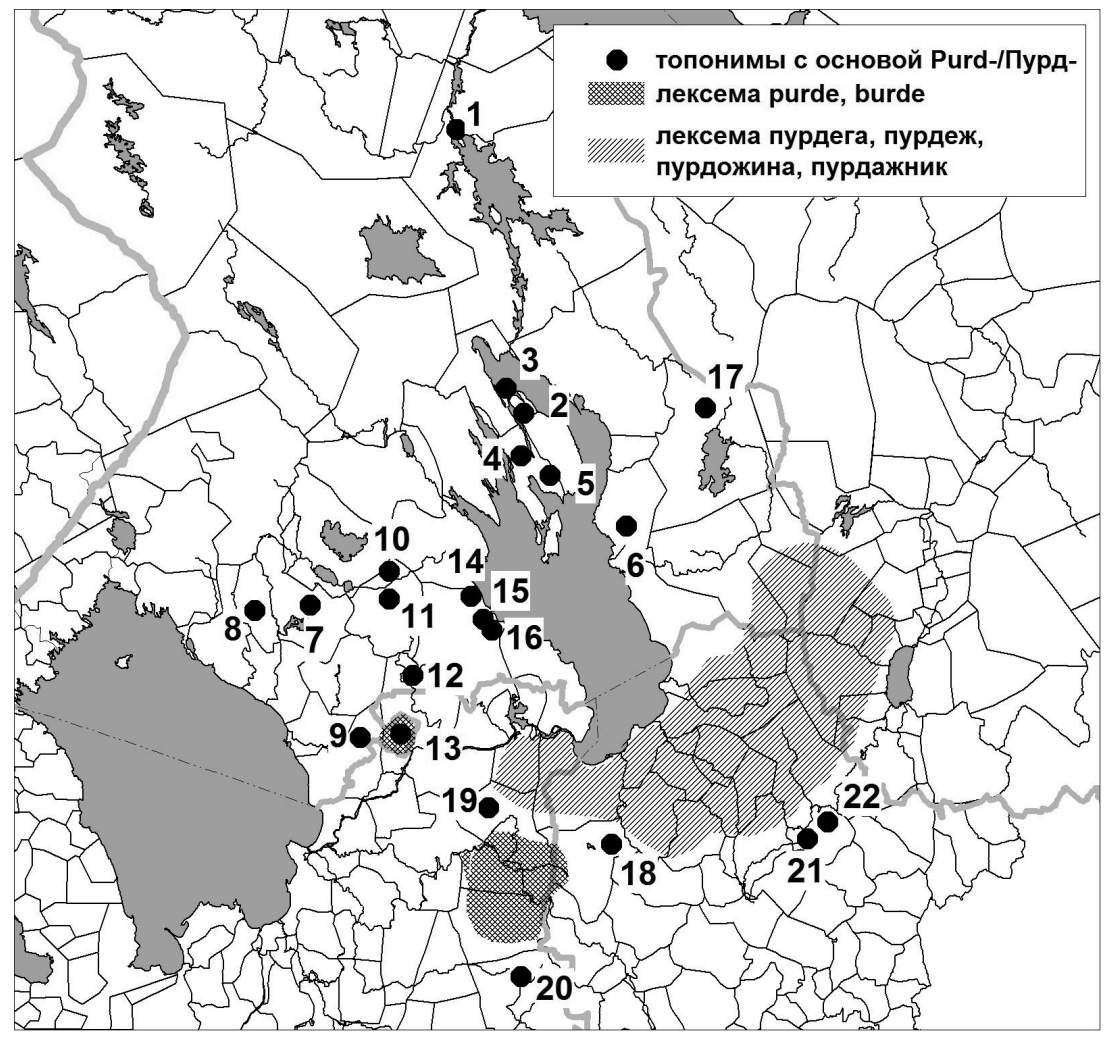

Рис. 1. Вепс. purde ‘родник'и его наследие в говорах и топонимии южной Карелии

Fig. 1. Vepsian purde 'spring' and its reflexes in the dialects and in the toponymy of southern Karelia 
в прошлом указывает относительно хорошая его сохранность в западных средневепсских говорах, включая и группу переходных говоров верховий Капши, спорадические фиксации в северновепсском, а также южновепсском ареале. Термин уже практически утрачен говорами вепсского Прионежья, его бытование в значительной степени реконструировано по топонимическим фиксациям конца ХХ в.: болото Purdeso, покос Purdeniit, поле Purdepöud, урочища Purdedorog, Purte. Южновепсская фиксация purte 'открытое место в лесу, поляна' [СВЯ], видимо, представляет собой результат семантического развития исходного значения, если только не является топонимом - названием лесной поляны, которое составители СВЯ ошибочно внесли в словарь как самостоятельную лексему. Однако в любом случае это свидетельство бытования термина в южновепсском ареале.

В контексте карело-вепсского диалога существенно бытование термина purde $~$ burde 'родник' за северными пределами собственно вепсского ареала: в михайловском говоре людиковского наречия карельского языка, содержащем мощный вепсский субстрат (Рисунок 1). Бытование слова в южнолюдиковском ареале, на северных рубежах вепсской территории, при полном отсутствии его на остальной карельской территории подтверждает его вепсские корни.

На Рисунке 1 также показан ареал топонимов с основой Purde- и ее вариантами за пределами собственно вепсской территории. Ниже приводится соответствующий номерам на карте список названий с указанием вида объекта, а также административной привязкой в формате «область, район, сельсовет (в некоторых случаях конкретный населенный пункт в составе сельсовета)» в соответствии с [СНМ 1926 и Рышкин 1933] ${ }^{1}$ :

1 - Пурдомох болото [К, Сегежа, Надвоицы, Кочкомозеро]

2 - Бурднаволок мыс [К, Шунгский, Кажма, Вершуньга]

3 - Пурдега деревня, Пурдежское болото [К, Шунгский, Кажма]

4 - Пурдега болото [К, Великогубский, Космозеро]

5 - Бурта покос [К, Великогубский, Яндомозеро]

6 - Бурдук покос [К, Шальский, Авдеево]

7 - Purdoilambi $\sim$ Purdolambi озеро [К, Сямозерский, Савиново, Сыссойла]

${ }^{1}$ В указанной в квадратных скобках административной привязке К — Карельская АССР, Л - Ленинградская область. 
8 - Purdosuo болото [К, Видлицкий, Колатсельга]

9 - Purde покос [К, Олонецкий, Куйтежи, Самбатукса]

10 - Purdepeldo $\sim$ Purdegenpeldo поле [К, Святозерский, Пряжа, Прякки]

11 - Burde родник [К, Святозерский, Святозеро]

12 - Agd'anpurde родник, Purdepeldo поле [К, Святозерский, Важинская Пристань, Кашканы]

13 - Purde угодье, Purdeniitud покосы, Purdesild мост, Purdesel'g угодье, Purdeoja ручей, Purdepalo $\sim$ Purtkenpalo угодье, Purdekaiv колодец [К, Олонецкий, Михайловское]

14 - Purde, Purdeniit, Purdepöиd угодье, Пурдеж угодье, Purde угодье, Purdedorog дорога, покос [К, Шелозерский, Шокша]

15 - Purdeso Purzoso болото, Purtkei покос [К, Шелтозерский, Вехручей]

16 - Purte $\sim$ Purtked покос [К, Шелтозерский, Шелтозеро Бережное]

17 - Пурмох болото, Пурручей ручей [К, Пудожский, Пильмасозеро, Загорье]

18 - Пурболото болото [Л, Оштинский, Сяргозеро]

19 - Пуртка покос [Л, Винницкий, Чикозеро]

20 - Purte поляна [Л, Ефимовский, Кортлахта]

21 - Пурдога покос [Л, Вашкинский, Индоман]

22 - Пурдога деревня, Пурдовский родник [Л, Вашкинский, Павшозеро]

Список включает в себя несколько топонимов с территории пограничного с михайловским святозерского людиковского говора и свидетельствует, таким образом, о более широком ареале бытования людиковского термина purde в прошлом. Единичные фиксации топоосновы известны и на территории смежных ливвиковских говоров Самбатуксы (покос Purde), Коткозера (ручей Burrinoja), ведлозерской Сыссойлы (Purdoilambi) и даже в довольно удаленном от современного вепсского ареала тулмозерском говоре (болото Purdosuo). Топонимический ареал, таким образом, выходит за северные границы лексического и, в совокупности с другими аналогичными топонимическими «вепсизмами», позволяет говорить о притоке вепсского населения и на Олонецкий 
перешеек и участии вепсского языкового компонента в формировании южных карельских наречий.

Для реконструкции исторического ареала лексемы важно учесть и севернорусские фиксации, в частности, олонецкое пурдажник (курдажник) 'еловый лес на топком месте', пурвиж 'торф, торфяное болото' [СРНГ], вытегское пурдожина 'торф', пурдежная земля 'глинистая почва, хорошо удерживающая влагу' [СРГК]. Сюда же, по-видимому, относятся территориально более отдаленные архангельские пурдеж 'низкое болотистое место на поле', пурдега 'низкая плохая трава на сырых местах' [СРНГ]. Стоит обратить также внимание на такие топонимы, как деревня Пурдега, мыс Бурднаволок, покос Бурда в Заонежье, покос Бурдук в Пудоже, а также урочище Пурдога, деревня Пурдога, родник Пурдовский в северном Белозерье, которые, видимо, являются вепсским языковым наследием на этих обрусевших территориях. Логичным продолжением обонежского ареала на север является наличие топоосновы в русском Сегозерье (Пурдомох). В контексте ряда других здешних вепсских топонимических фиксаций она отражает, очевидно, присутствие вепсов на транзитном водно-волоковом пути из Обонежья в Поморье и реконструирует, таким образом, северный предел ареала вепсской лексемы. Не менее значимо и наличие топоосновы на Онежско-Белозерском водоразделе, указывающее на проникновение вепсов в Белозерье. Сложнее интерпретировать топонимы на территории Архангельской области, ареально удаленные от вепсского этноязыкового ареала: Пурдосское болото (Коноша), Пурдевское озеро, Пурдево или Пурдевское болото, река Пурдева (Пинега), а также озеро Пурдом (Холмогоры) [КТЭ]. При этом они согласуются с отмеченными выше архангельскими диалектными лексемами пурдега и пурдеж. В любом случае, приведенные карельские и русские диалектные и топонимические данные подтверждают широкий ареал и активное бытование purde 'родник' на ранних этапах вепсской языковой истории.

В «Лингвистическом атласе прибалтийско-финских языков» для вепсского слова предложена германская этимология [ALFE], которая выглядит неубедительной и в силу семантики германского этимона, и в общем контексте отсутствия в вепсских говорах таких германских заимствований, которые не имели бы аналогов в других прибалтийско-финских языках. В свою очередь, финский исследователь Алпо Ряйсянен, анализируя истоки финского термина риго 'ручей', высказался за его родство с вепс. purde. При этом он возвел фин. puro к puristaa 'жать, выжимать', pursua 'сочиться, просачиваться', тем 
самым предполагая сходный отглагольный путь развития и для вепсского purde [Räisänen 2010: 515]. Однако такая интерпретация не объясняет $-d$ - в основе вепсского слова. Логичнее полагать, что термин purde < * purdeg является исконно вепсским производным от прибалтийско-финской глагольной основы puurta- (фин. puurtaa, карел. puurie), в широком семантическом поле которого присутствуют значения 'копать, формировать русло; суетиться', а в числе производных известны фин. puurto, puurtamo 'след на водной поверхности от подводного камня, водоворот', puurto 'труд, старание', а также lähteenpuurto 'небольшой родник, водянистое место', merenpuurto 'быстрое повышение и понижение уровня воды и море' и др. [SSA]. В этом ряду находится и вепс. purde, при том, что исходный глагол в вепсских говорах отсутствует, будучи, очевидно, утраченным. Вариант purte с глухим смычным может быть вызван ассимиляционным оглушением, которое произошло в основе слова (purtke-n) вследствие закономерного выпадения гласного второго слога. Наоборот, звонкий вариант с озвончением начального согласного (Burde) спровоцирован, очевидно, звонко-сонорным кластером -rd- внутри слова. Подобного рода озвончение глухих смычных $k, p, t$ известно в отдельных вепсских [Tunkelo 1946: 41-44] и людиковских [Turunen 1946: 48-52] примерах. В ряде русских вариантов (Пурдега, Пурдога) законсервирован исторический звук $-g$, который был представлен в абсолютном исходе слова в вепсском термине, т. е. purde <* purdeg. Русские топонимы демонстрируют также закономерное опрощение сочетания согласных на стыке структурных элементов сложных топонимов: Пурболото, Пурмох, Пурручей. Русская адаптация, отражающая, с одной стороны, вепсский оригинал, в котором последний согласный может быть как звонким, так и глухим, а с другой - русские фонетические особенности, приводит к бытованию таких топонимов, как Бурдук или Пуртка.

Интепретация вепс. purde как отглагольного имени косвенно может подтверждаться словообразовательным анализом другого термина: lähte 'колодец, родник', очевидного отглагольного имени, ср. lähtta (<

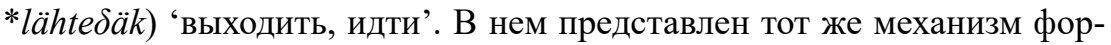
мирования ландшафтного термина.

Итак, в ситуации вепсско-карельского диалога на Олонецком перешейке термин purde является очевидным вепсским наследием, прочно закрепившимся в территориально смежных с вепсским ареалом южно-людиковских говорах, где представлен не только в топонимии, но и лексике. Знаменательно его бытование в русских говорах 
Присвирья и Обонежья [СРНГ, СРГК]. Совокупный лексико-топонимический ареал, видимо, может рассматриваться как вепсское субстратное наследие на обширной территории Обонежья. Именно такой генезис характерен для вепсской по истокам ландшафтной терминологии в русских говорах. Видимо, об этом же свидетельствуют топонимические фиксации основы за пределами территории непосредственных вепсских контактов.

\section{3. Карельские включения в северновепсском говоре}

Карельский след в вепсских говорах исследован мало, и, по-видимому, в силу этого складывается впечатление о его незначительности. Однако по мере накопления информации выявляются вполне убедительные «карелизмы» в вепсской языковой среде, причем на разных языковых уровнях. Они особенно убедительны в северном диалекте, а также в восточных говорах средневепсского диалекта [Зайцева 2016: 301309], согласуясь с этнографическими данными о заметном карельском воздействии на северных вепсов [Винокурова 2015: 177-178].

Появление карельского элемента в вепсском Прионежье вызвано, очевидно, исходом карелов из Корельского уезда в XVI-XVII вв. в связи с переходом территории под власть Швеции. Карельские выходцы оседают в Обонежье, особенно в бассейнах и приустьевой части рек Суны и Шуи, поглощая здесь предшествующее вепсское население. Южнее же, в отдалении от магистральных колонизационных путей, приток их не носит столь массового характера. Вселяясь в существовавшие на то время вепсские деревни, карелы, оказываясь в меньшинстве, растворялись со временем в вепсском большинстве. При этом они привнесли определенные карельские языковые особенности в местную вепсскую речь. Принято считать, что к таким карельским рудиментам относятся геминированные согласные, присущие северновепсскому диалекту [Tunkelo 1946: 148-149]. Карельским влиянием обусловлен ряд особенностей в глагольном спряжении, в том числе особый тип основы на -о в форме 3 лица ед. числа презенса индикатива, форма 3 лица мн. числа имперфекта, показатель инфинитивов возвратных глаголов [Зайцева 2016: 104, 114, 126]. На уровне лексики карельское наследие в вепсских говорах исследовано мало. В качестве примера приведем северновепсскую лексему ald 'волна'. Она функционирует 


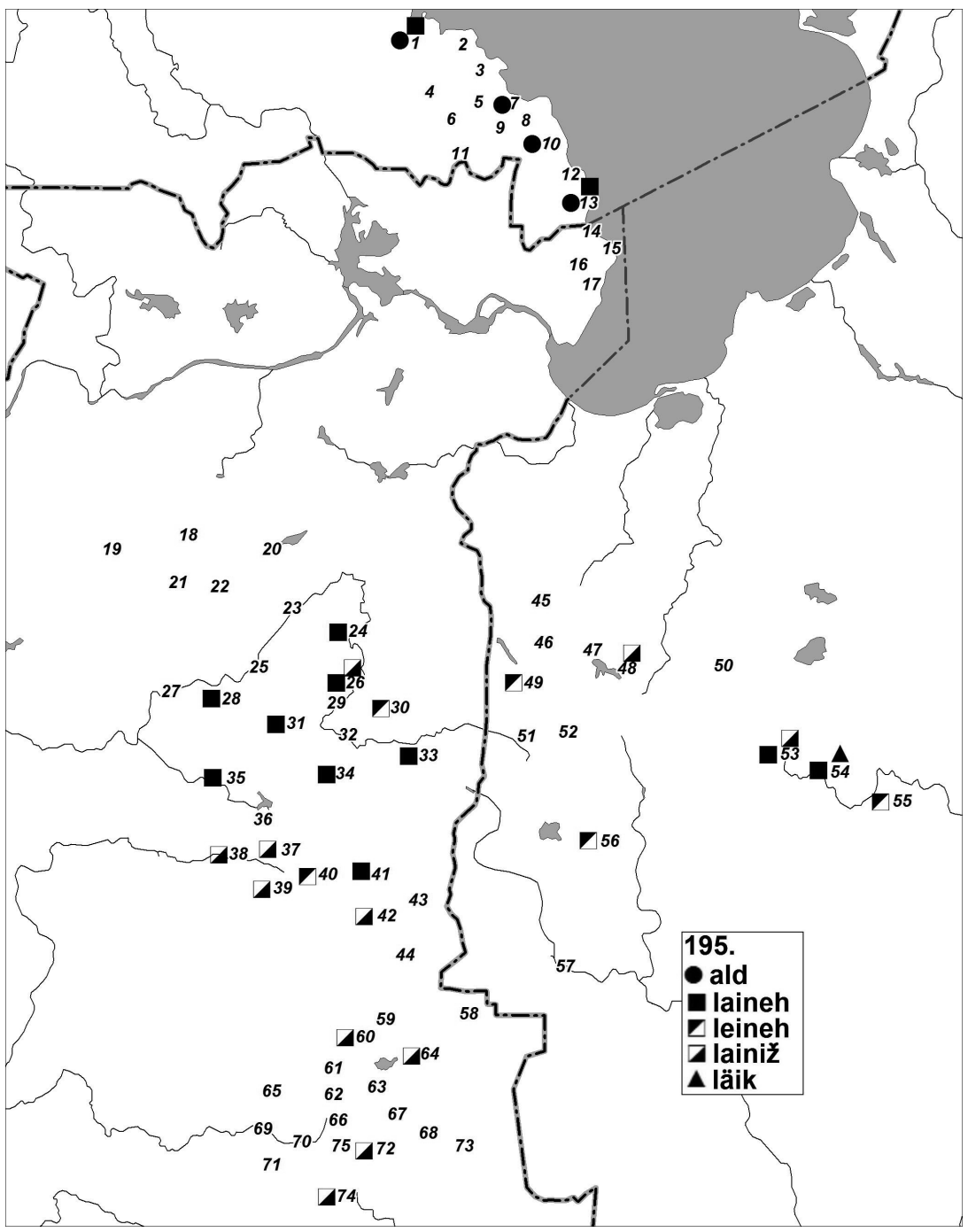

Рис. 2. Именования понятия 'волна' в вепсских говорах

Fig. 2. The word for 'wave' in Vepsian dialects

во всех говорах северновепсского диалекта, однако не известна другим вепсским диалектам, в которых для обозначения озерной или речной волны используется лексема laineh leineh $\sim$ lainiž. В виде laineh она зафиксирована и в двух северновепсских пунктах - Шокше и Каскесручье (Рисунок 2). Иначе говоря, прионежские говоры используют два 
синонимичных слова: общевепсское laineh и северновепсское ald. При этом сугубо северновепсский ареал слова ald обусловлен, конечно, карельским языковым воздействием. В виде oaldo, oalto [KKS] оно бытует в территориально смежных карельских говорах. Надо полагать, что его закрепление при уже бытовавшем laineh было обусловлено специфической семантикой слова ald, обозначающего, прежде всего, большую волну, характерную для Онежского озера.

Для реконструкции исторических позиций карельского языка как участника языкового диалога, происходившего на Олонецком перешейке, актуально и привлечение топонимического материала. В этом случае одна из принципиально важных задач состоит в выявлении дистрибуции карельских и вепсских моделей. В силу близкого родства языков их топосистемы в значительной степени идентичны. Один из существенных критериев разграничения лежит в ареальной характеристике, в выявлении центра топонимического ареала, а также путей распространения модели. Далее этот тезис будет продемонстрирован рядом топонимов с основой Kiidž- / Киж- с территории Онежско-Ладожского перешейка (Рисунок 3, с. 20). Среди них несколько заливов с названиями Kiislahti, Kiidžillahti (lahti ‘залив’) на северном берегу Ладожского озера, а также Kiidžinlahti, Kiidžilahti, Kiidžuguba в центральной части Онежско-Ладожского перешейка. В этом же ряду озера Kiismenlambi, Kiidžari, болота Kiižimensuo, Kid’žmansuo, на русской территории перешейка в восточной части ареала болото Кижечный мох, залив Кuжимлахта и др.

Названия восходят к карельскому слову kiidžin:kiidžime-, бытовавшему во всех диалектах карельского языка и обозначавшему разные виды мхов - от лишайников до ягеля и кукушкина льна $[\mathrm{KKS}]$. В этом контексте стоит отметить, что топонимия весьма избирательна в выборе тех растений, которые закрепляются в названиях мест. Выбор определяется в первую очередь использованием их в хозяйственной деятельности местных жителей. Судя по материалам традиционной культуры, к таким широко востребованным в традиционном быту растениям относилась водная разновидность мха kiidžin. Известно, что карелы-людики использовали его для мшения [уплотнения мхом] построек [Turunen 1946: 201]. Такая же информация имеется и из ливвиковского Сямозерья: “lammiz nostetah kiidžimet haravoil kuivah, pertti sammaldetah" [KKS] — “мох граблями поднимают из ламбы [лесного озера] на сушу, мшат избу”. В Линдозере Кондопожского района наши информанты вспоминали, как мох поднимали из залива Kiidžilahti 


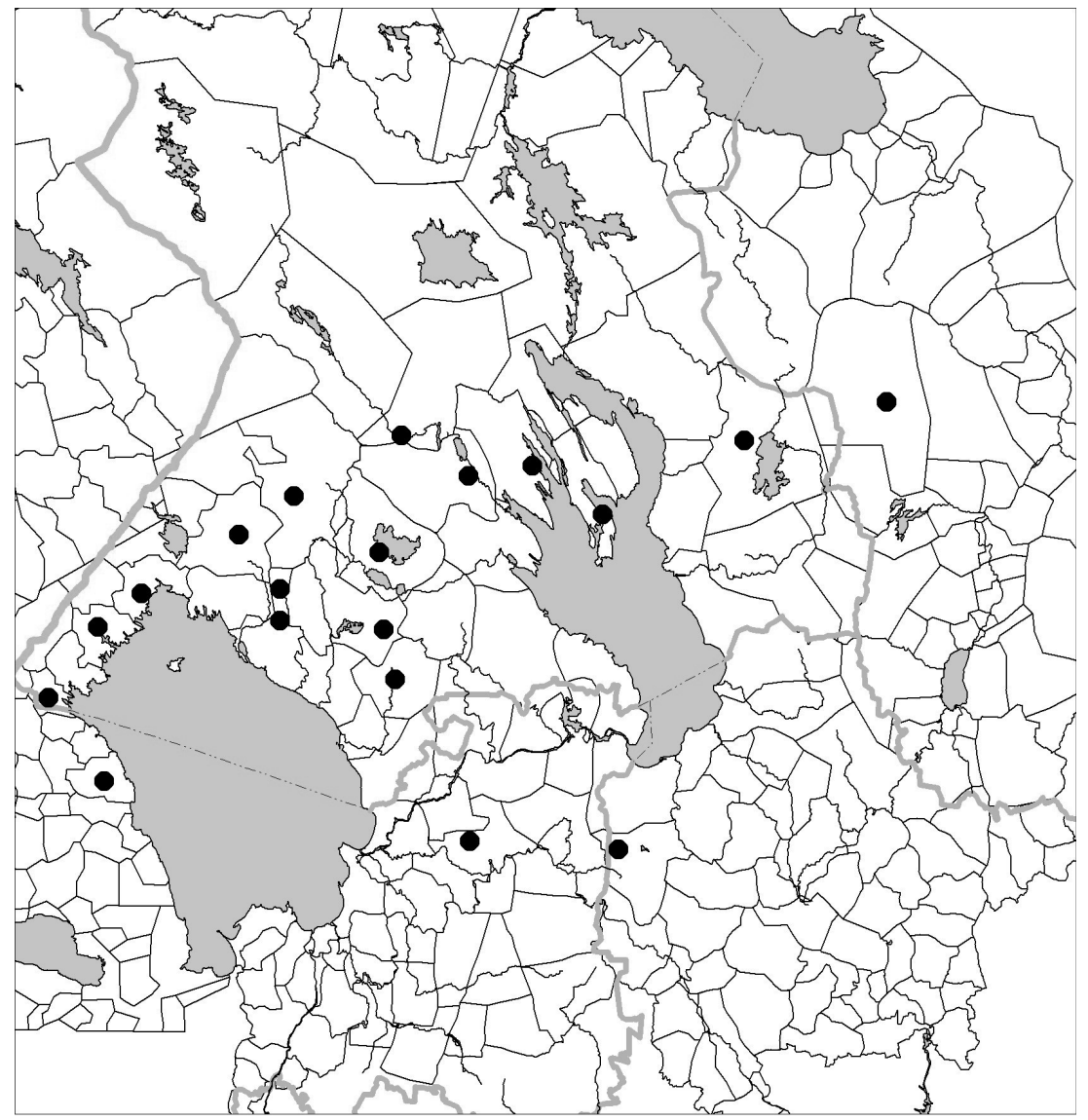

Рис. 3. Ареал карельской топоосновы Kiidž(in)-

Fig. 3. Areal of Karelian toponymic base Kiidž(in)-

с помощью специальной вертушки и затем, высушив на берегу, использовали при строительстве изб. Подобная практика бытовала и на заонежском острове Кижи - всемирно известном музее деревянного зодчества. Водный мох, поднятый специальными граблями со дна залива Мошгуба, использовался для мшения стен, полов, лодок-кижанок [Агапитов 1993: 20-21]. Показательно здесь, конечно, и само название залива Мошгуба, т. е. 'моховая губа': в нем как раз и отложилась память о мхе kiidžin, название которого переведено на русский словом мох. Сам структурный облик русского названия явно указывает на возможность кальки, иначе говоря, карельский оригинал Мошгубы мог выглядеть как 
*Kiidžilahti $(<*$ Kiidžillahti $<$ *Kiidžinlahti) и входить в один ряд с соответствующими названиями заливов в Суоярви, Линдозере, на Сямозере, кондопожском Мунозере и других местах. Карельский топоним *Kiidžilahti превращается в русскую Мошгубу на том не столь уж отдаленном этапе истории, когда в южном Заонежье еще бытовало двуязычие и название озерного мха kiidžin, растущего на дне неглубоких хорошо прогреваемых озерных заливов, еще не было здесь забыто. Карельская топооснова была переведена в названии залива, но сохранилась в названии острова Кижи.

Впервые «растительная» этимология названия острова Кижи была предложена В. Агапитовым [Агапитов 1993: 20]. Она, несомненно, лучше мотивирована, чем получившая в свое время широкую известность «игрищная» интерпретация, связывавшая топоним Кижи с карельским словом kižad 'игры, игрища'. В качестве мотива называния предлагался сакральный характер острова, на котором проводились некогда ритуальные праздники. Однако эта интерпретация не находит подтверждения в виде топонимов-тезок, образующих внятный ареал. Наоборот, как было ранее показано, название водного мха распространено в топонимии. Выявленный ряд топонимов формируется в довольно компактный ареал (Рисунок 3) на территории южной Карелии. Он протянулся от Северного Приладожья до северного Кенозерья и наиболее насыщен на Онежско-Ладожском перешейке - в карельском ливвиковско-людиковском языковом ареале, где зафиксирован и соответствующий апеллятив. Слово известно также некоторым восточно-финским говорам, например, в саволакских говорах kisilevä 'водоросль, используемая для окрашивания' [SMS]. Топооснова образует достаточно плотный ареал в восточной Финляндии, в зоне исторического карельского присутствия. В совокупности это позволяет реконструировать исконный карельский термин, в настоящее время уже практически утраченный. Помимо языковой составляющей (бытования термина в карельских диалектах) очертания топонимного ареала обусловлены также, по-видимому, и климатической зоной. Северная граница ареала следует очертаниям северной границы зоны среднетаежных сосновых лесов, а также т. н. южной климатической зоны, отличающейся наиболее благоприятными для проживания климатическими условиями [КЭ, т. 2: 21-22, 26].

Истоки самого слова не вполне ясны, хотя в нем возможно выделение суффикса -in с первоначальным диминутивным значением, которым оформлен ряд наименований растений, в том числе muurain 
'морошка', puolain ‘брусника', siestain 'смородина черная', vaarain 'малина', kuиsa(i)n 'жимолость' [Hakulinen 1968: 111].

С распространением карелов из Приладожья слово попало в Обонежье и достигло на востоке даже Кенозерья, где на Ундозере в местном русском говоре бытует слово кижа 'озерный ил' [СГРС]. Оно, по-видимому, является карельским включением, оставленным в наследие карелами, переселенцами из Корельского уезда. В наименовании озера Кижевато на Ундозере основа могла закрепиться как в карельском, так и в русском виде: kiidžin >кижа (киже-).

В контексте вепсско-карельского диалога особый интерес вызывают два топонима на вепсской территории в Шимозерье: озеро Kižidärv (рус. Кижозеро) и болото Kižiso. Еще один - Кижов остров на реке Ояти - засвидетельствован в д. Мустиничи Шапшенского сельсовета, на территории, которая еще в довоенное время была вепсской. В том ареальном контексте, который описан выше, они отражают карельское проникновение на смежную вепсскую территорию. Карельские корни топоосновы убедительно подтверждаются как присутствием исходной лексемы в карельских говорах и других производных древнекарельского языка, так и ареалом, который совпадает с путями миграции карелов из Приладожья на восток. В одной из своих ранних работ, не зная приведенного выше карельского контекста, один из авторов данной статьи ошибочно квалифицировал топонимы вепсской территории как законсервировавшие вепсский термин, бытовавший в прошлом в вепсских говорах [Муллонен 1994: 58-59]. Сейчас очевидно, что речь должна идти о карельском «следе».

Карельское наследие в вепсском лексическом и топонимическом континууме не исчерпывается, конечно, приведенными выше двумя примерами. Дополнительный лексический материал содержится в «Лингвистическом атласе вепсского языка», опубликованном в 2019 г. [ЛАВЯ].

\section{4. Ливвиковско-людиковская граница на Олонецком перешейке}

Вопрос о генезисе южных наречий карельского языка - ливвиковского и людиковского - и участия в их образовании вепсского субстрата был принципиально решен еще Д. В. Бубрихом [Бубрих 1947], 
а дальнейшие исследования развили и уточнили целый ряд высказанных им положений. При этом проблема формирования территориальной границы между ливвиковским и людиковским языковым ареалами, равно как и факторы, обусловившие становление северновепсского ареала на юго-восточной окраине Олонецкого перешейка, вплоть до последнего времени специально не обсуждались. Проведенный анализ топонимных ареалов показал, что культурные границы в регионе Обонежья обусловлены в первую очередь ландшафтно-географическими [Муллонен 2012]. Для становления границы между ливвиковским и людиковским языковыми ареалами исключительно важную роль сыграл транзитный водно-волоковой путь, соединяющий Присвирье через Онежское озеро с Белым морем. По северному участку этой дороги в XX веке прошел Беломорско-Балтийский канал. Южный участок полностью совпадает с ливвиковско-людиковской границей. Видимо, уже в период активного карельского освоения Онежско-Ладожского перешейка продолжалось проникновение вепсов на эту территорию, причем использовался путь по реке Важинке. Среднее и верхнее течение Свири изобилует порогами, поэтому издревле был известен обходной путь вдоль северного притока Свири, реки Важинки, через водораздел в озеро Святозеро и далее на реку Шую. Неслучайно в устье Важинки располагался центр древнего Важинского погоста - средневекового административного подразделения, из которого происходило расселение по территории речного бассейна и за его пределы.

Этот путь активно и на протяжении длительного времени использовался вепсами, о чем свидетельствуют четко накладывающиеся на него ареалы ряда вепсских топонимных моделей (напр., Kukoinharj, Pyhäjärv 'Святое озеро', топооснова Jalo-, ср. *jalo ‘большой' [Захарова и др. 2018: 36-40]). Яркий пример - вепсская метафорическая модель $K u$ koinhar'j 'петушиный гребень', которая использовалась для называния незначительных возвышенностей. Она является, очевидно, довольно поздней, поскольку не охватывает весь вепсский ареал и привязана исключительно к недолговечным по времени существования микротопонимам. Карта показывает (Рисунок 4, с. 24), что модель четко коррелирует с упомянутой уже водной дорогой на север и одновременно с людиковско-ливвиковской границей. Здесь отмечены урочище $K u$ kuoinhard' в дер. Мошничье на реке Важинке, поле Kukuenhard'a в старинном людиковском селе Святозеро, урочище Kukoiharja на восточном берегу озера Сямозеро. Этот ряд замыкается на севере названием расположенной на болоте песчаной возвышенности Петушиный Гребень 


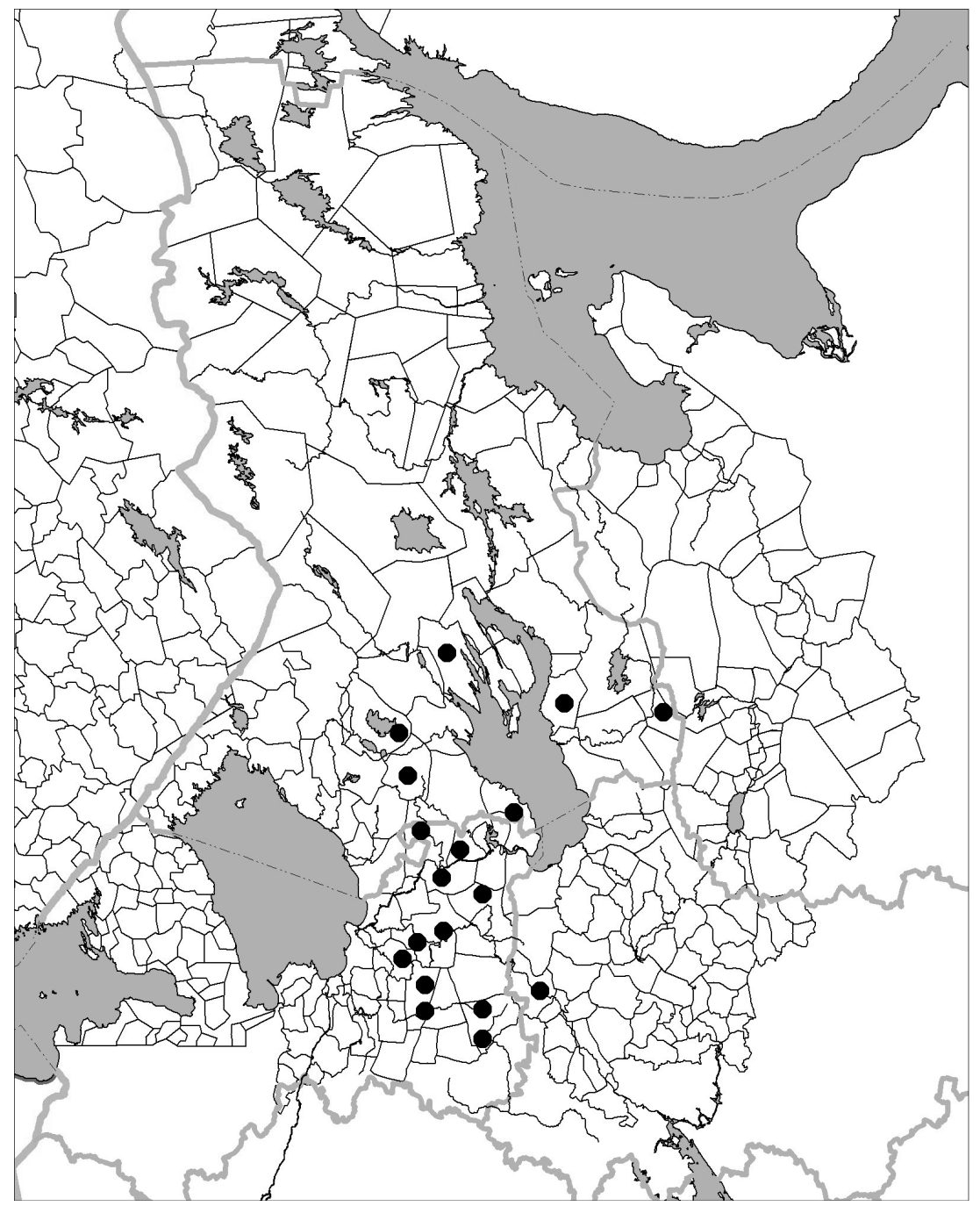

Рис. 4. Ареал вепсской топоосновы Kukoinharj

Fig. 4. Areal of Vepsian toponymic base Kukoinharj

(дер. Шайдома), которое, по всей видимости, является переводной калькой вепсского оригинала.

Используя путь по Важинке на север, вепсское освоение выходило к реке Шуе, которая в XV-XVII вв. стала основной дорогой карельского продвижения из Приладожья на восток. В результате в низовьях Шуи 
фактически столкнулись два потока: карельский с запада и вепсский с юга. Очевидно, выход вепсов на реку Шую препятствовал в определенной степени поступательному движению карелов с запада на восток по Шуе. В результате к востоку от вепсского пути сформировалась людиковская территория, где вепсский компонент значительно более мощный, чем в западном олонецком или ливвиковском диалекте. Однако «людизация» затронула в Прионежье прежде всего территории, тяготеющие к транзитным водным путям - Важинке, Шуе и Суне, - и лишь в малой степени коснулась более отдаленных от них мест, в частности, северновепсского ареала. На рубеже Средневековья и Нового времени (XV-XVII вв.), когда происходило активное карельское продвижение на Онежско-Ладожский перешеек, северновепсская территория была довольно глухой окраиной на границе двух погостов Обонежской пятины (Остречинского и Оштинского) с очень ограниченным количеством сельскохозяйственных земель. Это и защитило ее от карелизации.

\section{5. Выводы}

Языковые сюжеты, предложенные в статье, являются в определенном смысле эталонными в представлении вепсско-карельского языкового взаимодействия на Олонецком перешейке. На рубеже Средневековья и Нового времени (XV-XVII вв.) проникновение карельских переселенцев из Северного Приладожья проходило по основным водным артериям территории и приводило к карелизации населявших Онежско-Ладожский перешеек вепсов. Степень этой карелизации ослабевает по мере продвижения с запада на восток. При этом, как показал анализ топонимического материала, границы сформировавшихся языковых ареалов - ливвиковского, людиковского и вепсского - определялись в значительной степени ландшафтно-географическими особенностями местности и связанными с ними водно-волоковыми путями.

\section{Литература}

Агапитов 1993 - В. А. Агапитов. Кижи: что в имени твоем? (О происхождении названия Кижи и не только...) // Г. М. Керт, Н. Н. Мамонтова, Л. П. Михайлова (ред.). Родные сердцу имена (Ономастика Карелии). Петрозаводск: КарНЦ PAH, 1993. С. 20-21. 
Бубрих 1947 - Д. В. Бубрих. Происхождение карельского народа. Повесть о союзнике и друге русского народа на Севере. Петрозаводск: Госиздат КарелоФинской ССР, 1947.

Винокурова 2015 - И. Ю. Винокурова. Мифология вепсов. Энциклопедия. Петрозаводск: Изд-во ПетрГУ, 2015.

Зайцева 2016 - Н. Г. Зайцева. Очерки вепсской диалектологии (лингвогеографический аспект). Петрозаводск: КарНЦ РАН, 2016.

Захарова и др. 2018 - Е. В. Захарова, Д. В. Кузьмин, И. И. Муллонен, Н. Л. Шибанова. Топонимные модели Карелии в пространственно-временном контексте. М.: ЯСК, 2018.

Муллонен 1994 - И. Муллонен. Очерки вепсской топонимии. СПб.: Наука, 1994.

Муллонен 2012 - И. И. Муллонен. Природные и культурные факторы формирования вепсской этнической территории // Труды КарНЦ РАН. Серия Гуманитарные исследования. 2012. № 4. Вып. 3. С. 13-24.

Рышкин 1933 - П. Е. Рышкин. Административно-территориальное устройство Ленинградской области. Л.: Изд-во Леноблисполкома и Ленсовета, 1933.

Hakulinen 1968 — L. Hakulinen. Suomen kielen rakenne ja kehitys. Kolmas, korjattu ja lisätty painos. Helsinki: Otava, 1968.

Itkonen 1971 — T. Itkonen. Aunuksen äänneopin erikoispiirteet ja aunukselaismurteiden synty // Virittäjä. 1971. № 2. S. 153-182.

Räisänen 2010 - A. Räisänen. Kostamo, Onkamo ja muita paikannimiä // Virittäjä. 2010. № 4. S. 502-530.

Tunkelo 1946 — E. A. Tunkelo. Vepsän kielen äännehistoria (Suomalaisen Kirjallisuuden Seuran Toimituksia. Vol. 228). Helsinki: Suomalaisen Kirjallisuuden Seura, 1946.

Turunen 1946 — A. Turunen. Lyydiläismurteiden äännehistoria. Vol. I. Konsonantit (Suomalais-Ugrilaisen Seuran Toimituksia. Vol. LXXXIX). Helsinki: SuomalaisUgrilainen Seura, 1946.

\section{Источники}

КТЭ - Картотека топонимической экспедиции Уральского университета.

КЭ - А. Ф. Титов (ред.). Карелия. Энциклопедия. Т. 1. Петрозаводск: Петропресс, 2007.

ЛАВЯ - Н. Г. Зайцева (ред.). Лингвистический атлас вепсского языка. СПб.: Нестор-История, 2019.

СВЯ - М. И. Зайцева, М. И. Муллонен. Словарь вепсского языка. Л.: Наука, 1972.

СГРС - Словарь говоров Русского Севера. Т. 1- . Екатеринбург: Изд-во Уральского гос. университета, 2001-.

СНМ 1926 - Список населенных мест Карельской АССР (По материалам Переписи 1926 года). Петрозаводск: Изд-во Статистического управления, 1928.

СРГК - А. С. Герд (ред.). Словарь русских говоров Карелии и сопредельных областей. Вып. 1-6. СПб.: Изд-во Санкт-Петербургского гос. университета, 19942005. 
СРНГ - Словарь русских народных говоров. Вып. 1-. М.; Л; СПб.: Наука, 1965-. ALFE — T. Tuomi (päät.), S. Suhonen, T.-R. Viitso, V. Rjagoev (toim.). Atlas Linguarum

Fennicarum. T. I-III (Suomalaisen Kirjallisuuden Seuran Toimituksia. Vol. 1295; Kotimaisten kielten tutkimuskeskuksen julkaisuja. Vol. 159). Helsinki: Suomalaisen Kirjallisuuden Seura, 2004-2010.

IMS - R. E. Nirvi (toim.). Inkeroismurteiden sanakirja (Lexica Societatis Fenno-Ugricae. Vol. XVIII). Helsinki: Suomalais-Ugrilainen Seura, 1971.

KKS - Karjalan kielen sanakirja. T. I-VI (Lexica Societatis Fenno-Ugricae. Vol. XVI).

Helsinki: Suomalais-Ugrilainen Seura, 1968-2005.

SMS - Suomen murteiden sanakirja. Osa 1- (Kotimaisten kielten tutkimuskeskuksen julkaisuja, 36-). Helsinki: Kotimaisten kielten tutkimuskeskus, 1985- .

\section{References}

Agapitov 1993 - V. A. Agapitov. Kizhi: chto v imeni tvoem? (O proiskhozhdenii nazvaniya Kizhi i ne tolko...) [Kizhi: What's in your name? (On the origin of the names of Kizhi and not only ...)]. G. M. Kert, N. N. Mamontova, L. P. Mikhaylova (eds.). Rodnye serdtsu imena (Onomastika Karelii) [Names, dear to the heart (Onomastics of Karelia)]. Petrozavodsk: Karelian Scientific Center of the Russian Academy of Sciences, 1993. P. 20-21.

Bubrikh 1947 — D. V. Bubrikh. Proiskhozhdenie karelskogo naroda. Povest o soyuznike i druge russkogo naroda na Severe [The origin of the Karelian people. The story of an ally and friend of the Russian people in the North]. Petrozavodsk: State Publishing House of the Karelian-Finnish SSR, 1947.

Hakulinen 1968 - L. Hakulinen. Suomen kielen rakenne ja kehitys. Kolmas, korjattu ja lisätty painos. Helsinki: Otava, 1968.

Itkonen 1971 - T. Itkonen. Aunuksen äänneopin erikoispiirteet ja aunukselaismurteiden synty. Virittäjä. 1971. No. 2. S. 153-182.

Mullonen 1994 - I. Mullonen. Ocherki vepsskoy toponimii [Essays on Veps toponymy]. St. Petersburg: Nauka, 1994.

Mullonen 2012 - I. I. Mullonen. Prirodnye i kulturnye faktory formirovaniya vepsskoy etnicheskoy territorii [Natural and cultural factors of the formation of the Veps ethnic territory]. Trudy KarNTs RAN. Seriya Gumanitarnye issledovaniya. 2012. No. 4. Iss. 3. P. 13-24.

Räisänen 2010 - A. Räisänen. Kostamo, Onkamo ja muita paikannimiä. Virittäjä. 2010. No. 4. S. 502-530.

Ryshkin 1933 - P. E. Ryshkin. Administrativno-territorialnoe ustroystvo Leningradskoy oblasti [Administrative and territorial structure of the Leningrad region]. Leningrad: Publishing House of the Leningrad Executive Committee and the Leningrad City Council, 1933.

Tunkelo 1946 - E. A. Tunkelo. Vepsän kielen äännehistoria (Suomalaisen Kirjallisuuden Seuran Toimituksia. Vol. 228). Helsinki: Suomalaisen Kirjallisuuden Seura, 1946. 
Turunen 1946 - A. Turunen. Lyydiläismurteiden äännehistoria. Vol. I. Konsonantit (Suomalais-Ugrilaisen Seuran Toimituksia. Vol. LXXXIX). Helsinki: SuomalaisUgrilainen Seura, 1946.

Vinokurova 2015 - I. Yu. Vinokurova. Mifologiya vepsov. Entsiklopediya [The mythology of the Veps. Encyclopedia]. Petrozavodsk: Petrozavodsk State University Publishing House, 2015.

Zaharova 2018 - J. V. Zaharova, D. V. Kuzmin, I. I. Mullonen, N. L. Shibanova. Toponimnyye modeli Karelii v prostranstvenno-vremennom kontekste [Toponymic models of Karelia in the spatio-temporal context]. Moscow: LRC Publishers, 2018.

Zaytseva 2016 - N. G. Zaytseva. Ocherki vepsskoy dialektologii (lingvogeograficheskiy aspekt) [Essays on Veps dialectology (aspects of linguistic geography)]. Petrozavodsk: Karelian Scientific Center of the Russian Academy of Sciences, 2016.

\section{Sources}

ALFE — T. Tuomi (päät.), S. Suhonen, T.-R. Viitso, V. Rjagoev (toim.). Atlas Linguarum Fennicarum. T. I-III (Suomalaisen Kirjallisuuden Seuran Toimituksia. Vol. 1295; Kotimaisten kielten tutkimuskeskuksen julkaisuja. Vol. 159). Helsinki: Suomalaisen Kirjallisuuden Seura, 2004-2010.

IMS - R. E. Nirvi (toim.). Inkeroismurteiden sanakirja (Lexica Societatis FennoUgricae. Vol. XVIII). Helsinki: Suomalais-Ugrilainen Seura, 1971.

KE - A. F. Titov (ed.). Kareliya. Entsiklopediya [Karelia. Encyclopedia]. Vol. 1. Petrozavodsk: Petropress, 2007.

KKS - Karjalan kielen sanakirja. T. I-VI (Lexica Societatis Fenno-Ugricae. Vol. XVI). Helsinki: Suomalais-Ugrilainen Seura, 1968-2005.

KTE - Kartoteka toponimicheskoy ekspeditsii Uralskogo universiteta [File cabinet og the toponymic expedition of the Ural State University].

LAVJ - N. G. Zaitseva (ed.). Lingvisticheskiy atlas vepsskogo yazyka [Veps linguistic atlas]. St. Petersburg: Nestor-Istoriya, 2019.

SGRS - Slovar govorov Russkogo Severa [Dictionary of dialects of the Russian North]. Vol. 1- . Ekaterinburg: Ural State University Press, 2001-.

SMS - Suomen murteiden sanakirja. Osa 1- (Kotimaisten kielten tutkimuskeskuksen julkaisuja. Vol. 36-). Helsinki: Kotimaisten kielten tutkimuskeskus, 1985- .

SNM 1926 - Spisok naselennykh mest Karelskoy ASSR (Po materialam Perepisi 1926 goda) [List of populated areas of the Karelian Autonomous Soviet Socialist Republic (Based on materials from the 1926 Census)]. Petrozavodsk: Statistical Office Publishing, 1928.

SRGK - A. S. Gerd (ed.). Slovar russkikh govorov Karelii i sopredelnykh oblastey [Dictionary of Russian dialects of Karelia and adjacent areas]. Iss. 1-6. St. Petersburg: St. Petersburg State University Press, 1994-2005.

SRNG - Slovar russkikh narodnykh govorov [Dictionary of Russian folk dialects]. Iss. 1-. Moscow, Leningrad, St. Petersburg: Nauka, 1965-.

SVYa - M. I. Zaytseva, M. I. Mullonen. Slovar vepsskogo yazyka [Veps Dictionary]. Leningrad: Nauka, 1972. 


\section{О дискурсивных функциях энклитик $=m a$ и =m? в тундровом ненецком языке}

\section{С. И. Буркова}

Новосибирский государственный технический университет; burkova_s@mail.ru

Аннотация. В статье рассматриваются две энклитики, $=m a(=w a)$ и $=m ?(=w ?)$, употребляющиеся в тундровом ненецком языке в составе словоформы независимого сказуемого. Обе энклитики в описаниях тундрового ненецкого языка обычно описываются очень кратко, их функции остаются неясными, при этом в некоторых контекстах эти функции на первый взгляд кажутся идентичными.

Предпринятый в статье анализ «узких» (в составе словоформы и синтаксической конструкции) и широких контекстов употребления рассматриваемых показателей позволяет увидеть, что функции энклитик $=m a(=w a)$ и $=m ?(=w ?)$ различны, при этом принципиально важным свойством обеих форм является их связь со структурой дискурса.

Ключевые слова: тундровый ненецкий язык, энклитики, дискурсивная функция.

\section{On the discourse functions of the enclitics $=m a$ and $=m ?$ in Tundra Nenets}

\section{S. I. Burkova}

Novosibirsk State Technical University; burkova_s@mail.ru

Abstract. The paper discusses two enclitics, $=m a(=w a)$ and $=m ?(=w ?)$, which occur in the finite predicate in Tundra Nenets. Both forms are usually described in the literature very briefly and vaguely, and their functions remain obscure. In some contexts, these functions seem to overlap. For example, Tereščenko just mentioned the form =ma among other "assertive suffix particles" [Tereščenko 1973: 88]. Nikolaeva, who also treats $=m a$ as an assertive clitic, considers its central function to express certainty [Nikolaeva 2014: 120]. However, this does not answer the question why, if this form expresses certainty, it can combine with the non-indicative moods. The form $=m ?$ is considered "an affirmative suffix particle" in the section on affirmative sentences in [Tereščenko 1973], but in the 
section on interrogative sentences it is referred to as "a special marker used to emphasize the interrogative intonation". In the table of contents in [Nikolaeva 2014], the section on the enclitic $=m$ ? is entitled "Affirmative $=m^{\circ} h$ ", but further in the text this section is entitled "Dubitative $=m^{\circ} h$ ". The ambiguous interpretation of the forms under discussion is apparently due to the fact that each of them can be used in different contexts, and the features of a context are often attributed to the enclitic itself.

The analysis undertaken in this paper takes into account both "narrow" (a wordform or syntactic construction) and wide contexts of use of the enclitics $=m a$ and $=m$ ?. This analysis shows that a fundamentally important feature of both enclitics is their relation to the discourse structure. At the same time, these forms have different functions. A predicate marked with $=m a$ introduces a piece of information $\{\mathrm{B}\}$ that is associated with the previous or subsequent context $\{A\}$. By the speaker's assumption, $\{B\}$ may not be known to the addressee, but it is important for the addressee to build the correct knowledge of $\{\mathrm{A}\}$ or to choose the right behavior pattern. The main semantic component of the enclitic $=m$ ? is an indication of an alternative. As is the case with $=m a$, a predicate marked with $=m ?$ also introduces a piece of information $\{\mathrm{B}\}$ that is associated with the previous or subsequent context $\{\mathrm{A}\}$, but in the case of $=m$ ? , the speaker considers $\{\mathrm{B}\}$ to be known to the addressee. At the same time, the speaker believes that the addressee may also have an alternative piece of information $\left\{\mathrm{B}_{1}\right\}$. By using $=m ?(=w$ ? $)$ the speaker returns the addressee to the relevant information $\{\mathrm{B}\}$, which helps to make the necessary association with $\{\mathrm{A}\}$.

Keywords: Tundra Nenets, enclitics, discourse function.

\section{1. Введение}

В тундровом ненецком языке имеется ряд морфологических показателей, которые функционируют в составе независимого сказуемого, располагаясь в абсолютном конце словоформы после всех словоизменительных аффиксов. По своим характеристикам эти показатели соответствуют большинству критериев, сформулированных в [Zwicky, Pullum 1983] для клитик - единиц, занимающих на линейно-синтагматическом континууме промежуточное положение между словами и аффиксами. По сравнению со служебными словами, они обладают меньшей синтаксической свободой, в отличие от словообразовательных аффиксов не меняют лексического значения слова, а в отличие от словоизменительных аффиксов не являются обязательными показателями какой-либо грамматической категории. 
В статье речь пойдет о двух таких показателях - энклитиках $=m a$ $(=w a)$ и $=m$ ? (=w?). В утвердительных повествовательных высказываниях функции обеих энклитик, на первый взгляд, пересекаются. Например, неясно, чем обусловлен выбор говорящим энклитики =ma в (1)-(2) и энклитики $=m ?$ в (3)-(4) при одном и том же глаголе tara- ‘быть нужным': обе энклитики при употреблении в ассертивных контекстах переводятся на русский язык при помощи частиц ведь, же, $u, u$ вот, либо вообще никак специально не переводятся, а в литературе по ненецкому языку трактуются как выражающие эмфатическое утверждение, см., например, [Щербакова 1954: 204; Терещенко 1973a: 86, 88; Nikolaeva 2014: 120-121].

\begin{tabular}{|c|c|c|c|}
\hline $\begin{array}{l}н я к у-н д а \\
\text { к-POsS.3SG }\end{array}$ & $\begin{array}{l}x \ni-\sigma "-н a ” \\
\text { уйти-COND-1PL }\end{array}$ & $\begin{array}{ll}c a в a=н \ddot{е} " & c \\
\text { хороший.S.3SG=CLEXCL } & 1\end{array}$ & $\begin{array}{l}\text { сидна" } \\
\text { 1PL.ACC }\end{array}$ \\
\hline вуни & хада-нзгу-" & няндер-та & нзод" \\
\hline $\begin{array}{l}\mathrm{NEG}_{\mathrm{wN}} \cdot \mathrm{S} .3 \mathrm{sG} \\
\text { намда }\end{array}$ & 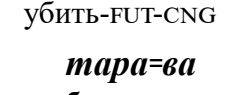 & иметь.соображения-PR & также \\
\hline
\end{tabular}

'К ней поближе надо бы пойти, она ведь нас не убьет. Нужно же послушать, что она говорит' [Янгасова 2001: 127].

(2)

\begin{tabular}{|c|c|c|}
\hline $\begin{array}{l}\text { mja"ăl } \\
\text { чум-ACC.SG.POss.2sG }\end{array}$ & $\begin{array}{l}s^{j} e r t a \\
\text { сделать.сvв }\end{array}$ & $\begin{array}{l}\text { tara }=w a \\
\text { быть.нужным.s.3sG=CL }\end{array}$ \\
\hline$m ?$ & $\breve{a}$ & $s^{j} a j-m ? \quad p^{j} i r^{j} e$ \\
\hline
\end{tabular}

\section{tara $=$ wa}

быть.нужным.s.3SG=CL

'(У матери хлопот много.) И чум сделать надо. Как чум сделаешь, и чай сварить надо’ [ПМ-Л-2006].

(3) ханя' ңзани' тара-ни=в'

конечно.же тоже быть.нужным-NEG.S.3SG= $\mathbf{C L}_{\mathrm{m} 2}$

'(Конечно же, пойдешь на собрание оленеводов.) Конечно же, тоже ведь надо' [ПМ-А-2006].

\begin{tabular}{|c|c|c|c|c|}
\hline $\begin{array}{l}\text { наңзгадя } \\
\text { целый }\end{array}$ & $\begin{array}{l}\text { яля- } p \\
\text { день-NOM.SG.POSS.2sG }\end{array}$ & $\begin{array}{l}\text { нуоб } \\
\text { один }\end{array}$ & $\begin{array}{l}\text { em } \\
\text { вот }\end{array}$ & $\begin{array}{l}\text { нзамгэ-хэвана } \\
\text { какой-ICL.LOC.SG }\end{array}$ \\
\hline & $\boldsymbol{H} \boldsymbol{u}^{\prime}=\boldsymbol{b}$, & mapa & & \\
\hline пересечь.С & NEG.S.3SG $=\mathrm{CL}_{\mathrm{M}}$ & быть.н & кНь & -CNG \\
\hline
\end{tabular}

[Из рассказа о жизни в войну] '(Хлеб нам стали так давать, детям, ученикам: вечером - двести, утром - двести.) Целый твой день, опять же, как-то надо же провести’ [ПМ-А-2006]. 
В настоящей статье мы попытаемся показать, что функции энклитик $=m a$ и $=m$ в в утвердительных повествовательных высказываниях различны, при этом принципиально важным свойством обеих форм является их связь с функционированием дискурса.

Единицы, основной функцией которых является дискурсивная, это единицы особого типа, «которые, с одной стороны, обеспечивают связность текста и, с другой стороны, самым непосредственным образом отражают процесс взаимодействия говорящего и слушающего» [Баранов и др. 1993: 7]. Обычно они обладают размытой, трудноуловимой семантикой, которая в разных контекстах может проявляться совершенно по-разному. Неслучайно в словарях и грамматических описаниях многих языков характеристика подобных единиц часто сводится к перечислению контекстов их употребления и приписыванию им очень общего значения в терминах усилительная, утвердительная, эмфатическая, выделительная и т. п. При этом остается неясным, как это общее значение реализуется в разных контекстах. В работах, посвященных анализу дискурсивных слов, неоднократно высказывалась идея о том, что все же естественно предполагать наличие у каждой такой единицы какой-либо одной функции (или, в другой терминологии, операции), которая сохраняется во всех контекстах, хотя и может подвергаться некоторым модификациям [Николаева 1985; Баранов и др. 1993; Киселева, Пайар 1998, 2003]. И, конечно, адекватный анализ таких единиц невозможен без учета широкого контекста.

\section{2. Энклитика =ma}

В «Синтаксисе самодийских языков» Н. М. Терещенко энклитика $=m a$ лишь упоминается среди прочих так называемых «утвердительных суффиксальных частиц» [Терещенко 1973a: 88]. Более подробно данный показатель описывается в грамматике тундрового ненецкого языка [Nikolaeva 2014: 120-121], где он назван ассертивной клитикой («assertive clitic»), центральной функцией которой является обозначение достоверности описываемой ситуации ${ }^{1}$. И. Николаева приводит следующие грамматические контексты употребления

\footnotetext{
${ }^{1}$ «Most commonly the clitic $=m a$ expresses certainty» [Nikolaeva 2014: 120].
} 
энклитики =ma: 1) глагол в форме индикатива, см. (1)-(2); 2) глагол в форме репутатива («reputative», аффикс -măna (-wăna) $)^{2}$, см. (13); 3) глагол в форме аппрехенсива («арprehensive», аффикс răwa) ${ }^{3}$, см. (5), причем энклитика =ma обязательна в словоформе аппрехенсива при отнесенности описываемой ситуации к временному плану прошлого.

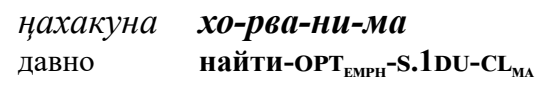

'(- Жена, ребенка родим.) - Что же мы раньше не родили (букв.: Давно найти бы нам [ребенка])' [Пушкарева 2003: 208].

И. Николаева также отмечает несовместимость энклитики $=m a$ с отрицанием; в конструкции стандартного отрицания в качестве

2 Т. Салминен считает -măna/-wăna показателем особого наклонения — «reputative mood» (от лат. reputo ‘исчисляю, обдумываю'), выражающего какую-то разновидность предположения [Salminen 1997: 98]. И. Николаева тоже квалифицирует этот аффикс как показатель наклонения, выражающего какую-то разновидность ирреального сравнения 'как будто бы, как если бы', реже - низкую степень вероятности ситуации, а также используемого в риторических вопросах, содержащих сомнение: «The main meaning of the reputative is some kind of irrealis comparison ('as if'). $\langle\ldots\rangle$ The reputative also expresses low probability $\langle\ldots\rangle$ and can be used to form rethorical questions asked with doubts» [Nikolaeva 2014: 104]. Однако, на наш взгляд, форму с показателем -тӑпа вряд ли можно отнести к числу наклонений. Этот аффикс в подавляющем большинстве случаев используется для выражения риторического вопроса, при этом он обычно требует присутствия в предложении вопросительного слова - местоимения, наречия или специализированного вопросительного глагола. Показатель -тӑпа правомернее рассматривать как аффикс, участвующий в выражении модальной семантики, но не являющийся обязательным показателем какой-либо грамматической категории. В глоссах мы обозначаем его символом RHET.

${ }^{3}$ Аффикс -răwa Т. Салминен и И. Николаева квалифицируют как показатель одного из косвенных наклонений [Salminen 1997; Nikolaeva 2014]. По мнению И. Николаевой, это наклонение выражает либо опасение по поводу нежелательной ситуации в будущем, либо сожаление по поводу нереализованной ситуации в прошедшем: «The core meaning of the apprehensive is fear about the future. $\langle\ldots\rangle$ The second meaning is regret about the past. To express this meaning the apprehensive cannot refer to future situations and must be combined with the clitic $=m a$. $\langle\ldots\rangle$ The omission of the clitic is impossible in this meaning» [Nikolaeva 2014: 90]. Мы тоже относим аффикс -răwa к показателям наклонений, однако считаем, что его правомернее квалифицировать как форму со значением эмфатического оптатива. Аргументы в пользу данной точки зрения см. [Буркова 2010: 282-283; Буркова 2012]. В глоссах мы обозначаем его символом ОРТ 


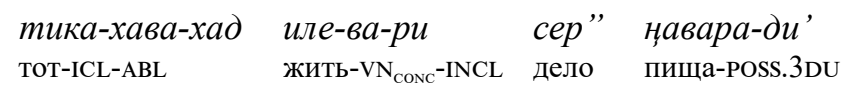

цока $=в а$

многочисленный.S.3SG= $\mathrm{CL}_{\text {мА }}$

'[Контекст: старик со старухой находят на дороге кошелек с золотыми монетами.] После этого только и живут, ведь полно у них пищи' [Янгасова 2001: 131].

Во-вторых, энклитика =ma достаточно часто употребляется с глаголом в форме императива 2-го и 3-го лица (10)-(11), а также гортатива (12).
та"ляю тутан
тюкоркан'
сюда прийти-FUT-S.2SG сюда
цамда $=$ ма

‘Сюда сядешь (букв.: придешь)? Ну так сюда садись' [ПМ-А-2006].

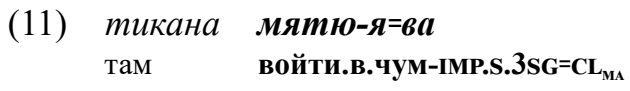

'(- Здесь ребенок пришел.) - Так пусть он в дом войдёт' [Пушкарева 2003: 178].

(12) $\boldsymbol{x э - х э - н и = м а ~}$

Уйти-HORT-S.1DU $=\mathbf{C L}_{\text {MА }}$

'(- И действительно, хорошо туда пойти.) - Ну, пойдем' [Пушкарева, Хомич 2001: 154].

Наконец, неясно, имеются ли ограничения, и если да, то какие именно, на использование энклитики =ma в вопросительных предложениях. В словаре [Терещенко 1965] обнаруживается всего лишь три примера, в которых энклитика =ma выступает в сочетании с показателем риторического вопроса - аффиксом -тӑnа (см. сноску 3), один из них мы приводим ниже, см. (13). Два примера, приводимые в грамматике [Nikolaeva 2014: 104], тоже взяты из словаря [Терещенко 1965]. Однако достоверных текстовых примеров сочетания в пределах словоформы показателей =ma и -măпа в нашем материале пока не имеется. Нами также обнаружен единичный пример, в котором энклитика =ma используется в общем вопросе, но не в обычном, когда говорящий хочет получить неизвестную ему информацию, а в констатирующем, когда говорящий запрашивает подтверждение уже имеющейся у него информации (14). В принципе, как будет видно из дальнейшего описания, ограничений на использование энклитики =ma в таких вопросах, 
которые по сути представляют собой утверждения, т. е. риторических и констатирующих, как будто бы и не должно быть.

(13) вадаха"на-т тюку-м' ехэра-вна-ра=ва

будто-POSS.2SG это-ACC.SG не.3нать-RHET-O.2SG=CL $\mathbf{C L}_{\text {мA }}$

‘Будто ты сам этого не знаешь?' [Терещенко 1965: 33].

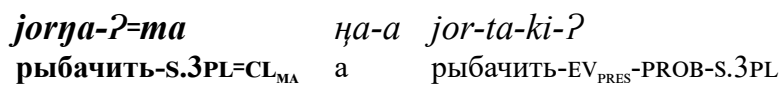

'(- Вот, так они жили.) - Рыбачили ведь? - А? - Рыбачили, наверное?' [ПМ-А-2006]

Глагол $w u n^{j} \breve{a}$-, который употребляется вместо энклитики =ma в конструкциях стандартного отрицания, по нашим данным, имеет более узкую сферу употребления - он используется только в индикативе и не сочетается с показателями косвенных наклонений.

Таким образом, можно выделить два основных контекста употребления энклитики =ma: 1) говорящий сообщает о $P$; =ma в этом случае выступает в сочетании с глаголом в индикативе или с именем; 2) говорящий выражает желание реализации $P$; =ma в этом случае выступает в сочетании с глаголом в форме императива, гортатива или эмфатического оптатива (аффикс -răwa, см. сноску 5). Другими словами, эта форма встречается в двух типах предложений с точки зрения их иллокутивной функции: ассертивных и побудительных. Анализ более «длинных» контекстов позволяет увидеть, что в обоих случаях функция энклитики =ma связана с маркированием каузальных отношений между двумя фрагментами дискурса, однако в первом случае $=m a$, как правило, маркирует причину/обоснование, а во втором - каузальное следование.

В том случае, когда энклитика =ma используется в ассертивных контекстах, она, как правило, вводит фрагмент информации $\{\mathrm{B}\}$, являющийся аргументом в пользу некоторого другого фрагмента информации $\{\mathrm{A}\}$. Информация, которая вводится при помощи энклитики $=m a$, с точки зрения говорящего, может быть неизвестна адресату, но необходима для адекватного понимания адресатом $\{\mathrm{A}\}$ : ' $\{\mathrm{A}\}$, потому что $\{\mathrm{B}=m a\}$ '. Например, в (15) информант, рассказывая о том, что никак не может получить квартиру в поселке, замечает, что в принципе может обойтись и без квартиры: 'просто на всякий случай была бы' (15a). Далее он считает нужным пояснить свое замечание, полагая, что слушатели могут этого и не знать: 'покрышки-то для чума у нас есть 
(т. е. жилье, чум, в принципе имеется)' (15б). Ср. также аналогичный пример (16), в котором (16б) представляет собой пояснение к (16а).

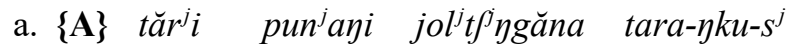
просто задний во.время быть.нужным-FUT-S.3SG.PAST

'(Они не хотят давать нам квартиру.) Просто на всякий случай была бы,'

б. $\{\mathbf{B}\} \quad j e j a-x ə \check{e} w^{j} i-n^{j} i ? \quad \tan ^{j} \boldsymbol{a}=\boldsymbol{w a}$ НюК-INCL-NOM.PL.POSS.1DU иметься.S.3SG $=\mathbf{C L}_{\text {MA }}$ ‘покрышки-то для чума у нас есть’ [ПМ-А-2006].

$$
\begin{array}{lllll}
\text { a. }\{\mathbf{A}\} & \text { cum } & \text { неле-сb } & \text { тара-н } & \text { mедa } \\
& \text { 2sG.ACC } & \text { женить-сVв } & \text { быть.нужным-S.2sG } & \text { сейчас }
\end{array}
$$

$\begin{array}{lll}\text { ханта-ни' } & \text { Паңзгдё } & я-\mu^{\prime} \\ \text { отправиться-S.1DU } & \text { пангдё } & \text { место-DAT.SG }\end{array}$

‘Тебя надо женить. Сейчас мы с тобой поедем в землю Пангдё'.

$\begin{array}{lllll}\text { б. }\{\mathbf{B}\} & \text { Панцддё } & \text { ерв } & \text { недко-да } & \text { ню-да } \\ & \text { паңгдё } & \text { хозяин } & \text { дочь-POSs.3sG } & \text { ребенок-NOM.SG.POSs.3sG }\end{array}$

\section{тане $=$ ва}

иметься.S.3SG= $\mathrm{CL}_{\mathrm{MA}}$

‘У Пангдё-Хозяина есть дочка' [Пушкарева, Хомич 2001: 236].

Реже, обычно в нарративах, =mа кодирует каузальное следование, когда фрагмент информации $\{\mathrm{B}\}$, вводимый энклитикой $=m a$, логически вытекает из предшествующего $\{\mathrm{A}\}:$ ' $\{\mathrm{A}\}$, и вот поэтому/и тогда $\{\mathrm{B}=m a\} '(17)-(18)$.

a. $\{\mathbf{A}\}$

मзэсbl-'
стойбище-GEN.SG

нзацеекь- "

$m b l-\partial a ”$

стойбище-GEN.SG

ребенок-NOM.PL

олень-NOM.PL.POSS.2PL

$\begin{array}{llll}\text { сюрте-хэр-ъя-да" } & \ddot{е} н э & \text { mэта } & \text { вэра } \\ \text { окружить-INCL-PL-O.2PL } & \text { средний } & \text { богатый } & \text { вэра.NOM.SG }\end{array}$

пой-м’ ныкал-та хасена-вы

промежуток-ACC.SG разорвать-FUT.S.3SG быть.спокойным-PR $\mathrm{PRF}_{\mathrm{PF}}$

$\ddot{e} \quad \ddot{e}$ манзабта-нугу

место.ACC.PL место.ACC.PL пошевелить-FUT.S.3SG

'«Пастухи, соберите оленей, Средний Вэра далеко уйдёт, шуму наделает!»’
б. $\{\mathbf{B}\}$ нээсbl-'
нзацекй-"
тольртии
стойбище-GEN.SG
ребенок-NOM.PL
быть.неисчислимым.СVB 


\section{ёнар-м’ нули’ паромбари сюрте-й-ду=ма \\ тысяча-ACC.SG очень поспешно окружить-PL-O.3PL=CL}

'[И вот] пастухи быстро собрали несчетное стадо' [Вануйто и др. 2010: 320].

\begin{tabular}{|c|c|c|c|c|c|}
\hline a. $\{\mathbf{A}\}$ & $\begin{array}{l}c u^{\prime} u в \\
\text { семь }\end{array}$ & $\begin{array}{l}я-M \\
\text { место-ACC.SG }\end{array}$ & \multicolumn{2}{|c|}{ цзавор-та-м’ } & $\begin{array}{l}\text { си'ив } \\
\text { семь }\end{array}$ \\
\hline \multicolumn{2}{|c|}{$я-M^{\prime}$} & пилю-та-м & & нчамгэ & иле \\
\hline \multicolumn{2}{|c|}{ место-ACC.SG } & бояться-PR & -ACC.SG & что & жить.CVB \\
\hline$\lambda$ & & нуэва $\mathrm{cbl}$ & вlдёда & & \\
\hline остағ & ить-0. $2 \mathrm{sc}$ & нэва & ыдёда-Ас & C.SG & \\
\hline
\end{tabular}

'Нэва Сыхыдёда, который уничтожил семь земель, напугал семь земель, зачем ты оставил его в живых?'

б. \{В\} теда' Нэва Сыхыдёда хунари сяхари' сейчас нэва сыхыдёда где.то сколько.то

\begin{tabular}{|c|c|c|}
\hline $\begin{array}{l}\text { u’лик } \\
\text { жидкий }\end{array}$ & $\begin{array}{l}в \ni u-\partial \\
\text { кровь-ACC.PL.POSS.2SG }\end{array}$ & $\begin{array}{l}\text { мянара-цду-дa=вa } \\
\text { разбрызгать-FUT-о.3SG=CL }\end{array}$ \\
\hline
\end{tabular}

'Теперь Нэва Сыхыдёда когда-нибудь разбрызжет твою жидкую кровь’ [Куприянова 1965: 71].

В случае, когда энклитика =ma используется в побудительных контекстах, во всех имеющихся в нашем материале примерах желание говорящего $\{\mathrm{B}\}$, маркируемое энклитикой =ma, представлено как обоснованно вытекающее из предшествующего или, реже, последующего $\{\mathrm{A}\}$ : 'Раз $\{\mathrm{A}\}$, так пусть $\{\mathrm{B}=m a\}$ ' или 'пусть $\{\mathrm{B}=m a\}$, так как $\{\mathrm{A}\}$ ', ср. пример с гортативом (19), императивом 2-го лица (20), императивом 3-го лица (21) и эмфатическим оптативом (22).

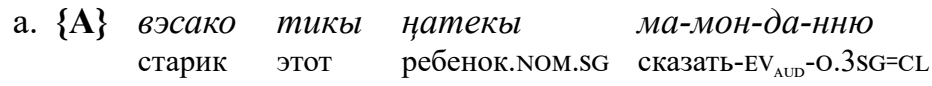

сими ююр-манда-ми юу

1SG.ACC искать-PR prosp -NOM.SG.POSS.1SG отсутствовать.S.3SG

'Старик! Этот ребенок сказал, что искать его некому,'

б. $\{\mathbf{B}\}$ ңзатекэ-д-ми'

МЭ-ХЭ-ми-ма

ребенок-DEST-POSS.1DU

BзяTb-HORT-S.1DU $=\mathbf{C L}_{\mathrm{MA}}$

'[так] в дитяти его возьмем-ка' [Пушкарева, Хомич 2001: 136].

(20)
a. $\{\mathbf{A}\}$ теда' сэдор-"
нумбъя-в
теперь шить-IMP.s.2sG
указательный.палец-ACC.SG.POss.1SG 
сu-ma- $\partial \mu^{\prime}$

проткнуть-FUT-S.

‘_ Теперь шей! — Проткну указательный палец'.

б. $\{$ В $\}$ еся нумбъяда-р сер-"=ма

железо наперсток-ACC.SG.POSS.2SG надеть-IMP.S.2SG=CL

‘_ [Так] надень железный наперсток’ [Янгасова 2001: 128].

(21) а. $\{\mathbf{A}\}$ ет ненэся нъэдатаңъго-ва-ба-т

ну правда отправить-INCL-COND-2SG

'(- Я же невкусный, лучше своего сына отправлю тебе. Его съешь.) - Если действительно его отправишь,'

б. $\{\mathrm{B}\} \quad \mu \ni-я=\boldsymbol{в} \boldsymbol{a}$ быть-IMP.S.3SG= $\mathbf{C L}_{\text {мА }}$

‘пусть будет так’ [Пушкарева, Хомич 2001: 92].

а. $\{\mathbf{A}\},\{\mathbf{B}\}$ пэ-хэва-нуэ мунзя-рава-на=ва

$$
\text { камень-CL-ADV } \text { TRANS }_{\text {молчать-OPT }} \text { ЕмPH }^{-} \mathbf{S . 2 S G}=\mathbf{C L}_{\text {MA }}
$$

'Камень (букв.: камнем будучи), ты бы лучше помолчал'.

б. $\{\mathbf{A}\}$ nыдъер сит иңгне-"я-р

2SG.PJR 2SG.ACC pocomaxa-AUG-NOM.SG.POSs.2sG

нзэ-м-да тибте-хэя хае-сетьлниё,

нога-ACC.SG-Poss.3sG приподняться-INCL.CVB оставить-HAB.S.3SG=CL $L_{\mathrm{ExcL}}$

'Мимо тебя же самого росомаха не пройдет, не приподняв ноги (т. е. ты не заслуживаешь того, чтобы высказывать свое мнение)'. [Янгасова 2001: 124].

\section{3. Энклитика =m?}

В статье [Щербакова 1954] энклитика =m? названа «вопросительным суффиксом» и, буквально через один абзац, «суффиксом утверждения» [Щербакова 1954: 204]. В «Синтаксисе самодийских языков» [Терещенко 1973a] на с. 86, где рассматриваются предложения, выражающие утверждение, энклитика $=m ?$ названа «утвердительной суффиксальной частицей», а на с. 93, где рассматриваются вопросительные предложения, — «особым морфолого-фонетическим показателем подчеркнутой вопросительной интонации». В грамматике [Nikolaeva 
2014] энклитика $=m ?$ в оглавлении названа «утвердительной» («affirmative» $=m^{\circ} h$ ) [Nikolaeva 2014: ix], однако далее в тексте раздел, посвященный данному показателю, озаглавлен «Дубитативная (клитика)» («dubitative» $\left.=m^{\circ} h\right)$ [Nikolaeva 2014: 121]. Неоднозначная интерпретация показателя =m? во всех указанных работах, в общем-то, неслучайна: рассматриваемая энклитика может употребляться в различных по своей коммуникативной цели предложениях, и это различие часто связывается с семантикой самой энклитики.

Так, энклитика $=m ?$ может употребляться в предложениях, сказуемое которых выражено лексическим глаголом в индикативе (23), условной формой глагола (24), (26) или именем (25). Такие предложения служат для выражения вопроса или предположения, а энклитике $=m ?$ в них обычно приписывается значение вопросительности или неопределенности ${ }^{5}$.

\begin{tabular}{|c|c|}
\hline $\begin{array}{l}\text { тикыl } \\
\text { этот }\end{array}$ & $\begin{array}{l}\text { ненэия-м' } \\
\text { человек-ACC.SG }\end{array}$ \\
\hline
\end{tabular}

‘Знаешь ли ты этого человека?’ [Терещенко 1973a: 91].

$\begin{array}{ll}\text { ири-ни } & \text { сярка-ко-да } \\ \text { дедушка-GEN.SG.POSS.1SG } & \text { рюмка-DIM-NOM.SG.POSS.3sG }\end{array}$

юңго-б-та=в' отсутствовать-COND-3SG= $\mathrm{CL}_{\mathrm{M}}$ ?

‘Нет ли у дедушки моего водочки?’ [ПМ-А-2006]

\begin{tabular}{|c|c|}
\hline $\begin{array}{l}n \text { пьдар } \\
2 \mathrm{sG}\end{array}$ & $\begin{array}{l}\text { пирибтя-ну=ө, } \\
\text { девушка-s.2sG }=\mathrm{CL}_{\mathrm{m}}\end{array}$ \\
\hline
\end{tabular}

‘Ты девушка или женщина?' [Терещенко 1973a: 94].
паранода-харт
ня- $p$
ңэ-б-ma=6,
царь-INCL.NOM.SG
товарищ-NOM.SG.POSS.2SG
быть-COND-3SG=CL

'Возможно, и не царь он' [Янгасова 2001: 80].

Кроме того, энклитика $=m ?$ часто выступает в сочетании с вспомогательным отрицательным глаголом $n^{j} i$ - в индикативе (27)-(29). Как правило, в присутствии показателя $=m$ ? меняется порядок следования частей аналитической отрицательной конструкции: отрицательный глагол помещается не перед знаменательным глаголом, как в конструкции

${ }^{5} \mathrm{Cp} .:$ «The second function of the clitic $=m^{\circ} h$ is realized in constructions that express doubts $\langle\ldots\rangle$, alternative questions $\langle\ldots\rangle$ and other disjunctions» [Nikolaeva 2014: 122]. 
стандартного отрицания, а после него. Однако возможно и сохранение исходного порядка, ср. примеры (27) и (28) из одного и того же сборника текстов на ямальском говоре тундрового ненецкого языка ${ }^{6}$.

Высказывания с энклитикой =m? при отрицательном глаголе обычно трактуются как выражающие эмфатическое утверждение, ср.: «Утвердительное значение личные формы глагола нись получают обычно в том случае, если они сочетаются с вопросительными суффиксами -в, -в', -м и др. Значение конструкций с вопросительными формами глагола нись имеют некоторое сходство с предложениями типа: “Не говорил ли я?”, “Не ходил ли я?”» [Щербакова 1954: 204]; «При вспомогательном отрицательном глаголе эта клитика выражает утверждение. Другими словами, в присутствии этой клитики полярность меняется на положительную, а утверждение тем или иным образом акцентируется» [Nikolaeva 2014: 121] ${ }^{7}$.

$$
\begin{array}{llll}
\text { ям-д’ } & \text { нуадахэй яха-' } & \text { ня”'ава-хана } \\
\text { большая.река-DAT.SG } & \text { далекий } & \text { река-GEN.SG } & \text { устье-LOC.SG }
\end{array}
$$

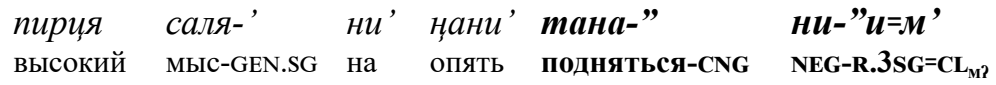

'В широком устье реки он опять поднялся на высокий мыс' [Янгасова 2001: 96].

$\begin{array}{llll}\text { вэсако-' } & \text { не } & \text { ню } & n u-\mu^{\prime} \\ \text { старик-GEN.SG }^{\prime} & \text { женщина } & \text { ребенок.NOM.SG } & \text { улица-GEN.SG }\end{array}$

$$
\begin{array}{ll}
\mu u-" u=\boldsymbol{M} & \text { mapn=" } \\
\text { NEG-R.3SG=CL } & \text { выйти-CNG }
\end{array}
$$

\begin{tabular}{|c|c|c|c|c|c|}
\hline $\begin{array}{l}\text { кают } \\
\text { каюта- }\end{array}$ & $\begin{array}{l}-\mathrm{HU} \\
\text { EN.SG.PO }\end{array}$ & $1 \mathrm{sG}$ & $\begin{array}{l}\text { мю’ } \\
\text { внутрь }\end{array}$ & $\begin{array}{l}\text { пумна-ни } \\
\text { следом-Poss.1sG }\end{array}$ & 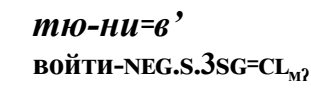 \\
\hline $\begin{array}{l}\text { тика } \\
\text { тот }\end{array}$ & $\begin{array}{l}\text { тарси } \\
\text { такой }\end{array}$ & $n u$ & абта & $\boldsymbol{u}=\boldsymbol{\theta}$ & $\begin{array}{l}\text { мa-нu }=\boldsymbol{b}^{\prime} \\
\text { сказать-NE}\end{array}$ \\
\hline
\end{tabular}

‘Дочь старика вышла на улицу’ [Янгасова 2001: 36].

${ }^{6}$ Аналитическая отрицательная конструкция с энклитикой $=m ?$, по-видимому, находится в процессе стяжения. В речи носителей тундрового ненецкого языка довольно часто наблюдается утрата гортанного смычного при основе знаменательного глагола (формального показателя коннегатива), при письме носители нередко пишут отрицательный и знаменательный глагол слитно, в одно слово.

7 «On the negative auxiliary this clitic expresses affirmation. In other words, in the presence of this clitic polarity changes to positive and the assertion is somehow emphasized» [Nikolaeva 2014: 121]. 


\section{национальнотя- $p$ \\ национальность-NOM.SG.POSS.2SG какой}

'Он зашел за мной в каюту. Так смешно было, спрашивает меня: «Какой ты национальности?»’ [ПМ-А-2007].

Таким образом, энклитика $=m$ ? может употребляться в двух типах высказываний: в вопросительных (при лексическом глаголе в индикативе, условной форме глагола или имени) и в утвердительных повествовательных (при отрицательном глаголе в индикативе) ${ }^{8}$. В первом случае она традиционно трактуется как выражающая неуверенность говорящего в достоверности $P$, а во втором случае - как выражающая эмфатическое утверждение. На наш взгляд, все же логичнее предположить, что данное семантическое различие определяется не столько энклитикой, сколько типом конструкции в целом. Например, и в (30), и в (31) энклитика = $m$ ? присоединяется к вспомогательному отрицательному глаголу. При этом в (30) отрицательный глагол стоит в условной форме и вся конструкция в целом выражает предположение, а в (31) отрицательный глагол стоит в финитной форме индикатива, и конструкция в целом имеет утвердительное значение.

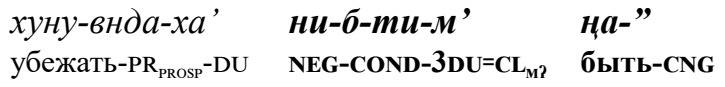

'По-видимому, собираются они бежать' [Янгасова 2001: 73].

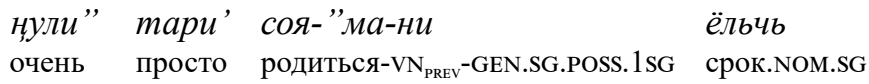

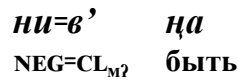

'(Когда по тундре ехали, в морозы я родился.) Как раз в это время я ведь родился' [ПМ-А-2006].

\footnotetext{
${ }^{8}$ Следует заметить, что энклитика $=m$ ? может сочетаться в пределах словоформы с аффиксом $-s(j) a$, который многие самоедологи считают показателем вопросительного наклонения, используемого по отношению к ситуациям с референцией к прошлому, см., например, [Прокофьев 1937: 44; Hajdú 1988: 18; Salminen 1997: 98; Mikola 2004: 116; Nikolaeva 2014: 97-98]. Однако в работах Н. М. Терещенко [Терещенко 1973a: 92, 19736, 1993: 336] и в учебном пособии «Ненецкий язык» [Куприянова и др. 1985: 211] аффикс $-s\left(^{j}\right) a$ определяется как как одна из модальных форм, примыкающих по своим функциям к наклонениям, но показателями последних не являющихся. Близкого подхода придерживаемся и мы: наш собственный анализ формы $-s\left(^{j}\right) a$ показывает, что ее функции скорее дискурсивные, они
} 


\section{4. Энклитики $=m a$ и $=m$ в в ассертивных контекстах}

Вернемся теперь к вопросу, чем же различаются функции рассмотренных энклитик в утвердительных повествовательных высказываниях.

Выше мы обозначили возможные морфосинтаксические контексты для энклитики =ma (ассертивные и побудительные), а также продемонстрировали более «длинные» контексты употребления этого показателя. Суммируя, можно сделать следующий вывод. Энклитика =ma вводит такую информацию $\{\mathrm{B}\}$, которая: 1) связана с предшествующим или, реже, последующим контекстом $\{\mathrm{A}\} ; 2$ ) может быть неизвестна, по предположению говорящего, адресату, но важна для построения адресатом правильного знания или выбора правильного поведения 9 .

Набор возможных морфосинтаксических контекстов для энклитики $=m ?$ (ассертивные при отрицательном глаголе в индикативе и вопросительные при лексическом глаголе в индикативе, условной форме глагола или при имени) позволяет предположить, что основным семантическим компонентом в значении этой энклитики является указание на наличие альтернативы. Неслучайно энклитика $=m$ ? употребляется в вопросительных предложениях. Неслучайно в ассертивном контексте она используется только в сочетании с отрицательным глаголом, меняя при этом полярность и, по сути, превращая предложение в риторический вопрос. Можно далее попытаться сформулировать условия употребления энклитики $=m ?$ в утвердительном повествовательном предложении. Эта энклитика вводит такую информацию $\{\mathrm{B}\}$, что: 1) она связана с предшествующим или последующим контекстом $\{\mathrm{A}\} ; 2)$ она

не связаны непосредственно ни с выражением временной локализации ситуации, ни с иллокутивной функцией вопроса. Более подробное обсуждение этого показателя см. [Буркова 2013].

9 Энклитика =ma может показаться близкой по своим функциям к русской частице ведь, ср.: «Ведь указывает на то, что вводимая информация, будучи адекватной, является одновременно релевантной для правильной интерпретации ситуации адресатом речи» [Бонно, Кодзасов 1998: 429]. Неслучайно и на русский язык =ma часто переводится при помощи ведь. Однако полного тождества у энклитики $=m a$ с частицей ведь все же нет. Ведь не сочетается с императивом, по крайней мере с императивом в значении прямого побуждения к действию (см. об этом [Левонтина 2005]), в то время как энклитика =ma свободно употребляется в побудительных высказываниях. 
известна, с точки зрения говорящего, адресату; 3) однако, по мнению говорящего, в поле зрения адресата может присутствовать альтернатива $\left.\{\mathrm{B}\}-\left\{\mathrm{B}_{1}\right\} ; 4\right)$ говорящий при помощи энклитики =m? возвращает адресата к релевантной информации, помогающей осуществить нужную ассоциацию с $\{\mathrm{A}\}$ : 'подчеркиваю/напоминаю, что $\{\mathrm{B}\}$, а не $\left\{\mathrm{B}_{1}\right\}$ '.

Продемонстрируем функциональное различие между энклитиками =ma и =m? на нескольких примерах из текстов. Пример (32) представляет собой фрагмент рассказа о жизни ненцев в старину. Сообщая (32a), информант далее дает ряд пояснений (326-е) для слушающих его русских лингвистов, предполагая, что для адекватного понимания сообщения у них может и не иметься соответствующих фоновых знаний. Все пояснения, как можно видеть, вводятся при помощи энклитики $=m a$.
a. tă-? mal ${ }^{j}$ ggăna $n^{j}$ enet $^{j} a-? \quad$ jul ${ }^{j} t \int^{j} e$ TOT-GEN.SG во.время человек-NOM.PL очень
tixina-wej-?
испытывать.трудности-EV $\mathrm{HsY}-\mathrm{S} .3 \mathrm{PL}$

'Тогда люди, говорят, очень мучились'.

б. tă? maljygăna xor-? juygu-wej-?=ma тот во.время печь-NOM.PL отсутствовать-EV $\mathbf{H s Y}_{\mathbf{H}} \mathbf{S . 3 P L}=\mathbf{C L}_{\text {мА }}$

‘Тогда ведь печек не было’.

в. $n^{j}$ enej tu-m' me-pej-P=ma

настоящий огонь-ACC.SG использовать-EV $\mathbf{H s Y}-\mathbf{S} .3 \mathbf{P L}=\mathbf{C L}_{\mathrm{MA}}$

'Использовали ведь настоящий огонь'.

г. $m^{j} u s^{j} e \quad$ tara-ygu=wa

кочевать.CVв быть.нужным-FUT.S.3SG= $\mathbf{C L}_{\text {мА }}$

'И кочевать ведь будет нужно'.

д. jaki-ygu=wa

быть.дымным-FUT= $\mathbf{C L}_{\text {MA }}$

'И дымно будет в чуме'.

$\begin{array}{llll}\text { e. } m^{j} a d-m P & \text { per- } t^{j} a & n^{j} \text { era } & \text { jake-? } \\ \text { чум-ACC.SG } & \text { заниматься-PR } \text { соNт }_{\text {NOM.SG }} & \text { ивняк } & \text { дым-GEN.SG }\end{array}$

pomna $t u-r^{j} i-m-d a \quad$ jajebta-ygo=wa

среди огонь-INCL-ACC.SG-POSS.3SG заняться-FUT.S.3SG=CL

'Хозяйка в ивняковом дыму, поддерживая костер, будет крутиться'. 


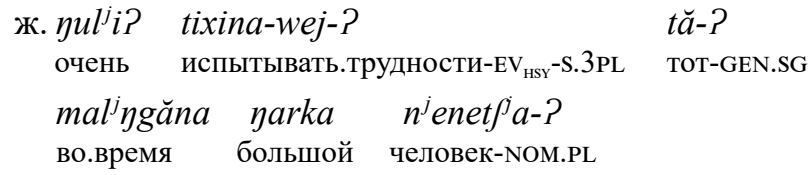

‘Очень они тогда мучились, старшее поколение' [ПМ-Л-2006].

Пример (33) представляет собой фрагмент из рассказа о жизни ненцев во время войны. Вопрос (33a) был задан рассказчику интервьюирующей его тундровой ненкой. Рассказчик предполагает, что она должна быть осведомлена о том, в какое время ненцы обычно рыбачат. Далее он вводит аргумент при помощи энклитики $=m$ ? (33б).

a. jor-ta-ki-?

рыбачить-EV PRES $^{-P R O B-S .3 P L}$

‘- Рыбачили, наверное?'

б. $j o r-t j^{j}$ рыбачить-СVв зима NEG.S.3SG=CL
jor- $\boldsymbol{n}^{j} \boldsymbol{i}$-P=m?
рыбачить-NEG-S.3PL=CL
'Рыбачить.. зима же была, летом же рыбачат' [ПМ-А-2006].

Пример (34) представляет собой фрагмент из речи депутата, обращенной к жителям поселка. В (34a-б) говорящий вводит аргумент, известный, с его точки зрения, слушающим, и использует при этом энклитику $=m$ ?. В (34в) говорящий вводит информацию, которая, по его мнению, может быть неизвестна слушающим, и использует при этом энклитику $=m a$.

а. тюку пыдара" хар-та" тика-нда"

этот 2PL сам-2PL TOT-GEN.SG.POSS.2PL

$\begin{array}{llll}\text { я-нда" } & \text { тер } & \boldsymbol{\mu \boldsymbol { u } = \boldsymbol { \theta }}, & \boldsymbol{\mu a - ”} \\ \text { место-GEN.SG.POSS.2PL } & \text { житель.NOM.SG } & \text { NEG-S.3SG=CL } & \text { быть-CNG }\end{array}$

'Вы сами, это вы сами решите [давать ему жилье или нет], это же ваш житель'.

б. тикы то"лаха вэсаку мятав мер' тот подобный старик чум.ACC.PL.INCL быстро

ми-па-то' тара-ни=е,

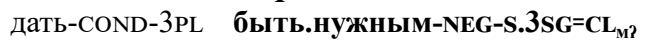

‘Таким старикам жилье надо быстрее давать'. 
$\begin{array}{clll}\text { в. } \text { пари } & \text { нуод } & \text { харда-до’ } & \text { тика-хана } \\ \text { просто } & \text { тоже } & \text { дом-NOM.SG.POSS.3PL } & \text { тот-LOC.SG }\end{array}$

$\boldsymbol{x} \boldsymbol{a} \ddot{\boldsymbol{e}}-\partial \boldsymbol{a}=\boldsymbol{в} \boldsymbol{a}$

остаться-FUT.S.3SG $=\mathrm{CL}_{\text {MA }}$

'Да и жилье их и так останется [т. е. после их смерти]' [ПМA-2006].

Глагол $w u n^{j} \breve{a}$-, упоминаемый в грамматике [Nikolaeva 2014: 121] в качестве отрицательного коррелята энклитики =ma, на самом деле, по-видимому, по своим дискурсивным функциям шире: в конструкциях стандартного отрицания он может выступать в качестве отрицательного коррелята обеих энклитик, рассматриваемых в данной статье. Например, в (35) этот глагол вводит информацию, неизвестную, с точки зрения говорящего, адресату, в то время как в (36) отсылает к общему знанию.

a. $\{\mathbf{A}\}$ пэдара-хӑна харда-ко-хо̆на иле-вы лес-LOC.SG дом-DIM-LOC.SG жил-EV ${ }_{\text {нsт. }}$.3SG

'(И он стал жить один.) В лесу в избушке он, говорят, жил'.

б. $\{\mathbf{B}\}$ мяд-м’ мярӑ хасава чум-ACC.SG поднять.CVB мужчина.NOM.SG

\section{выни-да пирас

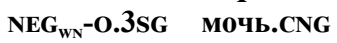

'Мужчина же не может поставить чум' ${ }^{10}$ [ЭМ-2012: 213].

(36)

\begin{tabular}{|c|c|c|}
\hline & $\begin{array}{l}\text { тикbl } \\
\text { тот }\end{array}$ & $\begin{array}{l}\text { ваде-та } \\
\text { рассказать-} \mathrm{PR}_{\mathrm{CONT}}\end{array}$ \\
\hline
\end{tabular}

$\begin{array}{lll}\text { ню-ни' } & \text { ню-хува-ха’ } & \text { сабе } \\ \text { ребенок-GEN.SG.POSS.1SG } & \text { ребенок-INCL-DU } & \text { очень }\end{array}$

ненчаң-г тэе-на-ха'

человек-DAT.PL быть.расположенным-PR $\mathrm{CONT}^{-\mathrm{DU}}$

ни-хи' нца-"

NEG-S.3DU быть-CNG

‘Эти дети детей сестры, о которых я говорю, особо не тянутся к людям'.

б. \{В $\}$ и-т харва-на ненэча- $p$

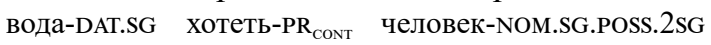

10 Чум у ненцев обычно устанавливают женщины. 


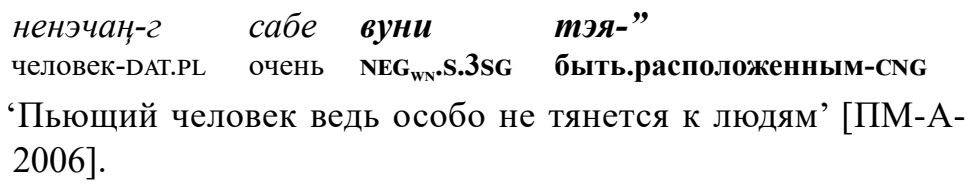

\section{Список условных сокращений}

1, 2, 3 - 1-е, 2-е, 3-е лицо; ABL - аблатив; $\mathrm{ACC}$ - аккузатив; $\mathrm{ADV}_{\mathrm{TRANS}}-\mathrm{aф-}$ фикс наречия с транслативным значением; $\mathrm{AUG}$ - аугментатив; $\mathrm{CL}_{\mathrm{ExCL}}-$ экскламативная энклитика; $\mathrm{CL}_{\mathrm{MA}}$ - энклитика $=m a ; \mathrm{CL}_{\mathrm{M}}-$ энклитика $=m$ ?; $\mathrm{CNG}$ - коннегатив; COND - условная форма глагола; CVB — деепричастие; DAT — датив; DEST - дестинативный аффикс; DIM - диминутив; DU — двойственное число; $\mathrm{EV}_{\mathrm{AUD}}$ - эвиденциальный аффикс аудитива; $\mathrm{EV}_{\text {нsч }}$ - эвиденциальный аффикс ренарратива; $\mathrm{EV}_{\mathrm{INF}}$ - эвиденциальный аффикс инферентива; $\mathrm{EV}_{\mathrm{PRES}}$ - эвиденциальный аффикс презумптива; FUT — будущее время; GEN — генитив; нAB — хабитуалис; HORT - гортатив; IMP - императив; INCH - инхоатив; INCL — интраклитика; LOC - локатив; NEG - отрицательный глагол $n_{j} i-; \mathrm{NEG}_{\mathrm{wN}}-$ отрицательный глагол $w u n^{j} \breve{a}$-; NOM - номинатив; о - объектное спряжение; ОРТ $_{\text {Емрн }}$ - эмфатический оптатив; PJR - пейоратив; PL — множественное число; POSS — притяжательный аффикс; $\mathrm{PR}_{\text {СоNт }}$ - континуативное причастие; $\mathrm{PR}_{\mathrm{PRF}}$ - перфектное причастие; $\mathrm{PR}_{\mathrm{PROSP}}$ - проспективное причастие; $\mathrm{R}$ - рефлексивное спряжение; RHET - показатель риторического вопроса; $\mathrm{s}$ - субъектное спряжение; SG - единственное число; $\mathrm{vN}_{\mathrm{CONC}}$ - имя одновременного действия; $\mathrm{VN}_{\mathrm{PREV}}$ - имя предшествующего действия.

\section{Литература}

Баранов и др. 1993 - А. Н. Баранов, В. А. Плунгян, Е. В. Рахилина. Путеводитель по дискурсивным словам русского языка. М.: Помовский и партнеры, 1993.

Бонно, Кодзасов 1998 - К. Бонно, С. В. Кодзасов. Семантическое варьирование дискурсивных слов и его влияние на линеаризацию и интонирование (на примере частиц же и ведь) // К. Л. Киселева, Д. Пайар (ред.). Дискурсивные слова русского языка: опыт контекстно-семантического описания. М.: Метатекст, 1998. С. 382-443.

Буркова 2010 - С. И. Буркова. Краткий грамматический очерк восточных говоров тундрового диалекта ненецкого языка // С. И. Буркова, Н. Б. Кошкарева, Р. И. Лаптандер и др. (сост.). Диалектологический словарь ненецкого языка. Тюмень: БАСКО, 2010. С. 179-349.

Буркова 2012 - С. И. Буркова. Формы с семантикой ирреальной модальности в ненецком языке // Вестник Томского государственного педагогического университета. 2012. № 1. С. 28-32. 
Буркова 2013 - С. И. Буркова. К вопросу о «вопросительной» форме -sa в ненецком языке // А. Е. Кибрик (отв. ред.), Т. Б. Агранат, О. А. Казакевич, Е. В. Кашкин (сост.). Лингвистический беспредел - 2. Сборник научных трудов к юбилею А. И. Кузнецовой. М.: МГУ, 2013. С. 46-65.

Киселева, Пайар 1998 - К. Л. Киселева, Д. Пайар (ред.). Дискурсивные слова русского языка: опыт контекстно-семантического описания. М.: Метатекст, 1998.

Киселева, Пайар 2003 - К. Киселева, Д. Пайар (сост.). Дискурсивные слова русского языка: контекстное варьирование и семантическое единство. М.: Азбуковник, 2003.

Куприянова и др. 1985 - 3. Н. Куприянова, М. Я. Бармич, Л. В. Хомич. Ненецкий язык: Учебное пособие для педагогических училищ. Изд. 4-е., перераб. Л.: Просвещение, 1985.

Левонтина 2005 - И. Б. Левонтина. Об одной загадке частицы ведь // И. М. Кобозева, А. С. Нариньяни, В. П. Селегей (ред.). Труды Международной конференции по компьютерной лингвистике и интеллектуальным технологиям «Диалог-2005». M.: Наука, 2005. URL: http://www.dialog-21.ru/media/2398/levontinai.pdf (дата обращения 12.11.2020).

Николаева 1985 - Т. М. Николаева. Функции частиц в высказывании (на материале славянских языков). М.: Наука, 1985.

Прокофьев 1937 - Г. Н. Прокофьев. Ненецкий (юрако-самоедский) язык // Г. Н. Прокофьев (ред.). Языки и письменность народов Севера. Ч. І. М.; Л.: Государственное учебно-педагогическое издательство, 1937. С. 5-52.

Терещенко 1965 - Н. М. Терещенко. Ненецко-русский словарь. М.: Советская энциклопедия, 1965.

Терещенко 1973a - Н. М. Терещенко. Синтаксис самодийских языков. Простое предложение. Л.: Наука, 1973.

Терещенко $1973 \mathrm{~b}$ - Н. М. Терещенко. Структурные особенности вопросительных и восклицательных предложений в самодийских языках // Советское финноугроведение. 1973. Вып. ХХ. № 4. С. 195-202.

Терещенко 1993 - Н. М. Терещенко. Ненецкий язык // Ю. С. Елисеев, К. Е. Майтинская, О. И. Романова (ред.). Языки мира: Уральские языки. М.: Наука, 1993. C. 326-343.

Щербакова 1954 - А. М. Щербакова. Формы отрицания в ненецком языке // Ученые записки Ленинградского педагогического института им. А. И. Герцена. 1954. T. 101. С. 181-231.

Hajdú 1988 - P. Hajdú. Die Samojedischen Sprachen // D. Sinor (ed.). The Uralic languages. Description, History and Foreign Influences. Leiden; New York; København; Köln: Brill, 1988. P. 3-146.

Mikola 2004 - T. Mikola. Studien zur Geschichte der Samojedischen Sprachen. Aus dem Nachlass herausgegeben von Beáta Wagner-Nagy (Studia Uralo-Altaica. Vol. 45). Szeged: SzTE Finnisch-Ugrisches Institut, 2004.

Nikolaeva 2014 - I. Nikolaeva. A Grammar of Tundra Nenets (Mouton Grammar Library. Vol. 65). Berlin: De Gruyter Mouton, 2014. 
Salminen 1997 - T. Salminen. Tundra Nenets Inflection (Mémoires de la Société Finno-Ougrienne. Vol. 227). Helsinki: Suomalais-Ugrilainen Seura, 1997.

Zwicky, Pullum 1983 - A. M. Zwicky, G. K. Pullum. Clitization vs Inflection: English n't // Language. 1983. Vol. 59. № 3. P. 502-513.

\section{Источники}

Вануйто и др. 2010 - Э. Б. Вануйто, В. М. Вануйто, С. И. Буркова. Няхар" Хэхо” то" Вэра" // С. И. Буркова (ред.) Материалы 3-й Международной научной конференции по самодистике. Новосибирск: Любава, 2010. С. 292-353.

Куприянова 1965 - 3. Н. Куприянова. Эпические песни ненцев. М.: Наука, 1965.

ПМ-А-2006 - полевые материалы, записанные в п. Антипаюта Тазовского района Ямало-Ненецкого АО в июле 2006 г.

ПМ-А-2007 - полевые материалы, записанные в п. Антипаюта Тазовского района Ямало-Ненецкого АО в августе 2007 г.

ПМ-Л-2006 - полевые материалы, записанные в д. Лаборовая Приуральского района Ямало-Ненецкого АО в июле 2006 г.

Пушкарева 2003 - Е. Т. Пушкарева. Историческая типология и этническая специфика ненецких мифов-сказок. М.: Мысль, 2003.

Пушкарева, Хомич 2001 - Е. Т. Пушкарева, Л. В. Хомич (сост.). Фольклор ненцев (Памятники фольклора народов Сибири и Дальнего Востока. Т. 23). Новосибирск: Наука, 2001.

ЭМ-2012 - С. И. Буркова (сост.). Тексты на надымском говоре тундрового диалекта ненецкого языка // Н. Н. Широбокова (ред.). Экспедиционные материалы по языкам народов Сибири (1995-2012 гг.). Новосибирск: ООО «Открытый квадрат», 2012. С. 211-260.

Янгасова 2001 - Н. М. Янгасова (сост.). Ненэцие” лаханако”, сюдбабц", ярабц" (Ненецкие сказки и эпические песни «сюдбабц», «ярабц»). Томск: ТГУ, 2001.

\section{References}

Baranov et al. 1993 - A. N. Baranov, V. A. Plungyan, E. V. Rakhilina. Putevoditel po diskursivnym slovam russkogo yazyka [Guide to the discursive words of the Russian language]. Moscow: Pomovskiy i partnery, 1993.

Bonnot, Kodzasov 1998 - Ch. Bonnot, S. V. Kodzasov. Semanticheskoe varirovanie diskursivnykh slov i ego vliyanie na linearizatsiyu i intonirovanie (na primere chastits zhe i ved) [The semantic variation of discursive words and its effect on linearization and intonation (on the example of particles zhe and ved)]. K. Kiseleva, D. Paillard (eds.). Diskursivnye slova russkogo yazyka: opyt kontekstno-semanticheskogo opisaniya [Discursive words of the Russian language: contextual-semantic description]. Moscow: Metatekst, 1998. P. 382-443. 
Burkova 2010 - S. I. Burkova. Kratkiy grammaticheskiy ocherk vostochnykh govorov tundrovogo dialekta nenetskogo yazyka [A brief grammar sketch of the Eastern subdialects of the Tundra dialect of the Nenets language]. S. I. Burkova, N. B. Koshkareva, R. I. Laptander et al. (comp.). Dialektologicheskiy slovar nenetskogo ya$z y k a$ [The dialectological dictionary of the Nenets language]. Tyumen: BASKO, 2010. P. 179-349.

Burkova 2012 - S. I. Burkova. Formy s semantikoy irrealnoy modalnosti v nenetskom yazyke [Forms with semantics of irreal modality in the Nenets language]. Vestnik Tomskogo gosudarstvennogo pedagogicheskogo universiteta. 2012. No. 1. P. 28-32.

Burkova 2013 - S. I. Burkova. K voprosu o «voprositelnoy» forme -sa v nenetskom yazyke [To the question of the "interrogative" form -sa in the Nenets language]. A. E. Kibrik (ed.), T. B. Agranat, O. A. Kazakevich, E. V. Kashkin (comp.). Lingvisticheskiy bespredel - 2. Sbornik nauchnykh trudov k yubileyu A. I. Kuznetsovoy [Linguistic chaos - 2. Collection of scientific works for the anniversary of A. I. Kuznetsova]. Moscow: Moscow State University Press, 2013. P. 46-65.

Hajdú 1988 - P. Hajdú. Die Samojedischen Sprachen. D. Sinor (ed.). The Uralic languages. Description, History and Foreign Influences. Leiden; New York; København; Köln: Brill, 1988. P. 3-146.

Kiseleva, Paillard 1998 - K. Kiseleva, D. Paillard (eds.). Diskursivnye slova russkogo yazyka: opyt kontekstno-semanticheskogo opisaniya [Discursive words of the Russian language: contextual-semantic description]. Moscow: Metatekst, 1998.

Kiseleva, Paillard 2003 - K. Kiseleva, D. Paillard (comp.). Diskursivnye slova russkogo yazyka: kontekstnoe varirovanie $i$ semanticheskoe edinstvo [Discursive words of the Russian language: contextual variation and semantic coherence]. Moscow: Azbukovnik, 2003.

Kupriyanova et al. 1985 - Z. N. Kupriyanova, M. Ya. Barmich, L. V. Khomich. Nenetskiy yazyk: Uchebnoe posobie dlya pedagogicheskikh uchilishch [Nenets language: a textbook for pedagogical colleges]. $4^{\text {th }}$ ed. Leningrad: Prosveshchenie, 1985.

Levontina 2005 - I. B. Levontina. Ob odnoy zagadke chastitsy ved [About one puzzle of the particle ved]. I. M. Kobozeva, A. S. Narinyani, V. P. Selegey (eds.). Trudy Mezhdunarodnoy konferentsii po kompyuternoy lingvistike i intellektualnym tekhnologiyam «Dialog-2005» [Proceedings of the International conference on computational linguistics and intellectual technologies "Dialog-2005”]. Moscow: Nauka, 2005. Available at: http://www.dialog-21.ru/media/2398/levontinai.pdf (accessed on 12.11.2020).

Mikola 2004 - T. Mikola. Studien zur Geschichte der Samojedischen Sprachen. Aus dem Nachlass herausgegeben von Beáta Wagner-Nagy (Studia Uralo-Altaica. Vol. 45). Szeged: SzTE Finnisch-Ugrisches Institut, 2004.

Nikolaeva 1985 - T. M. Nikolaeva. Funktsii chastits $v$ vyskazyvanii (na materiale slavyanskikh yazykov) [The functions of particles in the utterance (on the material of Slavic languages)]. Moscow: Nauka, 1985.

Nikolaeva 2014 - I. Nikolaeva. A Grammar of Tundra Nenets (Mouton Grammar Library. Vol. 65). Berlin: De Gruyter Mouton, 2014. 
Prokofev 1937 - G. N. Prokofev. Nenetskiy (yurako-samoedskiy) yazyk [Nenets (Yurak-Samoyedic) language]. G. N. Prokofev (ed.). Yazyki i pismennost narodov Severa [Languages and writing of the peoples of the North]. Pt. I. Moscow; Leningrad: State Pedagogical Publishing House, 1937. P. 5-52.

Salminen 1997 — T. Salminen. Tundra Nenets Inflection (Mémoires de la Société Finno-Ougrienne. Vol. 227). Helsinki: Suomalais-Ugrilainen Seura, 1997.

Shcherbakova 1954 - A. M. Shcherbakova. Formy otritsaniya v nenetskom yazyke [Forms of negation in the Nenets language]. Uchenye zapiski Leningradskogo pedagogicheskogo instituta im. A. I. Gertsena. 1954. Vol. 101. P. 181-231.

Tereshchenko 1965 - N. M. Tereshchenko. Nenetsko-russkiy slovar [Nenets-Russian dictionary]. Moscow: Sovetskaya entsiklopediya, 1965.

Tereshchenko 1973a — N. M. Tereshchenko. Sintaksis samodiyskikh yazykov. Prostoe predlozhenie. [Syntax of Samoyedic languages. Clausal structure]. Leningrad: Nauka, 1973.

Tereshchenko $1973 \mathrm{~b}$ - N. M. Tereshchenko. Strukturnye osobennosti voprositelnykh i vosklitsatelnykh predlozheniy v samodiyskikh yazykakh [Structural properties of interrogative and exclamatory sentences in Samoyedic languages]. Sovetskoe finno-ugrovedenie. 1973. Vol. XX. No. 4. P. 195-202.

Tereshchenko 1993 - N. M. Tereshchenko. Nenetskiy yazyk [Nenets language]. Yu. S. Eliseev, K. E. Maytinskaya, O. I. Romanova (eds.). Yazyki mira: Uralskie yazyki [Languages of the world: Uralic languages]. Moscow: Nauka, 1993. P. 326-343.

Zwicky, Pullum 1983 - A. M. Zwicky, G. K. Pullum. Clitization vs Inflection: English n't. Language. 1983. Vol. 59. No. 3. P. 502-513.

\section{Sources}

EM-2012 - S. I. Burkova (comp.). Teksty na nadymskom govore tundrovogo dialekta nenetskogo yazyka. N. N. Shirobokova (ed.). Ekspeditsionnye materialy po yazykam narodov Sibiri (1995-2012 gg.) [Field materials on the languages of the peoples of Siberia (1995-2012)]. Novosibirsk: Otkrytyy kvadrat, 2012. P. 211-260.

Kupriyanova 1965 - Z. N. Kupriyanova. Epicheskie pesni nentsev [Epic songs of Nenets]. Moscow: Nauka, 1965.

PM-A-2006 - field materials recorded in the village of Antipayuta, Tazovsky District, Yamalo-Nenets Autonomous Okrug in July 2006.

PM-A-2007 - field materials recorded in the village of Antipayuta, Tazovsky District, Yamalo-Nenets Autonomous Okrug in August 2007.

PM-L-2006 - field materials recorded in the village of Laborovaya in the Ural region of the Yamalo-Nenets Autonomous Okrug in July 2006.

Pushkareva 2003 - E. T. Pushkareva. Istoricheskaya tipologiya i etnicheskaya spetsifika nenetskikh mifov-skazok [Historical typology and ethnic specificity of Nenets myths-tales]. Moscow: Mysl, 2003. 
Pushkareva, Khomich 2001 - E. T. Pushkareva, L. V. Khomich (comp.). Folklor nentsev [Nenets folklore] (Pamyatniki folklora narodov Sibiri i Dalnego Vostoka [Folklore sources of the peoples of Siberia and the Far East]. Vol. 23). Novosibirsk: Nau$\mathrm{ka}, 2001$.

Vanuyto et al. 2010 - E. B. Vanuyto, V. M. Vanuyto, S. I. Burkova. Nyaxar" Xexo" to" Wera". S. I. Burkova (ed.). Materialy 3-y Mezhdunarodnoy nauchnoy konferentsii po samodistike [Proceedings of the $3^{\text {rd }}$ international conference on Samoyedology]. Novosibirsk: Lyubava, 2010. P. 292-353.

Yangasova 2001 - N. M. Yangasova (comp.). Nenecie" laxanako”, syudbabc”, yarabc" [Nenets tales and epic songs "syudbabts", "yarabts"]. Tomsk: Tomsk State University, 2001. 


\section{'Разве он дороги не знает': к грамматикализации риторических вопросов в северносамодийских языках ${ }^{*}$}

\section{В. Ю. Гусев}

Институт языкознания РАН, Москва; valentin.gusev@iling-ran.ru

Аннотация. В статье рассматриваются несколько форм и конструкций северносамодийских языков (ненецкого, энецкого и нганасанского), которые идентичны отрицательным вопросам или восходят к ним. Эти конструкции, изначально имевшие значение риторического вопроса, маркируют информацию, воспринимаемую и говорящим и адресатом как само собой разумеющуюся, и используются для обоснования других утверждений или действий. В нганасанском эти конструкции формально очень похожи на отрицательные: при отсутствии маркера вопроса они допускают и отрицательную, и утвердительную интерпретацию. В ненецком и энецком в их состав часто дополнительно входит специальная частица, которая сливается с лично-числовыми показателями, образуя специальные серии согласовательных маркеров. Кроме того, в утвердительном употреблении отрицательный глагол может находиться в постпозиции к основному глаголу, что невозможно для отрицательных употреблений.

Ключевые слова: риторические вопросы, отрицательные вопросы, северносамодийские языки.

\footnotetext{
* Мы признательны С. И. Бурковой, Н. Муш, А. Ю. Урманчиевой, О. В. Ханиной и А. Б. Шлуинскому за электронные версии ненецких и энецких текстов, в том числе неопубликованных, и консультации по ним. Нганасанские текстовые примеры взяты из корпуса NSLC (Nganasan Spoken Language Corpus [Brykina et al. 2016]); тексты обозначаются номерами, которые расшифровываются в конце статьи. Для примеров из прочих языков указываются источники. При цитировании мы в ряде случаев упрощаем транскрипцию и глоссирование и опускаем незначимые элементы (оговорки, маркеры хезитации и т. п.). Статья написана при поддержке гранта РНФ № 17-18-01649.
} 


\title{
'Does not he really know the way': On grammaticalization of rhetoric questions in North Samoyed languages
}

\section{Yu. Gusev}

Institute of Linguistics, Russian Academy of Sciences, Moscow; vgoussev@yandex.ru

\begin{abstract}
This paper deals with several types of forms and constructions in North Samoyed languages (Nenets, Enets and Nganasan) that are identical with, or go back to negative questions. It demonstrates that such constructions, originally rhetoric, have evolved into a special kind of structures that express information taken for granted by both the speaker and the addressee and are used to justify other statements or actions. Negation can also occur in the same function in other non-affirmative moods such as dubitative or irrealis.

In Nganasan, these structures are formally rather similar to negative constructions so that in the absence of an explicit interrogative marker (e.g., with nominal forms), they may be ambiguous admitting both affirmative and negative reading where a phrase like "he not Nenets" may mean either 'he isn't Nenets' or 'he is Nenets, you know'. In Nenets and Enets, these structures often additionally require a special particle which is fused with person-number suffixes to form a dedicated series of agreement markers. In addition, in affirmative uses the negative verb may occur after the main verb, which is impossible for its negation uses; similar cases are frequent in Nenets and Enets and rare in Nganasan.

A special use of the negative-interrogative construction in Nenets and Enets is attested with the verb of saying introducing direct speech. This use reflects the cross-linguistic tendency to reduce the assertiveness of quotative markers.
\end{abstract}

Keywords: rhetoric questions, negative questions, Samoyed languages.

\section{1. Введение}

Отрицательные вопросы вида «Разве неверно, что Р» являются достаточно распространенным - вероятно, универсальным - риторическим приемом. Как многократно отмечалось в литературе (см., например, [Роре 1976: 37; Падучева 1985: 232-245; Bechmann 2010: 31ff] и многие другие работы), в риторическом вопросе происходит «инверсия полярности», т. е. отрицательный риторический вопрос служит на самом 
деле для утверждения, а утвердительный - для отрицания. Ставя пропозицию под вопрос, говорящий тем самым выражает сомнение в ней.

Вместе с тем вопрос, даже риторический, хотя бы формально требует ответа: говорящий ждет (или как будто ждет), что собеседник подтвердит его мнение (ср. [Grésillon 1980: 257; Meibauer 1986: 90] и др.). Поэтому риторический вопрос не годится для сообщения новой информации в полном смысле этого слова; это должно быть такое утверждение, которое, как говорящий считает (или как он хочет представить), разделяет и собеседник тоже. Иными словами, некий факт представляется как заранее известный, как то, с чем согласны все участники диалога.

Как риторический прием такие вопросы давно известны и хорошо изучены. Три северосамодийские языка - ненецкий, энецкий и нганасанский - интересны тем, что отрицательные риторические вопросы в них грамматикализовались: они либо потеряли стилистическую выделенность, либо, в результате сочетания с другими элементами, вовсе утратили синхронную связь с вопросами.

В первом разделе данной статьи мы рассмотрим вопросы с отрицанием в нганасанском языке, которые, формально ничем не отличаясь от истинных вопросов, широко используются для выражения утверждения. Второй раздел будет посвящен ненецким и энецким так называемым «контрастивным» формам глагола, которые, как мы постараемся показать, также восходят к вопросительным формам ${ }^{1}$.

\section{2. Отрицательные вопросы в значении утверждения в нганасанском языке}

\section{1. Отрицательные вопросы в своем прямом значении}

Напомним, что в северосамодийских языках, как это типично для уральской семьи, отрицание выражается специальным вспомогательным глаголом, к которому переходят все словоизменительные

${ }^{1}$ В данной статье не рассматриваются две группы явлений, сходные с риторическими отрицательными вопросами, но заслуживающие отдельной работы. Во-первых, это присутствующие в обоих энецких идиомах конструкции с вспомогательным глаголом іïa-/iiji-, о которых см. [Siegl 2014]. Во-вторых, это нганасанские именные формы с послелогом mantə, о которых кратко см. [Gusev 2015: 118-119]. 
суффиксы, а смысловой глагол при этом ставится в особую неизменяемую форму коннегатива:

\begin{tabular}{|c|c|}
\hline $\begin{array}{l}\text { hedititi-ti } \\
\text { идти-PRAES }\end{array}$ & $\begin{array}{l}-\quad n i-n t i \\
\text { NEG-PRAES }\end{array}$ \\
\hline 'идет' & 'не идет' \\
\hline
\end{tabular}

При этом в нганасанском языке есть специальные вопросительные формы. Их пять: для трех времен индикатива (прошедшего, настоящего и будущего), итеративная и цитативная ${ }^{2}$ :
a. hediti-ni
- ńi- $\eta$ i
hediti-?
идти-INTERR
NEG-INTERR
идти-СN
'идет?'
'не идет?'
б. hediti-hi
- ńi-hi
hediti-?
идтИ-INTERR.PRAET
NEG-INTERR.PRAET
идти-СN
'шел?'
'не шел?'

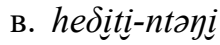
идти-INTERR.FUT
- ńi-ntaฤi
hediti-?
NEG-INTERR.FUT
идти-CN
‘будет идти?'
'не будет идти?'
г. hediti-kaว
идти-INTERR.ITER
- ńi-kaว
hediti-?
NEG-INTERR.ITER
идти-СN
'ходит?'
'не ходит?'
д. hediti-hia
идТИ-INTERR.RENARR
'идет, говорят?'
- ńi-bia
NEG-INTERR.RENARR
hediti-?
'говорят, не идет?'

Эти формы - и утвердительные, и отрицательные - употребляются как в общих, так и в частных вопросах, ср. ниже несколько примеров общих отрицательных вопросов с разными формами:
$\partial i^{2}$, toti yana'sa-gümü INTERJ TOT человек-TO
ńi-yi
NEG-INTERR
tuu-
ahi, прийти-CN PTCL

\footnotetext{
2 Некоторые из форм в примерах (2а-д) от данной основы не встретились в корпусе и сконструированы нами здесь для иллюстрации. Вопросительный цитатив употребляется тогда, когда либо информация, о которой задается вопрос, либо сам вопрос передается с чужих слов.
} 
maabta-yu?

илИ.ЧTO-INTERR

[Говорили же: сзади меня человек идет.] 'Оу, этот человек-то не пришел, нет?' (21: 617).

\begin{tabular}{|c|c|c|c|c|}
\hline$« T \partial$ & $k u n i^{i} a$ & $i$-t’eyu-mu? & ńi-nto-yi-mí? & labku \\
\hline ну & как & быть-FUT-INTERR-1PL.S & NEG-FUT-INTERR-1PL.S & магазин \\
\hline & & - «Toi-yәд-? & labka-t’ü. & \\
\hline
\end{tabular}

Dəmabtalu-ru-śü $\delta \ddot{u}-t \ddot{u}{ }^{\prime} 》$

кормить-PASS-FUT-2PL.R

'Ну что будем делать, что, в магазин даже не пойдём? - Не надо (в) магазины. Вас будут кормить’ (7: 28-30).

(5)

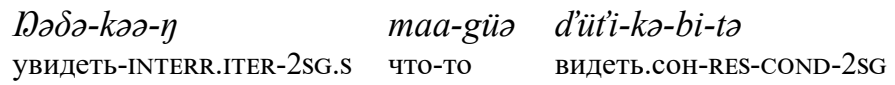

hiińd'a maa-gəlit’o ńi-kəo-y nəmto-??

ночью чTO-EMPH NEG-INTERR.ITER-2SG.S почувствовать-CN

'Ты что-нибудь видишь; ночью, во сне, ничего не замечаешь?' (26: 10).

(6) Tә mị munu-ntu-mu?: «Maa Balat'anka t'erə?

ну мы говорить-PRAES-1PL.S что Волочанка житель-PL

kuni'a i-hua-? n'i-bia-? hediti-??»

как быть-RENARR.INTERR-3PL.S NEG-RENARR.INTERR-3PL.S идти-CN

'Ну мы говорим: «Что [говорят про] тех, кто из Волочанки, как они, разве они не едут?»' (7: 15).

При именах (в том числе при именных формах глагола) используется специальная отрицательная частица ńintuu, которая не имеет вопросительной формы; соответственно, в именных конструкциях вопросы маркируются только интонационно:

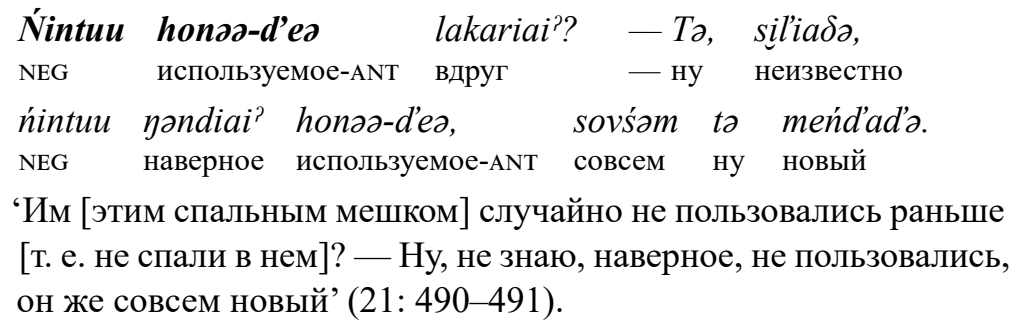




\section{2. Отрицательные вопросы \\ в значении риторического утверждения}

Впрочем, отрицательные общие вопросы не очень часты - очевидно, потому, что «честный», не несущий никаких презумпций отрицательный вопрос ничем не отличается от не-отрицательного. Однако в нганасанском языке конструкции с отрицательным вопросом активно используются для особого типа утверждения - для апелляции к фактам, известным собеседнику. Кажется, что в предложениях без вопросительного слова они по частотности существенно превышают «прямые», т. е. собственно вопросительные употребления отрицательновопросительных форм.

\begin{tabular}{|c|c|c|c|c|}
\hline $\begin{array}{l}\text { Kobtua-mtu } \\
\text { девушка-АCС.3sG }\end{array}$ & $\begin{array}{l}\text { buд-d'a } \\
\text { говорить-INF }\end{array}$ & $\begin{array}{l}\text { munu-ntu, } \\
\text { говорить-PRAES }\end{array}$ & $\begin{array}{l}\text { siti } \\
\mathrm{OH}\end{array}$ & $\begin{array}{l}\text { kobtua-tu } \\
\text { девушка-3sG }\end{array}$ \\
\hline $\begin{array}{l}\boldsymbol{n} \boldsymbol{i}-\boldsymbol{h i} \\
\text { NEG-INTERR.PRAET }\end{array}$ & $\begin{array}{l}\text { toibo-?, } \\
\text { иметься-СN }\end{array}$ & $\begin{array}{l}\text { Mәriddə-rə... } \\
\text { Марыда-2sG }\end{array}$ & & \\
\hline
\end{tabular}

'Сестренке он говорит - у него же сестренка была, у Марыда...' [Сестренке он говорит: за того ненецкого парня выходи.] (18: 408).

Такие употребления очень частотны в диалогах. Собственно, они и встречаются в первую очередь в диалогическом (он же речевой; см., например, [Падучева 1996: 13]) регистре, а в нарративах чаще всего возникают либо в диалогах, либо тогда, когда рассказчик решает напрямую обратиться к слушателям. Ср. примеры (9)-(11) из естественных диалогов.

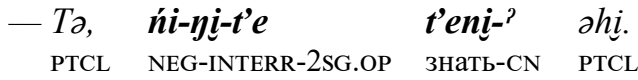

$$
\begin{aligned}
& \text { - T'eni-nti-ńe. } \\
& \text { знаTь-PRAES-1SG.OP } \\
& \text { ‘- Ты же их знаешь. - Знаю’ } 3 \text { (32: 26-27). }
\end{aligned}
$$

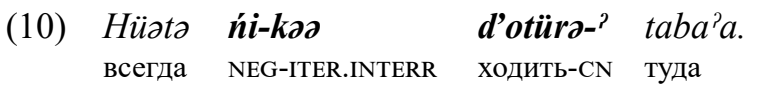

[Они давно встречаются.] 'Она же все время ходит туда [к нему]' (32: 160).

3 Вопросительная интерпретация здесь исключена: обоим участникам диалога известно, что один из них давно знаком с людьми, о которых идет речь, и может попросить у них в долг; второй же познакомился с ними недавно. 
(11) Miinia-ra yanua tu-l'egu, sat'i-tia tu-l'egu. этот-2SG прямо огонь-СОМР потрескивать-PT.PRAES огонь-СомР

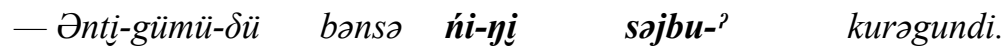
это.самое-To-3SG весь NEG-INTERR слышаться-CN даже

[Речь идет о заставке на экране компьютера, которая изображает огонь.] 'Вот это прямо как огонь, потрескивающий огонь. - Это прямо все слышно, [как по-настоящему]' (9: 53-54).

Пример (12) взят из речи персонажа в нарративе.

\begin{tabular}{|c|c|c|c|c|}
\hline $\begin{array}{l}\text { Tati-ra } \\
\text { тот-2sG }\end{array}$ & $\begin{array}{ll}\text { ńintuu } & k a \\
\text { не } & \text { пр }\end{array}$ & $\begin{array}{l}\text { 'әrәə } \\
\text { сто }\end{array}$ & $\begin{array}{l}\text { yanud'ztə } \\
\text { настоящий }\end{array}$ & $\begin{array}{l}n a^{2} s a, \\
\text { Іовек }\end{array}$ \\
\hline tati-ra & onti, & takəə & n'i-kəo-? & munд-? \\
\hline тот-2SG & этот.самый & тот & NEG-ITER-3PL & сказать-CN \\
\hline $\begin{array}{l}\text { D'ojba } \\
\text { сирота }\end{array}$ & ұuә təi-ti & & & \\
\hline
\end{tabular}

'Он не простой человек, он это, [люди] же говорили раньше, что есть Сирота-Бог’ (27: 606).

В следующем примере речь идет о нартах с зимними вещами, которые оставляли в тундре при перекочевках на летние стойбища. Рассказчик отвлекается от повествования и обращается к слушателям.

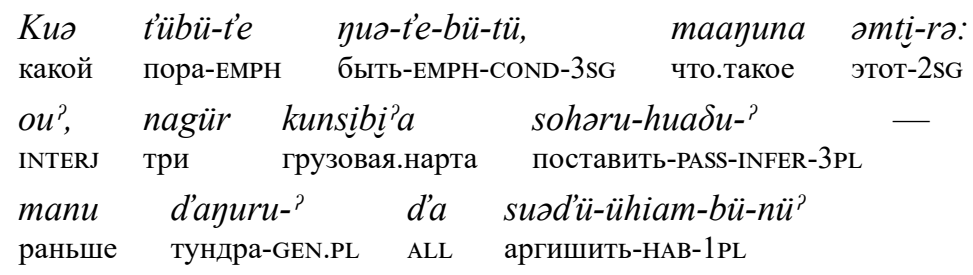

kəndü-ń̈̈?

ńi-kaว-mi

koi-?

нарта-ACC.PL.1PL NEG-ITER.INTERR-1PL

оставить-CN

Duali taradi-?.

конечно такой-PL

'Сколько-то времени [лиса] бежала, [вдруг видит]: что это, три грузовые нарты стоят, - помнишь, мы так оставляли в тундре санки, когда аргишили? - Конечно, такие [санки были]' (24: 71-72).

Помимо явных случаев риторического утверждения, примеры которых были приведены выше, отрицательные вопросы употребляются в некоторых менее очевидных контекстах. В нарративе они могут употребляться для обозначения событий, которые следуют 
из предшествующего изложения. Это могут быть ключевые события текста, однако слушателям уже становится ясно, что они должны произойти; ср. следующие примеры ${ }^{4}$.

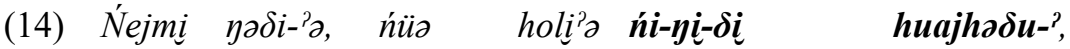 иголка найти-PF ребенок темя NEG-INTERR-3SG.o проколоть-CN ńejmi-ntani.
игла-LOC

[Персонаж подумал, что незаросшее темечко у ребенка - это нарыв, решил его проколоть, стал искать иголку.] 'Нашел иголку, иголкой проткнул ребенку темя' (1: 36).

\begin{tabular}{|c|c|c|c|c|c|}
\hline $\begin{array}{l}O u, \\
\text { INTERJ }\end{array}$ & $\begin{array}{l}t \partial-k \partial i-t^{\prime} e \\
\text { тот-DU-PL.2sG }\end{array}$ & $\begin{array}{l}\text { hiimtəki? } \\
\text { вечер }\end{array}$ & $\begin{array}{l}\text { ńiini } \\
\text { на }\end{array}$ & $\begin{array}{l}\text { ńenat'a?ku } \\
\text { огромный }\end{array}$ & $\begin{array}{l}\text { yarka-rə } \\
\text { медведь-2sG }\end{array}$ \\
\hline & yana'sanz-mtu & ńi- $\boldsymbol{\eta} \boldsymbol{i}$ & & to & 80 \\
\hline
\end{tabular}

Mou-nta d’übialmabti-’a-ti, tagata-ti mou-nta am-kümü-ra земля-LAT бросить-PF-3SG.O потом-3SG земля-LAT эTOT-TO-2SG

\section{ńi-yi kuə-güə-? \\ NEG-INTERR умереть-TO-CN}

[Человек с медведем весь день боролись.] 'Под вечер медведь человека на землю кинул. На землю кинул его, тогда тот на земле и умер' (17: 66-68).

Бывают, однако, и такие контексты, в которых причина употребления отрицательного вопроса непосредственно не видна. Вероятно, в примерах типа (16) расказчик имеет в виду, что описываемых событий «следовало ожидать»:
Kuиlüküəni
śiti
kolajt’ügu-t’üə-gəj
$n i-g \partial j$
когда-то

два
обрабатывать.рыбу-PT.PRAES-DU
женщина-DU

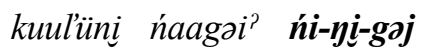
yańd'iimo-?, d'omtumu-'o-?
когда-то хорошо NEG-INTERR-3DU.S поругаться-CN поссориться-PF-3PL.S [Персонаж взял вторую жену; они перекочевали на берег реки, нашли рыбное место; муж ловит рыбу, а жены ее обрабатывают.] 'Однажды две женщины, обрабатывающие рыбу, вдруг начали ругаться, поссорились’ (15: 635).

\footnotetext{
${ }^{4}$ Кажется, что по-русски в таких случаях может быть употреблена частица $н y:$ Hy, тот на земле и умер из примера (15) и т. п.
} 


\begin{tabular}{|c|c|c|}
\hline $\begin{array}{l}\text { Tahariaa } \\
\text { Hy }\end{array}$ & 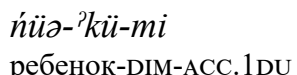 & $\begin{array}{l}\boldsymbol{n} \boldsymbol{i}-\boldsymbol{\eta} \boldsymbol{i} \mathbf{i}-\boldsymbol{m i} \\
\text { NEG-INTERR-1DU }\end{array}$ \\
\hline
\end{tabular}

\begin{tabular}{|c|c|c|}
\hline & $-\partial i^{?}$. & Mәпә? \\
\hline
\end{tabular}

[Ты тогда маленькая была, не помнишь. Однажды наши матери пошли за дровами. А мы играли с Марией.] 'Ну, ребенка мы и уронили. - Ой. Меня? - Ага, тебя' (8: 20-23).

В следующем примере речь идет о случае болезни, который произошел много лет назад, и одна из участниц разговора спрашивает, удачным ли было лечение, в вторая отвечает: да, конечно, ведь человек, о котором идет речь, умер совсем недавно. Очевидно, что первая собеседница этого не знает или, по крайней мере, не помнит. Тем не менее в ответе употреблена отрицательно-вопросительная форма по-видимому, потому, что эта информация полагается общеизвестной.

$$
\begin{aligned}
& \text { a. - Tә Halmaj to } \quad \text { ńaagim-hi? } \\
& \text { РтсL Халмай } \text { PTCL выздороветь-INTERR.PRAET } \\
& \text { 'Ну что, Халмай выздоровел?' }
\end{aligned}
$$

\begin{tabular}{|c|c|c|}
\hline $\begin{array}{c}\text { б. - Halmaj-yutu } \\
\text { Халмай-РтсL }\end{array}$ & $\begin{array}{ll}\text { bəjku-nayku } & i s ́ a \\
\text { старик-DIм } & \text { быть-INF }\end{array}$ & $\begin{array}{l}\text { timinia } \\
\text { теперь }\end{array}$ \\
\hline ERR.PRAET & 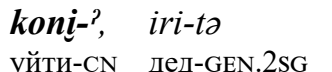 & huว-gal't'ว-tani. \\
\hline
\end{tabular}

'Халмай ведь недавно, уже старичком умер, позже, чем твой дед’ (10: 41-42).

Иногда в нганасанском языке - очень редко, в отличие от ненецкого и энецкого языков, о которых см. Раздел $3,-$ конструкция отрицательного вопроса употребляется с глаголом, вводящим прямую речь:

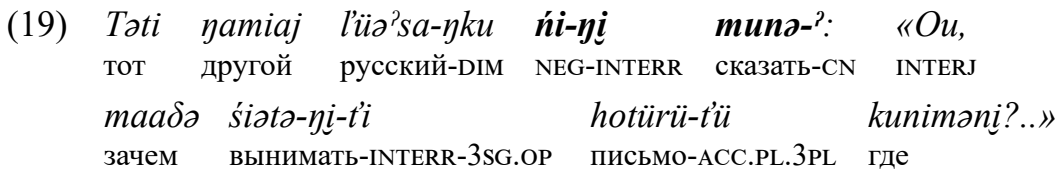

[Женщина привезла документы и собирается их показать.] 'Тот другой русский говорит: «Оу, зачем она вытаскивает свои документы?..»' (19: 303-304).

Впрочем, редкость подобных употреблений в нганасанском языке заставляет предположить, что ńipi munə? в этом примере не просто вводит прямую речь; вероятно, слова персонажа были ожидаемы. 
Грань между собственно риторическим вопросом и происходящим от него утверждением не всегда можно с надежностью провести. По сути дела, их различение зависит от того, насколько говорящий ждет реакции от собеседников или, по крайней мере, насколько он хочет представить свое высказывание как предполагающее такую реакцию. Если ответ ожидается или хотя бы в принципе возможен, то высказывание формально еще является вопросом; если же ответ в принципе невозможен, то, очевидно, соответствующая конструкция уже полностью утратила связь с вопросами. С надежностью мы можем видеть в высказывании вопрос в диалоге, когда за ним следует пауза для ответной реплики или - в диалоге внутри нарратива - сама ответная реплика, как в (7) ${ }^{5}$. В случаях же, где мы не можем твердо судить о намерении говорящего - например, в репликах персонажей повествования, - у нас остается простор для интерпретаций: так, в примере (34) ниже можно видеть и риторический вопрос (эта интерпретация кажется более вероятной), и риторическое утверждение.

\section{3. Риторические вопросы с другими не-утвердительными формами}

Помимо специализированных интеррогативных форм, в нганасанском языке есть еще несколько наклонений, которые могут менять истинностное значение высказывания.

Одно из этих наклонений - дубитатив, который указывает на неопределенность того, истинно высказывание или ложно (в большинстве случаев высказывание относится к будущему, хотя это не обязательно).

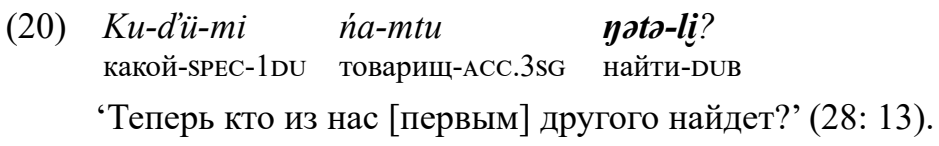

\footnotetext{
${ }^{5}$ В нарративе рассказчик, очевидно, предвидит действия персонажей, и, если за вопросительной репликой в диалоге следует ответ, можно предполагать (кроме случаев намеренного создания эффекта неожиданности), что эта реплика была построена так, чтобы повлечь за собой ответ. В этом отношении диалоги внутри нарратива являются более удобным объектом для изучения, чем обычные (реальные) диалоги, в которых всегда приходится считаться с возможностью неожиданной реакции собеседника.
} 


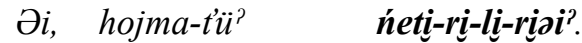

$$
\begin{aligned}
& \text { ой бокарь-ACC.PL.2PL намокнуть-CAUS-DUB-2PL.S.EXCL } \\
& \text { ‘Эй, осторожно, бокари не намочите' }{ }^{6} \text { (6: 35). }
\end{aligned}
$$

Дубитатив в сочетании с отрицательным глаголом также часто используется для выражения утверждения, истинность которого сама собой разумеется. Ср. пример (22д) и предшествующий ему диалог (форма

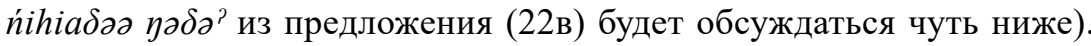

a. «Ou, tə, ńüə-gəi-ńə d'ayku-gəəj!

INTERJ PTCL ребенок-DU-1PL нет-3DU.S

'Оу, сыновей моих [давно] нет'.

б. Nü̈ə-mtə mütว-nandu-tu-m. сын-ACC.2SG отправить-VOL-PRAES-1SG.S

'Твоего сына я хочу отправить'.

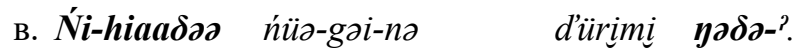
NEG-IRREAL ребенок-DU-GEN1PL новость найти-CN

'Узнал бы он, где мои дети там'.

г. Tə-ta, talibti-kəə-ra, koni-'sito i-hua».

PTCL спросить-ADM-2SG.O пойти-FUT быTb-RENARR.INTERR

'Давай, спроси его, пойдет он или нет'.

д. «Tə-ta, tə mənə mütəmə-bü-tə PTCL PTCL я отправить-COND-2SG пойти-CN

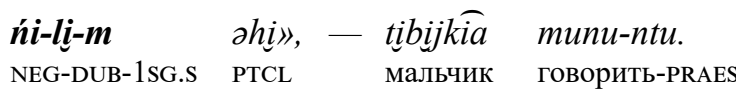

'Ну если ты меня отправляешь, конечно, пойду, — говорит мальчик' (4: 68-72).

В примере (23) тот факт, что долгане сильные, известен из предшествующего сюжета.

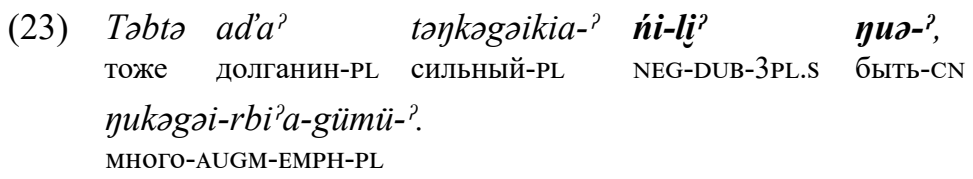

'Они вообще сильные, их много же' (4: 187).

6 По употреблениям такого типа эта форма была названа прохибитивом в [Хeлимский 1994]. 
Кажется, что если в конструкциях с интеррогативом отрицательный глагол обычно стоит перед смысловым глаголом, то с дубитативом он склонен ставиться после, см. пример (22д), что очевидно параллельно ненецким и энецким конструкциям (Раздел 3); впрочем, постановка отрицательного глагола в дубитативе перед смысловым тоже возможна, как в (23). Для риторических вопросов-утверждений с дубитативом особенно характерна частица əhi, как в примере (22д).

Еще одна форма нганасанского глагола, меняющая истинностное значение высказывания, - это ирреалис, указывающий на то, что соответствующая предикация ложна, ср. примеры (24)-(25).

\begin{tabular}{|c|c|}
\hline na & $\begin{array}{l}\text { koтәәпu-ntə } \\
\text { помимо-2SG }\end{array}$ \\
\hline
\end{tabular}

‘Если бы не ты, вы все бы не приехали’ (25: 735).

$\begin{array}{llll}N \text { Nüə-'kü-nə } & \text { koməəni } & \text { əmlad'i } & \text { ńilu-tə } \\ \text { ребенок-DIM-GEN.1SG } & \text { помимо } & \text { такой } & \text { жизнь-LAT }\end{array}$

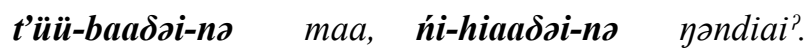
дойти-IRREAL-1SG.R что NEG-IRREAL-1SG.R наверное

'Без моего сына я до такой [хорошей] жизни дошел бы? Наверное, не [дошёл] бы' (20: 117).

Помимо этого, нганасанский ирреалис может употребляться в значении мягкого побуждения (что типологически характерно для таких форм [Гусев 2013: 153], ср. русское $T$ bl бы позвонил отиу):

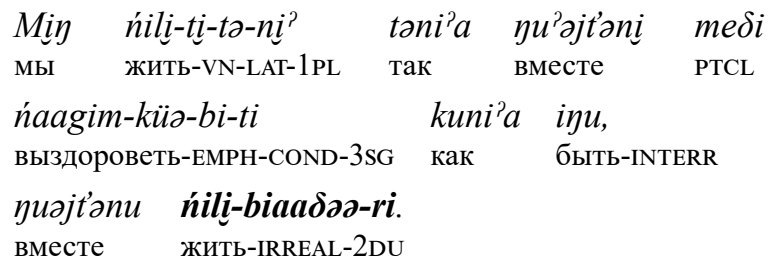

[Твой дядя хочет выдать за тебя свою дочь. Что в этом плохого]. 'Пока мы живы, если вдруг она выздоровеет, вы бы вместе жили' (30: 248).

Оказывается, что отрицательный ирреалис также активно употребляется в утвердительных контекстах — на этот раз именно в значении мягкого императива. Подавляющее большинство таких употреблений - это формы 1-го лица единственного числа, выражающие намерение (о связи намерения и так называемых форм «1 л. ед. ч. 
императива» с другими императивными формами см. [Гусев 2013: 255-260]), но встречаются формы и других лиц - см. следующие примеры, а также (22в) выше.

\begin{tabular}{lrll} 
Lakariai? & milis & təigu & әmni. \\
вдруг & милиционер & иметься-INTERR & здесь \\
- Tәitü & әmni. & & \\
\multicolumn{2}{c}{ иметься-PRAES } & здесь &
\end{tabular}

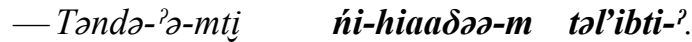
TOT-AUGM-ACC.3SG NEG-IRREAL-1SG спросить-CN

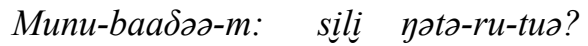
сказать-IRREAL-1SG.S кто найти-PASS-PT.PRAES

[B соседнем поселке нашли тело. У участницы диалога когда-то пропал брат, и она хочет узнать, не его ли нашли.] 'Может быть, милиционер здесь. - Он здесь. - Его бы я спросила. Спросила бы, кого нашли' (32: 121-124).

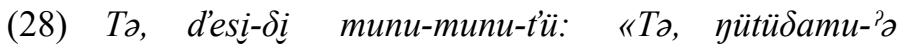
ну отец-3SG говорить-AUD-3SG PTCL настать.осень-PF

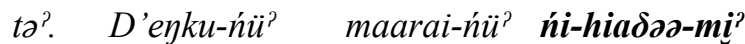
ведь капкан-ACC.1PL что-ACC.1PL NEG-IRREAL-1PL

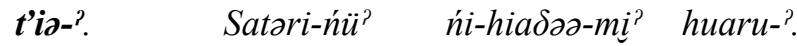
поставить-CN песец-ACC.1PL NEG-IRREAL-1PL заняться-CN

'Ну, отец говорит: «Ну, настала осень. Капканы надо поставить. Песцов ловить надо' (4: 4-6).

(29) Ta, manuə mana yaba-ńe ńini-ńe PTCL давний я старшая.сестра-PL.1SG старший.брат/PL.1PL

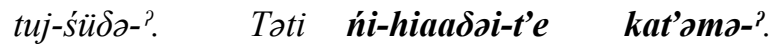
прийти-FUT-3PL тот NEG-IRREAL-2SG.OP увидеть-CN

'Теперь мои братья, сестры приедут. Ты бы с ними познакомилась' (26: 704-705).

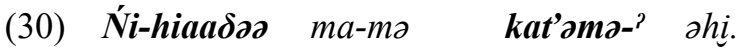

NEG-IRREAL чум-ACC.1SG увидеть-CN PTCL

Mamə kat’mə-huaadəa, kəti manə ńimśa'-sìd’วə-mə чум-ACC.1SG посмотреть-IRREAL PTCL я taiba-? aku-tu. иметься-CN наверное-PRAES

[Ко мне гость пришел.] 'Пусть он мой чум посмотрит. Чум пусть посмотрит, может, что-то я забыл’ (31: 4-5). 
По приведенным примерам видно также, что отрицательная и утвердительная формы ирреалиса могут употребляться параллельно, без заметной разницы в значении; при этом отрицательная форма идет обычно сначала.

С другой стороны, ирреалис (в том числе отрицательный) в императивном значении может употребляться параллельно с собственно императивом:

\begin{tabular}{|c|c|c|}
\hline $\begin{array}{l}\text { Нӥ }-\delta u \\
\text { год-3sG }\end{array}$ & $\begin{array}{l}\text { beri-’ə } \\
\text { пройти-РF }\end{array}$ & \\
\hline $\begin{array}{l}m o u-\delta u \\
\text { земля-3SG }\end{array}$ & $\begin{array}{l}\text { kandi-'nia-li'?-ə, } \\
\text { замерзнуть-мULT-INCH-PF }\end{array}$ & 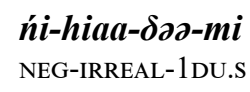 \\
\hline $\begin{array}{l}\text { suəd'd-', } \\
\text { аргишить-с }\end{array}$ & $\begin{array}{l}\text { suə?'-ku-mi. } \\
\text { аргишить-IMP-1DU.s }\end{array}$ & \\
\hline
\end{tabular}

'Вроде бы уже год-то прошел, земля уже начала замерзать, нам бы надо аргишить, давай аргишить’ (14: 4).

\section{4. Риторические вопросы без специализированных вопросительных форм}

Несмотря на наличие специализированных вопросительных форм, иногда общие вопросы в нганасанском языке могут строиться и с обычными индикативными формами. Соответственно, и риторические вопросительно-отрицательные конструкции могут содержать невопросительные отрицательные формы. Их значение определяется только контекстом и, по-видимому, интонацией.

В первую очередь здесь надо сказать о именных конструкциях. Как было сказано, при именных формах употребляется неизменяемая отрицательная частица ńintuи и вопрос отличается от утверждения только интонационно. «Риторические» употребления с именными формами тоже возможны, но поскольку в них нет маркера вопроса, то и риторическое утверждение не имеет формальных (сегментных) отличий от отрицания.

(32) Әmladii ńilu-kümü tahariaa n’intuи bəhia. такой жизнь-то PTCL NEG плохой

‘Жизнь-то плохая’ (5: 42).

(33) Nisima baarbə d'ebtu-'ki-’a-m, Nisima. Нисыма хозяин рассказать-RES-PF-1sG.s Нисыма 
D’üriaks ńintuu, Ńisima-gümü.

ненец NEG Нисыма-то

'Расскажу [сказку] «Нисыма баарба». Ненец ведь он, [этот] Нисыма-то’ (19: 4-5).

Поскольку именное предложение с отрицанием может быть и настоящим вопросом, оно, по-видимому, может иметь три различных интонационных контура: для утверждения («Дни не короткие»), для вопроса («Дни не короткие?») и для риторического вопроса («Дни ведь короткие»); впрочем, нганасанская интонация требует изучения, и мы не станем здесь делать каких-либо утверждений на этот счет.

Надо, однако, заметить, что в риторическом вопросе возможна инверсия вопросительной частицы: постановка ее после слова, к которому она относится (или, что то же самое, в конце предложения). Такой порядок, насколько известно, невозможен при утверждении, но возможен (хотя не обязателен) при риторическом вопросе.

\section{(34) Toliz yana'sa ńintuu? \\ вор человек не}

[Он вор, он, видать, лишь для обмана отдал мне аргиш, а потом он мой аргиш обратно выкрал.] 'Не вор ли [такой] человек?' (12: 1351).

Глагольные утвердительные формы настоящего и прошедшего времени индикатива, по-видимому, не могут употребляться в риторических отрицательных вопросах; во всяком случае, среди достаточно большого количества их употреблений с отрицанием риторических вопросов не встретилось. Что же касается употребления в риторическом отрицательном вопросе утвердительной формы будущего времени, оно не очень частотно, но возможно.

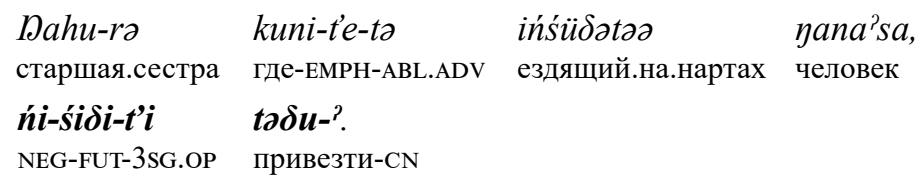

[Вызови своих оленей.] 'Твоя сестра ведь хорошо управляет упряжкой, она приведет их' (15: 753).

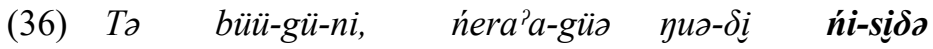
PTCL пойти-IMP-1DU вперед-то небо-3SG NEG-FUT

yünia-mi-?, mintiagi maagüə yana'sanə теплый-FACT-CN наверное что-то человек.АCC 


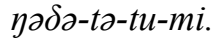

найти-FUT-PRAES-1DU

'Ну, пойдем, скоро ведь уже потеплеет, может быть, встретим каких-нибудь людей' $(23: 249)$.

Отрицательный ирреалис, помимо императивных употреблений, рассмотренных в предыдущем разделе, может употребляться в риторических конструкциях и в своем прямом, контрфактическом значении.

\begin{tabular}{|c|c|c|c|}
\hline $\begin{array}{l}\text { Tati-ra } \\
\text { тот-2SG }\end{array}$ & $\begin{array}{l}\text { bi } i \delta i-? \\
\text { вода-GEN.PL }\end{array}$ & $\begin{array}{l}\text { tajyiz } \\
\text { противоположный }\end{array}$ & $\begin{array}{l}k a i-t a \\
\text { сторона-LAT }\end{array}$ \\
\hline $\begin{array}{l}\text { koni-d'i } \\
\text { пойти-INF }\end{array}$ & $\begin{array}{l}\text { d'esi-ma } \\
\text { отец-ACC.1sG }\end{array}$ & $\begin{array}{lll} & \text { yəndiai } & k o \delta \\
\text { G } & \text { наверное } & \text { уби }\end{array}$ & $\begin{array}{l}-2 a, \\
-P F\end{array}$ \\
\hline
\end{tabular}

'Он, наверное, поехал на тот берег и убил моего отца; был бы отец живой, наверное, пришел бы’ (33: 220).

Императивные (собственно императив, императив будущего времени, оптатив) и эвиденциальные (инференциал, цитатив, аудитив) формы в риторических отрицательных вопросах, насколько известно, не употребляются.

\section{5. Схожие конструкции в энецком языке}

О. Ханина и А. Шлуинский [Khanina, Shluinsky forthc., пример 47] сообщают, что в тундровом энецком широко, а в лесном - изредка употребляются отрицательные конструкции в утвердительном контексте «с дополнительным модальным оттенком»:

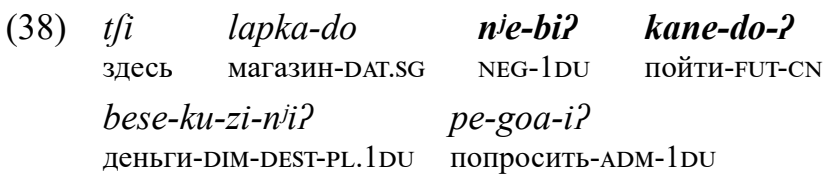

'Поскольку мы собираемся в магазин, давай попросим денег'.

В энецком языке встречаются примеры типа (39), относящиеся к прошедшему времени; в этом случае они имеют показатель вопроса эн. Т - $b a$, эн. Л -si: 


$\begin{array}{lll}\text { abure-j? } & \boldsymbol{i} \text {-ba } & \boldsymbol{d}^{\boldsymbol{j} \boldsymbol{e}-\boldsymbol{?}} \\ \text { голова-1SG } & \text { NEG-INTERR.PRAET } & \text { болеть-CN }\end{array}$

'У меня же голова болела' [поэтому пошла за водкой к соседям] (пример IP_VP100810VP_RAZZRA_048 из [Khanina, Shluinsky mscr. a]).

Обычное значение таких конструкций, судя по примерам, - объяснение неких иных действий путем апелляции к известным фактам. Очевидно, что примеры типа (39) по значению схожи с рассмотренными выше нганасанскими. Что касается примеров типа (38), то, поскольку в энецком языке особая интеррогативная форма существует только в прошедшем времени, легко предположить, что они также по своей природе вопросительные, но вопросительность эта не выражена из-за отсутствия показателя - аналогично нганасанским конструкциям, рассмотренным в разделе 2.4 .

\section{6. Отрицательные риторические утверждения}

Логично задать вопрос: если отрицательно-вопросительные конструкции выражают риторическое утверждение, то как выражается риторическое отрицание? Можно было бы ожидать, что оно будет выражаться соответственно положительным вопросом, т. е. просто вопросительной формой без отрицания (например, конструкция «пришел ли он?» могла бы означать «как известно, не пришел»).

Это, однако, не совсем так. Сами по себе вопросительные формы не используются для отрицательного риторического утверждения. Однако вполне распространены формулы с вопросительными словами

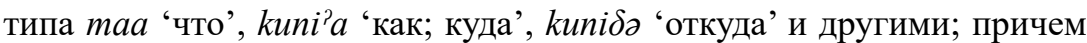
maа часто употребляется плеонастически.

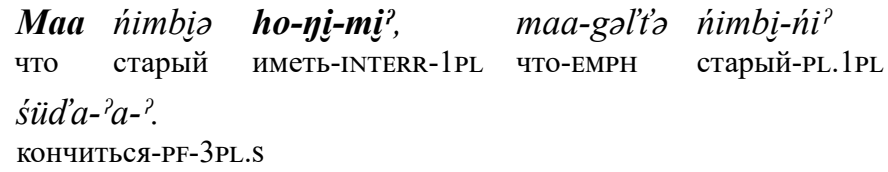

'Какие старики у нас есть, никаких стариков не осталось' (8: 140).

(41) D’ürimi-küə-rə maa kuntəgu i-t'e-yu.

сказка-то-2SG что долго быть-FUT-INTERR

'В речи (сказке) разве долго бывает (рассказывать недолго)' (29: 519). 
(42) Uškanąku maa mou d'eru-yu, bəjka'a?

Ушкананку что земля не.знать-INTERR старик

'Ушкананку всю землю знает, [потому что он] старик' (16: 18).

(43) To toti anika?a baarbo maa ńimśadi-to-yi PTCL тот большой хозяин что не.заметить-FUT-INTERR mii to?

Mы.DU PTCL

'Этот большой хозяин как может нас не видеть (не заметить)?' (11: 95).

Отрицательные формы в этой конструкции тоже возможны.

(44) T'üüńa-’i-tüü ńenatï-ª-? meńd'adii-?a-? спальный.мешок-AUGM-PL.3PL огромный-AUGM-PL новый-AUGM-PL

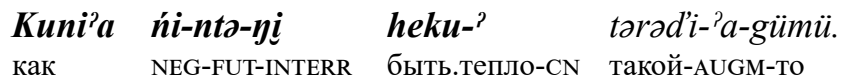

'Спальные мешки у них большие, новые. Как не будет тепло в таком?’ (13: 381-382).

$\begin{array}{llll}\text { D'ürimimi-t’a } & \text { tatu-d'a } & \text { maa } & \boldsymbol{n} \boldsymbol{n} \text { - } \boldsymbol{\eta} \boldsymbol{i} \text { - } \boldsymbol{\eta} \\ \text { весть-ACC.PL.2SG } & \text { принести-INF } & \text { что } & \text { NEG-INTERR-2SG.S }\end{array}$

t'ii-? ohi?

войти-CN PTCL

‘[Раз] ты новости принес, почему бы тебе не зайти?’ (14: 245).

Иногда в такой конструкции может употребляться невопросительная форма будущего времени:

\begin{tabular}{|c|c|c|c|}
\hline $\begin{array}{l}\text { Әmti } \\
\text { этот }\end{array}$ & $\begin{array}{l}\text { тои-gӥтӥ- } \\
\text { земля-то-АСс }\end{array}$ & $\begin{array}{l}-m t \ddot{u} \\
\mathrm{C} .3 \mathrm{sG}\end{array}$ & $\begin{array}{l}\text { kat’əmə-ku-mə } \\
\text { посмотреть-IMP-1sG.o }\end{array}$ \\
\hline $\begin{array}{l}\partial \delta \partial \partial^{?}, \\
\text { PTCL }\end{array}$ & $\begin{array}{l}\text { təbtวria } \\
\text { все.равно }\end{array}$ & $\begin{array}{l}\boldsymbol{m a a} \\
\text { что }\end{array}$ & \\
\hline
\end{tabular}

'Пойду посмотрю эту землю, всё равно как я заблужусь, не заблужусь' (25: 524).

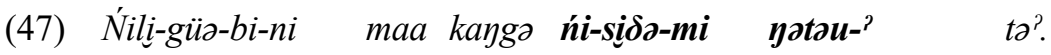
жить-тO-COND-1DU что когда NEG-FUT-1DU.s встретиться-CN PTCL 'Если мы будем живы, встретимся когда-нибудь' (3: 207). 
Этот способ менее грамматикализован, чем отрицательно-вопросительные формы, рассмотренные выше - связь с вопросами здесь гораздо более явна и, в отличие от отрицательно-вопросительных форм, рассмотренных выше, часто отражается в переводе. Отрицание здесь также возможно, как это видно по примерам. Тем не менее такие конструкции достаточно идиоматичны и употребляются намного чаще, чем, например, в русском языке. Стоит также упомянуть, что если отрицательно-вопросительные формы употребляются преимущественно в диалогах, то данные конструкции вполне характерны и для нарратива.

\section{3. Клитика «эмфатического утверждения» в энецком и ненецком языках}

Напомним, что в энецком и ненецком языках специализированная интеррогативная форма существует только в прошедшем времени (нен. -ca, в эн. Л -sa/-si, эн. Т - $b a$ ); в прочих временах и наклонениях вопрос выражается только вопросительным словом и/или интонацией ${ }^{7}$. Насколько нам известно, в этих языках не распространены вопросительно-отрицательные конструкции в значении утверждения, подобные рассмотренным выше нганасанским. Единичные примеры типа (48), которые нам удалось найти, укладываются в обычные рамки риторических вопросов и, по-видимому, не заслуживают того, чтобы считаться отдельной конструкцией:

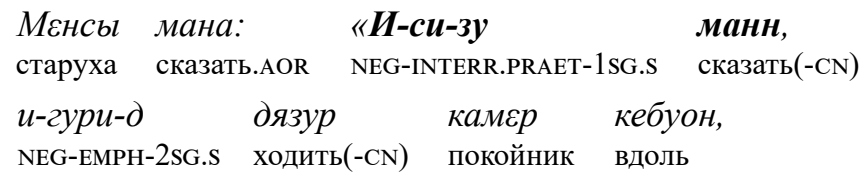

7 Такова традиционная точка зрения. Для ненецкого языка (как лесного, так и тундрового) С. И. Буркова убедительно показывает, что в современном языке аффикс - $c a$ не связан жестко ни с вопросительностью, ни с прошедшим временем, и ее функции скорее «связаны с восполнением информации, недостающей для адекватной интерпретации ситуации как слушающим, так и говорящим» [Буркова 2013: 65]. Для энецкого языка подобного исследования на большом текстовом материале, насколько известно, проведено не было. Здесь мы будем придерживаться традиционного обозначения этого аффикса как «вопросительного» - во-первых, для краткости, а во-вторых, потому, что ее нынешние функции, вероятно, все же развились на базе вопросительного употребления [Там же]. 
çu-m недра-да».

ACC-2SG заставить.мерещиться-FUT

'Старуха сказала: «Я тебе говорила: только не ходи около покойника, тебя чудить будет»' [Сорокина 2005: 17, 18].

С другой стороны, в этих языках есть постглагольная клитика нен. -м', эн. -mи?, которая сливается с личными окончаниями, претерпевая при этом ожидаемые морфонологические изменения. Это отмечала Н. М. Терещенко, говоря об «особых утвердительных частицах», с помощью которых «отрицательные предложения приобретают 〈... характер утвердительных» [Терещенко 1973: 86]. И. Николаева в ненецком языке описывает эту клитику как отдельный аффикс и называет еe «дубитативной» [Nikolaeva 2014: 121]; О. В. Ханина и А. Б. Шлуинский в энецком языке предпочитают говорить об особой «контрастивной» серии личных окончаний [Шлуинский 2010; Khanina, Shluinski mscr. b], которые возникли из сочетания собственно окончаний с этой клитикой. Для краткости и чтобы подчеркнуть происхождение этой серии личных окончаний из сочетаний с самостоятельной единицей (см. об этом ниже), мы будем говорить здесь о клитике (или частице). Мы не будем обсуждать здесь целесообразность того или иного синхронного описания; заметим лишь, что эта клитика демонстрирует на морфемной границе сандхи внутрисловного, а не межсловного типа (применительно к энецкому аргументы за и против обоих вариантов описания разбираются в [Khanina, Shluinski mscr. b]).

\section{1. Тундровый ненецкий}

В ненецком языке клитика $-\mu$ '/- ${ }^{\prime}\left(«=m^{\circ} h »\right)^{8}$ обладает следующими свойствами [Nikolaeva 2014: 121-123]:

— при личных формах глагола она меняет полярность на противоположную;

${ }^{8}$ В цитируемой грамматике эта частица приводится с «назализованным» гортанным смычным, но в публикациях ненецких текстов она часто пишется с «неназализованным» смычным -", либо смычный вовсе опускается. В примерах ниже мы сохраняем орфографию источника; если, как это часто бывает, коннегатив и стоящий за ним отрицательный глагол с контрастивной клитикой написаны вместе, мы разделяем их в глоссах, а показатель коннегатива указываем в скобках. 
- при употреблении с отрицательным глаголом (основным ни- или эмфатическим ханя- 'как не') она означает утверждение;

- утверждение, которое получается в результате, оказывается «somehow emphasized»;

- отрицательный глагол с этой клитикой может стоять после смыслового, что невозможно в обычной отрицательной конструкции;

- при любом порядке слов отрицательный глагол с этой клитикой не может быть отделен от смыслового другими словами, хотя обычный отрицательный глагол может отделяться;

- если речь идет о прошедшем времени, (отрицательный) глагол обязательно стоит в вопросительной форме, хотя высказывание не является вопросом;

- также эта клитика может употребляться в предположениях, альтернативных вопросах (либо просто при дизъюнкции типа 'или' в контекстах со значением предположения, которые очень напоминают альтернативный вопрос), с независимым условным деепричастием ${ }^{9}$, личной формой глагола или даже с именем [Nikolaeva 2014: 112, 268, 429-430], а также с формой так называемого «репутатива» -мӑна, обозначающего «низкую вероятность действия» [Nikolaeva 2014: 105 ${ }^{10}$.

Употребление этой частицы заслуживает отдельного исследования, однако уже при беглом взгляде на тексты можно заметить, что конструкции с ней и отрицательным глаголом используются в основном в двух типах контекстов: а) при перечислении известных прошедших событий и б) при упоминании каких-то общих истин. И то и другое, разумеется, важно не само по себе, а как обоснование для некоего вывода; в этом выводе конструкция с клитикой - $м$ ' уже не употребляется:

${ }^{9}$ К употреблению с условным деепричастием ср. ниже сходные примеры (68) и (69) из тундрового энецкого языка.

${ }^{10}$ Приводимые И. Николаевой формы, где эта клитика стоит перед лично-числовым показателем глагола [Nikolaeva 2014: 123], на самом деле ее не содержат и являются просто объектным спряжением императива, см. [Стенин 2015: 118].

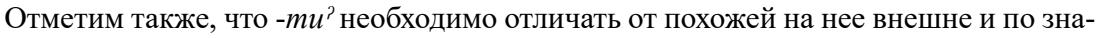
чению клитики -ma, «ассертивной», по терминологии [Nikolaeva 2014: 120-212]; однако эта последняя, напротив, никогда не употребляется с отрицательным глаголом и не меняет полярность высказывания. Здесь клитика -та не будет рассматриваться; см. об обеих клитиках специально [Буркова 2016; наст. сб.]. 
(49)

а. - Пьлд-хава- $p$ Вэнеко-тя- $p$ танянив,

2-EMPH-2SG собака-DIM-2SG иметься(-CN) NEG-CONTR

Вэнеко-тя-е-ми

хада-ни-да-в,

собака-DIM-PEJOR-ACC.1SG убить(-CN) NEG-3SG.O-CONTR

Вэнекомд тэмда-да-ва.

собака-ACC.2SG купить-FUT-1SG.O

'- У тебя-то есть твоя Собачка, мою Несчастную-Собаку [она] ведь убила. Куплю-ка твою'.

$\begin{array}{cll}\text { б. - Хэй! } & \begin{array}{l}\text { Вэнекотяеми } \\ \text { ох }\end{array} & \begin{array}{l}\text { побака-DIм } \\ \text { спутник-DIM-PEJOR-1SG }\end{array}\end{array}$

нисяв уа,

NEG-INTERR.PRAET-CONTR быть(-CN)

мань харвабта-на-вна-ни тэмда-уго-дакэ-р.

я сильно.хотеть-PT.PRAES-PROL-1SG купить-FUT-PROB-2SG.O

‘- Ох! Она мой товарищ, но раз уж она тебе нравится, то купи ее’ [Пушкарева, Хомич 2001: 102-103].

$(50)$

$\begin{array}{rll}\text { - Мани' я-ха-ни' } & x a н-m a-н u^{\prime} . \\ \text { мы.DU } & \text { земля-GEN.1DU } & \text { ехать-1DU.R }\end{array}$

Нано-да-ва” хамада-угу-ни, уано-ва” ха

лодка-DEST-1PL приготовить-FUT-? лодка-1PL уйти(-CN)

ни-ся-в.

NEG-INTERR.PRAET-CONTR

‘- Поедем мы в свою землю. Лодку нам приготовьте, наша-то уплыла' [Пушкарева, Хомич 2001: 170-171].

(51) Пьдар хасава-уэ нер-ня-на

ты мужчина-ESS впереди-LOC-1PL?

ни-ся-на-в

мэ-угу-".

NEG-INTERR.PRAET-2SG.R-CONTR идTИ-IMPF-CN

Маня” не-уэ пуда-угу-ва-ть.

мы женщина-ESS быть.замыкающим-IMPF-1PL-PRAET

'- Ты - мужчина, впереди должен быть. Мы, женщины, должны быть сзади' [Пушкарева, Хомич 2001:: 132-133].

Еще один, отличный от проиллюстрированных выше, но тоже объяснимый тип употреблений - это сообщение о событии, неизвестном собеседнику, но представляемом как естественное, само собой разумеющееся; в русском переводе в таких случаях часто стоят частицы типа же, ведь: 
а. - Сёмя-ко, яр-на-н? кукша-DIM плакать-PRAES-2SG.S

‘— Ой, Кукша, плачешь?'

б. -Ханя-дм' яр-”! Тёня-ко-р ню-ктя-хаю-ни как.не-1SG плакать-CN лиса-DIM-2SG ребенок-DIM-DU-ACC.PL.1SG

\section{ни-ся-в хана-".}

NEG-INTERR.PRAET-CONTR забраTь-CN

‘— Конечно, плачу! Лис двух детей моих ведь взял’.

в. - Амгэ хана-уа-хаю-да? что забрать-AOR-DU-3SG.O

‘— Почему он их взял?'

г. - Вада-внть ни-ся-ю-да-в хана, вырастить-SUP NEG-INTERR.PRAET-DU-3SG.O-CONTR забрать(-CN) ню-да-нда. ребенок-DEST-GEN.3SG

‘— Он взял их вырастить'.

д. - Хэй! Хадрю сала-на-н=ню. хэй какой глупый-PT.PRAES-2SG=EMPH

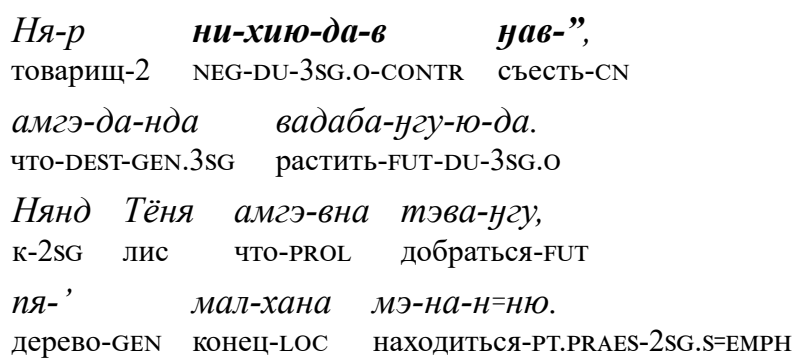

‘- Хэй! Какая же ты глупая! Он же их съел, зачем ему их растить? Как до тебя Лису добраться, ты же на верхушке дерева находишься’ [Пушкарева, Хомич 2001: 152-153].

По-видимому, сюда же относится распространенная эмфатическая частица и́и' (ню”/ню'/ню; ср. примеры (52е-д)); см. о ней [Урманчиева 2015]. Мы полагаем, что эта частица восходит к сочетанию 3-го лица отрицательного глагола с контрастивной клитикой ( $\left.n^{i}-w^{\prime}\right)$. Она была заимствована из ненецкого (или, возможно, из тундрового энецкого) в нганасанский язык в форме ńiu?/n̈üu?; в нганасанском она не имеет внутренней формы. 
Наконец, по текстам легко заметить, что эта же конструкция часто употребляется с глаголом ман- 'сказать', вводящим прямую речь; ср. пример из первого же абзаца первого текста сборника [Лар, Пушкарева 2001: 19, 156]:

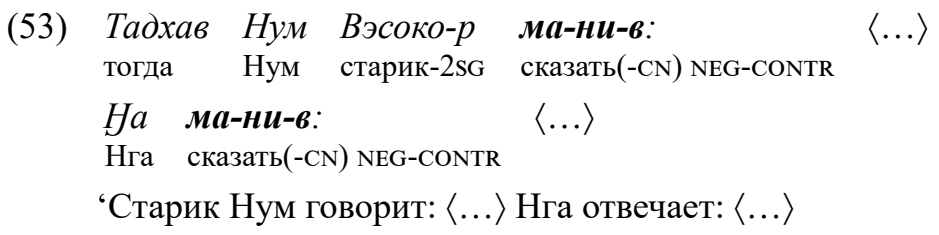

Это употребление выбивается из общего ряда: факт прямой речи персонажа является новой информацией и никак не следует из предыдущего текста. Аналогичное употребление есть в энецком языке, и в разделе 3.3 мы попытаемся дать ему объяснение.

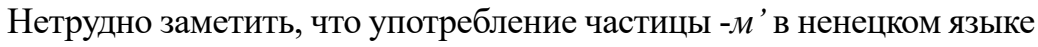
во многом параллельно нганасанским вопросительно-отрицательным конструкциям как в целом, так и в некоторых частностях. Как и в нганасанском, эта частица присоединяется в основном (или исключительно) к отрицательному глаголу, и в результате получается утвердительное высказывание. Как и в нганасанском, это утверждение не сообщает что-то новое, но напоминает об известных фактах либо представляет новые факты как само собой разумеющиеся. В нганасанском эти конструкции обычно содержат вопросительную форму (или другую форму со снятой утвердительностью). В ненецком показатель - $а$ встречается только в части употреблений. Однако если мы вспомним, что - $c a$ исходно является показателем вопроса в прошедшем времени, а в настоящем и прочих временах и наклонениях вопрос морфологически не маркируется, то - как и про энецкие конструкции в разделе 2.5 естественно будет предположить, что и в настоящем времени данная конструкция тоже ранее являлась вопросом; в противном случае появление - $а$ оказывается необъяснимой идиосинкразией.

В нганасанском, насколько известно, нет параллелей употреблениям клитики -м' с независимым условным деепричастием и «репутативом»; однако легко заметить, что и эти контексты (альтернативного вопроса и низкой вероятности действия) предполагают снятую или ослабленную утвердительность. Однако инвертирования полярности в этом случае не происходит.

Наконец, параллельна нганасанскому и возможность постановки отрицательного глагола с этой клитикой после смыслового глагола. 


\section{2. Лесной ненецкий}

Для лесного ненецкого языка употребление клитики $-8 /-м$ описано С. И. Бурковой (в работе [Буркова 2008] она называется вопросительным аффиксом). В настоящем времени (т. е. без аффикса вопро-

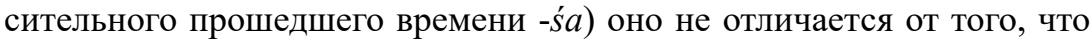
мы видели в тундровом ненецком: частица обозначает «экспрессивно усиленное утверждение», т. е., в наших терминах, заведомо истинное утверждение:

$$
\begin{aligned}
& \text { А! Калу-уди-мта нючу-уди... ни-в уа-”, } \\
& \text { a нож-DIM-ACC.3sG маленький-DIM NEG-CONTR быть-CN } \\
& \text { шепта мюня уэ-шту-” ни-в. Чики-мта ко-уа. } \\
& \text { карман в быть-HAB-CN NEG-CONTR TOT-ACC.3SG найти-AOR }
\end{aligned}
$$

В цитируемой работе совсем не упоминаются сочетания контрастивной клитики с вопросительным аффиксом -sa. Неясно, отсутствуют ли такие сочетания вовсе или они не встретились из-за своей относительной редкости, помноженной на относительно небольшой объем лесных ненецких текстов.

Интересной особенностью лесного ненецкого является, по данным той же работы, идиоматическое употребление вопросительно-отрицательных форм без контрастивной частицы, но обязательно с инвертированным порядком слов. Как утверждается, она выражает пробаби-

\begin{tabular}{|c|c|c|}
\hline $\begin{array}{l}\text { Амама-'куте-хэॅ̆а, } \\
\text { бабушка-DIм-LоC }\end{array}$ & $\begin{array}{l}\text { ката-хӑна } \\
\text { бабушка-цос }\end{array}$ & $\begin{array}{l}\boldsymbol{\kappa} \ddot{\jmath}-\boldsymbol{u m} \boldsymbol{y}-\boldsymbol{\eta} \\
\text { уйти-НАВ-СN }\end{array}$ \\
\hline ни-ша-н-"э & $m$ & \\
\hline
\end{tabular}
литив, т. е. «предположение, основанное на логическом выводе или общих знаниях говорящего» [Буркова 2008: 106], - соответственно, в прошедшем (с аффиксом -śa) или не-прошедшем (без этого аффикса) времени.

[Сейчас мне тетка говорит: «С кем бы еще ты туда ходила?] 'C бабулей, с бабушкой, наверное, ходила' [Буркова 2008: 134, 137].
(56) Ня-хатё-й”
тамна
еще
нюча-хаң
ңыb-”
родственник-DU-1DU
маленький-3DU
быть-CN 


$\begin{array}{lllll}\text { ни-иа-хаң } & \text { план } & \text { памна } & \text { ни-хиң-и } & \text { мэс } \\ \text { NEG-INTERR.PRAET-3DU } & \text { план } & \text { еще } & \text { NEG-3DU.R-PRAET } & \text { взяTь.CN }\end{array}$

'Братья, видимо, были еще молодыми - план им еще не давали (букв.: план еще не брали они)' [там же: 116].

\section{3. Лесной энецкий}

В энецком языке клитика, соответствующая ненецкой $-м$ ', имеет глубинный вид -mu? и присоединяется к личным окончаниям. Ее употребления немного различаются в лесном и тундровом диалектах.

В лесном энецком образование и употребление контрастивной серии личных окончаний было специально - и, насколько нам известно, впервые - описано А. Б. Шлуинским [2010]; в грамматике Ф. Зигля эти окончания рассматриваются вместе с предшествующими им суффиксами [Siegl 2013: 290-297].

По большей части эта серия употребляется аналогично ненецкой: с отрицательным глаголом в настоящем времени и в интеррогативе прошедшего времени с инвертированной полярностью для «напоминания слушающему известной ему информации» и маркирования «самоочевидных» истин; порядок смыслового и отрицательного глагола может инвертироваться, ср. примеры из [Шлуинский 2010: 288].
kun ${ }^{j}$ diut-da-u,
nenda $\boldsymbol{n}^{\boldsymbol{j}} \boldsymbol{e}-\boldsymbol{z} \boldsymbol{u} ?$
diiri-?
как избить-FUT-1SG.O он.LOC NEG-1SG.S.CONTR жить-CN
'Как же я ее изобью? Я же с ней живу (как ты знаешь)'.
(58) tiki-if bazi-t
tara-? $\boldsymbol{n}^{\boldsymbol{i} \boldsymbol{i}-\boldsymbol{u} \text { ? }}$
этот-ESS рассказывать-INF нужно-CN NEG-3SG.S.CONTR

'Об этом, конечно же, нужно рассказывать!'

В качестве третьего типа употребления в статье упоминается «маркирование фоновых пропозиций», см. примеры (59) и (60) оттуда же:
(59) too-j
па небо
$\boldsymbol{y} \boldsymbol{a}-\boldsymbol{?}$
быть-CN
$n^{i} i-u ?$
лето-ADJ небо быть-CN NEG-3SG.S.CONTR
'А погода ведь летняя' (в тот момент, когда происходили описы- ваемые события).
(60) diuk saxar-?u to diodii-gon кусок сахар-N.PL сюда время-LOC.SG




\section{$i$-si-m?}

\section{tonie-?}

NEG-INTERR.PRAET-3PL.S.CONTR иметься-CN

'А сахар ведь в то время был кусковой'.

«Фоновую пропозицию» не всегда просто отделить от «известной информации»; во всяком случае, для этого нужен достаточно широкий контекст. Так, в примере (60) не очевидно, считает ли рассказчик информацию о том, что сахар в описываемое время был только кусковой, известной слушателям или новой для них. Есть, впрочем, примеры, когда сообщаемая информация, очевидно, неизвестна слушающему, как в следующем примере:

\begin{tabular}{|c|c|c|c|c|c|}
\hline $\begin{array}{l}Н \mathrm{Ha} \\
\text { небо }\end{array}$ & $\begin{array}{l}\text { буси-с } \\
\text { старик }\end{array}$ & CAT & $\begin{array}{l}\text { пурзе } \\
\text { обратно }\end{array}$ & $\begin{array}{l}\partial я 3 y-c ̧ b \\
\text { идти-INF }\end{array}$ & $\begin{array}{l}\text { мана: } \\
\text { сказать.AOR }\end{array}$ \\
\hline$« O y$ & $\begin{array}{l}\text { модb } \\
я\end{array}$ & $\begin{array}{l}y \\
\text { ты }\end{array}$ & $\begin{array}{l}\mu \ni-\partial \\
\kappa-2 \mathrm{SG}\end{array}$ & $\begin{array}{l}\text { бази-нb } \\
\text { слово-PL.1sc }\end{array}$ & \\
\hline \multicolumn{3}{|c|}{$\begin{array}{l}\boldsymbol{u}-\boldsymbol{c} \boldsymbol{u}-\boldsymbol{\mu} \\
\text { NEG-INTERR-3PL.S.CONTR }\end{array}$} & \multicolumn{2}{|c|}{$\begin{array}{l}\text { тонэ, } \\
\text { иметься(-СN) }\end{array}$} & $\begin{array}{l}\text { थикинь } \\
\text { Tот-PL.1SG }\end{array}$ \\
\hline \multicolumn{3}{|c|}{$\begin{array}{l}\kappa u ч u-б u-н \\
\text { чуть.не-РF-1s }\end{array}$} & $\begin{array}{l}\text { юрта. } \\
\text { быть(-с }\end{array}$ & & \\
\hline
\end{tabular}

'К царю обратно возвращаясь, он сказал: «Ой, у меня ведь к тебе слова имелись, эти чуть не забыл я’ [Сорокина 2005: 227, 229].

Ф. Зигль приводит два примера отрицательной конструкции со значением (неуверенного) утверждения и к тому же с отрицательным глаголом, стоящим после смыслового, но без контрастивных окончаний [Siegl 201: 297]:

$$
\begin{array}{llll}
\text { bu } & \text { čenuju } & \text { to-? } & \boldsymbol{i} \text {-si } \\
\text { он } & \text { вчера } & \text { прийти-CN } & \text { NEG-INTERR }
\end{array}
$$

'Он, наверное, вчера приехал'.

Такого рода употребления, очевидно, объединяют лесной энецкий с лесным ненецким языком - см. примеры (55) и (56).

Кроме того, контрастивные окончания употребляются с пробабилитивом и с интеррогативом для выражения предположения без инверсии полярности; впрочем, с интеррогативом такие употребления маргинальны. С отрицательным глаголом употребления второго типа также возможны; таким образом, отрицательная контрастивная конструкция в прошедшем времени может иметь фактически противоположные значения, означая либо (редко) «скорее всего, нет», либо (обычно) «конечно, да». 
Отметим еще характерный случай второго типа употребления контрастивных окончаний - параллельно в утвердительной и отрицательной конструкциях для выражения неизвестности («может, да, а может, нет»; [Шлуинский 2010; Khanina, Shluinski mscr. b]).

Наконец, как и в ненецком языке (см. пример (53)), конструкция с инвертированным отрицанием регулярно используется с глаголом 'говорить', вводящим прямую речь:

\begin{tabular}{|c|c|c|c|c|}
\hline $\begin{array}{l}\text { ku-хиги, } \\
\text { куда-емРн }\end{array}$ & $\begin{array}{l}\text { man-? } \\
\text { сказать-CN }\end{array}$ & 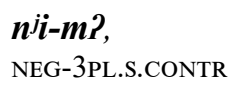 & $\begin{array}{l}n^{j} e-r a ? \\
\text { NEG-IMP.2PL.S }\end{array}$ & $\begin{array}{l}d^{j} a z u-r-? \\
\text { идти-мULT-CN }\end{array}$ \\
\hline
\end{tabular}

\section{4. Тундровый энецкий}

Употребление контрастивной серии окончаний в тундровом энецком языке кратко описано в [Khanina, Shluinski mscr. b]. В отличие от лесного, в тундровом их употребление с пробабилитивом невозможно, а с настоящим и прошедшим временем возможно только с отрицательным глаголом. Иными словами, с личными формами они употребляются только в отрицательных конструкциях с инвертированной полярностью. Значение этих конструкций такое же, как было описано выше для других северосамодийских языков, - это информация, которая полагается известной либо само собой разумеющейся, ср. примеры (64) и (65) из текста «Солда», предоставленного в наше распоряжение А. Ю. Урманчиевой, а также (66) и (67) из неопубликованного энецкого словаря Е. А. Хелимского:

\begin{tabular}{|c|c|c|}
\hline $\begin{array}{l}\text { Noo-da } \\
\text { место.возле[-LAT. }\end{array}$ & $\mathrm{ADV}]-3 \mathrm{SG}$ & $\begin{array}{l}\text { kane-da- } \delta o^{\text {? }} \\
\text { пойти-FUT-PRAES-1SG.S }\end{array}$ \\
\hline $\begin{array}{l}\boldsymbol{n}_{\boldsymbol{n}} \boldsymbol{i}-\boldsymbol{u}^{?} \\
\text { He-3SG.S.CONTR }\end{array}$ & $\begin{array}{l}a^{?}, \\
\text { быть-CN }\end{array}$ & $\begin{array}{l}\text { d'uroi-da- } \delta o^{\text {? }} \text {. } \\
\text { говорить-FUT-PRAES-1sG.s }\end{array}$ \\
\hline
\end{tabular}

‘Ты же видишь мои руки, я тоже полечу' (т. е. крылья; говорит чайка).
} 
(66)

$\begin{array}{lll}\text { ixuto-de } & \boldsymbol{i} \text { - } \boldsymbol{b} \boldsymbol{a}-\boldsymbol{u}^{\prime} & \boldsymbol{a}^{\text {? }} \\ \text { курить-PT.PRAES } & \text { NEG-INTERR.PRAET-[3SG.s]-CONTR } & \text { быть-CN } \\ \text { 'он был [ведь] курящим’ } & \end{array}$

$(67)$
$i-b a-u^{?}$
kane-?
NEG-INTERR.PRAET-[3SG.S]-CONTR уйTИ-CN
'ведь/же ушел'

Кроме того, окончания, идентичные контрастивным, могут присоединяться к условному деепричастию и употребляться аналогично тому, как это происходит в тундровом ненецком языке (примеры (68) и (69) взяты из работы [Khanina, Shluinski mscr. b]):

\begin{tabular}{|c|c|c|}
\hline $\begin{array}{l}\operatorname{modii} \\
\text { я }\end{array}$ & $\begin{array}{l}\text { mam-obi-z?, } \\
\text { сказать-HAB-1SG.s }\end{array}$ & $\begin{array}{ll}\eta u & t e a-d^{j} a \\
\text { один } & \text { олень-PEJOR }\end{array}$ \\
\hline $\begin{array}{l}e d u-z a \\
\text { рога-PL. }\end{array}$ & $\begin{array}{ll} & \text { mərusuj } \\
.3 \mathrm{sG} & \text { сломанный }\end{array}$ & $\begin{array}{l}\boldsymbol{a}-\boldsymbol{b} \boldsymbol{u}-\boldsymbol{t} \boldsymbol{u}-\boldsymbol{m} \boldsymbol{P} \\
\text { быть-COND-3PL-CONT1 }\end{array}$ \\
\hline
\end{tabular}

\begin{tabular}{|c|c|c|}
\hline $\begin{array}{ll}\text { motu?, } & \text { soburego } \\
\text { шесть } & \text { пять }\end{array}$ & $\begin{array}{l}\boldsymbol{a}-\boldsymbol{b} \boldsymbol{u}-\boldsymbol{t} \boldsymbol{a}-\boldsymbol{u}^{2}, \\
\text { быть-CND-3SG-CONTR }\end{array}$ & $\begin{array}{l}\text { motu? } \\
\text { шесть }\end{array}$ \\
\hline $\begin{array}{l}-\boldsymbol{u} ? \text {, } \\
\mathrm{ND}-3 \mathrm{SG}-\mathrm{c}\end{array}$ & $\begin{array}{ll}\text { soburego } & \text { nis-jed } \\
\text { пять } & \text { ребенок }\end{array}$ & \\
\hline
\end{tabular}

'Шесть или пять их было; шесть, наверное; пять детей у меня было'.

Наконец, в тундровом энецком схожие элементы могут сочетаться с именами и финитными формами глагола, однако, как указывается в той же работе, такие употребления очень маргинальны:

(70) nəńi $i^{\text {kunad'-u }}$ 'ne teza-d-?

я.LAT как-CONTR NEG.3SG.S даTь-FUT-CN

'Как это он мне не даст'.

(71) teńi’ $-x \jmath^{?}, \quad$ bахи'ว- $x \jmath^{?}$ mэna-?, думать-3DU.S старик-DU сказать-3PL.S

ou śio-zo-ba? toa- $\boldsymbol{u}^{\text {? }}$

о кTO-DEST-1PL прийти.3SG.S-CONTR

'Старики подумали: «Кто это к нам пришел?»' 


\section{5. Употребление контрастивной серии окончаний в ненецком и энецком языках: обсуждение}

Итак, в ненецком и энецком языках существует устойчивое употребление отрицательной конструкции с особыми личными окончаниями (или, этимологически, в сочетании с особой клитикой ${ }^{11}$ ). В прошедшем времени эта конструкция требует вопросительной формы, и это позволяет предположить, что и в настоящем времени она исходно была вопросительной, что не выражено формально просто из-за отсутствия в настоящем времени специального показателя. В этом случае ненецко-энецкая конструкция оказывается очень близка нганасанской за тем исключением, что в ненецком и энецком она обычно употребляется лишь в сочетании с данной частицей (хотя в энецком возможна и без нее, ср. раздел 2.5), а в нганасанском формально ничем (кроме иногда порядка слов) не отличается от обычных вопросов.

Однако конструкция риторического вопроса является хотя и основной, но не единственной областью употребления этой клитики. Другие случаи ее употребления различаются по языкам, но всегда это контексты снятой или, во всяком случае, ослабленной утвердительности. (Заметим, что некоторые из этих контекстов не особенно частотны, поэтому мы не можем быть уверены, что в тех языках и диалектах, где они не были зафиксированы, они невозможны.) При этом кажется, что клитика ничего не добавляет к значению контекста, разве что, возможно, усиливает его, но об этом трудно судить. В некоторых случаях (как в вопросах-предположениях в тундровом ненецком) она не обязательна. В других случаях, например при пробабилитиве в лесном энецком, она, напротив, обязательна, но форма эта значит то же, что пробабилитив в тундровом энецком, который с ней сочетаться, наоборот, не может.

Все указывает на то, что изначально эта клитика была самостоятельным (хотя, судя по сандхи, тесно примыкающим к предшествующему

\footnotetext{
11 Эта клитика очевидно этимологически тождественна; для общененецко-энец-

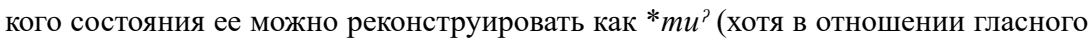
возможны и другие варианты). Дальнейшая реконструкция требует внешних сопоставлений, особенно учитывая трудности в определении «качества» гортанного смычного в ненецком, т. е. того, «назализованный» он или нет.
} 
слову) элементом со значением неуверенности, низкой вероятности, снятой утвердительности. Частично, в разных контекстах и/или идиомах, она сохранила свою самостоятельность до сих пор - это редкие сочетания с финитными глагольными формами или с именами. В других контекстах она стала обязательной либо, наоборот, невозможной (как в пробабилитиве в энецком тундровом языке). В частности, она грамматикализовалась в риторических вопросах. Как показывает нганасанский материал, использование отрицательных вопросов для выражения заведомо истинного утверждения характерно для всего северосамодийского ареала; однако в ненецко-энецкой его части после грамматикализации клитики *-mu? эти конструкции стали отличаться от обычных вопросов и формально.

Употребление контрастивной конструкции при введении прямой речи заслуживает отдельного обсуждения - см. об этом раздел 4.3.

\section{4. Самодийские языки на типологическом фоне}

\section{1. «Внутреннее» и «внешнее» отрицание в вопросах}

Риторическим вопросам, их семантике и внешним признакам посвящена обширная литература. В работе [Ladd 1981] было предложено разделение на вопросы с «внутренним» и «внешним» отрицанием («inner negated polar questions» и «outer negated polar questions»; см. также [Büring, Gunlogson 2000; Venhuizen 2011] и др.): в первом случае говорящий предполагает факт не-P и задает вопрос, чтобы подтвердить или опровергнуть свое предположение, во втором - предполагает $P$ и просит подтвердить его. Р. Ладд отмечает, что в английском эти два типа вопросов формально не различимы. Однако в других языках они могут различаться. В [Büring, Gunlogson 2000: 4] отмечается, что в немецком языке в случае «внешнего» (риторического) отрицания возможно сочетание nicht ein, которое во всех прочих случаях должно заменяться на kein:

(72) a. Gibt es kein vegetarisches Restaurant in dieser Ecke? 'Здесь нет поблизости вегетарианского ресторана?'

b. Gibt es nicht ein vegetarisches Restaurant in dieser Ecke? 'Неужели здесь нет поблизости вегетарианского ресторана?' 
В [Hackstein 2016: 158ff.] отмечается, что в древних индоевропейских языках при «внешнем» отрицании отрицательная частица выносится вперед. Подобные наблюдения применительно к другим языкам делаются в [Romero, Han 2004: 613-616] и в [Munshi, Bhatt 2009].

В рассмотренном в Разделе 2 нганасанском (и в небольшой степени энецком) материале в качестве признака, отличающего риторическое отрицание от «обычного», можно назвать возможность постановки отрицания после того слова, к которому оно относится. Однако такое изменение порядка слов не обязательно, и риторические вопросы могут ничем не отличаться от обычных. Что же касается ненецкого и энецкого материала, рассмотренного в Разделе 3 , то в нем маркером риторического вопроса служит (почти обязательная) частица * ти?.

Северосамодийские языки могут быть не уникальны в отношении грамматикализации риторических вопросов даже на сибирском фоне. В тунгусских языках Амура есть конструкция, которая полностью совпадает или очень похожа на сочетание отрицательной формы глагола с частицей $-k ə$; В. А. Аврорин в нанайском языке называет эту конструкцию «очевидным наклонением» [Аврорин 1961: 114-118]; С. А. Оскольская отказывает ей в статусе наклонения именно из-за ее материального тождества с отрицательными формами [Оскольская 2017: 134]. По употреблению, судя по примерам, эти сочетаниия очень напоминают северосамодийские вопросительно-отрицательные конструкции: это заведомо истинные утверждения, используемые, в частности, в «аргументативной» функции. Ср. примеры из [Аврорин 1961: 118]:

$$
\begin{array}{llll}
M u & y н-\partial э c u-u=\kappa э: & \text { лиас } & \text { тачиочи- } p y \\
я & \text { говорить-NEG-1SG=PTCL } & \text { все.время } & \text { учиться-IмР }
\end{array}
$$

'Ведь я же говорю (твержу): все время учись!'

(74) $С и$ турим-бэ ба-раси-си=ка, ты зарплата-ACC получать-NEG-2SG=PTCL

хайми син-ду даха аба? почему ты-DАт деньги нет

'Ведь ты же зарплату получаешь, почему же у тебя денег нет?'

Подобные примеры указывают на то, что рассмотренные в этой статье факты могут заслуживать изучения и в ареальном контексте. 


\section{2. Аргументативное употребление отрицательных вопросов}

Тот факт, что метаязыком при работе с северосамодийскими языками является русский, помогает увидеть очевидную параллель: легко заметить, что в русских переводах этих конструкций часто возникают частицы же и ведь. Именно для этих частиц, особенно для ведb, характерно, среди прочего, «аргументативное» употребление, и их толкования кажутся хорошо применимыми к части приведенных примеров; ср., например: «Ведь указывает на то, что вводимая информация, будучи адекватной, является одновременно релевантной для правильной интерпретации ситуации адресатом речи» [Бонно, Кодзасов 1998: 428], «...в основе ведь [лежит] идея: 'Я знаю и считаю, что нужно это принять во внимание'» [Левонтина 2005].

\section{3. Контрастивная форма, вводящая прямую речь}

Отдельный любопытный вопрос представляет употребление отрицательно-вопросительной конструкции с глаголом 'сказать' (нен. и эн. man-), вводящим прямую речь - см. примеры (53) и (63), а также нганасанский (19). Очевидно, это употребление уже следует считать идиоматичным; однако интересно, как оно возникло.

Е. В. Падучева отмечает, что вводный глагол речи «теряет коммуникативную значимость»; так, в первом из следующих двух примеров «повествователь рас сказы вает (разрядка автора. о ментальном акте Дука», а во втором «тот же ментальный акт представлен читателю непосредственно - без посредничества повествователя» [Падучева 1996: 334]:

а. Дук решил, что надо наказать Анджело за его жестокость.

б. Надо - решил Дук - наказать Анджело за его жестокость.

Т. Гюльдеманн [Güldemann 2008] пишет, что в конструкциях с прямой речью для вводящих ее элементов (в его терминологии «quotative indexes») не характерен статус ассертивного компонента. Можно было бы ожидать, что во фразе типа «Р, - сказал Х» предикат 'сказал' является вершиной высказывания и, соответственно, фокусом ассерции, но на самом деле это не так. Как демонстрируется на обширном 
африканском материале и как это подтверждают данные других языков, для единиц, вводящих прямую речь, характерна грамматикализация, сопровождающаяся фонетической редукцией, с одной стороны, и потеря признаков финитного глагола («QIs lack a canonical predicativity» [Güldemann 2008: 57]) вплоть до полного опущения глагола, - с другой. Цель конструкций с прямой речью - не сообщить о том, что нечто было сказано, а представить само содержание прямой речи; по выражению Гюльдеманна, эти конструкции обычно «downplay the DESCRIPTION of the speech event and focus more on the PRESENTATION of the quote, or else on its source and/or addressee» ([Güldemann 2008: 516]; выделено автором). Подобные замечания делались и для английского языка: «The main focus here (в конструкциях с прямой речью. - B. Г.) is on the speaker's words. The reporting signal is added at the end. It signals that this is a report, but in a way which makes the signal less important than the quote» [Thompson 1994: 78-79].

Цитирование без вводящего его глагола речи легко продемонстрировать и на русском языке, ср. пример (76). Фонетическая редукция во всяком случае, зафиксированная на письме - для русского языка менее характерна, но также возможна; ср., например, грит и грят из говорит/говорят (77); русские примеры здесь и далее - из Национального корпуса русского языка (www.ruscorpora.ru):

(76) - Нет его там, - спокойно и досадливо сказал парикмахер. Он только что мимо меня прошёл, я спрашиваю: «Ты куда?» А он мне: «Не ложись. Сейчас принесу, пить будем» (Ю. О. Домбровский. Леди Макбет).

(77) Никита и в рот этого вина не брал, да и должность у него такая, чтобы всегда быть в аккурате. "Не могу, — грит, — ваше сиятельство...» «А ежели, - грят, - не можешь, так пошли кого поумнее себя» (Д. Н. Мамин-Сибиряк. Клад)

С другой стороны, неассертивный статус единиц, вводящих прямую речь, легко показать и с помощью обычного теста на ассертивность подстановки отрицания. Фрагмент (78б) странен и во всяком случае не является отрицанием фрагмента с прямой речью в примере (78a).

(78) а. Хлопнула дверь, и на крыльце появился мужчина в застиранной железнодорожной гимнастёрке. Я поинтересовался, как найти Сорокина. - Толик меня зовут, - сказал он. 
Я представился и ещё раз объяснил, что мне нужен Сорокин (Сергей Довлатов. Заповедник).

б. ?? - Толик меня зовут, - не сказал он.

Может показаться, что контрастивная форма глагола «говорить» противоречит общетипологической тенденции к сокращению показателей прямой речи. Однако ее можно трактовать и как способ убрать ассертивность. Кроме того, стоит вспомнить, что в ненецком языке глагол man-, наряду с хєе- 'уйти' и ұсе- 'быть', использует в контрастивной конструкции нерегулярный, сокращенный коннегатив: та” вместо $\operatorname{man}^{o}$ " [Salminen 1997: 116]. Если два других глагола исторически представляют собой основы на глайды, то man- относится к достаточно многочисленному классу основ на $-n$, которые в норме не демонстрируют морфонологических неправильностей. Сокращение * man " "niw > $m a$ " niw можно объяснить именно фонетической редукцией, характерной для показателей, вводящих прямую речь.

\section{5. Заключение}

Как мы видели, в нганасанском, энецком и ненецком языках существует устойчивое употребление отрицания в сочетании с не-утвердительными наклонениями глагола (интеррогативом, дубитативом, ирреалисом) для выражения утверждения, которое полагается или преподносится как заведомо истинное. Разумеется, само по себе сообщение известной собеседнику информации не очень осмысленно, однако это естественный способ аргументации: апеллируя к тому, с чем собеседник заведомо согласен, говорящий обосновывает свои утверждения или действия. Это легко увидеть практически на всех приведенных выше примерах: все они (кроме употреблений контрастивной частицы с деепричастиями и именами в ненецком и энецком языках, а также употребления ее с глаголом 'говорить' при введении прямой речи) предназначены для объяснения или обоснования чего-либо.

В нганасанском, тундровом энецком и в небольшой степени лесном энецком языках риторическая вопросительно-отрицательная конструкция, в отличие от буквального вопроса, допускает постановку отрицания после того слова, к которому оно относится. Однако такая 
перестановка не обязательна, и риторический отрицательный вопрос может и не отличаться формально от «настоящего» вопроса.

Напротив, в ненецком и также энецком языках риторические отрицательные вопросы стали маркироваться особой частицей *mu?. Как кажется, обязательность ее употребления падает при движении в самодийском языковом ареале от ненецкого языка, в котором она полностью обязательна, через лесной энецкий и тундровый к нганасанскому, в котором она вовсе не употребляется в этих конструкциях. Однако утверждение о ее обязательности в ненецком языке еще требует проверки на материале тундровых и лесных ненецких диалектов.

Отдельное, идиоматическое употребление риторической вопросительно-отрицательной конструкции развилось в ненецком и энецком языках с глаголом 'говорить' для введения прямой речи, что соответствует типологической тенденции к снижению ассертивности у таких конструкций.

\section{Указатель нганасанских текстов}

(1) ChND_041213_Hibula_flkd

(2) DM-97_war1

(3) JDH_00_Njaakju_flkd

(4) JDH_060901_DolganChief_flkd

(5) JDS_16_Chiimi

(6) JSM_080212_Hibula_flkd

(7) KES_031115_Paris_nar

(8) KES-ChND_080725_Childhood_conv

(9) KES-SEN_031114_Dialog_conv

(10) KNT-KH_960810_Cure_conv

(11) KTD_86_BeturakuNy_flks

(12) KTD_SeuMelangana_flks

(13) KVB_9709_OrphanDeity_flks

(14) MDB_91_TwoBrothers_flkd

(15) MDB_91_TwoHuantie_flks

(16) MDN_97_War1_nar

(17) MVL_080303_TwoDolganBrothers_flk
(18) MVL_080304_TwoMeryde_flk

(19) PKM_93_Njisyme_flk

(20) TKF_031116_ShamanBoy_flkd

(21) TKF_031117_ThreeBrothers_flk

(22) TKF_031118_Ostyak_flk

(23) TKF_061102_Lakuna_flk

(24) TKF_061105_FoxFosterling_flk

(25) TKF_061107_CowBogatyr_flks

(26) TKF_99_TwoShamans_flkd

(27) TKF_990812_EvilSpirit_flkd

(28) TKF_990816_Lemming_flkd

(29) TKF_990816_Ngadjea_flk

(30) TKF_990819_SomatuShaman_flkd

(31) TKF_990823_Dolgans_nar

(32) TTD-ChND_080719_Dialog_conv

(33) VL-08_siti-nguamde

\section{Список условных сокращений}

1, 2, 3 - 1, 2, 3 лицо; АCC - аккузатив; ADJ - адъективизатор; ADM - адмонитив (мягкий императив); ADV - «адвербиальный» показатель падежа (при 
послелогах и наречиях); ALL — аллатив; ANT — «бывший»; AOR — аорист; AUD — аудитив; AUGM - аугментатив; CAUS - каузатив; CN — коннегатив; сOMP — сравнительная форма; COND - условное деепричастие; CONTR — контрастивный аффикс; DAT - датив; DEST - дестинатив; DIM - диминутив; DU - двойственное число; DUB - дубитатив; EMPH - эмфатический показатель; ESS - эссив; EXCL — экскламатив; FACT — фактатив («становиться чем-л.»); FUT — будущее время; GEN — генитив; НАВ - хабитуалис; IMP — императив; IMPF — имперфектив; INCH - инхоатив; INF — инфинитив; INFER — инференциал; INTERR — интеррогатив; IRREAL — ирpеалис; ITER — иTератив; LAT — латив; LOC — локатив; MULT — мультипликатив; NEG отрицательный глагол; о - объектное спряжение (для единственного числа объекта; оP — объектное спряжение для множественного числа объекта; PASS - пассив; PEJOR - пейоратив; PF — перфект; PL — множественное число; PRAES - настоящее время; PRAET - прошедшее время; PROB - пробабилитатив; PROL — пролатив; PT - причастие; PTCL — частица; R - рефлексивное спряжение; RENARR ренарратив; RES - результатив; s - субъектное спряжение; SG - единственное число; SPEC - выделительный суффикс («который из»); SUP — супин; VN - отглагольное имя; VOL — волитив («хотеть»); нен. — ненецкий язык; эн. Л - лесной энецкий язык; эн. Т — тундровый энецкий язык.

\section{Литература}

Аврорин 1961 - В. А. Аврорин. Грамматика нанайского языка. Т. 2. М.; Л.: Издво АН СССР, 1961.

Бонно, Кодзасов 1998 - К. Бонно, С. В. Кодзасов. Семантическое варьирование дискурсивных слов и его влияние на линеаризацию и интонирование (на примере частиц же и ведь) // К. Киселева, Д. Пайар (ред.). Дискурсивные слова русского языка: опыт контекстно-семантического описания. М.: Метатекст, 1998. С. $382-443$

Буркова 2004 - С. И. Буркова. Образцы текстов на лесном диалекте ненецкого языка (пуровский говор) // Н. Б. Кошкарева, Н. Н. Широбокова (ред.). Языки коренных народов Сибири. Вып. 13: Экспедиционные материалы. Новосибирск: НГУ, 2004. С. 149-162.

Буркова 2008 - С. И. Буркова. Аналитические глагольные формы сказуемого с модальным значением в текстах на лесном диалекте ненецкого языка // Научный вестник Ямало-Ненецкого АО. 2008. Вып. 6 (58). С. 104-138.

Буркова 2013 - С. И. Буркова. К вопросу о «вопросительной» форме -sa в ненецком языке // А. Е. Кибрик (отв. ред.), Т. Б. Агранат, О. А. Казакевич, Е. В. Кашкин (сост.). Лингвистический беспредел - 2. Сборник научных трудов к юбилею А. И. Кузнецовой. М.: МГУ, 2013. С. 46-65.

Буркова 2016 - С. И. Буркова. О дискурсивных функциях энклитики =ma в тундровом и лесном ненецких языках // VI Международная конференция 
по самодистике памяти А. И. Кузнецовой (1932-2015): сборник тезисов. М.: ИЯз РАН, 2016. С. 13-15.

Буркова наст. сб. - С. Ю. Буркова. О дискурсивных функциях энклитик $=m a$ и $=m$ ? в тундровом ненецком языке // Acta Linguistica Petropolitana. Труды Института лингвистических исследований. 2020. Т. XVI. Ч. 3. С. 29-52.

Гусев 2013 - В. Ю. Гусев. Типология императива. М.: Языки славянских культур, 2013.

Лар, Пушкарева 2001 - И. А. Лар, Е. Т. Пушкарева. Мифы и предания ненцев Ямала. Тюмень: Изд-во Института проблем освоения Севера СО РАН, 2001. Левонтина 2005 - И. Б. Левонтина. Об одной загадке частицы ведь // И. М. Кобозева, А. С. Нариньяни, В. П. Селегей (ред.). Труды Международной конференции по компьютерной лингвистике и интеллектуальным технологиям «Диалог-2005». М.: Наука, 2005. URL: http:/www.dialog-21.ru/media/2398/levontinai. $\operatorname{pdf}$ (дата обращения 12.11.2020).

Оскольская 2017 - С. А. Оскольская. Аспект в нанайском языке. Дисс. ... канд. филол. наук. СПб.: Институт лингвистических исследований, 2017.

Падучева 1985 - Е. В. Падучева. Высказывание и его соотнесенность с действительностью. М.: Наука, 1985

Падучева 1996 - Е. В. Падучева. Семантические исследования. М.: Языки русской культуры, 1996.

Пушкарева, Хомич 2001 - Е. Т. Пушкарева, Л. В. Хомич. Фольклор ненцев. Новосибирск: Наука, 2001.

Сорокина, Болина 2005 - И. П. Сорокина, Д. С. Болина. Энецкие тексты. СПб.: Наука, 2005.

Стенин 2015 - И. А. Стенин. Грамматика тундрового ненецкого языка И. А. Николаевой и проблемы описания самодийских языков // Вопросы языкознания. 2015. № 4. С. 91-133.

Терещенко 1973 - Н. М. Терещенко. Синтаксис самодийских языков. Л.: Наука, 1973. Урманчиева 2015 - А. Ю. Урманчиева. Сочетания ненецких глагольных временных форм с эмфатической частицей нё» ню»: взаимодействие значений // Acta Linguistica Petropolitana. Труды Института лингвистических исследований. 2015. T. XI. Ч. 3. С. 755-773.

Хелимский 1994 - Е. А. Хелимский. Очерк морфонологии и словоизменительной морфологии нганасанского языка // Е. А. Хелимский (ред.). Таймырский этнолингвистический сборник. Вып. 1: Материалы по нганасанскому языку и шаманству. М.: РГГУ, 1994. С. 190-221.

Шлуинский 2010 - А. Б. Шлуинский. «Контрастивные» глагольные окончания в лесном диалекте энецкого языка // С. И. Буркова (ред.). Материалы 3-й Международной конференции по самодистике. Новосибирск: Любава, 2010. С. 279-291.

Bechmann 2010 - S. Bechmann. Rhetorische Fragen. München: AVM Verlag, 2010.

Brykina et al. 2016 - M. Brykina, V. Gusev, S. Szeverényi, B. Wagner-Nagy. Nganasan Spoken Language Corpus (NSLC). Archived in Hamburger Zentrum für Sprachkorpora. Version 0.1. Publication date 2016-12-23. URL: http://hdl.handle. net/11022/0000-0001-B36C-С (дата обращения 12.11.2020). 
Büring, Gunlogson 2000 - D. Büring, C. Gunlogson. Aren't Positive and Negative Polar Questions the Same? URL: http://hdl.handle.net/1802/1432 (дата обращения 12.11.2020).

Grèssillon 1980 - A. Grèssillon. Zum linguistischen Status rhetorisher Fragen // Zeitschrift für germanistische Linguistik. 1980. Vol. 8. S. 273-289.

Güldemann 2008 - T. Güldemann. Quotative Indexes in African Languages: A Synchronic and Diachronic Survey. Berlin; New York: Mouton de Gruyter, 2008.

Gusev 2015 - V. Gusev. Negation in Nganasan // M. Miestamo, A. Tamm, B. Wagner-Nagy (eds.). Negation in Uralic languages. Amsterdam: John Benjamins, 2015. P. 103-132.

Hackstein 2016 - O. Hackstein. Negative Interrogatives and Whatnot: The Conversion of Negation in Indo-European // Indo-European Linguistics. 2016. Vol. 4. Iss. 1. P. 150-189.

Khanina, Shluinsky forthc. - O. Khanina, A. Shluinsky. Forest and Tundra Enets // D. Abondolo, R.-L. Valijärvi (eds.). The Uralic languages. Abingdon: Routledge.

Khanina, Shluinsky mscr. a - O. Khanina, A. Shluinsky. Corpus of Enets texts. Manuscript.

Khanina, Shluinsky mscr. b - O. Khanina, A. Shluinsky. Verbal inflection in Enets. Manuscript.

Ladd 1981 - R. D. Ladd. A first look at the semantics and pragmatics of negative questions and tag questions // R. A. Hendrick, C. S. Masek, M. F. Miller (eds.). Papers from the $17^{\text {th }}$ Regional Meeting of the Chicago Linguistic Society. Chicago: Chicago Linguistic Society, 1981. P. 164-171.

Meibauer 1986 - J. Meibauer. Rhetorische Fragen. Tübingen: Niyemeyer, 1986.

Munshi, Bhatt 2009 - S. Munshi, R. Bhatt. Two locations for negation. Evidence from Kashmiri // J. van Craenenbroeck (ed.). Linguistic Variation Yearbook 9. Amsterdam: Benjamins, 2009. P. 205-240.

Nikolaeva 2014 - I. Nikolaeva. A grammar of Tundra Nenets. Berlin: Mouton de Gruyter, 2014.

Pope 1976 - E. N. Pope. Questions and answers in English (Janua linguarum, Series practica. Vol. 226). The Hague; Paris: Mouton, 1976.

Romero, Han 2004 - M. Romero, Ch.-H. Han. On negative yes/no-questions // Linguistics and Philosophy. 2004. Vol. 27. P. 609-658.

Salminen 1997 - T. Salminen. Tundra Nenets inflection (Mémoires de la Société Finno-Ougrienne. Vol. 227). Helsinki: Suomalais-Ugrilainen Seura, 1997.

Siegl 2013 - F. Siegl. Materials on Forest Enets, an indigenous language of northern Siberia. (Mémoires de la Société Finno-Ougrienne. Vol. 267.) Helsinki: Suomalais-Ugrilainen Seura, 2013.

Siegl 2014 - F. Siegl. The counterfactive mood in Forest Enets and its origin // Finnisch-Ugrische Forschungen. 2014. Bd. 62. S. 184-206.

Thompson 1994 — G. Thompson. Reporting (Collins COBUILD English Guides. Vol. 5). London: Harper and Collins, 1994.

Venhuizen 2011 - N. J. Venhuizen. Negation in Questions. MSc Thesis. Amsterdam: Universiteit van Amsterdam, 2011. 


\section{References}

Avrorin 1961 - V. A. Avrorin. Grammatika nanayskogo yazyka [Grammar of the Nanai language]. Vol. 2. Moscow; Leningrad: Publishing House of the USSR Academy of Sciences, 1961.

Bechmann 2010 - S. Bechmann. Rhetorische Fragen. München: AVM Verlag, 2010.

Bonnot, Kodzasov 1998 - Ch. Bonnot, S. V. Kodzasov. Semanticheskoe varirovanie diskursivnykh slov i ego vliyanie na linearizatsiyu i intonirovanie (na primere chastits $z h e$ i ved) [The semantic variation of discursive words and its effect on linearization and intonation (on the example of particles zhe and ved)]. K. Kiseleva, D. Paillard (eds.). Diskursivnye slova russkogo yazyka: opyt kontekstno-semanticheskogo opisaniya [Discursive words of the Russian language: contextual-semantic description]. Moscow: Metatekst, 1998. P. 382-443.

Brykina et al 2016 - M. Brykina, V. Gusev, S. Szeverényi, B. Wagner-Nagy. Nganasan Spoken Language Corpus (NSLC). Archived in Hamburger Zentrum für Sprachkorpora. Version 0.1. Publication date 2016-12-23. Available at: http://hdl.handle. net/11022/0000-0001-B36C-C (accessed on 12.11.2020).

Büring, Gunlogson 2000 - D. Büring, C. Gunlogson. Aren't Positive and Negative Polar Questions the Same? Available at: http://hdl.handle.net/1802/1432 (accessed on 12.11.2020).

Burkova 2004 - S. I. Burkova. Obraztsy tekstov na lesnom dialekte nenetskogo yazyka (purovskiy govor) [Samples of texts in the Forest dialect of the Nenets language (Pur variety)]. N. B. Koshkareva, N. N. Shirobokova (eds.). Yazyki korennykh narodov Sibiri [Languages of Indigenous Peoples of Siberia]. Iss. 13: Ekspeditsionnye materialy [Fieldwork materials]. Novosibirsk: Novosibirsk State University Press, 2004. P. 149-162.

Burkova 2008 - S. I. Burkova. Analiticheskie glagolnye formy skazuemogo s modalnym znacheniem $\mathrm{v}$ tekstakh na lesnom dialekte nenetskogo yazyka [Analytical verb forms of the predicate with modal meaning in texts in the Forest dialect of the Nenets language]. Nauchnyy vestnik Yamalo-Nenetskogo AO. 2008. Iss. 6 (58). P. 104-138.

Burkova 2013 - S. I. Burkova. K voprosu o «voprositelnoy» forme -sa v nenetskom yazyke [To the question of the "interrogative" form $-s a$ in the Nenets language]. A. E. Kibrik (ed.), T. B. Agranat, O. A. Kazakevich, E. V. Kashkin (comp.). Lingvisticheskiy bespredel - 2. Sbornik nauchnykh trudov k yubileyu A. I. Kuznetsovoy [Linguistic chaos - 2. Collection of scientific works for the anniversary of A. I. Kuznetsova]. Moscow: Moscow State University Publishing House, 2013. P. 46-65.

Burkova 2016 - S. I. Burkova. O diskursivnykh funktsiyakh enklitiki =ma v tundrovom i lesnom nenetskikh yazykakh [On the discursive functions of the enclitic $=m a$ in the Tundra and Forest Nenets languages]. VI Mezhdunarodnaya konferentsiya po samodistike pamyati A. I. Kuznetsovoy (1932-2015): sbornik tezisov [6 $6^{\text {th }}$ International conference on Samoyedology in memory of A. I. Kuznetsova (1932-2015): book of abstracts]. Moscow: Institute of Linguistics RAS Press, 2016. P. 13-15. 
Burkova $2020-\mathrm{S}$. I. Burkova. O diskursivnykh funktsiyakh enklitik $=m a \mathrm{i}=m$ ? $\mathrm{v}$ tundrovom enetskom yazyke [On the discourse functions of the enclitics $=m a$ and $=m$ ? in Tundra Nenets]. Acta Linguistica Petropolitana. Trudy Instituta lingvisticheskikh issledovaniy. 2020. Vol. XVI. Pt. 3. P. 29-52.

Grèssillon 1980 - A. Grèssillon. Zum linguistischen Status rhetorisher Fragen. Zeitschrift für germanistische Linguistik. 1980. Vol. 8. S. 273-289.

Güldemann 2008 - T. Güldemann. Quotative Indexes in African Languages: A Synchronic and Diachronic Survey. Berlin; New York: Mouton de Gruyter, 2008.

Gusev 2013 - V. Yu. Gusev. Tipologiya imperativa [Typology of imperative]. Moscow: Yazyki slavyanskikh kultur, 2013.

Gusev 2015 - V. Gusev. Negation in Nganasan. M. Miestamo, A. Tamm, B. Wagner-Nagy (eds.). Negation in Uralic languages. Amsterdam: John Benjamins, 2015. P. 103-132.

Hackstein 2016 - O. Hackstein. Negative Interrogatives and Whatnot: The Conversion of Negation in Indo-European. Indo-European Linguistics. 2016. Vol. 4. Iss. 1. P. 150-189.

Helimsky 1994 - E. A. Helimsky. Ocherk morfonologii i slovoizmenitelnoy morfologii nganasanskogo yazyka [Essay on morphophonology and inflectional morphology of the Nganasan language]. E. A. Helimsky (ed.). Taymyrskiy etnolingvisticheskiy sbornik [Taimyr ethnolinguistic volume]. Iss. 1: Materialy po nganasanskomu yazyku i shamanstvu [Materials on Nganasan language and shamanism]. Moscow: Russian State University for Humanities Press, 1994. P. 190-221.

Khanina, Shluinsky forthc. - O. Khanina, A. Shluinsky. Forest and Tundra Enets. To appear in: D. Abondolo, R.-L. Valijärvi (eds.). The Uralic languages. Abingdon: Routledge.

Khanina, Shluinsky mscr. a - O. Khanina, A. Shluinsky. Corpus of Enets texts. Manuscript. Khanina, Shluinsky mscr. b - O. Khanina, A. Shluinsky. Verbal inflection in Enets. Manuscript.

Ladd 1981 - R. D. Ladd. A first look at the semantics and pragmatics of negative questions and tag questions. R. A. Hendrick, C. S. Masek, M. F. Miller (eds.). Papers from the $17^{\text {th }}$ Regional Meeting of the Chicago Linguistic Society. Chicago: Chicago Linguistic Society, 1981. P. 164-171.

Lar, Pushkareva 2001 - I. A. Lar, E. T. Pushkareva. Mify i predaniya nentsev Yamala [Myths and traditions of the Nenets of Yamal]. Tyumen: Publishing House of the Institute for the Development of the North of Siberian Branch of RAS, 2001.

Levontina 2005 - I. B. Levontina. Ob odnoy zagadke chastitsy ved [About one puzzle of the particle ved]. I. M. Kobozeva, A. S. Narinyani, V. P. Selegey (eds.). Trudy Mezhdunarodnoy konferentsii po kompyuternoy lingvistike i intellektualnym tekhnologiyam «Dialog 2005» [Proceedings of the International conference on computational linguistics and intellectual technologies "Dialog-2005"]. Moscow: Nauka, 2005. Available at: http://www.dialog-21.ru/media/2398/levontinai.pdf (accessed on 12.11.2020).

Meibauer 1986 - J. Meibauer. Rhetorische Fragen. Tübingen: Niyemeyer, 1986.

Munshi, Bhatt 2009 - S. Munshi, R. Bhatt. Two locations for negation. Evidence from Kashmiri. J. van Craenenbroeck (ed.). Linguistic Variation Yearbook 9. Amsterdam: Benjamins, 2009. P. 205-240. 
Nikolaeva 2014 - I. Nikolaeva. A grammar of Tundra Nenets. Berlin: Mouton de Gruyter, 2014.

Oskolskaya 2017 - S. A. Oskolskaya. Aspekt v nanayskom yazyke [Aspect in Nanai]. Candidate thesis. St. Petersburg: Institute for Linguistic Studies RAS, 2017.

Paducheva 1985 - E. V. Paducheva. Vyskazyvanie i ego sootnesennost s deystvitelnostyu [Utterance and its correlation with reality]. Moscow: Nauka, 1985.

Paducheva 1996 - E. V. Paducheva. Semanticheskie issledovaniya [Semantic Studies]. Moscow: Yazyki russkoy kultury, 1996.

Pope 1976 - E. N. Pope. Questions and answers in English. (Janua linguarum, Series practica, 226.) The Hague; Paris: Mouton, 1976.

Pushkareva, Khomich 2001 - E. T. Pushkareva, L. V. Khomich. Folklor nentsev [Folklore of the Nenets people]. Novosibirsk: Nauka, 2001.

Romero, Han 2004 - M. Romero Ch.-H. Han. On negative yes/no-questions. Linguistics and Philosophy. 2004. Vol. 27. P. 609-658

Salminen 1997 — T. Salminen. Tundra Nenets inflection (Mémoires de la Société FinnoOugrienne. Vol. 227). Helsinki: Suomalais-Ugrilainen Seura, 1997.

Shluinsky 2010 — A. B. Shluinsky. «Kontrastivnye» glagolnye okonchaniya v lesnom dialekte enetskogo yazyka ["Contrastive" verbal personal inflexions in Forest Enets]. S. I. Burkova (ed.). Materialy 3-y Mezhdunarodnoy konferentsii po samodistike [Proceedings of the $3^{\text {rd }}$ International conference on Samoyedology]. Novosibirsk: Lyubava, 2010. P. 279-291.

Siegl 2013 - F. Siegl. Materials on Forest Enets, an indigenous language of northern Siberia (Mémoires de la Société Finno-Ougrienne. Vol. 267). Helsinki: Suomalais-Ugrilainen Seura, 2013.

Siegl 2014 - F. Siegl. The counterfactive mood in Forest Enets and its origin. Finnisch-Ugrische Forschungen. 2014. Vol. 62. S. 184-206.

Sorokina, Bolina 2005 - I. P. Sorokina, D. S. Bolina. Enetskie teksty [Enets texts]. St. Petersburg: Nauka, 2005.

Stenin 2015 - I. A. Stenin. Grammatika tundrovogo nenetskogo yazyka I. A. Nikolaevoy i problemy opisaniya samodiyskikh yazykov [Grammar of the Tundra Nenets language by I. A. Nikolaeva and problems of describing Samoyedic languages]. Voprosy yazykoznaniya. 2015. No. 4. S. 91-133.

Tereshchenko 1973 - N. M. Tereshchenko. Sintaksis samodiyskikh yazykov [Syntax of Samoyedic languages]. Leningrad: Nauka, 1973.

Thompson 1994 - G. Thompson. Reporting (Collins COBUILD English Guides. Vol. 5). London: Harper and Collins, 1994.

Urmanchieva 2015 - A. Yu. Urmanchieva. Sochetaniya nenetskikh glagolnykh form s emfaticheskoy chastitsey $н \ddot{е} " \sim н ю ”:$ vzaimodeystvie znacheniy [Combinations of Nenets verbal tense forms with the emphatic enclitic нё" $\sim н$ ": the interaction of meanings]. Acta Linguistica Petropolitana. Trudy Instituta lingvisticheskikh issledovaniy. 2015. Vol. XI. Pt. 3. P. 755-773.

Venhuizen 2011 - N. J. Venhuizen. Negation in Questions. MSc Thesis. Amsterdam: Universiteit van Amsterdam, 2011. 


\section{К генезису маркеров вепсских диалектных ареалов*}

\section{Н. Г. Зайцева}

Институт языка, литературы и истории, Карельский научный центр РAH, г. Петрозаводск; zng@ro.ru

Аннотация. В данной статье на материале Лингвистического атласа вепсского языка [ЛАВЯ 2019] представлены примеры лингвистических маркеров, позволяющих очертить диалектные ареалы вепсского языка. Эти маркеры могут иметь фонетический, грамматический либо лексический характер.

Некоторые из них являются прибалтийско-финским наследием, другие - вепсскими инновациями, возникшими в центре вепсского ареала, третьи - результатом контактов языка вепсов с родственными и неродственными языками. Разные комбинации названных факторов составляет характеристику того или иного диалектного ареала.

Исследование выявило значительное единство вепсских диалектных ареалов и проницаемость их границ, а также их безусловную специфику.

Материалы [ЛАВЯ 2019] (150 лингвистических карт и комментариев ареального, этимологического, семантического характера) позволяют сделать выводы относительно формирования диалектной карты языка вепсов в целом, высказать некоторые суждения по поводу их исторической территории. Фонетические карты не позволяют четко обозначить границы, связанные с рефлексацией прибалтийско-финских фонем. Морфологические карты показывают, что прибалтийско-финская система именного словоизменения сохраняется во всех вепсских диалектах (изменения, происходившие в том числе и под влиянием языковых контактов, в наибольшей степени затронули семантику и синтаксические функции именных форм).

В области глагольного словоизменения можно наблюдать как прибалтийско-финские архаизмы, так и собственно вепсские инновации, а также изменения, вызванные контактом с карельским языком (преимущественно северного вепсского диалекта).

Лексические карты фиксируют определенное количество прибалтийско-финских лексем, сохранившихся только на окраинах восточно-вепсской территории. Одновременно с этим, именно здесь фиксируется наибольшее количество субстратной лексики.

Ключевые слова: вепсский язык, лингвистическая география, диалектный ареал, лингвистические маркеры.

\footnotetext{
* Статья подготовлена в рамках выполнения госзадания КарНЦ РАН.
} 


\section{On the genesis of markers of Veps dialectal areas}

\section{N. G. Zaitseva}

Institute of Language, Literature and History, Karelian Scientific Center, Russian Academy of Sciences, Petrozavodsk; zng@ro.ru

Abstract. This article, based on the Linguistic Atlas of the Veps Language (St. Petersburg, 2019), discusses examples of phonetic, grammatical, and lexical linguistic markers of the Veps dialectal areas. Some of them represent Balto-Finnic heritage, others are Veps innovations that arose in the center of the Veps dialect continuum, and yet others are contact-induced changes emerging under the influence of neighboring languages that are both genetically related and unrelated to Veps. Each Veps dialectal area can be characterized by different combinations of these linguistic features. The most significant factors that have shaped the modern dialectal map are landscape-geographical factors associated with migration routes. Administrative borders also contributed to the administrative disunity of the Veps territories.

Materials of the Linguistic Atlas of the Veps Language (150 linguistic maps) open a view to the formation of the Veps dialect map in general and to the picture of the historical Veps territory.

Phonetic maps do not allow a clear outline of the differences in the common Balto-Finnic heritage preservation. For example, the North Veps dialect retained the original long vowels (which may reflect Karelian influence as well) while losing any traces of vowel harmony. The South Veps dialect does not display traces of the primary long vowels and only shows weak signs of vowel harmony.

The Balto-Finnic system of nominal inflection is preserved in all Veps dialects. Its subsequent development and linguistic contacts have slightly affected their nominal forms, mostly in terms of their use and syntactic functions.

In the domain of verbal inflection, one can observe retained components of the Baltic-Finnish heritage, modern Veps innovations, as well as contact-induced changes under the influence of the Karelian (predominantly in the Northern Veps dialect).

Lexical maps show certain Balto-Finnic lexemes that have only survived at the outskirts of the East Veps area, thus demonstrating conservation of ethno-defining features on border territories. It is also there that most of the substratum words are registered.

Keywords: Veps language, linguistic geography, dialect area, linguistic markers.

\section{1. Постановка проблемы}

Вепсы и вепсский язык в поле зрения ученых попали довольно поздно. Их более или менее планомерное исследование началось 
в XIX веке, когда в регионы проживания вепсов были совершены экспедиции, прежде всего, учеными из Финляндии и Эстонии. Отечественная наука начала исследование вепсов и вепсского языка лишь в первой половине XX в. Их планомерное изучение в настоящее время сосредоточено в Институте языка, литературы и истории КарНЦ РАН. Начиная с 1950 г. исследователи Карелии выезжали в экспедиции на земли вепсов более 150 раз, посетив центры ареалов, их окраины и переходные зоны. В Фонограммархиве института хранится более 400 часов магнитофонных записей вепсской диалектной речи, которые в настоящее время все оцифрованы. При этом в словаре диалектов вепсского языка [СВЯ], в образцах вепсской речи, в Корпусе вепсского языка [Корпус] и в Открытом корпусе вепсского и карельского языков [ВепКар], а также в научных трудах использована их незначительная часть. Записи в основном не расшифрованы и поэтому доступны лишь узкому кругу исследователей.

Вепсские диалектные материалы представлены также на картах «Лингвистического атласа Европы» (см., например, [ALE]) и «Лингвистического атласа прибалтийско-финских языков» [ALFE]. Отметим, что в «Лингвистическом атласе Европы», материал для которого был собран, в том числе, и автором данной статьи, вепсские материалы практически невозможно обнаружить. В трехтомном «Лингвистическом атласе прибалтийско-финских языков» [ALFE 2004, 2007, 2010] вепсскому языку отводится важное место. Вепсские материалы здесь использовались активно, хотя вопросник атласа не всегда был направлен на поиск особенностей, касающихся именно языка вепсов (так, именования миноги или морских водорослей, свойственные приморским жителям, в вепсском языке не могли быть обнаружены). И это вполне закономерно, поскольку подобный атлас нацелен на выявление особенностей целых групп языков или диалектов, а более конкретные вопросы должен решать диалектологический атлас отдельно взятого языка.

Идея атласа, посвященного вепсскому языку, зародилась еще в 1940-е годы, когда в Петрозаводске в Институте языка, литературы и истории под руководством Д. В. Бубриха началась работа по подготовке «Атласа карельского языка» (опубликован значительно позднее [Бубрих и др. 1997]). Интерес к диалектам финно-угорских языков у Бубриха появился в конце 1920-х годов, когда он подготовил подробную инструкцию по собиранию материала по мордовским диалектам. В мае 1928 г. Бубрих впервые приехал в Карелию, и в этом же году вышла в свет «Инструкция по собиранию материала по финско-карельским говорам». Позднее были опубликованы первая и вторая редакции 


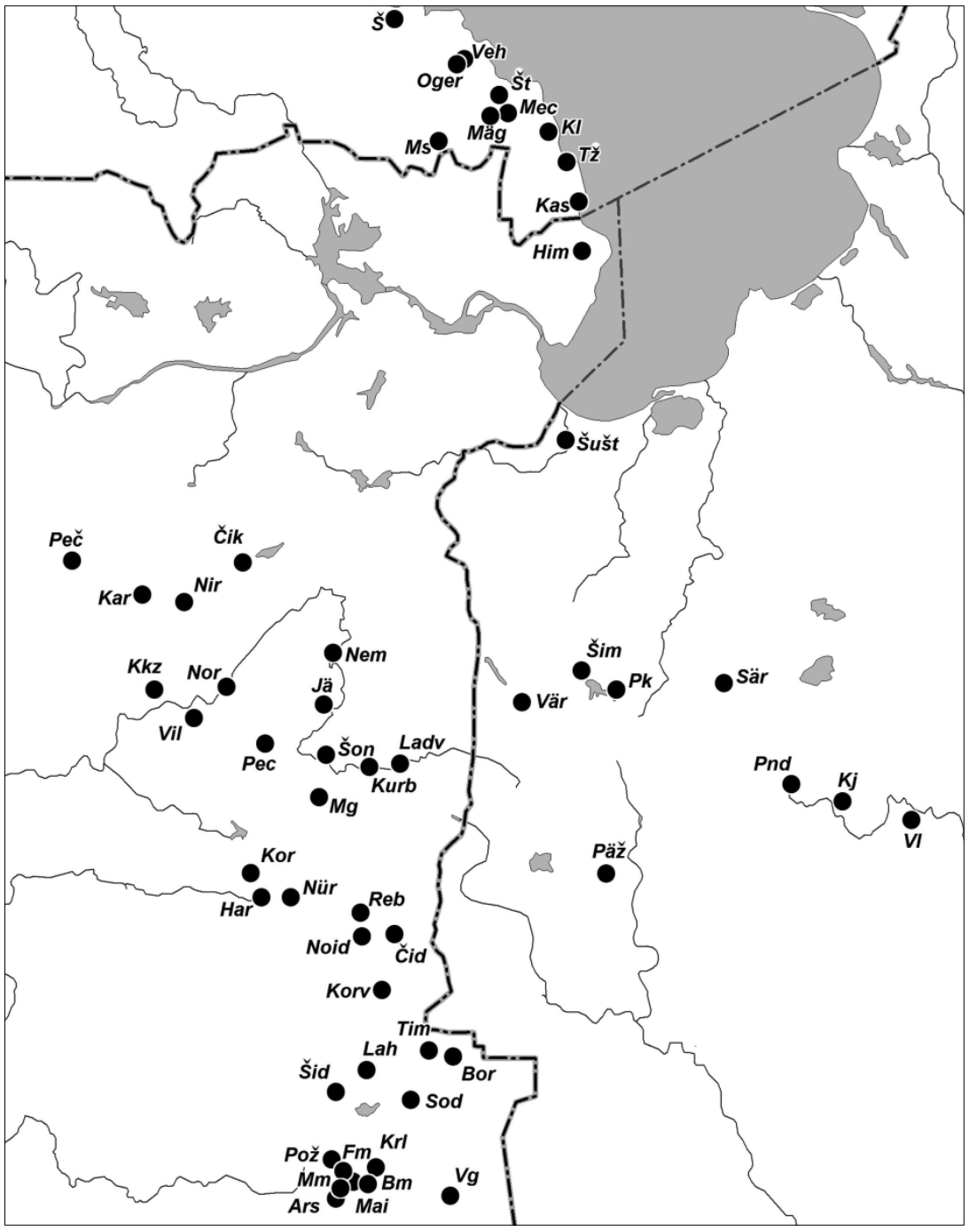

Карта 1. Экспедиционные маршруты сотрудников ИЯЛИ КарНЦ РАН на территории расселения вепсов (1950-2010-е гг.)

Map 1. Expeditionary routes of employees of the Institute of Language and Literature of the Karelian Scientific Center of the Russian Academy of Sciences on the territory inhabited by Vepses (1950-2010s) 


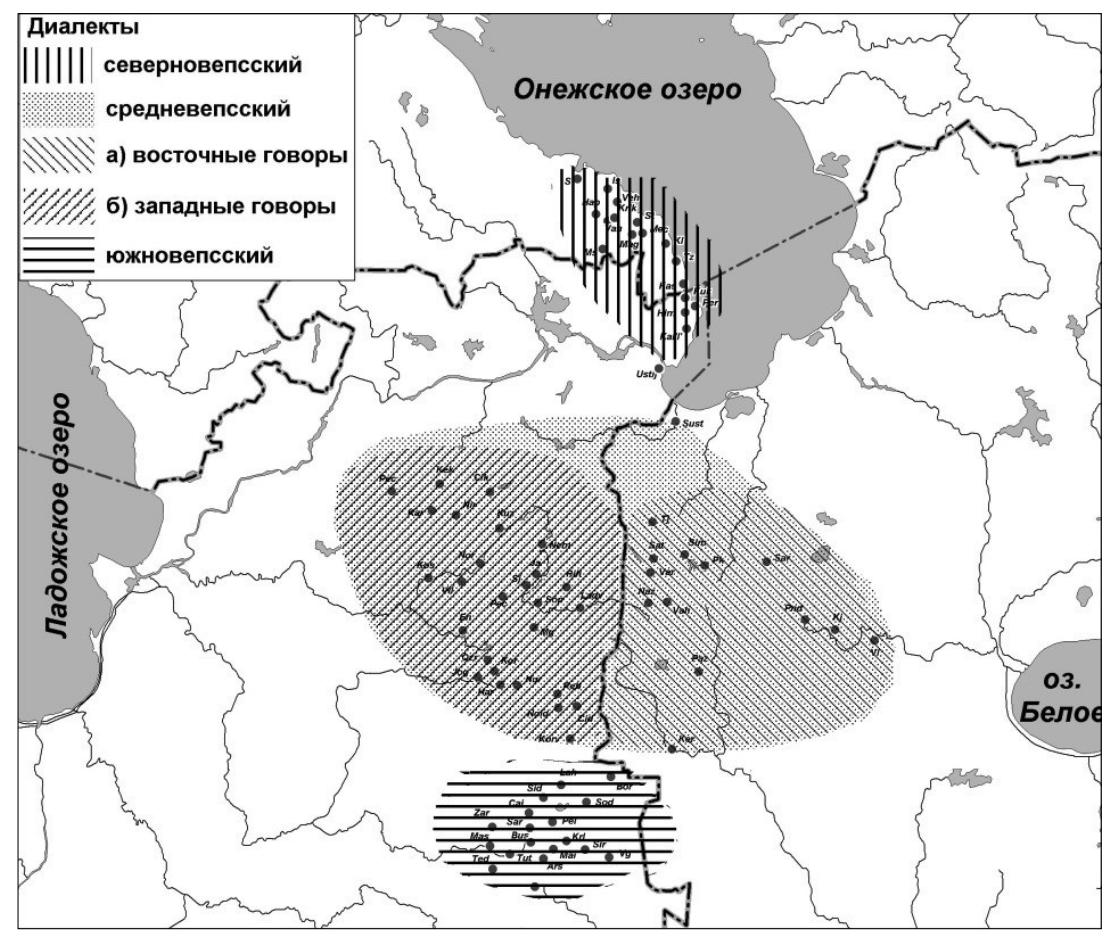

Карта 2. Диалекты вепсского языка

Map 2. Veps dialects

«Программы по собиранию материала для диалектологического атласа карельского языка» [Программа 1937; Программа 1946]. Примечательно, что редактором первого издания программы был исследователь вепсского языка М. М. Хямяляйнен, а в работе над вторым изданием принимал участие вепсолог Н. И. Богданов. Эта работа вдохновила обоих лингвистов на создание вопросника по сбору материала для атласа вепсского языка. Составленный ими пробный вариант анкеты был одобрен, и даже был начат процесс сбора материала, однако ввиду отсутствия кадров для выполнения темы работа не была завершена.

С 2012 года при поддержке РГНФ (позднее РФФИ) в течение шести лет велась работа ${ }^{1}$ по составлению «Лингвистического атласа вепсского языка» и исследованию формирования вепсских диалектных ареалов.

${ }^{1}$ Подготовку атласа осуществляли лингвисты ИЯЛИ КарНЦ РАН (Петрозаводск) с участием коллег из Санкт-Петербурга (ИЛИ РАН и РГПУ им. А. И. Герцена). 
Для атласа было разработано 395 вопросов по фонетике, грамматике, лексике, семантике [Вопросник 2013: 10-45]. К настоящему времени работа завершена, и участниками проекта подготовлено около 150 диалектных карт и комментариев к ним [ЛАВЯ 2019].

Отметим, что основные диалектные особенности вепсского языка науке известны. Однако генезис характерных диалектных различий (далее называемых маркерами), их распределение и участие в формировании диалектных ареалов пока не исследованы достаточным образом. По происхождению все маркеры можно условно разделить на три группы:

1) наследие прибалтийско-финского языка-основы;

2) результат самостоятельного развития вепсского языка;

3) следствия контактов с соседними народами и языками.

Контаминация и набор этих групп маркеров составляет специфику каждого отдельно взятого диалекта или говора. Для нашей статьи мы отобрали в качестве примера ряд маркеров из разных областей языка и представили на основе этого материала некоторые выводы по формированию вепсских диалектных ареалов.

\section{2. Образцы фонетических маркеров}

Фонетика вепсского языка с точки зрения ее исторического развития достаточно хорошо исследована финскими учеными, которые активно использовали ее факты в своих сравнительно-исторических изысканиях. Вепсский язык с легкой руки Д. Е. Д. Европеуса даже получил наименование «прибалтийско-финского санскрита» [Grünthal 2015: 22]. Более современные аспекты вепсской фонетики наиболее подробно изложены в работе известной исследовательницы языка вепсов, одного из авторов раритетного «Словаря вепсского языка» [СВЯ] М. И. Зайцевой, где представлены характеристики звуков и их сочетаний, продемонстрирована их дистрибуция в разных частях слова, показаны модификации звуков в потоке речи, а также проиллюстрированы возможности адаптации русских звуков языком вепсов [Зайцева 1981], что послужило серьезной источниковой базой при составлении фонетических карт [ЛАВЯ 2019].

Ниже представлены материалы лингвистической карты (Карта 3), которая посвящена рефлексам примарных долгих гласных в языке вепсов (на примере гласного $u и$ ). 


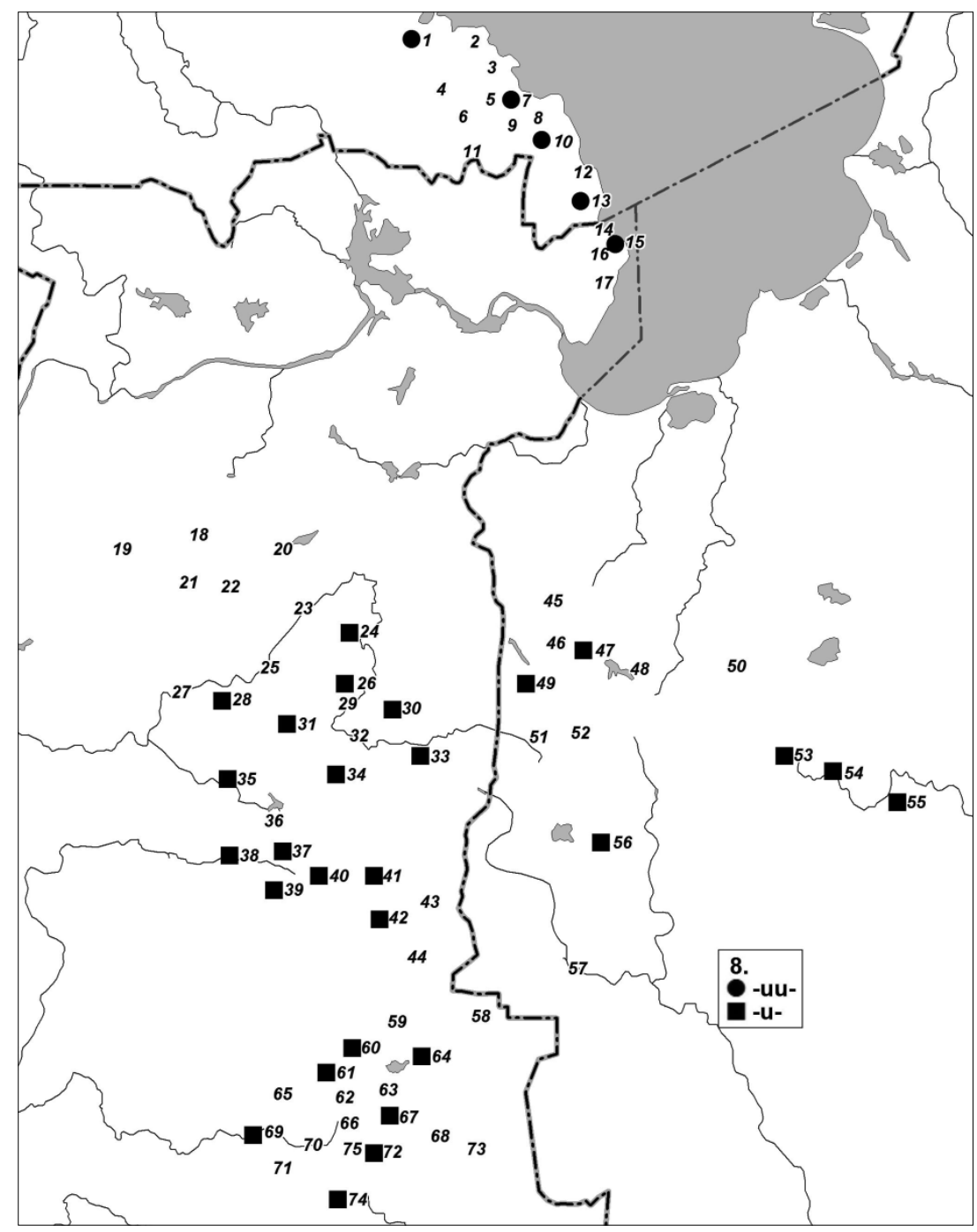

Карта $3\left(8^{2}\right)$. Рефлексы примарного долгого *-ии-

Map 3 (8). Reflexes of the primary long *-uu-

2 Здесь и далее номер карты в круглых скобках соответствует номеру вопроса «Вопросника вепсского языка» [Вопросник 2013: 11]. 
По мнению историков языка, праприбалтийско-финские языки корреляцию по долготе развили в результате исчезновения или вокализации $\eta, v$ или $j$ [Основы 1975: 37]. В эстонском языке она представлена в исходном виде и сейчас, в финском языке на месте долгих гласных в определенных позициях возникли восходящие дифтонги. Карельские наречия характеризуются еще более значительным количеством восходящих дифтонгов или даже трифтонгов, хотя в отдельных говорах имеют место и долгие гласные.

Любопытно отметить, что при расшифровке магнитофонных записей, сделанных в 1959 М. М. Хямяляйненом в д. Куккас на северной окраине западных средневепсских говоров (Лодейнопольский р-н Ленинградской обл.), нам удалось обнаружить повышение гласных среднего подъема: $l \boldsymbol{u} d a$ 'сновать основу ткани; бросать стог' (совр. вепсск. loda, финск. lиoda); juda 'пить' (совр. вепсск. joda, g'oda,

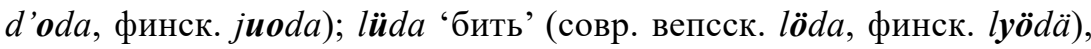

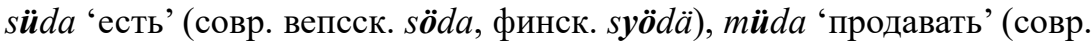

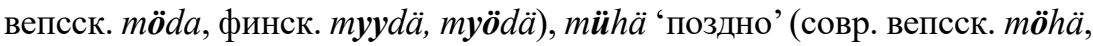
финск. туӛһ̈̈) [Зайцева 2016: 344]. Возможно, названный говор находился на пути образования дифтонгов на месте примарных долгих гласных сам по себе или же такое образование происходило под влиянием карельского языка.

В большинстве диалектов и говоров вепсского языка примарные долгие гласные практически бесследно исчезли. Лишь в ряде слов сохранились следы их былого наличия. Например, переднерядный $\ddot{u}$, по мнению историков языка, мог возникнуть в лексемах типа g'ür' 'корень', которая ранее была заднерядной (ср. финск. јиигі), именно из долгого $u и(\ddot{u}<u u)$ в позиции между двумя палатализованными согласными [Tunkelo 1946: 550-551].

В вопросник атласа вепсского языка были включены вопросы по функционированию долгих гласных *uи, *ü̈, *ii, которые проливали бы свет на распределение их рефлексов в языке современных вепсов. Собранный материал по названным звукам был примерно идентичен, и для лингвистической карты в качестве примера была избрана корреляция $u и \sim u$.

Как свидетельствует лингвистическая Карта 3, долгий гласный сохранился в настоящее время лишь в северновепсском диалекте. В языке северных вепсов можно обнаружить и редкие минимальные пары, в которых слова различаются долготой или краткостью гласных звуков, напр.: рuиhu InesSing существительного рии 'дерево' puhu 
2PSingImperat глагола puhuda 'дуть'. Это явление, однако, не простирается далее первого слога. В первом же слоге, кроме того, на месте примарных долгих гласных могут употребляться полудолгие или дифтонгизированные гласные или даже сочетания гласных с согласными (напр. kuvdman: GenSing существительного kuvdan' ‘луна, месяц'; ср. финск. kuиtaто 'лунный свет' [Tunkelo 1946: 550-551]).

В южновепсском ареале достаточно много случаев наличия долгих гласных, но это долгие гласные вторичного происхождения. Они возникли из дифтонгов, а также из согласных $l, v, n$, которые вокализовались и подверглись дифтонгизации (напр. nituu<nitul 'на покосе'; pertii< pertil 'на доме'; haag < haug (<*halg) 'дрова'; maazik < manzik 'земляника'; haad < haud 'яма'; kaah<kauh 'ковш'; eglaane < eglaine 'вчерашний’ и т. д.). Долгие гласные вторичного происхождения не учитывались на карте. Для южновепсского диалекта совсем не характерны рефлексы примарных долгих гласных, хотя некоторые лингвисты считают южновепсский наиболее архаичным именно с точки зрения системы гласных звуков, напоминающей систему гласных звуков финского языка [Wiik 1989: 17].

Таким образом, примарные долгие гласные, из которых сейчас, как известно, наиболее часто встречаются в односложных словах и первом слоге многосложных слов гласные $u и$, üü, ii: suu 'рот', pü̈̈ 'рябчик', viiž 'пять', kuulišt' '(он) услышал', рuиһu 'в дерево' (см. напр. [Tunkelo 1946: $550])$, - стали маркерами именно северновепсского диалектного ареала, что, возможно, могло быть поддержано также и контактными карельскими говорами.

\section{3. Образцы грамматических маркеров}

Вопросник по сбору материала для атласа вепсского языка содержит более четырех десятков вопросов по грамматике, однако далеко не все из них позволили построить карты. В частности, употребление генитивных конструкций, оформление прямого дополнения, управление глаголов в формах актива и пассива находятся под сильным влиянием русского языка, и диалектных различий здесь не удалось выявить. Синтаксис словосочетания сохранился в диалектах довольно хорошо, однако он практически однороден по диалектам, и никаких значимых диалектных различий здесь обнаружить также не удалось. 
Основные диалектные различия сосредоточены в сфере морфологии. Для примера в данной статье представлена лингвистическая карта, посвященная отрицательной форме имперфекта 3 лица мн. числа. Указанная форма является одной из важнейших, маркирующих диалектные зоны вепсского языка. Она строится, как и в других прибалтийско-финских языках, при помощи отрицательного глагола $e i$ и причастия имперфекта смыслового глагола (в картографируемом случае: ei tonugoi eba tond '[они] не принесли'). Различия в диалектных зонах обнаруживаются в отношении как отрицательного глагола, так и форм причастий; выбор формы зависит, прежде всего, от территориального расположения пункта на карте, его диалектного и языкового окружения.

Как свидетельствует карта, весь южновепсский ареал с примкнувшими к нему смежными говорами средневепсского диалекта (Nür, Noid, Har, Päž, Jog) ${ }^{3}$ обладает формой отрицательного глагола $e b a$. По предположению историков языка, отрицательный глагол в форме $e b a$ по составу даже более древен, нежели финский глагол eivät. В вепсской форме лично-числовое окончание - $b a$ присоединяется непосредственно к основе отрицательного глагола, как было в праязыке, в то время как в финском языке - к форме 3 лица ед. числа имперфекта ei: eivät [Häkkinen 1985: 121]. В одном из южновепсских пунктов (Mas, т. е. Маслозеро), вопросник по которому был заполнен от переселенцев первой половины XX века в Кемеровскую область, удалось зафиксировать отрицательный глагол в форме eibo. На наш взгляд, здесь представлена некая случайная инновация, которая не является параллелью финскому языку, поскольку подобная форма не сохранилась ни в одном из сборников образцов вепсской речи и не представлена более ни в одном южновепсском пункте.

Различия в построении картографируемой формы eba tond ocoбенно наглядно проявляются в фонетических вариациях причастия имперфекта: tond, ton, tot, в котором вариант tond является фонетически наиболее полным вепсским соответствием финской форме tuonut [Tunkelo 1946: 125-126], a ton и tot - ее сокращенными вариантами, утратившими конечные согласные звуки, что с точки зрения вепсского языка вполне объяснимо.

Форма eba tond с вариантами является прибалтийско-финским архаизмом (ср. финск. литературный eivät tuoneet '(они) не принесли').

\footnotetext{
${ }^{3}$ См. «Сокращения названий населенных пунктов ...» в конце статьи.
} 


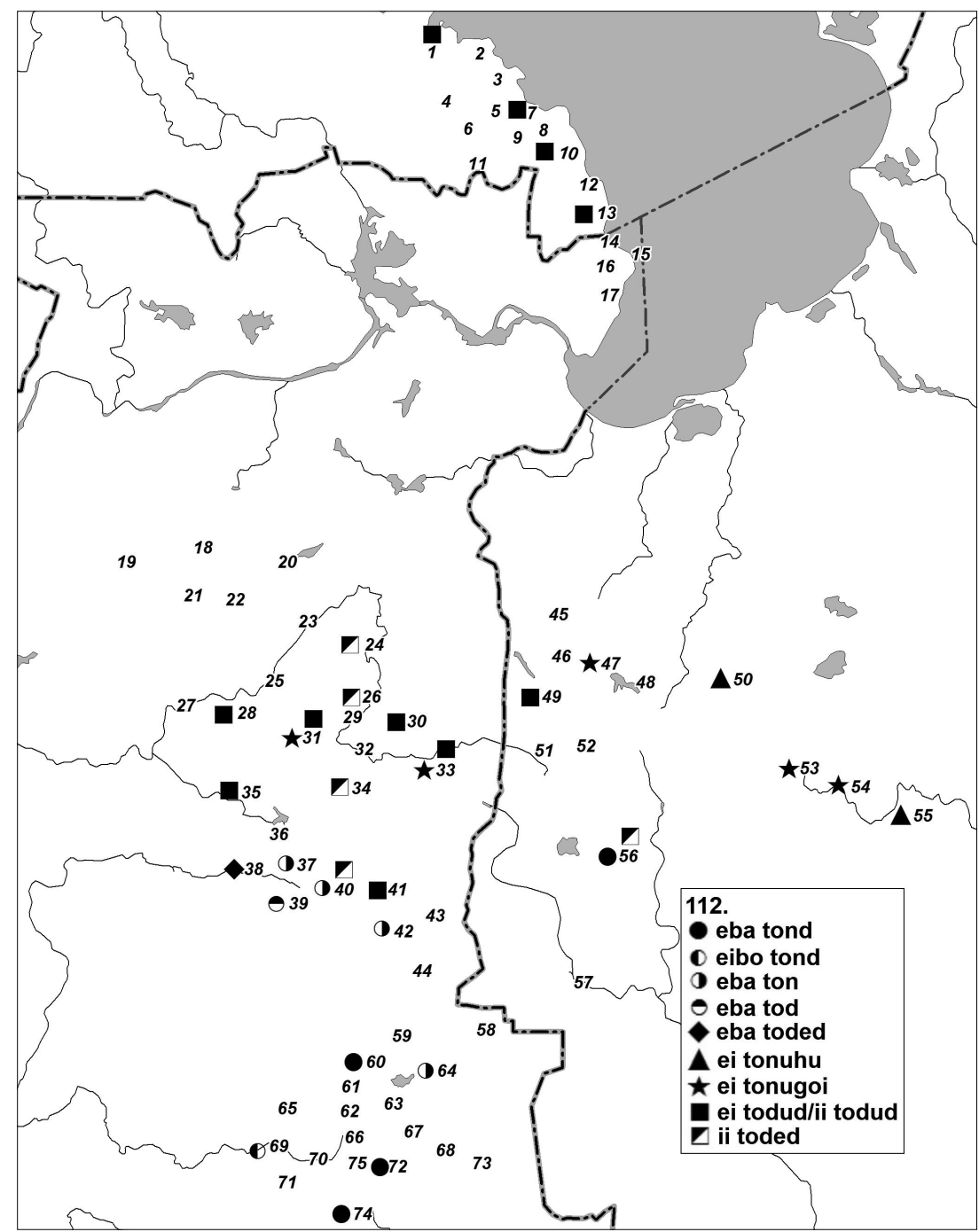

Карта 4 (112). Отрицательная форма имперфекта 3 лица мн. числа индикатива глагола toda '(у)нести’: ‘(они) не (у)несли'

Map 4 (112). Negative 3 P1 Imperfect Indicative of the verb toda 'to carry': 'they did non carry'

Как свидетельствует собранный материал, данная форма маркирует весь южновепсский диалект и переходные говоры средневепсского диалекта Тихвинского р-на (Nür, Jog, Noid). Названный вариант 
представлен также в пункте Пяжозеро (Рӓž, Бабаевский р-н Вологодской обл.), который тяготеет к южновепсской зоне, свидетельствуя о контактах или общем наследии. Любопытно, что этот вариант, наиболее соответствующий праязыковой форме, сохранился в южновепсской ареальной зоне, наиболее удаленной от прочих прибалтийско-финских языков. Очевидно, многие вепсские инновационные процессы до нее не дошли, поскольку были поздними и не настолько мощными.

В нескольких восточных пунктах средневепсского региона ( $\mathrm{Vl}, \mathrm{Kj}$, Sär) в образовании отрицательной формы участвует активное причастие имперфекта с показателем -nuhu (ei toпиhu '(они) не принесли'). Согласный $-h$-, представленный в данном форманте, является рефлексом древнего спиранта $*$, который в ряде языков выпал, в ряде языков развился по модели $* \delta>d$, как это случилось в большинстве вепсских говоров. По мнению историка вепсского языка Тункело [Tunkelo 1946: 211], для вепсского подобные звукопереходы $(* \delta>h)$ не характерны, скорее всего, - это позднее явление, заимствованное уже конкретно из ливвиковского наречия карельского языка. Исследователи полагают, что вблизи данного региона могли быть точечные поселения карелов-ливвиков, откуда и заимствован формант с данным согласным звуком.

Что касается средневепсского диалекта, то в нем при образовании обсуждаемой формы употребителен основной глагол, оформленный показателем -koi, -goi. Этот показатель участвует в образовании именно отрицательных конструкций мн. числа как презенса (em to-goi '[мы] не принесем'), так и имперфекта (em to-nu-goi '[мы] не принесли') и распространен довольно узко [Зайцева 2002: 70-71]. Он является, на наш взгляд, раритетной вепсской инновацией, отсутствующей в родственных языках. В них отрицание выражено только формой отрицательного глагола, а смысловой глагол одинаков в положительной и отрицательной конструкциях (ср. финск. ovat tulleet '(они) пришли', eivät tulleet '(они) не пришли'). В этом случае можно констатировать, что вепсский язык пошел по пути большей формализации явления, стремясь придать отрицательную информацию и смысловому глаголу. Очевидно, отрицательная форма смыслового глагола на -koi -goi получила распространение в центре вепсского региона как своеобразная инновация, но не успела завоевать более широкое пространство, став маркирующей чертой именно центрального вепсского ареала.

В северновепсском диалекте в построении отрицательной формы 3 лица мн. числа имперфекта на месте активного причастия выступает 
причастие пассива с суффиксами -tud $\sim-d u d, \sim-t e d, \sim-t e t:$ ei todud $~$ toded '(они) не принесли', ei pandud panded '(они) не положили'. Здесь наблюдается победа пассивных форм над активными также и в формах презенса и имперфекта 3 лица мн. числа. Это явление особенно свойственно всем наречиям карельского языка, где активная по происхождению форма в этом контексте даже не сохранилась [Зайков 2000: 80-81]; таким образом, в этом случае можно говорить о карельском влиянии на северновепсский диалект.

В переходных говорах средневепсского диалекта, представленных в атласе среди прочего населенным пунктом Jog (Тихвинский р-н, Ленинградская обл.), в качестве отрицательной формы 3 лица мн. числа имперфекта выступает некая инновативная конструкция, в которой отрицательный глагол обладает южновепсской формой $e b a$, а причастие имеет пассивную форму, что характерно для более северных средневепсских говоров и северновепсского диалекта: eba toded. Таким образом, данный пункт, находясь на стыке диалектных регионов, объединяет средне- и южновепсские говоры.

Как известно, угасание употребления активных форм 3 лица мн. числа презенса и имперфекта и расширение употребления в названной функции форм пассива является общей прибалтийско-финской тенденцией. В нашем случае употребление форм пассива в значении личных форм 3 лица мн. числа как презенса, так и имперфекта более всего характерно именно для северновепсского диалекта.

\section{4. Образцы лексических маркеров}

Лексика наиболее наглядно демонстрирует отличительные особенности говоров. В ней переплетаются как собственные инновации, так и инновации, возникающие под влиянием соседствующих языков и говоров, но определяющим все-таки является прибалтийско-финское наследие. В качестве примера можно привести именования понятия 'устать': в северновепсском диалекте и отчасти в восточных средневепсских говорах употребительна лексема $v \ddot{z} z u d a$, в западных средневепсских - surduda, в южновепсских —šsštuda. Как показал анализ, все они относятся к прибалтийско-финскому наследию [Зайцева 2016: 173-175; 298-299], причудливо сохранившись в разных говорах и характеризуя их. 
В качестве примера лексического маркера приведем сведения о названиях волос в языке вепсов (Карта 5 ниже), полученных как в экспедициях, так и из письменных источников. При сборе материала в полевых условиях по именованию понятия 'волосы (на голове)' были выявлены и 'волосы на голове', и 'волосяной покров на теле человека', и отчасти названия волос, которые выглядят неопрятно. Тем не менее было решено нанести на лингвистическую карту [ЛАВЯ 2019] все собранные лексемы, а в списке картографируемого материала и в комментариях поместить разъяснения по данному поводу.

Само понятие 'волосы человека, растущие на голове' в вепсском языке представлено двумя главными лексемами, которые делят вепсскую территорию на две части: средневепсскую и южновепсскую vs. северновепсскую.

В диалекте северных вепсов повсеместно используется лексема $t u k a d$, которая восходит к прибалтийско-финскому корню $t u k k a$ [SKES: 1386; SSA 2000: 323]. В северновепсском диалекте она употребляется в форме мн. числа. В материалах известного финского исследователя вепсского языка Л. Кеттунена, собранных в первой половине XX в. и размещенных в настоящее время на электронном ресурсе [VVS], содержится одна фиксация данного слова в форме ед. числа в северновепсском пункте Урицкое (Per): tuk. В словаре вепсского языка в пункте

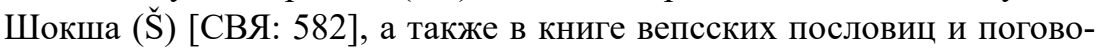
рок, записанных в Вехручье (Veh) [VV: 179], лексема отмечена в форме $t u k k$, с конечным удвоенным согласным. Употребление наименования в форме ед. числа является более древним. Очевидно, что на употребление слова в форме мн. числа оказал влияние русский язык (cp. волосы). Ограниченность ареала лексемы tukad $\sim$ tuk $\sim t u k k$ только северновепсским диалектом, а также наличие варианта с геминатой $-k k$ на конце слова, скорее всего, свидетельствует о влиянии карельского языка (ср. карел. $t u k k a \sim t u k k u$ 'волосы' [KKS 2005: 271]).

Для южно- и средневепсского ареала характерна лексема hibused, употребляемая также в форме мн. числа. Этимологи полагают, что ее следует рассматривать в связи с лексемой hipiä (ср. финск. hipiä 'тело, кожный покров' [SKES: 78; SSA 1992: 168]). Такое сопоставление свидетельствует о том, что лексема hibused ранее вполне могла обладать значением 'волосяной покров на теле'. В северновепсском диалекте она и употребляется чаще в значении 'волосяной покров на теле че-

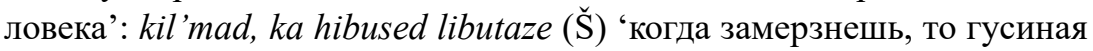
кожа появляется (волоски поднимаются)’ [СВЯ: 118]. 


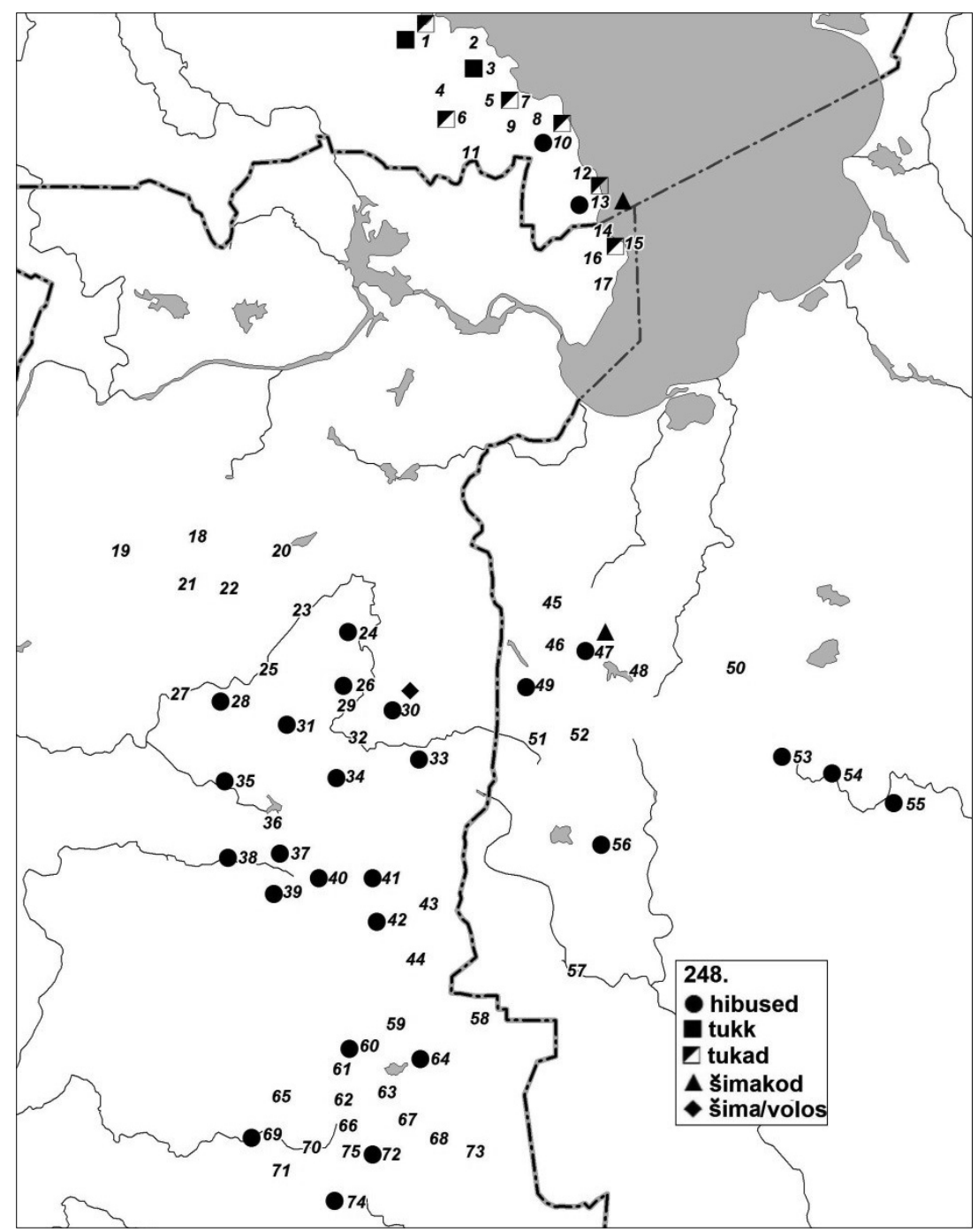

Карта 5. Именования понятия 'волосы на голове'

Map 5. The word for 'hair on the head'

В шимозерском ареале (Вологодская обл., Вытегорский р-н) и отчасти в Присвирье зафиксированы слова šimakod, šima/volos (сложное слово: šima+volos) со значением 'растрепанные, жесткие волосы; растрепа'. Лексема šimakod была отмечена локально и в северновепсском Каскесручье (Kas). Она, очевидно, была занесена туда 
из Шимозерья, поскольку именно на эту территорию переселилась довольно большая группа вепсов в 1950-годы при расселении Шимозерского сельского совета. Другим северновепсским говорам данная лексема неизвестна.

В словаре В. И. Даля отмечены лексемы шима 'верхушка, маковка, темя чего-либо; чуб, космы'; шимоволосый 'косматый, всклоченный' [Даль 1955, Т. 4: 633]. В словаре И. М. Дурова дано существительное шимоволоска с неясным разъяснением: «от девки шимоволоски, от бабы черноволоски» [Дуров 2011: 444]. Слово достаточно широко отмечается в словаре русских говоров Карелии: шимки, шимы 'волосы'и т. д. [СРГК 2005: 869-870]).

М. Фасмер по поводу этой лексемы пишет: шимы 'растрепанные волосы', давая помету «олонецкое» и добавляя, что ее «происхождение неясное» [Фасмер 1973: 438].

С. А. Мызников наряду с иными возможностями предлагает связь лексемы шимы с прибалтийско-финским гнездом siima 'леска; паутина' [Мызников 2003: 105]. Полагаем, что на семантическом уровне это вполне возможно. Вепсский вариант лексемы šimakod представлен в форме мн. числа, и ед. число могло бы звучать как *šimak, где можно выделить словообразовательный суффикс - $(a) k$, продуктивный в языке вепсов в разных сферах (например, nemak 'мыс, полуостров'; ripak 'лоскут, тряпка'; tažlak 'увалень'; kahmak 'мерзляк, мерзлячка' и т. д.). Слово, скорее всего, употреблялось в качестве прозвища человека, у которого растрепаны волосы. Таким образом, можно предположить, что, проникнув, очевидно, из прибалтийско-финских языков в русские говоры, лексема *siima приобрела иной фонетический облик и оттенок в значении и в форме šimak(od) вновь успешно вошла в язык вепсов.

\section{5. Некоторые выводы}

Приведенные в данной статье примеры дают определенное представление о «Лингвистическом атласе вепсского языка» [ЛАВЯ 2019], который включает в себя более 150 карт разного характера: фонетических, грамматических, лексических. Вся совокупность карт дает возможность более точно выявить главные маркеры вепсских диалектных ареалов, исследовать их происхождение, и, соответственно, 
высказать некоторые идеи относительно формирования диалектных ареалов языка вепсов.

Относительно картографирования фонетических рефлексов примарных долгих гласных на примере -uи-, а также других фонетических карт, представленных в [ЛАВЯ 2019], можно отметить, что они не позволяют пока более точно очертить различия в сохранении общеприбалтийско-финского фонетического наследия и его воздействие на формирование диалектных маркеров. Например, северновепсский диалект сохранил исконные долгие гласные (что может быть и карельским влиянием), однако совсем утратил следы гармонии гласных [Зайцева 2016: 60-66]. Южновепсский диалект, считающийся историками языка наиболее последовательно архаичным в отношении сохранения общеприбалтийско-финского наследия, не обнаруживает следов примарных долгих гласных и исключительно слабо представляет также и рефлексы гармонии гласных.

В области грамматики большая часть различий наблюдается в сфере глагольного словоизменения. В именном словоизменении специфика говоров является, если можно так выразиться, поверхностно-фонетической (напр. mechasai mechasā mechasae mechassai 'до леса'; mecaspäi mecaspei mecaspää ‘из леса' и т. д.). Можно констатировать, что древнюю общеприбалтийско-финскую систему именного словоизменения вепсский язык во всех своих диалектах сохранил достаточно хорошо. Его последующее развитие и языковые контакты незначительно отразились на формах имени, больше сказавшись на их употреблении и синтаксических функциях.

Как уже сказано, больше изменений наблюдается в сфере глагольной морфологии. Как свидетельствуют исследования в области исторической грамматики глагола [Зайцева 2002], а также работа по составлению карт [ЛАВЯ 2019], в глагольном словоизменении можно наблюдать и прибалтийско-финские архаизмы (например, отрицательная форма 3 лица ед. числа имперфекта, cp. eba tulend '(они) не пришли'), и вепсские инновации (формант -koi -goi в отрицательных формах смысловых глаголов), и влияние карельского языка, проявившееся особенно наглядно в вытеснении в северновепсском диалекте активных форм презенса и имперфекта, замещенных пассивными по происхождению. Наши выводы о карельском влиянии совпадают с мнением этнолога И. Ю. Винокуровой, согласно которому «с XV века прионежские вепсы с севера и запада находились в непосредственном окружении карельского населения и, как показывают этнографические 
данные, испытывали с его стороны заметное влияние» [Винокурова 2015: 177-178].

Лексические карты [ЛАВЯ 2019] иллюстрируют диалектное разнообразие в отношении общего прибалтийско-финского словарного фонда, характеризуя отдельные диалекты (см. в данном случае tukad hibused 'волосы на голове'), а также представляют следы языковых контактов (šimakod 'растрепанные волосы'). Часть же лексем, которые удалось обнаружить и исследовать при составлении атласа [ЛАВЯ 2019] и которые находятся за пределами данной статьи, можно охарактеризовать как инновативные (например, kurktuda 'сердиться', čigičaine ‘черная смородина' и т. д.). Любопытно, что какое-то количество прибалтийско-финских лексем сохранилось лишь на окраине восточновепсской территории, у белозерских вепсов (V1, Kj, Pnd, Sär: kü 'змея', $s a i$ 'свадьба', mod 'лицо', hul 'горячий', tomu 'пыль' и т. д.), демонстрируя в соответствии с универсальной закономерностью консервацию этноопределяющих признаков на пограничной территории и стремление к сохранению своей собственной языковой системы. Чаще всего именно в этом регионе отмечены также и довольно редкие слова типа роz'a 'сырое болотистое место', uhring urting 'родник' и т. д., которые являются, очевидно, субстратными, пока не поддающимися этимологизации. Топонимия этих мест позволяет обнаружить «наследие целого ряда финно-угорских народов и народностей, при этом о большинстве из них приходится говорить в прошедшем времени» [Муллонен 2006: 63], что могло сказаться и на происхождении именно названных говоров.

\section{Список условных сокращений}

Названия идиомов: вепс. - вепсский; карел. — карельский; обл. — область; p-н — район; с/в — северновепсский; ср/в — средневепсский; финск. - финский; ю/в - южновепсский.

\section{Индексы населенных пунктов:}

Čik (20) - Čikl (Чикозеро), Подпорожский р-н, Ленинградская обл. (ср/в, западный);

En (35) - Enar'v (Вонозеро), Лодейнопольский р-н, Ленинградская обл. (cp/в, западный); 
Jog (38) - Jogens (Усть-Капша), Тихвинский р-н, Ленинградская обл. (ср/в, западный);

Kar (21) - Karhil (Каргиничи), Подпорожский p-н, Ленинградская обл. (cp/в, западный);

Kas (13) - Kaskezoja (Каскесручей), Прионежский р-н, Республика Карелия (с/в);

Кј (54) — Кија (Куя), Бабаевский р-н, Вологодская обл. (ср/в, восточный);

Korv (44) - Korval (Корвала), Подпорожский p-н, Ленинградская обл. (ср/в, западный);

$\operatorname{Ladv}(33)$ - Ladv (Ладва), Подпорожский p-н, Ленинградская обл. (ср/в, западный);

Mas (69) - Maslagj (Маслозеро), Бокситогорский p-н, Ленинградская обл. (ю/в);

Noid (42) - Noidal (Нойдала), Тихвинский р-н, Ленинградская обл. (ср/в, западный);

Nür (40) - Nürgl (Нюрговичи), Тихвинский p-н, Ленинградская обл. (ср/в, западный);

Per (15) - Pervakat (Урицкая), Подпорожский р-н, Ленинградская обл. (с/в);

Pnd (53) - Pondal (Пондала), Бабаевский р-н, Вологодская обл. (ср/в, восточный);

Päž (56) — Päžar' (Пяжозеро), Бабаевский р-н, Вологодская обл. (ср/в, восточный);

Sär (50) - Särgjärv (Сяргозеро), Бабаевский p-н, Вологодская обл. (ср/в, восточный);

Š (1) — Šokš (Шокша), Прионежский p-н, Республика Карелия (с/в);

Veh (3) - Vehkoja (Вехручей), Прионежский р-н, Республика Карелия (с/в);

Vil (28) — Vil'häl (Ярославичи), Подпорожский р-н, Ленинградская обл. (cp/в, западный);

Vl (55) — Voilaht (Войлахта), Бабаевский р-н, Вологодская обл. (ср/в, восточный).

\section{Литература}

Аристэ 1953 - П. Аристэ. Примечания // Л. Хакулинен. Развитие и структура финского языка. Т. І. М.: Издательство иностранной литературы, 1953. С. 290-306.

Бубрих и др. 1997 - Д. В. Бубрих, А. А. Беляков, А. В. Пунжина. Диалектологический атлас карельского языка. Helsinki: Suomalais-Ugrilainen Seura, 1997.

ВепКар - Открытый корпус вепсского и карельского языков (электронный ресурс). URL: http://dictorpus.krc.karelia.ru/ru (дата обращения 06.12.2020).

Винокурова 2008 - И. Ю. Винокурова. Вепсско-карельские контакты в Бабаевском и Вытегорском районах Вологодской области (по данным народной демонологии) // О. П. Илюха, И. И. Муллонен (ред.). Границы и контактные зоны в истории и культуре Карелии и сопредельных регионов. Петрозаводск: КарНЦ РАН, 2008. С. 104-115.

Винокурова 2015 - И. Ю. Винокурова. Мифология вепсов. Энциклопедия. Петрозаводск: Издательство ПетрГУ, 2015.

Вопросник 2013 - Вопросник «Лингвистического атласа вепсского языка» // Н. Г. Зайцева, С. А. Мызников (ред.). Вепсские ареальные исследования. Петрозаводск: КарНЦ РАН, 2013. С. 7-45. 
Даль 1955 - В. И. Даль. Толковый словарь живого великорусского языка. T. I-IV. М.: ГИС, 1955.

Дуров 2011 - И. М. Дуров. Словарь живого поморского языка в его бытовом и этнографическом применении. Петрозаводск: КарНЦ РАН, 2011.

Зайков 2000 - П. М. Зайков. Глагол в карельском языке. Петрозаводск: Издательство ПетрГУ, 2000.

Зайцева 1981 - М. И. Зайцева. Грамматика вепсского языка. Л.: Наука, 1981.

Зайцева 2002 - Н. Г. Зайцева. Вепсский глагол. Сравнительно-сопоставительное исследование. Петрозаводск: Периодика, 2002.

Зайцева 2016 - Н. Г. Зайцева. Очерки вепсской диалектологии (лингвогеографический аспект). Петрозаводск: КарНЦ РАН, 2016.

Корпус - Корпус вепсского языка (электронный ресурс). URL: http://vepsian.krc. karelia.ru (дата обращения 14.11.2020)

ЛАВЯ 2019 - Н. Г. Зайцева, И. И. Муллонен, С. А. Мызников, О. Ю. Жукова, И. В. Бродский, Н. Л. Шибанова (сост.); Н. Г. Зайцева (ред.). Лингвистический атлас вепсского языка. СПб.: Нестор-История, 2019.

Муллонен 2006 - И. И. Муллонен. Топонимические этюды вологодской земли // А. Н. Башенькин (ред.). Вепсы: история, культура, современность. Вологда: Областной научно-методический центр культуры и повышения квалификации, 2006. С. 68-71.

Мызников 2003 - С. А. Мызников. Атлас субстратной и заимствованной лексики русских говоров Северо-Запада. СПб.: Наука, 2003.

Основы 1975 - В. И. Лыткин, К. Е. Майтинская, К. Редеи, Я. Гуя, А. П. Феоктистов, Г. И. Ермушкин (ред.). Основы финно-угорского языкознания. Прибалтийско-финские, саамский и мордовские языки. М.: Наука, 1975.

Программа 1937 - М. М. Хямяляйнен (ред.). Программа по собиранию материала для диалектологического атласа карельского языка. Петрозаводск: Карельский научно-исследовательский институт культуры, 1937.

Программа 1946 - В. И. Алатырев (ред). Программа по собиранию материала для диалектологического атласа карельского языка. Второе издание, дополненное при участии Н. А. Анисимова, Е. Н. Симаковой, Н. И. Богданова. Петрозаводск: Государственное издательство Карело-Финской ССР, 1946.

Пунжина 1994 - А. В. Пунжина. Словарь карельского языка (тверские говоры). Петрозаводск: Карелия, 1994.

СВЯ - М. И. Зайцева, М. И. Муллонен. Словарь вепсского языка. Л.: Наука, 1972.

СРГК - А. С. Герд. (ред.). Словарь русских говоров Карелии и сопредельных областей. Вып. 6. СПб.: Издательство Санкт-Петербургского гос. университета, 2005.

Фасмер 1973 - М. Фасмер. Этимологический словарь русского языка. Т. IV. М.: Прогресс, 1973.

Ahlqvist 1861 - A. Ahlqvist. Anteckningar i Nors-tschudiskan (Acta societatis scientiarum Fennicae. Vol. 6) Helsingfors: H. C. Friis, 1861.

ALE - Atlas Linguarum Europae. Vol. I. Fasc. I: Cartes et Commentaires. Assen: Van Gorcum, 1983. 
ALFE - Atlas Linguarum Fennicarum. T. I-III. Helsinki: Suomalaisen Kirjallisuuden Seura, 2004, 2007, 2010.

Grünthal 2015 - R. Grünthal. Vepsän kielioppi. Helsinki: Suomalais-Ugrilainen Seu$\mathrm{ra}, 2015$.

Hakulinen 1979 — L. Hakulinen. Suomen kielen rakenne ja kehitys. Helsinki: Otava, 1979.

Häkkinen 1985 - K. Häkkinen. Suomen kielen äänne- ja muotorakenteen historiallista taustaa. Turku: Åbo Akademi, 1985.

KKS - Karjalan kielen sanakirja. T. I-VI (Lexica Societatis Fenno-Ugricae. Vol. XVI). Helsinki: Suomalais-Ugrilainen Seura, 1968-2005.

Lönnrot 1853 - E. Lönnrot. Om det Nord-tschudiska språket. Helsingfors: Tryck hos J. C. Frenckell, 1853.

SKES - Suomen kielen etymologinen sanakirja. T. I-VII. Helsinki: Suomalais-Ugrilainen Seura, 1955-1981.

SSA - Suomen sanojen alkuperä. Etymologinen sanakirja. T. I-III. Jyväskylä: Suomalaisen Kirjallisuuden Seura, 1992-2000.

Tunkelo 1946 - E. A. Tunkelo. Vepsän kielen äännehistoria (Suomalaisen Kirjallisuuden Seuran Toimituksia. Vol. 228). Helsinki: Suomalaisen Kirjallisuuden Seura, 1946.

VV — V. Mälk, A. Hussar, A. Kährik, T.-R. Viitso (koost.), V. Oja (kuj. ja kaard). Vepsa vanasõnad. T. I-II. Tallinn: Eesti Teaduste Akademia, Keele ja Kirjanduse Instituu, 1992.

VVS - Vepsän verkkosanasto (электронный ресурc). URL: http://kaino.kotus.fi/sanat/vepsa (дата обращения 14.11.2020).

Wiik 1989 - K. Wiik. Vepsän vokaaalisontu. Helsinki: Suomalaisen Kirjallisuuden Seura, 1989.

\section{References}

Ahlqvist 1861 - A. Ahlqvist. Anteckningar i Nors-tschudiskan (Acta societatis scientiarum Fennicae. Vol. 6). Helsingfors: H. C. Friis, 1861.

ALE - Atlas Linguarum Europae. Vol. I. Fasc. I: Cartes et Commentaires. Assen: Van Gorcum, 1983.

ALFE - Atlas Linguarum Fennicarum. T. I-III. Helsinki: Suomalaisen Kirjallisuuden Seura, 2004, 2007, 2010.

Ariste 1953 - P. Ariste. Primechaniya [Notes]. L. Hakulinen. Razvitie i struktura finskogo yazyka [Development and structure of the Finnish language]. Vol. I. Moscow: Foreign Literature Publishing House, 1953. P. 290-306.

Bubrikh et al. 1997 - D. V. Bubrikh, A. A. Belyakov, A. V. Punzhina. Dialektologicheskiy atlas karelskogo yazyka [Dialectological atlas of the Karelian language]. Helsinki: Suomalais-Ugrilainen Seura, 1997.

Dal 1955 - V. I. Dal. Tolkovyy slovar zhivogo velikorusskogo yazyka [Explanatory Dictionary of the Living Great Russian Language]. Vol. I-IV. Moscow: State Publishing House of Dictionaries, 1955. 
Durov 2011 - I. M. Durov. Slovar zhivogo pomorskogo yazyka v ego bytovom i etnograficheskom primenenii [Dictionary of the living Pomor language in its everyday and ethnographic application]. Petrozavodsk: Karelian Scientific Center of the Russian Academy of Sciences, 2011.

Fasmer 1973 - M. Fasmer. Etimologicheskiy slovar russkogo yazyka [Etymological dictionary of the Russian language]. Vol. IV. Moscow: Progress, 1973.

Grünthal 2015 - R. Grünthal. Vepsän kielioppi. Helsinki: Suomalais-Ugrilainen Seura, 2015.

Hakulinen 1979 — L. Hakulinen. Suomen kielen rakenne ja kehitys. Helsinki: Otava, 1979.

Häkkinen 1985 - K. Häkkinen. Suomen kielen äänne- ja muotorakenteen historiallista taustaa. Turku: Åbo Akademi, 1985.

KKS - Karjalan kielen sanakirja. T. I-VI. Helsinki: Suomalais-Ugrilainen Seura, 1968-2005.

Korpus - Korpus vepsskogo yazyka [Veps corpora]. Available at: http://vepsian.krc. karelia.ru (accessed on 14.11.2020).

LAVYA 2019 - N. G. Zaytseva, I. I. Mullonen, S. A. Myznikov, O. Ju. Zhukova, I. V. Brodskiy, N. L. Shibanova (comp.); N. G. Zaytseva (ed.). Lingvisticheskiy atlas vepsskogo yazyka [Linguistic atlas of the Veps language]. St. Petersburg: Nestor-Istoriya, 2019.

Lönnrot 1853 - E. Lönnrot. Om det Nord-tschudiska språket. Helsingfors: Tryck hos J. C. Frenckell, 1853.

Mullonen 2006 - I. I. Mullonen. Toponimicheskie etyudy vologodskoy zemli [Toponymic Studies of the Vologda Land]. A. N. Bashenkin (ed.). Vepsy: istoriya, kultura, sovremennost [Vepses: history, culture, current state]. Vologda: Regional scientific and methodological center of culture and advanced training, 2006. P. 68-71.

Myznikov 2003 - S. A. Myznikov. Atlas substratnoy i zaimstvovannoy leksiki russkikh govorov Severo-Zapada [Atlas of substrate and borrowed vocabulary of Russian dialects of the North-West]. St. Petersburg: Nauka, 2003.

Osnovy 1975 - V. I. Lytkin, K. E. Maytinskaya, K. Rédei, J. Gulya, A. P. Feoktistov, G. I. Ermushkin (eds.). Osnovy finno-ugorskogo yazykoznaniya. Pribaltiysko-finskie, saamskiy i mordovskie yazyki [Basics of Finno-Ugric linguistics. Finnic, Sami and Mordovian languages]. Moscow: Nauka, 1975.

Programma 1937 — M. M. Hämäläinen (ed.). Programma po sobiraniyu materiala dlya dialektologicheskogo atlasa karelskogo yazyka [The program for collecting material for the dialectological atlas of the Karelian language]. Petrozavodsk: Karelian Scientific-Research Institute of Culture, 1937.

Programma 1946 - V. I. Alatyrev (ed.). Programma po sobiraniyu materiala dlya dialektologicheskogo atlasa karelskogo yazyka [The program for collecting material for the dialectological atlas of the Karelian language]. Second edition supplemented with the participation of N. A. Anisimov, E. N. Simakova, N. I. Bogdanov. Petrozavodsk: State Publishing House of the Karelian-Finnish SSR, 1946.

Punzhina 1994 - A. V. Punzhina. Slovar karelskogo yazyka (tverskie govory) [Dictionary of the Karelian language (Tver dialects)]. Petrozavodsk: Kareliya, 1994. 
SKES — Suomen kielen etymologinen sanakirja. T. I-VII. Helsinki: Suomalais-Ugrilainen Seura, 1955-1981.

SRGK - A. S. Gerd (ed.). Slovar russkikh govorov Karelii i sopredelnykh oblastey [Dictionary of Russian dialects of Karelia and adjacent areas]. Iss. 6. St. Petersburg: St. Petersburg State University Publishing House, 2005.

SSA - Suomen sanojen alkuperä. Etymologinen sanakirja. T. I-III. Jyväskylä: Suomalaisen Kirjallisuuden Seura, 1992-2000.

SVYa - M. I. Zaytseva, M. I. Mullonen. Slovar vepsskogo yazyka [Veps Dictionary]. Leningrad: Nauka, 1972.

Tunkelo 1946 - E. A. Tunkelo. Vepsän kielen äännehistoria (Suomalaisen Kirjallisuuden Seuran Toimituksia. Vol. 228). Helsinki: Suomalaisen Kirjallisuuden Seura, 1946.

VepKar - Open Corpus of Vepsian and Karelian languages (electronic resource). Available at: http://vepsian.krc.karelia.ru (accessed on 06.12.2020).

Vinokurova 2008 - I. Yu. Vinokurova. Vepssko-karelskie kontakty v Babaevskom i Vytegorskom rayonakh Vologodskoy oblasti (po dannym narodnoy demonologii) [Veps-Karelian contacts in Babaevsky and Vytegorsky districts of the Vologda Region (according to folk demonology)]. O. P. Ilyukha, I. I. Mullonen (eds.). Granitsy $i$ kontaktnye zony $v$ istorii $i$ kulture Karelii i sopredelnykh regionov [Borders and contact zones in the history and culture of Karelia and adjacent regions]. Petrozavodsk: Karelian Scientific Center of the Russian Academy of Sciences, 2008. P. 104-115.

Vinokurova 2015 - I. Yu. Vinokurova. Mifologiya vepsov. Entsiklopediya [The mythology of the Veps. Encyclopedia]. Petrozavodsk: Petrozavodsk State University Press, 2015.

Voprosnik 2013 - Voprosnik «Lingvisticheskogo atlasa vepsskogo yazyka» [Questionnaire of the "Linguistic Atlas of the Veps language"]. N. G. Zaytseva, S. A. Myznikov (eds.). Vepsskie arealnye issledovaniya [Veps areal studies]. Petrozavodsk: Karelian Scientific Center of the Russian Academy of Sciences, 2013. P. 7-45.

VV - V. Mälk, A. Hussar, A. Kährik, T.-R. Viitso (koost.), V. Oja (kuj. ja kaard). Vepsa vanasõnad. T. I-II. Tallinn: Eesti Teaduste Akademia, Keele ja Kirjanduse Instituu, 1992.

VVS - Vepsän verkkosanasto. Available at: http://kaino.kotus.fi/sanat/vepsa/ (accessed on 14.11.2020).

Wiik 1989 - K. Wiik. Vepsän vokaaalisontu. Helsinki: Suomalaisen Kirjallisuuden Seura, 1989.

Zaykov 2000 - P. M. Zaykov. Glagol v karelskom yazyke [Verb in the Karelian language]. Petrozavodsk: Petrozavodsk State University Press, 2000.

Zaytseva 1981 - M. I. Zaytseva. Grammatika vepsskogo yazyka [Grammar of the Veps language]. Leningrad: Nauka, 1981.

Zaytseva 2002 - N. G. Zaytseva. Vepsskiy glagol. Sravnitelno-sopostavitelnoe issledovanie [Veps verb. Comparative and contrastive study]. Petrozavodsk: Periodika, 2002.

Zaytseva 2016 - N. G. Zaytseva. Ocherki vepsskoy dialektologii (lingvogeograficheskiy aspekt) [Essays on Veps dialectology (aspects of linguistic geography)]. Petrozavodsk: Karelian Scientific Center of the Russian Academy of Sciences, 2016. 


\section{'На столе сидит чашка': \\ о контактных изменениях в коми-ижемских говорах Ямало-Ненецкого АО*}

\section{Е. В. Кашкин}

Институт русского языка им. В. В. Виноградова РАН, Москва; egorka1988@gmail.com

\section{Н. А. Муравьев}

Национальный исследовательский университет «Высшая школа экономики», Москва; nikita.muraviev@gmail.com

Аннотация. В статье рассматриваются изменения в коми-ижемских говорах Ямало-Ненецкого АО, предположительно происходящие под влиянием ненецкого и хантыйского языков. Материал собран в ходе полевой работы в 2008-2017 гг., также учтены некоторые архивные данные. Показано, что контактное влияние проявляет себя не только в лексических заимствованиях, но и в калькировании фрагментов языковой структуры (моделей полисемии лексических единиц, закономерностей фонотактики и др.). Обсуждаются некоторые социолингвистические предпосылки контактно обусловленных изменений.

Ключевые слова: коми язык, ижемский диалект, хантыйский язык, ненецкий язык, заимствования, кальки, контактное влияние, социолингвистика, ареальная лингвистика.

* Сбор данных ижемского диалекта коми языка поддержан грантом РГНФ № 1404-00476. Анализ материала и подготовка статьи поддержаны грантом РФФИ № 19012-00627. 


\title{
'A cup is sitting on the table': On the contact-induced change in the subdialects of Izhma Komi spoken in the Yamalo-Nenets Autonomous District
}

\section{E. V. Kashkin}

V. V. Vinogradov Russian Language Institute of the Russian Academy of Sciences, Moscow; egorka1988@gmail.com

\section{N. A. Muravyev}

National Research University Higher School of Economics, Moscow; nikita.muraviev@gmail.com

\begin{abstract}
The article deals with possible cases of contact-induced change in the subdialects of Izhma Komi spoken in the Yamalo-Nenets autonomous district along with Tundra Nenets and Western Khanty. The data were collected during our 20082017 field trips by elicitation (collection of wordlists, checking the collocational properties of lexical items, etc.) and by analyses of the field-recorded texts; some archival materials were taken into account as well. Our data are compared with the published data on various Komi dialects. We argue that the influence of Tundra Nenets and Western Khanty on Izhma Komi not only results in lexical borrowing (e.g., in the domain of reindeer herding), which has previously been the main point of discussion in the literature, but also in some formal or semantic changes in the borrowed lexemes or patterns. This means that the degree of interaction between Izhma Komi and the neighbouring languages can be higher than it was claimed previously. Pattern borrowing can be related to lexeme polysemy (e.g., the verbs for sitting or standing, some animal names which also involve certain cultural taboos borrowing), phonotactic features (e.g., avoidance of hiatus, consonant devoicing in the final position), grammatical construction properties (e.g., possessive constructions). Some examples analyzed involve Izhma Komi's interactions not only with Tundra Nenets / Western Khanty, but also with Russian (e.g., this is the case for some kinship terms). The sociolinguistic conditions of the possible contact-induced change are also discussed, such as the set of languages actively used in a particular village or area, the existence of mixed families and/or mixed reindeer herding communities.
\end{abstract}

Keywords: Komi, Izhma dialect, Khanty, Nenets, borrowing, calquing, contact-induced change, sociolinguistics, areal linguistics. 


\section{1. Введение}

Работа посвящена анализу контактно обусловленных изменений в коми-ижемских говорах Ямало-Ненецкого автономного округа (ЯНАО). Территория ЯНАО является многоязычной. Исконно ее населяют носители двух языков самодийской ветви - ненецкого (в северной части) и селькупского (в восточной части), - а также хантыйского языка (финно-угорская ветвь, распространен в западной и северо-западной частях округа). Помимо них, в Ямало-Ненецком округе проживают носители ижемского диалекта коми языка, переселившиеся с Европейской территории РФ. Согласно наиболее принятой точке зрения [Жеребцов 1982; Повод 2006], основная волна переселения происходила в XIX в. (начиная с его первой трети). Сейчас, по данным переписи населения 2010 г., на территории ЯНАО насчитывается около 5000 представителей народа коми, из них владеет языком около 2000. Попав в новую для себя языковую и культурную среду, коми-ижемцы, благодаря вступлению в смешанные браки и работе в смешанных оленеводческих бригадах, стали осваивать и языки коренного населения ЯНАО - ненецкий и хантыйский. В настоящее время результаты этой контактной ситуации оказываются серьезно затемнены в силу интенсивного влияния русского языка (и его статуса как основного языка межнационального общения), а также повсеместной утраты родного языка представителями молодого и среднего поколений зауральских коми-ижемцев. Тем не менее некоторые из этих результатов еще сохранны в современных говорах, а в отдельных районах поддерживаются существованием смешанных семей и оленеводческих бригад, где коми-ижемцы пользуются ненецким языком. Именно об изменениях, которые могут быть обусловлены влиянием ненецкого или хантыйского языка, и пойдет речь в этой работе.

Материал для статьи собран в экспедициях в места проживания коми-ижемцев ЯНАО, проводимых с 2008 г. (результатом первого этапа этих экспедиций стал словарь [Кузнецова (отв. ред.) 2010], многие из последующих результатов отражены в [Кошкарева и др. 2017]). В основном были обследованы ижемские говоры в западной и северо-западной частях округа: в Шурышкарском (Мужи, Шурышкары, Восяхово, Овгорт) и Приуральском (Белоярск) районах. В Шурышкарском районе коми-ижемцы контактируют с хантыйским населением, в с. Белоярск Приуральского района — в первую очередь с ненецким. Контакты 
с хантыйским населением существенно более активны в южной части Приуральского района в районе с. Аксарка (где проживает также и немало ненцев) и с. Катравож (где в основном проживают ханты). Малочисленные группы коми-ижемцев проживают также в Надымском районе (в частности в с. Нори, куда в 2011 г. была проведена экспедиция Института филологии СО РАН, предоставившая в наше распоряжение материалы по местному коми-ижемскому говору) и в Пуровском районе (здесь мы располагаем собственными данными из с. Самбург). В этих районах коми-ижемцы контактируют с ненцами. Помимо полевых данных, мы учитываем архивные материалы, в первую очередь охватывающие говоры Шурышкарского и Приуральского районов и в меньшей степени самбургский говор. Это записи из Научного архива Коми НЦ УрО РАН [Жилина 1959; Колегова 1959; Сорвачева 1959], а также тексты 1990-х - 2000-х гг. из архива телерадиокомпании «ЯмалоРегион» (г. Салехард).

Следует оговорить, что, поскольку идиомы, описываемые в этой статье, находятся под угрозой исчезновения, при дальнейшем обсуждении оказывается затруднительным приводить существенный объем статистических данных, которые бы иллюстрировали различные контактно обусловленные изменения. Некоторые утверждения основаны только на отдельных примерах, записанных от нескольких носителей (такие случаи оговариваются в тексте статьи, а в ходе исследования проверялось, что они не представляют собой случайные оговорки, а последовательно реализуются по крайней мере в некоторых идиолектах). С нашей точки зрения, такие данные значимы для исследования языковых контактов, поскольку они могут представлять только зарождающуюся или, наоборот, уходящую модель изменения, см. также обсуждение в [Matras, Sakel 2007: 847-848].

Вопросы взаимовлияния коми и ненецкого языков поднимались в литературе и раньше, см., например, [Жилина, Колегова 1960; Сорвачева 1960; Игушев 1976; Сахарова, Сельков 1976; Туркин 1985] и др. Вместе с тем основное внимание в этих работах уделяется случаям заимствования культурной лексики, когда один язык заимствует из другого языка лексему вслед за заимствованием ее денотата в результате межкультурных контактов (см. также обсуждение подобных вопросов в типологической перспективе в [Haspelmath 2008; Matras 2009: 166172]). Классическим примером может послужить лексика, связанная с традиционным бытом оленеводов. Сама эта отрасль была перенята коми-ижемцами у ненцев, и в результате в коми язык были заимствованы 
многие ненецкие термины, ср. приводимые в [Сахарова, Сельков 1976: 122-123] примеры хора 'олень-самец' (нен. хора); сынзы 'вертикальные шесты с двух сторон костра, куда прикрепляются поперечные шесты для подвешивания крюков' (нен. cblмзы, симзы); ваньдей 'сани для имущества и продуктов' (нен. вандако, вандад), и пр.

В свою очередь, в нашей работе мы продемонстрируем многоуровневость исследуемого контакта, которая отражается в формальных и семантических изменениях при заимствовании лексем (Раздел 2), моделей организации семантических полей (Раздел 3), фонологии и грамматики (Раздел 4). В заключение мы, помимо подведения итогов, обсудим некоторые социолингвистические предпосылки засвидетельствованных контактных ситуаций (Раздел 5).

\section{2. Заимствования: изменения формальных и семантических свойств лексем}

При анализе лексических заимствований необходимо учитывать множество разнообразных лингвистических и экстралингвистических факторов, влияющих на процесс заимствования и его конечный результат. К таким факторам относятся социолингвистическая специфика ситуации контакта, культурные особенности народов, говорящих на данных языках, и история их взаимоотношений, фонологические и грамматические особенности языков, состав и организация лексики и многое другое (см. также [Winford 2003: 61-64; Haspelmath 2009: 4243] и цитируемую в указанных работах литературу). Если говорить о непосредственно языковых факторах, влияние некоторых из них заметно уже из сопоставления внешнего облика исходной и заимствованной лексемы. Так, например, при заимствовании лексики из ненецкого языка в коми наблюдается тенденция к отпадению начального согласного [y] в словах коми амдёр 'шкура для сидения на нарте' < нен. уамдёр” [Терещенко 1965: 379], коми авко 'олень, вскормленный около чума' < нен. уавка [ibid.: 368], коми утыла 'нарта для перевозки шестов чума' < нен. ууmо” [ibid.: 405], коми blbl 'шест, жердь для чума' < нен. $\boldsymbol{y} y$ [ibid.: 401] и других. По всей видимости, носители коми языка далеко не всегда способны отчётливо услышать и адекватно передать начальный [n], поскольку в коми такая фонема отсутствует. Та же проблема возникает и у носителей русского языка: например, 
одно и то же ненецкое имя может записываться в паспорте двумя разными способами: Начал или Ачал (реальная записанная авторами история в с. Белоярск). В коми-ижемских говорах случаев перехода [n] в той же позиции в [n] в нашем материале не зафиксировано. Утрачивается и согласный [?] на конце слова, не имеющий аналогов в коми (ср. выше амдёр < уамдёр”). Нередко происходят изменения и при передаче гласных (условия этих изменений до конца не ясны), ср.: коми сятура 'щука' < нен. сяторӑ(сь) 'кусаться' [ibid.: 606], коми неблюй 'телячья шкура, снятая примерно в сентябре, пригодная для малицы' $<$ нен. няблюй ${ }^{1}$ [ibid.: 336] и вышеупомянутое коми bاbl 'шест, жердь для чума' < нен. $y \boldsymbol{y}$.

Изменения при заимствовании затрагивают также и значение лексем. Так, например, в обоих языках существует некоторое исходное наименование паука: лярц̧о в ненецком (см. [Терещенко 1965: 212], то же зафиксировано и в наших полевых данных) и черань в коми. Тем не менее в ситуации освоения коми-ижемцами ненецкого оленеводческого быта появляется новая для них реалия насекомых-вредителей, которые портят оленьи шкуры, и источником заимствования оказывается именно упомянутая ненецкая лексема — в виде лярцзо / ляртча. При этом, насколько можно судить по имеющимся данным, существительное лярияо не обозначает в ненецком языке насекомых, портящих шкуры, а в ижемском коми ни оно само, ни его вариант ляртча не являются наименованиями паука. Тем самым, в данном случае при заимствовании происходит сдвиг значения лексемы.

Другим подобным примером является заимствованное коми-ижемцами слово неблюй для обозначения шкуры оленьего телёнка. Исходное ненецкое слово няблюй используется для обозначения не только оленьей шкуры, но и собственно оленьего телёнка с такой шкурой, появившегося на свет осенью, но в коми язык из исходного набора значений заимствуется только одно.

Еще один пример заимствования с изменением семантики представлен ненецкой лексемой лимбика со значениями 'мягкий и тёплый; ласковый’ [Терещенко 1965: 191]. Оно имеет субстантивированное употребление в значении 'кусок оленьей шкуры, который кладётся в люльку', и именно в этом употреблении заимствуется в коми язык.

${ }^{1}$ В [Лыткин, Гуляев 1970: 187] данная лексема коми языка признается ненецким заимствованием. Обсуждение возможных более сложных процессов, связанных с этим словом, см. в [Аникин 2000: 405-406]. 
Тем самым, в данном случае результат заимствования в коми языке имеет не такую сферу употребления, как ненецкое слово-источник, не используясь, в отличие от ненецкого источника, как наименование признака предмета.

Наконец, любопытный случай представляет собой слово сятура, представленное в лексиконе северных коми-ижемских говоров ЯНАО (села Белоярск, Нори, Самбург) в значении 'щука', наряду с исконным словом сир. В ненецких говорах этой территории в том же значении используется никак не связанное с коми-ижемским словом существительное пыря, однако имеется также созвучный глагол сяторӑ(сь) со значением 'кусаться'. Одновременно с этим в говорах большеземельского и западного ненецкого обнаруживается слово сяторэй в значении 'щука' [ibid.: 606] как некоторая отглагольная деривация от сяторӑ $(c b)$. Таким образом, наиболее очевидная версия состоит в том, что слово сятура было заимствовано из сяторэй, однако затем последняя лексема вышла из употребления в рассматриваемых нами ненецких говорах, где в качестве наименования щуки закрепилось слово пыря. Альтернативный вариант развития событий состоит в том, что слово сятура все же было заимствовано напрямую из глагола сяторӑ(сь) с изменением морфосинтаксических свойств лексемы, ср. отчасти похожий пример с лексемой лимбика, разобранный выше.

Таким образом, как видно из приведенных примеров, заимствования лексем из ненецкого языка в коми могут сопровождается фонологической адаптацией и семантическими изменениями, которые состоят преимущественно в сужении значения или его корректировке под те конкретные реалии, наименования для которых в коми языке ранее отсутствовали.

\section{3. Лексические кальки}

\section{1. Методология}

Под лексическими кальками мы понимаем результат заимствования одним языком семантической структуры слова другого языка, ср. приводимый в [Zalizniak et al. 2012: 647-648] пример полисемии слова ячмень ('злаковое растение'; 'воспаление на глазу'), распространившейся из латыни и греческого языка в такие языки, как французский, русский, 
немецкий, турецкий, венгерский и др. Определение калек в работе с нашим материалом вызывает ряд методологических сложностей, которые мы и оговорим далее.

Материал коми-ижемских говоров ЯНАО собирался нами в зонах контактов с хантыйским и / или ненецким языком. Калькирование одним языком семантических моделей другого предполагает ситуацию достаточно тесного межъязыкового контакта и высокую степень билингвизма, ср. приводимую в [Thomason 2001: 70-71] шкалу развития заимствований (Borrowing scale), где заимствованиям семантической или грамматической структуры соответствует более тесная степень связи двух языковых сообществ. Тем самым, ненецкая калька в коми-ижемском говоре с. Самбург, многие носители которого владеют и повседневно пользуются ненецким языком в семьях либо в оленеводческих бригадах, априори более вероятна, чем хантыйская калька в коми-ижемском говоре с. Мужи, носители которого общаются друг с другом на коми или на русском, а с представителями народа ханты на русском, но не на хантыйском (кроме того, долгие годы в этом районе нет смешанных коми-хантыйских оленеводческих бригад). В нашей работе мы в каждом случае учитываем степень контактного влияния как для изучаемого идиома в целом, так и в социолингвистической биографии конкретного носителя языка.

Кроме того, крайне значимым является устройство рассматриваемого в качестве возможной кальки языкового явления в тех идиомах коми языка и ненецкого / хантыйского языков, которые распространены вне района контактной ситуации. Вероятная калька должна быть специфичной именно для контактной зоны и одновременно быть распространенной в языке-источнике вне контактной зоны. Например, если какая-либо модель полисемии встретилась в коми-ижемском говоре с. Самбург, контактном с ненецким языком, не встретилась в говоре с. Мужи, не контактном с ненецким языком, и широко распространена в ненецком языке, то в данном случае есть основания говорить о ненецкой кальке. Если же модель полисемии распространена и в с. Самбург, и в с. Мужи, то оснований говорить о калькировании из ненецкого языка становится меньше, поскольку район с. Мужи не населен ненцами и коми-ненецкий билингвизм для него не характерен ${ }^{2}$. Помимо наших собственных полевых данных, мы

2 При этом, конечно, нельзя исключать, что калькирование могло произойти в более ранний период коми-ненецких контактов. Рассуждения такого типа мы, 
учитываем, проводя аналогичные рассуждения, данные по коми языку (как по ижемскому диалекту, так и по другим диалектам), приводящиеся в лексикографических описаниях, в первую очередь в [Лыткин (ред.) 1961; ССКЗД 1961; КСК I, II]. Заметим, вместе с тем, что в некоторых случаях опубликованные лексикографические источники не содержат нужного нам объема данных о семантике и сочетаемости лексем.

Наконец, нужно понимать, что любое отмеченное совпадение структур коми языка и ненецкого / хантыйского языков логически может быть не только калькой, но и независимым развитием одной и той же языковой модели либо следом более древнего исторического состояния уральских языков, сохранившимся в отдельных идиомах. Строго говоря, в общем случае нельзя доказать сам факт калькирования, не имея в распоряжении надежных данных по разным диахроническим этапам развития языка, дополненных параллельными сведениями о контактной ситуации. В то же время, само указание на факт ареальных совпадений и на их социолингвистические корреляции представляется нам значимым (как и указание на то, что в ряде случаев контактная ситуация может способствовать сохранности старой модели полисемии либо возникновению какой-либо типологически распространенной модели), см. об этой проблеме также [Zalizniak et al. 2012: 647-648] и цитируемую в указанной работе литературу.

\section{2. Случаи калькирования}

Рассмотрим теперь встретившиеся нам примеры семантических калек. Первый из них касается названий женской груди и вымени. В говорах Шурышкарского района ЯНАО, контактных с хантыйским языком (с. Мужи, Восяхово, Шурышкары), наименованием вымени служит существительное вӧра, а наименованием женской груди существительное чуn (ср. также существительное морэс с более общим значением 'грудная клетка'). Такая же ситуация отмечается в говоре с. Белоярск Приуральского района (контактная зона с ненецким и в меньшей степени с хантыйским населением) и, насколько можно судить по данным [КСК I: 267; КСК II: 742], в других коми диалектах. Вместе с тем в говоре с. Самбург Пуровского района, где 
коми-ижемцы контактируют с ненцами, существительное чуп выражает и значение 'женская грудь', и значение 'вымя' (слово вӧра используется параллельно в значении 'вымя'). В отдельных случаях нами фиксировались и более сильные смешения языковых обозначений обсуждаемых денотатов. Так, одна из жительниц с. Самбург, много лет назад переехавшая туда из Республики Коми, на вопрос о том, как сказать на коми языке 'вымя', после некоторых размышлений ответила: «А не морэс?».

В данном случае самбургский говор коми языка демонстрирует полисемию ненецкого типа: существительное нуамя имеет в ненецком языке как значение 'женская грудь', так и значение 'вымя' (см. [Бармич 2015: 121, 151], наши полевые данные тоже это подтверждают). Заметим, что в хантыйском языке наблюдается та же модель полисемии у существительного esəm, см. [Соловар 2014: 384; Кошкарева (ред.) 2011: 157]. Вместе с тем в коми-ижемских говорах с. Мужи, Восяхово и Шурышкары калькирования этой модели из хантыйского языка не происходит. Один пример употребления слова чуn в значении 'вымя' записан нами в говоре с. Овгорт Шурышкарского района, где небольшая группа коми-ижемцев проживает в доминантном хантыйском окружении, но данных для надежных выводов об овгортском говоре в нашем распоряжении пока недостаточно.

Еще один пример семантического калькирования связан с глаголами позиции, а именно с семантикой и сочетаемостью глаголов $c y$ лооны 'стоять' и пукооны 'сидеть' (коми лит. сулавны и пукавны соответственно) ${ }^{3}$. В большинстве обследованных нами зауральских говоров глагол пукооны применяется только к сидящему человеку или животному. В свою очередь, глагол сулоонь имеет несколько классов употреблений. Во-первых, он описывает стоящего человека или животное. Во-вторых, этот глагол обозначает позицию вертикально вытянутых предметов, как в (1). В-третьих, он же описывает позицию некоторых артефактов (чашки, миски, бутылки, лодки и др.), естественную для их функционирования (2), ср. анализ русских примеров типа Чашка стоит на столе в [Рахилина 2008: 293].

Этая

$n y-я c-c \ni$

кол-э

этот

дерево-PL-ACC.POSS 3

быть.нужным-PRS.3SG

${ }^{3}$ Подробные сведения о сочетаемости глаголов позиции в ижемском коми доступны в [Кашкин 2016а]. Здесь мы сосредоточимся на ключевых фактах, важных в свете обсуждения контактного взаимодействия коми и ненецкого языков. 


\begin{tabular}{|c|c|c|c|c|c|}
\hline \multicolumn{2}{|c|}{$\begin{array}{l}n \ddot{o p}-э \partial-H b l, \\
\text { опрокинуться-TR-INF }\end{array}$} & $\begin{array}{l}\text { потому } \\
\text { потому }\end{array}$ & $\begin{array}{l}\text { umo } \\
\text { что }\end{array}$ & $\begin{array}{l}\text { ныла } \\
\text { они }\end{array}$ & $\begin{array}{l}\text { сулал-эныс } \\
\text { стоять-PRS.3PL }\end{array}$ \\
\hline myü & вblл- $a c^{4}$ & & & & \\
\hline дорога & верX-ESS/I & $3 \mathrm{SG}$ & & & \\
\hline
\end{tabular}

‘Эти деревья надо свалить, потому что они стоят на дороге'. (с. Мужи)

\begin{tabular}{lllll} 
Пьззан & вылл- $а c$ & \multicolumn{1}{c}{ сулал-ic } & сёй & macbmi \\
стол & верх-ESS/ILL.PoSS3SG & стоять-PST.3sg & глина & миска \\
'На столе стояла глиняная миска'. (с. Мужи)
\end{tabular}

В говоре с. Самбург, однако, регулярно фиксируется использование глагола пукооны в третьем из сформулированных выше классов употребления глагола сулооны. Лексема пукооны может применяться в Самбурге, в частности, по отношению к стоящей на столе посуде (чашке, тарелке, блюдцу), как в (3), силкам для ловли птиц, скамейке и т. д. С названиями вертикально вытянутых объектов (дерево, шест и т. п.) данная лексема, однако, не сочетается.

$$
\begin{array}{llll}
\text { Чашка-ыlc } & \text { пукал-э } & \text { пызан } & \text { вылл-blн } \\
\text { чашка-POss3sg } & \text { сидеть-PRs.3sg } & \text { стол } & \text { верx-Ess } \\
\text { 'Чашка стоит (букв.: сидит) } & \text { на столе'. (с. Самбург) }
\end{array}
$$

В данном случае говор самбургских коми опять оказывается близок к ненецкой системе. В ненецком языке именно глагол уамдёсь 'сидеть' (но не глагол нусь 'стоять') развил наиболее широкую сферу употребления среди позиционных предикатов, ср. (4), — и опрошенные нами носители ненецкого языка тоже подтверждают употребления глагола уамдёсь в контекстах, аналогичных приведенным нестандартным употреблениям коми-ижемского пукооны.

$$
\begin{array}{llll}
\text { Тол-' } & \text { ни-ня } & \text { хыддя-" } & \text { уамды-" } \\
\text { стол-GEN } & \text { на-LOC } & \text { чашка-PL } & \text { сидеть-3РL }
\end{array}
$$

'На столе стоят (букв.: сидят) чашки'. [Терещенко 1965: 378]

Среди носителей самбургского говора наиболее активный сдвиг употребления глагола пукооны отмечается в речи людей, которые в повседневной жизни регулярно пользуются ненецким языком (например, один из информантов женат на ненке и говорит с ней по-ненецки, а другой работает в смешанной с ненцами оленеводческой бригаде).

4 Здесь и далее примеры, при которых не стоит эксплицитной ссылки на источник, записаны от информантов. 
Кроме того, правильность самбургских примеров с расширением семантики пукооны отрицается носителями говоров Шурышкарского района, контактных с хантыйским языком ${ }^{5}$. Такие употребления глагола пукооны были оценены как неадекватные и носителем ижемского диалекта из с. Няшабож Республики Коми, опрошенным нами в с. Овгорт (на момент опроса информант проживал в Овгорте всего пять лет, поддерживая регулярную связь с носителями своего родного говора).

По данным [КСК II: 226-228] рассмотренные употребления глагола 'сидеть' (пукавны, пукалны и пукооны в разных диалектах) не являются типичными в коми диалектах. Для ижемского диалекта они не отмечены вовсе. Некоторые похожие примеры зафиксированы, однако, в говорах удорского, нижневычегодского и верхнесысольского диалектов. К сожалению, в нашем распоряжении нет подробных сочетаемостных анкет, которые могли бы детально прояснить свойства глаголов позиции в этих диалектах и позволить в полной мере сопоставить их с нашими ижемскими данными. В равной степени мы не можем достоверно утверждать, являются ли такие употребления инновациями, возникшими в нескольких коми диалектах, или реликтом прежнего состояния системы. В любом случае, однако, мы наблюдаем в одном из говоров ижемского диалекта модель полисемии, не встречающуюся в других доступных нам говорах того же диалекта - и эта система имеет явную параллель в распространенном (и доминантном) в том же ареале ненецком языке. По этой причине сценарий ненецкого влияния представляется здесь крайне вероятным, а его детальное прояснение (возникновение новой модели полисемии vs. поддержка черт прежнего состояния системы) - любопытным вопросом для дальнейшего исследования.

\section{3. Калькирование: семантика и культурные табу}

Некоторые из отмеченных нами примеров семантических калек сопряжены с более сложными механизмами взаимодействия языков и культур. Яркий пример этого представлен эвфемистическими наименованиями волка. В сибирских языках опасные животные

5 Заметим при этом, что в хантыйской системе позиционных глаголов наибольшую сферу употребления тоже имеет глагол 'сидеть' - oməsti, см. [Лельхова 2012: 118-120; Кашкин 2016b]. Однако обследованные нами коми-ижемские говоры, контактные с хантыйским языком, не перенимают эту модель. 
нередко именуются описательно, ср. упоминание этого факта в [Терещенко 1965: 938] и приводимые там ненецкие наименования медведя париденя (букв. 'черный'), ири (букв. 'дед’) и т. п., а также данные по наименованиям волка в уральских языках Ямало-Ненецкого АО [Кошкарева и др. 2011; Кошкарева и др. 2017: 128-131]. В коми языке табуированные наименования животных тоже отмечались [Хаузенберг 1972; Кузнецова 2010]. Однако для волка, по крайней мере в говорах Европейской части России (бывшего СССР), такие наименования практически не фиксировались: в [Хаузенберг 1972: 22-23] отмечается единственное табуированное наименование - лёк зьвер (букв. 'плохой зверь)', встреченное автором только в ижемском селе Гам и (по состоянию на 1972 г.) использовавшееся, по данным автора, только пожилыми людьми. Общеупотребимым же наименованием волка является, согласно А.-Р. Хаузенберг, существительное кӧйин / кӧин.

В обследованных нами коми-ижемских говорах ЯНАО наблюдается совершенно иная ситуация. Существительное кӧйин / кӧин практически не известно нашим информантам, вместо него используются только эвфемизмы. Повсеместно используется известное из [Хаузенберг 1972] наименование зверь /лёк зверь (с разными вариантами смягчения согласных в русском заимствовании, часто варьирующими даже в идиолекте одного и того же носителя языка - звер, зьвер, зверь, зьверь). В говорах с. Белоярск и Самбург, находящихся в ненецком ареале, эвфемизмов для волка оказывается еще больше. В с. Белоярск это ыллласа (букв.: 'Уличный'), лы бӧж / лы бӧжа (букв.: 'костяной хвост/ с костяным хвостом'), кузь бӧж/кузь бӧжа (букв.: 'длинный хвост/ с длинным хвостом'). В с. Самбург это эвфемизм лёк (букв.: 'плохой’; по-видимому, еще один вариант усечения «базового» наименования лёк зверь), отмеченные и в с. Белоярск варианты лы бӧж / лы бӧжа и кузь бӧж/кузь бӧжа, а также наименования ыллаьн ветлальсь (букв.: 'на улице ходящий'), вой ветлалысь (букв.: 'ночью ходящий'), бука (букв.: 'нечистая сила'), ёма (букв.: 'ведьма'). Некоторые примеры использования указанных эвфемизмов приведены ниже:

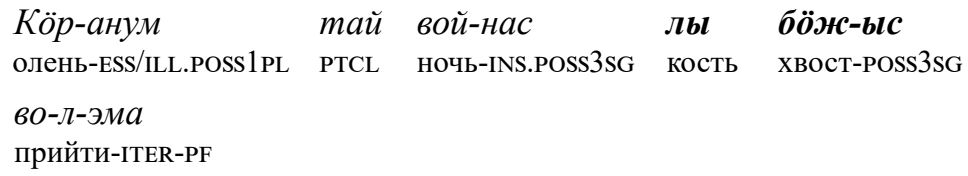

'В наше стадо ночью волк (букв.: костяной хвост) приходил' (с. Белоярск). 


\begin{tabular}{|c|c|c|c|c|c|}
\hline $\begin{array}{l}\text { Важээ } \\
\text { раньше }\end{array}$ & $\begin{array}{ll}H & \ddot{\boldsymbol{e}} \boldsymbol{M a} \text {-blc } \\
\mathrm{e} & \text { ведьма-POss3sG }\end{array}$ & $\begin{array}{l}\text { зэй } \\
\text { очень }\end{array}$ & $\begin{array}{l}\text { уна } \\
\text { много }\end{array}$ & $\begin{array}{l}\text { вӧл-ic, } \\
\text { быть-PS }\end{array}$ & $\mathrm{T} .3 \mathrm{SG}$ \\
\hline $\begin{array}{l}л у н \\
\text { день }\end{array}$ & $\begin{array}{lll}u & \text { вой } & \text { стад- } \\
\text { и } & \text { ночь } & \text { стадо- }\end{array}$ & $\begin{array}{l}-m \ni \\
\text { ACC.POSs2 }\end{array}$ & $\begin{array}{l}\text { карол } \\
\text { караул }\end{array}$ & $\begin{array}{l}\text { Uum- } a \mu, \\
\text { Iить-NPST }\end{array}$ & \\
\hline $\begin{array}{l}\kappa \ddot{p} p \\
\text { олень }\end{array}$ & $\begin{array}{l}\text { вошт- } а н- \\
\text { терять-NPST.2sG }\end{array}$ & $\begin{array}{l}\text { судит- } a c \\
\text { судить-FUT }\end{array}$ & $\begin{array}{l}\text { crublc. } \\
\text { JT.3PL }\end{array}$ & $\begin{array}{l}\text { Уна } \\
\text { много }\end{array}$ & $\begin{array}{l}\text { кӧр } \\
\text { олень }\end{array}$ \\
\hline $\begin{array}{l}\text { джаге } \\
\text { душить }\end{array}$ & $\begin{array}{ll}e d-i c & \ddot{\boldsymbol{e}} \boldsymbol{м a},_{\text {b-PST.3SG }} \text { ведьма }\end{array}$ & $\begin{array}{ll}\text { миме } & \lambda \\
\text { сразу } & \text { п }\end{array}$ & $\begin{array}{l}\text { мынын- } \\
\text { платить }\end{array}$ & $\begin{array}{l}a H \\
\text {-NPST.2SG }\end{array}$ & \\
\hline
\end{tabular}

Важно, что изобилие эвфемистических наименований волка встречается в зонах активного контакта коми и ненецкого языков. Многие коми-ижемские варианты, специфические для этих говоров, имеют ненецкие параллели. Так, эвфемизмы ылласа и ыллаын ветлалысь параллельны ненецким пихий (букв.: 'уличный'), пивня ядэрта (букв.: 'по улице гуляющий’) [Кошкарева и др. 2011] ${ }^{6}$. Вариант кузь бӧж/ кузь бӧжа устроен аналогично ненецкому тэва ямб (букв.: 'длинный хвост’), упомянутому в [Терещенко 1965: 684]. Сравнение волка с нечистой силой (ср. самбургские бука и ёма) сходно с полисемией ненецкого цыылека, буквально означающего 'злое страшное сверхъестественное существо, вызывающее болезнь', а переносно относящееся к волку [Терещенко 1965: 409]. Самбургский эвфемизм вой ветлальсьь (букв.: 'ночью ходящий'), отсылающий к волку по признаку времени, когда тот типично активен, повторяет ненецкое выражение пихиня ядэрта (букв.: 'ночью ходящий’), тоже отсылающее к волку и отмеченное в относительно близком территориально говоре с. Гыда (А. А. Козлов, личное сообщение). Из зафиксированных в ижемских говорах Самбурга и Белоярска эвфемизмов в ненецком языке нами пока не обнаружен только источник примера для лы бӧж/лы бӧжа (букв.: 'костяной хвост / с костяным хвостом'), хотя в целом в ненецком языке распространены метонимические наименования волка через отсылку к его хвосту, ср. уже упомянутое тэва ямб (букв.: ‘длинный хвост'), а также тэвта (букв.: 'хвостатый') [Терещенко 1965: 686].

${ }^{6}$ Написания ненецких вариантов приводятся в соответствии с указанными в тексте источниками. 
Тем самым, в данном случае в коми языке в зонах контакта с ненецким возникает целая серия полисемичных образований, абсолютно нетипичных для других территориальных разновидностей коми языка, что позволяет предположить здесь ненецкое влияние. Кроме того, сама культурная стратегия непрямого наименования волка поддерживается в смешанных оленеводческих бригадах и в окружающем языковом сообществе той практикой, которая сложилась у ненецких оленеводов.

\section{4. Калькирование: взаимодействие многих языков}

В некоторых случаях коми-ижемские говоры ЯНАО впитывают заимствования одновременно из двух источников - как из русского языка, так и из ненецкого. Первый пример такого полиязычного взаимодействия - это глагол каролитны и сдвиг его употребления в говоре с. Самбург. В других (помимо самбургского) обследованных нами говорах зауральских коми эта лексема означает 'караулить; пасти оленей' (в [КСК I: 638] ей соответствует лексема караулитны, имеющая ту же семантику в восьми диалектах коми языка и, по всей видимости, заимствованная из русского) ${ }^{7}$.

В самбургском говоре, помимо своего основного значения, глагол каролитны развивает значение 'хранить что-л. где-л.', как в (7). В других идиомах (а также в идиолектах многих жителей Самбурга) такую семантику обычно выражает глагол видьны (не имеющий, в то же время, значения 'пасти').

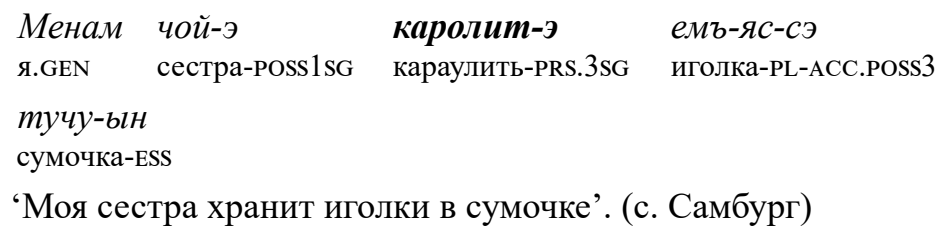

${ }^{7}$ В [Аникин 2000: 265-266] русское слово караул рассматривается как заимствование из монгольских языков через посредство тюркских. Для коми языка, по-видимому, наиболее вероятно заимствование непосредственно из русского языка, ср. также соответствие глагола караулитны крайне продуктивной модели словообразовательного освоения заимствованных русских глаголов: в нашем материале встречается немало образований типа белитны 'белить', вритны 'врать', жмитны 'сжимать', любитны 'любить' и т. д. 
Можно предположить, что такая полисемия развивается в самбургском коми в результате контактного ненецкого влияния. Глагол каролитны копирует в рассматриваемом случае полисемию ненецкого лэтмбась (согласно и [Терещенко 1965: 205], и нашим полевым данным).

Еще один пример полиязычного процесса заимствования касается зоны терминов родства, а именно наименований мужа. Обычно это значение выражается в говорах зауральских ижемцев русским заимствованием мужык (слово верес, соответствующее литературному верӧс, используется в подавляющем большинстве случаев только в составе устойчивых сочетаний верес сайын 'замужем', верес сае 'замуж', на основе последнего сочетания образуется также стяженная форма вересса). Однако в наших полевых материалах из с. Самбург, а также в архивном тексте из с. Харсаим в значении 'муж' встретилось и существительное тарик (из русского старик), ср. следующий пример из самбургского говора:

$$
\begin{array}{llll}
\begin{array}{l}
\text { Менам } \\
\text { я.GEN }
\end{array} & \text { старик-е } & \text { тон } & \text { скӧрал-э } \\
\text { 'Мой муж сегодня сердится'. (с. Самбург) } & \text { сегодня } & \text { сердиться-PRS.3SG }
\end{array}
$$

Такие примеры записаны как от пожилых информантов, так и от людей в возрасте 45-50 лет. В говоре с. Мужи данное употребление известно, но допустимо скорее для людей старшего поколения, в речи которых слово старик сдвигается уже в характеристику по возрасту. Для других говоров коми языка, по данным [КСК II: 425], подобная полисемия слова старик / тарик не отмечалась. Тем самым, в коми языке сдвиг с наименования по возрасту в наименование супруга возникает в говорах, контактных с ненецким языком, где точно такой же сдвиг имеет место у существительного вэсако [Терещенко 1965: 77]. Фиксируется этот сдвиг и в близкородственном энецком языке [Coрокина, Болина 2009: 86]. Поэтому в рассматриваемом случае можно предполагать калькирование коми-ижемскими говорами ненецкой модели полисемии, причем для лексемы, изначально заимствованной из русского языка ${ }^{8}$.

${ }^{8}$ Надо заметить, что такая полисемия слова старик не исключена и в просторечном русском языке. Поэтому здесь нельзя полностью исключать и русского влияния. В то же время важно, что в коми-ижемских говорах указанная модель полисемии отмечается именно в контакте с ненецким языком, что не могло бы быть объяснено только русским влиянием. 


\section{4. Контактно обусловленные изменения в фонетике и грамматике}

Помимо рассмотренных выше лексических калек, в зауральских говорах коми языка обнаруживаются изменения в фонетической и грамматической системах, для которых также можно предполагать контактное влияние. Они касаются структуры слога (Раздел 4.1), звонкости-глухости согласных (Раздел 4.2) и некоторых грамматических конструкций (Раздел 4.3). Далее обсудим все эти случаи более подробно.

\section{1. Устранение зияния гласных}

Первая из проблем, которую мы обсудим в этом разделе, касается случаев устранения зияния гласных в обследованных нами говорах. Вообще, устранение зияния достаточно распространено типологически, см. [Кодзасов, Кривнова 2001: 459-460]. Ненецкий и хантыйский языки также следуют этой стратегии в фонотактике, см. [Salminen 1998: 519] о ненецкой системе и [Nikolaeva 1999: 6] о хантыйской. Многие диалекты коми языка тоже принимают эту модель, см., например, [Сорвачева и др. 1966: 37-44] о верхневычегодском диалекте, [Жилина 1975: 47-48] о верхнесысольском диалекте, [Жилина 1985: 30-31] о лузско-летском диалекте и др. Такие примеры (не соответствующие данным других обследованных нами говоров) обнаружились и в с. Самбург и, пока в меньшем объеме, в с. Овгорт, ср. самбургские примеры puve 'варит' вместо стандартного ижемского варианта pue, lyjajen 'песком' вместо lyaen, juves 'острый' (о кончике) вместо jues, juvas 'ny 'спрашивать' вместо juas 'ny, lovannyd 'будете' вместо loannyd, lafkajyn 'в магазине' вместо lafkayn, vajys 'его вода; эта вода' вместо vays и др.

Учитывая типологическую распространенность данной фонотактической стратегии, несомненно, можно было бы утверждать, что в говорах Самбурга и Овгорта имеет место развитие некоторой частотной в языках мира модели, воспроизводящейся, помимо прочего,

9 При обсуждении фонетических различий примеры для большей наглядности даются в транскрипции латиницей. 
и в других коми диалектах. На самом же деле ситуация, по-видимому, не так проста. Во-первых, устранение зияния гласных прежде не отмечалось в ижемском диалекте - ни в работе [Сахарова, Сельков 1976], посвященной преимущественно европейским ижемским говорам, ни в словаре [Кузнецова (ред.) 2010], где представлены уже данные зауральского говора с. Мужи. Во-вторых, в социолингвистической биографии наших информантов, от которых записаны такие формы, не было и нет контактов с носителями тех диалектов коми языка, где происходит устранение зияния. В-третьих, те носители самбургского говора, в речи которых может устраняться зияние гласных, имеют явные связи с ненецким языком: все они либо живут (жили в детстве) в смешанных коми-ненецких семьях, либо имеют длительный стаж работы в смешанных оленеводческих бригадах ${ }^{10}$. В некоторых случаях возникают неожиданные на первый взгляд ситуации: так, в речи одной из жительниц с. Самбург 1932 г. р., переехавшей туда из с. Мужи и затем вышедшей замуж за ненца, устранение зияния не встречается (как не встречается оно и в ее родном мужевском говоре), но такое устранение почему-то возникает в речи ее дочери, выросшей уже в Самбурге и самбургской тундре. Всё это позволяет предположить контактное влияние и здесь: ненецкое для Самбурга и хантыйское для Овгорта. Сам механизм этого влияния может быть, однако, различным (и, по-видимому, не вполне верифицируемым). С одной стороны, устранение зияния в контактных зонах могло быть инновацией, развившейся под влиянием соседних языков. С другой стороны, нельзя логически исключать, что самбургский и овгортский говоры могли независимо развить типологически частотную модель либо сохранить следы какой-либо старой модели, широко распространенной в коми диалектах. Но и в этом случае примечательно, что такое развитие произошло именно в ситуации языковых контактов, которыми данный процесс мог быть поддержан.

${ }^{10} \mathrm{~B}$ с. Овгорт примеры с устранением зияния отмечались пока только спорадически, поэтому установить для этого говора надежные социолингвистические тенденции на данный момент невозможно. Вместе с тем его носители проживают в доминантном хантыйском окружении, сохранность хантыйского языка в этом районе достаточно хорошая, и многие коми-ижемцы в той или иной степени владеют не только русским, но и хантыйским языком. 


\section{2. Оглушение согласных}

Некоторые несоответствия коми-ижемских говоров ЯНАО картине, ожидавшейся по предыдущим публикациям, в имеющемся у нас материале носят существенно менее системный характер. Тем не менее нам кажется важным упомянуть здесь отмеченные сбои, поскольку в своей совокупности они могут образовывать некоторую тенденцию либо указывать на намечающееся языковое изменение (ср. также методологические соображения об «ошибках» как типе лингвистических данных в [Русакова 2013; Рахилина 2014]). Первый из примеров эпизодических изменений касается оглушения согласных. Коми язык имеет развитую систему оппозиций согласных по глухости-звонкости. Однако в современном языке, если судить по данным обследованных нами говоров, в некоторых точках она расшатывается. Наиболее частый класс таких случаев касается финальной позиции согласных. Для системы коми языка характерно наличие фонологической оппозиции по глухости-звонкости и в этой позиции, ср. пос 'пол' и поз 'гнездо'. Во многих случаях, однако, конечные звонкие согласные начинают оглушаться по всей видимости, под влиянием русского языка, см., например, č́olep 'шустрый' (ср. с́оl'eba 'шустро'), rəmyt 'сумерки' (ср. rəmdyny 'смеркаться'), posn 'it 'мелкий' (cp. posn'ida 'мелко') и т. д.

В говоре с. Овгорт, вместе с тем, эпизодически встречаются менее тривиальные примеры, когда оглушению подвергаются согласные не в конечной позиции, ср. kudyr 'мутный' (вм. gudyr), tomema pon 'привязанная собака' (вм. domema pon). Примеров с другими начальными согласными в наших данных не встретилось. Наиболее правдоподобным объяснением таких случаев представляется возможное влияние хантыйского языка, в системе которого нет звонких согласных фонем, cм. [Nikolaeva 1999: 6] ${ }^{11}$. Выявить четкие тенденции развития этого процесса в овгортском говоре пока, однако, сложно в силу небольшого объема материала.

11 Другое объяснение этих примеров, предложенное нам анонимным рецензентом, состоит в возможном копировании фонотактической стратегии ненецкого языка, где, как видно из [Терещенко 1965], исконные слова не начинаются с $g$ и $d$. Такое объяснение, однако, представляется нам менее правдоподобным, поскольку комиижемский говор с. Овгорт, по нашим данным, по крайней мере в последние десятилетия не подвержен ненецкому влиянию, но подвержен хантыйскому влиянию. 


\section{3. Изменения в грамматических конструкциях}

Примеры изменений в грамматических конструкциях, которые могли бы объясняться контактным воздействием хантыйского или ненецкого языков на коми, в нашем материале пока крайне немногочисленны. На данный момент нам встретился один пример такого рода он касается посессивных конструкций в говоре с. Овгорт. В идиолектах отдельных носителей этого говора маркирование посессора номинативом более распространено, чем в системе других говоров ижемского диалекта (см. об этой проблематике [Плешак, настоящий сборник]). В частности, в таких идиолектах встречаются примеры типа (9), где посессор в составе субъектной именной группы, выраженный личным местоимением, маркируется номинативом, а не генитивом. При этом стандартным средством маркирования такого посессора в ижемских говорах ЯНАО является именно генитив (менам маме 'моя мама').

$\begin{array}{llll}\text { Me } & \text { мам-e } & \text { рӧдич-ч-ис } & \text { Mblжbl-blн } \\ \text { я } & \text { мама-POSs1sG } & \text { родить-DETR-PST.3sg } & \text { Мужи-ESS } \\ \text { 'Моя мама родилась в Мужах'. } & \end{array}$

Учитывая тесный контакт коми-ижемского говора с. Овгорт с хантыйским языком, нельзя исключать, что появление таких конструкций обусловлено хантыйским влиянием. Поскольку в хантыйской падежной системе отсутствует генитив, варьирование структуры посессивных конструкций сводится в ней только к наличию/ отсутствию посессивного маркера на вершине, тогда как форма зависимого не претерпевает варьирования, оформляясь всегда номинативом (подробнее о посессивных конструкциях в хантыйском языке см., в частности, [Привознов 2010]). Интересно, что такая гипотеза находит типологическую параллель из другой контактной зоны хантыйского языка. Согласно [Кошкарева 2013], в говорах лесного ненецкого языка, распространенных в хантыйском окружении, также происходит расшатывание системы посессивных конструкций в силу нерегулярного употребления генитива на зависимом посессивной группы, тогда как в других ненецких идиомах генитив в этом случае, как правило, используется. Наши данные по овгортскому говору пока, однако, недостаточно объемны для полноценного сопоставления с материалами Н. Б. Кошкаревой, но, несомненно, рассмотренное явление представляет интерес и нуждается в дальнейшем изучении. 


\section{5. Заключение}

Итак, мы рассмотрели изменения в коми-ижемских говорах ЯмалоНенецкого АО, которые можно трактовать как результат контактного влияния ненецкого и хантыйского языков. Основной фокус был сделан не на прозрачных лексических заимствованиях, которые обозначают один и тот же денотат в языке-источнике и языке-доноре, а на тех случаях, где происходят какие-либо структурные изменения. В частности, было показано, что при заимствовании лексем могут происходить фонетические, грамматические и семантические изменения. Выявлены также лексические кальки - заимствования моделей полисемии (см., например, глаголы позиции или наименования некоторых животных). В ряде случаев взаимодействие ижемского коми с языками коренных народов Сибири дополнительно осложняется влиянием русского языка: некоторые лексемы, заимствованные из русского, предположительно развивают модель полисемии, свойственную ненецким говорам.

В фонетике и грамматике коми-ижемских говоров ЯНАО также выявлены некоторые черты, для которых можно предполагать контактную природу (не исключая полностью и того, что какие-то из этих моделей одновременно могут отражать распространенную типологическую тенденцию, см., например, устранение зияния гласных в самбургском коми). Вопросы грамматических изменений требуют, однако, дальнейшего исследования.

Полученные результаты поднимают вопрос о том, на каком уровне происходят заимствования в коми язык из соседних уральских языков. В теоретической литературе (см., например, [Thomason 2001: 70-71]) выделяются различные степени проникновения контактно обусловленных явлений. Важная граница в таких классификациях проходит между обычным лексическим заимствованием, с одной стороны, и заимствованием фрагментов языковой структуры, с другой стороны. Второй тип заимствования связан при этом с большей интенсивностью языкового контакта. Как видно из изложенных выше данных, коми-ижемские говоры ЯНАО характеризуются более высокой степенью контактного взаимодействия с окружающими уральскими языками, чем утверждалось ранее. 


\section{Список условных сокращений}

1, 2, 3 - 1, 2, 3 лицо; ESS - эссив; FUT - будущее время; GEN — генитив; ILL иллатив; INF - инфинитив; INS - инструменталис; ITER - итератив; LOC — локатив; NPST - непрошедшее время; PF — перфект; PL - множественное число; POSS - посессивное склонение; PRS - настоящее время; PST — прошедшее время; PTCL — частица; SG - единственное число; TR - повышающая актантная деривация.

лит. — литературный; нен. — ненецкий.

\section{Литература}

Аникин 2000 - А. Е. Аникин. Этимологический словарь русских диалектов Сибири: Заимствования из уральских, алтайских и палеоазиатских языков. М.; Новосибирск: Наука, 2000.

Бармич 2015 - М. Я. Бармич. Русско-ненецкий словарь. СПб.: Алмаз-Граф, 2015. Жеребцов 1982 - Л. Н. Жеребцов. Историко-культурные взаимоотношения коми с соседними народами. М.: Наука, 1982.

Жилина 1959 - Т. И. Жилина. Материалы диалектологической экспедиции в Ямало-Ненецкий национальный округ. Ч. 2. Научный архив Коми НЦ УрО РАН. Фонд 1, опись 11, дело 192. 1959.

Жилина 1975 - Т. И. Жилина. Верхнесысольский диалект коми языка. М.: Наука, 1975.

Жилина 1985 - Т. И. Жилина. Лузско-летский диалект коми языка. М.: Наука, 1985. Жилина, Колегова 1960 - Т. И. Жилина, Н. А. Колегова. Некоторые особенности говора обских коми (сс. Мужи и Шурышкары) // Историко-филологический сборник. Вып. 6. Сыктывкар: Коми книжное изд-во, 1960. С. 152-170.

Игушев 1976 - Е. А. Игушев. К вопросу о культурных связях коми и ненцев // Л. Н. Жеребцов (отв. ред.). Этнография и фольклор Коми (Труды Института языка, литературы и истории. Вып. 17). Сыктывкар: Коми филиал АН СССР, 1976. C. 116-118.

Кашкин $2016 \mathrm{a}$ - Е. В. Кашкин. Глаголы позиции и их переходные соответствия в ижемском диалекте коми-зырянского языка // Родной язык. 2016. № 1. С. 54 76.

Кашкин 2016b - Е. В. Кашкин. Семантика хантыйских позиционных предикатов // А. А. Кретов (ред.). Проблемы лексико-семантической типологии. Вып. 3. Воронеж: ВГУ, 2016. С. 78-88.

Кодзасов, Кривнова 2001 - С. В. Кодзасов, О. Ф. Кривнова. Общая фонетика. М.: РГГУ, 2001.

Колегова 1959 - Н. А. Колегова. Материалы диалектологической экспедиции в Ямало-Ненецкий национальный округ (сс. Мужи и Шурышкары). Ч. 1. Научный архив Коми НЦ УрО РАН. Фонд 1, опись 11, дело 193. 1959. 
Кошкарева (ред.) 2011 - Н. Б. Кошкарева (ред.). Диалектологический словарь хантыйского языка (шурышкарский и приуральский диалекты). Екатеринбург: Баско, 2011.

Кошкарева 2013 - Н. Б. Кошкарева. Отражение как вид подчинительной связи в языках с вершинным маркированием (на материале хантыйского и ненецкого языков) // Вестник НГУ. Серия «Лингвистика и межкультурная коммуникация». 2013. Т. 11. Вып. 2. С. 27-41.

Кошкарева и др. 2011 - Н. Б. Кошкарева, О. А. Казакевич, А. И. Кузнецова, Е. В. Кашкин, Ю. Б. Коряков. Опыт картографирования лексических данных по уральским языкам, распространенным на территории Ямало-Ненецкого АО // Научный вестник Ямало-Ненецкого автономного округа. 2011. Вып. 4 (73). С. 3-7.

Кошкарева и др. 2017 - Н. Б. Кошкарева, Е. В. Кашкин, Ю. Б. Коряков, О. А. Казакевич, С. И. Буркова, Н. А. Муравьев, Е. М. Будянская. Диалектологический атлас уральских языков, распространенных на территории Ямало-Ненецкого автономного округа. Калининград: Издательский дом «РОСТ-ДОАФК», 2017.

КСК I - Л. М. Безносикова (ред.). Коми сёрнисикас кывчукӧр. Словарь диалектов коми языка. В 2 т. Т. 1. Сыктывкар: Кола, 2012.

КСК ІІ - Л. М. Безносикова (ред.). Коми сёрнисикас кывчукӧр. Словарь диалектов коми языка. В 2 т. Т. 2. Сыктывкар: Кола, 2014.

Кузнецова 2010 - А. И. Кузнецова. Карнавал животных и проблемы ретрогностики (на материале уральских языков) // А. А. Кретов (ред.). Проблемы компьютерной лингвистики. Вып. 4. Воронеж: ВГУ, 2010. С. 126-133.

Кузнецова (ред.) 2010 - О. Л. Бирюк, Е. В. Кашкин, А. И. Кузнецова, М. Н. Усачёва. Словарь мужевского говора ижемского диалекта коми-зырянского языка. Екатеринбург: Баско, 2010.

Лельхова 2012 - Ф. М. Лельхова. Словарь глаголов хантыйского языка (шурышкарский диалект). Ханты-Мансийск: Издательский дом «Новости Югры», 2012.

Лыткин (ред.) 1961 - В. И. Лыткин (ред.). Коми-русский словарь. М.: Государственное изд-во иностранных и национальных словарей, 1961.

Лыткин, Гуляев 1970 - В. И. Лыткин, Е. С. Гуляев. Краткий этимологический словарь коми языка. М.: Наука, 1970.

Плешак, настоящий сборник - П. С. Плешак. Посессивные конструкции в самбургском коми // Настоящий сборник.

Повод 2006 - Н. А. Повод. Коми Северного Зауралья (XIX - первая четверть ХХ вв.). Новосибирск: Наука, 2006.

Привознов 2010 - Д. К. Привознов. Посессивные именные группы в тегинском говоре хантыйского языка // Acta Linguistica Petropolitana. Труды Института лингвистических исследований. 2010. Т. VI. Ч. 3. С. 137-141.

Рахилина 2008 - Е. В. Рахилина. Когнитивный анализ предметных имен: семантика и сочетаемость. М.: Русские словари, 2008.

Рахилина 2014 - Е. В. Рахилина. Грамматика ошибок: в поисках констант // О. В. Федорова, Е. А. Лютикова, М. А. Даниэль, В. А. Плунгян, С. Г. Татевосов (ред.). Язык. Константы. Переменные. Памяти Александра Евгеньевича Кибрика. СПб.: Алетейя, 2014. С. 87-95. 
Русакова 2013 - М. В. Русакова. Элементы антропоцентрической грамматики русского языка. М.: Языки славянской культуры, 2013.

Сахарова, Сельков 1976 - М. А. Сахарова, Н. Н. Сельков. Ижемский диалект коми языка. Сыктывкар: Коми книжное изд-во, 1976.

Соловар 2014 - В. Н. Соловар. Хантыйско-русский словарь (казымский диалект). Тюмень: ООО «Формат», 2014.

Сорвачева 1959 - В. А. Сорвачева. Материалы диалектологической экспедиции в Ямало-Ненецкий автономный округ (г. Салехард, ст. Лабытнанги и пос. Аксарка). Научный архив Коми НЦ УрО РАН. Фонд 1, опись 11, дело 101. 1959.

Сорвачева 1960 - В. А. Сорвачева. Ненецкие и хантыйские заимствования в говоре зауральских коми // Историко-филологический сборник. Вып. 6. Сыктывкар: Коми книжное изд-во, 1960. С. 171-177.

Сорвачева и др. 1966 - В. А. Сорвачева, М. А. Сахарова, Е. С. Гуляев. Верхневычегодский диалект коми языка. Сыктывкар: Коми книжное изд-во, 1966.

Сорокина, Болина 2009 - И. П. Сорокина, Д. С. Болина. Энецко-русский словарь. СПб.: Наука, 2009.

ССКЗД - В. А. Сорвачева (ред.). Сравнительный словарь коми-зырянских диалектов. Сыктывкар: Коми книжное изд-во, 1961.

Терещенко 1965 - Н. М. Терещенко. Ненецко-русский словарь. М.: Советская энциклопедия, 1965.

Туркин 1985 - А. Туркин. Коми-ненецкие языковые контакты // Советское финно-угроведение. 1985. Т. 21. № 3. С. 190-203.

Хаузенберг 1972 - А.-Р. Хаузенберг. Названия животных в коми языке (сравнительно-исторический анализ). Таллин: АН Эстонской ССР, 1972.

Haspelmath 2008 - M. Haspelmath. Loanword typology. Steps toward a systematic cross-linguistic study of lexical borrowability // T. Stolz, D. Bakker, R. Salas Palomo (eds.). Aspects of language contact: New theoretical, methodological and empirical findings with special focus on Romancisation processes. Berlin: Mouton de Gruyter, 2008. P. 43-62.

Haspelmath 2009 - M. Haspelmath. Lexical borrowing: concepts and issues // M. Haspelmath, U. Tadmor (eds.). Loanwords in the world's languages. Berlin: Mouton de Gruyter, 2009. P. 35-54.

Matras 2009 - Y. Matras. Language contact. Cambridge: Cambridge University Press, 2009.

Matras, Sakel 2007 — Y. Matras, J. Sakel. Investigating the mechanisms of pattern replication in language convergence // Studies in language. 2007. Vol. 31. Iss. 4. P. 829-865.

Nikolaeva 1999 - I. Nikolaeva. Ostyak. München, Newcastle: LINCOM Europa, 1999.

Salminen 1998 - T. Salminen. Nenets // D. Abondolo (ed.). The Uralic Languages. London; New York: Routledge, 1998. P. 516-547.

Thomason 2001 - S. Thomason. Language contact. Edinburgh: Edinburgh University Press, 2001.

Winford 2003 - D. Winford. An introduction to contact linguistics. Oxford: Blackwell Publishing, 2003. 
Zalizniak et al. 2012 - Anna A. Zalizniak, M. Bulakh, D. Ganenkov, I. Gruntov, T. Maisak, M. Russo. The catalogue of semantic shifts as a database for lexical semantic typology // Linguistics. 2012. Vol. 50. № 3. P. 633-669.

\section{References}

Anikin 2000 - A. E. Anikin. Etimologicheskiy slovar russkikh dialektov Sibiri: Zaimstvovaniya iz uralskikh, altayskikh i paleoaziatskikh yazykov [Etymological Dictionary of Russian dialects of Siberia: Borrowings from Uralic, Altaic and Paleo-Asiatic languages]. Moscow; Novosibirsk: Nauka, 2000.

Barmich 2015 - M. Ya. Barmich. Russko-nenetskiy slovar [Russian-Nenets dictionary]. St. Petersburg: Almaz-Graf, 2015.

Haspelmath 2008 - M. Haspelmath. Loanword typology. Steps toward a systematic cross-linguistic study of lexical borrowability. T. Stolz, D. Bakker, R. Salas Palomo (eds.). Aspects of language contact: New theoretical, methodological and empirical findings with special focus on Romancisation processes. Berlin: Mouton de Gruyter, 2008. P. 43-62.

Haspelmath 2009 - M. Haspelmath. Lexical borrowing: concepts and issues. M. Haspelmath, U. Tadmor (eds.). Loanwords in the world's languages. Berlin: Mouton de Gruyter, 2009. P. 35-54.

Hausenberg 1972 - A.-R. Hausenberg. Nazvaniya zhivotnykh v komi yazyke (sravnitelno-istoricheskiy analiz) [Names of animals in the Komi language (comparative historical analysis)]. Tallinn: Academy of Sciences of the Estonian SSR, 1972.

Igushev 1976 - Ye. A. Igushev. K voprosu o kulturnykh svyazyakh komi i nentsev [To the question of cultural relations of the Komi and Nenets people]. L. N. Zherebtsov (ed.). Etnografiya i folklor Komi [Ethnography and folklore of the Komi] (Trudy Instituta yazyka, literatury $i$ istorii. Iss. 17). Syktyvkar: Komi branch of the Academy of Sciences of the USSR, 1976. P. 116-118.

Kashkin 2016a - E. V. Kashkin. Glagoly pozitsii i ikh perekhodnye sootvetstviya $\mathrm{v}$ izhemskom dialekte komi-zyryanskogo yazyka [Posture verbs and their transitive correspondences in the Izhma dialect of the Komi-Zyryan language]. Rodnoy yazyk. 2016. No. 1. P. 54-76.

Kashkin 2016 b - E. V. Kashkin. Semantika khantyyskikh pozitsionnykh predikatov [Semantics of Khanty posture predicates]. A. A. Kretov (ed.). Problemy leksiko-semanticheskoy tipologii [Issues on lexico-semantic typology]. Iss. 3. Voronezh: Voronezh State University Press, 2016. P. 78-88.

Kodzasov, Krivnova 2001 - S. V. Kodzasov, O. F. Krivnova. Obshchaya fonetika [General phonetics]. Moscow: Russian State University for Humanities Press, 2001.

Kolegova 1959 - N. A. Kolegova. Materialy dialektologicheskoy ekspeditsii v Yamalo-Nenetskiy natsionalnyy okrug (ss. Muzhi i Shuryshkary) [Materials of the dialectological expedition to the Yamalo-Nenets National District (Shuryshkary and Muzhi villages)]. Pt. 1. 1959. Scientific archive of the Komi Scientific Center of the Ural branch of the RAS. Fund 1, inventory 11, file 193. 
Koshkareva (ed.) 2011 - N. B. Koshkareva (ed.). Dialektologicheskiy slovar khantyyskogo yazyka (shuryshkarskiy i priuralskiy dialekty) [Dialectological dictionary of Khanty language (Shuryshkary and Obdorsk dialects)]. Yekaterinburg: Basko, 2011.

Koshkareva 2013 - N. B. Koshkareva. Otrazhenie kak vid podchinitelnoy svyazi $\mathrm{v}$ yazykakh s vershinnym markirovaniem (na materiale khantyyskogo i nenetskogo yazykov) [Reflection as a type of subordination in head marking languages (based on the material of the Khanty and Nenets languages)]. Vestnik NGU. Seriya "Lingvistika i mezhkulturnaya kommunikatsiya". 2013. Vol. 11. Iss. 2. P. 27-41.

Koshkareva et al. 2017 - N. B. Koshkareva, E. V. Kashkin, Yu. B. Koryakov, O. A. Kazakevich, S. I. Burkova, N. A. Muravyev, E. M. Budyanskaya. Dialektologicheskiy atlas uralskikh yazykov, rasprostranennykh na territorii Yamalo-Nenetskogo avtonomnogo okruga [Dialectological atlas of the Uralic languages spoken in the Yamal-Nenets Autonomous District]. Kaliningrad: "ROST-DOAFK" Publishing House, 2017.

Koshkareva et al. 2011 - N. B. Koshkareva, O. A. Kazakevich, A. I. Kuznetsova, E. V. Kashkin, Yu. B. Koryakov. Opyt kartografirovaniya leksicheskikh dannykh po uralskim yazykam, rasprostranennym na territorii Yamalo-Nenetskogo AO [Mapping lexical data of the Uralic languages spoken in the Yamalo-Nenets Autonomous District]. Nauchnyy vestnik Yamalo-Nenetskogo avtonomnogo okruga. 2011. Iss. 4 (73). P. 3-7.

KSK I - L. M. Beznosikova (ed.). Komi syornisikas kyvchukör. Slovar dialektov komi yazyka [Dictionary of Komi language dialects]. In 2 vol. Vol. 1. Syktyvkar: Kola, 2012.

KSK II — L. M. Beznosikova (ed.). Komi syornisikas kyvchukör. Slovar dialektov komi yazyka [Dictionary of Komi language dialects]. In 2 vol. Vol. 2. Syktyvkar: Kola, 2014.

Kuznetsova (ed.) 2010 - O. L. Biryuk, E. V. Kashkin, A. I. Kuznetsova, M. N. Usacheva. Slovar muzhevskogo govora izhemskogo dialekta komi-zyryanskogo yazy$k a$ [Dictionary of the Muzhi variety of the Izhma dialect of the Komi-Zyryan language]. Yekaterinburg: Basko, 2010.

Kuznetsova 2010 - A. I. Kuznetsova. Karnaval zhivotnykh i problemy retrognostiki (na materiale uralskikh yazykov) [Carnival of animals and the problems of retrognostics (based on the material of the Uralic languages)]. A. A. Kretov (ed.). Problemy kompyuternoy lingvistiki [Issues in Computational Linguistics]. Iss. 4. Voronezh: Voronezh State University Press, 2010. P. 126-133.

Lelkhova 2012 - F. M. Lelkhova. Slovar glagolov khantyyskogo yazyka (shuryshkarskiy dialekt) [Dictionary of Khanty verbs (Shuryshkary dialect)]. Khanty-Mansiysk: "Novosti Yugry" Publishing House, 2012.

Lytkin (ed.) 1961 — V. I. Lytkin (ed.). Komi-russkiy slovar [Komi-Russian dictionary]. Moscow: State Publishing House of Foreign and National Dictionaries, 1961.

Lytkin, Gulyaev 1970 - V. I. Lytkin, E. S. Gulyaev. Kratkiy etimologicheskiy slovar komi yazyka [A brief etymological dictionary of the Komi language]. Moscow: Nauka, 1970. 
Matras 2009 - Y. Matras. Language contact. Cambridge: Cambridge University Press, 2009.

Matras, Sakel 2007 - Y. Matras, J. Sakel. Investigating the mechanisms of pattern replication in language convergence. Studies in language. 2004. Vol. 31. Iss. 4. P. 829-865.

Nikolaeva 1999 - I. Nikolaeva. Ostyak. München, Newcastle: LINCOM Europa, 1999.

Pleshak, this volume - P. S. Pleshak. Posessivnye konstruktsii v samburgskom komi [Possessive constructions in Samburg Komi]. This volume.

Povod 2006 - N. A. Povod. Komi Severnogo Zauralya (XIX - pervaya chetvert XX $v v$.) [Komi of the Northern Trans-Urals $\left(19^{\text {th }}\right.$ - the first quarter of the $20^{\text {th }}$ centuries)]. Novosibirsk: Nauka, 2006.

Privoznov 2010 - D. K. Privoznov. Posessivnye imennye gruppy v teginskom govore khantyyskogo yazyka [Possessive noun phrases in the Tegi dialect of the Khanty language]. Acta Linguistica Petropolitana. Trudy Instituta lingvisticheskikh issledovaniy. 2010. Vol. VI. Pt. 3. P. 137-141.

Rakhilina 2014 - E. V. Rakhilina. Grammatika oshibok: v poiskakh konstant [Grammar of errors: looking for constants]. O. V. Fedorova, E. A. Lyutikova, M. A. Daniel, V. A. Plungian, S. G. Tatevosov (eds.). Yazyk. Konstanty. Peremennye. Pamyati Aleksandra Evgenievicha Kibrika [Language. Constants. Variables. In memory of Alexandr Evgenievich Kibrik]. St. Petersburg: Aleteyya, 2014. P. 87-95.

Rakhilina 2008 - E. V. Rakhilina. Kognitivnyy analiz predmetnykh imen: semantika $i$ sochetaemost [Cognitive analysis of concrete nouns: semantics and combinability]. Moscow: Russkie slovari, 2008.

Rusakova 2013 - M. V. Rusakova. Elementy antropotsentricheskoy grammatiki russkogo yazyka [Elements of an anthropocentric grammar of the Russian language]. Moscow: Yazyki slavyanskoy kultury, 2013.

Sakharova, Selkov 1976 - M. A. Sakharova, N. N. Selkov. Izhemskiy dialekt komi yazyka [Izhma dialect of the Komi language]. Syktyvkar: Komi Book Publishing House, 1976.

Salminen 1998 - T. Salminen. Nenets. D. Abondolo (ed.). The Uralic Languages. London; New York: Routledge, 1998. P. 516-547.

Solovar 2014 - V. N. Solovar. Khantyysko-russkiy slovar (kazymskiy dialekt) [Khanty-Russian Dictionary (Kazym dialect)]. Tyumen: Format, 2014.

Sorokina, Bolina 2009 - I. P. Sorokina, D. S. Bolina. Enetsko-russkiy slovar [Enets-Russian dictionary]. St. Petersburg: Nauka, 2009.

Sorvacheva 1959 - V. A. Sorvacheva. Materialy dialektologicheskoy ekspeditsii v Yamalo-Nenetskiy avtonomnyy okrug (g. Salekhard, st. Labytnangi i pos. Aksarka) [Materials of the dialectological expedition to the Yamalo-Nenets National District (city of Salekhard, Labytnangi station and Aksarka village)]. Scientific archive of the Komi Scientific Center of the Ural branch of the RAS. Fund 1, inventory 11 , file 101.1959.

Sorvacheva 1960 - V. A. Sorvacheva. Nenetskie i khantyyskie zaimstvovaniya v govore zauralskikh komi [Nenets and Khanty borrowings in the dialect of the TransUral Komi]. Istoriko-filologicheskiy sbornik [Historical and Philological Collection]. Iss. 6. Syktyvkar: Komi Book Publishing House, 1960. P. 171-177. 
Sorvacheva et al. 1966 - V. A. Sorvacheva, M. A. Sakharova, E. S. Gulyaev. Verkhnevychegodskiy dialekt komi yazyka [Upper Vychegda dialect of Komi language]. Syktyvkar: Komi Book Publishing House, 1966.

SSKZD - V. A. Sorvacheva (ed.). Sravnitelnyy slovar komi-zyryanskikh dialektov [Comparative Dictionary of Komi-Zyryan dialects]. Syktyvkar: Komi Book Publishing House, 1961.

Tereshchenko 1965 - N. M. Tereshchenko. Nenetsko-russkiy slovar [Nenets-Russian dictionary]. Moscow: Sovetskaya entsiklopediya, 1965.

Thomason 2001 - S. Thomason. Language contact. Edinburgh: Edinburgh University Press, 2001.

Turkin 1985 - A. Turkin. Komi-nenetskie yazykovye kontakty [Komi-Nenets language contacts]. Sovetskoe finno-ugrovedenie. 1985. Vol. 21. No. 3. P. 190-203.

Winford 2003 - D. Winford. An introduction to contact linguistics. Oxford: Blackwell Publishing, 2003.

Zalizniak et al. 2012 - Anna A. Zalizniak, M. Bulakh, D. Ganenkov, I. Gruntov, T. Maisak, M. Russo. The catalogue of semantic shifts as a database for lexical semantic typology. Linguistics. 2012. Vol. 50. No. 3. P. 633-669.

Zherebtsov 1982 - L. N. Zherebtsov. Istoriko-kulturnye vzaimootnosheniya komi s sosednimi narodami [Historical and cultural relations of Komi with neighboring peoples]. Moscow: Nauka, 1982.

Zhilina 1959 - T. I. Zhilina. Materialy dialektologicheskoy ekspeditsii v Yamalo-Nenetskiy natsionalnyy okrug [Materials of the dialectological expedition to the Yamalo-Nenets National District]. Pt. 2. Scientific archive of the Komi Scientific Center of the Ural branch of the RAS. Fund 1, inventory 11, file 192. 1959.

Zhilina 1975 - T. I. Zhilina. Verkhnesysolskiy dialekt komi yazyka [Komi dialect of Upper Sysola]. Moscow: Nauka, 1975.

Zhilina 1985 — T. I. Zhilina. Luzsko-letskiy dialekt komi yazyka [Komi dialect of Luza and Letka]. Moscow: Nauka, 1985.

Zhilina, Kolegova 1960 - T. I. Zhilina, N. A. Kolegova. Nekotorye osobennosti govora obskikh komi (ss. Muzhi i Shuryshkary) [Some features of the dialect of $\mathrm{Ob}$ Komi (Shuryshkary and Muzhi villages)]. Istoriko-filologicheskiy sbornik [Historical and Philological Collection]. Iss. 6. Syktyvkar: Komi Book Publishing House, 1960. P. 152-170. 


\title{
Variations in Uralic words: The case of the Uralic * $t V r$-stem with a meaning 'trembling'
}

\section{Jeongdo Kim}

University of Helsinki (Finland); jeongdo.kim@helsinki.fi

\begin{abstract}
This paper presents words which describe, or are semantically connected with 'trembling' in Uralic languages and contain an initial consonant $t$, a middle consonant $r$, and variable vocalism. These words are to be regarded as onomatopoeics that imitate sounds or motion. This paper aims to reconstruct Proto-Uralic forms based on these words. The argument of this paper is that onomatopoeic words can undergo regular sound changes. This paper also aims to present convincing arguments for a semantic shift based on similar developments elsewhere.

The first Uralic cognate set that includes words with the meaning 'trembling' is: Finnic täristä 'tremble' Northern Saami dárrat 'be frantic, mad' Erzya Mordvin terńems $\sim$ Mokša Mordvin tärńzms 'tremble' Selkup tar(rə)- 'tremble'. The semantic correspondence between the meanings 'trembling' and 'mad' can be seen in the Finnish derivatives tärähtää 'shake; be mad', and täre (> täreellään, täreillään, täreessänsä, täreissänsä 'be excited, be on guard'). The words in the cognate set can be reconstructed to the Proto-Uralic stem *tärä-.

The second Uralic cognate set is: Mari tör $\gamma a \check{s}$ 'gallop, jump' Selkup tîrkə- 'tremble'. The semantic shift 'tremble' > 'jump' can be seen in Indo-European words like the Old English scacan 'shake, shiver; run, leave, flee'. The words in the cognate set can be reconstructed to the Proto-Uralic stem **tirka-.

Additionally, two hypothetical cognate sets can be presented. Both of them include the Northern Saami verb doarggistit 'tremble' which can be compared either to Tavda Mansi tark- 'tremble' and Vasjugan Khanty tărzyor 'tremble' or Sugurt Khanty tårz- 'tremble'. If the Northern Saami verb is compared to the Tavda Mansi and Vasjugan Khanty words, they can be reconstructed to the Proto-Uralic stem *tarki-. If it is compared to the Sugurt Khanty word, they can be reconstructed to the Proto-Uralic stem *torka-.
\end{abstract}

In conclusion, a secondary ablaut does not always cause irregularity of a diachronic vowel change.

Keywords: Uralic languages, onomatopoeic words, etymology, sound correspondences, cognate sets, semantic shift. 


\section{Вариантивность уральских слов на примере корня *tVr- 'дрожать'}

Ким Чондо

Хельсинкский университет (Финляндия); jeongdo.kim@helsinki.fi

Аннотация. В этой статье рассматриваются слова уральских языков, которые передают семантику 'дрожать' или смежные значения; первым согласным корня в них является $t$, вторым - $r$, вокализм корня вариантивен. Эти слова следует рассматривать как ономатопеи (слова, имитирующие звуки или движение). Цель данной работы - предложить реконструкцию уральских праформ этих слов. Будет показано, что развитие ономатопоэтических слов также характеризуется регулярными звуковыми изменениями. Кроме этого, в статье с опорой на типологические параллели рассматриваются семантические переходы, характерные для слов данной группы.

Первая группа родственных слов со значением 'дрожь' - это финское täristä 'дрожать' северносаамское dárrat 'быть неистовым, сумасшедшим' эрзя мордовское ternems мокша мордовское täŕńəms 'дрожать' селькупское $\operatorname{tar}(r \partial)$ - 'дрожать'. Связь значений 'дрожать’ и ‘быть безумным’ подтверждают финские производные от этой основы tärähtä̈̈ 'трясти; быть безумным’ и täre (> täreellään, täreillään, täreessänsä, täreissänsä ‘быть возбужденным, настороженным’). Уральская праформа для слов этой группы может быть восстановлена в виде * tärä-.

Вторая группа родственных слов с этим значением представлена марийским

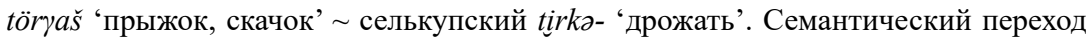
'дрожь’ > 'прыжок' подтверждается материалом индоевропейских языков, ср. древнеанглийское scacan 'трясти, дрожать; бежать, убегать'. Для слов этой группы можно предложить уральскую праформу **tirka-.

Кроме того, обсуждаются еще две гипотетически выделимых группы родственных слов из этого же семантического поля. Обе они включают северносаамский глагол doarggistit 'трепетать', который можно сравнить либо с тавдинским мансийским тарк- 'трепетать' и васюганским хантыйским тӑрәуор 'дрожать', либо с сургутским хантыйским та̊рәу- 'дрожать'. Сравнение северносаамского слова с тавдинским мансийским и васюганским хантыйским позволяет реконструировать уральскую праформу в виде *tarki-, сравнение с сургутским хантыйским в виде *torka-.

В статье также обсуждается проблема вторичного аблаута, который не всегда приводит к нерегулярным фонетическим изменениям вокализма.

Ключевые слова: уральские языки, ономатопеи, этимология, звуковые соответствия, семантические переходы. 


\section{Introduction}

In this paper, I present words describing or semantically connected with trembling in Uralic languages and reconstruct Proto-Uralic forms based on these words. All the Uralic words I present here contain stems that include an initial consonant $t$ and a middle consonant $r$ with variable vocalism. Phonetic similarity of words with a meaning 'trembling' is observed cross-linguistically, for example in Eng tremble, Kor ttēlta 'to tremble' [Martin et al. 1967: 448], and Bas dardara 'trembling' [Aulestia 1989: 138]. Words with a meaning 'trembling' can be regarded as onomatopoeic - that is, they imitate sounds or motion.

It has previously been argued that onomatopoeic words do not undergo regular sound changes, cf. [Anttila 1989: 86; Campbell 1998: 320]. Contrary to this traditional view, this paper aims to argue that onomatopoeic words can be reconstructed with the use of Neo-grammarian methodology that emphasizes the regularity of sound change. I examine sound correspondences in these words in light of recently updated theories of historical phonology of the Uralic languages.

Moreover, in earlier Uralic etymological studies, the words with a meaning 'trembling' have been etymologically compared with semantically different words, however no convincing arguments for the semantic shift were presented. In this paper, I examine semantic correspondences in previously proposed cognate sets that include words with the meaning 'trembling', searching for semantic parallels.

\section{The words}

\subsection{Finnic}

Finnic verbs meaning 'to tremble' are formed from the stem *tär- and the verb suffix *-istA, which is the most typical suffix for onomatopoeic verbs in Finnic [Jarva 2003: 84]: Fi täristä, Ka tärissä, Ing tärissä, Vo tärissä, Est täriseda, Liv de 'rž a [SKES V 1480-1481; SSA III 356]. Despite a wide distribution of this stem in Finnic, further cognates across Uralic have not previously been presented. However, regular cognates can be found in Saami, Mordvin and Selkup and reconstructed as a Proto-Uralic root *tärä-, as argued below (cf. Sections 2.2, 2.3, 2.7, 3). 
Aikio [2016: 41] regards the Finnish verb tarjeta 'to stand the cold, to feel warm enough' as inherited from the Proto-Uralic stem *tarki'to tremble', but the semantic shift 'to tremble' > 'to stand the cold' does not have any known parallels. Thus, it is rather dubious whether the original meaning of the Finnish verb was 'to tremble' '. Moreover, Karelian and Votic cognates of the verb tarjeta do not only mean 'to stand the cold' but also 'to dare', for example Ka tareta, tarreta 'to stand the cold; to dare; to have the heart to do something' [KKS VI 49-50], and Vo tarkema 'to dare' [Tsvetkov 1995: 333], hence which is the original meaning is not entirely clear.

Instead, the verb tarjeta represents the typical deadjectival verb stem *-ene- [ISK $§ 337$ ], which implies that the adjective tarkea 'willing, quick, busy; important' [Lönnrot 1930: 668] could be the root of such a verb (cf. pimeä 'dark'> pimene- 'to darken', kalpea 'pale' > kalpene- 'to pale').

\subsection{Saami}

Verbs with a meaning 'to tremble' that go back to a uniform ProtoSaami reconstruction are attested in all Saami languages except for Ter Sami: *tōrkēstē- > SaaS doårgiestidh, SaaU dåårgèstit, SaaP tåårkiestit, SaaL tår kēstit, SaaN doargestit, SaaI toargistid, SaaSk tuărggnjõs, SaaK toarkeo [Lehtiranta 2001: 138-139]. A Proto-Saami reconstruction includes a diminutive verb suffix - stē- which reflects a common Finnic-Saami protoform *-štA- [Sammallahti 1998: 92]. Aikio [2016: 41] has connected the aforementioned Proto-Saami reconstruction to the Proto-Uralic stem *tarki-. This is based on a new sound correspondence he proposed: PU *a-i > PWU *a-i > Pre-PFi *a-e $\sim$ PSaa $* o-\bar{e} \sim \mathrm{PMd} * u$. However, Proto-Saami *oa-e could also reflect a Proto-Uralic vowel combination *o-a-, for example PU *kota- $>$ PSaa *koate $>$ SaaN goahti, *ora 'awl' > PSaa *oarē > SaaN oar'ri [Aikio 2013: 12].

1 The meaning 'to tremble' seems to give rise to meaning connected with 'fever'. For instance, Lithuanian drugys 'fever, malaria, butterfly, moth' and Latvian drudzis 'fever' are cognates of Russian drož' 'shivering, tremor'. Their Balto-Slavic reconstruction *drugios has been compared with the verbs *drbgati and *drbžati 'to tremble, to shiver' [Derksen 2008: 123, 2015: 141-142]. Furthermore, in Selkup, there is a deverbal causative tirkolčampi- 'to cause fever' with the root tirkz- 'to tremble' [SlkWb 186]; cf. Section 2.7. However, the semantic correspondence between 'to stand the cold' and 'fever' is not flawless. According to my peer reviewer, 'standing the cold and getting fever are in fact opposite meanings'. I thank my peer reviewer for the comment. 
Northern Saami dárrat 'to be frantic, mad' and its cognates SaaP taarrat and SaaL tārrat inherited from Proto-Saami *tāre- [Aikio 2009: 200] ${ }^{2}$ can also be based on a meaning 'to tremble'. The similar semantic shift can be seen in Finnish derivatives tärähtää 'to shake; to be mad' and täre (> täreellään, täreillään, täreessänsä, täreissänsä 'excited, on guard' [SKES V 1481]). This kind of semantic shift appears to have been assumed in the etymological database of the Saami languages Álgu, where the Saami words mentioned above are compared with Swedish and Norwegian darra 'to tremble, to shiver'. However, these Scandinavian words do not have a regular reconstruction [Hellquist 1966: 87], which brings their archaic origins and their spread into Proto-Saami into question.

Instead, Northern Saami dárrat and its Saami cognates fit as regular cognates of Finnish täristä. This is based on the semantic correspondence discussed above and also on sound correspondences, for example PU *äjmä- > Fin äimä SaaN áibma [Lehtiranta 2001: 12]. As the latter cognate set implies, an initial vowel Proto-Saami $* \ddot{a}$ - has changed into $* \bar{a}$ in an $* \ddot{a}$-stem. The Proto-Uralic vowel combination * $\ddot{a}-\ddot{a}$ has changed into $* a-i(>a-e)$ in Finnic. However, according to Aikio [2016: 41], 'vowels belonging to derivative suffixes could block the backing of * $\ddot{a}$ to *a', as in Fi sälyttää 'put a burden on' ( $\leftarrow$ PU *sälä-) and tähde 'leftover' ( $\leftarrow$ PU *täktä 'bone'). Since a vowel $* i$ belongs to the verb suffix ${ }^{*}$-istA, it is phonetically regular to reconstruct the stem of Finnish täristä as *tärä- and connect it with the cognate set dárrat in Northern Saami.

\subsection{Mordvin}

In Mordvin, there are numerous verbs with a meaning 'to tremble' that are formed from stems containing consonants $t$ and $r$, e.g. MdE tarnoms, térnems 'to tremble', MdM tarâms 'to swing', tarnams, täŕńzms 'to tremble'. The verb suffix -nVms- is frequentative and typical for onomatopoeic words in Mordvin [Bartens 1999: 161]. MdE teŕnems and MdM täŕṅms are to be treated as regular cognates of Finnish täristä and Northern Saami dárrat. The Proto-Uralic first syllable * $\ddot{a}$ is reflected in Erzya $e$ and Mokša

2 Aikio [2009: 200-201] has suggested that the verb taroa, taruo 'to talk intensively', attested in some of the Eastern Savo dialects in Finnish and mainly the northern dialects of Karelian, is borrowed from either *tāre- or *tār-ō- 'to be dying, to be breathing one's last' of Proto-Saami. 
$\ddot{a}$, for example PU *käti- 'hand'> Fin käsi MdE ḱéd, MdM k̈äd; *täšti'star'> Fi tähti MdE tešte, MdM tääśtä [Bartens 1999: 55]; *pälä 'half'> Fin puoli MdE ṕéle, MdM ṕälä [Aikio 2016: 63].

In Veršinin's etymological dictionary of Mordvin [2009: 431] the afore-mentioned Mordvin verbs with the stem *tar-are compared with MdE tar'dems 'to ache, to be ill' and tarkstams 'to shiver (cold); to freeze'. The semantic correspondence between these sets of words seems to be satisfactory, because trembling is a natural symptom of aching or freezing. On the other hand, the phonetic correspondence between the two is not entirely regular, because the latter contains palatalized $r$. Moreover, among the words used in Veršinin's comparison there are some that show a substantial semantic difference from taŕdems, e.g. MdM tari 'racy', MdE MdM tarč 'fiery, brisk'.

In Veršinin's etymological dictionary, MdE taŕdems has been further compared with Komi turalni, turdini 'to freeze', Mari turtaš 'to contract, 'to shrink' and Finnish turtua 'to go numb'. The semantic correspondences between these verbs seem to be acceptable. However, regular sound correspondences are only found in the word pairs MdE taŕdems $\sim$ Ko turdinin and Fi turtua $\sim$ Ma turtaš, cf. [UEW 792]. Finnish turtua is obviously derived from turta 'numb', but Mari lacks such a noun, which would be the derivational basis for the verb turtas. On the other hand, turta has also been assumed to be a borrowing from Proto-Germanic *sturđa (> ON stord 'grass; young tree'). The latter has the same root as the adjective *sterdia- ( $>$ ON stirdr 'stiff, heavy' [SSA III 337; Koivulehto 1979: 151-152].

Aikio [2013: 9] connects MdE turgams 'to swell' to Fi tarjeta and SaaN doargestit on the basis of a sound correspondence he proposes (see Section 2.2). There are, however, no examples that show a semantic shift from 'to tremble' to 'to swell' ${ }^{3}$. Apparently for this reason, Aikio [2016: 41] has withdrawn MdE turgams from cognate sets based on Proto-Uralic *tarki-. On the other hand, it is most likely that MdE turgams is etymologically related to MdE turva MdM târva 'lip', as Veršinin has also suggested [2009: 449].

\footnotetext{
${ }^{3}$ Instead of a meaning 'to tremble', a meaning 'to blow' can give rise to a meaning 'to swell', for example Eng puff > puff up, Ka puhaltoa 'to blow; 'to make swell'. Mordvin languages have some examples that show a semantic shift from 'to tremble' to 'jelly', e.g. MdE térǵe, MdM täróg̈ä 'jelly' MdE teŕnems MdM täŕńams [Verši$\operatorname{nin}$ 2009: 435].
} 
There are also other verbs with a meaning 'to swell' formed from stems consisting of initial consonants $t$ and stem consonant $r$ : MdE targoźems MdM targəźəms, MdE toroźems MdM torâżams. The first two words have been regarded as derivatives from MdE MdM targams 'to drag' [MWb IV 2277], whereas the latter two have been compared with Fi turpea [SSA III 366]. Nevertheless, convincing etymologies for these words have not yet been proposed.

\subsection{Mari}

Mari seems to lack words meaning 'to tremble' that are formed from the stem containing an initial consonant $t$ and stem consonant $r$. Instead, Mari töryaš 'to jump, to skip', which has the initial syllable vowel $\ddot{o}$ in almost all Mari varieties (TschWb 813; Aikio 2014: 132) is probably an inherited word. Aikio (2014) argues that in Mari, a Proto-Uralic initial syllable vowel $*_{i}$ before liquid consonants has been changed to $\ddot{o}$, which is reflected in, e.g., PU *mirja 'berry' > PMari mürə > MaE MaW mör 'strawberry' (UEW: 264-265), PU *níri > PMari *nüra > MaE nörö, MaW nörə 'flexible, pliable' (Aikio 2014: 234). The semantic shift 'to tremble' > 'to jump' can be seen in Indo-European words like PG *skakan- 'to shake; 'to leave' > OE scacan 'to shake, shiver; to run, leave, flee' (> Eng shake) OFri. skeka 'to run away from home' $\sim$ OS skakan 'to leave' $\sim$ MDu schaken 'to leave, escape, run away with someone' [Kroonen 2013: 438].

\subsection{Permic}

In Komi, there are words formed from the stem *tar- semantically connected with motion: taredni 'to shiver, to shake', tarzzini 'to shiver', tarevtni 'to roll' [Wichmann, Uotila 1942: 271]. In the Malmyź-dialect of Udmurt, a phonologically and semantically similar word taretini 'to buzz' [WW 256] was also attested. The stem *tar- can be regarded as an ideophone, for example in Ko tara kilni 'to rattle', tur-tar uśni 'to stumble from stairs', turk-tark kerni 'to rattle' [Wichmann, Uotila 1942: 271]. In Komi, a reduplication where two vowels $* u$ and $* a$ alternate is common, as in gur-gar uśny 'to stumble on stony or bumpy ground', ńum-ńam kerny 'to eat quickly with a loud noise' (Bartens 2000: 326-327). Another Komi ideophone tur- has also been regarded as a derivative stem for words 
semantically connected with snowing, including tureb 'blizzard', turbil'alni 'to roll', turdni 'to snow' and turźini 'to snow heavily' (Wichmann and Uotila 1942: 285-286). However, it is also possible that the ideophone turis merely a variant of tar- and therefore etymologically unrelated to the afore-mentioned words.

In [KESKJ 278] tarźini 'to shiver' is compared with MdE tarnoms and MdM taroms, but sound correspondences between them are irregular. If the Komi verb tarźini is an inherited word, it could reflect Proto-Permic *a, which could eventually be inherited from Proto-Uralic * $\ddot{a}$, for example in PU *näke- > PPerm na-> Ud naani 'to watch' [Sammallahti 1988: 531]; PU *äjjä- 'old man' > PPerm aji > Ko aj, Ud aji 'father; male' [Sammallahti 1988: 552]. On the other hand, Proto-Uralic * $\ddot{a}$ is also reflected in Proto-Permic *ä: PU *tälwä- > PPerm *täl- > Ko tell, Ud tol 'winter'; $\mathrm{PU}$ *säppä > PPerm säp- > Ko sep, Ud sep 'bile' [Aikio 2016: 64; Sammallahti 1988: 548,550$]^{4}$. Therefore, it is uncertain whether the Komi verb actually goes back to a Proto-Uralic form *tärä-. Komi turźinini ([KESKJ 287], cf. turźiśsini as headword of the article) has been compared with Mari torlaš 'to move away; to become lose' and türgaš 'to swirl, to raise'. However, the former has been regarded as borrowed from a common Turkic form tara'to disperse, to spread, to open up' [Bereczki 2013: 279-280], and the latter manifests a phonologically irregular correspondence.

Aikio [2013: 9; 2016: 53] connects Komi turalni 'to freeze' to a cognate set based on Proto-Uralic *tarki- 'to tremble', which seems to be both phonologically and semantically acceptable. However, the etymological connection between turalni and other Komi words formed from the stem *turshould be explained before arguing that it goes back to PU *tarki-. Moreover, Komi turalni and turdini manifest a regular phonetic match with MdE taŕdems which cannot go back to PU *tarki-.

A Komi frequentative verb tiravni 'to shiver (with cold)' has been compared to Erzya teŕnems in [KESKJ 279], but sound correspondences between the two are irregular. If Komi tiravni is an inherited word, it would rather reflect the Proto-Uralic vowel combination $* i-i$, as in PU $* n i m i>$ PPerm *ńmm > Ko Ud ńim [Bartens 2000: 60].

${ }^{4}$ According to [Zhivlov 2014: 123], there are four Proto-Udmurt reflexes of the Proto-Permic * $\ddot{a}$. Their distribution depends on the following conditions: *e before palatalized consonants and $s ; *_{o}$ before non-palatalized sibilants and affricates (except $s$ ) and before $l$ after a dental stop; ${ }^{*} a$ before $l$ (except after a dental stop), ${ }^{*} e \sim{ }^{*} o$ before non-palatalized nasals, non-palatalized stops and $r$. 


\subsection{Ob-Ugric}

Aikio [2013: 9; 2016: 41] reconstructs a Proto-Mansi form *tārzy- which is reflected in, e.g., Tavda dialect tark- and Sosva dialect tōry- 'to tremble', cf. also [WWb 931]. This Proto-Mansi reconstruction goes back to PU *tarki- based on the sound change of the Proto-Uralic vowel combination *a-i, as in PU *ańi 'female in-law'> PMs *āńay > MsT āńi 'paternal uncle's wife', MsSo ǰńí 'stepmother, older brother's wife', cf. [Aikio 2016: 51].

On the other hand, Aikio reconstructs two Proto-Khanty forms connected with PU *tarki- that show irregular sound correspondences: PKh *tiray(> KhVVj tăray-, KhO tări-) *tāray- (> KhVVJ tarəy-, KhSur tåray-, KhIrt toraj-, KhNi torij-, KhKaz tori- [Aikio 2016: 53]). According to Aikio [2016: 35], Proto-Khanty $* a$ or $* i$ reflects the Proto-Uralic vowel combination $* a-i$, whereas $\mathrm{PKh} * \bar{a}$ comes from $\mathrm{PU} *_{o-a}$, as in $\mathrm{PU} * k o d w a>$ PKh *kāl $>$ KhVVj kal-; PU *kojra $>$ PKh *kār $>$ KhVVj kar.

In Mansi and Khanty, it appears that the afore-mentioned stems PMs *târay- and PKh *tiray- have further developed by addition of the stem consonant -n-: MsKU tòrn-, MsKM tōrn-, MsSo tōrn- 'to vibrate; to ring' [WWb 940] KhIrt VVj tărńa- 'to swing, to shake' [Owb 1024].

\subsection{Samoyed}

Selkup is the only one of the Samoyed languages where verbs with the meaning 'to tremble' are formed from stems containing an initial consonant $t$ and middle consonant $r$. The first is tirkz- 'to tremble' [SlkWb 186] whose initial syllable vowel $i$ reflects Proto-Uralic $* i$, for example PU *mitka 'passage' > PSam *mitå > SlkTaz miti 'way, track'; PU *siksa 'Siberian pine' > PSam *titåjy > SlkTaz tittin [Aikio 2016: 60]. Thus, Selkup tirka- shows a regular sound correspondence with Mari törgaš 'to jump, to skip', which goes back to a Proto-Uralic form *tirka(cf. Sections 2.4 and 3).

Another such verb is $\operatorname{tar}(r \partial)$ - 'to tremble' [SlkWb 183], which could reflect a Proto-Uralic vowel combination * $\ddot{a}$ - $\ddot{a}$, as in PU *käńśä- 'to freeze'> PSam *kanse- > Slk kaśa 'to cool down' [Aikio 2002: 21]. This Selkup verb seems to belong to the same cognate set as Fi täristä, SaaN dárrat and MdE térnems, MdM täŕñams. 


\section{Summary and discussion}

In conclusion, I present two new relatively clear Uralic cognate sets that have not been mentioned in any previous Uralic etymological studies:

PU *tirka- > Ma törraš 'to gallop, to jump' Slk tirka- 'to tremble'

PU *tärä- > SaaN dárrat 'to be frantic, mad' Fi täristä 'to tremble' MdE terńnems, MdM täŕŕms 'to tremble' SlkTy tar(ra) - 'to tremble'

Additionally, two hypothetical cognate sets are presented. The plausibility of one over the other depends on a cognate set to which a Northern Saami verb doarggistit is compared:

?PU *tarki- > SaaN doarggistit 'to tremble' MsT tark-, MsSo torr $-\sim$ KhVVj tăray, KhO tări- 'to tremble'

?PU *torka- > SaaN doarggistit 'to tremble' $\sim$ KhSur tårəy-, KhIrt toraj-, KhNi torij-, KhKaz tori- 'to tremble'

Mordvin words derived from the stem *tar- may reflect a Proto-Uralic initial syllable vowel $*_{i}$. However, due to the lack of a stem consonant $* k$ and its semantic diversity, these words are not treated as belonging to a cognate set based on Proto-Uralic *tirka-. Permic words formed from the stem *tarmay go back to PU *tärä-, as mentioned in Section 2.4, but due to the uncertainty of Permic vocalism, they cannot be straightforwardly compared with cognate sets based on PU *tärä-. Finnish tarjeta, Mordvin turgams and Komi turalni considered by Aikio [2013: 9] as going back to PU *tarki- are discarded from the cognate set due to an overly large semantic distance and other possibilities of their reconstructions, despite their regular sound correspondences to this set.

The Proto-Uralic forms presented above contain the same initial and middle consonants; only their vowels differ. Therefore, they may show a secondary ablaut, which is typical for onomatopoeic words [Bloomfield 1909: 245-288]. Proto-Uralic forms analyzed in this paper indicate that a secondary ablaut does not always cause irregularity of a diachronic vowel change.

Nevertheless, the database used in this paper is too restricted to make conclusions about the phonetic regularity of the whole Uralic onomatopoeic vocabulary. Therefore, broader studies are needed here. 


\section{Abbreviations}

Bas - Basque; Eng - English; Est - Estonian; Fi — Finnish; Ing — Ingrian; Ka — Karelian; Ko - Komi; Kor — Korean; KhV — Vakh Khanty; KhSur — Surgut Khnaty; KhIrt - Irtysh Khanty; KhKaz — Kazym Khanty; KhNi — Nizyam Khanty; Liv — Livonian; Ma — Mari; MaE — East Mari; MaW — West Mari; MdE — Erzya Mordvin; MdM — Moksha Mordvin; MsT — Tavda Mansi; MsKM — Mid Konda Mansi; MsKU — Upper Konda Mansi; MsSo — Sosva Mansi; MDu — Middle Dutch; OE - Old English; OFri — Old Frisian; ON — Old Norse; OS — Old Saxon; PG Proto-Germanic; PKh — Proto-Khanty; PMari — Proto-Mari; PMd — Proto-Mordvin; PMs - Proto-Mansi; PPerm — Proto-Permic; Pre-PFi — Pre-Proto-Finnic; PSaa — Proto-Saami; PSam — Proto-Samoyed; PU Proto-Uralic; PWU — Proto-West-Uralic; SaaI — Inari Saami; SaaK — Kildin Saami; SaaL — Lule Saami; SaaN — North Saami; SaaP — Pite Saami; SaaS — South Saami; SaaSk — Skold Saami; SaaU — Ume Saami; Slk — Selkup; SlkTaz — Taz Selkup; Ud — Udmurt.

\section{References}

Aikio 2002 - A. Aikio. New and old Samoyed etymologies. Finnisch-Ugrische Forschungen. 2002. Bd. 57. S. 9-57.

Aikio 2009 - A. Aikio. The Saami loanwords in Finnish and Karelian. PhD dissertation. Oulu: University of Oulu, 2009.

Aikio 2013 - A. Aikio. Uralilaisen kantakielen vokaalistosta. Paper presented at Etymologia ja kielihistoria: E. Itkosen ja A. J. Joen 100-vuotisjuhlaseminaari, Helsinki.

Aikio 2014 - A. Aikio. On the reconstruction of Proto-Mari vocalism. Voprosy yazykovogo rodstva. Journal of Language Relationship. 2014. No. 11. P. 125-157.

Aikio 2015 - A. Aikio. Studies in Uralic Etymology IV: Ob-Ugric etymologies. Linguistica Uralica. 2015. Vol. LI. No. 1. P. 1-20.

Aikio 2016 - A. Aikio 2016. The Finnic 'secondary e-stems' and Proto-Uralic vocalism. Suomalais-Ugrilaisen Seuran Aikakauskirja. Journal de la Société Finno-Ougrienne. 2016. No. 95. P. 25-66.

Anttila 1989 - R. Anttila 1989. Historical and comparative linguistics. $2^{\text {nd }}$, revised edition. Amsterdam; Philadelphia: Benjamins, 1989.

Álgu — Etymological database of the Saami languages. Helsinki: Instuitute for the languages of Finland. Available at: http://kaino.kotus.fi/algu/ (accessed on 03.12.2019).

Aulestia 1989 - G. Aulestia. Basque-English dictionary. Reno: University of Nevada Press, 1989.

Bartens 1999 - R. Bartens. Mordvalaiskielten rakenne ja kehitys (Suomalais-Ugrilaisen Seuran Toimituksia. Vol. 232). Helsinki: Suomalais-Ugrilainen Seura, 1999.

Bartens 2000 - R. Bartens. Permiläisten kielten rakenne ja kehitys (Suomalais-Ugrilaisen Seuran Toimituksia. Vol. 238). Helsinki: Suomalais-Ugrilainen Seura, 2000. 
Bereczki 2013 - G. Bereczki. Etymologisches Wörterbuch des Tscheremissischen (Mari). Der einheimische Wortschatz. Nach dem Tode des Verfassers herausgegeben von K. Agyagási und E. Winkler (Veröffentlichungen der Societas Uralo-Altaica. Bd. 86). Wiesbaden: Harrassowitz, 2013.

Bloomfield 1909 - L. Bloomfield. A semasiologic differentiation in Germanic secondary ablaut. Modern Philology. 1909. Vol. 7. No. 2. P. 245-288.

Campbell 1998 - L. Campbell. Historical linguistics: an introduction. Cambridge, Massachusetts: The MIT Press, 1998.

Hellquist 1966 - E. Hellquist. Svensk etymologisk ordbok. 3. upplag. Lund: Gleerups, 1966. ISK - A. Hakulinen, M. Vilkuna, R. Korhonen, V. Koivisto, T. R. Heinonen, I. Alho. Iso suomen kielioppi. Helsinki: Suomalaisen Kirjallisuuden Seura, 2004.

Jarva 2003 - V. Jarva. Venäläisperäisyys ja ekspressiivisyys suomen murteiden sanastossa (Jyväskylä Studies in Humanities. Vol. 5). Jyväskylä: University of Jyväskylä, 2003.

Koivulehto 1979 - J. Koivulehto. Baltisches und Germanisches im Finnischen: die finnische Stämme auf -rte und die finn. Sequenz VrtV. E. Schiefer (toim.). Explanationes et tractationes Fenno-Ugricae in honorem Hans Fromm. München: Wilhelm Fink Verlag, 1979. P. 129-164.

Kroonen 2013 - G. Kroonen. Etymological Dictionary of Proto-Germanic (Leiden Indo-European Etymological Dictionary Series. Vol. II). Leiden; Boston: Brill, 2013.

Lehtiranta 2001 - J. Lehtiranta. Yhteissaamelainen sanasto (Suomalais-Ugrilaisen Seuran Toimituksia. Vol. 200). Helsinki: Suomalais-Ugrilainen Seura, 2001.

Lönnrot 1930 — E. Lönnrot. Suomalais-Ruotsalainen Sanakirja. Osa I-II. Toinen, manul-menetelmällä jäljennetty painos. Helsinki: WSOY, 1930 [1867].

Martin et al. 1967 - S. E. Martin, Y. H. Lee, S. U. Chang (eds.). A Korean-English Dictionary. Massachusetts: Yale University Press, 1967.

Sammallahti 1988 - P. Sammallahti. Historical Phonology of the Uralic Languages with Special Reference to Samoyed, Ugric and Permic. D. Sinor (ed.). The Uralic languages. Description, History and Foreign Influences. Leiden; New York; København; Köln, 1988. P. 478-554.

Sammallahti 1998 — P. Sammallahti. The Saami languages: An introduction. Kárášjohka: Davvi girji, 1998.

Vaba 1994 - L. Vaba. Zu den baltischen $m$-Deverbalen in den ostseefinnischen Sprachen. Linguistica Uralica. 1994. Vol. XXX. No. 4. P. 241-247.

Zhivlov 2014 - M. Zhivlov. Studies in Uralic vocalism III. Voprosy yazykovogo rodstva. Journal of Language Relationship. 2014. No. 12. P. 113-148.

\section{Sources}

KESKJ - V. I. Lytkin, E. S. Gulyayev. Kratkiy etimologicheskiy slovar komi yazyka. [A brief etymological dictionary of Komi language]. Moscow: Nauka, 1970.

KKS — Karjalan kielen sanakirja (Lexica Societatis Fenno-Ugricae. Vol. XVI). Helsinki: Suomalais-Ugrilainen Seura, 1968-1997. 
$\mathrm{MWb}-$ H. Paasonens Mordwinisches Wörterbuch. Zusammengestellt von K. Heikkilä. Bearbeitet und herausgegeben von Martti Kahla (Kotimaisten kielten tutkimuskeskuksen julkaisuja. Vol. 59; Lexica Societatis Fenno-Ugricae. Vol. XXIII). Helsinki: Suomalais-Ugrilainen Seura. 1990-1999.

Owb - K. F. Karjalainens ostjakisches Wörterbuch. In 2 Bd. Bearbeitet und herausgegeben von Y. H. Toivonen (Lexica Societatis Fenno-Ugricae. Vol. X). Helsinki: Suomalais-Ugrilainen Seura, 1948.

SlkWb - Sölkupisches Wörterbuch aus Aufzeichnungen von K. Donner, U. T. Sirelius und J. Alatalo. Zusammengestellt und herausgegeben von J. Alatalo (Lexica Societatis Fenno-Ugricae. Vol. XXX). Helsinki: Suomalais-Ugrilainen Seura, 2004. SKES - Y. H. Toivonen, E. Itkonen, A. J. Joki, R. Peltola. Suomen kielen etymologinen sanakirja. T. I-VII (Lexica Societatis Fenno-Ugricae. Vol. XII). Helsinki: Suomalais-Ugrilainen Seura. 1955-1981.

SSA - E. Itkonen, U-M. Kulonen (eds.). Suomen sanojen alkuperä. Etymologinen sanakirja. Helsinki: Kotimaisten kielten tutkimuskeskus; Suomalaisen Kirjallisuuden Seura. 1992-2000.

Tsvetkov 1995 - D. Tsvetkov. Vatjan kielen Joenperän murteen sanasto. Helsinki: Suomalais-Ugrilainen Seura, 1995.

$\mathrm{TWb}$ - A. Moisio, S. Saarinen. Tscheremissisches Wörterbuch. Aufgezeichnet von V. Porkka, A. Genetz, Y. Wichmann, M. Räsänen, T. E. Uotila, E. Itkonen (Lexica Societatis Fenno-Ugricae. Vol. XXXII). Helsinki: Suomalais-Ugrilainen Seura; Kotimaisten kielten tutkimuskeskus, 2008.

UEW - K. Rédei (ed.). Uralisches Etymologisches Wörterbuch. Budapest: Akadémiai Kiadó. 1988-1991.

Veršinin 2009 - В. И. Вершинин. Этимологический словарь мордовских (эрзянского и мокшанского) языков. Том IV. Йошкар-Ола: Стринг, 2009 (V. I. Vershinin. Etimologicheskiy slovar mordovskikh (erzyanskogo i mokshanskogo) yazykov [Etymological dictionary of Mordvin (Erzya and Moksha) languages]. Vol. IV. YoshkarOla: String, 2009).

$\mathrm{WWb}$ - Wogulisches Wörterbuch. Gesammelt und geordnet von A. Kannisto, bearbeitet von V. Eiras. Herausgegeben von A. Moisio (Lexica Societatis Fenno-Ugricae. Vol. XXXIII). Helsinki: Suomalais-Ugrilainen Seura; Kotimaisten kielten keskus, 2013.

WW - Wotjakischer Wortschatz. Aufgezeichnet von Y. Wichmann, bearbeitet von T. E. Uotila und M. Korhonen (Lexica Societatis Fenno-Ugricae. Vol. XXI). Helsinki: Suomalais-Ugrilainen Seura, 1987.

Wichmann, Uotila 1942 - Y. Wichmann, T. Uotila. Syrjänischer Wortschatz nebst Hauptzügen der Formenlehre (Lexica Societatis Fenno-Ugricae. Vol. VII). Helsinki: Suomalais-Ugrilainen Seura, 1942. 


\title{
У истоков отечественной унгаристики: опыт первого научного русскоязычного описания венгерского языка
}

\author{
Н. Н. Колпакова \\ Санкт-Петербургский государственный университет; nnkolp@mail.ru
}

Аннотация. В статье представлен краткий анализ первых в российской лексикографии венгерско-русского и русско-венгерского словарей, а также определяется их значение в становлении отечественной унгаристики, в частности в формировании русскоязычной терминологии для грамматического описания венгерского языка. Особое внимание уделяется анализу краткого грамматического справочника венгерского языка для «Русско-венгерского словаря», в создании которого принял непосредственное участие член-корреспондент АН СССР Д. В. Бубрих.

Ключевые слова: унгаристика, Д. В. Бубрих.

\section{The dawn of Russian ungaristics: The experience of the first scientific Russian-language description of Hungarian}

\author{
N. N. Kolpakova \\ St. Petersburg State University; nnkolp@mail.ru
}

Absract. The article presents a brief analysis of the first Hungarian-Russian and Russian-Hungarian dictionaries as a phenomenon in Russian bilingual lexicography, dwelling on the importance of these dictionaries in the formation of Russian ungaristics, in particular in the creation of Russian-language terminology for grammatical descriptions of Hungarian. Particular attention is paid to the analysis of the brief grammatical reference guide of Hungarian in the Russian-Hungarian Dictionary, compiled with direct participation of the corresponding member of the USSR Academy of Sciences D. V. Bubrich.

Working on the Russian-Hungarian Dictionary, D. V. Bubrich aimed to remedy a significant drawback of the Hungarian-Russian Dictionary (published earlier in 1946) which lacked a systematic Russian-language description of at least the main grammatical features of Hungarian. Instead, it only provided a brief instruction for dictionary users and 
a short commentary on the verb conjugation tables printed at the end of the dictionary (with a number of incorrectly used grammatical terms).

In the Russian-Hungarian Dictionary published in 1947, D. V. Bubrich (with E. S. Haas as a co-author) presented a short grammatical reference guide on Hungarian that covered all the main aspects of grammar: phonetics, morphology, and syntax. The linguistic terminology used deserves special attention. In fact, it was the beginning of the creation of a terminology system for Russian-language descriptions of Hungarian.

The material of the grammar reference guide shows that D. V. Bubrich had his own opinion on a number of controversial issues of Hungarian grammar, in particular, on the presence and composition of cases, the composition of parts of speech, the status of verbal formations, etc. His basic linguistic Russian terminology has stood the test of time and is widely used today.

Keywords: ungaristics, D. V. Bubrich.

Первые в нашей стране венгерско-русский и русско-венгерский словари интересны во многих отношениях, прежде всего, для исследователей истории двуязычной лексикографии. Однако не следует забывать, что в них нашел отражение также и первый опыт русскоязычного грамматического описания венгерского языка. Непосредственное участие в создании краткого грамматического справочника венгерского языка для «Русско-венгерского словаря» принял член-корреспондент АН СССР Д. В. Бубрих. Особенности грамматического описания, а также используемую в этих словарях русскоязычную лингвистическую терминологию мы и рассмотрим в статье.

В 2016 году исполнилось 70 лет с тех пор, как на кафедре финно-угорской филологии СПбГУ началось преподавание венгерского языка. Как пишет в своей автобиографии первый преподаватель венгерского языка в СПбГУ (в те годы: ЛГУ) Вера Сергеевна Люблинская, в 1946 году ее пригласил работать на кафедре Д. В. Бубрих [ОАСПбГУ. Ф. 1: л. 60]. В то время не было ни учебных пособий, ни опыта преподавания венгерского языка как специальности. Нужно было создавать и двуязычные словари. Решению этой задачи отводили особую роль. В феврале 1945 года, когда еще не закончилась война, был сдан в набор, а в апреле 1946 года увидел свет первый в нашей стране венгерско-русский словарь [Венгерско-русский словарь 1946]. Этот маленький словарь карманного типа вышел тиражом 10000 экземпляров. Сразу вслед за ним, в июле 1946 года сдается в набор первый русско-венгерский словарь, который далее в 1947 году выходит из печати тем же тиражом [Русско-венгерский словарь 1947]. 
Эти словари небольшого формата давно стали библиографической редкостью и, по понятным причинам, не используются, однако забывать о них нельзя. Они уникальны потому, что представляют собой первый опыт создания венгерско-русского и русско-венгерского словарей в нашей стране и демонстрируют не только лексикографические представления коллектива их создателей, что само по себе интересно, но также и первые попытки системного русскоязычного описания венгерского языка. Нет сомнений, что темой отдельного исследования может стать анализ собственно корпуса каждого из этих словарей, однако мы предлагаем сосредоточить основное внимание на других разделах и приложениях, которыми принято сопровождать словари такого типа.

В «Венгерско-русский словарь» 1946 года включены лишь очень краткие, составляющие менее страницы текста, вводные статьи: от издательства и о том, как пользоваться словарем. Этот материал, впрочем, дает некоторое представление об используемой лингвистической терминологии (а точнее, о том, что на русском языке она к тому моменту еще не разработана), а также о построении словарной статьи и об отражении необходимой, по мнению составителей и редакторского коллектива, грамматической информации. Несмотря на отсутствие грамматического справочника венгерского языка, словарь снабжен таблицами спряжения неправильных глаголов. Эти таблицы предваряются краткими комментариями научно-контрольного редактора словаря, кандидата филологических наук К. Е. Майтинской [Венгерско-русский словарь 1946: 349-383]. Таблицы содержат неопределенную форму глагола (выступающую в качестве заглавного слова также и в словарной статье, вопреки венгерской лексикографической традиции использовать в этой функции форму настоящего времени безобъектного спряжения 3-го лица ед. ч.), форму настоящего времени 3-го лица единственного числа безобъектного и объектного спряжений (типы спряжений неудачно именуются в этом словаре субъективным и объективным), форму «устарелого» прошедшего времени, форму повелительного наклонения, а также причастия и деепричастия. Как известно, для К. Е. Майтинской венгерский язык был родным, однако изначально она не была финно-угроведом и защитила кандидатскую диссертацию по германистике. Для нее работа с венгерским языком в теоретическом плане также представляла определенные трудности, к тому же она тогда еще недостаточно хорошо владела русским языком. Очевидно, это обстоятельство не позволило ей написать грамматический очерк для словаря, а та краткая грамматическая информация, которая 
все же нашла здесь отражение, порой не лишена терминологических недостатков. В частности, выше уже упоминались неудачные термины субъективное и объективное спряжение. Следует отметить, что интенсивное изучение финно-угорских языков в нашей стране в довоенный период, естественно, сопровождалось и процессом выработки соответствующей терминологии. Вероятно, используя термин объективное спряжение в комментариях к таблицам спряжения неправильных глаголов в «Венгерско-русском словаре», К. Е. Майтинская ориентировалась на наименование этой парадигмы в грамматическом очерке к «Краткому мансийско-русскому словарю» 1936 года, с материалом которого она имела возможность познакомиться [Чернецов, Чернецова 1936: 35-36, 44, 48]. Уже по аналогии с этим термином она называет безобъектное / субъектное спряжение субъективным спряжением.

Обращает на себя внимание и то, что в этом словаре еще не употребляют используемый в «Русско-венгерском словаре» Д. В. Бубрихом и позднее ставший употребительным в научной и учебной литературе термин иковые глаголь: они именуются здесь глаголами на ik [Венгерско-русский словарь 1946: 4].

Несмотря на небольшой формат, объем словаря составляет 20000 слов. Такой большой словник удалось создать за счет включения минимального количества русских эквивалентов в каждую словарную статью (учитывались только основные значения заглавного слова), а также за счет очень небольшого количества иллюстративного материала. Для любого читателя, хоть сколько-нибудь знакомого с венгерской грамматикой, становится очевидным, что системного представления о ней предлагаемая в словаре грамматическая информация не дает. Более того, ряд принятых авторами решений вызывает вопросы (например, не понятны принципы лексикографического описания личных и притяжательных местоимений: к некоторым из них не дается никакой информации кроме русского эквивалента, другие же снабжены рядом произвольно выбранных падежных или притяжательных форм). Мы не ставим задачу подробно проанализировать все недостатки и достоинства «Венгерско-русского словаря». Его материал интересен, однако, в том смысле, что он позволяет в полной мере оценить написанный Д. В. Бубрихом и Э. С. Хаас грамматический справочник по венгерскому языку, являющийся приложением к «Русско-венгерскому словарю» 1947 года [Русско-венгерский словарь 1947: 416-443].

Словник «Русско-венгерского словаря» содержит около 25000 слов. Перечень источников, использованных при составлении словаря, 
существенно пополнился: в него включены пять словарей, причем один из них - единственный опубликованный к тому времени для пары языков венгерский - русский, военный венгерско-русский словарь Э. С. Хаас и Н. Н. Биязи 1943 года издания [Русско-венгерский словарь 1947: 3] (в «Венгерско-русском словаре» было только два довоенных источника). Более основательным и информативным, чем в «Венгерско-русском словаре», является раздел «Как пользоваться словарем» [Русско-венгерский словарь 1947: 4-7]. Ясно, что в процессе подготовки к публикации были учтены недочеты «Венгерско-русского словаря». Например, если соединительный гласный в форме множественного числа венгерского существительного представляет исключение из общего правила, при венгерском слове ставится соответствующая помета. Подобным же образом отражены и формы множественного числа существительных с изменениями в основе [Русско-венгерский словарь 1947: 5], что обычно не принято делать в русско-венгерских словарях. Бо́льшая часть раздела «Как пользоваться словарем», естественно, посвящена особенностям отражения в словарных статьях русскоязычного материала. Тем не менее уже здесь уделяется внимание некоторым особенностям венгерского языка и венгерской орфографии. Например, отмечается, что в венгерском нет грамматической категории рода, ударение всегда падает на первый слог, а «значки над гласными обозначают долготу данного звука, а не ударение» [Русско-венгерский словарь 1947: 6-7].

Безусловно, Д. В. Бубрих не мог не заметить недостатки «Венгерско-русского словаря» в части представления грамматики, что и побудило его написать (при участии Э. С. Хаас) грамматический очерк к новому словарю [Русско-венгерский словарь 1947: 416-422]. Этот очень краткий очерк охватывает все основные разделы грамматики: фонетику, морфологию и синтаксис. Особого внимания заслуживает используемая лингвистическая терминология. По сути дела, здесь положено начало созданию терминологической системы для русскоязычного описания венгерского языка. Стоит упомянуть, что Д. В. Бубрих специально не занимался исследованием венгерского языка, однако хорошо владел им, о чем говорят ссылки в его публикациях на венгероязычную лингвистическую литературу и ее тщательный анализ. В этом отношении заслуживает внимания опубликованный Г. М. Кертом доклад Д. В. Бубриха «Происхождение именного словоизменения в финно-угорских языках», прочитанный на пленарном заседании Института языка и мышления АН СССР в конце 30-х годов. Его текст хранится 
в архиве Карельского филиала Академии наук [Керт 1975: 61-102]. В докладе упоминаются и сопровождаются критическими замечаниями публикации на венгерском языке Йожефа Буденца по сравнительной морфологии угорских языков и Енё Юхаса по морфологии мордовского языка [Керт 1975: 78-79, 85].

Надо сказать, что предложенные Д. В. Бубрихом в кратком грамматическом очерке к словарю термины прошли испытание временем, они употребляются в русскоязычных учебниках венгерского языка [Сий 1981; Надь, Колпакова 2015 и др.] и в научной литературе и по сей день, в частности, в переводах научных работ на русский язык [Балашша 1951; Хайду 1985]. Перечислим некоторые из этих терминов: соединительный гласный, показатель множественного числа, безобъектные и объектные формы спряжения глагола (со временем появились терминологические дублеты), иковые глаголь (в анализируемом словаре термин записан как $i k$-овый [Русско-венгерский словарь 1947: 6]), глагольная приставка, префикс leg- формы превосходной степени и т. д. В связи с тем, что проблема принадлежности отдельных морфем к одному из трех классов аффиксов (суффиксов, показателей, окончаний), выделяемых в венгерском языке, до сих пор служит предметом споров, в грамматическом очерке недифференцированно употребляются термины суффикс, показатель, окончание при описании падежных окончаний, лично-притяжательных показателей, показателей степеней сравнения.

Д. В. Бубрих, как следует из грамматического очерка, не ставит под сомнение наличие падежей в венгерском и пишет, что их много. Однако, в отличие от трёх основных падежей (именительного, дательного и винительного), обстоятельственные падежи не получают наименований и только обозначаются «в данном справочнике вопросами, на которые они отвечают», что находит отражение в прилагающейся к словарю таблице склонения существительных и личных местоимений [Русско-венгерский словарь 1947: 417, 423, 425]. Кроме того, составлена весьма полезная таблица притяжательных форм существительных, структура которой наглядно демонстрирует основные правила образования этих форм [Русско-венгерский словарь 1947: 424].

Иначе построены таблицы спряжения глаголов (кстати, не только так называемых неправильных, как в «Венгерско-русском словаре»). Все глаголы делятся на группы в соответствии с типом основы, именно поэтому таблицы позволяют увидеть механизм образования форм глагола в венгерском языке в целом [Русско-венгерский словарь 1947: 426-443]. 
Таким образом, в справочнике на семи страницах небольшого формата представлена, по сути дела, первая научная краткая венгерская грамматика на русском языке. Этот грамматический очерк дополняется 18 небольшими таблицами, демонстрирующими не только спряжение неправильных глаголов, но и склонение существительных и местоимений, образование притяжательных форм существительных и спряжение глаголов в настоящем и прошедшем временах, в сослагательном (условном) и повелительном наклонениях. Приводится и алфавитный список неправильных глаголов, а так называемые «устарелые» глагольные формы, не используемые в современном языке, исключены.

Иными словами, речь идет не просто о стремлении устранить существенный недостаток уже опубликованного «Венгерско-русского словаря». Последний, как утверждалось, «рассчитан на широкие круги читателей и имеет целью дать возможность советскому читателю понимать газетную статью и нетрудную популярную книгу» [Венгерско-русский словарь 1946: 3] (и это при полном отсутствии венгерских грамматик на русском языке!). Д. В. Бубрих в соавторстве с Э. С. Хаас предпринимает очень важную для того времени попытку создания первого научного системного краткого русскоязычного описания венгерского языка. Отчетливо ощущается участие в работе над этим словарем талантливого финно-угроведа Д. В. Бубриха, хорошо ориентирующегося в венгерской грамматике и корректно использующего лингвистические термины. Процесс формирования венгероязычной лингвистической терминологии в венгерском языкознании имеет длинную историю, тесно связанную с решением спорных вопросов системно-категориального описания венгерского языка. Различия во взглядах исследователей на сущность многих языковых явлений и ряда категорий венгерской грамматики и разнообразие далеко не всегда адекватных венгерским терминов в иноязычных грамматических описаниях венгерского языка требуют пристального внимания [Somogyi 2000]. Не представляя себе всей сложности этих проблем (а многие из них окончательно не решены и сегодня) и не имея определенного мнения по ряду вопросов, невозможно было бы написать краткую грамматику венгерского языка, дающую необходимый минимум знаний и, к тому же, ориентированную на русскоязычную аудиторию. Д. В. Бубрих, несомненно, был знаком с научной литературой, и краткое описание основных особенностей венгерской грамматики в справочнике к словарю ясно показывает, что у него было свое мнение по целому ряду спорных вопросов, в частности о наличии и составе падежей, о составе частей речи, 
о статусе отглагольных образований и т. д. Здесь полезно вспомнить, что, например, в новой и самой полной на тот момент грамматике не было раздела «Морфология» и ничего не говорилось о падежной системе венгерского языка [Balassa 1943]. На эти особенности грамматики Й. Балашши обращает внимание К. Е. Майтинская в предисловии и в примечаниях к переводу этой книги на русский язык [Балашша 1951: 6-7, 287]. Следует отметить, что с 50-х гг. в нашей стране начинает активно публиковаться научная переводная и отечественная русскоязычная литература о венгерском языке, получает развитие двуязычная лексикография, в связи с чем возникает проблема унификации лингвистической терминологии. В одной из своих статей, посвященных анализу принципов составления описательных грамматик финно-угорских языков, К Е. Майтинская с одобрением отзывается о ряде терминов, которые «были введены давно» (например, объектное спряжение). Однако там же, критикуя Д. В. Бубриха за неудачный термин «распространительный гласный» в эрзя-мордовской грамматике-минимуме, К. Е. Майтинская предлагает применять переведенный с венгерского термин соединительный гласный [Майтинская 1961: 44], забывая, что он, как и многие другие термины, был использован Д. В. Бубрихом в грамматическом справочнике к русско-венгерскому словарю 1947 г. [Русско-венгерский словарь 1947: 418-419]. Примечательно, что в этой статье К. Е. Майтинской среди 76 ссылок нет ни одной на этот краткий грамматический очерк Д. В. Бубриха. О нем не вспоминают уже в начале 60-х гг., хотя активно используют в предшествующее десятилетие применяемые в нем термины. В дальнейшем используемая в этом грамматическом справочнике терминология находит отражение не только в учебной и научной, но также и в лексикографической литературе. В частности, многократно переиздававшийся с момента выхода в свет в 1974 г. венгерско-русский словарь большого объема под редакцией Ласло Гальди содержит русскоязычный грамматический очерк венгерского языка [Magyar-orosz szótár 1976: 817-871], в котором употребляются многие термины, впервые использованные Д. В. Бубрихом в составленной для первого «Русско-венгерского словаря» краткой грамматике.

Краткий анализ первых венгерско-русского и русско-венгерского словарей позволяет не только показать их значимость с историко-лексикографической точки зрения. Он дает возможность увидеть, что в этих работах было положено начало созданию базовой русскоязычной терминологии для описания венгерского языка, были заложены 
традиции отечественного системно-категориального описания этого языка и принципы систематизации языкового материала для преподавания венгерского как иностранного в нашей стране.

\section{Литература}

Балашша 1951 - Й. Балашша. Венгерский язык М.: Изд-во иностранной литературы, 1951.

Венгерско-русский словарь 1946 - М. Г. Кахана (сост.). Венгерско-русский словарь М.: Гос. Изд-во иностранных и национальных словарей, 1946.

Керт 1975 - Г. М. Керт. Дмитрий Владимирович Бубрих. Очерк жизни и деятельности. Л.: Наука, 1975.

Майтинская 1961 - К. Е. Майтинская. Принципы составления описательных грамматик финно-угорских языков // С. Г. Бархударов и др. (ред.). Вопросы составления описательных грамматик. М.: Изд-во АН СССР, 1961. С. 37-54.

Надь, Колпакова 2015 - Ч. И. Надь, Н. Н. Колпакова. Венгерский язык. Базовый курс. СПб.: КАРО, 2015.

ОАСПбГУ. Ф. 1. - Объединенный архив СПбГУ. Фонд 1, опись ОК 1957, свод 17, дело 432.

Русско-венгерский словарь 1947 - Э. С. Хаас (сост.). Русско-венгерский словарь. М.: Гос. изд-во иностранных и национальных словарей, 1947.

Сий 1981 - Э. Сий. Курс венгерского языка. Budapest: Tankönyvkiadó, 1981.

Чернецов, Чернецова 1936 - В. Н. Чернецов, И. Я. Чернецова. Краткий мансийско-русский словарь. М.; Л.: Учпедгиз, 1936.

Хайду 1985 - П. Хайду. Уральские языки и народы. М.: Прогресс, 1985.

Balassa 1943 - J. Balassa. A magyar nyelv könyve. Budapest: Dante, 1943.

Magyar-orosz szótár 1976 — L. Gáldi (fősz.). Magyar-orosz szótár. Budapest: Akadémiai Kiadó; М.: Русский язык, 1976.

Somogyi 2000 - T. Somogyi Magda. Toldalékrendszerezésünk vitás kérdései (Segédkönyvek a nyelvészet tanulmányozásához. K. III). Budapest: Tinta Könyvkiadó, 2000.

\section{References}

Balassa 1943 - J. Balassa. A magyar nyelv könyve. Budapest: Dante, 1943.

Balassa 1951 - J. Balassa. Vengerskiy yazyk [Hungarian language]. Moscow: Foreign Literature Publishing House, 1951.

Chernetsov, Chernetsova 1936 - V. N. Chernetsov, I. Ya. Chernetsova. Kratkiy mansiysko-russkiy slovar [Short Mansi-Russian Dictionary]. Moscow; Leningrad: State Educational and Pedagogical Publishing House, 1936.

Hajdú 1985 - P. Hajdú. Uralskie yazyki i narody [Uralic languages and peoples]. Moscow: Progress, 1985. 
Kert 1975 - G. M. Kert. Dmitriy Vladimirovich Bubrikh. Ocherk zhizni i deyatelnosti. [Dmitry Vladimirovich Bubrich. Essay on life and activity] Leningrad: Nauka, 1975. Magyar-orosz szótár 1976 — L. Gáldi (fősz.). Magyar-orosz szótár. Budapest: Akadémiai Kiadó; Moscow: Russkiy yazyk, 1976.

Maytinskaya 1961 - K. Ye. Maytinskaya. Printsipy sostavleniya opisatelnykh grammatik finno-ugorskikh yazykov [Principles for compiling descriptive grammars of Finno-Ugric languages]. S. G. Barkhudarov et al. (ed.). Voprosy sostavleniya opisatelnykh grammatik [Issues of compiling descriptive grammars]. Moscow: Publishing House of the USSR Academy of Sciences, 1961. P. 37-54.

Nagy, Kolpakova 2015 - Cs. I. Nagy, N. N. Kolpakova. Vengerskiy yazyk. Bazovyy kurs [Hungarian language. Basic course]. St. Petersburg: KARO, 2015.

OASPbGU. F. 1. - Obedinennyy arkhiv SPbGU [Joint archive of St. Petersburg State University]. Fund 1, inventory OK 1957, Code 17, Case 432.

Russko-vengerskiy slovar 1947 — E. S. Khaas (comp.). Russko-vengerskiy slovar [Russian-Hungarian dictionary]. Moscow: State Publishing House of Foreign and National Dictionaries, 1947.

Somogyi 2000 - T. Somogyi Magda. Toldalékrendszerezésünk vitás kérdései (Segédkönyvek a nyelvészet tanulmányozásához. K. III). Budapest: Tinta Könyvkiadó, 2000.

Szij 1981 - E. Szij. Kurs vengerskogo yazyka [Hungarian language course]. Budapest: Tankönyvkiadó, 1981.

Vengersko-russkiy slovar 1946 - M. G. Kakhana. Vengersko-russkiy slovar [Hungarian-Russian dictionary]. Moscow: State Publishing House of Foreign and National Dictionaries, 1946. 


\section{Картографирование уральских языков ${ }^{*}$}

\section{Ю. Б. Коряков}

Институт языкознания РАН, Москва; ybkoryakov@gmail.com

Аннотация. Данная работа посвящена особенностям картографирования уральских языков. Сначала в ней рассматриваются история создавания этнографических, языковых и диалектологических уральских карт. Далее говорится о методике создания языковых карт на основе данных переписей. Подробно обсуждаются специфика картографирования уральских языков, связанная с особенностями расселения уралоязычных народов и другими факторами. В конце кратко говорится о создании исторических языковых карт, позволяющих показать изменения в распространении уральских языков во времени.

Ключевые слова: картография, языковые карты, уральские языки, лингвогеография, переписи.

\section{Mapping of Uralic languages}

\section{Yu. B. Koryakov}

Institute of Lingusitics, Russian Academy of Sciences, Moscow;

ybkoryakov@gmail.com

Abstract. The paper is dedicated to the specifics of mapping the Uralic languages. It draws a distinction between two types of maps, viz. language maps and linguistic maps. Language maps display the distribution of languages/dialects, while linguistic maps show the geography of linguistic phenomena.

The history of language and ethnographic Uralic maps is described beginning from the Köppen's Atlas of European Russia of 1848.

The next section focuses on the use of census data for creating language maps. The availability of quality census data on the settlement level makes it possible to create detailed and up-to-date maps for most Uralic language areas.

The unusual challenges for the Uralic languages mapper include a low percentage of Uralic speakers in the total population of many traditional areas. Sparsely populated areas with very low population density and very small absolute population numbers

\footnotetext{
* Исследование выполнено при поддержке гранта РНФ № 17-18-01649.
} 
present another difficulty. Yet another problem is the seasonal mobility of nomadic and semi-nomadic groups including some Uralic peoples (Nenets, and partly Komi and Khanty). The difficulty of obtaining information about pasture lands for different groups and their routes is exacerbated by the fact that in cases involving semi-nomadic groups, the language repertoire of the nomadic populations may differ quite strongly from that of the permanent residents of a given settlement. Additional difficulties are presented by the strong influx of seasonal but numerous (mainly Russian-speaking) personnel of oil-and-gas industries rapidly developing in many Uralic areas. The main problem is to decide if these should be plotted on the maps.

Another interesting subject is creating maps showing the historical distribution of Uralic languages and its dynamics. Though the overall Uralic languages area has not significantly changed, the language situations at the microlevel have undergone fundamental changes. While in the early $20^{\text {th }}$ century Uralic speakers made the majority in many parts of this spacious area, they disappeared in some places or became minorities by the end of the century.

The conclusion recapitulates the main points of the paper including a general lack of quality maps of Uralic languages, the importance of such maps, and the proposed ways and methods of their creation.

Keywords: language mapping, Uralic, linguistic geography, census.

\section{1. Языковые vs. лингвистические карты}

Можно выделить два типа карт, связанных с языковыми представлениями: языковые и лингвистические.

Лингвистические карты (linguistic maps) показывают распространение языковых явлений с помощью точек, изоглосс или ареалов (как, например, в «Atlas Linguarum Fennicarum» или «Диалектологическом атласе карельского языка») [Зайцева 2010]. Географически они могут покрывать:

- один язык (скажем, на диалектологических картах);

- группу языков или целый регион (см., например, «Общеславянский лингвистический атлас» [ОЛА 1965-2011]; «Atlas Linguarum Europae» [ALE 1975-2002]);

- весь мир (например, [WALS 2005]).

Собственно языковые карты (language maps) показывают распространение самих языков или их диалектов или языковую ситуацию 
на определённой территории. Такие карты также могут объединяться в атласы на основе:

— общей территории, например, в «Атласе языков Китая» [LAC 1987],

- общей (территории и) генеалогической принадлежности, например, в «Атласе кавказских языков» [АКЯ 2006];

- иной общей характеристики, например, в «Atlas of languages of intercultural communication in the Pacific, Asia, and the Americas» [ALICPAA 1996].

\section{2. Существующие карты уральских языков}

Как языковые, так и лингвистические карты уральских языков имеют достаточно долгую историю. В XIX в. картографирование языков в целом было неразрывно связано с картографированием народов. Собственно языковых карт тогда ещё не было, однако для большинства народов было верно то, что большая часть народа говорит на своём этническом языке. Поэтому этнографические карты в целом достаточно точно показывали и распространение языков. Собственно язык был одним из важнейших критериев определения народа [Петронис 2010: 313], и, например, во время Первой всероссийской переписи 1897 года спрашивался только родной язык, но не народность. Хотя уже и тогда существовали случаи, когда значительная часть народа не говорила на своём этническом языке. Так, в списке населенных мест Олонецкой губернии представлены сёла с так называемой «обруселой чудью», в которых к тому времени вепсский язык уже был полностью утрачен, а этническое самосознание, судя по всему, ещё сохранялось [Списокъ 1879].

Первыми картами, на которых были представлены уральские народы / языки, являются «Этнографический атлас Европейской России» [Кёппен 1848], «Этнографическая карта Европейской России» [Кёппен 1851] и ««Этнографическая карта Европейской России» [Риттих 1875]. Эти карты в течение долгих лет оставались единственными и в то же время очень качественными картографическими источниками по уральским языкам Европейской части России. И если в XIX веке отсутствие новых карт можно было объяснить нехваткой подробных 
статистических данных, то после переписи 1897 года, а особенно после Первой Всесоюзной переписи 1926 года данных было вполне достаточно. Кстати, стоит отметить, что данные переписи 1926 года вообще практически не использовались в советской этноязыковой картографии.

Следующей серьёзной работой, впервые охватившей все уральские народы, стал «Атлас народов мира» [АНМ 1964], соответствующие карты в котором основаны на картах из серии «Народы мира» [НЕЧС 1964: 336; НС 1956: вкладка]. Однако, как ни странно, распространение уральских языков Европейской России в этих изданиях показано иногда более искажённо, чем на той же карте Риттиха, хотя к этому времени были доступны данные переписи 1926 года, а ко времени издания «Атласа народов мира», возможно, уже и данные переписи 1959 года. Так, огромные территории, отмеченные как незаселённые у Риттиха, были отмечены в этих более поздних изданиях как слабозаселённые ближайшим коренным народом. Если в некоторых случаях это могло хотя бы частично соответствовать действительности, например, у ненцев Ямала, то в большинстве случаев для этого не было никаких оснований. Так, вся территория Кольского полуострова, кроме территорий, вплотную прилегающих к русским городам и посёлкам, была отмечена как слабозаселённая саамами, хотя по карте Риттиха саамы имели кочевья лишь в отдельных местах, в основном на северо-востоке полуострова.

Тем не менее авторитет «Атласа» был так высок, что карты расселения народов на его основе до сих пор помещаются практически во всех обзорных отечественных работах, где требуется, скажем, карта народов России. Более того, в авторитетном «Atlas of the world's languages» [AWL 1993/2007] карты, покрывающие территорию бывшего СССР, также сделаны преимущественно на основе карт из [АНМ 1964]. Карты в издании [Ethnologue 2016], на которых есть уральские языки, сделаны независимо, но во многих случаях вообще не соответствуют действительности. Так, в качестве территории нганасанского языка показано побережье Карского моря от Диксона до Пясины (где нганасаны никогда не жили), а территория распространения ижорского и финского языка в Ленинградской области в несколько раз превышает их ареал даже в XIX веке и т. д.

Первая языковая карта, посвящённая только уральским языкам, была издана в Финляндии лишь в 1980 году под редакцией Ю. Янхунена [Janhunen 1980], а затем переиздана в 1993, уже под редакцией Р. Грюнтхаля и Т. Салминена [Grünthal, Salminen 1993]. Впрочем, 
масштаб этих карт не позволяет отобразить подробности распространения уральских языков.

Собственно, мелкомасштабность является проблемой всех вышеперечисленных карт. Если карта Риттиха имеет достаточно крупный масштаб (в 1 см 25,2 км), то релевантные карты в [АНМ 1964] — от 30 (Поволжье) до 120 (Восточная Сибирь) км в 1 см, в [AWL 1993/2007] от 75 км и выше, в [Ethnologue 2016] - от 120 км. Языковые карты, подготовленные в Финляндии, имеют масштаб в 1 см 175 км. Понятно, что при таком масштабе отразить в деталях распространение уральских языков, особенно малых, крайне затруднительно.

Параллельно с этноязыковыми картами развивалось лингвистическое картографирование, которое было представлено в основном диалектологическими картами и атласами. Так, в 1940 году Лаури Кеттунен издал свой «Диалектный атлас Финляндии« [Kettunen 1940]. Недавно были изданы «Atlas linguarum fennicarum» [ALF 2004-2010], посвящённый прибалтийско-финским языкам, и «Диалектологический атлас уральских языков, распространённых на территории Ямало-Ненецкого автономного округа» [Кошкарева и др. 2017]. В настоящее время идёт работа над картами уральских языков, распространённых в циркумполярной зоне [Koryakov 2017]. Отдельные диалектологические атласы существуют для эстонского [Saareste 1938-1941; 1955], карельского [ДАКЯ 1997], удмуртского [ДАУЯ 2009-2016] языков, идёт работа над диалектологическими атласами мордовских языков и Ингерманландии.

Диалекты некоторых других языков отражены на картах (как правило, схематических) в работах, посвящённых данному языку. Так, есть достаточно подробные диалектные карты марийского языка [Грузов 1964: 7; Cheremis 1971: 64], мордовских [Bartens 1999: 183], вепсского [Grünthal 2011: 269], ижорского [Кузнецова, Сидоркевич 2012: 566567] и др. Очень схематические карты некоторых уральских языков даны в [ОФУЯ 1975] (финский, саамские, мордовские) и [ОФУя 1976] (мансийский, хантыйский, марийский, удмуртский, коми, венгерский).

\section{3. Использование данных переписей при создании языковых карт}

Обычно данные переписей используются лишь в качестве источника справочной информации в масштабе страны, реже в масштабе 
отдельных краёв, областей и республик. Насколько мне известно, поселенные переписные данные (т. е. данные по каждому населённому пункту) до сих пор не использовались при создании этнографических или языковых карт, связанных с уральскими языками или народами. В то же время ещё в советское время существовали изданные этноязыковые поселенные данные по многим регионам СССР (обычно называются «Список населенных мест ...»), в т. ч. населённым уральскими народами. Это относится, например, к Карелии [СНМКА 1928] или к Уральской области [СНПУО 1928], включавшей в том числе территории пермяков, хантов, манси и восточных ненцев. По более поздним советским переписям доступны лишь поселенные этнические данные по переписи 1959 года, хранящиеся в Российском государственном архиве экономики (РГАЭ).

Гораздо более удобно организован доступ к данным двух последних российских переписей - 2002 и 2010 годов. Вся информация хранится в базе данных, доступной через онлайн-интерфейс на сайте «Микроданные переписей» ГМЦ Росстата (http://std.gmcrosstata.ru/). Данные можно извлечь на основе большого количества параметров и для любого территориального разбиения, в том числе по отдельным населённым пунктам. Хотя к характеру проведения переписей в России можно услышать немало нареканий, и, соответственно, доверие к данным переписей не очень высоко, выборочная сверка по коренным национальностям и их языкам по некоторым районам ЯНАО и Красноярского края с полевыми данными (предоставлены О. А. Казакевич) показывает очень хорошее качество переписных данных с отклонениями в пределах 5-10\%.

Таким образом, в распоряжении лингвистов и картографов имеются подробные этноязыковые данные по каждому населённому пункту по данным переписей 1926 (часть регионов), 1959, 2002 и 2010 годов. На их основе можно создавать подробные этнические и языковые карты по отдельным регионам с детализацией до отдельных населённых пунктов, которые затем могут в той или иной степени обобщаться. Конечно, данные переписей по возможности необходимо сверять с полевыми данными лингвистов и этнографов. В качестве примера создания подробных карт на основе данных нескольких переписей в сочетании с полевыми данными лингвистов можно привести три вепсские карты: основной территории вепсского языка в XIX и нач. XXI веков и общую карту основной и периферийной территории вепсского языка в XIX веке в [Koryakov 2014], а также карты распространения энецкого языка с XVII века по начало XXI века [Khanina et al. 2018]. 


\section{4. Особенности картографировании уральских языков}

Несмотря на наличие качественных подробных данных по этноязыковому составу населённых пунктов, создание языковых карт вообще и карт уральских языков в частности имеет ряд особенностей.

Одной из сложностей при создании карт является тот факт, что носители многих уральских языков, особенно в северных районах, составляют очень небольшой процент среди жителей населённых пунктов даже в местах традиционного проживания. Это связано как с проживанием представителей малых народностей в крупных многонациональных посёлках (куда их переселяли в советское время, часто принудительно; так, доля энцев, кроме одного посёлка, нигде не превышает $7 \%$ ), так и с очень сильной утратой языка среди представителей соответствующего этноса (например, хотя нганасаны составляют в двух основных посёлках 37 и $45 \%$ населения соответственно, доля говорящих по-нганасански в этих посёлках не превышает 4 \%). Дополнительную сложность представляет то обстоятельство, что процент говорящих от численности этнической группы может сильно варьировать даже в пределах одной территории. Так, согласно переписи 2010 года, в Ненецком автономном округе доля говорящих по-ненецки от численности ненцев лишь в двух населённых пунктах превышала $30 \%$, ещё в трёх была около $20 \%$, в остальных 25 была ниже $15 \%$.

Разные регионы требуют разной картографической техники. Если в более южных районах, где расстояния между населёнными пунктами не очень велики, возможно сплошное представление языковых разновидностей, то в более северных широтах, где населённые пункты находятся друг от друга на расстоянии десятков, а то и сотен километров, возникает вопрос, как наиболее адекватно представлять языковую территорию. В случае с оседлым населением можно прибегать к точечному нанесению отдельных поселений и небольшой территории вокруг них. Бо́льшую сложность представляет отображение мест кочевий северных народов, особенно для более ранних периодов. Во-первых, не всегда просто найти информацию о точных маршрутах кочевий (хорошим примером, где такая информация подробно представлена, является работа [Головнёв и др. 2016]). Во-вторых, языковой репертуар в местах кочевий может отличаться от такового в постоянных поселениях. Скажем, в Ненецком автономном округе с оленями кочуют 
в основном взрослые мужчины (а основным языком посёлков, в которых остаются семьи, является, как правило, русский), а в Ямало-Ненецком $\mathrm{AO}$ - семьи целиком (и основным языком всей семьи является ненецкий) [Амелина, у. с.].

Помимо постоянного русского населения, которое и так преобладает на значительной части традиционной территории распространения уральских языков, во многих районах Севера в связи с развитием добычи нефти и газа в последние десятилетия появились (и появляются все новые) так называемые вахтовые посёлки. Они, как правило, не отмечены на картах, не приводятся в переписях, люди живут там лишь по несколько месяцев в году и потом уезжают, но им на смену приезжают новые. Так что в таких посёлках постоянно есть население, и, как правило, довольно большое. Часто эти посёлки расположены на традиционных территориях коренных народов, и их население во много раз превышает численность живущих рядом носителей местных языков. Возникает вопрос, нужно ли их отображать на картах, показывающих общий языковой состав населения соответствующей территории, или следует считать их временными поселениями?

\section{5. Исторические языковые карты}

Создание языковых карт одной и той же территории для нескольких исторических периодов наглядно показывает изменения в языковой географии, в частности сокращение традиционных территорий распространения большинства уральских языков России. Для одних языков это сокращение выражается прежде всего в уменьшении доли говорящих на соответствующем языке на определённой территории, для других и в сокращении территории распространения языка. Так, значительно сократилась территория распространения саамских языков на Кольском полуострове [Шеллер 2010], водского языка [Агранат 2008], вепсского языка [Koryakov 2014] и многих других. Несколько уральских языков вообще исчезло в течение XX века: три из четырёх мансийских (южный, западный и восточный), бабинский саамский (аккала) и камасинский.

В связи с этим особую ценность приобретают языковые карты, сделанные на основе даных переписи 1926 года, а также - там, где это возможно — на основе данных конца XIX века. Племенной или языковой состав населения иногда приводился в списках населённых 
мест по губерниям, например, для Олонецкой губернии [Списокъ 1879], а данные переписи 1897 года по Сибири подробно разработаны С. К. Паткановым [1911-1912]. Однако при создании подобных карт возникает такая сложность, как отсутствие значительной части населённых пунктов, упоминаемых в данных конца XIX - начала XX веков, на современных картах. Так, как показывает сравнение, по данным переписи 1926 года в Автономной Карельской ССР насчитывалось 2852 населённых пункта [СНМКА 1928], а по переписи 2010 года 640 жилых населённых пунктов [Микроданные 2010]. Таким образом, на этой территории почти 80 \% населённых пунктов исчезло. Часть из них обезлюдела не так давно и ещё сохраняется на советских картах, часть можно найти только на труднодоступных картах 1920-30-х годов. Ещё более сложная ситуация возникает с языками кочевых народов Севера. Ещё в начале XX века большая часть представителей таких народов кочевали вне постоянных населённых пунктов, время от времени меняя места расположения стойбищ.

\section{6. Заключение}

Таким образом, для большинства уральских языков ощущается явная нехватка качественных, подробных карт, отображающих не только диалектные границы, но и детальное современное распространение на фоне окружающих языков. Хотя при создании языковых карт возникают разного рода сложности, уже в процессе самой работы открываются многие неочевидные компоненты языковых ситуаций и другие интересные аспекты распространения уральских языков. Сравнение карт, отражающих распространение уральских языков в разные временные периоды, может оказать неоценимую помощь для понимания того, как складывались современные языковые ареалы и как стремительно сокращается языковая территория многих уральских языков.

\section{Литература}

Агранат 2008 - Т. Б. Агранат. Малые языки Российской Федерации: водский // Вопросы языкознания. 2008. № 2. С. 65-72.

АКЯ 2006 - Ю. Б. Коряков. Атлас кавказских языков. М.: Институт языкознания РАН, 2006. 
АНМ 1964 - С. И. Брук, В. С. Апенченко (отв. ред.). Атлас народов мира. М.: Главное управление геодезии и картографии Государственного геологического комитета СССР; Институт этнографии им. Н. Н. Миклухо-Маклая АН СССР, 1964.

Головнёв и др. 2016 - А. В. Головнёв, Н. П. Гарин, Д. А. Куканов. Оленеводы Ямала (материалы к Атласу кочевых технологий). Екатеринбург: УрО РАН, 2016.

Грузов 1964 - Л. П. Грузов. Фонетика диалектов марийского языка в историческом освещении. Йошкар-Ола: Маркнигоиздат, 1964. (На обл. 1965.)

ДАКЯ 1997 - Д. В. Бубрих, А. А. Беляков, А. В. Пунжина. Диалектологический атлас карельского языка. Хельсинки: Suomalais-Ugrilainen Seura, 1997.

ДАУЯ 2009-2016 - Р. Ш. Насибуллин и др. Диалектологический атлас удмуртского языка. Карты и комментарии. Вып. I-IV. Ижевск: НИЦ «Регулярная и хаотическая динамика», 2009-2016.

Зайцева 2010 - Н. Г. Зайцева. Прибалтийско-финские языки в зеркале лингвистической географии // Труды Карельского научного центра РАН. 2010. № 4. C. 34-47.

Кёппен 1848 - Этнографический атлас Европейской России, составленный Петром Кеппеном. СПб.: б. и., 1848.

Кёппен 1851 - П. И. Кёппен (сост.). Этнографическая карта Европейской России. СПб.: б. и., 1851.

Кошкарева и др. 2017 - Н. Б. Кошкарева, Е. В. Кашкин, Ю. Б. Коряков, О. А. Казакевич, С. И. Буркова, Н. А. Муравьев, Е. М. Будянская. Диалектологический атлас уральских языков, распространённых на территории Ямало-Ненецкого автономного округа. Калининград: РОСТ-ДОАФК, 2017.

Кузнецова, Сидоркевич 2012 - Н. В. Кузнецова, Д. В. Сидоркевич. Приложение 6. Карты к статьям // Acta Linguistica Petropolitana. Труды Института лингвистических исследований. 2012. Т. VIII. Ч. 1. С. 559-567.

Микроданные 2010 - Микроданные переписей. Всероссийская перепись населения 2010 года. ГМЦ Росстата. URL: http://std.gmcrosstata.ru. (дата обращения 11.05.2019)

НЕЧС 1964 - В. Н. Белицер, Н. И. Воробьев, Л. Н. Терентьева, Н. Н. Чебоксаров, Н. В. Шлыгина (ред.). Народы Европейской части СССР. Т. 2 (Серия «Народы мира: Этнографические очерки»). М.: Наука, 1964.

НС 1956 - М. Г. Левин, Л. П. Потапов (ред.). Народы Сибири (Серия «Народы мира: Этнографические очерки»). М.: Изд-во Академии наук СССР, 1956.

ОЛА 1965-2011 - Общеславянский лингвистический атлас. М.: Наука, 1965-2011.

ОФУЯ 1975 - В. И. Лыткин, К. Е. Майтинская, К. Редеи (ред.). Основы финноугорского языкознания. Прибалтийско-финские, саамский и мордовские языки. М.: Наука, 1975.

ОФУЯ 1976 - В. И. Лыткин, К. Е. Майтинская, К. Редеи, Я. Гуя, А. П. Феоктистов, Г. И. Ермушкин (ред.). Основы финно-угорского языкознания. Марийский, пермские и угорские языки. М.: Наука, 1976.

Патканов 1911-1912 - С. К. Патканов. Статистические данные, показывающие племенной состав населения Сибири, язык и роды инородцев. В 3-х т. СПб.: Тип. «Ш. Буссель», 1911-1912. 
Петронис 2010 - В. Петронис. Pinge, divide et impera: взаимовлияние этнической картографии и национальной политики в позднеимперской России (вторая половина ХІХ века) // М. Ауст, Р. Вульпиус, А. Миллер (ред.). Imperium inter pares: Роль трансферов в истории Российской империи. М.: Новое литературное обозрение, 2010. С. 308-329.

Риттих 1875 - А. Ф. Риттих (сост.). Этнографическая карта Европейской России. СПб.: б. и., 1875.

СНМКА 1928 - Список населенных мест Карельской АССР (по материалам переписи 1926 года). Петрозаводск: б. и., 1928.

СНПУО 1928 - Список населенных пунктов Уральской области. Тт. I-XVI. Свердловск: б. и., 1928.

Списокъ 1879 - Списокъ населенныхъ мъстъ по свъдъніямъ 1873 года. Олонецкая губернія (XXVII). СПб.: б. и., 1879.

Шеллер 2010 - Э. Шеллер. Ситуация саамских языков в России // Наука и бизнес на Мурмане. 2010. № 2 (69). С. 15-27.

ALE 1975-2002 — Atlas Linguarum Europae. Assen; Roma: Van Gorcum; Poligrafico, 1975-2002.

ALF — T. Tuomi (päät.), S. Suhonen, T.-R. Viitso, V. Rjagoev (toim.). Atlas Linguarum Fennicarum. T. I-III. (Suomalaisen Kirjallisuuden Seuran Toimituksia. Vol. 1295; Kotimaisten kielten tutkimuskeskuksen julkaisuja. Vol. 159). Helsinki: Suomalaisen Kirjallisuuden Seura, 2004-2010.

ALICPAA 1996 - S. A. Wurm, P. Mühlhäusler, D. T. Tyron. Atlas of languages of intercultural communication in the Pacific, Asia, and the Americas. 2 vol. Berlin; New York: Walter de Gruyter, 1996.

AWL 1994 / 2007- C. Moseley, R. E. Asher (eds.). Atlas of the world's languages. London: Routledge, 1994 ( $1^{\text {st }}$ ed. $) ; 2007$ ( $2^{\text {nd }}$ ed. $)$.

Bartens 1999 - R. Bartens. Mordvalaiskielten rakenne ja kehitys. Helsinki: SuomalaisUgrilainen Seura, 1999.

Cheremis 1971 — L. Vikár, G. Bereczki. Cheremis folksongs. Budapest, Akadémiai Kiadó, 1971.

Ethnologue 2016 - M. P. Lewis, G. F. Simons, C. D. Fennig (eds.). Ethnologue: Languages of the World. $19^{\text {th }}$ edition. Dallas (Texas): SIL International, 2016. URL: http://www.ethnologue.com.

Grünthal, Salminen 1993 - R. Grünthal, T. Salminen (eds.). Geographical Distribution of the Uralic languages [map] (Des. by P. Numminen). Helsinki: Suomalais-Ugrilainen Seura, 1993.

Janhunen 1980 - J. Janhunen (ed.). Geographical Distribution of the Uralic languages [map]. Helsinki: Suomalais-Ugrilainen Seura, 1980.

Kettunen 1940 - L. Kettunen. Suomen Murrekartasto. Helsinki: Suomalaisen kirjallisuuden seura, 1940.

Khanina et al. 2018 - O. Khanina, Yu. Koryakov, A. Shluinsky. Enets in space and time: a case-study in linguistic geography // Finnisch-Ugrische Mitteilungen. 2018. Bd. 42. S. 109-135. 
Koryakov $2014-$ Yu. B. Koryakov. The changes of the Veps language area in the $19^{\text {th }}$ and $20^{\text {th }}$ century: cartographic perspective // J. Sullõv (ed.). Finnic languages on the map / Õdagumeresoomõ keeleq kaartõ pääl (Publications of Võro Institute. Vol. 28). Võro: Võro Institute, 2014. P. 34-51.

Koryakov 2017 - Yu. B. Koryakov. Database of language contacts in the Circumpolar region // О. А. Казакевич, А. А. Кибрик, Н. М. Стойнова, О. В. Ханина. Языковые контакты в циркумполярном регионе. 27-29 октября 2017 г. Институт языкознания РАН, Москва: Тезисы конференции. М.: Институт языкознания PAH, 2017. C. 32.

LAC 1987 - S. A. Wurm et al. (eds.). Language atlas of China. Parts 1, 2 (Pacific Linguistics C-102). Canberra; Hong Kong: Longman Group, 1987.

Saareste 1938-1941 — A. Saareste. Eesti murdeatlas. I: Tartu, 1938; II: Tartu, 1941.

Saareste 1955 - A. Saareste. Petit atlas des parlers estoniens. Väike eesti murdeatlas. Uppsala: Kungl. Gustav Adolfs Akademien, 1955.

WALS 2005 - M. Haspelmath, M. S. Dryer, D. Gil, B. Comrie (eds.). The World Atlas of Language Structures. Oxford: Oxford University Press, 2005.

\section{References}

Agranat 2008 - T. B. Agranat. Malye yazyki Rossiyskoy Federatsii: vodskiy [Minor languages of the Russian Federation: the Votic language]. Voprosy yazykoznaniya. 2008. No. 2. P. 67-72.

AKYa 2006 - Yu. B. Koryakov. Atlas kavkazskikh yazykov [Atlas of Caucasian languages]. Moscow: Institute of Linguistics RAS Press, 2006.

ALE 1975-2002 - Atlas Linguarum Europae. Assen; Roma: Van Gorcum; Poligrafico, 1975-2002.

ALF — T. Tuomi (päät.), S. Suhonen, T.-R. Viitso, V. Rjagoev (toim.). Atlas Linguarum Fennicarum. T. I-III. (Suomalaisen Kirjallisuuden Seuran Toimituksia. Vol. 1295; Kotimaisten kielten tutkimuskeskuksen julkaisuja. Vol. 159). Helsinki: Suomalaisen Kirjallisuuden Seura, 2004-2010.

ALICPAA 1996 - S. A. Wurm, P. Mühlhäusler, D. T. Tyron. Atlas of languages of intercultural communication in the Pacific, Asia, and the Americas. 2 vol. Berlin; New York: Walter de Gruyter, 1996.

ANM 1964 - S. I. Bruk, V. S. Apenchenko (eds.). Atlas narodov mira [Atlas of the peoples of the world]. Moscow: General Directorate of Geodesy and Cartography of the State Geological Committee of the USSR; Miklukho-Maklay Institute of Ethnography of the Academy of Sciences USSR Press, 1964.

AWL 1994 / 2007 - C. Moseley, R. E. Asher (eds.). Atlas of the world's languages. London: Routledge, 1994 ( $1^{\text {st }}$ ed.); 2007 ( $2^{\text {nd }}$ ed.).

Bartens 1999 — R. Bartens. Mordvalaiskielten rakenne ja kehitys. Helsinki: Suomalais-Ugrilainen Seura, 1999.

Cheremis 1971 — L. Vikár, G. Bereczki. Cheremis folksongs. Budapest: Akadémiai Kiadó, 1971. 
DAKYa 1997 - D. V. Bubrikh, A. A. Belyakov, A. V. Punzhina. Dialektologicheskiy atlas karelskogo yazyka [Dialectological atlas of the Karelian language]. Helsinki: Suomalais-Ugrilainen Seura, 1997.

DAUYa 2009-2016 - R. Sh. Nasibullin et al. Dialektologicheskiy atlas udmurtskogo yazyka. Karty i kommentarii [Dialectological atlas of the Udmurt language. Maps and comments]. Iss. I-IV. Izhevsk: Scientific Publishing Center «Regulyarnaya i khaoticheskaya dinamika», 2009-2016.

Ethnologue 2016 - M. P. Lewis, G. F. Simons, C. D. Fennig (eds.). Ethnologue: Languages of the World. $19^{\text {th }}$ edition. Dallas (Texas): SIL International, 2016. URL: http://www.ethnologue.com.

Golovnev et al. 2016 - A. V. Golovnev, N. P. Garin, D. A. Kukanov. Olenevody Yamala (materialy $k$ Atlasu kochevykh tekhnologiy) [Reindeer breeders of Yamal (materials for the Atlas of nomadic technologies)]. Ekaterinburg: Ural Branch of the RAS, 2016.

Gruzov 1964 - L. P. Gruzov. Fonetika dialektov mariyskogo yazyka v istoricheskom osveshchenii [Phonetics of Mari dialects in historical perspective]. Yoshkar-Ola: Mari Book Publishing House, 1964. (On the cover: 1965.)

Grünthal, Salminen 1993 - R. Grünthal, T. Salminen (eds.). Geographical Distribution of the Uralic languages [map] (Des. by P. Numminen). Helsinki: Suomalais-Ugrilainen Seura, 1993.

Janhunen 1980 - J. Janhunen (ed.). Geographical Distribution of the Uralic languages [map]. Helsinki: Suomalais-Ugrilainen Seura, 1980.

Keppen 1848 - Etnograficheskiy atlas Evropeyskoy Rossii, sostavlennyy Petrom Keppenom [Ethnographic atlas of European Russia, compiled by Peter Keppen]. St. Petersburg: S. n., 1848.

Keppen 1851 - P. I. Keppen (comp.). Etnograficheskaya karta Evropeyskoy Rossii [Ethnographic map of European Russia]. St. Petersburg: S. n., 1851.

Kettunen 1940 — L. Kettunen. Suomen Murrekartasto. Helsinki: Suomalaisen Kirjallisuuden Seura, 1940.

Khanina et al. 2018 - O. Khanina, Yu. Koryakov, A. Shluinsky. Enets in space and time: a case-study in linguistic geography. Finnisch-Ugrische Mitteilungen. 2018. Bd. 42. S. 109-135.

Koryakov 2014 - Yu. B. Koryakov. The changes of the Veps language area in the $19^{\text {th }}$ and $20^{\text {th }}$ century: cartographic perspective. J. Sullõv (ed.). Finnic languages on the map / Õdagumeresoomõ keeleq kaartõ pääl (Publications of Võro Institute. Vol. 28). Võro: Võro Institute, 2014. P. 34-51.

Koryakov 2017 - Yu. B. Koryakov. Database of language contacts in the Circumpolar region. O. A. Kazakevich, A. A. Kibrik, N. M. Stoynova, O. V. Khanina. Yazykovyye kontakty $v$ tsirkumpolyarnom regione [Language contacts in the circumpolar area]. October 27-29, 2017. Institute of linguistics RAS, Moscow. Book of abstracts. Moscow: Institute of linguistics RAS Press, 2017. P. 32.

Koshkareva et al. 2017 - N. B. Koshkareva, E. V. Kashkin, Yu. B. Koryakov, O. A. Kazakevich, S. I. Burkova, N. A. Muravev, E. M. Budyanskaya. Dialektologicheskiy atlas uralskikh yazykov, rasprostranennykh na territorii Yamalo-Nenetskogo 
Avtonomnogo Okruga [Dialectological atlas of the Uralic languages spoken in the Yamal-Nenets Autonomous District]. Kaliningrad: Rost-Doafk, 2017.

Kuznetsova, Sidorkevich 2012 - N. V. Kuznetsova, D. V. Sidorkevich. Prilozhenie 6. Karty k statyam [Appendix 6. Maps to the papers]. Acta Linguistica Petropolitana. Trudy Instituta lingvisticheskikh issledovaniy. 2012. Vol. VIII. Pt. 1. P. 559-567. LAC 1987 - S. A. Wurm et al. (eds.). Language atlas of China. Pt. 1, 2 (Pacific Linguistics C-102). Canberra; Hong Kong: Longman Group, 1987.

Mikrodannye 2010 - Mikrodannye perepisey. Vserossiyskaya perepis naseleniya 2010 goda. Glavnyy mezhregionalnyy tsentr Rosstata [Census microdata. 2010 All-Russian Census. The main interregional center of Rosstat]. Available at: http://std. gmcrosstata.ru (accessed on 11.05.2019).

NEChS 1964 - V. N. Belitser, N. I. Vorobev, L. N. Terentev, N. N. Cheboksarov, N. V. Shlygina (eds.). Narody Yevropeyskoy chasti SSSR [The peoples of the European part of the USSR]. Vol. 2. (Ser. «Narody mira: Etnograficheskie ocherki» [Peoples of the World: Ethnographic Essays]). Moscow: Nauka, 1964.

NS 1956 - M. G. Levin, L. P. Potapov (eds.). Narody Sibiri [The peoples of Siberia] (Ser. «Narody mira: Etnograficheskie ocherki» [Peoples of the World: Ethnographic Essays]). Moscow: Publishing House of the Academy of Sciences of the USSR, 1956.

OFUYA 1975 - V. I. Lytkin, K. E. Maytinskaya, K. Redei (eds.). Osnovy finno-ugorskogo yazykoznaniya. Pribaltiysko-finskiye, saamskiy i mordovskiye yazyki [Basics of Finno-Ugric linguistics. Balto-Finnic, Sami and Mordovian languages]. Moscow: Nauka, 1975.

OFUYA 1976 - V. I. Lytkin, K. E. Maytinskaya, K. Rédei, J. Gulya, A. P. Feoktistov, G. I. Ermushkin (eds.). Osnovy finno-ugorskogo yazykoznaniya. Mariyskiy, permskiye i ugorskiye yazyki [Baisics of Finno-Ugric linguistics. Mari, Perm and Ugric languages]. Moscow: Nauka, 1976.

OLA 1965-2011 - Obshcheslavyanskiy lingvisticheskiy atlas [The Slavic Linguistic Atlas]. Moscow: Nauka, 1965-2011.

Patkanov 1911-1912 — S. K. Patkanov. Statisticheskie dannye, pokazyvayushchie plemennoy sostav naseleniya Sibiri, yazyk i rody inorodtsev [Statistical data showing the tribal composition of the population of Siberia, language and clans of foreigners]. 3 vols. St. Peterburg: Tip. “Ch. Bussel”, 1911-1912.

Petronis 2010 - V. Petronis. Pinge, divide et impera: vzaimovliyanie etnicheskoy kartografii i natsionalnoy politiki v pozdneimperskoy Rossii (vtoraya polovina XIX veka) [Pinge, divide et impera: the interaction of ethnic cartography and national politics in late imperial Russia (second half of the twentieth century)]. M. Aust, R. Vulpius, A. Miller (eds.). Imperium inter pares: Rol transferov $v$ istorii Rossiyskoy imperii [The role of transfers in the history of the Russian Empire]. Moscow: Novoe literaturnoe obozrenie, 2010. P. 308-329.

Rittich 1875 - A. F. Rittich (comp.). Etnograficheskaya karta Evropeyskoy Rossii [Ethnographic map of European Russia]. St. Petersburg: S. n., 1875.

Saareste 1938-1941 — A. Saareste. Eesti murdeatlas. I: Tartu, 1938; II: Tartu, 1941. Saareste 1955 - A. Saareste. Petit atlas des parlers estoniens. / Väike eesti murdeatlas. Uppsala: Kungl. Gustav Adolfs Akademien, 1955. 
Scheller 2010 - E. Sheller. Situatsiya saamskikh yazykov v Rossii [The situation of Sami languages in Russia]. Nauka i biznes na Murmane. 2010. No. 2 (69). P. 15-27.

SNMKA 1928 - Spisok naselennykh mest Karelskoy ASSR (po materialam perepisi 1926 goda) [List of inhabited areas of the Karelian Autonomous Soviet Socialist Republic (based on the 1926 census)]. Petrozavodsk: S. n., 1928.

SNPUO 1928 - Spisok naselennykh punktov Uralskoy oblasti [List of settlements of the Ural region]. Vol. I-XVI. Sverdlovsk: S. n., 1928.

Spisok 1879 - Spisok naselennykh mrst po svrodroniyam 1873 goda. Olonetskaya guberniya (XXVII) [List of inhabited areas according to the data of 1873 . Olonets province (XXVII)]. St. Peterburg: S. n., 1879.

WALS 2005 - M. Haspelmath, M. S. Dryer, D. Gil, B. Comrie (eds.). The World Atlas of Language Structures. Oxford: Oxford University Press, 2005.

Zaytseva 2010 - N. G. Zaytseva. Pribaltiysko-finskie yazyki v zerkale lingvisticheskoy geografii [Balto-Finnic languages in the mirror of linguistic geography]. Trudy Karelskogo nauchnogo tsentra RAN. 2010. No. 4. P. 34-47. 


\title{
Рукописи Н. Д. Пыдера
}

\section{на нижнелужском диалекте ижорского языка (р. Россонь) с комментариями}

\section{Н. В. Кузнецова}

Институт лингвистических исследований РАН, Санкт-Петербург; nkuzn@yandex.ru

Аннотация. Публикация содержит рукописи 1980-2010-х гг. краеведа и хранителя традиции Н. Д. Пыдера (1924 г. р.) из д. Ванакюля на его родном нижнелужском ижорском говоре. Тексты, пословицы, поговорки, шутки, отдельные слова опубликованы в оригинальной записи автора и снабжены фонологической транскрипцией, морфологическим глоссированием, литературным переводом на русский язык и подробными комментариями к различным аспектам фонетики, фонологии, морфологии, лексики и синтаксиса рукописей.

Ключевые слова: нижнелужский диалект ижорского языка, публикация текстов, филологическое комментирование рукописей, языковые контакты, прибалтийско-финские языки Ингерманландии.

\section{Manuscripts by N. D. Põder in the Lower Luga dialect of Ingrian (Rosona river) with comments}

\author{
N. V. Kuznetsova \\ Institute for Linguistic Studies, Russian Academy of Sciences, St. Petersburg; \\ nkuzn@yandex.ru
}

Abstract. These manuscripts were written in the 1980-2010s by a cultural leader from the Vanakülä village in the Rosona river valley of Ingria, Nikolai Dmitrievič Põder (b. 1924), in his native Lower Luga Ingrian variety. The corpus contains narratives on how Põder learned to read in three languages (Russian, Estonian, and Finnish) and on practices of splint collection, translations of texts and words from other Finnic languages (most notably, from Votic and Soikkola Ingrian), proverbs, jokes, and single words, including some pairs of homonyms which Põder discovered in Ingrian.

The manuscripts in Põder's original orthography (in some cases, also with his translation into Russian and glossing) were prepared for publication and enriched with phonological transcription, interlinear glossing, a translation into Russian, as well as with 
philological comments on particular aspects of phonetics, phonology, morphology, lexicon, and syntax. The manuscripts were read and commented by Põder himself in 20082014, and the audiorecords of these sessions were also used in the publication.

The introduction contains Põder's brief biography, a note on the history of Vanakülä, a list of the manuscript physical carriers (1.1), data on the previous text publications in Ingrian and on the types of Põder's manuscripts (1.2), the ways of data presentation in the publication, the glossing rules (1.3) and the transcription principles, together with the main facts on Lower Luga Ingrian phonology (1.3). Among the most prominent phonological features which can be clearly traced in the manuscripts, are ongoing reduction of vowels and consonants and emergent consonantal palatalisation. Subsection 1.4 summarises the most interesting grammatical features of the texts, including case syncretism triggered by vowel reduction, and the emergence of a new allomorph -si- of the imperfect suffix $-i$ - through morphological reanalysis.

Põder fluently speaks Ingrian, Estonian, and Russian, as well as some Finnish. The latter three languages used to be the official languages of instruction and administration in Vanakülä in different historical periods, and the texts reflect the influences of them all. The contacts between Slavic and Finnic languages in the area are very old, and it is not always easy to distinguish between occasional code-switching/-mixing, recent borrowings into the Finnic languages of this particular area, which belonged to Estonia in 1920-1940, and the older layers of borrowings into Proto-Ingrian or even ProtoFinnic. Possible phonetic/phonological, lexical, and syntactic influences from different time periods discovered in the manuscripts are summarised in 1.5. Põder's written texts in Russian, some examples of which are also given (e.g., his autobiography and an essay on the principles of his Ingrian orthography) reflect Finnic influences, e.g., the elision of prepositions or grammatical gender mixing.

Keywords: Lower Luga dialect of Ingrian, text publications, philological commentary to texts, language contacts, Finnic languages of Ingria.

\section{1. Введение}

\section{1. Об авторе и историческом контексте рукописей}

Николай Дмитриевич Пыдер родился в 1924 г. в д. Ванакюля, одной из деревень по р. Россони, входившей в состав т. н. Эстонской Ингерманландии (эст. Eesti Ingeri). В дневниках Н. Д. ${ }^{1}$, изучавшего историю

${ }^{1}$ Русскоязычные дневники Н. Д. Пыдера в семи тетрадях были набраны на печатной машинке в отредактированном виде В. А. Пилли, перепечатаны на компьютере 
деревни (см. тж. [Пыдер 2006]), содержится «Разъяснение к административному положению д. Ванакюля» [Пыдер 2019: 145]:

Деревня Ванакюля (Илькино) до 1914 года относилась к Наровской волости (правление в дер. Большое Кузёмкино) Ямбургского уезда Санкт-Петербургской губернии. С 1914 года — к Петроградской губернии. Местное население называло д. Ванакюля. Официально деревня сотни лет называлась Илькино. В связи с провозглашением 24 февраля 1918 года Эстонской республики и заключением мирного договора между Россией и Эстонией 2 февраля 1920 года, часть земель Ямбургского уезда вошла в состав Эстонской республики, в том числе д. Ванакюля. С того времени деревня и официально стала называться Ванакюля. Относилась она к Нарвской волости, правление которой находилось в дер. Венкуль, а с 1939 года в городе Нарва на улице Рюютли. Нарвская волость входила в уезд Вирумаа Эстонии.

В июле 1940 года была образована Эстонская советская социалистическая республика, а 6 августа 1940 года Эстонская республика вошла в состав СССР. Эстонская советская социалистическая республика осталась в границах Эстонской республики с тем же административным делением. Во время немецкой оккупации, с 3-й декады августа 1941 года, Ванакюля осталась в тех же границах и административном делении до февраля 1944 года. 24 ноября 1944 года Верховный Совет СССР принял указ о включении в состав Ленинградской области части территории Эстонской ССР, расположенной восточнее реки Нарова. Вследствие этого деревеня Ванакюля вошла в состав Ленинградской области Кингисеппского района, Нарвского сельского совета (правление в дер. Калливере).

Жители дер. Ванакюля имели давние отношения с гор. Нарва. Многие работали на текстильной фабрике «Кренгольмская мануфактура». После установления советской власти в Эстонии, фабрика стала работать на полную мощь. Многие жители семьями переехали в Нарву, где работали. Поэтому мобилизацию в армию в 1941 году производил Нарвский горвоенкомат, а сельские жители призывались Вирумским уездным комиссариатом города Раквере.

Н. С. Дьячковым и изданы как [Пыдер 2019]). Отрывки опубликованы в газете «Время» от 31.05 и 18.06 за 1997 г. Н. Д. Пыдеру посвящен сюжет кингисеппского телевидения [ЯмТВ 2011]. 
Н. Д. Пыдер пользуется авторитетом местного краеведа и хранителя традиции. Он говорит на южном, наиболее инновационном в фонологическом отношении, варианте нижнелужского диалекта ижорского языка, который, в свою очередь, имеет много инновационных фонологических черт на фоне других ижорских диалектов [Кузнецова 2009]. Н. Д. также владеет эстонским (основной язык обучения в школе), русским и в определенной степени финским языком. Согласно его дневниковым записям, до вхождения Ванакюли в Эстонскую республику делопроизводство и обучение в школе велось на русском языке, но население говорило на ижорском. В записях, описывающих начало войны (1939-1941), и в аудиозаписях Н. Д. упоминает, что в те годы владел и русским, и финским языком слабо, хотя финский был более понятен. В 1940 году он собрал радиоприемник и начал слушать радио на русском (Ленинград) и финском (станция Лахти и программа из Петрозаводска на ленинградском радио) языках, постепенно понимая все больше. Знания этих языков значительно укрепились во время войны. В частности, Н. Д. отмечает, что осенью 1940 года, уже при советской власти, ему пришлось снова сесть за парту и изучать русский язык в Калливерской школе. А в 1944 г. он прошел курсы обучения военных переводчиков с финского языка на русский и затем несколько месяцев, до ранения с потерей левой руки и демобилизации, работал переводчиком на фронте (в аудиозаписях Н. Д. упоминает, что переводить на русский язык ему было непросто). Ниже приводится автобиографическая справка из одной из русскоязычных тетрадей Н. Д., посвященных воспоминаниям о войне:

[Запись №] 19. Пыдер Николай Дмитриевич 1924 г. рожд, дер. Ванакюля Нарвской волости уезда Вирумаа Эстонии.

Отец Дмитрий Григорьевич 1887 г., мать Евдокия Петровна 1883 г. рожд., из деревни Кейкино. Крестьяне, православные, ижоры. Николай, окончив Калливерскую 6-ти кл. нач. школу 1932-1938 г. работал в своём х-ве. 1937 г. умер отец. Связи с войной в августе 1941 г. эвакуировался в глубь страны, Кировскую обл., Опаринский р-он, Шабурский с/с деревню Журавлёнки. к-з «Организатор». Работал в колхозе. В мае 1942 г. ходил на призыв, а августе 1942 г. был мобилизован Красную Армию, 1 ЭЗСП, учебный батальон. Окончив курс, присвоили чин младшего сержанта. Был направлен на фронт в район города Великие Луки, 27 СП 7 СД. 31 января 1944 г был передислоцирован на Ленинградский фронт около города Кингисепп 
на реке Луге. Всё время был должности командира отделенья. В мае 1944 г был направлен военпереводчиком 372-ю Новгородскую, ордена Кутузова гвардейскую дивизию, в 440 отдельную разведроту. В боях на Карельском перешейке был тяжело ранен. Лечился гор. Ленинграде, и около города Кинешма Ивановской области. После лечения присвоено II гр. инвалидности. Демобилизован сентябре 1944 г. Прибыл деревню Кальмус Волосовского района, где находилась мать, эвакуированная из постоянного места жительства связи остановкой фронта на реке Нарва. Весной 1945 г. вернулся дер. Ванакюля. Работал своём х-ве. Был назначен уполномоченным деревни. 1947 г женился на Морозовой Раисе Васильевне с 1923 г рождения из дер. Приречье. 1948 г был организован колхоз «Восход», был председателем колхоза, после объединения колхозом «1 мая» бригадиром. 1955 г земли к-за «Восход» были переданы совхозу «Ударник-Ропша» работал бригадиром. Потом на разных должностях в совхозе. 1975 по 1978 г Кингисеппском лесхозе лесником. 1978 г. умерла мать. С этого времени прекратил работу и перешел полностью на пенсию. Имеет двоих детей. Был в комсомоле с 1943 по 1946 год. Настоящее время живёт в своем хозяйстве с супругой [см. Рисунок 1. Раисы Васильевны не стало в 2011 г. - H. K.] ${ }^{2}$.

Дневники и другие рукописи Н. Д. содержат разнообразные сведения, в основном посвященные истории и культуре. Их автор активно интересовался языками: в рукописях содержатся сведения и тексты на разных языках, переписные и оригинальные. Ниже приводится список тех рукописей Н. Д. Пыдера, которые, в числе прочего, содержат и публикуемые ниже записи на его родном ижорском говоре. В большинстве манускриптов часть записей датирована. На основе первой и последней даты можно более или менее точно установить охватываемый в каждой из рукописей временной период. Каждой тетради присвоен условный индекс.

1. ЧОТ (до 1991): школьная тетрадь в клетку с белой бумажной обложкой, на обложке название «Что-то о топонимах». На внешней

2 Тетрадь 48 л. в клетку; надпись на обложке: «Великая отечественная война 1941-1945 г. г. Ванакюля», с. 49; орфография и пунктуация оригинала здесь и далее сохранены. Запись № 19, очевидно, сделана в июне 2004 г. (запись № 17 датирована 14 июня 2004, а № 20 - июнем 2004). 


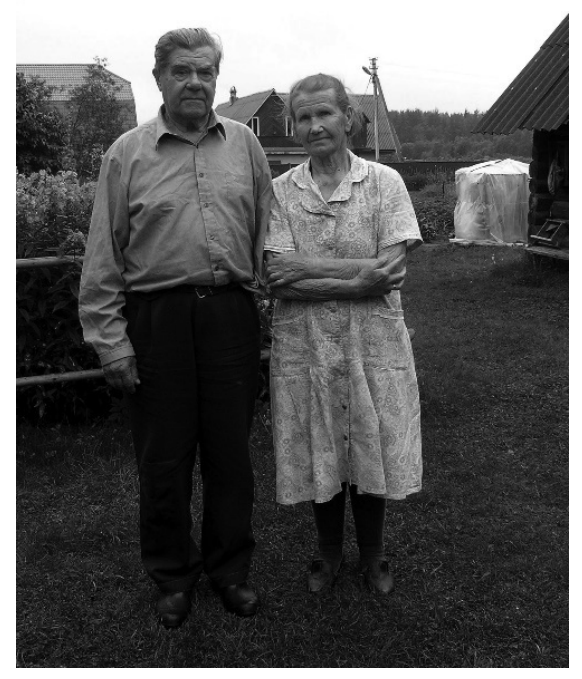

Рисунок 1. Н. Д. Пыдер с женой во дворе их дома (11.08.2008; фото автора)

Fig. 1. N. D. Põder with his wife in the courtyard of their house (11.08.2008; photo by the author)

стороне задней обложки типографские данные: «Фабрика “Светоч”, ЛПО “Бумага", Арт. 1 Р1-0280383, 12 листов». В тетради 24 страницы записей в основном на русском языке с вкраплениями на ижорском, финском, шведском, эстонском. Единственная датировка в самом конце тетради после самой последней записи: «декабрь 1990 год».

2. ВВ (1989-2009): школьная тетрадь в клетку, на обложке название «Тетрадь всякой всячины», коричневый коленкоровый переплет. На внутренней стороне задней обложки типографские данные: «Tallinna TRK “Kaustik", ART. 6302-E, GOST 13309-79. Hind 41 kop., 96 lehte». Фактически же в тетради 189 страниц записей в основном на русском, но также на эстонском, ижорском (сойкинском и нижнелужском), финском, водском, карельском (северном, олонецком / ливвиковском, тверском, людиковском), вепсском, ливском языках, с вкраплениями на немецком, французском, английском, латыни, древнерусском, греческом. Они охватывают период с 11.10.1989 по 02.12.2009 и содержат основной корпус публикуемых ниже рукописей. В записи за 10.11.97 (с. 118) прокомментировано название тетради: 


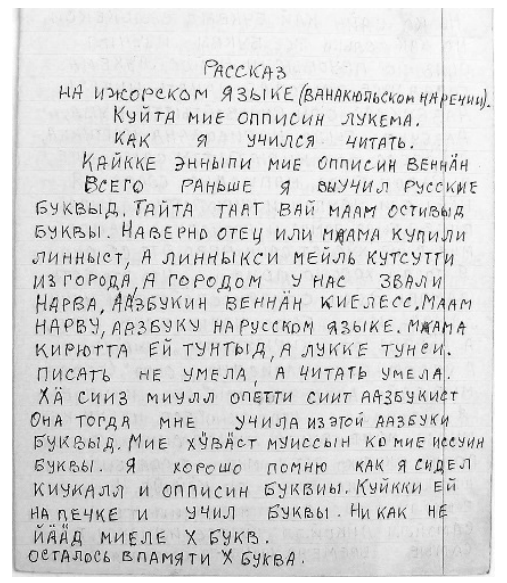

Рисунок 2. Начало текста КМОЛ (страница 1)

Fig. 2. Begginning of the text KMOL (page 1)

О всякой всячине. Узнал, что Екатерина II издавала журнал «Всякая всячина». Настоящая моя тетрадь называется также, независимо от названия журнала Екатерин II. Это просто случайное совпадение.

Мои записи в семи тетрадях [дневники. - H. K.] я назвал «Страницы жизни прожитые и не прожитые». В одном Роман-газете после я видел почти похожее заглавие (дословно не помню). Просто совпадение.

3. КМОЛ (2000): нескрепленные двойные тетрадные листы в широкую линейку, сложенные книжечкой и озаглавленные «Рассказ на ижорском языке (ванакюльском наречии). Куйта мие опписин лукема. Как я учился читать». Рукопись (6 с.), очевидно, переписана с аналогичной рукописи на с. 20-24 тетради ЧОТ «Рассказ на ижорском (ванакюльском диалекте). Как я научился читать. Куйта мие опписин лукема» с добавлением подстрочного перевода каждого слова (см. Puсунок 2). Датирована «12 сентября 2000 года».

4. ПМ ( после 2011 г.): школьная тетрадь в клетку с розовой бумажной обложкой, на обложке заглавие «Памятка». На внешней стороне задней обложки типографские данные: «АО “Архангельский УБК”». 12 листов. Арт. С-60-7224354». В тетради ведется учет посещений Н. Д. Пыдера учеными, журналистами, студентами и др. Не закончена до сих пор; последние зафиксированные записи 2018 г., начата не позже 2011 г., как мин. 20 с. записей. 
5. ВВ2 (2014): школьная тетрадь в широкую линейку, 12 или 18 листов, на обложке заглавие: «[для] Всякой всячины». Единственная запись на с. 1 датирована «12 апр. 2014».

6. ПН: одинарные тетрадные листы в клетку, исписанные с одной стороны, скрепленные скрепкой, пронумерованные от 1 до 7 и озаглавленные: «Деревня Ванакюля. Пыдер Н. Пища наша». Рукопись содержит сведения о традиционных блюдах д. Ванакюля на русском языке; некоторые термины и названия даны на русском и ижорском языках. Не датирована.

7. Разрозненные недатированные тетрадные листы:

1) НР: одна белая страница (очевидно, из блокнота) с названиями родственников по-ижорски с русским переводом;

2) ФС: одна тетрадная страница в клетку с фрагментом словаря - переводными эквивалентами слов на разных языках. Шесть колонок: русский, эстонский, финский, ижорский, немецкий (на немецкий переведены только первые два слова), пустая колонка.

\section{2. О структуре рукописей}

Данная работа является первой глоссированной публикацией нижнелужских ижорских текстов ${ }^{3}$. Единственный глоссированный ижорский текст на сойкинском диалекте был опубликован в [Рожанский, Маркус 2012]. В целом изученность нижнелужского диалекта ниже, чем сойкинского и хэваского ${ }^{4}$. Как словарь [Nirvi 1971] (далее [N]), так и неглоссированные публикации образцов ижорской речи содержат относительно мало материала на нижнелужском диалекте. Попытка разработки письменности на ижорском языке относятся к началу 1930-х гг. (прекращены с окончанием политики коренизации в 1938 г.), но в основу литературного языка был положен сойкинский диалект.

3 Пользуясь случаем, хотела бы выразить огромную признательность автору текстов за помощь в их анализе, а также М. З. Муслимову, Ю. Пюстюнену, Ф. И. Рожанскому, С. С. Саю и А. Ю. Урманчиевой за ценные замечания.

4 Четвертый ижорский диалект, оредежский, практически исчез к моменту начала основного этапа исследования ижорского языка в 1950-1960-х гг. эстонскими лингвистами, поэтому описан наиболее слабо. 
Нижнелужский диалект, подвергшийся интенсивным контактным влияниям внутри нижнелужского языкового союза со стороны водского, ингерманландского финского и эстонского языков, наиболее сильно отличается от остальных ижорских диалектов. Это также наиболее раздробленный в диалектном отношении вариант ижорского языка [Лаанест 1966а: 148, Муслимов 2005]. С точки зрения организации просодической системы в нем выделяется четыре зоны: северная (наиболее консервативная), южная (наиболее инновационная) и переходная, подразделяемая на восточную (ближе к северной) и западную (ближе к южной) [Кузнецова 2012, Kuznetsova 2016, 2019]. Наибольшая часть опубликованных текстов происходит из северо-восточной зоны:

— северная зона: д. Липово [Лаанест 1966b: 155-186], д. Остров [Virtaranta 1967: 157-169];

— восточная зона: д. Краколье [Лаанест 1966b: 186-221], д. Лужицы [Kryger 2009, Krjukov 2011].

Печатных текстов из западной зоны, по-видимому, не представлено. Из южной зоны происходит один текст из [Лаанест 1966b: 221-228] (д. Ванакюля) и некоторые из 83 пословиц и поговорок в [Mägiste 1925: 125-128] (д. Калливере и Ванакюля; основная часть их, очевидно, записана от местных ингерманландских финнов). Имеются также тексты, переведенные на ижорский Н. Д. Пыдером [Mirenkov 2001; Mirenkov, Põder 2009]. Во втором из них предложенная редакторами транскрипция достаточно точно отображает просодическую систему идиолекта Н. Д. При этом для своих тетрадных рукописей Н. Д. разработал собственную систему записи. Его русскоязычные размышления об ижорском и водском языках включены в настоящую работу перед текстами.

Публикация направлена на максимально полное отражение ижорских рукописей Н. Д. Пыдера. Публикуемые материалы содержат несколько типов записей: оригинальный ижорский текст (1) с авторским подстрочником к каждому слову или (2) без него; (3) переводы Н. Д. на свой говор с опубликованных сойкинских ижорских или водских текстов; (4) переводные соответствия между русскими, ижорскими, финскими, эстонскими, водскими, немецкими словами (в разных комбинациях); (5) отдельные идиоматические фразы: пословицы, поговорки, шутки; (6) пары омонимов (и псевдо-омонимов) в ижорском языке, отмеченные самим Н. Д. 


\section{3. Представление текстов и глоссирование}

Записи опубликованы в нескольких форматах:

1) для текста с подстрочником автора: четырехстрочная пофразовая запись (ижорская запись и подстрочник автора, фонологическая транскрипция, глоссирование) с последующим литературным переводом всей фразы;

2) для текстов и предложений без подстрочника: трехстрочная пофразовая запись с литературным переводом каждой фразы;

3) для отдельных слов в формате словаря, где в оригинале имеется и русский перевод автора: трех- или четырехстрочная запись, в зависимости от необходимости глоссирования (русский перевод автора в целом является достаточно точным, поэтому дополнительного пояснения слов обычно не требуется);

4) для отдельных ижорских слов, вкрапленных в иноязычные записи (обычно на русском): либо трехстрочная запись, как в (3), либо запись в одну строку (слово, транскрипция, <глоссирование>, 'перевод'). Часто приводится и ближайший русскоязычный контекст записи, поясняющий значение или употребление слова.

Некоторые тексты, фразы и слова повторяются в рукописях от 2 до 4 раз, часто с вариациями. В таких случаях использован один из двух форматов подачи материала.

1. Полное дублирование повторяющегося фрагмента (используется при итерации отдельных фраз или слов). Отдельные слова в таких случаях поданы через «/» с указанием в сноске источников каждого варианта. Итерации фраз обычно дублируются под буквами (а, б, в....); в ряде случаев даны в сносках. Особенности подачи текста «Как я научился читать», имеющего три различных по длине и формату итерации, описаны перед самим текстом.

2. Указание в сносках только на частные разночтения между итерациями (используется в основном для текстов).

Для каждого фрагмента рукописей (и итераций внутри него) приводится источник: индекс тетради, максимально возможная по точности датировка, страница. В редких случаях (см. список рукописей выше) страницы были пронумерованы самим Н. Д. Пыдером. В прочих случаях номера страниц были присвоены автором настоящей публикации. Итерациям номера даются в хронологическом порядке (от более ранних к более 
поздним; недатированные версии условно помещены в конец списка) и обозначены как № 1, № 2 и т. д. (например, Текст № 1, Текст № 2 и пр.).

Практически все рукописи (за исключением случайно пропущенных единичных примеров), включая и все итерации, были прочитаны Н. Д. Пыдером и разобраны вместе с автором публикации под запись в 2008, 2010 (диктофон Olympus WS-310), 2012 и 2014 (диктофон Zoom H4n) годах. Фонетическая транскрипция конкретных произнесений в записях приводится фрагментарно, для иллюстрации тех или иных явлений. В случае чтения разных итераций одного и того же фрагмента, номера вариантов чтения представлены как \#1, \#2 и т. д. Номера чтений соответствуют номерам итераций в рукописях. Два текста («Как я научился читать» в итерации № 2, и «За лыком») были записаны дважды, в 2010 и 2014 г. В этих случаях варианты чтений обозначены буквами (\#2a, \#2b; \#1a,\#1b). Произнесения и комментарии при разборе рукописей обозначены как \#r. Транскрипция приводится в квадратных скобках либо около соответствующего фрагмента, либо в сноске.

Глоссирование в целом использует систему, описанную в [Кузнецова, Холодилова 2012] (список глосс приведен в конце статьи). Так, в частности, не глоссируются следующие граммемы: (1) именные и местоименные - номинатив, единственное число, положительная степень прилагательных; (2) глагольные - непрошедшее время (кроме причастий), активный залог, индикативное наклонение, утвердительная полярность, второе лицо для форм императива. Нулевая морфема использована только для глагольной граммемы 3SG в индикативе. Помимо грамматических показателей, в некоторых случаях также выделяются словообразовательные морфемы (<>) и части композитов. Принцип авторской записи композитов варьирует между раздельным написанием частей, написанием через дефис и слитным: акань ваккой аканывакакси, витс-ваккой витс ваккой, пуукэрекя и др. Все формы, более или менее удовлетворяющие морфосинтаксическим критериям композитов, содержат в транскрипции знак <+>, соединяющий их части (не до конца прозрачные случаи оговорены в сносках).

Точка используется для соединения (1) двух элементов грамматического значения простого по составу показателя (например, $-k a<$ IMP.PL $>$ ) или (2) двух различных грамматических показателей или корня и показателя в случае отсутствия четкой границы между ними (например, опо $<$ быть.3SG>) или несегментной морфемы.

Дифтонг и гемината членятся, если через них проходит морфемная граница (например, vuot-t(ә)<год-PART>, aiko-i-ll(ә) <время-PL-AD>). 
В единичном случае, где можно было бы говорить о морфемной границе внутри долгого гласного, возможна и такая фонологическая трактовка, при которой между двумя краткими гласными в действительности проходит слоговая граница: $p i-i-n<$ держать-PST-1SG>.

В некоторых случаях сложно разграничить падежные формы имен и местоимений и образованные от них путем лексикализации наречия и предлоги. Ср., например, si-l'l'(ә) <тот-АD>, но sil 'tä 'оттого', которое исходно представляло собой аблатив от se 'тот' (очевидно, с притяжательным суффиксом $3 \mathrm{sG}$ ). Если все же есть основания говорить о падежной форме, но падежный показатель отличается от регулярного, то граница между корнем и показателем не проводится (напр., $\operatorname{sitt}($ (ә) 'Tот.EL', vīttä способ.PART, mittä 'который.PART.NEG'). Предлоги, в значении которых сохраняются локативные значения местных падежей, плохо передаваемые русским переводом, дополнительно снабжены пометой локативного значения в круглых скобках: pä́l'l'(ә)<на(AD)>.

В случае, если морфемное членение словоформы по каким-то причинам опущено, используется двоеточие <:>. Слова Pluralia tantum глоссируются как обычные формы мн.ч: lat'i-d $<$ настил-PL>.

В ижорских текстах Н. Д. встречаются вкрапления других языков, а также случаи языковой интерференции (например, черты ижорской и финской фонетики в одном слове или корень из одного языка, морфология из другого, см. тж. Раздел 1.5). В таких случаях при глоссе каждой морфемы приводятся подстрочные индексы интерферирующего

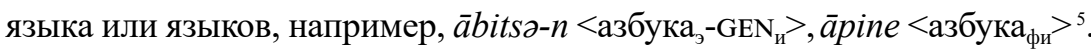
В литературном переводе язык указан в скобках (список сокращений языков см. в конце статьи).

\section{4. Фонетическая и фонологическая транскрипция}

Фонетическая и фонологическая транскрипция материала использует систему записи финно-угорской фонетической транскрипции $(\mathrm{FUT})^{6}$. Она основана, во-первых, на аудиозаписях чтений тек-

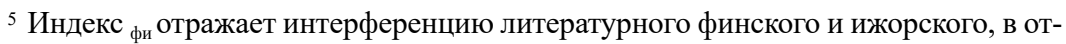
личие от иф - индекса ингерманландского финского.

6 Ударение при этом обозначается по правилам МФА, т. е. как ['] и [.]. Дефолтной позицией ударения является начало стопы. В транскрипции отображается только неначальное ударение (но в композитах — все ударения).
} 
стов Н. Д. Пыдером, во-вторых, на исследованиях нижнелужской ижорской фонологии автором публикации [Кузнецова 2009, 2012; Kuznetsova 2012, 2016; Kuznetsova, Verkhodanova 2019]. Основной формат записи - фонологическая транскрипция. Фонетическая транскрипция используется только в иллюстрациях отдельных слов и в ижороязычных комментариях Н. Д. При разборе рукописей (в последнем случае в квадратных скобках приводится литературный русский перевод комментария). Основные транскрипционные знаки перечислены в списке сокращений в конце.

Особо следует оговорить представление в фонологической транскрипции сокращения долготы гласных и согласных, а также консонантной палатализации. Южные нижнелужские говоры характеризуются сильной количественной и качественной редукцией гласных неначальных слогов (далее называемых также «неначальными гласными») в ряде позиций. Редукция кратких гласных, в числе прочего, включает в себя формирование фонологического шва, оглушение и утрату гласного. Палатализация согласных перед гласными переднего ряда и $j$ также широко представлена в этих говорах. Редукция и палатализация связаны: фонологические палатализованные согласные закрепляются в результате редукции и отпадения последующих гласных или $j$. Оба явления находятся в процессе развития и потому трудны для стандартизации транскрипции. Отметим, что наибольшее число исправлений в рукописи, сделанных самим Н. Д., а также разночтений в итерациях текстов, связаны именно с этими двумя явлениями (все подобные случаи отображены в записи). В фонетической транскрипции приводятся те конкретные аллофоны редуцированных гласных и палатализованных согласных, которые были произнесены автором при чтении или разборе. Принципы подачи этих явлений в фонологической транскрипции описаны ниже.

Редукция гласных представлена во втором слоге 2-3-сложной стопы с первым долгим слогом и в третьем слоге 3-сложной стопы [Кузнецова 2012]. Первый долгий слог может иметь любую структуру кроме (C) V. В стопе с первым слогом (C)V гласный второго слога, на-

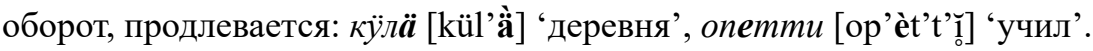
Гласные подвергаются редукции в разной степени; ср. иерархию от максимально до минимально подверженных редукции групп неначальных гласных и дифтонгов (здесь и далее знак «*» передает уровень реконструкции не глубже пранижнелужского):

$$
\text { (1) *a, ä, ai, äi<(2) *e<(3)*o, ö, u, ü, i, oi, öi, ui, üi. }
$$


Исходный стопический характер редукции в современном состоянии языка размыт. Так, в кӥнтиылль /künt'(ә)јəl'l'(ә)/, туттывылкси / tuttəvəkšl/, редукции подвергаются гласные всех трех неначальных слогов, что затрудняет выделение двух стоп. Тут, впрочем, можно говорить и о редукции, рекурсивно (циклично) применяемой при превращении 4-сложного двустопного слова в 3-сложное одностопное (см. [Кузнецова 2012: 29-30] и сноску 160).

На основе того, какие группы гласных охвачены редукцией, выделяется два типа редукционных процессов: (a) более слабый и (b) более сильный. В идиолекте Н. Д. группа гласных 1 теряет свое качество и переходит в фонологический шва при обоих типах редукции (отдельные исключения оговорены в Разделе 1.4). Группа 2 иногда переходит в шва при обоих процессах, а группа 3 может переходить в шва только при процессе (b). Редукционные рефлексы одиночных гласных и соответствующих дифтонгов не различаются; ср., например, в списке приводимых Н. Д. омонимов пару кайво (kaivŏ < *kaivo) 'колодец’ и кайво (kaivŏ < *kaivoi) 'копал'.

Неодинаковы по своим редукционным свойствам и просодические позиции в стопе. Выделяется два основных типа позиций: (I) «стабильные» (гласный может редуцироваться, но в силу фонотактических ограничений не может выпадать) и (II) «нестабильные» (гласный может редуцироваться и выпадать). Перемножение типов редукции на типы позиций дает следующую матрицу ( $*$ условно обозначает группу гласных $1,{ }^{*} o$ - группу 3 :

Таблища 1. Позиции и типы редукции неначальных гласных

Table 1. Positions and types of reduction of non-initial vowels

\begin{tabular}{|c|c|c|}
\hline & тип редукции (а) & тип редукции (b) \\
\hline $\begin{array}{l}\text { «стабиль- } \\
\text { ная» } \\
\text { позиция } \\
\text { (I) }\end{array}$ & $\begin{array}{l}\text { Ia: } \\
* a>\partial, *=o: \\
* \text { lammaz > [łamməz] 'овца'; } \\
\text { *aukod > [aukod] 'дыра:PL' }\end{array}$ & 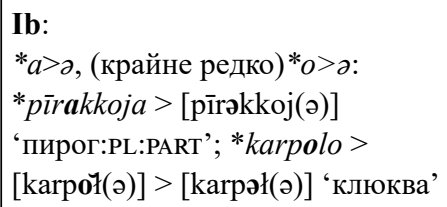 \\
\hline $\begin{array}{l}\text { «неста- } \\
\text { бильная» } \\
\text { позиция } \\
\text { (II) }\end{array}$ & 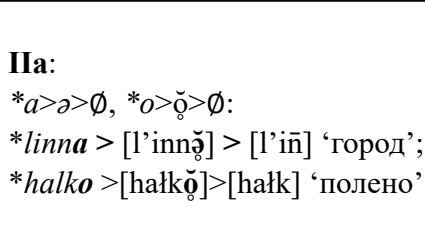 & 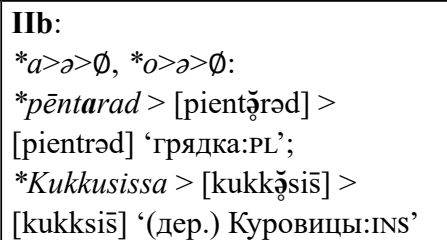 \\
\hline
\end{tabular}


Н. Д. в норме осознает наличие шва в стабильных позициях (записывая его обычно как $b l$ или $\tilde{o}$, иногда как $u$ ) и не осознает в нестабильных, например: линн $/$ /l'inn(ә)/vs. линныст/l'innəst(ә)/. Он также осознает его краткий характер, см. сноску 226. Случаи сохранения шва в нестабильной позиции обычно связаны с позицией после $j: \bar{\jmath}$, где конечный шва почему-то осознается Н. Д. лучше всего: мариы / marj(ә)/, кӥнтыли $/$ küntәj(ә)/, кайкий кайкиы $/ \operatorname{kaik}(\mathrm{k}) \mathrm{ij}(ә) /$ и др. Несколько случаев сохранения конечного шва зафиксировано и после n: Saаtõñ, аканы ваккой аканывакакси, панны панн, анны; ср. тж. лехм леэхмъ(b). Интересен пример шва в односложном безударном слове: сиэ ды миэ 'ты да я'. В ӥхтыки к ӥh-t(ә) <один-РАRT> была прибавлена эмфатическая частица $-k \breve{l}$, что сделало позицию стабильной: üht(a) Ia > ühtok(li) Ib. ${ }^{\urcorner}$

Три группы гласных и дифтонгов в отношении редукции достаточно четко выделяются в рукописях. Гласные группы 1 в позициях редукции практически никогда не представлены полными вариантами. К единичным контрпримерам можно отнести пиккарайне 'маленький' - однако такая форма встретилась в пословице, которая, по словам Н. Д., была либо ингерманландской финской, либо водской (ср. тж. закономерное пиккрайсен с выпадением гласного). Исключение хуймая 'кружится' также является специфическим, т. к. фраза построена на игре слов с русской нецензурной лексикой. Отсутствие редукции под влиянием других языков описано в Разделе 1.5. Незакономерными случаями также представляются виттӓ <способ:РАRT> (здесь фактором сохранения полного гласного может быть идиоматизация конструкций с этой формой, см. тж. Раздел 1.4), вад'я-н /vadja(/ə)n/ <водский-GEN>, минья-д $/ \operatorname{minja}(/$ ) d/ <невестка-PL $>$. В двух последних примерах наличие полного гласного может быть вызвано специфической позицией после $j$ (в первом из них также возможно влияние водского оригинала текста, см. сноску 184). Наконец, в läkkämä̈s, произнесенном как ['l'äkkämə̄̄], можно говорить о рекурсивности редукции при утрате второго ударения и, соответственно, второй стопы: [*'läkkä, mässä > *'läkkä, mäs̄ > 'l'äkkämäs̄ > 'l'äkkäməs̄].

${ }^{7}$ В трехсложной стопе могут подвергаться редукции гласные и 2-го, и 3-го слога. Если стопа конечная, то максимальной редукции с отпадением подвергается гласный 3-го слога (процесс IIb). Гласный 2-го слога в таком случае оказывается в стабильной позиции и претерпевает редукцию Ib: [*karpoło $]>[$ karpŏłŏ $]>\left[\right.$ karpəł $\left.^{’}\right]>$ [karpəł] 'клюква', ср. карпъғолө. 
В случае редукции типа IІа гласные группы 3 и частично 2 представлены в речи Н. Д. еще не перешедшими в фонологический шва, но редуцированными и часто оглушаемыми или выпадающими в речи аллофонами. Гласные среднего подъема могут также повышаться, ср. пример лиукупӓив liukopäiv лиукопяйв 'Масленица'. Редуцированные гласные фонологически противопоставлены полным кратким гласным, которые образовались в результате редукции этимологически долгих гласных. Так, например, NOM и ILL слова 'петух' противопоставлены как [kukkŏ] (<*kukko) vs. [kukko] (<*kukkō). К неначальным полным фонологически кратким гласным относится и второй фонетически продленный гласный в стопах типа [kül'ä̀, op'èt't'⿳⺈⿴囗丷。] (см. выше) ${ }^{8}$.

Н. Д. обычно осознает наличие редуцированных гласных в случае группы гласных 3 , но на письме не отличает их от «полных» кратких гласных. Лишь в редких случаях он отмечает их краткость, как в $в a$ наксй, коффй, газеттй. Редукция до шва и выпадение гласных группы 3 встречается в рукописи относительно редко и почти только в случае редукции IIb: Куккыси (<*Kukkusi), куомныссс (<*kuominassa), енсмӓйсекси (<*ensimmäiseksi), naapriss (<*nāpurissa), вӓрплӓйн (<*värpüläine). Единственным важным исключением является суффикс -pц (см. ниже).

Рефлекс краткого гласного * $е$ занимает промежуточное положение между группами гласных 1 и 3 . В одних случаях и в речи, и в рукописях Н. Д. он редуцируется до шва и в нестабильных позициях выпадает, в других нет. На синхронном уровне эта вариативность не вполне обусловлена позицией, она может быть представлена даже в одном

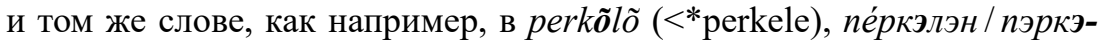
лен пэрклен/пе́рклен (<* perkelen), ср. тж. кирютетту, но кейтытти в аналогичной позиции. Возможно, в распределении слов, где на синхронном уровне в одной и той же позиции может или не может быть представлена редукция * $e$, играют роль исторические или морфо(но) логические факторы, однако здесь необходимы дополнительные исследования. Решение о выборе варианта транскрипции рефлексов *e принималось для каждой словоформы индивидуально, на базе конкретных вариантов его редукции в рукописях и в речи Н. Д.

В фонологической транскрипции рукописей неначальные полные гласные записываются как /a, o/ и др. Указанные четыре типа редукции отображены в фонологической транскрипции следующим образом:

${ }^{8}$ Интересно, что в этой позиции, несмотря на отсутствие редукции гласного, в идиолекте Н. Д. выпал второй элемент дифтонгов на $-i$, cp. сано 'сказал' (<*sanoi). 
Таблица 2. Фонологическая запись редукции неначальных гласных

Table 2. Phonological transcription of the reduction of non-initial vowels

\begin{tabular}{|c|c|c|}
\hline & тип редукции (a) & тип редукции (b) \\
\hline $\begin{array}{l}\text { «ста- } \\
\text { бильная» } \\
\text { позиция } \\
\text { (I) }\end{array}$ & $\begin{array}{l}\text { Ia: } \\
*_{a>\partial \rightarrow / \curvearrowright / / \text { tamməz/ }} \\
\left({ }^{*} o=o \rightarrow / \mathrm{o} / / \text { aukod/, т. е. полный }\right. \\
\text { гласный })\end{array}$ & 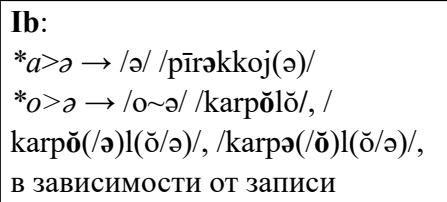 \\
\hline $\begin{array}{l}\text { «неста- } \\
\text { бильная» } \\
\text { позиция } \\
\text { (II) }\end{array}$ & 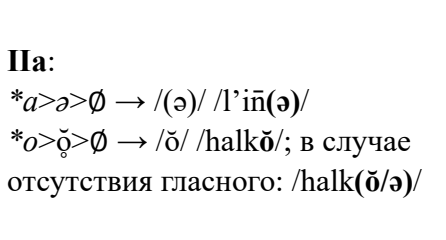 & 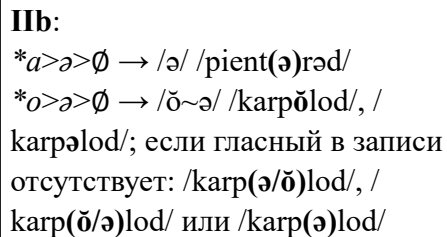 \\
\hline
\end{tabular}

Следует отметить, что позиции Ib и IIb являются сложными для фонологического транскрибирования групп гласных 2 и 3, если в слове нет выраженной качественной редукции и (в IIb) выпадения гласного. В этих позициях в основе могут быть представлены рефлексы как долгих, так и кратких гласных. Например, у возвратного глагола oppiss(ə) 'учиться' форма оппима SUP восходит к *оррїmā, а форма опписин к *oppisin. На письме Н. Д. не различает полные и редуцированные гласные, если нет сильной качественной редукции до шва. В произношении данные формы различались: [opp's's'in] vs. [opp'ima], поэтому были записаны как oppц̌sin (IIb) vs. oppima. Форма этсимӓ <искать:SUP> (<*etsim $\overline{\ddot{a})}$ была произнесена с редукцией [ets' ${ }^{\mathrm{i}} \mathrm{mä]}$ и записана как etsimä. Однако в формах, содержащих *u (редукция которого в целом слабее, чем *i [Kuznetsova, Verkhodanova 2019]), ситуация менее очевидна. Например, в кутсума <звать:SUP> (<*kutsumā) во всех четырех чтениях на слух не отмечалось сильного сокращения гласного. С истума ситуация еще сложнее, т. к. эта форма теоретически может восходить как к *istumā <сидеть:SUP>, так и к возвратному $*_{i s t u} m \bar{a}<\mathrm{ca}-$ диться:SUP> (исходя из контекста рукописи, в данном случае можно предположить первое). Форма исmувыл <сидеть:PST:3PL > безусловно относится к невозвратному глаголу, и признаком редукции в ней является отсутствие второго элемента дифтонга (<*istuivad), но сам $u$ при этом не подвергается сильной редукции, поэтому форма записана как istuvad. В целом, как и в случаях с *e, выбран индивидуальный подход к каждой форме. 
Долгие неначальные гласные в речи Н. Д. не зафиксированы и в рукописях не отмечены, за исключением топонимов Лаукаансуу 'д. Остров', Лаукаa 'р. Луга'. В данном случае можно было бы предполагать копирование написания топонимов из письменных источников, но долгий гласный тут был отмечен и в произношении Н. Д. При этом начальные долгие гласные передаются им последовательно (как удвоенные краткие, в единичном случае - как ий в рийс(c)bld), и ошибки сравнительно редки. Написания долгих гласных как кратких обычно связаны с влиянием орфографии русского языка в случае либо русских заимствований в ижорский (шиныд /šīnəd/ 'шины', думысин дуумысин /dūm(ә) $\sin /$ 'думал', улиц /ūl'its(ə)/ ‘улица' (в значении 'пространство вне дома', а не в значении 'дорога'), либо прибалтийско-финских заимствований в русский (рихи /rīhǐ/ 'рига'), с влиянием предшествующих глайдов $j$ (йуре юууре, йӓпи йяӓбь йябь (јӓӓb) и $v($ виттӓ, виикко $\sim$ викко, ви(и)мин), а также с односложным характером слова $(n \boldsymbol{a} \sim n a а н$, eй $и \ddot{\boldsymbol{a}} \sim \ddot{u} а \ddot{a})$. В случае односложных слов долгота гласного действительно варьирует в произношении (например, в $в a[\mathrm{va} \sim \mathrm{va}]$, $x \ddot{a} \ddot{a} \sim x \ddot{a}[$ hä $\sim$ hä] $)$ и часто есть основания постулировать и фонологическое варьирование типа /hä hä/.

Гармония гласных также нарушается на письме крайне редко (напр. энсимайсисс 'в первом' с гармонией гласных энсимӓсен 'первого'), ср. тж. гиперкорректную вставку гармонирующего гласного в эстонском süda 'сердце' 9 - сӥдя. Размышления Н. Д. об отображении «умляутных» передних гласных $\ddot{a}: \bar{a}, \ddot{o}: \bar{o}, \ddot{u}: \overline{\ddot{u}}$ на письме представлены в эссе «О языке ижорском».

Иногда Н. Д. отмечает краткость первого или второго компонента начальных дифтонгов, ср. куй, кӓйн, найн, койр, пӓив пяйв пӓйив, тж. кйука, Мйун. В его идиолекте в некоторых случаях вторые элементы неисконных дифтонгов, образовавшихся при выпадении согласного между ними, подверглись фонологической редукции: мие (< *miä $<*$ minä), сӥ̈̈н ( $<*$ süän $<*$ südän).

Согласные также отчасти подвержены процессу редукции. Вариативность на письме долготы согласных, особенно находящихся в позиции после долгого гласного или дифтонга, а в еще большей степени - дальше границы первого и второго слогов, более сильная, чем вариативность долготы начальных гласных. Она проявляется

9 Здесь и ниже эстонские параллели даются по [EVS 2019], а для комментариев к финской лексике привлекался [Куусинен 1999]. 
не только на письме, но и в произношении слов в спонтанной речи:

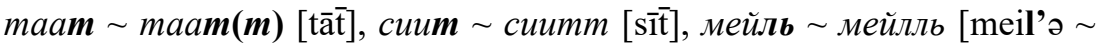
meil'], кайкиы кайкий [kaik' 'ij kaik'k'i kaik'k'ij kaik' 'ij] кайкке [kaik'e $\sim$ kaik'k'e kaik'e]. Для конечных долгих согласных, попадающих в абсолютный исход слова при утрате конечного шва, сокращение и на письме, и в речи особенно характерно: классил, нелльннес, илльл, лаулойм, läkkӓt, колмыннел куувыннел [kuvvәnne $\bar{\imath} \sim$ kuvvənel], виеннель [vījenəl' vījenel' vījənəl'] и пр. Вариативность может быть также отчасти обусловлена влиянием эстонской орфографии. Это можно

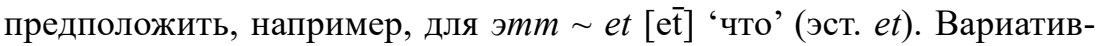
ность нӥтm [nüț] нӥд [nüt nüd] 'сейчас' может быть обусловлена просодикой односложной стопы [Кузнецова 2009: 77-89]. Поскольку при тщательном произнесении долгота согласного восстанавливается, в фонологической транскрипции указан долгий согласный (в редких случаях — с вариативной долготой $/ \mathrm{t}(\mathrm{t}) /)$.

Палатализация согласных представлена в контексте перед $j$, а также перед гласными переднего ряда, особенно $i, \ddot{u}$, в меньшей степени $\ddot{a}, e$, еще реже - перед $\ddot{o}$. Наиболее сильно ей подвергаются согласные $l: \bar{l}$ и $t: \bar{t}$. Они последовательно сохраняют палатализацию при исчезновении гласных и $ј$ в произношении Н. Д., ср. pienill lapsill

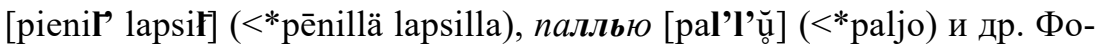
немы $l$ ' : $\bar{l}$ ' всегда представлены перед передними гласными и $j$ и акустически четко противопоставлены непалатализованным велярным $l: \bar{l}$, ср. линн [l'in̄] vs. лухти [luht'⿳̌丷] ]. Оппозиция $t: t$ 'на синхронном уровне сформировалась перед $i$ и $\ddot{u}$ в т. ч. и в первом слоге, где гласные не исчезают. Так, фонема /t'/ представлена перед этимологиче-

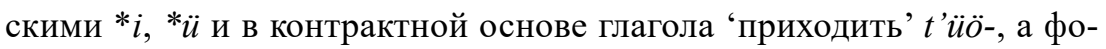

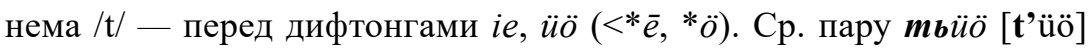
'1. приходи; 2. вы' vs. тӥӧ [tüö] 'работа', отмечаемую среди омонимов и самим Н. Д., или тиен [t'ījen] 'знаю' vs. Тиенсуy ['tien'sū] 'д. Извоз' (см. сноски 204, 216, 230). Перед е оппозиция также отчасти сформировалась, но не до конца. Ср., например, формы, в которых палатализация не зафиксирована: теккӧ [tekkö], этесnӓй [etèspäi]], üxme [ühte], отетmu [otèt't'i], — и формы с (варьирующей) палатализацией техти [teht'i t'eh-t'i], тетрылид [t'etrət'i-d]. По-видимому, $t$ 'перед (синхронным) $e$ последовательно представлен в случае происхождения последнего из дифтонга *ia, как в acmbe [ast'e] (<*astia) 'посуда'. В фонологической транскрипции палатализация отмечена следующим образом: 
- перед всеми задними гласными, ср. pal'l'u 'много' (<*paljo, т. е. при исчезновении $j$ ), заимствования: Kol'a 'Коля', sed'olk(ә) 'седёлка (часть упряжи)';

- в случаях отсутствия редукции и выпадения гласных: $l$ ' : l' отмечаются перед всеми передними гласными и $j$, а $t^{\prime}: \bar{t}$ ' - только перед $i, \ddot{u}$ и $e$, там, где они представлены по факту;

- перед шва, возникшем из * $\ddot{a}, * \ddot{a} i, * e$ : все гласные (кроме случаев явного отсутствия палатализации в произношении, как метсыст

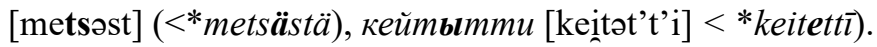

Во всех указанных случаях палатализация согласных иногда отмечена и самим Н. Д., чаще всего в случае $l$ '’ $\bar{l}^{\prime}$, например: пӓӓлль п пӓӓлл, пильви, селькнахк, пельдикко, мӧлскӓмӓ мӧльскӓмӓ, палььз, тьӥтӓр, тьӥӧ, астье, лехм леэхмь(bl), пӓйвӥккӓйн пӓйвӥкӓйнь. В иных контекстах палатализация в транскрипции не отображается. Сюда входят также случаи редукции типа ІІа, где в речи Н. Д. в действительности часто бывает представлена элизия гласного при сохранении палатализации. Такая палатализация все же достаточно неустойчива и нередко отсутствует. Интересно, что в случае /е/ в рукописи отмечается колебание Н. Д. между орфографическими вариантами с $е$ и э: пе́ркэлэн $\sim$ пэркэлен, лехм леэхмъ(bl), пэле $\sim$ пэ́лэ пеле, кэлло келло. Очевидно, он ощущает более слабый характер ижорской палатализации по сравнению с русской.

Отдельно следует упомянуть процесс озвончения кратких согласных, которые оказываются в абсолютном исходе словоформы при утрате краткого *i в двух омонимичных показателях *-p̌ (3SG у глаголов с односложной основой и компаратив у прилагательных). В речи Н. Д. представлены следующие варианты: *-pi $>\left[\mathrm{pi}>\mathrm{p} \overline{\mathrm{1}}>\mathrm{p}^{\prime}>\mathrm{b}^{\prime}>\mathrm{b}\right]$; ср. также орфографические варианты йӓпи йяӓбь йябь (јӓӓb), лӥоб, voib; тж. в компаративе: эннылnu $\sim$ эннылкки, таркыб. В транскрипции

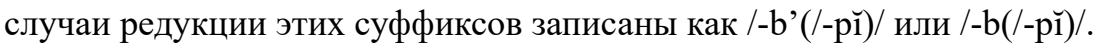
Данный процесс морфологизован, т. е. касается только данных суффиксов, а для других показателей он отмечен не был, ср. *mā-ta $>$ [māt] 'земля-PART / лежать-INF' (с сохранением глухости конечного согласного) vs. $m \bar{a}-d$ 'земля-PL' (тж. в эст. voib, но maat vs. maad).

В целом Н. Д. последовательно передает на письме конечные звонкие согласные, даже в кластерах с глухими согласными, как в нӓхд, при том что в речи степень их реальной звонкости варьирует. Варьирование в Tхалуз Txaлyc может быть обусловлено влиянием эстонской орфографии (эст. Thalus). 
В результате выпадения гласного иногда возникают кластеры долгого и краткого согласного, которые могут упрощаться как фонетически, так и фонологически до кластера двух кратких согласных - процесс наблюдается как в речи Н. Д., так и на письме. В случае упрощения кластера фонологическая запись выглядит как (1)/kortt(ə)l'i-n/ в случае сохранения на письме долготы первого согласного (корттлин) или как (2) uotlimm /uot(tə)l'-i-mm(ə)/ в случае орфографической утраты долготы согласного.

В связи с транскрипцией следует также упомянуть сочетания гласных и согласных с глайдами $j: \bar{j}$ и $v: \bar{v}$. Выше уже говорилось об особом характере влияния глайдов на последующий гласный, повышающего распознаваемость шва для Н. Д. Сочетания $\mathrm{c} j: \bar{j}$ в целом отличаются сильной вариативностью написаний в рукописи. Ср., например, запись сочетаний согласных с $j$ : мариы /marj(ә)/, вельи /vel'j(ə)/, паллью

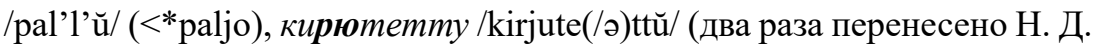
как кир-ютетту, что указывает на место слоговой границы), кириойст /kirjojst(ə)/, вад́ян /vadja(/ə)n/, миньяд /minja(/ə)d/.

Сочетания гласных с глайдами с этимологической точки зрения делятся на два типа случаев: (1) исконные сочетания с согласными $* j$, $* v$; (2) вставка протетических глайдов $(j: \bar{j}$ и $v: \bar{v})$, если в праижорском выпал интервокальный согласный и возникло «зияние» - сочетание гласных, разделенное слоговой границей [Кузнецова 2009: 257-259].

Если глайды $j: \bar{J}, v: \bar{v}$ стоят после краткого гласного, то протетические глайды реализуются в речи и в рукописи Н. Д. и отображены в фонологической транскрипции так же, как и долгие этимологические (для пранижнелужского уровня) глайды. Например, (1) кеввӓлль /kevvä-l'l'(ә)/ (н.-л. *evv < иж. *ev) так же, как и (2) раввытma /ravvətta/, jоввуйм/jovvuimm(ә)/, риввуд/rivvud/ с протезой; (1) опеттайа /opettajja/ (н.-л. *ajj < иж. *aj; ср. с записью в случае краткого $j$ в onemтая /opettaja/) так же, как и (2) хейекӓ /hejjekä/, mеiеn мейен /mejjen/ с протезой.

После долгого гласного или дифтонга в говоре Н. Д. возможны только краткие этимологические $j, v$ : тайвасc /taivass(ə)/, /suoj(ə)/ 'теплый' (второй пример взят из аудиоматериалов Н. Д.). Среди сочетаний долгих гласных и дифтонгов с протезой следует особо выделить случай $i: \bar{\imath}, u: \bar{u}$ перед e/ə. В речи Н. Д. тут наблюдается вариатив-

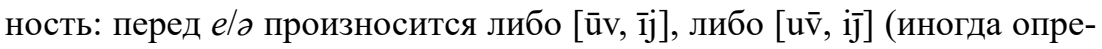
делить на слух один из двух вариантов сложно, особенно в случае [ī̄ ij]). На письме также отмечена определенная вариативность, например, 
куувыннел [kuvvəneł kuvvənnē̄], куувынте [kūvənte $\sim$ kuvvənte], кyyвыннесс [kuvvənes], куувыз [kūvəz]; вииез [vїjəz], виеннель виеннелль [vïjenəl' $\sim$ vïjenel' $\sim$ vïjənəl'], вииыннетт [vijənnet $\sim$ vijjəntet], виезпӓив/ vijespäiv вииез [vījes(päiv')], эн тийь эн тий [en 't'ìj], тиен [t'ïjen]. Поскольку на письме и в речи Н. Д. в данном контексте преобладает вариант [ūv, īj], он и был выбран для фонологической транскрипции

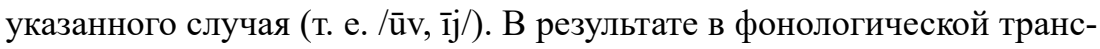
крипции после долгого гласного или дифтонга представлены только краткие глайды любого происхождения.

Непростой вопрос о фонемной интерпретации /ts $\sim$ cc/vs. /c/ в н.-л. диалекте подробно рассмотрен в [Кузнецова 2009: 273-280]. Для всех случаев в данной рукописи был принят вариант /ts/. Следует, однако, обратить внимание, что после краткого гласного Н. Д. последовательно записывает $t$ к как тс (метсӓ, этсисимм, витс, кутсутти, мильтси и др.). Исключениями являются улиц 'улица' - освоенное заимствование с долгим [cс] в произношении, где появление краткого $u$ на письме скорее всего вызвано влиянием русской орфографии - и оценкьлд. Последнее не полностью освоено на фонологическом уровне (неначальное ударение, краткое [c]), и его следует скорее относить к случаям интерференции, а не к полноценным заимствованиям. При этом в позиции после дифтонга Н. Д. выбрал вариант й: пяйщед, суйщед.

В случаях интерференции, т. е. переключения и смешения кодов, фонологическая транскрипция русских и финских слов примерно передает их реальное произношение при чтении текстов Н. Д. (например, pyc. окно /o(/a)k'no/ [ok'no ak'no], фин. aapinen > aапине /āpine/ [āpine]). Эстонские слова записаны в стандартной орфографии, но орфографическая долгота гласных передана с помощью диакритики: pblbмycm /rȭmu-st/, эст. rõ õmust.

\section{4. Основные грамматические особенности рукописей}

Тексты обильно снабжены примечаниями к конкретным языковым особенностям, и ниже описаны лишь самые общие особенности их фонологии, морфо(но)логии, лексики и синтаксиса.

Одно из наиболее существенных последствий редукции гласных для словоизменения - развитие синкретизма различных форм. Так, в говоре Н. Д. представлен синкретичный падеж адессива-аллатива 
с показателем -ll(ə)/-l'l'(ə) на месте двух различных показателей *-lla/llä и *-lle (глоссирован как $\mathrm{AD})$. У некоторых классов существительных не различаются формы иллатива и инессива, ср., например, тайвасс $<$ небо:IN/ILL >. У глаголов вследствие редукции неначальных дифтонгов также иногда не различаются некоторые формы непрошедшего и прошедшего времени: вайхтувыд <меняться:PRS/PST:3PL>, истувы $<<$ сидеть:PRS/PST:3PL $>$. У существительных с основой на $-i$ - могут совпадать формы ед. и мн. ч.: классисс <класс:SG/PL:IN>, naapriss $<$ сосед:SG/ PL:IN $>$. Если у других классов аналогичные указанным формы различаются, то они разводятся и в случае синкретичных форм. Но в последнем примере даже из контекста сложно установить, имеет ли форма ед. или мн. число. Поскольку в сойкинском оригинале, с которого переписывал Н. Д., была использована форма ед. ч. nāburiz, то была выбрана глосса ед. числа.

Одно из ярких инновационных явлений в сфере синкретизма форм связано с образованием нового алломорфа -si- у глагольного показателя прошедшего времени, наряду с исконным $-i$-. Этот процесс в завершенном виде представлен в эстонском языке, где $-i$ - сохранился только у небольшого числа глаголов. В идиолекте Н. Д. явление находится в стадии формирования. Основным источником его, очевидно, является переразложение конечного -s- согласной основы ряда глаголов (в т. ч. возвратных), а также глаголов на -i- : -itse- [Lehtinen 1984: 19-21, 36-37, Koivisto 1990: 134]. Оно поддержано омонимией некоторых форм настоящего и прошедшего времени в глаголах с гласной основой на $-i-$, а также смешением с суффиксом условного наклонения -is( $i)$-. Так, в рукописях несомненные примеры переразложения зафиксированы именно в основах на -i-: этси-си-мм (INF etse), тӓрки-си-мм (INF tärke). При этом в примерах валитси (INF val'it(ә)) и istusim (INF istus̄(ว)) появление -s- как части основы закономерно.

Проиллюстрируем процесс формирования алломорфа $-s i$ - на примере сопоставления фрагментов двух глагольных парадигм в нижнелужском говоре Н. Д. и в более консервативном в этом отношении сойкинском диалекте. Взяты двухосновный глагол с согласной основой на -s- (№ 1), глагол на -i- : -itse- (№ 2) и одноосновный глагол на - $i$ - (№ 3) ${ }^{10}$. В сойкинском диалекте этимологическое различие между

10 Парадигмы н.-л. глаголов (от Н. Д.) и сойк. etsiä записаны автором публикации (вариант парадигмы val'it(ә) от Н. Д. также записан Ф. И. Рожанским); парадигмы сойк. oppissa и valita записаны Е. Б. Маркус. 
этими тремя классами сохраняется. Исключением является проникновение форманта -ja- из глаголов с согласной основой в состав суффикса условного наклонения других типов глаголов, т. е. *oppija-isi- $n>$ *oppija-ǐš $\bar{l}-n>$ oppi-jaišs $\bar{l}-n \rightarrow$ тип valitse-jaišs $\bar{l}-n$ и др. За исключением этого суффикса, $-s$ - (и его коррелят -j- в некоторых формах) последовательно представлены в конце соответствующих основ в типах 1 и 2, но отсутствуют в типе 3 и поэтому могут считаться частью основы. В нижнелужском говоре Н. Д. наблюдается выравнивание парадигм, cp. почти полную утрату -ts(e)- в val'it(a) и, наоборот, появление алломорфа -si- в глаголах с гласной основой (подчеркнут).

Там, где $-s$ - этимологически закономерно, в синхронии возможно двоякое членение (кроме формы IMP.PL): $-s$ - можно считать относящимся уже к суффиксу (т.е., например, оппи-сu-н, пруовь-си-н) или же считать частью согласной основы (опnис- $u-\mu, n p y o в b l c-u-\mu)$, см. об этой проблеме в литературном финском языке в [VISK, §59]). Во втором случае у глаголов с согласной основой на -t- приходится постулировать чередование $t: s$ (pruovət-ə : pruovət-ka:pruovəs- $i-n<$ пробовать $>$ ), у возвратных глаголов на $-s-$ - потенциально, вводить чередование в основе $s: \bar{s}$ (oppiss-ə : oppis-ka : oppis-in <учиться>) и, кроме того, вводить сильноступенную согласную основу у глаголов с чередованием ступеней, например māt-ə : māt-ka : makas-i-n<спать>. Несмотря на эти проблемы, был все же выбран второй вариант морфемного членения во всех случаях потенциально двойственной интерпретации, чтобы подчеркнуть отличие этимологического $-s$ - от полностью неэтимологичных случаев типа тӓрки-си-мм и т. о. более наглядно продемонстрировать формирование нового алломорфа -si- (см. Таблицу 3, с. 208).

На письме и при чтении у Н. Д. зафиксировано варьирование более краткого и более полного варианта показателя причастия у глаголов с односложной основой: ол-луд ол- $\partial$, cal-нуд cal- $\partial$, отмеченное, по моим данным, и в сойкинском диалекте; при чтении однократно

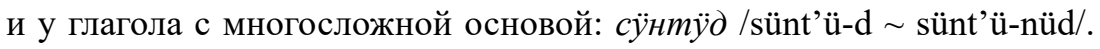
Также зафиксировано варьирование вида лексемы 'весь, все' в номинативе: частотное кай единичное kaig (см. сноску 163).

Из других морфологических особенностей следует отметить показатели комитатива и терминатива, имеющие в нижнелужском ижорском пограничный статус между суффиксом и послелогом [Markus, Rozhanskiy 2014]. В этом диалекте присоединение показателя комитатива $-k a /-k \ddot{a}$ возможно либо к форме генитива, либо к чистой основе. В рукописях представлен только второй вариант: хейекӓ, кенекӓ, 
Таблица 3. Образование нового алломорфа -si- у показателя прошедшего времени

Table 3. Ongoing formation of a new allomorph $-s i$ - of the past tense marker

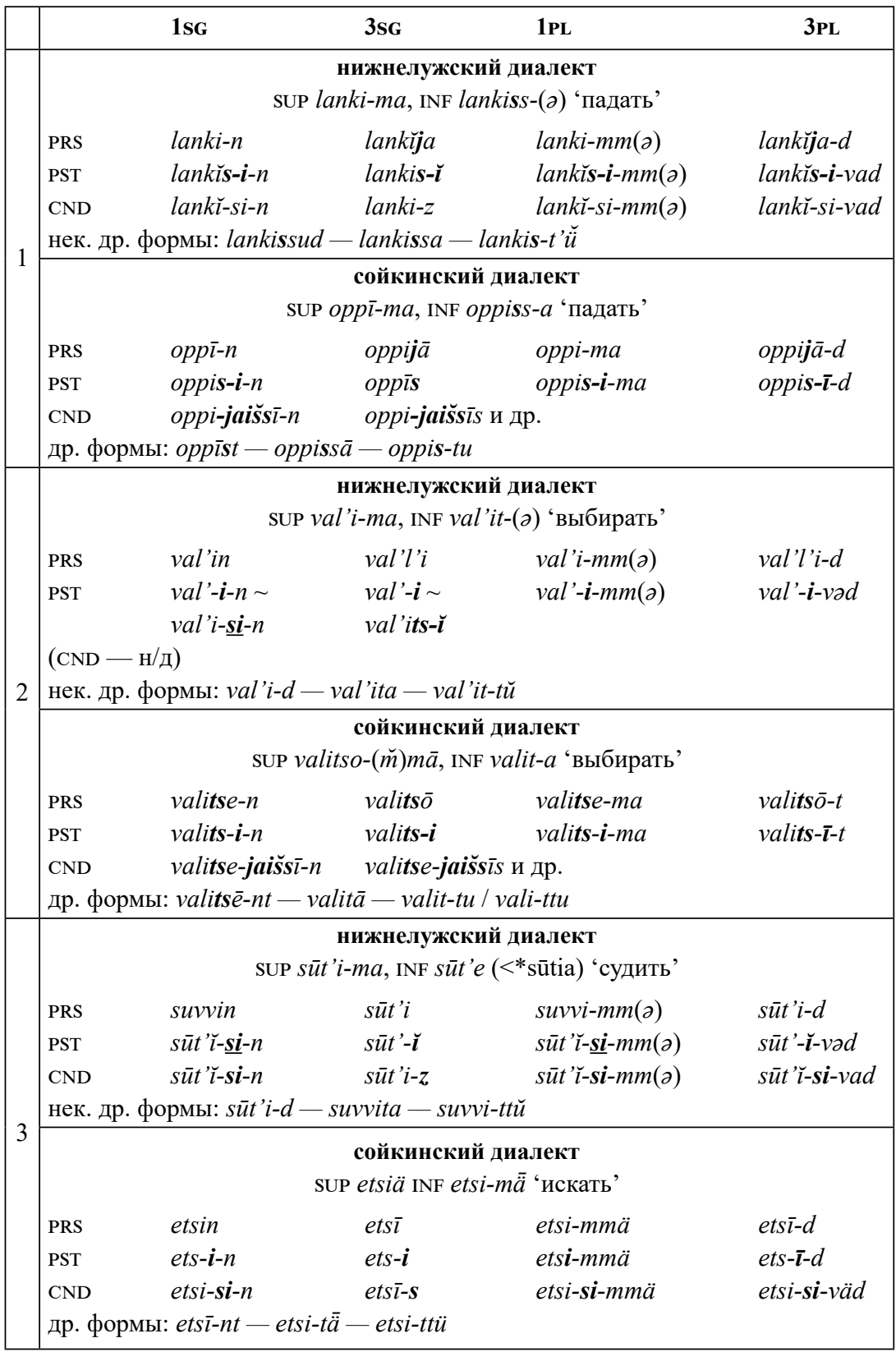


кирвекӓ, терӓкӓ, пуукэрекя, ляпятикӓ. Показатель -ka/-kä присоединяется к вершине группы, а зависимое стоит в генитиве: харвын GEN сӥйкӓ Сом, мильтсен GEN сӥӥкӓ сом. Отметим, что кера, выполняющее функции комитативного послелога в сойкинском диалекте, отмечено в рукописи в значении 'тоже'.

В текстах зафиксирован всего один пример терминатива: куувынте классиса ['kūvənte 'kłassi'ssa]. Он демонстрирует начальную геминату и второе главное ударение в показателе -ssa/-ssä. Был отмечен и единичный пример редкого падежа эссива (см. [Markus, Rozhanskiy 2017]) с показателем -nn(ә): Ко паймененн оли Захарк... 'Когда пастухом был Захарка...'.

В рукописях встречается немало составных порядковых числительных. Система их склонения достаточно сложна, и формы Н. Д., как записанные, так и произнесенные при чтении и разборе (приведены в сносках), не всегда закономерны. В случае, если ожидаемый фрагмент формы пропущен в рукописи, в фонологической транскрипции он восстанавливается в скобках.

Рассогласованием по числу в глагольных группах можно считать примеры типа Хейлль оли(выд) SG PL ...mуннид PL 'у них были ... часы', а также отсутствие согласования в 3PL между отрицательным глаголом и предикативом эй SG пайнуннед PL '(они) не гнулись'. Последний случай нехарактерен для н.-л. диалекта и может быть следствием эстонского влияния в речи Н. Д.; ср тж. закономерную конструкцию в 1PL эмм саанед '(мы) не получили'.

Рассогласование по падежу в именных группах не свойственно прибалтийско-финским языкам; единственным случаем, зафиксированным в текстах, можно считать группу с квантификатором: терве Noм лайвын GEN 'полный корабль' (однако, возможно, этот квантификатор в данном случае выступает как несклоняемый).

При этом в именных группах изредка отмечается такое явление как dependency reversal, когда семантический атрибут выступает как синтаксическая вершина [Malchukov 2000]. Например, оно представлено в рукописях в именных группах со значением образа действия (тойселл AD виттӓ PART 'другим способом') и времени (силль AD вуотm PART ‘в том году', но ср. и более канонический вариант кахексыннелл $\mathrm{AD}$ вуоелл АD 'в восьмом году').

В рукописи зафиксирован один случай плюсквамперфекта (в отрицательной конструкции) - редкой в современном языке аналитической формы: A пӓрепуym мие конса эн олд туод [отрицательный 
плюсквамперфект], $и$ эн нӓхд [отрицательное простое прошедшее] куй таaт хӓнт валитси [простое прошедшее] 'А лыка я никогда не приносил и не видел, как отец его выбирал’. Прибалтийско-финский плюсквамперфект может передавать либо предшествование по времени одного действия другому, либо отдаленное прошлое. В данном примере плюсквамперфект передает предшествование ситуации в прошлом. По-видимому, его появление обусловлено наречием 'никогда' Интересно, что вторая глагольная форма, которая также ожидалась бы в плюсквамперфекте, употреблена в простом прошедшем.

Следует также упомянуть аналитические конструкции с инессивом супина - склоняемого по некоторым падежам отглагольного имени. Основная форма супина на -ma/-тӓ исторически является формой иллатива. В рукописи, помимо этой частотной формы, отмечено три примера конструкций инессива супина, передающих длительное незавершенное действие: олин туомылсс 'приносил' (во фразе, досл. 'Это был первый и последний раз, когда я лыко был носившим'), käi pienill lapsill skaaskoi läkkämäss (в переводном с сойк. диалекта тексте в контексте 'Она всегда ходила к детишкам рассказывать сказки'), а также в заглавии рассказа Пярепуym саамысс 'За лыком' (досл. 'получая лыко').

\section{5. Иноязычные влияния в рукописях}

Ижорский язык содержит разновременные пласты заимствований. Например, kиотә(//)n(ə) (ср. куомнысс 'на гумне') является раннеславянским заимствованием в прибалтийско-финском праязыке. Заимствованиями древнерусского периода в ижорский язык, представленными и в сойк. диалекте, являются, например, $\operatorname{du} т ә t(ә)$ 'думать' (думысин $\sim$ дуумыссин) и улиц /ūl'its(ә)/ 'улица'. К более поздним заимствованиям из русского языка уже в нижнелужский диалект, по-видимому, можно отнести, термины родства маам 'мама', maат $(m)$ 'отец' (<mятя), диед 'дед’, бааб baabušk 'бабушка', отмеченные в моих полевых данных наряду с исконными (ср. тж. сойк. ätti, emä, ämmä, äjjä); cp. тж. pšina (пшинака '[колеса телеги] с железным ободом', cp. sina [N:526] и рус. шина). Эстонскими заимствованиями в диалекте можно считать кортыли ([N:196], эст. korter), не отмеченные в словаре Нирви kere (пуукэрекя 'с деревянным каркасом', эст. kere 'туловище, каркас') и l'äpät't’’ (ляпятикӓ 'с маятником', эст. lapats язычок, клапан). 
Отсутствует в сойкинском диалекте и лухти (эст. разг. luhvt 'воздух', нем. Luft 'воздух'; в сойк. диалекте исконное п.-ф. ilma). Лексема мая в значении 'дом', а не 'шалаш', как в сойк. диалекте [N:292], может отражать эстонское или водское влияние.

Сложность анализа рукописей заключается в том, что на эти уже существующие в н.-л. диалекте пласты дополнительно наслаиваются новейшие заимствования из русского, финского и особенно эстонского языков, характерные либо для идиолекта Н. Д., либо для говоров Эстонской Ингерманландии, а также окказиональные вставки иноязычных элементов на разных языковых уровнях в случае переключения и смешения кодов. Такого рода интерференция и совсем недавние заимствования отмечаются индексами языков в глоссировании (см. Раздел 1.3) или/и в сносках к соответствующим фрагментам; основные случаи суммированы ниже.

1. Заимствования и переключения кодов часто имеют особенности в фонетике и фонологии. В первую очередь это неначальное ударение в русских словах при чтении текстов, нехарактерное для ижорского языка (окно [ok'no ak'no], Екатерина [Ekat'e'r'ina]), и палатализованные согласные перед гласными заднего ряда: Коляка /Kol'aka/ 'c Колей', седёлк /sed'olk(ə)/ 'седёлка' (последние две лексемы имеются и в других иж. говорах). К менее тривиальным особенностям можно отнести случаи отсутствия на письме редукции неначальных гласных, связанные с тем, что в словах языка-источника в этих позициях представлен либо ударный гласный (рус. буква́рь > буквари ['bukvăr' 'bukvər'], pyc. сентябрь > сентябри ['sent'ab ${ }^{2} \mathrm{r}$ ' 's'ent'abr'ə 'sent'abrī], либо просто полный гласный (эст. Narva > Hapва, при чтении [narva], но при разборе Н. Д. отмечает, что по-ижорски правильнее говорить [narvə̊ narv], c. 31), Куутанен (фин. фамилия) [kūttənen], фин. aapinen 'азбука'> aaпине [āpine], при том, что в аналогичном по структуре пойкыне 'мальчик' конечный гласный редуцируется до [poikənə poikən]). К редким признакам эстонского акцента при чтении и разборе относятся окказиональное озвончение кратких смычных (селькекси [sel'k'əks'i sel'g'eks1̄] 'ясным', опеттая [opèttaja obèttaja] 'учитель') и окказиональная геминация орфографического краткого $t$, который геминировался бы в соответствующих позициях в эстонском языке (километри ['k'iło'metr'i 'k'iło'mefr'i] 'километра', Куутанен [kūttənen]).

2. К явным недавним лексическим эстонизмам в лексике, характерным либо для идиолекта Н. Д., либо для говоров всей Эстонской Ингерманландии, входившей в состав Эстонии и, возможно, чуть шире, 
можно отнести, например, лэннуки 'самолет' (эст. lепnиk), ялкратаз ‘велосипед’ (эст. jalgratas), яӓӓнлохкоиь 'ледокол’ (<jäälõhkuja) ‘ледокол', kuratti 'черт’ (эст. kurat), школьные реалии: pinkkй 'парта' (пинк$\kappa u($ ILL); эст. pink), хинтед 'оценки' (эст. hinded), юхатая 'руководитель' (эст. juhataja), miezopettaja 'учитель' и naizopettaja 'учительница' (миезоnетmайа(РАRT), найзопетайа(РАRT); эст. теesо̃petaja, naisõpetaja). Несколько менее очевидными случаями являются пельдикко 'туалет', maтар 'гречиха', хирсс 'пшено', тӓхенси 'означало' (см. сноски к соответствующим лексемам в текстах).

Такого же рода эстонизмами могут быть и некоторые служебные слова: эхки 'или же' [N:28] (эст. ehk), куйта 'как' (эст. kuidas) и нинта ‘так’ (эст. nõnda; cp. тж. N:341). Два последних характеризуются отсутствием редукции неначального $a$ и имеют типично ижорские корреляты с тем же значением: куй ко (частотны в рукописи) и $n \bar{\imath}$ (встречается в составе грамматикализованного сочетания нику 'как бы' < *ni kui).

Недавними русизмами являются некоторые лексемы, также относящиеся к школьным реалиям: оценкыд 'оценки', аазбука 'азбука', тетрытид 'тетради', буквари 'букварь', сентябри 'сентябрь'. Из служебных слов можно упомянуть веде 'ведь', вод 'вот' и префикс kojoв неопределенном местоимении от русского кое- (они могут относиться и к более раннему времени).

Финнизмами, по-видимому, является $k \operatorname{ert}($ ) не в значении 'раз' [N:155-156], а в значении 'этаж': керрылл 'на этаже', каксикертыне 'двухэтажная' (ср. фин. kerta, но эст. korrus), а также, возможно, melken 'почти' (ср. сноску 159).

3. Из синтаксических особенностей можно упомянуть различные типы аналитических глагольных конструкций. Такие конструкции типичны для эстонского языка и не характерны для более консервативного в синтаксическом отношении финского. По-видимому, они в целом менее свойственны и сойкинскому диалекту, однако здесь необходимы дополнительные исследования и сопоставление с ингерманландским финским и водским. Сложно однозначно установить, является ли каждая конкретная из таких конструкций следствием влияния синтаксиса эстонского или других соседних языков. Поэтому ниже просто указаны типы конструкций, имеющих параллели в эстонском языке, с указанием на информацию о положении дел в сойкинском диалекте по [Nirvi 1971].

а) Предельные конструкции с глаголом $s \bar{a} v v(\partial)$ и именным предикативом: сайн арво <получил понимание> 'понял' (ср. [N:514]; в [N:21] 
отмечается как эст. влияние на н.-л. диалект, но приводятся аналогичные сойк. конструкции), сай валмекси <получила готовым> 'изготовилась' (в [N:637] приводится аналогичная сойк. конструкция, но с глаголом tulla 'приходить'), сайн селькекси <получил ясным> 'понял' и похожая конструкция опписин селькекси <выучил ясным> 'выучил' (в [N:365, 518] аналогичные сойк. конструкции отсутствуют), сайвылд туттыльыкси <получили знакомыми> 'познакомились' (в [N:214] даны похожие сойк. конструкции, но с именным предикативом tuDuks или с глаголом tuttahǚmā ‘познакомиться', ср. тж. [N:611]).

б) Конструкция перфективного значения с глаголом тӓnn(ә) и наречным предикативом väl'l'ä (его исходное значение - 'наружу, на улицу'), например, мӓни вӓлля <ушел наружу> 'ушел прочь': подобная конструкция в сойк. диалекте также представлена, но väljä̈ в основном имеет либо прямое значение 'наружу', либо значение 'скоро' а в конструкции со значением 'выйти прочь' используется наречный предикатив poiz 'прочь' (ср. [N:421 и 685], где отмечена такая же конструкция в эст. и вод. языках).

в) Конструкции долженствования с наречным предикативом tarviz 'нужно': оли киелиы тарвиз <было языков нужно> 'языки понадобились', тарвиз олл тихин сӥйкӓ 'должно быть плотным'; в сойк. диалекте первая конструкция употребима [N:576], а вместо второй, по-видимому, обычно используется конструкция pittä olla с глаголом pittä̈ 'быть должным'.

г) Т. н. «глагольные цепи», где спрягаемый глагол передает значения модальности, направления, образа действия, а смысловой глагол в инфинитиве зависит от него, например, алко панны истума <начал класть сидеть> 'начал усаживать' (глагол раппа в аналогичном каузативном значении есть и в сойк. диалекте [N:382]), трехвысин истума $<$ оказался сидеть> 'оказался за одной партой' (в [N:597] глагол trehvada упоминается, но без отглагольного зависимого), нойсин мӧльскӓмӓ лукке <начал разбираться читать> 'начал кое-как читать' (Н. Д. при разборе текста упоминает, что слово мӧльскӓмӓ «придумал сам», ср. од-

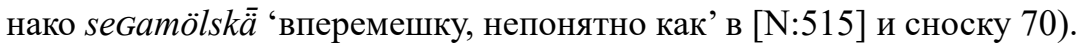

д) Т. н. «глагольные рамки», когда между первым и последним элементом «глагольной цепи» помещаются наречия: Cие айн таход maкуппери тайвасс мӓнн ('ты всегда хочешь задом на небо идти'). Интересно, что в другом фрагменте рукописи и при чтении текстов Н. Д. спонтанно воспроизвел и два других возможных порядка слов: Cue айн таход такуппери мӓнн тайвасс и Сие айн таход мӓнн такупери 
mайвасс. К «глагольным рамкам» можно было бы отнести и случай, когда первая часть аналитической отрицательной глагольной конструкции (спрягаемый отрицательный глагол $e i$ ) начинает всю клаузу, а отглагольное причастие замыкает ее: эмм мӥӧ сиивуллист пуут нинта и саанед ('мы так и не достали приличного дерева'). Такая конструкция как раз нехарактерна для эстонского языка и, наоборот, типична для финского.

Выразительным примером интерференции родственных языков может служить пересказ в ижороязычной рукописи речи на уроке учителя Тхалуза, который, будучи эстонцем, преподавал в первом классе финский язык (знакомый ему, по свидетельству Н. Д., не очень хорошо). Например, во фразе аватка аапине ауки 'откройте книгу' первое слово аватка 'откройте' является правильной ижорской формой и не совсем правильной финской (с редукцией последнего гласного до краткого, cp. с фин. avatkaa). Второе слово аапине является финской литературной лексемой aapinen 'азбука' в «эстонско-ижорской» огласовке (с потерей конечного - $n$ ). Третье слово ауки 'открыто' подчеркивает завершенность действия - как уже говорилось, такого типа аналитические конструкции свойственны эстонскому языку, а не финскому. Сложно сказать, можно ли считать данную конкретную конструкцию avatka aukĭ 'открыть' влиянием эстонского синтаксиса, поскольку она отмечена и в сойк. ижорском [N:23], но для финского языка она в любом случае аграмматична (правильной финской фразой было бы avatkaa aapinen, без перфективного форманта).

Влияние эстонского языка можно предположить и в ряде именных, послеложных и др. конструкций:

6) послеложная конструкция с puol'e <половина.ILL> 'в сторону': в прямом пространственном значении, как в Калливерен пуоле 'в сторону Калливере', мейен пуоле 'в нашу сторону', она характерна как для сойкинского диалекта [N:427-428], так и для финского языка, однако использование ее в переносном временном значении в ванеna $\boldsymbol{n y -}$ оле миез <в более старую сторону мужчина> 'пожилой мужчина' может быть именно эстонским влиянием;

7) использование pä̈ll'l'(ә) ‘на' в качестве предлога во временном значении: пӓӓль миехелль мӓнемисен 'после замужества', пӓӓлль соан 'после войны' (ср. эст. peale в этой же функции), а не как послелога в пространственном [N:453-454]; ср. тж. идиоматизированную конструкцию тихти пӓ̈̈лль 'зачастую, частенько' и н.-л. t'iht'ipällä в [N: 584] с аналогичным разг. эст. tihtipeale. 
8) конструкция ӱхен вануне в значении 'одного возраста' (ср. эст. ühevanune; примечательно, что Н. Д. два раза из четырех заменяет ее при чтении на другой, по-видимому, более естественный для ижорского языка вариант üht(ә) vuott(ә) 'одного года');

9) послеложная конструкция хӓнен асемелл 'вместо него' (ср. эст. tema asemel).

Интересно, что русская письменная речь Н. Д., некоторые образцы которой также приведены в публикации, в свою очередь, обнаруживает следы влияния прибалтийско-финских языков (наиболее яркие черты частый пропуск предлогов и окказиональное смешение грамматических родов, напр. Белая Вася).

\section{2. «О языке ижорском»}

(а) Письменности на ижорском языке нет. Поэтому разных местах, деревнях, язык имеет своии особенности. Сейчас проижсрская организация в Петербурге занята введением (составлением) учебника на ижорском языке. Учебники ижорского языка были уже 1936 годы. Но вопрос, на каком диалекте начать составление учебника. И нужны ли учебники на ижорском языке, молодежь языка незнает и начинать учить сейчас на ижсорском языке мне кажется нет смысла. Другое дело сохранить язык.

Попьттаюсь сейчас писать на Ванакюльском ижорском языке. Но какой алфавит принять - латинскии или русскии. Лучше русскии - но употреблением некоторых букв латинских: ̈̈место я, и-место ю, ӧ место ё (ЧОТ, до 1991, с. 17).

(b) Как известно, на ижорском языке нет письменности. Это однако не значит, что на данном языке нельзя писать. Ижорский язык с родни финским языком, но финн не полностью понимает ижорский, потому что слова многих случаях имеют другое значение, много слов из других языков, например русских, эстонских, даже немецких и наконец коренные слова ижорского языка. Какой алфавит принять для письма на ижорском языке? Латинскии будет иметь больше букв для нужд ижорского языка. Некоторые буквы приходится использовать из русского алфавита. 
На каком алфавите остановиться? Это зависит от того, для кого писать. Дети (собственные) лучше владеют русским алфавитом. Но нехватает многих букв: ӓ обозначает звук, у которого нет соответствия в русском языке; он приближается в произношении к русскому звуку а в положении между двумя мягкими согласными, который обозначается буквой я. Ӧ не имеет русского аналога. Чтобы произнести этот звук, следует приготовиться к произнесению звука е и дополнительно выдвинуть губы, как при произнесении о. Звук ӧ - это, по существу, звук е, произнесенный с участием губ. Чтобы произнести ӥ, необходимо приготовиться к произнесению звука і и дополнительно выдвинуть губы, как при произнесении ӧ; звук ӥ - это по существу, звук i, произнесенный с участием губ.

Таким образом прибавляем к русскому алфавиту ӓ, ӧ, ӥ-будем писать на ижорском языке. Но так как нет ижорской письменности, нет и грамматики. По этому в каждой деревне говорят или теперь уже можно сказать говорили немного по другому.

Я буду писать на Ванакюльском наречии, или точнее сказать на том языке которым я говорю. Но беда только в том, что люди которые будут это читать не поймут, что здесь написано, читать они могут, а понять не могут. Для того чтобы понятно было, надо иметь словарь - скажем, ижорское слово, переведенное на русский язык. Но такого нет. Вот и пойми! Конечно я не претендую, что каждое слово будет написано совершенно правильно с научной точки, посколко это есть первая попытка мною изложить на бумаге слова языка на котором не писали и не пишут (BВ, с. 68-70, 08.07.1992) ${ }^{11}$.

\section{3. «Как я научился читать»}

Публикуемый ниже текст является кумулятивным вариантом трех версий: Текст № 1 (ЧОТ, декабрь 1990, с. 20-25), Текст № 2 (ВВ, с. 7180, между 8 и 29.VII.92; наиболее длинная версия) и Текст № 3 (КМОЛ,

11 \#r (разбор рукописей): Н. Д. подчеркивает, что выбрал русские буквы для рукописей и сделал подстрочный перевод к тексту КМОЛ именно для того, чтобы могли прочитать его дети и внуки. 
12.09.2000; в целом совпадает с Текстом № 1 и первой частью Текста № 2, но добавлен авторский подстрочник к каждому слову). Первая часть текста до фразы (42) дана по Тексту № 3 с указанием в сносках разночтений с остальными версиями. В Тексте № 3 фонема / ̈// передается везде как $\ddot{y}$, а в Текстах № 1, № 2 - как $\ddot{u}$; данное отличие далее не отмечается. Также не отмечена несколько иная разбивка на предложения в одном случае в Тексте № 1, по сравнению с двумя другими (одно длинное предложение вместо двух более коротких). Чтения \#1, \#2a-b, \#3 соответствуют номерам текстов (Текст № 2 был прочитан дважды). Продолжение текста составляет вторую часть Текста № 2, отсутствующую в более коротких версиях или не до конца совпадающую с ней. Конец совпадающей части Текстов № 1, № 2 и № 3 помечен в тексте знаком «*» (фраза 36). С фразы (43) дано продолжение Текста № 2 от конца этой совпадающей во всех трех текстах части.

$\begin{array}{llll}\text { (1) Куйта } & \text { мие } & \text { опписин } & \text { лукема } \\ \text { Как } & \text { я } & \text { учился } & \text { читать } \\ \text { kuita } & \text { mie } & \text { оррігs-i-n } & \text { luke-ma } \\ \text { как } & \text { я } & \text { учиться-PST-1sG } & \text { читать-SUP }\end{array}$

'Как я научился читать'.

(2) Кайкке энныпи мие опписин веннӓн буквылд. Всего раньше я выучил русские буквы.

kaikk-e ${ }^{12}$ ennə(/e)-pi [\#1-2b: enn²p'i, \#2a-3: ennep'i] mie весь-PL.PART раньше-СOмP Я

oppǐs-i-n vennä-n ${ }^{13}$ bukvə-d

учиться-PST-1SG русский-GEN буква-PL

'Раньше всего выучил я русские буквы'.

(3) Tайта таат вай маам остивыд линныст, Наверно отец или мєама купили из города, taita $\operatorname{tātt}(\partial)(\# 1-3:$ [tā̄̄] $)$ vai mām(ə) ost'-̌̄-vəd может_быть ${ }^{14}$ отец или мать покупать-PST-3PL

\footnotetext{
12 \#2a, 3: [kaik'e], \#2b: [kaik'k'e], \#3: [kaik'e].

${ }^{13}$ Названия языков, народов и стран (являющиеся существительными в ижорском языке) в целях экономии передаются в глоссировании здесь и ниже единым образом через прилагательные 'русский’, ‘финский', ‘эстонский’ и т. п.

14 Исходно модальный глагол taitā, по-видимому, сохранил в ижорском языке только форму 3SG.PRS и стал частицей, см. примеры в [N:568].
} 
l'innə-st(ə)

город-ЕL

А линныкси мейль ${ }^{15}$ кутсутти Нарва,

A городом унас звали Нарву, -

A l'innə-kšr me-i-l'l'(ə) kutsu-t't'i Narva(/ə) [\#1-3:Narva] ${ }^{16}$

a город-тRL мы-PL-AD звать-IPS.PST Нарва,

Аазбукин веннӓн киелесс.

аазбуку нарусском языке.

āzbuki-n vennä-n kiel'e-ss(ə)

азбука-GEN русский-GEN язык-IN

'Наверно, отец или мать купили в городе - а городом у нас звалась Нарва, - азбуку на русском языке' ${ }^{17}$.

(4) Маам кирютта ей тунтыд, а лукке тунси.

мєама писать не умела, а читать умела.

mām(ə) kirjutta ei tuntə-d a lukke

мать писать.INF NEG.3sG узнавать-PC_PST а читать.INF

tuns- $-\overline{1} \emptyset$

узнавать-PST-3SG

'Мама писать не умела, а читать умела'.

(5) Хӓ сииз миулл опетти сиит ${ }^{18}$ аазбукист буквыд.

Она тогда мне учила из этой аазбуки буквы.

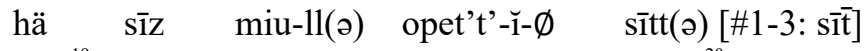

он/a ${ }^{19}$ тогда я-AD учить-PST-3SG тот.ЕL ${ }^{20}$

15 Текст № 1, № 2: мейлль, \#2: [meil’’], \#1, 3: [meil’].

16 \#r: «No Narvən jokì... Narvə... Lin̄ ol’ì Narvə.. Narv. Narva ei ołłud [Ну Нарвская река... Нарва... Город был $\operatorname{Narv(ə).~} \operatorname{Narv}($ ə). Narva не был]».

17 \#r: Н. Д. упоминает, что автором азбуки был Григорьев.

18 Текст № 1, № 2: сиитm.

19 В ижорском языке грамматический род не различается.

${ }^{20}$ Местоимение $s e$ 'тот' (во мн. ч. пе 'те') указывает на невидимый для говорящего объект и используются в функции коррелята анафорического местоимения. Эта пара противопоставлена tämä - nämä '(вот) этот — эти’ и tuo (фраза 108) ?nио '(вон) тот - те', используемые при непосредственном указании на более близкий / более отдаленный предмет, видимый говорящему. Данные местоименные се-

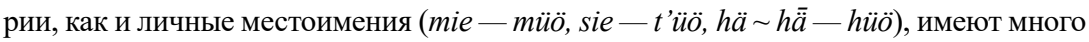
иррегулярных форм. Отметим, что местоимения мн. ч., помимо указания на мн. ч. в значении самой основы, могут иметь дополнительный именной показатель 


\section{āzbuki-st(ə) bukvə-d \\ азбука-EL буква-PL}

'Она тогда научила меня по этой азбуке буквам'.

(6) Мие хӥвӓст муиссыл ко мие иссуин

Я хорошо помню как я сидел

mie hüväst(ə) muissə-n ko mie issu-i-n

я хорошо помнить-1SG как ${ }^{21}$ я сидеть-PST-1SG

киукалл и опписин буквиьг 22 .

напечке и учил буквы.

kiuka-1l(ә) i oppis-i-n bukv-ij(ə)

печка-AD и учить-PST-1SG буква-PL.PART

'Я хорошо помню, как я сидел на печке и учил буквы'.

(7) Куйкки еййӓӓд миеле $х$ букв.

Никак осталось в памяти х буква

kui-kkĭ ei jä-d miel'e

как-ЕMPH NEG.3SG оставаться-PC_PST сознание.ILL

hā [\#1-3: hā] $\operatorname{bukv(ə)}$

$\mathrm{x}_{\mathrm{p}} \quad$ буква

'Как-то не запоминалась буква $x$ '.

(8) Но ко сайн кай буквыд селькекси

Но как только все буквы изучил

no ko sa-i-n kai bukvə-d sel'ke-kš̆

но как получать-PST-1SG весь буква-PL ясный-TRL

сииз йо пруовысин нойсс лукема.

тогда уже пробовал начать читать.

sīz jo pruov(ə)s-i-n noiss(ə) luke-ma

тогда уже пробовать-PST-1SG подниматься.INF ${ }^{23}$ читать-SUP

'Но когда изучил все буквы, тогда уже попытался начать читать'.

мн. ч. - $i$-. Такие формы глоссируются как $n e-i-t(\partial)<$ они-PL-PART $>$, если суффикс четко выделим, и как $n \bar{l}-t(\partial)<$ они.PL-PART>, если морфемное членение затруднено.

${ }^{21}$ Вариант союза куй.

${ }^{22}$ Текст № 1, № 2: Мие хӥвӓст муйссын ко мие иссуйн кйукалл [№ 2: киукалл] и опписин буквиьл.

23 Глагол noiss(z) ‘поднимать(ся)’ в большинстве случаев употреблен в рукописи как вспомогательный глагол в инхоативной конструкции (кроме строки (160), где он представлен в своем прямом значении). 
(9) Аазбукисс оли рисовойтьытту кува, Аазбуке была нарисована картинка, āzbuki-ss(ə) ol'-i- $\varnothing \quad$ risovoitə-ttŭ kuva азбука-IN быть-PST-3SG рисовать-PC_IPS.PST картинка

а ӓӓресс оли кирютытту сана.

а рядом было написано слово.

a äress(ə) ol'-i- $\varnothing \quad$ kirjutə-ttŭ sana

a рядом(IN) быть-PST-3SG писать-PC_IPS.PST слово

'В азбуке была нарисована картинка, а рядом было написано слово'.

(10) Мие нӓйн, оли ламппи и кирютьлтту ${ }^{24}$ «лампа». Я видел, была лампа и написано «лампа». mie nä-i-n ol'-i- $\varnothing$ lamppǐ i я видеть-PST-1SG быть-PST-3SG лампа и kirjutə-ttŭ lampa писать-PC_IPS.PST лампа 'Я увидел, что [там] была лампа и написано лампа'.

(11) Мие сииз хӥвӓст сайн арво, этт се оно ламппи. Я тогда хорошо понял, что это есть лампа mie sīz hüväst(ə) sa-i-n arvo я тогда хорошо получать-PST-1SG понимание.PART ett(ə) se ono lamppr что тот быть.3SG лампа

'Я тогда хорошо понял, что это лампа'.

(12) Эхки оли рисовойтытту иккун, Или было нарисовано окно, Ehkîn $^{25}$ ol'-i- $\varnothing \quad$ risovoitə-ttŭ $\quad$ ikkun(ə) или_же быть-PST-3sg рисовать-PC_IPS.PST окно a ӓӓресс оли кирютытту ${ }^{26}$ «окно». а рядом было написано «окно».

\footnotetext{
24 Перенос на другую строку в тексте № 2: кир-ютытmу.

25 \#r: «'Eh’k’i sie tahod männə Kal'l'ivere?' 〈...〉 Ehkĭ — это как бы с сомнением немножко. 〈... 'Может быть, ты хочешь идти [в Калливере]?'.

26 Перенос на другую строку в тексте № 1: кир-ютылтmу.
} 
$\begin{array}{lllll}\text { a } & \overline{a ̈ r e s s(ə)} & \text { ol'-i- } \varnothing & \text { kirjutə-ttŭ } & \text { o(/a)k'no }{ }^{27} \\ \text { a } & \text { рядом(IN) } & \text { быть-PST-3sG } & \text { писать-PC_IPS.PST } & \text { окно } \text { о }\end{array}$

'Или же было нарисовано окно, а рядом было написано окно'.

(13) Сиитт мие сайн арво, этт «окно» оно иккун.

Отсюда я понял, что «окно» есть иккун.

$\operatorname{Sītt}(ә)$ mie sa-i-n arvo ett(ə)

TOT.EL я получать-PST-1SG понимание.PART что

o(/a)k'no [\#2a-b: ok'no, \#1,3: ak'no] ono ikkun(ə)

окно $_{\mathrm{p}}$ быть.3sG окно

'Из этого я понял, что окно - это окно'.

(14) Ен муйсс ${ }^{28}$ монт $^{29}$ вуотт миулл сииз

Не помню сколько лет мне тогда

E-n muiss(ə) mon-t(ə) vuot-t(ə) miu-1l(ə) sīz

NEG-1SG помнить многий-PART год-PART я-AD тогда

оли, но икоулусс мие виель ${ }^{30}$ ен кӓ̈йуд.

было, но в школу я ещзе не ходил.

ol'-i- $\varnothing$ no škoulu-ss(ə) mie viel'(ə) e-n

быть-PST-3SG но школа-IN я еще NEG-1sG

käü-nüd

ходить-РC_PST

'Не помню, сколько лет мне тогда было, но в школу я еще не ходил'.

(15) Ниилль самойлл айкойлл кустле

теже самые времена откуда-то

nī-l'l'(ә) samo-i-ll(ə) aiko-i-ll(ə) ${ }^{31} \quad \operatorname{kust}(\partial)-l^{\prime} \mathrm{e}^{32}$

Te.PL-AD тот_же_самый-PL-AD время-PL-AD откуда(EL)-IDF

27 [\#2a-b: ak'no, \#1, 3: ok'no].

28 Текст № 1, № 2: Эн муйсс.

${ }^{29}$ В рукописи представлены как прилагательное топі 'многий’ [N:314], согласующееся с зависимым именем и передающее считаемую множественность, так и неизменяемый квантификатор pal 'l' ‘̆ ‘много' [N:379], передающее или несчитаемую множественность, или очень большое количество.

30 Текст № 1: виел; \#1-3: [viel’].

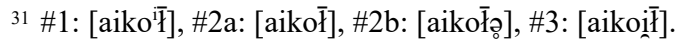

32 Формант -l'e в неопределенных местоимениях происходит из $l \bar{e}-$, основы глаголы 'быть' в исчезнувшем потенциальном наклонении. 


\begin{tabular}{|c|c|}
\hline илмахту тойн & буквари ${ }^{33}$. \\
\hline ооявился второй & букварь \\
\hline $\begin{array}{l}\text { ilma(/ə)htŭ }{ }^{34} \\
\text { появляться.PST.3sG }\end{array}$ & 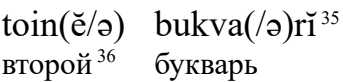 \\
\hline
\end{tabular}

'В те же самые времена откуда-то взялся второй букварь'.

(16)

$\begin{array}{llll}\text { Се оли «Аабитс» вирон } & \text { киелесс. } \\ \text { Это был «Аабитс» на эстонском языке. }\end{array}$

se ol'-i- $\varnothing$ äbits viro-n kiel'e-ss(ә)

тот быть-PST-3SG азбука, эстонский-GEN язык-IN

‘Это была азбука на эстонском языке’.

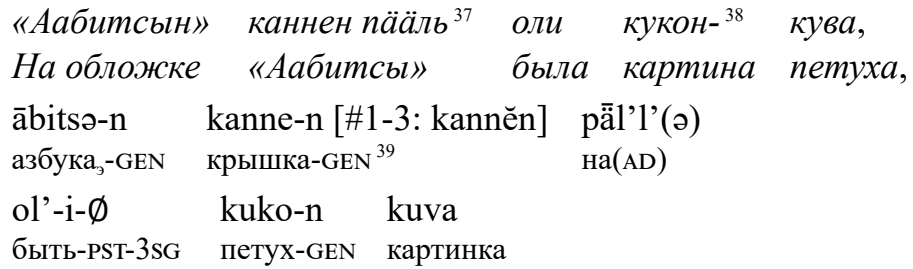

сильтӓ хӓнт кутсутти «Куке аабитс». поэтому его звали «Петушиный аабитс».

sil'tä ${ }^{40}$ hän-t(ə) kutsu-t't'i kukke [\#1-3:kukk'e] ābits оттого он/a-PART звать-IPS.PST петух.GEN, 'На обложке азбуки была картинка с петухом, поэтому она [книга] называлась «Петушиная азбука»' .

33 Текст № 1, № 2: букварь.

34 \#1, 2a: [iłmahtŭ ], \#2b, 3 [iłmahtŭ], \#r: [iłməhtu]. В [N:91] сойк. ilmahtua, но для н.-л. дана форма 3sG ilmaahtu, где второй гласный долгий.

35 \#2a-b: ['bukvər', \#1, 3: 'bukvăr'].

36 Лексема toin(е̌/ə) имеет два основных значения: ‘второй’ и 'другой’; в данной публикации всегда глоссируется как 'второй'.

37 Текст № 1, № 2: пӓӓлл. \#r (к Тексту № 3): «A voib ō̄ pāl' pitäiz ō kaks ełła [А может быть $p \overline{a ̈ l}$ ' должно быть два $л] »$.

38 Текст № 1, № 2: кукон кува.

39 Возможно, финнизм или эстонизм в этом значении (фин. kansi: kannen, эст. kaas : kaane 'крышка, обложка'). В сойк. диалекте kanz 'стол', но в н-л. отмечается только данное значение; н.-л. 'стол’ laut(ə), ср. тж. (192).

40 Второй слог содержит рефлекс долгого гласного, т. к. форма, по-видимому, происходит из siltä, содержавшего притяжательный суффикс 3sG. 


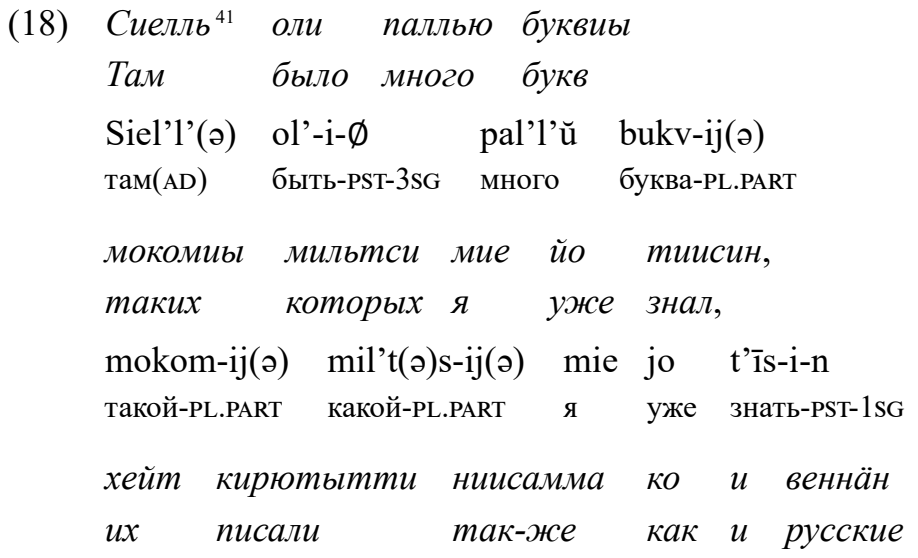

$\begin{array}{llllll}\text { he-i-t(ə) } & \text { kirjutə-t't'i } & \text { nīsamma } & \text { ko } & \text { i } & \text { vennä-n } \\ \text { они-PL-PART } & \text { писать-IPS.PST } & \text { так_же } & \text { как } & \text { и } & \text { русский-GEN }\end{array}$

буквиы, а лукке пити

буквы, а читать надо

bukv-ij(ə) a lukke pit'-i- $\varnothing$

буква-PL.PART a читать.INF быть_должным-PST-3SG

тойселл виттӓ, но паллью оли

по другому, но много было

toise-11(ə) vīttä [\#1-3: vīttä] no pal'l'ŭ ol'-i- $\varnothing$

другой-AD способ.PART но много быть-PST-3sG

буквиы мильтси мие ен тиитьлд.

букв каких я не знал.

bukv-ij(ə) mil't(ə)s-ij(ə) mie e-n t’’̄tə-d ${ }^{42}$

буква-PL.PART какой-PL.PART я NEG-1SG знать-PC_PST

'Там было много таких букв, которые я уже знал, их писали так же, как и русские буквы, а читать надо было по-другому’.

41 Текст № 1, № 2: сиелл.

42 В \#2а читает другое слово: tuntə- $d$ [tuntəd] < уззнавать-PC_PST>, имеющее значения 'узнавать, быть знакомым, уметь' (практическое, личное знакомство с чем-то / кем-то, в отличие от абстрактного знания tietä). 
(19) Но куйле мие хейед опписин селькекси. Но как-то я их выучил доясности.

no kui-l'e mie hejje-d opprs-i-n sel'ke-kšri ${ }^{43}$ но как-IDF я они.PL-ACC ${ }^{44}$ учиться-PST-1SG ясный-TRL

'Но как-то я их выучил'.

(20) Сииз оли моком ассе.

Тогда было такое дело.

sīz ol'-i- $\varnothing \quad \operatorname{mokom}($ ə) asse [\#1, 3: asse, \#2: ass'e]

тогда быть-PST-3SG такой дело

‘Тогда было такое дело'.
Километри маат
Калливерен
пуоле

Километр расстояния Калливерскую сторону

kilometri $^{45}$ mā-t(ə) Kal'l'ı̌vere-n puol'e

километр земля-PART Калливере-GEN половина.ILL

мейен кӥлӓст оли техтӥ46

от намей деревни было построено

mejje-n kül'ä-st(ə) ol'-i- $\varnothing \quad$ teh-t' $\breve{u}$

Mы.PL-GEN деревня-EL быть-PST-3SG делать-PC_IPS.PST

палккист суури каксикертыне ${ }^{47}$ шкоулу.

из бревен большая двухэтажная школа.

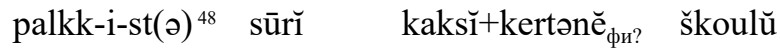

бревно-PL-EL большой два+этажный школа

'В километре в сторону Калливере от нашей деревни была построена из бревен большая двухэтажная школа'.

43 \#1-3: [s'el'gek's', sel'g'eksị]]; \#r: «sel'g'eks'i, mie sain bukvəd sel'k'əks'ị. — Sel'geks' или selk'eks'? - Sel'-k'eks'i, $k$. Sel'k'e - это 'ясно'». Отметим, что во фразе (8) во всех трех чтениях были произнесены [k].

44 Аккузатив, формально отличный от генитива, сохранился в ижорском языке только у личных местоимений мн. ч. (ср. с hejjen < они.PL:GEN>).

45 \#2a: ['k'iło'metr'in] (GEN), \#1: ['k'iło'metr'i], \#2b, 3: ['k'iło'meț'i]. В данном случае, по-видимому, представлена фонетическая и, возможно, морфонологическая интерференция с эстонским языком.

46 Текст № 1, № 2: вместо оли техтӥ записана форма техти teh-ti <делать-IPS.PST>, \#1-2: [teht'i].

47 Текст № 2: какси кертыне; \#1: ['kaks'kertənə], \#2: ['kaks''kertən], \#3: ['kaks' kertənə].

48 \#2a: [pałk' 'ist], \#1, 2b, 3: [pałk'ist] (cp. тж. palki-st(ə) <бревно-ЕL> в ед. ч.). 


\begin{tabular}{|c|c|c|c|}
\hline & $\begin{array}{ll}\text { сай } & \text { валмекси } \\
\text { была } & \text { готова }\end{array}$ & $\begin{array}{l}\text { тухад } \\
\text { тыссяча }\end{array}$ & $\begin{array}{l}\text { ӱхекссатта } \\
\text { девятсот (sic!) }\end{array}$ \\
\hline & $\begin{array}{l}\text { sa-i- } \varnothing \\
\text { получать-PST-3sG }\end{array}$ & $\begin{array}{l}\text { valme-ksī } \\
\text { готов-TRL }\end{array}$ & $\begin{array}{l}\text { tuhad üheks(ə)+satta.PAl } \\
\text { тысяча девять+сто.PART }\end{array}$ \\
\hline & $\begin{array}{l}\text { плкёммнелль- } \\
\text { цать }\end{array}$ & $\begin{array}{l}\text { уувыннел }{ }^{49} \\
\text { иестом }\end{array}$ & $\begin{array}{l}\text { вуотт. } \\
\text { году. }\end{array}$ \\
\hline & $\mathrm{RD}$ & 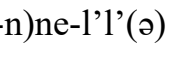 & $\begin{array}{ll}\text { kūvə-nne-ll(ə) } & \text { vuot-t(ə) } \\
\text { шесть-ORD-AD } & \text { год-PART }\end{array}$ \\
\hline
\end{tabular}

'Она была построена в 1926 году'.

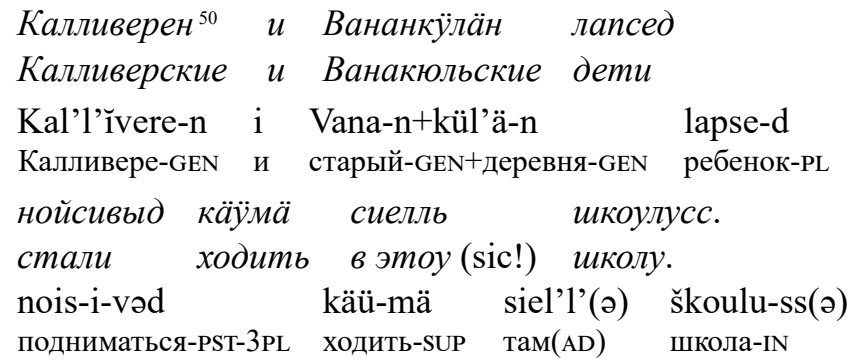

‘Дети из Калливере и Ванакюля стали ходить в эту школу'.

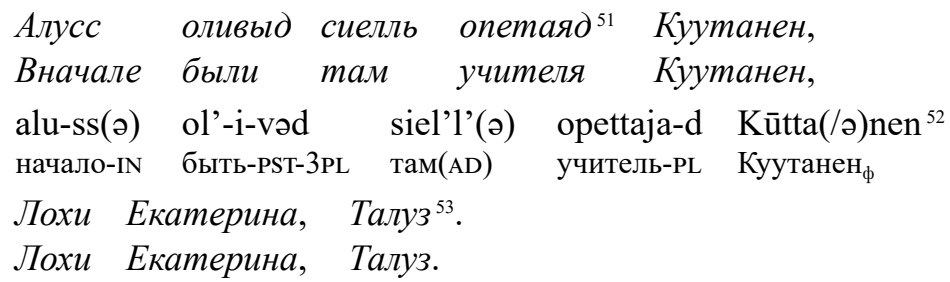

49 Текст № 1, № 2: кахеллкёммнелль куувыннел; \#1, 2b: ['kahèł' küm̀nel' kuvvənnē̄], \#2a: ['kahèł' kümnennel'' kuvvəneł], ['kahèł' kümnennel̄' kuvvənnē̄].

50 Текст № 2: ...вуотт, и Калливерен ... (т. е. (22) и (23) - одна фраза).

51 Текст № 1, 2: опеттаяд.

52 \#1-3 тут и в (26): [kūttənen]. Геминация тут - очевидно, влияние эст. языка.

${ }^{53}$ Н. Д. при разборе о происхождении учителей: Лохи была из Ванакюля [девичья фамилия Pärnönen, т. е., видимо, инг. финка], Тхалус - «suomłain rohk’ep» [больше финн], Элькен, Корп, Сандер, Миккельсаар, Пюсс, Лохур, Кивимяги, Хакк - эстонцы. «Kai ižorka ei läned, кроме Lohì — a вот läkằz' hän? Mie nikù its

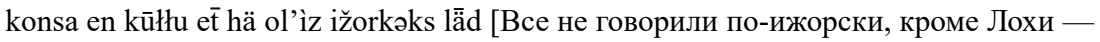
а вот говорила она? Я, как бы, сам никогда не слышал, чтобы она по-ижорски говорила]». 
Lohi Ekat'e'rina Tāluz [\#1-3: tālus]

Лохи Екатерина $_{\mathrm{p}}$ Талуз

'Вначале там были учителями Куутанен, Екатерина Лохи, Талуз'.

\begin{tabular}{lll} 
Опетылтти & суомен & \multicolumn{1}{c}{ киелесс. } \\
Учили & на финском & языке. \\
opetə-t't'i & suome-n & kiel'e-ss('ə) [\#1: kiel'es̄, 2b: kiel'es̄'] \\
учить-IPS.PST & финский-GEN & язык-IN
\end{tabular}

'Преподавали на финском языке'.

(26) Куутанен ${ }^{54}$ мӓни вӓлля, вай куоли.

Куутанен ушел (прочь), или умер.

Kūtta(/ə)nen män-i- $\varnothing$ väl'l'ä vai kuol'-1̄- $\varnothing$

Куутанен $_{\phi}$ уходить-PST-3SG 55 наружу(ILL) или умирать-PST-3SG

'Куутанен ушел или умер'.

(27) Хӓнен асемелл саатытти Вирост ӥкси

На его место послали из Эстоний (sic!) один

häne-n aseme-ll(ə) sātə(/e)-t't' ${ }^{\prime 56}$ Viro-st(ə) ükšr

он/a-GEN место -AD посылать-IPS.PST Эстония-EL один

нуори опеттая, хӓ оли сӥнтӥд

молодой учитель, он был рождения

nuorǐ opettaja hä ol'-i- $\varnothing \quad$ sünt'ü-d ${ }^{57}$

молодой учитель он/а быть-PST-3SG рождаться-PC_PST

тухад ӥхекссатта виеннель ${ }^{58}$ вуотт.

тысяча девятсот (sic!) пятом году.

tuhad üheks(ə)+satta vīje(/ə)-nne-l'l'(ə) vuot-t(ə)

тысяча девять+сто.PART пять-ORD-AD ГОД-PART

'Вместо него прислали из Эстонии одного молодого учителя, он был 1905 года рождения’.

\footnotetext{
54 Текст № 2: Сииз Куутанен...

55 В ижорском языке глагол männ(ә) имеет значение 'идти в направлении от чего-то / кого-то’ и противопоставлен $\operatorname{tull(\partial )~'идти~в~направлении~к~чему-то~/~кому-то'~}$ (глоссированы как < уходить > и <приходить >). Аналогичной парой являются $v \overline{i j j}($ ә) и $t \bar{u} v v($ ә) (<уносить $>$ и <приносить $>)$.

${ }^{56} \# 1$, 2a, 3: [sātət't'i], \#2b: [sātet't'i].

57 \#1-2: [sünt'üd], \#3: [sünt'ünüd] (краткий и полный варианты суффикса -PC_PST).

58 Текст № 1, № 2: виеннелль; \#1: [vījenəl'], \#2a: [vījenel'], \#2b, 3: [vījənəl'].
} 
(28) Кутсутти хӓнт Карл Элькен, Звали его Карл Элькен, kutsu-t't'i hän-t(ə) Karl El'kken [\#1-3: el'k'k'en] звать-IPS.PST он/a-PART Карл ${ }_{3}$ Элькен,

а мейен вӥки нойси хӓнт кутсума Эльккин.

а наш народ стал его звать Эльккин.

a mejje-n väki nois-ī- $\varnothing$ hän-t(ə)

a Mы.PL-GEN народ подниматься-PST-3SG он/a-PART

kutsu-ma [\#2a-b: kutsuma, \#1, 3: kutsŭma] El'kkin звать-SUP

Эльккин

‘Звали его Карл Элькен, а наш народ стал звать его Эльккин’.

(29) Хӓнекё ӥхесс тули и эмӓ.

Сним месте (sic!) пришла и мать.

häne-kä ühess(ə) tul'-i- $\varnothing$ i emä

он/a-сом вместе приходить-PST-3SG и мать

'Вместе с ним приехала и мать'.

(30) Эливыд хӥо шкоулусс.

Жили они в школе.

el'-i-v'əd [\#1-3: el'ìv'əd] hüö škoulu-ss(ə)

жить-PST-3PL они школа-IN

‘Жили они в школе’.

(31) Се оли тухад ӥхекссатта

Это было тысяча девятсот (sic!)

se ol'-i- $\varnothing$ tuhad üheks(ə)+satta

тот быть-PST-3SG тысяча девять + сто.PART

кахеллкёмнелль ${ }^{59}$ кахексыннелл вуоелл ${ }^{60}$.

двадиать восьмом году.

kahe-11(ə)+kümm(əne-n)ne-l'l'(ə) kaheksə-nne-11(ə) vuoe-11(ə)

два-АD+десять-(ORD-)AD

восемь-ORD-AD год-AD

‘Это было в 1928 году’.

59 Текст № 1 (с переносом): кахеллкӥмм-нелль, текст № 2: кахеллкӥммнелль; \#2а:

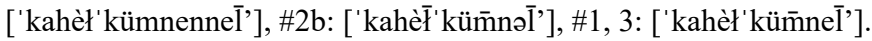

${ }^{60}$ Текст № 2: виоелл; \#2a: [vuoē]], \#2b: [vūv’eł, vūeł]; текст № 1: вуотm <vuot-t(ə) год-РАRT>, \#1: [vuō̄] . 
(32) Миун $^{61}$ сисар Зиин оли Эльккиныка почти Моя сестра Зина была Эльккиным почти miu-n $\quad \operatorname{sisar}(\partial) \quad Z \bar{i} n(ə) \quad$ ol'-i- $\varnothing \quad$ El'kkĭnə-ka ${ }^{62}$ poč't'i я-GEN сестра Зина быть-PST-3SG Эльккин-сом почти ӱхен вануне, хӥо сайвыд туттывывыкси одинакового возраста, они познакомились ühe-n vanune ${ }^{63}$ hüö sa-i-vəd tuttəvə-kš̄ один-GEN возрастной ${ }_{9}$ они получать-PST-3PL знакомый-TRL

и ӱлитсе сенен мейен перред сайвыд $u$ через это наши семьи стали

i ül'itsě ${ }^{64}$ sene-n ${ }^{65}$ mejje-n perre-d sa-i-vəd и через от-GEN Mы.PL-GEN семья-PL получать-PST-3PL нику тойн тойст тунтымма ${ }^{66}$. какбы (sic!) друг друга узнавать. niku [\#1-3: nikù] toin(ě/ə) tois-t(ə) tunt(ə)-ma так_как другой другой-PART узнавать-SUP

'Моя сестра Зина была почти одного возраста с Эльккиным, и благодаря этому наши семьи, как бы, познакомились'.

(33) Но сииз Эльккин сай тиитӓ

Но тогда Эльккин узнал

no sīz El'kkin sa-i- $\varnothing \quad$ t'ītä

но тогда Эльккин получать-PST-3SG знать.INF

етт Зиинылл оно вельи, се оно мие.

Что у Зинь есть брат, то есть я.

ett(ə) Zīnə-1l(ə) ono vel'j(ə) se ono mie что Зина-AD быть.3Sg брат тот быть.3Sg я

'Ну тогда Эльккин узнал, что у Зины есть брат, то есть я'.

${ }^{61}$ Текст № 1, № 2: Мйунн.

62 \#2a: [El'kkinəga], \#1, 3: [El'kkinəka] (влияние эст. произношения).

63 \#1: [poč't'i ühèv vanùně], \#2a: [poč't'i ühèn vanùn], но \#2b, \#3: [poč't'i üht vuot] < $<$ üh-t(ə) vuot-t(ə) один-РАRТ год-РАRT>.

${ }^{64}$ \#1-2: [ül'ìtsě], \#3: [ül'ìtsə], \#r: [ül'ìtse (медленно), ül'ìtsə (быстро)].

${ }^{65}$ В [N: 514] отмечено варьирование в GEN: sen $\sim$ senen; оно зафиксировано и в моих полевых материалах по н.-л. диалекту, но не в речи Н. Д.

66 Текст № 1, № 2: тинтылмӓ (видимо, ошибочно); \#2b: [tuntma... t’ìtəmä]. 


$\begin{array}{llllll}\text { Сииз хӓ саатто миулл икоулу } & \text { кириын } \\ \text { Тогда он послал мне } & \text { школьную } \\ \text { книгу }\end{array}$
йоулукси. на Рождество.

$\begin{array}{lllll}\text { sīZ hä } & \text { sāttǒ } & \text { miu-ll(ə) } & \text { škoulŭ+kirjə-n } \\ \text { тогда он(/a) } & \text { посылать.PST.3sG } & \text { я-AD } & \text { школа+книга-GEN } \\ \text { joulu-kš̃ } & & & \\ \text { рождество-тRL } & & & \end{array}$

'Тогда он прислал мне школьную книгу на Рождество'.

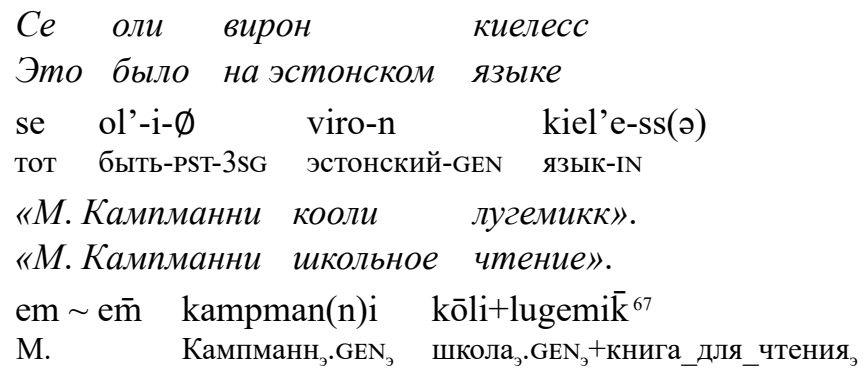

‘Это было «Школьное чтение» М. Кампманна на эстонском языке'.

(36) Мие нойсин сииз сиитт кириыст йо Я стал тогда из этой книги уже

mie nois-i-n ${ }^{68} \quad$ sīz $\quad$ sītt(ə) $\quad$ kirjə-st(ə) jo
я подниматься-PST-1SG тогда тот.EL книга-EL уже мӧльскӓмӓ лукке.* зубрить читать. * $\begin{array}{ll}\text { möl'skä-mä } & \text { lukke }^{69} \\ \text { разбираться-SUP }^{70} & \text { читать.INF }\end{array}$

'Я начал тогда читать и учить из этой книги'.*

${ }^{67} \# 1$-2a: [em kampmani kōl'i lugèmik̄] \#, \#2b-3: [ē̄ kampmaǹi kōl'i lugèmik̄]].

68 \#2b: [noizin] (влияние эст. произношения), \#1, 2a, 3: [noinsin].

${ }^{69} \mathrm{~B} \# 2$ а говорит форму супина: [lukèma] luke-ma <читать-SUP>.

70 Текст № 1: мӧл(ь)скӓмӓ (ь вставлен сверху), № 2: мӧлскӓмӓ. Пояснение в \#r: «möl'skämä lukema — 'коё-как читать'. 〈... Möl'skl'eväd, hüö kera mölsksivad siē̄' sitä asset — 'рассуждать', vai [или]? 〈..〉 Как бы 'рассуждали', да. 〈...〉 Нüö kera möl'ksiväd sitä asset, tunsivəd vähäsen, tunsivad niku vähäsen jo, saivəd arvo sīt assest [Они тоже разбирались в этом деле, знали немного, как бы немного уже знали, 
(37) Тухад ӥхекссатта колмеллкӥммненнелль

Тысяча девятсот (sic!) тридиать

tuhad üheks(ə)+satta kolme-ll(ə)+kümm(ə)ne-nne-l'l'(ə) ${ }^{71}$

тысяча девять +сто.PART три-AL+десять-ORD-AL

тойселл вуотт мие мӓнин шкоулу.

втором году я пошел школу.

toise-ll(ə) vuot-t(ə) mie män-i-n škoulu

второй-AL год-PART я уходить-PST-1SG школа.ILL

‘В 1932 году я пошел в школу'.

(38) Се оли сентябри куу.

Это было сентябре месяи.

se ol'-i- $\varnothing \quad$ sent'abrĭ [\#1: 'sent'ab'r', \#3: 's'ent'abr'’ $]$ kū

тот быть-PST-3SG сентябрь месяц

'Это было в сентябре'

(39) Опеттая анто мейлль кириын, Учитель дал нам книгу, opettaja antǒ me-i-l'l'(ə) kirjə-n учитель давать.PST.3SG мы-PL-AD книга-GEN

се оли суомен киелесс,

это было на финском языке,

se ol'-i- $\varnothing \quad$ suome-n kiel'e-ss(ə)

тот быть-PST-3SG финский-GEN язык-IN

и сано, этт тӓмӓ оно «Аапине»,

и сказал, что это есть "Аапине»,

i sano (<*sanoi) ett(ə) tämä ono āpine ${ }^{72}$

и сказать.PST.3Sg что этот быть.3sg азбука фи

мие сайн арво этт се оно «Аазбукки».

я понял что это есть «Аазбука».

mie sa-i-n arvo ett(ə) se

я получать-PST-1SG понимание.PART что тот

понимали в этом деле]». Н. Д. думает, что сам придумал это слово, не уверен, есть ли оно в ижорском. Но ср. н.-л. seGamölskä (д. Остров) 'вперемешку, непонятно как' [N: 515], тж. фин. разг. melskata 'шуметь, возиться', эст. разг. möllama 'буйствовать, гулять, шалить'.

71 \#1: ['kahèł' küm̄nennel̄'] (sic!), \#3: ['kołməl' küm̄nennel̄'].

72 \#1, 3: [āpine] тут и в (40), но в \#r: [āpinen]. 
ono āzbukk

быть.3sG азбука

'Учитель дам нам книгу, она была на финском языке, и сказал, что это Аапине, я понял, что это азбука'.

(40) Веннӓн киелесс оли «Азбука», вирон

Нарусском языке была «Азбука», на эстонском

vennä-n kiel'e-ss(ə) ol'-i- $\varnothing \quad$ azbuka $^{73}$ viro-n

русский-GEN язык-IN быть-PST-3SG азбука

киелесс «Аабитс», суомен киелесс «Аапине».

языке «Аабитс», нафинском языке «Аапине».

kiel'e-ss(ə) ābits suome-n kiel'e-ss(ə) āpine

язык-IN азбука

'На русском языке была Азбука, на эстонском языке Aабитс, на финском Аапине'.

(41) Нинта сииз мие опписин лукема колмесс киелесс. Так тогда я научился читать на трех языках.

ninta sīz mie oppǐs-i-n luke-ma kolme-ss(ə)

итак тогда я учиться-PST-1SG читать-SUP три-IN

kiel'e-ss(ə)

язык-IN

'Так я и научился читать на трех языках'.

(42) Этеспӓй элосс оли нейт кайкиы киелиы тарвиз.

В дальнеищем вжизни был этих всех языков надо.

etespäi elo-ss(ə) ol'-i- $\varnothing \quad$ ne-i-t(ə) ${ }^{74}$

в_дальнейшем ${ }^{75}$ жизнь-IN быть-PST-3SG Te-PL-PART

$\operatorname{kaik}(\mathrm{k})-\mathrm{ij}(ә)$ [\#1: kaikkijə, \#3: kaikij] kiel'-ij(ə) tarviz весь-PL.PART

язык-PL.PART надо

'В дальнейшем в жизни все эти языки пригодились'.

12 сентября 2000 года [текст № 1: Декабрь 1990 год.]

Пыдер Николай Дмитриевич

[текст № 1: c] 1924 года рождения, деревня Ванакюля

\footnotetext{
73 \#1: ['āzbuka], \#2-3: ['azbuka].

74 \#3: [neit], но в \#1 другой морфонол. вариант: [nīt], cp. с ниит в (109).

75 Etespäi — ‘в будущем, в дальнейшем'; \#r: «в следующий раз, как бы».
} 
Куземкинского округа [текст № 1: Куземкинской волости]

Кингисеппского района [текст № 1: p-на]

Ленинградской области

*Продолжение Текста № 2 после фразы (36):

(43) Муйссын энсъимайсисс лехтисс оли моком

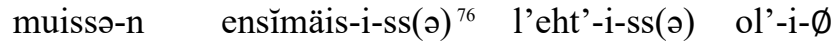

помнить-1SG первый-PL-IN лист-PL-IN быть-PST-3SG

mokom(ə)

такой

лукемине муйтыски вирон киелесс:

luke-mine muitəs-kı̆ viro-n kiel'e-ss(ə)

читать-NMLZ вообще-ЕMPH ${ }^{77}$ эстонский-GEN язык-GEN

'Помню, на первых страницах был такой текст, по-эстонски'.

(44) «Маа он муст я ваод валгед,

mā on must ja vao-d valge-d

земля, быть $_{3} .3 \mathrm{SG}_{3}$ черный $\mathrm{u}_{3}$ борозда, $-\mathrm{PL}_{3}$ белый $-\mathrm{PL}_{3}$

Кӥндял аллес нооред палгед,

kündja-1 alles nōre-d palge-d

сеятель

Кӥндя сӥдя рыьммуст кееб,

kündja süda [\#2a-b: südà] rỗmu-st kē-b

сеятель ${ }_{9} \cdot \mathrm{GEN}_{9}$ сердце ${ }_{3 и} \quad$ радость $-\mathrm{EL}_{9}$ кипеть

Сест этт кӥнд та таргакс тееб».

sest et künd ta targa-ks tē-b

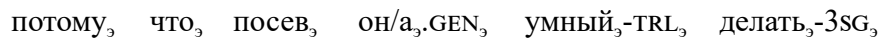

'Земля черна и борозды белы, /У сеятеля еще молодые щеки, /

Сердце сеятеля кипит от радости, /Потому что сев делает его умным'.

(45) Кайкиы саной мие арво

kaik(k)-ij(ə) [\#2a: kaikij, 2b: kaikki] sano-j(ə) mie весь-PL.PART слово-PL.PART я

arvo

понимание.PART

\footnotetext{
76 \#2a: [ens'imäis'es̄... ensəmäis'is̄], \#2b: [ens'mäis'es̄] (ошибочно sG).

77 \#r: «Muitəsk'i. Muitəsk, nī. Muitəsk' viròn k'iel'es̄ — ‘Однако, на эстонском языке'».
} 
ен саануд, но а нику митӓ се

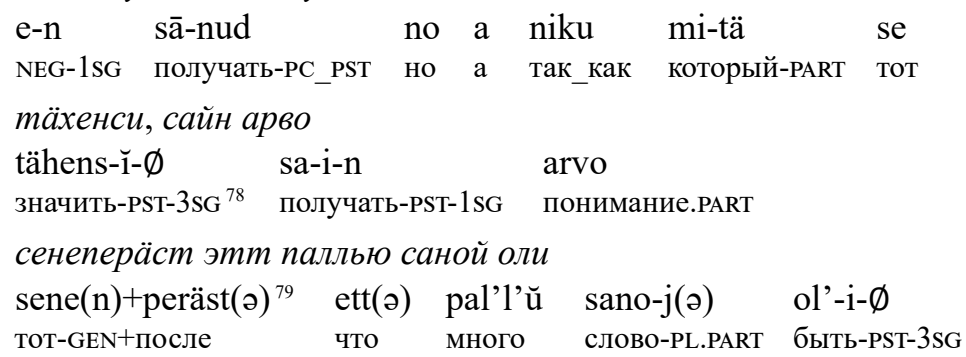

мокомиы нику и мейен киелесс:

$\begin{array}{lllll}\text { mokom-ij(ə) } & \text { niku } & \text { i } & \text { mejje-n } & \text { kiel'e-ss(ə) } \\ \text { такой-PL.PART } & \text { так как } & \text { и } & \text { Mы.PL-GEN } & \text { язык-GEN }\end{array}$

'Всех слов я не понял, но а как бы, что означало, понял, потому что многие слова были такими же, как и на нашем языке'.

(46) «Маа оно муст и ваод валкед, кӥнтиылль

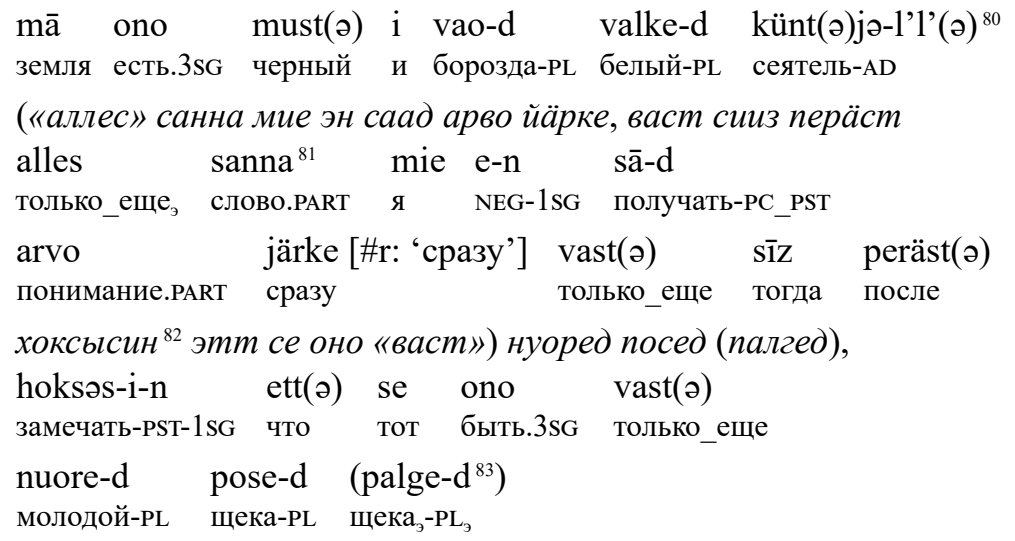

78 Tähentä отмечено как эстонизм в [N:616] (ср. эст. tähendama 'значить').

79 \#2a-b: ['senèn' perầst]; cp. тж. сенен перӓст в (46), (116). Утрата -n, возможно, связана с идиоматизацией сочетания в союз 'поэтому'.

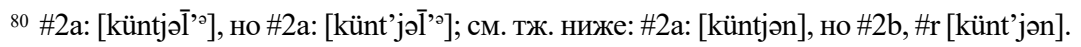

${ }^{81}$ В \#2a-b произносит sana [sanà] ( моми или NOM/GEN/PARTэ).

82 \#r: «hokss'in — 'заметил, 〈...〉 обнаружил'. Сp. в [N:67] (перевод с фин.): «hoksata гл. hoksajāt 'замечают' (Ропша). Не иж.».

${ }^{83}$ Про эстонское palged в \#r: «Põsed [щеки, эст.], да, но и говорят palged тоже это в старом эстонском, как бы, языке ещё. Это по-старому. Это книги... это тысяча восемьсот какого-то конца года». 
Кӥнтыин сӥӧн хӥвӓст миелест киеху,

künt(ə)jə-n süön hüvä-st(ə) miel'e-st(ə) kiehu

сеятель-GEN сердце хороший-EL сознание-EL кипеть.3SG

Сенен перӓст этт кӥнтымине хӓнт таркыкси теккӧ».

sene-n peräst(ə) ett(ə)

тот-GEN после что

künt(ə)-mine [\#2a: küntminè, \#2b: küntəminè]

сеять-NMLZ

hän-t(ə) tarkə-kš̃ tekkö

OH/a-PART умный-TRL делать.3SG

'Земля черна и борозды белы, /У сеятеля (слова аллес я не понял значения, только потом догадался, что это «еще только») молодые щеки, /Сердце сеятеля кипит от радости, /Потому что сев делает его умным'.

(47) А сииз виель перрӓпуоле, войболл кен

a sīz viel'(ə) $\quad$ per(r)äpuol'e ${ }^{84} \quad$ voi-b(/pǐ) oll(ə) $\quad$ ken

a тогда еще впоследствии мочь.3SG быть.INF кто

сано, этт «маа он муст», не олла

sano ett(ə) mā on must ne olla

сказать.PST.3SG что земля быть $_{3} 3 \mathrm{sG}_{3}$ черный ${ }_{3}$ те быть.IPS

буквыд, ваод валгед не олла буквин

bukvə-d vao-d valge-d ne ${ }^{85}$ olla bukv-i-n

буква-PL борозда,-PL

ритойн вӓлисс валке, кӥнтыи оли итс

rito-i-n väl'i-ss(ə) valke küntəj(ə) ol'-i- $\varnothing \quad$ its(ə)

ряд-PL-GEN между(IN) белый сеятель быть-PST-3SG сам

нуори но школьникк и хӓнелл оли хӥвӓ

nuorǐ no škol'nikk(ə) i häne-l'l'(ə) ol'-i- $\varnothing$ hüvä

молодой но школьник и он/a-AD быть-PST-3SG хороший

миели этт оппимине хӓнт таркыкси теккӧ.

miel'̌̌ ett(ə) oppi-mine hän-t(ə) tarkə-kš̄ tekkö

сознание что учиться-NMLZ он/a-PART умный-TRL делать.3sG

'А еще потом, возможно, кто-то говорил, что маа он муст [эст. 'земля черна'] — это буквы, ваод валгед [эст. 'белые борозды'] —

${ }^{84}$ B \#2a ['perä' puol'e], но в \#r: «‘потом', ‘после' — [perräpuol'e]». В \#2b немного другая форма: ['perằst'puol'e].

${ }^{85}$ В \#2а пропускает при чтении это слово. 
это белое между рядов букв, сеятель был сам молодым, ну, школьником, и ему было радостно, что учеба делает его умным'.

(48) Но хӥвӓ.

no hüvä

но хороший

'Ну хорошо'.

(49) Тухад ӥхекссатта колмеллкӥммненнелль

tuhad üheks(ə)+satta kolme-ll(ə)+kümm(ə)ne-nne-l'l'(ə) ${ }^{86}$

тысяча девять + сто.PART три-AD+десять-ORD-AD

тойселл вуотт мие мӓнин шкоулу.

toise-ll(ə) vuot-t(ə) mie män-i-n škoulu

второй-AD год-PART я уходить-PST-1SG школа.ILL

'В 1932 году я пошел в школу'.

(50) Се оли сентябри куу.

se ol'-i- $\varnothing \quad$ sent'abrī [\#2a: 'sent'abrǐ, \#2b: 's'ent'ab'r'] kū

тот быть-PST-3Sg сентябрь

месяц

'Это было в сентябре'.

(51) Маам тули минно сааттыма шкоулу.

mām(ə) tul'-i- $\varnothing \quad$ minno sātt(ə)-ma škoulu

мама приходить-PST-3SG я.PART посылать-SUP школу.ILL

'Мама пришла проводить меня в школу'.

(52) Шкоулуст мейт виети кирикко.

škoulu-st(ə) me-i-t(ə) vie-t'i kirikko

школа-EL мы-PL-PART уносить-IPS.PST церковь.ILL

'Из школы нас повели в церковь'.

(53) Сиелль паппи митӓле луки,

siel'l'(ə) pappǐ mi-tä-l'e luk-i- $\varnothing$

Taм(AD) священник который-PART-IDF читать-PST-3SG

пӓӓлль сенен мӥӧ тулимм (ялле) шкоулу, а маам мӓни котти.

pāl'l'(ə) sene-n müö tul'-i-mm(ə) jäl'l'e škoulu

на(AD) Tот-GEN мы приходить-PST-1PL опять $^{87}$ школа.ILL

86 \#2a: ['kołmeł, kümnel'’], \#2b: ['kołmeł, kümnel''... 'kołmeł, küm̄nenel'’].

87 В рукописях встречаются два варианта наречий со значением 'опять, снова': jäl'l'e (cp. [N:115], эст. jälle, фин. jälleen) и tāz (во фразе (124) в переводном с сойк. диалекта тексте; cp. [N:579], фин. taas). 
a mām(ə) män-i- $\varnothing \quad$ kot't'i

a мама уходить-PST-3SG дом.ILL

'Там священник что-то прочитал, после этого мы (опять) вернулись в школу, а мама отправилась домой'.

(54) Мӓнимм мӥӧ класси, се оли алумайселл

män-i-mm(ә) müö klassi se ol'-i- $\varnothing$ alumaise-1l(ә) уходить-PST-1PL мы класc.ILL тот быть-PST-3SG нижний-AD

керрылл, Эльккинын корттлин ӓӓресс.

kerrə-1l(ə) El'kkinə-n $\quad$ kortt(ə)l'i-n ${ }^{88}$ äress(ə)

этаж

'Пошли мы в класс, это было на нижнем этаже рядом с квартирой Эльккина'.

(55) Тули опеттая Талуз, хӓнен фамилль

tul'-i- $\varnothing \quad$ opettaja $^{89}$ Tāluz häne-n famil'l'(ə) ${ }^{90}$

приходить-PST-3SG учитель Талуз он/a-GEN фамилия

оли Тхалуз, а мейлль кутсутти Талуз.

ol'-i- $\varnothing$ Thaluz ${ }^{91}$ a me-i-l'l'(ə) kutsu-t't'i Tāluz

быть-PST-3SG Тхалус

'Пришел учитель Талуз - его фамилия была Тхалус, а у нас [его] звали Талуз'.

(56) Хӓ оли мейен классин юхатая,

hä ol'-i- $\varnothing \quad$ mejje-n klassi-n juhataja [juhàtaja]

он/a быть-PST-3SG мы.PL-GEN класc-GEN руководитель

йо ванепа пуоле миез, паллью хӓнелл вуосиьл оли эн тийьн.

jo vane-pa puol'e miez

уже старый-COMP.ILL половина.ILL мужчина

88 \#2a-b: [kortl'in]; \#r: «Korttl' — это ‘квартира'. — Это ижорское слово? (соб.) Ei, voip sanno, et niku вошедшее от слова квартира ižòrin kiel'е как korttal' [Нет, можно сказать, что как бы вошедшее от слова квартира в ижорский язык как korttəl']. 〈...〉 На эстонском korttel' [эст. korter], и sīz vist i mejjen kiel'e sīt viron jazykast tul'ì korttel' [и тогда, наверно, и в наш язык из эстонского языка пришло korttel'. Korttel' - эстонский, a korttal'i - ižorkan kiel'es̄ [на ижорском языке]».

89 \#2a: [obèttaja] (озвончение согласного - влияние эст. произношения).

90 \#2a: ['famil'i], \#2b: ['famil', 'famìl'̌́]; cp. тж. фамиль [\#2a-b: 'famil'] в (85). Фонологический облик варьирует между /famil'l'(ә)/ и /famil’⿳亠丷厂.

91 \#r: [Thāłuz]. «Mie en t'īj, on hā sīz ruotsin sanà, vai [я не знаю, это тогда шведское слово, что ли]» 


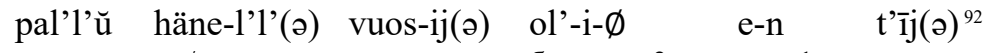
много он/a-AD год-PL.PART быть-PST-3SG NEG-1sG знать

'Он был нашим классным руководителем, уже стареющий человек, сколько ему было лет, не знаю’.

(57) Хӓ пани мейт ритта, ӥхте ритта

hä pan-i- $\varnothing$ me-i-t(ə) ritta ühte ritta

он/a класть-PST-3SG ${ }^{93}$ мы-PL-PART ряд.ILL один.ILL ряд.ILL

пойксед, тойсе ритта тьӥтӧк(к)ёйсед. ${ }^{94}$

poik(ə)se-d toise ritta t'ütökkäise-d

мальчик-PL второй.ILL ряд.ILL девочка-PL

'Он построил нас в ряд, в один ряд мальчиков, в другой - девочек'.

(58) Сииз алко панньл мейт, ӥкси

sīz alkŏ $\operatorname{pann(ə)~me-i-t(ə)~üksĭ~}$

тогда начинать.PST.3SG класть.INF мы-PL-PART один

тьӥтӧккӓйн, ӥкси пойкыне пинкки истума

t’ütökkäin(ĕ) ükš̆ poikənĕ pinkki istu-ma[\#2a-b: istuma]

девочка один мальчик парта..ILL сидеть-SUP

'Потом начал рассаживать нас за парты по парам, мальчик-девочка'.

(59) Мие трехвысин истума ӥхте пинкки Роюн Дагмарыка.

mie $\operatorname{trehv(ə)s-i-n~istu-ma~}{ }^{95}$ ühte pinkki

я попадать-PST-1SG сидеть-SUP один.ILL парта..ILL

Roju-n Dagmar(ə)-ka

Рою-GEN Дагмар-сом

'Я попал за одну парту с Дагмар Рою’.

(60) Нинта сииз истувыд кай энсимӓйсен классин

ninta sīz istu-vəd [2b: istŭvəd] kai ensīmäise-n

так тогда сидеть.PST-3PL весь первый-GEN

klassi-n

класс-GEN

\footnotetext{
92 \#2a-b: [en 't'īij].

93 Глагол рапn(ә) имеет значения ‘класть, ставить, помещать, располагать'.

94 Второе $к$ вставлено сверху.

95 \#2a: [istuma], 2b: [istŭma] (сильной редукции не отмечено).
} 
икольникьлд тӥтӧккӓйн и пойкьне ӥхесс пинкисс.

škol'nikə-d t'ütökkäin(ĕ) i poikənĕ ühe-ss(ə) $\operatorname{pinki-ss(ə){}^{96}}$ школьник-PL девочка и мальчик один-IN парта ${ }_{9}$-IN

'Так и сидели все первоклассники: мальчик и девочка за одной партой'.

(61) Опеттая анто мейлль кириьн;

opettaja antŏ me-i-l'l'(ə) kirjə-n

учитель давать.PST.3SG мы-PL-AD книга-GEN

се оли суомен киелесс,

se ol'-i- $\varnothing$ suome-n kiel'e-ss(ə)

тот быть финский-GEN язык-IN

и сано, этт тӓмӓ оно аапине,

i sano ett(ə) tämä ono $^{97}$ āpine

и сказать.PST.3SG что этот быть.3sG азбука

мие сайн арво этт се оно аазбукки,

$\begin{array}{llllll}\text { mie } & \text { sa-i-n } & \text { arvo } & \text { ett(ə) } & \text { se } & \text { ono } \\ \text { я } & \text { получать-PST-1sG } & \text { понимание.PART } & \text { что } & \text { тот } & \text { быть.3sG }\end{array}$

āzbukkĭ

азбука

микӓ вирон киелесс оли аабитс,

mikä viro-n kiel'e-ss(ə) ol'-i- $\varnothing \quad$ ābits

который $^{98}$ эстонский-GEN язык-IN быть-PST-3SG азбука

а суомен киелесс оно аапине.

a suome-n kiel'e-ss(ə) ono āpine

a финский-GEN язык-IN быть.3SG азбука

'Учитель дам нам книгу, она была на финском языке, и сказал, что это аaпине, я понял, что это азбука, которая на эстонском языке была аабитс, а на финском языке аапине'.

(62) Сииз хӓ сано, этт аватка

sīz hä sano ett(ə) avat-ka

тогда он/a сказать.PST.3SG что открывать-IMP.PL

96 \#2a: [ping'is̄] (влияние эстонского произношения), \#2b: [pink'is̄].

97 \#2a-b: [on]; просодических условий для редукции нет, но конечный гласный отпадает, по-видимому, в силу частотности данной лексемы.

${ }_{98}$ Местоимение mikä 'который, какой’ используется в ижорском языка в качестве относительного и вопросительного. 
аапине ауки и панка сорми сенен

āpine [\#2a-b: āp'ině] aukĭ i pan-ka sormĭ sene-n азбука $_{\text {фи }}$ открытый и класть-IMP.PL палец TOT-GEN буквын июре микӓ оно $A$.

$\begin{array}{lllll}\text { bukvə-n } & \text { jūre } & \text { mikä } & \text { ono } & \text { A [ā] } \\ \text { буква-GEN } & \text { рядом(ILL) } & \text { который } & \text { быть.3sG } & \text { A }\end{array}$

'Потом он сказал, что откройте азбуку и покажите пальцем букву $A$ '.

(63) Эн тий кай ли школьникыл тиисивылд буквыл, $\begin{array}{lllllll}\text { e-n } & \text { t'ijj(ə) } & \text { kai } & \text { l'i } & \text { škol'nikə-d } & \text { t'īs-i-v'əd }{ }^{100} & \text { bukvə-d } \\ \text { NEG-1sG } & \text { знать } & \text { весь } & \text { ли } & \text { школьник-PL } & \text { знать-PST-3PL } & \text { буква-PL }\end{array}$ мие кайкий ен нӓхд, итсыксе

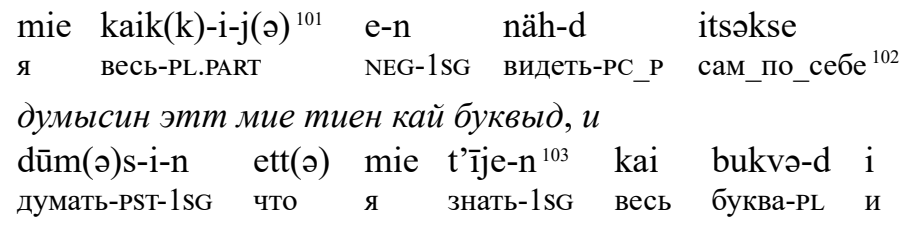

тахойн олл тайта тойсист таркыб,

$\begin{array}{lllll}\text { taho-i-n } & \text { oll(ə) } & \text { taita } & \text { tois-i-st(ə) } & \text { tarkə-b(/pǔ }) \\ \text { хотеть-PST-1sG } & \text { быть.INF } & \text { может быть } & \text { второй-PL-EL } & \text { умный-сомР }\end{array}$

панин сормен а буквын

$\begin{array}{llll}\text { pan-i-n } & \text { sorme-n } & \text { a [ā] } & \text { bukvə-n } \\ \text { класть-PST-1SG } & \text { палец-GEN } & \text { a } & \text { буква-GEN }\end{array}$

[piene-n \#2a: ā-n bukvə / \#2b: $\bar{a}$ bukvə-n] ${ }^{104}$

[маленький-GEN a-GEN буква / а буква-GEN]

июре, не какси буквыл оливыл риннынтикко

jūre ne kaksǐ bukvə-d ${ }^{105}$ ol'-i-vəd rinnənt'ikko ${ }^{106}$ рядом(ILL) те два буква-PL быть-PST-3PL бок_о_бок

${ }^{99} \# 2 \mathrm{a}-\mathrm{b}$ : [en t'īj].

100 \#2a-b: [t'̄̄siv'əd].

101 \#2a: [kaik'k'ij], \#2b: [kaik'’ij].

102 Форма содержит следы посессивного показателя 3SG, cp. itseksē [N:98].

103 \#2a: [t’ijen], \#2b: [tien... t’ījen]. Т. е. в \#2b вначале Н. Д. читает слово как tien ‘делаю’ без палатализации (см. тж. (193), (206)), затем исправляется.

104 \#2a: [ā bukvən, se on pienen ān bukvə jūre], \#2b: [pienen ā bukvən jūre]

105 Незакономерная форма; в \#2a-b закономерное [bukva] <буква.PART>.

106 \#r: «'Rinnən' t'ikko — это 'рядом' [друг с другом]»; cp. тж. rinnaDikkō в [N:478] (конечный долгий гласный - след посессивного показателя $3 \mathrm{SG}$ ). 
'Не знаю, все ли школьники знали буквы, я всех не видел, про себя думал, что я знаю все буквы, и хотел, наверно, быть умнее других - поставил палец около [строчной] буквы $a$ (эти две буквы [прописная и строчная] были рядом)'.

(64) Опеттая нойси мейен пуоле

$\begin{array}{llll}\text { opettaja }^{107} & \text { nois-i- } \varnothing & \text { mejje-n } & \text { puol'e } \\ \text { учитель } & \text { подниматься-PST-3SG } & \text { мы.PL-GEN } & \text { половина.ILL }\end{array}$

тулема, катсо мильтыст буква школьникыд нӓйттӓд.

tul'e-ma katsŏ mil'təs-t(ə) bukva ${ }^{108}$

приходить-SUP смотреть.PST.3SG какой-PART буква.PART

škol'nikə-d näüttä-d

школьник-PL показывать-3PL

'Учитель пошел в нашу сторону, смотрел, какую букву школьники показывают’.

(65) Мие сииз катсойн милльст буква

mie sīz katso-i-n mil'l'ə(/i)s-t(ə) ${ }^{109}$ bukva

я тогда смотреть-PST-1PL какой-PART буква.PART

нӓйттӓд тойсед школьникыд, нӓйн, этт хӥӧ нӓӥттӓд $A$.

näüttä-d toise-d škol'nikə-d nä-i-n

показывать-3PL второй-PL школьник-PL видеть-PST-1SG

ett(ə) hüö näüttä-d A [\#2a: sūr-t $\bar{a} / \# 2 b$ : sūr-t $\bar{a}-t]$

что они показывать-3PL A [большой-PART a(-PART)]

' Я тогда посмотрел, какую букву показывают другие школьники, и увидел, что они показывают [прописную] $A^{\prime}$.

(66) Мие сииз кера киире-киире панин сормен

mie sīz kera kīre-kīre pan-i-n sorme-n

я тогда тоже быстро-быстро класть-PST-1SG палец-GEN

А буквын июре, этт олл тойсика ӥхелль виттӓ.

A [sūre-n $\quad \bar{a}]$ bukvə-n jūre ett(ə) oll(ə)

A [большой-GEN a] буква-GEN рядом(ILL) что быть.INF

\footnotetext{
107 \#2a-b: [obèttaja] (влияние эстонского произношения).

108 \#2a: [mil'tsij bukvij] (PART.PL), \#2b: [mil'təst bukva] (PART.SG).

109 \#2a-b: [mil'ist]. В ижорском языке имеется несколько морфологических вариантов местоимения 'какой' (cp. [N:310-311]). В (65) и (140) записаны формы местоимения millin(ә) (см. millin в [N:310]), в отличие от остальных форм в рукописях, производных от miltan(ә) (см. miltain в [N:311]).
} 
tois-i-ka ühe-l'l'(ə) vīttä

второй-PL-Сом один-AD способ.PART

'Я тогда тоже быстро-быстро поставил палец около [прописной] буквы $A$, чтобы быть как все'.

(67) Нинта сииз алко оппимине шкоулусс суомен киелесс. ninta sīz alkŏ oppi-mine škoulu-ss(ə) так тогда начинаться.PST.3sG учиться-NMLZ школа-IN suome-n kiel'e-ss('ə) [\#2a: kiel'es̄, \#2b: kiel'es̄'] финский-GEN язык-IN

'Так вот и началась учеба в школе на финском языке'.

(68) Оли ва какси тунне вирон киельт виикосс. ol'-i- $\varnothing \quad$ va [\#2a-b: va] kaksǐ tunne viro-n быть-PST-3SG только два час.PART эстонский-GEN

kiel'-t(ә) vīko-ss(ə)

язык-PART неделя-IN

‘Было всего два урока эстонского языка в неделю'.

(69) Эльккин опетти мейт лаулма, хӓ оли виролайн, El'kkin opet't'-i- $\varnothing \quad$ me-i-t(ə) laul(ə)-ma Эльккин учить-PST-3SG Mы-PL-PART петь-SUP hä ol'-i- $\varnothing \quad$ virolain( $\breve{\mathrm{e}})$ он/a быть-PST-3SG эстонец но итс опписи коваст суомен киельт. no its(ə) oppis-i- $\varnothing \quad$ kovast(ə) suome-n kiel'-t(ə) но сам учиться-PST-3SG крепко финский-GEN язык-PART 'Эльккин учил нас петь, он был эстонцем, но сам активно изучал финский язык’.

(70) А лаулма опетти вирокси a laul(ə)-ma opet't'-̌̄- $\varnothing \quad$ viro-kš̄

a петь-SUP учить-PST-3SG эстонский-TRL

'А петь учил по-эстонски'.

(71) Кеввӓлль май куусс лопетимм шкоулун кӓймисен. kevvä-l'l'(ə) mai kū-ss(ə) весна-AD май месяц-IN lopet(')-i-mm(ə) [2a: łopètim, 2b: łopèt'im] заканчивать-PST-1PL 
škoulu-n käü-mise-n [\#2a-b: 'käümǐ, sen]

школа-GEN ходить-NMLZ-GEN

‘Весной в мае закончили ходить в школу'.

(72) Мие пӓӓсин тойсе класси.

mie päs-i-n toise klassi

я попадать-PST-1SG второй.ILL класc.ILL

'Я перешел во второй класс'.

(73) Сӥксӥлль тухад ӥхекссатта

süksü-l'l'(ə) tuhad üheks(ə)+satta

осень-AD тысяча девять +сто.PART

колмеллкӥммнелль колмыннел вуотт

kolme-1l(ə)+kümm(ə)ne(nne)-l'l'(ə) ${ }^{110}$ kolmənne-ll(ə) vuot-t(ə)

три-АD+десять-АD

три-ORD-AD год-PART

мӥӧ мӓнимм шкоулу ӥмпрӓ

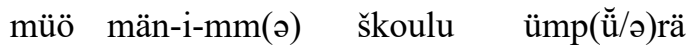

мы уходить-PST-1PL школа.ILL около

(25) кахткӥммнетт вииыннетт сентября

kah-t(ə)+kümm(ə)-ne-tt(ə) vījə-nne-tt(ə) $\quad$ sent'abr'a ${ }^{111}$

два-PART+десять-ORD-PART Пять-ORD-PART сентябрь.PART pи? $_{\text {p }}$

‘Осенью 1933 года мы пошли в школу около 25 сентября’.

(74) Шкоулусс оли уутист.

škoulu-ss(ə) ol'-i- $\varnothing \quad$ ut' is-t(ə)

школа-IN быть-PST-3SG новость-PART ${ }^{112}$

'В школе были новости'.

110 \#2a: [küm̄nel̄'], \#2b: [küm̄nel'].

111 \#2a: ['ümprä 'kaht'kümment 'vī̄onneț 'sent'abr'a], \#2b: ['ümprä 'kaht'kümnä

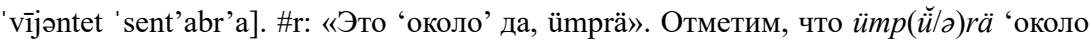

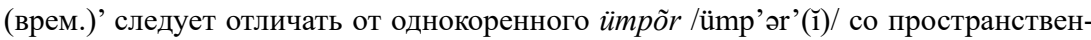
ным значением 'вокруг' в (122). Неясно, насколько закономерной является форма sent'abr'a, т. к. от Nом сентябри /sent'abrï(/ə)/ (cp. (38), (50), [N:519]), ожидался бы PART /sent'abre/.

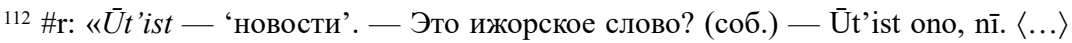
$\bar{U} t$ 'iz — 't'ījed, millin ūt'iz ono?' [новость (РАRT), да. 'Новость' — 'Знаешь, какая новость?'] Ну это реже, может, такое sana $\bar{u} t$ ' $i z$ сказать, a saod $\bar{u} t$ ' ist или $\bar{u} t$ ' $\bar{s}$ ' $i j$ [слово ‘новость' (NOM), а скажешь ‘новость' (PART) или 'новость' (PL.PART)]». Возможно, все же финнизм (ср. uutinen) или эстонизм (ср. uudis). 
(75) Техти суомен и вирон классид

t'eh-t'i [\#2a-b: t'eht'i] suome-n i viro-n klassi-d делать-IPS.PST финский-GEN и эстонский-GEN класc-PL

'Сделали финский и эстонский классы' ${ }^{113}$.

(76) Кен тахто мӓнн суомен класси оппима,

ken tahtǒ männ(ə) suome-n klassi oppi-ma

кто хотеть.PST.3SG уходить.INF финский-GEN класc.ILL учиться-SUP

мӓни синн, кен тахто мӓнн вирон класси, мӓни вирон класси.

män-i- $\varnothing \quad \operatorname{sinn}(ə) \quad$ ken tahtŏ männ(ə)

уходить-PST-3SG туда(ILL) кто хотеть.PST.3SG уходить.INF

viro-n klassi män-i- $\varnothing \quad$ viro-n klassi

эстонский-GEN класc.ILL уходить-PST-3SG эстонский-GEN класc.ILL

'Кто хотел пойти учиться в финском классе, пошел туда, кто хотел пойти в эстонский класс, пошел в эстонский класс'.

(77) Эн тий митӓ и куй мие дуумылсин, а мӓнин вирон класси.

e-n t’ìj(ə) [\#2a-b: t’'̄ij] mi-tä i kui mie

NEG-1SG знать который-PART и как я

dūm(ə)s-i-n a män-i-n viro-n klassi думать-PST-1SG а уходить-PST-1SG эстонский-GEN класc.ILL

'Не знаю, что и как я думал, но пошел в эстонский класс'.

(78) Нинта сииз тойсест классист куувынте классиса

$\begin{array}{lllll}\text { ninta } & \text { sīz } & \text { toise-st(ə) } & \text { klassi-st(ə) } & \text { kūvə-nte } 114 \\ \text { так } & \text { тогда } & \text { второй-EL } & \text { класc-EL } & \text { шесть-ORD.ILL } \\ \text { klassi-ssa } & & & \\ \text { класc-TERM } & & & \end{array}$

${ }_{113}$ При разборе Н. Д. отмечает, что большинство детей из Калливере и Мертвицы пошли в финские классы (там жили в осн. инг. финны; ижоры из Калливере пошли в эстонские классы). В Ванакюля в финские классы пошли либо дети инг. финнов, либо ижор-баптистов (последние поддерживали контакт с Финляндией). За год до этого местные эстонцы, дети которых ходили в школу в Калливере, начали требовать обучение на эстонском языке вместо финского, чтобы им потом было легче учиться дальше (в гимназии в Нарве и пр.). Они отправили делегацию к К. Пятсу (главе Эстонии в 1920-1937 гг.), но финны тоже отправили свою делегацию. Пятс разрешил сделать и финские, и эстонские классы.

114 \#2a: [kūvənte], \#2b: [kuvvənte].

115 \#2a-b: ['kłassi'ssa]. 
мие опписин вирокси.

mie oppiss-i-n viro-kš̆

я учиться-PST-1SG эстонский-TRL

'Итак, со второго класса по шестой я учился по-эстонски'.

(79) Суомекси энебы ей оллуд ӥхтыки урокка.

suome-kš̄ ene-b('ə)(/p̌̌) [2a-b: enèb'] ei oll-ud

финский-TRL больше-СOMP NEG.3SG быть-PC_PST

üh-tə-k $\quad$ urokka

один-РART-ЕМРН урок.РАRT

'По-фински больше не было ни одного урока'

(80) Ко мие опписин энсимӓйсесс классисс,

$\begin{array}{lllll}\text { ko } & \text { mie } & \text { oppǐs-i-n } & \text { ensĭmäise-ss(ə) } & \text { klassi-ss(ə) } \\ \text { когда } & \text { я } & \text { учиться-PST-1sG } & \text { первый-IN } & \text { класc-IN }\end{array}$

сииз оливыд ӥхесс руумисс какси классе,

sīz ol'-i-vəd ühe-ss(ə) rūmi-ss(ə) kakš̄ klasse

тогда быть-PST-3PL один-IN помещение-IN ${ }^{116}$ два класс.PART

саомм, энсимӓйн и тойн, тойсесс руумисс

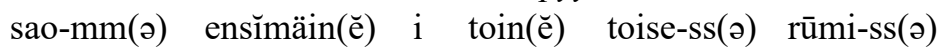

сказать-1PL первый и второй второй-IN помещение-IN

колмыз и нелльыз, колмыннесс руумисс

kolmə-z i nel'l'ə-z kolmə-nne-ss(ə) rūmi-ss(ə)

три-ORD и четыре-ORD три-ORD-IN помещение-IN

вииез и куувыз класси.

vīje(/ə)-z i kūvə-z [\#2a, b: vījəz i kūvə-z] klasš̆

пять-ORD и шесть-ORD класс

'Когда я учился в первом классе, тогда были в одной комнате два класса, скажем, первый и второй, в другой комнате - третий и четвертый, в третьей комнате - пятый и шестой классы'.

(81) Опеттайой оли колд.

opettajo-j(ə) ${ }^{117}$ ol'-i- $\varnothing \quad$ kold

учитель-PL.PART быть-PST-3SG три

'Учителей было трое'.

116 \#r: «Есть в ижорском языке слово rūm? (соб.). — Да, ну, ‘помещение’ или ‘внутренность помещения’ оn rūm. Вот да, мы в доме — вот это rūm».

117 \#2a: [opèttajij], 2b: [obèttajij]. По-видимому, записанная Н. Д. форма является более закономерной, чем произнесенные им; ср. тж. форму opettajoj( $t$ ), отмеченную в моих данных для южной нижнелужской деревни Орлы. 
(82) Нӥтт тули какстойст классе, nütt(ə) [\#2a-b: nü̈ $] \quad$ tul'-i- $\varnothing \quad$ kaksǐ̀tois-t(ə) сейчас приходить-PST-3SG два+второй-PART

klasse

класс.PART

отетти виель нелльыз рууми, и икӓ

ote-t't'i viel'(ə) nel'l'ə-z rūmı̌

брать-IPS.PST еще четыре-ORD помещение и каждый

рууми тули нӥд колд классе.

rūmi tul'-i- $\varnothing$ nüd [\#2a: nüt, 2b: nüd]

помещение.ILL приходить-PST-3SG сейчас

kold klasse

три класс.PART

'Теперь стало 12 классов, заняли еще четвертую комнату, и в каждой комнате стало теперь по три класса'.

(83) Опеттая Лохи мӓни вӓллӓ.

opettaja Lohi män-i- $\varnothing$ väl'l'ä

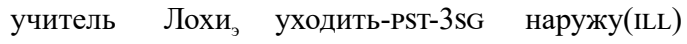

'Учительница Лохи ушла'.

(84) А пити олл нелль опеттайа.

a pit'-i- $\varnothing \quad$ oll(ə) nel'l'(ə) opettajja

a должно_быть-PST-3SG быть.INF четыре учитель.PART

'А должно было быть четыре учителя'.

(85) Оли какси миезопеттайа Тхалус, хӓ оли

ol'-i- $\varnothing \quad$ kaksǐ miez+opettajja $\quad T(h) \bar{l} l u z{ }^{118}$

быть-PST-3SG два мужчина +учитель.PART Тхалус,

hä ol'-i- $\varnothing$

он/a быть-PST-3SG

шкоулун юхатая, $и$ Эльккин, и туливыд

škoulu-n juhattaja i El'kkin i tul'-i-vəd

школа-GEN руководитель , $_{3}$ Эльккин и приходить-PST-3PL

Вирост какси найзопетайа Сандер и Корп

Viro-st(ə) kaksǐ naiz+opettajja Sander i Korp̄

Эстония-EL два женщина+учитель.PART Сандер, и Корп,

118 \#2a: [tāluz], \#2a: [t $\left.\mathrm{t}^{\mathrm{h}} \mathrm{a} l u z\right]$. 
Юлия, хӓ мӓни перӓст миехелль и

Jul'i(j)a ${ }^{119}$ hä män-i- $\varnothing$ peräst(ə) miehe-l'l'(ə) i

Юлия $_{\text {эр }}$ он/а уходить-PST-3SG после мужчина-AD и

хӓнен фамиль оли Наз(с)аров.

häne-n famil'l'(ə) [\#2a-b: 'famil'] ol'-i- $\varnothing$

oн/a-GEN фамилия

быть-PST-3SG

Na'zarov [na'zārof]

Назаров $_{\mathrm{p}}$

'Было двое учителей-мужчин: Тхалуз - он был школьным директором, - и Эльккин, и из Эстонии приехали двое учительниц: Сандер и Юлия Корп - она потом вышла замуж и ее фамилия была Назаров'. **

** Примечание Н. Д.: «Здесь нет ошибки - эстонском и ижорском языке нет родов - мужчина и женщина Наз(c)аров (Nasarov)». [В эстонском языке интервокальное слабое $s$ фонетически часто озвончается; грам. род в фамилии не отражен].

(86) Муйссын, ко мие кӓйн колмыннесс классисс,

$\begin{array}{lllll}\text { muissə-n } & \text { ko } & \text { mie } & \text { kä-i-n } & \text { kolmə-nne-ss(ə) } \\ \text { помнить-1sG } & \text { как } & \text { я } & \text { ходить-PST-1sG } & \text { три-ORD-IN }\end{array}$

klassi-ss(ə)

класc-IN

мейен классин юхатая оли Назаров(а).

mejje-n klassi-n juhattaja ${ }^{120}$ ol'-i- $\varnothing$

мы.PL-GEN класc-GEN руководитель, быть-PST-3sG

$\mathrm{Na}{ }^{\prime} \operatorname{zarov}(\mathrm{a})^{121}$

Назаров $(\mathrm{a})_{\mathrm{p}}$

'Помню, когда ходил в третий класс, нашей классной руководительницей была Назаров(а)'

(87) Митӓле хӓ сйлль вуотт пӓӓль миехенлль

mi-tä-l'e hä si-l'l'(ə) vuot-t(ə) päl'l'(ə)

который-PART-IDF он/a TOT-AD Год-PART Ha(AD)

miehe-l'l'(ə)

мужчина-AD

119 \#2a: ['korp 'jul'ija], \#2a: ['korp 'jul'ia].

120 \#2a: [juhàttaja]; \#2b: [juhàtaja].

121 \#2a-b: [na'zārof]. 
мӓнемисен тихти пӓӓлль оли лӓсив.

$\begin{array}{llll}\begin{array}{l}\text { mäne-mise-n }{ }^{122} \\ \text { уходить-NMLZ-GEN }\end{array} & \begin{array}{l}\text { t'iht'i } \\ \text { часто }\end{array} & \begin{array}{l}\text { päl'l'(ə) } \\ \text { на(AD) }\end{array} & \begin{array}{l}\text { ol'-i- } \varnothing \\ \text { быть-PST-3sG }\end{array} \\ \text { l'äsi-v(ə) } & & & \\ \text { болеть-PC_PRs }{ }^{124} & & & \end{array}$

'Что-то она в том году, после замужества, частенько болела'

(88) Мейен класси оли ӥлӓкеррысс, а хӓнен

$\begin{array}{llllll}\text { mejje-n } & \text { klassĭ } & \text { ol'-i- } \varnothing & \text { ül'ä+kerrə-ss(ə) } & \text { a } & \text { häne-n } \\ \text { мы.PL-GEN } & \text { класс } & \text { быть-PST-3sG } & \text { верх+этаж фи?-IN } & \text { а } & \text { он/a-GEN }\end{array}$

кортыли оли колмыннен классин риннылл.

korttəl'̌̌ำ ol'-i- $\varnothing \quad$ kolmə-nne-n klassi-n rinnəll(ə)

квартира быть-PST-3SG три-ORD-GEN класc-GEN сбоку(AD)

'Наш класс был на втором этаже, а ее квартира была сбоку от третьего класса'.

(89) Сииз хӓ кутсу минно итсен юууре и

$\begin{array}{lllllll}\text { sīz } & \text { hä } & \text { kutsŭ } & \text { minno } & \text { itse-n }^{126} & \text { jūre } & \text { i } \\ \text { тогда } & \text { он/a } & \text { звать.PST.3sg } & \text { я.PART } & \text { сам-GEN }^{\text {рядом(ILL) }} & \text { и }\end{array}$

сано этт аннь классил урокка,

$\begin{array}{lllll}\text { sano } & \text { ett(ə) } & \text { ann(ə) } & \text { klassi-1l(ə) } & \text { urokka } \\ \text { сказать.PST.3sG } & \text { что } & \text { давать.IMP } & \text { класc-AD } & \text { урок.PART }\end{array}$

нӓиттти кириойст мильтсед урокьљ анта.

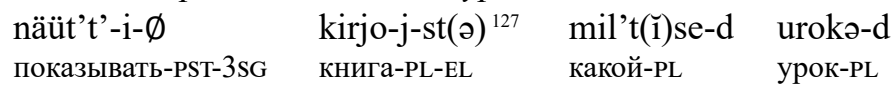

anta

давать.INF

'Тогда она позвала меня к себе и сказала провести в классе урок; показала в книгах, какие задания дать'.

122 \#2b: [mänèmist] mäne-mis-t(ə) <уходить-NMLZ-PART>.

123 \#2a-b: [t'iht'i]; \#r: «В вашем языке тоже так говорят? (соб.) - T'iht'i päl', meīi '

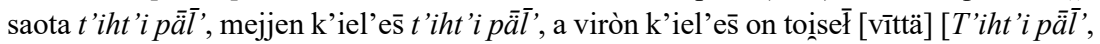
у нас говорят $t^{\prime} i h t^{\prime} i \mathrm{p} \bar{a} \bar{l}$, в нашем языке $t^{\prime} i h t^{\prime} i$ p $\bar{a} \bar{l}$ ', а в эстонском языке по-другому]». Cp. н.-л. t'iht'ipällä в [N:584] и отсутствие фонетической редукции при произнесении тихти.

124 Данное причастие, возможно, следует уже считать прилагательным.

125 \#2a: [korttəl'], \#2b: [korttəl].

126 \#2a: [its'e] (возможно, эстонское влияние); \#2а: закономерное [its'en].

127 В \#2a-b произносит EL.SG: [kirjəst]. 
(90) Нинта сииз мие аннойн классилл урокка.

ninta sīz mie anno-i-n [\#2a-b: anno'n] klassi-ll(ə) urokka так тогда я давать-PST-1SG класc-AD урок.PART

'Вот так вот я и провел в классе урок'.

(91) А перӓст кӓски виель и проверойтта

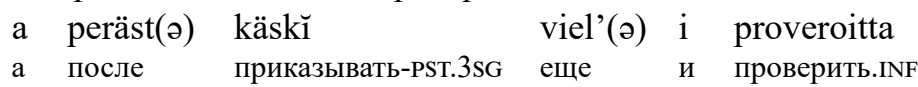

тетрытид и панн хинтед эхки оценкыд.

t'etrət'i-d i pann(ə) hinte-d ${ }^{128}$ ehkĭ o'cenkə-d ${ }^{129}$

тетрадь-PL и класть.INF оценка $\mathrm{sn}_{\text {-PL }}$ или_же оценка $\mathrm{pu}_{\mathrm{pn}}$-PL

'А потом приказала еще и проверить тетради, и поставить hinted (эст.), или оценки'.

(92) Монт керта мие пиин ситӓ аммытте.

mon-t(ə) kerta mie pi-i-n si-tä ammət't'e многий-PART ра3.PART я держать-PST-1SG TOT-PART профессия.PART 'Много раз я выполнял эту работу' ${ }^{130}$.

(93) Нелльннес классисс тули ууси шкоулун юхаттая Миккельсаар, nel'l'ə-nne-ss(ə) klassi-ss(ə) tul'-i- $\varnothing \quad \bar{u} s \check{1}$ четыре-ORD-IN класc-IN приходить-PST-3SG новый škoulu-n juhattaja Mikkel'saar школа-GEN руководитель

хӓ оли и мейен классин юхаттая.

hä ol'-i- $\varnothing$ i mejje-n klassi-n juhattaja он/а быть-PST-3SG и мы.PL-GEN класc-GEN руководитель,

'В четвертом классе пришел новый директор школы Миккельсаар, он был и нашим классным руководителем’.

128 \#r: «Hinted (эст. / иж.) — ну это ocenkəd, это по-эстонски, mejjen k'iel'es̄ kui sanno, en t'ìjĕ sanno [на нашем языке как сказать, не умею сказать] даже, не придумал, a hinded (эст.) — это эстонский».

129 \#2a: [oc̀'enkəd], \#2b: [oc'enkəd], по-видимому, следует считать интерференцией русского и ижорского языка, а не заимствованием.

130 \#2a-b: [ammət't'e] (cp. c [hinted] выше в той же фразе). \#r: «Ammət't'e — 'pa-

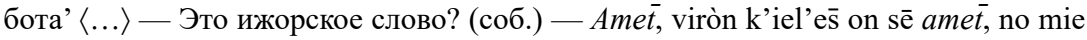
kir'jut'in ku omas̄ k'iel'es̄ ammət't'e. 〈...〉 'Hä on ammət'miez' [Amet, в эстонском языке это amet, но я написал, как бы, на своем языке ammət't'e. 'Он профессиональный рабочий'] — знает какую-то свою работу. 'Hänel' ono mokom ammət't'i, hän katta kattoj olk'ika' ['У него такая профессия, он кроет крыши соломой']. 
(94) Перӓст вайхтувыд виель опеттаяд. peräst(ə) vaihtu-vəd ${ }^{131}$ viel'(ə) opettaja-d после меняться.PST-3PL еще учитель-PL

'Потом менялись еще учителя'.

(95) Тули Пюсс, Сальме Хакк.

tul'-i- $\varnothing \quad$ Püs's' [\#2a-b: püs’'] Sal'me Hakk

приходить-PST-3SG Пюсс,

'Пришли Пюсс, Сальме Хакк'.

(96) Сандер и Назаров(а) мӓнивыд вӓлля.

Sander $_{э}$ i Na'zarov(a) $)_{p{ }^{132}}$ män-i-vəd väl'l'ä

Сандер и Назаров(a) уходить-PST-3PL наружу(ILL)

'Сандер и Назарова ушли'.

(97) Куувыннесс классисс туливыд виель

kūvə-nne-ss(ə) [\#2a-b: kuvvənes] klassi-ss(ə) tul'-i-vəd

шесть-ORD-IN класс-IN приходить-PST-3PL

viel'(ə)

еще

Юхан Лохур и Тамара Кивимӓги.

Juhan Lohur i Ta'mara Kivimägi.

Юхан $_{9}$ Лохур

'В шестом классе пришли еще Юхан Лохур и Тамара Кивимяги'.

\section{4. «За лыком» (BВ, 29.07.1992, с. 81-82)}

(98) Пярепуут саамысс.

päre+pū-t(ə) sā-mə-ss(ə)

лучина ${ }^{133}+$ дерево-PART получать-SUP-IN

‘За лыком'.

(99) Се оли пӓӓлль соан.

se ol'-i- $\varnothing$ päl'l'(ə) soa-n

тот быть-PST-3SG на(AD) война-GEN

‘Это было после войны'

131 \#2a: [vaihtuvəd], \#2b: [vaihtŭvəd].

132 \#2a: [na'zārof], \#2a: [na'zārəva].

133 Päre, как и аналогичное эстонское peerg, имеет два значения: '1. лучина.

2. дранка'; здесь и ниже приведено первое и основное значение. 
(100) Мӓнимм мӥӧ Трофимынн Василен Коляка män-i-mm(ə) müö Trofimə-n Vasil'e-n ${ }^{134}$ Kol'a-ka уходить-PST-1PL мы Трофим-GEN Василий-GEN Коля-Сом этсимӓ метсыст пӓрепуут.

etsǐ-mä metsə-st(ə) [\#2a-b: metsəst] päre+pū-t(ə) искать-SUP лес-EL лучина+дерево-PART

'Пошли мы с Колей Василия Трофимова искать в лесу лыко'.

(101) Хӓ сано, этт мӓӓмм муссын оян пӓӓлль.

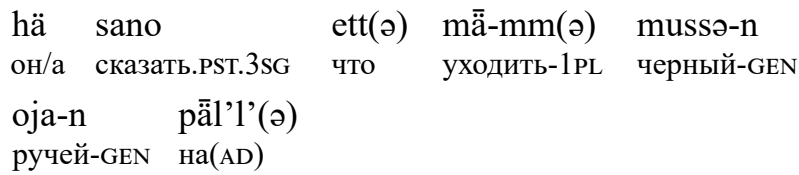

'Он сказал, что пойдем за черный ручей'.

(102) Миун таат теки пяре ваккой.

$\begin{array}{llll}\text { miu-n } & \text { tātt(ə) } & \text { tek-i- } \varnothing & \text { päre+vakko-j(ə) } \\ \text { я-GEN } & \text { отец } & \text { делать-PST-3SG } & \text { лучина+корзина-PL.PART }\end{array}$

'Мой отец плел из лыка корзины'.

(103) Мие нӓйн куй хӓ теккӧ, сиитт

mie nä-i-n kui hä tekkö ${ }^{135}$ sītt(ə)

я видеть-PST-1SG как он/a делать.3SG тот.ЕL

и мие опписин текемӓ.

i mie oppǐs-i-n teke-mä [\#2a: tegèmä ${ }_{э н}, 2 b$ : tekèmä]

и я учиться-PST-1SG делать-SUP

'Я видел, как делает он, отсюда и я научился делать'.

(104) A пӓрепуут мие конса эн олд туод, и эн нӓхд

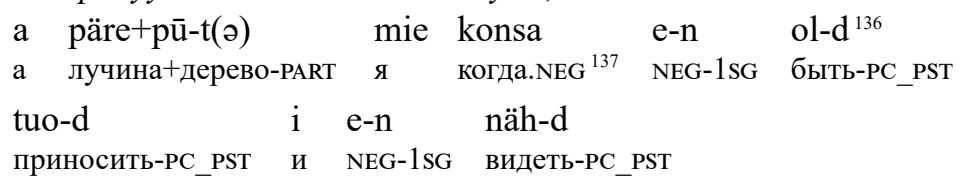

134 \#2a: [Vas'il'’en], \#2b: [Vas'il'’on].

135 \#2a: [tekì] tek-i- $\varnothing$ <делать-PST-3sG> 'делает', \#2b: [tek'k'ö].

136 \#2a: [en ollut... en olt tuot], \#2a: [en ollut tuot], о вариативности см. Раздел 1.4.

137 Данное местоименное наречие является отрицательным вариантом kons(ə) 'когда', ср. (113) и [N:192]. 
куйтаат хӓнт валитси

kui tātt(ə) hän-t(ə) val'its-ī- $\varnothing$

как отец он/а-PART выбирать-PST-3SG

'А лыка я никогда не приносил и не видел, как отец его выбирал’.

(105) Пӓрепуу тарвиз олл тихин сӥӥкӓ, ей саа олл лӥлӥ.

päre+pū tarviz oll(ə) t'ihi-n sü̈-kä

лучина+дерево надо быть.INF частый-GEN текстура-сOM

ei sā oll(ə) l'ül'ü

NEG.3SG получать быть.INF ядровая_древесина

'Лыко должно быть плотной текстуры и не может быть из ядровой древесины' ${ }^{138}$.

(106) Йоввуйм мӥӧ метсӓ.

jovvu-i-mm(ə) müö metsä

достигать-PST-1PL мы лес.ILL

'Пришли мы в лес'.

(107) Коля сано, этт нӥтт нойсымм кирвекӓ пруовама,

Kol'a sano ett(ə) nütt(ə) [\#2a-b: nü̈] noisə-mm(ə)

Коля сказать.PST.3SG что сейчас подниматься-1PL

kirve-kä pruova-ma [\#2a-b: pruovăma]

топор-сом пробовать-SUP

138 \#r: «Это надо с лесу идти, найти, значит, такое дерево, частое дерево, где хорошо эта лучина выделяется, она рвётся, как бы. 〈...〉 $S^{\prime} \bar{u} k \ddot{a}$ - это имеется в виду, это вот, 'годовые круги'. Они были бы частые, значит, плотно выросшие.

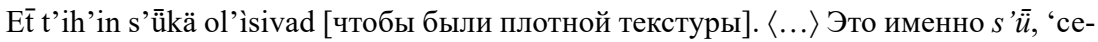
редина', и, этот, кругом все - это $s$ 'й. Это весь этот вот кругляш должен быть частыми годовыми кругами, вот это и есть весь этот тогда $s$ 'ü $\langle\ldots\rangle$ Вот l'ül'ü̈это когда в какой-то стороне смолистый [ствол], $\langle\ldots\rangle$ красный даже такой, с него pärē̄ [лыка] не делаешь.〈...〉 В определенном месте такой слой, красноватый слой идёт этого, смолы. 〈... С него pärepūt не делаешь, он ломается, а не колется ровно, как надо». При разборе (107): «Да, вот и pihàst [от смолы] в дереве получается красноватый он, с соком сосны как-то смешается, наверно, и получается красноватый это. To pihk [смола] бывает такой светлый, белый, как бы, а в l'ül'üs [в ядровой древесине] он красноватый». О значении l'ül'ӥ см. тж. [ЭСБЭ 1904: 504, 505-507] (статьи «Ядро ствола» и «Ядро древесины) и [N:282]. Лексема sï упоминается в [N:560] только в значении 'вина', но ср. эст. sӥй '1. строение, текстура; 2. вина'. 
лӥӧмм кирвен терӓкӓ петӓйӓ васс,

l'üö-mm(ə) kirve-n terä-kä petäjä vass(ə)

бить-1PL топор-GEN лезвие-СOM сосна.PART по

тиемм пиккрайсен тӓрккен, сииз нӓемм мильтсен сӥӥкӓ оно nyy.

\begin{tabular}{|c|c|c|c|c|}
\hline tie-mm(ə) ${ }^{139}$ & pikk(ə)raise-n & tärkke-n & Sīz & näe-mm(ə) \\
\hline делать-1PL & маленький-GEN & надрез-GEN ${ }^{140}$ & тогда & видеть-1PL \\
\hline se-n & sü̈- & ono & & \\
\hline какой-GEN & текстура-сом & быть.3sG & & \\
\hline
\end{tabular}

'Коля сказал, что начнем делать пробы топором - ударим острием топора по сосне, сделаем маленькую засечку, тогда увидим, какой текстуры древесина'.

(108) Тӓркисимм мӥӧ монт петӓйӓ, туо оли лӥлӥ, tärkĭ-si-mm(ə) müö mon-t(ə) petäjä tuo надрезать-PST-1PL мы многий-PART сосна.PART воH_тот

ol'-i- $\varnothing \quad$ l'ül'ü

быть-PST-3sG ядровая_древесина

а лӥлӥ се оно пунертава пуу и пихакьз,

$\begin{array}{lllll}\text { a } & \text { l'ül'ü } & \text { se } & \text { оno } & \text { punerta-va } \\ \text { a } & \text { ядровая_древесина } & \text { тот } & \text { быть.3sG } & \text { краснеть-PC_PRS }\end{array}$

pū i pihakəz

дерево и смолистый

туо оли харвын сӥикӓ.

tuo ol'-i- $\varnothing \quad$ harvə-n sü-kä

вон_тот быть-PST-3SG редкий-GEN текстура-СOM

'Пометили мы много сосен, одна была ядровая (а ядровая древесина - это красноватое дерево, в котором много смолы), другая - рыхлой текстуры'.

139 \#2a-b: [tiē̄'].

140 \#r: «Это топором делаешь ... такую зарубку, и тут видно, значит, круги роста как они, частые или редкие. 〈...〉 Ну делаешь какую-то глубину вот, осечку, глубину такую делаешь туда. Ну даже хватает сантиметров пять если - это порядочно уже будет. Вот по этому следу тогда видишь, частые эти или редкие»; NOM.SG: tärken

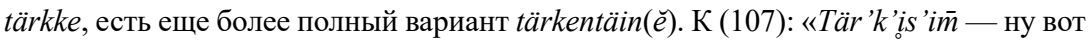
ударяли и делали эти...». Ср. тж. эст. tärkäma 'пробиваться', кар. tärkitä, tärkätä 'надрезать, надрубать' [KKVS 2015]. 
(109) Нӓймм, этт ниит пуйт оли и энньпки тӓркиттӥ.

\begin{tabular}{|c|c|c|}
\hline nä-i-mm(ə) & pu-i-t(ə) & ol'-i- $\varnothing$ \\
\hline видеть-PST-1PL что & дерево-PL-PART & быть-PST-3SG \\
\hline ennə-p( $\breve{1} / \mathrm{i})-\mathrm{k} \breve{1}^{141}$ & tärki-t’t’ $\ddot{u}$ & \\
\hline раньше-СОМР-ЕМРН & надрезать-PC_IPS.PST & \\
\hline
\end{tabular}

'Увидели, что эти деревья были уже и раньше помечены'.

(110) Этсисимм мӥӧ, этсисимм, эмм мӥӧ

etš̌-si-mm(ə) müö etš̄-si-mm(ə) ${ }^{142}$ e-mm(ə) müö

искать-PST-1PL мы искать-PST-1PL NEG-1PL мы

сиивуллист пуут нинта и саанед.

sīvul'l'is-t(ə) ${ }^{143}$ pū-t(ə) ninta i sā-ne-d

приличный-PART дерево-PART так и получить-PC_PST-PL

'Искали мы, искали, так и не нашли приличного дерева'.

(111) Отимм коё мильтсед пакод, ${ }^{144}$ тойм котти.

ot'-i-mm(ə) kojo+mil't(ə)se-d (<pyc. *koe-) pako-d

брать-PL-1PL кое+какой-PL чурка-PL

to-i-mm(ә) kot't'i

приносить-PST-1PL домой.ILL

'Взяли кое-какие чурки, принесли домой'.

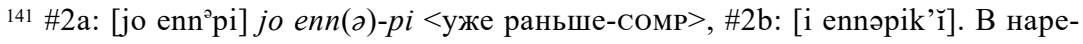
чии епne(/ə)-pi представлен показатель сравнительной степени наречий, имевший долгий гласный, в отличие от показателя прилагательных. В синхронии он должен был бы содержать полный краткий гласный, не подвергающийся редукции и выпадению (ср. фразы (2), (145)). В данном случае, однако, гласный в записи отсутствует (но при чтении все же был произнесен). Возможно, это связано с наличием эмфатической частицы $-k$ ' $\iota$ или же говорит о тенденции к слиянию в языке показателей наречия и прилагательного (ср. тж. редукцию во фразе (79), где тоже ожидался бы суффикс наречия).

142 \#2a: [ets's'im̄ müö, ets's'ī̄̄], \#2b: [ets'ī̄m müö, ets'ī̄m].

143 \#r: «S'ìvul'l'ine — как бы 'хорошеe'. 〈...〉 s'îvul'l'in - настоящий топор, а вот 'Siul ei uo s'īvul'l'ist k'irv'est' [у тебя нет приличного топора]». Ср. тж. [N:533] и фин. siivullinen 'приличный, порядочный'.

144 \#r: «Pakko — 'чурак'. Но эти... pakkŏ имеется в виду чурак такой короткий, скажем, для печки, а эти же надо было длиннее для этих..., для изготовления корзин надо бы лучины подлиннее, метра полтора. — Это уже не pakko? (соб.) — Это не pakkŏ, но я написал pakko. 〈...〉 Halkŏ [полено] — ну это расколотый pakko». См. тж. [N:377] и эст. pakk: paku.
} 
(112) Пӓрред кискхувыд кехност, эй пайнуннед хӥвӓст ${ }^{145}$, pärre-d kisk(ŏ)hu-vəd ${ }^{146}$ kehnost(ə) ei лучина-PL сдираться.PST-3PL худо NEG.3SG

painu-nne-d hüväst(ə)

гнуться-PC_PST.PL-PL хорошо

вакад туливыд коёмильтсед.

vaka-d tul'-i-vədkojo+mil't(ə)se-d

корзина-PL приходить-PST-3PL кое+какой-PL

'Лыко сдиралось плохо, хорошо не гнулось, корзины получились кое-какие’.

(113) Се оли энсимӓйн и ви(и)мин ${ }^{147}$ керт конс

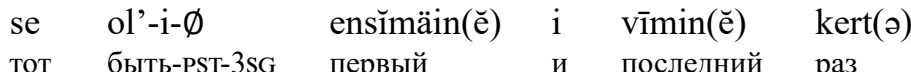

тот быть-PST-3SG первый и последний раз

kons(ə)

когда

мие пӓрепуут олин туомысс

mie päre+pū-t(ə) ol'-i-n tuo-mə-ss(ə)

я лучина+дерево-PART быть-PST-1SG приносить-SUP-IN

‘Это был первый и последний раз, когда я ходил за лыком’.

(114) А ванад миехед текивыд хӥвий ваккой.

a vana-d miehe-d tek-i-vəd hüv-ij(ə)

a старый-PL мужчина-PL делать-PST-3PL хороший-PL.PART

vakko-j(ə)

корзина-PL.PART

'А старики делали хорошие корзины'.

(115) Хейлль пӓрред туливьд нику ременид;

he-i-l'l'(ə) pärre-d tul'-i-vəd niku remeni-d

они-PL-AD лучина-PL приходить-PST-3PL как ремень-PL

мокомист пӓррейст сай техӓ мильтсий ва тахойд ваккой.

mokom-i-st(ə) pärre-i-st(ə) sa-i- $\varnothing$ teh-ä

такой-PL-EL лучина-PL-EL получать-PST-3SG делать-INF

145 \#r: «Ломались, особенно если немножко l'ül'ü, даже чуточку l'ül'ǜ попалось какой-то, ломается. А это нежелательно для изготовления... Ei painunned - 'не гнулись', да».

146 \#2a: [kiskŭhhəvəd], \#2b: [kiskŭvəd], \#r: [kiskhuvəd].

147 Второе $u$ вставлено сверху. 


$\begin{array}{llll}\text { mil’t(ə)s-ij(ə) } & \text { va } & \text { taho-i-d } & \text { vakko-j(ə) }{ }^{148} \\ \text { какой-PL.PART } & \text { только } & \text { хотеть-PST-2sG } & \text { корзина-PL.PART }\end{array}$

'У них лыко получалось как ремень, из такого лыка можно было делать какие угодно корзины'.

(116) Техти мариьл ваккой, вай муна ваккой,

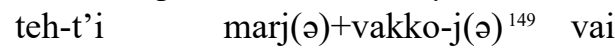
делать-IPS.PST ягода+корзина-PL.PART или muna+vakko-j(ə)

картофель/яйцо ${ }^{150}+$ корзина-PL.PART

техти и аканы ваккой, не оливыд сууред вакад, teh-t'i i akan(ə)+vakko-j(ə) делать-IPS.PST и мякина+корзина-PL.PART ne ol'-i-vad sūre-d vaka-d те быть-PST-3PL большой-PL корзина-PL

хейекӓ каннытти риихельт аканой сарая, hejje-kä kannə-t't'i rīhe-l't(ə) akano-j(ə) saraja они.PL-COM носить-IPS.PST рига-ABL мякина-PL.PART сарай.ILL ниит ваккой сенен перӓст кутсуттики

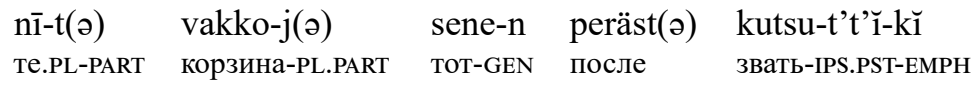
виель и пӓревакакси и аканъвакакси ${ }^{151}$. viel' i päre+vaka-kš̆ i akan(ə)+vaka-ksı̆ еще и лучина+корзина-TRL и мякина+корзина-TRL 'Делали корзины для ягод или картофеля, делали и корзины для мякины - это были большие корзины, в них носили мякину

148 \#2а: как в тексте, \#2b: [mil’tsij vakkoj tahod] 'какие корзины хочешь'.

149 \#2a-b: ['marjə'vakkoj], cp. далее \#2a-b: ['akàn'vakkoj], ['akàn'vakàks']. O значении $\operatorname{akan}(\partial)$ см. тж. [N:10].

150 \#r: «Marjəv[akkoj] — ягодные, да, корзины, munàvakàd — картофельные <далее диалог о том, что имеются в виду именно для картофеля (māmunà), а не для яиц (kanàmunà), т. к. и то, и другое может называться и просто munà>. Māmunàvak no sē on nikù [ну это как бы] само собой понятно, а начинаешь рассуждать - скажешь, может быть, яйца туда положить».

151 \#r: «Akàn - это когда после молотьбы... это отходы от зерновых. Колос и зерны - зерны отмолачивается, а эти, вот это, остатки. 〈... Н Называли, да, большие эти для akàna, большие называли и pärèvakàd. И называли вообще, значит, pärèvakàd. 〈...〉 Общее слово, да. Pärèvakàd все — и munàvakàd, и akànəvakàd, все были pärèvakàd. 
в сарай, эти корзины потому и называли еще как лыковыми, так и мякинными корзинами'.

(117) А вод витс-ваккой миксле мейен кӥлӓсс почти ей техтӥ.

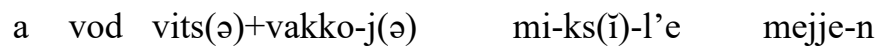

a вот прут+корзина-PL.PART ${ }^{152}$ который-TRL-IDF Mы.PL-GEN

kül'ä-ss(ə) poč't'i ei teh-t' $\breve{u}$

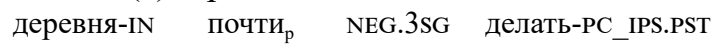

'А вот лукошек [корзин из ивовых прутьев] в нашей деревне почему-то почти не делали’.

(118) Ко паймененн оли Захарк, сииз хӓ теки витс ваккой,

$\begin{array}{llllll}\text { ko } & \text { paimene-nn(ə) } & \text { ol'-i- } \varnothing & \text { Zahark(ə) } & \text { sīz } & \text { hä hä } 153 \\ \text { когда } & \text { пастух-Ess } & \text { быть-PST-3sG } & \text { Захарка } & \text { тогда } & \text { он/a }\end{array}$

tek-i- $\varnothing \quad$ vits(ə)+vakko-j(ə)

делать-PST-3SG прут+корзина-PL.PART

монед остивыд.

mone-d ost'- -

многий-PL покупать-PST-3PL

'Когда пастухом был Захарка, он плел лукошки; многие покупали'.

(119) Хӥӧ оливылд вӓхӓ ранкьмылд ко пӓревакад, но хӥвӓд кера.

hüö ol'-i-vəd vähä rankə-m(m)ə-d ${ }^{154}$ ko

они быть-PST-3PL мало ${ }^{155}$ тяжелый-COMP-PL как

päre+vaka-d no hüvä-d kera

лучина+корзина-PL но хороший-PL тоже

'Они были потяжелее, чем лыковые корзины, но тоже хорошие'.

152 \#r: «Из ивовых прутьев, да. У нас больше из лучины делали, а вот у нас Захар был пастухом, так он в промежутке там... это самое, пас скот и делал эти самые, vitsvakkoj. 〈... Тяжелее были, да, по весу. Хотя и высохли потом, но все равно как-то массивнее были, это материал. На прут это какой-то санти́метр хотя бы, он толще, чем эти лучинные».

153 \#2a: [hä], 2b: [hä].

154 \#2a: [rankəməd], \#2b: [rankəmməd].

155 Лексема vähä может выступать в функции как существительного, так и наречия (ср. примеры в [N:683]). 


\section{5. «Огашка-сватья»}

В тетради ВВ на с. 162-172 переписаны тексты на северном и тверском карельском, ливвиковском, людиковском, вепсском, ливском, а также на сойкинском диалекте ижорского языка. Источник текстов не указан, однако сойкинский текст, очевидно, является первым абзацем текста, опубликованного в [Virtaranta, Suhonen 1978: 54 или 1983: 50]. На с. 169170 (между 23.12.2000 и 14.09.2001) записаны переводы этого отрывка на «ванакюльское наречие» и на русский язык, приводимые ниже ${ }^{156}$.

(120) Oli vana baabušk, Ogašk-lanko

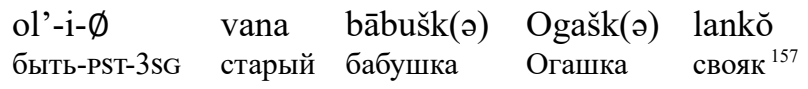

oli meill, viel ${ }^{158}$ kahekskümmen vuott

ol'-i- $\varnothing \quad$ me-i-l'l'(ə) viel'(ə) kaheks(ə)-kümmen vuot-t(ə)

быть-PST-3SG мы-PL-AD еще восемь+десять год-PART

vana, pikkrain i paksu mokom, vana baabušk.

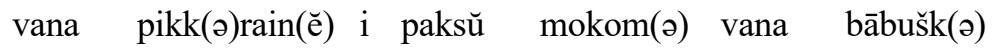
старый маленький и толстый такой старый бабушка

'Была у нас старая бабушка, Огашка-ланго (ланго, финское ланко - родственница сестриного мужа) ['сватья, свойственница, своячка'; запись в круглых скобках - это перевод Н. Д. Пыдером финноязычного пояснения Виртаранты и Сухонена к оригинальному сойкинскому тексту. - H. K.], лет восьмидесяти уже, маленькая ростом и такая толстая старушка'.

(121) Se oli meien naapriss melken

$\begin{array}{lllll}\text { se } & \text { ol'-i- } \varnothing & \text { mejje-n } & \text { nāp(ŭ/ə)ri-ss(ə) } & \text { mel'ken }{ }^{159} \\ \text { тот } & \text { быть-PST-3sG } & \text { мы.PL-GEN } & \text { сосед-IN } & \text { почти }\end{array}$

'Она жила почти по соседству с нами'.

156 Переводы фраз и текстов, сделанные самим Н. Д., даются здесь и далее в марровских кавычках курсивом.

157 Более подробно о значении иж. слова см. [N:248]; cp. тж. фразу (197). В водском языке lanko 'свойственни/к, -ца; сват, сватья' [VKS: 575-576], ср. тж. эст. lang 'свояк, свойственник'.

158 В оригинальной публикации запятая стоит после viel.

159 В [N:304] melkēn упоминается как возможный финнизм; в рукописях Н. Д. его частотным аналогом является русизм рос́ ' $t$ ' $i$ 'почти'. В данном случае появление 
(122) Se ain käi pienill lapsill skaaskoi läkkämäss.

se $\operatorname{ain}(\partial)$ kä-i- $\varnothing \quad$ pien-i-l'l'(ə) [pienil’’]

тот всегда ходить-PST-3SG маленький-PL-AD

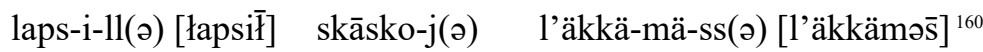
ребенок-PL-AD сказка-PL.PART говорить-SUP-IN

'Она всегда ходила к детишкам рассказывать сказки'.

(123) Muut hä ei jaksõd.

mū-t(ə) hä ei jaksə-d

другой-PART он/a NEG.3SG быть_в_силаX-PC_PST

'Больше у нее ни на что не было сил'.

(124) Mü̈ ko uotlimm ain kovast ko katsoimm et Ogašk-lanko tullo,

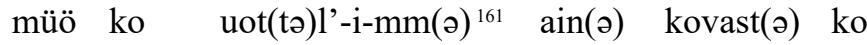
мы когда ждать-PST-1PL всегда крепко когда

katso-i-mm(ə) ${ }^{162}$ ett(ə) Ogašk(ə) lankŏ tullo смотреть-PST-1PL что Огашка свойственник приходить.3SG jo taaz müö kaig ümpõr hänt istusim.

jo tāz müö kaig ${ }^{163}$ ümp'ər('‘̌ $)^{164}$ hän-t(ə)

уже снова мы весь вокруг он/а-PART

istŭ-si-m(mə)

сидеть-PST-1PL

' «Mы всегда очень ждали ее и, как увидим, что Огашка-ланго идет, ты [= то] тут же все рассаживались вокруг нее'. ${ }^{165}$

mel'ken может быть вызвано melkein в оригинальном сойкинском тексте (записанном от информантки, прожившей в Финляндии уже 20 лет на момент интервью Виртаранты).

160 Рекурсия редукции: [*'läkkāä,mässä > *'läkkä, mäs̄ > 'läkkämäs̄ > 'läkkämə̄̄]].

161 [uot̀l'im̄ ].

162 [katsō̄ ềt].

163 Наиболее частотным вариантом местоимения 'весь, все' в рукописи Н. Д. является кай. Вариант kaig возникает тут, по-видимому, под влиянием kaig в оригинале сойкинской публикации. В словаре [N:122-123] kaig дано как единственный вариант для сойк. диалекта, а для н.-л. диалекта указаны и kaig (в большей степени для северо-восточной н.-л. зоны), и kai; это совпадает с ситуацией, зафиксированной и в моих полевых данных.

164 [ümp'ŏr], ср. тж. ӥтрё̈r в [N:693-694]; ср. тж. сноску 111.

${ }^{165}$ Н. Д. убирает некоторые особенности разговорной речи, отраженные в публикации сойкинского текста и отчасти меняет пунктуацию (что, возможно, связано с ориентацией на финноязычный перевод текста, ср. (120)), однако в данной фразе 


\section{6. Пословицы, поговорки, шутки, фразы}

Фразы (125)-(134) взяты из ВВ (с. 186-187, 27.06.2009). Датировка более ранних вариантов некоторых фраз, данных под литерой (б), и фраз (135)-(138) приведена после самих этих фраз.

(125а) 1. Хейлль оливыд пуукэрекя киука, $\begin{array}{llll}\text { he-i-l'l'(ә) } & \text { ol'-i-vəd } & \text { pū+kere-kä } & \text { kiuka } \\ \text { они-PL-AD } & \text { быть-PST-3PL } & \text { дерево+каркас-сом }{ }^{166} & \text { печь }\end{array}$ пиинака раттад и ляпятикӓ туннид. pšina-ka ratta-d i l'äpät'i-kä tunni-d обод-сом ${ }^{167}$ колесо-PL и маятник-сом час-PL

' У них были: печка на бревенча́той основе, колеса телеги на железной ободке́ и часы с маятником' (ударения в переводе расставлены согласно чтению Н. Д.).

(126б) Хейлль оли(выд) пуукэрекя киука,

$\begin{array}{llll}\text { he-i-l'l'(ә) } & \text { ol'-i- } \varnothing(/- \text {-vad }) & \text { pū+kere-kä } & \text { kiuka } \\ \text { они-PL-AD } & \text { быть-PST-3sG(/3PL) } & \text { дерево+каркас-сом } & \text { печь }\end{array}$

ляпятикя туннид, пшинака раттад.

l'äpät'i-kä tunni-d pšina-ka ratta-d маятник-сом час-PL шина-сом колесо-PL

' У них были: печка на деревянном оснований, маетником часы, колеса на телеге железными ободами (шиныд)' (ВВ, между 6.3.1990 и 27.1.1991, с. 54-55. По-видимому, шиныд - это другая лексема šĭnə- $<$ шшина-PL>, cp. сноску 167).

разговорное повторение $k$ сохранено. Характерно, что Н. Д. заменил последнее слово оригинала istumā <сидеть:SUP> ('...уже опять мы все вокруг нее сидеть') на форму 1PL, что также сделало синтаксис менее разговорным.

166 \#r: «Mejjen kant'is̄ ol'ì. Ei old, māst ül'l'äl' ei old järk'e k'irp'ičəst teht'ü, a ol'ì pūst, pałk'ist. Kui nī kork'ił ol'ì pałk'ist teht'ü, sīz vast pant'i... pałk'in pâ̄l' noisst'i k'irp'ičəst tek'emä. Vot se ol'ì pūk'erèkä kiụka. [В нашем краю было. Не было, от земли вверх не было сразу из кирпичей сделано, а было из дерева, из бревен. Когда на такой высоте было из бревен сделано, только тогда клали... на бревна начинали делать из кирпича. Вот это была печка на бревенчатой основе]» (Н. Д. считает, что так делали из экономии кирпича).

167 \#r: «Это pšinàka имел в виду колесо, обведенное железом. 〈...〉 [Автомобильная шина — это] auton šīn, [а тут] pšinà». 
(127a) 2. Хуомиколл переннайн лӓкӓјӓ: Пэрэ нику пэрклен пэле

huomǐko-ll(ə) pere+(n)nain(ə) ${ }^{168}$ l'äkäjä

утро-AD семья+женщина говорить.3sG

pere niku perk(ě/ə)l'en ${ }^{169}$ pel'e

семья так_как черт-GEN пасть ${ }^{170}$

хуомиколл паад паан гуща, тойсен гаща, иллькки йяӓбь ва таари и лейп.

huomǐko-ll(ə) pā-d pā-n gūšša [gūšša] toise-n Утро-AD класть-2SG горшок-GEN гуща.PART второй-GEN

gāšša [gāšša] illə-kš̃ $\quad$ jä-b'(/p̌i) $\quad$ vā [\#3: vā] $\quad$ tārǐ жижа.PART вечер-TRL оставаться-3SG только квас

i l'eip'(ə)

и хлеб

'Утром хозяйка говорит: семья как чортово пасть, утром положишь горшок густой каши, другой жидкой каши, к вечеру остается только квас да хлеб'.

(128б) Пэ́рэ ко́ пе́ркэлэн пэ́лэ; ху́омколл паад паан

pere ko perkěl'e-n pel'e huomǐko-ll(ə)

семья как черт-GEN пасть утро-AD

pā-d pā-n

класть-2SG горшок-GEN

гу́щุа то́йсен га́щุа, и́ллькси йябь (јӓӓb) ва та́ари и ле́йп.

gūšša toise-n gāšša illə-kš̃ jā̄-b'(/pǐ)

гуща.PART второй-GEN жижа.PART вечер-TRL оставаться-3SG

vā [\#2: vā] tārǐ i l'eip'(ə)

только квас и хлеб

'[На ижорском языке. Хозяйка сетует:] семья как чортова пасть, утром ставишь в печку чугун (железный горшок) гущи (густой каши) другой гащи (жидкой каши), на вечер остается

168 По-видимому, случай т. н. пограничной геминации (rajageminaatio): удвоения согласного после исторически закрытого конечного слога в pere (< п.-ф. *pereh).

169 \#3: [perkl'ən], ср. чтение (129б): \#1: [perkel'en].

170 Лексема pel'e в словаре не отмечена, ср., однако, pelehellä, pe llēhüz [N:396] '1. привиждаться, 2. колядовать (на Рождество), ходить чудями (на Масленицу)', а тж. эст. pele - междометие в современном языке (с функциями 'ишь ты', ‘фу ты’, 'вот это да'). 
только квас да хлеб' (между 6.3.1990 и 27.1.1991, ВВ, с. 50-51; ударения расставлены в записи самим Н. Д.) ${ }^{171}$.

(129) 3. Ванамиехед истуд и муйстлод: кетӓ

$\begin{array}{lllll}\text { vana }+ \text { miehe-d } & \text { istu-d } & \text { i } & \text { muist(ə)lo-d } & \text { ke-tä } \\ \text { старый+мужчина-PL } & \text { сидеть-3PL } & \text { и } & \text { вспоминать-3PL } & \text { кто-PART }\end{array}$

оно виель элосс, сиэ ды миэ, ды мэйен

ono viel'(ə) elo-ss(ə) sie də[də] mie də [də] mejje-n

быть.3sG еще жизнь-IN ты да я да мы.PL-GEN

Микит, отс Трошо ды Валке Вася.

Mikit(ə) ots(ə)+Trošo də [da] valke Vas’a

Микита конец+Трофим да белый Вася

'Старики сидят и вспоминают: кто еще в живых, ты ды я, ды наш Микита, Трофим с конца ды Белая Вася'.

(130) 4. Пӓӓ нику пӓревакк, эй муйсс миттӓ.

$\begin{array}{lllll}\text { pā } & \text { niku } & \text { päre+vakk(ə) } & \text { ei } & \text { muiss(ə) } \\ \text { голова } & \text { так_как } & \text { лучина +корзина } & \text { NEG.3sG } & \text { помнить } \\ \text { mittä } & & & & \end{array}$

который.PART.NEG ${ }^{172}$

${ }^{171}$ Еще более ранний вариант записи (ЧОТ, с. 20, № 1; 128c): «Пе́ре ко́ пе́рклен пеле; хуомиколл паад паан гущуа тойсен гащча, иллькси яябь (јӓӓb) ва таари и лейп. Хозяйка сетует: Семья как чортова пасть; утром ставишь (в печку) горшок гущи (густой каши), другой горшок гащи (жидкой каши). На вечер остается только квас да хлеб». Недатированный вариант записи («Пища наша», с. 1, № 4; 128d): «Хозяйка сетует: пэрэ ко пэркэлен пеле; хуомиколл паад [вставлено сверху: кйукасс $<$ kiuka-ss(ә) печь-IN>] паан гуща, тойсен гащуа, а иллькси ияябь ва таари и лейп. Семья как чертова пасть, утром ставишь в печку гориок густой каши, второй жидкой каши, а на вечер остается только квас да хлеб». Здесь же пояснение про каши: «Раньше семьи были большие, питания не очень хватало. Пишу готовили в основном в русской печке. Каши. Основная каша была перловая или ячневая (измельченная перловка). I. Крупу залили молоком, посолили. Тушилась (Варилась) в печке до обеда. II. Ту же крупу залили кипятком, добавили свиной жир, соль. Тушилась в печке. Варилась. III. Гаща - жидкая, из разньх круп на молоке, тоже тушилась в печке. Так же готовили каши из других круп, пшено, реже рис». Пояснение в \#r: «Mejjen kiel'es̄ niku gūšša и gāšša, видимо, ei old, ne on vennän sanad, буквально, sīhe tulled [В нашем языке, как бы, 'гуща' и 'гаща', видимо, не было, это русские слова, буквально, в него пришли]». Там же обсуждение происхождения: $g \bar{u} \check{s} \check{s}(\partial)<$ рус. 'гуща', gāšš (ә) < рус. 'каша'.

172 Данное местоимение является отрицательным вариантом $m i$ - $t \ddot{a}<$ который-PART> (см. (45), тж. mikä в (61)). 
'Голова как корзина из лучины, ничего не помнит. [Ниже еще пояснение:] К 4. У корзины крупные дырки, многое покидает то, что ранще знал'.

(131a) 5. Сие айн таход мӓнн такупери тайвасс.

sie ain(ə) taho-d männ(ə) takupperi [takù̀̄'er'ì]

ты всегда хотеть-2SG уходить.INF задом_наперед

taiva-ss(ə)

небо-ILL

' $T$ bl все хочешь задом идти на небо. [Ниже пояснение:] $К 5$. Человек своим мнением, не всегда прав'. Комментарий при чтении (131a): «Ну по своему мнению вот идет, понимаешь, как бы свое мнение. Надо передом идти на небо, а ты идешь задом как бы, ну, своим мнением, но твое мнение не всегда верно»; \#r: «Ты делаешь не то, что надо, или делаешь так, как не надо».

(131б) Сие айн таход такуппери тайвасс мӓнн. ${ }^{173}$

sie ain(ə) taho-d takupperi taiva-ss(ə) männ(ə)

ты всегда хотеть-2SG задом $^{174}$ небо-ILL уходить.INF

' $T$ bы все хочешь задом идти на небо' (между 10.10.1993

и 15.12 .1998$, с. 107 ; аналогичная более ранняя запись в ЧОТ, с. 20). Пояснение при чтении (131б): «Против воли, что ли... на небо прёшь задним ходом».

(132) а). В... виети Виипури терве лайвын ласти, $\mathrm{v}$ [ittŭ] vie-t'i Vìpuri terve [terve] vagina уносить-IPS.PST Выборг.ILL здоровый ${ }^{175}$

laivə-n las-t'i

корабль-GEN опускать-IPS.PST (см. laskia в [N:250])

173 Текст № 2: мӓнн вставлено в конце фразы сверху; чтение \#2: иной порядок слов [män̄ं taivas̄ə̊, män̄ taivas̄].

174 B [N:566] даны только варианты taGaperin (сойк., н.-л.), takap̌peri (н.-л.).

175 Лексема terve ‘здоровый’ использована здесь в метафорическом значении 'весь, целый’, которое указано для н.-л. диалекта как возможный эстонизм в [N:583] (эст. terve '1. здоровый; 2. весь, целый'; ср. тж. с koko в (152)). Н. Д. называет инг. финский источником поговорки, при этом в [Оллыкайнен 2003: 351] данное значение для инг. финского не отмечено. 
т... оли кескелл нику лайвын машти.

t['ürä] ol'-i- $\varnothing \quad$ keske-l'l'(ә) niku laivə-n penis $_{\text {иф }}$ быть-PST-3SG середина-AD так_как корабль-GEN

\section{mašt' $\breve{1}$}

мачта ${ }^{176}$

'П... везли Выборг полный груз корабля, х.. был на середине как корабельная мачта' ['Vagina везли в Выборг - нагрузили полный корабль, penis был в середине как корабельная мачта'] (шуточная поговорка). Комментарий в \#r: «Это ингерманландские финны рассказ такой. 〈..> Hejjen kiel'es̄ on t'urä, a meil' on mułkku [В их языке penis — türä, а у нас mulkkŭ]».

(133) Пришла ижсрская старушка к русскому доктору и говорит:

миулл сиин пистӓ и сиин пистӓ и хуймая голова.

$\begin{array}{lllllll}\operatorname{miu}-11(\partial) & \sin (ә) & \text { pistä } & \text { i } & \sin (ә) & \text { pistä } & \text { i } \\ \text { я-AD } & \text { тут(IN) } & \text { колоть.3sG } & \text { и } & \text { тут(IN) } & \text { колоть.3sG } & \text { и }\end{array}$

huimaja [huiməja] (cp. huimada [N:72]) galava [gəła'va]

кружиться.3SG

голова

'Мне тут колит и тут колит и кружится голова. [У меня здесь колет, и тут колет, и кружится голова]' (шуточная игра слов, связанная с тем, что некоторые ижорские слова частично совпадают по звучанию с русской нецензурной лексикой). Пояснение при чтении [речь про pistä]: «Ну он[а] говорил[а] немножко как бы вроде по-другому, немножко... Да, $\partial$ вместо $m$, и з... 3 и $\partial$ тут, по-настоящему».

(134) Тӥттӧ хӥвӓ нӓнн кова, пилу пиккарайне.

t’üttö hüvä nänn('ə) kova pilu pikka(/ə)rainĕ ${ }^{177}$ девушка хороший сосок крепкий vagina маленький

‘Девушка хорошая, груди крепкие, п... маленькая)’ (шуточная поговорка). Пояснение при чтении: [vittu и pilu — это одно и то же.] «Но это так, реже, piłu реже у нас как бы говорят. Не знаю, это с финского, что ли, это перешло или как-то $\langle.\rangle$.$\rangle Но как-то я где-то$ слыхал, говорят так, понимаешь, вот я и писал, ai voi-voi». Комментарий в \#r: «Это vad'd' əlainsed [водь] так говорили».

${ }^{176}$ В [N:299] masti (сойк.) / mast'i (н.-л.) дано как эстонизм (эст. mast : masti GEN), однако это может быть и русизм, на что указывает наличие фонемы $\check{s}$ (вместо $s$ ) в форме, записанной у Н. Д.

177 [pikkərainə]. 
(135) Пиер ветте, па виералл этте, айн он пареб ко пальыз веси. pier('ə) [\#1: pier] vette pā viera-11(ə) ette пукать.IMP вода.ILL класть.IMP гость-AD перед(ILL)

ain(ə) ono [\#1:on] pare-b(/pĩ) ko pal'jəz vesi всегда быть.3SG лучше-сомР ${ }^{178}$ как голый вода

'Пёрни в воду, угости гостя, все лучше, чем так вода' (BВ, между 6.3.1990 и 27.1.1991, с. 56; шуточная поговорка).

(136) Веде талви тайвасс ей иӓ “јӓ" 179.

vede [\#1: vedè, \#r: vet] talv̌ ведь ${ }^{180}$

зима небо-ILL NEG.3SG оставаться

'Ведь зима на небе не останется' (ЧОТ, с. 20). 'Зима на небе не остается’ (BВ, между 10.10.1993 и 15.12.1998, с. 107; поговорка со значением 'Все пройдет').

(137) Tü̈ läkkät izorin kieless?

t’üö l'äkkä-t(tə) ižori-n kiel'e-ss(ə)

вы говорить-2PL ижорский-GEN язык-IN

'Вы говорите по-ижорски?' (между 15.12.1998 и 09.10.2000, с. 146; не было прочитано под аудиозапись).

(138) Hüvvä ilta Saatõnõ, onoko kuratti/Perkõlõ koiss?

hüvvä ilta Sātən(ə) ono-ko

хороший.PART вечер.PART Сатана быть.3SG-Q

kurat't'̌̌lperk'ə(/е̌)l'(ə) koi-ss(ə)

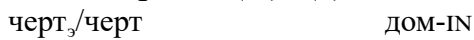

‘Добрый вечер Сатана, дома ли черт?' (BВ2, 12.04.2014, с. 1).

Данная фраза записана в двух вариантах, первый с kuratti, втоpoй с Perkõlõ. Sātən(ə): [\#1: sātənə, \#2: sātən], kurat't'̌̌: [kuràt'’], perk'ə(/е̌)l'(ə): [per̀k'əl'ə]. Комментарий в \#r: «Так никто и не говорил и не говорит, я сам, наверно, придумал так. $\langle\ldots\rangle$ Но не знаю, где-то вообще-то я какой-то такой звук, может быть слыхал где-то. Да. И оттуда я развил вот все это на трех языках только [запись на финском, эстонском, ижорском, русском языке].

178 Прилагательное и наречие сравнительной и превосходной степени от 'хороший' (hüvä) имеют супплетивную основу pare-.

179 Последнее слово приписано во ВВ другой ручкой; в ЧОТ отсутствует.

180 \#r: «Vedè — se on mejjen ižòrkən sanà [vede — это наше ижорское слово]. 〈...〉 'Ведь' вроде, или как-то так». Исторический русизм [N:650]. 
$\langle\ldots\rangle$ Я, видишь ли, делал черт и делал kurat (эст. 'черт'). Это perk’əl'е̌, да. Ну я сперва как-то, может быть, немножко ошибся, kuràt 't' $i$ не надо было записать. — Так не говорили? (соб.). - Ну, говорят иногда тоже, как бы, похоже на эстонский, kuràtti говорят тоже. Ну a p'erk'əl'’ meil' oǹ ižor'in sanà все-таки. 〈...〉 Mie l'äkkänk' p'erk'al'ə — не p'erk'el'e, a p'erk'əl'ə [Hy a perkěl'ĕ у нас ижорское слово все-таки. Я и говорю perk'al'a, не perkel'e, a perk'əl'ə] — bl, ну, слабый bl».

\section{7. «О водском языке»}

В тетради ВВ за 09.10.2000 (c. 147-150) переписан из [Ariste 1969: 10-11] весь текст № 2 по-водски с русским переводом. На с. 150 отдельно перечислены дни недели по-водски и по-ижорски. Затем на с. 151-155 проведено этимологическое сравнение отдельных слов водского, «ижорского (ванакюльского)», эстонского и русского языков из текста № 2 Аристе и из последующих (№ 3-5) [Ariste 1969: 10-12] (139)-(153), а также из различных околопасхальных сюжетов и, очевидно, ряда других текстов (154)-(162) (особ. ср. с [Ariste 1969: 12-16, 35-49]). Затем переписан по-водски текст Аристе № 8 [Ariste 1969: 24 25]. Предваряется все вышеперечисленное следующим рассуждением автора о водском языке (с. 146-147):

Получил от Кузьмина Эльмара Григорьевича на временное пользование книгу Paul Ariste "Vadja rahvakalender”, выпущен Таллинне 1969 г. С 1932 года Пауль Аристе записывал водский язык по рассказам людей, которые были из разных мест уехавшие жить около рек Нарва и Россонь ижорские и финские деревни. Кигориа (Григорий) Кузьмин из Пуммала (около Котлов) жил деревне Калливере и Дарья Лехти из Йыгиперя (Краколье) жила Ванакюля. Позднее он бывал и других местах где была водь. Книге записаны рассказы до 1966 г. Темы рассказов о праздниказ и днях которые отмечали по разным поводам.

Текстах водского языка использованы месте латинскими буквами и некоторым славянские, и разные знаки препинания, к сожалению не объяснено их произношение. Каждому рассказу имеется перевод на эстонском языке. (Благодаря этому переводу многие мне непонятные слова на водском языке понятны). 
(139) Ууси вуоси оли валетти сулатетти тина Новый год был сливали таяли олово ūsǐ vuosĩ ol'-i- $\varnothing \quad$ val'e-t't'i sulate-t't'i t'ina ${ }^{181}$ новый год быть-PST-3SG лить-IPS.PST топить-IPS.PST олово

(140) кен митӓ думыси келль миллисед

кто чего думал кому какие

ken mi-tä dūməs-ī- $\varnothing$ [dūməsi] ke-l'l'(ə) mil'l'ı̌se-d кто что-PART думал-PST-3SG кTO-AD какой-PL

(141) кувад туливыд ихмисен

картинки пришли человека

kuva-d tul-i-vad ihmisse-n

картинка-PL приходить-PST-3PL человек-GEN

(142) еллӓмын вай сииз ӥӧлл туоти

животного или тогда ночью принесли

el'l'ämə(/e)-n [el'l'ämen] vai sīz üö-l'l'(ə)

животное-GEN или тогда ночь-AD

tuo-t'i

приносить-IPS.PST

(143) кукко пертти йока тӥттё сипутти одриы петух комнату ${ }^{182}$ каждый девушка сыпал ячменя

kukko pert't'i joka t'üttö петух комната.ILL каждый девушка

siput't'-i- $\varnothing \quad$ odr-ij(ə)

сыпать-PST-3SG ячмень-PL.PART

\begin{tabular}{|c|c|c|c|c|}
\hline мaаха & $\begin{array}{l}\text { кенен } \\
(\text { из) чей }\end{array}$ & $\begin{array}{l}\text { куост } \\
\text { (из) кучи }\end{array}$ & $\begin{array}{l}\text { енсмӓйсекси } \\
\text { первымм }\end{array}$ & $\begin{array}{l}\text { мӓннё } \\
\text { идет }\end{array}$ \\
\hline lā-ha & $\begin{array}{l}\text { kene-n } \\
\text { кто-GEN }\end{array}$ & $\begin{array}{l}\text { kuo-st(ə) } \\
\text { куча-EL }{ }^{183}\end{array}$ & $\begin{array}{l}\text { ens(苂mäise-ksī } \\
\text { первый-TRL }\end{array}$ & дить. $3 \mathrm{sc}$ \\
\hline
\end{tabular}

181 \#r: [tinna] < олово:РART> (т. е. ожидаемая здесь форма партитива).

182 Pert't' ‘̆ обозначает жилую часть избы (ср. тж. [N:400]).

183 Куост и куон в (124) являются формами склоняемого сущ. koko 'куча', типичного для н.-л. диалекта (vs. сойк. müttü); cp. с неизменяемым koko 'весь, целый' в (128) (даны как разные леммы koGo в [N:181]). 
суоӧмӓ мӓннӧ кайкке энныпи миехелл кушать идет всего ранше замуж süö-mä männö kaikke ennə(/e)-pi [ennĕpi] есть-SUP уходить.3SG весь.PL.PART раньше-сOMP miehe-l'l'(ә)

мужчина-AD

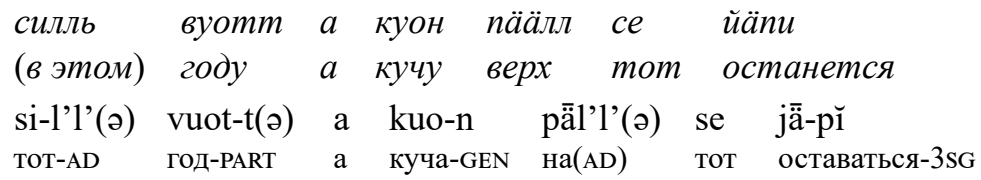

(147) ванаксй тулти саотти веннӓкси старый пришли сказали по русский vana-kš̌ tul-t'i sao-t't'i vennä-kš̌ старый-TRL приходить-IPS.PST сказать-IPS.PST русский-TRL

(148) миттӓ ей вад'ян ничего не (на) водском mittä ei vadjan [\#vadjan, vad'jan] который.PART.NEG NEG.3SG водский-GEN ${ }^{184}$

(150) ситӓ луетти оннекакси того читали счастливым si-tä lue-t't'i onneka-kš̌ TOT-PART читать-IPS.PST счастливый-TRL

(151) хуомиколл еймӓнтӥ кӥсӥмӓ утром не пошли спрашивать

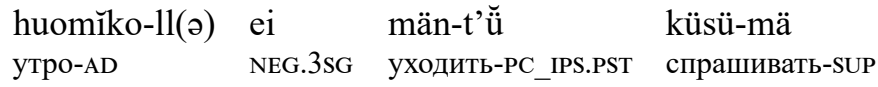

184 Выбор формы генитива в данном случае не до конца понятен; закономерной в данном контексте была бы форма транслатива, как и в оригинальном водском примере, ср. ряд, приведенный в тетради Н. Д. (с. 153): «vad'd'assi (вод.) вад'ян (иж.) - вад'я (эст.) - (на) водском (рус.)». Возможно, Н. Д. ориентировался на эстонский перевод водской фразы «...midagi ei öeldud vadja keeli» [Ariste 1969: 11], где представлена форма генитива. Данный пример является также единственным случаем указания мягкости согласного с помощью диакритики - по-видимому, это влияние водского оригинала, с которого переписывал Н. Д. (при этом в его собственном произношении согласный был смягчен слабо). 
(152) тойсест талост нойсыд коко вуоси с другого схозяйства (дома) будешь весь год toise-st(ə) talo-st(ə) noisə-d [noisət] koko vuoš̄ второй-EL дом-EL подниматься-2SG целый год

Ниже дан перевод Н. Д. водского текста № 2 из [Ariste 1969: 10-11] (ВВ, с. 149-150; во фразах (139)-(152) был представлен ижорский перевод большей части слов из него):

Новылй год. Было так под Новылй год. Таяли олово, разливали. Кто чего думал, кому какие картинки пришли, кому человеческие, кому животные. Разливали и растаяли олово. Ночью принесли комнату петух и каждая девушка рассыпала ячмень на пол. Из чьей кучи петух начинает первым клевать, эта девушка выйдет первая замуж в этом году. А на чей куче разбрасывает зерно и испражняется на ней, она останется старой девой. Это было старом году (перед Новым годом). Пришли сказали по русский, ничего не сказали на водском языке, сказали по русский: «Здравствуйте вам, сновым годом, сновым счастьем». Того считали несчастным человеком кому пришла первым женщина комнату. Тогда сказали: «Не будет счастливый год». Если пришел мужчина, тогда был счастливый год. Утром нового года не пошли ничего спрашивать с другого дома. Сказали так: тогда будешь весь год спрашивать.

(153) ваатед отетти рахад панти кармонто одежда взяли деньги положили в карман

vātte-d ote-t't'i raha-d pan-t'i karmonto
одежда-PL брать-IPS.PST деньги-PL класть-IPS.PST карман.ILL

'Одежда. Брали деньги, клали в карман' (отрывки из текстов № 4-5 [Ariste 1969: 11]).

(154) куу оливьљд пӥхӓпӓйв/pуhӓрӓiv енсыпnӓив/епsо̃ррӓiv луна были воскресенье понедельник kū ol'-i-vəd pühä+päiv'(ə) ${ }^{185}$ ensə-(p)päiv'(ə) месяц быть-PST-3PL праздник+день первый+день

185 Варианты названий дней недели латиницей приводятся по отдельному списку дней недели в ВВ, с. 147. Чтение \#1 в случае дней недели относится к этому списку, чтение \#2 - к повторному перечислению дней недели в общем списке сравниваемых слов на с. 154. Поскольку названия дней недели имеют много фонетических 
(155) тойсеппӓив/toiseppäiv кескивиикко/sered вторник среда

toise-(p)päiv'(ə) keskǐ̀+vīkkŏ/ser'ed(ə) второй+день середина + неделя / среда

(156) неллезпӓив/nellõespäiv виезпӓив/vijespäiv лауккопайв/laukkopäiv четверг пятница суббота nel'l'ə-z+päiv'(ə) vīje-z+päiv'(ə) laukkŏ+päiv'(ə) четыре-ORD+день пять-ORD+день laukko+день ${ }^{186}$

$\begin{array}{lll}\text { чаё (чаю) } & \text { яани } & \text { йоулу } \\ \text { чай } & \text { иванов день } & \text { рождество } \\ \text { с̌ājŭ [čājŭ] } & \text { jānī }^{187} & \text { joulŭ } \\ \text { чай } & \text { иванов_день } & \text { рождество }\end{array}$

лиукупӓив /liukорӓiv-лиукопяйв

масленица

l'iukŭ(/ŏ)+päiv'(ə) ${ }^{188}$

скользить+день

\begin{tabular}{|c|c|c|c|c|}
\hline $\begin{array}{l}\text { миккели } \\
\text { Михайлов день }\end{array}$ & весерист & кейтытти & $\begin{array}{l}\text { олутт } \\
\text { пива }\end{array}$ & \\
\hline & veserist(ə) ${ }^{190}$ & & & olut-t(ə) \\
\hline михайлов_день & Крещение & варить-IPS.Ps & & Пиво-PART \\
\hline
\end{tabular}

и фонологических особенностей, приводим чтение всего списка: [\#1: 'pühä 'päív', 'ensəp'päiv', 'toisep 'päiv', 's'er'èdo, 'nel'l’əs 'päiv', 'vījes 'päivi', 'łaukkoo'päiv'; \#2:

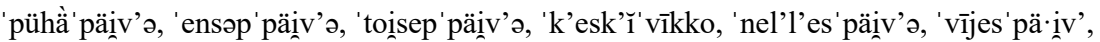
'łaū $\bar{k}^{\circ}$ päiv']. В названиях понедельника и вторника, в частности, представлена пограничная геминация $p>\bar{p}$, как и $n>\bar{n}$ в (127a).

186 Названия дней недели различаются в сойк. и н.-л. диалектах; н.-л. laukköpäiv'(ə) (этимология laukkŏ непрозрачна; ср. эст. laupäev) является одним из наиболее ярких отличий от сойк. славизма sōvotta.

187 Отмечено как возможный эстонизм в [N:104] (эст. Jaanipäev).

188 Две итерации во ВВ: на с. 65 два варианта с $о$ (чтение \#1: ['liuko'päiv', liuko' päiv']) и на с. 154 вариант с $u$ (чтение \#2: ['liuku' päinv’’]).

189 В [N:310] вариант mikkeli отмечен для н.-л. диалекта; в сойк. диалекте, по моим полевым данным, представлено mihkeli.

190 Лексема, очевидно, содержит основы слов ‘вода' (vesi) и 'крест' (ristī), однако морфонологические варианты основ являются иррегулярными (ср. тж. с сойк. vezerista в [N:658]). 
(159) соймелти рихи куомнысс

бранились рига гумне

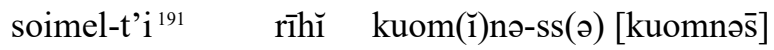

браниться-IPS.PST рига гумно-IN

(160)

$\begin{array}{llrll}\text { кёлӓ } & \text { нойсо } & \text { пӓӓсе } & \text { краасытти } & \text { кирютетту } \\ \text { деревня } & \text { поднимется } & \text { пасха } & \text { красили } & \text { написано } \\ \text { kül'ä } & \text { поізо } & \text { pā̄se } & \text { krāsə-t't'i } & \text { kirjute(/ə)-ttŭ } \\ \text { деревня } & \text { подниматься.3sg } & \text { Пасха } & \text { красить-IPS.PST } & \text { писать-PC_IPS.PST }\end{array}$

(161) катсомысс тиитые урпопайв сиотти кенекӓ смотреть знающий вербное воскресенье завязали скем katso-mə-ss(ə) t'ītəj(ə) ${ }^{192}$ urpǒ+päiv'(ə) смотреть-SUP-IN знающий верба+день sio-t't'i kene-kä связывать-IPS.PST кто-сОм $\begin{array}{cllll}\text { (162) кӓтт илльл хӓмӓрикко хепоне лаулойм паасто } \\ \text { руку вечером сумерки ломадь пели } & \text { пост }\end{array}$ kät-t(ə) illə-1l(ə) hämärikkŏ heponĕ laulo-i-mm(ə) рука-PART вечер-AD сумерки лошадь петь-PST-1PL pāst(o) пост (церковный)

\section{8. Отдельные слова}

Слова в (163)-(174) извлечены из ЧОТ (с. 1-16), где собраны известные Н. Д. сведения о происхождении названий местных деревень. Ниже приводятся только ижорские и русские названия деревень, в ряде случаях с ближайшим русскоязычным контекстом.

В распоряжении автора публикации имеется копия еще одной тетради, содержащей переписанные архивные сведения о названиях и населении деревень Россони (ЧТ). Это школьная тетрадь с черной коленкоровой обложкой в широкую линейку: как минимум, 46 л.; записи

191 В словаре Нирви данная лексема не отмечена; ср. эст. sо̃imama 'ругаться, браниться'.

192 [t'ītəjə]. 
на русском, финском, шведском языках; выдержки из эстонского издания про местных репрессированных жителей по-эстонски. На внутренней стороне передней обложки запись: «Начато 17 сентября 1998 года», страницы пронумерованы до с. 13, записи заканчиваются на с. 47, единственная имеющаяся датировка на с. 29 перед началом эстонских записей: «23.24 VI-01». В данной тетради имеется единственное эксплицитное упоминание ижорского (на с. 13): Molokotka (ижсорскии Mellankatko $<$ mella-n+katko весло-GEN+cлом>). Как написано в шведских хрониках 17 века, m. е. место где было сломано весло. В остальных случаях невозможно четко отделить переписанное из источников от авторских комментариев Н. Д., поэтому другие топонимы из нее не приводятся (за исключением информации в сноске 193).

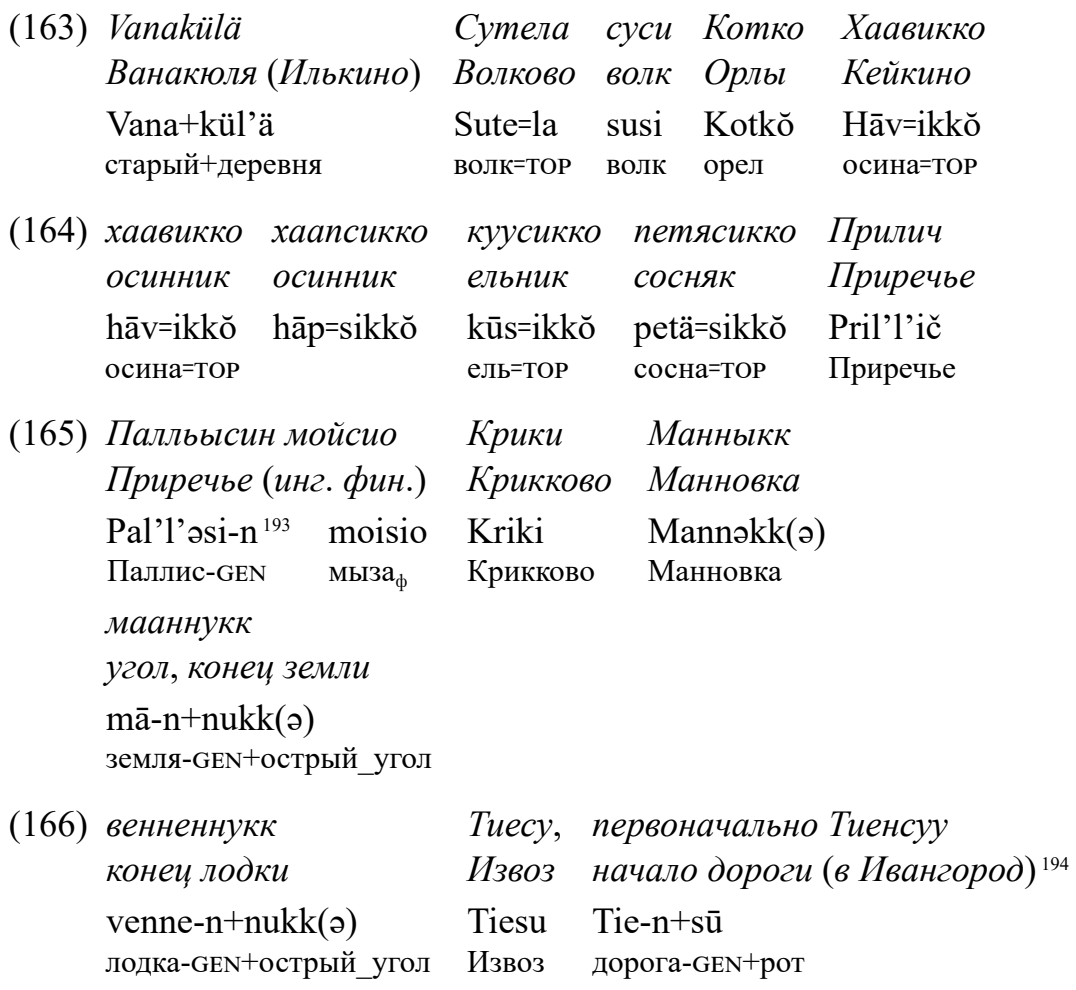

193 В ЧТ (с. 2): мызза Pallisi [видимо, переписанный из источника вариант], мыза Паллиса (перевод) [видимо, русский перевод Н. Д.].

194 \#r: «В реке $s \bar{u}$ ['устье'] входит в море, как бы, или в другой какой водоем, a tiensū идет ‘начало', наверно, ‘начало дороги'» [а не ‘конец дороги']. 


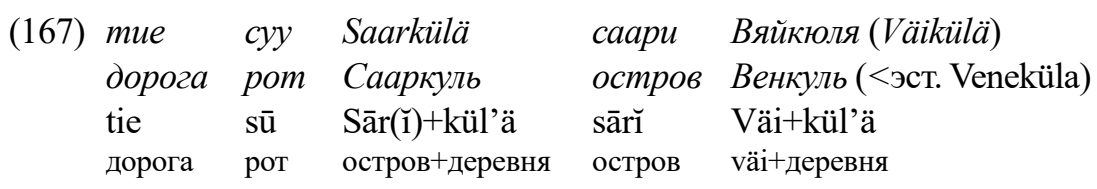

(168) Росон Карстыл Калливере

Куккыси

Россонь Каростель Калливере (Фитинка) Куровиць

Roson(ə) Karstəl(ə) Kal'l'ı̌vere

Kukkəš

Россонь Коростель Калливере

Куровицы

(169)
курви
Наруси; Нарвуси (инг. фин.)
Кривульк
корюшка ${ }^{195}$
Большое Куземкино
Малое Куземкино
kurvĭ
Narusĭ Narvŭš̆
Krivul'k(ә)
корюшка
Большое Куземкино
Малое Куземкино

(170) Kullõnkül̈̈, Кулльнкюля

Мертвица

мерт витс

Kullə-n+kül'ä

мережа ивовый прут

золото-GEN+деревня

$\operatorname{mert}(\partial) \quad \operatorname{vits}(\partial)$

мертвитс

мережа прут

снасть из прута

mert(ə)+vits(ə)

мережа из прута

(171) Раякюля - «Межевая» или «Пограничная деревня» Межники Raja+kül'ä <граница+деревня $>$

рая

межа

raja $<$ граница $>$

(172) Йоенперя йоки перя

Кроколье, Краколье, Караколье река конещ, зад

Joe-n+perä $<$ река-GEN+зад $>$ joki perä

195 Пояснение в \#r: «Mejjen talòs̄̄, vai ninta, kōr'uškaks rohk'eb loet't'i hant. A kurvi meil' niku ei old mōdəs̄, ei old. Kurv'iks niku meil' ei saottu, meil' kōr 'ušk saot't'i. 〈... Kuk̄sin kant'is vist olì kurv’̌̀» [В нашем доме, или как, ее больше считали корюшкой. А kurvi у нас, как бы, не было в моде. Kurvi, как бы, у нас не говорили, у нас говорили корюшка. В районе Куровиц, наверно, было kurvi]. 
(173) нуотын перя веннен перя перямиез йоенперя мотня невода ${ }^{196}$ задний конецллодки кормчий конеи реки nuotə-n perä venne-n perä perä + miez joe-n+perä невод-GEN зад лодка-GEN зад зад+мужчина река-GEN+зад

(174) йоенсуу Лаукаансуу (Laukaansuи) Лаукаа устье реки Усть-Луга река Луга joe-n+sū Laukā(/a)-n+sū [\#r: 'łaụkan, sū] $\quad$ Laukā(/a) ${ }^{197}$ река-GEN+pot Луга-GEN+pot Луга

Слова в (175)-(190) извлечены из «Сравнения слов ижорского, финского, эстонского и русского языков», имеющего две итерации: более полную (ВВ, 12.10.1992, с. 84-88) и более краткую (меньше слов; ЧОТ, c. 18-19). Ижорский и русский варианты даются ниже по ВВ (Текст № 2 и чтение \#2); расхождения с ЧОТ (Текст № 1 и чтение \#1) указаны в сносках.

\begin{tabular}{|c|c|c|c|c|}
\hline ихмин $(е)$ & $\operatorname{maam}(m)^{198}$ & маам & диед & бааб \\
\hline 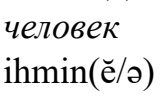 & $\begin{array}{l}\text { omeu } \\
\text { tātt(ə) }\end{array}$ & $\begin{array}{l}\text { мamb } \\
\text { mām(ə) }\end{array}$ & $\begin{array}{l}\text { дедушка } \\
\operatorname{died(ə)}\end{array}$ & $\begin{array}{l}\text { бабушка } \\
\text { bāb(ә) }\end{array}$ \\
\hline вельй & ucap & & & \\
\hline бpam & естра & & & \\
\hline vel'j(ə) si & $\operatorname{sar}(\partial)$ & & & \\
\hline
\end{tabular}

$\begin{array}{clllll}\text { (176) пойкыне } & \text { пойк } & \text { тьӥтӓр } & \text { тьӥттӧ } & \text { миез } & \text { найн } \\ \text { мальчик } & \text { сын } & \text { дочь } & \text { девочка } & \text { мужчина } & \text { женщина } \\ \text { poikənӗ } & \operatorname{poik}(ә) & \text { t'ütär(ə) } & \text { t'üttő̆ } & \text { miez } & \text { nain(ĕ/ə) }\end{array}$

196 \#r: «...Куда, это самое, рыба и остается, когда тянут - крылья есть, nuotən [невода] крылья - a sīz [тогда] рыба идет туда, и в конец туда самый, $\ldots \ldots\rangle$ nikù $\operatorname{kot}^{\prime} \mathrm{i} \overline{\mathrm{k}}(\mathrm{o})$ ono mokom [как такой мешок]».

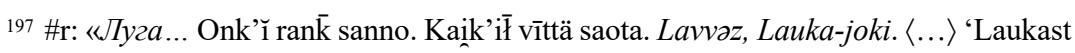
jäd kevväl' mäniv’əd jo'. 'Lavvəz on sūr jokì'. [Вот сложно сказать. По-всякому говорят. Lavvəz, Lauka-joki. 'С Луги лёд уже весной сошел'. 'Луга - большая река']. Так что этот Laukān jok’̀̀ - как бы, ну по-разному можно его сказать».

198 Текст № 1: ихмин, таaт; в тексте № 2 конечные элементы в скобках. Чтение \#1: [ihmin, tātt ${ }^{\circ}$, \#2: [ihmin, tā̄t]. \#r: < ответ на вопрос, почему написал $е$ в скобках> «Mejjen kiel'es̄ mie by sanòsin ihmin, en sao ihmine, a ihmin, a monèd, čto ihmine. Sīz mie niku t'ījen sitâ, monèd sannod ninta [В нашем языке я бы сказал ihmin, не говорю ihmine, а ihmin, а многие, что ihmine]». 


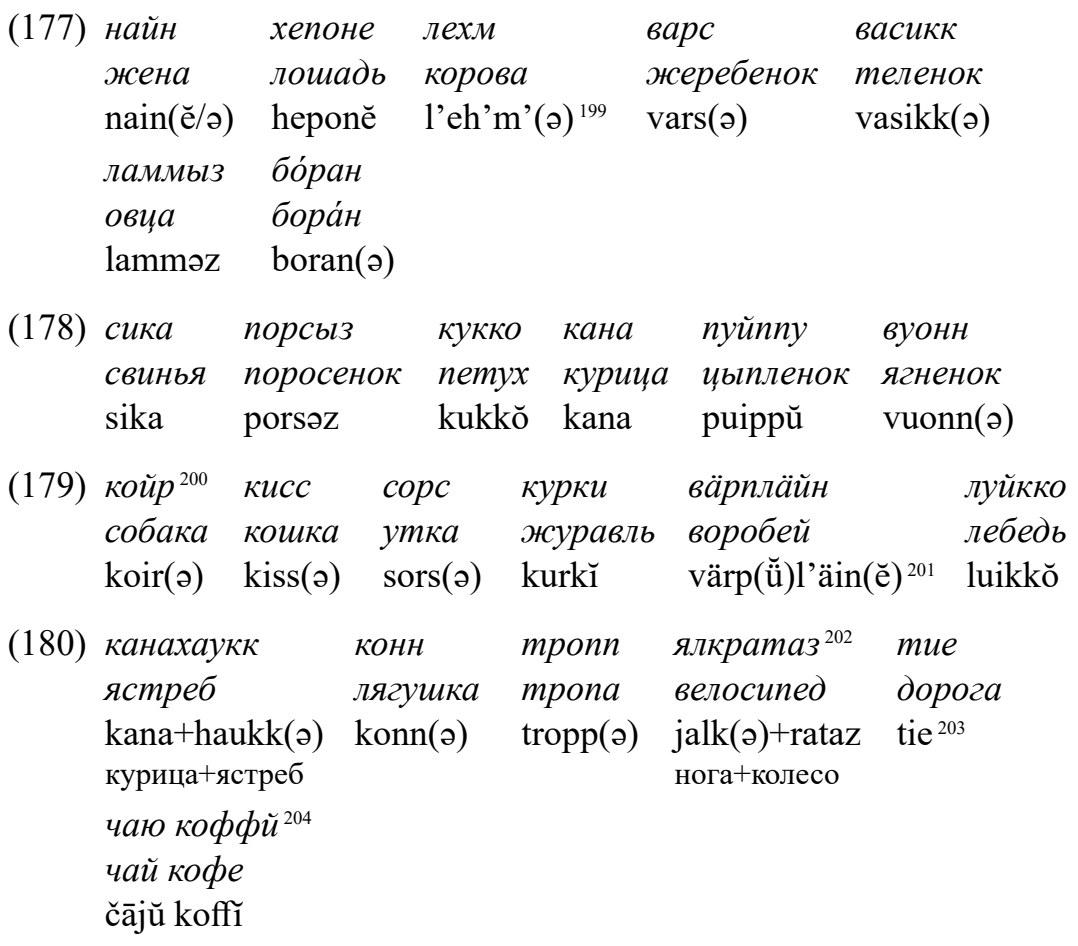

$\begin{array}{cllll}\text { (181) чайникк } & \text { панки } 205 & \text { вене } & \text { лусикк } & \text { вилк } \\ \text { чайник } & \text { ведро } & \text { лодка } & \text { ложкка } & \text { вилка } \\ \text { čainikk(ә) } & \text { pankî } & \text { vene } & \operatorname{lusikk(ə)} & \operatorname{vilk(ə)}\end{array}$

199 \#2: [leh'`m'].

${ }^{200}$ Koŭp, кисс: \#r: «Onò «и» краткий, koir. Ei uo koir [«И краткий, koirr. He koir]». Лексема kiss(ә) (< фин.), по моим полевым данным, характерна именно для н.-л. диалекта, в противоположность сойк. kazi (kissa отмечена только в северных сойк. деревнях, где был контакт с финским языком (ср. [N:141]).

201 \#2: [värpläin]; ср. фин. varpunen и эст. varblane.

202 В иж. языке rataz в ед. ч. имеет узкоспециальное значение 'колесо телеги'; обычно употребляется Pl. tantum rattad в значении 'телега' (см. raDaz в [N:460461]). \#r: <разница иж. и эст.> «Jałkratàz — jalgrattaz».

${ }^{203}$ В тексте № 1 даны подряд тие - дорога и тие - делай. Чтение \#1, \#2: [tie] (без мягкости); \#1: «это два разных слова: дорога и делай».

204 Текст № 1: коффи.

205 Данная лексема отсутствует в словаре Нирви и в сойк. диалекте (где представлено $u h l \bar{u}[\mathrm{~N}: 621]$ ), но характерна для всего н.-л. ареала (ижорского, водского, 


$\begin{array}{ll}\text { вейтси } & \text { зерккьлл } \\ \text { ножь (sic!) } & \text { зеркало } \\ \text { veitš̌ } & \text { zerkkəl(ə) }{ }^{206}\end{array}$

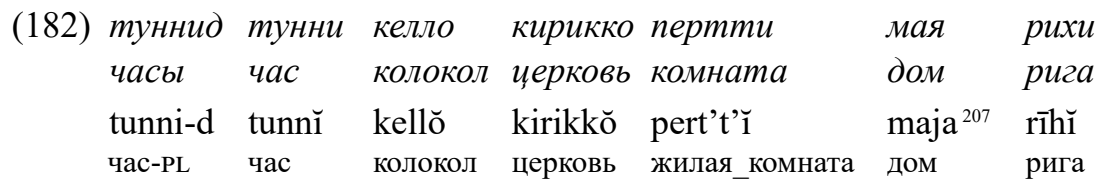

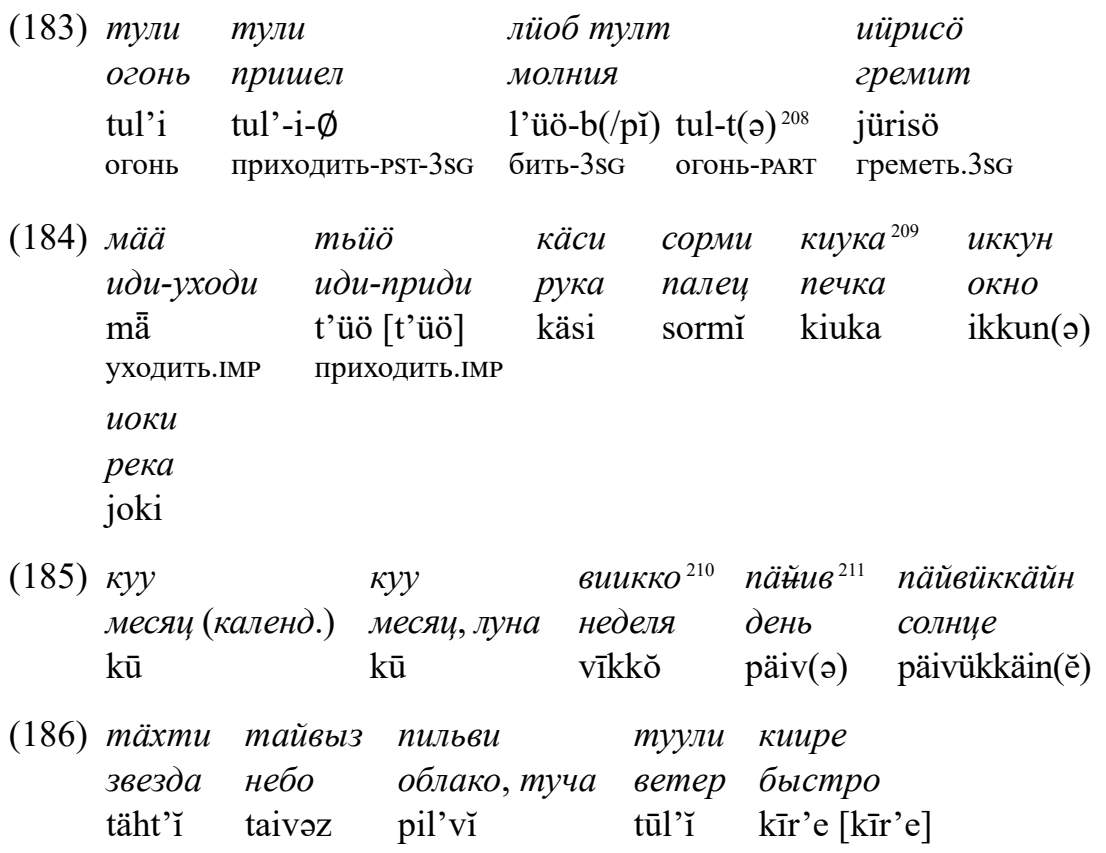

инг. финского); ср. тж. эст. pang. Ее можно отнести к водской субстратной лексике этого ареала [Муслимов, наст. сборник].

206 \#2: [zerkkəł], без палатализации.

207 В сойк. диалекте представлено только значение 'шалаш, палатка', но на Нижней Луге характерно также значение 'дом', типичное и для эстонского языка (ср. тж. [N:292]).

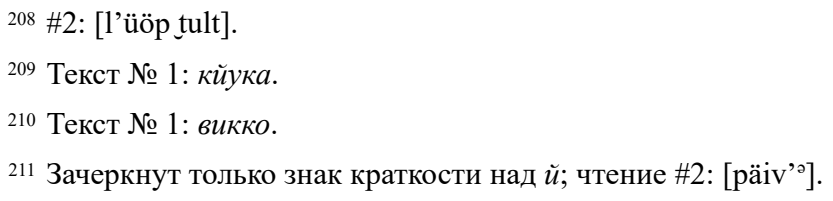




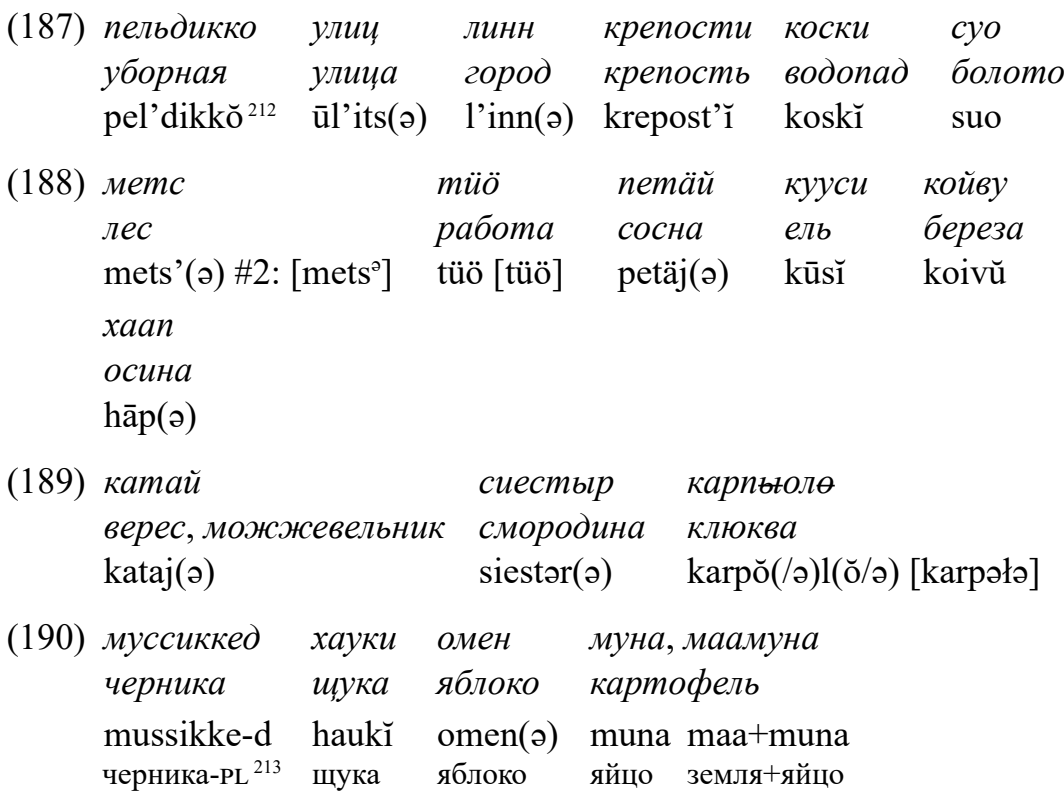

Ижорские и русские слова в (191)-(195) извлечены из ФС (на отдельном листе, не датировано). Судя по типу отображения ижорских слов, это относительно поздняя запись, т. к. здесь более тщательно отмечены редуцированные гласные (особенно ср. отображение шва как $b l$ в скобках в некоторых «стабильных» и «нестабильных» позициях, что не характерно для других записей Н. Д.).

$\begin{array}{llllll}\text { лухти } & \text { хатту } & \text { васар } & \text { кйука } & \text { леэхмь(ы) } & \text { хепоне } \\ \text { воздух } 214 & \text { шапка } & \text { молоток } & \text { печка } & \text { корова } & \text { лошадь } \\ \text { luht'̌ } & \text { hattŭ } & \text { vasar(ə) } & \text { kiuka } & \text { l'eh'm'(ə) } & \text { heponě }\end{array}$

${ }^{212}$ В [N] не зафиксировано. Н. Д. приводит нейтральные по стилистике эст. и фин. корреляты (väljakäik и ulkohuone), но ср. эст. разг. peldik. \#r: «Viròn kiel'es̄ kerà onò hä, mie en t'īje sanno, kui hän on nī распространенное, a pel'dik иногда võib sanno. 〈...〉 Meill' on sīz vist viròn kiel'est tullud [В эстонском тоже есть оно, я не могу сказать, насколько оно распространенное, a pel'di $\bar{k}$ иногда можно сказать. К нам тогда, наверно, из эстонского пришло]».

${ }^{213}$ В [N:321] в значении 'черника' приводятся mussikkain (сойк., ор.) и mussikka (н.-л., хэв., ор.) и mussikki в качестве клички коровы (сойк., н.-л.), однако в говоре Н. Д. 'черника' в NOM.SG имеет вид mussik'k'ё.

214 Пояснение в \#r: «Luht'̌ — это 'воздух', а $\operatorname{ilm}($ ə) - это только 'погода'. Почти что saksan sana on [немецкое слово], Luft». Ср. тж. эст. разг. luhvt 'воздух'. 


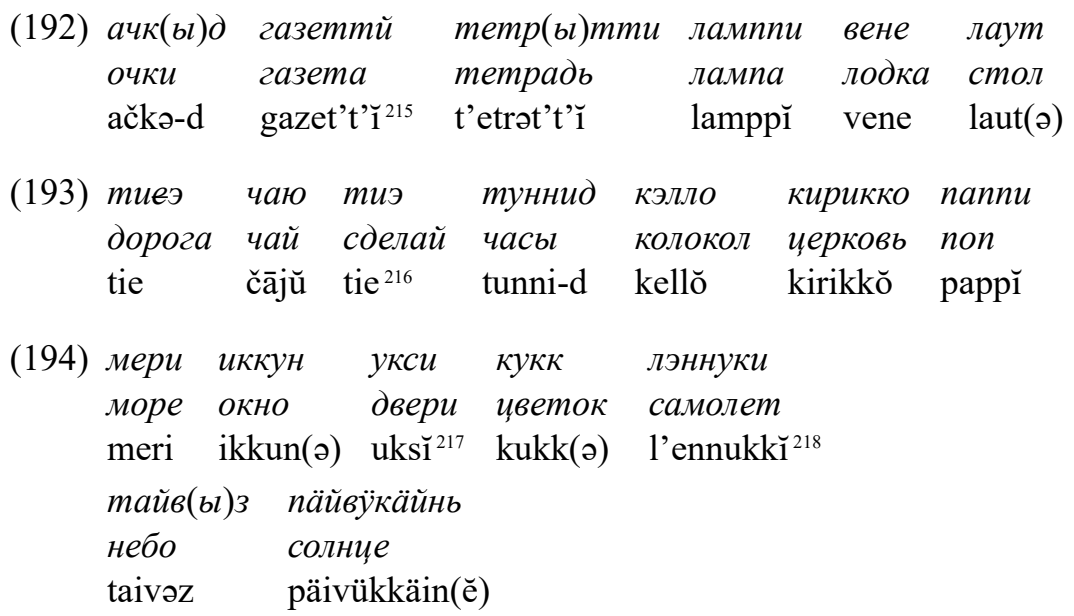

\begin{tabular}{|c|c|c|c|c|}
\hline$\kappa y y$ & $\kappa y y$ & наагл & наагл & яӓӓнлохкоиьл \\
\hline луна & месяи (календ.) & гвоздb & фунт & ледокол \\
\hline$k \bar{u}$ & $\mathrm{ku}$ & nāgl(ə) & nāgl(ə) & jä̈-n+lohkojə \\
\hline
\end{tabular}

(196) Няяльмиез Кютю Нато тоже? Нато.

Шурин Деверь Золовка Свояченииа nāl'(ə)+miez küt'ü nato nato

Кялю Маатко

Жены братьев Мать жень

käl'ü mātkŏ

(ВВ, между 18.3 .92 и 8.7.92, с. 67 ; ижорским словам предшествует рассуждение о том, как называются разные родственники по-русски, возможно, переписанное откуда-то).

215 \#: [gazèt't' '̌, t'etrět't'i].

216 \#: «t'ie, čāju, tie. Два раза́. tie — ‘дорога' и tie — 'делай’».

217 Также водский субстрат в н.-л. ареале [N:622; Муслимов, наст. сборник; ср. сойк. ovi в N: 369], см. тж. сноску 205.

218 \#: «Meil' rohk'eb viroǹ aikin̄ vob'še l'ennuk̄ ain. Sama 'l'ot se ol'ì ku vennän sanà, meil' ol'i se nikù vierəz, a l'ennuk̄ ol'ì viròn sanà, müö l'ennuk'iks kutsum̄ ain [У нас больше в эстонское время вообще всегда lennukki. Самолет - это было как русское слово, для нас, как бы, чужое, а lennuk было эстонское слово, мы всегда звали lennukki]». 


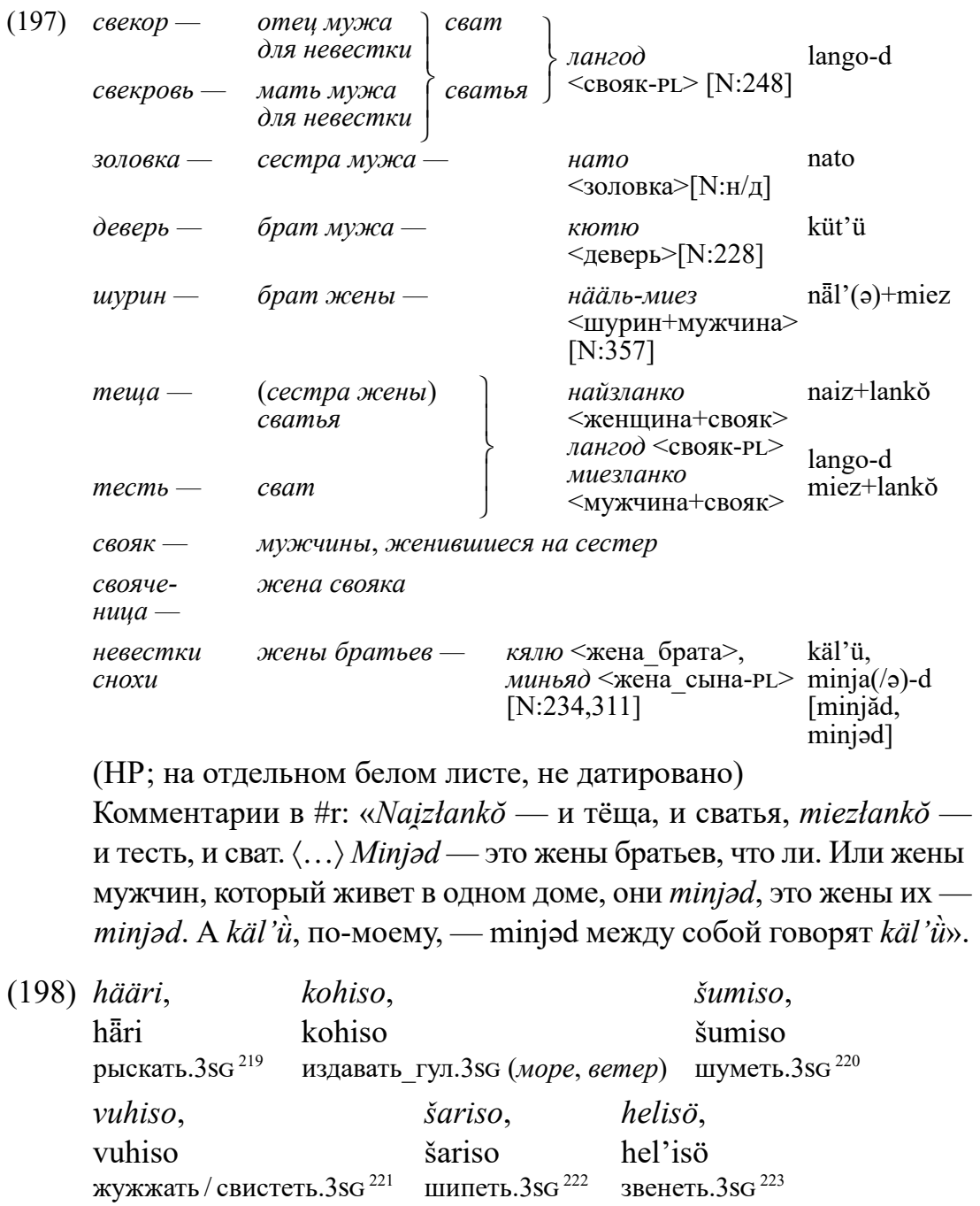

219 \#r: «Ходит туда-сюда, как бы, что-то ищет». Дальнейшие пояснения в скобках и в ссылках к экспрессивной лексике в (198) представляют собой обобщение комментариев Н. Д. при чтении и разборе.

220 Лес; кипяток на плите; ветер, море; похоже по значению на kohiso.

221 Мотор; «воздух проходит где-то, скажем, сквозь какую-то дырку».

222 Еж; филин; сало на сковородке.

223 Ухо; будильник; колокольчик и большой колокол. 


\begin{tabular}{|c|c|c|}
\hline $\begin{array}{l}\text { paukka, } \\
\text { paukka } \\
\text { издавать_хлопок.3sG (ружье) }\end{array}$ & $\begin{array}{l}\text { präkkä, } \\
\text { präkkä } \\
\text { трещать.3sG (ог }\end{array}$ & ОНь) \\
\hline $\begin{array}{l}\text { praizahti, } \\
\text { praizaht'-1- } \varnothing \\
\text { шлепнуться-PST-3sG (с шумом) }\end{array}$ & $\begin{array}{l}\text { plikka, } \\
\text { pl'ikka } \\
\text { мигать.3. }{ }^{224}\end{array}$ & $\begin{array}{l}\text { praukka, } \\
\text { praukka } \\
\text { трешать. } 3 \mathrm{sG}^{225}\end{array}$ \\
\hline
\end{tabular}

(BВ, между 9.10.2000 и 14.09.2001, с. 173).

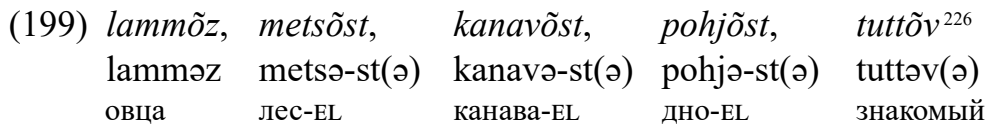

(BВ, между 9.10.2000 и 14.09.2001, с. 173).

(200) Хепосен рийс(с)ылд Пяйцед Суйщед Лянгед

сбруялошади недоуздка Уздечка Хомут

hepose-n rīssə-d ${ }^{227}$ päitse-d suitse-d ${ }^{228}$ l'änge-d

лошадь-GEN инструмент-PL недоуздок-PL узда-PL хомут-PL

Седёлк Селькнахк Ватсвӥӧ Охиьд Руоск

Седёлка Череседельник Подбрюшник Вожжи Кнут

sed'olk(ə) sel'k(ə)+nahk(ə) vats(ə)+vü ohjə-d ruosk(ә)

седёлка спина+кожа живот+пояс вожжи-PL кнут

Хепосен раут Раввытта хепост

Подкова Подковать лошадь

hepose-n raut(ə) ravvətta $\quad$ hepos-t(ə)

(ПМ, между 9.03.2011 и 28.03.2012, с. 15).

${ }^{224}$ Свет; глаз.

225 Лед; ветки, дерево; синоним präkisö.

226 Комментарий при чтении: «Я тут подчеркиваю именно $b l-$ tamməz. То говорять łammaz, и в эстонский łammas, или lampan <овца-GEN>, a täs̄ vot bl. Metsəst, mie t'üən metsəst, mie hüpsin üli kanavəst, tūl' puhhu pohjəst, hä on miun tuttəv [тут вот bl. Из леса, я иду из леса, я перепрыгнул через канаву, ветер дует с севера, он мой знакомый], вот в таком духе». Комментарий в \#r: «В ижорском языке такой крепкой буквы $b$ нету.

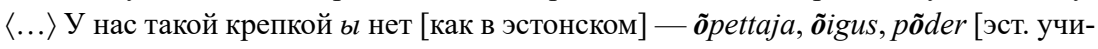
тель, право, лось]. Вот я это и имел в виду, что вот маленькие $b l$ есть, коротенькие».

227 Единственный случай отображения начального долгого гласного как сочетания с $j$ (uй) (такая практика принята, например, при передаче на русском языке эстонских слов, ср. Viitso > Buйmco); см. rīsta 'инструмент' [N:483].

${ }_{228}$ См. päitsed [N:450], suitsed [N:548]; об особенностях /ts cс/ см. в Разделе 1.3. 
(201) Pуoтемед [ruot'ěme-d <peбро_жесткости-PL> 'pёбра жесткости'] - руотем риввуд [ruot'ĕm(ә/ё)+rivvu-d < ребро_жесткости+ жердь-PL > 'рёбра жесткости'] = поперечные жерди по стропилам (кокад [koka-d <крюк-PL> 'стропила']) при покрытий крыши соломой. Kaтmо-риввуд [kattǒ+rivvu-d <крыша+жердь-PL> 'прижимные планки'] — прижавщие солому к руотемед. Затягивали березовыми прутьями, скрученные для мягкости, позднее для крепления использовалась проволока. Латид [lat'i-d < настил-PL $>$ 'потолочный настил' (Pluralia tantum) ${ }^{229}$ ] — настил из жердей на потолке хлева́, двора (ПМ, между 9.03.2011 и 28.03.2012, с. 16; подчеркивания сделаны Н. Д.).

Комментарий в \#r: «Ruot'əmed - это на крыше жерди, которые вот так идут, в длину. 〈...〉 Стропила — это вот так [горизонтально]. На эти стропилы ставятся жерди. 〈...〉 Вот это стропила, а жёрди. Когда соломой, это, крыли крышу, тогда к этим жердям привязывали в старое время прутом, скрутили прут, а последнее время проволокой. Это уже kattorivvvd. К этим, значит, привязывали, а нажимали эти солому ишшо жердями, тонкими жердями, проволкой, вот к этим ruot'emis̄ [к рёбрам жесткости]. 〈...> Lat'id как бы потолок, но но не с досо́к было плотно сделано, а из жердей. Эти жерди назывались lat'ìd, когда они так стояли». B [N: 487] отмечены варианты rōpiain (сойк.) и $r^{u} o \bar{t} t^{\prime} i a i m e r \imath^{u} v v u d$ (н.-л.).

Слова в (202)-(204) и русскоязычный контекст извлечены из описания местной традиционной пищи в ПН (не датировано).

(202) специальная бочка на ножках (таари астье) [tārĭ+ast'e <квас+ посуда > 'бочка для производства пива и кваса'] (c. 5)

(203) раствор первач (вирре) [virrě(/’ə) [\#r: virr'ə, virr'ě] <первач> 'первач, не перебродившее пиво, солодовый раствор на воде']. Для пива первачу добавили хмеля и дрожжей. Пиво начинало бродить (с.6). Пояснение в \#r, что virrě — это «жидкость, как бы».

(204) Мӓтmі. (Мямми.) [mämmі̆ <вид традиционной еды>]. Ржаную муку размешали с водой до образования полугустой массы.

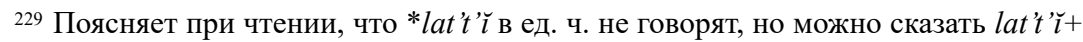
rivvu-d <настил+жердь-PL> 'потолочные жерди'. В словаре Нирви данная лексема отсутствует. 
Ставили в печку для томления. Мука разбухала, густела, приобретая сладкий вкус. Добавляли бруснику. Получилась вкусная еда (с. 7).

\section{9. Омонимы}

Эти наблюдения относятся к одним из наиболее поздних записей Н. Д. (ПМ, после 03.07.2013, с. 18-19). Жирным шрифтом ниже отмечены истинные омонимы, т. е. слова, даже исторически не имеющие общего корня. Среди прочих пар некоторые находятся на грани омонимии и полисемии.

\begin{tabular}{|c|c|c|c|}
\hline $\begin{array}{ll}\text { Mue } & \text { mo } \\
\text { mie } & \text { tal } \\
\text { я } & \text { хо }\end{array}$ & $\begin{array}{ll}\text { пахон } \\
\text { aho-n } \\
\text { tотеть-1sG }\end{array}$ & $\begin{array}{l}\text { мaаm. } \\
\text { mā-t(ə) } \\
\text { лежать-INF }\end{array}$ & \\
\hline Миулл & оно & палью & мaаm \\
\hline miu-1l(ə) & ə) ono & pal'jŭ & mā-t(ə) \\
\hline я-AD & быть.33c & G много & земЛЯ-PART \\
\hline
\end{tabular}

(206) тие тие лоуныд лоуныд туули куу куу делай дорога обед южный ветер луна месяи tie [tie] tie [tie] lounəd lounəd+tūl'̌̌ kū kū делать.IмР дорога обед юг+ветер месяц месяц

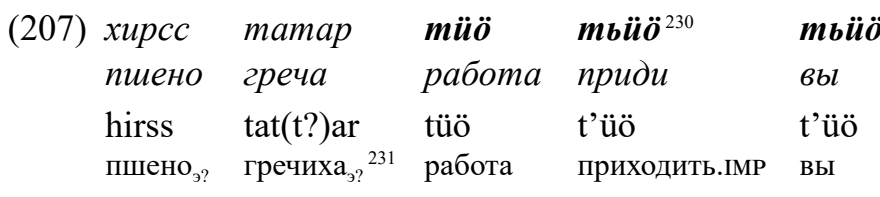

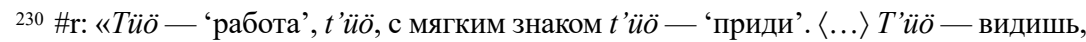
почти что ‘приди’ и $t$ ’ӥӧ — 'вы’. В нашем языке мало практикуют слово 'вы’, $t$ 'ӥо̆,

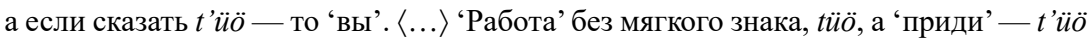
и 'вы'-t'ӥӧ».

231 Хирсс и татар скорее всего являются эстонизмами. Их произношение, к сожалению, не зафиксировано, однако орфографический облик обнаруживает эстонское влияние (отсутствие этимологического конечного $i$ и ожидаемой геминации интервокального согласного в татар на письме). В словаре Нирви не отмечены; для сойк. диалекта приводятся русские заимствования sanasūrima 'пшённая крупа' 


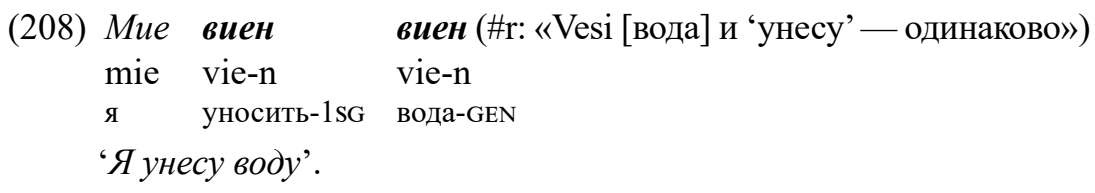

\begin{tabular}{|c|c|c|c|}
\hline (209) мӥ̈̈ & мӥ̈̈ & кайво & кайво 232 \\
\hline продай & $M b l$ & колодец & копал \\
\hline $\begin{array}{l}\text { müӧ } \\
\text { продавать.IмP }\end{array}$ & $\begin{array}{l}\text { müö } \\
\text { мы }\end{array}$ & $\begin{array}{l}\text { kaivŏ } \\
\text { колодец }\end{array}$ & $\begin{array}{l}\text { kaivŏ } \\
\text { копать.PST.3sG }\end{array}$ \\
\hline мӓ̈̈ & мие & хӓ̈̈ & \\
\hline$u \partial u$ & $я$ & он, она & \\
\hline $\begin{array}{l}\text { mä } \\
\text { уходить.ІмР }\end{array}$ & mie & $\begin{array}{l}\text { hä hä } \\
\text { oн/a }\end{array}$ & \\
\hline
\end{tabular}

$\begin{array}{llll}\text { (210) канамуна } & \text { маамуна } & \text { наагл } & \text { наагл } \\ \text { яйцо } & \text { картофель } & \text { гвоздь } & \text { фунт } \\ \text { kana+muna } & \text { mā+muna } & \text { nāgl(ə) } & \text { nāgl(ə) } \\ \text { курица+яйцо } & \text { земля+яйцо } & \text { гвоздь } & \text { фунт }^{233}\end{array}$

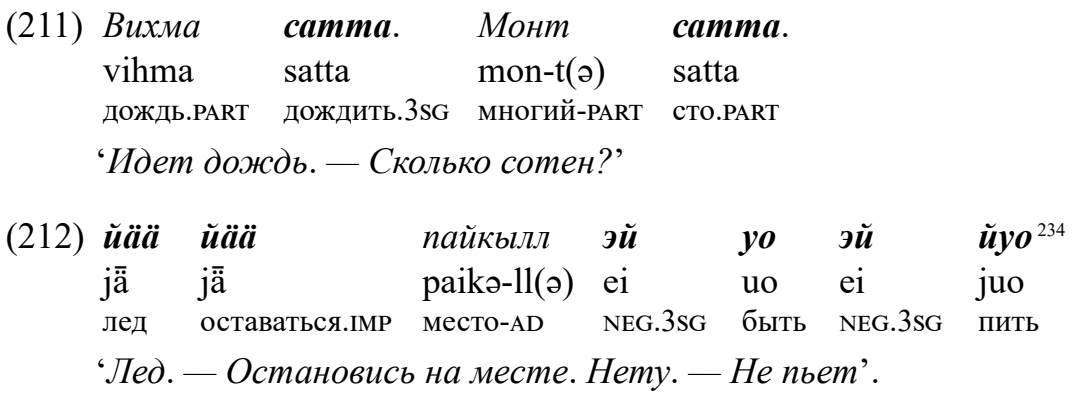

(< pyc. пшено) и krētsisuurima (< pyc. греча). В тексте «Пища наша» Н. Д. сам отмечает, что основные типы каш у них были из ячменя (см. сноску 171).

232 Данные слова являются однокоренными омонимами, но исторически их фонологический облик различался: кайво (kaivŏ <*kaivo) 'колодец' и кайво (kaivŏ $<$ *kaivoi) 'копал'.

233 \#r: «У меня безмен сейчас тысячу восемьсот восемьдесят третьего года, там фунтовая, это самое, шкала. Ну и когда вешаешь, то в фунтах. 〈... Да, раньше фунтами было. Килограммы позже вошли».

234 Данная пара не является полностью омонимичной (это отражено в записи Н. Д. и отмечено им при чтении), т. к. в сандхи одиночный $j$ оказывается противопоставлен геминированному $\bar{\jmath}$. 


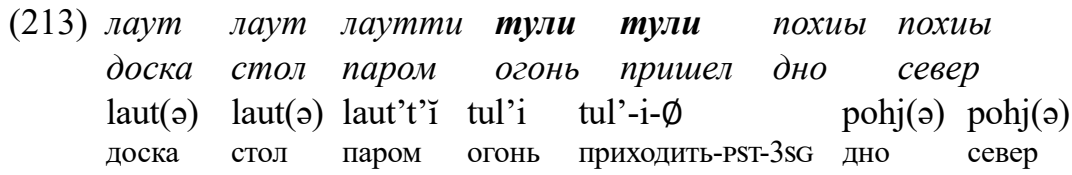

(214) тьӥо тӓнн мӓӓ синн эн кехта

иди сюда иди туда эй виитси (эст.) $)^{235}$

t’üö tänn(ə)(ILL) mā

приходить.IмP сюда уходить.IMP туда NEG-1SG

kehta

иметь_желание

'Иди сюда. - Иди туда'. 'Неохота'.

\section{Список условных сокращений}

Индексы языков: вод. - водский язык, инг. фин. - ингерманландские финские диалекты; кар. — карельский язык; н.-л. нижнелужский ижорский диалект; ор. - оредежский ижорский диалект; рили рус. - русский язык, п.-ф. — прибалтийско-финские языки; сойк. - сойкинский

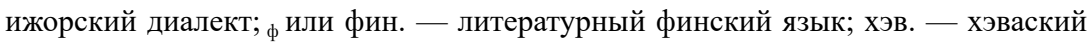

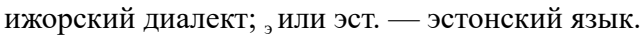

Глоссы: + - соединение частей композитов, = - словообразовательная морфема, $\varnothing$ - нулевой показатель (3SG глаголов), 1, 2, 3 - 1, 2, 3 лицо, ABL - аблатив, $\mathrm{ACC}$ - аккузатив, ADJ - прилагательное, $\mathrm{AD}$ - синкретичный показатель адессива-аллатива, ALL - аллатив (в эст. языке), сом - комитатив, сOMP - сравнительная степень (показатели прилагательного и наречия не разводятся, см. сноску 141), CND - условное наклонение, EL — элатив, EMPH - положительно поляризованная усилительная частица, ESS - эссив, GEN - генитив, IDF - неопределенная частица, ILL - иллатив, IMP - повелительное наклонение, IN - инессив, INF - инфинитив, IPS - имперсональный залог, NEG - отрицание, NOM - номинатив, NMLZ - глагольная номинализация, ORD - порядковое числительное, PART — партитив, PC_IPS. PST - имперсональное причастие со значением предшествования, PC_PRS - активное причастие со значением одновременности, PC_PST - активное причастие со значением предшествования, PL - множественное число, PRS - непрошедшее время, PST - прошедшее время, Q - вопросительная частица, SG - единственHое число, SUP - супин, TERM - терминатив, TRL - транслатив, тOP — топонимический формант.

235 В данном случае Н. Д. перевел не на русский язык, а на эстонский, поскольку ему, очевидно, было проще подобрать переводной эквивалент (трудность подбора русского эквивалента для Н. Д. обнаружилась и при разборе данного фрагмента). 
Транскрипция: ['] — главное ударение, [,] — второстепенное ударение, [] — межсловесное сандхи, [i] - редуцированный гласный призвук, [i] - оглушенный гласный, [1] — редуцированный гласный, [i] — неслоговой гласный, [i] — краткий гласный, [i] — продленный гласный, [ī] — долгий гласный, [ә] — «шва», редуцированный нелабиализованный гласный среднего ряда среднего подъема, [tt] — гемината, [t't] — полупалатализованная гемината, [t't'] — палатализованная гемината, $\left[\mathrm{t}^{\circ}\right]$ - лабиализованный согласный; /ə/ — шва в стабильной позиции, /(ә)/ — шва в нестабильной позиции, $/ \mathbf{1} /$ — прочие редуцированные гласные (в основном) в нестабильной позиции, /i/ — полные краткие гласные.

\section{Литература}

Кузнецова 2009 - Н. В. Кузнецова. Фонологические системы ижорских диалектов. Дисс. ... канд. филол. наук. СПб.: ИЛИ РАН, 2009.

Кузнецова 2012 - Н. В. Кузнецова. Просодика словоформы в нижнелужском диалекте ижорского языка // Acta Linguistica Petropolitana. Труды Института лингвистических исследований. 2012. Т. VIII. Ч. 1. С. 43-103.

Кузнецова, Холодилова 2012 - Н. В. Кузнецова, М. А. Холодилова. Приложение 8. Правила представления языкового материала и список глосс // Acta Linguistica Petropolitana. Труды Института лингвистических исследований. 2012. T. VIII. Ч. 1. С. 575-586.

Куусинен 1999 - М. Э. Куусинен (ред.). Новый большой русско-финский словарь. T. I-II. М.: Русский язык, 1999.

Лаанест 1966а - А. Лаанест. Ижорские диалекты. Лингвогеографическое исследование. Таллинн: Академия наук Эстонской ССР, Институт языка и литературы, 1966.

Лаанест 1966b - А. Х. Лаанест. Ижорские диалектные тексты. Таллинн: Академия наук Эстонской ССР, Институт языка и литературы, 1966.

Муслимов 2005 - М. З. Муслимов. Языковые контакты в Западной Ингерманландии (нижнее течение реки Луги). Дисс. ... канд. филол. наук. СПб.: ИЛИ РАН, 2005.

Муслимов 2012 - М. 3. Муслимов. «Народная диалектология» в нижнелужском ареале // Acta Linguistica Petropolitana. Труды Института лингвистических исследований. 2012. Т. VIII. Ч. 1. С. 135-193.

Муслимов, наст. сборник - М. З. Муслимов. Об идиоме дер. Куровицы (Kukkõsi/ Kukkuzi). Наст. сборник.

Оллыкайнен 2003 - В. М. Оллыкайнен (сост.). Словарь северно-ингерманландских говоров финского языка (говоры вуолэ и колтушский) (Kotimaisten kielten tutkimuskeskuksen julkaisuja, 127). Vantaa: Kotimaisten kielten tutkimuskeskus; ИЯЛИ КарНЦ РАН, 2003.

Пыдер 2006 - Н. Д. Пыдер. Деревня Ванакюля - Илькино. Краткий исторический очерк (подг. к печати библиотека д. Б. Куземкино), 2006.

Пыдер 2019 - Н. Пыдер. Родился я в Эстонской Ингерманландии / Сост. В. А. Пилли. СПб.: Гйоль, 2019. 
Рожанский, Маркус 2012 - Ф. И. Рожанский, Е. Б. Маркус. «Золотая птица» (публикация ижорской сказки, записанной в XIX веке) // Acta Linguistica Petropolitana. Труды Института лингвистических исследований. 2012. Т. VIII. Ч. 1. С. 448-503. ЭСБЕ 1904 - Ф. А. Брокгаузъ, И. А. Ефронъ (изд.). Энциклопедический словарь. В 86 т. Т. 81. Эрданъ - Яйценошеніе. СПб.: Типографія Акц. Общ. Брокгаузъ-Ефронъ, 1904.

ЯмТВ 2011 - Николай Пыдер, др. Ванакюле. Опубликовано: 17.02.2011 23:25. Автор: ЯмTB. URL: https://городкингисепп.рф/54-ямтв-2011-02-17-20-27-32; https://www.youtube.com/watch?v=PKoMqN5FUPk (дата обращения: 11.12.2020).

Ariste 1969 - P. Ariste. Vadja rahvakalender. Tallinn: Valgus; NSV Teaduste Akadeemia, 1969.

EVS 2019 - Eesti-vene sõnaraamat. 2019. 2., täiendatud ja kohandatud veebiväljaanne. URL: http://www.eki.ee/dict/evs/index.cgi (дата обращения: 11.12.2020).

KKVS 2015 - M. Torikka, L. Joki. (eds). Karjalan kielen verkkosanakirja. 2009-2015. URL: http://kaino.kotus.fi/cgi-bin/kks/karjala.cgi (дата обращения: 11.12.2020).

Koivisto 1990 - J. Koivisto. Suomen murteiden refleksiivitaivutus. Helsinki: Suomalaisen kirjallisuuden seura, 1990.

Krjukov 2011 - A. Krjukov. Laukaal // Inkeri. 2011. No. 1 (074). P. 13.

Kryger 2011 - O. Kryger. Jäniksin peltoi (kaasku Ala-Laukaan murteella) // Inkeri. 2009. No. 2 (071). S. 11.

Kuznetsova 2012 - N. Kuznetsova. Vowel reduction in Lower Luga Ingrian: scientific description and "folk" perception // 'Folk linguistics': Language from speakers' perspective: Paper abstracts for the conference, St. Petersburg, November 19-21. St. Petersburg: Institute of Linguistic Studies, 2012. P. 85-87.

Kuznetsova 2016 - N. Kuznetsova. Evolution of the non-initial vocalic length contrast across Finnic varieties of Ingria and the adjacent areas // Linguistica Uralica. 2016. № 52 (1). P. 1-25.

Kuznetsova, Verkhodanova 2019 - N. Kuznetsova, V. Verkhodanova. Phonetic realisation and phonemic categorisation of the final reduced corner vowels in the Finnic languages of Ingria // Phonetica. 2019. Vol. 76. № 2-3. P. 201-233.

Lehtinen 1984 - T. Lehtinen. Eräiden paradigmatyyppien taustaa // Virittäja. 1984. № 17. S. 17-46.

Malchukov 2000 - A. L. Malchukov. Dependency reversal in noun-attributive constructions: towards a typology. (LINCOM Studies in Language Typology 3). München: LINCOM Europa, 2000.

Markus, Rozhanskiy 2014 - E. Markus, F. Rozhanskiy. Comitative and terminative in Votic and Lower Luga Ingrian // Linguistica Uralica. 2014. № 50 (4). P. 241-257.

Markus, Rozhanskiy 2017 - E. Markus, F. Rozhanskiy. The essive in Ingrian // C. de Groot (ed.). Uralic essive and the expression of impermanent state (Typological studies in language, 119). Amsterdam: John Benjamins, 2017. P. 113-129.

Mirenkov 2001 - V. Mirenkov. Izorid (käänsi Nikolai Poder, Vanakylä) // Izoran meeli. 2001. № 4. S. 11.

Mirenkov, Põder 2009 - V. Mirenkov, N. Põder (toim. A. Krjukov, M. Muslimov). Inkerikot itsestään // Inkeri. 2009. № 2 (071). S. 9-10. 
Mägiste 1925 - J. Mägiste. Rosona (Eesti Ingeri) murde pääjooned. (Acta et commentationes Universitatis Tartuensis; B, Humaniora 7, 3). Tartu: E.K.Ü. "Postimehe" trükk, 1925.

Nirvi 1971 - R. E. Nirvi (toim.). Inkeroismurteiden sanakirja (Lexica Societatis Fenno-Ugricae, 18). Helsinki: Suomalais-Ugrilainen Seura, 1971.

Virtaranta 1967 - P. Virtaranta. Lähisukukielten lukemisto (Suomalaisen Kirjallisuuden Seuran Toimituksia, 280). Helsinki: Suomalaisen Kirjallisuuden Seura, 1967.

Virtaranta, Suhonen 1978 - P. Virtaranta, S. Suhonen. Lähisukukielet. Helsinki: Suomalaisen Kirjallisuuden Seura, 1978.

Virtaranta, Suhonen 1983 - P. Virtaranta, S. Suhonen. Lähisukukielet. 2. korjattu painos. Helsinki: Suomalaisen Kirjallisuuden Seura, 1983.

VISK 2008 - A. Hakulinen, M. Vilkuna, R. Korhonen, V. Koivisto, T. Heinonen, I. Alho. Iso suomen kielioppi. Helsinki: Suomalaisen kirjallisuuden seura, 2004. URL: http://scripta.kotus.fi/visk/etusivu.php (дата обращения: 11.12.2020).

VKS 2013 - S. Grünberg (ed.). Vadja keele sõnaraamat. 2., täiendatud ja parandatud trükk. Tallinn: Eesti Keele Sihtasutus, Eesti Keele Instituut, 2013.

\section{References}

Ariste 1969 - P. Ariste. Vadja rahvakalender. Tallinn: Valgus; NSV Teaduste Akadeemia, 1969.

ESBE 1904 - F. A. Brockhaus, I. A. Efron (ed.). Entsiklopedicheskiy slovar [Encyclopedic Dictionary]. In 86 vol. Vol. 81. Erdan - Yaytsenoshenie. St. Petersburg: Typography of Brockhaus-Efron Joint Stock Company, 1904.

EVS 2019 - Eesti-vene sõnaraamat. 2019. 2., täiendatud ja kohandatud veebiväljaanne. Available at: http://www.eki.ee/dict/evs/index.cgi (accessed: 11.12.2020).

KKVS 2015 - M. Torikka, L. Joki (eds). Karjalan kielen verkkosanakirja. 2009-2015. Available at: http://kaino.kotus.fi/cgi-bin/kks/karjala.cgi (accessed: 11.12.2020).

Koivisto 1990 - J. Koivisto. Suomen murteiden refleksiivitaivutus. Helsinki: Suomalaisen kirjallisuuden seura, 1990.

Krjukov 2011 - A. Krjukov. Laukaal. Inkeri. 2011. No. 1 (074). P. 13.

Kryger 2011 - O. Kryger. Jäniksin peltoi (kaasku Ala-Laukaan murteella). Inkeri. 2009. No. 2 (071). S. 11.

Kuusinen 1999 - M. E. Kuusinen (ed.). Novyy bolshoy russko-finskiy slovar [New big Russian-Finnish dictionary]. Vol. I-II. Moscow: Russkiy yazyk.

Kuznetsova 2009 - N. V. Kuznetsova. Fonologicheskie sistemy izhorskikh dialektov [Phonological systems of Ingrian dialects]. Candidate thesis. St. Petersburg: Institute for linguistic studies, Russian Academy of Sciences, 2009.

Kuznetsova 2012 - N. V. Kuznetsova. Prosodika slovoformy v nizhneluzhskom dialekte izhorskogo yazyka [Wordform prosody in the Lower Luga dialect of Ingrian]. Acta Linguistica Petropolitana. Trudy Instituta lingvisticheskikh issledovaniy. 2012. Vol. VIII. Pt. 1. P. 43-103. 
Kuznetsova 2012 - N. Kuznetsova. Vowel reduction in Lower Luga Ingrian: scientific description and 'folk" perception. 'Folk linguistics': Language from speakers' perspective. Paper abstracts for the conference, St. Petersburg, November 19-21. St. Petersburg: Institute of linguistic Studies, 2012. P. 85-87.

Kuznetsova 2016 - N. Kuznetsova. Evolution of the non-initial vocalic length contrast across Finnic varieties of Ingria and the adjacent areas. Linguistica Uralica. 2016. No. 52 (1). P. 1-25.

Kuznetsova, Holodilova 2012 - N. V. Kuznetsova, M. A. Kholodilova. Appendix 8. Principles of presenting language material and the list of glosses. Acta Linguistica Petropolitana. Trudy Instituta lingvisticheskikh issledovaniy. 2012. Vol. VIII. Pt. 1. P. 575-586.

Kuznetsova, Verkhodanova 2019 - N. Kuznetsova, V. Verkhodanova. Phonetic realisation and phonemic categorisation of the final reduced corner vowels in the Finnic languages of Ingria. Phonetica. 2019. Vol. 76. No. 2-3. P. 201-233.

Laanest $1966 \mathrm{a}$ - A. Laanest. Izhorskiye dialekty. Lingvogeoraficheskoye issledovaniye [Ingrian dialects. Linguistic-geographical study]. Tallinn: Institute of Language and Literature, Academy of Sciences of the Estonian SSR Press, 1966.

Laanest 1966b - A. H. Laanest. Izhorskie dialektnye teksty [Ingrian dialectal texts]. Tallinn: Institute of Language and Literature, Academy of Sciences of the Estonian SSR Press, 1966.

Lehtinen 1984 - T. Lehtinen. Eräiden paradigmatyyppien taustaa. Virittäja. 1984. No. 17. S. 17-46.

Mägiste 1925 - J. Mägiste. Rosona (Eesti Ingeri) murde pääjooned. (Acta et commentationes Universitatis Tartuensis; B, Humaniora 7, 3). Tartu: E.K.Ü. "Postimehe" trükk, 1925.

Malchukov 2000 - A. L. Malchukov. Dependency reversal in noun-attributive constructions: towards a typology. (LINCOM Studies in Language Typology 3). München: LINCOM Europa, 2000.

Markus, Rozhanskiy 2014 - E. Markus, F. Rozhanskiy. Comitative and terminative in Votic and Lower Luga Ingrian. Linguistica Uralica. 2014. No. 50 (4). P. 241-257.

Markus, Rozhanskiy 2017 - E. Markus, F. Rozhanskiy. Essive in Ingrian. C. de Groot (ed.). Uralic Essive and the Expression of Impermanent State (Typological studies in language, 119). Amsterdam: John Benjamins, 2017. P. 113-129.

Mirenkov 2001 - V. Mirenkov. Izorid (käänsi Nikolai Poder, Vanakylä). Izoran meeli. 2001. No. 4. S. 11.

Mirenkov, Põder 2009 — V. Mirenkov, N. Põder (toim. A. Krjukov, M. Muslimov). Inkerikot itsestään. Inkeri. 2009. No. 2 (071). S. 9-10.

Muslimov 2005 - M. Z. Muslimov. Yazykovyye kontakty v Zapadnoy Ingermanlandii (nizhneye techeniye reki Lugi) [Language contacts in West Ingria (a lower course of the Luga river)]. Candidate thesis. St. Petersburg: Institute for Linguistic Studies, Russian Academy of Sciences, 2005.

Muslimov 2012 - M. Z. Muslimov. «Narodnaya dialektologiya» v nizhneluzhskom areale ["Folk dialectology" in the Lower Luga area]. Acta Linguistica Petropolitana. Trudy Instituta lingvisticheskikh issledovaniy. 2012. Vol. VIII. Pt. 1. 135-193. 
Muslimov, this volume - M. Z. Muslimov. Ob idiome der. Kurovitsy (Kukkõsi/Kukkuzi) [On the idiom of the Kurovitsy (Kukkõsi/Kukkuzi) village]. This volume.

Nirvi 1971 - R. E. Nirvi (toim.). Inkeroismurteiden sanakirja (Lexica Societatis Fenno-Ugricae, 18). Helsinki: Suomalais-Ugrilainen Seura, 1971.

Ollikainen 2003 - V. M. Ollikainen (comp.). Slovar severno-ingermanlandskikh govorov finskogo yazyka (govory vuole $i$ koltushskiy) [Dictionary of North Ingrian Finnish varieties (Vuole and Koltushi varieties)] (Kotimaisten kielten tutkimuskeskuksen julkaisuja, 127). Vantaa: Kotimaisten kielten tutkimuskeskus; Institute of Language and Literature of the Karelian Scientific Center of the Russian Academy of Sciences Press, 2003.

Põder 2006 — N. D. Põder. Derevnya Vanakülä — Ilkino. Kratkiy istoricheskiy ocherk (podg. k pechati biblioteka d. B. Kuzemkino) [Village of Vanakülä — Ilkino. A brief historical overview. Prepared for print at the library of the B. Kuzemkino village], 2006.

Põder 2019 - N. Põder. Rodilsya ya v Estonskoy Ingermanlandii [I was born in Estonian Ingria]. Comp. by V. A. Pilli. St. Petersburg: Gyol, 2019.

Rozhanskiy, Markus 2012 - F. I. Rozhanskiy, E. B. Markus. «Zolotaya ptitsa» (publikatsiya izhorskoy skazki, zapisannoy v XIX veke) ["The golden bird" (publication of an Ingrian folktale collected in the $19^{\text {th }}$ century)]. Acta Linguistica Petropolitana. Trudy Instituta lingvisticheskikh issledovaniy. 2012. Vol. VIII. Pt. 1. P. 448-503.

Virtaranta 1967 — P. Virtaranta. Lähisukukielten lukemisto (Suomalaisen Kirjallisuuden Seuran Toimituksia, 280). Helsinki: Suomalaisen Kirjallisuuden Seura, 1967.

Virtaranta, Suhonen 1978 - P. Virtaranta, S. Suhonen. Lähisukukielet. Helsinki: Suomalaisen Kirjallisuuden Seura, 1978.

Virtaranta, Suhonen 1983 - P. Virtaranta, S. Suhonen. Lähisukukielet. 2. korjattu painos. Helsinki: Suomalaisen Kirjallisuuden Seura, 1983.

VISK 2008 - A. Hakulinen, M. Vilkuna, R. Korhonen, V. Koivisto, T. Heinonen, I. Alho. Iso suomen kielioppi. Helsinki: Suomalaisen Kirjallisuuden Seura, 2004. Available at: http://scripta.kotus.fi/visk/etusivu.php (accessed: 11.12.2020).

VKS 2013 - S. Grünberg (ed.). Vadja keele sõnaraamat. 2., täiendatud ja parandatud trükk. Tallinn: Eesti Keele Sihtasutus, Eesti Keele Instituut, 2013.

YamTV 2011 - Nikolay Pyder dr. Vanakyule. Published: 17.02.2011 23:25 Author: YamTV. Available at: https://gorodkingisepp.rf/54-yamtv-2011-02-17-20-27-32; https://www.youtube.com/watch?v=PKoMqN5FUPk (accessed: 11.12.2020). 


\section{Межэтническое контактирование в Карелии в свете данных карелоязычной географической терминологии"}

\section{Д. В. Кузьмин}

Институт языка, литературы и истории, Карельский научный центр РАН, Петрозаводск; kusmiccu@hotmail.com

Аннотация. Географические названия традиционно используются в качестве источника информации по истории заселения того или иного региона, и Республика Карелия не является исключением. Недавние исследования показали, что важная роль в топонимии принадлежит местной географической лексике, представленной в большом количестве географических названий. Мы считаем, что исследование ареалов ее распространения является многообещающим направлением как с точки зрения топонимических исследований как таковых, так и с точки зрения этноисторических проблем. Причина этого заключается в том, что ареальная дистрибуция целого ряда местных географических терминов может указывать на связь исследуемой территории с другими языковыми и диалектными зонами. В карельском языке, например, наиболее ранними из достоверно определяемых заимствований в этой области являются географические термины (пра)саамского и вепсского происхождения, датируемые периодом первой половины второго тысячелетия, в то время как русская и финская ландшафтная терминология относится к более позднему временному срезу — периоду второй половины прошлого тысячелетия. Таким образом, выявление и изучение заимствованной географической лексики позволит глубже понять этноязыковые процессы в Карелии, которые в конечном итоге привели здесь к формированию карельского населения.

Ключевые слова: топонимия, географическая терминология, языковые контакты, Карелия.

* Публикация подготовлена в рамках выполнения проекта РФФИ № 19-01200068А «Ойконимическая система южной Карелии: на стыке традиций и инноваций». 


\title{
Transethnic Contacts in Karelia as Revealed by Karelian Toponymy Evidence
}

\section{V. Kuzmin}

Institute of Language, Literature and History, Karelian Scientific Center, Russian Academy of Sciences, Petrozavodsk; kusmiccu@hotmail.com

\begin{abstract}
Geographical names are traditional sources of information on the settlement history of a region, and the Republic of Karelia is no exception. Recent studies have demonstrated that toponymy is an essential source for investigating the history of the region. The local geographical vocabulary represented by an immense amount of place names is an important source of toponymic data and a promising object of toponymic research proper as well as of ethno-historical studies. The fact is that the distribution of the fairly numerous local geographical terms may reveal certain links between a given area and other language and dialect zones.

The Sami are known to be native inhabitants of Karelia, and their traces in the toponymy of Karelia are quite significant. Furthermore, Karelian dialects contain quite a number of geographical terms of the Sami origin: cf. čiekerö 'reindeer herding ground', čulppo 'upland', jänkä 'large wetland', köynäs 'waterfall', lašša 'rocky shoal, rocky bottom exposed at low tide', puahto 'cliff; precipice', or vuara 'wooded upland'.

The presence of some typical Finnish lexis in the Karelian toponymy is an indication of ancient migrations from the Finnish territory. Further evidence for this is found in the lexical borrowings in Karelian dialects: cf. heittijö 'abandoned field', hitelikkö 'wooded ridge; dense young pine stand', juokšu 'water current', kunnaš 'mount, hill, slope', kutveikko 'rough, densely overgrown site', lamu 'flatbottomed hollow between hills', letto 'small rocky site', loma 'gully, ravine, hollow between hills; crevice', nikara 'small mound; (small) river rapid'.

A close affinity of the South Karelian and Vepsian toponymic systems makes identification of different Vepsian traits in the toponymy of Karelia rather a challenging task. The geographical lexical borrowings from Vepsian to Karelian are not numerous either. Nonetheless, some known toponymic and lexical facts do suggest that Vepsians could have directly contributed to the formation of the population of the southern parts of Karelia: cf. *čuhakko 'hill', kuare 'gully', kuarakko 'lowland, hollow', palde 'slope of a mount or knoll; hillside', burde, purde, 'spring, fountainhead', *viranda, *veran$d u z$ 'slashed site ready for burning'.

Both toponymic and lexical material provide evidence of centuries of contacts with Slavic population whereby Karelian has acquired many words of the Russian origin, including borrowings into the landscape vocabulary: cf. *bojovišš $u$ 'site where spawning fish is caught', bruudu 'pond; lakelet', *bukl'a 'backwater (with springs)', dremužik 'site overgrown with mixed forest', loššina 'hollow, lowland', or *lovišša 'hunting or fishing ground'.

Thus, further efforts to identify and study the borrowed vocabulary will ensure deeper understanding of the linguistic and ethnic processes in Karelia that have eventually shaped its current population.
\end{abstract}

Keywords: toponymy, geographic terminology, language contacts, Karelia. 


\section{1. Введение}

Географические названия традиционно используют в качестве источника по истории заселения того или иного региона. Не является исключением и Республика Карелия.

В топонимии, как известно, важную роль играет местная географическая лексика, которая представлена в огромном количестве топонимических названий. Ее ареальное изучение является одним из перспективных направлений, как в рамках исследований по самой топонимии, так и в работах этноисторической направленности. Распространение целого ряда местных географических терминов может указывать на связи той или иной территории с другими языковыми и диалектными зонами. В частности, появление в топонимии и апеллятивной лексике Карелии некоторых географических терминов может быть увязано с освоением исследуемого региона представителями различных этнических групп: саамами, вепсами, финнами, русскими. В статье последовательно рассматривается географическая терминология различного происхождения: саамского (Раздел 2), финского (Раздел 3), русского (Раздел 4), вепсского (Раздел 5); в Разделах 6 и 7 рассматриваются топонимические модели с детерминантами -vesi/-vezi и -puro, наличие которых может свидетельствовать о проникновении в Карелию восточно-финского саволакского населения. В Заключении (Раздел 8 ) подводятся итоги исследования.

\section{2. Географическая терминология саамского ${ }^{1}$ происхождения}

Известно, что коренными обитателями территории Карелии были саамы. Вопрос об их пребывании в данном регионе на ранних этапах его истории не вызывает сомнения, хотя степень участия саамов в формировании этнической общности карел до сих пор остается невыясненной. Саамы оставили значительный след в топонимии Карелии. Кроме

${ }^{1}$ При написании этого раздела были использованы словари и исследования по саамскому языку [Itkonen 1958; Itkonen 1986; Lehtiranta 1989]. 
этого, и в языке карельского населения фиксируется целый ряд географических терминов саамского ${ }^{2}$ происхождения.

Kap. čiekerö, kiekerö 'место выпаса оленей' <*čieker' ' 'зимнее пастбище для оленей'.

Кар. с̌eyri, с̌еuru 'песок', с̌ӓyri ‘крупный песок; галька', с̌eyrikkö, čäyreikkö 'пески; песчаное место; место с галькой (галечник)', čeyripohja 'место, с каменистым дном или почвой' < саамН. čievra '(крупный) гравий; галька'.

Кар. čokka 'вершина сопки, холм или горка' < *cokke '(горный) пик, острая вершина, холм, гора'.

Кар. ̌̌ulpро 'возвышенность' < саамР. с̌u'lpp 'холм, высокая возвышенность с крутыми склонами'.

Кар. епо 'глубокое место в реке; фарватер реки, где наиболее сильное течение; большой и глубокий рукав реки' < *еапо̄ 'крупная река'.

Kap. hieruva' 'обнажающаяся при отливе береговая полоса; морской отлив’ < саамН. fiervá с тем же значением.

Kap.jok(k)oh 'звериная тропа; прогон для скота; тропа, дорога' < caамК. čuokkac, čuə' kas 'зимник, дорога'.

Кар. jänkä 'крупное болото’ < *jeaђkē 'болото’.

Kap. kentti, kenttä 'лужайка или луг на ровном сухом месте; песчаное место на берегу реки, неплодородный участок земли; ягельник' $<$ *kientē 'природный луг'.

Kap. korgo 'подводная скала, каменистая мель, риф; (каменистый) мыс'<*kuorkō(j) 'мель, риф'.

Kap. k(u)otkova, kuotkuo, kuotkut 'перешеек'<*kuotkō(j) 'перешеек'.

Кар. kuršo, kuržu 'сырая низина, заросшая кустарником; бугристое место, поросшее кустарником' < *korse 'глубокий овраг, узкая глубокая ложбина’.

${ }^{2} \mathrm{C}$ разработкой вопросов о саамских заимствованиях в карельском и финском языках, в том числе и в области географической лексики, можно познакомиться в диссертации Анте Айкио [Aikio 2009].

3 Знаком астериска обозначены прасаамские формы, реконструированные для используемых в статье географических терминов.

${ }^{4}$ Нельзя исключать, что данная лексема саамского происхождения могла быть заимствована в карельский язык при посредстве финских говоров, ср. фин. hierua с тем же значением. Финский язык мог быть посредником и в случае с кар.jok(k)oh, cp. фин. jokos с тем же значением. В данном случае обращает на себя внимание переход саамского анлаутного с̌ в ј в начале слова. 
Кар. könkäš, köynäš ‘водопад’ < *keavjēs 'водопад’.

Кар. lašša 'каменистая мель, скалистое место, обнажающееся во время отлива' < *lāse 'гладкая скала, скалистая луда'.

Кар. n'uоrи 'подводный песочный риф, отмель' < *ńиore 'мель'.

Кар. иаје 'родник; окно в болоте; зыбун; бездонное или глубокое место в водоеме' < *ājęk 'родник, источник'.

Кар. pahta, puahto 'скала; обрыв' < *pāktēe 'скала'.

Кар. poža, poša 'залив' < *роаг̌̌so 'задняя часть, задний угол саамского чума' > 'залив'.

Кар. ruораš 'груда камней; камни в озере, выступающие над поверхностью воды' < *roape 'скалистый холм; груда камней'.

Kap. tunturi, tundurvuara 'безлесая сопка или вершина крупной возвышенности' < *tuonter 'возвышенность'.

Кар. vuara, vиағи 'лесистая возвышенность' <* vārē 'лесистая возвышенность'.

\section{3. Географическая лексика финского происхождения}

О приходе населения с территории Финляндии свидетельствует распространение в топонимии Карелии ряда характерных финских топонимических типов с атрибутивными элементами Savo-, Hieta-, Pahakala- и др. Это подтверждают также и перечисленные ниже лексические заимствования, фиксирующиеся в карельских говорах.

Кар. aro 'луг на сыром месте; открытое травянистое болото; сырая ложбинка; крупная лужа; мелкий заросший травой залив в реке' $<$ фин. aro 'сухая неплодородная земля; сырой покос на берегу озера или реки; топкая заболоченная ложбина; окно в болоте; трясина; бессточное лесное озеро'. В топонимии термин фиксируются только в Беломорской Карелии.

Kap. audivo, autie, autijo, autivo 'заброшенное сельскохозяйственное угодье; пустошь, незаселенная территория' < фин. autio с теми же значениями. В топонимии термины фиксируются только в Беломорской Карелии и финляндской Карелии.

Кар. heittijö 'заброшенное поле, зарастающее лесом' < фин. heittiö. Термин зафиксирован в ухтинском говоре собственно-карельского наречия. 
Кар. *hede , hete 'источник, родник’, кар. (Иломантси) hedehikkö, кар. hette(h)ikkö 'влажное место, богатое ключами'; кар. hetešuo 'топкое болото' < фин. hete 'трясина; топкое болото, окно в болоте; болотистое место, зыбкое колыхающееся пространство вокруг источника; водянистый прибрежный покос; родник'. В топонимии термин зафиксируется только на территории северных частей Республики Карелии.

Kap. hitelikko, hitelikkö 'лесистая гряда с песчаной почвой; густой молодой сосняк' < фин. hitelikko, hitelikkö 'густой сосновый лес'. Термин фиксируется только в северных частях Карелии.

Kap. juokšu 'течение в водоеме' < фин. juoksu с тем же значением. Термин фиксируется только в тихтозерском говоре в западной части Беломорской Карелии.

Kap. kunnaš, kunnahikko 'горка, холм, пригорок' < фин. kunnas с теми же значениями. Термины фиксируются в говорах западной части Беломорской Карелии в Вокнаволоцкой и Тихтозерской волостях.

Kap. kutveikko '(заболоченный) труднопроходимый участок, поросший густыми зарослями' < фин. диал. kutveikko, kutvelikko 'болотистое труднопроходимое место, поросшее кустарником, ивняком'. Термин фиксируется в вокнаволоцком говоре.

Кар. Іати 'низкое ровное место между холмами' < фин. lати 'низкий, ровный, постепенно понижающийся (о месте, территории, водоеме)'. Термин фиксируется в ухтинском говоре.

Кар. letto 'небольшое по размеру каменистое место' < фин. letto 'близко к берегу расположенный скалистый островок; риф; мель'. Термин фиксируется в Беломорской Карелии.

Кар. liehu 'грязь; трясина; зыбкая почва', ск. liehunurmi 'зыбкий, болтистый покос' < фин. liehu с теми же значениями. Слово фиксируется в западных говорах Беломорской Карелии.

Кар. lота 'овраг, ложбина, (болотистая) низина между холмами; расщелина' < фин. lота с теми же значениями. Слово фиксируется в говорах Беломорской Карелии.

Kap. nikara 'небольшая горка; (небольшой) порог в реке' < фин. nikara 'холм, подъем в гору'. Термин фиксируется в ухтинском и вокнаволоцком говорах.

5 Знаком астериска (*) здесь и далее обозначены географические термины, бытующие только в топонимии. Их значение восстанавливается на основе значений, представленных в языке-источнике. 
Кар. rimbi, rimmi(suo), rimpi 'топкое болотистое место; мягкое безлесое болото; трясина' < фин. rimmi, rimpi с теми же значениями. Слово фиксируется в западных говорах Беломорской Карелии.

Приведенная выше географическая терминология представлена, главным образом, в западных частях Беломорской Карелии, а также в карельских говорах финляндской Приграничной Карелии, где наиболее заметны следы контактирования карел с финским населением сопредельных территорий. Эти контакты можно датировать преимущественно периодом XVII-XIX веков.

\section{4. Географическая лексика русского происхождения}

Имеющийся в нашем распоряжении топонимический и лексический материал указывает также на контакты карел с русским населением. Со временем в процессе контактов карелами была усвоена и переработана в том числе и местная географическая терминология. Русские заимствования в местной географической лексике Карелии весьма разнообразны и отражают как характер местности и ее физикогеографические особенности, так и экономико-географические реалии. В результате контактов с русским населением в карельский язык пришло много слов русского происхождения, в том числе и заимствования в области ландшафтной лексики.

Кар. (ливв.) *bojoviššu 'место ловли (боя) нерестящейся рыбы' < рус. боевище 'место ловли (боя) нерестящейся рыбы'. Термин фиксируется только в топонимии.

Кар. bruиdu, bruиtu 'пруд; крупная лужа, небольшое озерко' < рус. nрyд.

Kap. *bukl'a 'заводь (с родниками)' < рус. букля 'глубокое тихое место в реке; заводь; омут; залив; поворот реки; небольшая вымоина'. Термин фиксируется только в топонимии.

Kap. dereun'a, derevn'a, derein, deren', jereynä, tereynä 'хутор, деревня; сельскохозяйственные угодья, относящиеся к какому-либо дому' $<$ рус. деревня.

Kap. Aremužik(ko) 'место, поросшее смешанным лесом'< pус. дрем 'дремучий лес, непроходимая чаща, трущоба, вековые недоступные леса', осложненное карельским словообразовательным суффиксом с собирательной семантикой. Термин фиксируется у карел-людиков. 
Kap. gleimikkö, leimikko, gleimužikko '(помеченный) участок леса, предназначенный для рубки' < ср. рус. клеймо 'отметка, пометка', осложненное карельским словообразовательным суффиксом с собирательной коллективной семантикой.

Kap. huabrikka, fuabrikku, fabrikk(i) 'место, где что-либо изготовляли или заготовляли' < pус. фабрика.

Кар. loššina, loššin(u) 'ложбина, низина' < рус. лощчина (с теми же значениями).

Кар. *lovišša 'охотничье или рыболовное угодие' < pус. ловище (с теми же значениями).

Здесь можно отметить, что бо́льшая часть заимствованных от русского населения терминов фиксируется в южных частях Карелии, в ливвиковских и особенно в людиковских говорах на карело-русском пограничье.

\section{5. Географическая терминология вепсского происхождения}

В силу близкого родства южнокарельской и вепсской топонимических систем выявление дифференцирующих вепсских признаков в топонимии Карелии - задача весьма непростая. Немногочисленны в карельском языке и вепсские лексические заимствования географического характера. Тем не менее ряд лексических фактов, перечисляемых ниже, позволяет полагать, что в формировании населения южных частей Карелии вепсы могли принять самое непосредственное участие.

Kар. *čuhakko 'холм, возвышенность' < вепс. *čuhak, *čuhuk (с теми же значениями) [Муллонен 1994: 56-57]. Термин фиксируется только в топонимии людиковского ареала.

Kap. kuare 'овраг', kuarakko 'низина, ложбина', kuarandeh 'углубление вытянутой формы; борозда, выбоина' < вепс. kar 'яма; низина; овраг', осложненное, в одном из случаев, карельским словообразовательным суффиксом -ndeh.

Кар. (люд.) burde, purde, 'родник, ключ, источник' < вепс. purde (с теми же значениями).

Kap. verando, *veranduz, *viranda, *virandu 'подсека (подготовленная для сжигания)' < вепс. verand 'костер при сжигании подсеки'. Термин фиксируется только в топонимии. 


\section{6. Топонимическая модель с детерминантом -vesi/-vezi}

Далее мы остановимся более подробно на двух топонимических моделях, в составе которых фиксируются географические термины -vesi/-vezi 'вода; водное пространство' и рuго 'ручей'. Появление рассматриваемых моделей в топонимии может свидетельствовать, на наш взгляд, о проникновении в Карелию восточно-финского саволакского ${ }^{6}$ населения.

Если обратиться к карте-схеме распространения названий (Рисунок 1, с. 298), можно увидеть, что данный топонимический тип широко представлен в Финляндии на территории распространения восточно-финских саволакских говоров. Там модель фиксируется в названиях озер, а также частей крупных водоемов, которые являлись некогда важными водными магистралями [Hakanen 1989: 55].

Появление данной модели можно увязывать с эпохой Средневековья. Свидетельством этому являются наиболее ранние фиксации названий рассматриваемого типа в документе Ореховецкого мирного договора 1323 года, ср. Уловежи (совр. Ylävesi) и Соумовиси (совр. Sиоmenvesi) на средневековых карельских территориях в окрестностях современного Выборга. Можно полагать, что этот топонимический тип несколько старше, чем его упоминание в тексте договора, поскольку, согласно его условиям, в западной части Корельской земли за карелами оставались в собственности рыболовные угодия, в названиях которых мы можем уже видеть рассматриваемый нами детерминант -vezi: cp. «...наших погостов Новгородских воды....у Уловежи половина, Соумовиси половина» [ПИОК: 42]. К этой группе относится и название озера Коневые водыl, упомянутое в Карельском уезде в берестяной грамоте, датируемой рубежом XIV-XV веков. Оно, без сомнения, является калькой с карельского названия озера Orihvesi (букв. 'конь' + ‘вода').

${ }^{6}$ Саволаксы являются одним из ответвлений древней карелы, связь с которой они стали утрачивать после передачи Швеции трех карельских погостов (Саволакс, Яяски и Эвряпяя) согласно условиям Ореховецкого мирного договора 1323 года. В результате вхождения древних карелов в сферу влияния Шведского средневекового государства на территории этих погостов была принята шведская система административного управления и католичество. Это, в свою очередь, повлекло за собой принятие населением западноевропейских культурных норм и постепенное обособление от новгородских приладожских карелов. 


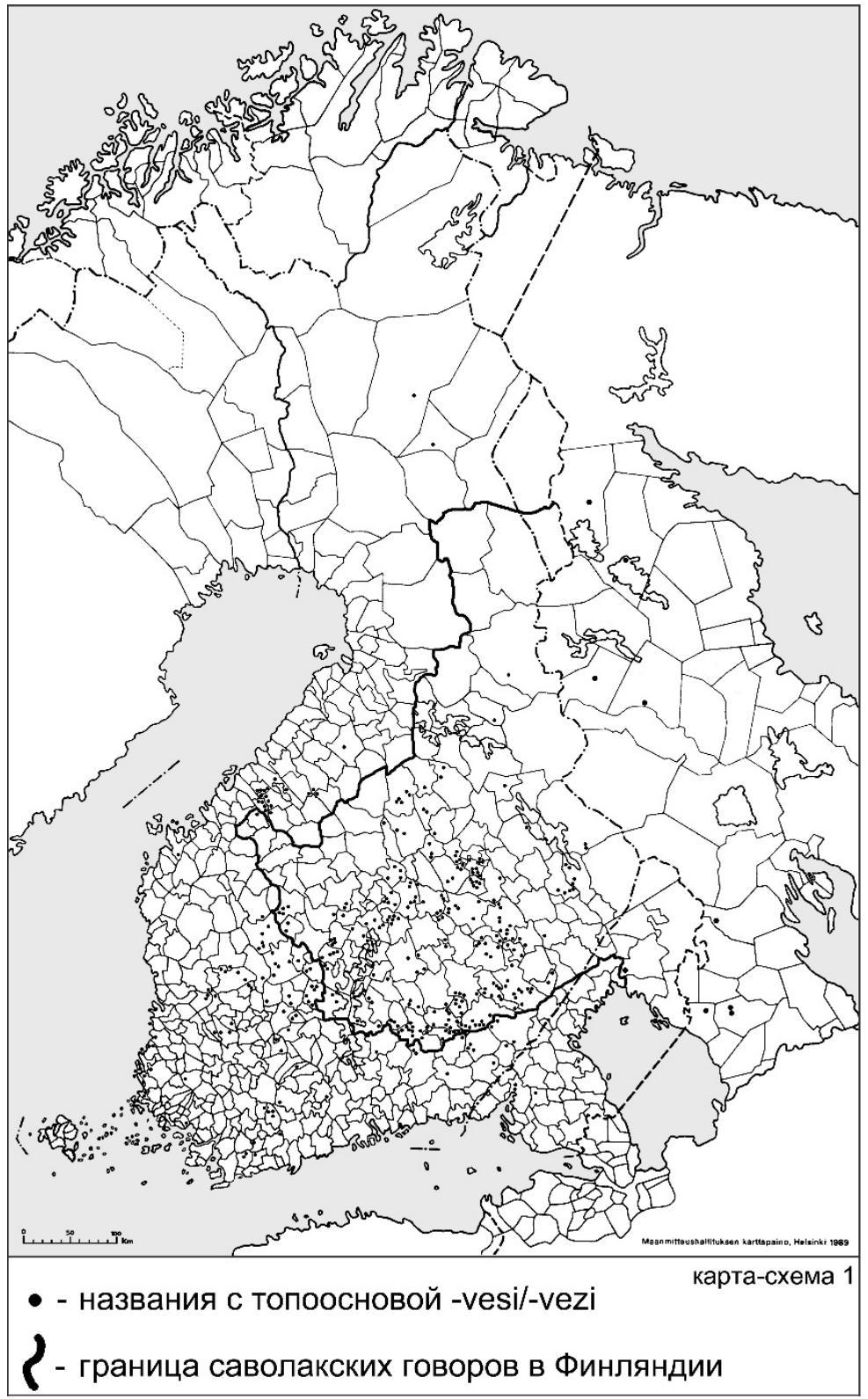

Рис. 1. Названия с топоосновой -vesi/-vezi

Fig. 1. Toponims with the topoformant-vesi/-vezi 
Ранние фиксации свидетельствуют, на наш взгляд, о том, что рассматриваемый топонимический тип мог появиться первоначально в среде средневековых карел в северных частях Карельского перешейка. Необходимо отметить, что в самом карельском Приладожье модель на -vesi/-vezi представлена слабо. Данный факт можно объяснить тем, что этот топонимический тип к моменту заключения Ореховецкого мирного договора только набирал свою популярность при наименовании новых объектов и не получил еще в то время широкого распространения в топонимии. Таким образом, после передачи Швеции карельских погостов Яски, Саволакс и Эвряпя его функционирование и распространение происходило уже в среде финнизирующихся средневековых карел или формирующегося саволакского населения.

Карта-схема на Рисунке 1 свидетельствует о том, что современное распространение модели практически полностью вписывается в границы бытования восточно-финского диалекта саво. Наибольшей популярности в топонимии модель, видимо, достигает здесь к началу XVI века. Об этом свидетельствуют документы с территории Финляндии, в которых неоднократно фиксируются топонимы с интересующим нас формантом: ср. Iisvesi (1552), Maavesi, Onkivesi, Paasvesi, Porovesi (1561), Lietvesi (1562), Suvasvesi, Enonvesi (1563), Heinävesi (1571) [Nimiarkisto]. Но к началу XVII века рассматриваемый тип уже, видимо, теряет свою популярность в среде саволаксов, поскольку на территории северного Саво, например, в Кайнуу, тип на -vesi представлен только немногочисленными фиксациями.

Данное предположение подтверждают и названия с территории современной Карелии, где модель, как уже упоминалось выше, имеет саволакские корни, хотя по происхождению является древнекарельской. В топонимии Карелии известно 9 названий рассматриваемого типа. Четыре из них зафиксировано в топонимии ${ }^{7}$ Южной Карелии: озера Buoluvezi (Тopocoзеро), Soudovezi (Кескозеро), Ristuvezi (Кукойваapa $\left.^{8}\right)$, Kalavezi (Сяпчезеро), — и пять в северных частях Карелии:

${ }^{7}$ В статье представлен карелоязычный лексический и топонимический материал, хранящийся в Научной топонимической картотеке Института ЯЛИ КарНЦ РАН, а также в Топонимическом архиве национальных языков Финляндии «Котус».

${ }^{8} \mathrm{O}$ том, что название на -vezi могло быть перенесено с территории современной Финляндии, свидетельствует, на наш взгляд, и наименование самой деревни Kukoinvuaru у ливвиков. Детерминант -vuaru со значением «возвышенность» 
Liinavezi (Пизьмагуба), Šuovesi (Костомукша), Halkivesi (Кестеньга), Niskovesi (Кукасозеро) и Valaisvesi (Валасрека) [Картотека ИЯЛИ]. Как и на территории Финляндии, модель выступает на севере Карелии в наименовании частей крупных водоемов, таких как, например, Топозеро и озеро Нюк. В то же самое время на юге Карелии у ливвиков она представлена в наименовании относительно небольших озер. Можно также упомянуть, что два названия с детерминантом -vezi зафиксировано и на бывшей карелоязычной территории Финляндии в Приграничной Карелии (фин. Raja-Karjala). Это название озерца Lähdevesi в деревне Алатту в бывшей Суйстамской волости и название части Ладожского озера - Laččuvezi, фиксируемое в бывшем приходе Салми.

Модель с топоосновой -vezi/-vesi является в топонимии Карелии относительно поздней, поскольку известно, что саволаксы начинают активно осваивать территории к северу и востоку от своей прародины только начиная с конца XVI века. Распространение названий на -vesi/-vezi в Карелии также может быть увязано с этим периодом истории. Кроме этого известно, что крестьянское освоение карелами и финнами северных частей Карелии начинается только на рубеже XVII-XVIII веков. Так, например, деревня Кестеньга упомянута новообразовавшимся однодворным поселением в 1679 году, в то время как двудворная деревня Валасрека появляется впервые в документах только в 1723 году. В топонимии этих деревень, как было упомянуто выше, фиксируется топонимический тип на -vesi.

Можно также предположить, что средневековые карелы, проживавшие на Карельском перешейке, могли усвоить термин vezi (рус. воды) от русских, первоначально, вероятно, в качестве именно промыслового термина. На это, на наш взгляд, могут указывать документы XVXVI веков, касающиеся территории проживания карельского населения, где термин воды (кар. vezi) неоднократно фиксируется для обозначения водоемов на промысловых территориях. Таким образом, нельзя исключать, что в данном значении термин использовался и в средневековой Карелии.

не свойственен в целом ливвиковской топонимии и может быть свидетельством того, что основатели этой деревни могли быть переселенцами как из Саво, так и из бывшего Корельского уезда. 


\section{7. Топонимическая модель с детерминантом -риго}

Модель названий с топоосновой -риго также может рассматриваться как маркер освоения территории Карелии саволаксами. Подтверждением этого служит карта-схема распространения названий на -риго (фин. puro «ручей»), см. Рисунок 2 (с. 302). Она свидетельствует о том, что основной ареал бытования данного топонимического типа - это центральные и восточные части современной Финляндии, главным образом, территория саволакских говоров, где тип представлен в топонимии в названиях 8600 ручьев [Suomalainen paikannimikirja: 354].

На финской территории рассматриваемая модель на -риго является относительно поздней. На это указывает, на наш взгляд, немногочисленность названий данного типа на коренных саволакских территориях в окрестности Сайменской водной системы. В то же время здесь, в южном Саво, а также на сопредельных территориях фиксируется большое количество названий с детерминантом -рuru (ср. puru 'ручей, небольшая речка; сырое топкое место'). Таким образом, можно думать, что появление лексемы риго могло стать языковым новшеством, которое появилось в языке новопоселенцев благодаря термину риги на освоенных саволаксами в XVI веке территориях к северу от их прародины. Как известно, появление топонимических новообразований связано часто с освоением новых территорий, когда в среде новопоселенцев резко увеличивается потребность в наименовании географических объектов на местности. Можно, например, отметить, что на новозаселенных территориях в Pien-Savo (букв. Малое Саво) рассматриваемый тип уже хорошо известен в середине XVI века. Об этом свидетельствуют топонимы с детерминантом -puro, фиксирующиеся в документах того времени: ср. Kolkonpuro, Kurenpuro, Lehmäpuro (Rantasalmi), Kukkaropuro, Kylmäpuro, Sulkavapuro (Tavisalmi), Närvinpuro, Puronaho (Sääminki) [Alanen 2009].

Как уже было отмечено выше, основной ареал бытования данного типа - это центральные и восточные территории современной Финляндии. Таким образом, появление названий на -риго за пределами основного ареала распространения саволакских говоров может указывать на освоение саволаксами новых территорий, которое происходило главным образом начиная с середины XVI века и продолжалось на всем протяжении XVII века. 


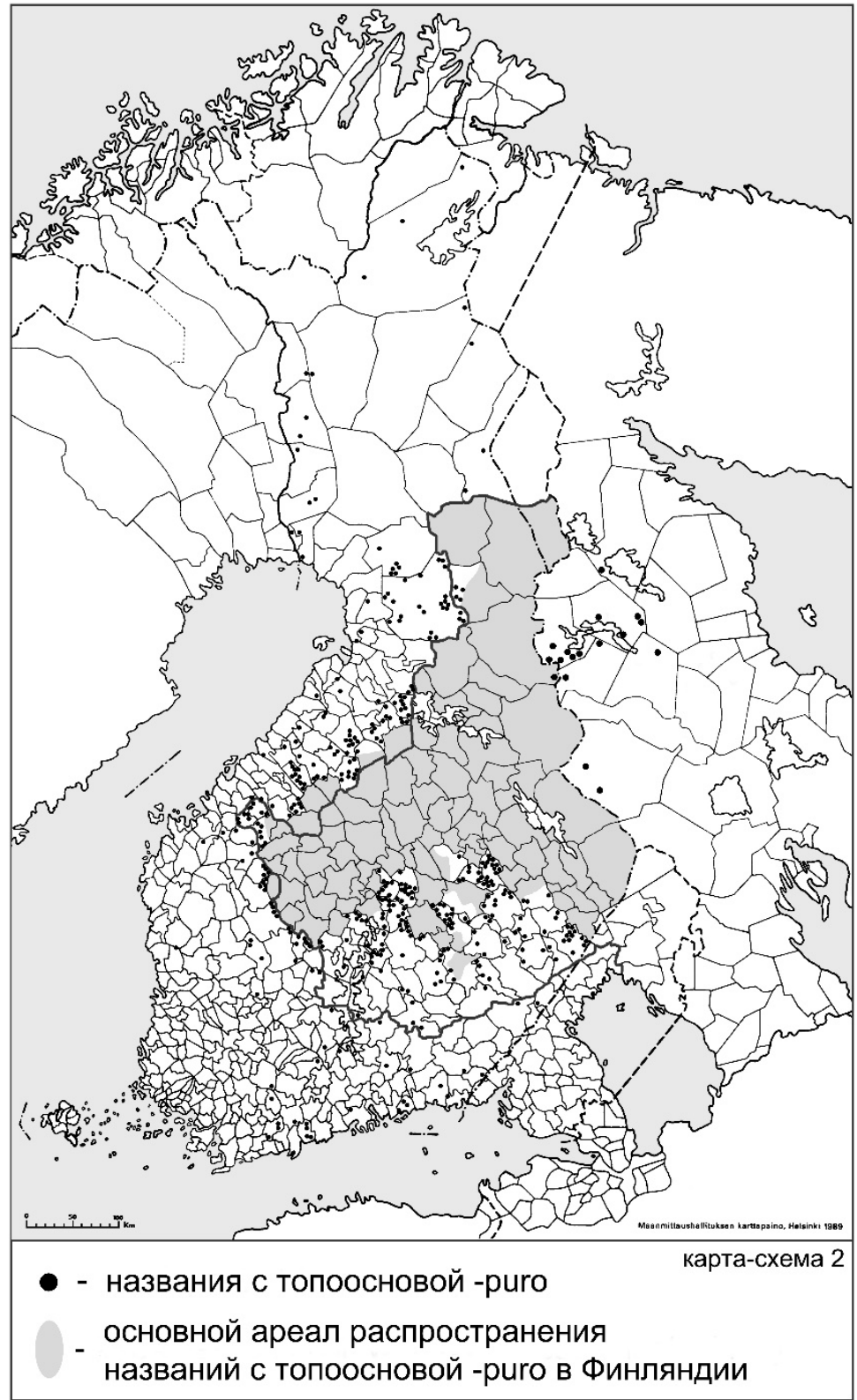

Рис. 2. Названия с топоосновой -puro

Fig. 2. Toponims with the topoformant -puro 
С этим периодом нужно, на наш взгляд, связывать и появление подобных названий на территории современной Карелии. Тем не менее можно отметить, что на коренных карельских территориях в Приладожье названия, в которых закрепилась лексема -риго, появляются несколько раньше - в конце эпохи Средневековья. Об этом свидетельствует, например, переписная книга Корельского уезда Водской пятины 1500 года, где в Сердобольском погосте (совр. Сортавала) упоминается деревня Пуроярва (*Purojärvi) (совр. Purujärvi) [Переписная книга: 151]. Деревня находится сейчас на территории Финляндии в окрестностях озера с названием Puruvesi, которое упоминается, в свою очередь, в XV веке в формах Pwrowäsi и Puroijvesi [Gallén 1968: 212, 213]. Более ранних сведений о бытовании данной модели в средневековой Карелии пока не известно. Необходимо все же заметить, что рассматриваемая топонимическая модель слабо представлена на коренных карельских территориях в Приладожье. Это, видимо, свидетельствует о том, что она могла быть принесена сюда с запада, с территории Саво. На это может указывать и тот факт, что деревня Пуроярви располагалась до подписания Столбовского мирного договора 1617 года на карело-саволакском пограничье.

В топонимии современных карельских территорий модель представлена 32 топонимами. Карельскому населению известен также и апеллятив puro, который представлен как на юге Карелии, в том числе в Сямозерье и в финляндской Приграничной Карелии (например, Салми, Суйстамо, Суорви), так и в Средней (Ругозеро) и Северной Карелии (Контокки, Ухта, Вокнаволок). Лексема риго в карельском языке представлена в значении 'ручей; небольшая речка, (большая по размеру, чем оја 'ручей')' . На севере Карелии в кестеньгском говоре в значении 'ручей' фиксируется также апеллятив purakko. Кроме этого, в Ухте зафиксировано прилагательное purokas 'ручьевистый, т. е. с ручьями', а в суоярвском говоре - слово риготиа в значении 'земля, изрезанная ручьями' [KKS]. Здесь необходимо все же отметить, что лексема представлена в языке карельского населения тех волостей, которые расположены или располагались недалеко от границы с восточно-финскими говорами. На территории последних не только бытует соответствующий апеллятив, но и представлены названия на -риго в топонимии.

Распространение карелоязычных названий свидетельствует, что ареал бытования топонимов данного типа в Карелии несколько шире, чем у апеллятива. Топонимы на -риго представлены двумя примерами в Ребольской волости: Haikanlamminpuro (Гафостров) и Tuuzarvenpuro 
(Лужма), - а также в Кестеньгской и Панозерской волостях: Hetepuro (Тунгозеро) и Muštapuro (Сопасалма). Наиболее широко модель представлена на западе Беломорской Карелии, особенно в пограничных деревнях Ладвозеро (например, Hamarapuro, Hoikanpuro, Kuikanpuro, Nakrispuro, Puatolaisenpuro, Siltapuro, Ukonpuro) и Каменное озеро (например, Kokkopuro, Kylmäpuro, Lippipuro, Mal'l'opuro, Viijankinpuro), а также находящейся на территории Финляндии в непосредственной близости от границы карельской деревне Хиетаярви (Aronpuro, Autivopuro, Karsikkopuro, Losopuro). Кроме этого, топонимы на -риго фиксируются в деревнях Аконлакша (Kuikkapuro), Алозеро (Pienipuro), Вокнаволок (Keltopuro), Куйваярви (Lössänpuro, Vuokinpuro), Ухта (Juurikkapuro), Хайколя (Konkeluspuro, Litmapuro), Луусалми (Kukkopuro), Пиежунги (Lihapuro), Толорека (Čaijupuro) и Суднозеро (Kokkopuro) [Картотека ИЯЛИ]. Можно отметить, что на ливвиковских территориях на юге современной Карелии представлены также названия с топоосновой -рuru: Puruоја (Рогокоски) и Рurusuo (Видлица), ср. фин. puru 'ручей, небольшая речка; сырое топкое место' [Картотека ИЯЛИ].

Обращает на себя внимание тот факт, что в ряде случаев на территории северных и центральных частей Беломорской Карелии, а также северных частей бывшей Олонецкой губернии не наблюдается единства в употреблении детерминанта -риго в топонимии. На его месте часто выступает традиционный карельский термин оја 'ручей'. Это, видимо, может свидетельствовать о недавнем появлении некоторых из рассматриваемых названий на -риго в этом регионе: ср. параллельные варианты названий Pienioja = Pienipuro (Алозеро), Konkelušoja = Konkelušpuro (Хайколя), Muštaoja = Muštapuro (Сопасалми), Lihaoja = Lihapuro (Пиежунги) и др. Нельзя исключать, что данное явление может быть связано, например, с преподаванием финского языка как родного в школах Карелии. В финском литературном языке в качестве обозначения ручья используется именно лексема puro, в то время как апеллятив оја известен в значениях 'канава, ров'.

В то же время в западных частях Северной или Беломорской Карелии бытование модели имеет все же более длительную историю. Согласно архивным данным, названия рассматриваемого типа фиксируются в топонимии деревни Ладвозеро Вокнаволоцкой волости уже в 1876 году, ср. Хойканпуро и Куйканпуро [ГААО: 147]. Это позволяет говорить о том, что географический термин -риго на территории западной Беломорской Карелии бытовал в среде местного населения еще до начала преподавания финского языка в школах. Данный факт 
указывает на вливание восточно-финского населения на определенном этапе истории в среду карельского населения. Подтверждением этому могут быть как другие модели саволакского происхождения, зафиксированные в топонимии упомянутых выше деревень (например, Savon-, Kolmišoppi, Hietajärvi и др.), так и родовые предания, которые повествуют о переселении населения с территории соседней Финляндии.

\section{8. Заключение}

Подводя итог, еще раз отметим, что Карелия на протяжении многих веков являлась регионом межэтнических связей, которые отчетливо проявляются в языке и топонимии современного карелоязычного населения. Появление рассмотренных разноязыковых географических терминов имеет при этом разную хронологию. Наиболее ранними из них являются, видимо, лексемы саамского и вепсского происхождения, датируемые периодом первой половины второго тысячелетия, в то время как русская и финская ландшафтная терминология относится к более позднему временному срезу - периоду второй половины прошлого тысячелетия. Таким образом, дальнейшее выявление и изучение заимствованной географической лексики будет способствовать более глубокому пониманию происходивших на территории Карелии языковых и этнических процессов, которые привели в конечном итоге к формированию здесь карельского населения.

\section{Список условных сокращений}

вепс. — вепсский язык; кар. — карельский язык; рус. — русский язык; саамР. - саамские языки России; саамН. - саамские языки Норвегии; фин. — финский язык.

\section{Литература}

Муллонен 1994 - И. И. Муллонен. Очерки вепсской топонимии. СПб.: Наука, 1994. ПИОК - С. И. Кочкуркина, А. М. Спиридонов, Т. Н. Джаксон (сост.). Письменные известия о карелах. Петрозаводск: Карелия, 1990. 
Aikio 2009 - A. Aikio. The Saami Loanwords in Finnish and Karelian. Doctoral dissertation. Oulu: University of Oulu, 2009.

Alanen 2009 - T. Alanen. Pien-Savon pohjoisosan maantarkastusluettelo vuosilta 15621564. Helsinki: Kotimaisten kielten tutkimuskeskus, 2009.

Gallén 1968 - J. Gallén. Nöteborgsfreden och Finlands medeltida östgräns. Helsingfors: Svenska Litteratursällskapet i Finland, 1968.

Hakanen 1989 - A. Hakanen. Liekovesi ja Hauhajärvi // Sananjalka. 1989. Vol. 31. № 1. P. 53-60.

Itkonen 1986 — E. Itkonen. Inarilappisches Wörterbuch. Bd. I-III (Lexica Societatis Fenno-Ugricae. Vol. XX). Helsinki: Suomalais-Ugrilainen Seura, 1986-1989.

Itkonen 1958 - T. I. Itkonen. Koltan- ja Kuolanlapin sanakirja. Bd. I-II (Lexica Societatis Fenno-Ugricae. Vol. XV). Helsinki: Suomalais-Ugrilainen Seura, 1958.

Lehtiranta 1989 - J. Lehtiranta. Yhteissaamelainen sanasto (Suomalais-Ugrilaisen Seuran Toimituksia. Vol. 200). Helsinki: Suomalais-Ugrilainen Seura, 1989.

Suomalainen paikannimikirja — S. Paikkala (toim.). Suomalainen paikannimikirja. Helsinki: Kotimaisten kielten tutkimuskeskus; Gummerus Kirjapaino OY, 2007.

\section{Источники}

ГААО - Государственный архив Архангельской области. Фонд 6, опись 15, дело 37. Картотека ИЯЛИ - Научная топонимическая картотека Института языка, литературы и истории КарНЦ РАН.

Переписная книга - Переписная окладная книга Водской пятины 7008 (1500) года. Корела с уездом // Временник Императорского Московского общества истории и древностей российских. Книга 12, материалы 1-188. М.: В университетской типографии, 1852.

KKS - Karjalan kielen sanakirja, T. 1-6 (Lexica Societatis Fenno-Ugricae XVI). Helsinki: Soumalais-Ugrilainen Seura, 1968-2005.

Nimiarkisto — Kotimaisten kielten keskus. Helsinki.

\section{References}

Aikio 2009 - A. Aikio. The Saami Loanwords in Finnish and Karelian. Doctoral thesis. Oulu: University of Oulu, 2009.

Alanen 2009 - T. Alanen. Pien-Savon pohjoisosan maantarkastusluettelo vuosilta 15621564. Helsinki: Kotimaisten kielten tutkimuskeskus, 2009.

Gallén 1968 - J. Gallén. Nöteborgsfreden och Finlands medeltida östgräns. Helsingfors: Svenska Litteratursällskapet i Finland, 1968.

Hakanen 1989 - A. Hakanen. Liekovesi ja Hauhajärvi. Sananjalka. 1989. Vol. 31. No. 1. P. 53-60.

Itkonen 1958 - T. I. Itkonen. Koltan- ja Kuolanlapin sanakirja. Bd. I-II (Lexica Societatis Fenno-Ugricae. Vol. XV). Helsinki: Suomalais-Ugrilainen Seura, 1958. 
Itkonen 1986 - E. Itkonen. Inarilappisches Wörterbuch. Bd. I-III (Lexica Societatis Fenno-Ugricae. Vol. XX). Helsinki: Suomalais-Ugrilainen Seura, 1986-1989.

Lehtiranta 1989 - J. Lehtiranta. Yhteissaamelainen sanasto (Suomalais-Ugrilaisen Seuran Toimituksia. Vol. 200). Helsinki: Suomalais-Ugrilainen Seura, 1989.

Mullonen 1994 - I. I. Mullonen. Ocherki vepsskoy toponimii [Essays on Veps toponymy]. St. Petersburg: Nauka, 1994.

PIOK - S. I. Kochkurkina, A. M. Spiridonov, T. N. Dzhakson (comp.). Pismennye izvestiya o karelakh [Written sources about Karelians]. Petrozavodsk: Kareliya, 1990.

Suomalainen paikannimikirja — S. Paikkala (toim.) Suomalainen paikannimikirja. Helsinki: Kotimaisten kielten tutkimuskeskus; Gummerus Kirjapaino OY, 2007.

\section{Sources}

GAAO - Gosudarstvennyy arkhiv Arkhangelskoy oblasti [State Archive of the Arkhangelsk Region]. Fund 6, inventory 15, case 37.

Kartoteka IYaLI - Nauchnaya toponimicheskaya kartoteka Instituta yazyka, literatury i istorii KarNTs RAN [Scientific toponymic card cabinet of the Institute of Language, Literature and History of the Karelian Scientific Center of the Russian Academy of Sciences].

KKS - Karjalan kielen sanakirja. T. 1-6 (Lexica Societatis Fenno-Ugricae. Vol. XVI). Helsinki: Soumalais-Ugrilainen Seura, 1968-2005.

Nimiarkisto - Kotimaisten kielten keskus. Helsinki.

Perepisnaya kniga — Perepisnaya okladnaya kniga Vodskoy pyatiny 7008 (1500) goda. Korela s uezdom [The census book of Vodskaya Pyatina of the year 7008 (1500). Korela County]. Vremennik Imperatorskogo Moskovskogo obshchestva istorii i drevnostey rossiyskikh [Journal of the Imperial Moscow society of Russian history and antiquities]. Book 12, materials 1-188. Moscow: In the University Printing House, 1852. 


\title{
К интерпретации некоторых калек в топонимии Белозерья: виды калькирования и способы верификации
}

\author{
А. А. Макарова \\ Уральский федеральный университет, Екатеринбург; \\ Институт русского языка им. В. В. Виноградова РАН, Москва; \\ toponimist@yandex.ru
}

Аннотация. В статье на материале озерной гидронимии Белозерья (как русского, так и прибалтийско-финского происхождения) рассматриваются виды калькирования в топонимии. Разбираются как довольно распространенные случаи семантико-словообразовательного (полного) калькирования популярных прибалтийско-финских топонимических моделей в русскую топонимию, так и неочевидные случаи калькирования топонимических моделей, требующие привлечения дополнительных данных. В ряду таких случаев исследуются модели ареально ограниченные, изолированные по семантическим / лексическим причинам на фоне русской топонимической системы или имеющие нетипичную для русской топонимии структуру. Для верификации направления калькирования привлекаются параллельные вепсские названия северозапада Белозерья и карельские названия Республики Карелия, семантические параллели из топонимии Восточной Финляндии, а также топонимические аналоги с территории Присвирья, Приоятья и др. Отдельно рассматриваются случаи «мнимых» калек, где основа русского типа на самом деле оказывается фонетически переработанной прибалтийско-финской основой, что подтверждается ее топонимическим окружением.

Ключевые слова: языковые контакты, топонимия, русский язык, прибалтийско-финские языки, калькирование, Русский Север, Белозерье.

\section{Towards interpretation of some calques in the Belozerye toponymy: Loan translation types and verification methods}

\section{A. A. Makarova}

Ural Federal University, Yekaterinburg; V. V. Vinogradov Russian Language Institute, Russian Academy of Sciences, Moscow; toponimist@yandex.ru

Abstract. The article discusses the types of loan translation in toponymy based on the lake hydronymy of Belozerye (of Russian and Finnic origins). The toponymy 
of Belozerye is a multilayered phenomenon. On the one hand, it clearly shows Northern Russian toponymy types associated with the Novgorod expansion to Belozerye and the subsequent settlement of the Slavic population on this territory. On the other hand, the extant substratum names contain traces of the previous Finno-Ugric (Finnic, Sami, and in the South, possibly, Volga-Finnic) population. The consequences of the ethnic contacts were reflected, in particular, in the calqued toponyms (primarily, names of lakes or other water bodies) attested on a wide strip running from the South-West to the North-East of this zone. Some of these names reflect historical (starting from the $10^{\text {th }}-13^{\text {th }}$ centuries) contacts, while other names are related to the modern (mainly, the $20^{\text {th }}$-century) interactions in the area where Belozerye borders on the territories of Finnic peoples - the Veps (some of them live in the extreme North-West of Belozerye) and the Karelians.

The article considers irregular patterns in the toponymy of Belozerye, for which contact origins can be assumed, and also discusses the criteria that make it possible to qualify specific patterns as either borrowed or native. Fairly common cases of semantic and derivational (full) replication of popular Finnic patterns in the Russian toponymy, as well as not so obvious cases of toponymic pattern copying are investigated. Some patterns have a limited distribution, or appear semantically/lexically isolated against the background of Russian toponyms, or else have a structure that is typical of the Russian toponymy. In some cases, a Russian-looking stem is in fact a phonetically adapted Finnic stem; these cases are considered separately against the background of their toponymic environment.

Our methods of verification involve consideration of parallel Veps place names from the North-West of Belozerye and Karelian place names from the Republic of Karelia, as well as semantic parallels from the toponymy of East Finland and their toponymic counterparts from the territories of Prisvirye, Prioyatye, etc. The analysis tool uses toponymic parallels attested in the territory of the Russian North (using data from the Toponymic Expedition of the Ural Federal University) and Karelia (GIS "Toponymy of Karelia" and the KarNC RAS data).

Keywords: language contacts, toponymy, Russian language, Finnic languages, loan transition, Russian North, Belozerye.

\section{1. Введение}

Топонимия Белозерья представляет собой многослойное явление. С одной стороны, в ней ярко представлены севернорусские топонимические типы, связанные с новгородским освоением Белозерья и последующим расселением славянского населения на этой территории. С другой стороны, в сохранившихся субстратных названиях 
присутствуют следы предшествующего финно-угорского (прибалтийско-финского, саамского, а на юге, возможно, и волжско-финского) населения. Последствия этнических контактов отразились, в частности, в калькированных названиях (в первую очередь, озер и других водных объектов), засвидетельствованных на широкой полосе, идущей с юго-запада на северо-восток этой зоны. Часть таких названий отражает исторические (начиная с X-XIII вв.) контакты, другая часть связана с современным (преимущественно на протяжении XX в.) взаимодействием в той зоне, где Белозерье граничит с территорией проживания прибалтийско-финских народов - вепсов (часть из них проживает на крайнем северо-западе Белозерья) и карелов.

В статье рассматриваются нерегулярные номинативные модели в топонимии Белозерья, для которых можно предполагать контактное происхождение, а также обсуждаются критерии, позволяющие отнести конкретные модели к заимствованным или исконным. В качестве инструмента анализа привлекаются топонимические параллели, отмеченные на территории Русского Севера (использованы данные Топонимической экспедиции Уральского университета, УрФУ) и Карелии (ГИС «Топонимия Карелии», ИЯЛИ КарНЦ РАН).

Предметом рассмотрения в данной статье выступают два типа случаев. Во-первых, это гидронимы на -озеро, которые при наличии внешне русской основы имеют нетипичную для русской гидронимии словообразовательную структуру. Их внешний облик дает все основания предполагать калькирование, а обратное нуждается в доказательстве. Во-вторых, это озерные гидронимы-прилагательные с русскими основами, которые характеризуются низкой частотностью и ограниченным ареалом и на других территориях нередко употребляются в составе топонимов на -озеро.

\section{2. Семантико-словообразовательное калькирование}

Наиболее наглядным проявлением топонимического контактирования является существование семантико-словообразовательных калек (как в составе параллельных названий - вепсско-русских на территории Белозерья, карельско-русских на территории соседней Карелии, - так и вне их). Некоторые из этих калькированных топонимов существуют в рамках регулярных моделей, характеризующихся 
частотностью, относительно широким ареалом и принадлежностью к одному из распространенных семантических типов. Как отмечает И. И. Муллонен в работе, посвященной языковым контактам в топонимии Свири, «одно из важных условий переводимости прибалтийско-финских атрибутивных топооснов заключается в наличии эквивалентной модели в воспринимающей русской топосистеме данной или смежной территории» [Mullonen 2007: 152]. Аналогичная закономерность справедлива и для территории Белозерья: семантико-словообразовательные кальки легко возникают в том случае, если внутренняя форма названия прозрачна для носителя воспринимающей системы и в последней имеется аналогичная топонимическая модель. К числу номинативных моделей, которые обычно калькируются, относятся названия, указывающие на свойства объектов (типа Долгозеро ${ }^{1}$, Кривозеро и др.), а также на элементы ландшафта (Порогозеро) и особенно на названия деревьев: Липозеро, Ольхозеро, Клёнозеро и др.

Наиболее надежные примеры полных калек, в которых русским формам соответствуют параллельные вепсские формы с аналогичными прибалтийско-финскими основами, зафиксированы на территории Бабаевского и Вытегорского районов, например: Pitkär' [КТК] // Долгозеро ${ }^{2}$, ср. вепс. pit'k 'длинный; долгий' [СВЯ: 421-422], Vahtjärv // Клёнозеро, ср. вепс. vahtaŕ 'клен' [там же: 608], Väras'är' [КТК] // Кривозеро, ср. вепс. vär 'кривой, косой, изогнутый’ [СВЯ: 646], Süväjärv // Глубокое Озеро, ср. вепс. sӥvӓ ‘глубокий’ [там же: 536].

Кроме того, достаточно надежными примерами калькирования выглядят случаи, когда в рамках одной и той же территории фиксируется топоним-полукалька с прибалтийско-финской основой и топоним-калька с аналогичной переводной основой, сохраняющий двухкомпонентную структуру прибалтийско-финского оригинала: Большое Коскозеро, Малое Коскозеро и Порогозеро (Выт.), ср. фин. koski, карел. koški, люд., вепс. košk 'порог' [SSA 1: 409]; Нинозеро и Липозеро (Бел.), ср. фин. niіni ‘лыко’, ижор. nїni, карел. niіni ‘липа; лыко’, люд. niń 'лыко', вепс. niń, ńiń 'лыко; липа', вод. nīni 'лыко', эст. niin, лив. nī́ 'лыко, жила' [SSA 2: 218]; Лепозеро (Бел., Выт.) и Ольхозеро (Кад.), ср. фин., карел. lеррӓ, люд. Іер (ре), вепс. Іер 'ольха' [SSA 2: 64].

${ }^{1}$ Все примеры топонимов, если они не паспортизированы, извлечены из Топонимической картотеки Топонимической экспедиции Уральского университета [ТК ТЭ].

2 Через двойную косую черту подаются параллельные названия одного и того же объекта. 
В отдельных случаях можно предполагать нерегулярное калькирование некоторых частотных моделей, известных в прибалтийско-финской топонимии. Нерегулярные переводные русскоязычные модели характеризуются низкой частотностью и ареальной ограниченностью на фоне русской топонимии, а иногда семантической или лексической специфичностью. Некоторые сохраняют исходную структуру ${ }^{3}$ : Грязьозеро (Выт.) и Редозеро (Выт., Карг.), Redojär'(v) (Выт.), ср. вепс. redu 'грязь' [СВЯ: 466]; Рыбозеро (Бел.) и Калозеро (Выт.), ср. вепс. kала 'рыба' [СВЯ: 172] ${ }^{4}$. Другие приобретают структуру, свойственную русской топонимии: Сорожьве (Ваш., Кир.) и Сяргозеро (Баб., Бел., Выт., Карг.), Särgijärvi // Плотвица (Кем.), ср. фин., ижор., карел. särki

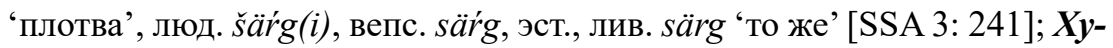
дое (Ваш.) и Пагозеро (Выт.), Pahad'är'v (Олон.), ср. вепс. paha 'плохой' [там же: 390]; Узкое Озеро // Кайдозеро // Kaidagär’v (Баб.), ср. вепс. kaid 'узкий' [там же: 167]; Тонкое (Ваш., Выт.) и Хойкозеро, Hoikkajärvi (Костомукша), ср. карел. hoikka 'тонкий' [ССКГК: 50] ${ }^{5}$ и др.

Вероятно, доводом в пользу калькирования модели можно считать сохранение словообразовательной структуры прибалтийско-финского оригинала. При разборе отдельных примеров складывается впечатление, что создание новых топонимов такой структуры на собственно русской почве не происходит, и во всех таких случаях можно предполагать калькирование (см. далее модели типа Святозеро, Грязнозеро, и т. п.).

В ряде случаев могут быть полезны параллели с других территорий. В качестве источников для поиска параллелей нами использовались картотека Топонимической экспедиции УрФУ (Архангельская, Вологодская, Костромская области) [ТК ТЭ], ГИС «Топонимия Карелии» [ГИС ТК], «Словарь гидронимов Юго-Восточного Приладожья» [СГБС]. Эти источники в большинстве случаев позволяют получить представление о моделях прибалтийско-финского происхождения.

3 Полужирным шрифтом выделена анализируемая топонимическая модель.

${ }^{4}$ Актуальность данной модели для прибалтийско-финского топонимикона подтверждается также наличием примеров типа карел. Kalalambi // Pblбa (Кем.).

${ }^{5}$ Отметим, что на территории данных районов встречаются и субстратные топонимы, по фонетическим признакам соотносимые именно с карельским языком, ср. Пелтозеро (Баб., Бел., Ваш., Выт.), Рантозеро (Выт.). О присутствии карел на территории Белозерья см. в публикациях [Жербин 1956; Дмитриева 2003]; по языковым данным [Соболев 2015; Захарова 2017: 265, 267; Макарова 2017: 67-69] и др. 
Кроме того, проводилась проверка по «Своду названий гидрографических объектов РФ и стран СНГ» [СНГО]. Определенные корректировки в понимание происхождения и распространения моделей внесли также «Словник гидронимов Украины» [СГУ] и «Гидронимия бассейна Оки» [Смолицкая 1976]. Эти источники дают представление о моделях, характерных для русской топонимии широкой территории, а также для славянской топонимии в целом. При этом наличие модели в словаре Г. П. Смолицкой интерпретировалось с учетом того обстоятельства, что бассейн Оки также содержит топонимию финно-угорского происхождения (меряно-муромского типа).

Количество названий, внешний облик которых допускает, что они могут быть полными семантико-словообразовательными кальками, невелико (около 40). Они фиксируются преимущественно в топонимии Бабаевского и Вытегорского районов - на территории еще живого или недавнего вепсско-русского двуязычия:

- Бабаевский р-н: Грязнозеро, Доброзеро, Долгозеро, Ёршозеро, Жабозеро, Жёлтозеро, Клёнозеро, Кольиозеро, Кривозеро, Святозеро, Соколозеро, Холмозеро;

- Вытегорский р-н: Березникозеро, Блинозеро, Блудозеро, Грязьозеро, Грязнозеро, Долгозеро, Кольчозеро, Крайозеро, Линьозеро (Линье), Листозеро, Порогозеро, Ратозеро (Ратное), Рогозеро, Сигручей, Сольозеро.

Несколько полных калек отмечено в Белозерском и Каргопольском районах:

- Белозерский р-н: Липозеро, Рогозеро, Рыбозеро, Светлозеро, Святозеро;

- Каргопольский р-н: Долгозеро, Листозеро, Синеозеро (Синее), Спасскозеро (Спасское).

Единичные примеры засвидетельствованы в Вашкинском (Святозеро), Кадуйском (Ольхозеро) и Кирилловском (Вещозеро (Вещее)) районах.

Так, часть русских названий Святое, Святозеро и т. п. может быть калькой прибалтийско-финской гидронимной модели P̈̈hä/järvi 'Святое озеро' (предполагаемая ранняя семантика прибалтийско-финской лексемы рӥһä 'изгородь, ограда, граница' ${ }^{6}$ [Муллонен 2002: 148]).

${ }^{6}$ В плане развития семантики этой модели интересна пара названий Pühär 'jär 'v // Постное, ср. приб.-фин. рӥһӓ ‘пост’ [Муллонен 2002: 147]. 
На территории Белозерья известно 8 Святых озер и 3 Святозера. Анализ распространения данной основы в русской топонимии Русского Севера показывает, что Святые озера (и Святозера) встречаются только в Белозерье и его ближайших окрестностях, а также в бассейне Северной Двины (см. Схемy 1) 7 . Большинство Святых озер соотносятся с местами реального существования церквей, храмов, монастырей.

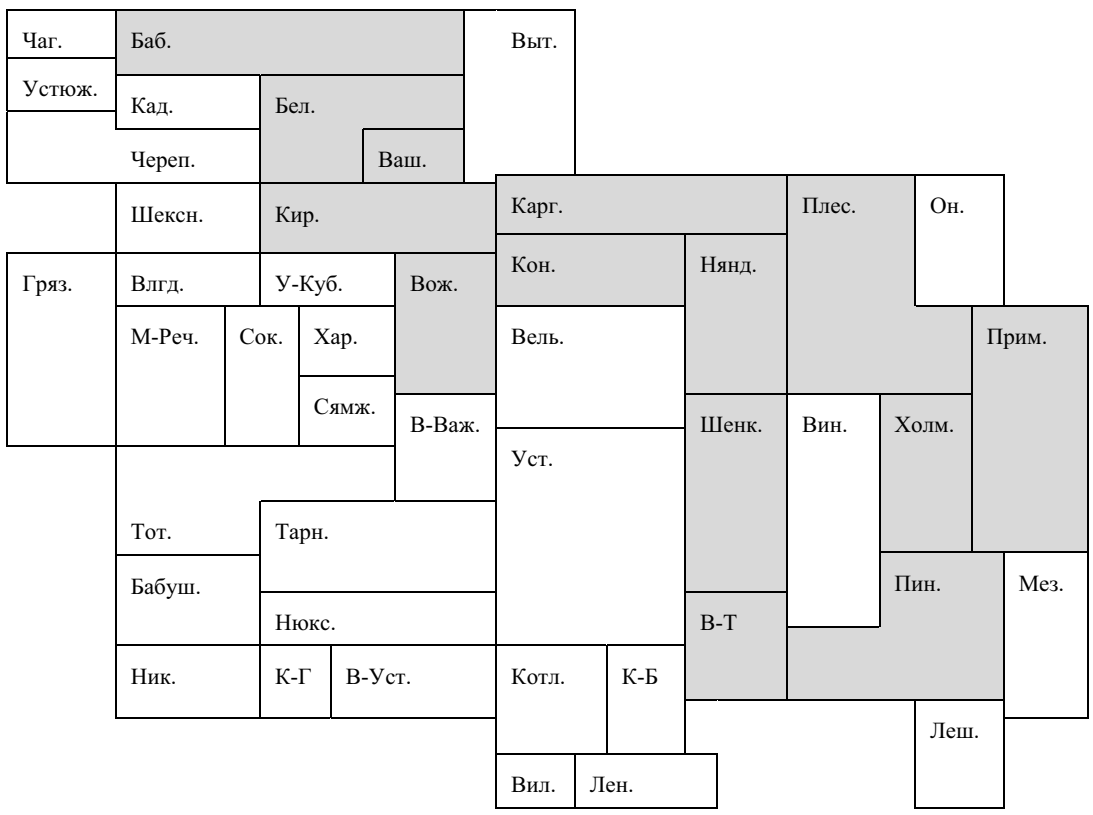

Схема 1. Распространение названий озер с основой Святна территории Русского Севера

Fig. 1. Distribution of the names of lakes with the stem Святin the territory of the Russian North

Обозначение темного цвета воды с помощью прилагательного грязный также имеет ареальную обусловленность: Грязное (Баб., Карг., Кир.); Грязнуха (Баб.), Грязнеи (Выт.); Грязнозеро, Грязьозеро (Выт.).

7 Здесь и далее схематично представлено расположение административных районов Архангельской и Вологодской областей на карте Русского Севера. Районы, в которых зафиксирована рассматриваемая топонимическая модель, обозначены серой заливкой. 
Большая часть названий зафиксирована на северо-западе Белозерья; за его пределами Грязные озера известны только в Верхнетоемском, Няндомском, Плесецком, Приморском и Шенкурском районах (см. Схему 2), что в совокупности с фактом функционирования в составе полных словообразовательных калек может указывать на переводной характер части этих основ. Данная модель распространена в топонимии прибалтийско-финского происхождения: Редозеро (Выт., Карг.), Redojär'(v) (Выт.), ср. люд., вепс. redu 'грязь; слякоть' [SSA 3: 68-69], русской параллелью которого является Грязнозеро (Выт.). Основа redu- известна в топонимии Карелии в составе топонимов Redulambi, Redulampi, а также в живой вепсской топонимии Карелии и Ленинградской области в виде Redujärv // Грязное [ГИС ТК].

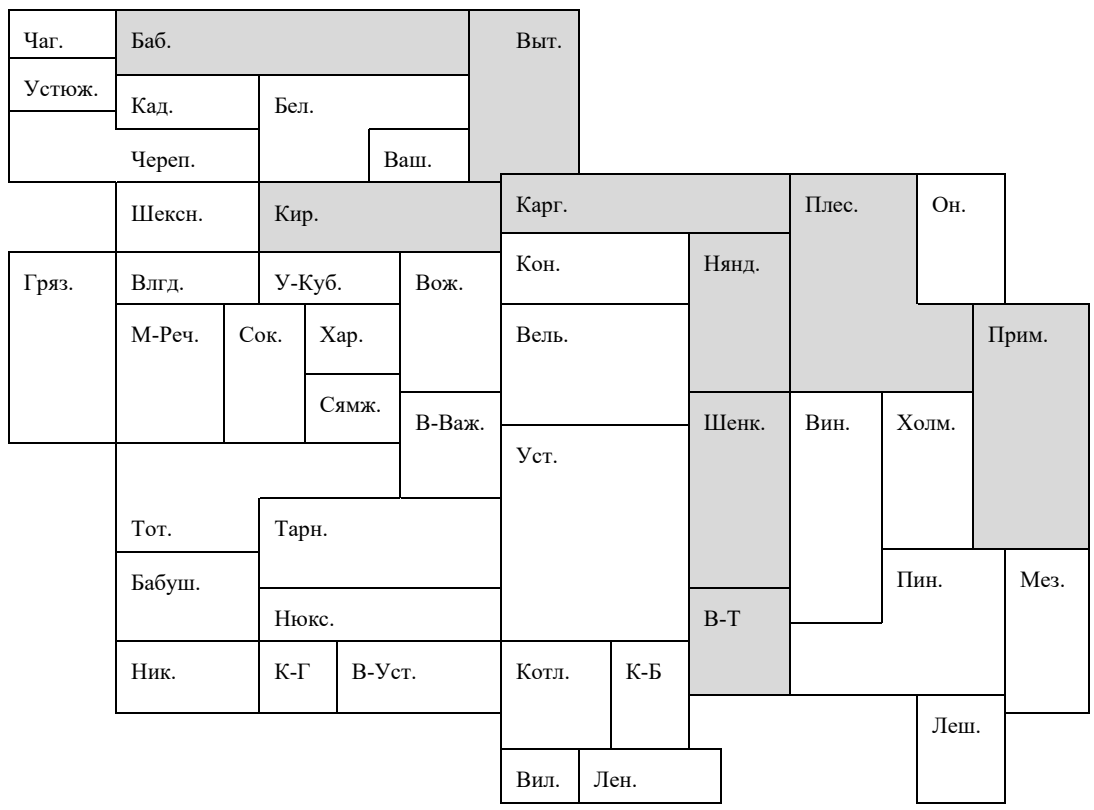

Схема 2. Распространение названий озер с основой Грязна территории Русского Севера

Fig. 2. Distribution of the names of lakes with the stem Грязin the territory of the Russian North

Другая широко распространенная прибалтийско-финская модель Kalajärvi («Рыбное озеро») - также могла быть калькирована, по крайней мере, в некоторых топонимах из следующего ряда: Рыбное Озеро (Баб.), 
Рығбное (Выт.), Рыєблохта, Рыбозеро (Бел.), ср. картографическое название оз. Kalalambi (Кем.) - Рыба. Рыбные озера известны лишь в некоторых районах Русского Севера (см. Схему 3), в форме Рыбозеро - только в Белозерском и Онежском районах, а также в Присвирье. При этом на территории Белозерья представлены и полукальки типа Калозеро (Выт.), Калазерко (Кир.). Для собственно русской топонимии в данном случае, видимо, более характерно давать указание на определенный вид рыбы (ср. частотные в русской топонимии $\mathrm{Ka}$ расье, Щучье, Окунье и пр.).

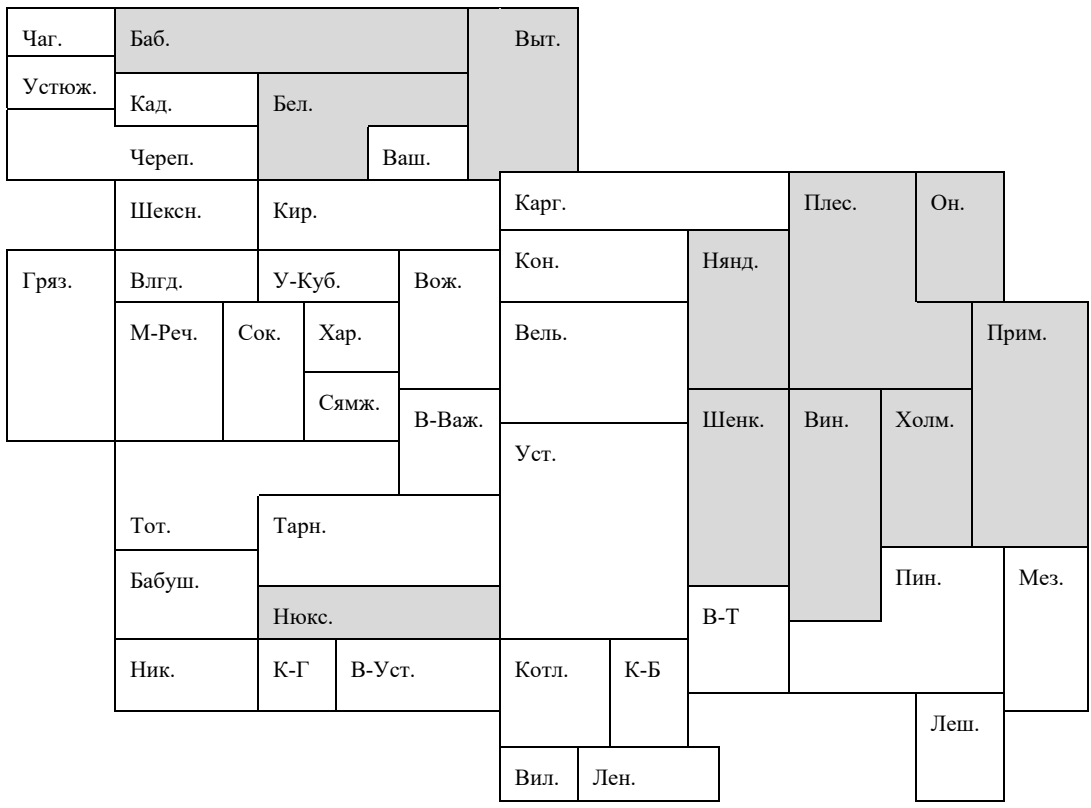

Схема 3. Распространение названий озер с основой Рыбна территории Русского Севера

Fig. 3. Distribution of the names of lakes with the stem $Р$ рыбin the territory of the Russian North

Сокол (Соколозеро) (Баб.) по форме выглядит как полная калька, но ни в вепсской, ни в карельской топонимии соседней Карелии аналогичных названий не обнаружено. Озеро Сокол зафиксировано в Чагодощенском районе Вологодской области и в Лешуконском районе Архангельской области; Соколозеро, по данным [СНГО], отмечено 
в Беломорской Карелии. В прибалтийско-финских языках отсутствует специальное слово для обозначения сокола, а при необходимости используется обозначение ястреба (фин., карел. haukka). В вепсском sokol 'сокол' заимствовано из русского языка [Винокурова 2006: 73]. Можно предполагать, что Соколозеро является не вполне точным переводом *Habukjärvi (cp. вепс. habuk 'ястреб' [СВЯ: 101]). Аналогичные названия известны в Присвирье: Гаукозеро в басс. р. Шокша [СГБС: 51]; залив Habukankuar в басс. p. Усланка [там же: 25] и др.

Жабозеро (Баб.), вероятно, является калькой распространенной в вепсской топонимии модели Sambajär'v, cp. вепс. samba 'лягушка' [СВЯ: 495], rubisamba 'жаба' [там же: 482].

Вероятно, калькой вепсской модели является и Доброзеро (Баб.) (аналогичное название с вариантом Доброе известно и в Приоятье) и Хорошее (Выт.), ср. hӥvӓ 'хороший', ‘добрый' [СВЯ: 138; НРВС: 123]. Соответствующая модель распространена в топонимии Восточной Финляндии, где озер с названиями Hyväjärvi (Kuusamo, Leppävirta, Pieksamäki, Posio, Suomussalmi) ${ }^{8}$, Hyvälampi (Kuusamo, Lieksa, Mäntyharju) насчитывается более 10.

Некоторые факты могут объясняться как на собственно русской, так и на прибалтийско-финской почве.

Так, в названии Сигручей (Выт.) более вероятной видится возможность заимствования в русский из прибалтийско-финских языков, cp. фин. siika, ижор. sīka, карел. siika, люд. šl̆, вепс. sīg, вод. sīka, эст. siig, лив. sig 'сиг (Coregonus)' [SSA 3: 175] и этимологию рус. сиг [Фасмер 3: 617]. Сигозера отмечены в Пинежском и Холмогорском районах Архангельской области; названия островов, ручьев, заливов, угодий с основой Сиг- (Сигача, Сигостров и др.) распространены в Карелии (Медвежьегорский, Пудожский районы) [ГИС ТК].

Также возможна ситуация, когда этимон может иметь общие истоки в русском, прибалтийско-финских и саамском языках, cp. вепс. sol 'соль' и историю этого слова в указанных языках [SSA 3: 214-215], что затрудняет определение направления калькирования. Топонимы, аналогичные Сольозеро (Выт.), - названия покосов Сольгуба и Сольнаволок [ГИС ТК] - обнаружены только в Заонежье, на территории, наиболее

8 Здесь и далее все примеры из финской топонимии приводятся по данным реcypca retkikartta.fi. В скобках указаны финские названия муниципалитетов Финляндии, в которых зафиксированы данные топонимы. 
рано подвергшейся русскому влиянию, что позволяет отдать предпочтение русским истокам модели. Возможно, однако, что в данном случае имеет место упрощение исходного *Сольмозеро, ср. аналогичный топоним Сольмозеро, известный в Приоятье [СГБС: 36].

\section{3. «Мнимые» кальки и случаи народной этимологии}

Наряду со словообразовательно-семантическими кальками (типа Долгозеро, Клёнозеро, Кривозеро, Порогозеро), встречаются названия, в которых основа топонима лишь выглядит русской. Так, формам Вещозеро, Линьозеро, Ратозеро, Синеозеро, Спасскозеро соответствуют собственно русские варианты Вещее, Ленье, Ратное, Синее, Спасское. Однако наличие собственно русской вариантной формы не всегда свидетельствует о русском происхождении названия: так, Ратное // Pатозеро (Выт.) можно сопоставить с приб.-фин. rataa 'проводить лодки' ([SSA 3: 53], в вепсском слово отсутствует), а также карел. rata, rada 'путь' [ССКГК: 234], а Рогозеро (Бел., Выт) - с вепс. rogo 'камыш, тростник; рогоз’ [СВЯ: 478], ср. оз., дер. Рогозеро, руч., уг. Верхний / Нижний Рогой, руч. Рогойручей (Пуд.) [ГИС ТК].

Предпочтение в пользу прибалтийско-финского происхождения следует также отдать в случае названия Листозеро (Выт., Карг.), ср. название р. Листега, Листнаволок (Конд.), Листозеро (Пуд.) [ГИС ТК] и вепс. l'istuida 'резать' [СВЯ: 293]. В таких случаях критерием является то, что основа употребляется в составе топонимов с формантами субстратного происхождения -га, -ча: ср., с одной стороны, Сигручей, Листозеро, Синезеро, а с другой - Сигача, Листега, Синига и др.

Также Вещцзеро (Вещеозеро) (Кир.) может восходить к субстратному оригиналу, ср. р. Вещаница (В-Т), оз. Вещанища (В-Т, Пин.), лес Вешая Лужа (Устюж.), ур. Вещчелма, руч. Вещчинский Ручей = Вешкинский (Бел.), руч. Вещиияа (Баб.); ср. также Вечостров, о-в в губе Святуха на Онежском озере (Медв.) [ГИС ТК].

В названии Кольцозеро основа, на первый взгляд, могла быть заимствована в прибалтийско-финские языки из русского, cp. карел. kolttša, вепс. kol'ts < pус. кольцьо [SSA 1: 392], однако в реальности в основе топонима, скорее всего, прасаам. *kōlsē, саам. сев. goal'se, Инари koalssi, Колтта kuälss, Кильдин kuēls, тер. kięlse 'крохаль (род нырковых уток)' 
[YS: 56-57; Матвеев 2007: 94], в пользу чего свидетельствует вепсская форма того же названия Kol'c 'ar', а также русская параллельная форма Кольчезеро.

В отдельных случаях возможно народно-этимологическое преобразование прибалтийско-финского оригинала. В нашем материале наиболее показательные примеры данного процесса — это Блудозеро (Выт.), которое, скорее всего, возникло в результате народной этимологии по аналогии с рус. блуд, а оригинальной формой названия могло быть *Лудозеро (ср., например, Лоудозеро // Loudjärv в басс. р. Оять [СГБС: 34]), и Вшивозеро (Ваш.) < Шивозеро, ср. карел. šуvӓ 'глубокий’ [ССКГК: 280]. Аналогичный случай, вероятно, представлен в названии Спасскозеро (Карг.): здесь в качестве исходной можно предполагать форму Паскозеро (ср. в Кирилловском районе: в Спасское озеро впадает р. Паска), ср. вепс. pask ‘жидкий кал' [СВЯ: 402], а также в Крайозеро (Выт.), в основе которого лежит фин., карел., ливв., люд. raja 'граница, край, конец' < рус. край [SKES: 722].

\section{5. Калькирование моделей номинации}

В некоторых случаях могут калькироваться сами модели номинации, без сохранения структуры ${ }^{9}$. Обычно такие названия выглядят уникальными на фоне русской топонимической системы и имеют ареальные характеристики, свойственные субстратной топонимии.

Название сороги представлено как в русской, так и в субстратной топонимии. Примечательно, что в Белозерье модель Сорожье фиксируется на территории только двух районов - Вашкинского и Кирилловского. Основа шире представлена на территории Архангельской области (см. Схему 4) и преобладает в названиях озер. В субстратной топонимии соответствующая основа известна в следующих вариантах: Саргозеро (Выт., Карг.), Сергозеро (Бел., Выт., Кон.), Сиргозеро (Выт.), Сяргозеро (Бел., Выт., Карг.), ср. фин., ижор., карел. särki 'плотва', люд. šärg(i), вепс. särg, эст., лив. särg ‘то же’ [SSA 3: 241], а также

\footnotetext{
9 Возможность калькирования прибалтийско-финских названий без сохранения словообразовательной структуры доказывают примеры вепсско-русских параллельных названий типа Pohjatomg'är'f// Бездонное, ср. вепс. pohjatoi ‘бездонный’ [Муллонен 1988: 106].
} 
caам. Йоканьга sirrk [ССДКВС: 65]. Ближе всего к современной вепсской форме стоит вариант основы Сярг-; она представлена не только на Русском Севере, но и в Карелии - в Пудожском районе и в Заонежье [ГИС ТК]. Отметим, что в Карелии русским соответствием данной основы выступает уже не сорога, а плотва, сp. Särgijärvi // Плотвица (Кем.).

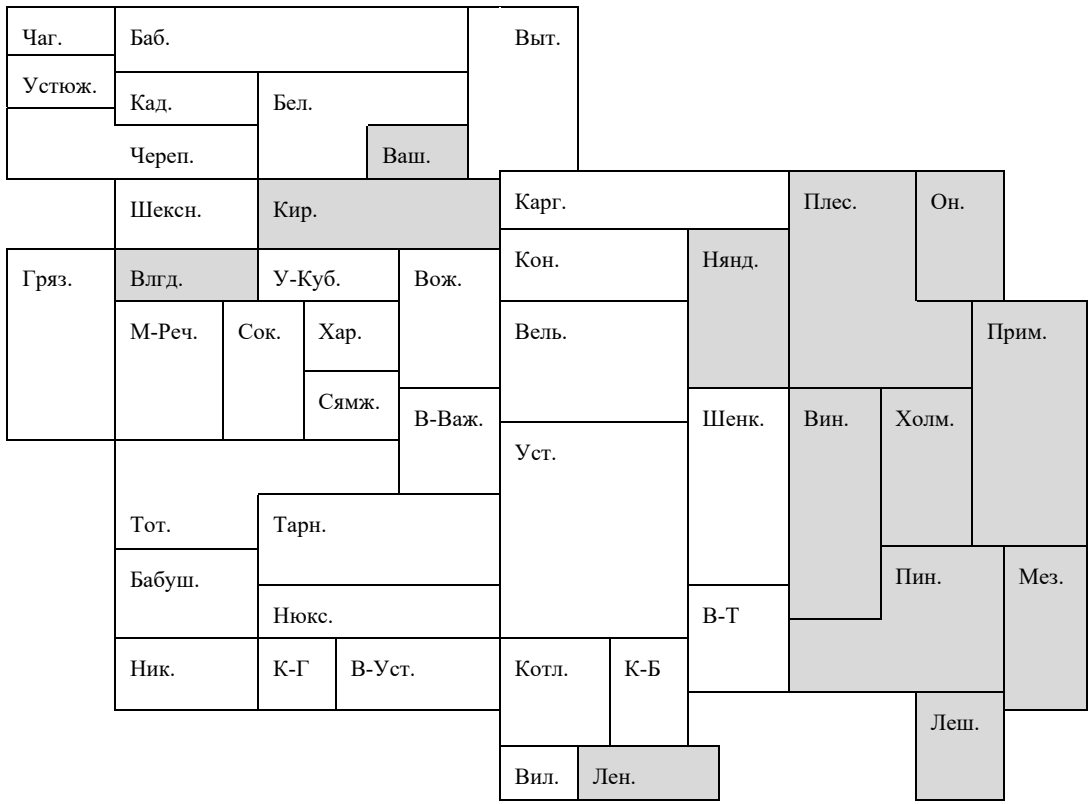

Схема 4. Распространение названий озер с основой Сорожна территории Русского Севера

Fig. 4. Distribution of the names of lakes with the stem Сорожin the territory of the Russian North

Узкие озера отмечены в Белозерском районе Вологодской области, а также в Виноградовском, Красноборском, Котласском, Лешуконском, Мезенском и Онежском районах Архангельской области (см. Схему 5); в названиях болот это прилагательное используется в Присвирье и Приоятье. Данная модель могла применяться в том числе для адаптации прибалтийско-финской топонимии: Kaidagär'v [КТК] // Кайдозеро // Узкое Озеро, ср. вепс. kaid 'узкий' [СВЯ: 167]. Основа Кайд- распространена в топонимии Карелии и известна как на карельской, так и на вепсской территории [ГИС ТК]. 


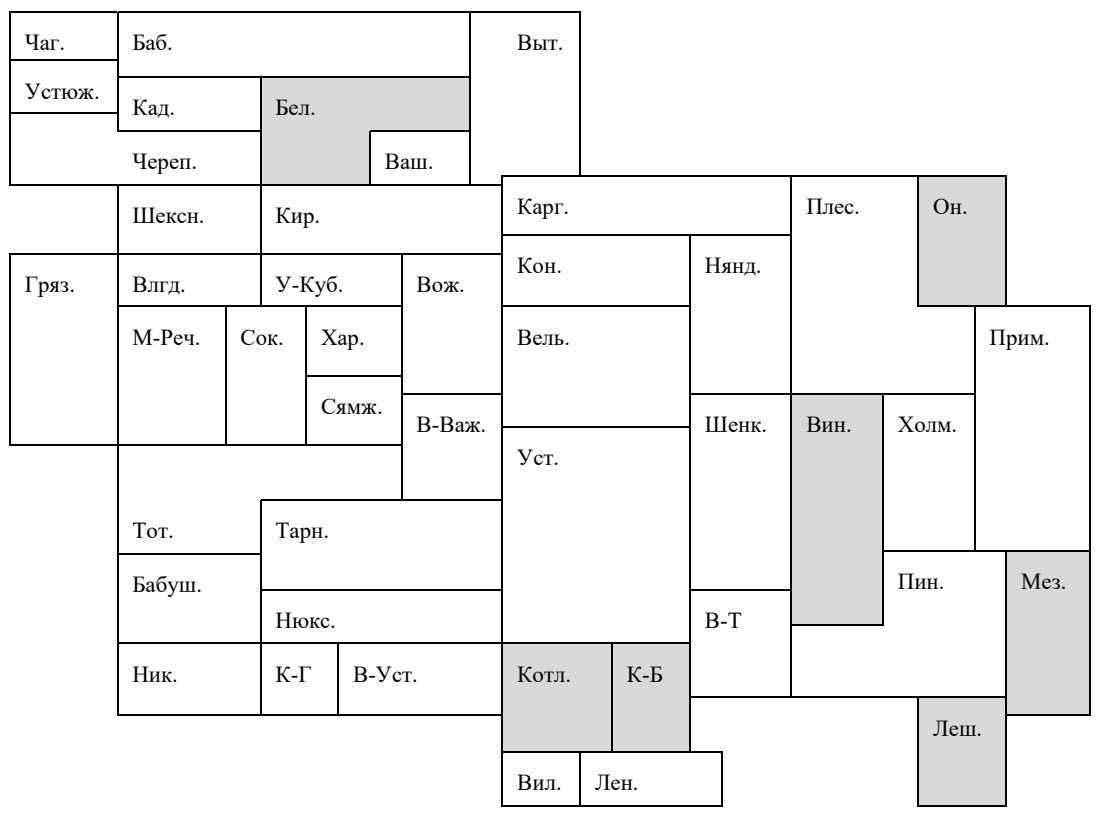

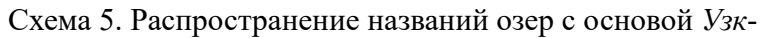
на территории Русского Севера

Fig. 5. Distribution of the names of lakes with the stem $У_{3} \kappa-$ in the territory of the Russian North

Tонкие озера отмечены в Вашкинском и Вытегорском районах, известны в топонимии Беломорской Карелии [ГИС ТК], где они считаются кальками саволакской модели Hoikkajärvi, Hoikkalampi [Кузьмин 2011: 50].

Широкие озера отмечены в Вашкинском, Кирилловском и Шекснинском районах Вологодской области, Верхнетоемском, Виноградовском, Котласском, Лешуконском, Онежском районах Архангельской области (см. Схему 6); в названии болота это же прилагательное используется в Присвирье. Ср. карельскую модель Leviejärvi (Костомукша), Levielambi // карт. Левьялампи (Кем.) [ГИС ТК].

Еще одной ареально ограниченной моделью является название оз. Худое (Ваш.): «Водилась одна сорога, вот и Худое» (Ваш., Липин Бор). Худые озера с аналогичными мотивировками (в озере водится мелкая рыба либо само озеро имеет малые размеры) известны на территории Карелии: в Пудожском, Кондопожском, Медвежьегорском 


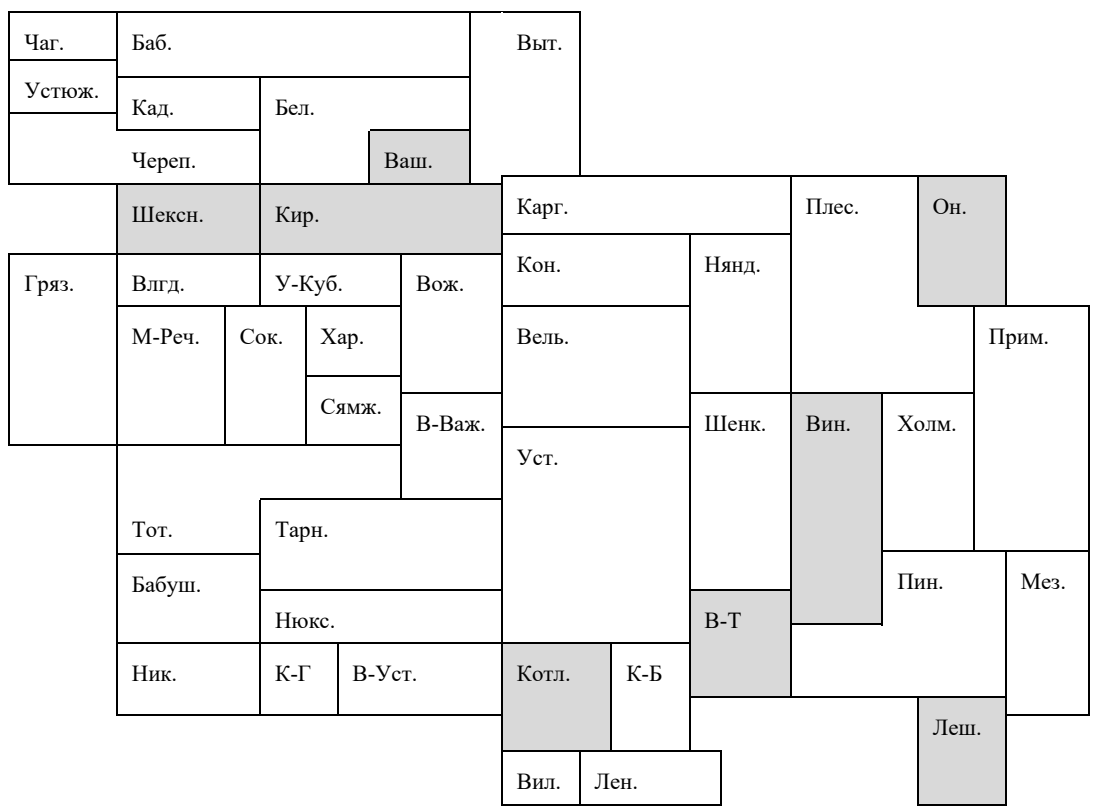

Схема 6. Распространение названий озер с основой Широкна территории Русского Севера

Fig. 6. Distribution of the names of lakes with the stem Широкin the territory of the Russian North

районах [ГИС ТК]. Гидроним Худое может быть калькой вепсской модели Pahad'är'v (Олон.), засвидетельствованной в топонимии Белозерья в виде полукалек: Пагаозерко (Карг.), Пагача, Пагозеро (Выт.), Пахаз // Pahag'ärv(ut) (Баб.), ср. вепс. paha 'плохой' [СВЯ: 390]. Показательным является также наличие вепсско-русской пары Pahadärvi // Худое в Присвирье [СГБС: 23].

Название озера Половинное (Выт.) можно интерпретировать как 'находящееся на половине пути', что подтверждается контекстами: «на половине дороги в Поржалу», «на половине дороги от пос. Совза до Кречетово» (Кир., Березово). Аналогичный мотив содержится в названиях Большое Половинное (Карг.) и Малое Половинное (Половинный Летник) - озера находятся вдоль дороги, соединяющей два куста деревень, примерно на половине пути между ними. Ср. также оз. Половинная Ляга (Уст.), Половинное (В-Т, Карг., Нянд., Он.): «По обеим сторонам озера идет Губернская просека, которая разделяет озеро 
на два района» (В-Т, Кондратовская); «Половина наша, а половина Шенкурского района» (В-Т, Мальцевская), «Там Вага-река есть, так озеро на половине пути так и Половинным зовется» (В-Т, Шаповская). Ограниченное распространение (см. Схему 7) вкупе с наличием модели Полозеро (Баб., Выт., Карг., Он., Холм.) позволяют предполагать калькирование известной в карельской (Медв., Костомукша) и очень распространенной в финской топонимии модели Puoliväli - обозначения места, помечающего половину пути. Другим возможным источником модели могут быть карельские названия Keskijärvi (Кем.), Keskilambi (Белом., Конд.) [ГИС ТК], ср. карел. keski 'середина, центр', 'посреди, посредине чего-либо' [ССКГК: 95].

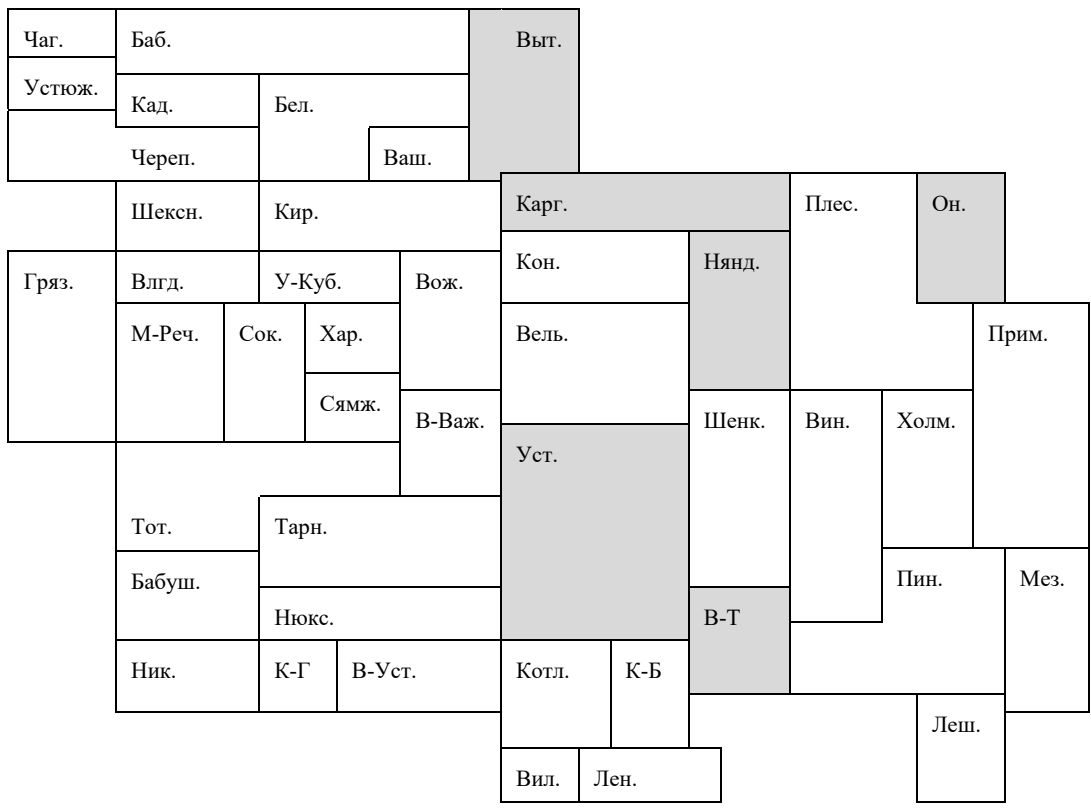

Схема 7. Распространение названий озер с основой Половинна территории Русского Севера

Fig. 7. Distribution of the names of lakes with the stem Половинin the territory of the Russian North

Еще один интересный пример отражения прибалтийско-финской модели представляет собой параллель Ištun // Иитамозеро // Сидячее, cp. вепс. ištta 'сидеть', а также ištund- в ištund/sija 'место для сидения' 
[СВЯ: 151-152]. Аналогичные названия известны в топонимии Финляндии: Istunlampi («Сидячее озеро») (Konnevesi), Istuinlampi («Сидячеe озеро») (Nurmes). Другие примеры топонимов с основой Сидячна территории Русского Севера и Карелии также имеют параллели в прибалтийско-финской топонимии, ср. покос Сидячий Камень (Выт.) и распространенную финскую модель Istuinkivi («Сидячий камень») (Pyhäjärvi, Sonkajärvi), Istunkallio («Сидячая скала») (Haapavesi); Cuдячая Грива (У-Куб.) и фин. Istunтӓki («Сидячая гора») (Konnevesi, Nivala, Haapavesi), Istuinvaara («Сидячая гора») (Nurmes), а также ур. Сидячая Берёза (Конд.) [ГИС ТК] и фин. Istunhonka («Сидячая сосна») (Rejsjärvi).

\section{6. Выводы}

Рассмотрение калькированных топонимов Белозерья показывает, что способы освоения прибалтийско-финских названий были различны. В одних случаях происходило калькирование и словообразовательной структуры, и семантики названия. Такой способ взаимодействия прибалтийско-финской и русской топонимических систем в большей степени характерен для Бабаевского и Вытегорского районов Вологодской области - территории живого или недавнего вепсско-русского двуязычия. В других случаях имела место фонетическая адаптация иноязычного названия к русской топонимической системе с последующей ремотивацией путем «народной этимологии». Такие названия немногочисленны и представлены преимущественно в северо-восточном Белозерье, в зоне доприбалтийско-финского субстрата и большего распространения топонимии русского происхождения. В третьих случаях имело место калькирование номинативной модели, что наиболее трудно доказуемо. Тем не менее анализ ареальной дистрибуции и прибалтийско-финских топонимических параллелей позволяет предполагать существование калькированных номинативных моделей на территории северного и северо-восточного Белозерья, где двуязычие, как представляется, поддерживалось достаточно длительно. 


\section{Список условных сокращений}

Баб. - Бабаевский район Вологодской области; Бабуш. - Бабушкинский район Вологодской области; басс. - бассейн; Бел. - Белозерский район Вологодской области; Белом. - Беломорский район Республики Карелия; В-Важ. - Верховажский район Вологодской области; В-Т - Верхнетоемский район Архангельской области; В-Уст. Великоустюгский район Вологодской области; Ваш. - Вашкинский район Вологодской области; Вель. - Вельский район Архангельской области; вепс. - вепсский язык; Вил. - Вилегодский район Архангельской области; Вин. - Виноградовский район Архангельской области; Влгд. - Вологодский район Вологодской области; Вож. - Вожегодский район Вологодской области; Выт. - Вытегорский район Вологодской области; ижор. - ижорский язык; Гряз. - Грязовецкий район Вологодской области; К-БКрасноборский район Архангельской области; К-Г — Кичменгско-Городецкий район Вологодской области; Кад. - Кадуйский район Вологодской области; Карг. - Каргопольский район Архангельской области; карел. — карельский язык; Кем. - Кемский район Республики Карелия; Кир. - Кирилловский район Вологодской области; Кон. Коношский район Архангельской области; Конд. - Кондопожский район Республики Карелия; Котл. - Котласский район Архангельской области; Лен. - Ленский район Архангельской области; Леш. - Лешуконский район Архангельской области; лив. ливский язык; люд. - людиковское наречие карельского языка; М-Реч. - Междуреченский район Вологодской области; Медв. - Медвежьегорский район Республики Карелия; Мез. - Мезенский район Архангельской области; Ник. - Никольский район Вологодской области; Нюкс. - Нюксенский район Вологодской области; Нянд. Няндомский район Архангельской области; оз. - озеро; Олон. - Олонецкий район Республики Карелия; Он. - Онежский район Архангельской области; Пин. - Пинежский район Архангельской области; Плес. - Плесецкий район Архангельской области; приб.-фин. - прибалтийско-финский; Прим. - Приморский район Архангельской области; Пуд. - Пудожский район Республики Карелия; p. - река; р-н — район; руч. - ручей; Сок. - Сокольский район Вологодской области; Сямж. - Сямженский район Вологодской области; Тарн. - Тарногский район Вологодской области; Тот. Тотемский район Вологодской области; У-Куб. - Усть-Кубенский район Вологодской области; уг. - угодье; ур. - урочище; Уст. - Устьянский район Архангельской области; Устюж. - Устюженский район Вологодской области; фин. - финский язык; Хар. - Харовский район Вологодской области; Холм. - Холмогорский район Архангельской области; Чаг. — Чагодощенский район Вологодской области; Череп. — Череповецкий район Вологодской области; Шексн. - Шекснинский район Вологодской области; Шенк. - Шенкурский район Архангельской области; эст. — эстонский язык.

\section{Литература}

Винокурова 2006 - И. Ю. Винокурова. Животные в традиционном мировоззрении вепсов. Петрозаводск: ПетрГУ, 2006. 
Дмитриева 2003 - 3. В. Дмитриева. «Корельские выходцы» на землях КириллоБелозерского монастыря в XVII веке // Ф. Я. Коновалов (ред.). Кириллов: краеведческий альманах. Вып. 5. Вологда: Легия, 2003. С. 81-90.

Жербин 1956 - А. С. Жербин. Переселение карел в Россию в XVII в. Петрозаводск: Госиздат КФССР, 1956.

Захарова 2017 — Е. В. Захарова. Отэтнонимические названия Корел- / Карельский в топонимии Русского Севера // Альманах североевропейских и балтийских исследований. 2017. Вып. 2. С. 255-273.

Кузьмин 2011 - Д. В. Кузьмин. Наследие саволаксов в топонимии Карелии // Труды Карельского научного центра РАН. 2011. № 6: Гуманитарные исследования. Вып. 2. С. 45-56.

Макарова 2017 - А. А. Макарова. К вопросу о картографировании этнолокальных групп Белозерья по ономастическим данным // Известия Уральского федерального университета. 2017. Т. 19. № 4 (169). С. 63-83.

Матвеев 2007 - А. К. Матвеев. Субстратная топонимия Русского Севера. В 4 ч. Ч. 3. Екатеринбург: Издательство Уральского университета, 2007.

Муллонен 1988 - И. И. Муллонен. Гидронимия бассейна Ояти. Л.: Наука, 1988.

Муллонен 2002 - И. И. Муллонен. Топонимия Присвирья: проблемы этноязыкового контактирования. Петрозаводск: ПетрГУ, 2002.

НРВС - Н. Г. Зайцева, М. И. Муллонен. Uz’ venä-vepsläine vajehnik. Новый русско-вепсский словарь. Петрозаводск: Периодика, 2007.

СВЯ - М. И. Зайцева, М. И. Муллонен. Словарь вепсского языка. Л.: Наука, 1972.

СГБС - И. И. Муллонен, И. В. Азарова, А. С. Герд. Словарь гидронимов Юго-Восточного Приладожья (бассейн реки Свирь). СПб.: СПбГУ, 1997.

СГУ — К. К. Цілуйко (ред.). Словник гідронімів Україны. Київ: Наукова думка, 1979.

Смолицкая 1976 - Г. П. Смолицкая. Гидронимия бассейна Оки (список рек и озер). М.: Наука, 1976.

СНГО - Г. И. Донидзе (ред.). Словарь названий гидрографических объектов России и других стран - членов СНГ. М.: Картгеоцентр; Геодезиздат, 1999.

Соболев 2015 - А. И. Соболев. Карельское наследие в топонимии Юго-Восточного Обонежья // Вопросы ономастики. 2015. № 1 (18). С. 47-68.

ССДКВС - Ю. С. Елисеев, Н. Г. Зайцева (ред.). Сопоставительно-ономасиологический словарь диалектов карельского, вепсского, саамского языков. Петрозаводск: КарНЦ РАН, 2007.

ССКГК - В. П. Федотова (ред.), В. П. Федотова, Т. П. Бойко (сост). Karjalan varšinaismurtehien šanakirja. Словарь собственно-карельских говоров Карелии. Петрозаводск: КарНЦ РАН, 2009.

Фасмер - М. Фасмер. Этимологический словарь русского языка. В 4 т. Пер. с нем. и доп. чл.-корр. АН СССР О. Н. Трубачева. 2-е изд. М.: Прогресс, 1986-1987.

Mullonen 2007 - I. Mullonen. Toponym Contacts along the River Svir // Onomastica Uralica. 2007. Vol. 4: Borrowing of Place Names in the Uralian Languages. P. 141-157.

SKES - E. Itkonen, A. J. Joki, R. Peltola (toim.). Suomen kielen etymologinen sanakirja. O. 1-7 (Lexica societatis Fenno-ugricae. Vol. XII). Helsinki: Suomalaisen Kirjallisuuden Seura, 1955-1981. 
SSA - E. Itkonen, U.-M. Kulonen (toim.). Suomen sanojen alkuperä. Etymologinen sanakirja. O. 1-3 (Suomalaisen Kirjallisuuden Seuran toimituksia. Vol. 556). Helsinki: Suomalaisen Kirjallisuuden Seura, 1992-2000.

YS — J. Lehtiranta. Yhteissaamelainen sanasto. Helsinki: Suomalais-Ugrilainen Seura, 1989.

\section{Источники}

ГИС ТК - Геоинформационная система «Топонимия Карелии». Институт языка, литературы и истории КарНЦ РАН. Петрозаводск.

КТК - Картотека топонимов Карелии и сопредельных областей (хранится в Институте языка, литературы и истории КарНЦ РАН, г. Петрозаводск).

ТК ТЭ - Топонимическая картотека Топонимической экспедиции Уральского университета (хранится на кафедре русского языка, общего языкознания и речевой коммуникации УрФУ, г. Екатеринбург).

Retkikartta.fi — Metsähallistus. URL: retkikartta.fi (дата обращения 01.12.2020).

\section{References}

Dmitrieva 2003 - Z. V. Dmitrieva. «Korelskie vykhodtsy» na zemlyakh Kirillo-Belozerskogo monastyrya v XVII veke ["Korel natives" on the lands of the Kirillo-Belozersky monastery in the XVII century]. F. Ya. Konovalov (ed.). Kirillov: kraevedcheskiy almanakh [Kirillov: local history almanac]. Iss. 5. Vologda: Legiya, 2003. P. 81-90.

Kuzmin 2011 - D. V. Kuzmin. Nasledie savolaksov v toponimii Karelii [Savolax heritage in the toponymy of Karelia]. Trudy Karelskogo nauchnogo tsentra RAN. 2011. № 6: Gumanitarnye issledovaniya. Iss. 2. P. 45-56.

Makarova 2017 - A. A. Makarova. K voprosu o kartografirovanii etnolokalnykh grupp Belozerya po onomasticheskim dannym [On the issue of mapping ethnolocal groups of Belozerye according to onomastic data]. Izvestiya Uralskogo federalnogo universiteta. 2017. Vol. 19. № 4 (169). P. 63-83.

Matveev 2007 - A. K. Matveev. Substratnaya toponimiya Russkogo Severa [Substrate toponymy of the Russian North]. In 4 pt. Pt. 3. Yekaterinburg: Ural University Press, 2007.

Mullonen 1988 - I. I. Mullonen. Gidronimiya basseyna Oyati [Hydronymy of Oyat basin]. Leningrad: Nauka, 1988.

Mullonen 2002 - I. I. Mullonen. Toponimiya Prisvirya: problemy etnoyazykovogo kontaktirovaniya [Toponymy of Svir region: problems of ethnic and linguistic contact]. Petrozavodsk: Petrozavodsk State University, 2002.

Mullonen 2007 - I. Mullonen. Toponym Contacts along the River Svir. Onomastica Uralica. 2007. Vol. 4: Borrowing of Place Names in the Uralian Languages. P. 141-157.

NRVS - N. G. Zaytseva, M. I. Mullonen. Uz'venä-vepsläine vajehnik. Novyy russko-vepsskiy slovar [New Russian-Veps dictionary]. Petrozavodsk: Periodika, 2007. 
SGBS - I. I. Mullonen, I. V. Azarova, A. S. Gerd. Slovar gidronimov Yugo-Vostochnogo Priladozhya (basseyn reki Svir) [Dictionary of hydronyms of Southeast Ladoga (Svir basin)]. St. Petersburg: St. Petersburg State University Press, 1997.

SGU — K. K. Tsiluyko (ed.). Slovnik gidronimiv Ukraïny [Dictionary of hydronyms of Ukraine]. Kiïv: Naukova dumka, 1979.

SKES - E. Itkonen, A. J. Joki, R. Peltola (toim.). Suomen kielen etymologinen sanakirja. O. 1-7 (Lexica Societatis Fenno-Ugricae. Vol. XII). Helsinki: Suomalaisen Kirjallisuuden Seura, 1955-1981.

Smolitskaya 1976 - G. P. Smolitskaya. Gidronimiya basseyna Oki (spisok rek i ozer) [Hydronymy of Oka basin (list of rivers and lakes)]. Moscow: Nauka, 1976.

SNGO - G. I. Donidze (ed.). Slovar nazvaniy gidrograficheskikh obektov Rossii i drugikh stran - chlenov SNG [Dictionary of names of hydrographic objects of Russia and other CIS member countries]. Moscow: Kartgeotsentr; Geodezizdat, 1999.

Sobolev 2015 - A. I. Sobolev. Karelskoe nasledie v toponimii Yugo-Vostochnogo Obonezhya [Karelian heritage in the toponymy of Southeast Onega]. Voprosy onomastiki. 2015. No. 1 (18). P. 47-68.

SSA - E. Itkonen, U.-M. Kulonen (toim.). Suomen sanojen alkuperä. Etymologinen sanakirja. O. 1-3 (Suomalaisen Kirjallisuuden Seuran Toimituksia. Vol. 556). Helsinki: Suomalaisen Kirjallisuuden Seura, 1992-2000.

SSDKVS - Yu. S. Yeliseev, N. G. Zaytseva (ed.). Sopostavitelno-onomasiologicheskiy slovar dialektov karelskogo, vepsskogo, saamskogo yazykov [Comparative-onomasiological dictionary of dialects of Karelian, Veps, Sami languages]. Petrozavodsk: Karelian Scientific Center of the Russian Academy of Sciences, 2007.

SSKGK - V. P. Fedotova (ed.), V. P. Fedotova, T. P. Boyko (comp.). Karjalan varšinaismurtehien šanakirja. Slovar sobstvenno-karelskikh govorov Karelii [Dictionary of Karelian proper dialects of Karelia]. Petrozavodsk: Karelian Scientific Center of the Russian Academy of Sciences, 2009.

SVYa - M. I. Zaytseva, M. I. Mullonen. Slovar vepsskogo yazyka [Dictionary of the Veps language]. Leningrad: Nauka, 1972.

Vasmer - M. Vasmer. Etimologicheskiy slovar russkogo yazyka [Etymological dictionary of the Russian language]. In 4 vols. Translated from German and supplemented by O. N. Trubachev. $2^{\text {nd }}$ ed. Moscow: Progress, 1986-1987.

Vinokurova 2006 - I. Yu. Vinokurova. Zhivotnye v traditsionnom mirovozzrenii vepsov [Animals in the traditional Veps worldview]. Petrozavodsk: Petrozavodsk State University Press, 2006.

YS - J. Lehtiranta. Yhteissaamelainen sanasto. Helsinki: Suomalais-Ugrilainen Seura, 1989.

Zakharova 2017 - Ye. V. Zakharova. Otetnonimicheskie nazvaniya Korel-/ Karelskiy $\mathrm{v}$ toponimii Russkogo Severa [Names derived from ethnonyms Korel-/Karelian in the toponymy of the Russian North]. Almanakh severoevropeyskikh i baltiyskikh issledovaniy. 2017. Iss. 2. P. 255-273.

Zherbin 1956 - A. S. Zherbin. Pereselenie karel v Rossiyu v XVII v. [Resettlement of Karelians to Russia in the XVII century]. Petrozavodsk: State Publishing House of the Karelo-Finnish SSR, 1956. 


\section{Sources}

GIS TK - Geoinformatsionnaya sistema «Toponimiya Karelii» [Geographic Information System "Toponymy of Karelia”]. Institute of Language, Literature and History Karelian Scientific Center of the Russian Academy of Sciences. Petrozavodsk. KTK — Kartoteka toponimov Karelii i sopredelnykh oblastey [File cabinet of toponyms of Karelia and adjacent areas]. Institute of Language, Literature and History Karelian Scientific Center of the Russian Academy of Sciences. Petrozavodsk.

Retkikartta.fi — Metsähallistus. Available at: retkikartta.fi (accessed on 01.12.2020).

TK TE - Toponimicheskaya kartoteka Toponimicheskoy ekspeditsii Uralskogo universiteta [Toponymic file cabinet of the Toponymic expedition of the Ural University]. Department of Russian Language, General Linguistics and Verbal Communication, Ural Federal University, Yekaterinburg. 


\title{
Об идиоме дер. Куровицы (Kukkõsi / Kukkuzi)
}

\author{
М. 3. Муслимов \\ Институт лингвистических исследований РАН, Санкт-Петербург; \\ mehmet@yandex.ru
}

Аннотация. Статья посвящена описанию современного состояния смешанного водско-ижорского идиома дер. Куровицы. Данный идиом может быть отнесен к классу смешанных языков, причем от водского языка была унаследована морфология, а от нижнелужского ижорского - лексика. В частности, в идиолектах наиболее консервативных носителей этого идиома сохраняются генитив с нулевым показателем, элатив на $-s s(A)$, транслатив на $-s s(I), 3 S g$ презенса на $-b$, частично сохраняются водские чередования ступеней $k / g$ и $s / z$. С точки зрения исторической фонетики в куровицком идиоме присутствуют как общеижорские черты (сохранение $h$-, отсутствие перехода $k>c$ ) , так и водские (переходы $k s>h s, p s>h s, s t>s s$ ). Существует довольно много куровицко-общеижорских лексических изоглосс (maitU 'молоко', paitA 'рубашка', veitsI ‘ножик', iltA ‘вечер', tiitä 'знать:Inf', muissa 'помнить:Inf'), однако заметную долю составляют и куровицко-нижнелужские ижорские изоглоссы (lautA 'стол', aukkU 'дырка', pankI ‘ведро', valo 'навоз', uhs 'дверь', rättI 'платок', lustI 'красивый’, kitsI ‘коза'). Как правило, изоглоссы, объединяющие куровицкий идиом и нижнелужский ижорский, противопоставляя их сойкинскому ижорскому, характерны и для водского языка. Из других куровицко-водско-нижнелужских ижорских изоглосс можно упомянуть переходы $n h>n, r h>r$, выпадение интервокального $h$ в непервых слогах, отсутствие перехода $i r>e r$, терминатив на $-s s a$, комитатив на $-k a$, компаратив на - $p$, партитив единственного числа имен на *-e $\delta a$ с элементом $-t /-d$, отсутствие показателя множественного числа в косвенных падежах -loi-. В некоторых случаях распределение вариантов по идиомам оказывается довольно сложным, отражая тем самым взаимные влияния языков и диалектов в нижнелужском ареале. Уникальной чертой куровицкого идиома является презенс имперсонала на $-t t A Z /-t t \ddot{A Z}$. В генезисе куровицкого идиома можно выделить несколько этапов. На первом этапе происходило формирование нижнелужского ижорского диалекта под сильным влиянием водского языка, вероятно даже водского субстрата. На втором этапе в ходе контактов нижнелужского ижорского и незадокументированного водского куровицкого говора произошла релексификация, что привело к возникновению смешанного куровицкого идиома. На третьем этапе, продолжающемся в настоящее время, происходит постепенная утрата куровицкой морфологии, иными словами, «реморфологизация», и идиолекты «инновационных» носителей уже почти не отличаются от южных говоров нижнелужского диалекта ижорского языка.

Ключевые слова: водский язык, ижорский язык, Куровицы, языковые контакты, смешанные языки, релексификация, субстрат, диалектология. 


\title{
On Kurovitsy (Kukkõsi / Kukkuzi) linguistic variety
}

\section{Z. Muslimov}

Institute for Linguistic Studies, Russian Academy of Sciences, St. Petersburg; mehmet@yandex.ru

\begin{abstract}
The paper proposes a description of the mixed Votic-Ingrian idiom of Kukkuzi in its current state. This idiom belongs to mixed languages, with its morphology inherited from Votic and its lexicon, from the Lower Luga Ingrian. Inter alia, the idiolects of the most conservative Kukkuzi speakers have retained the genitive with a zero ending, the Elative in $-s s(A)$, the Translative in $-s s(I)$, the $3 \mathrm{Sg}$ Present in $-b$; the Votic grade alternations $k / g$ and $s / z$ are partially preserved as well. From the historical phonetics' perspective, the Kukkuzi idiom has both Common Ingrian (e.g., the retained initial $h$-, lack of the sound change $k>\grave{c}$ ), and Votic (e.g., the sound changes $k s>h s, p s>h s, s t>s s$ ) features. Though there are numerous Kukkuzi-Common Ingrian lexical isoglosses (mait $U$ 'milk', paitA 'shirt', veitsI 'knife', iltA 'evening', tiitä 'know:Inf', muissa 'remember:Inf'), a significant number of Kukkuzi-Lower Luga Ingrian lexical isoglosses also can be found; e.g., lautA 'table', aukkU 'hole', pankI 'bucket', valo 'manure', uhs 'door', rättI 'headscarf', lustI 'beautiful', kitsI 'nanny goat'. As a rule, Kukkuzi and Lower Luga Ingrian features, absent in Soikkola Ingrian, are typical of Votic. Other Kukkuzi-Votic-Lower Luga Ingrian isoglosses are 1) the sound changes $n h>n, r h>r, 2$ ) loss of the intervocalic $h$ in non-first syllables, 3) lack of the sound change $i r>e r, 4)$ the Terminative in -ssa, 5) the Comitative in -ka, 6) the Comparative in $-p, 7)$ the Partitive singular in nouns in *-e $\delta a$ with the consonant $-t /-d$, and 8) lack of the Oblique Plural affix -loi-. In some cases, the distribution of variants by idioms is quite complex, reflecting the mutual influences of languages and dialects in the Lower Luga region. A unique feature of Kukkuzi idiom is the Present Impersonal in -ttAZ/-tẗ̈Z. There are several stages in the genesis of the Kukkuzi idiom. At the first stage, the formation of the Lower Luga Ingrian dialect took place under a strong influence of the Votic language. The second stage, marked by contacts between Lower Luga Ingrian and the undocumented Kukkuzi Votic, brought relexefication that led to the emergence of the mixed Kukkuzi idiom. The third stage, continuing at the present time, shows a gradual loss of Kukkuzi morphology or "remorphologization" where the idiolects of "innovative" speakers almost do not differ from the southern dialects of the Lower Luga Ingrian.
\end{abstract}

Keywords: Votic, Ingrian, Kukkuzi, language contact, mixed languages, relexification, substrate, dialectology.

\section{1. Введение}

Прибалтийско-финский идиом, на котором говорят в дер. Куровицы, уже давно привлекает внимание исследователей. Традиционно его 
относят к водским диалектам, наряду с западно-водским, восточно-водским и кревинским [Адлер 1966: 118]. С другой стороны, Лаанест в своей работе [Лаанест 1966], посвященной детальному описанию основных ижорских диалектов, приводит данные по куровицкому диалекту для сравнения с соседними ижорскими говорами. Обсуждению вопроса о принадлежности куровицкого идиома к ижорскому или водскому языку была также посвящена работа С. Сухонена [Suhonen 1985]. В работе [Markus, Rozhanskiy 2012: 92] предлагается рассматривать его как смешанный идиом с водской морфологией и нижнелужской ижорской лексикой.

Мы собирали полевые материалы по куровицкому идиому и другим прибалтийско-финским (водским, ижорским, финским) говорам Западной Ингерманландии начиная с 1999 года ${ }^{1}$, причем проводилось как анкетирование по специальной диалектной анкете, так и запись спонтанной речи. Одной из целей экспедиций в Куровицы являлась проверка встречавшихся в ряде работ [Posti 1980: XIX, Адлер 1966: 118] утверждений, что он является вымершим. Экспедиция 1999 года показала, что в Куровицах продолжал существовать местный прибалтийско-финский идиом, и в речи его носителей продолжали сохраняться особенности, отмеченные предшествующими исследователями как характерные именно для куровицкого. Рассматривая вопрос о принадлежности куровицкого идиома к водским или ижорским говорам, мы можем утверждать, что анализ собранного в 1999-2013 годах материала показал, что более адекватным, на наш взгляд, является подход Маркус и Рожанского. Иными словами, куровицкий идиом корректнее всего описывать не как водский или ижорский диалект, а как смешанный язык, аналогичный, например, так называемому городскому фризскому [van Bree 1994]. Следует, однако, отметить, что куровицкий идиом в том состоянии, в котором он был зафиксирован нами, представляет собой идиолектный континуум, и описание Маркус и Рожанского описывает только часть этого континуума, в то время как другая часть довольно далеко сдвинулась в направлении нижнелужского ижорского говора дер. Орлы.

Целью данной статьи является дать более подробную диалектологическую характеристику куровицкого идиолектного континуума,

1 Экспедиция 1999 г. была поддержана Фондом полевых исследований, экспедиции 2001-2003 гг. были проведены при поддержке Европейского университета в Санкт-Петербурге. 
чем это делают Маркус и Рожанский, а также, опираясь на нее, предложить вероятный сценарий возникновения такого континуума. Это будет своего рода дальнейшим развитием идей Рожанского и Маркус ${ }^{2}$. Далее мы подробно рассмотрим изоглоссы, объединяющие куровицкий идиом с соседними водскими и ижорскими говорами. В выборе изоглосс мы в основном опираемся на те изоглоссы, которые были рассмотрены нами в работе [Муслимов 2005], затрагивающей диалектологию нижнелужского ареала. В отличие от Маркус и Рожанского [Markus, Rozhanskiy 2012], рассматривавших в своей работе морфологические, лексические и фонологические изоглоссы, мы будем касаться, наряду с морфологическими и лексическим изоглоссами, только важных с точки зрения исторической фонетики фонологических изоглосс. С другой стороны, мы уделим особое внимание изоглоссам, связанным с чередованием ступеней, которые не рассматривались Рожанским и Маркус. Кроме того, мы будем учитывать неоднородность нижнелужского ижорского диалекта, в котором можно выделить несколько подгрупп говоров, что не было учтено в работе [Markus, Rozhanskiy 2012]. Среди водских говоров территориально наиболее близким к куровицкому идиому является говор дер. Краколье и Межники. Для него характерно определенное ижорское влияние, в результате которого некоторые характерные для водского языка особенности оказались утрачены. Из ижорских говоров самыми близкими территориально к куровицкому являются говоры дер. Орлы и Волково. Кроме того, к северу от Куровиц на том же (правом) берегу р. Луга ранее существовала дер. Новая, говор которой был близок к говору дер. Остров. Все эти ижорские говоры относятся к нижнелужскому диалекту, причем

\footnotetext{
2 Следует отметить, что указав на асимметрию дистрибуции водских и ижорских черт по уровням языка в куровицком идиоме, Маркус и Рожанский делают оговорку, что квалификация куровицкого идиома как водского или ижорского зависит от того, «whether a researcher considers grammar or vocabulary as the basic language component». С их точки зрения «grammar is more essential for characterising a language, thus we prefer to treat Kukkuzi as a specific Votic variety» [Markus, Rozhanskiy 2012: 92]. С нашей точки зрения, нет никакой необходимости вообще в самом выборе лексики или грамматики как критерия для классификации смешанного идиома. Смешанные языки образуют особый тип контактных языков и не нуждаются в отнесении к одному из своих «языков-родителей». Мичиф не является ни французским, ни кри, и медиа ленгуа - не кечуа и не испанский.
} 
говоры дер. Волково и Орлы относятся к южной подгруппе говоров, а говор дер. Новая относился к северной. Хотя ижорские говоры в долине р. Россонь, а также говор дер. Б. Куземкино значительным числом изоглосс объединяются с другими южными нижнелужскими говорами, существуют и такие изоглоссы, которые объединяют их с северными нижнелужскими ижорскими говорами и финскими нижнелужскими говорами.

Следует также отметить, что в ряде случаев для понимания места куровицкого идиома на диалектной карте нижнелужского ареала оказывается полезным и привлечение данных водских, ижорских и финских диалектов Западной и Центральной Ингерманландии за пределами нижнелужского ареала. В таких случаях мы будем обращаться к данным сойкинского ижорского диалекта, центрально-водским говорам, финским говорам прихода Каттила.

Поскольку целью данной статьи является уточнение места куровицкого идиома среди других языков и диалектов нижнелужского ареала, то далее мы не относим куровицкий идиом ни к водским, ни к ижорским диалектам.

Краткие сведения об упоминаемых в статье диалектах приводятся в Приложении.

\section{2. Куровицкий идиом на диалектной карте нижнелужского ареала}

\section{1. Куровицко-ижорские изоглоссы (КИ)}

В этом разделе мы рассмотрим те изоглоссы, которые объединяют куровицкий с южными нижнелужскими ижорскими говорами и противопоставляют его водскому языку, в первую очередь кракольскому говору. Как мы покажем далее, многие из этих изоглосс характерны также и для сойкинского ижорского диалекта и/или для некоторых ингерманландских финских говоров. Все примеры из языков и диалектов Ингерманландии мы даем в упрощенной транскрипции, аналогичной использованной авторами «Vadja keele sõnaraamat» [Grünberg 2013]. При этом редуцированные гласные нижнелужского ижорского (которые часто реализуются как глухие) передаются прописными буквами как в [Posti 1980], а аффриката $t \check{s}$ как $\check{c}$. 


\section{Лексика}

1КИ. Kiuka 'печь': эта лексема представлена также в сойкинском ижорском и почти во всех финских диалектах Западной и Центральной Ингерманландии; в водском языке и в отдельных финских говорах прихода Каттила представлена лексема ahjo.

2КИ. MaitU 'молоко', paitA 'рубашка', veitsI 'ножик', iltA 'вечер', tiitä 'знать:Inf', muissa 'помнить:Inf' представлены во всех ижорских и финских диалектах; в водском языке им соответствуют лексемы piim ${ }^{4}$, čuиtto, kuraZ, ohtogo, täätä, mälehtä. Эти 6 изоглосс точно отделяют ижорские и финские говоры от водских, в отличие от других изоглосс, рассматриваемых в этом разделе, ср., например, с 1КИ и ЗКИ.

3КИ. Kiss A 'кошка': эта лексема широко представлена во всех финских диалектах и в нижнелужском ижорском, однако в сойкинском

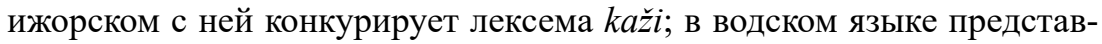
лена лексема katti.

4КИ. Hoom(n)ikkU 'утро': этот вариант является, по-видимому, куровицко-нижнелужской изоглоссой. Близкий вариант представлен в водском языке: oomnikko [Grünberg 2013: 846], - однако в сойкинском ижорском выступает вариант hoomuZ huитuZ, а в финских ингерманландских диалектах и в некоторых северных нижнелужских ижорских говорах — варианты аати, иати.

5КИ. Рeezaz 'куст’: очень близкий вариант peesaz, отличающийся только отсутствием чередования $s / z$, представлен в южных нижнелужских ижорских говорах. Однако в южном нижнелужском ижорском долины р. Россонь и в говоре дер. Б. Куземкино зафиксирована лексема pehko, которая характерна и для всех финских диалектов Ингерманландии, и для сойкинского ижорского диалекта. В водском языке присутствуют несколько вариантов:

a. Pehko, по данным словаря [Grünberg 2013: 884], представлен во всех нижнелужских водских деревнях (Краколье, Межники,

3 Здесь и далее мы даем тот фонетический вариант, который представлен в куровицком; в других идиомах возможны небольшие отличия.

${ }^{4}$ Для водского языка мы приводим в первую очередь вариант, характерный для кракольского говора.

${ }^{5}$ Именно этот вариант был зафиксирован нами в дер. Куровицы. 
Пески и Лужицы), а также в дер. Маттия, Котлы (центрально-водский ареал) и Иципино (восточно-водский диалект). Этот же вариант зафиксирован в вышеупомянутом словаре и в Куровицах ${ }^{6}$. В наших водских полевых материалах ${ }^{7}$ этот вариант представлен почти у всех информантов.

b. Põhko представлен только в Краколье (фиксируется также и в словаре водского говора дер. Краколье [Tsvetkov 1995: 219]) и в центрально-водской деревне Корветино. В наших материалах он также встретился только у кракольских информантов.

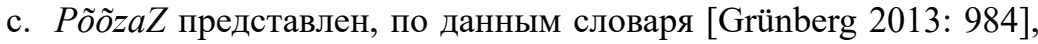
в основном в центрально-водских деревнях, а также в Краколье и Куровицах. В наших материалах этот вариант не встретился ни в Краколье, ни в Куровицах.

Таким образом, в нижнелужском ареале присутствуют два главных варианта: peesaz и pehko. Первый из них распространен только в куровицком и в ижорских говорах вдоль Луги южнее Куровиц. Второй, помимо Куровиц, отмечен также в ижорских говорах севернее и западнее Куровиц и во всех нижнелужских финских и водских говорах. По-видимому, лексему peesaz следует считать относящейся к водской субстратной лексике в южном нижнелужском ижорском, а лексему pehko - заимствованием из ижорского языка в нижнелужский водский. Такая ситуация могла возникнуть в том случае, если вариант ре$h k o$ проник в кракольский водский говор сравнительно недавно, о чем свидетельствует и фиксация в этом же говоре старого варианта põ z̃aZ. Вариант же peesaz в куровицком мог возникнуть либо в результате фонологической адаптации унаследованной водской лексемы во вновь возникшем смешанном куровицком идиоме, либо в результате заимствования из находящегося южнее говора дер. Орлы. Вариант pehko, зафиксированный в куровицком в словаре [Grünberg 2013: 884], мог попасть в куровицкий только с севера из дер. Краколье. Эта изоглосса примечательна тем, что несмотря на то, что в соседних с куровицким ижорских говорах употребляется этимологически водский вариант, а в соседних водских - этимологически ижорский, куровицкий

${ }^{6}$ В словаре [Grünberg 2013] куровицкий идиом включен в число водских диалектов.

7 В наших полевых материалах есть данные только по нижнелужским водским говорам (дер. Краколье, Пески, Лужицы) 
оказывается объединенным с нижнелужским ижорским, а не с нижнелужским водским, как это имеет место и для других лексических изоглосс, рассмотренных в этом разделе.

6КИ. Личное местоимение 3Sg hän. Этот же вариант господствует и в нижнелужском ижорском, хотя у отдельных информантов в дер. Липово, Лужицы, Хамолово, Б. Куземкино, Ропша, Ванакюля, Волково зафиксирован и вариант hä̈̈. В водском языке выступает tämä, в финских нижнелужских говорах и сойкинском ижорском господствует вариант $h \ddot{a} \ddot{a}$, изредка встречается и hän. Эта изоглосса объединяет куровицкий говор с нижнелужским ижорским диалектом, особенно с его южными говорами по обоим берегам р. Луга.

\section{Историческая фонетика}

7КИ. Отсутствие перехода $k>\check{c}$ перед гласными переднего ряда (вод. čülä 'деревня', ижор. külä). Наличие этого фонетического перехода отделяет водский язык (кроме кревинского диалекта) от других прибалтийско-финских языков, в том числе всех ижорских и финских диалектов Ингерманландии. Следует отметить, что в ижорском говоре дер. Межники, в которой ранее говорили и на водском языке, зафиксирована лексема čimolain 'пчела', которую следует считать относящейся к водской субстратной лексике в ижорском говоре дер. Межники ${ }^{8}$. С другой стороны, Л. Пости считает, что перехода $k>\check{c}$ в старом водском куровицком говоре не было, и этот говор вместе говором предков кревинов, выселенных в середине XV века в район современного г. Бауска в Латвии, образовывали особый «крайне-западный» (läntisin) диалектный ареал водского языка [Posti 1980: XVI-XVII].

8КИ. Сохранение $h$ в анлауте (вод. $\ddot{u} v \ddot{a}$ 'хороший', ижор. hüvä). Утрата анлаутного $h$ отделяет водский язык и некоторые эстонские диалекты от ижорского и финского языков. Следует отметить, что в водских говорах нижнелужского ареала (Краколье, Пески, Лужицы) и в южных нижнелужских ижорских говорах встречаются и отклонения от этого: Dpo ${ }^{9}$ avahhun 'просыпаться:1Sg:Pres', Kuk (h)avahtua 'просыпаться:Inf' [Posti 1980: 62], Joe havattsua 'просыпаться:Inf'

${ }^{8}$ По крайней мере некоторые из родителей наших ижорских информантов из дер. Межники были носителями водского языка.

9 Здесь и далее деревни указываются трехбуквенными индексами, список индексов представлен в конце статьи. 
[Tsvetkov 1995: 62]. В куровицком встречаются также и гиперкорректные формы, например hairo 'весло' (ижор., фин. airo) [Posti 1980: 53]. Анлаутное $h$ в водских говорах встречается чаще всего в деревнях нижнелужского ареала, где оно является результатом влияния ижорского языка.

9КИ. Кластер $d r$ в $o d r A$ 'ячмень' представлен в куровицком и во всех говорах нижнелужского ижорского. Во всех финских диалектах Ингерманландии, включая нижнелужский финский, в данной лексеме выступает $t r$, в сойкинском ижорском диалекте и в водском языке представлен кластер $z r$ (водск. о̃z $A$, сойк. ижор. ozra ${ }^{10}$ ). Лаaнест отмечает, что водский вариант возник под влиянием сойкинского ижорского [Лаанест 1966: 53].

10КИ. Анлаут в глаголе otta ‘брать:Inf’. В водском языке ижорскому $o$ - в этой лексеме соответствует võ- (вод. võtta).

\section{Морфонология}

11 КИ. Чередование ступеней $s k / s \sim z$ характерно для всех ижорских диалектов; в финских ингерманландских диалектах оно менее последовательно [Лаанест 1966: 41]. В водском языке слабоступенным соответствием $s k$ является $z g$. Куровицкий идиом в этом отношении оказывается ближе к нижнелужскому ижорскому, однако необычным для ижорского является звонкое $z$ как слабоступенное соответствие $s k$ (uskoa 'верить:Inf'/ иzon 1Sg:Pres).

12КИ. Чередование ступеней $t k / t$ (pitkI 'длинный'/ pited Nom:Pl) также характерно для всех ижорских диалектов ${ }^{11}$ и является одной из немногих изоглосс, отделяющих все ижорские диалекты от соседних прибалтийско-финских языков Ингерманландии [Лаанест 1966: 42-43]. В нижнелужском ареале оно было также зафиксировано нами у носителей смешанных ижорско-финских идиолектов в дер. Б. Куземкино и Ванакюля и у единственной представительницы финского говора дер. Волково. В водском языке существует чередование $t k / d g$,

\footnotetext{
10 По данным Рожанского и Маркус в сойкинском встречается также и вариант odra.

11 Мы рассматриваем полузвонкие одиночные смычные в сойкинском как глухие и не приводим отдельно сойкинские варианты в тех случаях, когда они отличаются от нижнелужских только наличием полузвонкого, иными словами, варианты pata и paDa мы считаем эквивалентными.
} 
в финских диалектах чередование кластера $t k$ вообще отсутствует. Куровицкий идиом в этом отношении совпадает с ижорским языком.

13КИ. Чередование $h k / h$ (pehko 'куст'/ pehod Nom:Pl) характерно для всех ижорских диалектов и для всех финских ингерманландских диалектов, хотя в некоторых из них оно не вполне последовательно. В водском языке ему соответствует чередование $h k / h g$, но в куровицком идиоме ситуация такая же, как и в ижорском.

14КИ. Основа косвенных падежей множественного числа имен

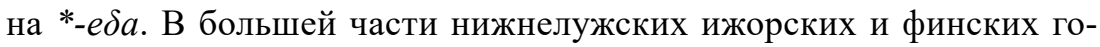
воров основным вариантом такой основы является основа на -ei. Помимо этого, нами зафиксированы также случаи стяжения на -e, - $i$. Куровицкий идиом в наших материалах представлен вариантами -ei и -ii, (valkei- valkii- 'белый:Pl'). В словаре куровицкого идиома Л. Пости встречаются варианты -ii, -iai: pimmiiZ 'темный.Iness:Pl', ruskiaitA 'рыжий.Part:Pl' [Posti 1980: 373, 440]. Лаанест дает аналогичные примеры для нижнелужского ижорского: Kot valkeiD 'белый:Part:Pl', makkiiD ‘сладкий:Part:Pl', Pär valkeiZ ‘белый:Iness:Pl', Joe valkein ‘белый:Gen:Pl'. В сойкинском ижорском эта основа оканчивается на -ioi (Vii valGioiZ ‘белый:Iness:Pl’) [Лаанест 1966: 112], однако в наших материалах такие формы были отмечены и в говоре дер. Новая. Ситуация в водском языке более сложная. В центрально-водском ареале эта основа оканчивается на -õi/-ei -ii (valkõi-, pehmei- pehmii-) [Ariste 1948: 50], иными словами, ситуация такая же, как и в нижнелужском ижорском, с точностью до сингармонических вариантов. В нижнелужских водских деревнях данная основа зависит от рядности: заднерядный вариант имеет вид -ai (valkai-) [Маркус, Рожанский 2011a: 298], переднерядный -ii (pehmii-) [Tsvetkov 1995: 219]. Таким образом, эта изоглосса объединяет нижнелужский ижорский, современный куровицкий и центрально-водские говоры, противопоставляя их нижнелужскому водскому, сойкинскому ижорскому и отчасти куровицкому говору начала XX века, отраженному в словаре Пости.

15КИ. Иллатив единственного числа. В нижнелужском ижорском и нижнелужском финском, а также в куровицком выбор алломорфа иллатива зависит от вида основы, к которой он присоединяется. В основах на краткий гласный в нижнелужском ижорском происходит переход редуцированного гласного в полный и в определенных структурах геминация согласного (nappU 'пуговица'/ nappu Ill:Sg, pata 'горшок'/ patta Ill:Sg). К основам стяженных имен и имен на *-ебa присоединяется показатель -ss(E) (vene 'лодка'/ venness $(E)$ Ill:Sg, valke 'белый'/ 
valkess(E) Ill:Sg), к односложным основам - показатель - $h V$ (рии 'дерево'/ puиhu Ill:Sg). В центрально-водских говорах употребляется показатель -see/-sõ o, который у слов с основами на краткий гласный мо-

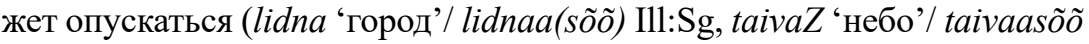
Ill:Sg), а у односложных имен может добавляться к показателю $-h V V$ (таa 'земля'/ mahaasõõ Ill:Sg) [Ariste 1948: 26]. В нижнелужском ареале иллатив образуется по-разному в кракольском и песоцко-лужицком водских говорах. В Краколье показатель -se/-sõ присоединяется ко всем именам (čülä 'деревня', čüläse Ill:Sg), в том числе и к односложным именам после показателя - $h V$ (maa 'земля'/ mahasõ Ill:Sg ) [Маркус, Poжанский 2011a: 321; 2011b: 90, 91], в то время как в Лужицах этот показатель встречается гораздо реже. В лужицком водском говоре имена с основой на краткий гласный образуют иллатив с помощью геминации согласного, если это возможно (с̌ӥlä ‘деревня’, čüllä Ill:Sg), а у стяженных имен в данном случае выступает нулевой показатель (vargõz 'вор', varka Ill:Sg). Односложные имена присоединяют показатель - $h \mathrm{hV}$ (таa 'земля'/ mahha Ill:Sg) [Маркус, Рожанский 2011a: 321; 2011b: 70, 301-302]. В финском диалекте Дубровки $s$-овый иллатив распространен гораздо шире, чем в других прибалтийско-финских говорах Нижней Луги. В частности, он обязателен и для имен с основой на краткий гласный: tupa 'изба' / tuppas Ill:Sg, при этом обнаруживается специфическая близость с водским кракольским говором, cp. Suo pä̈̈hӓs 'голова:Ill:Sg' с вод. Јое pähäse и, с другой стороны, ижор., инг. фин. рӓӓhӓ. Эта изоглосса примечательна тем, что наиболее близкими к куровицкому оказываются нижнелужский ижорский и нижнелужский финский (кроме говора дер. Дубровка), а не водский, несмотря на то, что она затрагивает морфологию, а не лексику, ср. раздел 2.2). При этом отличия между куровицким и любым локальным водским говором затрагивают в основном дистрибуцию по словоизменительным типам похожих показателей.

\section{2. Куровицко-водские изоглоссы (КВ)}

Здесь мы рассмотрим те изоглоссы, которые объединяют куровицкий с водским, противопоставляя его нижнелужскому ижорскому и нижнелужскому финскому. Следует отметить, что нам, так же как Рожанскому и Маркус, не удалось найти исключительно водско-куровицких лексических изоглосс, поэтому мы начинаем с подраздела «историческая фонетика». 


\section{Историческая фонетика}

1КВ. Переходы $* k s>h s,{ }^{*} p s>h s$ характерны только для всех водских говоров и куровицкого, ср. вод., кур. uhs 'дверь', lahs 'ребенок' и н.-луж. ижор. uks, laps.

2 КВ. Переход * $s t>s s$ в идиомах Ингерманландии характерен только для водского языка и куровицкого, однако отсутствует во всех ижорских и ингерманландских финских диалектах, cp. вод. muss A 'черный', ижор. musta. Следует отметить, что гемината ss имеет слабоступенное соответствие $s$ в водском и куровицком. При этом чередованию подвергается и $s s<* s t$, и «исконное» ss: mussA 'черный' <*musta / musaD Nom:Pl, püss $\ddot{U}$ 'ружье'/ püsü [Posti 1980: 296, 404]. Однако в парадигме куровицкой лексемы kissA 'кошка' (см. п. ЗКИ), отсутствующей в водском языке, чередования не происходит [Posti 1980: 161]. Вероятно, отсутствие чередования связано именно с заимствованным характером данной лексемы.

3КВ. Гласный $e$ в глаголе тепnё ‘идти:Inf'. Вариант с гласным $e$ в корне представлен в Ингерманландии только в водском языке и куровицком идиоме. Во всех ижорских и ингерманландских финских диалектах отмечается гласный $\ddot{a}$ (тӓnпӓ), хотя в финском литературном языке и значительной части финских диалектов Финляндии представлен именно водско-куровицкий вариант. Следует отметить, что Маркус и Рожанский дают в качестве куровицкого вариант тӓпnӓ, что связано с его преобладанием в речи современных носителей куровицкого идиома, и тем самым эта изоглосса, по Маркус и Рожанскому, оказывается ижорско-куровицкой.

\section{Морфонология}

4КВ. Чередование ступеней $\mathrm{k} / \mathrm{g}$ характерно для водского языка, в то время как в ижорском языке $k$ обычно чередуется с нулем (после долгого гласного в зиянии возникают глайды $v$ или $j$ ). В куровицком идиоме встречаются оба варианта, cp. maatA 'спать'/ makazin 1Sg:Impf vs. hoogAtA 'отдыхать'/ hookan 1Sg:Pres (cp. с ижор. maata и hoovata), однако полное выпадение встречается гораздо чаще. Дистрибуция этих вариантов остается неясной. Из других примеров слабоступенного $g$ на месте ожидаемого зияния отметим rookA 'пища'/ roog $a D$ Nom:Pl, haukI 'щука'/ haugi ( havve) Gen:Sg, laugaZ 'Луга'/laukaaZ Iness:Sg 
[Posti 1980: 437, 61, 230]. В наших материалах встретился также один случай сохранения слабоступенного $g$ в одном ижорском идиолекте дер. Лужицы: oman rooganka 'со своей пищей' .

5КВ. Чередование ступеней $s / z$ : pesä 'гнездо'/ pezäd Nom:Pl. Оно также является характерным именно для водского языка, а почти во всех ижорских и во всех ингерманландских финских диалектах отсутствует. В куровицком оно регулярно, в отличие от чередования $\mathrm{k} / \mathrm{g}$. В наших материалах это чередование было отмечено также в большинстве ижорских идиолектов дер. Лужицы. Эта изоглосса, также как и 4КВ, примечательна тем, что отделяет некоторые лужицкие ижорские идиолекты ото всего остального ижорского языка ${ }^{12}$.

6 КВ. Основа косвенных падежей личных местоимений $1 \mathrm{Sg}$ и $2 \mathrm{Sg}$ : mill(A) ‘я:Adess' sill(A) ‘ты:Adess'. Такой вариант характерен только для куровицкого идиома и водского языка, во всех ижорских и финских диалектах Ингерманландии представлен варианты miul, siul.

\section{Морфология}

7КВ. Нулевой показатель генитива характерен для куровицкого идиома (karu 'медведь'/ karu Gen:Sg, mäki 'гора'/ mäe Gen:Sg), водского и эстонского языков. В ижорских диалектах показатель генитива - $n$ сохраняется $(k a r(h) u$ 'медведь'/ kar(h)un Gen:Sg, mäki 'гора'/ mäen Gen:Sg). В финских диалектах Ингерманландии он также обычно сохраняется, хотя в некоторых локальных говорах возможно и отпадение. В нижнелужском ареале к таким говорам относится, в частности, говор дер. Дубровка (karu 'медведь'/ karu Gen:Sg, mäki 'гора'/ mäe Gen:Sg).

8 КВ. Показатель элатива $-s s(A)$. Такого рода элатив в Ингерманландии встречается только в водском языке и куровицком идиоме: Kuk nahkA 'кожа:Nom:Sg'/ nahassA El:Sg. Во всех ижорских и финских диалектах Ингерманландии выступает показатель $-s t(A)^{13}$ : Kot külä 'деревня:Nom:Sg'/ küläst El:Sg.

9КВ. Показатель транслатива $-s s(I)$ в Ингерманландии представлен только в водском языке и в куровицком идиоме (Kuk opettaja 'учитель:Nom:Sg'/ opettajass Trans:Sg), а в ижорском языке

12 По крайней мере некоторые из родителей носителей этих лужицких ижорских идиолектов были водскоязычными.

13 В восточном диалекте эстонского языка он также имеет вид $-s$ [Pajusalu et al. 2009: 149]. 
и ингерманландских финских диалектах выступает показатель $-k s(I)^{14}$ : Nar opettajaks 'учитель:Trans:Sg'.

10КВ. Глагольный показатель $3 \mathrm{Sg}$ презенса всегда имеет вид $-b$ в водском языке и в куровицком идиоме. В ижорском языке и ингерманландских финских диалектах выбор показателя зависит от морфонологического класса глагола. В частности, показатель - $p(I)$ выступает в глаголах с односложной основой. В глаголах с основой на краткий гласный и в так называемых стяженных глаголах этот показатель отсутствует, ср. вод. lugõb 'читать:3Sg:Pres', makkab 'спать:3Sg:Pres', кур. lueb, makkab, но ижор., фин. lukkoo, makajaa. Следует отметить, что в южных нижнелужских ижорских говорах в стяженных глаголах спорадически встречается и показатель - $b$. Такие формы были зафиксированы нами в дер. Орлы, Кейкино, Дальняя Поляна и Манновка: Kot makkab 'спать:3Sg:Pres'. Этот показатель есть и в финском говоре дер. Дубровка, однако там он выступает после сильноступенной основы (antap 'дать:3Sg:Pres'). Мягисте отмечает подобные формы в нижнелужских ижорских россонских (южных) говорах для рефлексивных глаголов: tekehüb ‘делаться:3Sg:Pres’ [Mägiste 1925: 6-7].

\section{3. Изоглоссы, объединяющие куровицкий, водский (хотя бы только его нижнелужские говоры или только кракольский говор) и нижнелужский ижорский (КВИ)}

Эти изоглоссы могут охватывать и более широкий круг локальных говоров и почти во всех случаях они отделяют сойкинский ижорский от трех указанных идиомов. В трех случаях эти изоглоссы включают также и сойкинский ижорский, однако противопоставляют куровицкий, кракольский говор водского и нижнелужский ижорский либо центрально-водским говорам (изоглосса 10КВИ), либо некоторым нижнелужским финским говорам (изоглоссы 7КВИ, 14КВИ). Все изоглоссы, рассматриваемые в этом разделе, объединяют куровицкий говор с его северным (водский говор дер. Краколье) и южным (ижорский говор дер. Орлы) соседями. В тех случаях, когда они объединяют почти все водские говоры с нижнелужскими идиомами, их обычно можно считать водскими субстратными чертами в этих идиомах, однако существуют

14 Параллель этому водско-куровицкому показателю также можно найти в южноэстонских диалектах [Pajusalu et al. 2009: 78]. 
и специфические нижнелужские изоглоссы, характерные именно для данного ареала и не представленные в диалектах прибалтийско-финнских языков Ингерманландии за пределами Нижней Луги.

\section{Лексика}

1КВИ. LautA ‘стол', aukkU 'дырка' представлены в нижнелужском ижорском, куровицком идиоме, а также в водском языках. Во всех финских ингерманландских диалектах им соответствуют лексемы рӧ̈̈ӓ 'стол' и reikä 'дырка', а в сойкинском ижорском - kanZ 'стол' и uuttu 'дырка'. В нижнелужском ареале нами зафиксированы три лексемы: aukko (и вариант aukkU у отдельных информантов), reikä и uuttu. Последняя лексема в наших материалах представлена только в дер. В. Лужицы и восточнее, в сойкинском ижорском, в то время как наиболее распространенной является aukko. Она представлена в всех водских нижнелужских говорах, в ижорских говорах долины р. Россонь и вообще в южной части нижнелужского ареала (в том числе и в дер. Федоровка и Дубровка), а также у некоторых информантов в дер. Б. Куземкино, Остров и Новая. Лексема reikä распространена в финских деревнях Курголовского полуострова. За его пределами она представлена также у отдельных информантов в дер. Липово, Остров, Новая, Волково, Мундировка, Ропша, М. Куземкино, Б. Куземкино и Калливере. Мягисте также отмечает reikä в ижорских россонских говорах [Mägiste 1925: 75]. Лексемы lautA и aukkU можно считать водским субстратом в нижнелужском ижорском, при этом они не были заимствованы в нижнелужский финский, за исключением отдельных говоров.

2КВИ. PankI ‘ведро', valo ‘навоз', uhs ‘дверь', rättI ‘платок' широко распространены по всему нижнелужскому ареалу. Они представлены во всех нижнелужских ижорских говорах, в водском языке и в куровицком идиоме. При этом они отсутствуют в сойкинском ижорском, где им соответствуют uhlu, tae, ovi, kor(vi)luZ, однако имеются почти во всех нижнелужских финских говорах, а также в финских говорах прихода Каттила ${ }^{15}$. Эти лексемы также можно отнести к водскому субстрату, причем в отличие от предыдущего случая они представлены и в ряде финских диалектов Западной Ингерманландии.

15 rätti представлено и в сойкинском ижорском (Рожанский, личное сообщение), однако там его значением является 'полотенце'. Эта лексема известна также в центрально-ингерманландских финских говорах со значением 'портянка’. 
3КВИ. LustI 'красивый', kitsI 'коза' характерны именно для нижнелужского ареала, в других частях Ингерманландии они не встречаются. На Нижней Луге они представлены и в ижорских, и в водских, и в финских говорах (за исключением Дубровки). Вариант kits имеется также в эстонском языке. К востоку от нижнелужского ареала им соответствует большое количество локальных вариантов: käppiä, ilosa, iloza, sorja как соответствие lusti; kilo, kili, kile, voho как соответствие kitsi. Источник лексемы lustI неясен, kitsI является заимствованием из эстонского языка.

\section{Историческая фонетика}

4КВИ. Переходы ${ }^{*} h>n,{ }^{*} h>r$ характерны в первую очередь для водского и эстонского языков. На большей части нижнелужского ареала представлены варианты без $h$, причем для каждой лексемы характерен свой ареал этого процесса. Мы рассмотрим две лексемы: $v a n(h) a$ 'старый' и $k a r(h) u$ 'медведь'. В сойкинском ижорском и в финских диалектах Центральной Ингерманландии такое выпадение неизвестно.

Для лексемы vanha ареал выпадения охватывает почти всю Нижнюю Лугу, в него не входит только дер. Курголово. В финских деревнях Курголовского полуострова, как правило, встречается и выпадение, и сохранение $h$.

Для лексемы karhu ареал выпадения состоит из двух слабо связанных подареалов. Южный подареал включает в себя деревни долины p. Россонь и деревни по Луге выше впадения Россони в Лугу, в том числе и Куровицы. Северный подареал включает в себя водские деревни Краколье, Пески, Лужицы, Межники и ижорские деревни Новая и отчасти Остров. В Краколье и Лужицах формы с выпадением отмечены и в местных ижорских идиолектах. В дер. Калливере была зарегистрирована и форма с сохранившимся $r h$. По данным Мягисте, такие формы были ранее гораздо более распространены [Mägiste 1925: 48], причем именно у россонских финнов.

Эта черта в нижнелужском ижорском является субстратной водской, а в нижнелужский финский она была впоследствии заимствована из нижнелужского ижорского, о чем свидетельствует разная скорость проникновения вариантов с выпавшим $h$.

5КВИ. Интервокальный $h$ в слогах дальше второго выпал в именных словоформах, образованных от гласной основы: lampaaD ‘овца:Nom:Pl', 
lampai 'овца:Part:Pl'. Выпадение отмечено во всех нижнелужских ижорских и финских ${ }^{16}$ говорах и в водском языке. В сойкинском ижорском, начиная с переходного говора дер. Косколово, $h$ сохраняется: lamBahia 'овца:Part:Pl' ${ }^{17}$. Следует отметить, что Поркка отмечал формы без выпадения и в нижнелужском ареале [Porkka 1885: 68-74]. В данном случае в сойкинском ижорском сохраняются более архаичные варианты, в нижнелужском ижорском данная черта может быть как субстратной водской, так и результатом влияния нижнелужского финского.

6КВИ. Переход ir >er, например, *kirveZ > kerveZ 'топор', является характерной особенностью всех ижорских диалектов, кроме нижнелужского [Лаанест 1966: 75]. В водском языке он встречается только в восточно-водском диалекте [Kettunen 1986: 138]. В нижнелужском ижорском, тем не менее, есть отдельные слова, в которых этот переход произошел, например, pertti 'дом'. В остальных водских говорах и в нижнелужском финском этот переход отсутствует. Ситуация в куровицком идиоме аналогична нижнелужской ижорской. В отличие от изоглоссы $5 К В И$, в данном случае мы имеем дело с ижорской инновацией, и отсутствие данного перехода в нижнелужском ижорском может быть как субстратной водской чертой, так и результатом влияния нижнелужского финского.

\section{Морфология}

7КВИ. Показатель терминатива $-s s{ }^{18}$. В нижнелужском ижорском показатель имеет форму -ssa; этот же вариант характерен для водского языка, куровицкого идиома и подавляющего большинства нижнелужских финских говоров (Joe čülässa ‘деревня:Term:Sg', Kuk, Kot küllässa). Еще одним вариантом, встречающимся у некоторых финноязычных информантов из дер. Выбье и Конново, является конструкция «иллатив + ast 'до'», которая широко распространена в финских

16 В Ингерманландии существуют и такие финские диалекты, в которых выпадения в большинстве случаев не произошло, например диалекты приходов Каприо и Тюрё.

${ }^{17}$ B GenSg и NomPl выпадение $h$ встречается и в тех говорах, в которых в других падежах выпадения не происходит.

18 Этот показатель занимает промежуточное положение между падежными аффиксами и послелогами. В частности, подобно послелогам, он не имеет сингармонических вариантов. 
диалектах Центральной Ингерманландии: küllää ast ‘деревня:Ill:Sg до’. В сойкинском ижорском, наряду с уже упомянутым показателем, широко распространена конструкция «иллатив + nas (se) ‘до’» ${ }^{19}$ : Ksk iltaa nasse 'вечер:Ill:Sg до', iltaassaa 'вечер:Term:Sg' [Лаанест 1966: 104; Leppik 1975: 173]. Терминатив на -ssaa является специфической для водского языка особенностью, поэтому его тоже можно считать одной из водских субстратных черт в нижнелужском ижорском, из которого она распространилась и на нижнелужский финский.

8 КВИ. Показатель комитатива $-k a$ представлен в водском и эстонском языках, а также в южных нижнелужских говорах, куровицком идиоме и финском говоре дер. Дубровка: Kuk veitsekä 'нож:Com:Sg', majjuka 'молоко:Com:Sg'. Следует отметить, что этот же вариант был зафиксирован и в одном смешанном финско-водском идиолекте дер. Раннолово в приходе Каттила. В северной части нижнелужского ижорского, начиная с говора дер. Ропша и включая ижорские идиолекты дер. Лужицы, а также в нижнелужском финском выступает показатель -nka: Pär vellonka 'брат:Com:Sg'. Водский показатель отличается от ижорского и финского отсутствием переднерядного варианта $k a ̈$. В сойкинском ижорском выступает конструкция «генитив + kera 'c'» (Ksk jauhon kera 'мука:Gen:Sg c') [Лаанест 1966: 105], ареал этой формы начинается с Верхних Лужиц. Этот вариант представлен также в финском диалекте прихода Каттила. У отдельных финских информантов из дер. Выбье и Конново вместо комитатива выступает конструкция «генитив + kans 'c'», которая широко представлена в финских диалектах Центральной Ингерманландии. Эта черта также является субстратной водской чертой в нижнелужском ижорском.

9КВИ. Показатель сравнительной степени прилагательных -p (в косвенных падежах -pa) характерен для водского языка: parõp 'лучший:Nom:Sg'/ parõpa 'Part:Sg'/ parõpõlt 'Abl:Sg'. В нижнелужском финском, сойкинском и северных нижнелужских ижорских говорах сравнительная степень образуется при помощи показателя -mp(I) (в косвенных падежах -mma/-mpa): Pär paremp 'лучший:Nom:Sg'/ parempaa 'Part:Sg'/ paremmalt) 'Abl:Sg'. При этом в южных нижнелужских говорах в номинативе этот показатель имеет вид - $p$, а в косвенных падежах его алломорфы совпадают с общеижорскими: Kot parep 'лучший:Nom:Sg'/ parempa 'Part:Sg'/ paremmAlt 'Abl:Sg'. В куровицком

19 Этот же послелог представлен в хэвасском и оредежском диалектах ижорского языка. 
в номинативе данный показатель имеет вид - $p$, как и в южных нижнелужских говорах, однако в косвенных падежах сильноступенная гласная основа имеет водский вид - $а$, хотя слабоступенная основа соответствует общеижорской -тma: parep 'лучший:Nom:Sg'/ parepa 'Part:Sg'/ paremmAlt 'Abl:Sg'. Следует отметить, что «северный» показатель -mp спорадически может встречаться и у некоторых информантов из южно-нижнелужского ареала. Дистрибуция разных алломорфов данного показателя отражена в Таблиц̧е 1.

Таблица 1 Алломорфы показателя сравнительной степени

Table 1. Allomorphs of the comparative degree marker

\begin{tabular}{|l|c|c|c|}
\hline \multicolumn{1}{|c|}{ Идиом } & NomSg & $\begin{array}{c}\text { Сильноступенный } \\
\text { алломорф } \\
\text { в косвенных падежах }\end{array}$ & $\begin{array}{c}\text { Слабоступенный } \\
\text { алломорф } \\
\text { в косвенных падежах }\end{array}$ \\
\hline водский & $p$ & $p a$ & $p a$ \\
\hline куровицкий & $p$ & $p a$ & $m m a$ \\
\hline $\begin{array}{l}\text { южный } \\
\text { нижнелужский }\end{array}$ & $p$ & $m p a$ & $m m a$ \\
\hline $\begin{array}{l}\text { прочие ПФЯ } \\
\text { Ингерманландии }\end{array}$ & $m p$ & $m p a$ & $m m a$ \\
\hline
\end{tabular}

Таким образом, куровицкий фактически занимает промежуточное положение между водским и южным нижнелужским, отражая бо́льшую, чем в южном нижнелужском, сохранность водских алломорфов для косвенных падежей.

10КВИ. Личное местоимение 3P1 hü̈̈ отмечено в словаре куровицкого идиома [Posti 1980: 81]. Почти для всех говоров водского языка местоимения 3P1 имеет вид пӓmӓ $(d)$, однако в кракольском говоре преобладает заимствованное из ижорского местоимение hӥ̈̈. Во всех

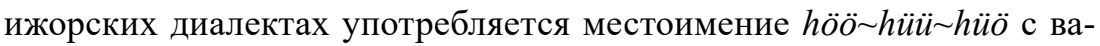
риантами hööD hü̈̈D [Лаанест 1966: 114], в нижнелужских финских говорах выступает вариант hü̈, за исключением говора Дубровки, где зафиксирован вариант пӓтӓ. Эта изоглосса, в отличие от предыдущих, отражает ижорское влияние на один из водских говоров. Вариант дер. Дубровка, вероятно, является заимствованием из водского языка.

11 КВИ. Иллатив множественного числа. В нижнелужском ижорском и финском, а также в куровицком идиоме встречается почти исключительно иллатив с показателем -ss(E) (vene 'лодка'/ venneiss(E) Ill:Pl). У отдельных информантов зарегистрированы и формы без элемента $s$, 
например Van repoi 'лиса:Ill:Pl'. Такова же ситуация и в кракольском водском говоре, где для всех имен обязателен -se/-sõ (čülä ‘деревня’/ čülijse Ill:P1) [Маркус, Рожанский 2011b: 91], а также в центрально-водских говорах [Ariste 1948: 26]. По данным Лаанеста, в сойкинском ижорском диалекте у имен с основой на краткий гласный выступает нулевой показатель (Vol paDa 'горшок'/ pattoi Ill:P1), а у стяженных имен - показатель -sse (lammaZ 'овца' / lamBahisse Ill:P1) [Лаанест 1966: 111] ${ }^{20}$. В переходном сойкинско-нижнелужском говоре дер. Косколово зафиксированы формы нижнелужского типа. Особо следует отметить нижнелужский водский говор дер. Лужицы и Пески, в котором вместо показателя -se используется -je: venneje 'лодка:Ill:Pl', lampaje 'овца:Ill:Pl' [Маркус, Рожанский 2011b: 301-302]. При этом в имеющихся у нас материалах по ижорским идиолектам дер. Лужицы, как и в других нижнелужских ижорских говорах, представлен показатель -sse: kotisse 'дом:Ill:Pl', patoiss 'горшок:Ill:Pl'. Таким образом, по отношению к данной изоглоссе почти все водские говоры, за исключением песоцко-лужицкого, оказываются близки к нижнелужским финским и ижорским, отличаясь при этом от сойкинского ижорского. По-видимому, такое особое положение водского лужицкого говора - сравнительно недавнее явление.

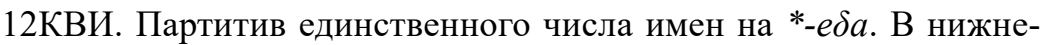
лужском ижорском и нижнелужском финском, включая дер. Дубровка, Верхние Лужицы и Косколово, в наших материалах зафиксированы формы с элементом -t/-d (Van, Sut, Nar, Kot valked 'белый:Part:Sg', Kot, Kuk valkead, Sut valkeatA), в то время как в сойкинском ижорском формы без -t/-d (Vol valGijaa, pimijää) [Лаанест 1966: 99]. В водском языке также выступает партитив с показателем -ta -tA -t: valkõata [Ariste 1948: 50].

13КВИ. Основа косвенных падежей множественного числа имен с основой на краткий гласный. Для нижнелужского ареала в целом характерны два явления:

a) отсутствие показателя множественного числа -loi в тех случаях, когда основа оканчивается на $u, o, \ddot{u}, \ddot{o}$, i tüttöi 'девушка:Part:Pl', Kuk karui 'медведь:Part:Pl' ${ }^{21}$;

${ }^{20}$ В современном сойкинском диалекте -sse может встречаться не только у стяженных имен (Рожанский, личное сообщение).

${ }^{21}$ Показатель -loi в большинстве ижорских и ингерманландских финских диалектов может встречаться только с основами на лабиальный гласный, $i$ и иногда $e$. 
б) употребление сильноступенной основы множественного числа в косвенных падежах. Следует отметить, что в генитиве, партитиве и иллативе множественного числа сильноступенная основа выступает во всех языках Ингерманландии, поэтому дистинктивным признаком является употребление сильноступенной основы в пространственных падежах за исключением иллатива: sikkoil 'свинья:Adess:Pl'.

Обе эти особенности характерны для всего нижнелужского ижорского, всех говоров нижнелужского финского, кроме говора дер. Дубровка, для куровицкого идиома и для водских говоров дер. Краколье, Межники, Пески и Лужицы. Для сойкинского ижорского характерны слабоступенная основа и наличие показателя -loi (Saa nahoist 'кожа:Elat:Pl', Röl tüttölöille ‘девушка:All:Pl') [Laanest 1986: 106-107]. Данный показатель также нерегулярно встречается в некоторых ижорских идиолектах дер. Лужицы, а также в Верхних Лужицах. Начиная с Косколова, его употребление становится регулярным. Этот же показатель совершенно неожиданно обнаружился в финском говоре дер. Арсия у единственной информантки, представлявшей на момент записи данный говор. В финском говоре дер. Дубровка показатель мн. ч. имеет вид $-l o<*-l o i$, например, karulo 'медведь:Part:Pl', как во всех ижорских и финских диалектах Ингерманландии за пределами района нижней Луги [Alvre 1971; 1991: 6, 11; Laanest 1986: 110]. Леппик в курголовском нижнелужском финском и Мягисте в ижорских и финских россонских говорах также фиксируют формы без этого показателя, причем в основе множественного числа выступает сильная ступень: püttüis ‘бочка:Iness:Pl' [Leppik 1975: 162, 187], säkkist 'мешок:El:Pl' [Mägiste 1925: 37]. Что касается сильноступенной основы в ингерманландских финских диалектах за пределами Нижней Луги, то ареал таких форм захватывает говоры приходов Каттила, Новасолкка, Молосковицы и западную часть прихода Губаницы, то есть те же районы, где вероятно наличие водского субстрата [Муслимов 2009, 2014]. В водском языке за пределами нижнелужского ареала можно наблюдать весьма пеструю картину. Наряду с сильноступенной основой встречается и слабоступенная (seppiissä $\sim$ sepissä 'кузнец:El:Pl'), спорадически возможно и употребление показателей -loi (дер. Маттия) или -lai (дер. Корветино) [Ariste 1948: 43-45]. Формы с показателями -loi и -lai считаются заимствованными из ижорского языка [Ariste 1948: 45]. Отсутствие показателя -loi в нижнелужском ижорском, по-видимому, можно также считать водской субстратной чертой. 
14КВИ. Показатель инфинитива в глаголах saavvA 'получать' и јӓ̈̈vvд̈ 'оставаться’. В сойкинском и нижнелужском ижорских диалектах у этих двух глаголов представлен только формант - $v$ A, хотя в хэваском возможны и $-a G\left(\operatorname{Syr} s a a^{2} a G\right)$ и $-h a($ Knd saaha) [Лаанест 1966: 34]. В водском языке преобладающим также является вариант -vva, хотя спорадически встречаются и варианты $-h a$, - $a G$, -ta [Grünberg 2013: 338, 1101]. Следует, однако, отметить, что в нижнелужских водских гово-

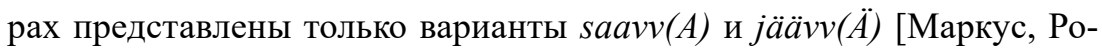
жанский 2011b: 152-153, 309]. Куровицкий идиом в этом отношении совпадает с нижнелужским и сойкинским ижорским и нижнелужским водским. Вариант jä̈̆hhä, saahha широко представлен в финских диалектах Ингерманландии, в том числе и в нижнелужском (курголовском) финском. Однако для многих нижнелужских финских информантов из дер. Кайболово, Тисколово, Вейно и Конново характерен «водско-ижорский» вариант. Наличие двух вариантов в курголовском финском отмечает также Леппик [Leppik 1975: 43]. Эта изоглосса отражает водскую и ижорскую инновацию, затронувшую только более западные водские и ижорские диалекты, причем остается неясным, какой идиом был ее первоначальным источником.

\section{4. Особые случаи (ОС)}

В этот раздел мы включили те изоглоссы, которые не дают четкого противопоставления между куровицким идиомом и соседними водскими, ижорскими и финскими диалектами.

1ОС. Форма 3Sg имперфекта стяженных глаголов. В Ингерманландии представлены два варианта: с дифтонгом (makais 'спать:3Sg:Impf', putois 'падать:3Sg:Impf') и без дифтонга (makas', putos'). В сойкинском ижорском выступает вариант с дифтонгом, а в водском языке и в нижнелужском финском - без дифтонга. В нижнелужском ижорском преобладают формы без дифтонга, однако в говорах дер. Липово, Верхние Лужицы и Орлы выступают варианты с дифтонгом. Лаанест также отмечает формы с дифтонгом в дер. Орлы (läkäiZ 'говорить:3Sg:Impf', makaiZ 'спать:3Sg:Impf') [Лаанест 1966: 128, Laanest 1986: 131]. Для куровицкого идиома, как в наших материалах, так и по данным Лаанеста, характерными являются формы без дифтонга. Эта изоглосса является уникальной в том отношении, что противопоставляет куровицкий не всему южному нижнелужскому ижорскому, а только соседнему говору дер. Орлы. 
2ОС. Форма $3 \mathrm{Sg}$ имперфекта глаголов с основой на лабиальный гласный. В Ингерманландии представлены два варианта: с дифтонгом (küsüi 'спросить.3Sg:Impf') и без дифтонга (küsü). В сойкинском ижорском представлен тип с дифтонгом, в водском - без дифтонга, а в нижнелужском ижорском - оба варианта. В частности, вариант с дифтонгом был зафиксирован нами в дер. Извоз, Дальняя Поляна, Кейкино, Липово, в ижорском говоре дер. Межники, а форма без дифтонга - в дер. Волково, Новая, Хамолово, в окрестностях Б. Куземкина, в деревнях россонского ареала, в ижорском говоре дер. Краколье. В деревнях Федоровка, Орлы, Манновка, Остров в наших материалах встретились варианты как с дифтонгом, так и без него. В курголовском финском вариант с дифтонгом не был зафиксирован. В куровицком идиоме вариант без дифтонга, по нашим данным, преобладает. Следует отметить, что дистрибуция форм с дифтонгом и без него у Лаанеста несколько отличается от зафиксированной нами: он отмечает формы с дифтонгом и в дер. Волково [Лаанест 1966: 88], в которой нам не удалось зафиксировать таких форм. Мягисте фиксирует подобные формы и в россонских говорах [Mägiste 1925: 93, 95-96]. В целом куровицкий идиом оказывается близок к южным нижнелужским говорам правого берега Луги, занимая вместе с ними промежуточное положение между южными нижнелужскими говорами левого берега Луги, с одной стороны, и водскими и нижнелужскими финскими говорами, с другой стороны. Формы без дифтонга в нижнелужском ижорском могут быть как водскими субстратными, так и результатом влияния нижнелужского курголовского финского.

3ОС. Показатель имперфекта глаголов с основой на лабиальный гласный в 1 и 2 лице. В Ингерманландии представлены четыре варианта: показатели $-z i,-s i,-i$ и нулевой показатель. Наиболее распространенным является показатель $-i$, который широко представлен в финских диалектах Ингерманландии и в сойкинском ижорском. В нижнелужском финском с формами вида küsӥіn 'спросить:1Sg:Impf' конкурируют варианты типа küsün. В последнем случае форма имперфекта оказывается омонимична форме презенса. Для водского языка характерен показатель -zi (čüsüzin). В нижнелужском ижорском конкурируют варианты -si и $-i$, причем от одного и того же информанта зачастую можно услышать оба (küsüin küsüsin), либо же эти два алломорфа оказываются распределены по разным глаголам. В целом $s i$-имперфекты оказываются представлены почти во всех ижорских нижнелужских деревнях за исключением прежних смешанных ижорско-финских деревень Хамолово и М. Куземкино, такие формы имперфекта представлены 
также в финском говоре дер. Дубровка. Что касается нижнелужских ижорских говоров Межников и Краколья, то в первом представлен вариант -si, а во втором - -zi. В нижнелужском ижорском Лаанест фиксирует вариант -zi в Краколье, Б. Куземкине и Орлах, вариант -si в Волкове: Joe sanozin 'сказать:1Sg:Impf', Kot kutozid 'ткать:2Sg:Impf', Sut ampusin 'стрелять:1Sg:Impf' [Laanest 1986: 131]. В куровицком идиоме представлен вариант -zi, аналогичный водскому. Таким образом, в нижнелужском ижорском алломорф -si является заимствованным из водского, хотя и в адаптированной форме, и с нашей точки зрения его следует рассматривать как пример водской субстратной морфологии в нижнелужском ижорском; в пользу этого говорит и фиксация этого варианта в ижорском говоре дер. Межники, вытеснившем местный водский говор ${ }^{22}$. С другой стороны, куровицкий показатель -zi нельзя рассматривать как хороший пример сохранения водской морфологии в смешанном куровицком идиоме, поскольку в данном случае нет яркого контраста между водским и нижнелужским ижорским; особенно показателен тот факт, что Лаанест зафиксировал показатель -zi даже в говоре дер. Орлы, южном соседе куровицкого говора.

4ОС. Партитив единственного числа имен с основой на краткий гласный. Показатель партитива $-a /-\ddot{a}$ при добавлении к именной основе мог ассимилироваться с последним гласным основы, образуя долгий гласный (который в ряде говоров затем сократился). В частности, это происходило во всех основах на -a/-ä: Kuk kana 'курица:Nom:Sg',

Таблица 2. Партитив имен с основой на краткий гласный

Table 2. Partitive of short vowel nominal stems

\begin{tabular}{|c|c|c|c|c|}
\hline \multirow{2}{*}{$\begin{array}{c}\text { Основа } \\
\text { оканчивается на }\end{array}$} & \multicolumn{4}{|c|}{ Основа+показатель партитива } \\
\cline { 2 - 5 } & иа-тип & оа-тип & и-тип & о-тип \\
\hline$u$ & $u a$ & $o a$ & $u$ & $o$ \\
\hline$i$ & $i a$ & $e a$ & $i$ & $e$ \\
\hline$\ddot{u}$ & $\ddot{u} \ddot{a}$ & $\ddot{o} \ddot{a}$ & $\ddot{u}$ & $\ddot{o}$ \\
\hline$o$ & $o a$ & $o a$ & $o$ & $o$ \\
\hline$e$ & $e a, i a$ & $e a$ & $e$ & $\ddot{o}$ \\
\hline$\ddot{o}$ & $\ddot{o} \ddot{a}$ & $\ddot{o}$ & $\ddot{o}$ & \\
\hline
\end{tabular}

22 Две наши ижороязычные информантки из дер. Межники являлись дочерями Оудекки Фигуровой, одной из водских информанток П. Аристе. 
kanna Part:Sg (<*kannaa). Либо же он мог сохраняться, иногда оказывая некоторое влияние на гласный основы. Нам встретились 4 типа возможных окончаний (приводятся все типы основ, кроме оканчивающихся на $-a /-\ddot{a}$ ):

Территориальное распределение типов:

a) $u$-тип ( *karhua 'медведь:Part:Sg' >> karru) распространен в основном в деревнях по Россони (Ванакюля, Калливере, Волково), на левом берегу Луги, как в ижорских, так и в финских деревнях, на Курголовском полуострове, включая дер. Хамолово, но исключая дер. Липово, а также в дер. Дубровка;

b) o-тип (karro) представлен в дер. Ванакюля и в деревнях выше дер. Федоровка (Кейкино, Дальняя Поляна, Извоз, Орлы, Манновка), спорадически также и в дер. Куровицы и Б. Куземкино;

c) иа-тип (karrua) преобладает в приморских водских и ижорских деревнях (Липово, Остров, Краколье, Межники, Пески, Лужицы), а также в дер. Куровицы и Орлы. Следует отметить, что в водских говорах при образовании форм партитива возможны переходы $е \ddot{a}>i \ddot{a}, \tilde{o} a>i a, o a>$ и [Маркус, Рожанский 2011b: 66; Ariste 1948: 51-52].

d) oa-тип (karroa) представлен только в дер. Новая и отчасти в дер. Остров. Следует отметить, что в [Лаанест 1966: 89-90; Laanest 1986: 99] для деревень нижнелужского ареала отмечены только $u$-тип и $u a$-тип. При этом $u a$-тип представлен шире, чем в наших материалах: помимо приморских деревень, он отмечен Лаанестом в дер. Куровицы, Орлы, Волково и Кейкино. С другой стороны, в дер. Ванакюля $о$-тип отмечен Мягисте [Mägiste 1925: 91] и Аристе [Ariste 1968-1969]. У Леппик для курголовского финского отмечен только $u$-тип [Leppik 1975: 134, 140], так же как и у Мягисте для россонских говоров [Mägiste 1925: 36, 87].

Таким образом, по отношению к этой изоглоссе куровицкий идиом оказывается переходным говором между северными и южными нижнелужскими ижорскими, причем более распространенным в нем оказывается вариант, характерный для северного нижнелужского и водского.

5ОС. Вытеснение старой формы 3Р1 глаголов формами имперсонала. В [Markus, Rozhanskiy 2012: 82] эта изоглосса рассматривается как противопоставляющая нижнелужские водские и ижорские говоры и куровицкий идиом сойкинскому ижорскому и центрально-водским говорам, причем в нижнелужском ижорском старые формы еще встречаются. В наших полевых материалах по различным говорам 
нижнелужского ижорского окказиональное вытеснение старых форм формами имперсонала доминирует, однако в большинстве говоров старые и новые формы конкурируют, и старые формы частично сохраняются. Кроме того, в материалах Лаанеста, относящихся к 50-60 годам XX века, также представлены оба варианта, например, Joe tullooD ‘приходить:3Pl:Pres', läätää ‘говорить:3Pl:Pres, Impers:Pres', Pär ellääD ‘жить:3P1:Pres', Kot mänпӓӓ ‘идти:3Pl:Pres, Impers:Pres'. Более того, старую форму 3P1 Лаанест фиксирует даже в самом куровицком говоре: Kuk läkävät 'говорить:3Pl:Pres' [Лаанест 1966: 122]. С другой стороны, в сойкинском диалекте возможность употребления имперсонала вместо 3Pl отмечает уже Поркка: höö tullaa 'они приходят' [Porkka 1885: 92] Таким образом, в данном случае речь идет о процессе, происходившем совсем недавно, и данная изоглосса для реконструкции генезиса куровицкого идиома нерелевантна.

\section{5. Уникальные черты куровицкого идиома (У)}

Здесь мы рассмотрим три такие черты, которые выделялись другими исследователями.

1 У. Сильная палатализация и аффрикатизация $t$ перед $i$ и $\ddot{u}$ [Posti 1980: 537-543, Kettunen 1915: 166]. Эта черта отмечалась рядом исследователей еще в первой половине XX века, однако в наших материалах такого рода сильной палатализации и аффрикатизации $t$ именно в куровицком не было зафиксировано. По данным Кузнецовой, в нижнелужских ижорских говорах сильная палатализация представлена в южных нижнелужских говорах и в северных говорах дер. Липово и Остров, в то время как в северных говорах дер. Хамолово и дер. Новая она практически отсутствует, равно как и в ижорских говорах в районе Краколья. В нижнелужском водском и нижнелужском финском палатализация также отсутствует, а в куровицком она все же есть [Кузнецова 2009: 209-210]. Таким образом, не приходится говорить о палатализации как уникальной черте именно куровицкого идиома.

2У. Презенс имперсонала на -ttAZ/-tt $\ddot{A Z}$ [Posti 1980]. В сойкинском и нижнелужском ижорском и в большинстве финских диалектов Ингерманландии презенс имперсонала образуется с помощью показателя -taa/-ttaa. Этот показатель для большинства типов глаголов фузионно сливается с основой, причем получающаяся словоформа обычно отличается от формы 1-го инфинитива только долготой конечного 
гласного a: pessä 'мыть:Inf'/ pessää Impers:Pres, tulla 'приходить:Inf’/ tullaa Impers:Pres, maata 'спать:Inf'/ maataa Impers:Pres. В целом образование формы презенса имперсонала в подавляющем большинстве ижорских и финских диалектов Ингерманландии можно описать следующим образом: 1) у одноосновных глаголов с основой на краткую гласную данная форма образуется от слабоступенного варианта основы с помощью показателя -taa/-ttaa: antaa 'дать:Inf'/ annetaa Impers:Pres; 2) у всех остальных глаголов презенс имперсонала на поверхностном уровне образуется путем удлинения конечного гласного в форме инфинитива. В центрально- и восточно-водских говорах показатель презенса имперсонала фузионно сливается с основой для всех типов глаголов, в том числе и у глаголов с основой на краткий гласный, у которых данный показатель присоединяется к сильноступенной, а не слабоступенной основе. При этом изменения, происходящие на морфемном шве, являются точно такими же, как и в случае присоединения показателя инфинитива. Приведем примеры форм презенса имперсонала в говоре дер. Котлы: õssaa 'купить:Inf'/ óssaassa Impers:Pres; pesä ‘мыть:Inf'/ pesässä Impers:Pres, jutõlla 'говорить'/ jutõllassa Impers:Pres, irmuta 'бояться:Inf'/ irmutassa Impers:Pres [Ariste 1948: 98, 104-106]. В силу этого на поверхностном уровне образование формы презенса имперсонала можно описать как добавление особого форманта -ssa к форме инфинитива, причем это справедливо для всех типов глаголов, в отличие от ижорских и финских диалектов. В водском языке в разных говорах употребляются разные форманты, присоединяющиеся к форме инфинитива. Аристе [Ariste 1948: 82-83] упоминает такие

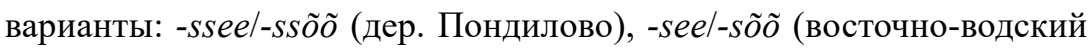
диалект), -ssa/-ssä (окрестности дер. Котлы), -Z/-se/-sо̃ (дер. Маттия). В Краколье и других нижнелужских водских деревнях употребляется «ижорский» показатель -ta/-tä, который ведет себя точно так же, как в ижорском языке. Куровицкий показатель -ttaz выглядит как комбинация двух показателей, ижорского и водского, не совпадая ни с одним из них, при этом он присоединяется к слабоступенной основе: anta 'дать:Inf'/ annEttAz Impers:Pres. Этот показатель присоединяется только к глаголам с основой на краткий гласный. Для всех других типов глаголов презенс имперсонала образуется на поверхностном уровне от формы инфинитива с помощью форманта $-z$. Этот формант присоединяется к форме инфинитива глаголов с односложной основой на долгий гласный (sü̈̈vv̈̈z 'есть:Impers:Pres'), а также к глаголам с согласной основой на - $h$ (tehäz 'делать:Impers:Pres'), на сонорный (tullAz 
‘приходить:Impers:Pres', pannAz ‘положить:Impers:Pres') и на -s (jooss $A z$ 'бежать:Impers:Pres'). Аналогичная форма зафиксирована и в [Posti 1980: 524]. Таким образом, по крайней мере для некоторых глаголов форма презенса имперсонала в куровицком идиоме оказывается совпадающей с формой из водского говора дер. Маттия. В Таблице 3 мы сравниваем способы образования имперсонала в ижорском, водском и куровицком, в качестве образца взяты глаголы lukkia 'читать' и juvvA 'пить'. Ижорские и куровицкие примеры взяты из наших материалов, центрально-водские цитируются по [Ariste 1948: 93, 98].

Таблица 3. Образование презенса имперсонала

Table 3. Formation of the present tense of the impersonal

\begin{tabular}{|l|c|c|c|c|}
\hline \multirow{2}{*}{} & \multicolumn{2}{|c|}{$\begin{array}{c}\text { глаголы с основой } \\
\text { на краткий гласный }\end{array}$} & \multicolumn{2}{c|}{ прочие глаголы } \\
\cline { 2 - 5 } & инфинитив & $\begin{array}{c}\text { презенс } \\
\text { имперсонала }\end{array}$ & инфинитив & $\begin{array}{c}\text { презенс } \\
\text { имперсонала }\end{array}$ \\
\hline $\begin{array}{l}\text { ижорский, } \\
\text { дер. Ванакюля }\end{array}$ & lukke & lueta & $j u v v A$ & $j u v v a$ \\
\hline куровицкий & lukkia & luettAz & $j u v v A$ & $j u v v A z$ \\
\hline водский, дер. Котлы & lukõa & lukõassa & $j u v v a$ & $j u v v a s s a$ \\
\hline
\end{tabular}

Следует отметить, что нижнелужские водские говоры по способу образования данной формы совпадают с ижорским языком и тем самым куровицкий говор образует своего рода анклав.

3У. Лексема zabora ‘забор'. В работе [Маркус, Рожанский 2007] в отличие от более поздней работы [Markus, Rozhanskiy 2012] эта лексема была выделена как характерная именно для куровицкого, противопоставляющая его другим нижнелужским идиомам. В наших полевых материалах, однако, она была зафиксирована и в других деревнях нижнелужского ареала, а лексема aitA опознавалась некоторыми куровицкими информантами. В словаре куровицкого идиома зафиксирован вариант aitA [Posti 1980: 4], а вариант zabora отсутствует. По-видимому, в данном случае мы имеем дело либо с переключением кодов, либо с проявлением аттриции на лексическом уровне. В обоих случаях данную лексему следует рассматривать как русскую вставку в куровицкую речь.

Таким образом, из данных трех уникальных черт куровицкого идиома действительно уникальным следует считать только показатель презенса имперсонала. При этом у части глаголов его форма совпадает 
с аналогичным показателем в водском говоре дер. Маттия. Для других глаголов он может быть интерпретирован как пример контаминации водского и ижорского показателей.

\section{3. Возникновение «традиционного» куровицкого идиома}

В данном разделе под «традиционным куровицким идиомом» мы понимаем то состояние куровицкого идиома, которое представлено в словаре [Posti 1980] и отражено в текстах, опубликованных П. Аристе во второй половине ХХ века [Ariste 1962, 1974, 1977, 1979, 1982]. Идиолекты наиболее консервативных из наших информантов также могут быть охарактеризованы как «традиционный куровицкий». Развивая идеи Рожанского и Маркус и опираясь на анализ, проделанный выше, мы можем предложить вероятный сценарий развития языковой ситуации в дер. Куровицы в прошлом.

Процесс возникновения традиционного куровицкого идиома можно условно разделить на два этапа. На первом этапе происходило формирование нижнелужского ижорского диалекта. На наш взгляд, независимо от того, считать ли влияние водского языка на нижнелужский ижорский адстратным или субстратным, это влияние обусловило появление в формирующемся нижнелужском диалекте довольно большого числа черт, характерных для водского языка. Некоторые из таких черт были рассмотрены нами в разделе 2.3. Водский язык оказал влияние на лексику (черты 1КВИ, 2КВИ раздела 2.3), фонетику (черты 4КВИ, 5КВИ, 6КВИ), морфологию (черты 7КВИ, 8КВИ, 12КВИ, 13КВИ). В некоторых случаях водские черты заимствовались частично (образование компаратива, черта 9КВИ) или же взаимное влияние водского и ижорского носило более сложный характер. В результате такого влияния в некоторые водские говоры проникали отдельные ижорские особенности (черта $11 \mathrm{KBИ).} \mathrm{При} \mathrm{этом} \mathrm{некоторые} \mathrm{из} \mathrm{общих} \mathrm{нижне-}$ лужско-куровицко-кракольских изоглосс нельзя связать с водским влиянием (черты 3КВИ, 10КВИ, 14КВИ). В этот период в Куровицах продолжал существовать старый водский говор ${ }^{23}$, в котором, однако, могли

23 Этот старый водский недокументированный куровицкий говор не следует смешивать с описанным в цитированных выше работах традиционным куровицким 
быть и некоторые важные отличия от других водских говоров, в частности, отсутствие перехода $k>\check{c}$, см. выше изоглоссу 7КИ. Это же утверждение можно сделать и о тех водских говорах по берегам Луги, которые на этом этапе были вытеснены ижорским языком.

На втором этапе исходный незадокументированный водский куровицкий говор подвергался влиянию южных говоров нижнелужского ижорского, что привело к проникновению в него черт, характерных для ижорского языка и нехарактерных для водского, некоторые из которых были рассмотрены нами в разделе 2.1. Ижорский язык оказал влияние на лексику (черты 1 КИ - 6КИ раздела 2.1), фонетику (черты 7КИ $10 К И)$ и морфонологию, в частности на чередование ступеней (черты 11 КИ - 13КИ) и на выбор алломорфов (черты 14КИ, 15КИ). При этом куровицкий сохранил ряд черт, общих с водским языком. К таким чертам относятся и те особенности, которые были заимствованы в южный нижнелужский из водского (черты 1КВИ, 2КВИ, 4КВИ - 8КВИ, 13 КВИ, вероятно также 11 КВИ и 12КВИ раздела 2.3). В отношении черты 9КВИ (образование компаратива) можно сказать, что нижнелужский ижорский оказал влияние только на слабоступенный алломорф, в то время как сильноступенный алломорф остался «водским». Особенности, которые относятся к водским архаизмам в куровицком, были рассмотрены нами в разделе 2.2. Они затрагивают фонетику (черты $1 \mathrm{~KB}$ - 3КВ раздела 2.2), морфонологию, в том числе чередование ступеней (черты 4КВ и 5КВ) и выбор алломорфа основы (черта 6КВ), морфологию (черты $7 \mathrm{~KB}-10 \mathrm{~KB})$. Если принять точку зрения Л. Пости об отсутствии перехода $k>c ̌$ в куровицком, то тогда черта 7КИ является просто общим архаизмом куровицкого и нижнелужского ижорского.

Что касается изоглосс со сложным географическим распределением (раздел 2.4), то они также могут быть проинтерпретированы как «водские архаизмы в куровицком». Форма 3Sg имперфекта стяженных глаголов без дифтонга противопоставляет почти все нижнелужские говоры говору дер. Орлы. Последний, таким образом, можно считать сохранившим ижорскую инновацию и не подвергшимся в этом отношении водскому влиянию. Куровицкий сохраняет положение вещей, характерное для водского. Форма 3Sg имперфекта глаголов с основой на лабиальный гласный в куровицком также в основном сохраняет водскую форму без дифтонга, при этом в южном нижнелужском «ижорские»

говором, который частью исследователей считается особым водским диалектом, а нами рассматривается как смешанный водско-ижорский идиом. 
формы с дифтонгом и «водские» без дифтонга конкурируют. В формах 1 и 2 лица имперфекта глаголов с основой на лабиальный гласный куровицкий использует тот же алломорф - $z i$, что и водский. Южный нижнелужский ижорский вариант -si хотя и был заимствован из водского, отличается от водского показателя фонетически. Наконец, нестянувшиеся формы партитива также являются общими для водского языка и куровицкого идиома, область их распространения охватывает северовосток нижнелужского ареала, а стяженные формы тем самым являются нижнелужской инновацией, распространяющейся с запада и юга.

Подводя итоги, можно сказать, что нижнелужское влияние на куровицкий проявлялось в основном на лексическом уровне, в то время как на морфологическом уровне сохранялись «водские архаизмы», хотя в отдельных случаях (изоглоссы 14КИ, 15КИ) имели место сложные взаимные влияния языков и говоров нижнелужского ареала. На фонетическом уровне нижнелужское влияние носило частичный характер (изоглосса 8КИ), которое также можно объяснить релексификацией, при которой заимствовались конкретные лексемы с начальным $h$. Для системы чередования ступеней характерно скорее преобладание ижорского влияния, хотя в куровицком сохранились чередования «водского» типа $\mathrm{k} / \mathrm{g}$ и $\mathrm{s} / \mathrm{z}$. Примечательно, что именно эти два чередования частично сохраняются и в ижорских идиолектах дер. Лужицы.

Куровицкий имперсонал также может быть проинтерпретирован как пример сохранения водского форманта $-z$, который у части глаголов присоединяется не к форме инфинитива, как это имеет место в центрально-водских говорах, а к «ижорской» форме имперсонала, характерной также для нижнелужских водских говоров.

Асимметрия в распределении водских и ижорских черт по разным уровням этого идиома, вероятно, может быть объяснена асимметрией в степени престижности этих двух языков в период возникновения куровицкого идиома. В таких смешанных языках, как городской фризский [van Bree 1994] или медиа ленгуа [Muysken 1997], словоизменительные показатели были унаследованы из фризского и кечуа соответственно, в то время как лексика была заимствована из голландского и испанского, иными словами, из более престижных языков. Обратное распределение лексики и морфологии встречается в смешанных цыганских языках (параромани) [Boretzky, Igla 1994], в которых лексика унаследована из цыганского, а морфология - из доминирующего языка. Однако параромани имеют специфическую сферу употребления - они использовались как тайные языки. Поскольку отсутствуют упоминания 
об использовании куровицкого идиома как тайного языка в первой половине XX века, более вероятна возможность возникновения его по модели городского фризского или медиа ленгуа. Более престижный нижнелужский ижорский диалект не вытеснил водский язык в Куровицах полностью, вместо этого произошла релексификация. В пользу именно такого сценария, на наш взгляд, говорит и наличие идиолектного континуума в Куровицах, рассматриваемое далее.

\section{4. Современное состояние куровицкого идиома}

В начале XXI века в дер. Куровицы продолжали говорить на местном идиоме (вопреки утверждениям об исчезновении куровицкого в [Адлер 1966, Posti 1980]), однако в речи его носителей наблюдалась бо́льшая вариативность, чем в «традиционном куровицком идиоме».

Мы приведем данные по идиолектам семи информантов (собственно куровицкие варианты выделены жирным курсивом):

Таблица 4. Куровицкие идиолекты ${ }^{24}$

Table 4. Kukkuzi idiolects

\begin{tabular}{|c|c|c|c|c|c|c|c|c|}
\hline Изоглосса & № & ЛПГж & ВВВм & ИИГм & АМПж & ЛДМж & МПНж & КЕВж \\
\hline *ps & $1 \mathrm{~KB}$ & $h s$ & $h s$ & $\boldsymbol{h s}, p s$ & $\boldsymbol{h s}, p s$ & hs, $p s$ & $p s$ & $p s$ \\
\hline *ks & $1 \mathrm{~KB}$ & hs & $h s$ & $\boldsymbol{h s}, k s$ & hs, $k s$ & $\boldsymbol{h s}, k s$ & $h s$ & $k s$ \\
\hline$*_{\mathrm{st}}$ & $2 \mathrm{~KB}$ & ss & ss, $s t$ & ss & ss & ss, $s t$ & st & st \\
\hline men-/män- & $3 \mathrm{~KB}$ & men- & $\begin{array}{l}\text { men- } \\
\text { män- }\end{array}$ & $\begin{array}{l}\text { men- } \\
\text { män- }\end{array}$ & $\begin{array}{l}\text { men- } \\
\text { män- }\end{array}$ & $\begin{array}{l}\text { men- } \\
\text { män- }\end{array}$ & $\begin{array}{l}\text { men- } \\
\text { män- }\end{array}$ & $\begin{array}{l}\text { men- } \\
\text { män- }\end{array}$ \\
\hline $\mathrm{mill} / \mathrm{miul}$ & $6 \mathrm{~KB}$ & mill & \begin{tabular}{|l|} 
mill \\
miul \\
\end{tabular} & $\begin{array}{l}\text { mill } \\
\text { miul } \\
\end{array}$ & \begin{tabular}{|l|} 
mill \\
miul \\
\end{tabular} & $\begin{array}{l}\text { mill } \\
\text { miul }\end{array}$ & $\begin{array}{l}\text { mill } \\
\text { miul }\end{array}$ & mill \\
\hline генитив & $7 \mathrm{~KB}$ & $-\theta$ & $-\infty$ & $-\boldsymbol{\theta},-n$ & $-\boldsymbol{\theta},-n$ & $-\boldsymbol{\theta},-n$ & $-\boldsymbol{\theta},-n$ & $-\boldsymbol{\theta}$ \\
\hline элатив & $8 \mathrm{~KB}$ & $-S S A$ & $-\mathbf{s s} \boldsymbol{A},-s t$ & $-s s$ & $-\mathbf{s s} \boldsymbol{A},-s t$ & -ss, $-s t$ & $-s t$ & $-s t$ \\
\hline транслатив & $9 \mathrm{~KB}$ & $-s s i$ & $-s s i$ & $-s s i$ & $-\mathbf{s s i},-k s$ & $-s s i,-k s$ & -ssi, $-k s i$ & $-k s$ \\
\hline имперсонал & $2 y$ & $-t t a z$ & $-t t a z$ & $-t t a z$ & $-t t a z,-t a$ & $-t t a z,-t a$ & $-t a$ & $-t a$ \\
\hline 3Sg:Pres & $10 \mathrm{~KB}$ & $-b$ & $-b$ & $-b,-\varnothing$ & $-b,-\varnothing$ & $-b,-\varnothing$ & $-b,-\varnothing$ & $-\varnothing$ \\
\hline
\end{tabular}

${ }^{24}$ Приводятся инициалы информантов, а также их пол. 
Следует отметить, что мы приводим здесь только те варианты, которые зафиксированы в наших полевых материалах, а реальная вариативность в некоторых случаях могла быть и более значительной. При этом одни информанты предпочитали куровицкие формы, другие - формы, которые они относили к говору находящейся южнее дер. Орлы. Приведем несколько примеров из речи информантки АМПж (подчеркнуты те фрагменты, которые отличаются в куровицком и нижнелужском ижорском, подстрочные индексы указывают на куровицкий (к) или ижорский (и)):

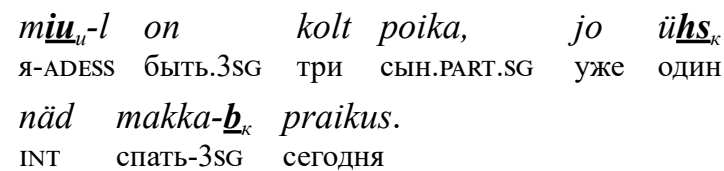

'У меня три сына, уже один, видишь, спит сегодня' .

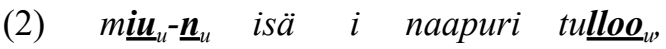

я-GEN отец и сосед приходить.3SG

ote- $\underline{\boldsymbol{t a}}_{u} \quad$ hango-d kätte

брать-IMPERS вилы-NOM.PL рука.ILL

'Мой отец и сосед приходят, берут вилы в руки'.

$\begin{array}{llll}\text { oottele-mm } & \text { kons } & \underline{t u \boldsymbol{a}}_{k}-\underline{\boldsymbol{b}}_{k} & \text { mašina } \\ \text { ждать-1PL } & \text { когда } & \text { приходить-3SG } & \text { машина } \\ \text { 'Ждем, когда придет машина'. } & \end{array}$

В целом для этой информантки характерно преобладание в речи собственно куровицких вариантов, хотя почти для всех изоглосс в ее речи встречались и ижорские соответствия. С другой стороны, для речи информантки КЕВж характерная невысокая вариативность и преимущественное употребление собственно нижнелужских ижорских, а не куровицких форм, хотя в ее идиолекте сохраняются и отдельные следы куровицкого, например, генитив с нулевым окончанием.

Как уже было показано в Разделе 2, куровицкий и южный нижнелужский ижорский различаются в основном некоторыми глагольными и именными аффиксами и отчасти фонетически. И если сам куровицкий идиом можно рассматривать как результат релексификации прежнего недокументированного водского говора, то в настоящее время мы можем наблюдать у части куровицких информантов постепенную потерю морфологических особенностей и местного идиома, иными словами, своего рода «реморфологизацию» (по аналогии 
с релексификацией). В будущем (при условии, что в Куровицах продолжали бы говорить на местных прибалтийско-финских языках) она могла бы привести к завершению языкового сдвига в сторону нижнелужского ижорского.

\section{Приложение. Диалектное членение нижнелужского ижорского и соседних идиомов}

Нижнелужский диалект ижорского языка неоднороден, и говоры даже соседних деревень могут заметно отличаться друг от друга. Несколько упрощая реальную картину, нижнелужские ижорские говоры можно поделить на северные и южные, граница между которыми проходит по р. Россонь.

Южные говоры довольно близки друг к другу, однако и среди них можно выделить подгруппы говоров. Таких подгрупп можно выделить три: говоры левого берега р. Луга (дер. Кейкино, Дальняя Поляна, Извоз), говоры правого берега (дер. Манновка и Орлы), говоры на р. Россонь (дер. Ванакюля и Волково). В дер. Калливере и Федоровка ижоры составляли меньшинство, и их идиолекты подверглись сильному финскому влиянию.

Северные говоры различаются между собой гораздо сильнее, фактически у говора каждой деревни существует свой собственный набор изоглосс, отделяющих его от соседних говоров. Можно выделить говоры следующих деревень: Ханике, Ропша, Б. Куземкино, М. Куземкино, Новая, Остров, Липово, Хамолово. Особую группу образуют ижорские говоры тех деревень, где говорят (или говорили по крайней мере в 90-х годах XX века) на водском языке - Краколье, Лужицы, Пески и Межники. Часть изоглосс сближает говоры Ропши и Б. Куземкина с южными говорами, а говор дер. Липово - с сойкинским диалектом ижорского языка. Следует отметить, что в XIX веке в Ханике, Ропше, Б.Куземкине, М. Куземкине, Хамолове наряду с ижорами проживали и ингерманландские финны.

В следующих таблицах мы даем сведения по изоглоссам, рассмотренным выше. С целью сделать их более компактными мы сгруппировали упоминаемые в статье локальные говоры в 7 групп: нижнелужский финский (НЛФ), южный нижнелужский ижорский (ЮНЛИ), северный нижнелужский ижорский (СНЛИ), нижнелужский водский 
(НЛВ), центральный водский (ЦВ), сойкинский ижорский (СИ), куровицкий (Ку). В некоторых случаях в столбце «нижнелужский финский» приводятся также сведения о финских говорах прихода Каттила (КА). В случае необходимости в соответствующей клетке таблицы дается подробная информация по говорам отдельных деревень. Первым приводится вариант, наиболее распространенный в данной группе говоров, для менее распространенных указываются деревни, в которых данный вариант был зафиксирован. В некоторых случаях могут встречаться нерегулярные соответствия между разными идиомами, например čimolain 'пчела' в ижорском говоре дер. Межники представляет собой единичный пример соответствия ижор. $\check{c}-$ вод. $\check{c}$. Такие варианты подчеркнуты и взяты в скобки. 


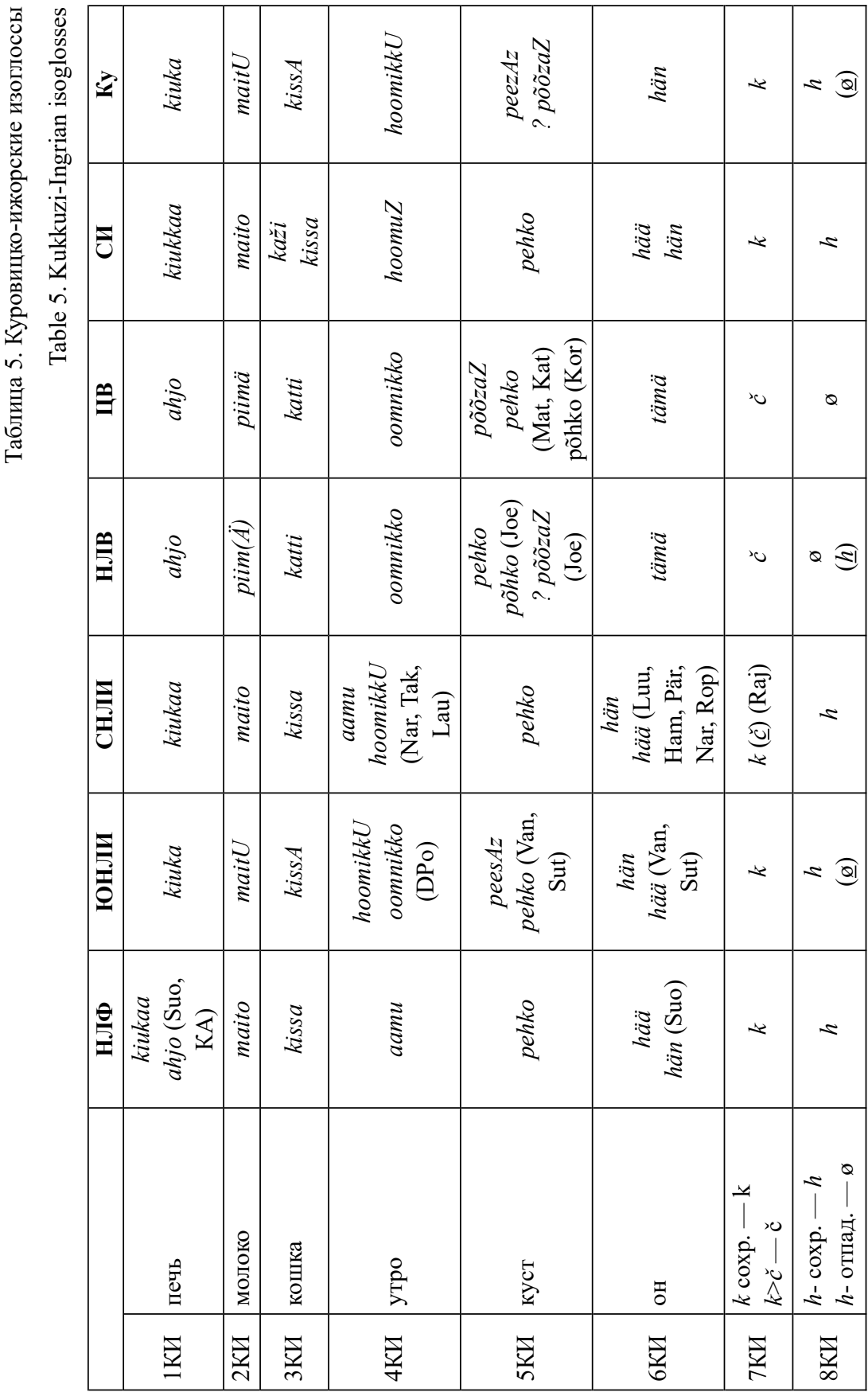




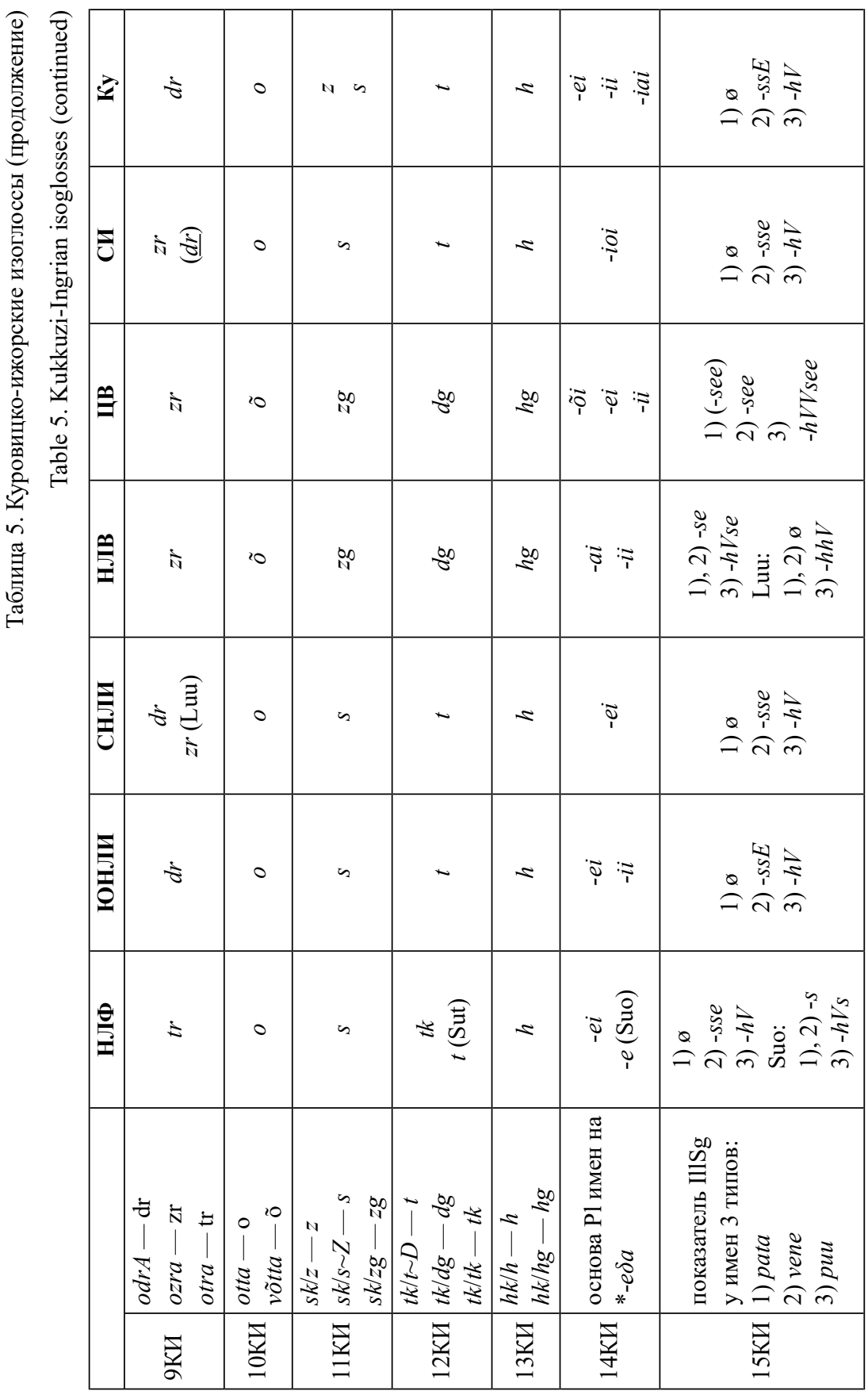




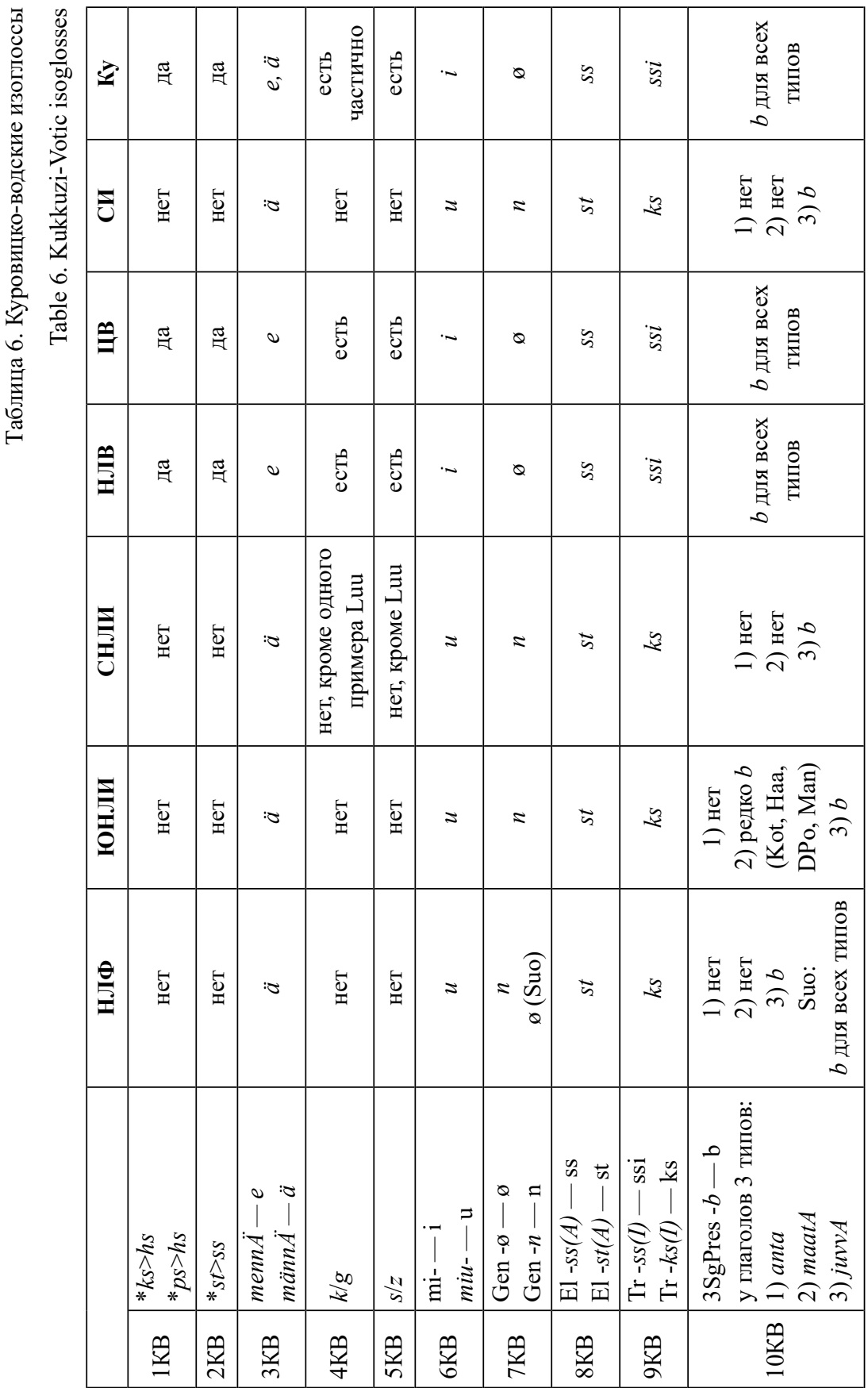




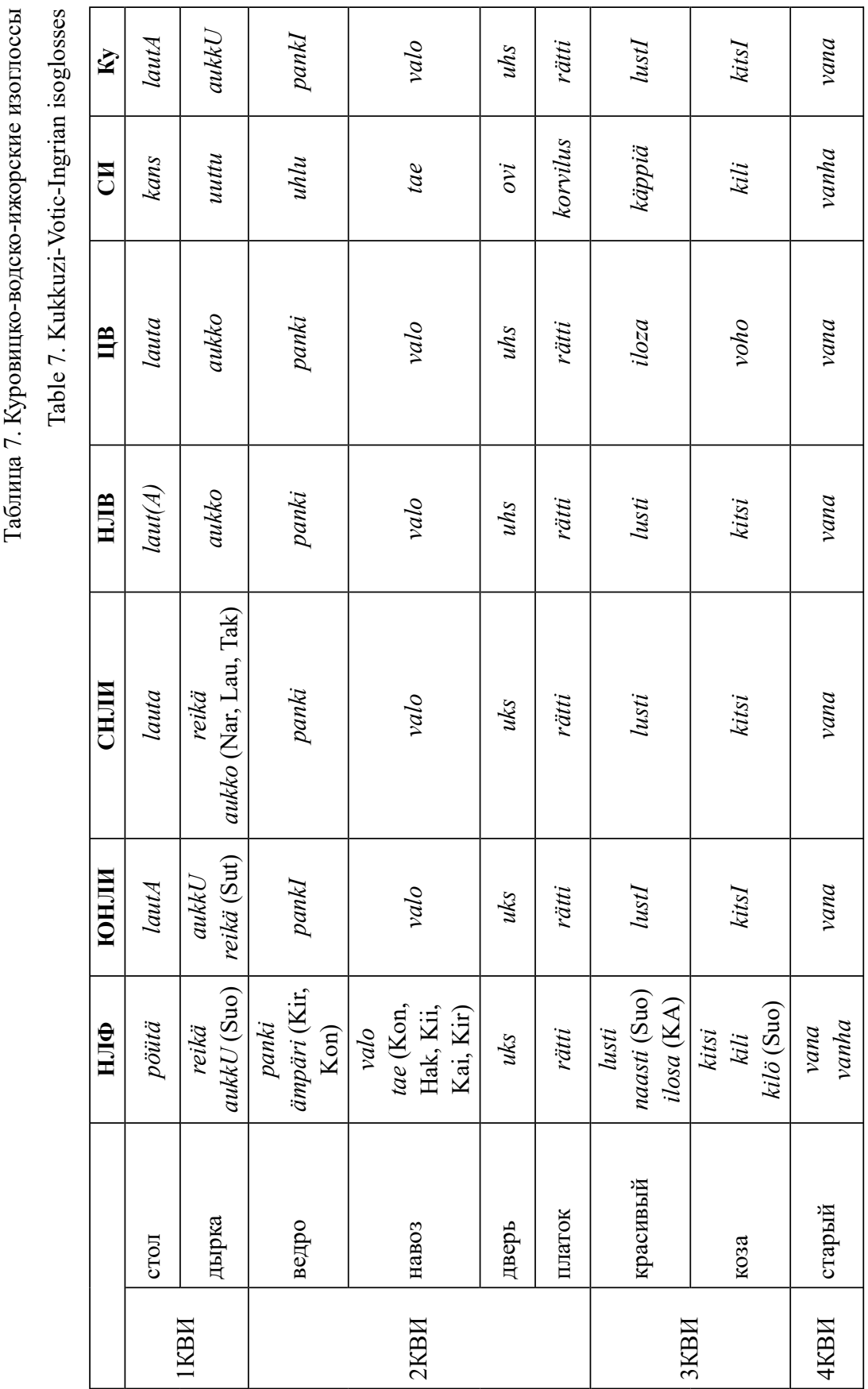




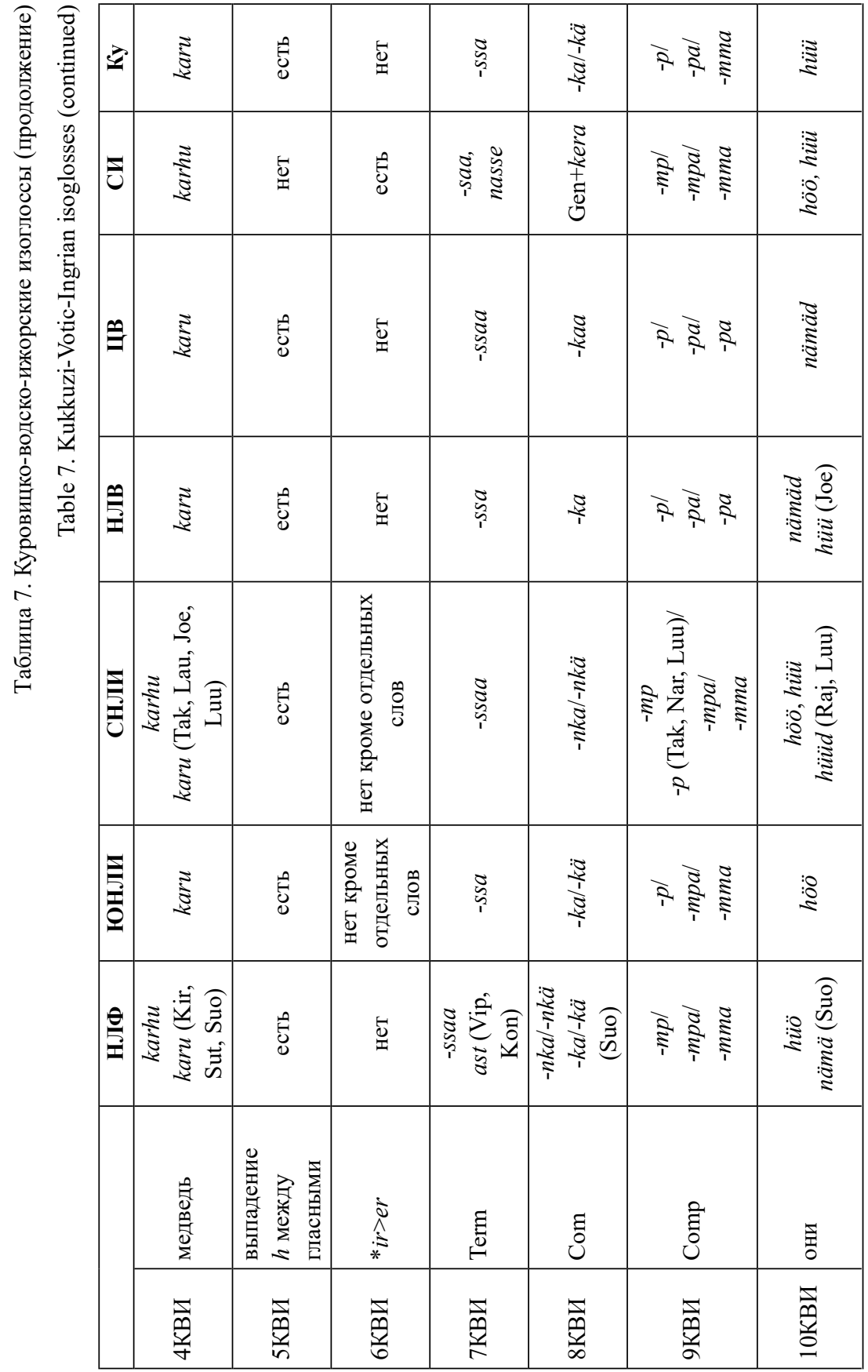




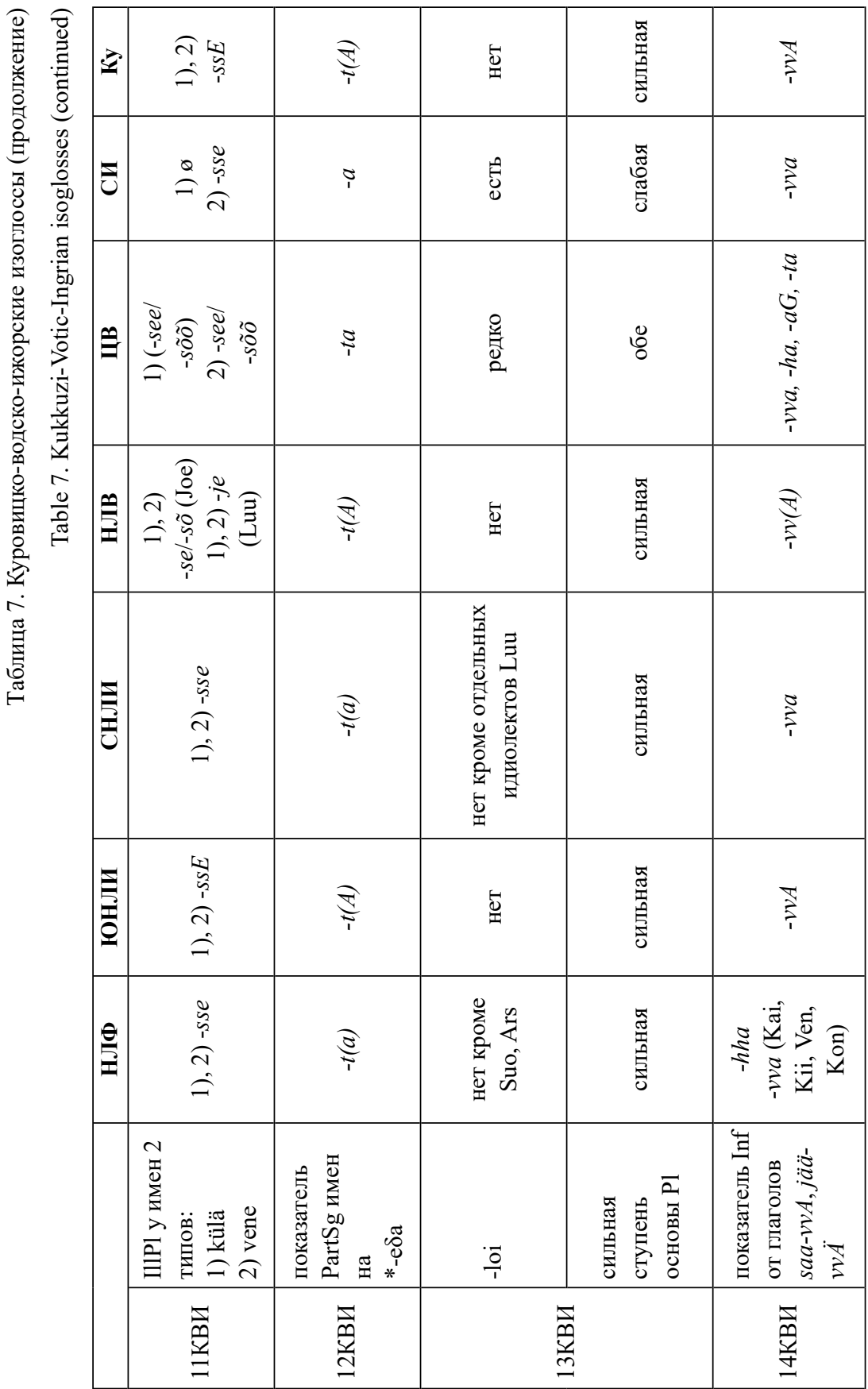




\begin{tabular}{|c|c|c|c|c|c|}
\hline 兽 & $n$ & $\tilde{r}$ & $\dot{N}$ & $\begin{array}{l}0 \\
2 \\
\vdots \\
3\end{array}$ & 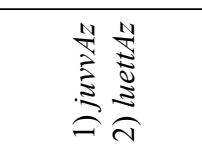 \\
\hline 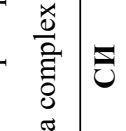 & $\sim$ & $\sim$ & $\sim$ & $\$$ & 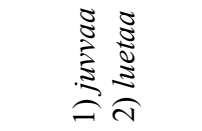 \\
\hline 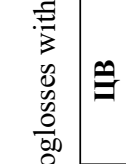 & $n$ & $Q$ & $\bar{N}$ & 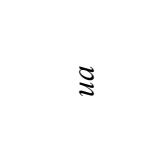 & 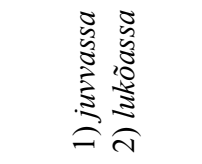 \\
\hline 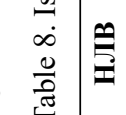 & $n$ & $Q$ & $\tilde{N}$ & $\$$ & 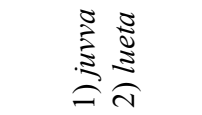 \\
\hline 章 & $\underset{n}{\stackrel{E}{E}}$ & 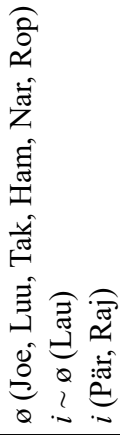 & 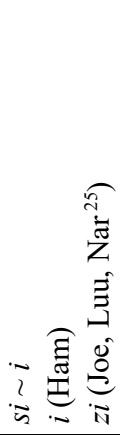 & 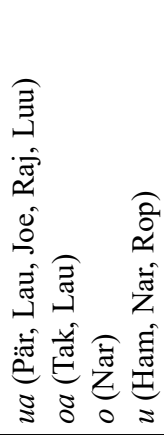 & 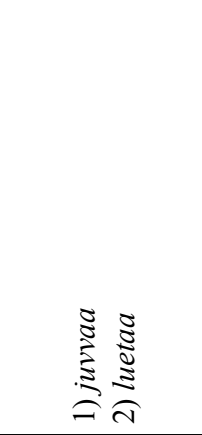 \\
\hline$\underline{\underline{3}}$ & $\underbrace{\stackrel{\hat{0}}{\hat{\theta}}}_{n}$ & 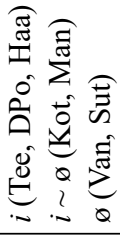 & $\therefore \stackrel{\overparen{0}}{i}$ & 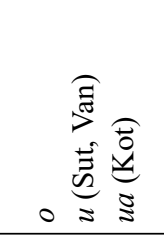 & 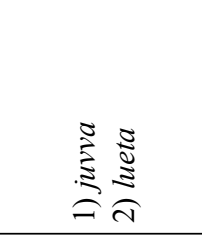 \\
\hline$\frac{\theta}{\underline{3}}$ & $n$ & $Q$ & $\therefore \underset{\pi}{\stackrel{0}{\stackrel{0}{2}}}$ & $\approx$ & 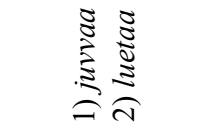 \\
\hline & 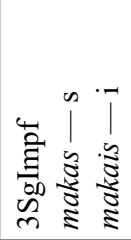 & 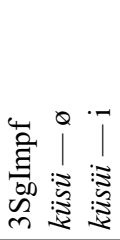 & 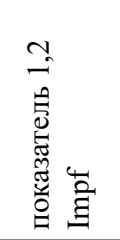 & 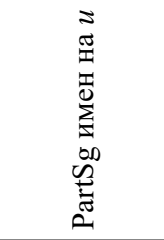 & 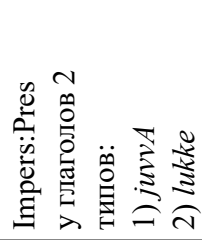 \\
\hline & $\underset{\varrho}{\varrho}$ & $\underset{৩}{\circlearrowright}$ & ర্ల & ঠֶ & $\gtrsim$ \\
\hline
\end{tabular}

它 


\section{Список условных сокращений}

Названия идиомов: вод. - водский язык; ижор. - ижорский язык; кур. куровицкий идиом; н.-луж. - нижнелужский диалект ижорского языка; сойк. сойкинский диалект ижорского языка; фин. - финский язык; инг. - ингерманландские финские диалекты.

Индексы деревень: Ars - Арсия; Dpo - Дальняя Поляна; Joe - Краколье; Наa - Кейкино; Нak - Гакково; Нат - Хамолово; Каі - Кайболово; Kat — Котлы; Kii — Тисколово; Kir — Кирьямо; Knd — Кандикюля; Kon - Конново; Kor Корветино; Kot - Орлы; Kuk - Куровицы; Ksk - Косколово; Lau - Oстров; Luu - Лужицы (и Пески); Man — Манновка; Mat — Маттия; Nar — Б. Куземкино; Pär — Липово; Raj — Межники; Röl — Александровка; Saa - Югантово; Suo Дубровка; Sut - Волково; Syr - Сюрья; Tak - Новая; Теe - Извоз; Van — Baнакюля; Ven - Вейно; Vii - Вистино; Vip - Выбье; Vol - Валяницы.

Список глосс: ABL — аблатив; ADESS - адессив; ALL — аллатив; COM — комитатив; EL — элатив; GEN — генитив; ILL — иллатив; IMPERS — имперсонал; IMPF имперфект; INESS - инессив; INF — инфинитив; INT — междометие; NOM — номинатив; PART - партитив; PL — множественное число; PRES - настоящее время; SG - единственное число; TERM - терминатив; TRANS - транслатив; 1SG, 2SG, $3 \mathrm{SG}-1,2,3$ лицо единственного числа; 1PL, 3PL - 1, 3 лицо множественного числа.

\section{Литература}

Адлер 1966 - Э. Адлер. Водский язык // В. И. Лыткин, К. И. Майтинская (отв. ред.). Языки народов СССР. Т. 3: Финно-угорские и самодийские языки. М.: Наука, 1966. С. 118-137.

Кузнецова 2009 - Н. В. Кузнецова. Фонологические системы ижорских диалектов. Дисс. ... канд. филол. наук. СПб.: ИЛИ РАН, 2009.

Лаанест 1966 - А. Лаанест. Ижорские диалекты. Лингвогеографическое исследование. Таллин: Валгус, 1966.

Маркус, Рожанский 2007 - Е. Б. Маркус, Ф. И. Рожанский. Феномен куровицкого идиома // Материалы XXXVI Международной филологической конференции. 12-17 марта 2007 г., Санкт-Петербург. Вып. 9. Уралистика. СПб.: СПбГУ, 2007. С. 61-75.

Маркус, Рожанский 2011a - Е. Б. Маркус, Ф. И. Рожанский. Современный водский язык. Тексты и грамматический очерк. Т. 1. СПб.: Нестор-История, 2011.

Маркус, Рожанский 2011 b - Е. Б. Маркус, Ф. И. Рожанский. Современный водский язык. Тексты и грамматический очерк. Т. 2. СПб.: Нестор-История, 2011.

Муслимов 2005 - М. 3. Муслимов. Языковые контакты в Западной Ингерманландии (нижнее течение реки Луги). Дисс. ... канд. филол. наук. СПб.: ИЛИ PAH, 2005. 
Муслимов 2009 - М. 3. Муслимов. К классификации финских диалектов Ингерманландии // С. А. Мызников (ред.). Вопросы уралистики 2009. Научный альманах. СПб.: Наука, 2009. С. 179-204.

Муслимов 2014 - М. 3. Муслимов. Заметки о молосковицком ингерманландском диалекте // В. Ф. Выдрин, Н. В. Кузнецова (отв. ред.). От Бикина до Бамбалюмы, из варяг в греки. Экспедиционные этюды в честь Елены Всеволодовны Перехвальской. СПб.: Нестор-История, 2014. С. 277-287.

Alvre 1991 — P. Alvre. Inkerin suomalaismurteiden nominitaivutus // Virittäjä. 1991. № 1 . S. 1-5.

Ariste 1948 - P. Ariste. Vadja keele grammatika. Tartu: Teaduslik kirjandus, 1948.

Boretzky, Igla 1994 - N. Boretzky, B. Igla. Romani mixed dialects // B. Peter, M. Mous (eds.). Mixed languages: 15 case studies in language intertwining. Amsterdam: IFOTT, 1994. P. 35-68

van Bree 1994 - C. van Bree. The Development of so-called Town Frisian // B. Peter, M. Mous (eds.). Mixed languages: 15 case studies in language intertwining. Amsterdam: IFOTT, 1994. P. 69-82.

Kettunen 1915 — L. Kettunen. Vatjan kielen äännehistoria (Suomi. Vol. IV: 15: I) Helsinki: Suomalaisen Kirjallisuuden Seura, 1915.

Laanest 1986 - A. Laanest. Isuri keele ajalooline foneetika ja morfoloogia. Tallinn: Valgus, 1986.

Leppik 1975 - M. Leppik. Ingerisoome Kurgola murde fonoloogilise süsteemi kujunemine. Tallinn: Keele ja kirjanduse instituut, 1975.

Markus, Rozhanskiy 2012 - E. Markus, F. Rozhanskiy. Votic or Ingrian: new evidence on the Kukkuzi variety // Finnisch-Ugrische Mitteilungen. 2012. Bd. 35. P. 77-95.

Mägiste 1925 - J. Mägiste. Rosona (Eesti Ingeri) murde pääjooned (Lexica Societatis Fenno-Ugricae. Vol. XVIII; Acta et Commentationes Univ. Tartuensis B. Vol. VII: 3). Tartu: S. n., 1925.

Muysken 1997 - P. Muysken. Media lengua // S. G. Thomason (ed.) Contact languages: a wider perspective. Amsterdam: John Benjamins, 1997. P. 365-426.

Pajusalu et al. 2009 - K. Pajusalu, T. Hennoste, E. Niit, P. Päll, J. Viikberg. Eesti murded ja kohanimed (toim. T. Hennoste). Tallinn: Eesti Keele Sihtasutus, 2009.

Porkka 1885 - W. Porkka. Ueber den ingrischen Dialekt mit Berücksichtigung der übrigen finnisch-ingermanländischen dialekte. Helsingfors: S. n., 1885.

Suhonen 1985 - S. Suhonen. Wotisch oder Ingrisch? // W. Veenker (ed.). Dialectologia Uralica. Materialen des ersten Internationalen Symposions zur Dialektologie der uralischen Sprachen 4.-7. September 1984 in Hamburg (Veröffentlichungen der Societas Uralo-Altaica. Vol. 20). Wiesbaden: Harrassowitz, 1985. S. 139-148.

\section{Источники}

Alvre 1971 - P. Alvre. Soome keelenäiteid // Emakeele Seltsi Aastaraamat. 1971. № 17. Lk.173-186.

Ariste 1962 - P. Ariste. Vadja muinasjutte (Emakeele Seltsi Toimetised. Vol. 4). Tallinn, 1962. 
Ariste 1968-1969 — P. Ariste. Vanaküla isuri murrakust // Emakeele Seltsi Aastaraamat. 1968-1969. № 14-15. Lk. 173-180.

Ariste 1974 — P. Ariste. Vadja muinasjutte ja muistendeid (TRÜ toimetised. Vol. 323) // Töid eesti filoloogia alalt. 1974. № 4. Lk. 3-34.

Ariste 1977 — P. Ariste. Vadja muistendeid (Emakeele Seltsi Toimetised. Vol. 12). Tallinn: Valgus, 1977.

Ariste 1979 - P. Ariste. Vadja mõistatusi (Emakeele Seltsi Toimetised. Vol. 13). Tallinn: Valgus, 1979.

Ariste 1982 - P. Ariste. Vadja pajatusi (Emakeele Seltsi Toimetised. Vol. 18). Tallinn: Valgus, 1982.

Grünberg 2013 - S. Grünberg (toim.). Vadja keele sõnaraamat. 2 trükk. Tallinn: Eesti Keele Sihtasutus, 2013.

Kettunen 1986 - L. Kettunen. Vatjan kielen Mahun murteen sanasto (Castrenianumin toimitteita. Vol. 27). Helsinki: Suomalais-Ugrilainen Seura, 1986.

Nirvi 1971 - R. E. Nirvi. Inkeroismurteiden sanakirja (Lexica Societatis Fenno-Ugricae. Vol. XVIII). Helsinki: Suomalais-Ugrilainen Seura, 1971.

Posti 1980 - L. Posti. Vatjan kielen Kukkosin murteen sanakirja (Lexica Societatis FennoUgricae. Vol. XIX). Helsinki: Suomalais-Ugrilainen Seura, 1980.

Tsvetkov 1995 - D. Tsvetkov. Vatjan kielen Joenperän murteen sanasto (Lexica Societatis Fenno-Ugricae. Vol. XXV). Helsinki: Suomalais-Ugrilainen Seura, 1995.

\section{References}

Adler 1966 - E. Adler. Vodskiy yazyk [Votic language]. V. I. Lytkin, K. I. Maytinskaya (eds.). Yazyki narodov SSSR. Vol. 3: Finno-ugorskiye i samodiyskiye yazyki [Languages of peoples of the USSR. Vol. 3: Finno-Ugric and Samoyedic languages]. Moscow: Nauka, 1966. P. 118-137.

Alvre 1991 - P. Alvre. Inkerin suomalaismurteiden nominitaivutus. Virittäjä. 1991. No. 1. S. 1-5.

Ariste 1948 - P. Ariste. Vadja keele grammatika. Tartu: Teaduslik kirjandus, 1948

Boretzky, Igla 1994 — N. Boretzky, B. Igla. Romani mixed dialects. B. Peter, M. Mous (eds.). Mixed languages: 15 case studies in language intertwining. Amsterdam: IFOTT, 1994. P. 35-68.

van Bree 1994 - C. van Bree. The Development of so-called Town Frisian. B. Peter, M. Mous (eds.). Mixed languages: 15 case studies in language intertwining. Amsterdam: IFOTT, 1994. P. 69-82.

Kettunen 1915 — L. Kettunen. Vatjan kielen äännehistoria (Suomi. Vol. IV: 15: I). Helsinki: Suomalaisen Kirjallisuuden Seura, 1915.

Kuznetsova 2009 - N. V. Kuznetsova. Fonologicheskiye sistemy izhorskih dialektov [Phonological systems of Ingrian dialects]. Candidate thesis. St. Petersburg: Institute for Linguistic Studies, 2009.

Laanest 1966 - A. Laanest. Izhorskiye dialekty. Lingvogeoraficheskoye issledovaniye [Ingrian dialects. Linguistic-geographic study]. Tallinn: Valgus, 1966. 
Laanest 1986 - A. Laanest. Isuri keele ajalooline foneetika ja morfoloogia. Tallinn: Valgus, 1986.

Leppik 1975 - M. Leppik. Ingerisoome Kurgola murde fonoloogilise süsteemi kujunemine. Tallinn: Keele ja kirjanduse instituut, 1975.

Markus, Rozhanskiy 2007 - E. B. Markus, F. I. Rozhanskiy. Fenomen kurovitskogo idioma [The phenomenon of Kukkuzi idiom]. Materialy XXXVI Mezhdunarodnoy filologicheskoy konferentsii. 12-17 marta 2007. Sankt-Peterburg. Vyp. 9. Uralisti$k a$. [Proceedings of the XXXVI International philological conference. 12-17 March 2007. St. Petersburg. Iss. 9. Uralistics]. St. Petersburg: St. Petersburg State University Press, 2007. P. 61-75.

Markus, Rozhanskiy 2011a - E. B. Markus, F. I. Rozhanskiy. Sovremennyy vodskiy yazyk. Teksty i grammaticheskiy ocherk [Modern Votic language. Texts and grammar sketch]. Vol. 1. St. Petersburg: Nestor-Istoriya, 2011.

Markus, Rozhanskiy 2011 b - E. B. Markus, F. I. Rozhanskiy. Sovremennyy vodskiy yazyk. Teksty i grammaticheskiy ocherk [Modern Votic language. Texts and grammar sketch], Vol. 2. St. Petersburg: Nestor-Istoriya, 2011.

Markus, Rozhanskiy 2012 — E. Markus, F. Rozhanskiy. Votic or Ingrian: new evidence on the Kukkuzi variety. Finnisch-Ugrische Mitteilungen. Bd. 35. P. 77-95.

Muslimov 2005 - M. Z. Muslimov. Yazykovyye kontakty v Zapadnoy Ingermanlandii (nizhneye techeniye reki Lugi) [Language contacts in the West Ingria (lower course of Luga)]. Candidate thesis. St. Petersburg: Institute for Linguistic Studies, 2005.

Muslimov 2009 - M. Z. Muslimov. K klassifikatsii finskikh dialektov Ingermanlandii [On the classification of Finnish dialects of Ingermanland]. S. A. Myznikov (ed.). Voprosy uralistiki 2009. Nauchnyy almanakh [Topics in Uralistics 2009. Almanac]. St. Petersburg: Nauka, 2009. P. 179-204.

Muslimov 2014 - M. Z. Muslimov. Zametki o moloskovitskom ingermanlandskom dialekte [Notes on the Moloskovitsa Ingrian Finnish dialect]. V. F. Vydrin, N. V. Kuznetsova (eds.). Ot Bikina do Bambalyumy, iz varyag v greki. Ekspeditsionnyye etyudy v chest E. V. Perekhvalskoy. [From Bikin to Bambaluma, from the Varangians to the Greeks. Field-inspired essays in honour of Elena V. Perekhvalskaya]. St. Petersburg: Nestor-Istoria, 2014. P. 277-287.

Mägiste 1925 - J. Mägiste. Rosona (Eesti Ingeri) murde pääjooned. (Lexica Societatis Fenno-Ugricae. Vol. XVIII; Acta et Commentationes Univ. Tartuensis B. Vol. VII: 3). Tartu: S. n., 1925.

Muysken 1997 - P. Muysken. Media lengua. S. G. Thomason (ed.). Contact languages: a wider perspective. Amsterdam: John Benjamins, 1997. P. 365-426.

Pajusalu et al. 2009 - K. Pajusalu, T. Hennoste, E. Niit, P. Päll, J. Viikberg. Eesti murded ja kohanimed (toim. T. Hennoste). Tallinn: Eesti Keele Sihtasutus, 2009.

Porkka 1885 — W. Porkka. Ueber den ingrischen Dialekt mit Berücksichtigung der übrigen finnisch-ingermanländischen dialekte. Helsingfors: S. n., 1885.

Suhonen 1985 - S. Suhonen. Wotisch oder Ingrisch? W. Veenker (ed.). Dialectologia Uralica. Materialen des ersten Internationalen Symposions zur Dialektologie der uralischen Sprachen 4.-7. September 1984 in Hamburg (Veröffentlichungen der Societas Uralo-Altaica. Vol. 20). Wiesbaden: Harrassowitz, 1985. S. 139-148. 


\section{Sources}

Alvre 1971 - P. Alvre. Soome keelenäiteid. Emakeele Seltsi Aastaraamat. 1971. No. 17. Lk.173-186.

Ariste 1962 - P. Ariste. Vadja muinasjutte (Emakeele Seltsi Toimetised. Vol. 4). Tallinn, 1962.

Ariste 1968-1969 — P. Ariste. Vanaküla isuri murrakust. Emakeele Seltsi Aastaraamat. 1968-1969. No. 14-15,. Lk. 173-180.

Ariste 1974 - P. Ariste. Vadja muinasjutte ja muistendeid (TRÜ toimetised. Vol. 323). Töid eesti filoloogia alalt. 1974. No. 4. Lk. 3-34.

Ariste 1977 - P. Ariste. Vadja muistendeid (Emakeele Seltsi Toimetised. Vol. 12). Tallinn: Valgus, 1977.

Ariste 1979 - P. Ariste. Vadja mõistatusi (Emakeele Seltsi Toimetised. Vol. 13). Tallinn: Valgus, 1979.

Ariste 1982 - P. Ariste. Vadja pajatusi (Emakeele Seltsi Toimetised. Vol. 18). Tallinn: Valgus, 1982.

Grünberg 2013 - S. Grünberg (toim.). Vadja keele sõnaraamat. 2 trükk. Tallinn: Eesti Keele Sihtasutus, 2013.

Kettunen 1986 - L. Kettunen. Vatjan kielen Mahun murteen sanasto (Castrenianumin toimitteita. Vol. 27). Helsinki: Suomalais-Ugrilainen Seura, 1986.

Nirvi 1971 - R. E. Nirvi. Inkeroismurteiden sanakirja (Lexica Societatis Fenno-Ugricae. Vol. XVIII). Helsinki: Suomalais-Ugrilainen Seura, 1971.

Posti 1980 - L. Posti. Vatjan kielen Kukkosin murteen sanakirja (Lexica Societatis FennoUgricae. Vol. XIX). Helsinki: Suomalais-Ugrilainen Seura, 1980.

Tsvetkov 1995 - D. Tsvetkov. Vatjan kielen Joenperän murteen sanasto (Lexica Societatis Fenno-Ugricae. Vol. XXV). Helsinki: Suomalais-Ugrilainen Seura, 1995. 


\section{Конкуренция иллатива и послелогов В коми-зырянском языке}

\section{Г. А. Некрасова}

Институт языка, литературы и истории Коми научного центра УрО РАН, Сыктывкар; komilang@gmail.com

Аннотация. В статье на материале Корпуса коми языка анализируются случаи конкуренции между иллативом и послелогами при выражении пространственных отношений. Обсуждаются тенденции дистрибуции падежа и послелогов в различных лексико-семантических условиях. Исследование показало, что в современном коми языке при выражении направленности движения во внутренние пределы ориентира конкуренцию иллативу составляют послелоги пытшкӧ 'в' (ориентир - полые вместилища); пиӧ 'в’ (ориентир — вещество), послелог пӧвстӧ ‘в’ (ориентир совокупность однородных предметов, нерасчлененная совокупность предметов); при выражении направленности на поверхность ориентира — послелог вылӧ 'на'; при выражении направленности на конечную часть ориентира - послелог йылӧ ‘на'; при выражении направленности к ориентиру - послелог дорӧ 'к’; при выражении контактных локализаций - послелог бердё 'к’; при выражении направленности к месту жительства лица - послелог ордё 'к’. В одном и том же контексте параллельно с иллативом возможно употребление более одного послелога, но при этом наблюдается различное осмысление одного и того же ориентира. В результате исследования выяснилось, что в большинстве случаев иллатив обладает большей частотностью, уступая в количественном отношении только послелогам пӧвстӧ ‘в’, вылӧ ‘на' и йьллӧ ‘на'.

Ключевые слова: коми-зырянский язык, падеж, иллатив, послелоги, пространственные значения.

\section{The illative vs. postpositions in Komi-Zyryan}

\section{G. A. Nekrasova}

Institute of Language, Literature and History, Komi Scientific Center, Ural Branch of the Russian Academy of Sciences, Syktyvkar; komilang@gmail.com

Abstract. The paper, based on the Komi Corpus materials, analyzes cases of the competition between the illative and postpositions within syntactic structures expressing spatial relations. The trends in the distribution of case and postpositions in various 
lexical and semantic conditions are discussed. The study showed that in constructions describing the direction of movement into various objects in modern Komi, the illative is emulated by the postpositions pičke 'in' (into hollow receptacles); pie 'in' (into a substance), pevste 'in' (into a set or mass of homogeneous objects). The illative's competitors in expressing other directions of movement are: the postposition vile 'on' (to the surface of an object); the postposition jile 'on' (to the end part of an object); the postposition dore 'to' (toward an object); the postposition berde 'to' (localization of contact); the postposition orde 'to' (toward smb's place of residence). Sometimes, the same context allows for the use of more than one postposition paralleling the illative, though with a different view of the movement goal. For example, in the constructions pirni bad'd'e bad'picke ( bad'pie bad'pevste) 'go to the willows', the illative and the postposition pičke imply an object with an inner space, the postposition pie, an object with a continuous space, and the postposition pevste, an object made of a set of items. The choice of the postposition depends on what characteristics of the object the speaker aims to emphasize. Unlike the illative, the postpositions have more specific spatial meanings and are less frequent in most cases except in the case of the postpositions pevste 'in', vile 'on', and jile 'on'. The expansion of the use of spatial postpositions may be attributed to their specific meanings which set them apart from the illative, as well as to the Russian language influence.

Keywords: the Komi-Zyryan language, case, illative, postpositions, spatial meanings.

\section{1. Введение}

Коми-зырянский язык вместе с коми-пермяцким и удмуртским относится к пермской группе финно-угорских языков. По территориальному признаку в составе этого языка различаются десять диалектов, которые по наличию общих и отличительных признаков объединяются в северную (вымский, ижемский, удорский, нижневычегодский) и южную (среднесысольский, верхнесысольский, лузско-летский) группы. Присыктывкарский диалект, положенный в основу коми литературного языка, является переходным от среднесысольского к нижневычегодскому. Верхневычегодский и печорский диалекты являются поздними образованиями, сформировавшимися на основе разных диалектов.

В литературном коми-зырянском языке традиционно выделяется 16 падежей: номинатив, аккузатив, генитив, аблатив, датив, инструменталь, комитатив, абессив, консекутив, инессив, иллатив, элатив, эгрессив, аппроксиматив, пролатив, терминатив [Бубрих 1949: 27-28; Лыткин (ред.) 1955: 137-138]. В современной грамматике коми языка 
представлена парадигма из 24 падежей: наряду с традиционно описываемыми в парадигму включены приблизительно-местные падежи и компаратив, пролативные суффиксы рассмотрены как показатели двух разных падежей: пролатив I (суффикс -ӧд) и пролатив II (суффикс -mi) [Лудыкова и др. 2000: 64]. При выражении пространственных отношений конкуренцию падежам составляют послелоги, формирование которых началось в период прапермского языка на основе падежных форм локативных существительных [Rédei 1962: 201-213]. С образованием послелогов, которое изначально было обусловлено стремлением к более точному выражению пространственных значений, возникает варьирование падежей и послелогов. Следует отметить, что в финно-угроведении представлено узкое и широкое понимание послелога как части речи. При узком понимании разграничиваются послелоги и реляционные имена, различие между которыми заключается в том, что послелоги выполняют только служебные функции, а реляционные имена способны выполнять служебные функции, но обладают некоторыми свойствами имен [Усачёва 2012: 147-158; Бирюк, Усачёва 2012: 610-611]. При широком понимании формы местных падежей реляционных имен включаются в состав послелогов. В этом случае разграничиваются две группы послелогов: собственно послелоги и послелоги-имена [Лыткин (ред.) 1955: 263; Перевощиков (ред.) 1962: 316]; послеложные слова синтаксической службы и послеложные слова лексико-синтаксической службы [Бубрих 1949: 165]; серийные и несерийные (одиночные) послелоги [Лудыкова и др. 2000: 443-444]. В настоящей работе принято традиционное понятие послелога, представленное в пермском языкознании, послелоги и формы местных падежей реляционных имен не разграничиваются.

Существование в языке грамматических единиц, имеющих сходные функционально-семантические свойства, является достаточно распространенным явлением. Рассмотрению этого явления посвящена обширная литература, как типологическая, так и написанная на материале отдельных языков, включая и финно-угорские языки [Кондратьева 2010; Бирюк, Усачёва 2012; Мосина 2013; Некрасова 2016; Klavan et al. 2010; Klavan et al. 2015; Klavan, Veismann 2017 и др.]. Интерес вызывают степень синонимичности и факторы выбора конкурирующих средств выражения. Как показали исследования, падежные суффиксы используются для выражения абстрактных отношений, послелоги - для конкретных [Кондратьева 2010; Klavan et al. 2010; Klavan et al. 2015; Klavan, Veismann 2017]. Выбор конкурирующих средств выражения может 
быть обусловлен семантическими и морфосинтаксическими факторами [Кондратьева 2010; Klavan et al. 2010; Klavan et al. 2015; Klavan, Veismann 2017], эмфатическим выделением [Бирюк, Усачёва 2012; Baker 1985: 167], степенью активации референта [Бирюк, Усачёва 2012].

В статье описываются типичные контексты, допускающие конкуренцию иллатива и послелогов при выражении пространственных отношений. Материалом исследования послужили тексты из Корпуса коми языка (далее ККЯ), который включает более 20 миллионов словоупотреблений. Ввиду того, что в системе корпуса не предусмотрен поиск по грамматическим параметрам, для сбора данных в графе «поиск» вводилась словоформа в иллативе или соответствующий послелог. Для каждой из конкурирующих единиц создавались выборки контекстов, характеризующихся семантической общностью, что позволило определить сравнительную частоту употребления иллатива и послелога.

Иллатив является общепермским падежом, его показатель (кз., кп. -ӧ, удм. -э) сформировался на основе конечной гласной основы после отпадения лативного суффикса *-k [Лыткин, Тепляшина 1976: 147]. Пространственные употребления падежа связаны с выражением направленности движения во внутреннюю зону ориентира, которая «включает сам ориентир и, если ориентир объемный, пространство внутри ориентира. 〈... Во внутренней зоне различается поверхность (контактные локализации) и внутренняя часть ориентира» [Плунгян 2002: 67]. В вариативные отношения с иллативом могут вступать серийные послелоги пытшикӧ 'в', вылӧ 'на', йылё 'на', бердё 'к', ордё 'к', пиӧ 'в', пёвстӧ 'в', дорӧ ‘к’, восходящие к иллативным формам существительных.

\section{2. Конкуренция между иллативом и послелогом пытикӧ 'в, внутрь'}

Послелог пытшкӧ 'в, внутрь', как и иллатив, выражает направленность движения во внутреннюю часть ориентира. Ориентир может представлять собой вместилище, участок пространства, а также вещество и совокупность предметов.
(1)
Керка-ё пыр-и-с
дзодзӧгпи
дом-ILL зайти-PRT-3SG гусенок
'В дом вошел гусенок'. (М. Игнатов) 


\section{(2) Кор-кӧ найӧ керка пытшкӧ кырныци пьц-и-с когда-то они дом в(IN.ILL) ворон зайти-PRT-3SG \\ uоHmbl-Cb-Hbl \\ греть-PEFL-INF \\ ‘Когда-то в их дом ворон зашел погреться'. (М. Елькин)}

Падеж и послелог могут использоваться в сходных семантических условиях, однако послелог значительно уступает иллативу в сочетании с существительными класса «вместилище, участок пространства», что продемонстрировано на некоторых примерах в Таблице 1.

Таблица 1. Частотность употребления иллатива и послелога пытшкӧ 'в’ Table 1. The frequency of the illative and the postposition pičke 'in'

\begin{tabular}{|l|c|c|}
\hline \multicolumn{1}{|c|}{ Лексема } & Иллатив & Послелог пытшкё 'в' \\
\hline Керка ‘дом' & 2365 & 95 \\
\hline Нюр 'болото' & 242 & 1 \\
\hline Рас ‘березовая роща' & 79 & 1 \\
\hline Пестер 'пестерь' & 27 & 4 \\
\hline Гьрнич 'глиняный горшок’ & 21 & 1 \\
\hline Всего & $\mathbf{2 7 3 4}$ & $\mathbf{1 0 2}$ \\
\hline
\end{tabular}

Выбор послелога и падежного показателя может быть связан со степенью дальности перемещения объекта в пределы ориентира. Для выражения направленности в глубину ориентира, далеко внутрь, на большое расстояние от начальной границы ориентира предпочтительно употребление послелога пытикӧ: нюр пытшккӧ 'вглубь болота', вӧр пьтшккӧ 'вглубь леса'. При передаче такой ситуации иллативом значение удаленности актуализируется наречиями расстояния ( ылӧ 'далеко’, неылӧ 'недалеко’).

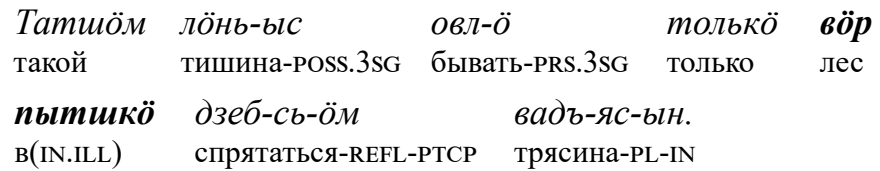

'Такая тишина бывает только на спрятавшихся вглубь леса трясинах'. (И. Торопов)
(4)
Кьттчӧ-кӧ
ылло

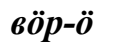
мун- $\ddot{M}-a-\ddot{o} c b$
Ёгор
Сава
куда-то
далеко
лес-ILL идти-PF-3-PL
Егор Савва 


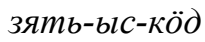

зять-POSS.3SG-COMIT

'Егор Савва со своим зятем ушли куда-то далеко в лес'. (Фольклор)

Употребление иллатива и послелога пьлтикӧ в контексте с названиями, обозначающими вещество и совокупность предметов, описано в последующих разделах.

\section{3. Конкуренция между иллативом и послелогами пиӧ, пытикӧ 'в'}

Послелог пиӧ 'в’ выражает направленность в пределы ориентира в случае, когда ориентир представлен веществом. В отношениях варьирования с этим послелогом могут быть иллатив и послелог пытмикӧ 'в' при глаголах, которые в своей собственной семантике содержат компонент направленности в среду (вӧйны 'погрузиться; увязнуть, утонуть', сибдыныь 'Увязнуть', пьрны 'зайти').

\begin{tabular}{|c|c|c|c|}
\hline $\begin{array}{l}\ddot{E} \kappa м b l л ь-н а-c \\
\text { сверток-INSTR-POSS.3sG }\end{array}$ & $\begin{array}{l}\text { вӧл-ӧ } M-a \\
\text { быть-РF-3 }\end{array}$ & $\begin{array}{l}\text { джынвыйӧ } \\
\text { наполовину }\end{array}$ & $\begin{array}{l}\text { няйт-ӧ } \\
\text { грязь-ILL }\end{array}$ \\
\hline $\begin{array}{ll}\text { вӧй-ӧм } & p a \\
\text { провалиться-РТсР } & \text { pa }\end{array}$ & & & \\
\hline
\end{tabular}

'Свертком оказалась наполовину провалившаяся в грязь рация'. (М. Игнатов)

(6)

$$
\begin{aligned}
& \text { 〈..〉кокъ-яс вӧй-и-с-ньл кизьӧр няйт пытшкӧ } \\
& \text { нога-PL провалиться-PRT-3-PL жидкий грязь в(IN.ILL) }
\end{aligned}
$$

$$
\begin{array}{cllll}
\langle\ldots\rangle \text { кок-blc } & \text { бытттьӧ } & \text { сук } & \text { няйm } & \text { пиӧ } \\
\text { нога-POSS.3sg } & \text { будто } & \text { густой } & \text { грязь } & \text { в(INTER.ILL) }
\end{array}
$$

сибд-i-c

увязнуть-PRT-3SG

‘ ...> как будто ноги увязли в густой грязи'. (К. Туркин)

В ККЯ просматривается преимущественное употребление послелога пиӧ при лексемах, обозначающих массообразное (лым 'снег', вый ‘масло', шыд ‘суп') и газообразное вещество ( $р y$ 'туман', тшын 'дым') 
(Таблица 2). Лексемы, обозначающие жидкое вещество, оформляются преимущественно иллативом. Судя по материалам ККЯ, послелог пиӧ расширяет употребление при лексемах, обозначающих жидкое вещество; так, из 35 употреблений послелога при лексеме ва 'вода' 29 приходится на тексты 2000-2017 гг., но количественный перевес в пользу иллатива сохраняется, ср. употребления в тот же период лексемы ва в иллативе 630, с послелогом пытшкӧ - 14 .

Таблица 2. Частотность употребления иллатива и послелогов пиӧ, пытшикӧ 'в' (ориентир - вещество)

Table 2. The frequency of the illative and the postpositions pie, pičke 'in' (with nouns denoting substances)

\begin{tabular}{|c|c|c|c|}
\hline Лексема & Иллатив & $\begin{array}{c}\text { Послелог } \\
\text { пиё 'в' }\end{array}$ & $\begin{array}{c}\text { Послелог } \\
\text { пылтикё 'в' }\end{array}$ \\
\hline$B a$ 'вода' & 1311 & 35 & 33 \\
\hline Няйт 'грязь' & 134 & 10 & 12 \\
\hline Лblм 'снег' & 72 & 115 & 53 \\
\hline$P y$ 'туман' & 16 & 42 & 35 \\
\hline Шылд 'суп' & 15 & 20 & 3 \\
\hline Йӧв ‘молоко' & 5 & 9 & 8 \\
\hline Вый ‘масло’ & 2 & 9 & 2 \\
\hline Тшын 'дым' & 2 & 5 & 1 \\
\hline Всего & 1557 & 245 & 147 \\
\hline
\end{tabular}

Конкуренция иллатива, послелогов пиӧ и пытшкӧ наблюдается также в контекстах, описывающих ситуацию, при которой объект завернут в ориентир. Предпочтительной в таких контекстах является форма иллатива (Таблица 3 , с. 384), что вполне ожидаемо, так как сфера употребления иллатива охватывает все контексты, описывающие перемещение объекта внутрь ориентира, независимо от его типа. Использование послелога пиӧ объясняется тем, что объект покрыт ориентиром со всех сторон, словно он погружен в ориентир.

$$
\begin{array}{rlllll}
\langle\ldots\rangle \text { ид } & \text { да } & \text { зӧр } & \text { кӧйдыс } & \text { пукm-blл-i-c } & \text { торъя } \\
\text { ячмень } & \text { и } & \text { овес } & \text { семена } & \text { класть-ASP-PRT-3SG } & \text { отдельный }
\end{array}
$$

рузумъ-яс-ӧ

лоскут-PL-ILL

'〈...> семена ячменя и овса [он] заворачивал в отдельные лоскутки’. (Г. Юшков) 


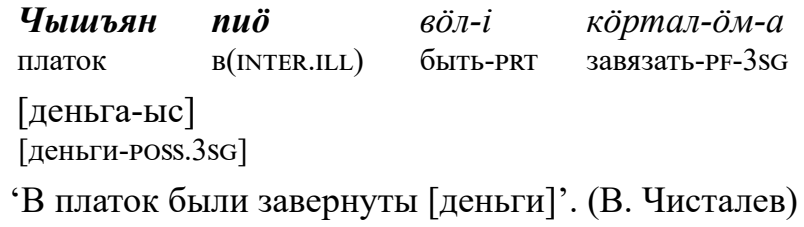

'В платок были завернуты [деньги]'. (В. Чисталев)

$\begin{array}{lllll}\text { Яким } & \text { пестер-cbbl-c } & \text { перъ-ял-i-c } & \text { деньга } & \text { пачка-яс } \\ \text { Яким } & \text { пестерь-EL-POSS.3sG } & \text { достать-ASP-PRT-3SG } & \text { деньги } & \text { пачка-PL }\end{array}$

да гарт-бышт-і-с важ пызандӧра пытшкӧ

и завернуть-ASP-PRT-3SG старый скатерть в(IN.ILL)

'Яким вытащил из пестера пачки денег и завернул в старую скатерть’. (И. Коданев)

Таблица 3. Частотность употребления иллатива и послелогов пиӧ, пытшкё 'в' (ориентир — «упаковка»)

Table 3. The frequency of the illative and the postpositions pie, pičke ‘in' (with nouns denoting “package”)

\begin{tabular}{|l|c|c|c|}
\hline \multicolumn{1}{|c|}{ Лексема } & Иллатив & $\begin{array}{c}\text { Послелог } \\
\text { пиӧ 'в' }\end{array}$ & $\begin{array}{c}\text { Послелог } \\
\text { пытшкӧ 'в' }\end{array}$ \\
\hline Бумага & 48 & 9 & 5 \\
\hline Рузум 'пеленка, лоскут' & 46 & 5 & 5 \\
\hline Чыцшъян 'платок' & 32 & 11 & 5 \\
\hline Дӧра 'ткань' & 12 & 7 & 8 \\
\hline Всего & $\mathbf{1 3 8}$ & $\mathbf{3 2}$ & $\mathbf{2 3}$ \\
\hline
\end{tabular}

\section{4. Конкуренция между иллативом и послелогами пӧвстӧ, пиӧ, пытикё 'в'}

Послелог пӧвстӧ 'в’, выражающий направленность в пределы ориентира, употребляется при лексемах, обозначающих совокупность одушевленных и неодушевленных предметов, а также при существительных, оформленных суффиксом множественности, ср. вошны йӧз пӧвстӧ, пожӧмъяс пӧвстӧ 'затеряться средь людей, в соснах'.

Вариативные отношения иллатива и этого послелога возможны только в тех случаях, когда ориентир представляет собой нерасчлененную совокупность неодушевленных предметов. При употреблении 
иллатива ориентир осмысляется как единая однородная совокупность, при использовании послелога пӧвстӧ - как совокупность, состоящая из множества объектов. Параллельно с послелогом пӧвстӧ могут использоваться также послелог пытшкӧ в случае, когда ориентир воспринимается как имеющий внутреннюю сферу, и послелог пиӧ в случае, когда ориентир воспринимается как сплошное пространство. Между тем употребление послелога пӧвстӧ в типичных для послелогов пиӧ и пытшикӧ контекстах невозможно, ср. ва пиӧ/*ва пӧвстӧ ‘в воду', керка пыттикӧ / *керка пӧвстӧ 'в дом'.

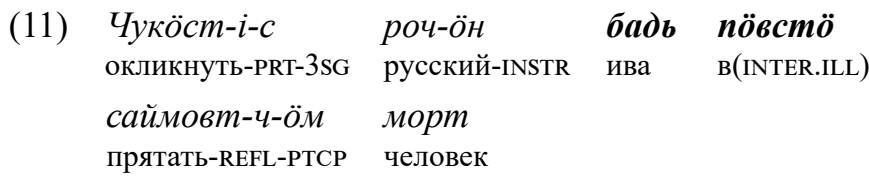

'Окликнул по-русски спрятавшийся среди ивняка человек'. (А. Ванеев)

(12) И дзеб-сb-blл- $a-c$ кӧ кытчё-кӧ, ляк

и спрятать-PEFL-ASP-PRS/FUT-3SG если куда-то низкорослый

баддь-ё пьр-ал-а-с пьюс-на-с

ива-ILL зайти-ASP-PRS/FUT-3SG лодка-INSTR-POSS.3SG

'Если [он] где-то и спрячется ненадолго, то на лодке в мелкий ивняк заедет’. (Г. Юшков)

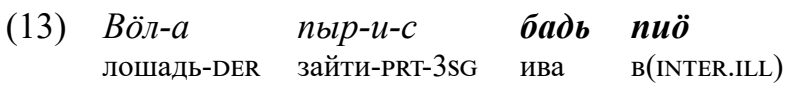

'Подвода заехала в куст ивы’. (Я. Рочев)

(14) Бадb пытmucbblc кӧч-bld пет-i-c да ива из(IN.EL.POSS.3SG) заяц-POSS.2SG выйти-PRT-3SG да

$\begin{array}{llll}\text { мун- } i-c & \text { мӧд } & \text { бады } & \text { пытшикё } \\ \text { идти-PRT-3SG } & \text { второй } & \text { ива } & \text { в(IN.ILL) }\end{array}$

‘Заяц вышел из куста ивы и зашел в другой куст’. (Фольклор)

В данном случае иллатив количественно уступает послелогам. Наиболее частотным является послелог пӧвстӧ (Таблицза 4, с. 386), который указывает не только на движение во внутреннюю зону ориентира, но и на тип ориентира, являясь специальным средством выражения пространственных отношений при лексемах класса «нерасчлененная совокупность». 
Таблица 4. Частотность употребления иллатива и послелогов пӧвстӧ, пиӧ, пытикӧ 'в'

Table 4. The frequency of the illative and the postpositions pevste, pie, pičke 'in'

\begin{tabular}{|l|c|c|c|c|}
\hline \multicolumn{1}{|c|}{ Лексема } & Иллатив & $\begin{array}{c}\text { Послелог } \\
\text { пиӧ 'в' }\end{array}$ & $\begin{array}{c}\text { Послелог } \\
\text { пытикӧ 'в' }\end{array}$ & $\begin{array}{c}\text { Послелог } \\
\text { пӧвстӧ 'в' }\end{array}$ \\
\hline Турун 'трава' & 8 & 37 & 24 & 40 \\
\hline Бадь 'ива, ивняк' & 6 & 5 & 8 & 11 \\
\hline Идзас 'солома' & 4 & 7 & - & 2 \\
\hline Петиӧр 'крапива' & 2 & 8 & 19 & 10 \\
\hline Дзоридз/РL ‘цветок' & - & $8 / 1$ & - & $13 / 8$ \\
\hline Всего & $\mathbf{2 0}$ & $\mathbf{6 5 / 1}$ & $\mathbf{5 1}$ & $\mathbf{7 6 / 8}$ \\
\hline
\end{tabular}

\section{5. Конкуренция между иллативом и послелогом вылё 'на'}

Послелог вылӧ ‘на’ выражает направленность на поверхность ориентира. Параллельное употребление иллатива и послелога вылӧ наблюдается в нескольких типах контекстов.

1. С лексемами, выражающими плоские, визуально необъемные предметы (джодж 'пол', стен 'стена', пӧтӧлӧк 'потолок'), типично употребление иллатива (см. Таблицу 5, с. 387). Послелог при таких лексических условиях встречается в переводных и газетных текстах, в чем явно просматривается калькирование предложных конструкций русского языка.

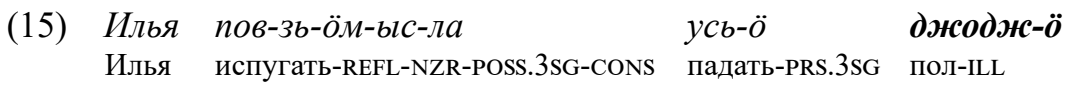
'Илья от испуга падает на пол'. (Н. Дьяконов, С. Ермолин)

\begin{tabular}{|c|c|c|c|c|}
\hline $\begin{array}{ll}И & \text { талун } \\
\text { и } & \text { сегодня }\end{array}$ & $\begin{array}{l}\text { на } \\
\text { еще }\end{array}$ & $\begin{array}{l}\text { мe }\langle\ldots\rangle \\
\text { я }\end{array}$ & $\begin{array}{l}\text { вольсав-л- } a \\
\text { стелить-ASP-PRS/FUT.1SG }\end{array}$ & $\begin{array}{l}\text { джсоджс } \\
\text { пол }\end{array}$ \\
\hline $\begin{array}{l}\text { вылл̈̈ } \\
\text { Ha(SUPER.ILL) }\end{array}$ & $\begin{array}{l}\text { мич } \\
\text { крас }\end{array}$ & $a$ & $\begin{array}{l}\text { жоджсдӧра-сӧ } \\
\text { оловик-Poss.3sG.ACC }\end{array}$ & \\
\hline
\end{tabular}

'И я еще сегодня постелю ненадолго на пол красивый половик' (Л. Прокопьева. Выль туйӧд, 2013) 
Таблица 5. Частотность употребления иллатива и послелога вылӧ 'на' (ориентир — плоские предметы)

Table 5. The frequency of the illative and the postpositions vile 'on' (with nouns denoting flat objects)

\begin{tabular}{|l|c|c|}
\hline \multicolumn{1}{|c|}{ Лексема } & Иллатив & Послелог выл̈ 'на' \\
\hline Джодж ‘пол’ & 845 & 33 \\
\hline Стен(а) ‘стена' & 566 & 17 \\
\hline Пӧтӧлӧк ‘потолок' & 92 & 1 \\
\hline Всего & $\mathbf{1 5 0 3}$ & $\mathbf{5 1}$ \\
\hline
\end{tabular}

2. Различные предпочтения в выборе грамматических средств проявляют лексемы, обозначающие предметы, функциональная часть которых является плоской. Например, типичным для слов пызан 'стол' и улӧс 'стул' является послеложное оформление.

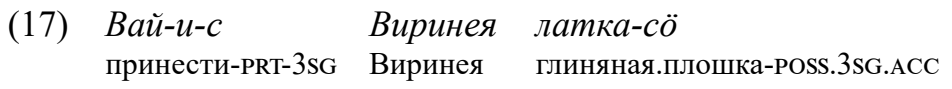

\section{пьзан вылӥ}

стол на(SUPER.ILL)

‘Принесла Виринея глиняную плошку на стол'. (Г. Юшков)

В форме иллатива слово 'стол’ спорадически встречается в отдельных диалектах. Слово улӧс 'стул’ допускает показатель иллатива только в значении 'должность'.

(18) верхнесысольский диалект (Койгородок)
Сакар, сукар вай-и
пьзан-ё

Сахар сухарь принести-PRT.1SG стол-ILL

'На стол [я] принесла сахар, сухари’ [Жилина 1975: 70].

(19) Архитектура, стрӧит-ч-ӧм да коммунальнӧй архитектура строить-REFL-NZR и коммунальный

овмӧс-са министр-лӧн улӧс-ё пукс-и-с

хозяйство-DER министр-GEN стул-ILL сесть-PRT-3SG

Николай Смьишляев

Николай Смышляев

'Должность министра архитектуры, строительства и коммунального хозяйства занял Николай Смышляев’. (Коми му, 2012) 
Слова лабич 'скамья' и пӧлать 'полати' предпочитают иллативное оформление. Спорадическое использование послелога со словом 'полати' отмечается преимущественно в случаях с глаголом кайны 'подняться' при описании движения снизу вверх. Весьма активно конкурируют иллатив и послелог вылӧ 'на' при оформлении слова лабич 'скамья'. Соотношение между этими грамматическими формами меняется, в текстах периода 2000-2017 гг. наблюдается количественный перевес в пользу послелога: в иллативе 72 употребления, с послелогом - 86, между тем в материалах ККЯ без учета хронологических рамок отмечается доминирование иллатива (Таблица 6, с. 389).

$\begin{array}{lllll}\text { Степан } & \text { пукс-и-с } & \text { лабич-ӧ, } & \text { куm-i-c } & \text { видзӧд-ныл } \\ \text { Степан } & \text { сесть-PRT-3SG } & \text { лавка-ILL } & \text { начать-PRT-3sG } & \text { смотреть-INF } \\ \text { дзодзӧг } & \text { бӧрся } & & & \\ \text { гусь } & \text { за(РоSт.сом) } & & & \end{array}$

‘Степан сел на лавку, начал следить за гусем’. (М. Игнатов)

(21) $\begin{array}{lll}\text { Пукс-и-м } & \text { фонтан-дор-са } & \text { лабич } \\ \text { сесть-PRT-1.PL } & \text { фонтан-край-DER } & \text { скамья } \\ \text { '[Ма(SUPER.ILL) }\end{array}$
[Мы сели на скамью около фонтана'. (Н. Куратова)

Уместно отметить параллельное использование падежа и послелога в схожих семантических условиях у одного автора, а также индивидуально-авторские употребления. Так, из 13 случаев нетипичного для слова диван иллативного оформления 11 встречаются в текстах одного и того же автора, в тех же текстах при той же лексеме послелог вылӧ используется в 8 случаях.

$\begin{array}{lllll}\text { Диван } & \text { вылӧ } & \text { вод-ӧмён } & \text { дыр } & \text { лыlддbbl-c-u-c } \\ \text { диван } & \text { на(SUPER.ILL) } & \text { лечь-CONV } & \text { долго } & \text { читать-REFL-PRT-3SG }\end{array}$

'[Он] долго читал, лежа на диване'. (В. Напалков)

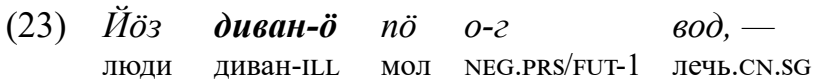

вочавидз-и-с Сусанна Матвеевна

ответить-PRT-3SG Сусанна Матвеевна

'На чужой диван, мол, не лягу, — ответила Сусанна Матвеевна'. (В. Напалков) 
Таблица 6. Частотность употребления иллатива и послелога вылӧ 'на' (ориентир - предметы с плоской функциональной частью) Table 6. The frequency of the illative and the postpositions vile 'on' (with nouns denoting objects with a flat functional part)

\begin{tabular}{|l|c|c|}
\hline \multicolumn{1}{|c|}{ Лексема } & Иллатив & Послелог вылӧ 'на' \\
\hline Лабич 'скамья' & 276 & 200 \\
\hline Пӧлать 'полати' & 181 & 11 \\
\hline Диван ‘диван' & 13 & 141 \\
\hline Улӧс 'стул' & $(3)$ & 339 \\
\hline Пьзан 'стол' & - & 2097 \\
\hline Всего & $\mathbf{4 7 0}(3)$ & $\mathbf{2 7 8 8}$ \\
\hline
\end{tabular}

3. С лексемами, обозначающими открытые пространства ( ыб 'поле', улич(a) 'улица', изэрд ‘площадь', эрд 'открытое место, поле'), чаще используется послелог, чем падежная форма (Таблицуа 7).

(24) Ирина пет-і-с улич-ё да кытчӥ-кӧ саял-i-c Ирина выйти-PRT-3SG улица-ILL и куда-то скрыться-PRT-3SG 'Ирина вышла на улицу и куда-то скрылась'. (В. Безносиков)

(25) Пет-ал- $a$

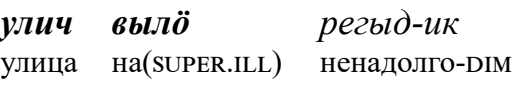
выйти-ASP-PRS/FUT.1SG улица на(SUPER.ILL) ненадолго-DIM ‘[Я] выйду ненадолго на улицу'. (А. Мишарин)

Таблица 7. Частотность употребления иллатива и послелога вылӧ 'на' (ориентир - открытое пространство) Table 7. The frequency of the illative and the postpositions vile 'on' (with nouns open spaces)

\begin{tabular}{|l|c|c|}
\hline \multicolumn{1}{|c|}{ Лексема } & Иллатив & Послелог выл̈ 'на' \\
\hline Улич(а) 'улица' & 84 & 392 \\
\hline $\begin{array}{l}\text { Эрд ‘поляна, } \\
\text { открытое место' }\end{array}$ & 11 & 224 \\
\hline Изэрд ‘площадь' & 3 & 21 \\
\hline Видз ‘луг' & - & 690 \\
\hline Всего & $\mathbf{9 8}$ & $\mathbf{1 3 2 7}$ \\
\hline
\end{tabular}


Выбор грамматических средств может зависеть от того, в каком значении употребляется существительное. Например, лексема эрд 'поляна, поле, открытое место; простор' в значении 'поляна, поле, открытое место' чаще оформляется послелогом; при использовании того же существительного в значении 'простор, пространство' выбирается иллатив, ср. петны космос эрдё/ *космос эрд вылӧ 'выйти в космическое пространство'; петны паськыд эрдё nаськыљ эрд вылӧ 'выйти на широкое поле, поляну'. В ККЯ зафиксировано употребление лексемы эрд в значении 'поляна, поле, открытое место' с послелогом в 195 случаях, в иллативе - в 11 случаях.

Иллативная форма встречается в составе устойчивых словосочетаний петны эрд-ё 'всплыть, выясниться, обнаружиться, выйти наружу’, эрд-ё петкӧдньl 'разоблачить, вывести на чистую воду'.

\begin{tabular}{|c|c|c|c|c|c|}
\hline $\begin{array}{l}\text { Мун-i-c } \\
\text { идти-PRT-3SG }\end{array}$ & $\begin{array}{l}\text { руч } \\
\text { лиса }\end{array}$ & $\begin{array}{l}\text { эрд } \\
\text { поляна }\end{array}$ & $\begin{array}{l}\text { вылл̈̈ } \\
\text { Ha(SUPER.ILL) }\end{array}$ & $\begin{array}{l}\partial a \\
и\end{array}$ & $\begin{array}{l}\text { вод-i-c } \\
\text { лечь-PRT-3SG }\end{array}$ \\
\hline 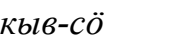 & \multicolumn{5}{|c|}{ нюжс̈̈д-ём ̈н } \\
\hline язык-POSS.3sc & $\mathrm{CCC}$ & \multicolumn{4}{|c|}{ высунуть-CONV } \\
\hline
\end{tabular}

‘Пошла лиса на поляну и легла, высунув язык’. (Фольклор)

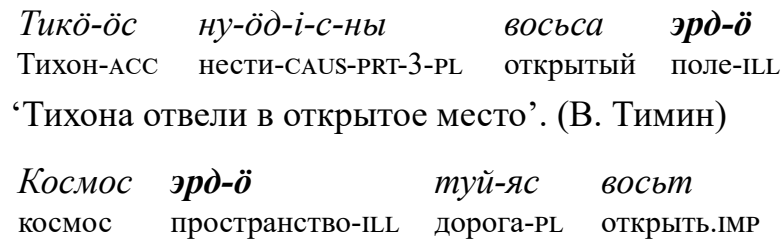

'Открой дорогу в космическое пространство'. (П. Образцов)

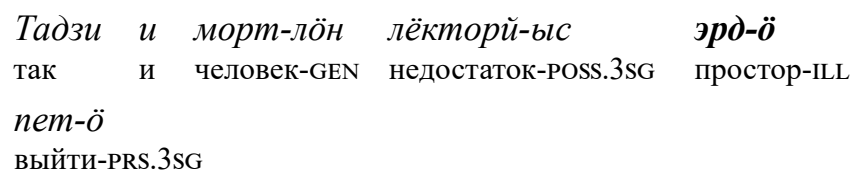

‘Так и проявляются недостатки человека'. (В. Попов)

4. Иллатив используется реже, чем послелог, в контекстах с лексемами, обозначающими события. В современном коми-зырянском языке иллатив относительно последовательно употребляется со словом войпук 'посиделки' (см. Таблищу 8, с. 391).

$\begin{array}{llllll}\text { (30) Дерт, } & \text { войпук- } & \text { мун-нbl } & \text { сёр } & \text { нин } & \text { вӧл- } i \\ \text { конечно } & \text { посиделки-ILL } & \text { идти-INF } & \text { поздно } & \text { уже } & \text { быть-PRT }\end{array}$ ‘Конечно, идти на посиделки было уже поздно'. (В. Юхнин) 


$\begin{array}{lllll}\text { Мылькдор } & \text { сикт-ылсb } & \text { том } & \text { йӧз } & \text { век-джык } \\ \text { Мылькдор } & \text { село-еL } & \text { молодой } & \text { люди } & \text { постоянно-сомР }\end{array}$
чукӧрт-ч-ьлл-ӧ-ныл войпук вылё сикт пом-ӧ coбрать-PEFL-ASP-PRS.3-PL посиделки на(SUPER.ILL) село конец-ILL 'Молодежь села Мылькдор чаще всего собирается на посиделки на окраине села'. (Н. Куратова)

В отдельных диалектах засвидетельствованы единичные случаи иллативного оформления еще некоторых лексем класса «событие».

(32) верхнесысольский диалект (Койгородок)
Пир-ё кор-и-нbl-с талун

пир-ILL пригласить-PRT-PL-3 сегодня

‘Сегодня пригласили на пир’. [Жилина 1975: 70]

(33) верхневычегодский диалект (Вольдино)

$\begin{array}{lllll}\text { Мэн-э } & \text { пэ } & \text { тшӧтш } & \text { ну-ли } & \text { свад'ба-д } \\ \text { я-АСС } & \text { мол } & \text { тоже } & \text { нести-ASP.IMP } & \text { свадьба-ILL.POSs.2sG }\end{array}$

‘Меня, мол, тоже свози на свадьбу'. [Сорвачева и др. 1966: 77]

Таблица 8. Частотность употребления иллатива и послелога вылӧ ‘на' (ориентир — событие)

Table 8 . The frequency of the illative and the postpositions vile 'on' (with nouns denoting events)

\begin{tabular}{|l|c|c|}
\hline \multicolumn{1}{|c|}{ Лексема } & Иллатив & Послелог вылӧ 'на' \\
\hline Войпук 'посиделки' & 22 & 9 \\
\hline Кӧлысь 'свадьба' & - & 68 \\
\hline Собранньё 'собрание' & - & 33 \\
\hline Всего & $\mathbf{2 2}$ & $\mathbf{1 1 0}$ \\
\hline
\end{tabular}

\section{6. Конкуренция между иллативом и послелогами вылӧ, йылё 'на'}

Послелог йылё 'на' выражает направленность на конечную часть ориентира. Конкуренция между иллативом и послелогами вылӧ и йылӧ 'на' наблюдается в контексте с лексемами, обозначающими возвышенности ('гора', 'возвышенность'), а также линейные предметы ('дерево', 
'столб', ‘жердь'). Выбор между падежной формой и послелогами связан с различной концептуализацией ситуации. В контекстах с иллативом описывается ситуация, где в пространственные отношения вовлечен весь ориентир.

$\begin{array}{lllll}\text { Кутшӥм } & \boldsymbol{n y - \ddot { \boldsymbol { o } }} & \text { нӧ } & \text { пукс-и-с } & \text { [сьӧла-ыс] } \\ \text { какое } & \text { дерево-ILL } & \text { же } & \text { сесть-PRT-3SG } & \text { [рябчик-POSS.3SG] }\end{array}$

'На какое же дерево сел [рябчик]'. (Г. Юшков)

При использовании послелога йылӧ ситуация может осмысляться и как направленная на верхнюю часть ориентира (на крону дерева, на вершину горы и т. п.), и как направленная на ориентир в целом.

$\begin{array}{llll}\text { Мишка } & \text { кай-и-с } & \boldsymbol{n y} & \text { йыл̈̈ } \\ \text { мишка } & \text { подниматься-PRT-3SG } & \text { дерево } & \text { на(APEX.ILL) }\end{array}$

'Мишка залез на верхнюю часть дерева'. (Н. Дьяконов)

(36) Кыр возвышенность

бӧрын после(POST.IN)

\section{йылӧ} на(APEX.ILL)

\section{кай-ьıмт-ӧм}

подниматься-ASP-NZR

'Немного поднявшись на возвышенность, они оказались в месте, где растет много брусники’. (И. Коданев)

Такая интерпретация ситуации возможна и в случае употребления послелога вылӧ с существительными 'гора', 'возвышенность' при глаголах со значением движения снизу вверх. При глаголах, описывающих изменение позиции субъекта, перемещение объекта ('сесть', 'ставить’ и т. п.), ориентир воспринимается в качестве опорной поверхности.

$$
\begin{array}{cllll}
\langle\ldots\rangle \text { учитель } & \text { да } & \text { Яков } & \text { кавшас-u-c-Hbl } & \text { джуджыд } \\
\text { учитель } & \text { и } & \text { Яков } & \text { карабкаться-PRT-3-PL } & \text { высокий }
\end{array}
$$

\section{керӧс вьллӧ}

гора Ha(SUPER.ILL)

‘ (..> учитель и Яков забрались на высокую гору’. (В. Ширяев)

\begin{tabular}{|c|c|c|c|c|}
\hline $\begin{array}{l}\text { Нuм-blc } \\
\text { название-г }\end{array}$ & 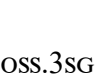 & $\begin{array}{l}\text { мича, } \\
\text { красивый }\end{array}$ & $\begin{array}{l}\text { лӧсbblda } \\
\text { хорошо }\end{array}$ & $\begin{array}{l}\text { ладм-ё } \\
\text { подходить-PRS.3SG }\end{array}$ \\
\hline жва & керӧс & выл & силеть-р & $\begin{array}{ll}n & \text { сикт-ыс-ль }\end{array}$ \\
\hline
\end{tabular}

'Название красивое, хорошо подходит для села, расположившегося на высоком берегу Вычегды’. (А. Туркин) 
В отличие от послелога йылӧ при употреблении послелога вылӧ с существительными, обозначающими вертикальные предметы ('дерево', 'столб'), описываемая ситуация связана с вовлечением в пространственную конфигурацию не верхней части ориентира, а ориентира в целом.
(39) $A \check{u}-b l c$
$\kappa a \check{u}-u-c$
яблӧг $\boldsymbol{n y}$
вылй
отец-POSS.3SG
подняться-PRT-3SG
яблоко
дерево
на(SUPER.ILL)
‘Его отец поднялся на яблоню’. (В. Чисталев)

В сочетании с существительными, обозначающими возвышенности, иллатив количественно уступает послелогам, доминирующим оказывается послелог йылӧ (см. Таблииу 9).

Таблица 9. Частотность употребления иллатива и послелогов вылӧ, йылӧ 'на' (ориентир — возвышенности)

Table 9. The frequency of the illative and the postpositions vile 'on' (with nouns denoting elevated places)

\begin{tabular}{|l|c|c|c|}
\hline \multicolumn{1}{|c|}{ Лексема } & Иллатив & $\begin{array}{c}\text { Послелог } \\
\text { йылл̈ 'на' }\end{array}$ & $\begin{array}{c}\text { Послелог } \\
\text { вылл “на' }\end{array}$ \\
\hline Керӧс ‘гора, возвышенность' & 48 & 48 & 22 \\
\hline Кыр ‘обрыв, крутой берег’ & 38 & 185 & 11 \\
\hline Н̈̈рыс ‘холм’ & 34 & 50 & 24 \\
\hline Мыльк ‘бугорок’ & - & 36 & 82 \\
\hline Всего & $\mathbf{1 2 0}$ & $\mathbf{3 1 9}$ & $\mathbf{1 3 9}$ \\
\hline
\end{tabular}

2. Конкуренция между иллативом и послелогами йылӧ, вылӧ обнаруживается также в случае, когда в качестве ориентира выступают «кронштейны» (тув 'гвоздь', сёр 'перекладина для одежды').

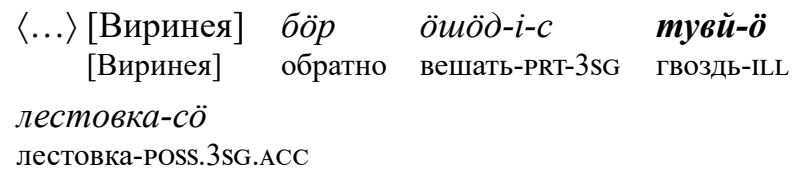

'Виринея обратно повесила лестовку ${ }^{1}$ на гвоздь'. (Г. Юшков)

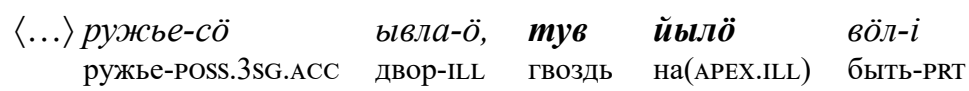

1 Лестовка - разновидность чёток у старообрядцев. 
$\ddot{o ̈} u \ddot{\partial} \partial-a-\mu$

вешать-PRS/FUT-1PL

‘ $\langle$.$\rangle ружье вешали во дворе, на гвоздь'. (И. Торопов)$

$(42)$

$\begin{array}{llll}\text { Митя } & \text { бать-ылс } & \text { бӧрын } & \text { чылик-ал-i-c } \\ \text { Митя } & \text { отец-POSS.3SG } & \text { после(POST.INESS) } & \text { вытереть-ASP-PRT-3SG }\end{array}$

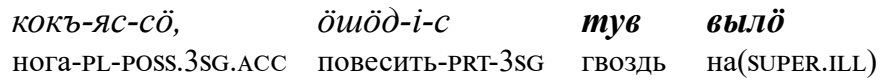

важс фуфайка-сӧ

старый фуфайка-POSS.3SG.ACC

'Митя вслед за отцом вытер ноги, повесил старую фуфайку на гвоздь'. (С. Раевский)

С лексемой тув 'гвоздь', обозначающей типичный «кронштейн», чаще употребляется иллатив (Таблицза 10, с. 395).

В случае, когда в качестве «кронштейна» используются длинные линейные предметы, помимо параметра «вовлеченность в пространственное отношение крайней части ориентира или ориентира в целом», выбор послелогов обусловлен также положением ориентира: при описании вертикального положения применяется чаще послелог йылё, при описании горизонтального положения ориентира послелог вылӧ:

(43) Тшӧтшӧд-ӧм да кӧртав-л-ӧм корӧсь подровнять-РТСР и завязать-АSP-РTCP веник

гозъ-яс-сӧ ӧшл-і-м поти вылё

пара-PL-Poss.3SG.ACC вешать-PRT-1PL жердь на(SUPER.ILL)

сарай-ӧ

сарай-ILL

'Подровненные и связанные пары веников развесили на жердь в сарае'. (В. Афанасьев)

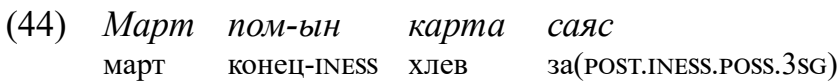

кузь поти йылё выль скворечник

длинный шест на(APEX.ILL) новый скворечник

ӧmӧд-i-c

вешать-PRT-3SG

'В конце марта за хлевом на длинный шест [он] повесил новый скворечник'. (А. Некрасов) 
Таблица 10. Частотность употребления иллатива и послелогов вылӧ, йылӧ ‘на' (ориентир — «кронштейны»)

Table 10. The frequency of the illative and the postpositions vile, jile 'on' (with nouns denoting hangers)

\begin{tabular}{|l|c|c|c|}
\hline \multicolumn{1}{|c|}{ Лексема } & Иллатив & $\begin{array}{c}\text { Послелог } \\
\text { йылӧ ‘на' }\end{array}$ & $\begin{array}{c}\text { Послелог } \\
\text { вылӧ 'на' }\end{array}$ \\
\hline Тув 'гвоздь' & 106 & 79 & 28 \\
\hline Сёр 'перекладина' & 45 & - & 56 \\
\hline Поти 'жердь' & 3 & 7 & 23 \\
\hline Зіб ‘длинный шест' & 1 & 40 & - \\
\hline Всего & $\mathbf{1 5 5}$ & $\mathbf{1 2 6}$ & $\mathbf{1 0 7}$ \\
\hline
\end{tabular}

\section{7. Конкуренция между иллативом и послелогом бердё 'к'}

Послелог бердӧ используется для выражения контактных отношений объекта с ориентиром. Варьирование иллатива и послелога прослеживается в нескольких типах контекстов:

1. При глаголах со значением жесткого контакта (лемавны 'приклеить', вурны 'пришить', тувъявны 'прибить' и т. п.) для описания плотного контакта, который осуществляется с помощью дополнительного предмета.

$$
\begin{aligned}
& \langle\ldots\rangle \text { быттьӧ ки-яс-сӧ генеральскӧй лампасъ-яс-ӧс } \\
& \text { будто рука-PL-Poss.3sG.ACC генеральский лампас-PL-ACC }
\end{aligned}
$$

моза вур-ыишт-ӧм-а гач бердас

как шить-ASP-PF-3SG брюки к(CONT.ILL.POSS.3SG)

‘ (..> руки будто пришиты к брюкам как генеральские лампасы'. (Е. Рочев)

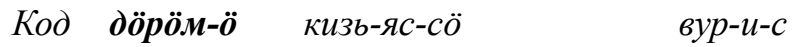

$$
\begin{aligned}
& \text { кто рубашка-ILL пуговица-PL-Poss.3SG.ACC шить-PRT-3SG }
\end{aligned}
$$

'Кто пришил на рубашку пуговицы'. (В. Лодыгин)

При использовании послелога бердӧ ситуация осмысляется как присоединение объекта к ориентиру; при употреблении иллатива ситуация может восприниматься двояко: как присоединение объекта 
к поверхности ориентира и как перемещение объекта в пределы ориентира, который представляет собой основу.

$\begin{array}{lll}\text { Мун- } a-\mu & \text { мун- } a-\mu & \text { maдзи, } \\ \text { идти-PRS/FUT-2SG } & \text { идти-PRS/FUT-2SG } & \text { так }\end{array}$

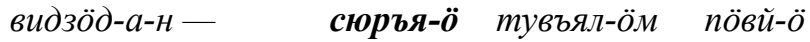

смотреть-PRS/FUT-2SG столб-ILL прибить-PTCP доска-ILL

гиж-ӧм-а: «Ивановка» либё «Петровка»

писать-PF-3SG Ивановка или Петровка

'Идешь-идешь так - смотришь на доске, прибитой к столбу, написано: «Ивановка» или «Петровка»'. (И. Торопов)

2. При контактных глаголах со значением прикосновения и охвата (ниртчыны 'тереться', кутчысьны 'держаться, хвататься', босьтчыны 'взяться', 'зацепиться') для описания плотного контакта без дополнительного предмета.

\begin{tabular}{|c|c|c|c|c|}
\hline $\begin{array}{l}A \partial \partial 3-u-c, \\
\text { видеть-PRT-3SG }\end{array}$ & $\begin{array}{l}\text { Mblŭ } \\
\text { что }\end{array}$ & $\begin{array}{l}\text { кутшиӧм-кӧ } \\
\text { какой-то }\end{array}$ & $\begin{array}{l}\text { выджыlд } \\
\text { большой }\end{array}$ & $\begin{array}{l}\text { сюр } b-Я c-a \\
\text { рог-PL-DER }\end{array}$ \\
\hline
\end{tabular}

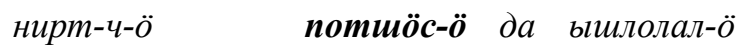

тереть-REFL-PRS.3SG забор-ILL и вздыхать-PRS.3SG

'[Он] увидел, как какой-то [зверь] с крупными рогами трется об забор и вздыхает’. (И. Белых)

(49) Со эстӧн код-лӧн-кӧ кукань-ысс потиӧс вот там кто-GEN-To теленок-POSS.3SG забор

бердё нирт-ч-ӧ

к(CONT.ILL) тереть-REFL-PRS.3

‘Вот там чей-то теленок трется об забор'. (В. Леканов)

(50) Виренея кут-ч-blc-u-c ӧдзӧс вугй-ӧ

Виринея держать-REFL-REFL-PRT-3SG дверь ручка-ILL

'Виринея взялась за ручку двери'. (Г. Юшков)

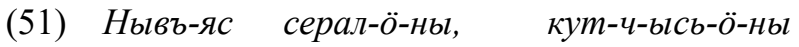

девушка-PL смеяться-PRS.3-PL держать-REFL-REFL-PRS.3-PL

мешӥк бердӧ

мешок к(CONT.ILL)

‘Девушки смеются, берутся за мешки’. (В. Чисталев)

3. При глаголе домныл, домавны 'привязать' для описания опосредованного контакта, ситуации, когда объект и ориентир соединены 
при помощи дополнительного предмета без непосредственного контакта их поверхностей.

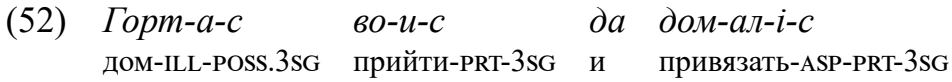

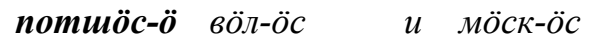

забор-ILL лошадь-АCС и корова-АCC

'[Он] пришел домой и привязал к забору лошадь и корову'. (В. Чисталев)

$\begin{array}{llll}\text { Горm- }-\mathrm{-c} & \text { Кьлккока } & \text { во-и-c } & \partial a \\ \text { дом-ILL-POSS.3SG } & \text { двуногий } & \text { прийти-PRT-3SG } & \text { и }\end{array}$

\begin{tabular}{|c|c|c|c|}
\hline $\begin{array}{l}\text { дом-ал-i-c } \\
\text { привязать-ASP-PRT-3sG }\end{array}$ & $\begin{array}{l}\text { blж- } \ddot{о} c \\
\text { овца-АСС }\end{array}$ & $\begin{array}{l}\boldsymbol{n y} \\
\text { дерево }\end{array}$ & $\begin{array}{l}\text { бердё } \\
\text { к(CONT.ILL) }\end{array}$ \\
\hline
\end{tabular}

‘Пришел домой Двуногий и привязал овцу к дереву’. (В. Чисталев)

Для описания свободного контакта объекта и ориентира ('встать, сесть, лечь вплотную к ориентиру’) употребляется только послелог.
Морт-льг тиӥкт-ӧ- $\mathrm{Hbl}$
сувm-Hbl
стен бердё
человек-DAT
велеть-PRS.3-PL встать-INF
стена к(CONT.ILL)
'Человеку велят встать к стене'. (И. Торопов)

\section{(55)}
Поп да прӧскурня пуксь-ӧ-ны
поп и просвирня
садиться-PRS.3-PL
пьзан бердё

'Поп и просвирня садятся к столу'. (В. Савин)

Сравнительный анализ частотности употребления иллатива и послелога бердӧ ‘к’ в корпусе ККЯ показал, что во всех рассмотренных контекстах иллатив употребительнее, чем послелог (см. Таблицу 11).

Таблица 11. Частотность употребления иллатива и послелога бердё ‘на' при контактных глаголах

Table 11. The frequency of the illative and the postpositions berde 'on' (with contact verbs)

\begin{tabular}{|c|c|c|}
\hline Глаголы & Иллатив & Послелог бердӧ \\
\hline Кутчыссьны 'держаться, хвататься' & 93 & 2 \\
\hline Домавны 'привязать' & 42 & 11 \\
\hline Кӧтравныл 'завязать' & 25 & 19 \\
\hline Вурньь 'шить' & 8 & 3 \\
\hline Всего & 168 & 35 \\
\hline
\end{tabular}




\section{8. Конкуренция между иллативом и послелогом ордё 'к'}

Послелог ордё 'к’ употребляется при указании на направленность участника ситуации в место жительства лица. Конкуренция между послелогом ордӧ и иллативом наблюдается в контексте с одушевленными существительными и личными местоимениями мн. ч., местоимения ед. ч. допускают только послелог. Суффикс иллатива присоединяется к генитивной форме местоимений 1-го и 2-го л. мн. ч. и к номинативной форме местоимения 3-го л. мн. ч. Послелог употребляется при местоимениях 1-го и 2-го л. в номинативе и генитиве, а также при усеченной форме местоимения 3-го л. В контексте с местоимениями обладает большей частотностью иллатив, в материалах ККЯ он встречается два раза чаще, чем послелог. С существительными ед. ч. на фоне преимущественного употребления послелога зафиксированы единичные случаи употребления иллатива, тогда как с существительными множественного числа послелог имеет минимальное преимущество над иллативом (см. Таблииу 12, с. 399). Показатель мн. ч. при существительном имеет значение ассоциативной множественности, в этом случае может меняться стандартный порядок морфем $\mathrm{PlCx} P \mathrm{PxPlCx}$.

$\begin{array}{llll}\text { Mu } & \text { ордӧ } & \text { во-льввл-ӧ- } H b l & \text { вӧл- } i \\ \text { мы } & \text { к(DOMUS.ILL) } & \text { приходить-ASP-PRS.3-PL } & \text { быть-PRT } \\ a c & \text { грезд-ca } & \text { челяд } b & \\ \text { свой } & \text { деревня-DER } & \text { дети } & \end{array}$

'К нам приходили дети из нашего села'. (В. Лыткин)

(57) Мама, тӧрыт коді миян ордӧ

мама вчера кто мы.GEN к(DOMUS.ILL)

во-л-i-c?

прийти-ASP-PRT-3SG

'Мама, вчера к нам кто приходил?' (Н. Попов)

(58) Миян-ё гӧсьтъ-яс во-и-с-ны

MЫ.GEN-ILL гость-PL прийти-PRT-3-PL

'К нам пришли гости'. (А. Попов)
Пет-ал- $i$
сосед ордё
лямпа-ла
выйти-ASP-PRT.1SG
сосед к(DOMUS.ILL)
охотничьи лыжи-CONS

‘[Я] сходил к соседу за охотничьими лыжами'. (И. Белых) 


\begin{tabular}{|c|c|c|c|c|}
\hline $\begin{array}{l}\text { Ворс- } \ddot{O} \\
\text { играть-PRS.3sG }\end{array}$ & 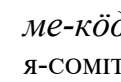 & $\begin{array}{ll}\partial & \partial з и \kappa \\
\text { T } & \text { совершенно }\end{array}$ & $\begin{array}{l}\text { былд } \\
\text { каждый }\end{array}$ & $\begin{array}{l}л y н, \\
\text { день }\end{array}$ \\
\hline$O-3$ & $\kappa \ddot{O}$ & 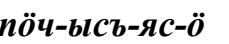 & & мун \\
\hline NEG.PRS/FUT-3 & если & бабушка-Poss.3sG & PL-ILL & идти.CN.SG \\
\hline
\end{tabular}

' $[\mathrm{OH}]$ играет со мной абсолютно каждый день, если не идет к бабушке'. (В. Лодыгин)

Таблица 12. Частотность употребления иллатива и послелога ордӧ 'к'

Table 12. The frequency of the illative and the postpositions orde 'to'

\begin{tabular}{|c|c|c|}
\hline Лексема & Иллатив & Послелог орд̈̈ ‘к’ \\
\hline Миян / ми 'наш / мы' & $1236 / 0$ & $107 / 97$ \\
\hline Тіян / mi ‘ваш / вы’ & $220 / 0$ & $68 / 14$ \\
\hline Найӧ / на 'они' & $7 / 0$ & $0 / 490$ \\
\hline Всего с местоимениями & $1463 / 0$ & $175 / 601$ \\
\hline$\langle\ldots\rangle$ ов / PL ‘фамилии на -ов’ & $0 / 31$ & $70 / 27$ \\
\hline Ёрm / PL ‘друг’ & 0 & $17 / 4$ \\
\hline Tьӧт / PL 'тетя' & $0 / 2$ & $27 / 0$ \\
\hline Чой / PL'сестра' & 0 & $28 / 0$ \\
\hline Пӧч/PL ‘бабушка’ & $0 / 2$ & $1 / 0$ \\
\hline Сосед / PL 'сосед' & $4 / 2$ & $5 / 13$ \\
\hline Всего с существительными & $4 / 37$ & $148 / 44$ \\
\hline Всего & 1504 & 924 \\
\hline
\end{tabular}

\section{9. Конкуренция между иллативом и послелогом дорӧ ' $к$ '}

Послелог дорӧ 'к’ используется для выражения значения направленности к ориентиру. Конкуренция между иллативом и послелогом наблюдается в случае, если в качестве ориентира выступают водные пространственные объекты ('река', 'ручей', 'колодец', 'ключ'). При употреблении иллатива значение направленности к ориентиру осложняется семантикой последующего контакта с ориентиром. В этом случае ориентир осмысляется как объект с функциональным назначением: место, где можно поймать рыбу; место, где можно взять воду; 
место, где можно осуществлять разные действия, связанные с водой (стирать, полоскать, купаться и т. п.). В таких предложениях обязательным является наличие компонента с целевым значением, в качестве которого выступает инфинитив или именная группа в консекутиве. Судя по материалам ККЯ, частотность употребления падежа и послелога в таких конструкциях различается незначительно. Так, при описании целевого ('за водой') движения к водному ориентиру со словом юкмӧс ‘колодец' отмечен иллатив в 13 случаях, послелог - в 17; со словом шор 'ручей' иллатив и послелог каждый использованы в 6 случаях.

$\begin{array}{lllll}\text { (61) } & \text { Ветл- } i-\mu & \text { шор } & \text { дорӧ } & \text { ворс-Hbl } \\ \text { сходить-PRT-1PL } & \text { ручей } & \text { к(APUD.ILL) } & \text { играть-INF }\end{array}$

‘Мы сходили играть к ручью’. (М. Сажина)

(62) Кӧлуй пожъяв-ньл шор-ӧ мӧд- $i$

белье полоскать-INF ручей-ILL направляться-PRT.1SG

'[Я] иду полоскать белье к ручью'. (Н. Куратова)

(63) Меньлм и юкмӧс-ӧ ва-ла о-з

я.DAT и колодец-ILL вода-CONS NEG.PRS/FUT-3

КОв $\mathrm{MYH}-\mathrm{Hbl}$

быть.нужным.CN.SG идти-INF

'Мне и за водой к колодцу не надо идти'. (Н. Куратова)

(64) Ме иор дорӧ пожсъя-сь-ныл лэчч-ылля ручей к(APUD.ILL) полоскать-REFL-INF спуститься-ASP-PRS/FUT.1SG 'Я схожу к ручью полоскать'. (Н. Куратова)

В ряде диалектов (удорском, ижемском, верхневычегодском, среднесысольском) при глаголах движения наблюдаются вариативные отношения между послелогом и иллативом в контексте с существительными, обозначающими растения, животных, продукты их переработки. В данном случае происходит метонимический перенос «объект цели» $\rightarrow$ «ситуация», именные группы выражают последующую за ситуацией движения ситуацию. Семантическая разница между послелогом и иллативной формой не проявляется.

(65) верхневычегодский диалект (Вочь)
Бат'-э
чэри-йэ мун-и-с
отец-POss.1SG рыба-ILL идти-PRT-3SG

'Мой отец ушел рыбачить'. [Сорвачева и др. 1966: 76] 
(64) верхневычегодский диалект (Вочь)

$\begin{array}{llll}\text { Бат'-э } & \text { чэри } & \text { дорэ } & \text { мун-и-с } \\ \text { отец-POSS.1SG } & \text { рыба } & \text { к(APUD.ILL) } & \text { идти-PRT-3SG }\end{array}$

'Мой отец ушел рыбачить'. [Сорвачева и др. 1966: 76]

(66) верхневычегодский диалект (Вольдино)

Кукан'-э пыр-и

теленок-ILL зайти-PRT.1SG

‘[Я] нанялась телятницей’. [Сорвачева и др. 1966: 76]

(67) верхневычегодский диалект (Вольдино)

Кукан' дорэ пьр-и

теленок к(APUD.ILL) зайти-PRT.1SG

‘[Я] нанялась телятницей’. [Сорвачева и др. 1966: 76]

В удорском и ижемском диалектах в таких случаях обычно употребляется иллатив.

(68) удорский диалект (Кослан)

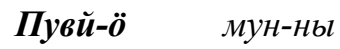

брусника-ILL идти-INF

'Идти за брусникой’. [Сорвачева 1972: 248].

(69) ижемский диалект (Сизябск)

Мэ $\boldsymbol{y} \boldsymbol{p}-\boldsymbol{a}-\boldsymbol{c} \quad 0-2 \quad$ вэтльь

я белка-ILL-POSS.3SG NEG.PRS/FUT-1 ходить.CN.SG

‘Я на охоту на белок не хожу’. [Сахарова, Сельков 1976: 45]

Послеложные конструкции кер дорӧ букв. 'к бревну', кёр дорё букв. 'к оленям': кер дорӧ мунны 'идти на лесозаготовки', кӫр дорӧ мунны 'идти пасти оленей', лексикализировались, получили распространение во всех диалектах.

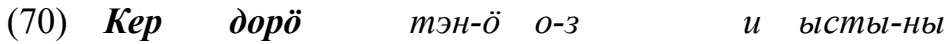
бревно к(APUD.ILL) TH-ACC NEG.PRS/FUT-3 и

‘Тебя на лесозаготовки и не пошлют'. (Г. Юшков)

(71) Гозъя уна во ветл-ӧм-а-ёсь кӧр дорё супруги много лет ходить-PF-3-PL олень к(APUD.ILL)

'Супруги много лет ездили пасти оленей'. (А. Попов, Коми му, 2013) 


\section{0. Выводы}

Рассмотрение вариативных отношений между иллативом и послелогами показало, что в коми языке конкуренция грамматических форм является весьма активным процессом. Иллатив может конкурировать с пространственным послелогом при выражении направленности движения как во внутреннюю часть, так и на поверхность ориентира. Такая ситуация свидетельствует о том, что в случае использования показателя иллатива физические свойства ориентира не релевантны, не имеет значения, обладает ли ориентир внутренней полостью. В каждом случае он указывает на то, что объект направлен во внутреннюю зону ориентира. В отличие от иллатива, выбор послелога задается типом ориентира, каждый послелог имеет свой тип контекста. Количество вовлеченных в конкуренцию с иллативом послелогов варьируется от одного до трех. Наибольшее количество конкурирующих единиц наблюдается при выражении направленности движения во внутреннюю часть ориентира. Компонент «внутренняя часть ориентира» дает возможность параллельного использования специализированных по топологическому типу ориентира послелогов пытшкё (типичный ориентир - вместилище), пиӧ (типичный ориентир - вещество), пӧвстӧ (типичный ориентир - нерасчлененная совокупность) при различном осмыслении ориентира. Конкурирующие единицы различаются частотными характеристиками в различных типах контекстов. Несмотря на то, что послелоги более точно передают пространственную ситуацию, иллатив в большинстве случаев сохраняет преимущество при выражении направленности движения во внутреннюю часть (если ориентир - вместилище и вещество) и поверхность ориентира. Заметно вытеснение иллатива послелогами вылӧ ‘на' и йылӧ 'на'. Расширение возможностей употребления послелогов, тенденция постепенного вытеснения иллатива в пространственных значениях может быть объяснена семантической специализированностью послелогов.

\section{Список условных сокращений}

Языки: кз. - коми-зырянский; кп. - коми-пермяцкий; удм. - удмуртский.

Глоссы: 1; 2; 3 - лицо; ASP — аспект; CAUS — каузатив; CN — коннегатив; Соміт — комитатив; сом — компаратив (падеж); сОмР — сравнительная степень; CONS - консекутив; CONV — конверб; DAT — датив; DER — деривационный суффикс; DIM — диминутив; EL — элатив; FUT — будущее время; GEN — генитив; ILL — иллатив; 
IMP - императив; INESS - инессив; INF — инфинитив; INSTR - инструменталис; NEG - отрицательный глагол; NZR — номинализатор; PF — модальный перфект; PL — множественное число; POSS - посессивность; PRS - настоящее время; PRT — претерит; PTCP - причастие; REFL — рефлексив; SG - единственное число.

Локализация: APEX — 'конец вытянутого объекта'; APUD — 'любая область пространства рядом с ориентиром / вблизи ориентира'; CONT — 'пространство рядом; вплотную; в полном контакте с ориентиром'; DOMUS - 'место жительства'; IN - 'пространство внутри ориентира'; INTER — 'в сплошном пространстве; пространство внутри ориентира'; POST — 'пространство позади ориентира'; SUPER 'верхняя поверхность ориентира'.

\section{Литература}

Бирюк, Усачёва 2012 - О. Л. Бирюк, М. Н. Усачёва. Дискурсивные факторы, влияющие на выбор между послеложной и послеложно-падежной формой в бесермянском диалекте удмуртского языка // А. И. Кузнецова (отв. ред.). Финно-угорские языки: фрагменты грамматического описания. Формальный и функциональный подходы. М.: Русские словари, 2012. С. 607-646.

Бубрих 1949 - Д. В. Бубрих. Грамматика литературного коми языка. Л.: Изд-во ЛГУ, 1949.

Жилина 1975 - Т. И. Жилина. Верхнесысольский диалект коми языка. М.: Наука, 1975.

Кондратьева 2010 - Н. В. Кондратьева. Выражение пространственных отношений в современном удмуртском языке // Урало-алтайские исследования. 2010. № 1(2). С. 5-16.

Лудыкова и др. 2000 - В. М. Лудыкова, Г. А. Некрасова, Э. Н. Попова, Г. В. Федюнева, Е. А. Цыпанов. Ӧнія коми кыв. Морфология [Современный коми язык. Морфология]. Сыктывкар: Коми небӧг лэдзанін, 2000.

Лыткин (ред.) 1955 - В. И. Лыткин (ред.). Современный коми язык. Ч. 1. Фонетика, лексика, морфология: Учебник для высших учебных заведений. Сыктывкар: Коми книжное изд-во, 1955.

Лыткин, Тепляшина 1976 - В. И. Лыткин, Т. И. Тепляшина. Пермские языки // В. И. Лыткин, К. Е. Майтинская, К. Редеи, Я. Гуя, А. П. Феоктистов, Г. И. Ермушкин (ред.). Основы финно-угорского языкознания. Марийский, пермские и угорские языки. М.: Наука, 1976. С. 97-228.

Мосина 2013 - Н. М. Мосина. Система глубинных падежей в эрзянском языке. Саранск: Изд-во Мордовского университета, 2013.

Некрасова 2016 - Г. А. Некрасова. Конкуренция грамматических форм в семантической зоне адвербиаля в удмуртском языке // Вестник угроведения. 2016. № 3 (26). С. 59-68.

Перевощиков (ред.) 1962 - П. Н. Перевощиков (ред.). Грамматика современного удмуртского языка. Фонетика и морфология. Ижевск: Удмуртское книжное изд-во, 1962. 
Плунгян 2002 - В. А. Плунгян. Общая морфология. Введение в проблематику. М.: Эдиториал УРСС, 2002.

Сахарова, Сельков 1976 - М. А. Сахарова, Н. Н. Сельков. Ижемский диалект коми языка. Сыктывкар: Коми книжное изд-во, 1976.

Сибатрова 1986 - С. Сибатрова. К вопросу о синонимике синтетических форм и послеложных конструкций в марийском языке // Советское финно-угроведение. 1986. Вып. ХХІІ. № 2. С. 108-115.

Сорвачева 1972 - В. А. Сорвачева. Удорский диалект коми языка. Отчет о научно-исследовательской работе за период 1969-1972 гг. Сыктывкар, 1972. (Архив Коми научного центра УрО РАН, ф. 5, оп. 2, ед. хр. 92).

Сорвачева и др. 1966 - В. А. Сорвачева, М. А. Сахарова, Е. С. Гуляев. Верхневычегодский диалект коми языка. Сыктывкар: Коми книжное изд-во, 1966.

Усачёва 2012 - М. Н. Усачёва. Локативные падежи в составе групп с пространственным значением в пермских языках // А. И. Кузнецова (отв. ред.). Финноугорские языки: фрагменты грамматического описания. Формальный и функциональный подходы. М.: Русские словари, 2012. С. 142-221.

Baker 1985 - R. Baker. The Development of the Komi Case System. A Dialectological Investigation (Suomalais-Ugrilaisen Seuran Toimituksia. Vol. 189). Helsinki: Suomalais-Ugrilainen Seura, 1985.

Klavan et al. 2010 - J. Klavan, K. Kesküla, L. Ojava. Eesti keele adessiivi ja kaassõna peal kasutus kahes keelelises katses // Emakeele Seltsi Aastaraamat. 2010. Vol. 55. P. 63-86.

Klavan et al. 2015 - J. Klavan, M.-L. Pilvik, K. Uiboaed. The use of multivariate statistical classification models for predicting constructional choice in spoken, nonstandard varieties of Estonian // SKY Journal of Linguistics. 2015. Vol. 28. P. 187-224.

Klavan, Veismann 2017 - J. Klavan, A. Veismann. Are corpus-based predictions mirrored in the preferential choices and ratings of native speakers? Predicting the alternation between the Estonian adessive case and the adposition peal 'on'. ESUKA JEFUL. 2017. Vol. 8. № 2. P. 59-91.

Rédei 1962 - K. Rédei. Die Postpositionen im Syrjänischen unter Berücksichtigung des Wotjakischen. Budapest: Akadémiai Kiadó, 1962.

\section{Источники}

ККЯ - Корпус коми языка. URL: http://komicorpora.ru/ (дата обращения 11.12.2020).

\section{References}

Baker 1985 - R. Baker. The Development of the Komi Case System. A Dialectological Investigation (Suomalais-Ugrilaisen Seuran Toimituksia. Vol. 189). Helsinki: Suomalais-Ugrilainen Seura, 1985. 
Biryuk, Usacheva 2012 - O. L. Biryuk, M. N. Usacheva. Diskursivnye faktory, vliyayushchie na vybor mezhdu poslelozhnoy i poslelozhno-padezhnoy formoy v besermyanskom dialekte udmurtskogo yazyka [Discursive factors affecting the choice between the postpositional and case-postpositional forms in the Besermyan dialect of the Udmurt language]. A. I. Kuznetsova (ed.). Finno-ugorskie yazyki: fragmenty grammaticheskogo opisaniya. Formalnyy i funktsionalnyy podkhody [Finno-Ugric languages: fragments of a grammatical description. Formal and functional approaches]. Moscow: Russkie slovari, 2012. P. 607-646.

Bubrikh 1949 - D. V. Bubrikh. Grammatika literaturnogo komi yazyka [Grammar of the Komi literary language]. Leningrad: Leningrad State University Press, 1949.

Klavan et al. 2010 - J. Klavan, K. Kesküla, L. Ojava. Eesti keele adessiivi ja kaassõna peal kasutus kahes keelelises katses. Emakeele Seltsi Aastaraamat. 2010. Vol. 55. P. 63-86.

Klavan et al. 2015 - J. Klavan, M.-L. Pilvik, K. Uiboaed. The use of multivariate statistical classification models for predicting constructional choice in spoken, nonstandard varieties of Estonian. SKY Journal of Linguistics. 2015. Vol. 28. P. 187-224.

Klavan, Veismann 2017 - J. Klavan, A. Veismann. Are corpus-based predictions mirrored in the preferential choices and ratings of native speakers? Predicting the alternation between the Estonian adessive case and the adposition peal 'on'. ESUKA JEFUL. 2017. Vol. 8. No 2. P. 59-91.

Kondrateva 2010 - N. V. Kondrateva. Vyrazhenie prostranstvennykh otnosheniy v sovremennom udmurtskom yazyke [The expression of spatial relations in the modern Udmurt language]. Uralo-altayskie issledovaniya. Ural-Altaic Studies. 2010. No. 1 (2). 2010. P. 5-16.

Ludykova et al. 2000 - V. M. Ludykova, G. A. Nekrasova, E. N. Popova, G. V. Fedyuneva, E. A. Tsypanov. Öniya komi kyv. Morfologiya. [Modern Komi language. Morphology]. Syktyvkar: Komi Book Publishing House, 2000.

Lytkin (red.) 1955 - V. I. Lytkin (ed.). Sovremennyy komi yazyk. Pt. 1. Fonetika, leksika, morfologiya: Uchebnik dlya vysshikh uchebnykh zavedenij [Modern Komi language. Pt. 1. Phonetics, vocabulary, morphology: Textbook for higher education]. Syktyvkar: Komi Book Publishing House, 1955.

Lytkin, Teplyashina 1976 - V. I. Lytkin, T. I. Teplyashina. Permskie yazyki [Permian languages]. V. I. Lytkin, K. E. Maytinskaya, K. Rédei, J. Gulya, A. P. Feoktistov, G. I. Ermushkin (eds.). Osnovy finno-ugorskogo yazykoznaniya. Mariyskiy, permskie i ugorskie yazyki [Basics of Finno-Ugric linguistics. Mari, Permian and Ugric languages]. Moscow: Nauka, 1976.

Mosina 2013 - N. M. Mosina. Sistema glubinnykh padezhey v erzyanskom yazyke [The system of deep cases in Erzya]. Saransk: Mordovian University Press, 2013.

Nekrasova 2016 - G. A. Nekrasova. Konkurentsiya grammaticheskikh form v semanticheskoy zone adverbialya $\mathrm{v}$ udmurtskom yazyke [Competition of grammatical forms in the semantic zone of adverbial case in the Udmurt language]. Vestnik ugrovedeniya. 2016. No. 3 (26). P. 59-68.

Perevoshchikov (red.) 1962 — P. N. Perevoshchikov (ed.). Grammatika sovremennogo udmurtskogo yazyka. Fonetika i morfologiya [Grammar of the modern Udmurt 
language. Phonetics and morphology]. Izhevsk: Udmurt Book Publishing House, 1962.

Plungian 2002 - V. A. Plungian. Obshchaya morfologiya. Vvedenie v problematiku [General morphology. Introduction to the issue]. Moscow: Editorial URSS, 2002.

Rédei 1962 - K. Rédei. Die Postpositionen im Syrjänischen unter Berücksichtigung des Wotjakischen. Budapest: Akadémiai Kiadó, 1962

Sakharova, Selkov 1976 - M. A. Sakharova, N. N. Selkov. Izhemskiy dialekt komi yazyka [Izhma dialect of Komi language]. Syktyvkar: Komi Book Publishing House, 1976.

Sibatrova 1986 - S. Sibatrova. K voprosu o sinonimike sinteticheskikh form i poslelozhnykh konstruktsiy $\mathrm{v}$ mariyskom yazyke [To the question of synonymy of synthetic forms and postpositional constructions in the Mari language]. Sovetskoe finno-ugrovedenie. 1986. Iss. XXII. No. 2. P. 108-115.

Sorvacheva 1972 - V. A. Sorvacheva. Udorskiy dialekt komi yazyka. [Udora dialect of Komi language]. Report on research work for the period 1969-1972. Syktyvkar, 1972. (Archive of the Komi Scientific Center of the Ural Branch of the Russian Academy of Sciences, fund 5, inventory 2, storage unit 2).

Sorvacheva et al. 1966 - V. A. Sorvacheva, M. A. Sakharova, E. S. Gulyaev. Verkhnevychegodskiy dialekt komi yazyka [Upper Vychegda dialect of the Komi language]. Syktyvkar: Komi Book Publishing House, 1966.

Usacheva 2012 - M. N. Usacheva. Lokativnye padezhi v sostave grupp s prostranstvennym znacheniem $\mathrm{v}$ permskikh yazykakh [Locative cases in groups with spatial meaning in Permic languages] // A. I. Kuznetsova (ed.). Finno-ugorskie yazyki: fragmenty grammaticheskogo opisaniya. Formalnyy i funktsionalnyy podkhody [Finno-Ugric languages: fragments of a grammatical description. Formal and functional approaches]. Moscow: Russkie slovari, 2012. P. 142-221.

Zhilina 1975 - T. I. Zhilina. Verkhnesysolskiy dialekt komi yazyka [Komi dialect of Upper Sysola]. Moscow: Nauka, 1975.

\section{Sources}

KKYa - Komi language corpora. Available at: http://komicorpora.ru/ (accessed on 11.12.2020). 


\section{Посессивные конструкции в самбургском коми*}

\section{П. С. Плешак}

Университет Мэриленда, Колледж Парк (США); polinapleshak@yandex.ru

Аннотация. Статья посвящена выражению посессивных отношений в самбургском коми. На основе полевых материалов, собранных в с. Самбург, описывается инвентарь возможных посессивных конструкций, рассматриваются такие морфосинтаксические свойства, как маркирование зависимого и вершины, а также приводятся факторы, влияющие на выбор конструкции. Посессивное оформление вершины в самбургском говоре более обязательно, чем в литературном комизырянском. Кроме того, этот говор имеет больше ограничений на маркирование посессора. Помимо стандартного поведения посессивных аффиксов, в самбургском коми также обнаружился интересный пример изменения функций посессивного показателя Poss.3PL из обозначения множественности посессора в обозначение множественности обладаемого.

Ключевые слова: коми-зырянский язык, посессивные конструкции, семантические отношения, синтаксическая позиция ИГ, языковые изменения.

\section{Possessive constructions of Samburg Komi}

\section{P. S. Pleshak}

University of Maryland, College Park (USA); polinapleshak@yandex.ru

Abstract. This paper discusses the expression of adnominal possessive relations in Samburg Komi (Izhma dialect, Komi-Zyrian). Possessive relations are considered a part of the scale of different adnominal relations, with splits on that scale being language specific. $\mathrm{O}$ ne of the goals of this study is to identify the adnominal relations that pattern with the core possessive (kinship, body part, legal ownership) relations in their encoding. Based on the field data collected in the village of Samburg, I discuss the structural types of possessive constructions that can encode possessive relations in Samburg Komi. I consider such morpho-syntactic properties as case-marking of the dependent component and possessive marking on the head. Another goal of this study is to find out what morpho-syntactic and semantic factors affect the construction

\footnotetext{
* Работа поддержана грантом РФФИ № 16-24-17003.
} 
choice. Finally, an additional goal is to compare these data to the standard variety of the Komi-Zyrian language. I show that only those relations that involve specific possessors can pattern with core possessive relations in Samburg Komi in terms of their encoding. Possessors can be marked with two types of the genitive case (the first and the second genitive) or with the nominative case. Samburg Komi also has a set of possessive markers that can attach to the head noun (possessum) and express the person and number of the dependent component (possessor). Combinations of these possibilities produce the whole range of possessive constructions. The two main factors influencing the choice of a construction are the animacy of the possessor and the syntactic position of the possessive noun phrase. Possessive marking of the head in Samburg Komi is more obligatory than in the standard Komi. Samburg Komi also has more restrictions on possessor marking. For instance, the only possible marking for specific possessors in non-oblique noun phrases is that by the genitive. Moreover, I show that one of the possessive markers (POSS.3PL) undergoes an interesting functional change: its functions shift from encoding the plurality of the possessor to the encoding of the plurality of the possessum.

Keywords: Komi language, possessive constructions, semantic relations, syntactic position of NP, language change.

\section{1. Введение}

Данная статья посвящена выражению посессивности в самбургском диалекте коми языка. Материалом исследования послужили данные коми-ижемского говора, собранные в с. Самбург Ямало-Ненецкого автономного округа зимой 2015 г. В связи с отсутствием необходимых для сопоставления данных литературного коми-зырянского языка и других разновидностей коми-ижемского мы не имеем возможности сказать, насколько самбургский говор отличается от них в описываемой области. Возможно, многое было бы возможно обобщить для коми-ижемского языка в целом, поскольку самбургский говор разделяет большинство ареальных черт, характерных для данного региона [Кошкарева и др. 2017: 8], например, с мужевским говором ${ }^{1}$ [Бирюк и др. 2010]. Однако аккуратнее будет на протяжении всего описания учитывать то, что данные собраны именно в с. Самбург.

${ }^{1}$ На мужевском коми говорят в селе Мужи (Шурышкарского района ЯмалоНенецкого АО). Этот говор достаточно близок к самбургскому. 
Посессивность принято разделять на атрибутивную (дом Пети), предикативную (У Пети есть дом) и на еще один тип, представленный в конструкциях с внешним посессором (У Пети сгорел дом). В данной статье мы ограничимся рассмотрением атрибутивной посессивности. О категории посессивности в коми существуют работы [Сидоров 1945; Sazhina 2005]. В книге об 1-овых падежах [Некрасова 2002] в рамках рассмотрения функций генитива дается описание различных способов маркирования посессора (но вопрос маркирования обладаемого не рассматривается подробно).

Нашей задачей является описание посессивных отношений как подвида отношений между двумя сущностями в именной группе (ИГ) в рамках подхода М. Копчевской-Тамм [Koptjevskaja-Tamm 2002]. Он предполагает наличие некоторой шкалы отношений: от ядерных посессивных, таких как родство (мама Васи) или часть тела (рука Васи), до периферийных, таких, как материал (кольц̧о чистого золота). В последнем случае зависимое уже не является референтным, и термин «посессор» применяется для него условно. Посессивными конструкциями называются те, которые кодируют ядерные посессивные отношения. В более широком понимании все отношения, выражаемые посессивными конструкциями, будут называться посессивными (для данного конкретного языка) [Koptjevskaja-Tamm 2003]. При этом в разных языках границы на шкале могут быть расставлены по-разному. Таким образом, набор посессивных отношений оказывается разным для разных языков.

В настоящей статье будет определено, какие отношения являются посессивными для самбургского говора коми-ижемского, а также будут изучены морфосинтаксические свойства самих посессивных конструкций в сопоставлении с другими типами ИГ.

Одной из особенностей коми-ижемского языка является то, что кодирование посессивных отношений может происходить не только посредством падежного маркирования зависимого, но также и при помощи присоединения к вершине специализированного лично-числового маркера - посессивного суффикса.

$\begin{array}{llll}\text { Петя-лэн } & \text { пи-ысc } & \text { менам } & \text { ёрm-э } \\ \text { Петя-GEN } & \text { сын-P3SG } & \text { я.GEN } & \text { друг-P1SG } \\ \text { 'Петин сын — мой друг'. } & \end{array}$

Поскольку не всегда возможно четко провести границу между показателем посессивности и падежа, принято представлять их вместе, 
в виде парадигмы посессивного склонения. Она представлена в Таблице $1^{2}$.

Таблица 1. Парадигма посессивного склонения

Table 1. Paradigm of Possessive declension

\begin{tabular}{|c|c|c|c|c|c|c|}
\hline & 1SG & 2SG & 3SG & 1PL & 2PL & 3PL \\
\hline $\mathrm{NOM}$ & $-e$ & $-y d$ & $-y s$ & -num & $-n y d$ & $-n y s$ \\
\hline $\mathrm{ACC}$ & -es & $-t e$ & $-s e$ & -num-es & -nyd-te & $-n y s-s e$ \\
\hline INS & -nam & $-n a d$ & $-n a s$ & -nanum & -nanyd & -nanys \\
\hline ESS/ILL & $-a m$ & $-a d$ & $-a s$ & -anum & -anyd & -anys \\
\hline EL & $-s^{\prime} u m$ & $-s^{\prime} i d /-s^{\prime} y d$ & $-s^{\prime} i s /-s^{\prime} y s$ & -s'unum & $-s$ 'inyd & $-s^{\prime}$ inys \\
\hline GEN & -e-len & $-y d$-len & $-y s-l e n$ & -num-len & -nyd-len & -nys-len \\
\hline
\end{tabular}

Прочие падежные показатели, как и показатели родительного падежа (GEN), агглютинативно присоединяются к номинативным посессивным показателям.

В составе именной словоформы посессивные суффиксы располагаются в различных позициях в зависимости от падежа [Симоненко, Леонтьев 2012]. Локативные падежи предшествуют маркеру посессивности (I), тогда как прочие следуют за ним (II). Показатели аккузатива с посессором единственного числа кумулятивны. В этом случае сложно говорить что-либо о порядке морфем, выражающих категории падежа и посессивности.

\section{(I) N-PL-LocCASE-POSS \\ (II) N-PL-POSS-CASE}

Все маркирование в именной группе осуществляется на крайне правом слове - вершине ИГ.

Данная статья имеет следующую структуру. В Разделе 2 рассматривается инвентарь возможных посессивных конструкций в самбургском коми: маркирование зависимого и вершины, а также порядок слов в именной группе и дискурсивные функции посессивного показателя. В Разделе 3 рассматриваются факторы, влияющие на выбор той или иной из возможных конструкций. В Разделе 4 рассматривается пример

2 Парадигмой посессивных аффиксов самбургский говор не отличается от мужевского [Бирюк и др. 2010]. 
интересного изменения функций одного из посессивных показателей. В Разделе 5 подводятся итоги исследования.

\section{2. Инвентарь возможных посессивных конструкций}

Мы ограничимся рассмотрением таких ИГ, зависимыми в которых являются имена существительные (или имена прилагательные, образованные от существительных при помощи суффиксов-атрибутивизаторов) и личные местоимения. Помимо собственно посессивных, сюда включены и конструкции, кодирующие периферийные отношения в самбургском коми. Поведение таких зависимых, как прилагательные (непроизводные), кванторы, числительные и местоимения (все, кроме личных), в данной статье затрагиваться не будет.

\section{1. Оформление зависимого}

Зависимое имя («посессор» в широком смысле) в самбургском коми может быть оформлено различными способами.

1. Первый генитив (первый родительный падеж, GEN) -лэн (2) (ср. литературное -лӧн). У местоимений также имеется специальная форма для этого падежа (3).

$\begin{array}{llll}\text { Вася-лэн } & \text { ай-blc } & \text { ол-э } & \text { чомй-blн } \\ \text { Вася-GEN } & \text { отец-P3SG } & \text { жить-PRS.3sg } & \text { чум-ESS }\end{array}$

'Васин отец живет в чуме'.

$\begin{array}{llll}\begin{array}{l}\text { менам } \\ \text { я.GEN }\end{array} & \text { сын-е } & \text { воед-іс } & \text { пундраб- } \\ \text { 'Мой сын уехал в тундру'. } & \end{array}$

2. Второй генитив ${ }^{3}$ (второй родительный падеж, GEN.O) -льсь (4) (ср. лит. -льсь). В [Бубрих 1955] он назван притяжательным падежом. У местоимений также имеется специальная форма для этого падежа (5).

3 Два генитива имеют различную синтаксическую дистрибуцию, более подробно это освещается в Разделе 3.3 . 


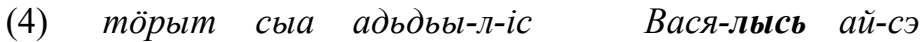
вчера он видеть-ITER-PST.3SG Bacя-GEN.O отец-P3SG.ACC 'Вчера он видел Васиного отца'.

$\begin{array}{lllll}\text { ме } & \text { мэнчыц } & \text { пон-тэ } & u \text {-ट } & \text { верд } \\ \text { я } & \text { ты.GEN.O } & \text { собака-P2SG.ACC } & \text { NEG.PST-1 } & \text { кормить }\end{array}$

'Я не кормил твою собаку'.

3. Номинатив (именительный падеж, NOM)

(6) сыл ол-э ай-blс керка-ьин он жить-PRS.3SG отец-P3SG дом-ESS

'Он живет в доме отца'.

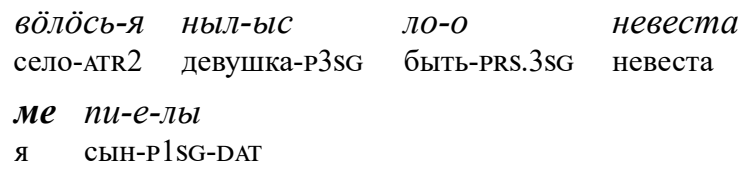

‘Девушка из села будет невестой моему сыну’.

\section{4. Неоформленное имя $\left(\mathrm{ABS}^{4}\right)$}

(8) кёр яй зэй чӧскьд олень мясо очень вкусный

'Оленье мясо очень вкусное'.

\section{5. Атрибутивизатор (ATR2)}

Атрибутивизатор может оформлять как единичное существительное (вӧлӧсь — 'село’ в примере (7)), так и целую ИГ с зависимым (9).
$л \ddot{0} 3$
синм-a
$\mathrm{Hblbl}$
nolp-uc
лавка-э
синий глаз.OBL-ATR2 девушка
войти-PST.3sg
магазин-ILL
'Голубоглазая девушка вошла в магазин'.

В коми-зырянском выделяются несколько атрибутивизаторов, имеющих различную семантику [Лудыкова 2010]. Поскольку, как будет видно из дальнейшего изложения, конструкции с зависимыми, оформленными атрибутивизаторами, не являются собственно посессивными, подробное рассмотрение атрибутивизаторов выходит за рамки данной статьи.

${ }^{4}$ Сокращение ABS восходит к обозначению в финно-угорской традиции неоформленной формы как абсолютной [Бубрих 1947]. Причины различения номинативного и неоформленного зависимых подробнее обсуждаются в Разделе 3.3.1. 


\section{2. Оформление вершины}

Вершина (обладаемое) может маркироваться (1)-(5), (7) или не маркироваться (6), (8) посессивным показателем.

При детальном рассмотрении влияния различных факторов можно выделить четыре степени обязательности оформления вершины:

1) обязательное оформление посессивным показателем

2) возможное опущение посессивного показателя

3) факультативное присоединение посессивного показателя

4) невозможность оформления посессивным показателем.

При перечислении конструкций для более удобного чтения таблицы мы будем пользоваться бинарным противопоставлением: (1)-(2) обозначены как +POSS, (3)-(4) - как -POSS. Обязательность или невозможность в таблице не отражены.

Важно отметить, что в коми-ижемском засвидетельствовано непосессивное употребление суффикса P3SG, см. (10) [Кашкин 2008], характерное и для многих других родственных языков [Кузнецова 2003; Nikolaeva 2003; Брыкина, Судобина 2005; Simonenko 2014]. Его наличие зависит от референциального статуса ИГ и коммуникативной структуры высказывания и связано с идентифицируемостью референта в дискурсе (identifiability в терминах [Nikolaeva 2003]), а не обусловлено посессивными отношениями внутри ИГ.

$$
\begin{aligned}
& \text { ме мун-i улича кузя } и \text { адьд-и пон } \\
& \text { я идти-PST.1SG улица по и увидеть-PST.1SG собака } \\
& \text { понм-blc куч-ис уут-Hbl } \\
& \text { собака-P3SG начать-PST.3SG лаять-INF }
\end{aligned}
$$

'Я шел по улице и увидел собаку. Собака залаяла'. [Кашкин 2008: 37]

Параллельно с приобретением новой функции показатель -ыс (-P3SG) постепенно утрачивает собственно поссесивную функцию согласования с посессором по лицу и числу даже в посессивной конструкции. В доказательство приводятся примеры с употреблением P3SG при посессорах других лиц в различных коми-ижемских говорах (11)-(13).

МУЖЕВСКИЙ ГОВОР

(11) менам ай-ьсс врач я.GEN отец-P3SG врач

'Мой отец врач'. [Кашкин 2008: 38] 
ВОСЯХОВСКИЙ ГОВОР

(12) менам керка-ыс ьлжылд-джык, чем ныльёрт-э-лэн я.GEN дом-P3SG большой-CMPR чем девушка.друг-P1SG-GEN 'Мой дом больше, чем дом моей подруги'. (Кашкин л. с.) БЕЛОЯРСКИЙ ГОВОР

(13) менам сос-ыс косяс-ис, кол-э вур-ньл я.GEN рукав-P3SG рваться-PST.3SG быть.нужным-PRS.3SG шить-INF 'У меня рукав порвался, надо зашить'. (Кашкин л. с.)

Такие примеры существуют и для самбургского говора (14). САМБУРГСКИЙ ГОВОР
тэяд ай-blс мун-іс чомй-э TЫ.GEN отец-P3SG уйти-PST.3SG чум-ILL
'Твой отец уехал в тундру (букв. «в чум»)'.

Bсё же мы утверждаем, что показатель P3SG, по крайней мере в самбургском говоре, не утратил своей основной функции - обозначения посессивного отношения - и не превратился в дискурсивный маркер.

Во-первых, пример (14) спонтанный. Позже его грамматичность отрицалась самим носителем, выдавшим данный пример в качестве первой реакции. Он был заменен на (15).

САМБУРГСКИЙ ГОВОР

\begin{tabular}{|c|c|c|c|}
\hline мэяд & $a \check{u}-\boldsymbol{b l d}$ & мyн-ic & чомй-э \\
\hline ты.GEN & отец-P2SG & уйти-PST.3sG & чум-ILL \\
\hline
\end{tabular}

При обладателях других лиц употребление P3.SG на обладаемом допускается пока что в качестве отступления от нормы (16).

(16) менам кукла-э/? кукла-ысс/*кукла диван-сььсс ус-ис я.GEN кукла-P1sG/кукла-P3SG/кукла диван-P3SG.EL упасть-PST.3sG

'Моя кукла упала с дивана'.

Во-вторых, именные группы с одним и тем же референциальным и дискурсивным статусом предпочитают употребление / неупотребление P3.SG в зависимости от референтности посессора (влияющей также и на посессивное отношение): референтный ${ }^{5}$ посессор,

5 Термин «референтный» здесь использован для упрощения картины, более подробно этот вопрос освещается в Разделе 3.1. 
оформленный генитивом, обусловливает появление посессивного маркера на вершине (17), при генерическом посессоре обладаемое посессивным показателем не оформляется (18). Поскольку от дискурсивного показателя ожидается скорее чувствительность именно к дискурсивному статусу именной группы, а не к типу посессора, функции P3.SG нельзя считать чисто дискурсивными. Посессивная семантика по-прежнему оказывает влияние на его поведение.

(17) (неопределенный статус, новое, фокус, референтный посессор)

$\begin{array}{llll}\text { пьззан } & \text { вылл-blн } & \text { куйл-э } & \text { кутшем-ке } \\ \text { стол } & \text { верX-ESS } & \text { лежать-PRS.3SG } & \text { какой-INDEF }\end{array}$

мича баба-лэн сумка-ыс

красивый женщина-GEN сумка-P3SG

'На столе лежит сумка какой-то красивой женщины'.

(18) (неопределенный статус, новое, фокус, нереферентный посессор)

$\begin{array}{llll}\text { пызан } & \text { вылл-blн } & \text { куйл-э } & \text { мича } \\ \text { стол } & \text { верх-EsS } & \text { лежать-PRS.3SG } & \text { красивый }\end{array}$

баба сумка $/{ }^{*}$ сумка-ьсс

женщина сумка/сумка-P3sG

'На столе лежит красивая женская сумка'.

В рамках данной статьи обсуждаются только случаи прямого, недискурсивного употребления посессивного показателя - указание на наличие посессора и согласование с ним в лице и числе. Каждый раз, говоря о неграмматичности / невозможности маркирования вершины посессивным показателем, мы имеем в виду только его появление, обусловленное наличием посессора. В своей дискурсивной функции, близкой к функции маркера определённости [Кашкин 2008], P3SG может появляться при определенных условиях в любом из рассматриваемых нами контекстов.

\section{3. Набор посессивных конструкций и порядок слов в ИГ}

Из перечисленных выше способов оформления зависимого и вершины видно, что аналитически возможны 8 комбинаций признаков, из которых не все оказываются представлены в языке. В Таблице 2 (c. 416) указывается грамматичность / неграмматичность каждой из логически возможных конструкций в самбургском коми. Можно заметить, 
что таблица отражает обязательность посессивного согласования при различном оформлении зависимых: посессивное согласование (+POSS) является обязательным только при оформлении посессора вторым генитивом (GEN.O). C первым генитивом и номинативом оно факультативно. В случае оформления зависимого атрибутивизатором и неоформленным именем посессивное согласование невозможно.

Таблица 2. Набор конструкций

Table 2. The range of constructions

\begin{tabular}{|c|c|c|c|c|c|}
\hline & GEN & NOM & GEN.O & ABS & ATR \\
\hline+ POSS & OK & OK & OK & $*$ & $*$ \\
\hline- POSS & OK & OK & $*$ & OK & OK \\
\hline
\end{tabular}

Зависимое в ИГ в обычном случае стоит перед вершиной (19), однако иногда возможна постпозиция генитивного зависимого ${ }^{6}(20)$ :

\begin{tabular}{|c|c|c|c|}
\hline $\begin{array}{l}\text { детина-blc-лэн } \\
\text { мальчик-P3SG-GEN }\end{array}$ & $\begin{array}{l}\text { дёля } \\
\text { маленький }\end{array}$ & $\begin{array}{l}\text { вок-blc } \\
\text { брат-P3SG }\end{array}$ & $\begin{array}{l}\text { чача-сэ } \\
\text { игрушка-P3SG.ACC }\end{array}$ \\
\hline$-i c$ & & & \\
\hline
\end{tabular}

'Младший брат мальчика сломал игрушку'.

(20)

$\begin{array}{llll}\text { дёля } & \text { вок-blc } & \text { нылл-blс-лэн } & \text { кол-яс } \\ \text { маленький } & \text { брат-P3SG } & \text { девочка-P3SG-GEN } & \text { остаться-FUT.3SG } \\ \begin{array}{l}\text { керка-blн } \\ \text { дом-ESS }\end{array} & & & \end{array}$

'Младший брат девочки останется дома'.

В отличие от генитивного, номинативное зависимое не может быть постпозитивным.
*кок-blc пьззан ус-ис
нога-P3SG стол упасть-PST.3SG
'Ножка стола отвалилась'.

В собранном нами материале встречаются, вместе с тем, интересные ошибки: несмотря на то, что сохраняется общий принцип

${ }^{6}$ Возможность постпозиции генитивного зависимого для других говоров коми отмечалась также в [Симоненко, Леонтьев 2012]. 
построения ИГ (маркирование ИГ на последнем слове), информанты иногда пытаются следовать русскому порядку слов. Это приводит к следующему эффекту: существительные образуют конструкцию с неоформленным именем, но в неправильном, неграмматичном порядке; последнее из двух идущих друг за другом слов остается локусом маркирования, являясь носителем посессивного показателя (в данном случае в его дискурсивной функции), хотя не является вершиной (22), (ср. правильное (23), где вершина занимает крайне правую позицию в ИГ и является локусом маркирования).

(22) кок пьзан-ысс ус-ис

нога стол-P3SG упасть-PST.3SG

'Ножка стола отвалилась'.

(23) пьзан кок-вlс ус-ис

стол нога-P3SG упасть-PST.3SG

'Ножка стола отвалилась'.

Ниже мы рассмотрим факторы, влияющие на выбор той или иной конструкции из представленных в Таблице 2 как возможные.

\section{3. Правила выбора конструкции}

Влияние на маркирование зависимого и вершины в ИГ в самбургском коми оказывают такие факторы, как семантическое отношение между вершиной и зависимым, позиция посессора в иерархии одушевленности и синтаксическая позиция ИГ.

\section{1. Семантические отношения}

Ядерными посессивными отношениями являются родство (omeu девочки), часть тела (нога девочки) и законное обладание, или шире отношение принадлежности (дом оти̧а). Напомним, что посессивными конструкциями называются конструкции, выражающие эти отношения.

В самбургском коми ядерные посессивные отношения - родство (24), часть тела (25) и принадлежность (27) - в позиции субъекта 
и объекта (26) кодируются конструкцией с двойным маркированием, то есть посессор оформлен первым (1)-(3),(24)-(25), (27) или вторым (4)-(5), (26) генитивом, а на зависимом есть посессивный показатель:
детина-лэн
ă̌-blc
воед-ic
чомй-э
мальчик-GEN
отец-P3SG
пробежать-PRS.3SG
чуM-ILL

'Отец мальчика уехал в тундру (букв. «в чум»)'.

(25)

$\begin{array}{lll}\text { ай-э-лэн } & \text { юр-ыс } & \text { сивейт-іс } \\ \text { отец-P1SG-GEN } & \text { голова-P3SG } & \text { седеть-PST.3SG }\end{array}$

'Голова отца поседела'.

(26)

$\begin{array}{lllll}\text { cbla } & \text { о-3 } & \text { пӧмнит } & \text { мам-blc-льссь } & \text { рожса-сэ } \\ \text { тот } & \text { NEG.NPST-3 } & \text { помнить.CN } & \text { мама-P3SG-GEN.O } & \text { лицо-P3SG.ACC }\end{array}$

'Он не помнит лицо матери'.

$\begin{array}{lllll}\text { велэдыссь-лэн } & \text { керка-ысc } & \text { сулал-э } & \text { aбy } & \text { blльын } \\ \text { учитель-GEN } & \text { дом-P3SG } & \text { стоять-PRS.3SG } & \text { NEG } & \text { далеко } \\ \text { 'Дом учителя стоит неподалеку'. } & & \end{array}$

В косвенной позиции эти же отношения оформляются конструкцией с номинативным посессором, подробнее см. Раздел 3.3.

Таким же образом, как и ядерные посессивные, в самбургском коми могут оформляться и некоторые другие отношения: социальные (28), авторство (29), член группы - группа (30), целое - часть (для неодушевленных посессоров) (31), хотя для выражения последних двух чаще всего используется конструкция с неоформленным именем (32).

$\begin{array}{llll}\text { детина-blc-лэн } & \ddot{e} p m-я c-\boldsymbol{b l c} & \text { во-иснысc } & c b l \\ \text { мальчик-P3SG-GEN } & \text { друг-PL-P3SG } & \text { прийти-PST.3PL } & \text { тот }\end{array}$

дор-э гӧсти

край-ILL в.гости

‘Друзья мальчика пришли к нему в гости'.

$\begin{array}{lllll}\text { миян } & \text { зэй } & \text { лэсял-іс } & \text { Вася-лэн } & \text { сььллан.кblл-ысc } \\ \text { мы.DAт } & \text { очень } & \text { нравиться-PST.3SG } & \text { Вася-GEN } & \text { песня-P3SG }\end{array}$

'Нам очень понравилась Васина песня'.

(30) Вася-лэн клас-ысс зэй ьуджыд

Вacя-GEN класc-P3SG очень большой

'Васин класс очень большой'. 


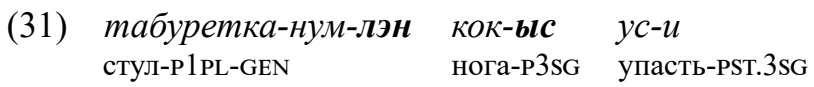

'Ножка стула отвалилась'.
ния
вожъ-яс
$m \ddot{o} \ddot{O}-c b b l c$
вӧр-энblс
лиственница
ветка-PL
ветер-P3SG.EL
шевелиться-PRS.3PL

'Ветви лиственницы шевелятся на ветру'.

Примеры выше демонстрируют исключительно ИГ в позиции подлежащего, однако одинаковое оформление ядерных и более периферийных посессивных отношений характерно и для других синтаксических позиций. Ниже для отношения авторства показано использование конструкции с посессором во втором генитиве и обязательным посессивным согласованием в позиции прямого объекта (33) и конструкции с номинативным посессором и посессивным согласованием в косвенной позиции (34).

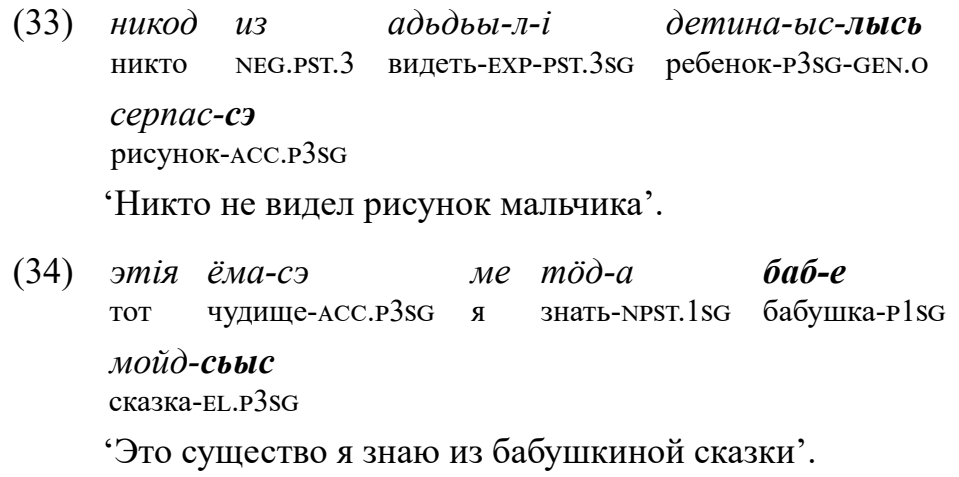

Остальные отношения не являются для самбургского коми посессивными (с точки зрения выбора морфосинтаксической стратегии маркирования). В Таблице 3 (с. 420) приведены все соответствия между семантическими отношениями и конструкциями. В рядах 1-6 Таблицьь 3 находятся прототипические посессивные отношения. Чаще всего тип семантического отношения коррелирует с референциальным статусом и одушевлённостью зависимого. Так, отношения с одушевлёнными зависимыми оказываются среди посессивных с наибольшей вероятностью. Далее идут отношения с неодушевлёнными, но якорными (anchoring в терминологии М. Копчевской-Тамм [Koptjevskaja-Tamm 2002]) зависимыми (ряды 7-9). Особенность якорных отношений в том, что посессор имеет референта (хотя бы потенциально) и через него 
возможно идентифицировать и референт обладаемого. Генерические зависимые (non-anchoring), такие, которые обозначают не некоторую сущность, а скорее набор признаков, подобно прилагательным, располагаются внизу таблицы (ряды 10-13), и отношения, обозначаемые ими, часто не входят в набор посессивных. Якорный посессор не является полным синонимом референтного. Примером ИГ с якорным нереферентным посессором является ИГ сумка какой-нибудь женщины, где зависимое референта не имеет, но потенциально может иметь его. ИГ женская сумка представляет собой пример с неякорным посессором, в котором зависимая ИГ обозначает набор признаков и не может иметь референта.

Таблица 3. Соотношение семантических отношений и конструкций

Table 3. The correlation between semantic relations and constructions

\begin{tabular}{|c|c|c|c|c|c|c|c|c|}
\hline & & Семантика & $\begin{array}{c}\text { GEN; } \\
+/-\mathbf{P}^{7}\end{array}$ & $\begin{array}{c}\text { GEN.O } \\
+\mathbf{P}\end{array}$ & $\begin{array}{l}\text { NOM; } \\
+/- \text { P }\end{array}$ & $\begin{array}{l}\text { ABS; } \\
-\mathbf{P}^{8}\end{array}$ & $\begin{array}{c}\text { ATR; } \\
-\mathbf{P}\end{array}$ \\
\hline \multirow{9}{*}{ 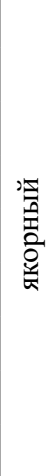 } & \multirow{6}{*}{ 청 } & 1 & Родство & $\mathrm{OK}$ & $\mathrm{OK}$ & $\mathrm{OK}$ & $*$ & $*$ \\
\hline & & 2 & Социальные & $\mathrm{OK}$ & $\mathrm{OK}$ & $\mathrm{OK}$ & * & $*$ \\
\hline & & 3 & Авторство & $\mathrm{OK}$ & $\mathrm{OK}$ & $\mathrm{OK}$ & $*$ & $*$ \\
\hline & & 4 & Член - группа & $\mathrm{OK}$ & $\mathrm{OK}$ & $\mathrm{OK}$ & $*$ & $*$ \\
\hline & & 5 & Принадлежность & $\mathrm{OK}$ & $\mathrm{OK}$ & OK & $*$ & $*$ \\
\hline & & 6 & Часть тела & $\mathrm{OK}$ & $\mathrm{OK}$ & $\mathrm{OK}$ & $*$ & $*$ \\
\hline & \multirow{3}{*}{ 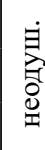 } & 7 & Целое - часть & $\mathrm{OK}$ & $\mathrm{OK}$ & OK & $\mathrm{OK}$ & $*$ \\
\hline & & 8 & Локативные & $*$ & * & $*$ & $\mathrm{OK}$ & $\mathrm{OK}$ \\
\hline & & 9 & Временны́е & $*$ & $*$ & $*$ & $*$ & $\mathrm{OK}$ \\
\hline \multirow{4}{*}{\multicolumn{2}{|c|}{ 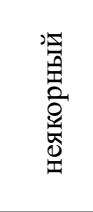 }} & 10 & Предназначение & $*$ & $*$ & $*$ & $\mathrm{OK}$ & $*$ \\
\hline & & 11 & Вид & $*$ & $*$ & $*$ & $\mathrm{OK}$ & $*$ \\
\hline & & 12 & Цель & $*$ & $*$ & $*$ & $\mathrm{OK}$ & $*$ \\
\hline & & 13 & Материал & $*$ & $*$ & $*$ & $\mathrm{OK}$ & $*$ \\
\hline & & 14 & Атрибут, ингредиент & $*$ & $*$ & $*$ & $*$ & $\mathrm{OK}$ \\
\hline & & 15 & Качество & $*$ & $*$ & $*$ & $*$ & $\mathrm{OK}$ \\
\hline
\end{tabular}

${ }^{7}$ Наличие / отсутствие посессивного показателя на вершине регулируется другими факторами (см. ниже), поэтому в таблице семантических отношений две конструкции могут быть объединены в одну.

${ }^{8}$ Более подробно это обсуждается в конце Раздела 3.3.1. 
Так как дальше речь пойдет исключительно о собственно посессивных отношениях в самбургском коми, приведем лишь несколько примеров на отношения из нижней части таблицы: временны́е отношения выражаются только конструкцией с атрибутивизатором (35), локативные (место) - как с атрибутивизатором (7), так и с неоформленным именем (36). Отношения с неякорным посессором, такие как предназначение (37), вид (8), цель (38) и материал (39), все кодируются конструкцией с неоформленным именем.

(35) временны́е

тӧрыт-ча ${ }^{9}$ шыд-сэ ми тон сёй-ам

вчера-ATR2 суп-P3SG.ACC мы сегодня есть-NPST.1PL

'Вчерашний суп мы съедим сегодня'.

(36) локативные

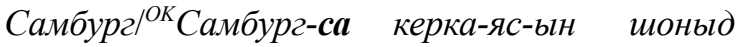

Самбург/Самбург-АTR 1 дом-PL-ESS теплый

дажэ тӧл-ьин

даже зима-ESS

'В домах Самбурга тепло даже зимой'

(37) предназначение

челядь комната югыд $и$ ьджыд

ребенок комната светлый и большой

'Детская комната большая и светлая'.

(38) цель

нянь пурт-ыс лэчыд

хлеб нож-P3SG острый

'Хлебный нож острый'.

(39) материал

сыа кар-іс пу керка

тот делать-PST.3SG дерево дом

'Он построил деревянный дом'.

На периферии находятся отношения, названные нами «ингредиент» (40) и «качество» (41), они оформляются только конструкцией с атрибутивизатором (ATR1).

9 Реализация суффикса как [ча] является особенностью самбургского говора. В литературном коми этому соответствует суффикс [йа] [Лудыкова 2010]. 
(40) ингредиент

$\begin{array}{llll}\text { бабе } & n y-u c & \text { уллё- } \boldsymbol{a} & \text { шыд } \\ \text { бабушка } & \text { варить-PST.3SG } & \text { молоко-АTR2 } & \text { суп }\end{array}$

'Бабушка сварила молочный суп'.

(41) качество

сивей юр-а старик-лэн выйым кык вес-я керка седой голова-ATR2 старик-GEN EX два этаж-ATR2 дом

'У седоголового старика есть двухэтажный дом'.

Как видно из Таблищы 3, граница между якорными и неякорными отношениями, характерная для языков Европы [Koptjevskaja-Tamm 2002], оказывается релевантной и для (самбургского) коми. Статус посессора тесно связан с семантическим отношением (что заложено и в типологическую классификацию М. Копчевской-Тамм). При одном и том же лексическом составе разные конструкции имеют разную семантику. Ниже представлена пара предложений, где в (42) ИГ, оформленная генитивной конструкцией, выражает отношение «часть тела», тогда как в (43) конструкцией с немаркированным именем выражается отношение вида.

$\begin{array}{lllll}\text { челядь-лэн } & \kappa и-\boldsymbol{b l c} & \text { оз } & \text { тыр } & \text { варежка- } а с \\ \text { ребенок-GEN } & \text { рука-P3SG } & \text { NEG.NPST.3 } & \text { наполниться } & \text { варежка-ILL.P3SG }\end{array}$

'Рука ребёнка не помещается в эту варежку'.
$\begin{array}{lll}\text { челядь } & \boldsymbol{\kappa} \boldsymbol{~ о з ~} & \text { оз } \\ \text { ребенок } & \text { рука } & \text { NEG }\end{array}$
molp
варежка-ас
'Детская рука не помещается в эту варежку'.

Группа отношений с якорным одушевленным посессором оказывается не вполне однородной. Так, при якорном посессоре (выраженном генитивом), если ИГ выражает родственные (1)-(3), (24) или социальные отношения (44), или часть тела (25)-(26), посессивный показатель на вершине является обязательным ${ }^{10}$. При всех прочих отношениях посессивное маркирование на вершине может отсутствовать (например, принадлежность (45)).

\begin{tabular}{|c|c|c|c|}
\hline $\begin{array}{l}\text { миянтэ } \\
\text { мЫ.АСС }\end{array}$ & $\begin{array}{l}\text { рисуйт-ic } \\
\text { рисовать-PST.3sG }\end{array}$ & $\begin{array}{l}n и-е-л э \boldsymbol{H} \\
\text { сын-P1SG-GEN }\end{array}$ & $\begin{array}{l}\text { ёpm-ысc/ *ёpm } \\
\text { друг-P3sG/друг }\end{array}$ \\
\hline
\end{tabular}

10 Это верно не для всех синтаксических позиций ИГ, а только для позиции субъекта. Подробнее данный вопрос будет рассмотрен в Разделе 3.3.2. 


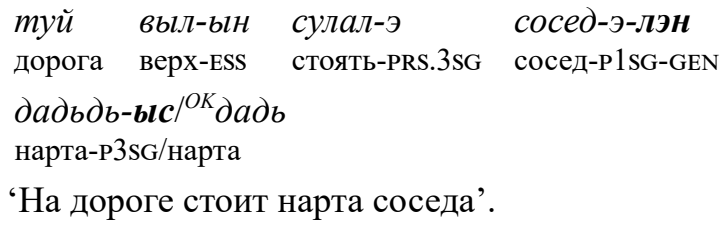

В таблице невозможно отобразить влияние одновременно всех факторов. Помимо различий в обязательности посессивного маркирования при разных отношениях, нельзя все же однозначно утверждать, что отношение родства при посессоре в генитиве (ИГ в позиции субъекта) единственным образом задает посессивный показатель на вершине: при модификации посессора неопределенным местоимением посессивное оформление вершины становится необязательным (46), что демонстрирует нам влияние референциального статуса посессора на выбор конструкции.
тэныд звӧнит-іс
звонить-PST.3SG
код-лэн-кэ
мам-blc/ ${ }^{\text {оK }}$ мaм
Tы.DAT
KTO-GEN-INDEF
мать-P3SG/мать
'Тебе звонила чья-то мама'.

Как можно заметить, таблица семантических отношений даже со всеми сделанными оговорками задает основные тенденции, но не помогает однозначно выбрать конструкцию. По этой причине далее мы обратимся к дополнительным факторам.

\section{2. Позиция посессора в иерархии одушевленности}

Место посессора в иерархии одушевленности (47) также влияет на маркирование членов ИГ.

(47) мест. 1, 2л. > мест. 3л. > человек, имена собственные > термины родства $>$ человек, прочие имена нарицательные $>$ прочие одушевленные > неодушевленные > абстрактные [Silverstein 1976]

Сперва будут рассмотрены наиболее грубые и явные границы, затем более тонкие.

В Таблище 3, помимо основной границы, пролегающей между якорным и неякорным посессором, можно также заметить границу между одушевленностью и неодушевленностью посессора: отношения 
с неодушевленным якорным посессором кодируются не так, как с одушевленным; внутри группы с неодушевленным посессором также есть различия. Если отношения с одушевленным посессором выражаются конструкцией с генитивом или номинативом (в зависимости от синтаксической позиции ИГ) и в основном с посессивным показателем на вершине, то отношения с неодушевленным посессором обычно кодируются конструкцией с неоформленным именем или атрибутивизатором. За редким исключением конструкции с неодушевлённым якорным посессором также могут быть выражены посессивной конструкцией с зависимым в генитиве / номинативе и оформлением вершины посессивным суффиксом. Ниже мы рассмотрим выражение отношений с неодушевленным якорным посессором более подробно.

Как можно заметить, единственным отношением с якорным посессором, которое можно кодировать конструкцией с посессором в немаркированной форме и без показателя посессивности на вершине, является отношение целое - часть (32).

В литературном коми такое зависимое имеет более широкую сферу употребления, чем в самбургском [Некрасова 2002]. В некоторых конструкциях, выражающих отношения, при которых посессор явно является референтным одушевленным (термин родства (48), профессия (49), имя собственное (50)), он может быть оформлен и номинативом.

ЛИТЕРАТУРНЫЙ КОМИ

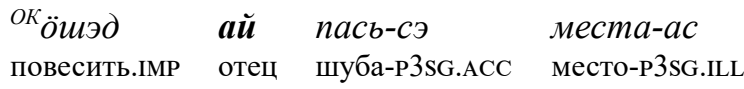

'Повесь отцовскую шубу на место'.

ЛИТЕРАТУРНЫЙ КОМИ

(49) тракторист гӧтыр

тракторист супруга

‘Жена тракториста’ [Некрасова 2002: 40]

ЛИТЕРАТУРНЫЙ КОМИ

(50) Петыр гӧтыр

Петр супруга

‘Жена Петра' [там же: 39]

В самбургском же говоре референтные употребления посессора, не маркированного генитивным показателем, запрещают (см. (51)(53) соответственно, где (52), в отличие от (51) и (53) содержит ИГ без маркирования на вершине, и потому является грамматичным, однако 
допускает исключительно нереферентную интерпретацию зависимого, недоступную при наличии посессивного маркирования).

САМБУРГСКИЙ КОМИ

\begin{tabular}{|c|c|c|c|c|}
\hline $\begin{array}{l}\text { *öшэд } \\
\text { повесить.ІмР }\end{array}$ & $\begin{array}{l}\boldsymbol{a} \check{\boldsymbol{u}} \\
\text { отец }\end{array}$ & $\begin{array}{l}\text { шуба-сэ } \\
\text { шуба-P3sG.ACC }\end{array}$ & $\begin{array}{l}(a c) \\
\text { свой }\end{array}$ & $\begin{array}{l}\text { места-ас } \\
\text { место-P3SG.ILL }\end{array}$ \\
\hline
\end{tabular}

САМБУРГСКИЙ КОМИ
(52) лафка-а пьр-іс кӧрдор.морт баба
магазин-ILL войти-PST.3SG оленевод жена
'В магазин вошла женщина-оленевод'.
*‘В магазин вошла жена оленевода’.

САМБУРГСКИЙ КОМИ
(53) *Вася баба-ысс бур-а cbblл-э
Вася жена-P3sG хороший-ADV петь-PRS.3SG
‘Жена Васи хорошо поет'.

В (52) кӧрдор.морт не является якорным посессором, так как в данной конструкции может быть добавлен другой якорный посес$\operatorname{cop}(54)$.

САМБУРГСКИЙ КОМИ
(54) лафка- $а$ пьр-іс
ларка-а код-лэн-кэ кордор.морт баба
'В магазин вошла чья-то жена-оленевод'.

Еще большего внимания заслуживает граница между посессором-личным местоимением и посессором-существительным.

Как уже упоминалось выше, личные местоимения, как и существительные, имеют специальные формы для первого (3) и второго (5) родительных падежей.

Однако разница между посессором-существительным и посессором - личным местоимением состоит в том, что при местоименном посессоре наличие посессивного показателя на вершине обязательно как в позиции субъекта (55) и объекта (56), так и в косвенной позиции (57), тогда как при посессоре-существительном это не так.

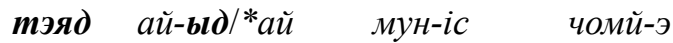

$$
\begin{aligned}
& \text { Tы.GEN отец-P2SG/отец уйти-PST.3SG чум-ILL } \\
& \text { 'Твой отец уехал в тундру (букв. «в чум»)'. }
\end{aligned}
$$


(56) ме пасьтал-а сы-льсь цапка-сэ/*иапка ${ }^{11}$

я надеть-NPST.1SG тоT-GEN.O шапка-P3SG.ACC/шапка

' $Я$ надену его шапку'.

(57)

\begin{tabular}{|c|c|c|c|}
\hline $\begin{array}{l}\text { вӧлӧсb-Я } \\
\text { село-АТR2 }\end{array}$ & $\begin{array}{l}\text { нblл-blc } \\
\text { девушка-P3SG }\end{array}$ & $\begin{array}{l}\text { ло- } О \\
\text { быть-PRS.3sG }\end{array}$ & $\begin{array}{l}\text { невеста } \\
\text { невеста }\end{array}$ \\
\hline
\end{tabular}

'Девушка из села будет невестой моему сыну'.

В следующем подразделе будет продемонстрировано влияние синтаксической позиции на оформление членов ИГ.

\section{3. Синтаксическая позиция ИГ}

Мы выделяем четыре синтаксических позиции в самбургском коми, влияющих как на оформление вершины, так и на оформление зависимого.
1) Позиция субъекта
2) Позиция прямого объекта
3) Косвенная позиция
4) Предикативная позиция

\subsection{1. Влияние на оформление зависимого}

В самбургском коми первым генитивом оформляется якорное зависимое только для ИГ в субъектной позиции (1)-(3), (24)-(25), (27) (28)-(31). Никакой другой падеж использован быть не может (см. пример (2), с добавлениями продублированный в (58)).
Вася-лэн/*Вася-лысь/*Вася
$a \check{u}-b l c$
ол-э
чомй-ьıн
Bacя-GEN/Bacя-GEN.O/Bacя
отец-P3SG
жить-PRS.3SG
чуM-ESS
'Васин отец живет в чуме'.

Если же ИГ стоит в позиции прямого объекта, то используется второй генитив (4)-(5), (26), и никакие другие падежи здесь невозможны (59).

\footnotetext{
11 Специализированный показатель аккузатива вне посессивного склонения в ижемском коми отсутствует [Бирюк и др. 2010: 385].
} 


\begin{tabular}{|c|c|c|c|c|}
\hline 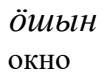 & $\begin{array}{l}\text { nblp } \\
\text { сквозь }\end{array}$ & $\begin{array}{l}\text { мe } \\
\text { я }\end{array}$ & $\begin{array}{l}a \partial b \partial b b l-л-i \\
\text { видеть-ЕXP-PST.1SG }\end{array}$ & $\begin{array}{l}\text { кӧръ-яс-льись/ } \\
\text { олень-PL-GEN.O/ }\end{array}$ \\
\hline 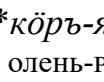 & $\begin{array}{l}-\boldsymbol{Л} \boldsymbol{~} \boldsymbol{H} / *_{\boldsymbol{T}} \\
\text {-GEN/ оЛ }\end{array}$ & $\begin{array}{l}\text { Ppz- } \\
\text { Hb-PL }\end{array}$ & $\begin{array}{l}\text { мушккy-нblc-cэ } \\
\text { спина-P3PL-AсC }\end{array}$ & \\
\hline
\end{tabular}

Для ИГ во всех косвенных позициях зависимое оформляется номинативом (6)-(7), (60).

\begin{tabular}{|c|c|c|c|}
\hline $\begin{array}{l}\text { cbla } \\
\text { тот }\end{array}$ & $\begin{array}{l}\text { мyн-ic } \\
\text { уйти-PST.3SG }\end{array}$ & $\begin{array}{l}\text { bылла- } a \\
\text { улица-ILL }\end{array}$ & $\begin{array}{l}\boldsymbol{a и ̆ - b l c} \\
\text { отец-P3SG }\end{array}$ \\
\hline
\end{tabular}

‘Он пошел на улицу в шубе отца'.

Влияние фактора синтаксической позиции / падежного оформления ИГ характерно и для близкородственных финно-угорских языков, таких как удмуртский, марийский, эрзянский мокшанский [Pleshak 2016]. Синтаксическая позиция и падежное маркирование ИГ непосредственно связаны между собой: падеж ИГ определяется её синтаксической позицией. В некоторых случаях кажется, что всё же можно развести эти два фактора. Более того, оказывается, что то, что именно влияет на выбор конструкции, является параметром межъязыкового варьирования. Так, в мокшанском языке решающим оказывается именно падежное маркирование. В том случае, когда генитивная ИГ является зависимым послелога, оформление членов ИГ происходит так же, как и тогда, когда генитивная ИГ стоит в позиции прямого дополнения: посессор выражен генитивом, а посессивный показатель на вершине обязателен (в мокшанском языке послелоги управляют тем же падежом, который маркирует и прямое дополнение - генитивом). Можно было бы ожидать от зависимых послелога такого же поведения, как от ИГ в косвенных падежах, поскольку они являются косвенными аргументами, однако в косвенных падежах посессивное маркирование на вершине факультативно. В коми представлена обратная ситуация: послелоги управляют номинативом, однако зависимое оформляется в этом случае именительным (как с вершиной в косвенных падежах), а не первым родительным падежом (как с вершиной в номинативе) (61).
(61) мича-мича красивый-красивый малица быть-PST.3SG учитель/ мальча вӧл-і велэдысь/
*велэдыссь-лэн нылл-blc вылл-blн учитель-GEN дочь-P3SG Ha-ESS
‘Самая красивая малица была на дочери учителя'. 
Таким образом, относительно выбора маркирования зависимого послелоги и косвенные падежи ведут себя одинаково, что является аргументом в пользу того, что на маркирование зависимого в коми действительно влияет не падежное маркирование вершины, а синтаксическая позиция ИГ. Впрочем, различное поведение послелогов в разных языках может быть связано с различной степенью их грамматикализации [Бирюк 2005] (большей схожестью с именными вершинами, как в мокшанском, или с локативными падежами, как в коми). Тогда единственным фактором, влияющим на выбор конструкции, остается синтаксическая позиция ИГ.

И для литературного коми, и для некоторых коми-ижемских говоров приводились примеры, нарушающие сформулированное выше правило о номинативном маркировании зависимого при вершине в косвенном падеже или с послелогом. Наблюдается возможность оформлять посессора при вершине с послелогом так же, как и при вершине в номинативе, то есть не номинативом, а генитивом (62)-(63). Носители самбургского коми такое употребление запрещают (64).

ЛИТЕРАТУРНЫЙ КОМИ

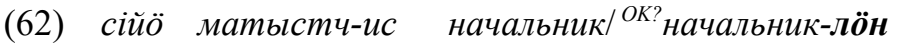
он подойти-PST.3SG начальник/начальник-GEN

пьззан дор-ӧ

стол край-ILL

'Он подошел к столу начальника'. [Некрасова 2002: 38]

МУжЕВСКИй КОМИ

$\begin{array}{lllll}\text { (63) } & \text { детина-blc } & \text { пук-ал-іс } & \text { ай-ыс-лэн } & \text { пельпом } \\ \text { мальчик-P3SG } & \text { сидеть-DUR-PST.3SG } & \text { отец-P3SG-GEN } & \text { плечо }\end{array}$

вblл- $a c$

верx-P3SG.ESS

'Мальчик сидел на плечах отца'. [Бирюк et al. 2010: 384]

САМБУРГСКИЙ КОМИ

(64) кӧрдор.морт/*кӧрдор.морт-(всс)-лэн пи выл-ас оленевод/оленевод-P3SG-GEN сын верx-P3sG.ESS

вӧл-іныс шоныд кӧмкот-ъяс

быть-PST.3PL теплый обувь-PL

'На сыне оленевода была теплая обувь'

В то же время и в самбургском коми есть отступления от этого правила - возможность генитивного, а не номинативного оформления 
зависимого в ИГ в комитативе (65)-(66). Хотя такие употребления признаются грамматичными не всеми носителями, их можно услышать и в качестве первой реакции.

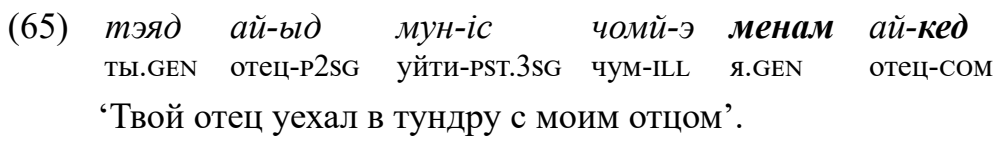
(66) ме лафка-ын адыдыbl-сb-л-i сосед-э я магазин-ESS видеть-DETR-EXP-PST.1SG сосед-P1SG баба-ьсс-лэн вок-ыс-кед жена-P3SG-GEN брат-P3SG-COM

'Я встретился в магазине с братом жены соседа'.

Такие отклонения можно объяснять как неустойчивостью системы в области периферийных падежей, так и влиянием «тяжести» ИГ посессора на его оформление. К сожалению, этот вопрос специально не изучался ни автором статьи, ни предыдущими исследователями (или по крайней мере автору неизвестны работы, описывающие различные возможности маркирования посессора в ИГ с вершиной в комитативе).

Здесь же нам бы хотелось сказать несколько слов о том, почему в Таблиие 3 конструкция с посессором без показателей зависимостного маркирования разведена на две: допускающая посессивный маркер на вершине конструкция с собственно номинативным посессором (NOM; +/-P3SG) и запрещающая посессивный маркер конструкция с неоформленным именем (ABS; -P3SG). Еще в [Бубрих 1955] упоминалось, что «именительный определения» не имеет категории падежа, определенности и притяжательности, не может нести никакого суффикса. Но приводились исключения, где к зависимому в именительном падеже присоединялись суффиксы множественного числа или притяжательный. Можно, однако, заметить, что существует два случая употребления посессора без показателей зависимостного маркирования, в которых он проявляет различные свойства.

1) Номинативный посессор в составе посессивных ИГ в косвенных падежах и внутри послеложной группы может быть референтным, присоединять P3SG в его основной функции (67), иметь зависимые (68) и отделяться от вершины (69).
детина-ыс-лэн
$a \check{u}-b l c$
пук-ал-э
мальчик-P3SG-GEN
отец-P3SG
сидеть-DUR-PRS.3SG 


$\begin{array}{lll}\text { hblbl/ }^{\text {OK }} \text { Hblл-blc } & \text { ă̈-blc } & \text { бӧк-blн } \\ \text { девочка/девочка-P3SG } & \text { отец-P3SG } & \text { бок-ESS }\end{array}$

'Отец мальчика сидит рядом с отцом девочки'.

(68) Вася локт-іс озыр сусед кӧр выл-ылн Вася приехать-PST.3SG богатый сосед олень верx-ESS

'Вася приехал на олене богатого соседа'.

$\begin{array}{llllll}\text { (69) cbla } & \text { матысьс-ис } & \text { Вася } & \text { дёля } & \text { чой } & \text { дор-э } \\ \text { тот } & \text { приближаться-PST.3sg } & \text { Вася } & \text { маленький } & \text { сестра } & \text { край-ILL }\end{array}$

‘Он подошел к Васиной младшей сестре'.

2) В конструкции с неоформленным неякорным посессором ни зависимое, ни маркер P3SG невозможны (70), такое зависимое не может отделяться от вершины (71).

\begin{tabular}{|c|c|c|c|}
\hline $\begin{array}{l}\text { blджсылд } \\
\text { большой }\end{array}$ & $\begin{array}{l}\text { Hblbl/*Hblл-blc } \\
\text { девочка/девочка-P3sG }\end{array}$ & $\begin{array}{l}\text { книга } \\
\text { книга }\end{array}$ & $\begin{array}{l}\text { куйл-э } \\
\text { лежать-PRS.3sG }\end{array}$ \\
\hline зан & вlл-ьын & & \\
\hline стол & epx-ESS & & \\
\hline
\end{tabular}

'Большая книга для девочек лежит на столе'.

*'Книга большой девочки лежит на столе'.

(71)
а. ме неб-и свежей кӧр яй
я купить-PST.1SG свежий олень мясо
b. *ме неб-и кӧр свежей яй
я купить-PST.1SG олень свежий мясо
‘Я купил свежее оленье мясо'.

\subsection{2. Факторы, влияющие на оформление вершины}

1) В позиции субъекта при якорном посессоре (выраженном генитивом), если ИГ выражает родственные (24), социальные отношения (28), часть тела (25)-(26), оформление вершины посессивным показателем обязательно.

2) В позиции прямого дополнения посессивный показатель обязателен при всех отношениях, включая отношения принадлежности (72). В том числе на его маркирование не влияет и определенность посессора (ср. (46) в Разделе 3.1 для посессора, модифицированного неопределенным местоимением в ИГ в позиции субъекта) (73). 
(72) туй кузя мун-ігмоз ме адьдыbl-л-i дорога по идти-CVB я видеть-EXP-PST.1SG

сосед-льсь дадю-сэ/*дадю

сосед-GEN.O упряжка-P3SG.ACC/Упряжка

'Проходя по дороге, я увидел упряжку соседа'.

(73) cыла пригласит-іс ектыл-ны

тот пригласить-PST.3SG танцевать-INF

код-льсь-кэ баба-сэ/*баба

кTO-GEN.O-INDEF жена-P3SG.ACC/жена

‘Он пригласил танцевать чью-то жену'.

3) В косвенной позиции (74)-(75) и в позиции предиката (76) посессивный показатель факультативен.
(74) мам-blс пет-іс пи-ьсс комната-ысь / мама-P3SG выйти-PST.3SG сын-P3SG комната-EL
ок комната-cbblc
комната-EL.P3SG
'Мама вышла из комнаты сына'.
(75) вок-ыс керка дор-ас/дор-ьлн пон-ъяс войл-эныс брат-P3SG дом край-P3SG.ESS/край-ESS собака-PL бегать-PRS.3PL
'Около дома его брата бегают собаки'.
(76) этія детина-ьлс-лэн ай $/{ }^{\circ K} a \check{\text { - } ы с ~}$ вон_тот мальчик-P3SG-GEN отец/отец-P3SG
‘Это - отец мальчика'.

\section{4. Изменение функции показателя -ныс}

В самбургском коми замечено постепенное смещение функций показателя -нысс из обозначения множественности посессора (77)-(78) в обозначение множественности обладаемого (79).

$\begin{array}{llll}\text { детина-яс-лэн } & \text { ай-ныс } & \text { мун-іс } & \text { чомй-э } \\ \text { мальчик-PL-GEN } & \text { отец-P3PL } & \text { идти-PST.3SG } & \text { чум-ILL }\end{array}$

'Отец мальчиков уехал в тундру (букв. «в чум»)'. 
Суффикс -ныс, исходно являясь маркером, указывающим именно на множественность посессора третьего лица, не содержит информации о количестве обладаемых (референтов вершины ИГ), поэтому в случае множественности обладаемого необходимо присоединение суффикса множественного числа (78).

$\begin{array}{llll}\text { (78) детина-яс-лэн } & \text { мам-ъяс-ныс } & \text { мун-існысс } & \text { лавка-э } \\ \text { мальчик-PL-GEN } & \text { мать-PL-P3PL } & \text { идти-PST.3PL } & \text { магазин-ILL }\end{array}$

'Мамы мальчиков пошли в магазин'.

Однако, несмотря на это, суффикс множественного числа на обладаемом опускают (79), что могло бы означать сочетание в показателе -ныс функций обозначения множественности одновременно и посессора, и обладаемого.

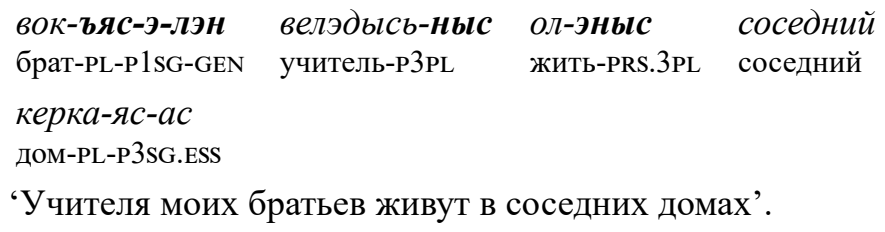

В то же время, как было сказано выше, показатель -ыс имеет дискурсивное значение и может употребляться как при посессорах других лиц (14), так и при посессоре 3 л. мн. ч. (80)-(81). Создаются контексты, где возможны оба показателя, (-blc и -ныс). Необязательность указания на множественность посессора как бы смещает показатель -ныс из его основной функции.
сосед-вяс-нум-лэн пи-ыс мун-іс школа-э coceд-PL-P1PL-GEN сын-P3SG идти-PST.3SG школа-ILL
‘Сын наших соседей пошел в школу'.
сосед-ияс-э-лэн
на велэдч-иныс сосед-PL-P1SG-GEN дочь-PL-P3SG NEG.NPST-3 ещё учиться-PRS.3PL 'Дочери соседей еще не учатся'.

При работе с носителем встречались следующие интересные интерпретации. На вопрос, возможно ли сказать (82), был дан утвердительный ответ и перевод. Употребление -ысc (P3SG) при множественном посессоре не было воспринято как неграмматичное и невозможное. На стимул 'Игрушки детей упали на пол', последовавший за этим, было дано предложение (83), без суффикса множественного числа 
на обладаемом. При этом сказуемое согласуется с субъектной посессивной ИГ по множественному числу.

$\begin{array}{lllll}\text { челядь-яс-лэн } & \text { чача-ылc } & y c-u & \text { пос } & \text { вblл- } a c \\ \text { ребенок-PL-GEN } & \text { игрушка-P3SG } & \text { упасть-PST.3SG } & \text { пол } & \text { верx-P3SG.ILL }\end{array}$
'Игрушка детей упала на пол'.

$$
\begin{array}{lllll}
\text { челядь-яс-лэн } & \text { чача-ныс } & y c-и c н b l c & \text { nос } & \text { вblл- } a c \\
\text { ребенок-PL-GEN } & \text { игрушка-P3PL } & \text { упасть-PST.3PL } & \text { пол } & \text { верx-P3SG.ILL }
\end{array}
$$
'Игрушки детей упали на пол'.

Наконец, встречаются примеры, в которых -ныс маркирует только множественное число обладаемого при посессоре в ед. ч., хотя маркер множественного числа тоже остается (84).

(84) детина-ыс-лэн рӧдъ-яс-ныс

мальчик-P3SG-GEN родители-PL-P3PL

$\kappa a-э м a-c b \quad$ чомй-э

подниматься-PST2-PL чум-ILL

'Родители мальчика уехали в тундру (букв. «в чум»)'.

\section{5. Выводы}

\section{1. Влияние факторов на выбор конструкции}

Посессивные отношения в самбургском коми могут быть выражены несколькими конструкциями, выбор между которыми регулируется действием таких факторов, как тип семантического отношения, позиция посессора в иерархии одушевленности и синтаксическая позиция ИГ.

Собственно посессивными отношениями в самбургском коми являются родство, часть тела, принадлежность, социальные, авторство, член группы - группа и целое - часть. Главным противопоставлением, отличающим собственно посессивные отношения (кодирующиеся как ядерные посессивные) от остальных, является якорность посессора. Все якорные посессоры в ед. ч. требуют появления посессивного показателя на вершине в позиции прямого объекта, а также в позиции субъекта при выражении родства, социальных отношений и части тела. 
В косвенной позиции посессивный показатель на вершине факультативен, за исключением тех случаев, когда посессор выражен личным местоимением. При нереферентном посессоре посессивный показатель в недискурсивной (посессивной) функции невозможен.

\section{2. Сходства и различия с литературным коми}

В целом система самбургского коми не сильно отличается от литературной, представление о которой было получено нами из таких работ, как [Некрасова 2002] и [Sazhina 2005], однако для изученного нами идиома можно выделить ряд особенностей.

1) В самбургском говоре посессивный маркер на вершине более обязателен.

2) В самбургском говоре референтный одушевленный посессор не может стоять в номинативе в ИГ не в косвенных падежах.

3) В литературном коми наблюдается тенденция к расширению сферы употребления генитивного зависимого и на ИГ в косвенной позиции, тогда как в самбургском говоре такой тенденции нет. Исключение составляет комитатив, допускающий, хоть и не для всех носителей, зависимое в генитиве.

4) В самбургском говоре происходит изменение функций показателя -ныс из обозначения множественности посессора в обозначение множественности обладаемого, хотя процесс этот еще не завершен.

5) В самбургском говоре (предположительно под влиянием русского языка) встречаются ошибки в порядке слов даже в конструкциях, имеющих очень жесткую структуру.

\section{3. Типологические особенности самбургского коми}

Имея в своем распоряжении похожий на близкородственные финно-угорские языки (удмуртский, марийский, мордовские) набор конструкций, коми проявляет ряд интересных отличительных особенностей (см. также [Pleshak 2016]). Среди них наиболее яркой является оформление зависимого номинативом в том случае, когда ИГ стоит в косвенной позиции. В родственном удмуртском посессор маркируется генитивом при обладаемом как в позиции подлежащего, так и в косвенной позиции. Особым образом маркируется только посессор 
при прямом объекте [Edygarova 2010]. В остальных перечисленных языках синтаксическая позиция и падежное маркирование вершины влияют только на оформление вершины, но не на оформление посессора. Кроме того, как уже упоминалось, в коми играет ключевую роль именно синтаксическая позиция, тогда как в мокшанском - падежное маркирование [Плешак 2014].

\section{Список условных сокращений}

1, 2, 3 - 1, 2, 3 лицо; АCC - аккузатив; ATR - атрибутивизатор; CAUS - каузатив; CMPR - сравнительная степень; CVB - деепричастие; DAT — датив; EL — элаTив; ESS - эссив; DETR - детранзитив; EXP — экспериентив; FUT — будущее время; GEN - первый генитив; ILL — иллатив; INDEF — неопределенность; INF — инфиниTUв; ITER - итератив; NEG - отрицание; NPST — непрошедшее время; о — объект; P - посессивность; PL - множественное число; PRS - настоящее время; PST прошедшее время; PST2 - второе прошедшее время; SG - единственное число.

\section{Литература}

Бирюк 2005 - О. Л. Бирюк. Морфосинтаксические критерии выделения послелогов в уральских языках. Дипломная работа. М.: МГУ, 2005.

Бирюк и др. 2010 - О. Л. Бирюк, Е. В. Кашкин, А. И. Кузнецова, М. Н. Усачева. Словарь мужевского говора ижемского диалекта коми-зырянского языка. Екатеринбург: Баско, 2010.

Брыкина, Судобина 2005 - М. М. Брыкина, А. Н. Судобина. Посессивные показатели в роли дискурсивных маркеров (на материале некоторых уральских языков) // Четвертая типологическая школа (21-28 сентября 2005 г., Ереван). М.: РГГУ, С. 98-101.

Бубрих 1947 - Д. В. Бубрих. Эрзя-мордовская грамматика. Минимум. Саранск: Мордовское книжное изд-во, 1947.

Бубрих 1955 - Д. В. Бубрих. Современный коми язык. Ч. 1. Фонетика. Лексика. Морфология. Сыктывкар: Коми книжное изд-во, 1955.

Гращенков 2006 - П. В. Гращенков. Синтаксис и типология генитивной группы. Дисс.... канд. филол. наук. М.: МГУ, 2006.

Едыгарова 2010 - С. Едыгарова. Категория посессивности в удмуртском языке. Дисс.... канд. филол. наук. Тарту: Тартусский университет, 2010.

Кашкин 2008 - Е. В. Кашкин. Посессивное склонение в мужевском говоре ижемского диалекта коми-зырянского языка // Научный вестник ЯНАО. 2008. Вып. 6 (58). C. 33-46.

Колпакова 1988 - Н. Н. Колпакова. Посессивность в венгерском языке. Автореф. дисс. ... канд. филол. наук. М.: МГУ, 1988. 
Кошкарева и др. 2017 - Н. Б. Кошкарева, Е. В. Кашкин, Ю. Б. Коряков, О. А. Казакевич, С. И. Буркова, Н. А. Муравьев, Е. М. Будянская. Диалектологический атлас уральских языков, распространенных на территории Ямало-Ненецкого автономного округа. Калининград: Рост-Доафк, 2017.

Кузнецова 2003 - А. И. Кузнецова. Кумуляция грамматических значений в агглютинативных показателях: дейктические функции посессива в уральских языках // П. Суйхконен, Б. Комри (ред.). Международный симпозиум по дейктическим системам и квантификации в языках Европы и Северной и Центральной Азии. Сборник статей. Ижевск: Институт компьютерных исследований, 2003. С. 249-259.

Лудыкова 2010 - В. М. Лудыкова. Имя прилагательное в синтаксисе агглютинативных языков: функционально-коммуникативный аспект. Сыктывкар: Сыктывкарский государственный университет, 2010.

Некрасова 2002 - Г. А. Некрасова. Система l-овых падежей в пермских языках: происхождение и семантика. Сыктывкар: Коми научный центр УрО РАН, 2002.

Плешак 2015 - П. С. Плешак. Иерархия одушевленности и выбор посессивной конструкции в мокшанском языке // Е. А. Лютикова, А. В. Циммерлинг, М. Б. Коношенко (ред.). Типология морфосинтаксических параметров. Материалы Международной конференции «Типология морфосинтаксических параметров 2014». Вып. 1. М.: МГГУ им. М. А. Шолохова, 2015. С. 146-164.

Сидоров 1945 - А. С. Сидоров. Принадлежностно-указательные суффиксы в коми языке. Дисс. ... канд. филол. наук. Сыктывкар: Коми база АН СССР, 1945.

Симоненко, Леонтьев 2012 - А. П. Симоненко, А. П. Леонтьев. Морфо-синтаксис именного комплекса в финно-пермских языках: анализ в рамках программы минимализма // А. И. Кузнецова и др. (ред). Финно-угорские языки: Фрагменты грамматического описания. Формальный и функциональный подходы. М.: Рукописные памятники Древней Руси, 2012. С. 262-339.

Феоктистов 1963 - А. П. Феоктистов. Категория притяжательности в мордовских языках. Саранск: Мордовское книжное издательство, 1963.

Kokla 1963 - P. Kokla. Possessiivsuffiksid mari keeles. Väitekiri filoloogiakandidaadi teadustiku kraadi taotlemiseks. Tallinn: Eesti NSV Teaduste Akadeemia. Keele ja Kirjanduse Instituut, 1963.

Koptjevskaja-Tamm 2002 - M. Koptjevskaja-Tamm. Adnominal possession in the European languages: form and function // Sprachtypologie und Universalienforschung. 2002. № 55. P. 141-172.

Koptjevskaja-Tamm 2003 - M. Koptjevskaja-Tamm. Possessive noun phrases in the languages of Europe // F. Plank (ed.). Noun Phrase Structure in the Languages of Europe. Berlin; New York: Mouton de Gruyter, 2003. P. 621-722.

Mark 1925 - J. Mark. Die Possessivsuffixe in den uralischen Sprachen (Suomalais-Ugrilaisen Seuran Toimituksia. Vol. 54). Helsinki: Suomalais-Ugrilainen Seura, 1925. Nichols 1988 - J. Nichols. On alienable and inalienable possession // W. Shipley (ed.). In honor of Mary Haas. Berlin: Mouton de Gruyter, 1988. P. 557-609.

Nikolaeva 2003 - I. Nikolaeva. Possessive affixes as markers of information structuring: Evidence from Uralic // П. Суйхконен, Б. Комри (ред.). Международный 
симпозиум по дейктическим системам и квантификации в языках Европы и Северной и Центральной Азии. Сборник статей. Ижевск: Институт компьютерных исследований, 2003. С. 130-145.

Pleshak 2016 - P. Pleshak. Adnominal possessive constructions in Mordvin, Mari and Permic. Talk at $49^{\text {th }}$ Annual Meeting of the Societas Linguistica Europaea, 31.0803.09.2016, University of Naples Federico II, Naples.

Sazhina 2005 - N. Sazhina. Possessiivsuse väljandamise viisid tänapäevase eesti ja sürjakomi keeles. Magistritöö. Tartu: Tartu Ülikool, 2005.

Silverstein 1976 - M. Silverstein. Hierarchy of Features and Ergativity // R. M. W. Dixon (ed.). Grammatical Categories in Australian Languages. Canberra: Australian National University, 1976. P. 112-171.

Simonenko 2014 - A. Simonenko. Microvariation in Finno-Ugric possessive markers // H.-L. Huang, E. Poole, A. Rysling (eds.). Proceedings of the $43^{\text {rd }}$ annual meeting of the North East Linguistic Society. Vol. 2. Amherst: University of Massachusetts, 2014. P. 127-140.

\section{References}

Biryuk 2005 - O. L. Biryuk. Morfosintaksicheskie kriterii vydeleniya poslelogov $\mathrm{v}$ uralskikh yazykakh [Morphosyntactic criteria for identifying postpositions in the Uralic languages]. Graduate work. Moscow: Lomonosov Moscow State University, 2005.

Biryuk et al. 2010 - O. L. Biryuk, E. V. Kashkin, A. I. Kuznetsova, M. N. Usacheva. Slovar muzhevskogo govora izhemskogo dialekta komi-zyryanskogo yazyka [Dictionary of the Muzhi variety of the Izhma dialect of the Komi-Zyryan language]. Yekaterinburg: Basko, 2010.

Brykina, Sudobina 2005 - M. M. Brykina, A. N. Sudobina. Posessivnye pokazateli $\mathrm{v}$ roli diskursivnykh markerov (na materiale nekotorykh uralskikh yazykov) [Possessive suffixes as discursive markers (based on some Uralic languages)]. Chetvertaya tipologicheskaya shkola (21-28 sentyabrya 2005 g., Erevan) [Fourth typological school (21-28 September 2005, Yerevan)]. Moscow: Russian State University for the Humanities Press, 2005. P. 98-101.

Bubrikh 1947 — D. V. Bubrikh. Erzya-mordovskaya grammatika. Minimum [Erzya-Mordovian grammar. Minimum]. Saransk: Mordovian Book Publishing House, 1947.

Bubrikh 1955 - D. V. Bubrikh. Sovremennyy komi yazyk [Modern Komi language]. Pt. 1. Fonetika. Leksika. Morfologiya [Phonetics. Vocabulary. Morphology]. Syktyvkar: Komi Book Publishing House, 1955.

Edygarova 2010 - S. Edygarova. Kategoriya posessivnosti v udmurtskom yazyke [The category of possessivity in the Udmurt language]. Candidate thesis. Tartu: Tartu University, 2010.

Feoktistov 1963 - A. P. Feoktistov. Kategoriya prityazhatelnosti v mordovskikh ya$z y k a k h$ [The category of possessivity in Mordovian languages]. Saransk: Mordovian Book Publishing House, 1963. 
Grashchenkov 2006 - P. V. Grashchenkov. Sintaksis i tipologiya genitivnoy gruppy [Syntax and typology of the Genitive Phrase]. Candidate thesis. Moscow: Lomonosov Moscow State University, 2006.

Kashkin 2008 - E. V. Kashkin. Posessivnoe sklonenie v muzhevskom govore izhemskogo dialekta komi-zyryanskogo yazyka [Possessive declension in the Muzhi variety of the Izhma dialect of the Komi-Zyryan language]. Nauchnyy vestnik YaNAO. 2008. Iss. 6 (58). P. 33-46.

Kokla 1963 - P. Kokla. Possessiivsuffiksid mari keeles. Väitekiri filoloogiakandidaadi teadustiku kraadi taotlemiseks. Tallinn: Eesti NSV Teaduste Akadeemia. Keele ja Kirjanduse Instituut Press, 1963.

Kolpakova 1988 - N. N. Kolpakova. Posessivnost v vengerskom yazyke [Possessivity in Hungarian]. Author's abstract of candidate thesis. Moscow: Lomonosov Moscow State University, 1988.

Koptjevskaja-Tamm 2002 - M. Koptjevskaja-Tamm. Adnominal possession in the European languages: form and function. Sprachtypologie und Universalienforschung. 2002. No. 55. P. 141-172.

Koptjevskaja-Tamm 2003 - M. Koptjevskaja-Tamm. Possessive noun phrases in the languages of Europe. F. Plank (ed.). Noun Phrase Structure in the Languages of Europe. Berlin; New York: Mouton de Gruyter, 2003. P. 621-722.

Koshkareva et al. 2017 - N. B. Koshkareva, E. V. Kashkin, Yu. B. Koryakov, O. A. Kazakevich, S. I. Burkova, N. A. Muravev, E. M. Budyanskaya. Dialektologicheskiy atlas uralskikh yazykov, rasprostranennykh na territorii Yamalo-Nenetskogo avtonomnogo okruga [Dialectological atlas of the Uralic languages spoken in the Yamal-Nenets Autonomous District]. Kaliningrad: Rost-Doafk, 2017.

Kuznetsova 2003 - A. I. Kuznetsova. Kumulyatsiya grammaticheskikh znacheniy v agglyutinativnykh pokazatelyakh: deykticheskie funktsii posessiva $\mathrm{v}$ uralskikh yazykakh [Cumulation of grammatical meanings in agglutinative markers: deictic functions of the possessive in the Uralic languages]. P. Suikhonen, B. Comrie (eds.). Mezhdunarodnyy simpozium po deykticheskim sistemam i kvantifikatsii v yazykakh Evropy $i$ Severnoy $i$ Tsentralnoy Azii [International symposium on deictic systems and quantification in languages spoken in Europe and North and Central Asia]. Collection of papers. Izhevsk: Institute for Computational Research, 2003. P. 249-259. Ludykova 2010 - V. M. Ludykova. Imya prilagatelnoe $v$ sintaksise agglyutinativnykh yazykov: funktsionalno-kommunikativnyy aspekt [Adjective in the syntax of agglutinative languages: functional-communicative aspect]. Syktyvkar: Syktyvkar State University, 2010.

Mark 1925 - J. Mark. Die Possessivsuffixe in den uralischen Sprachen (Suomalais-Ugrilaisen Seuran Toimituksia. Vol. 54). Helsinki: Suomalais-Ugrilainen Seura, 1925.

Nekrasova 2002 - G. A. Nekrasova. Sistema l-ovykh padezhey v permskikh yazykakh: proiskhozhdenie i semantika [The system of l-cases in Permian languages: origin and semantics]. Syktyvkar: Komi Scientific Center of Ural Branch of Russian Academy of Sciences, 2002.

Nichols 1988 - J. Nichols. On alienable and inalienable possession. W. Shipley (ed.). In honor of Mary Haas. Berlin: Mouton de Gruyter, 1988. P. 557-609. 
Nikolaeva 2003 - I. Nikolaeva. Possessive affixes as markers of information structuring: Evidence from Uralic. P. Suikhonen, B. Comrie (eds.). Mezhdunarodnyy simpozium po deykticheskim sistemam i kvantifikatsii v yazykakh Evropy i Severnoy i Tsentralnoy Azii [International symposium on deictic systems and quantification in languages spoken in Europe and North and Central Asia]. Collection of papers. Izhevsk: Institute for Computational Research Press, 2003. P. 130-145.

Pleshak 2015 - P. S. Pleshak. Ierarkhiya odushevlennosti i vybor posessivnoy konstruktsii v mokshanskom yazyke [Animacy Hierarchy and Choice of Possessive Construction in Moksha]. E. A. Lyutikova, A. V. Tsimmerling, M. B. Konoshenko (eds.). Tipologiya morfosintaksicheskikh parametrov. Materialy Mezhdunarodnoy konferentsii "Tipologiya morfosintaksicheskikh parametrov 2014" [Typology of morphosyntactic parameters. Materials of the International conference "Typology of morphosyntactic parameters 2014"]. Iss. 1. Moscow: Sholokhov Moscow State University for the Humanities Press, 2015. P. 146-164.

Pleshak 2016 - P. Pleshak. Adnominal possessive constructions in Mordvin, Mari and Permic. Talk at $49^{\text {th }}$ Annual Meeting of the Societas Linguistica Europaea, 31.0803.09.2016, University of Naples Federico II, Naples.

Sazhina 2005 - N. Sazhina. Possessiivsuse väljandamise viisid tänapäevase eesti ja sürjakomi keeles. Magistritöö. Tartu: Tartu Ülikool, 2005.

Sidorov 1945 - A. S. Sidorov. Prinadlezhnostno-ukazatelnye suffiksy v komi yazyke [Possessive-deictic suffixes in the Komi language]. Candidate thesis. Syktyvkar: Komi base of USSR Academy of Sciences, 1945.

Silverstein 1976 - M. Silverstein. Hierarchy of Features and Ergativity. R. M. W. Dixon (ed.). Grammatical Categories in Australian Languages. Canberra: Australian National University, 1976. P. 112-171.

Simonenko 2014 - A. Simonenko. Microvariation in Finno-Ugric possessive markers. H.-L. Huang, E. Poole, A. Rysling (eds.). Proceedings of the $43^{\text {rd }}$ annual meeting of the North East Linguistic Society. Vol. 2. Amherst: University of Massachusetts, 2014. P. 127-140.

Simonenko, Leontev 2012 - A. P. Simonenko, A. P. Leontev. Morfo-sintaksis imennogo kompleksa $\mathrm{v}$ finno-permskikh yazykakh: analiz $\mathrm{v}$ ramkakh programmy minimalizma [Morpho-syntax of the noun complex in Finno-Permian languages: analysis within the framework of the minimalism program]. A. I. Kuznetsova et al. (ed). Finno-ugorskie yazyki: Fragmenty grammaticheskogo opisaniya. Formalnyy i funktsionalnyy podkhody [Finno-Ugric languages: Fragments of a grammatical description. Formal and functional approaches]. Moscow: Rukopisnye pamyatniki Drevney Rusi, 2012. P. 262-339. 


\section{О фонологическом статусе аффрикаты $t s$ в сойкинском диалекте ижорского языка*}

\section{Ф. И. Рожанский}

Институт лингвистических исследований РАН, Санкт-Петербург, Тартуский университет (Эстония); handarey@yandex.ru

\section{Е. Б. Маркус}

Институт языкознания РАН, Москва, Тартуский университет (Эстония); helenmarkus@yahoo.com

Аннотация. Статья посвящена анализу аффрикаты $t s$ в сойкинском диалекте ижорского языка. Варьирование фонологического статуса аффрикаты $t s$ в прибалтийско-финских языках и ее неочевидный статус в ижорском языке потребовали детального исследования, проведенного методами экспериментальной фонетики. Были выделены семь критериев, на основе которых оценивалась рассматриваемая аффриката: следование фонетическому процессу «переход свистящих в шипящие», структура смычки у взрывного компонента аффрикаты, способность находиться в начале слова, наличие чередования ступеней, относительная длительность частей аффрикаты, общая длительность аффрикаты, возможность блокирования редукционных процессов второго гласного в структуре CVCV. В качестве материала использовались полевые записи авторов, сделанные в период 2013-2017 годов. Исследование показало, что аффриката $t s$ в сойкинском ижорском демонстрирует как признаки консонантного кластера, так и признаки одиночной фонемы, что, с одной стороны, оставляет исследователю свободу выбора в приписывании данной аффрикате фонологического статуса, с другой стороны, требует признания ее аномальности (как в качестве фонемы, так и в качестве консонантного кластера). Краткий анализ второй из имеющих в данном идиоме аффрикат ( $t \grave{s}$ ) также выявил ее аномальные свойства, которые, однако, не совпадают со свойствами $t s$. Сопоставление двух аффрикат позволило сделать вывод о том, что их фонологический статус не является независимым. Принятие решения о фонологическом статусе одной аффрикаты зависит от статуса второй аффрикаты, а также от некоторых других особенностей консонантной системы.

Ключевые слова: ижорский язык, прибалтийско-финские языки, фонетика, фонология, аффрикаты, редукция, чередование ступеней.

* Исследование выполнено при финансовой поддержке Эстонского совета по науке, проект IUT2-37 (работа Ф. И. Рожанского) и Но̃imurahvaste programm, проект SHVEE20194 (работа Е. Б. Маркус).

Авторы выражают искреннюю признательность И. В. Бродской и Н. В. Кузнецовой за высказанные ими ценные замечания к статье. 


\section{On the phonological status of the affricate $t s$ in Soikkola Ingrian}

\section{F. I. Rozhansky}

Institute for Linguistic Studies, Russian Academy of Sciences, St. Petersburg, University of Tartu (Estonia); handarey@yandex.ru

\section{E. B. Markus}

Institute of Linguistics, Russian Academy of Sciences, Moscow, University of Tartu (Estonia); helenmarkus@yahoo.com

Abstract. This paper considers the affricate $t s$ in Soikkola Ingrian. The research is based on the field data recorded in 2013-2017 from Ingrian native speakers. The data were collected by elicitation using specially elaborated phonetic questionnaires.

The aim of the study is to determine the phonological status of $t s$ in Soikkola Ingrian by analyzing its acoustic phonetic properties. The affricate is tested against seven criteria; and it is shown that the Soikkola Ingrian $t s$ has properties of both a phoneme and a cluster.

Three criteria bring out the difference between $t s$ and a typical consonant cluster: the component $s$ does not change into $\check{s}$ when a part of $t s$ (unlike in other contexts); the burst of $t$ is often spread as opposed to the compact burst in other clusters with plosives; and the duration ratio of $t$ and $s$ is different from the ratio of the components in other clusters ( $t$ is significantly longer than $s$ ).

Four criteria distinguish $t s$ from a typical single phoneme: $t s$ is rare as an initial consonant in a word; it does not participate in grade alternations (unlike in the neighboring Votic language where $t s$ alternates similarly to plosives); the duration of $t s$ is similar to the duration of a cluster but not a singleton; and $t s$ does not block the reduction of the second vowel in the CVCV structure (in this structure, the second vowel is prolonged if the preceding consonant is a singleton, but it gets reduced both qualitatively and quantitatively if preceded by a geminate or a cluster).

The conclusion is that the affricate $t s$ has to be considered either as a non-prototypical phoneme or as a non-prototypical consonant cluster.

The paper also briefly addresses the properties of the affricate $t \grave{s}$ in the same variety. The affricate $t \grave{s}$ behaves differently from $t s$ (it can appear as a word-initial consonant, the duration of its two components is comparable, etc.), but still cannot be considered as a regular consonant or a regular cluster.

The research demonstrates that the phonological system of Soikkola Ingrian is non-orthogonal: the decision about the phonological status of either affricate correlates with the phonological interpretation of the other affricate and some other consonants.

Keywords: Ingrian language, Finnic languages, phonetics, phonology, affricates, reduction, consonant gradation. 


\section{1. Предварительные замечания}

Проблема «одна фонема или две» существует с момента появления фонологии. Уже в «Основах фонологии» Н. С. Трубецкого мы находим раздел, озаглавленный «Отдельная фонема и сочетание фонем», который начинается с утверждения: «Не всегда легко установить разницу между отдельной фонемой и группой фонем» [Трубецкой 1960: 62].

Предложенный Трубецким набор правил не является достаточным инструментом для решения этой проблемы. Даже первое правило, гласящее, что «реализацией одной фонемы можно считать только сочетание звуков, составные части которого в данном языке не распределяются по двум слогам», может быть оспорено ${ }^{1}$. Утверждение о том, что фонема «образуется с помощью единой артикуляции или создается в процессе постепенного убывания или сокращения артикуляционного комплекса», плохо применимо из-за отсутствия четкого определения единой артикуляции. Следуя этому критерию, Трубецкой отказывает кластерам типа st в праве называться фонемой и признает такое право за аффрикатами, но для того, чтобы определить, является ли сочетание звуков $t$ и $s$ фонемой или кластером, правило единой артикуляции, по всей видимости, не годится [Трубецкой 1960: 64-65]. Следующее правило о том, что «группу звуков следует считать реализацией одной фонемы, если ее длительность не превышает длительности других фонем данного языка» [Трубецкой 1960: 65], сам Трубецкой оценивает как менее важное (при этом остается совершенно непонятным, что делать с языками, у которых длительность сегментов является фонологическим признаком). Как эти, так и остальные правила Трубецкой иллюстрирует конкретными ситуациями в определенных языках, но за пределами таких ситуаций применение правил оказывается затруднительным.

\footnotetext{
${ }^{1}$ Например, если соблюдать это правило, придется однозначно отказаться от всех фонологических интерпретаций, считающих геминаты отдельными фонемами (ведь граница слога обычно проходит через геминату). Как в таком случае должен интерпретироваться консонантизм сойкинского диалекта ижорского языка, в котором существуют одиночные согласные, краткие геминаты и долгие геминаты (cp. kana 'курица.NOM' vs kănnaa ‘курица.PART/ILL' vs linnaa 'город.PART/ILL')? Либо придется переносить количественные признаки на супрасегментный уровень, либо потребуется вводить отдельный ряд согласных для первой части кратких геминат. И то, и другое решение представляется нам неоправданным усложнением фонологического описания.
} 
В данном исследовании мы остановимся на одной конкретной проблеме, а именно на вопросе о фонемном статусе аффрикаты ${ }^{2} t s$ в сойкинском диалекте ижорского языка. Ижорский язык относится к прибалтийско-финским языкам. Несмотря на свою схожесть во многих аспектах фонетики, фонологии и грамматики, прибалтийско-финские языки не демонстрируют единообразия в вопросе фонологического статуса $t s$. В частности, в работе [Lippus 2005] продемонстрировано различие статуса $t s$ в эстонском и южноэстонском языках.

Вопрос о фонологическом статусе ижорской аффрикаты $t s$ затрагивался разными исследователями, однако их мнения различались (см. подробнее [Кузнецова 2009а: 272-273] ${ }^{3}$ ). Инструментальные фонетические исследования сойкинской аффрикаты $t s$ представлены только в работе [Sovijärvi 1944]. Ниже эти результаты будут обсуждаться более подробно.

Статья имеет следующую структуру. В Разделе 2 приводятся данные и описываются методы исследования. В Разделе 3 рассматриваются критерии, релевантные для определения статуса аффрикаты $t s$, описываются проведенные фонетические эксперименты и их результаты. В Разделе 4 обсуждается фонологическая интерпретация $t s$ в свете проведенных фонетических экспериментов. Раздел 5 посвящен краткому обзору свойств ижорской аффрикаты $t \grave{s}$ и ее сопоставлению $\mathrm{c} t s$. В заключительном Разделе 6 формулируются обобщения и выводы. В Приложении приводятся дополнительные экспериментальные данные, которые не были включены в основной текст, чтобы избежать его перегруженности.

\section{2. Данные и методы}

Большинство данных, используемых в статье, было собрано авторами в процессе полевой работы с носителями сойкинского диалекта ижорского языка в 2013-2017 годах. Основным методом сбора данных было анкетирование: специально разработанная фонетическая анкета, где исследуемые слова были помещены в простые контексты,

\footnotetext{
2 Здесь и далее, слово «аффриката» используется как нейтральное с точки зрения проблемы «фонема или не фонема?». То есть, называя $t s$ аффрикатой, мы не утверждаем, что $t s$ является фонемой, а не двумя фонемами.

${ }^{3}$ Сам автор этого исследования приходит к выводу, что $t s$ в сойкинском диалекте является кластером фонем $t$ и $s$ [Кузнецова 2009а: 273].
} 
предлагалась носителям языка для перевода с русского на ижорский. Позиция слов в предложении и их количество зависели от исследуемого вопроса (эта информация эксплицитно указывается при описании каждого эксперимента). Анализ собранных данных производился при помощи компьютерной программы PRAAT [Boersma, Weenink 2014]. Статистическая значимость результатов проверялась при помощи однофакторного анализа ANOVA.

Основные анкеты были записаны от двух носительниц языка, обозначаемых далее AG и AL. AG родилась в 1936 году в д. Репино, жила в д. Логи, затем в д. Валяницы. AL родилась в 1933 году в д. Гамолово, а затем тоже жила в д. Валяницы, где и была сделана запись обеих носительниц. С диалектологической точки зрения обе носительницы являются представителями северных говоров сойкинского диалекта.

При анализе материалов, записанных от других носителей языка, необходимая информация приводится в соответствующем разделе.

Когда в статье приводятся ижорские примеры без эксплицитного указания диалекта, то имеется в виду сойкинский диалект.

\section{3. Эксперименты и результаты}

Для анализа ижорской аффрикаты $t s$ было выделено семь критериев ${ }^{4}$. Эти критерии, последовательно рассматриваемые в данном разделе, следующие:

- следование фонетическому процессу «переход свистящих в шипящие»;

- структура смычки у взрывного компонента аффрикаты в сопоставлении с консонантным кластером;

- способность находиться в начале слова, связанная с фонотактическим запретом на консонантный кластер в этой позиции;

- противопоставление сильной и слабой ступени $t s$ (чередование ступеней свойственно отдельным фонемам, но не кластерам «взрывной + фрикативный» ${ }^{5}$ );

4 Это те критерии, которые мы квалифицировали как релевантные для поставленной задачи. О некоторых отвергнутых критериях см. ниже в этом разделе.

${ }^{5}$ Список чередующихся фонем и кластеров в сойкинском диалекте ижорского языка приведен в [Saar 2014: 260]. 
- относительная длительность частей аффрикаты в сопоставлении с частями консонантного кластера;

- соотношение общей длительности аффрикаты с длительностью консонантного кластера и одиночного согласного;

- наличие редукции, характерной для второго гласного в структуре CVCCV, но не в структуре CVCV.

Ряд потенциальных критериев мы не рассматриваем, поскольку считаем их нерелевантными. Выше, например, было отмечено, почему мы не считаем применимым первый критерий Трубецкого (принадлежность к одному слогу) ${ }^{6}$.

В [Кузнецова 2009а: 272-273] внимание уделяется графическому представлению аффрикаты: на основе того, как тот или иной исследователь записывает аффрикату, делается вывод о ее монофонемной или бифонемной сущности ${ }^{7}$. С нашей точки зрения, это имело бы смысл, только если бы исследователь эксплицитно постулировал принцип однозначного соответствия фонемы и графемы. Обычно же выбор системы записи основывается на других принципах (удобстве записи, традиции, сопоставимости с генетически или территориально близкими языками, собственном опыте и пр.), а не на указанном принципе ${ }^{8}$.

${ }^{6}$ Такого же рода критерий (членение на слоги, проводимое носителем языка) применяется в [Кузнецова 2009а: 273].

${ }^{7}$ Справедливости ради заметим, что автор работы не считает этот критерий основным и также ищет другие подтверждения представлений исследователей о фонологическом статусе аффрикат. Кроме эксплицитно выраженного мнения исследователя (то есть постулирования фонемного статуса аффрикаты) это, например, присутствие аффрикат в приводимом исследователем консонантном инвентаре. Последний критерий, впрочем, тоже не всегда может считаться определяющим (не все исследователи указывают, какой инвентарь они приводят: фонологический или фонетический). Особенно сомнительны выводы, касающиеся грамматики В. Поркки (см. [Porkka 1885]), который «не считает фонемами ни $t s$, ни $\check{c}^{\prime} / \bar{c}^{\prime}$ » [Кузнецова 2009a: 272]. Обратим внимание, что работа Бодуэна де Куртенэ «Опыт фонетических чередований», где было введено понятие фонемы и заложены основы фонологии, появилась через 10 лет после ижорской грамматики Поркки.

${ }^{8}$ Кстати, сойкинский диалект ижорского является одной из самых ярких иллюстраций того, насколько неудачна была бы орфография или транскрипция, построенная по принципу «одна фонема - одна графема». В этом диалекте противопоставление глухих и звонких согласных не фонологическое, а позиционно обусловленное. Однако правильное прочтение ижорских слов становится затруднительным без различения на письме глухих и звонких согласных. 
Для ижорского же языка, который фактически является бесписьменным, опрос носителей языка о способе написания $t s$ не представлялся хоть сколько-нибудь осмысленным, и поэтому соответствующий критерий нами не использовался.

Критерий 1. Переход свистящих в шипящие

Специфической особенностью современного сойкинского диалекта является появление шипящего $\check{s}(\check{z})$ на месте исходного свистящего $s(z)$, cp., например, финское и нижнелужское ижорское sota, водское seta, эстонское sõda с сойкинским ижорским šoda 'война'; финское, эстонское и нижнелужское ижорское osa, водское esa c сойкинским ижорским оža 'часть, доля'.

Свистящие $s$ и $z$ в современном сойкинском наблюдаются только в заимствованиях инновационных идиолектов, в архаичных же идиолектах свистящие замещаются шипящими, ср. zavoda $\sim$ šavoda 'завод' .

У нас нет точных данных, когда именно произошел этот переход, но обращает на себя внимание тот факт, что в грамматике [Porkka 1885: 130-134, 145-146] сойкинский материал записан со свистящими, а не с шипящими согласными. При этом при записи материала оредежского диалекта используются шипящие согласные. Таким образом, гипотеза о том, что автор грамматики не считал нужным различать свистящие и шипящие, не находит подтверждения.

Отмеченный факт позволяет предположить, что переход свистящих в шипящие произошел не очень давно ${ }^{10}$.

${ }^{9}$ В [Кузнецова 2009а: 236-238] отмечается появление $s$ в речи носителей сойкинского ижорского при некоторых специфических условиях. Например, $\check{s}$ в начале слова может произноситься как $s$, если предыдущее слово заканчивалось на $t$; в некоторой периферийной лексике зафиксировано появление палатализованного $s$ ' и т. д. Однако эти явления никоим образом не противоречат общей тенденции перехода свистящих в шипящие. Они либо не актуальны для решения вопросов, рассматриваемых в нашей статье, либо являются дополнительным подтверждением наших собственных наблюдений (так, например, отмеченное появление $s$ на стыке слов после $t$ хорошо согласуется с идеей запрета на переход $t s \rightarrow t \check{s}$, см. Раздел 5).

${ }^{10}$ См. обсуждение этого вопроса в [Лаанест 1966: 54-58] и в [Лаанест 1978: 8690]. Хотя неустойчивость в произнесении свистящего или шипящего могла возникнуть уже давно, тенденция произносить $\check{s}$, отмеченная А. Лаанестом у молодого поколения, свидетельствует об инновационном характере данного перехода в сойкинском диалекте. 
Если аффриката $t s$ представляет собой две отдельных фонемы, то в описанной ситуации следовало бы ожидать перехода $s$ в $\check{s}$, как это произошло в словах, содержавших $s$ в составе консонантного кластера с начальным взрывным: lüpšän 'доить.PRS.1SG' < lüpsän, makšan 'платить.PRS.1SG' < maksan, okša 'ветка' < oksa. Однако в случае $t s$ подобного перехода не наблюдается: vatsa 'живот', но не *vatša, katson 'смотреть.PRS.1SG', но не *katšon.

Таким образом, в данном случае $t s$ ведет себя не как консонантный кластер, а скорее как одна фонема.

\section{Критерий 2. Структура смычки у аффрикаты}

В нашем материале консонантные кластеры, состоящие из взрывного и фрикативного, обычно демонстрируют четкое разделение двух звуков: первый представлен паузой и разрывом смычки, второй - соответствующим шумом, см. Рисунок 1 .

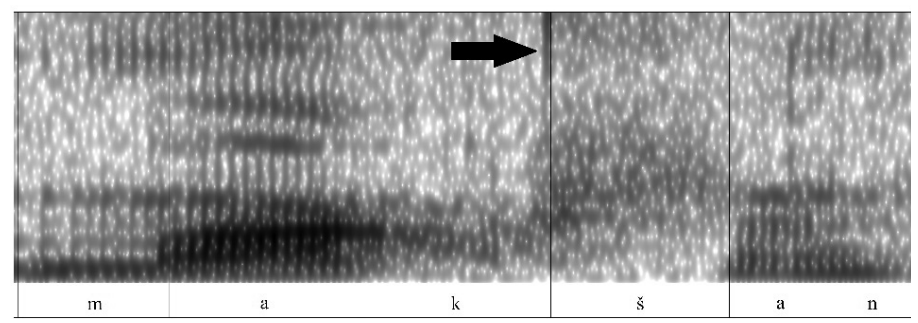

Рисунок 1. Разрыв смычки при произнесении консонантного кластера с взрывным в форме makšan 'платить.PRs.1sG'

Figure 1. The burst in a cluster with plosive in the form makšan 'pay.PRs.1sG'

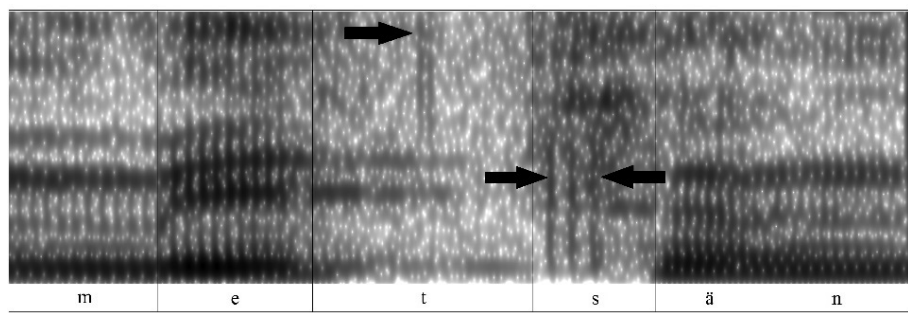

Рисунок 2. Разрыв смычки при произнесении аффрикаты $t s$ в форме metsän 'лес.GEN'

Figure 2. The burst in the affricate $t s$ in the form metsän 'forest.GEN' 
В случае аффрикаты $t s$ такая картина наблюдается далеко не всегда: часто разрыв смычки «размывается» по всему кластеру, в том числе попадает и на его фрикативную часть, см. Рисунок 2.

Этот критерий говорит в пользу того, что $t s$ является не кластером, а отдельной фонемой. Впрочем, с нашей точки зрения, этот критерий является одним из наименее значимых. Во-первых, он отражает только тенденцию: конкретные произнесения не всегда ей соответствуют. Во-вторых, различие между $t s$ и несомненными кластерами с взрывными в качестве первого компонента может являться следствием фонетических особенностей сегментов: взрывной $t$ по месту образования довольно близок к $s$, что способствует «перетеканию» одного звука в другой, невозможному в случае сегментов, существенно различающихся по месту образования.

Критерий 3. Позиция в начале слова

Для ижорского и других прибалтийско-финских языков нехарактерно появление консонантных кластеров в начале слова. Такое случается лишь в заимствованиях или словах звукоподражательного происхождения. В [Кузнецова 2009а: 273] отмечается отсутствие примеров с начальным $t s$, однако никаких эксплицитных выводов из этого факта не формулируется. В словаре [Nirvi 1971: $599,601,602]$ приводятся только шесть слов, начинающихся с $t s$ : tseвa 'цепь', tse p̌pōtška 'цепочка', tselkka 'целка', tsementti 'цемент', tsirinap $\bar{u}$ 'сирень', tsollu 'долбленка, челн'. Первые четыре из них являются тривиальными заимствованиями, пятое - заимствование с не совсем понятным переходом $s$ в $t s$, и последнее, по-видимому, тоже заимствование, фонетический облик которого претерпел серьезные изменения. При этом первое из названных слов существует и в варианте с другой, более типичной для начала слова аффрикатой: $t$ 'š́eppi 'цепь'. Такой переход $t s$ в $t \check{s}$ при заимствовании наблюдается и в других словах, например, íšigarGa 'цигарка', ťšsikkūri 'цикорий', tšifrpD 'цифры' (подробнее о варьировании аффрикат см. [Кузнецова 2009a: 270-271]).

Таким образом, в исконно ижорских словах $t s$ в начале слова не встречается, количество заимствований с начальным $t s$ невелико, и есть ряд примеров, где в заимствованиях $t s$ перешло в $t \check{s}$. Тем самым, появление $t s$ в начале слова не является естественным для языка. Наиболее простое объяснение этого факта следующее: $t s$ 
воспринимается именно как консонантный кластер, а присутствие консонантного кластера в начале слова нежелательно ${ }^{11}$.

\section{Критерий 4. Чередование ступеней}

В прибалтийско-финских языках (кроме ливского и вепсского) существует система чередований согласных, называемая чередованием ступеней. Чередование ступеней возникло как фонетическое явление (то есть как изменение согласных в определенных фонетических контекстах), но в современных языках его следует рассматривать как морфологический или морфонологический феномен (ср., например, в западных водских говорах формы api 'помощь.Nом' и $a v i$ 'помощь.GEN', различающиеся только согласным). Согласный (или консонантный кластер) может выступать в слабой или сильной ступени в зависимости от формы слова, ср., например, ижорское keppi 'палка. NOM' и kebin 'палка.GEN', где в первой форме в качестве сильной ступени выступает гемината $p p$, а во второй в качестве слабой ступени одиночный $b$. В тех прибалтийско-финских языках, где аффрикаты фонологичны, они участвуют в системе чередования ступеней; это относится, например, к $t s$ и $t s ̌$ в водском языке (kuttsuma 'звать.SUP' kutsun 'звать.PRs.1sG', klänttšimä 'клянчить.SUP' — kläntšin 'клянчить. PRS.1SG' [Маркус, Рожанский 2017: 380-381]) или к с̌ в карельском

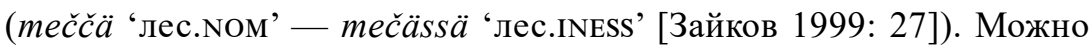
утверждать, что в целом в прибалтийско-финских языках наблюдается корреляция между общепринятой трактовкой аффрикаты как консонантного кластера или отдельной фонемы и наличием или отсутствием чередующихся ступеней у этой аффрикаты. Так, например, в финском и эстонском аффрикаты не считаются фонемами и не включены в систему чередования ступеней, в отличие от водского и карельского.

В ижорском языке все согласные ${ }^{12}$ включены в систему чередования ступеней ${ }^{13}$. Основные виды чередования ступеней следующие:

\footnotetext{
11 Другими словами, в языке существует запрет, который нарушается лишь в некоторых маргинальных случаях.

12 Кроме маргинальных согласных, которые встречаются только в периферийной лексике типа заимствований или звукоподражаний.

${ }^{13} \mathrm{~B}$ понятие чередования ступеней мы не включаем геминацию, приводящую в сойкинском диалекте к появлению кратконачальных геминат. Говоря
} 
- слабой и сильной ступеням взрывного согласного соответствуют одиночный и гемината (как в приведенном выше примере $b$ и $p p^{14}$ );

- согласный чередуется с качественно другим согласным или с нулевой ступенью (возможно, в составе консонантного кластера): kubu 'сноп.NOM' - kuvun 'сноп.GEN', pоški 'щека.NOM' — požen 'щека.GEN', nahka 'кожа.NOM' - nahan 'кожа.GEN';

- согласный чередуется как компонент согласного кластера: hinda ‘цена.NOM' - hinnan 'цена.GEN'.

При этом в сойкинском ижорском отсутствуют чередования одиночного фрикативного, аппроксиманта или назального с соответствующей полной геминатой (например, $\check{z}-\check{s} \check{s}, v-v v$ или $n-n n)$ и чередования кластеров, состоящих из начального взрывного и фрикативного (впрочем, вообще единственным чередующимся кластером с начальным взрывным является $t k$, которому в слабой ступени соответствует $d$ ).

Это позволяет выдвинуть гипотезу, что если ижорская аффриката ts является согласным, а не консонантным кластером, то она должна участвовать в системе чередования ступеней. Если же $t s$ является кластером, то мы ожидаем, что он не будет чередоваться.

Никаких качественных различий у форм с $t s$ не наблюдается, поэтому если можно предполагать наличие ступеней у $t s$, то они должны различаться количественно (как это происходит у взрывных консонантов).

Прежде чем переходить к детальному анализу ижорского материала, рассмотрим, как выглядит чередование ступеней у аффрикат в водском языке. Факт наличия такого чередования не вызывает сомнений. В водском языке и слабая, и сильная ступень могут встречаться в формах схожих структур. Возьмем для примера несколько форм слова metts 'лес': номинатив, генитив, партитив, инессив единственного числа и номинатив множественного числа. На Рисунках 3-7 приведены спектрограммы этих форм (запись сделана от носительницы водского языка 1928 г. р., которая родилась и жила в д. Пески). Для каждого сегмента указана его длительность в миллисекундах.

о чередовании ступеней, мы всегда рассматриваем весь чередующийся консонантный кластер, не выделяя в нем «основные» и «сопутствующие» согласные.

${ }^{14}$ Обратим внимание, что противопоставление одиночного $b$ и геминаты $p p$ имеет в своей основе количественный характер. Одиночный взрывной может быть звонким, полузвонким или глухим в зависимости от контекста, идиолекта и конкретного произнесения. С точки зрения фонологии глухость - звонкость не является дистинктивным признаком в сойкинском консонантизме. 


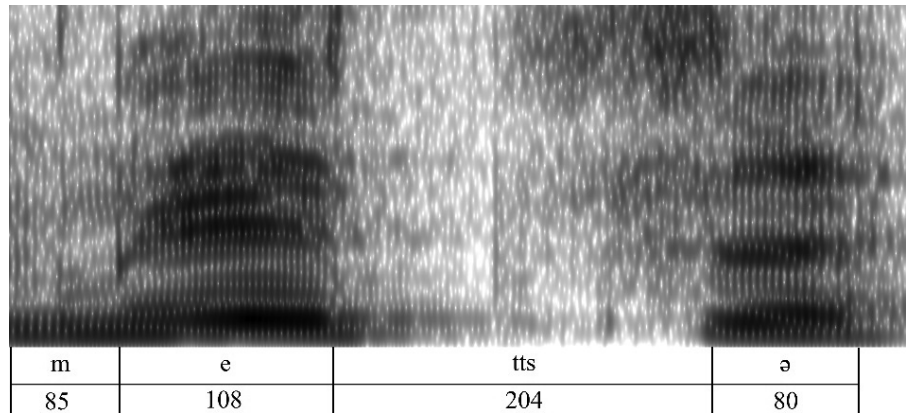

Рисунок 3. Водская форма mettsə 'лес.мом'

Figure 3. Votic form mettsa 'forest.NOM'

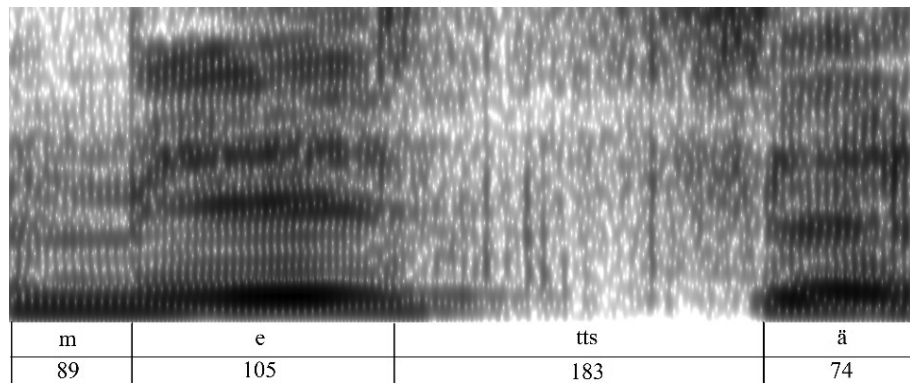

Рисунок 4. Водская форма mettsä 'лес.PART’

Figure 4. Votic form mettsä 'forest.PART'

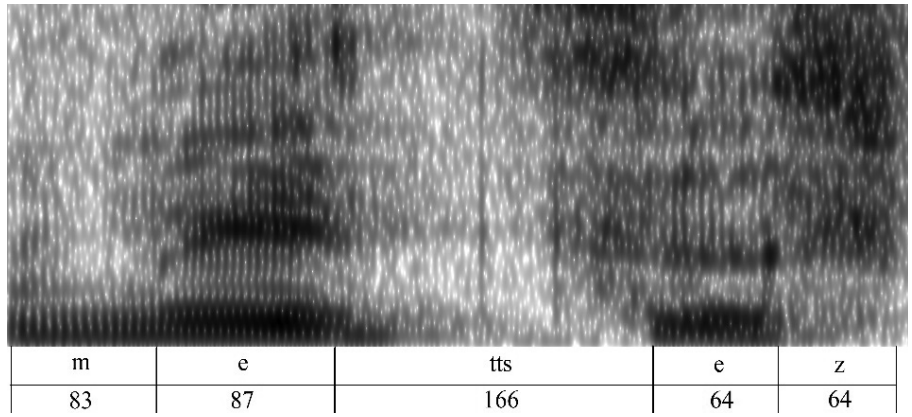

Рисунок 5. Водская форма mettsez 'лес.INESS'

Figure 5. Votic form mettsez 'forest.INEss' 


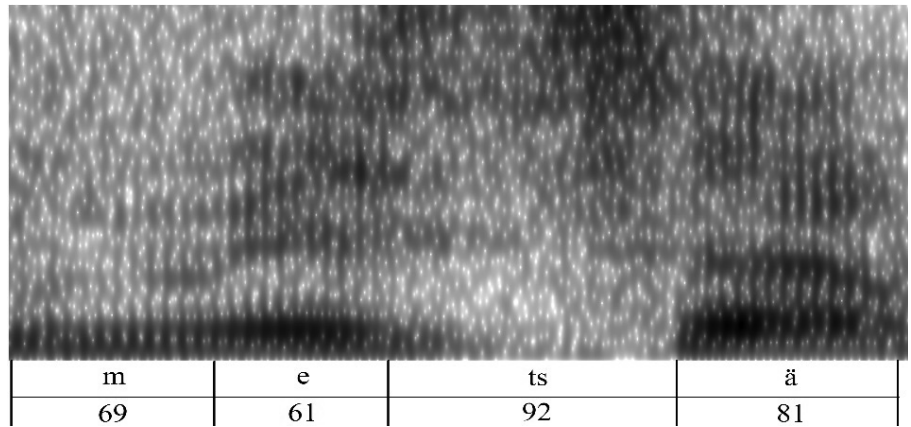

Рисунок 6. Водская форма metsä 'лес.GEN'

Figure 6. Votic form metsä 'forest.GEN'

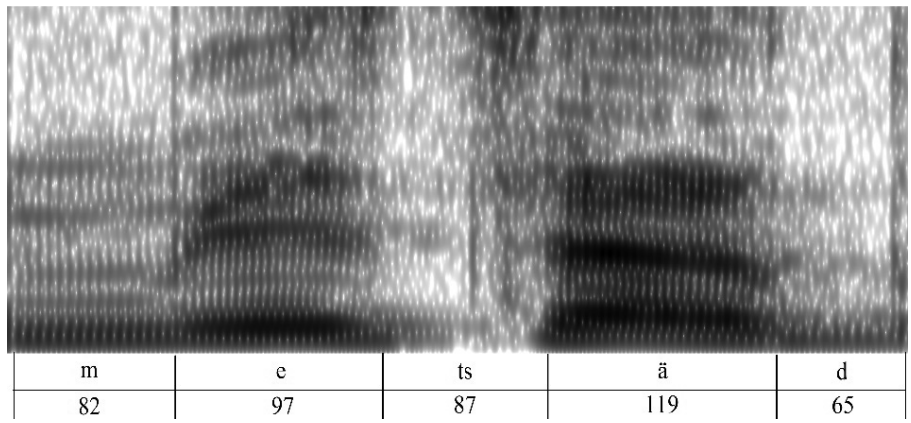

Рисунок 7. Водская форма metsäd 'лес.PL.NOM'

Figure 7. Votic form metsäd 'forest.PL.NOM'

В Таблище 1 (с. 453) сопоставлены структуры исследуемых форм и длительность аффрикаты. Как несложно заметить, различие между длительностью одиночной и геминированной аффрикаты ярко выражено (первая наблюдается в формах GEN и PL.NOM, вTорая в NOM, PART и INESS). При этом принципиальных изменений длительности, обусловленных структурой слова (в данном случае открытостью или закрытостью второго слога) не наблюдается. Даже если такие различия и были бы обнаружены (для этого, естественно, требуется привлечение большего количества данных), они оказались бы несопоставимо менее существенными, чем различия по длительности разных ступеней аффрикаты. 
Таблица 1. Длительность геминаты в произвольно взятых произнесениях форм водского слова mettsa 'лес'

Table 1. The duration of the geminate in random pronunciations of several forms of the Votic word mettsa 'forest'

\begin{tabular}{|l|l|c|l|}
\hline Форма & Глосса & Длина ts/tts (мс) & Структура \\
\hline mettsa & NOM & 204 & CVttsV \\
\hline mettsä & PART & 183 & CVttsV \\
\hline mettsez & INESS & 166 & CVttsVC \\
\hline metsä & GEN & 92 & CVtsV \\
\hline metsäd & PL.NOM & 87 & CVtsVC \\
\hline
\end{tabular}

Перейдем к ижорскому материалу. Первое же отличие водского языка от ижорского состоит в том, что в парадигме ижорского имени нет оппозиции сильной и слабой ступеней в формах одинаковой структуры. Такие именные формы как номинатив, партитив, иллатив единственного числа одноосновных слов, где обычно наблюдается сильная ступень согласного, заканчиваются на гласный. В отличие от них генитив и прочие падежи единственного числа, а также номинатив множественного числа, для которых характерны слабоступенные формы, заканчиваются на согласный (а в аллативе единственного числа добавляется еще один слог). Прочие формы множественного числа обычно содержат дифтонг (образуемый конечным гласным основы и показателем множественного числа $i$ ), а не одиночный гласный, либо же имеют большее количество слогов, поэтому несопоставимы с остальными формами. В результате оказывается невозможно подобрать формы, которые содержали бы в себе аффрикату $t s$ и различие между которыми сводилось бы только к возможному различию ступеней этой аффрикаты.

Для сравнения были выбраны три группы форм. Каждая группа содержала следующие падежные формы заданных структур:

1. Номинатив (структура $\left.\mathrm{CV}(\mathrm{t}) \mathrm{tsV}^{15}\right)$.

2. Партитив (структура $\mathrm{CV}(\mathrm{t}) \mathrm{tsVV})$.

3. Генитив (структура CVtsVC).

15 Запись (t)ts подразумевает, что по результатам измерений аффриката может оказаться сильноступенной или слабоступенной. 
Например, от слова 'лес' соответствующие формы выглядят как me(t)tsä, me(t)tsä̈̈ и metsän.

Гипотеза, проверяемая в эксперименте, предполагала, что если чередование ступеней существует, то длительность $t s$ в генитиве должна соответствовать слабой ступени и быть существенно ${ }^{16}$ меньше, чем длительность $t s$ в номинативе и партитиве, где ожидается сильная ступень. Запись осуществлялась от двух носителей языка (AG и $\mathrm{AL}$ ), форма записывалась в серединной позиции, на каждую группу было записано приблизительно по 20-30 произнесений.

На Схеме 1 представлены результаты эксперимента (см. также Таблицу 7 в Приложении).

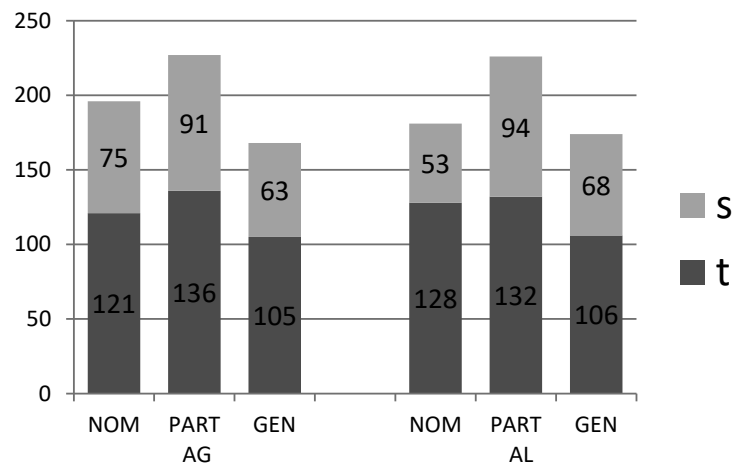

Схема 1. Средняя длительность компонентов аффрикаты $t s$ в различных падежных формах

Diagram 1. Average duration of the components within the affricate $t s$ in three case forms

16 Под «существенно» мы подразумеваем разницу, сопоставимую с различием длительности сильно- и слабоступенных аффрикат в приведенном выше водском примере или с различием одиночного согласного и геминаты в ижорском, см. [Markus 2011: 112]. Небольшое же сокращение длительности аффрикаты в форме генитива по сравнению с формой номинатива ожидается в силу изохронности стопы (то есть тенденции стопы сохранять одинаковую длительность), см. [Кузнецова 2009б: 35-37, Markus 2010: 47-48]. Ср., например, различие между слабой и сильной ступенями аффрикаты в приведенном водском примере (Таблица 1), которое находится в интервале от 74 до 117 мс, и значительно меньшее различие по длительности у ижорских геминат в открытом и закрытом слоге (по [Маркус 2010: 47] это различие составляет в среднем 46 мс для долгой геминаты и 27 мс для краткой). 
Аффриката $t s$ в генитиве, вне всякого сомнения, отличается от $t s$ в партитиве как меньшей длиной отдельных компонентов, так и меньшей общей длиной. Во всех случаях разница статистически значима $\left(\mathrm{p}<1^{*} 10^{-4}\right)$. Однако различие $t s$ в номинативе и генитиве уже не столь впечатляюще. У носителя языка $\mathrm{AG}$ различие общей длины аффрикат и компонента $t$ статистически значимо ( $\mathrm{p}<0,001$ и $\mathrm{p}=0,003$ соответственно). Однако различие длин компонента $s$ (75 и 63 мс соответственно) оказывается на границе статистической значимости $(\mathrm{p}=0,036){ }^{17}$ и возможно меньше дифференциального порога восприятия по длительности ${ }^{18}$. У носителя AL ситуация несколько отличается: различия длин у компонентов $s$ статистически значимы $\left(\mathrm{p}<1 * 10^{-4}\right)$, однако за счет того, что в номинативе $t$ несколько длиннее, а $s$ несколько короче, различие общих длин аффрикат в формах номинатива и генитива (181 и 174 мс соответственно) статистически не значимо.

При этом статистически значимым оказывается различие длин аффрикат в формах номинатива и партитива $\left(\mathrm{p}<1 * 10^{-4}\right)$, которые не могут различаться ступенью аффрикаты, но имеют отличную структуру (в номинативе конечный гласный краткий, а в партитиве долгий) ${ }^{19}$.

Таким образом, мы видим совсем не такую картину, которую наблюдали в водском языке. Долгота аффрикаты существенно зависит от структуры слова, но яркого отличия аффрикат в формах, потенциально различающихся ступенью, не наблюдается. В водском языке $t s$

17 Следует обратить внимание на интерпретацию р-значения, являющегося ключевым при формулировании выводов статистического анализа. Традиционно выделяются два значения 0,05 и 0,01, называемые «уровнем значимости», см., например, [Levshina 2015: 11-12]. Принято считать, что величина р-значения, меньшая 0,05 (то есть низшего уровня статистической значимости) свидетельствует о наличии различия между выборками, а 0,01 (достаточный уровень значимости) является уже совсем надежным свидетельством. Основываясь на собственном опыте фонетических измерений, мы исходим из несколько отличной интерпретации. Р-значения от 0,05 до 0,01 мы считаем свидетельством возможных, но не достоверных различий, р-значение от 0,01 до 0,001 мы рассматриваем как наличие различия между выборками, но не совсем уверенного, а значения ниже 0,001 интерпретируются как свидетельствующие о надежном различии.

${ }^{18}$ К сожалению, экспериментально полученные данные о дифференциальном пороге восприятия по длительности для сойкинского ижорского отсутствуют [Brodskaya 2015: 22].

${ }_{19}$ См. [Кузнецова 2013] об удлинении сегментов в формах партитива по сравнению с формами номинатива. 
и tts по длительности похожи на прочие согласные (длительность одиночного согласного обычно находится в интервале 60-110 мс, а геминаты - в интервале 130-200 мc). Сравнение же ижорской аффрикаты $t s$ с прочими согласными не выявляет подобного сходства. Так в [Markus 2011: 115] приводятся долготы взрывных в сойкинском ижорском: средняя длительность одиночного составляет 97 мс (структуры kada 'крыть. IMP.2SG', saada 'провожать.IMP.2SG', maadaa 'спать.IMPRS.PRS'), средняя длительность полной геминаты после долгого гласного составляет 245 Mc (структуры vuutta 'год.PART', saattaa 'провожать.PRS.3SG'), а средняя длительность полной геминаты после краткого гласного составляет 289 мс (структуры kukka 'цветок.NOM', tappaa 'убивать.PRS.3sG'). В нашем ижорском материале нет никаких намеков на существование варианта $t s$, сопоставимого с длительностью одиночного согласного ${ }^{20}$.

Обратим внимание, что [Sovijärvi 1944: 15-16] различает у $t s$ сильную и слабую ступень, которые отличаются длительностью компонента $t$, но при этом отмечает связь длительности с открытостью/ закрытостью слога. Кроме того, он выделяет «вторичную сильную ступень» ${ }^{21}$, возникшую в формах косвенных падежей, где отпал конечный гласный, удлинился предшествующий гласный, а перед ним произошло удлинение консонантного кластера или $t s$.

Эта «вторичная сильная ступень» зафиксирована и нашими экспериментами. От носителя языка AL были записаны произнесения форм слова 'лес' в серединной позиции: номинатив metsä, генитив metsän, партитив metsä̈̈, иллатив metsä̈̈, инессив metsä̈̈ž, элатив metsääšt, см. Таблицу 2 (с. 457). «Вторичная сильная ступень» ожидалась в инессиве и элативе, поскольку в этих падежах произошло отпадение конечного гласного с последовавшим продлением предыдущего гласного. Сравнение долгот показало, что между аффрикатами в инессиве и генитиве, а также в инессиве и партитиве существует статистически значимое различие $(\mathrm{p}<0,01)$, а между аффрикатами в инессиве и номинативе его нет $(\mathrm{p}>0,05)$. Также есть различие между элативом

20 Здесь и далее, сопоставляя длительности различных сегментов, мы учитываем, что сегменты разного качества могут различаться по длительности (см., например, [Lehiste 1976: 227]). Этот вопрос будет обсуждаться ниже, см., в частности, Таблицу 9.

21 Этот термин, предложенный А. Совиярви, не выглядит очень удачным. Описываемое явление имеет природу, отличную как от чередования ступеней, так и от геминации. 
и партитивом $(\mathrm{p}<0,01)$, на грани стирания различие между элативом и генитивом $(p=0,014)$, и отсутствует различие между элативом и номинативом. При этом все наблюдаемые различия опять-таки выглядят как небольшое варьирование, обусловленное структурой формы, но не как контраст, характерный для полноценного чередования ступеней.

Таблица 2. Длительность аффрикаты в формах слова metsä 'лес'

Table 2. The duration of the affricate in the forms of the word metsä 'forest'

\begin{tabular}{|l|r|r|r|r|r|c|}
\hline & GEN & NOM & ELAT & INESS & ILL & PART \\
\hline Ср. длительность & 171 & 185 & 189 & 196 & 210 & 229 \\
\hline Ст. отклонение & 21 & 22 & 18 & 23 & 25 & 25 \\
\hline Кол-во произнесений & 15 & 11 & 16 & 11 & 11 & 8 \\
\hline
\end{tabular}

Среди прочего А. Совиярви приводит сведения о длительности аффрикаты $t s$ в формах номинатива, партитива и генитива единственного числа для слова metsä ‘лес' [Sovijärvi 1944: 15], что позволяет сопоставить эти данные с нашими. Считая первые две формы содержащими сильную ступень, он рассматривает среднее арифметическое длин аффрикаты и сравнивает с длиной аффрикаты в генитиве, где, по его мнению, представлена слабая ступень.

В Таблице 3 (с. 458) приводится сопоставление данных А. Совиярви с нашими данными (носители AG и AL, от слов mets ̈̈ 'лес', vatsa 'живот' и vitsa 'прут' для каждого носителя записано по 15-20 произнесений форм номинатива и форм партитива и по 30-40 произнесений форм генитива). В качестве длительности «сильноступенной» аффрикаты (S) берется среднее арифметическое длин в формах номинатива и партитива, а в качестве длительности «слабоступенной» аффрикаты $(\mathrm{W})$ берется длина $t s$ в форме генитива. В двух правых колонках рассматривается разность длин и отношение длин. Как несложно заметить, тенденции, наблюдаемые у А. Совиярви, вполне сохранились ${ }^{22}$, хотя

22 А. Лаанест отмечает, что его наблюдения «в основном совпадают с наблюдениями А. Совиярви, но надо добавить, что в настоящее время в сойкинском диалекте чередование при вышеупомянутых условиях [т. е. чередование, зависящее от открытости слога. — Ф. Р. \& E. M.] нерегулярно» [Лаанест 1978: 78]. Э. Саар поддерживает утверждение А. Лаанеста: «However, nowadays the quantitative alternation in the dialect of Soikkola is not as consistent under the conditions described above» [Saar 2014: 261]. 
стали несколько менее выраженными (как в абсолютном, так и в относительном значении). Это вполне соответствует тенденции сокращения длительности долгих сегментов, см., например, про ижорские гласные [Markus 2011: 100] ${ }^{23}$.

Таблица 3. Длительность аффрикаты $t s$ по разным источникам

Table 3. The duration of the affricate $t$ in different sources

\begin{tabular}{|l|c|l|l|l|}
\hline \multicolumn{1}{|c|}{ Источник } & $\mathbf{S}=\left(\boldsymbol{t s}_{\text {Noм }}+\boldsymbol{t s}_{\text {PART }}\right) / \mathbf{2}$ & $\mathbf{W}=\boldsymbol{t s}_{\text {GEN }}$ & $\mathbf{S}-\mathbf{W}$ & $\mathbf{W} / \mathbf{S}$ \\
\hline Sovijärvi 1944 & 282,5 & 207,5 & 75 & 0,73 \\
\hline AG & 211,5 & 168 & 43,5 & 0,79 \\
\hline AL & 203,5 & 174 & 29,5 & 0,86 \\
\hline
\end{tabular}

Для полноты картины приведем результаты еще одного эксперимента. Он основан на материале, полученном от другой носительницы сойкинского ижорского (родилась в 1936 году в д. Вистино и живет там до настоящего времени). От нее были записаны в конечной позиции пять падежных форм слова voloitsa 'д. Валяницы': генитив, партитив, иллатив, инессив и элатив. Средняя длина аффрикаты и стандартное отклонение представлены в Таблице 4. Падежи расположены в порядке увеличения длительности аффрикаты.

Таблица 4. Длительность аффрикаты в различных формах слова voloitsa 'Валяницы'

Table 4. The duration of the affricate in different forms of the word voloitsa

\begin{tabular}{|l|r|r|r|r|c|}
\hline & ELAT & GEN & INESS & ILL & PART \\
\hline Ср. длительность & 178 & 179 & 200 & 205 & 219 \\
\hline Ст. отклонение & 17 & 20 & 24 & 26 & 17 \\
\hline Кол-во произнесений & 5 & 11 & 5 & 5 & 6 \\
\hline
\end{tabular}

Как мы видим, средняя длительность этих пяти форм распределена на интервале примерно 40 мс. Ни у каких двух соседних форм длительность не различается настолько, чтобы демонстрировать статистически достоверную разницу. Однако отличие партитива от элатива и генитива

23 Отметим, что в отличие от нас А. Совиярви использует изолированные произнесения, что может дать несколько бо́льшие долготы по сравнению с произнесениями в середине предложения. 
статистически значимо $(\mathrm{p}<0,01)$. Обратим внимание, что анализируемое слово трехсложное. Можно было ожидать, что различия в длительности аффрикаты будут либо такими же, как у форм двухсложных слов, либо несколько нивелированными. Действительно, разница между партитивом и генитивом оказывается чуть меньше (58 мс для двухсложной и 41 мс для трехсложной формы) ${ }^{24}$, но общая тенденция сохраняется. При этом разница в длительности аффрикаты между генитивом и элативом полностью потеряна.

Таким образом, наш материал не противоречит данным А. Совиярви, но расхождение возникает на уровне интерпретации: Совиярви называет ступенями различия в длительности, которые обусловлены структурой формы, в нашем же понимании эти различия не являются ступенями ${ }^{25}$, а возникают в силу других причин, в частности, изохронности стопы и удлинения согласного перед компенсаторно удлиненным гласным.

Отсутствие у аффрикаты четкой оппозиции сильноступенного и слабоступенного вариантов является свидетельством того, что $t s$ не является отдельной фонемой.

Критерий 5. Относительная длительность компонентов консонантного кластера

Этот критерий основывается на гипотезе о том, что, если $t s$ является обычным консонантным кластером, то его поведение должно быть схоже с кластером $k \grave{s}$, также состоящим из взрывного и фрикативного ${ }^{26}$, то есть отношение длин $k / \check{s}$ должно примерно равняться отношению длин $t / s^{27}$.

${ }^{24}$ Такой эффект может быть как результатом различия в структуре слов, так и результатом различий в говорах или идиолектах.

25 Конечно, исходно все чередования ступеней были обусловлены фонетическим контекстом [Лаанест 1975: 34], но затем они фонологизировались, и их жесткая детерминация фонетическим контекстом была потеряна.

${ }^{26}$ Мы не рассматриваем кластер $p \check{s}$ по двум причинам. Во-первых, он реже встречается в ижорских словах, и сбор данных в количестве, достаточном для фонетического анализа, был бы затруднительным. Во-вторых, длительность лабиального согласного может существенно отличаться от длительности нелабиального (см. Таблицу 9), что затрудняет сопоставление длительностей $p \check{s}$ и $t s$.

27 Следует подчеркнуть, что здесь разговор идет именно о примерной близости отношений. Ожидать точного совпадения не приходится, поскольку у согласных 
Для проверки гипотезы был проведен эксперимент, в котором сравнивались две группы произнесений. В первой группе содержались формы с кластером $k s ̌$ (okšan 'ветка.GEN', makšan 'платить.PRS.1SG'), во второй - с аффрикатой ts (vatsan 'живот.GEN', metsän 'лес.GEN'). Все формы были одинаковой структуры и были произнесены в серединной позиции. Данные были записаны от двух носителей языка (AG и $\mathrm{AL})$, по 30-40 произнесений на каждую группу слов.

Результаты эксперимента представлены на Схеме 2 (см. также Таблииу 8 в Приложении).

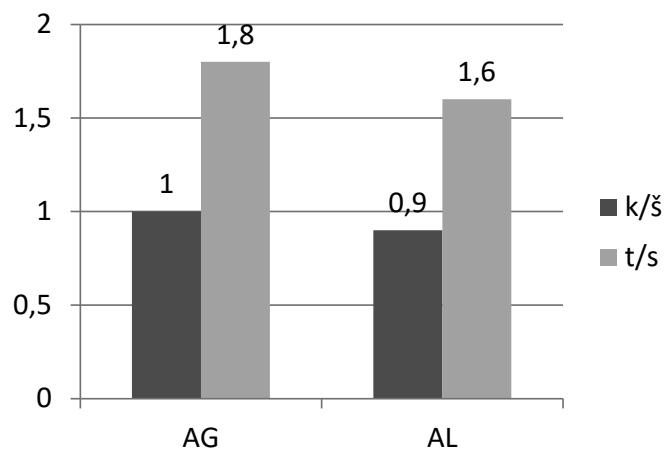

Схема 2. Относительная длительность компонентов кластера $k \check{s}$ и аффрикаты $t s$

Diagram 2. The relative duration

of components of the cluster $k \grave{s}$ and of the affricate $t s$

У обоих носителей языка наблюдается похожая картина: в кластере $k \grave{s}$ длины его компонентов примерно одинаковы, что и ожидается от двух отдельных фонем (при условии, что эти фонемы не являются максимально разнесенными на шкале собственной длительности фонем).

может различаться собственная длительность. Однако собственная длительность рассматриваемых согласных ( $k$ vs $t$ и $\check{s}$ vs $s$ ) не должна давать серьезного расхождения. Нелабиальные взрывные близки по длительности (ср. с представленными в Таблице 9 данными для звонких взрывных). Возможность замерить собственную длительность $s$ вне $t s$ отсутствует (как было сказано выше, в ижорских словах $s$ перешел в $\check{s}$, сохранившись только в $t s)$, но оба согласных ( $s$ и $\check{s}$ ) совпадают по способу образования и глухости / звонкости и лишь немного различаются по месту образования. 
Однако в аффрикате $t s$ мы видим совершенно другую ситуацию: длительность $t$ превышает длительность $s$ более чем в полтора раза: средняя длина $t$ составляет 105 мс для AG и 106 мс для AL (стандартное отклонение 16 и 18 мс соответственно), а средняя длина $s-63$ мс для AG и 68 мс для AL (стандартное отклонение 17 и 13 мс соответственно).

Такое поведение аффрикаты $t s$ не характерно для консонантных кластеров.

Критерий 6. Общая длительность консонанта / консонантного кластера

Выше в Разделе 4 в контексте чередования ступеней уже обсуждались вопросы, связанные с длительностью аффрикаты. Рассмотрим еще один эксперимент, в котором проводилось сопоставление длительности аффрикаты с консонантным кластером и одиночным согласным. В эксперименте сравнивались три группы произнесений, одна из которых содержала аффрикату $t s$, другая — консонантный кластер $k s ̌$, а третья согласный $\check{z}$ в интервокальной позиции ${ }^{28}$. Данные по первым трем группам были такие же, как и в предыдущем эксперименте, а для третьей группы было взято 15-20 произнесений, также в серединной позиции.

Таким образом, сравнивались три группы произнесений:

1. Структура CVkšVC (например, okšan 'ветка.GEN').

2. Структура CVtsVC (например, vatsan 'живот.GEN').

3. Структура CVžVC (например, kežän 'лето.GEN').

Как видно из Схемы 3 ниже, длительность аффрикаты очень близка к длительности консонантного кластера, но значительно превосходит длительность одиночного консонанта ${ }^{29}$.

${ }^{28}$ Конечно, чтобы уменьшить зависимость от собственной длительности звуков, было бы удобнее сравнивать кластер и аффрикату с глухим одиночным согласным. Но в интервокальной позиции одиночные согласные реализуются как звонкие (исключением является согласный $h$, но он неудобен из-за большой вариативности в длительности, см. Таблицу 9).

${ }^{29}$ В Таблице 9 приведены собственные длительности различных согласных. На фоне одиночных согласных, у которых весь диапазон варьирования собственной длительности составляет менее 50 мс (от 56 мс для $n$ до 103 мс для $b$ ), длительность $t s$ явно не может быть объяснена таким варьированием (ср. с рассмотренными выше водскими примерами, где собственная длительность аффрикаты близка к длительности одиночного согласного). 


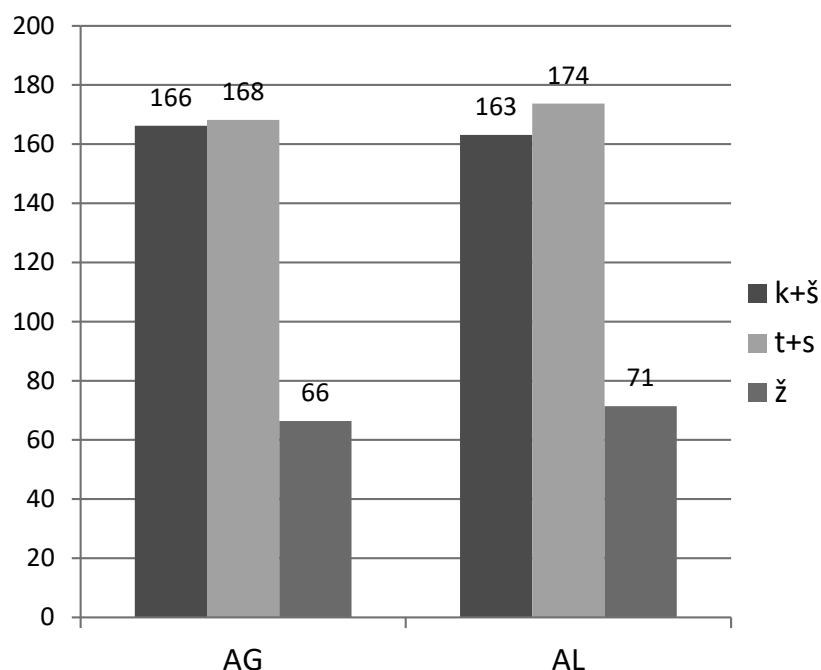

Схема 3. Соотношение длительности кластера $k \check{s}$, аффрикаты $t s$ и одиночного согласного $\check{z}$

Diagram 3. Comparison of the duration of the cluster $k \grave{s}$, of the affricate $t s$ and of the singleton $\check{z}$

Таким образом, по данному критерию аффриката сближается с консонантным кластером, но никак не с одиночным согласным.

Критерий 7. Отсутствие редукции второго гласного в структурах типа $\mathrm{CVCV}$

В прибалтийско-финских языках особое место занимает стопа структуры (C) $\mathrm{VCV}(\mathrm{C})^{30}$, где длительность второго гласного оказывается большей, чем у кратких гласных непервого слога в других структурах (см., например, [Suomi et al. 2008: 76]). Традиционно это явление считается чисто фонетическим и обычно даже не отражается в транскрипционной записи. Однако на фоне различных редукционных процессов его значение выходит за пределы чистой фонетики. Например, в водском языке краткие гласные в рассматриваемой структуре

30 Далее для краткости мы будем обозначать эту структуру CVCV, аналогично и для других структур мы будем использовать упрощенные обозначения, например, CVCCV вместо (C)VCCV(C). 
не подверглись качественной редукции, ср. например, лаіп $\hat{\boldsymbol{\varepsilon}}<$ лаina 'волна' (CVVCV) и kana 'курица' < kana (CVCV), jaлgessâ 'нога.ELAT' < jaлga- + -ssa (CVCCV) и lihassâ 'мясо.ELAT' < liha- + -ssa (CVCV). В peзультате изменилась система парадигматических классов.

Хотя в сойкинском ижорском редукция гласных непервого слога не фонологизировалась ${ }^{31}$, она очень заметна: длительность гласных сокращается, а краткие гласные $a$ и $\ddot{a}$ существенно меняют качество (за исключением описываемой структуры CVCV).

Таким образом, формы lehmän 'корова.GEN' и nenän 'нос.GEN' различаются не только согласными, но и вторым гласным: в lehmän (структура CVCCV) длительность V2 меньше, а подъем выше, чем в пепӓn (структура CVCV). На Рисунках 8 и 9 представлены спектрограммы указанных форм, записанные от носителя AG.
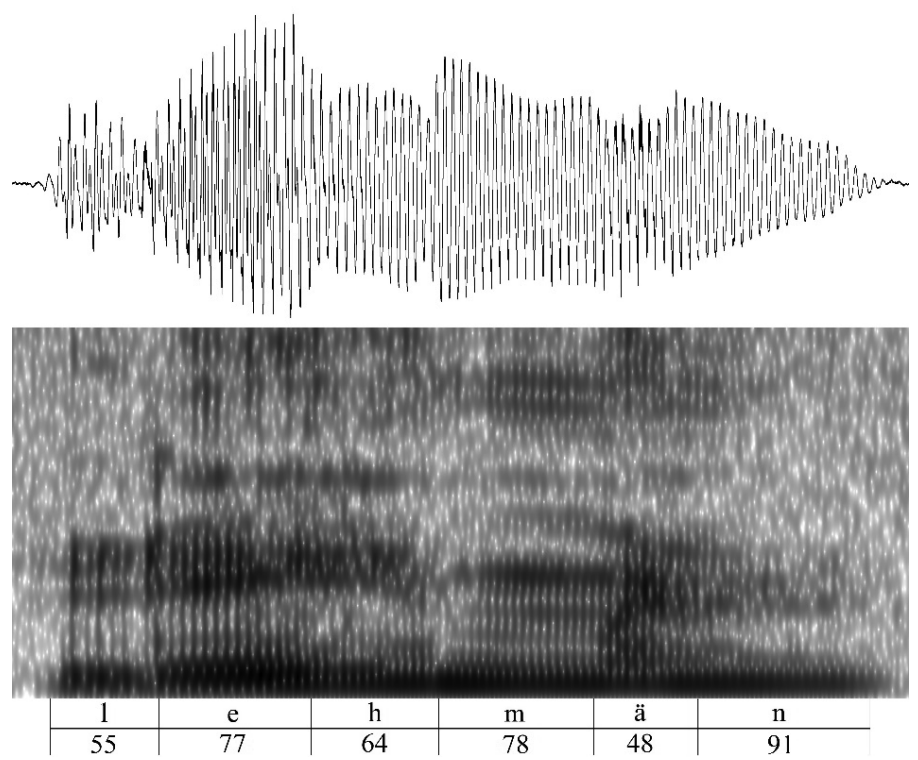

Рисунок 8. Ижорская форма lehmän 'корова.GEN'

Figure 8. Ingrian form lehmän 'cow.GEN'

${ }^{31}$ Имеется в виду, что при намеренно четком произнесении произносится исходный краткий гласный. 

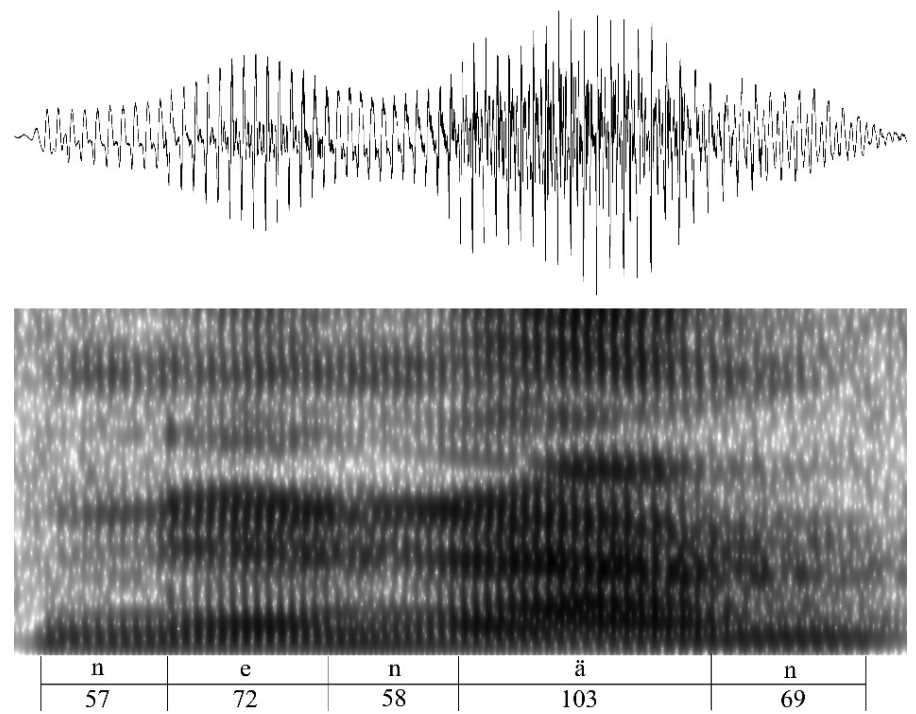

Рисунок 9. Ижорская форма пепӓn 'Hоc.GEN'

Figure 9. Ingrian form nenän 'nose.GEN'

Длительность второго гласного в пепӓп существенно больше, чем в lehmän (103 мс против 48 мс). Различаются эти гласные и по качеству. Если вторая и третья форманты в пепӓn $(\mathrm{F} 1=738, \mathrm{~F} 2=1767, \mathrm{~F} 3=2501$ Гц и в lehmän (F1=428, F2=1690, F3=2428 Гц) более или менее близки, то первая форманта существенно отличается: в lehmän второй гласный значительно более закрытый, чем в nenän.

Описанное явление позволяет провести тест, сравнив количество и качество второго гласного в словах структуры CVts V с гласными в словах двух описанных выше типов. Гипотеза эксперимента по количественной редукции была следующая: если $t s$ является одиночной фонемой, то V2 в словах структуры CVtsV должен быть продленным (как, например, в форме [nenän]). Если же нет, то длина V2 в metsän должна быть близка к длине V2 в форме [lehmă̈n].

Для эксперимента было взято по 30-50 произнесений на каждый из трех типов:

1. Структура CVCV (например, nenän 'нос.GEN').

2. Структура CVCCV (например, lehmän 'корова.GEN').

3. Структура CVtsV (например, metsän 'лес.GEN'). 
Все формы были записаны в серединной позиции в предложении. Вторым гласным был всегда $a$ или $\ddot{a}$ (длительности этих двух гласных не демонстрировали существенных различий).

На Схеме 4 представлена средняя длительность V2 относительно V1 (использование относительной, а не абсолютной длительности позволяет нивелировать эффект различной скорости произнесений).

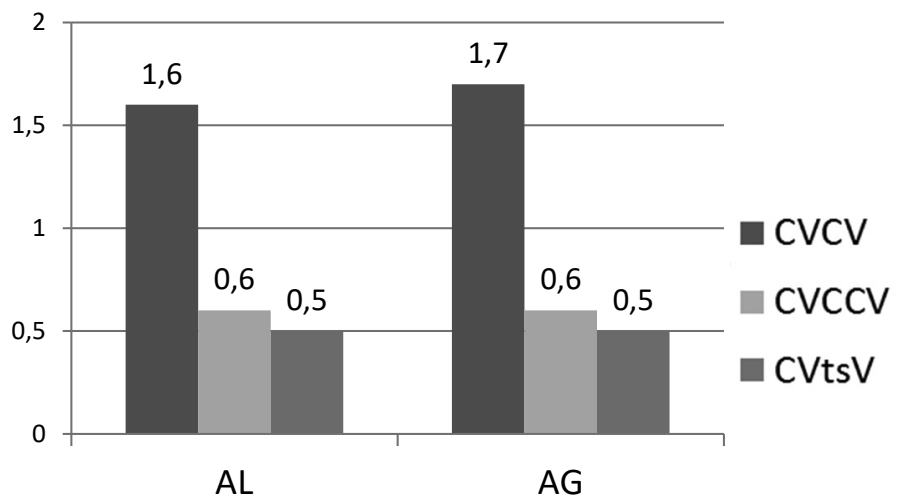

Схема 4. Длительность V2 относительно V1 в словах различных структур

Diagram 4. The ratio of V2 to V1 in words of different structures

Как несложно заметить, в словах структуры CVCV второй гласный в полтора с лишним раза длиннее первого, в то время как в остальных двух структурах он примерно в два раза короче первого. Таким образом, аффриката не ведет себя как одиночная фонема.

Для анализа качественной редукции было проведено два эксперимента, поскольку анализ заднерядных и переднерядных слов следовало проводить отдельно.

Гипотеза эксперимента была следующая: если $t s$ является одиночной фонемной, то V2 в форме vatsan должен быть близок по качеству к V2 в форме kanan. Если же нет, то он должен быть близок к V2 в okšan. Аналогичным образом качество V2 в metsän должно быть близко либо к пепӓn, либо к lehmän. Анализировались следующие типы форм: 
1. Структура CVCVC (например, заднерядное kanan 'курица.GEN', переднерядное пепӓn 'нос.GEN').

2. Структура CVCCVC (например, заднерядное kaglan 'шея.GEN', переднерядное lehmän 'корова.GEN').

3. Структура CVtsVC (например, заднерядное vatsan 'живот.GEN', переднерядное metsän 'лес.GEN').

На каждый тип было взято 20-40 произнесений ключевых слов, записанных в серединной позиции.

Также в качестве «эталона» для заднерядных слов был рассмотрен первый (ударный) гласный $a$ (в тех формах, где он присутствовал),

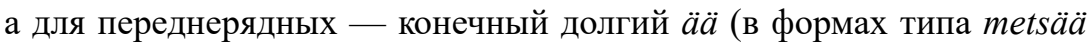
'лес.PART').

Результаты эксперимента показали, что значения F2 и F3 не демонстрируют существенного различия у полного и редуцированного гласного. Однако F1 демонстрирует такое различие. На Схемах 5 и 6 представлены средние частоты F1 для заднерядных и переднерядных форм соответственно.

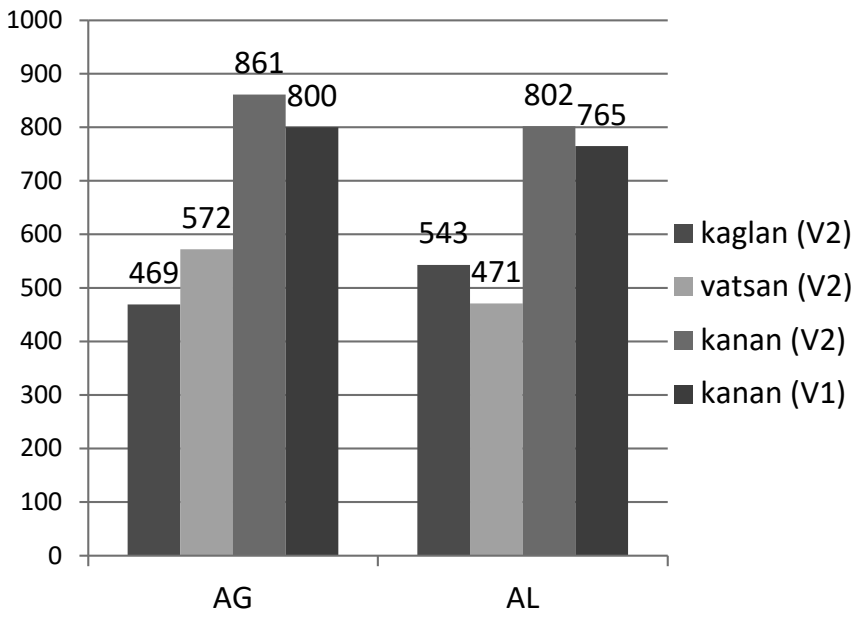

Схема 5. Величина F1 (Гц) для гласного в заднерядных словах различных структур

Diagram 5. F1 value (Hz) of the vowel in back-vocalic words of different structures 


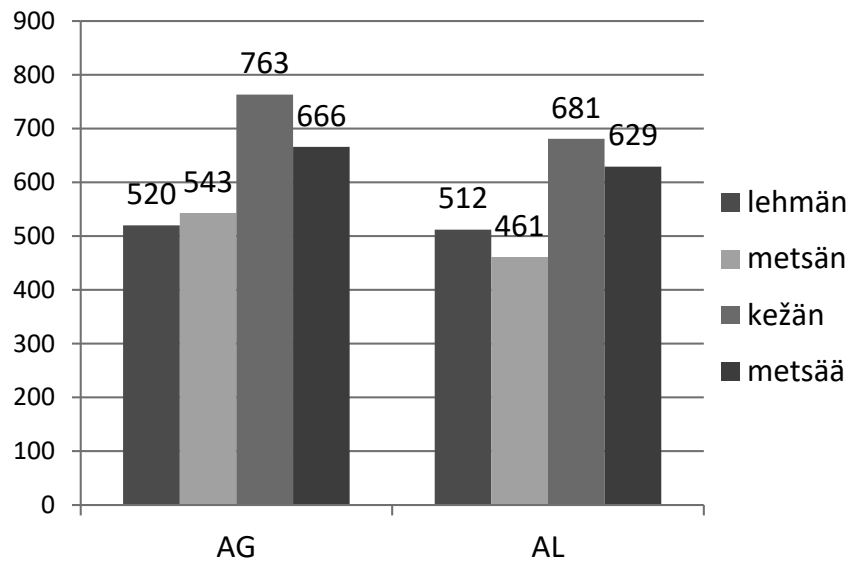

Схема 6. Величина F1 (Гц) у второго гласного в переднерядных словах различных структур

Diagram 6. F1 value $(\mathrm{Hz})$ of the second vowel in front-vocalic words of different structures

И заднерядные, и переднерядные формы демонстрируют примерно одну и ту же картину: в двух формах наблюдаются более открытые гласные (второй гласный в CVCV и эталонный гласный), а в двух - более закрытые (CVCCV и слова с аффрикатой).

Различие между любым «открытым» и любым «закрытым» гласным всегда статистически значимо $\left(\mathrm{p}<1 * 10^{-6}\right)$. Различия между открытыми или между закрытыми гласными зависят от носителя языка и могут быть как статистически незначимы, так и статистически значимы, но лишь в одном случае $\mathrm{p}<0,001$ (различие между гласными в типе kežän и теtsä̈̈ у носителя AG).

Таким образом, гласный после аффрикаты несомненно ближе к более закрытому редуцированному гласному в словах структуры CVCCV, чем к нередуцированным открытым гласным. Таким образом, рассматриваемый гласный подвержен и количественной, и качественной редукции. Это не позволяет рассматривать аффрикату $t s$ как одиночный согласный. 


\section{4. Фонологическая интерпретация аффрикаты ts}

Рассмотрим, как результаты проведенных фонетических исследований сказываются на фонологической интерпретации аффрикаты $t s$. В Таблице 5 представлена оценка $t s$ по каждому из семи критериев.

Таблица 5. Оценка статуса $t s$ на основе использованных критериев

Table 5. Assessment of the status of $t s$ based on the proposed criteria

\begin{tabular}{|l|c|c|}
\hline \multicolumn{1}{|c|}{ Критерий } & $\begin{array}{c}\text { Консонантный } \\
\text { кластер }\end{array}$ & $\begin{array}{c}\text { Одна } \\
\text { фонема }\end{array}$ \\
\hline 1. Переход свистящих в шипящие & нет & да \\
\hline 2. Структура смычки у аффрикаты & нет & да \\
\hline 3. Невозможность появления в начале слова & да & нет \\
\hline $\begin{array}{l}\text { 4. Чередование ступеней } \\
\text { к. Относительная длительность компонентов } \\
\text { консонантного кластера }\end{array}$ & нет \\
\hline $\begin{array}{l}\text { 6. Общая длительность консонанта/ } \\
\text { консонантного кластера }\end{array}$ & да & нет \\
\hline $\begin{array}{l}\text { 7. Отсутствие редукции второго гласного } \\
\text { в структурах СVCV }\end{array}$ & да & нет \\
\hline
\end{tabular}

Как несложно заметить, ни один из двух вариантов ( $t s$ является консонантным кластером vs $t s$ является одной фонемой) не демонстрирует очевидного доминирования. Таким образом, проведенное исследование раскрывает двойственную природу ижорской аффрикаты $t s$, которая содержит как признаки одиночной фонемы, так и признаки консонантного кластера, выводя нас за рамки примитивной дихотомии «фонема vs сочетание фонем». Исследователь, описывающий фонологию языка и, тем самым, вынужденный принять какое-либо решение, оказывается перед выбором: либо объявить $t s$ аномальной фонемой, либо считать $t s$ аномальным кластером. Подчеркнем, что рассмотренные критерии несомненно различаются по своей значимости, но поскольку никаких объективных оценок веса этих критериев не существует, решение о значимости критериев (и соответственно о статусе $t s$ ) принимается каждым исследователем индивидуально. Рассмотрим проблемы, которые возникают при каждом из выбранных вариантов. 
Если исследователь признает $t s$ фонемой, то противоречия возникают с критериями 3, 4, 6 и 7. Критерий 6 (общая длительность) не создает системных проблем. Если объявить большую длительность специфическим свойством одной фонемы, то это не скажется на описании консонантизма в целом. Не является серьезной проблемой и критерий 3 (позиция в начале слова). Можно предположить, что $t s$ избегает начальной позиции как кластер, но можно допустить, что фонотактические требования накладываются и на определенные фонемы (само по себе это не является чем-то уникальным). Поэтому системного противоречия здесь тоже не возникает. Отсутствие чередования ступеней (критерий 4) представляется нетипичным для фонологизированной аффрикаты (по крайней мере, на фоне водского и карельского языков). Однако наиболее проблематичным оказывается критерий 7. $\mathrm{B}$ соответствии с ним $t s$ никак не может быть одиночной фонемой. Можно, конечно, представить $t s$ как особую «сильную / долгую» фонему, не имеющую одиночного коррелята (то есть не как аналог одиночного $b$, а как аналог геминаты $p p$ ). С формальной точки зрения наличие редукции в структуре CVtsV будет тогда объяснимым. Однако введение долгой фонемы без краткого коррелята выглядит неоправданным с точки зрения фонологической типологии ${ }^{32}$. Фактически же введение такой «долгой» фонемы означает то же самое признание $t s$ аномальной фонемой.

Если же $t s$ признается консонантным кластером, то противоречия возникают с критериями 1, 2 и 5. Если несоответствия критериям 2 (структура смычки) и 5 (относительная длительность) не несут системного характера и могут быть объяснены специфическими фонетическими процессами, по каким-то причинам характерными именно для данного сочетания консонантов, то критерий 1 создает очень серьезную

32 Для проверки этого тезиса мы просмотрели 317 фонологических инвентарей генетически и типологически различных языков из [UPSID 1981]. Долгие фонемы без краткого коррелята были отмечены в консонантных инвентарях следующих языков: (1) в финском велярный назальный $\eta$ : с пометой, что сегмент иногда рассматривается как фонема, но также может рассматриваться как образованный из других сегментов; (2) в японском глухая дентоальвеолярная аффриката $t s:$ и глухая палатальная аффриката с̧: - обе с аналогичной пометой; (3) в гренландском эскимосском глухой лабиовелярный фрикативный $f:$, который тоже является периферийным (ср., например, с описанием [Вахтин 1996: 94], где данная фонема отсутствует). Таким образом, ни в одном из 317 языков не было обнаружено чистого примера долгой согласной фонемы, существующей в отсутствие краткой. 
проблему, затрагивающую фонологическую систему в целом. Рассмотрим эту проблему подробнее. В сойкинском диалекте произошел переход свистящих в шипящие. При этом в более архаичных идиолектах правило перехода распространялось на все случаи появления $s$, то есть даже заимствованные слова произносились с $\check{s}$. В таких идиолектах coxранение $s$ пусть даже в определенном сочетании выглядит очень странно. Но еще проблематичнее оказываются инновационные идиолекты, где многие заимствования из русского произносятся именно с $s$ и соответственно противопоставление шипящих и свистящих сохраняется. С какой из фонем ( $s$ или $\breve{s})$ в таком случае следует отождествлять $s$ в сочетании $t s$ ? Если с $s$, то, во-первых, маргинальность $s$ как фонемы из заимствованной лексики полностью теряется, во-вторых, фонологическая система становится особенно хаотичной из-за имеющего место варьирования $s$ или $\breve{s}$ в произнесении заимствований (ранее это можно было объяснять маргинальностью $s$, но при рассматриваемом подходе это объяснение уже не годится). Отождествление же $s$ с $\check{s}$ в сочетании $t s$ противоречит всем принципам фонологии: у фонемы появляются два аллофона, один из которых полностью совпадает с основным аллофоном другой фонемы.

\section{5. Замечания об аффрикате $t \check{s}$}

В данной работе не проводилось детальное исследование второй

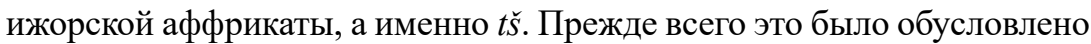
отсутствием необходимого количества материала. Тем не менее для полноты картины необходимо провести краткое сопоставление $t s ̌$ и $t s$.

Рассмотрим те же критерии, которые применялись нами для оценки аффрикаты $t s$.

Критерий 1 (переход свистящих в шипящие) для $t \check{s}$ нерелевантен. По всей видимости, аффриката $t \check{s}$ существовала еще до этого перехода. А. Лаанест отмечает, что $t \check{s}$ «встречается, кроме русских заимствований, в ряде звукоподражательно-дескриптивных слов, из которых часть имеет соответствия и в родственных языках; возможно, что в таких случаях имеется дело с продолжателем палатализованной аффрикаты финно-угорского происхождения» [Лаанест 1978: 85]. Скоpeе всего, именно наличие аффрикаты $t \check{s}$ блокировало переход $t s$ в $t \check{s}$, иначе аффриката $t \check{s}$ совпала бы с кластером $t+s$, превратившимся в $t+\check{s}$. 


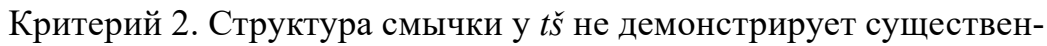
ных отличий от смычки в консонантном кластере. У $t \check{s}$ не наблюдается такой сильной интерференции двух компонентов аффрикаты, как у $t s$.

Критерий 3 (позиция в начале слова). Существует немало слов, начинающихся на $t \check{s}$ (в словаре [Nirvi 1971] их количество существенно превышает сотню). В этом смысле $t \grave{s}$ не отличается от обычных одиночных согласных.

Критерий 4. Чередование ступеней.

В подавляющем большинстве ижорских слов, содержащих аффрикату $t \check{s}$, эта аффриката оказывается в позиции, где чередование ступеней невозможно, например, lutšikkain 'клоп' (здесь чередуется только согласный $k k$ ), tšagattaa 'стрекотать (о сороке)' (чередование невозможно в начале слова), pitška 'спичка' (в ижорском языке первый согласный кластера не бывает подвержен чередованию).

Нам известны только три слова, где следовало бы ожидать чередования $t \check{s}$, если бы в принципе оно было допустимо: kläätšü 'мышиный горошек', daatša 33 'дача', zadatšu 'задача'.

В Таблице 6 представлены данные эксперимента, проведенного на материале, записанном от носительницы сойкинского ижорского, родившейся в 1930 году в д. Репино. В таблице указана длительность аффрикаты в формах слова 'мышиный горошек': номинатив klä̈̈tšü, партитив kläätšüä, генитив kläätšün и номинатив множественного числа kläätšüd (последние две формы объединены вместе - они имеют одинаковую структуру и не демонстрируют существенного различия по длительности сегментов).

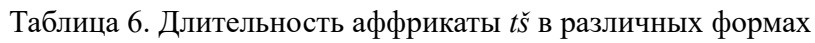
слова klä̈̈tš̈̈ 'мышиный горошек'

Table 6. Duration of the affricate $t s ̌$ in different forms of the word kläätšü 'tufted vetch (Vicia cracca)'

\begin{tabular}{|l|c|c|c|}
\hline & GEN/PL.NOM & NOM & PART \\
\hline Ср. длительность & 216 & 241 & 251 \\
\hline Ст. отклонение & 40 & 24 & 26 \\
\hline Кол-во произнесений & 5 & 4 & 9 \\
\hline
\end{tabular}

33 Обратим внимание, что в [Nirvi 1971: 27] это слово приводится с кратким первым гласным: datša. У трех опрошенных нами носителей языка это слово было с долгим гласным. 
Как несложно заметить, в целом картина очень похожа на ту, которую мы наблюдали для аффрикаты $t s$ (с точностью до темпа речи, свойственного конкретному идиолекту). Формы с закрытым вторым слогом (генитив единственного и номинатив множественного числа) несколько короче (разница с партитивом, возможно, значима: $\mathrm{p}=0,015$, разница с номинативом незначима: $p>0,05)$, но не настолько, чтобы предполагать здесь наличие чередования ступеней. Этот вывод также подтверждает приведенная в Приложении Таблица 10, где указаны длины аффрикаты $t \check{s}$ в различных формах слова daatša 'дача'.

Обратим внимание еще на один факт: кроме указанных данных, в нашем материале имеется еще около двадцати произнесений тех форм слов daatša 'дача' и zadatšu задача', в которых при чередовании могла бы наблюдаться слабая ступень. Эти произнесения записаны от разных носителей языка. Три из этих произнесений, записанные от двух носителей, обнаруживают нетипично краткую аффрикату длительностью 104-108 мс. Вполне вероятно, что такое произнесение неслучайно и является неосознанной попыткой включения аффрикаты $t \grave{s}$ в систему чередующихся консонантов ${ }^{34}$. Для аффрикаты $t s$ отклонения такого рода в нашем материале не встретились.

Критерий 5. Длительность компонентов аффрикаты $t \check{s}$ примерно одинакова. Таким образом, с этой точки зрения $t \check{s}$ приближается к обычному консонантному кластеру, а не к аффрикате $t s$, ср. с данными, представленными на Схеме 2.

Критерий 6 (общая длительность аффрикаты). В большинстве случаев длительность аффрикаты $t \check{s}$ находится в диапазоне 160-180 мс, хотя возможны отклонения в результате специфики идиолекта (cp., например, с данными, приведенными в Таблице 6) ${ }^{35}$. Таким образом, длительность $t s ̌$ совпадает как с длительностью $t s$, так и с длительностью консонантного кластера, но отличается от длительности обычного одиночного согласного.

Критерий 7 (отсутствие редукции второго гласного в структуpax CVCV). Нам неизвестны примеры с аффрикатой $t \check{s}$, аналогичные

34 Из этого не следует, что есть идиолекты с чередованием ступеней у аффрикаты: остальные произнесения у тех же носителей не выбиваются из общей картины.

35 В [Кузнецова 2009a: 271-272] отмечается, что на приведенной в диссертации

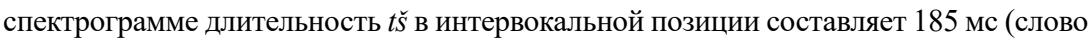
lutšikkain 'клоп', записанное в д. Валяницы от носителя сойкинского ижорского 1931 года рождения). 
рассмотренным выше примерам типа metsän 'лес.GEN', где аффриката оказывается в позиции между двумя краткими гласными, вторым из которых является $a$ или $\ddot{a}$, подверженный ярко выраженной качественной редукции. В [Кузнецова 2009а: 271] отмечается, что в слове lutšikkain ‘клоп' характерного для структуры CVCV продления гласного после аффрикаты не наблюдается, a, скорее, имеет место редукция. Это свидетельствует о том, что $t \grave{s}$ не может считаться одиночным консонантом.

Получается, что аффриката $t \check{s}$ по своим характеристикам не схожа с аффрикатой $t s$. Полностью у них совпадает лишь оценка по критерию 6 (длительность консонантного кластера). Частичное совпадение наблюдается по критериям 4 и 7: у $t \grave{s}$ нет чередования ступеней, но есть намеки на его возможное зарождение, а отсутствие продления в структуре CVCV у $t \check{s}$ не имеет столь яркого подтверждения, как у $t s$. Критерии 2 и 5, в случае $t s$ свидетельствующие против консонантного кластера, для $t \check{s}$ такого результата не дают. Критерий 3 (позиция в начале слова), наоборот, подтверждает однофонемность $t \grave{s}$ в отличие от $t s$. Фактически только он и оказывается критерием, свидетельствующим в пользу однофонемности $t \check{s}$.

Здесь необходимо обратить внимание на соображение, высказанное Н. В. Кузнецовой: если допустить, что обе аффрикаты являются консонантными кластерами, то придется признать, что в сойкинском ижорском противопоставлены $s$ и $\check{s}$, что «повлечет за собой трудности в фонемной идентификации $s$ и $\check{s}$ во всех прочих контекстах» [Кузнецова 2009а: 270]. Это соображение представляется нам очень важным, однако с одной оговоркой: оно верно для более архаичной фонологической системы, где свистящие почти отсутствуют. В более инновационных идиолектах (см. пример zavoda vs šavoda 'завод', приведенный в Разделе 3 при обсуждении Критерия 1) избежать противопоставления свистящих и шипящих все равно невозможно.

В любом случае аффриката $t \check{s}$, так же, как и $t s$, аномальна: она может считаться либо аномальной фонемой, либо аномальным консонантным кластером.

\section{6. Выводы}

В исследовании было показано, что в сойкинском диалекте ижорского языка аффриката $t s$ может интерпретироваться либо как 
аномальная фонема, либо как аномальный консонантный кластер. Выбор интерпретации зависит от конкретного исследователя, поскольку аргументы, свидетельствующие об однозначном предпочтении фонемной или же кластерной интерпретации, отсутствуют. Также неоднозначным является фонологический статус аффрикаты $t \check{s}$.

Проведенный анализ аффрикат становится прекрасной демонстрацией того, насколько неортогональна фонологическая система: все ее элементы взаимосвязаны. Такой, казалось бы, чисто фонетический процесс, как переход $s$ в $\check{s}$, оказывается неавтоматическим из-за того, что аффриката $t \check{s}$ не позволяет произойти этому переходу в контексте после $t$. В результате $s$ сохраняется в сочетании с предшествующим $t$, что в свою очередь становится одним из аргументов в пользу однофонемной интерпретации $t s$.

Обе аффрикаты в сойкинском диалекте допускают их признание консонантными кластерами, но при этом нельзя одновременно считать их консонантными кластерами в рамках архаичной фонологической системы с отсутствующим противопоставлением свистящих и шипящих: как минимум одна из аффрикат должна быть признана фонемой. Если же принять инновационную фонологию, где допускается противопоставление свистящих и шипящих, то данное ограничение на интерпретацию аффрикат снимается, но могут возникать другие проблемы при построении фонологической системы.

Проведенное исследование также позволяет сформулировать следующий вывод: признак наличия / отсутствия фонемы $t s$ (а вероятно и фонологических аффрикат в целом) не является типологически релевантным признаком, характеризующим прибалтийско-финские языки. Во-первых, если аффриката имеет неоднозначный статус (как в сойкинском диалекте ижорского языка), то ее появление в фонологической системе обусловлено лишь выбором исследователя. Во-вторых, свойства аффрикат варьируют от языка к языку и не являются общими для данной группы языков. 


\section{Приложение}

Таблица 7. Длительность (мс) аффрикаты $t s$ и ее компонентов в разных падежных формах (к Схеме 1)

Таблица 7. The duration (ms) of the affricate $t s$ and its components in different case forms (see Diagram 1)

\begin{tabular}{|c|c|c|c|c|c|c|c|c|c|}
\hline & \multicolumn{9}{|c|}{ AG } \\
\hline & \multicolumn{3}{|c|}{ NOM } & \multicolumn{3}{|c|}{ GEN } & \multicolumn{3}{|c|}{ PART } \\
\hline & $t$ & $s$ & ts & $t$ & $s$ & ts & $t$ & $s$ & $t s$ \\
\hline Длительность & 121 & 75 & 196 & 105 & 63 & 168 & 136 & 91 & 227 \\
\hline Ст. отклонение & 21 & 25 & 25 & 18 & 17 & 19 & 23 & 24 & 16 \\
\hline \multirow[t]{4}{*}{ Кол-во произнесений } & & 22 & & & 36 & & & 19 & \\
\hline & \multicolumn{9}{|c|}{$\mathbf{A L}$} \\
\hline & \multicolumn{3}{|c|}{ NOM } & \multicolumn{3}{|c|}{ GEN } & \multicolumn{3}{|c|}{ PART } \\
\hline & $t$ & $s$ & $t s$ & $t$ & $s$ & ts & $t$ & $s$ & $t s$ \\
\hline Длительность & 128 & 53 & 191 & 106 & 68 & 174 & 132 & 94 & 226 \\
\hline Ст. отклонение & 13 & 14 & 21 & 16 & 13 & 19 & 22 & 25 & 20 \\
\hline Кол-во произнесений & & 20 & & & 40 & & & 13 & \\
\hline
\end{tabular}

Таблица 8. Длительность абсолютная (мс) и относительная компонентов кластера $k \check{s}$ и аффрикаты $t s$ (к Схеме 2)

Table 8. Absolute ( $\mathrm{ms}$ ) and relative duration of the components of the cluster $k \grave{s}$ and of the affricate $t s$ (see Diagram 2)

\begin{tabular}{|c|c|c|c|c|c|c|}
\hline & \multicolumn{6}{|c|}{ AG } \\
\hline & $k$ & $\check{S}$ & $k / \check{s}$ & $t$ & $s$ & $t / s$ \\
\hline Длительность & 78 & 85 & 0,9 & 106 & 68 & 1,6 \\
\hline Ст. отклонение & 8 & 9 & 0,2 & 16 & 13 & 0,4 \\
\hline \multirow[t]{3}{*}{ Кол-во произнесений } & \multicolumn{3}{|c|}{32} & \multicolumn{3}{|c|}{36} \\
\hline & \multicolumn{6}{|c|}{$\mathbf{A L}$} \\
\hline & $k$ & $\check{s}$ & $k / \check{s}$ & $t$ & $s$ & $t / s$ \\
\hline Длительность & 82 & 84 & 1,0 & 105 & 63 & 1,8 \\
\hline Ст. отклонение & 11 & 16 & 0,2 & 18 & 17 & 0,6 \\
\hline Кол-во произнесений & \multicolumn{3}{|c|}{33} & \multicolumn{3}{|c|}{40} \\
\hline
\end{tabular}


Таблица 9. Длительность различных согласных

Table 9. The duration of different consonants

\begin{tabular}{|l|r|r|r|r|r|r|r|r|r|r|r|}
\hline & $n$ & $r$ & $\check{z}$ & $h$ & $l$ & $m$ & $j$ & $d$ & $g$ & \multicolumn{1}{c|}{$b$} & \multicolumn{1}{c|}{$t s$} \\
\hline Длительность & $\mathbf{5 6}$ & $\mathbf{6 8}$ & $\mathbf{7 0}$ & $\mathbf{7 5}$ & $\mathbf{7 5}$ & $\mathbf{7 7}$ & $\mathbf{7 8}$ & $\mathbf{7 9}$ & $\mathbf{8 2}$ & $\mathbf{1 0 3}$ & $\mathbf{1 7 4}$ \\
\hline Ст. отклонение & 6 & 7 & 10 & 25 & 7 & 7 & 6 & 7 & 4 & 6 & 19 \\
\hline Кол-во произнесений & 14 & 16 & 11 & 12 & 14 & 15 & 14 & 16 & 12 & 14 & 40 \\
\hline
\end{tabular}

В Таблище 9 приведена длительность второго согласного, посчитанная в словах структуры CVCVC (kanan 'курица.GEN', kuran 'левый. GEN', šahan 'пила.GEN' и т. д.), которые были записаны в серединной позиции от носителя AL. Полученные результаты совпадают с общим принципом, постулирующим бо́льшую длительность у лабиальных согласных, см. [Lehiste 1976: 227]. Однако представленный там же тезис о глухих фрикативных как наиболее долгих согласных на нашем материале не находит подтверждения.

Таблица 10. Длительность аффрикаты в формах слова daatša 'дача' Table 10. The duration of the affricate in different forms of the word daatša 'country house'

\begin{tabular}{|l|r|r|r|r|r|r|}
\hline & ELAT & INESS & GEN & NOM & ILL & PART \\
\hline Ср. длительность & 147 & 149 & 150 & 162 & 173 & 176 \\
\hline Ст. отклонение & 11 & 11 & 17 & 15 & 13 & 24 \\
\hline Кол-во произнесений & 6 & 6 & 6 & 6 & 6 & 6 \\
\hline
\end{tabular}

Данные записаны от носителя AL в конечной позиции. Их можно сопоставить с данными, представленными в Таблице 2, где указана длительность аффрикаты $t s$ в формах слова metsä 'лес'. Обратим внимание, что в формах элатива daatšaašt и инессива daatšaaž не наблюдается удлинения аффрикаты («вторичной сильной ступени» по А. Совиярви), как в формах metsä̈̈šst ‘лес.ELAT' и metsääž ‘лес.INESS'. Вероятно, это связано с различием структур: в daatša ударный гласный долгий, а в metsä краткий. 


\section{Список условных сокращений}

GEN — генитив; ELAT — элатив; ILL — иллатив; IMP — императив; IMPRS — имперсонал; INESS - инессив; NOM - номинатив; PART — партитив; PL — множественное число; PRS - настоящее время; SG - множественное число; 1SG — форма 1 лица единственного числа.

\section{Литература}

Вахтин 1996 - Н. Б. Вахтин. Гренландский язык // А. П. Володин, Н. Б. Вахтин, А. А. Кибрик (ред.). Языки мира. Палеоазиатские языки. М.: Индрик, 1996. С. 93-100.

Зайков 1999 - П. М. Зайков. Грамматика карельского языка (фонетика и морфология). Петрозаводск: Периодика, 1999.

Кузнецова 2009а - Н. В. Кузнецова. Фонологические системы ижорских диалектов. Дисс. ... канд. филол. наук. СПб.: ИЛИ РАН, 2009.

Кузнецова 2009б - Н. В. Кузнецова. Супрасегментная фонология сойкинского диалекта ижорского языка в типологическом аспекте // Вопросы языкознания. 2009. № 5. C. 18-47.

Лаанест 1966 - А. Лаанест. Ижорские диалекты. Лингвогеографическое исследование. Таллин: Институт языка и литературы АН ЭССР, 1966.

Лаанест 1975 - А. Лаанест. Прибалтийско-финские языки // В. И. Лыткин, К. Е. Майтинская, К. Редеи (ред.). Основы финно-угорского языкознания. Т. 2. Прибалтийско-финские, саамский и мордовские языки. М.: Наука, 1975. С. 5-247.

Лаанест 1978 - А. Лаанест. Историческая фонетика и морфология ижорского языка. Дисс. ... доктора филол. наук. Таллин: Институт языка и литературы АН ЭССР, 1978.

Маркус, Рожанский 2017 - Е. Б. Маркус, Ф. И. Рожанский. Современный водский язык. Тексты и грамматический очерк. 2-е издание, исправленное и дополненное. СПб.: Нестор-История, 2017.

Трубецкой 1960 - Н. С. Трубецкой. Основы фонологии. М.: Изд-во иностранной литературы, 1960.

Boersma, Weenink 2014 - P. Boersma, D. Weenink. Praat: doing phonetics by computer [Computer program]. Version 5.3.82, retrieved 26 July 2014 from http://www. praat.org.

Brodskaya 2015 - I. Brodskaya. Durational patterns of the trisyllabic foot in Soikkola Ingrian. M.A. thesis. San Francisco: San Francisco State University, 2015.

Kuznetsova 2013 - N. Kuznetsova. Finnic foot nucleus lengthening: From phonetics to phonology // E. Liina Asu, P. Lippus (eds.). Nordic Prosody. Proceedings of the $\mathrm{XI}^{\text {th }}$ Conference, Tartu 2012. Frankfurt am Main: Peter Lang, 2013. P. 205-214.

Lehiste 1976 - I. Lehiste. Suprasegmental Features of Speech // N. J. Lass (ed.). Contemporary Issues in Experimental Phonetics. New York; San Francisco; London: Academic Press, 1976. P. 225-239. 
Levshina 2015 - N. Levshina. How to do Linguistics with R. Data exploration and statistical analysis. Amsterdam; Philadelphia: Benjamins, 2015.

Lippus 2005 - P. Lippus. Võru afrikaat ts ja eesti konsonantühend $t s / /$ Tartu Ülikooli Lõuna-Eesti keele- ja kultuuriuuringute keskuse aastaraamat. 2005. № 4. L. 54-64. Markus 2010 - E. Markus. Primary and secondary geminates in Ingrian // Linguistica Uralica. 2010. Vol. 46. № 1. P. 38-52.

Markus 2011 - E. Markus. The phonetics and phonology of a disyllabic foot in Soikkola Ingrian // Linguistica Uralica. 2011. Vol. 47. № 2. P. 103-119.

Nirvi 1971 - R. Nirvi (ed.). Inkeroismurteiden sanakirja (Lexica societatis Fenno-Ugricae. Vol. XVIII). Helsinki: Suomalais-Ugrilainen Seura, 1971.

Porkka 1885 - V. Porkka. Über den ingrischen Dialekt mit Berücksichtigung der übrigen finnisch-ingermanländischen Dialekte. Helsingfors: J. C. Frenckell \& Sohn, 1885 .

Saar 2014 - E. Saar. Types of consonant alternation in the inflectional system of Soikkola Ingrian // Linguistica Uralica. 2014. Vol. 50. № 4. P. 258-275.

Sovijärvi 1944 - A. Sovijärvi. Foneettis-äännehistoriallinen tutkimus Soikkolan inkeroismurteesta (Suomi-kirjan eripainoksia. Vol. 5). Helsinki: Suomalaisen Kirjallisuuden Seura, 1944.

Suomi et al. 2008 - K. Suomi, J. Toivanen, R. Ylitalo. Finnish sound structure. Phonetics, phonology, phonotactics and prosody. Oulu: University of Oulu, 2008.

UPSID 1981 - UPSID: UCLA Phonological Segment Inventory Database. Data and Index (UCLA Working Papers in Phonetics. Vol. 53). Los Angeles: UCLA, 1981.

\section{References}

Boersma, Weenink 2014 - P. Boersma, D. Weenink. Praat: doing phonetics by computer [Computer program]. Version 5.3.82, retrieved 26 July 2014 from http://www. praat.org.

Brodskaya 2015 - I. Brodskaya. Durational patterns of the trisyllabic foot in Soikkola Ingrian. M.A. thesis. San Francisco: San Francisco State University, 2015.

Kuznetsova 2009a - N. V. Kuznetsova. Fonologicheskie sistemy izhorskikh dialektov [Phonological systems of Ingrian dialects]. Candidate thesis. St. Petersburg: Institute of Linguistic Studies RAS, 2009.

Kuznetsova 2009 b - N. V. Kuznetsova. Suprasegmentnaya fonologiya soykinskogo dialekta izhorskogo yazyka $\mathrm{v}$ tipologicheskom aspekte [Suprasegmental phonology of the Soikkola dialect of Ingrian in a cross-linguistic perspective]. Voprosy yazykoznaniya. 2009. No. 5. P. 18-47.

Kuznetsova 2013 - N. Kuznetsova. Finnic foot nucleus lengthening: From phonetics to phonology. E. Liina Asu, P. Lippus (eds.). Nordic Prosody. Proceedings of the XIth Conference, Tartu 2012. Frankfurt am Main: Peter Lang, 2013. P. 205-214.

Laanest 1966 - A. Laanest. Izhorskiye dialekty. Lingvogeoraficheskoye issledovaniye [Ingrian dialects. A linguistic geographic study]. Tallinn: Institute of Language and Literature, Academy of Sciences of the Estonian SSR, 1966. 
Laanest 1975 - A. Laanest. Pribaltiysko-finskie yazyki [Balto-Finnic languages]. V. I. Lytkin, K. E. Maytinskaya, K. Rédei (eds.). Osnovy finno-ugorskogo yazykoznaniya [Basics of Finno-Ugric Linguistics]. Vol. 2. Pribaltiysko-finskie, saamskiy i mordovskie yazyki [Balto-Finnic, Sami and Mordovian languages]. Moscow: Nauka, 1975. P. 5-247.

Laanest 1978 - A. Laanest. Istoricheskaya fonetika i morfologiya izhorskogo yazyka [Historical phonetics and morphology of Ingrian]. Doctoral thesis. Tallinn: Institute of Language and Literature, Academy of Sciences of the Estonian SSR, 1978.

Lehiste 1976 - I. Lehiste. Suprasegmental Features of Speech. N. J. Lass (ed.). Contemporary Issues in Experimental Phonetics. New York; San Francisco; London: Academic Press, 1976. P. 225-239.

Levshina 2015 - N. Levshina. How to do Linguistics with R. Data exploration and statistical analysis. Amsterdam; Philadelphia: Benjamins, 2015.

Lippus 2005 - P. Lippus. Võru afrikaat $t$ ja eesti konsonantühend ts. Tartu Ülikooli Lõuna-Eesti keele-ja kultuuriuuringute keskuse aastaraamat. 2005. No. 4. L. 54-64.

Markus 2010 - E. Markus. Primary and secondary geminates in Ingrian. Linguistica Uralica. 2010. Vol. 46. No. 1. P. 38-52.

Markus 2011 - E. Markus. The phonetics and phonology of a disyllabic foot in Soikkola Ingrian. Linguistica Uralica. 2011. Vol. 47. No. 2. P. 103-119.

Markus, Rozhanskiy 2017 - Ye. B. Markus, F. I. Rozhanskiy. Sovremennyy vodskiy yazyk. Teksty i grammaticheskiy ocherk [Modern Votic language. Texts and grammar sketch]. $2^{\text {nd }}$ edition. St. Peterburg: Nestor-Istoriya, 2017.

Nirvi 1971 - R. Nirvi (ed.). Inkeroismurteiden sanakirja (Lexica societatis FennoUgricae. Vol. XVIII). Helsinki: Suomalais-Ugrilainen Seura, 1971.

Porkka 1885 - V. Porkka. Über den ingrischen Dialekt mit Berücksichtigung der übrigen finnisch-ingermanländischen Dialekte. Helsingfors: J. C. Frenckell \& Sohn, 1885.

Saar 2014 - E. Saar. Types of consonant alternation in the inflectional system of Soikkola Ingrian. Linguistica Uralica. 2014. Vol. 50. No. 4. P. 258-275.

Sovijärvi 1944 - A. Sovijärvi. Foneettis-äännehistoriallinen tutkimus Soikkolan inkeroismurteesta (Suomi-kirjan eripainoksia. Vol. 5). Helsinki: Suomalaisen Kirjallisuuden Seura, 1944.

Suomi et al. 2008 - K. Suomi, J. Toivanen, R. Ylitalo. Finnish sound structure. Phonetics, phonology, phonotactics and prosody. Oulu: University of Oulu, 2008.

Trubetskoy 1960 - N. S. Trubetskoy. Osnovy fonologii [Principles of phonology]. Moscow: Foreign Literature Publishing House, 1960.

UPSID 1981 - UPSID: UCLA Phonological Segment Inventory Database. Data and Index (UCLA Working Papers in Phonetics. Vol. 53). Los Angeles: UCLA, 1981.

Vakhtin 1996 - N. B. Vakhtin. Grenlandskiy yazyk [The Greenlandic language]. A. P. Volodin, N. B. Vakhtin, A. A. Kibrik (eds.). Yazyki mira. Paleoaziatskie yazyki [Languages of the world. Paleo-Asiatic languages]. Moscow: Indrik, 1996. P. 93-100. Zaykov 1999 - P. M. Zaykov. Grammatika karelskogo yazyka (fonetika i morfologiya) [Grammar of the Karelian language (phonetics and morphology)]. Petrozavodsk: Periodika, 1999. 


\section{Грамматический статус показателей субъектно-объектного согласования в конструкциях с сентенциальными актантами (мокша-мордовский язык)*}

\section{Н. В. Сердобольская}

Институт языкознания РАН, Государственный институт русского языка им. А. С. Пушкина, Москва; serdobolskaya@gmail.com

\section{А. Д. Егорова}

Московский государственный университет им. М. В. Ломоносова, Москва; astya28@mail.ru

Аннотация. В мордовских языках переходные глаголы могут выступать с показателями субъектно-объектного или субъектного согласования в зависимости от ряда факторов - определенности и одушевленности прямого дополнения, аспектуальных характеристик. Если же переходный глагол присоединяет не именное прямое дополнение, а финитную клаузу, также возможен выбор из двух моделей согласования. Мы показываем, что союзные актантные предложения в зависимости от типа спряжения делятся на два типа: клаузы без именной вершины и с именной вершиной. Данные конструкции обладают различными синтаксическими свойствами. Первый тип конструкций, в отличие от второго, обладает именными синтаксическими свойствами - способностью замещаться именной анафорой (в том числе плеонастической) и анафорическим квантором.

Ключевые слова: сентенциальные актанты, согласование, субъектно-объектное спряжение, комплементайзер, анафора, факт, событие, пресуппозиция.

* Исследование выполнено при поддержке гранта РФФИ № 20-512-14003 АНФ_а и проекта «Параметрическое описание языков Российской Федерации», реализуемого в Государственном институте русского языка им. А. С. Пушкина. 


\title{
Subject-object agreement markers in Moksha-Mordvin complement clauses
}

\author{
N. V. Serdobolskaya \\ Institute of Lingusitics, Russian Academy of Sciences, \\ Pushkin State Russian Language Institute, Moscow; serdobolskaya@gmail.com
}

\section{A. D. Egorova}

Lomonosov Moscow State University, Moscow; astya28@mail.ru

\begin{abstract}
In Moksha-Mordvin, transitive verbs can occur with either subject agreement markers, or subject-object agreement markers. The choice between the two sets of markers depends on a number of factors, such as definiteness and animacy of the Direct Object, or aspectual characteristics. Both agreement sets can be used if the object of the transitive verb is a clause. The paper is focused on the syntactic structure of sentential arguments occurring in the context of subject and subject-object agreement patterns of transitive verbs. We are considering 24 matrix verbs and three most frequent complementizers, što 'that', maz'ardə/mojardo 'when' and koda 'how'. The data have been collected during our field trips to the villages of Lesnoe Cibaevo, Lesnoe Ardashevo and Lesnye Siyali (Temnikovskiy region of the Republic of Mordovia) in 2014-2016 by means of elicitation. Some examples have been taken from the newspaper «Mokshen' pravda» (2008-2014).

We show that complement clauses triggering object agreement on transitive verbs have syntactic properties of NPs, namely, they can be replaced by nominal anaphoric devices (including pleonastic anaphora) and can be referred to by the universal quantifier. It is not allowed with complement clauses occurring with subject agreement. We conclude that complement clauses triggering object agreement on the verb contain a nominal head, while complement clauses occurring with subject agreement do not. The two types of clauses are semantically distributed: the subject-object agreement is triggered by eventive and factive complements, while the subject agreement occurs in the context of propositional and irrealis complements. Thus, the presence of the nominal head correlates with the presence of a presupposition of truth of the complement clause. Similar correlation has been observed in other languages, see [Dalrymple, Lødrup 2000; Kastner 2015], as well as[Hanink, Bochnak 2016]).
\end{abstract}

Keywords: clausal arguments, complementation, complementizer, subject-object conjugation, subject-object agreement, anaphora, fact, event, presupposition. 


\section{1. Введение}

Сентенциальные актанты (далее: СА) обычно определяют как предложения или предикации, которые являются аргументом матричного предиката (“a notional sentence or predication is an argument of a predicate" [Noonan 1985: 52]), например Вася съел яблоко в предложении Я знаю, что Вася съел яблоко. Исследование синтаксических свойств СА показывает, что данные конструкции лишь отчасти демонстрируют свойства именных актантов [Dalrymple, Lødrup 2000, Летучий 2012, 2016; Kastner 2016; Hanink, Bochnak 2016]. В частности, именной и сентенциальный актант при одном и том же матричном глаголе требуют различного предложно-падежного оформления в каталанском [Alsina, Mohanan, Mohanan 2005], в калмыцком [Князев 2009], в адыгейском языке: $\begin{array}{llllll}\text { (1a) estàvem } & d & \text { acord } & \text { en alguns punts } \\ \text { были.1PL от согласие } & \text { в несколько пункты }\end{array}$

'Мы согласились друг с другом в нескольких пунктах'.

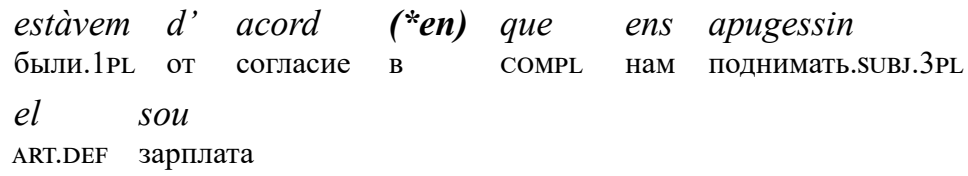

‘Мы согласились, что они должны нам поднять зарплату'. [Alsina, Mohanan, Mohanan 2005: 23]

\section{АДЫГЕЙСКИЙ}

(2a)

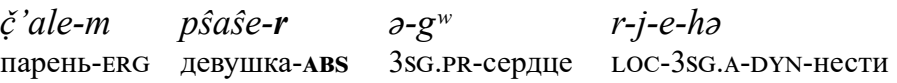

'Парню нравится девушка'.

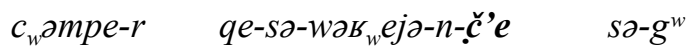

клубника-ABS DIR-1SG.A-собирать-POT-INS 1SG.PR-сердце

$r-j-e-h \partial$

LOC-3SG.A-DYN-нести

'Мне нравится собирать клубнику'.

\footnotetext{
1 Здесь сохранены глоссы источника.
} 
В адыгейских примерах именной актант, выражающий стимул при глаголе 'нравиться', оформляется абсолютивом, в то время как СА с той же семантической ролью присоединяет показатель инструментального падежа. Таким образом, именные и сентенциальные актанты, заполняющие одну и ту же семантическую валентность, имеют различное морфологическое оформление.

Есть языки, где СА при переходных глаголах не проявляют синтаксические свойства именного прямого дополнения (далее: ПД): например, в русском и английском актантные предложения не всегда естественно звучат в позиции подлежащего при пассивизации матричного глагола [Dalrymple, Lødrup 2000, Летучий 2012]:

(3а) На празднике, как всегда, говорилось много глупостей.

(3б) 'На празднике говорилось, что все любят юбиляра. [Летучий 2012: 67]

Ср. допустимость такой конструкции при глаголе показать:

(3в) В предыдущем параграфе было показано, что между продольными колебаниями стержней и колебаниями тока и напряжения в длинных линиях электропередач существует прямая аналогия. [Л. Ф. Лепендин. Акустика. М.: Высшая школа, 1978: 124]

(4a) That the earth is round was not believed.

'В то, что земля круглая, не верили'. [Dalrymple, Lødrup 2000: 5]

(46) *That it would rain was hoped.

'В то, что пойдет дождь, верили'. [Dalrymple, Lødrup 2000: 6]

Для теоретического объяснения этих и других аналогичных фактов предлагаются варианты анализа, выполненные в различных формальных парадигмах. В частности, предлагается трактовать союзные CA как семантические модификаторы [Elliott 2018] (формально-семантический анализ), а не как аргументы (т. е. именные актанты); различение CA с оболочкой DP и без таковой [Kastner 2016] (в рамках минималистской программы); противопоставление «именных» (тип Obj) и «неименных» (тип Comp) CA [Dalrymple, Lødrup 2000] (в рамках Лексико-функциональной грамматики).

Приведенные выше примеры ставят вопрос о том, насколько СА, которые, на первый взгляд, занимают позицию подлежащего или ПД, 
могут характеризоваться именными грамматическими категориями: определенность, согласовательный класс, падеж, число. В этой связи интересны данные языков с полиперсональной системой глагольного согласования. Например, в адыгейском языке и в языке камбера некоторые семантические типы СА могут контролировать согласование на матричном предикате, а другие - нет [Serdobolskaya 2016; Klamer 2006]. Согласование с клаузой опционально в ряде уральских языков, см. [Molnár 1998] относительно венгерского и мордовских языков. В уральских языках, наряду с вариативным падежным маркированием ПД (differential object marking [Bossong 1985]), есть вариативное согласование с ПД (differential object indexing [Iemmolo 2011]). Рассмотрим следующие примеры из мокша-мордовского языка²:
(5a) d'cd' $\varepsilon-s$ ' $s$ 'uc'ว-z'ə
id'-anc
мать-DEF.SG ругать-PST.3SG.O.3SG.S ребенок-3SG.P.SG.GEN
'Мама поругала ребенка'.
(56)
d'cd' $\varepsilon-s$ ' s'uc'ว-z'n'ə
id'-ənzว-n
мать-DEF.SG ругать-PST.3PL.O.3sG.S ребенок-3SG.P.PL-GEN
‘Мама поругала детей'.

(6a)
$a v a$
$s^{\prime} u c^{\prime} \partial-s^{\prime}$
c'ora-n'c
женщина
ругать-PST.3SG
парень-DIM

‘Женщина поругала мальчика'.

(6б)
$a v a$
s'uc'ว-s'
c'ora-n'a-t
женщина
ругать-PST.3SG
парень-DIM-PL

‘Женщина поругала мальчиков'.

В (5аб) ПД выступает в генитиве определенного склонения и контролирует глагольные показатели согласования, выражающие единственное и множественное число 3-го лица объекта. В (6а-б) ПД не маркируется специальным показателем и не контролирует глагольное согласование. Глагол согласуется только с субъектом, как и непереходные глаголы, ср.:

2 Для записи мокшанских примеров используется практическая транскрипция, разработанная в рамках экспедиционного проекта по изучению мокшанского языка в 2013-2018 гг. (рук. С. Ю. Толдова). Подробнее о принципах транскрипции см. [Кухто 2018: 35]. 


$\begin{array}{lll}\text { son } & s a-s & k u d-u \\ \text { он } & \text { прийти-PST.3sG } & \text { дом-ILL }\end{array}$

'Он пришел домой'.

Таким образом, данные примеры иллюстрируют явления вариативного падежного маркирования ПД (differential object marking) и вариативного согласования с ПД (differential object indexing).

Данные два типа согласования принято описывать как субъектно-объектное (5) и субъектное (6)-(7) спряжения (далее: СОи С-спряжение, соответственно) [Колядёнков 1962: 132, Феоктистов 1975: 313].

Противопоставление субъектного и субъектно-объектного спряжения подробно описано для многих уральских языков, включая венгерский [Molnár 1998, Kiss 2004], хантыйский [Nikolaeva 1999], ненецкий [Nikolaeva 2014], энецкий [Ханина, Шлуинский 2015]. Изучены как факторы выбора спряжения, так и синтаксические свойства ПД при первой и второй согласовательной модели. В частности, авторы активно обсуждают вопрос о синтаксических свойствах ПД: занимает ли ПД в (5) и (6) одну и ту же синтаксическую позицию или же речь идет о различных синтаксических конструкциях.

Частным случаем вариативного кодирования ПД являются конструкции, где позицию ПД занимают не именные группы, а предикации:

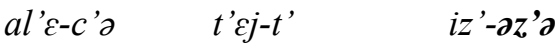

$$
\begin{aligned}
& \text { отец-2SG.P.SG PRON.DAT-2SG.P NEG.PST-PST.3SG.o.3SG.S } \\
& \text { azand-ə koda kunda-z'z kelaz'-t'? } \\
& \text { рассказывать-CN как ловить-PST.3SG.O.3SG.S лиса-DEF.SG.GEN }
\end{aligned}
$$

$$
\begin{aligned}
& \text { rad'io-sa mer'k-s't' što ul'-i ps'i } \\
& \text { радио-IN сказать-PST.3PL что быть-NPST.3SG горячий }
\end{aligned}
$$

'По радио сказали, что будет жарко'

В таких случаях также возможны оба спряжения [Феоктистов 1975; Molnár 1998]. Выбор спряжения регулируется рядом семантических и синтаксических факторов, где определяющим является наличие логической пресуппозиции (см. Раздел 3.1), см. подробнее [Сердобольская, Кожемякина 2014] и [Кожемякина 2016]. 
Относительно конструкций с СА при переходных глаголах возникает вопрос, можно ли их рассматривать как занимающие ту же синтаксическую позицию, что и именное ПД, с одной стороны, а с другой стороны - имеют ли согласовательные показатели в таких конструкциях тот же морфосинтаксический статус, что и при именном ПД. В частности, мы ставим задачу проверить, обладают ли СА в позиции ПД свойствами актантов (или сирконстантов), свойствами именных групп и свойствами ПД (например, способность становиться подлежащим при пассивизации, как в (3)-(4)).

Настоящее исследование призвано решить данные задачи. Мы рассмотрим союзные СА при переходных глаголах и попытаемся обосновать связь между семантикой зависимой предикации и ее синтаксическим статусом ${ }^{3}$.

Исследование основано на данных, полученных в 2014-2016 гг. в ходе полевой работы с жителями сёл Лесное Цибаево, Лесное Ардашево и Лесные Сияли Темниковского района Республики Мордовия, а также на примерах, взятых из мини-корпуса текстов газеты «Мокшень правда» за 2008-2014 гг. Нами исследовано 24 матричных глагола и три союза, наиболее распространенные в актантных предложениях (što 'что', məz'ardə/məjardə 'когда', koda 'как').

В Разделе 2 мы кратко опишем систему кодирования ПД в мокшамордовском языке и синтаксические свойства ПД в различных конструкциях. Раздел 3 посвящен семантическим и синтаксическим особенностям конструкций с $\mathrm{CO}$ и С-спряжением при СА. Результаты обсуждаются в Разделе 4.

\footnotetext{
${ }^{3}$ Настоящая работа носит пре-теоретический дескриптивный характер; мы не предлагаем формальный анализ, а лишь рассматриваем синтаксические свойства рассматриваемых конструкций. Формальный анализ дается в работе [Belyaev et al. 2017], выполненной в рамках Лексико-функциональной грамматики. Авторы показывают, что рассматриваемые конструкции имеют различные грамматические функции. СА с субъектно-объектным спряжением характеризуются функцией объекта (ОВЈ), как и именные группы, а СА с субъектным спряжением имеют особую функцию сентенциального актанта (СОМР), зарезервированную именно для клауз. В настоящей работе, выполненной вне формальной теоретической парадигмы, мы будем говорить о «синтаксическом статусе» СА.
} 


\section{2. Именное прямое дополнение в мокша-мордовском языке: семантика и синтаксис}

\section{1. Выбор оформления прямого дополнения в мокша-мордовском языке}

Мокша-мордовский язык характеризуется богатой именной парадигмой (кроме 16 падежей ${ }^{4}$ и единственного vs. множественного числа выделяются определенное / указательное, неопределенное и посессивное склонение, различающее лицо и число посессора) и большим инвентарем средств оформления прямого дополнения (далее: ПД). Кроме выбора согласования, описанного во Введении, само ПД может присоединять целый ряд показателей — генитив определенного (10) или посессивного (11) склонения, послелог еsә 'в' ${ }^{5}$ (12), или же может выступать в номинативе неопределенного склонения (13) 6 .

\begin{tabular}{|c|c|c|c|}
\hline $\begin{array}{ll}d^{\prime} e n ' i s & c^{\prime} \\
\text { Денис } & \text { па }\end{array}$ & $\begin{array}{l}\text { c'ora-snə } \\
\text { парень-3PL.P }\end{array}$ & $\begin{array}{l}\text { vas'ən'c'ə } \\
\text { первый }\end{array}$ & $\begin{array}{l}\text { s'en't'abor } \\
\text { сентябрь-еL }\end{array}$ \\
\hline $\begin{array}{l}m o l '-s ' \\
\text { идти-PST.3SG }\end{array}$ & $\begin{array}{ll} & \text { kolmə-c'ə } \\
\text { G } & \text { три-ORD }\end{array}$ & $\begin{array}{l}\text { klas-u } \\
\text { класc-LAт }\end{array}$ & $\begin{array}{l}o c^{\prime} u \\
\text { большой }\end{array}$ \\
\hline
\end{tabular}

${ }^{4}$ Количество падежей приводится в соответствии с [Холодилова 2018: 81].

5 Такие группы рассматриваются в числе ПД, т. к. они заполняют соответствующую валентность переходных глаголов и отчасти (но не вполне) обладают синтаксическими свойствами ПД, см. [Козлов 2017; Толдова 2018: 590].

${ }^{6}$ Номинатив неопределенного склонения выражается нулевым показателем, в отличие от номинатива определенного и посессивного склонения. Ниже, для краткости, мы используем термин «номинатив», не уточняя, что речь идет именно о номинативе неопределенного склонения.

Кроме перечисленных выше способов оформления, при переходных глаголах возможны также аблативные именные группы. Это зафиксировано при непредельных ингестивных глаголах, например, jarcams 'есть', siməms 'пить' [Толдова 2018: 556], ср. тж. [Колядёнков, Заводова 1962: 115]):

$\begin{array}{lll}\text { katə-n’ } \varepsilon \text {-s' } & \text { s'im-i } & \text { lofc-tə } \\ \text { кошка-DIM-DEF.SG } & \text { пить-NPST.3SG } & \text { молоко-ABL } \\ \text { 'Кошка пьет молоко'. } & \end{array}$

Согласно [Толдова 2018: 583], данные именные группы не обладают синтаксическими свойствами ПД (за исключением контроля вторичного предиката) и не контролируют объектные показатели на глаголе. 
$\begin{array}{lll}\text { tonafn'ə-si } & \text { mokšən' } & \boldsymbol{k} \boldsymbol{\varepsilon} \boldsymbol{l} \text { '-t' } \\ \text { учить.IPFV-NPST.3SG.O.3SG.S } & \text { мокшанский } & \text { язык-DEF.SG.GEN }\end{array}$

'Их сын Денис первого сентября пошел в третий класс, с большим удовольствием учит мокшанский язык'. [«Мокшень правда», 8.09.2011 № 35]

(11) kosə af-əl'-əmə ul'-ə kozə af-əl'-əmaz' pačft-ə где NEG-PQP-1PL быть-CN куда NEG-PQP-1.o.3sG.s довезти-CN sud'ba-n'ka maz'ardo-vak af juksta-s'k судьба-1PL.P когда-ADD NEG забыть-NPST.3.o.1PL.S šačəma vel'ə-n'k-ən' kel'gəma škola-n'k-ən' родной село-1PL.P-GEN любимый школа-1PL.P-GEN

'Где бы мы ни были, куда бы ни забросила нас судьба, мы никогда не забудем нашу родную деревню, любимую школу’. [«Мокшень правда», 2.06.2011 № 21]

$\begin{array}{lllll}s t \text { 'ir'- } n \text { ' } \varepsilon-t \text { ' } & \text { esa } & \text { vešanc't' } & \text { kafta } & \text { ned'al'a-t } \\ \text { девушка-DIM-DEF.SG.GEN } & \text { в.IN } & \text { искать.PST.3PL } & \text { два } & \text { неделя-PL }\end{array}$

[ЛК: Жени в спальне не было. Кровать заправлена, пижама лежит на подушке. 〈...〉] 'Девочку искали две недели'. [«Мокшень правда», 15.12.2011 № 49]

'В одном магазине я увидела очень красивый и вовсе не дорогой букет’. [«Мокшень правда», 21.01.2010 № 2]

Что касается модели согласования (спряжения), переходные глаголы могут выступать и с С, и с СО-спряжением (5)-(6), в отличие от непереходных глаголов, для которых характерно С-спряжение (7). Выбор той или иной стратегии согласования зависит от морфологического оформления ПД. Как показано в [Колядёнков 1962; Тихонова 1986; Bartens 1999: 125; Толдова 2017; Козлов 2017], генитивное ПД (в определенном или посессивном склонении) в основном требует СО-спряжения (в редких случаях это нарушается (14)), а в остальных случаях используется С-спряжение, ср. Таблицу 1 (с. 489). ставить-PST.3.o.1sG.S
mon put-in'z
( ${ }^{O K} p u t-\boldsymbol{\partial n}$ ') pen'ckud-u 
[sival-t'] $]_{F O C}$

MяCO-DEF.SG.GEN

' $\{\text { Что ты положил в печку?\} — Я положил в печку [мясо }]_{\text {FOC }}$. [Козлов 2016]

Таблица 1. Оформление ПД и глагольное согласование в мокша-мордовском языке

Table 1. Direct object marking and verbal agreement in Moksha Mordvin

\begin{tabular}{|l|l|}
\hline \multicolumn{1}{|c|}{ Оформление ПД } & \multicolumn{1}{c|}{ Тип спряжения } \\
\hline генитив определенного или посессивного склонения & $\mathrm{CO} / \mathrm{C}^{7}$-спряжение \\
\hline ПД в номинативе (неопределенного склонения) & С-спряжение \\
\hline ПД в генитиве с послелогом еsə 'в' & С-спряжение \\
\hline
\end{tabular}

Факторы, определяющие выбор оформления ПД в мордовских языках, описаны в ряде работ, включая [Бубрих 1962: 107; Колядёнков 1962; Серебренников 1967: 29-31; Тихонова 1986; Molnár 1998; Bartens 1999: 175; Zirnask 2004; Цыпкайкина 2007: 64-66; Толдова 2017, 2018]. Исследователи показывают, что стратегия «генитив + субъектно-объектное спряжение» выбирается для определенных ПД:

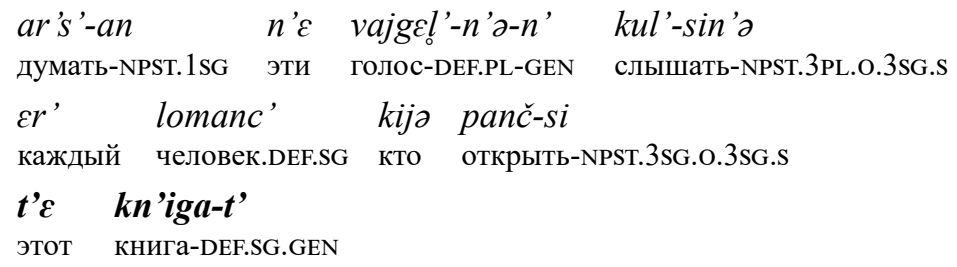

'Думаю, эти голоса услышит каждый человек, который откроет эту книгу’. [«Мокшень правда», 5.11.2009 № 43]

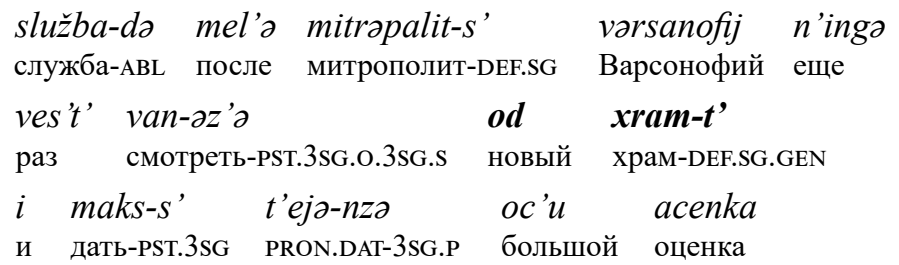

${ }^{7} \mathrm{C}$-спряжение в этом случае сильно маркировано с точки зрения информационной структуры. 
' $\{$ На днях в мокшанской деревне Сомазлей Ковылкинского района состоялся большой праздник, там открылась новая православная церковь. $\langle\ldots\rangle\}$ После службы митрополит Варсонофий еще раз осмотрел новый храм и дал ему высокую оценку'. [«Мокшень правда», 23.12.2010 № 50]

Неопределенные ПД выступают без падежного показателя:
ves't' kirks-s'
$m u-s^{\prime}$
mak-ən' vid'm'ə-n'c
однажды
воробей-DEF.SG
найти-PST.3SG
мак-GEN
семечко-DIм

'Один раз воробей нашел маковое семечко'. [Толдова 2017: 139]

Родовые ПД оформляются генитивом, если находятся в топикальной позиции в начале предложения (18), а в остальных случаях не оформляются (19) [Толдова 2017].

$\begin{array}{lll}\text { modamar'-n'ə-n' } & \text { s'oks'əndə } & \text { tarks' ə-saz' } \\ \text { картошка-DEF.PL-GEN } & \text { осенью } & \text { копать-NPST.3.o.3.PL.S }\end{array}$

'Картошку надо осенью копать'. [Толдова 2017: 146]

$\begin{array}{lllll}t \text { ' } \varepsilon & \text { kotf-t' } & e z-d \partial & \text { štakšni-jt' } & \text { jupka-t } \\ \text { этот } & \text { ткань-DEF.SG.GEN } & \text { в-ABL } & \text { шить-NPST.3PL } & \text { юбка-PL } \\ \text { af } & \text { panar-t' } & & & \\ \text { NEG } & \text { pубашка-PL } & & & \end{array}$

'Из этой ткани шьют юбки, а не рубашки'. [Толдова 2017: 146]

В целом выбор согласования определяется маркированием ПД: $\mathrm{CO}$-спряжение при генитиве и С-спряжение при номинативе. Однако в некоторых маркированных случаях генитив ПД может сочетаться с C-спряжением (ср. тж. [Grünthal 2008]):
(20) $[\text { vas' } \varepsilon-\boldsymbol{n} \text { ' }]_{\text {CONTTOP }}\left[s^{\prime} \varepsilon v-\boldsymbol{s}^{\prime} \boldsymbol{t} \text { ' } \quad \text { saldak-ən'd'i }\right]_{F O C}$ Вася-GEN взять-PST.3PL солдат-DAT

'Васю взяли в солдаты'. \{А ты - откосил; произносится с упрёком.\} [Козлов 2016]

Такой тип кодирования выбирается в тех случаях, когда определенное прямое дополнение находится в фокусе (14) или в контрастном топике, как в (20).

Конструкция с послелогом в мокша-мордовском выбирается при непредельной акциональной интерпретации глагола в контексте определенного ПД [Козлов 2017]: 


$\begin{array}{llllll}\text { (21) vagə } & \text { vas'e } & \text { pəlta-j } & \text { [taštə } & \text { or-t' } & \text { esə] } \\ \text { вон } & \text { Вася } & \text { сжигать-NPST.3sg } & \text { старый } & \text { шуба-DEF.SG.GEN } & \text { в.IN } \\ \text { 'Смотри, Вася сжигает старую шубу'. [Козлов 2017] } & \end{array}$

Как уже говорилось выше, в этом случае возможно только С-спряжение. Учитывая, что СО-спряжение в мокшанском языке возникает, если ПД оформлено простым (в случае имен собственных), определенным или посессивным генитивом, получается, что СО-спряжение выбирается только при определенных и/или топикальных ПД. Как мы покажем ниже (см. Раздел 3.1), для сентенциальных ПД действуют несколько иные факторы.

В следующем разделе мы рассмотрим синтаксические свойства ПД с различным оформлением, согласно работе [Козлов 2017]. Эти свойства будут релевантны в последующих разделах, когда мы будем анализировать синтаксис СА при СО- и С-спряжении.

\section{2. Синтаксическая позиция прямого дополнения с генитивом, номинативом и с послелогом}

В языках с вариативным оформлением ПД или субъекта возникает интересная проблема: какую синтаксическую позицию занимает ПД или субъект с разным оформлением? Ей посвящены такие работы по вариативному оформлению ПД в языках мира, как [Dalrymple, Nikolaeva 2011; Bošković, Șener 2014; Lyutikova, Pereltsvaig 2015] и др. С точки зрения синтаксической позиции языки с вариативным оформлением ПД можно разделить на два типа. В языках первого типа оформление ПД определяется его синтаксической позицией, при этом ПД с различным оформлением характеризуется различными синтаксическими свойствами. Такова ситуация, например, в хантыйском языке, где при субъектном спряжении ПД не может контролировать нулевой субъект инфинитива и других нефинитных форм, выступать антецедентом рефлексива и т. п. [Nikolaeva 1999]. Напротив, ПД при субъектно-объектном спряжении обладает названными свойствами. Второй тип языков включает, например, печорский диалект коми-зырянского [Сердобольская, Толдова 2016] и тундровый ненецкий Dalrymple, Nikolaeva 2011], где синтаксические свойства ПД вне зависимости от оформления одинаковы (аккузатив, посессивный аккузатив, отсутствие оформления в коми-зырянском; субъектное vs. субъектно-объектное спряжение в ненецком). 
К вопросу о взаимодействии синтаксической структуры клаузы и кодирования ПД в мордовских языках обращается Р. Грюнталь в статье [Grünthal 2008]. В исследовании [Козлов 2017] подробно рассматриваются синтаксические свойства ПД с различным типом оформления, в частности, способность контролировать инфинитив с аблативом, конверб с показателем - $d$, партиципантно-ориентированные локативы, а также правила оформления ПД и causee при каузативах. На базе данных свойств показано, что именные группы в генитиве и номинативе vs. послеложные группы с esə (выражающие пациентив ${ }^{8}$, как в (21)) обладают различными синтаксическими свойствами и, по-видимому, занимают различные синтаксические позиции.

Так, нулевой субъект инфинитива на -mdə может контролироваться именной группой в генитиве, но не послеложной группой:

$$
\begin{array}{clll}
\text { mon } & \text { son' } & n \text { 'cj-sa } & \text { kol'zn'd'ə-m-do } \\
\text { я } & \text { он.OвL } & \text { видеть-NPST.3SG.O.1SG.s } & \text { играть-INF-ABL }
\end{array}
$$

‘Я вижу, как он играет’. [Козлов 2017: 179]

\begin{tabular}{|c|c|c|}
\hline *mon & eso-nzo & n'cj-an \\
\hline & & -NPST.1SG \\
\hline
\end{tabular}

Ожидаемое значение: ‘Я вижу, как он играет’. [Козлов 2017: 179]

Такое же ограничение касается субъекта деепричастия на -də. При наличии ПД в генитиве нулевой субъект деепричастия может отсылать как к субъекту, так и к ПД; если же пациентив оформляется послеложной группой, то возможен только субъектный контроль:

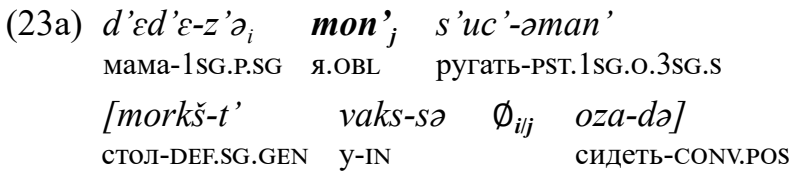

а. 'Мама ругала меня, сидя за столом'.

б. 'Мама ругала меня, сидящего за столом'. [Козлов 2017: 175]

\footnotetext{
8 Пациентив в [Кибрик 2003: 124] определяется как наиболее пациенсоспособный из всех участников ситуации (гиперроль, в отличие от семантической роли). Мы используем данный термин, т. к. в рассматриваемых конструкциях не всегда речь идет о пациенсе (например, 'читать книгу') и не всегда о ПД — в [Козлов 2017] показано, что пациентив в генитиве и номинативе занимает не ту же синтаксическую позицию, что пациентив с послелогом (т. е. при одном и том же глаголе и имени возможны разные конструкции).
} 


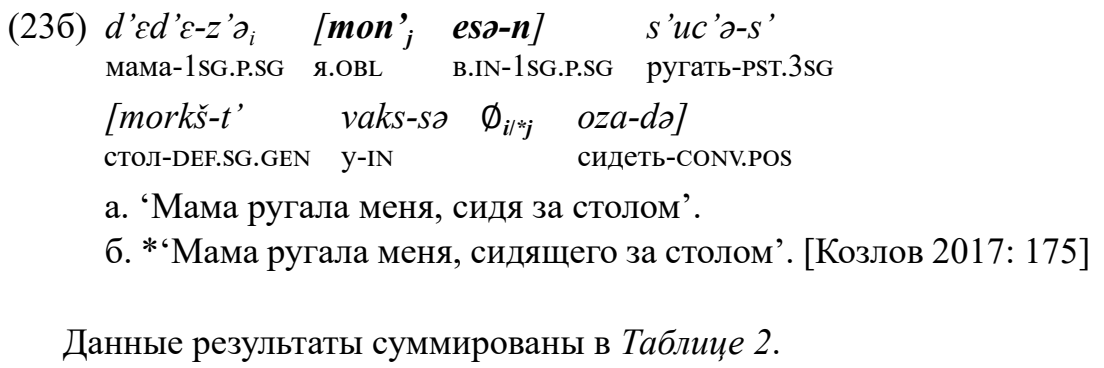

Таблица 2. Синтаксическая позиция и выбор кодирования ПД в мокша-мордовском (основана на работе [Козлов 2017])

Table 2. Syntactic position and choice of direct object marking in Moksha Mordvin (based on [Kozlov 2017])

\begin{tabular}{|l|c|c|c|}
\hline \multicolumn{1}{|c|}{ оформление ПД } & генитив & номинатив & $\begin{array}{c}\text { послеложная } \\
\text { группа }\end{array}$ \\
\hline тип спряжения & СО & С & С \\
\hline $\begin{array}{l}\text { контроль инфинитива с аблативом, } \\
\text { контроль конверба на -do, } \\
\text { контроль партиципантно- } \\
\text { ориентированных локативов }\end{array}$ & + & + & - \\
\hline $\begin{array}{l}\text { каузативизация: оформление саusee } \\
\text { генитивом при наличии эксплицитно } \\
\text { выраженного ПД }\end{array}$ & - & - & + \\
\hline
\end{tabular}

Можно видеть, что модель согласования глагола не зависит от синтаксического статуса ПД: и при СО- (если ПД в генитиве), и при С-спряжении (ПД в номинативе) пациентив вполне обладает свойствами ПД (послеложная группа проявляет лишь часть свойств ПД, см. подробнее [Козлов 2017; Толдова 2018]). При этом послеложные группы, по-видимому, занимают другую синтаксическую позицию (по всей вероятности, позицию адъюнкта, из которой невозможен контроль инфинитива, конверба и т. п.), см. подробнее [Козлов 2017].

Приведенные факты релевантны для настоящей работы, так как мы ставим целью сопоставить синтаксические свойства именных и сентенциальных актантов с $\mathrm{CO} / \mathrm{C}$-спряжением. Ниже мы кратко опишем семантическое распределение СО- и С-спряжения при СА, а также попытаемся ответить на вопрос о том, насколько СА с различными типами согласования обладают свойствами ПД матричного глагола. 


\section{3. Согласование матричного предиката с сентенциальным актантом}

\section{1. Семантика зависимой предикации и выбор согласования}

Проблема выбора согласования матричных глаголов, присоединяющих CA, обсуждается в литературе по мокша-мордовскому языку значительно реже, нежели аналогичная проблема для именных ПД. Некоторые обобщения сформулированы в работе [Molnár 1998]. Дж. Молнар формулирует правило, по которому СО-спряжение обязательно, если СА оформляется номинализацией с генитивом определенного или посессивного склонения. В остальных случаях используется С-спряжение. Кроме того, в работе показано, что матричные глаголы 'думать' и 'знать' тяготеют к различным типам спряжения (C и $\mathrm{CO}$, соответственно), а также приводится список глаголов, присоединяющих показатели С-согласования, и глаголов, присоединяющих показатели СО-согласования в контексте СА.

На основании анализа 24 матричных глаголов мокша-мордовского языка в [Сердобольская, Кожемякина 2014] уточняются выводы Дж. Молнар и формулируется утверждение, что выбор согласования при союзных СА определяется наличием пресуппозиции истинности зависимой предикации.

Следует уточнить, что мы не рассматриваем конструкции с союзом клауз (clause union) и конструкции, напоминающие по своим свойствам подъем аргумента СА 9 (примеры (24)-(25), соответственно), подробно описанные в [Кожемякина 2016]:
min' ton' jora-t' $\varepsilon d$ ' $\varepsilon z$ '
мы ты.OBL хотеть-NPST.2.o.1PL.S
$s^{\prime} \varepsilon v-\partial m-s$
kunda-mo
ловить-INF
'Мы хотим взять тебя на рыбалку'.
(25)
$d^{\prime} \varepsilon d^{\prime} \varepsilon-z$ 'ə $\quad u c ̌-a m a n '$
mon' lavka-sto
мать-1SG.P.SG
ждать-PST.1SG.O.3sG.S
я.OBL магазин-EL

kal-ən'

взять-INF-ILL рыба-GEN

${ }^{9}$ В [Кожемякина 2016] показано, что данные конструкции являются результатом кореферентного сокращения, а не подъема аргумента. 
$s a-m-d \partial$

прийти-INF-ABL

'Мама ждала, когда я вернусь из магазина'.

В первом случае объектные показатели на матричном глаголе отсылают к ПД зависимой клаузы (24), во втором случае - к ее субъекту (25). Первый тип конструкций возникает только при нефинитных $\mathrm{CA}$; второй тип возможен также в союзных актантных предложениях.

Субъектно-объектное согласование с самим СА возможно только для переходных матричных глаголов.

Для нефинитных СА (номинализаций или инфинитивов ${ }^{10}$ ) действует правило, сформулированное в [Molnár 1998]: CO-спряжение обязательно, если СА оформляется номинализацией с генитивом определенного или посессивного склонения. В остальных случаях используется С-спряжение. Например, в паре $u$ šədəms 'начинать' - ad'əlams 'заканчивать' глагол 'начинать' требует субъектного спряжения (и инфинитива на -тә), а глагол 'заканчивать' - субъектно-объектного (и, соответственно, номинализации в генитиве):

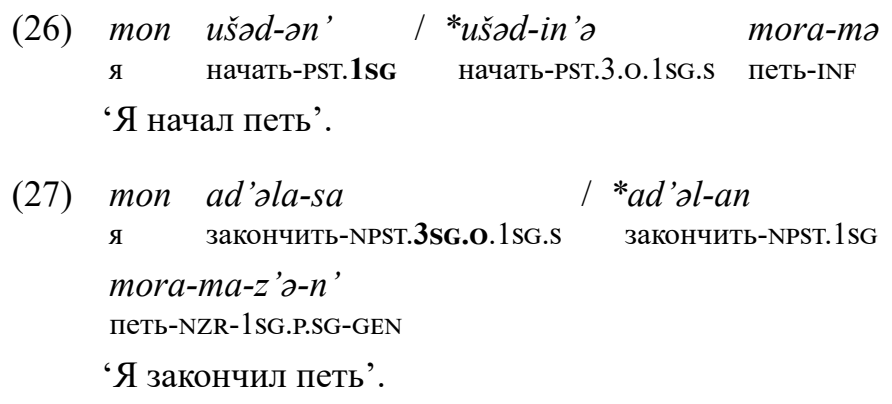

Правила выбора спряжения матричного глагола с финитными СА можно сформулировать следующим образом. Матричные глаголы, управляющие СА с союзом koda 'как', строго требуют СО (были проверены матричные глаголы 'видеть', 'слышать', 'говорить, рассказывать', 'помнить', 'забыть'):

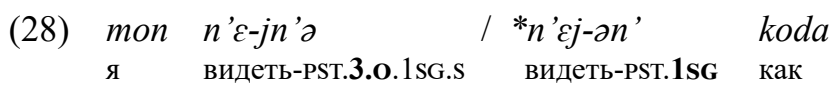

${ }^{10}$ См. [Колядёнков 1962: 241-249] о проблеме разграничения инфинитивов и номинализаций в мордовских языках. 


$\begin{array}{llll}\text { it 't' } & \text { lang-s } & \text { koməc' } & \text { pin’ə } \\ \text { peбенок.DEF.SG.GEN } & \text { на-ILL } & \text { прыгнуть.PST.3sG } & \text { собака } \\ \text { 'Я увидела, как на ребенка собака прыгнула'. }\end{array}$

При союзах što 'что', məz'ardə / majardə 'когда', štobə 'чтобы' и при бессоюзной финитной стратегии зафиксированы оба типа согласования. Глаголы mer' 'gəms 'сказать', kortams 'говорить', dumandams и ar 's 'әms 'думать', abəščandams 'обещать', pel' ’ms 'бояться', verandams 'верить', tonadəms 'привыкнуть' (первые два глагола в этом списке переходные, глаголы 'думать' и 'обещать' маргинально присоединяют непроизводное ПД, остальные - непереходные) и др. в основном присоединяют показатели С-спряжения:

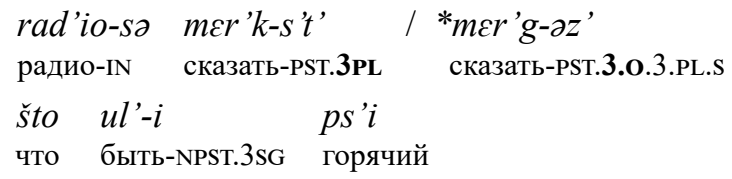

'По радио сказали, что будет жарко'.
(30) dumand-an što vas'e palučanda-j egzamən-t' думать-NPST.1SG что Вася получить-NPST.3SG экзамен-DEF.SG.GEN inksa kafta за два

‘Думаю, что Вася получит на экзамене двойку’.

Глаголы sodams 'знать', jukstams 'забыть', mel'aftəms 'помнить' в основном требуют СО-спряжения:

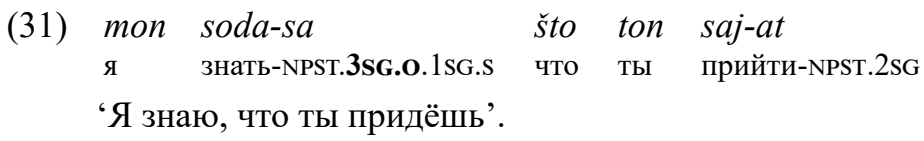

Как объяснить различие между выбором спряжения в (26)-(31)? Глаголы окончания ситуации во многих теоретических работах описываются как вводящие пресуппозицию [Spenader 2002; Beaver, Geurts 2012]: они предполагают, что ситуация в СА имела место до момента речи. При 'начинать', наоборот, такой пресуппозиции не возникает. В частности, при отрицании матричного глагола происходит следующее: при 'заканчивать' сохраняется истинность СА ('Он не закончил писать статью про клитики’ предполагает, что истинно утверждение 'Он писал статью про клитики'), а при 'начинать' - нет ('Он не начал 
писать статью про клитики’ предполагает, что не было такого момента, когда утверждение 'Он писал статью про клитики' истинно). Соответственно, выбор спряжения при данных глаголах коррелирует с семантическим типом СА: субъектно-объектное спряжение используется при глаголе 'заканчивать', т. е. при наличии пресуппозиции истинности СА.

Так же можно объяснить выбор С-спряжения при глаголах sodams ‘знать' и dumandams 'думать'. Глаголы знания в литературе по пресуппозиции относят к фактивным [Kiparsky, Kiparsky 1971] или к средствам, вводящим пресуппозицию (presupposition triggers) [Beaver, Geurts 2012]: они предполагают истинность ситуации в зависимой предикации. Напротив, глаголы мнения к таковым не относятся. Описанная закономерность, однако, действует не строго для тех или иных матричных предикатов: например, при 'знать' С-спряжение возможно в контекстах снятия пресуппозиции (presupposition-opaque contexts); при 'думать' и 'сказать' СО-спряжении возникает в контексте фактивных СА (например, 'Я и не думал, что сегодня уже 31 декабря'), см. подробнее [Сердобольская, Кожемякина 2014].

Таким образом, в целом выбор спряжения отражает семантику СА: факты, которые имеют пресуппозицию истинности зависимой предикации ${ }^{11}$, оформляются СО-спряжением, а пропозиции и ирреальные СА присоединяют показатели С-спряжения.

Уточним, что, следуя терминологии [Подлесская 1990; Asher 1993], мы используем термин «пропозиция» ${ }^{12}$ для контекста СА при 'знать', 'думать' и др. Пропозиции, таким образом, могут быть фактивными (или фактами), как при глаголе ‘знать' или нефактивными, как при глаголе 'думать, полагать'. Пропозиции обычно определяются через понятия «ментальной обработки» и истинностного значения, в отличие от событий, которые не имеют истинностного значения, не могут включать отрицание, доступны чувственному восприятию, имеют длительность и локализованы во времени и в пространстве [Арутюнова 1988; А. Зализняк 1992; Asher 1993].

11 Речь идет именно о логической (а не о прагматической) пресуппозиции, т. к. в контекстах предупомянутости (т. е. при наличии прагматической пресуппозиции, например: 'Ася говорит, что Вася сдал экзамены. - Если Ася говорит, что Вася сдал экзамены, я не верю, она всегда все путает') при глаголах мнения выбирается С-спряжение.

12 Мы используем термин «пропозиция» в узком смысле, т. е. имеем в виду противопоставление фактам и событиям, а не как семантический инвариант предложения. 
Есть семантический тип СА, строго требующий СО-спряжения. При СА со значением события СО-спряжение необходимо даже в контекстах, где не предполагается истинности СА ('Я не видел, чтобы он выходил - этого не было') и в контекстах, где обсуждаемое событие не является предупомянутым ('Что ты там увидел? - Я увидел, как собака в окно прыгнула'), см. подробнее [Сердобольская, Кожемякина 2014].

В этом смысле функциональное распределение двух спряжений при СА не соответствует их распределению при именных актантах, где играет роль предупомянутость и топикальность [Толдова 2017].

\section{2. Синтаксические свойства именных и сентенциальных актантов при СО- и С-спряжении}

\subsection{1. Цели изучения синтаксических свойств обсуждаемых конструкций}

Итак, переходные матричные предикаты могут оформляться маркерами СО-спряжения, если они присоединяют СА со значением события или с пресуппозицией истинности. Однако возникает вопрос, можно ли трактовать показатели СО-спряжения в таких конструкциях так же, как в конструкциях с именным ПД. Напомним, что у именных групп в позиции ПД синтаксические свойства (такие как поведение при каузативе, контроль конвербов и копредикатов) в конструкциях с $\mathrm{CO}$ и С-спряжением совпадают, см. Раздел 2.2. Имеет смысл проверить, насколько это выполняется для СА. Далее, как будет показано ниже, не все конструкции, которые мы обозначаем как CA, в полной мере обладают актантными свойствами: часть рассматриваемых конструкций ведут себя как сирконстанты. Поэтому одной из задач исследования является определение актантного статуса конструкций с $\mathrm{CO}$ и С-спряжением. Наконец, основная цель исследования - определить, одинаков или различен синтаксический статус CA с CO- и С-спряжением. Если считать способность контролировать объектное согласование именным свойством, то встает вопрос, обладают ли СА с разным типом спряжения другими именными свойствами и в какой мере (ср. выводы [Летучий 2012] относительно именных свойств то, что в русском языке и отсутствия данных свойств у СА с союзом что). 
Чтобы ответить на эти вопросы, мы проанализировали синтаксические свойства СА в конструкциях с СО и С-спряжениями. Использованные критерии лишь отчасти соответствуют критериям, разработанным в [Козлов 2017] для именных групп. Дело в том, что многие синтаксические критерии, дающие надежные результаты для именных групп, неприменимы к клаузам. СА обозначают ситуации, а для ситуаций затруднительно придумать естественные примеры с контролем инфинитива, копредикатов, партиципантно-ориентированных локативов и деепричастий; некоторые попытки, однако, сделаны в следующих двух пунктах.

Однако к СА применим критерий продвижения в позицию подлежащего, который нельзя проверить для генитивных, номинативных ПД и послеложных групп (в силу того, что, если проверяемая именная группа занимает позицию подлежащего, нет способа определить, какое оформление она бы имела в позиции ПД). Кроме того, для СА применим критерий вопросительного выноса - критерий, предложенный Дж. Poccom [Ross 1967] и различающий CA и обстоятельственные (а также относительные и некоторые другие) предложения во многих языках.

Далее, для уточнения статуса объектных показателей мы проверяли допустимость маркеров множественного числа для отражения множественности СА (или множественности ситуаций в рамках одного СА).

Для выявления именных свойств СА мы привлекали следующие критерии, предложенные в работах [Dalrymple, Lødrup 2000; Alsina et al. 2005; Moulton 2009; Летучий 2012; Kastner 2015]: сочинение с непроизводным именем, замена СА на проформу, экстрапозиция (плеонастическое 'это'), добавление квантора 'всё'. Перечисленные источники используют данные свойства как аргумент за наличие / отсутствие именных свойств у СА.

Таким образом, рассматривались следующие синтаксические свойства СА: контроль копредикатов и деепричастий, пассивизация матричного глагола, вопросительный вынос из зависимой клаузы, сочинение именных и сентенциальных актантов, замена на анафору и плеонастическая анафора, добавление квантора.

Нами рассмотрены конструкции при матричных глаголах трех типов: глаголы, допускающие преимущественно ${ }^{13} \mathrm{CO}$-спряжение, гла-

13 Часть этих глаголов допускает и С-спряжение, однако это происходит в особых контекстах «снятия пресуппозиции». Глаголы, допускающие преимущественно C-спряжение, также могут выступать в контексте СО-спряжения, если выступают 
голы, допускающие преимущественно С-спряжение, и глаголы, допускающие оба спряжения. К первой группе относятся предикаты sodams ‘знать', n'عjәms 'видеть', jukstams 'забыть' и kel'gəms 'любить'. Во вторую группу входят предикаты $m \varepsilon r$ 'gəms 'сказать' (в нефактивном значении) и ar 's 'әms/dumandams 'думать' (в значении 'считать', 'полагать' $\left.{ }^{14}\right)$. К третьей группе относятся предикаты šarkad'əms 'понимать' и $u$ с̌əms 'ждать'.

Мы исследовали особенности согласования при следующих союзах: što 'что’ при 'знать', ‘понимать', 'сказать', ‘думать', koda 'как' при ‘забывать' и 'видеть', məz 'ardə / məjardə 'когда' при 'ждать', 'любить', ‘бояться', ‘стесняться', см. Таблицу 3.

Таблица 3. Список проанализированных матричных глаголов и союзов ${ }^{15}$

Table 3. List of the matrix verbs and conjunctions under consideration

\begin{tabular}{|c|c|c|}
\hline c013 & СО-спряжение & С-спряжение \\
\hline što 'что' & $\begin{array}{l}\text { sodams 'знать’, сказать } \\
\left.\text { (в фактивном } \mathrm{CA}^{16}\right), \\
\text { šarkad'əms 'понимать' }\end{array}$ & $\begin{array}{l}\text { mer'gəms 'сказать' (в нефакт. } \\
\text { значении), ar 's 'әms / dumandams } \\
\text { 'думать' }\end{array}$ \\
\hline koda 'как' & $\begin{array}{l}\text { n'cjams 'видеть', } \\
\text { jukstams 'забыть' }\end{array}$ & - \\
\hline $\begin{array}{l}\text { məz'ardə/ } \\
\text { məjardo } \\
\text { 'когда' }\end{array}$ & $\begin{array}{l}\text { učəms 'ждать', } \\
\text { kel'gəms 'любить' }\end{array}$ & $\begin{array}{l}\text { pel'əms 'бояться', viz'd'əms } \\
\text { 'стесняться', ken'cr'd'əms } \\
\text { 'радоваться', ис̌əms 'ждать' }\end{array}$ \\
\hline
\end{tabular}

в другом значении или в особых конструкциях, где СА фактивный (например, 'А я и не думал, что это ты!'). Вне контекста выбор типа спряжения у этих двух групп глаголов легко предсказуем. Дело обстоит иначе в третьей группе, где оба спряжения довольно частотны в текстах и регулярно встречаются в элицитированных примерах — на первый взгляд, в одних и тех же контекстах.

14 В значении 'обдумывать' носители выбирают для данных глаголов СО-спряжение.

15 Конечно, многие глаголы в этом списке присоединяют несколько различных союзов - например 'ждать' присоединяет što, məz'ardə ‘когда', štobə и pəka 'пока'. В некоторых случаях мы проверяли для таких глаголов самые частотные союзы, в некоторых - сопоставляли данные по всем возможным союзам.

${ }^{16}$ Например, 'Я не сказал матери, что разбил стекло (разбил и не сказал)'. 


\subsection{2. Контроль копредикатов и деепричастий}

Как уточнялось выше, первые два признака (см. список выше) контроль копредикатов и деепричастий - довольно трудно применить для ситуаций; большинство сконструированных примеров звучат неестественно. Наиболее удачные, на наш взгляд, примеры не были одобрены носителями, вне зависимости от спряжения и союза в СА:

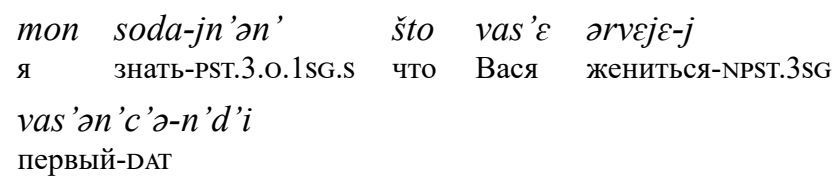

а. 'Я первая узнала, что Вася женится'.

б. *‘Я узнал, что Вася женится, в первую очередь. (Из всех новостей, которые я узнал, эта была первой.)'

Копредикат в дативе может отсылать только к подлежащему ('первая узнала'), но не к СА. Вместе с тем именные ПД в мокшанском языке могут контролировать вторичный предикат в дативе:
son' $\quad$ ' $\varepsilon j-\partial z$ '
он.OBL увидеть-PST.3s.o.3PL.S первый-DAT
Его увидели первым.

Способность контролировать вторичный предикат наблюдается у именных ПД (33) и подлежащих (32); для именных групп в косвенных падежах требуется не датив, а падеж, совпадающий с падежом контролера ('узнал от него первого').

Аналогичным образом СА не могут контролировать нулевой субъект деепричастия на -(ә)ms и -(ә)mstz:

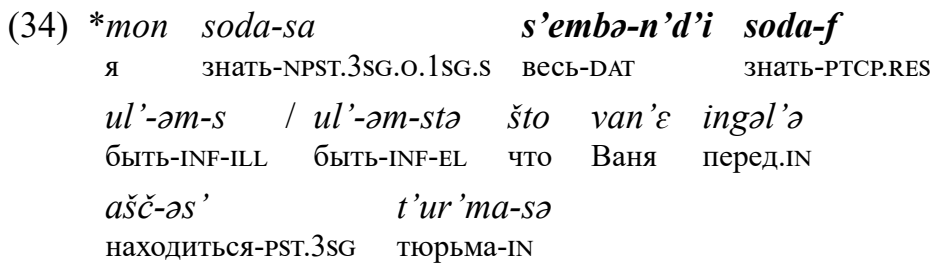

Ожидаемое значение: 'Я знаю, так как это всем известно (букв. 'будучи всем известно'), что Вася раньше сидел в тюрьме'.
(35) *mon n'cj-in'ə
is'ak ul'-om-s /
я
увидеть-PST.3.O.1SG.S
вчера быть-INF-ILL 
ul'-am-sto što vas'e kola-z’o

быть-INF-EL что Вася разбить-PST.3SG.o.3sG.S

sas'ed-ən' val'mə-t'

coсед-GEN окно-DEF.SG.GEN

Ожидаемое значение: 'Я видел — и это произошло вчера (букв. 'произойдя вчера') — как Вася у соседки окно разбил'.

Контроль субъекта данных деепричастий возможен как для подлежащих, так и для ПД, в случае отсутствия выраженного субъекта и маркера согласования [Муравьев 2018: 746]:
son $\check{a} a v-\partial z ’ \partial$
c'ora- $n$ ' $\varepsilon-t^{\prime}$
pra-m-s
он бить-PST.3SG.O.3sG.S мальчик-DIM-DEF.SG.GEN упасть-INF-ILL

‘Он бил мальчика, пока тот не упал’. [Муравьев 2018: 746]

$$
\begin{array}{llll}
\text { mon }_{i} & n{ }^{\prime} \varepsilon j-i n ' \partial & v a s ' \varepsilon-n & \text { mor-s'-əm-sto } \\
\text { я } & \text { видеть-PST.3.O.1SG.S } & \text { Вася-GEN } & \text { петь-IPFV-INF-EL }
\end{array}
$$

‘Я видел Васю, когда он пел'. [Муравьев 2018: 746]

В данном пункте мы приводим примеры на СА с СО-спряжением, поскольку такие СА обладают наибольшим количеством «актантных» свойств, как будет показано ниже. Однако даже такие конструкции не могут контролировать копредикаты и деепричастия. В принципе, носители затрудняются при попытке интерпретировать конструкции такой сложности. Не вполне ясно, следует ли это объяснять отсутствием именных свойств или же общей сложностью конструкции (ср. неестественность русских переводов (34) и (35)).

\subsection{3. Пассивизация матричного глагола}

Одним из свойств глагольных аргументов является способность занимать позицию субъекта при пассивизации. Согласно [Стенин 2018] пассивизация в мокшанском языке возможна при всех переходных глаголах, а также при переходных употреблениях непереходных глаголов.

В рассматриваемых конструкциях таким свойством обладают СА при всех матричных предикатах, присоединяющих показатели СО-спряжения, ср. примеры с союзами što и koda:

$\begin{array}{llll}\text { son'-d'aja-nza } & \text { soda-v-s' } & \text { što } & \text { son' } \\ \text { он.OBL-PRON.DAT-3SG.P } & \text { знать-PASS-PST.3SG } & \text { что } & \text { он.OBL }\end{array}$




$$
\begin{array}{ll}
\text { jora-saz’ } & \text { valt } \\
\text { хотеть-NPST.3.o.3PL.s } & \text { уволить-INF-ILL }
\end{array}
$$

'Ему было известно, что его собираются уволить'.

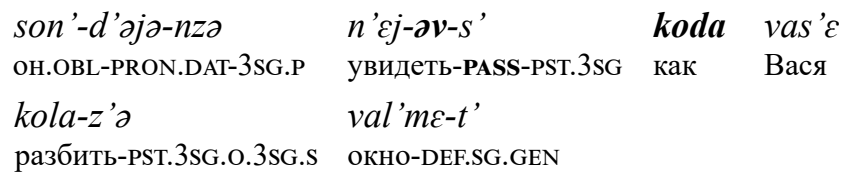

‘Он мог видеть / Ему было видно, как Вася разбил окно’.

Большинство матричных предикатов, предпочитающих С-спряжение, такую конструкцию не допускают, ср. (40б), в отличие от (40а):

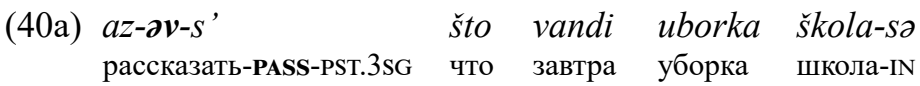

'Было сказано, что завтра уборка в школе'.

$\begin{array}{lllll}\text { (40б) *mer'g-əv-s' } & \text { sto } & \text { vandi } & \text { uborka } & \text { skola-sə } \\ \text { сказать-PASS-PST.3sG } & \text { что } & \text { завтра } & \text { уборка } & \text { школа-IN }\end{array}$

Ожидаемое значение: ‘Было сказано, что завтра уборка в школе'.

Примеры, аналогичные (40б) (с тем же матричным глаголом), маргинально встречаются в корпусе, но опрошенные носители чаще трактуют их как неграмматичные.

Тем не менее пассивизация легко допускается для глаголов $a r$ 's 'əms и dumandams 'думать', употребляющихся с С-спряжением и союзом što:

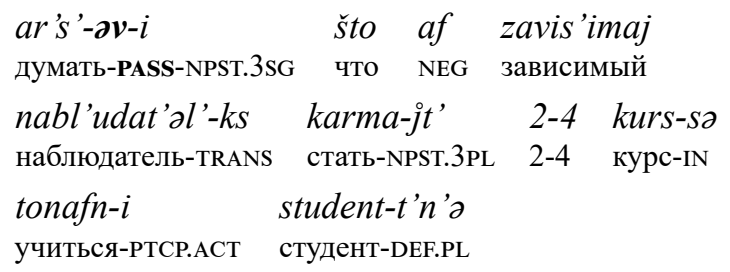

'Предполагается (букв. 'думается'), что независимыми наблюдателями станут студенты 2-4 курсов’. [«Мокшень правда», 09.02.2012, № 5.]

Глаголы речи и эмотивные глаголы с С-спряжением такую конструкцию не допускают. По-видимому, это говорит о том, что актантные предложения в конструкциях с СО-спряжением занимают позицию ПД, в отличие от предложений с С-спряжением. Что касается исключений (41), допустимость такой конструкции при 'думать', вероятно, 
объясняется тем, что здесь речь идет не о каноническом, а о статальном пассиве (результативе), где нет позиции подлежащего [Летучий 2012:] (см. пример с глаголом sodams 'знать' (36б) в [Стенин 2018: 508] - экпериенцер при 'знать' в пассиве выражается дативной ИГ, а не послеложной, как это обычно происходит с агенсом в акциональном пассиве, ср. мне думается в русском языке) - то есть СА в (41) не занимает позицию подлежащего.

\subsection{4. Вопросительный вынос из зависимой клаузы}

Возможность вопросительного выноса из зависимой клаузы [Ross 1967] - свойство, различающее актантные и обстоятельственные (а также относительные ${ }^{17}$ ) предложения во многих языках, ср. рус. Что ты хочешь, чтобы я купил? vs. * Что ты закричал, когда я купил? В мокша-мордовском языке вопросительный вынос возможен из всех союзных актантных предложений с СО-спряжением ${ }^{18}$, ср.:

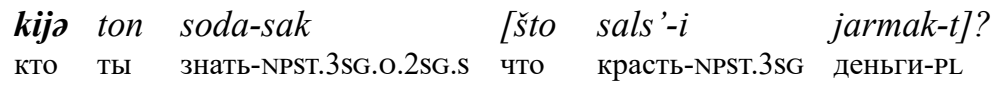

' \{Я давно знал, что Вася таскает деньги из кассы. $\}$ Кто ты знаешь, что ворует деньги?'

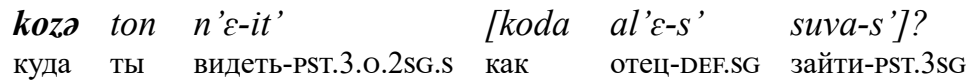

'Куда ты видел, как отец заходил?'
kin' ton kel'k-sak
[maz'arda
кто.GEN ты любить-NPST.3SG.O.2sG.S когда
d'cd'є-z'ว
t'ern'ว-si
inži-ks]?
мать-1SG.P.SG приглашать-NPST.3SG.O.3SG.S гость-TRANS
'Кого ты любишь, когда мама зовет в гости?'

17 Вопросительный вынос также невозможен из некоторых видов актантных предложений, например, из предложений с косвенным вопросом и СА в позиции подлежащего. Однако в обсуждаемом материале такие конструкции не анализируются. Можно предположить, что СА при 'радоваться' (47) и 'стесняться' представляют собой конструкцию с косвенным вопросом; однако для СА с 'ждать' (46) такая интерпретация кажется невозможной.

18 В ходе опроса мы контролировали, чтобы данные предложения не интерпретировались, как эхо-вопрос ('Петя знает, что ... пришел. - Петя знает, что КТО пришел?'). 
Вопросительный вынос также допускается из клауз с što при С-спряжении с глаголами речи и мнения:

$\begin{array}{llllll}\boldsymbol{k} \boldsymbol{i j} \boldsymbol{j} \text { ton } & m \varepsilon r r^{\prime} g-\partial t & {[\check{s} t o} & t \text { ' } \varepsilon c ̌ i & s a-j] ? \\ \text { кто ты } & \text { сказать-PST.2sG } & \text { что } & \text { сегодня } & \text { прийти-NPST.3sG }\end{array}$

'Кто ты сказал, что придет сегодня?'

Однако при məz’ardə/məjardə ‘когда' с С-спряжением (эмотивные глаголы 'радоваться', ‘бояться', ‘стесняться' и глагол 'ждать') вопросительный вынос практически не допускается (46)-(47), так же, как и из обстоятельственных клауз (48).

$\begin{array}{rllll}\text { (46) *kozə } & \text { ton } & \text { uč-sat } & \text { maz'arda } & \text { min' mol'-t'amə? } \\ \text { куда } & \text { ты } & \text { ждать-NPST.3.o.2sG.s } & \text { когда } & \text { мы }\end{array}$

Ожидаемое значение: 'Ты ждешь, когда мы пойдем куда?’(букв.

?‘Куда ты ждешь, когда мы пойдем?')

$\begin{array}{lll}\text { *kozə paša } & \text { ken'er'kšn'-i } & \text { [məz'ardə } \\ \text { куда Паша радоваться.нав-NPST.3sG } & \text { когда } \\ \text { sašənd-i]? } & & \\ \text { приходить-NPST.3sG } & \end{array}$

Ожидаемое значение: 'Паша радуется, когда приходит куда?' (букв. *‘Куда Паша радуется, когда приходит?’)

\begin{tabular}{|c|c|c|c|c|}
\hline *mez'o & ton & $s a-t$ & $k u d-u$ & [maz'arda \\
\hline что & ты & прийти-PST.2SG & доМ-LAT & когда \\
\hline $\begin{array}{l}t^{\prime} \varepsilon d ' \varepsilon- \\
\text { мать-2s }\end{array}$ & & $\begin{array}{l}\text { pid'-әs']? } \\
\text { варить-Рsт.3sG }\end{array}$ & & \\
\hline
\end{tabular}

Ожидаемое значение: 'Ты пришел домой, когда мама варила что?' (букв. *‘Что ты пришел домой, когда мама варила?’)

Таким образом, с точки зрения допустимости вопросительного выноса, CA распределяются следующим образом: конструкции с što проявляют актантные свойства вне зависимости от спряжения глагола, а конструкции с остальными союзами проявляют актантные свойства только при СО-спряжении. Сравнивая этот критерий и способность матричного глагола к пассивизации, можно видеть, что в плане проявления актантных свойств не удается постулировать четко выраженное противопоставление. Скорее, можно наблюдать две тенденции: с одной стороны, СО-конструкции обладают большим количеством актантных свойств, чем С-конструкции, и с другой стороны, конструкции с союзом što в большей мере обладают актантными свойствами, чем 
конструкции с другими союзами (ср. допустимость пассива с 'думать' и союзом što). Ту же тенденцию можно проследить в Разделе 3.2.5.

Уточним, что несмотря на вышесказанное, мы продолжаем называть изучаемые конструкции сентенциальными актантами, в силу того, что на настоящий момент не готовы предложить альтернативную теоретическую трактовку.

\subsection{5. Сочинение именных и сентенциальных актантов}

В мокша-мордовском языке при сочинении непроизводных ПД при порядке VO предикат может маркироваться как показателем множественного числа объекта, так и показателем единственного числа объекта:

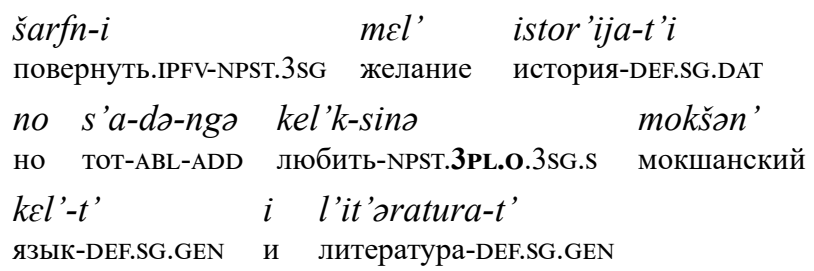

'Интересуется историей, но больше любит мокшанский язык и литературу’. [«Мокшень правда», 16.05.2013 № 19]

$\begin{array}{llll}\text { (50) midvetka-s' } & p \varepsilon k & \text { af } & \text { kel'k-si } \\ \text { медведка-DEF.SG } & \text { очень } & \text { NEG } & \text { любить-NPST.3sG.o.3sG.S }\end{array}$

šur'ke-t' $\quad i \quad x r$ 'izantema- $t^{\prime}$

лук-DEF.SG.GEN и хризантема-DEF.SG.GEN

'Медведка очень не любит лук и хризантему'. [«Мокшень правда», 02.07.2009 № 25]

Таким образом, сочиненные имена в позиции ПД могут контролировать объектные показатели множественного числа на глаголе, однако в конструкциях с такими ПД возможна и форма единственного числа. Проанализируем конструкции с сочинением союзных СА. Обратим внимание, что в этом пункте мы рассматриваем только конструкции с СО-спряжением.

1) СА с союзами koda 'как' и məz'ardə/məjardə 'когда'. При сочинении актантных зависимых клауз с koda 'как' и məz'ardə/məjardə 'когда' матричный глагол не принимает показателей множественности объекта, ср.: 


$\begin{array}{llll}\text { son } & \text { uže } & \text { juksta-z’ə } & \text { / *juksta-z’n’ə } \\ \text { он } & \text { уже } & \text { забыть-PST.3sg.o.3sG.s } & \text { забыть-PST.3PL.o.3sG.S }\end{array}$

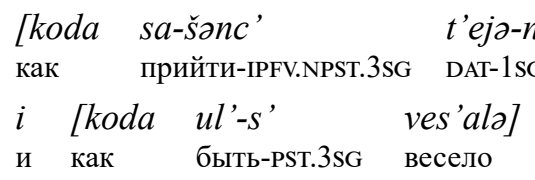

'Он уже забыл, [как приходил к нам в гости] и [как было весело]'.

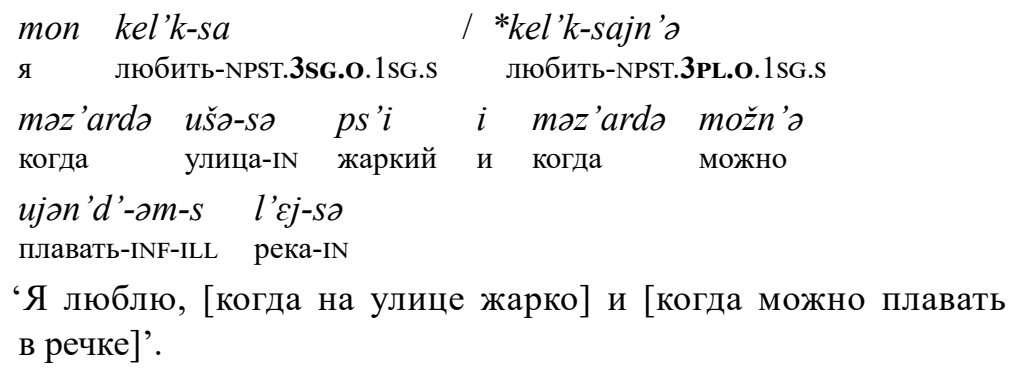

Это говорит о том, что согласовательный показатель в (51)-(52) не отсылает к множественному ПД, а выступает в «окаменевшей» (грамматикализованной) форме 3-го лица единственного числа.

Если речь идет о семантической множественности ситуаций в составе единичного СА, большинство носителей также предпочитают показатель единственного числа объекта:

$$
\begin{aligned}
& \text { son juksta-z’̀ } \\
& \text { / *juksta-z'n’ } \\
& \text { koda } \\
& \text { он забыть-PST.3SG.o.3SG.S } \\
& \text { забыть-PST.3PL.o.3SG.S как } \\
& \text { ingal'a šir'az-nak sa-šanc } \quad \varepsilon r \text { ' } \\
& \text { перед.IN } \quad \text {.LAT-1PL.P идти-IPFV.PST.3SG каждый день-TMPR } \\
& \text { ‘Он забыл, как приходил к нам каждый день'. }
\end{aligned}
$$

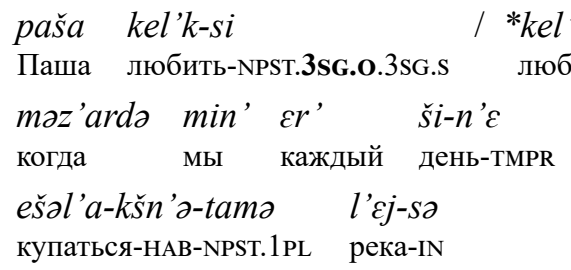

'Паша любит, когда мы каждый день купаемся в речке'.

Уточним, что в принципе показатели множественности объекта на матричном предикате возможны, но это происходит только в случаях 
т. н. прозрачного согласования ${ }^{19}$, которые в настоящей работе не рассматриваются.

2) СА с союзом što 'что'. При сочинении актантных клауз с союзом što 'что’ матричный глагол принимает показатели множественности, хотя и довольно редко (такие примеры допускают 4 из 7 опрошенных носителей, однако они практически не порождаются самостоятельно):

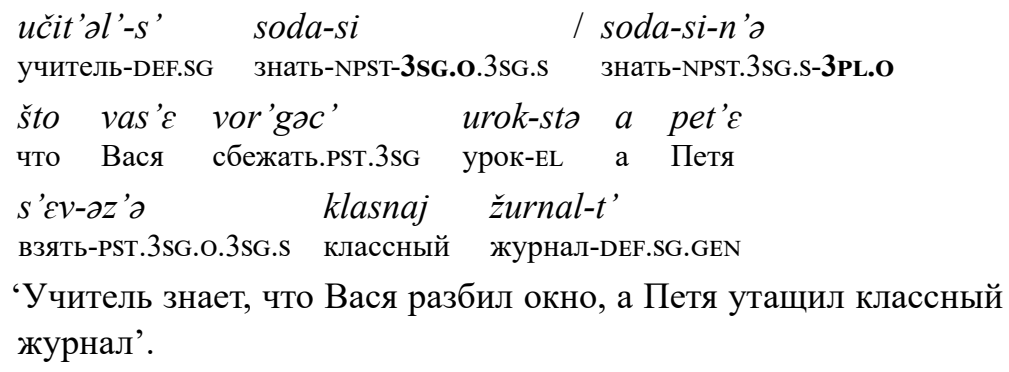

[Комментарий носителя: «sodasin’ə — всё знает учитель, и то, что Вася разбил окно, и то, что Петя утащил классный журнал».]

(56) n'aužel'i ton af šar'kacak

неужели ты NEG понимать.NPST.3SG.o.2sG.S

šar'kaca-jt' $\quad$ sto t' $t^{\prime} \quad$ c'ora-n' $\varepsilon-s$,

понимать.NPST.3PL.o.2SG.S что этот парень-DIM-DEF.SG

sala-j i mi-šancin’ว

воровать-NPST.3SG и продать-IPFV.NPST.3PL.O.3SG.S

'Неужели ты не понимаешь, что этот парень ворует и продает краденое?'

[Комментарий носителя: «все знает — и то, что продает, и то, что ворует».]

В зависимой клаузе нет ИГ с множественной интерпретацией, поэтому, по-видимому, показатель множественного объекта отсылает

${ }^{19}$ Согласование матричного глагола с элементом вложенной предикации, а не с самим СА. Например, множественное число объекта в следующем примере отсылает к субъекту СА:

(ii) vas'c n'cj-əz'-n'วn'

Вася видеть-PST.3.S.PL.S/O-3PL.o[SG.S] как коза-DEF.PL

suva-s't' ber'ə-n' $\varepsilon$ - $v$

войти-PST.3PL огород-DIM-ILL

'Вася видел, как козы зашли в огород'. 
именно к двум ситуациям. Однако, в отличие от конструкций с именными ПД, для конструкций с СА такой выбор является маркированным и возможен при условии эмфазы на множественности ситуации, см. комментарии информантов. В частности, вероятность выбора такого показателя повышается, если главная клауза не утвердительная, а вопросительная с эмфазой (например, с 'неужели' (56)).

В редких случаях носители допускают множественное согласование, если в зависимой клаузе содержатся обстоятельства множественности ситуации:

\begin{tabular}{|c|c|c|c|c|c|}
\hline & $\begin{array}{l}\text { Pl'-s' } \\
\text { ЛЬ-DEF. }\end{array}$ & $\begin{array}{l}\text { soda } \\
\text { знать }\end{array}$ & $\begin{array}{l}i \\
\text { JPST.3SG.o }\end{array}$ & $\begin{array}{ll} & \text { / soda-sin's } \\
\text { SG.S } & \text { Знать-NPST.3PL. }\end{array}$ & o.3sG.s \\
\hline što & pet' $\varepsilon$ & $\varepsilon r^{\prime}$ & mejn' $\varepsilon$ & vor 'gačn'-i & urok-sta \\
\hline что & Петя & каждый & ЧTO.TMPR & сбежать.IPFV-NPST.3SG & урок-EL \\
\hline
\end{tabular}

Уточним, что в таких конструкциях также возможно прозрачное согласование с субъектом.

Таким образом, объектные показатели при СА с союзом što ‘что’ coхраняют числовую семантику, т. е. могут указывать на число ситуаций, выраженных в СА, в отличие от конструкций с koda 'как' и məz'ardə/ majardə 'когда'.

Заметим, что сделанные выводы в целом подтверждаются данными сочинения разнотипных актантов, т. е. союзных СА и номинализаций, именных групп и номинализаций. Как видно из примера (58), если сочиняется непроизводное имя и номинализация, глагол может согласовываться по множественному числу.

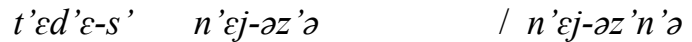

$$
\begin{aligned}
& \text { мать-DEF.SG видеть-PST.3SG.O.3sG.S видеть-PST.3PL.o.3sG.S } \\
& \text { ton' jalga-c'ว-n' } i \quad t^{\prime}{ }^{\prime}{ }^{\prime 20} \text { kišt'ว-ma-n't'ว-n' } \\
& \text { ты.oвL друг-2sG.P.SG-GEN и вы[GEN] плясать-NZR-2PL.P-GEN } \\
& \text { 'Мать видела твою подружку и ваш с ней танец'. }
\end{aligned}
$$

Если же сочиняется непроизводное имя и клауза с союзом, согласование по множественному числу запрещается вне зависимости от союза:

20 Формы местоимений множественного числа в номинативе и генитиве омонимичны, в отличие от местоимений единственного числа. 


\begin{tabular}{|c|c|}
\hline$\varepsilon-S$ & n'cj-əz’ว \\
\hline
\end{tabular}

$\begin{array}{llllll}\text { ton' } & \text { jalga-c'ə- } n \text { ' } & i & \boldsymbol{k o d a} & \text { t'in' }^{\prime} & \text { kel'ks'-əd'ə } \\ \text { ты.OвL } & \text { друг-2SG.P.SG-GEN } & \text { и } & \text { как } & \text { вы } & \text { обниматься-PST.2PL }\end{array}$

'Мать видела твою подружку и как вы обнимались' .

\begin{tabular}{|c|c|c|c|c|c|}
\hline $\begin{array}{l}\text { mon } \\
\text { я }\end{array}$ & $\begin{array}{l}\text { pel'-an } \\
\text { бояться-NPST.1SG }\end{array}$ & $\begin{array}{l}t^{\prime} \varepsilon \\
\text { этот }\end{array}$ & $\begin{array}{l}\text { c'ora-t' } \\
\text { парень-DEF.SG.GEN }\end{array}$ & $\begin{array}{l}e z d \partial \\
\text { B.ABL }\end{array}$ & $\begin{array}{l}\text { son } \\
\mathrm{OH}\end{array}$ \\
\hline & & & 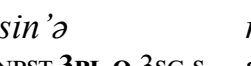 & & \\
\hline
\end{tabular}

$\begin{array}{llllll}k u d-\partial z z^{\prime} \partial-n & i & \text { što } & \text { pozda } & s a-s ̌ a n d-a n & k u d-u \\ \text { дом-1SG.P.SG-GEN } & \text { и } & \text { что } & \text { поздно } & \text { идти-IPFV-NPST.1SG } & \text { дом-LAT }\end{array}$

'Я боюсь этого парня. Он знает мой дом и что вечером я возвращаюсь поздно'.
(61) mon kel'k-sa / *kel'k-sajn'a
я любить-NPST.3SG.o.1sG.S любить-NPST.3PL.o.1sG.S
$s$ 'oks'ว-t' $i$ moz'ardo piz'-i
осень-DEF.SG.GEN и когда идти.о.дожде-NPST.3sG

'Я люблю осень и когда идет дождь'.

Таким образом, контролировать объектные показатели множественного числа могут только СА с союзом što; остальные союзы данных показателей не допускают. При этом показатели множественного числа не просто обозначают множественность ситуаций, а еще добавляют эмфатический оттенок. При сочинении непроизводных имен и СА показатели множественности не используются вне зависимости от союза. В этом плане союзные СА ведут себя иначе, нежели непроизводные имена, при которых показатели множественного числа всегда возможны (хотя и необязательны).

Наблюдаемая десемантизация ${ }^{21}$ числового значения объектных показателей при СА говорит о том, что союзные СА (в отличие от номинализаций и непроизводных имен) не обладают в полной мере синтаксическими свойствами именных ПД, несмотря на наличие показателей СО-спряжения.

21 Говоря о десемантизации, мы имеем в виду, что показатели единственного числа, отсылая к СА, теряют числовую семантику и используются для обоих чисел (в отличие от именных актантов, где сохраняется противопоставление по числу). 
3.2.6. Замена на проформу и плеонастическая анафора (при экстрапозиции)

Это и следующее свойство (добавление квантора) касается именных свойств конструкции, а не ее актантного статуса. В [Kastner 2015: 35] это свойство используется как аргумент за наличие «оболочки» (shell) DP над клаузой: $\left[_{D P}[D\right.$ [CP That these nouns behave differently]] is captured by this formulation of the rule] (ср. трактовку в терминах объектной грамматической функции в [Alsina et al. 2005]).

В мокша-мордовском языке неодушевленные именные актанты могут быть заменены на проформу (анафору) $t$ ' $\varepsilon$ 'этот' (для одушевленных используется анафорическое местоимение son 'он / она / оно'):

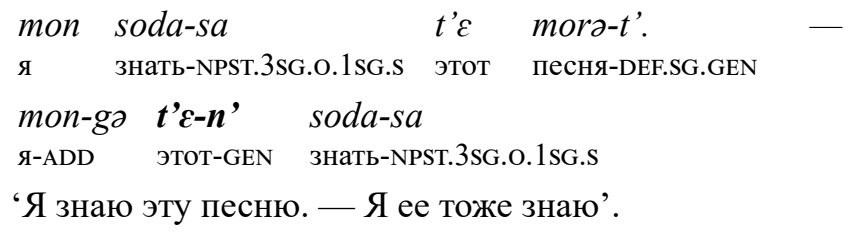

Замена на проформу возможна при всех матричных предикатах, употребляющихся с СО-согласованием:

\begin{tabular}{|c|c|c|c|c|c|}
\hline mon & $\begin{array}{l}\text { kunaro } \\
\text { давно }\end{array}$ & $\begin{array}{l}\text { soda-jn’ə } \\
\text { знать-PST.3.o.1sG.s }\end{array}$ & $\begin{array}{l}\text { što } \\
\text { что }\end{array}$ & $\begin{array}{l}\operatorname{vas}^{\prime} \varepsilon \\
\text { Вася }\end{array}$ & $\begin{array}{l}a \check{s} \check{c} \text {-əl' } \\
\text { находиться-PQP.3sG }\end{array}$ \\
\hline & & $\begin{array}{lll}\text { - } d \boldsymbol{m o n - g a} & \text { t'c } \\
\text { да } & \text { я-ADD } & \text { эт }\end{array}$ & & $\begin{array}{l}s o d a \\
\text { знать }\end{array}$ & PST.3sG.0.1SG.S \\
\hline
\end{tabular}

'Я давно знал, что Вася раньше сидел в тюрьме. - Да, я тоже это знаю’.

(64) šar'kad'-at mon n'cj-in'a koda vas'c понимать-NPST.2SG я видеть-PST.3.O.1SG.S как Вася

kola-z'ə is'ak sas'ed-ən' val'me-t'.

разбить-PST.3SG.o.3sG.s вчера сосед-GEN окно-DEF.SG.GEN

da mon-ga t' $\boldsymbol{\varepsilon}-\boldsymbol{n}$ ' n'cj-in'ə

да я-ADD этот-GEN видеть-PST.3.O.1sG.S

'Представляешь, я видел, как Вася вчера соседское окно разбил. - Да, я это тоже видел’

В случае С-согласования допустимость такой замены зависит от глагола. Это возможно при глаголе 'ждать' и при непереходных матричных глаголах — 'бояться' (65), 'стесняться', 'радоваться’ 
(66), - однако при глаголах речи и мнения носители предпочитают заменять зависимую клаузу на проформу $t$ 'aftz 'так' (местоимение $t$ ' $\varepsilon$ в генитиве маргинально допускается лишь при kortams 'говорить'), ср. (67) и (68).

(65) mon dumand-an što vas' $\varepsilon$ af pastupanda- $v-i$ я думать-NPST.1SG что Вася NEG поступить-PASS-NPST.3SG institut-u. - mon tožə t'a-do pel'-an институT-LAT я тоже этоT-ABL бояться-NPST.1SG 'Я думаю, что Вася не поступит в институт. - Да, я тоже этого боюсь'.

(66) sasec' ken'er'čn'-i što mi-z'a сосед.DEF.SG радоваться.HAB-NPST.3SG что продать-PST.3SG.O.3sG.S traks-ənc pitn'i-sta son' semika-c корова-3SG.P.SG.GEN дорогой-EL он.OBL семья-3SG.P.SG

toža t'e-n'd'i ken'cr'čn'-ijt' тоже этот-DAT радоваться.HAB-NPST.3PL

'Сосед радуется, что дорого продал корову. Его семья тоже этому радуется’.

(67) vas'e t'aftamə jožu soda-v-i što son Вася такой умный знать-PASS-NPST.3SG что он zdavanda-si egzamen-t' atl'ičnaj-stz. сдать-NPST.3SG.O.3SG.S экзамен-DEF.SG.GEN отличный-EL nu mon t'afto af dumand-an / *'t' $\boldsymbol{\varepsilon}-\boldsymbol{n}$ ' af ну я так NEG думать-NPST.1SG этот-GEN NEG dumanda-sa думать-NPST.3SG.O.1SG.S

'Вася такой умный, что он наверняка сдаст экзамены на отлично! - Ну, я так не думаю’.

(68) n'eužel'i paša arveje-s'? - mon t'afto неужели Паша жениться-PST.3SG я так iz'-әn' korta /(режке) t' $\boldsymbol{\text { ' } - \boldsymbol { n } \text { ' }}$ ' iz'-in'ə NEG.PST-PST.1sG говорить.CN этоT-GEN NEG.PST-PST.3.o.1SG.S korta kosta ton sev-it'? говорить.СN откуда ты взять-PST.3.O.2SG.S 'Неужели Паша женится? — Я этого не говорил. Откуда ты это взял?' 
Аналогично ведут себя рассматриваемые конструкции в контексте плеонастической анафоры 'это’, или при экстрапозиции: ‘Я это говорил, что он приедет завтра'. Уточним, что в мокша-мордовском языке конструкции с экстрапозицией более естественны, чем соответствующие примеры в русском.

Как и при замене на проформу, актантные предложения с СО-спряжением допускают экстрапозицию с местоимением $t$ ' $\varepsilon$ в генитиве:

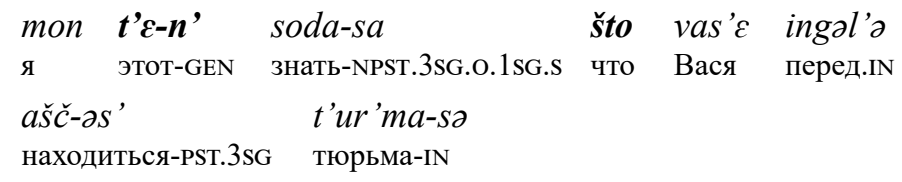

'Я знаю (букв. 'я это знаю'), что Вася раньше сидел в тюрьме'.

\begin{tabular}{|c|c|c|c|c|}
\hline $\begin{array}{l}\text { sOn } \\
\mathrm{OH}\end{array}$ & $\begin{array}{l}\boldsymbol{t}^{\prime} \boldsymbol{\varepsilon}-\boldsymbol{n} \\
\text { ЭТОТ-GEN }\end{array}$ & $\begin{array}{l}\text { juksta-z’ə } \\
\text { забыть-PST.3sG.o.3sG.s }\end{array}$ & $\begin{array}{l}\text { koda } \\
\text { как }\end{array}$ & $\begin{array}{l}\min \\
\text { мы }\end{array}$ \\
\hline & $z \partial$ & -әma & & \\
\hline $\mathrm{c}-3 \mathrm{sc}$ & SSG & Iсать-PST.1SG & & \\
\hline
\end{tabular}

'Он забыл (букв. 'он это забыл'), как мы с ним танцевали'.

В случае С-спряжения с глаголами речи и мнения (с нефактивным CA) при экстрапозиции требуется форма $t$ 'aftz:
(71) vas'c t'afto iz' korta / t'c-n'
Вася так NEG.PST.3SG говорить.CN этоT-GEN
iz'-in'a korta što son
NEG.PST-PST.3.O.1SG.S говорить.CN что он
pastupanda-s, institut-u
поступить-PST.3SG институт-LAT
'Вася не сказал (букв. 'Вася так не сказал'), что он поступил в институт'.

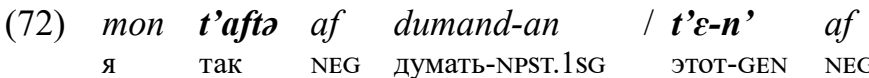
dumanda-sa što vas'e pastupanda-j institut-u
думать-NPST.3SG.o.1sG.S что Вася поступить-NPST.3sG институт-LAT
'Я не думаю (букв. 'я так не думаю') / не раздумываю о том (букв.
'это не раздумываю'), что Вася поступит в институт'.

Как видно из (71)-(72), при использовании местоимения $t$ ' $\varepsilon$ носители сразу заменяют спряжение на СО (это местоимение в принципе 
требует CO-спряжения). При этом матричный глагол выступает в другом значении, например dumandams 'думать' имеет значение 'размышлять, раздумывать', как в (72), или 'обдумывать'.

Эмотивные глаголы и 'ждать' допускают экстрапозицию с местоимением $t^{\prime} \varepsilon$ :

\begin{tabular}{|c|c|c|c|c|}
\hline mon & $t^{\prime} \varepsilon-n^{\prime}$ & esa & $u \check{c}-a n$ & moz'ardo \\
\hline$g$ & ЭтоT-GEN & B.IN & ждать-NPST.1sG & когда \\
\hline $\begin{array}{l}\text { 'eja- } \\
\text { RON }\end{array}$ & -1 SG.P.P & $\begin{array}{l}s a j-a \\
\text { прийт }\end{array}$ & и-NPST.2sG & \\
\hline
\end{tabular}

'Я жду (букв. 'я этого жду'), когда ты ко мне приедешь'.

(74)

$\begin{array}{llllll}\text { mon } & \boldsymbol{t} \text { 'a-do } & \text { pel'-an } & \text { što } & \text { vas'c } & \text { pozdo } \\ я & \text { этот-ABL } & \text { бояться-NPST.1SG } & \text { что } & \text { Вася } & \text { поздно } \\ s a-j & k u d-u & & & \\ \text { прийти-NPST.3SG } & \text { дом-LAT } & & & \end{array}$

'Я боюсь (букв. 'я этого боюсь'), что Вася поздно придет домой’.

\subsection{7. Кванторные группы в позиции ПД}

Аналогичным образом, т. е. так же, как и в контексте анафоры, ведут себя рассматриваемые конструкции при попытке добавления анафорического 'всё’:

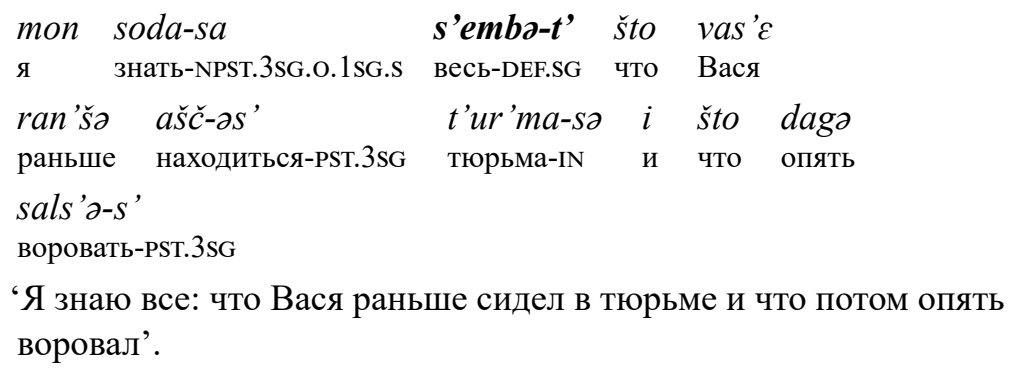

'Я знаю все: что Вася раньше сидел в тюрьме и что потом опять воровал'.

(76) učit'วl'-s' n'عj-əz'ว

учитель-DEF.SG увидеть-PST.3SG.O.3SG.S весь-DEF.SG.GEN

koda kola-jt' val'me-t' i koda

как разбить-PST.3.o.2sG.s окно-DEF.SG.GEN и как

r'isava-jt' st'ena-t'

рисовать-PST.3.o.2sG.s стена-DEF.SG.GEN

'Учитель видел все: как ты разбил окно и как разрисовал стену'. 
Вне зависимости от союза, сентенциальные актанты при СО-спряжении допускают употребление анафорического 'все', то есть ведут себя как именные актанты, ср.:

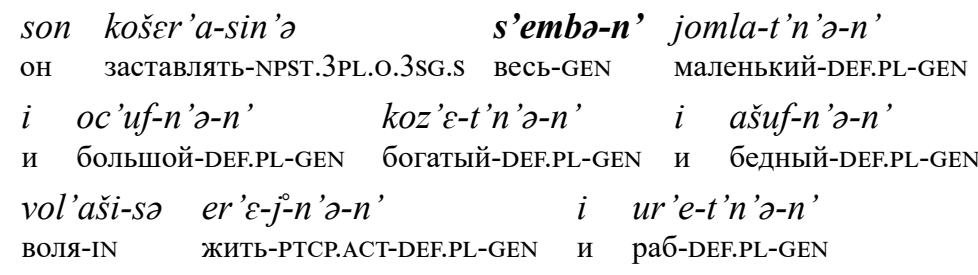

put-am-s t'ešt'fks vid'i ked'-azว-st al'i kon'a-zว-st ставить-INF-ILL отметка правый рука-ILL-3PL.P или лоб-ILL-3PL.P 'Он будет заставлять всех, молодых и старых, богатых и бедных, живущих на воле и рабов, ставить отметку на правую руку или лоб'. [http://finugorbib.com/bible/moksha/66_Rev13_na.html]

Глаголы речи и мнения, которые обычно выступают с C-спряжением, также могут употребляться с квантором, однако при этом носители отмечают изменение значения матричного предиката и меняют спряжение на СО. Так, глагол dumandams 'думать' в этой конструкции переводится носителями как 'обдумывать' (78), а глагол $m \varepsilon r$ 'gəms 'сказать' - как 'высказать' (79).

(78) mon dumanda-sa

я думать-NPST.3SG.O.1SG.S весь-GEN что он

pastupanda-j institut-u $i$ što

поступить-NPST.3SG инститУт-LAT и что

mu-j c'eber' rabota.

найти-NPST.3SG хороший работа

'Я обдумываю все ситуации (букв. 'обдумываю все'): и что он поступит в институт, и что найдет хорошую работу’.

(79) štoba son' bas'a-m-s mon mer'g-in's

чтобы он.OBL утешить-INF-ILL я сказать-PST.3.o.SG.S

s'embo-n' što son pastupanda-s' institut-u весь-GEN что он поступить-PST.3SG институт-LAT

$i$ što mu-j c'ebsr' rabota

и что найти-NPST.3SG хороший работа

'Чтобы ее утешить, я сказал все: и что он поступил в институт и что найдет хорошую работу'. 
Эмотивные глаголы и 'ждать' допускают квантор при СА в контексте С-спряжения:

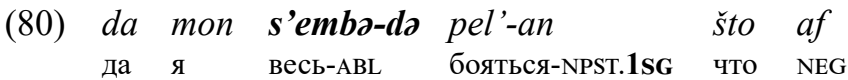

pastupand-at intitut-u i af muj-at rabota поступить-NPST.2SG институт-LAT и NEG найти-NPST.2SG работа \{'Ну чего ты боишься, думаешь, я в институт не поступлю?’\} 'Да, я всего боюсь: и что не найдешь работу, и что в институт не поступишь'.

Итак, контекст анафорического квантора также противопоставляет конструкции с СО-спряжением и конструкции с С-спряжением при переходных глаголах речи и мнения. Эмотивные непереходные глаголы 'радоваться', ‘бояться', 'стесняться', а также 'ждать' с С-спряжением допускают как замену на анафору, так и плеонастическую анафору и квантор.

Заметим, что три последние свойства, рассмотренные выше (замена на анафору, экстрапозиция, добавление квантора), наблюдаются также у обстоятельственных предложений, ср. пример с заменой на анафорическое местоимение $t$ ' $\varepsilon$ в генитиве и на плеонастическую анафору:

$\begin{array}{llll}\text { lomat-t'n'z } & \text { tušanc't' } & \text { šir'-i } & \text { rabota-n' } \\ \text { человек-DEF.PL } & \text { уходить.PST.3PL } & \text { y-LAT } & \text { работа-GEN }\end{array}$

$\begin{array}{llll}\text { veš-əmə } & \boldsymbol{t} \text { ' } \boldsymbol{\varepsilon}-\boldsymbol{n}, \quad \boldsymbol{i n k s a} & \text { s'olgəv-s' } & \text { kafksa } \\ \text { искать-INF } & \text { этот-GEN из-за } & \text { закрыться-PST.3SG } & \text { восемь } \\ \text { klas-ən' } & \text { škola-s', } & & \\ \text { класc-GEN } & \text { школа-DEF.SG } & & \end{array}$

'Люди ушли искать работу на сторону. Из-за этого закрылась восьмиклассная школа’. [«Мокшень правда», 07.07.2011 № 26]

\begin{tabular}{|c|c|c|c|c|}
\hline $\begin{array}{l}\text { mon } \\
\text { я }\end{array}$ & $\begin{array}{l}\boldsymbol{t} \boldsymbol{a}-\boldsymbol{d} \boldsymbol{\partial} \\
\text { эТОТ-АВL }\end{array}$ & $\begin{array}{l}\text { mel’s } \\
\text { после }\end{array}$ & $\begin{array}{l}\text { sargaz'-әn' } \\
\text { проснуться-PST.1SG }\end{array}$ & $\begin{array}{l}m \partial z \text { 'ard } \\
\text { когда }\end{array}$ \\
\hline $\begin{array}{l}t u-s ' \\
\text { уйти- }\end{array}$ & T.3PL & $\begin{array}{l}d^{\prime} \varepsilon-z \text { ' } \\
\end{array}$ & $\begin{array}{l}a l^{\prime} \varepsilon-z \text { ' } \\
\text { отец-1sG }\end{array}$ & \\
\hline
\end{tabular}

'Я (букв. после этого) проснулась, когда мама с папой уже уехали'.

В свете этого данные три свойства следует трактовать не как критерий, противопоставляющий актанты и сирконстанты, а как свойство именных групп в целом (сp. [Dalrymple, Lødrup 2000] и [Kastner 2015]; 
см., однако, [Elliott 2018]). CA в конструкциях с CO-спряжением при переходных глаголах обладают данными свойствами, в отличие от СА при С-спряжении.

\section{4. Обсуждение}

Синтаксические свойства актантных предложений, которые обсуждались в Разделе 3, суммированы в Таблице 4 (с. 518).

В целом можно видеть, что проанализированные свойства кластеризуются следующим образом.

Во-первых, союзные СА (вне зависимости от согласования) совсем не обладают двумя свойствами, характерными для ПД и субъектов 22 это контроль копредикатов и деепричастий.

Во-вторых, два свойства глагольных актантов - способность становиться подлежащим при пассивизации глагола и возможность вопросительного выноса - наблюдаются для конструкций с СО-спряжением (вне зависимости от союза) и союзных клауз с što (с любым спряжением $)^{23}$. В случае С-спряжения при što наблюдается расхождение по носителям, в зависимости от конкретного матричного глагола. Таким образом, эти два свойства выделяют зависимые клаузы с mәz'ardə/məjardə при С-спряжении, как не обладающие свойствами глагольного актанта. Мы не готовы предложить теоретическую трактовку данных конструкций, поэтому пока оставляем за ними термин «СА».

В-третьих, согласование с множественным СА выделяет конструкции с союзом što на фоне остальных союзных СА: в них возможно согласование по множественности ситуаций. Это свойство сближает данные СА с именными актантами, при которых возможно согласование по множественности.

Наконец, четвертая группа критериев выделяет конструкции с СО-спряжением, как обладающие свойствами именных групп (так же,

22 Контроль копредикатов, в отличие от контроля деепричастий, возможен также для именных групп в косвенных падежах.

${ }^{23}$ Если считать, что в случае с ‘думать’ речь идет о статальном пассиве, где СА не является подлежащим, тогда можно сказать, что все же это свойство именно CO-конструкций, а не любых CA с союзом što. Однако на настоящий момент мы не можем с уверенностью судить о типе пассивной конструкции при 'думать'. 
как и СА при непереходных матричных глаголах и при 'ждать'), в отличие от конструкций с С-спряжением.

Таблица 4. Синтаксические свойства союзных актантных предложений в контексте $\mathrm{CO}$ и С-спряжения

Table 4. Syntactic properties of the conjunctional complement clauses with subject-object and subject agreement patterns

\begin{tabular}{|c|c|c|c|c|}
\hline Спряжение & \multicolumn{2}{|c|}{$\mathrm{CO}$} & \multicolumn{2}{|c|}{$\mathbf{C}$} \\
\hline Союз & što & $\begin{array}{c}\text { koda, } \\
\text { maz'ardo / } \\
\text { majardə }\end{array}$ & što & $\begin{array}{c}\text { što, } \\
\text { maz'ardo / } \\
\text { majardo }{ }^{24}\end{array}$ \\
\hline $\begin{array}{l}\text { Контроль } \\
\text { копредикатов }\end{array}$ & - & - & - & - \\
\hline $\begin{array}{l}\text { Контроль } \\
\text { деепричастий }\end{array}$ & - & - & - & - \\
\hline $\begin{array}{l}\text { СА становится } \\
\text { подлежащим при } \\
\text { пассивизации } \\
\text { матричного глагола }\end{array}$ & + & + & $+/-$ & - \\
\hline $\begin{array}{l}\text { Вопросительный } \\
\text { вынос из зависимой } \\
\text { клаузы }\end{array}$ & + & + & + & $-(+)$ \\
\hline $\begin{array}{l}\text { Согласование } \\
\text { с множественным СА }\end{array}$ & + & - & $\mathrm{n} / \mathrm{a}$ & $\mathrm{n} / \mathrm{a}$ \\
\hline Замена на проформу & $t \varepsilon n^{\prime}$ & $t \varepsilon n^{\prime}$ & t'afto & $t \varepsilon n^{\prime}$ \\
\hline $\begin{array}{l}\text { Плеонастическая } \\
\text { анафора }\end{array}$ & $+\left(t \varepsilon n^{\prime}\right)$ & $+\left(t \varepsilon n^{\prime}\right)$ & $+\left(t^{\prime} a f t z\right)$ & $+\left(t \varepsilon n^{\prime}\right)$ \\
\hline \multirow[t]{2}{*}{$\begin{array}{l}\text { Анафорический } \\
\text { квантор }\end{array}$} & + & + & - & + \\
\hline & $\begin{array}{l}\text { ‘знать', } \\
\text { ‘говорить', } \\
\text { ‘понимать' }\end{array}$ & $\begin{array}{l}\text { ‘видеть', } \\
\text { ‘забывать', } \\
\text { 'любить' }\end{array}$ & $\begin{array}{l}\text { ‘думать’, } \\
\text { ‘говорить' }\end{array}$ & $\begin{array}{c}\text { ‘ждать’, } \\
\text { ‘бояться’, } \\
\text { 'стесняться', } \\
\text { 'радоваться' }\end{array}$ \\
\hline
\end{tabular}

${ }^{24}$ Мы не рассматриваем косвенный вопрос с koda (например, 'Он сказал, как надо делать Р'), при котором возможно и С-спряжение. Вне косвенного вопроса C-спряжение при koda запрещается носителями. 
Мы объясняем изложенные факты следующим образом. Недопустимость копредикатов и деепричастий, по-видимому, объясняется семантическими причинами. Довольно проблематично придумать естественные примеры, где субъектом копредиката выступал бы не конкретный объект, а абстрактное понятие, включая ситуации (каковыми являются CA). Уточним, однако, что в русском языке такие примеры с абстрактными именами находятся, а с СА - нет [Летучий 2012].

Вторая группа свойств ориентирована на статус зависимой клаузы как глагольного актанта. Согласно этим критериям, зависимые клаузы с məz'ardə/məjardə 'когда' при С-спряжении (при матричных глаголах 'ждать', ‘бояться', ‘стесняться') не являются актантами матричного глагола. Это хорошо согласуется с семантическим типом зависимых клауз в таких конструкциях. Глагол 'ждать' с С-спряжением и союзом 'когда' употребляется в значении эмоциональной оценки, как и 'бояться' и 'стесняться'. В «эмоциональных» употреблениях данных глаголов стимул необязателен для синтаксического выражения (Она ждала с беспокойством. Мама, я боюсь! Не трогайте его, он стесняemcя) и отчасти теряет актантные свойства (несмотря на то, что 'ждать' в мокшанском - переходный глагол, в отличие от 'бояться' и 'стесняться'). Это соответствует замечанию А. Зализняк [1992] о факультативности стимула при «эмоциональном» значении ждать $I V^{25}$ и других глаголов русского языка.

Третья и четвертая группы признаков различают конструкции, обладающие признаками именной группы, и СА, не обладающие именными признаками. В ряде исследований по синтаксису СА показано, что некоторое подмножество СА в английском и других языках обладает именными свойствами, включая способность замещаться именной анафорой (it/which, в отличие от so/as), сочиняться с непроизводным именем, топикализоваться и занимать позицию подлежащего при пассивизации. Те СА, которые обладают данными свойствами, в терминах минималистской программы в [Kastner 2015] анализируются как клаузы, включенные в состав именной группы (т. е. СР, имеющие оболочку DP, в отличие от СР, не имеющих оболочки DP [Kastner 2015]). В Лексико-функциональной грамматике СА первого типа в функциональной структуре (грубо говоря, аналог аргументной структуры) вводятся тем же функциональным элементом ОВЈ, что и именные ПД,

${ }^{25}$ Например, ждать последнего удара (ждать IV, с эмотивным оттенком) в отличие от Хочешь, я тебя подожду? (ждать I), см. подробнее [А. Зализняк 1992: 523-526]. 
в то время как СА второго типа вводятся элементом COMP [Dalrymple, Lødrup 2000] (альтернативное решение в терминах наличия уровня NP предлагается в [Alsina et al. 2005]). В основе обоих подходов лежит обобщение о том, что СА в ряде языков могут обладать или не обладать синтаксическими свойствами именной группы. В работах [Dalrymple, Lødrup 2000; Alsina et al. 2005; Kastner 2015] показывается, что довольно часто эти синтаксические свойства коррелируют с семантическим типом СА: те СА, которые обладают свойствами именной группы, относятся к типу фактивных (или предупомянутых, cp. [Kastner 2015]) пропозиций. Аналогичное обобщение оказывается верно для мордовских СА: союзные клаузы, контролирующие объектное согласование и обладающие свойствами именной группы (замена на анафорический квантор и на анафору $t$ ' $\varepsilon n$ ', а также на плеонастическую анафору $t$ ' $\varepsilon n$ ' (экстрапозицию)), кодируют факты и события. Напротив, конструкции с C-спряжением при переходных глаголах, не обладающие именными свойствами, вводят нефактивные пропозиции и ирреальные СА. При этом в мокша-мордовском именными свойствами обладают также событийные СА и СА при непереходных эмотивных глаголах и глаголе ‘ждать'. В работе [Belyaev et al. 2017], где предлагается формальный анализ мокша-мордовских конструкций, на основании проанализированных выше синтаксических свойств показано, что СА с СО-спряжением имеют грамматическую функцию ОВЈ (как и именные ПД при переходном глаголе), в отличие от СА с С-спряжением, обладающих функцией СОМР (которая зарезервирована для клауз).

Интересно, что CO-конструкции распадаются на два типа в зависимости от возможности согласования по множественной ситуации. Союз što, который вводит пропозиции (фактивные или нет), допускает такое согласование в отличие от остальных союзов, которые вводят преимущественно событийные СА. Таким образом, контролировать согласование по множественности ситуации могут фактивные, но не событийные СА. На настоящий момент мы не можем предложить объяснения данному явлению.

Заметим, что с точки зрения сочинения есть одно свойство, объединяющее все три союза в СА, а именно: все союзы при СО-спряжении допускают сочинение СА с именем (59)-(61). Согласно [Dalrymple, Lødrup 2000] (и в некоторой степени [Kastner 2015: 173]), сама возможность сочинения с именами является одним из аргументов за именной статус СА. В английском языке сочинение с именем невозможно для СА ассертивных глаголов, ср.: 
(83a) *John claimed [DP responsibility] and [CP that the building collapsed]. Ожидаемое значение: 'Джон взял на себя ответственность и заявил, что здание обрушилось.'

(836) 'John denied [DP the allegations] and [DP that the building collapsed]. 'Джон отказался от своих заявлений и опроверг, что здание обрушилось.' [Kastner 2015: 173]

Однако в мокша-мордовском языке, по-видимому, сочинение устроено иным образом - об этом говорит то, что оно возможно и для СА, демонстрирующих именные свойства (грамматическую функцию ОВЈ), и для СА, не имеющих данных свойств.

Таким образом, различие между СО и С-конструкциями СА в мокша-мордовском языке можно объяснить следующим образом: фактивные и событийные СА имеют синтаксический статус именных групп и, соответственно, они обладают рядом синтаксических свойств имени (СО-спряжение, способность сочетаться с именем, замещаться анафорическим местоимением и квантором, допустимость в конструкции плеонастической анафоры). Что касается пропозиций и ирреальных СА, то они не имеют именного статуса и не обладают вышеперечисленными свойствами.

В отличие от английского и некоторых других языков, в мокша-мордовском противопоставление проходит именно между фактами (и событиями) vs. пропозициями, вне зависимости от предупомянутости / ожидаемости ситуации в $\mathrm{CA}^{26}$.

\section{5. Выводы}

В работе были проанализированы семантические и синтаксические свойства СА в контексте $\mathrm{CO}$ и С-спряжений в мокша-мордовском языке. В [Сердобольская, Кожемякина 2014] было показано, что распределение двух спряжений при союзных СА зависит от семантического типа

\footnotetext{
${ }^{26}$ В частности, в английском языке СА при глаголах deny 'отрицать', accept 'признать' и других глаголах ответной реакции (т. е. глаголах, вводящих предупомянутые ситуации) проявляют те же синтаксические свойства, что и фактивные СА при глаголах know 'знать' и realize 'понять' и др. В этом плане они отличаются от нефактивных глаголов, вводящих новую информацию (say 'сказать', claim 'утверждать’ и т. п.). В мокша-мордовском параметр данности / предупомянутости не влияет на выбор спряжения, ср. Раздел 3.1.
} 
зависимой клаузы: события и факты требуют СО-спряжения, а пропозиции и ирреальные СА - C-спряжения.

Союзные СА в зависимости от типа спряжения делятся на два типа: СА с именным статусом и СА без именного статуса. Первый тип конструкций обладает именными синтаксическими свойствами - способностью замещаться именной анафорой (в том числе плеонастической) и анафорическим квантором. Второй тип конструкций не обладает данными свойствами. Такое различие в синтаксической структуре отражает различие в семантике СА: бытийные и фактивные союзные клаузы вводятся конструкцией с именными свойствами, в то время как пропозитивные и ирреальные СА - конструкцией без именных свойств. Таким образом, наличие именных свойств на синтаксическом уровне отражает наличие пресуппозиции (или семантики события). Непереходные эмотивные глаголы и 'ждать' демонстрируют именные свойства вне зависимости от типа спряжения.

Распределение двух типов спряжений при именных и сентенциальных актантах имеет различную функциональную базу: в то время как для именных актантов действует ряд таких факторов, как определенность, топикальность, аспектуальные характеристики ситуации, для СА важна пресуппозиция истинности ${ }^{27}$ или семантика события.

Итак, показатели объектного согласования при СА имеют несколько иной грамматический статус, нежели при именных ПД. Именные ПД с генитивом и номинативом в контексте $\mathrm{CO}$ и С-спряжения, соответственно, обладают одними и теми же синтаксическими свойствами и, по-видимому, занимают одну и ту же синтаксическую позицию [Козлов 2017]. В отличие от них, СА в контексте СО- и С-спряжения демонстрируют различные синтаксические свойства: СА с СО-спряжением имеют именные свойства (что в [Belyaev et al. 2017] трактуется в терминах грамматической функции ОВJ), а CA с С-спряжением их не имеют (соответственно, они вводятся грамматической функцией СОМР). Таким образом, показатели СО-спряжения при СА сигнализируют о наличии именных синтаксических свойств, в отличие от показателей C-спряжения.

27 Хорошо известно, что определенность в формальной семантике анализируется через понятие пресуппозиции - в этом семантика именных и сентенциальных ПД при СО-спряжении схожа. Однако другие перечисленные здесь семантические параметры не связаны с пресуппозицией столь непосредственным образом. 
С точки зрения согласования СА по числу противопоставлены фактивные (с союзом što) и событийные СА (с союзами koda и məz'ardə/mə$j a r d \partial)$. В первом случае показатель множественного числа, хотя и нечасто, может обозначать множественность ситуации в одном СА ('знаю, что он часто приходил') или множественность СА ('знаю, что пришел Юра и что Катя обрадовалась'). Во втором случае показатель множественного числа запрещается носителями, что говорит о десемантизации числовых показателей объекта при событийных СА. Таким образом, объектные показатели при сентенциальных актантах с союзами имеют иной грамматический статус, нежели объектные показатели при именных актантах (и номинализациях). Мы предполагаем, что объектные показатели в конструкциях с союзами koda и məz'ardə/məjardə находятся в процессе грамматикализации в функции комплементайзера, в то время как в конструкциях с союзом što они сохраняют числовую семантику.

В языках широко засвидетельствованы случаи грамматикализации падежных показателей, в частности аккузативных, в функции комплементайзеров, см. [Ноpper, Traugott 2003: 188]. Показатель аккузатива на СА появляется в контексте матричных глаголов, не способных приписывать аккузатив именным актантам, например, в калмыцком [Князев 2009] и в ижемском диалекте коми-зырянского языка [Митева 2008]. В мокша-мордовском в функции комплементайзера грамматикализуются ${ }^{28}$ объектные маркеры согласования, т. к. они вводят особые типы СА - событийные и фактивные. Уточним, однако, что обсуждаемые показатели, по-видимому, находятся в начале процесса грамматикализации, т. к. в целом они сохраняют функцию показателей ПД (это выражается в том, что при непереходных матричных глаголах данные показатели невозможны).

Что касается актантных свойств (способность занимать позицию подлежащего при пассивизации и допускать вопросительный вынос), можно было бы ожидать, что они будут присутствовать у матричных глаголов с СО-спряжением и отсутствовать в случае С-спряжения. Однако такого разбиения не наблюдается: проведенное исследование показывает, что, помимо конструкций с СО-спряжением, актантные свойства

${ }^{28}$ В данном случае мы говорим о грамматикализации в широком смысле, включая как собственно грамматикализацию, так и закрепление грамматических элементов в некоторой новой функции. В мокшанском, по-видимому, происходит закрепление за объектными показателями функции союза, вводящего СА в пресуппозиции и событийные СА. 
проявляют также клаузы с С-спряжением при союзе što. Конструкции с C-спряжением при союзах koda и məz'ardə/məjardə данные свойства не проявляют. Однако это, по-видимому, связано с тем, что все исследованные матричные глаголы такого типа являются непереходными эмотивными глаголами ('бояться', ‘стесняться'), в контексте которых зависимая клауза, действительно, отчасти демонстрирует сирконстантные свойства (в частности, может опускаться). Глагол 'ждать' при союзе məz'ardə/məjardə также употребляется для обозначения эмоционально окрашенного ожидания ('ждать, переживая') в смысле [А. Зализняк 1992].

\section{Список условных сокрашений}

ПД - прямое дополнение;

СА - сентенциальный актант;

$\mathrm{CO}$ - субъектно-объектное спряжение;

$\mathrm{C}$ - субъектное спряжение;

OBJ - грамматическая функция прямого дополнения (в терминах Лексико-функциональной грамматики);

СОМР — грамматическая функция сентенциального актанта (в терминах Лексико-функциональной грамматики).

1, 2, 3 - 1, 2, 3 лицо; А — агенс переходного глагола; ABL — аблатив; ABS абсолютив; ACT - активный залог; ADD - аддитивная частица; ART — артикль; $\mathrm{CN}$ - коннегатив; COMPL - комплементайзер; CONV.POS - деепричастие позиции; DAT - датив; DEF - определенность; DIM - диминутив; DIR - директив; DYN - показатель динамичности; EL — элатив; ERG — эргатив; GEN — генитив; HAB - хабитуалис; ILL — иллатив; IN — инессив; INF — инфинитив; INS - инструменталис; IPFV — имперфектив; LAT — латив; LOC — локатив; NEG — отрицание; NPST — непрошедшее время; NZR — номинализатор; о — объект; OBL — косвенный падеж; ORD - порядковое числительное; P - посессивный показатель; PASS - пассив; POT — потенциалис; PL — множественное число; PQP — плюсквамперфект; PR — личный посессивный префикс; PROL — пролатив; PRON — основа личных местоимений; PST — прошедшее время; PTCP — причастие; RES — результатив; S — субъект; SG — единственное число; SUBJ — сослагательное наклонение; TMPR - темпоралис; TRANS — транслатив.

\section{Литература}

Бубрих 1962 - Д. В. Бубрих. Грамматика мордовских языков. Фонетика и морфология. Саранск: Мордовское книжное изд-во, 1962.

Зализняк 1992 - Анна А. Зализняк. Исследования по семантике предикатов внутреннего состояния. München: Otto Sägner, 1992. 
Кибрик 2003 - А. Е. Кибрик. Константы и переменные языка. СПб.: Алетейя, 2003. Князев 2009 - М. Ю. Князев. Сентенциальные дополнения в калмыцком языке // Acta Linguistica Petropolitana. Труды Института лингвистических исследований. 2009. Т. V. Ч. 2. С. 525-581.

Кожемякина 2016 - А. Д. Кожемякина. Согласование матричного предиката в конструкциях с сентенциальным актантом в мокшанском языке. Выпускная квалификационная работа бакалавра лингвистики. М.: МГУ, 2016.

Козлов 2016 - А. А. Козлов. Штрихи к портрету мокшанского DOM'a. Доклад на конференции «Типология морфосинтаксических параметров», МПГУ; ИЯз РАН, Москва, 12-14 октября 2016 г.

Козлов 2017 - А. А. Козлов. Акциональный DOM в мокшанском языке и проблема циклов грамматикализации // Acta Linguistica Petropolitana. Труды Института лингвистических исследований. 2017. Т. ХІІІ. Ч. 3. С. 158-193.

Колядёнков, Заводова (ред.) 1962 - М. Н. Колядёнков, Р. А. Заводова (ред.). Грамматика мордовских (эрзянского и мокшанского) языков. Ч. 1. Фонетика и морфология. Саранск: Мордовское книжное изд-во, 1962.

Кухто 2018 - А. В. Кухто. Фонология // С. Ю. Толдова, М. А. Холодилова, С. Г. Татевосов, Е. В. Кашкин, А. А. Козлов, Л. С. Козлов, А. В. Кухто, М. Ю. Привизенцева, И. А. Стенин (ред.). Элементы мокшанского языка в типологическом освещении. М.: Буки Веди, 2018. С. 19-37.

Летучий 2012 - А. Б. Летучий. О некоторых свойствах сентенциальных актантов в русском языке // Вопросы языкознания. 2012. № 5. С. 57-87.

Летучий 2016 - А. Б. Летучий. Модификатор «сам по себе» и синтаксическая структура сентенциальных актантов // Acta Linguistica Petropolitana. Труды Института лингвистических исследований. 2016. Т. ХІІ. Ч. 1. С. 548-573.

Митева 2008 - П. С. Митева. Конструкции с сентенциальными актантами в ижемском диалекте коми-зырянского языка. Отчет по материалам экспедиции 2008 г. Рукопись. М., 2008.

Муравьев 2018 - Н. А. Муравьев. Деепричастные конструкции // С. Ю. Толдова, М. А. Холодилова, С. Г. Татевосов, Е. В. Кашкин, А. А. Козлов, Л. С. Козлов, А. В. Кухто, М. Ю. Привизенцева, И. А. Стенин (ред.). Элементы мокшанского языка в типологическом освещении. М.: Буки Веди, 2018. С. 732-752.

Подлесская 1990 - В. И. Подлесская. «Факты», «события» и «пропозиции» в свете фактов японского языка // Вопросы языкознания. 1990. № 4. С. 93-106.

Сердобольская, Кожемякина 2014 - Н. В. Сердобольская, А. Д. Кожемякина. Семантика сентенциального актанта и выбор модели согласования матричного глагола в мокша-мордовском языке // Е. А. Лютикова, А. В. Циммерлинг, М. Б. Коношенко (ред.). Типология морфосинтаксических параметров. Материалы Международной конференции «Типология морфосинтаксических параметров 2014». Вып. 1. М.: МГГУ им. М. А. Шолохова, 2014. С. 179-199.

Сердобольская, Толдова 2016 - Н. В. Сердобольская, С. Ю. Толдова. Структурная позиция прямого дополнения и его коммуникативный статус (на материале печорского диалекта коми-зырянского языка) // А. В. Циммерлинг, 
Е. А. Лютикова (ред.). Архитектура клаузы в параметрических моделях. М.: Языки славянских культур, 2016. С. 417-443.

Серебренников 1967 - Б. А. Серебренников. Историческая морфология мордовских языков. М.: Наука, 1967.

Стенин 2018 - И. А. Стенин. Пассив // С. Ю. Толдова, М. А. Холодилова, С. Г. Татевосов, Е. В. Кашкин, А. А. Козлов, Л. С. Козлов, А. В. Кухто, М. Ю. Привизенцева, И. А. Стенин (ред.). Элементы мокшанского языка в типологическом освещении. М.: Буки Веди, 2018. С. 490-545.

Тихонова 1986 - Т. М. Тихонова. Артиклевые функции форм объектного спряжения глагола в мордовских языках. Саранск: МордГУ им. Н. П. Огарева, 1986.

Толдова 2017 - С. Ю. Толдова. Кодирование прямого дополнения в мокшанском языке. // Acta Linguistica Petropolitana. Труды Института лингвистических исследований. 2017. Т. ХІІІ. Ч. 3. С. 123-157.

Толдова 2018 - С. Ю. Толдова. Предикации с глагольным сказуемым // С. Ю. Толдова, М. А. Холодилова, С. Г. Татевосов, Е. В. Кашкин, А. А. Козлов, Л. С. Козлов, А. В. Кухто, М. Ю. Привизенцева, И. А. Стенин (ред.). Элементы мокшанского языка в типологическом освещении. М.: Буки Веди, 2018. С. 545-616.

Феоктистов 1975 - А. П. Феоктистов. Мордовские языки // В. И. Лыткин, К. Е. Майтинская, К. Редеи (ред.). Основы финно-угорского языкознания. Т. 2. Прибалтийско-финские, саамский и мордовские языки. М.: Наука, 1975. C. 248-343.

Ханина, Шлуинский 2015 - О. В. Ханина, А. Б. Шлуинский. Прямой объект в энецком языке: объектное согласование глагола. Е. А. Лютикова, А. В. Циммерлинг, М. Б. Коношенко (ред.). Типология морфосинтаксических параметров. Материалы Международной конференции «Типология морфосинтаксических параметров 2015». Вып. 2. М.: МГГУ им. М. А. Шолохова. С. $392-411$.

Холодилова 2018 - М. А. Холодилова. Морфология имени // С. Ю. Толдова, М. А. Холодилова, С. Г. Татевосов, Е. В. Кашкин, А. А. Козлов, Л. С. Козлов, А. В. Кухто, М. Ю. Привизенцева, И. А. Стенин (ред.). Элементы мокшанского языка в типологическом освещении. М.: Буки Веди, 2018. С. 63-122.

Цыпкайкина 2007 - В. П. Цыпкайкина. Темпоральность в мордовских языках и принципы её описания. Саранск: Изд-во Мордовского университета, 2007.

Alsina et al. 2005 - A. Alsina, K. P. Mohanan, T. Mohanan. How to get rid of the COMP // M. Butt, T. Holloway King (eds.). Proceedings of the LFG05 Conference. Stanford: CSLI Publications, 2005. URL: http://web.stanford.edu/group/cslipublications/cslipublications/LFG/10/pdfs/lfg05.pdf (дата обращения 12. 11. 2020).

Asher 1993 - N. Asher. Reference to abstract objects in discourse. Dordrecht; Boston; London: Kluwer Academic Publishers, 1993.

Bartens 1999 - R. Bartens. Mordvalaiskielten rakenne ja kehitys. Helsinki: SuomalaisUgrilainen Seura, 1999.

Beaver, Geurts 2012 — D. Beaver, B. Geurts. Presupposition // C. Maienborn, K. von Heusinger, P. Portner (eds.). Semantics. An International Handbook of Natural Language Meaning. Vol. 3. Berlin; Boston: Mouton de Gruyter. 2012. P. 2432-2460. 
Belyaev et al. 2017 - O. Belyaev, N. Serdobolskaya, A. Kozhemyakina. In defense of COMP: complementation in Moksha Mordvin // M. Butt, T. Holloway King (eds.). Proceedings of the LFG17 Conference. Stanford: CSLI Publications, 2017. URL: http://web.stanford.edu/group/cslipublications/cslipublications/LFG/LFG-2017/ lfg2017.pdf (дата обращения 12. 11. 2020).

Bošković, Șener 2014 - Ž. Bošković, S. Șener. The Turkish NP // P. C. Hofherr, A. Zribi-Hertz (eds.). Crosslinguistic studies on noun phrase structure and reference. Leiden: Brill, 2014. P. 102-140.

Bossong 1985 - G. Bossong. Differentielle Objektmarkierung in den neuiranischen Sprachen. Tübingen: Gunter Narr, 1985.

Dalrymple, Lødrup 2000 - M. Dalrymple, H. Lødrup. The grammatical functions of complement clauses // M. Butt, T. Holloway King (eds.). Proceedings of the LFG00 Conference. Stanford: CSLI Publications, 2000. URL: https://web. stanford.edu/group/cslipublications/cslipublications/LFG/LFG5-2000/ (дата обращения 12. 11. 2020).

Dalrymple, Nikolaeva 2011 - M. Dalrymple, I. Nikolaeva. Objects and Information Structure. Cambridge: Cambridge University Press, 2011.

Elliott 2018 - P. D. Elliott. Explaining DPs vs. CPs without syntax // J. Kantarovich, T. Truong, O. Xherija (eds.). Proceedings of CLS 52 (2016). Chicago: Chicago Linguistic Society, 2018. P. 171-185.

Grünthal 2008 - R. Grünthal. Transitivity in Erzya Mordvin // A. Bereczki, M. Csepregi, L. Klima (szerk.). Ünnepi írások Havas Ferenc tiszteletére (Urálisztikai Tanulmányok. K. 18). Budapest: ELTE BTK Finnugor Tanszék-Numi Tórem Finnugor Alapítvány, 2008. P. 219-240.

Hanink, Bochnak 2016 - E. Hanink, R. Bochnak. Factivity and two types of embedded clauses in Washo // A. Lamont, K. Tetzloff (eds.). Proceedings of North East Linguistic Society 47. Vol. 2. Amherst: University of Massachusetts, 2016. P. 65-78.

Hopper, Traugott 2003 - P. J. Hopper, E. C. Traugott. Grammaticalization (Cambridge Textbooks in Linguistics). $2^{\text {nd }}$ ed. Cambridge: Cambridge University Press, 2003.

Iemmolo 2011 - G. Iemmolo. Towards a typological study of differential object marking and differential object indexation. Ph.D. thesis. Pavia: University of Pavia, 2011.

Kastner 2015 - I. Kastner. Factivity mirrors interpretation: The selectional requirements of presuppositional verbs // Lingua. 2051. Vol. 164. P. 156-188.

Kiparsky, Kiparsky 1971 - P. Kiparsky, C. Kiparsky. Fact // L. Jakobovits, D. Steinberg (eds.). Semantics: An Interdisciplinary Reader. Cambridge: Cambridge University Press, 1971. P. 345-369

Kiss $2004-$ K. É. Kiss. The syntax of Hungarian. Cambridge: Cambridge University Press, 2004.

Klamer 2006 - M. Klamer. Complement Clause Type and Complementation Strategy in Kambera // R. M. W. Dixon, A. Aikhenvald (eds.). Complementation: a cross-linguistic typology. Amsterdam: Benjamins, 2006. P. 245-263.

Lyutikova, Pereltsvaig 2015 - E. Lyutikova, A. Pereltsvaig. The Tatar DP // Canadian Journal of Linguistics. Revue Canadienne de linguistique. 2015. Vol. 60. № 3. P. 289-325. 
Molnár 2001 — J. Molnár. Zur Verwendung der Objekt- und Subjektkonjugation im Ungarischen und im Mordwinischen // J. Pusztay (ed.). Zur (Morpho-)Syntax der uralischen Sprachen: Materialien zweier Konferenzen, Szombathely, Oktober 1997, 1998 (Specimina Sibirica. Vol. XVI). Szombathely: Savariae, 2001. P. 67-92.

Moulton 2009 - K. Moulton. Natural selection and the syntax of clausal complementation. Ph.D. thesis. Amherst: University of Massachusetts. URL: http://scholarworks.umass.edu/open_access_dissertations/99/(дата обращения 12. 11. 2020).

Nikolaeva 1999 - I. Nikolaeva. Object agreement, grammatical relations, and information structure // Studies in Language. 1999. Vol. 23. P. 331-376.

Nikolaeva 2014 - I. Nikolaeva. A grammar of Tundra Nenets. Berlin; Boston: Mouton de Gruyter, 2014.

Noonan 1985 - M. Noonan. Complementation // T. Shopen (ed.). Language Typology and Syntactic Description 2: Complex Constructions. Cambridge: Cambridge University Press, 1985. P. 42-140.

Ross (1967) - J. R. Ross. Constraints on variables in syntax. Doctoral dissertation. Massachusetts: Massachusetts Institute of Technology. (Published as Ross 1986). URL: http://hdl.handle.net/1721.1/15166 (дата обращения 12. 11. 2020).

Serdobolskaya 2016 - N. Serdobolskaya. Semantics of complementation in Adyghe // K. Boye, P. Kehayov (eds.). Complementizer Semantics in European Languages (Empirical Approaches to Language Typology. Vol. 57). Berlin; Boston: Mouton de Gruyter, 2016. P. 691-744.

Zirnask 2004 — T. Zirnask. Objektikäänded mokša keeles. Bakalaureusetöö. Tartu, 2004.

\section{References}

Alsina et al. 2005 - A. Alsina, K. P. Mohanan, T. Mohanan. How to get rid of the Comp. M. Butt, T. Holloway King (eds.). Proceedings of the LFG05 Conference. Stanford: CSLI Publications, 2005. Available at: http://web.stanford.edu/ group/cslipublications/cslipublications/LFG/10/pdfs/lfg05amm.pdf (accessed on 12.11.2020).

Asher 1993 - N. Asher. Reference to abstract objects in discourse. Dordrecht; Boston; London: Kluwer Academic Publishers, 1993.

Bartens 1999 - R. Bartens. Mordvalaiskielten rakenne ja kehitys. Helsinki: SuomlaisUgrilainen Seura, 1999.

Beaver, Geurts 2012 - D. Beaver, B. Geurts. Presupposition. C. Maienborn, K. von Heusinger, P. Portner (eds.). Semantics. An International Handbook of Natural Language Meaning. Vol. 3. Berlin; Boston: Mouton de Gruyter. 2012. P. 2432 2460.

Belyaev et al. 2017 - O. Belyaev, N. Serdobolskaya, A. Kozhemyakina. In defense of COMP: complementation in Moksha Mordvin. M. Butt, T. Holloway King (eds.). Proceedings of the LFG17 Conference. Stanford: CSLI Publications, 2017. Available at: http://web.stanford.edu/group/cslipublications/cslipublications/LFG/LFG2017/lfg2017.pdf (accessed on 12. 11. 2020). 
Bošković, Șener 2014 - Ž. Bošković, S. Șener. The Turkish NP. P. C. Hofherr, A. ZribiHertz (eds.). Crosslinguistic studies on noun phrase structure and reference. Leiden: Brill, 2014. P. 102-140.

Bossong 1985 - G. Bossong. Differentielle Objektmarkierung in den neuiranischen Sprachen. Tübingen: Gunter Narr, 1985.

Bubrikh 1962 - D. V. Bubrikh. Grammatika mordovskikh yazykov. Fonetika i morfologiya [Grammar of Mordovian languages. Phonetics and morphology]. Saransk: Mordovian Book Publishing House, 1962.

Dalrymple, Lødrup 2000 - M. Dalrymple, H. Lødrup. The grammatical functions of complement clauses. M. Butt and T. H. King (eds.). Proceedings of the LFG00 Conference. Stanford: CSLI Publications, 2000. Available at: https://web.stanford.edu/ group/cslipublications/cslipublications/LFG/LFG5-2000/ (accessed on 12.11.2020).

Dalrymple, Nikolaeva 2011 — M. Dalrymple, I. Nikolaeva. Objects and Information Structure. Cambridge: Cambridge University Press, 2011.

Elliott 2018 - P. D. Elliott. Explaining DPs vs. CPs without syntax. J. Kantarovich, T. Truong, O. Xherija (eds.). Proceedings of CLS 52 (2016). Chicago: Chicago Linguistic Society, 2018. P. 171-185.

Feoktistov 1975 - A. P. Feoktistov. Mordovskie yazyki [Mordovian languages]. V. I. Lytkin, K. E. Maytinskaya, K. Rédei (eds.). Osnovy finno-ugorskogo yazykoznaniya [Basics of Finno-Ugric Linguistics]. Vol. 2. Pribaltiysko-finskie, saamskiy i mordovskie yazyki [Balto-Finnic, Sami and Mordovian languages]. Moscow: Nauka, 1975. P. 248-343.

Grünthal 2008 - R. Grünthal. Transitivity in Erzya Mordvin. A. Bereczki, M. Csepregi, L. Klima (szerk.). Ünnepi írások Havas Ferenc tiszteletére (Urálisztikai Tanulmányok. K. 18). Budapest: ELTE BTK Finnugor Tanszék-Numi Tórem Finnugor Alapítvány, 2008. P. 219-240.

Hanink, Bochnak 2016 - E. Hanink, R. Bochnak. Factivity and two types of embedded clauses in Washo. A. Lamont, K. Tetzloff (eds.). Proceedings of North East Linguistic Society 47. Vol. 2. Amherst: University of Massachusetts, 2016. P. 65-78.

Hopper, Traugott 2003 - P. J. Hopper, E. C. Traugott. Grammaticalization (Cambridge Textbooks in Linguistics). $2^{\text {nd }}$ ed. Cambridge: Cambridge University Press, 2003.

Iemmolo 2011 — G. Iemmolo. Towards a typological study of differential object marking and differential object indexation. Ph.D. thesis. Pavia: University of Pavia, 2011.

Kastner 2015 - I. Kastner. Factivity mirrors interpretation: The selectional requirements of presuppositional verbs. Lingua. 2015. Vol. 164. P. 156-188.

Khanina, Shluinskiy 2015 - O. V. Khanina, A. B. Shluinskiy. Pryamoy obekt v enetskom yazyke: obektnoe soglasovanie glagola [The direct object in the Enets language: the object agreement of the verb]. E. A. Lyutikova, A. V. Zimmerling, M. B. Konoshenko (eds.). Tipologiya morfosintaksicheskikh parametrov [Typology of morphosyntactic parameters]. Materials of the International conference "Typology of morphosyntactic parameters 2014". Iss. 2. Moscow: Sholokhov Moscow State University for the Humanities Press, 2015. P. 392-411.

Kholodilova 2018 - M. A. Kholodilova. Morfologiya imeni [Nominal morphology]. S. Yu. Toldova, M. A. Kholodilova, S. G. Tatevosov, E. V. Kashkin, A. A. Kozlov, 
L. S. Kozlov, A. V. Kukhto, M. Yu. Privizentseva, I. A. Stenin (eds.). Elementy mokshanskogo yazyka v tipologicheskom osveshchenii [Elements of Moksha in cross-linguistic perspective]. Moscow: Buki Vedi, 2018. P. 63-122.

Kibrik 2003 - A. E. Kibrik. Konstanty i peremennye yazyka [Language constants and variables]. St. Petersburg: Aleteyya, 2003.

Kiparsky, Kiparsky 1971 — P. Kiparsky, C. Kiparsky. Fact. L. Jakobovits, D. Steinberg (eds.). Semantics: An Interdisciplinary Reader. Cambridge: Cambridge University Press, 1971. P. 345-369

Kiss 2004 - K. É. Kiss. The syntax of Hungarian. Cambridge: Cambridge University Press, 2004.

Klamer 2006 - M. Klamer. Complement Clause Type and Complementation Strategy in Kambera. R. M. W. Dixon, A. Aikhenvald (eds.). Complementation: A cross-linguistic typology. Amsterdam: Benjamins, 2006. P. 245-263.

Knyazev 2009 - M. Yu. Knyazev. Sententsialnye dopolneniya v kalmytskom yazyke [Sentencial objects in the Kalmyk language]. Acta Linguistica Petropolitana. Trudy Instituta lingvisticheskikh issledovaniy. 2009. Vol. V. Pt. 2. P. 525-581.

Kolyadenkov, Zavodova (ed.) 1962 - M. N. Kolyadenkov, R. A. Zavodova (eds.). Grammatika mordovskikh (erzyanskogo i mokshanskogo) yazykov [Grammar of Mordovian (Erzyan and Mokshan) languages]. Pt. 1. Fonetika i morfologiya [Phonetics and morphology]. Saransk: Mordovian Book Publishing House, 1962. Kozhemyakina 2016 - A. D. Kozhemyakina. Soglasovanie matrichnogo predikata $\mathrm{v}$ konstruktsiyakh s sententsialnym aktantom $\mathrm{v}$ mokshanskom yazyke [Agreement of matrix predicate in constructions with a sentential actant in the Moksha language]. Final qualifying work of the bachelor of linguistics. Moscow: Moscow State University, 2016.

Kozlov 2016 - A. A. Kozlov. Shtrikhi k portretu mokshanskogo DOM'a [Strokes to the portrait of Moksha's DOM]. Talk at the conference "Typology of morphosyntactic parameters", Moscow Pedagogical State University; Institute of linguistics Russian Academy of Sciences, Moscow, 12-14 October 2016.

Kozlov 2017 - A. A. Kozlov. Aktsionalnyy DOM v mokshanskom yazyke i problema tsiklov grammatikalizatsii [Actionality and DOM in Mokshan: grammaticalization cycles]. Acta Linguistica Petropolitana. Trudy Instituta lingvisticheskikh issledovaniy. 2017. Vol. XIII. Pt. 3. P. 158-193.

Kukhto 2018 - A. V. Kukhto. Fonologiya. S. Yu. Toldova, M. A. Kholodilova, S. G. Tatevosov, E. V. Kashkin, A. A. Kozlov, L. S. Kozlov, A. V. Kukhto, M. Yu. Privizentseva, I. A. Stenin (eds.). Elementy mokshanskogo yazyka v tipologicheskom osveshchenii [Elements of Moksha in cross-linguistic perspective]. Moscow: Buki Vedi, 2018. P. 19-37.

Letuchiy 2012 - A. B. Letuchiy. O nekotorykh svoystvakh sententsialnykh aktantov $\mathrm{v}$ russkom yazyke [On some properties of complement clauses in Russian]. Voprosy yazykoznaniya. 2012. No. 5. P. 57-87.

Letuchiy 2016 - A. B. Letuchiy. Modifikator «sam po sebe» i sintaksicheskaya struktura sententsialnykh aktantov [The modifier "sam po sebe" and the syntactic structure of sentential actants]. Acta Linguistica Petropolitana. Trudy Instituta lingvisticheskikh issledovaniy. 2016. Vol. XII. Pt. 1. P. 548-573. 
Lyutikova, Pereltsvaig 2015 - E. Lyutikova, A. Pereltsvaig. The Tatar DP. Canadian Journal of Linguistics. Revue Canadienne de linguistique. 2015. Vol. 60. No. 3. P. 289-325.

Miteva 2008 - P. S. Miteva. Konstruktsii s sententsialnymi aktantami v izhemskom dialekte komi-zyryanskogo yazyka [Constructions with complement clauses in the Izhma dialect of the Komi-Zyryan language]. Expedition Report 2008. Moscow, 2008.

Molnár 2001 - J. Molnár. Zur Verwendung der Objekt- und Subjektkonjugation im Ungarischen und im Mordwinischen. J. Pusztay (ed.). Zur (Morpho-)Syntax der uralischen Sprachen: Materialien zweier Konferenzen, Szombathely, Oktober 1997, 1998 (Specimina Sibirica. Vol. XVI). Szombathely: Savariae, 2001. P. 67-92.

Moulton 2009 - K. Moulton. Natural selection and the syntax of clausal complementation. Ph.D. thesis. Amherst: University of Massachusetts. Available at: http:// scholarworks.umass.edu/open_access_dissertations/99/(accessed on 12. 11. 2020).

Muraviev 2018 - N. A. Muraviev. Deeprichastnye konstruktsii [Converbial constructions]. S. Yu. Toldova, M. A. Kholodilova, S. G. Tatevosov, E. V. Kashkin, A. A. Kozlov, L. S. Kozlov, A. V. Kukhto, M. Yu. Privizentseva, I. A. Stenin (eds.). Elementy mokshanskogo yazyka $v$ tipologicheskom osveshchenii [Elements of Moksha in cross-linguistic perspective]. Moscow: Buki Vedi, 2018. P. 732-752.

Nikolaeva 1999 - I. Nikolaeva. Object agreement, grammatical relations, and information structure. Studies in Language. 1999. Vol. 23. P. 331-376.

Nikolaeva 2014 - I. Nikolaeva. A grammar of Tundra Nenets. Berlin; Boston: Mouton de Gruyter, 2014.

Noonan 1985 - M. Noonan. Complementation. T. Shopen (ed.). Language Typology and Syntactic Description 2: Complex Constructions. Cambridge: Cambridge University Press, 1985. P. 42-140.

Podlesskaya 1990 - V. I. Podlesskaya. «Fakty», «sobytiya» i «propozitsii» v svete faktov yaponskogo yazyka ["Facts", "events" and "propositions" in the light of the facts of the Japanese language]. Voprosy yazykoznaniya. 1990. No. 4. P. 93-106.

Ross (1967) - J. R. Ross. Constraints on variables in syntax. Doctoral dissertation. Massachusetts: Massachusetts Institute of Technology. (Published as Ross 1986). Available at: http://hdl.handle.net/1721.1/15166 (accessed on 12. 11. 2020).

Serdobolskaya 2016 - N. Serdobolskaya. Semantics of complementation in Adyghe. K. Boye, P. Kehayov (eds.). Complementizer Semantics in European Languages (Empirical Approaches to Language Typology. Vol. 57). Berlin; Boston: Mouton de Gruyter, 2016. P. 691-744.

Serdobolskaya, Kozhemyakina 2014 - N. V. Serdobolskaya, A. D. Kozhemyakina. Semantika sententsialnogo aktanta i vybor modeli soglasovaniya matrichnogo glagola v moksha-mordovskom yazyke [The semantics of the sentential actant and the choice of the agreement model of the matrix verb in the Moksha-Mordovian language]. E. A. Lyutikova, A. V. Zimmerling, M. B. Konoshenko (eds.). Tipologiya morfosintaksicheskikh parametrov [Typology of morphosyntactic parameters]. Materials of the International conference "Typology of morphosyntactic parameters 2014". Iss. 1. Moscow: Sholokhov Moscow State University for the Humanities Press, 2014. P. 179-199. 
Serdobolskaya, Toldova 2016 - N. V. Serdobolskaya, S. Yu. Toldova. Strukturnaya pozitsiya pryamogo dopolneniya i ego kommunikativnyy status (na materiale pechorskogo dialekta komi-zyryanskogo yazyka) [The structural position of the direct object and its communicative status (based on the material of the Pechora dialect of the Komi-Zyryan language)]. A. V. Zimmerling, E. A. Lyutikova (eds.). Arkhitektura klauzy v parametricheskikh modelyakh [Clause architecture in parametric models]. Moscow: Yazyki slavyanskikh kultur, 2016. P. 417-443.

Serebrennikov 1967 - B. A. Serebrennikov. Istoricheskaya morfologiya mordovskikh yazykov [Historical morphology of Mordovian languages]. Moscow: Nauka, 1967.

Stenin 2018 - I. A. Stenin. Passiv [Passive]. S. Yu. Toldova, M. A. Kholodilova, S. G. Tatevosov, E. V. Kashkin, A. A. Kozlov, L. S. Kozlov, A. V. Kukhto, M. Yu. Privizentseva, I. A. Stenin (eds.). Elementy mokshanskogo yazyka v tipologicheskom osveshchenii [Elements of Moksha in cross-linguistic perspective]. Moscow: Buki Vedi, 2018. P. 490-545.

Tikhonova 1986 - T. M. Tikhonova. Artiklevye funktsii form obektnogo spryazheniya glagola $v$ mordovskikh yazykakh [Article functions of the verb object conjugation in Mordovian languages]. Saransk: Ogarev Mordovia State University Press, 1986.

Toldova 2017 - S. Yu. Toldova. Kodirovanie pryamogo dopolneniya v mokshanskom yazyke [Encoding direct objects in Mokshan]. Acta Linguistica Petropolitana. Trudy Instituta lingvisticheskikh issledovaniy. 2017. Vol. XIII. Pt. 3. P. 123-157.

Toldova 2018 - S. Yu. Toldova. Predikacii s glagol'nym skazuemym [Verbal predications]. S. Yu. Toldova, M. A. Kholodilova, S. G. Tatevosov, E. V. Kashkin, A. A. Kozlov, L. S. Kozlov, A. V. Kukhto, M. Yu. Privizentseva, I. A. Stenin (eds.). Elementy mokshanskogo yazyka v tipologicheskom osveshchenii [Elements of Moksha in cross-linguistic perspective]. Moscow: Buki Vedi, 2018. P. 545-616.

Tsypkaykina 2007 - V. P. Tsypkaykina. Temporalnost v mordovskikh yazykakh i printsipy ee opisaniya [Temporality in Mordovian languages and principles of its description]. Saransk: Mordovia University Press, 2007.

Zaliznyak 1992 - Anna A. Zaliznyak. Issledovaniya po semantike predikatov vnutrennego sostoyaniya [Studies on the semantics of internal state predicates]. München: Otto Sägner, 1992.

Zirnask 2004 - T. Zirnask. Objektikäänded mokša keeles. Bakalaureusetöö. Tartu, 2004. 


\section{Несколько наблюдений над основами ненецкого глагола*}

\section{С. Г. Татевосов}

Московский государственный университет им. М. В. Ломоносова, Московский педагогический государственный университет; tatevosov@gmail.com

Аннотация. В статье предлагается несколько наблюдений о структуре глагола в ненецком языке. В общем случае ненецкий глагол допускает выбор между несколькими способами ауслаутного оформления основы. Цель статьи состоит в том, чтобы показать, что это явление имеет регулярный характер, что позволяет говорить о наличии в ненецком языке четырехчленной деривационной парадигмы. Элементы этой парадигмы характеризуют не только ненецкие непроизводные глаголы, но и продуктивные дериваты. Глагольные основы, полученные от разных ауслаутных вариантов, - исходная, общая финитная и основа коннегатива, — используются не только при построении финитных форм, но и в процессах дальнейшей морфологической деривации, создающей каузативы, инхоативы и т. д.

Ключевые слова: морфологическая структура глагола, структура события, деривационная морфология, каузатив, инхоатив.

* Статья опирается на данные по малоземельскому говору тундрового диалекта ненецкого языка в варианте, представленном в п. Нельмин Нос (Ненецкий автономный округ), которые были собраны в ходе экспедиций Отделения теоретической и прикладной лингвистики филологического факультета МГУ в 2003-2005 годах. В экспедициях в разные годы участвовали Лев Блюменфельд, Екатерина Волович, Николай Воронцов, Филипп Дудчук, Павел Иосад, Наталья Зевахина, Денис Иванов, Михаил Иванов, Дарья Кавицкая, Екатерина Лютикова, Ирина Николаева, Анна Пазельская, Петр Староверов, Сергей Татевосов, Мария Цюрупа, Андрей Шлуинский, Елена Ханина, Ольга Ханина. Наблюдения и обобщения, изложенные здесь, стали возможны благодаря совместным усилиям всех участников экспедиции. Автор выражает искреннюю и бесконечно глубокую благодарность информантам-переводчикам А. Г. Апицыной, Е. Н. Ардеевой, М. И. Канюковой, В. П. Марюевой, К. П. Талеевой, Е. Н. Тайбарей и М. К. Тайбарею, общение с которыми навсегда останется источником надежды и оптимизма. Исследование поддержано грантом РНФ № 16-18-02081. 


\title{
Notes on the structure of the verb stem in Tundra Nenets
}

\section{S. G. Tatevosov}

Lomonosov Moscow State University, Moscow Pedagogical State University; tatevosov@gmail.com

\begin{abstract}
This paper surveys the structure of the verb stem in Tundra Nenets, focusing on stem-final elements $a,(y) o$, and $\varnothing$. The latter appears in two varieties, known as "non-alternating $\varnothing "$ ", or " $\varnothing$ ", and "alternating $\varnothing "$ ", or " $\varnothing$ ". In Tundra Nenets, the same stem can surface with more than one stem-final vowel as in xona / xonyo 'fall asleep, sleep' $\left(a\right.$ and $o$ ); nømta / nømt $\varnothing^{\wedge}$ 'hear' $\left(a\right.$ and $\left.\varnothing^{\wedge}\right)$, wøntar ${ }^{\circ} t a / w \varnothing n t a r^{\circ} t \varnothing^{i}$ 'bend, be bent' $\left(a\right.$ and $\varnothing^{i}$ ), and so on. The goal of this paper is to establish two related empirical generalizations. First, the scope of this phenomenon exceeds by far the limits identified in the previous studies. The paper argues that the stem-final alternations are to be reanalyzed in terms of productive derivational morphology that operates on event-structural characteristics of a verbal predicate. Second, the four-way opposition created by the stem-final morphology does not only characterize non-derived verbs, but also extends to verbs with productive derivational morphology. For example, the inchoative morpheme, identified as $l(\varnothing)$ in the previous studies, features the entire array of options including, apart from (non-alternating) $l \varnothing^{\wedge}, l a, l \sigma^{i}$, and $l y o$. The empirical reality of these inchoatives can be assessed by looking at the subjective and reflexive subparadigms of Aorist and, when the forms of Aorist cannot tell different options apart, at the so called connegative subparadigm. Other productive derivational morphemes of Tundra Nenets, the Durative (the -mpø morpheme), the Imperfective (-nø), the Frequentative $(-r)$, and the Iterative (-ngkø) exhibit similar behavior: they are attested with different stem-final elements. This view of stem-final morphology makes a significant prediction. If $a, \varnothing^{\wedge}, \varnothing^{i}$, and $o$ are derivational morphemes rather than "vowel alternations" epiphenomenal on the formation of the form of Aorist, one can expect to find them elsewhere, that is, outside of the Aorist paradigm. This prediction is borne out: as our study confirms, verbs stems derived from the four elements of this event-structural paradigm (the basic stem, the general finite stem, and the connegative stem) are involved in further morphological derivation yielding causatives, inchoatives, and so on. Thus, for example, the verb yakøl 'start itching', the inchoative of yakø 'itch', shows the multiplicity of ways of deriving the Iterative: yakøl-a-ngkø, yakøl- ${ }^{\circ} n g k ø, y a k ø l-u-n g k ø$, yakøl-yo-ngkø, yakøl-yu-ngkø. The stems, which the Iterative affix -ngkø- merges with, all come from different stem-final variants of yakøl: yakøla (cf. yakøl-a-ngkø), yakølø (cf. yakøl- ${ }^{\circ}-n g k \varnothing$ ), yakølø (cf. yakøl-u-ngkø), and yakølyo (cf. yakøl-yo-ngkø and yakøl-yu-ngkø). The reality of the stem-final event-structural morphology thus receives a strong empirical support.
\end{abstract}

Keywords: verb structure, event structure, derivational morphology, causative, inchoative. 


\section{1. Введение}

Эта статья - составная часть проекта исследования ненецкого глагола, в первую очередь деривационной глагольной морфологии. Основная ее цель - обосновать два взаимосвязанных обобщения. Во-первых, глагольная основа в ненецком языке в общем случае возможна в комбинации с несколькими типами ауслаута, и это явление представлено в языке шире, чем принято считать. Во-вторых, дистрибуция типов ауслаута подкрепляет их анализ как самостоятельных деривационных морфем, а не (мор)фонологических чередований, сопутствующих глагольному словоизменению.

\section{2. Некоторые морфологические факты}

Согласно имеющимся описаниям, в первую очередь [Salminen 1997, 1998], ненецкий глагол демонстрирует значительное разнообразие возможных типов вокалического ауслаута основы.

Среди выделяемых типов - основы на неальтернирующий -, основы на альтернирующий -ø, основы на (неальтернирующий) - $a$, основы на (альтернирующий) - (последний в большинстве случаев вызывает палатализацию предшествующего согласного). Каждый из типов отличается способами образования общей (GFS) и специальной (SFS) финитной основ, а также коннегатива, которые иллюстрируются в Таблице 1 (с. 536).

Примеры глаголов на - $a$, неальтернирующий -ø, альтернирующий -ø, и -(y)о показаны в Таблище 2 (с. 536).

Общая и специальная финитная основы дополнительно распределены по группам словоизменительных форм, составляющих глагольную парадигму. Согласно обобщениям Т. Салминена, аорист третьего лица единственного числа субъектного спряжения («3SGs») образуется от общей финитной основы, аналогичный аорист возвратного спряжения («3SGr») — от специальной финитной основы. B форме 3SGs показатель аориста нулевой, так что эта форма совпадает с общей финитной основой ${ }^{1}$.

${ }^{1}$ О глагольном словоизменении см. также [Терещенко 1965; Salminen 1997; Буркова 2010]; типы спряжения обсуждаются в [Терещенко 1947; 1965; 1973; Körtvély 2005; Nikolaeva 2014; Ristinen 1973a; 1973b; Татевосов 2016а] и др. 
Таблица 1. Диагностические формы основ с различным типом ауслаута ${ }^{2}$

Table 1. Diagnostic forms of stems with different stem-final elements

\begin{tabular}{|c|c|c|c|}
\hline Ауслаут & $\begin{array}{c}\text { Аорист 3SGs } \\
\text { (GFS) }\end{array}$ & $\begin{array}{c}\text { Аорист 3SGr } \\
(\mathrm{SFS}+\mathrm{q})\end{array}$ & Коннегатив \\
\hline (неальтернирующий) a & $-^{a-}{ }^{\circ}$ & $-e-y^{\circ}-q$ & $-a-q$ \\
\hline неальтернирующий ø & $\varnothing^{\varnothing-{ }^{\circ}}$ & ${ }_{-1}-^{\circ}-\mathrm{q}$ & $-{ }^{\circ}-q$ \\
\hline альтернирующий ø & $\mathrm{i}^{3}$ & $-i-q$ & _u-q \\
\hline (альтернирующий) (у)о & $-\mathrm{i}$ & $-\mathrm{i}-\mathrm{q}$ & _(y)u-q \\
\hline
\end{tabular}

Таблица 2. Примеры глаголов с различным типом ауслаута

Table 2. Examples of verbs with different stem-final elements

\begin{tabular}{|c|c|c|c|}
\hline Основа & $\begin{array}{c}\text { Аорист 3SGs } \\
\text { (GFS) }\end{array}$ & $\begin{array}{c}\text { Аорист 3SGr } \\
\text { (SFS) }\end{array}$ & Коннегатив \\
\hline xona 'засыпать, идти спать' & xona $-^{\circ}[$ xona $]$ & $\begin{array}{l}\text { xone }-y^{\circ}-q \\
\text { [xonej?] }\end{array}$ & xona-q $[$ xona? $]$ \\
\hline yadø 'идти, ходить' & yadø- ${ }^{\circ}[\operatorname{yad} \Lambda:]$ & yadi $-^{\circ}-q$ [jadi? $]$ & $y a d^{\circ}-q[\mathrm{jad} ?]$ \\
\hline пуепø 'сердиться' & nyeni $[\mathrm{n}$ ieni] & nyeni- $q[$ nieni?] & nуепи- $q$ [nienu?] \\
\hline xоnуo 'спать' & xoni [xoni] & $x o n i-q$ [xoni?] & xonyu- $q$ [xon'u?] \\
\hline
\end{tabular}

В Таблице 1 показаны два из трех основных способов образования общей финитной основы. Основы на неальтернирующий гласный (в частности, - $a$ и неальтернирующий -ø) используют -ø (редуцирующийся до $-^{\circ}$ ), ср. $x o n a^{-}{ }^{\circ}$ и yadø- ${ }^{\circ}$ из Таблищы 2. Альтернирующие, или «смешанные» основы (в частности, основы на альтернирующие -ø и -o) производят «замену гласного на $i$ » [Salminen 1998: 532], как nуeni и xoni.

2 Здесь и далее мы придерживаемся следующих принципов представления материала. Отдельные ненецкие слова и морфемы приводятся в словарной форме по [Терещенко 1965] и/или в записи Т. Салминена, заключенной в фигурные скобки, например, мадӑр (ць) \{madør\}. Примеры предложений, такие, как (3) и далее, coстоят из четырех строк: фонетической записи, фонематической записи, которая следует принципам и описательным решениям Т. Салминена [Salminen 1997, 1998], подстрочной поморфемной глоссы, русского перевода. Фонетическая запись опирается на описание фонетики исследуемого говора, предложенное в [Kavitskaya, Staroverov 2010].

${ }^{3} \mathrm{~B}$ альтернирующих основах на заднеязычный $i$ систематически реализуется как [u], см., в частности, [Урманчиева 2013]. Эти случаи далее особо не оговариваются. 
Третий способ образования общей финитной основы, который не показан в Таблице 1, характерен для основ на согласный: они присоединяют показатель - $\eta$ a nga\}.

Специальная финитная основа, наблюдаемая в форме аориста $3 \mathrm{SGr}$ из Таблии 1-2, от основ на - $a$ образуется с помощью суффикса $-y \varnothing$, от основ на неальтернирующий -ø - «заменой конечного гласного на $i$-ø», у альтернирующих основ совпадает с общей финитной. В результате аорист 3SGr от основы с неальтернирующим -ø (например, yadi- ${ }^{\circ}-q$ [jadi?] из Таблищы 2) фонетически совпадает с аористом от альтернирующих основ (nyeni-q [njeni?]). Первые имеют в исходе $\{\mathrm{i}-\varnothing\}$, в котором ø редуцируется до ${ }^{\circ}$, и цепочка фонетически реализуется как [i]. Вторые имеют [i] в ауслауте с самого начала. Кроме того, у основ на - $a$ наблюдается дополнительное чередование - переход - $a$ в $-e$, как у хопе- $y^{\circ}-q$. К специальной финитной основе в аористе $3 \mathrm{SGr}$ присоединяется показатель третьего лица $-q$.

Коннегатив - глагольная форма, которая используется при образовании отрицательных финитных форм, состоящих из отрицательного вспомогательного глагола, принимающего лично-числовое согласование, и как раз-таки коннегатива лексического глагола. Показатель коннегатива присоединяется к исходной основе. У основ на альтернирующий гласный (nyenu-q и хопуи-q из Таблищь 2) дополнительно происходит замена этого гласного на $-u$.

Неальтернирующий -ø мы будем далее обозначать как «Ø^», а альтернирующий — как «øi » — по ауслауту аориста субъектного спряжения.

Мы подходим к наблюдениям, которые составляют предмет обсуждения в этой статье. Значительное количество основ допускается более чем с одним типом ауслаута. Несколько характерных пар из [Терещенко 1965] приводятся в (1)-(2):

\section{(1) Основы на (альтернирующий или неальтернирующий) $\theta$ vs. основы на $a$}

a. cырuтӑ(cb) \{siryitø\} 'быть заснеженным, быть покрытым снегом'

cbipuma(cb) \{siryita\} 'наполнить, набить что-либо снегом'

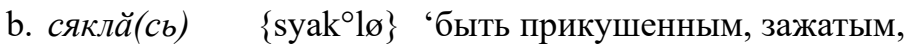
прищемленным’

сякла(сь) $\left\{\right.$ syak $\left.^{\circ} \mathrm{la}\right\}$ 'впиться чем-л. во что-л'. 
c. $с ы н д а ̆(c b) \quad\{\operatorname{sint} ø\} \quad$ 'заниматься тем, что доставать продукты из продуктовой нарты' = 'использовать запас'

сында(cb) $\quad\{$ sinta $\} \quad$ 'отложить про запас'

(2) Основы на $о$ vs. основы на $a$

a. хонё $(c b) \quad\{$ xonyo $\} \quad$ 'спать' хона $(c b) \quad\{$ xona $\}$ 'идти спать, ложиться спать'

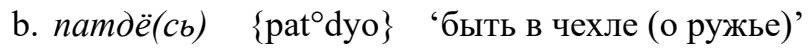
$n a m \partial a(c b) \quad\left\{\mathrm{pat}^{\circ} \mathrm{da}\right\} \quad$ 'положить ружье в чехол, зачехлить'

Как видно уже из этих примеров, различия в ауслауте основы имеют семантические последствия. Это показывает, что в случаях (1)-(2) уместно говорить не столько об «ауслауте», сколько о деривационно-морфологическом процессе, воздействующем на событийную структуру предиката. А. Ю. Урманчиева, которая рассматривает чередования в ауслауте как компонент процесса построения формы аориста, отмечает, в частности, что аористы, имеющие в ауслауте $-i$ (т. е. такие, как nyeni и хопi из Tаблицы 2), представляют собой «стативы различных типов» [Урманчиева 2013]. (Речь в статье А. Ю. Урманчиевой идет об аористах субъектного спряжения.) Примеры глаголов из (3)-(4) подтверждают это: аорист субъектного спряжения глагола хонё(cb) \{xonyo\}

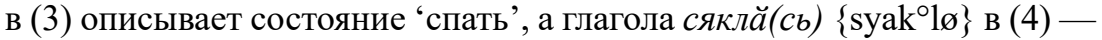
состояние 'быть прикушенным, зажатым, прищемленным':

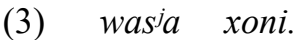

wasya xoni

Вася спать.GFS.3SGS

'Вася спит'.

(4) noxo? yeda jaygoxod sjakli.

noxo-h nge-ta yango-xød ${ }^{\circ}$ syak $^{\circ} \mathrm{li}$

песец-GEN нога-3SG ловушка-ABL прищемляться.GFS.3SGS

'Нога песца зажата капканом'.

Перед нами возникает ясная эмпирическая задача: построить более полную сумму обобщений о возможных «ауслаутных чередованиях» и их дистрибуции. 


\section{3. Парадигма в одном примере}

Составить полное представление об этом явлении мешают сразу несколько факторов. Во-первых, словарные данные Н. М. Терещенко (и тем самым Т. Салминена, который в большой степени опирался на ее словарный материал), как показало наше полевое исследование, во многих отношениях существенно неполны. Во-вторых, описанию глаголов, различающихся ауслаутом, мешает значительный фонетический синкретизм в парадигме, затрудняющий идентификацию форм аориста как относящихся к той или другой лексеме.

Синкретизм показан в Таблице 3 .

Таблица 3. Фонетическая форма основ с различным типом ауслаута

Table 3. Phonetic shape of stems with different stem-final elements

\begin{tabular}{|c|c|c|c|}
\hline Ауслаут & Аорист 3SGs & Аорист 3SGr & Коннегатив \\
\hline (неальтернирующий) -а & $--^{a-}{ }^{\circ}[\mathbf{a}]$ & e-yo $-q$ [ej?] & $a^{a-}{ }^{\circ}-q \quad[a ?]$ \\
\hline неальтернирующий -ø & $\varnothing^{\varnothing--^{\circ}}[\Lambda:]$ & i-o & ${ }_{-}^{\circ}-\mathrm{q}$ \\
\hline альтернирующий - $\varnothing^{\mathrm{i}}$ & $\mathrm{i} \quad[\mathbf{i}]$ & i-q & -u-q \\
\hline (альтернирующий) -о & $-\mathrm{i}$ & $-i-q$ & (y)u-q [(j)u?] \\
\hline
\end{tabular}

Как видно из таблицы, аорист субъектного спряжения не различает глаголы с альтернирующим - $\varnothing^{i}$ и -(y)o. Еще более значителен синкретизм в возвратном спряжении, где глаголы на - $a$ противопоставлены всем остальным. Хотя аорист $3 \mathrm{SGr}$ у глаголов с неальтернирующим - $\varnothing^{\wedge}$ ( i- $\left.^{\circ}-q\right)$ морфологически отличается от аналогичной формы от глаголов с - $\varnothing^{i}$ и -o ( $\left.\mathrm{i}-\mathrm{q}\right)$, их фонетическая реализация идентична: [i?].

Последовательно четыре возможности разводятся лишь в коннегативе, так что именно эту форму надо принимать к рассмотрению, чтобы определить точный инвентарь ауслаутных противопоставлений.

Дополнительные сложности в анализе глаголов с разными типами ауслаута возникают из-за того, что большинство парадигм реализует лишь какое-то подмножество возможностей из Таблищь 3, зачастую очень ограниченное.

Обсудим возникающие затруднения и пути их преодоления на примере глагола со значением 'слышать'. В [Терещенко 1965: 283] имеется единственный такой глагол - намдӑ(cb) \{nømtø\}. 
Проблема в том, что словарь не дает информации о характере -б у намдӑ(cb) \{nømtø\} - альтернирующем или неальтернирующем. намдӑ(cb) \{nømtø\} - один из тех достаточно многочисленных глаголов, которые допускают исключительно образование возвратного, но не субъектного или объектного спряжения (непереходных R-глаголов, согласно классификации, предложенной в [Татевосов 2016]). Возвратное спряжение показано в (5):

$\begin{array}{lll}\text { was }^{j} a n ? & t^{j} o r & n \wedge m d i ? . \\ \text { wasya-n }^{\circ} \mathrm{h} & \text { tyor } & \text { nømti-q } \\ \text { Вася-DAт } & \text { крик } & \text { слышать.GFS-3SGR }\end{array}$

'Васе послышался крик'.

Возвратное спряжение [n^mdi?] в (5), как видно из Таблицы 3, может быть формой как глагола $\left\{\right.$ nømtø $\varnothing^{\wedge}$, так и глагола $\left\{n ø m t \varnothing^{i}\right\}$.

Два омонимичных -ø можно было бы различить по аористу субъектного спряжения - [nımd $\Lambda$ :] vs. [nımdi]. Однако ни та, ни другая форма для намдӑ(cb) \{nømtø\} не доступна, причем независимо от того, создаем ли мы переходное или непереходное предложение. Это видно из (6)-(7):
a. *wasjan? tior $\quad n \wedge m d \wedge:$ :
wasya- $\mathrm{n}^{\circ} \mathrm{h}$ tyor namtø- ${ }^{\circ}$
Bacя-DAT крик слышать-GFS.3SGS
'Васе слышен крик'.
b. ${ }^{*}$ wasja tiorm $\quad$ nımdn:
wasya tyor-m namtø- ${ }^{\circ}$
Вася крик-АCC слышать-GFS.3SGS
'Вася слышит крик'.
a. *wasjan? tior nımdi. wasya- ${ }^{\circ} \mathrm{h}$ tyor nømti
Вася-DAT крик слышать.GFS.3SGS
b. ${ }^{*}$ was $^{j} a$ tjorm $\quad n \wedge m d i$. wasya tyor-m nømti
Вася крик-АCC слышать.GFS.3SGS

Таким образом, тип ауслаута намдӑ(cb) \{namtø\} с опорой на формы аориста не проясняется. 
Следующая сложность возникает в связи с тем, что при полевой работе в ненецком материале обнаруживается форма возвратного спряжения, иллюстрируемая в $(8)^{4}$ :

$$
\begin{array}{lll}
\text { wasjan? }^{2} & \text { tjor }^{j} & \text { nımdej?. } \\
\text { wasya-n }^{\circ} \mathrm{h} & \text { tyor } & \text { nømte-y } \\
\text { Вася-DAT } & \text { крик } & \text { слышать-SFS-3SGR }
\end{array}
$$

'Васе послышался крик'.

Вариант [n^mdej?] не может быть формой глагола намдӑ(cь) \{namtø\}, как видно из Таблиць 3. Для [nımdej?] приходится предположить основу намда(сb) \{nømta\} с ауслаутом - $a$, не зарегистрированную в словаре.

Реальность намда(сь) \{nømta\} подтверждается и примером (9), в котором показана форма аориста субъектного спряжения этого глагола 5 :

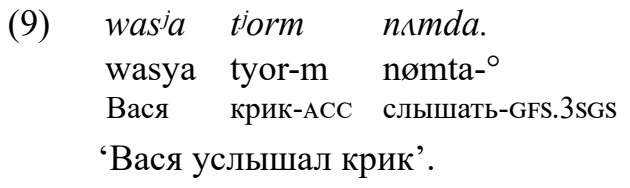

Становится ясно, что интересующий нас глагол представлен по меньшей мере в двух разновидностях - namtø $\}$, как у Н. М. Терещенко и в (5)-(7), и \{nømta $\}$, как в (8)-(9). Последний вариант, очевидно, в словарные материалы Н. М. Терещенко не попал.

Осознание этого вызывает к жизни следующий вопрос. Согласно Таблице 3, [n^mdi?] в (5) может быть формой аориста возвратного спряжения не только $\left\{\right.$ namt $\left.^{\wedge}\right\}$ и $\left\{\right.$ namt $\left.\varnothing^{i}\right\}$, но и еще одного глагола намдё (cь) \{nømtyo\}. Если словарь Н. М. Терещенко упускает из вида намда(сь) \{nømta\} в (8)-(9), можно ли исключить, что то же самое происходит с намдё(сь) \{nømtyo\}? Снять вопрос о существовании намдё(сь) \{nømtyo\} представленные выше примеры, однако, не позволяют из-за

4 Здесь и далее мы опираемся на материал «Базы данных по ненецкой деривационной морфологии и событийной структуре» (см. Приложение).

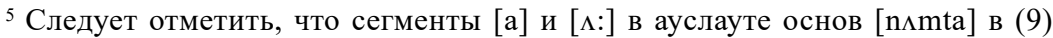
и [nımt $:$ в в (6) акустически довольно близки (см. [Kavitskaya, Staroverov 2010]), однако носители языка отчетливо различают эти две фонемы. Последний воспринимается, согласно их комментариям, как «ударный». Различить формы типа [nımt $:]$ и [nımta], таким образом, не составляет большого труда. 
уже обсуждавшегося синкретизма: аорист возвратного спряжения, один на три глагола, неинформативен, а аорист субъектного спряжения, который должен выглядеть как [nımdi], не только не информативен (он совпадал бы с аналогичным аористом от намдӑ(cb) \{namtø ; $^{\mathrm{i}}$ с альтернирующим - $\left.\varnothing^{i}\right)$, но еще и недоступен.

Засвидетельствованные в нашем материале формы аориста сведены в Таблице 4 .

Таблица 4. Формы аориста глагола со значением 'слышать' Table 4. Aorist forms of the verb 'to hear'

\begin{tabular}{|c|c|c|}
\hline Глагол & Аорист 3SGs & Аорист 3SGr \\
\hline намда(сь) \{nømta $\}$ & [nsmda] & [nımdej?] \\
\hline $\begin{array}{l}\left.\text { намдӑ(cb) \{namt } \varnothing^{\wedge}\right\} \\
\left.\text { (неальтернирующий } \emptyset^{\wedge}\right)\end{array}$ & — (ожид.: [n^md $\Lambda:])$ & \multirow{3}{*}{ [nsmdi?] } \\
\hline $\begin{array}{l}\text { намдӑ }(c b)\{\text { namtøi }\} \\
\text { (альтернирующий } \varnothing^{\mathrm{i}} \text { ) }\end{array}$ & \multirow{2}{*}{ — (ожид.: [nımdi]) } & \\
\hline намдё (cb) \{nømtyo\} & & \\
\hline
\end{tabular}

Таким образом, рассмотрение только форм аориста не позволяет разрешить морфологическую неоднозначность, обусловленную синкретизмом в парадигме. На помощь приходят формы коннегатива, которые различают все четыре случая. В Таблиц̧е 5 к засвидетельствованным формам аориста добавлены ожидаемые формы коннегатива:

Таблица 5. Формы аориста и коннегатива глагола со значением 'слышать' Table 5. Aorist forms and Connegative forms of the verb 'to hear'

\begin{tabular}{|c|c|c|c|}
\hline Глагол & Аорист 3SGs & Аорист 3SGr & Коннегатив \\
\hline намда(сь) \{nømta\} & [nsmda] & [nsmdej?] & [nımda?] \\
\hline $\begin{array}{l}\text { намдӑ(cb) }\left\{\text { namt }^{\wedge}\right\} \\
\left.\text { (неальтернирующий } \emptyset^{\wedge}\right)\end{array}$ & — (ожид.: [nımd $\Lambda:])$ & \multirow{3}{*}{ [nsmdi?] } & [n $\wedge \mathrm{md} ?]$ \\
\hline $\begin{array}{l}\text { намдӑ }(c b)\left\{\text { namt } \varnothing^{\mathrm{i}}\right\} \\
\left.\text { (альтернитующий } \varnothing^{\mathrm{i}}\right)\end{array}$ & \multirow{2}{*}{ — (ожид.: [nımdi] $)$} & & [nımdu?] \\
\hline намдё(сb) \{nømtyo\} & & & [nımdju?] \\
\hline
\end{tabular}

Следующий и последний шаг - выяснить, какие из гипотетических форм коннегатива из Таблицы 5 реальны. Примеры (10a-d) показывают парадигму коннегатива: 


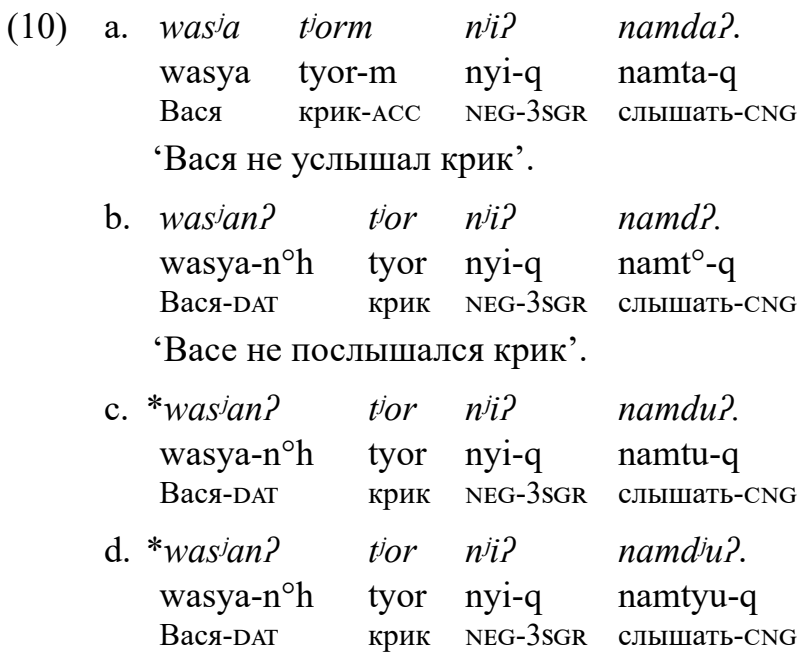

Благодаря примерам (10a-d) становится возможным исключить две из четырех возможностей: глаголы намдӑ(cb) \{namtøi\} с альтернирующим - $\varnothing^{i}$ и намдё(cb) \{nømtyo\}. На это указывает недопустимость коннегативов в (10c) и (10d). Заметим, что во всей парадигме в (10) представлены формы возвратного спряжения, как и в допустимой утвердительной форме в (5). Это позволяет свести к минимуму возможность того, что (10c) и (10d) неграмматичны из-за неверного выбора типа спряжения.

Таким образом, остаются два глагола из четырех возможных:

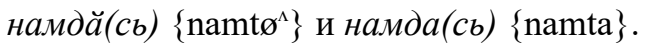

Важные, хотя и косвенные свидетельства, подтверждающие реальность обоих глаголов, обнаруживаются в [Терещенко 1965: 283-284]. Часть производных глаголов от 'услышать', которые записаны в её словаре, судя по всему, образуется от \{namtø\}, а другая — от \{namta\}. Например, глагол нӑмдра(сb) 'довести что-либо до сведения кого-либо', по-видимому, представляет собой каузатив от \{namtø\} и имеет морфологическое представление \{namtø-ra\}, с последующей редукцией второго -ø до ${ }^{\circ},\left\{\mathrm{n}^{\circ} \mathrm{mt}^{\circ}\right.$-ra $\}$. С другой стороны, в [Терещенко 1965: $283]$ приводится словоформа аориста объектного спряжения намдаpaдa со значением 'сообщил'. Она также представляет собой каузатив, но уже от основы $\{$ namta\}. Форма имеет вид \{namta-ra-da\}, а сегмент $a$, в отличие от $\varnothing$, не редуцируется до ${ }^{\circ}$. (Отсутствие редукции - важное различие в фонологическом поведении этих двух сегментов.)

Рассмотрев на одном примере устройство интересующей нас парадигмы, а также практические трудности, с которыми приходится 
сталкиваться при опознании ее элементов, можно перейти к следующей группе наблюдений. В Разделе 4 будет показано, что среди непроизводных глаголов представлены пары глаголов почти со всеми логически возможными комбинациями ауслаутов - $-a$ и - $\varnothing^{i},-a$ и -(y)o и т. д.

\section{4. Непроизводные глаголы ${ }^{6}$}

Как мы видели в предыдущем разделе, ауслаутная парадигма состоит из четырех единиц - $-a,-\varnothing^{\wedge},-\varnothing^{i}$ и -(y)o. Полная парадигма, однако, реализуется крайне редко: как правило, мы видим лишь частичные подпарадигмы. Обсуждавшийся выше глагол со значением 'слышать' дает нам пример ауслаутной пары с $-a$ и $-\varnothing^{\wedge}$. В этом разделе охарактеризованы другие засвидетельствованные в нашем материале пары.

Материал организован в таблицы, в которых исчислены все возможные элементы парадигмы - четыре варианта основы и формы аориста от каждой из них. Засвидетельствованные формы показаны обычным шрифтом, не засвидетельствованные - более бледным. Формы коннегатива показаны только тогда, когда они позволяют разрешить морфологическую неоднозначность.

Первый случай - пары с - $a$ и - $\varnothing^{i}$. Пример такой пары - вӑндар$m a(c b)\left\{\right.$ wøntar $^{\circ}$ ta $\}$ и вӑндарmă(cb) \{wøntar`tø\} 'сгибать, изгибать'. Три засвидетельствованные формы аориста для этих глаголов показаны в Таблице 6.

Таблица 6. Глаголы вӑндарта(сb) \{wøntarºta\} и вӑндартӑ (cb) \{wøntar ${ }^{\circ}$ tø\} 'сгибать, изгибать'

Table 6. The verbs вӑндарта (cb) \{wøntar ${ }^{\circ}$ ta and вӑндартӑ(сь) \{wøntar ${ }^{\circ}$ tø 'to bend'

\begin{tabular}{|c|c|c|c|}
\hline Глагол & Аорист 3SGs & Аорист 3SGr & Коннегатив \\
\hline$\left\{\right.$ wøntar ${ }^{\circ}$ ta $\}$ & [wındarta] & [wındartej?] & \\
\hline$\left\{\right.$ wøntar $^{\circ}$ t $\left.^{\wedge}\right\}$ & [wındart $\Lambda:]$ & \multirow{3}{*}{ [wındarti?] } & [wandart?] \\
\hline$\left\{\right.$ wøntar $^{\circ}$ tø $\left.^{\mathrm{i}}\right\}$ & \multirow{2}{*}{ [wsndarti] } & & [wındartu?] \\
\hline$\left\{\right.$ wøntar ${ }^{\circ}$ tyo $\}$ & & & [wındartiu?] \\
\hline
\end{tabular}

${ }^{6}$ Непроизводными здесь и далее называются (с известной долей условности) формы, в которых отсутствует продуктивная деривационная морфология. 
Согласно Таблице 6, вӑндарта(сb) \{wøntar ${ }^{\circ}$ ta $\}$ имеет формы аориста как субъектного, так и возвратного спряжений, тогда как вӑндартӑ (cb) \{wøntar $\left.{ }^{\circ} \varnothing^{\mathrm{i}}\right\}$ - только субъектного. Эти формы иллюстрируются в (11a-c):
a. was $^{j} a$ piam wandarta.
wasya pya-m wøntar $^{\circ}$ ta- $^{\circ}$
Вася дерево-АCC скрючивать-GFS.3SGS
'Вася согнул дерево'.
b. pia wandartej?.
pya wøntar ${ }^{\circ}$ te- $\mathrm{y}^{\circ}-\mathrm{q}$
дерево скрючивать-SFS-3SGR
'Дерево скрючилось'.
c. $p^{j} a \quad$ wandarti.
pya wøntar ${ }^{\circ}$ ti
дерево быть.скрюченным.GFS.3SGS
‘Дерево скрючено’.

В примерах (11a-b) глагольные формы идентифицируются как принадлежащие глаголу $\left\{w_{ø n t a r}{ }^{\circ} \mathrm{ta}\right.$. Однако чтобы убедиться, что аорист 3SGs [wındarti] в (11c) однозначно относится к глаголу $\left\{w ø n t a r^{\circ} \operatorname{tø}^{\mathrm{i}}\right.$ \}, надо исключить возможность того, что мы имеем дело с аористом гипотетических глаголов вӑндартӑ(сь) \{wøntar $\left.{ }^{\circ} \varnothing^{\wedge}\right\}$ и вӑндартё(cb) \{wøn$\left.\operatorname{tar}^{\circ} \operatorname{tyo}\right\}$. Сделать это вновь помогает коннегатив:

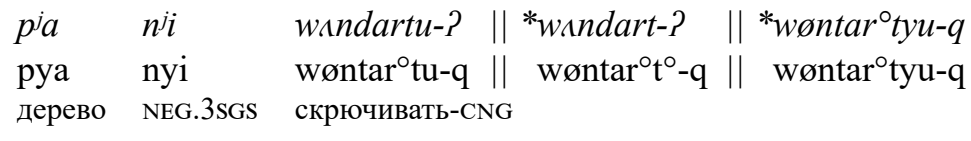
'Дерево не скрючено'.

Невозможность коннегатива с основами [wındart] и [wındar$\mathrm{t}^{\mathrm{j} \mathrm{u}}$ ] не оставляет сомнений, что глаголов вӑндартӑ(cb) \{wøntar $\left.{ }^{\circ} \operatorname{ø}^{\wedge}\right\}$ и вӑндартё (сь) \{wøntar ${ }^{\circ}$ tyo $\}$ не существует, а значит, [wsndarti] и [wیndarti?] — это формы глагола вӑндартӑ(сb) \{wøntar ${ }^{\circ}$ $\left.ø^{\mathrm{i}}\right\}$ с альтернирующим -

Следующая пара - основы на - $a$ и на -(y)o. Характерный пример глаголы хона (сь) \{xona\} и хонё(сb) \{хоnyo\} 'спать'. Их формы представлены в Таблице 7 (с. 546).

В отличие от глаголов вӑндарта $(c b)\left\{\right.$ wøntar $\left.^{\circ} \mathrm{ta}\right\}$ и вӑндартӑ $(\mathrm{cb})$ $\{$ wøntar'tø\} 'сгибать, изгибать', хона(cb) \{xona\} и хонё(cb) \{хоnyo\} 
Таблица 7. Глаголы хона(сь) \{xona\} и хонё(cb) \{xonyo\} 'ложиться спать, спать' Table 7. The verbs хона (сb) \{xona\} and хонё(сb) \{xonyo\} 'to go to bed, to sleep'

\begin{tabular}{|c|c|c|c|}
\hline Глагол & Аорист 3SGs & Аорист 3SGr & Коннегатив \\
\hline$\{$ xona $\}$ & [xona $]$ & [xonej?] & \\
\hline$\left\{\right.$ xon $\left.^{\wedge}\right\}$ & [xonı:] & \multirow{3}{*}{ [xoniq] } & \\
\hline$\left\{\right.$ xon $\left.^{\mathrm{i}}\right\}$ & \multirow{2}{*}{ [xoni] } & & [xonuq] \\
\hline$\{$ xonyo $\}$ & & & [xon'u?] \\
\hline
\end{tabular}

имеют в совокупности две формы аориста, а не три. От глагола хоHa(cb) \{xona\} образуется только аорист возвратного спряжения, а от хо$н \ddot{e}(c b)\{$ xonyo $\}$ - субъектного. Как и в предыдущем случае, [xoni] может быть аористом двух гипотетически возможных глаголов - $\{$ xonyo $\}$ и $\left\{\right.$ хопø $\left.\varnothing^{\mathrm{i}}\right\}$. На помощь вновь приходит форма коннегатива, которая показывает, что существует только один из этих двух глаголов, а именно $\{$ xonyo $\}$.

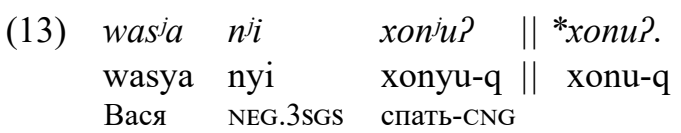

'Вася не спит'.

Следующий случай — глаголы, образующие пару на -Ø` и -(y)o, иллюстрацией которой выступают ңяамдӑ(cb) \{ngamtø\} 'садиться' и ңзамдё(cb) \{ngamtyo\} 'сидеть'. Их формы показаны в Таблице 8.

Таблица 8. Глаголы ц̧амдӑ(cb) \{ngamtø\} и нңамдё(cb) \{ngamtyo\} 'садиться, сидеть'

Table 8 . The verbs н̧амдӑ(cb) \{ngamtø\} and ң̧амдё(cb) \{ngamtyo\} 'to sit, to sit down'

\begin{tabular}{|c|c|c|c|}
\hline Глагол & Аорист 3SGs & Аорист 3SGr & Коннегатив \\
\hline$\{$ ngamta\} & [yamda] & [namdej?] & \\
\hline$\left\{\right.$ ngamt $\left.^{\wedge}\right\}$ & [yamdᄉ:] & \multirow{3}{*}{ [yamdi?] } & [yamd?] \\
\hline \{ngamtøi\} & \multirow{2}{*}{ [yamdi] } & & [yamdu?] \\
\hline$\{$ ngamtyo & & & [yamdju?] \\
\hline
\end{tabular}

Как видно из таблицы, из пяти возможных засвидетельствованы две фонетически различные формы аориста — [yımdi] и [yımdi?]. 
Немедленно становится ясно, что глагола цุамда(сь) \{ngamta\} в ненецком языке нет. Однако [ysmdi] можно анализировать двумя способами, a [yımdi?] — тремя. Выбрать верные среди имеющихся логических возможностей опять помогает коннегатив.

Неграмматичность примеров (14a-b) исключает возможность того, что фонетические формы аориста в Таблице 8 - это формы гипотетического глагола $\{$ ngamtøi $\}$ :

$$
\begin{aligned}
& \text { a. *ni namdu? } \\
& \text { nyi ngamtu-q } \\
& \text { NEG.3SGS сидеть-CNG }
\end{aligned}
$$

$\begin{array}{ll}\text { b. }{ }^{*}{ }_{\mathrm{ni}} \mathrm{i} \text {. } & \text { yamdu? } \\ \text { nyi-q } & \text { ngamtu-q } \\ \text { NEG-3sGR } & \text { сидеть-CNG }\end{array}$

Коннегатив от \{ngamtøí $\}$ выглядел бы как [yamdu?]. Примеры в (14) показывают, что он невозможен ни в субъектном, ни в возвратном спряжении, а значит, такого глагола не существует. Отсюда следует, что аорист субъектного спряжения [yamdi] — это форма глагола цุамдё(сь) \{ngamtyo\} 'сидеть'.

Остается понять, чему соответствует аорист возвратного спряжения [yamdi?]. После исключения гипотетического \{ngamtøi\} из рассмотрения остается две возможности - $\left\{\right.$ ngamt $\varnothing^{\wedge}$ \} и \{ngamtyo .

Их отрицательные формы иллюстрируются в (15a-b):

$$
\begin{aligned}
& \text { a. nii? namd? } \\
& \text { nyi-q } \text { ngamt }^{\circ}-\mathrm{q} \\
& \text { NEG-3SGR сидеть-CNG }
\end{aligned}
$$

$$
\begin{array}{ll}
\text { b. *nij? } & \text { yamdju? } \\
\text { nyi-q } & \text { ngamtyu-q } \\
\text { NEG-3SGR } & \text { сидеть-CNG }
\end{array}
$$

Примеры (15a-b) показывают, что отрицательный аорист возвратного спряжения от \{ngamtø $\varnothing^{\wedge}$ возможен, (15a), а от \{ngamtyo\} нет, (15b). Следовательно, [yımdi?] - это форма аориста возвратного спряжения от глагола $\left\{\right.$ ngamtø ${ }^{\wedge}$, а не от $\{$ ngamtyo $\}$. \{ngamtyo\}, таким образом, это глагол, у которого есть только субъектное спряжение, или, в терминах [Татевосов 2016], непереходный непредельный S-глагол.

Следующий случай, насколько нам известно, не обсуждавшийся в литературе, за исключением [Гусев 2010] 7 , - это оппозиция основ с альтернирующим и неальтернирующим -ø. Таковы, например, мӑясь $\left\{\right.$ тøуø $\varnothing^{\wedge}$ и $\{$ пøуøі\} 'радоваться'. Их формы показаны в Таблице 9 (с. 548).

\footnotetext{
${ }^{7}$ Мы признательны рецензентам, указавшим нам на работу В. Ю. Гусева в связи с глаголами этого типа.
} 


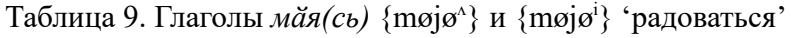

Table 9. The verbs $м a ̆ я(c b)\{$ møjø $\}$ and $\left\{\right.$ møjø $\varnothing^{i}$ 'to rejoice'

\begin{tabular}{|c|c|c|c|}
\hline Глагол & Аорист 3SGs & Аорист 3SGr & Коннегатив \\
\hline$\{$ møja $\}$ & {$[\mathrm{m} \wedge \mathrm{ja}]$} & [m^jej?] & \\
\hline$\left\{\mathrm{møy} \varnothing^{\wedge}\right\}$ & {$[\mathrm{m} \wedge \mathrm{j} \Lambda:]$} & \multirow{3}{*}{ [m^jii?] } & {$[\mathrm{m} \wedge \mathrm{j}$ ?] } \\
\hline$\left\{\right.$ møyø $\left.\varnothing^{\mathrm{i}}\right\}$ & \multirow{2}{*}[\mathrm{m}\wedge\mathrm{ji}]{} & & \multirow{2}{*}{ [m^ju?] } \\
\hline$\{$ møуо $\}$ & & & \\
\hline
\end{tabular}

Для глагола мӑя (cb) \{møуø\} 'радоваться’ носители допускают два фонетических варианта аориста 3SG субъектного спряжения - [mیј :] и [m^ji] - и один вариант возвратного - [m^ji?]. Ровно такая дистрибуция ожидается, если -ø может интерпретироваться и как альтернирующий и как неальтернирующий. Это дополнительно показано в (16); два аориста субъектного спряжения иллюстрируются примерами в $(17 \mathrm{a}-\mathrm{b})$ :

(16) неальтернирующий $\theta^{a}$ vs. альтернирующий $\theta^{i}$ :

\{тøјø\} 'радоваться':

mıjı: $\left\{\right.$ møуø- $\left.{ }^{\circ}\right\} \quad m a j i ?\left\{\right.$ møyi- $\left.{ }^{\circ}-\mathrm{q}\right\}$

maji $\{$ møyi $\} \quad m a j i ?\{$ møyi-q

(17) a. was $^{j} a \quad m ı j \wedge:$ :

wasya møуø- ${ }^{\circ}$

Вася радоваться-GFS.3SGS

'Вася обрадовался'.

b. was $^{j} a$ maji.

wasya møyi

Вася быть.обрадованным.GFS.3sGS

'Вася обрадован'.

Пример (17a) однозначно указывает на реальность основы $\left\{\right.$ тøу $\left.{ }^{\wedge}\right\}$ с неальтернирующим - $\varnothing^{\wedge}$. К сожалению, (17b) не дает однозначной информации об основе, от которой образован аорист: это может быть как $\left\{\right.$ møуø $\boldsymbol{x}^{\mathrm{i}}$, так и гипотетический глагол $\{$ пøуо $\}$. А форма аориста возвратного спряжения [m^jii] с ее тройственным синкретизмом, как мы уже неоднократно видели, малоинформативна и не позволяет снять неоднозначность. 
К сожалению, не помогает в этом случае и форма коннегатива: гласный ауслаута следует за сегментом [j], не реализующим противопоставления по палатализованности, в отличие, например, от зубных согласных, которые были в примерах выше. Соответственно, коннегативы от гипотетических глаголов $\{$ пøуø $\}$ и $\{$ møуо $\}$ оказывались бы фонетически идентичны:

a. $n^{i} i \operatorname{maju} ?\left(\leftarrow\left\{\operatorname{møy} \varnothing^{\mathrm{i}}\right\}\right)$

b. $n^{i} i \operatorname{maju}$ ? $(\leftarrow\{\mathrm{møyo}\})$

Принять решение в пользу основы \{пøуø $\}$ позволяют лишь косвенные данные. Если бы основа \{møуо $\}$ была реальна, можно было бы ожидать, что она обнаружится в составе производных глаголов, даже если для нее нет основного словарного вхождения в [Терещенко 1965]. Однако в словообразовательном гнезде глагола 'радоваться' (ни среди лексем, перечисленных в словаре Н. М. Терещенко, ни в наших полевых материалах) дериваты от основы $\{$ бøуо $\}$ не представлены. Мы заключаем, что [mлji] в (17b) - форма \{тøуøi\} и что пары с ауслаутом на $-\varnothing^{\wedge}$ и $-\varnothing^{i}$ также реальны, хотя этот случай менее очевиден, чем предыдущие.

Подведем промежуточный итог. Среди непроизводных глаголов в ненецких словарях можно обнаружить пары основ, различающиеся практически всеми логически возможными типами ауслаута, как суммировано в (19). Единственная не засвидетельствованная возможность - минимальная пара с двумя альтернирующими основами $\left\{\varnothing^{\mathrm{i}},(\mathrm{y}) \mathrm{o}\right\}$.

(19) а. Засвидетельствованы: $a$ и $\emptyset^{\wedge}, a$ и $\emptyset^{i}, a$ и (y)o, $\emptyset^{\wedge}$ и $\emptyset^{i}, o^{\wedge}$ и $(y) o$.

b. Не засвидетельствованы: $\emptyset^{i}$ и $(y) o$.

Обобщение в (19b), однако, не исключает того, что варианты с - $\varnothing^{i}$ и -(y)о способны образовываться от одной и той же основы. Напротив, ниже на примере некоторых производных глаголов мы увидим, что основы на эти сегменты могут благополучно сосуществовать в составе большей парадигмы.

В следующих двух разделах наблюдения о непроизводных глаголах предстоит распространить на продуктивные дериваты. Мы рассмотрим каузативы и в особенности инхоативы, но полученные на этом материале обобщения будут верны и для большинства других дериватов. 


\section{5. Продуктивные дериваты}

До сих пор мы видели лишь пары глаголов, но не тройки и тем более не четверки глаголов, хотя в Таблииах 1-9 всякий раз рассматривались четыре логические возможности. В этом разделе обсуждаются глаголы с продуктивными деривационными показателями, и благодаря этому материалу становится ясно, что диапазон возможностей отнюдь не ограничен парами.

В ненецком языке деривационные показатели можно распределить по трем категориям:

— показатели актантной деривации;

- показатели аспектуальной деривации;

- показатели временной референции к будущему и хабитуалиса.

Показатели актантной и аспектуальной деривации образуют наиболее многочисленную группу. Разделение на эти два класса в значительной степени условно. Показатели актантной деривации не только изменяют аргументную структуру основы, но и воздействуют на ее акциональные / аспектуальные характеристики. Аналогично, показатели аспектуальной деривации не только влияют на аспектуальные свойства основы, но и преобразуют ее актантную структуру. Отнесение к одному из классов, таким образом, лишь отражает интуицию о том, какая функция - актантная или аспектуальная - первична.

К продуктивным аспектуальным деривациям относятся, в частности, дуратив, имперфектив, фреквентатив, итератив и инхоатив.

Дуратив (показатель -мбӑ $\{\mathrm{mp} ø\}$ ) и имперфектив (показатель -нӑ / $-m a \check{a}\{\mathrm{n} \sim \mathrm{tø}\})$ иллюстрируются в (20)-(21) и (22)-(23):

(20) wasja xidiam xnlta.

wasya xidya-m $\quad$ xøl $^{\circ}$ ta- $^{\circ}$

Вася тарелка-АCC мыть-GFs.3sGS

'Вася вымыл тарелку'.

(21) was ja xidiam xnltambii.

wasya xidya-m $\quad x ø 1^{\circ}$ ta-mpyi

Вася тарелка-АCC мыть-DUR.GFS.3SGS

'Вася моет тарелку'. 
(22) wesako xa.

wæsako xa- $^{\circ}$

старик умирать-GFS.3SGS

'Старик умер'.

(23) wesako xanı:

wæsako xa-nø- ${ }^{\circ}$

старик умирать-IPFV-GFS.3sGS

'Старик умирает'.

Предложения с дуративом и имперфективом функционируют как аналоги предложений в прогрессиве в языках со словоизменительным видом или предложений с глаголами несовершенного вида в русском языке.

Фреквентатив (показатель $\left.-p^{8}\{\mathrm{r}\}\right)$ и итератив -нугӑ $\{\mathrm{ngkø}\}$ обычно рассматриваются как показатели глагольной множественности. Фреквентатив - одна из наиболее продуктивных аспектуальных дериваций. Пример фреквентатива представлен в (25), непроизводный глагол показан в (24).

(24) wasia yoxoli.

wasya ngoxøli

Вася плыть.GFS.3SGS

'Вася плывет'.

(25) was $^{j} a$ yoxoliurya.

wasya ngoxølyu-r-nga

Вася плавать-FREQ-GFS.3SGS

'Вася плавает \{сейчас || регулярно\}'.

Семантические последствия присоединения показателя фреквентатива достаточно многообразны. Например, фреквентатив глагола 'плыть' в (25) в актуально-длительной интерпретации описывает множество перемещений, возможно, разделенных временными промежутками. Это создает семантику, похожую на ту, которую мы наблюдаем в русском языке у так называемых глаголов ненаправленного движения типа плавать.

Итератив также описывают ситуации, разбивающиеся на множество атомарных подситуаций:

\footnotetext{
${ }^{8}$ В [Терещенко 1965] и [Буркова 2010] записан как -p”.
} 
(26) was ja radion? jinzielje.

wasya radio- ${ }^{\circ} \mathrm{h}$ yincyelye- ${ }^{\circ}$

Вася радио-DAT слушать-GFS.3SGS

'Вася слушает радио'.

(27) was $^{j} a$ radion? jinz'eljeygn:

wasya radyio- $n^{\circ} \mathrm{h}$ yincyelye-ngkø- ${ }^{\circ}$

Вася радио-DAT слушать-ITER-GFS.3SGS

'Вася (временами) прислушивается к радио'.

Предложения с непроизводными глаголами ничего не сообщают о том, как описываемая ситуация членится на подситуации. Предложения с итеративом не только указывают на наличие множества подситуаций, но и на то, что между элементами этого множества имеются временные промежутки. Предложение в (27), в частности, уместно, когда радио привлекает внимание участника ситуации лишь время от времени. Подробнее об итеративе см. [Татевосов 2017; 2020].

Еще одна чрезвычайно продуктивная деривация - инхоатив (по-

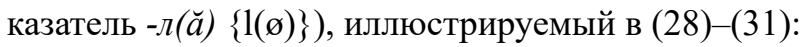

(28) wasja warkxıd pii'nı:

wasya wørk $^{\circ}-\mathrm{x}^{\circ} \mathrm{d}^{\circ}$ pyínø- ${ }^{\circ}$

Вася медведь-ABL бояться-GFS.3SGS

'Вася боится медведя'.

(29) was'a warkxıd pii'nılya.

wasya wørk $^{\circ}$-xød ${ }^{\circ}$ pyínø-l-nga

Вася медведь-ABL бояться-INCH-GFS.3SGS

'Вася начал бояться медведя'.

(30) was'a petjam ju'tı::

wasya petya-m yútø- ${ }^{\circ}$

Вася Петя-АCC бить-GFS.3SGS

'Вася избил Петю'.

(31) wasja petjam ju'tılya.

wasya petya-m yútø-l-nga

Вася Петя-АCC бить-INCH-GFS.3SGS

'Вася начал избивать Петю'.

Инхоатив не имеет регулярных лексических ограничений и может описывать и наступление состояния, как в (29), и наступление процесса, 
как в (31). В терминах В. П. Недялкова [Недялков 1987], в случае ненецкого инхоатива мы имеем дело с тремя разными возможностями собственно инхоативом, ингрессивом и инцептивом.

Единственная продуктивная актантная деривация - каузатив, который представлен несколькими каузативными суффиксами - -ma $\{\mathrm{ta}\}$, -me \{tye\}, -pa $\{\mathrm{ra}\},-p e$ rye, , -nma $\{\mathrm{bta}\}$; см. [Терещенко 1960, Tерещенко 1965, Salminen 1997, Nikolaeva 2014]. (Показатели \{ta\} / \{tye\} и $\{\mathrm{ra}\}$ / rye\}, вероятно, диахронически представляют собой варианты одного аффикса, однако мы пока не видим способа объяснить их дистрибуцию в фонологических терминах.) Ненецкий каузатив, как и его аналоги в других языках, добавляет к описываемой ситуации каузирующее подсобытие и его аргумент. В качестве иллюстрации в (32)-(35) представлены каузативы на -nma $\{\mathrm{bta}\}$ :

(32) jimbit? $\quad$ jıdırı:

yimpit ${ }^{\circ} \mathrm{q}$ ngødørø- ${ }^{\circ}$

платье рваться-GFS.3SGS

'Платье порвалось'.

(33) man jimbit?m yıdırıptaw.

many $^{\circ}$ yimpit $^{\circ} \mathrm{q}-\mathrm{m}$ ngødørø-bta- $\varnothing-\mathrm{w}^{\circ}$

$я$ платье-АCC рваться-CAUS-GFS-1SGO

'Я порвал платье'.

(34) was $^{j a} n^{j} e r \wedge n z^{j} \wedge m$ jikına panda.

wasya nyerøncyø-m ji-k ${ }^{\circ}$ a $\operatorname{pan}^{\circ} \mathrm{da}-^{\circ}$

Вася ведро-АСC вода-LOC наполнять-GFS.3SGS

'Вася наполнил ведро водой'.

(35) man $^{j} n^{j} e r \wedge n z^{j} \wedge m$ jikına wasjan?

many $^{\circ}$ nyerøncyø-m ji- $\mathrm{k}^{\circ}$ na wasya- ${ }^{\circ} \mathrm{h}$

я ведро-АСС вода-Lос Вася-DАт

pandaptaw.

pan $^{\circ}$ da-bta- ${ }^{\circ}-\mathrm{w}^{\circ}$

наполнять-CAUS-GFS-1SGO

' Я заставил / приказал/ позволил/ помог Васе наполнить ведро водой’.

Каузативный показатель присоединяется к глаголам с любой актантной структурой - в диапазоне от непереходных пациентивных, как в (32), до переходных агентивных, как в (34). В последнем случае 
каузатив допускает значение непрямой каузации. Поскольку каузатив вводит в рассмотрение подсобытие деятельности каузатора с неспецифицированными дескриптивными свойствами, в (35) наблюдаются многообразные прочтения типа 'заставил', ‘приказал', 'помог' и т. д. ${ }^{9}$

К продуктивным деривациям относятся также хабитуалис и футурум. Первый представлен в (36), второй — в (37):

$$
\begin{array}{lll}
\text { pida } & \text { pisismo? }^{\text {p }} & \text { padbrsiti. } \\
\text { pida } & \text { pyisymoq } & \text { pad }^{\circ} \text {-pø-sy }{ }^{\circ} \mathrm{ti} \\
\text { он } & \text { письма.ACC.PL } & \text { написать-DUR-HAB.GFs.3sGs } \\
\text { '(После завтрака) он пишет письма'. }
\end{array}
$$

$\begin{array}{llll}\text { pida } & \text { nnacjekin? }^{j} & \text { mjadoncejm }^{j} & \text { temdangu. } \\ \text { pida } & \text { ngøcyeki-n }{ }^{\circ} \mathrm{h} & \text { myadoncey }^{\circ} \text {-m } & \text { temta-ngku } \\ \text { он } & \text { ребёнок-DAT } & \text { подарок-ACC } & \text { купить-FUT.GFs.3sGS }\end{array}$

'Он купит ребенку подарок'.

Основная функция футурума — выражение временно́й референции к будущему. Хабитуалис описывает ситуации, которые имеют место постоянно или регулярно. В отличие от деривационных показателей, охарактеризованных выше, хабитуалис и футурум лишены даже минимальных лексических ограничений и находятся в дополнительной дистрибуции со словоизменительными показателями. С точки зрения системно-типологических соображений, выражение временной референции к будущему и хабитуальности деривационной морфологией, а не словоизменительной также весьма нетипично, см. [Dahl 1985; Bybee et al. 1994]. Все это указывает на то, что действительное место суффиксов хабитуалиса и футурума - среди словоизменительных показателей. Такое описание хабитуалиса и футурума предлагается и в грамматике И. А. Николаевой [Nikolaeva 2014]; некоторые соображения на эту тему высказываются также в [Буркова 2010: 301-302].

Т. Салминен, однако, приводит их в одном ряду с прочими деривационными показателями. Аргументы за и против такого анализа

\footnotetext{
${ }^{9}$ И. А. Николаева [Nikolaeva 2014] утверждает, что в ненецком языке каузативизация продуктивна для непереходных глаголов и непродуктивна для переходных. Этот вывод, однако, следует признать слишком поспешным: в нашей «Базе данных по ненецкой деривационной морфологии и событийной структуре» (см. Приложение) все исследованные переходные глаголы допускают тот или иной вариант каузативизации.
} 
обсуждаются в [Salminen 1997: 53-55]. Судить об их убедительности мы предоставляем читателю. Для наших дальнейших целей вопрос о статусе этих форм не имеет принципиального значения, и мы поэтому принимаем анализ Т. Салминена в неизменном виде.

Кроме перечисленных, Т. Салминен [Salminen 1998; 2002] выделяет еще целый ряд деривационных показателей: моментатив на -хал ${ }^{10}$ $\{\mathrm{xøl}\}$, интенсив на -хая $\{$ хøуа $\}$, интранзитив на -нзго \{ngko\}, инкомплетив на -йбте $\{\mathrm{jøbtye}\}$, пассив на - $\not \breve{a}\{\mathrm{ra}\}$, прекатив на -xap $\{\mathrm{x} ø \mathrm{r}\}$; см. также [Буркова 2010; Nikolaeva 2014]. Их дистрибуция отмечена большим количеством нетривиальных лексических ограничений, обсуждение которых мы отложим на будущее. Дополнительные сведения о дуративе и имперфективе можно найти в [Дудчук 2004], о дуративе, фреквентативе и итеративе - в [Шлуинский 2004] и [Татевосов 2017; 2020].

\section{6. Деривации и ауслауты}

Основное наблюдение над продуктивными дериватами в контексте сюжета этой статьи состоит в том, что абсолютно все они проявляют те же «ауслаутные чередования», что и непроизводные глаголы, только более системно и продуктивно. Инхоативы, дуративы, каузативы и т. д. могут существовать в нескольких разновидностях - с ауслаутами на $-a,-\varnothing^{\wedge},-\varnothing^{i}$ и $-y(o)$. Этот факт, по-видимому, не отмечался предыдущими исследователями.

Рассмотрим несколько примеров. Предложения (38) и (39) иллюстрируют зафиксированные в наших данных случаи каузатива.

a. was ja yacjekim mınzapta.

wasya ngacyeki-m mønca-bta- ${ }^{\circ}$

Вася ребенок-АCC шевелиться-CAUS-GFS.3SGS

'Вася пошевелил ребенка'.

b. yacieki manzapti.

ngacyeki mønca-bti

ребенок шевелиться-CAUS.GFS.3SGS

‘Ребёнок шевелится'.

${ }^{10}$ В [Терещенко 1965; Буркова 2010] имеет вид -хал’. 
a. yacjeki mınzaptej?.

ngacyeki mønca-bte- $\mathrm{y}^{\circ}$-q

ребенок шевелиться-CAUS-SFS-3SGR

'Ребёнок шевельнулся (по какой-то причине)'.

b. yacieki mınzapti?.

ngacyeki mønca-bti-q

ребенок шевелиться-CAUS.SFS-3SGR

‘Ребёнок начал шевелиться’.

В (38)-(39) мы видим четыре варианта: два аориста субъектного спряжения и два возвратного. Они показаны в Таблице 10.

Таблица 10. Каузатив мӑнзапта(сь) \{møncabta\} и его варианты

Table 10. Causative мӑнзапта(сь) \{møncabta\} and its variants

\begin{tabular}{|c|c|c|}
\hline Глагол & Аорист 3SGs & Аорист 3SGr \\
\hline$\{$ møncabta $\}$ & [mınzapta] & [mınzaptej?] \\
\hline$\left\{\right.$ møncabt $\left.\varnothing^{\wedge}\right\}$ & [mınzapt $\Lambda]$ & \multirow{3}{*}{ [mınzapti?] } \\
\hline$\{$ møncabtøi $\}$ & \multirow{2}{*}{ [mınzapti] } & \\
\hline$\{$ møncabtyo $\}$ & & \\
\hline
\end{tabular}

Из примеров (38)-(39) и Таблицы 10 становится ясно, что каузатив имеет вариант с основой на $-a$, создающий формы [m^nzapta] и [mınzaptej?], а также по меньшей мере один из трех других вариантов, благодаря которому возникают формы [m^nzapti] и [m^nzapti?]. Субъектное спряжение [mınzapt $\Lambda:]$ от основы $\left\{\right.$ møncabtø $\left.{ }^{\wedge}\right\}$ невозможно. Однако и исключить существование самой основы на основании (38)-(39) нельзя, поскольку возвратное спряжение [mınzapti?] может оказаться среди прочего и формой от $\left\{\right.$ møncabtø ${ }^{\wedge}$.

В нашей базе данных представлено около двух десятков каузативов на - pta $\{\mathrm{bta}\}$, устроенных похожим образом. Это достаточно существенная (не менее $25 \%$ ) доля каузативов из выборки. Можно говорить о том, что явление имеет совершенно регулярный характер.

То же самое наблюдается и у других деривационных морфем. Согласно всем грамматическим описаниям, показатели имперфектива на $-н \breve{a}\{\mathrm{nø}\}$ и итератива -н̧гӑ $\{$ ngkø\}, например, имеют -ø в ауслауте. Следовательно, независимо от того, имеем ли мы дело с - $\varnothing^{\wedge}$ или - $\varnothing^{i}$, единственная ожидаемая фонетическая форма аориста возвратного спряжения имеет в исходе последовательность сегментов [i?]. 
Эта возможность действительно преобладает. Однако в базе данных представлена заметная доля имперфективов и итеративов, аналогичных тем, которые иллюстрируются в (40)-(41):

sarjo x^wnıygej?.

saryo $\quad \mathrm{x} ø \mathrm{w}^{\circ}$ nø-ngke- ${ }^{\circ}-\mathrm{q}$

дождь идти-ITER-SFS-3SGR

'Начало моросить'.

(41) was'a majımlanej?.

wasya møyøm-la-ne-y ${ }^{\circ}-q$

Вася радоваться-CAUS-IPFV-SFS-3SGR

'Вася начал испытывать радость (по какой-то причине)'.

Как ясно из предшествующего обсуждения, глаголы в (40)-(41) не могут быть формами итератива хӑвнӑнугӑ(cb) \{xøw'nøngkø\} 'идти (о дожде)' и имперфектива мӑямланӑ(сь) \{møуømlanø\} 'радоваться'. Это формы глаголов хӑвнӑңрга(cb) \{xøwºøngka\} 'идти (о дожде)' и имперфектива мӑямлана(сь) \{møуømlana\} 'радоваться', в которых показатели имперфектива и итератива имеют $-a$, а не -ø в ауслауте - $-н a$ \{na\} и -нцга \{ngka\}.

Однако наибольшее разнообразие возможностей зафиксировано для инхоатива - $\{1 \mathrm{a}\},\left\{1 \varnothing^{\wedge}\right\},\left\{1 \varnothing^{\mathrm{i}}\right\},\{1 \mathrm{yo}\},\{1\}$. K уже обсуждавшимся четырем случаям здесь добавляется пятый: нулевой элемент ауслаута, при котором создается консонантная основа. Доступные возможности показаны в Таблице 11 на примере основы лохомбӑл- \{loxom-pø-1-\} 'закипать', которая представляет собой инхоатив от дуратива глагола лохом(зь) \{loxom\} 'закипать':

Таблица 11. Глагол лохомбӑлӑ(сb) \{loxom-pø-lø\} 'закипать' и его варианты

Table 11. The verb лохомбӑлӑ(cь) \{loxom-pø-lø\} 'закипать' и его варианты

\begin{tabular}{|c|c|c|c|}
\hline Глагол & Аорист 3SGs & Аорист 3SGr & Коннегатив \\
\hline$\{$ loxompøla\} & [loxomb 4 la] & [loxombslej?] & [loxombsla?] \\
\hline$\{$ loxompølø^\} & [loxomb $\Lambda 1 \Lambda:]$ & \multirow{3}{*}{ [loxombsli?] } & [loxomb $\Lambda$ l?] \\
\hline$\{$ loxompølø' & \multirow{2}{*}{ [loxomb $\Lambda$ li] } & & [loxomb $\Delta l u ?]$ \\
\hline$\{$ loxompølyo & & & [loxomb $\Delta$ liu?] \\
\hline$\{$ loxompøl\} & [loxombslya] & [loxomb $\wedge \mathrm{lj} 2]$ & \\
\hline
\end{tabular}


Парадигма, показанная в Таблице 11, - относительно редкий случай, когда все ожидаемые формы реально засвидетельствованы. В (42)(43) иллюстрируются формы глаголов лохомбӑла(сь) \{loxompøla\} и лохомбӑлӑ(сь) \{loxompølø^\} с неальтернирующим -ø^:

(42) лохомбӑла(сь) \{loxompøla\} 'закипать, начинать кипеть'

a. loxombıla loxom-pø-la- ${ }^{\circ}$ закипать-DUR-INCH-GFS.3SGS

b. loxomb^lej? loxom-pø-le-y ${ }^{\circ}$-q закипать-DUR-INCH-SFS-3SGR

c. $n^{i} i \quad$ loxombala?

nyi loxom-pø-la-?

NEG.3SGS закипать-DUR-INCH-CNG

(43) лохомбӑлӑ(сь) \{loxompølø^ ' 'закипать, начинать кипеть'

a. loxombalı: loxom-pø-lø- ${ }^{\circ}$ закипать-DUR-INCH-GFS.3SGS

b. $n^{i} i \quad$ loxombal?

nyi loxom-pø-1 ${ }^{\circ}-\mathrm{q}$

NEG.3SGS закипать-DUR-INCH-CNG

В примерах (42)-(43) заслуживает внимания хорошо регистрируемый фонетический контраст форм аориста субъектного спряжения. Редуцированный [^:] в (43a) интуитивно воспринимается носителями как «безударный» по сравнению с «ударным» гласным полного образования в (42a). (В (42a) и (43a) «ударный» гласный подчеркнут. В действительности, по всей вероятности, носители интерпретируют как «ударность» напряженность гласных. (Подлинные правила акцентуации, согласно [Salminen 1997; Nikolaeva 2014: 28], определяются просодическим членением фонетического материала на хореические стопы.)

Коннегативы в (42c) и (43b) образуются по регулярным правилам; в (43b), как и, например, в (10b) и (15a) выше, -ø редуцируется до ${ }^{\circ}$.

В (44)-(45) показаны формы субъектного спряжения и коннегативы инхоативов с альтернирующими основами лохомбӑлӑ(cb) \{loxompøløi и лохомбӑлё (сь) \{loxompølyo\}. 
(44) лохомбӑлӑ(cь) \{loxompøløi\} 'закипать'

a. loxombali loxom-pø-li закипать-DUR-INCH.GFS.3SGS

b. $n^{j i} \quad$ loxombalu?

nyi loxom-pø-lu-q

NEG.3SGS закипать-DUR-INCH-CNG

(45) лохомбӑлё(сь) \{loxompølyo\} 'закипать, кипеть'

a. loxombali

loxom-pø-li

закипать-DUR-INCH.GFS.3SGS

b. $n^{i} i \quad$ loxombıliu?

nyi loxom-pø-lyu-q

NEG.3SGS закипать-DUR-INCH-CNG

Реальность обоих глаголов, как и прежде, подтверждается формами коннегатива, который различает их смягчением согласного в показателе инхоатива у лохомбӑлё(сь) \{loxompølyo $\}$ в (45b) и его отсутствием у лохомбӑлӑ (cb) \{loxompøløi $\}$ в (44b). Аорист субъектного спряжения у двух глаголов идентичен, так что форма [loxombsli] может относиться к любому из них, как в (44a) и (45a).

Форма в (46), как видно из Таблицы 11 , показывает, что по меньшей мере один из трех глаголов - на - $\varnothing^{\wedge}$, на -ø или на $-(y) o-$ допускает образование аориста возвратного спряжения.

(46) Форма аориста возвратного спряжения

от лохомбӑлӑ (сь) \{loxompølø $\},$ лохомбӑлӑ(сb) \{loxompøløi $\}$

или лохомбӑлё(сь) \{loxompølyo\}

loxomb^li?

loxom-pø-li-q

закипать-DUR-INCH.SFS-3SGR

Наконец, возможность, которая не обсуждалась на материале непроизводных глаголов, иллюстрируется в (47). Это глагол лохомбӑл(u̧ь) $\{$ loxompøl\}, у которого показатель инхоатива представлен моноконсонантным вариантом. Глаголы с консонантной основой легко отличить: для них показателем общей финитной основы выступает -ң̧а \{nga\}. Специальная финитная основа создается при помощи уже известного нам показателя $\{\mathrm{yø}$. 
(47) лохомбӑл(ць) \{loxompøl\} 'закипать, вскипать'
a. loxombalya
b. loxomb^lj?
loxom-pø-1-nga
закипать-DUR-INCH-GFS.3SGS

Все эти примеры показывают, что обобщения, опирающиеся на материал непроизводных глаголов из Раздела 4, воспроизводятся в большинстве дериватов с достаточной систематичностью. Появляются основания говорить о том, что в общем случае ненецкая глагольная основа, неважно производная или непроизводная, имеет выбор между несколькими вариантами «ауслаута».

Эмпирическая реальность этого обобщения подкрепляется и еще одним морфосинтаксическим фактом. Основы глаголов, различающихся «ауслаутом», участвуют в дальнейших деривационных процессах.

В ходе полевого исследования мы провели простой эксперимент. Взяв несколько инхоативов, мы предположили для них три из пяти возможностей, которые показаны в Таблице 11 , - с ауслаутом на - , - $\varnothing^{i}$ и $-(y) o$. Затем для каждой из возможностей были исчислены три случая: исходная основа (ИО), общая финитная основа (GFS), основа коннегатива (CNG). Исчисление показано в (48) в виде иерархической структуры на примере инхоатива от глагола якӑ (cb) \{jakø\} 'чесаться':

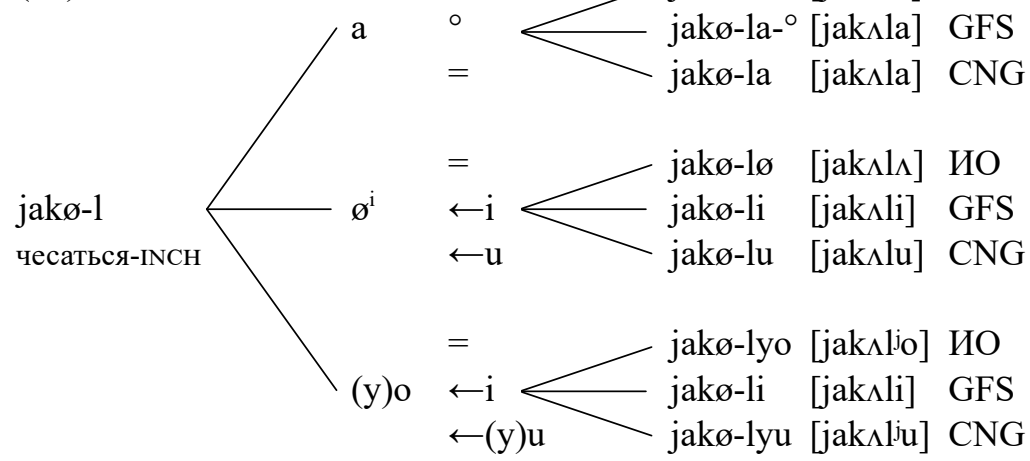

При ауслауте на - $a$ основы ИO, GFS и CNG фонетически идентичны ([jaksla]). Также идентичны GFS при двух альтернирующих типах ауслаута - на - $\varnothing^{i}$ и на -(y)o ([jaksli]). С учетом этого исчисление дает шесть фонетически различных объектов — [jakla], [jakl $]$, [jakli], [jaklu], [jakljo] и [jaklju].

Задача эксперимента - проверить, могут ли эти объекты участвовать в дальнейших деривационных процессах. Если да, мы получаем 
важное дополнительное свидетельство в пользу реальности морфологического противопоставления вариантов на $-a,-\varnothing^{i}$ и $-(y)$ o.

Для целей эксперимента было отобрано четыре деривата - дуратив, имперфектив, фреквентатив и итератив. К каждому из объектов в (48) присоединялся соответствующий показатель и получившаяся основа предъявлялась носителю языка. Испытание считалось успешным, если носитель опознавал как грамматичную хотя бы одну форму построенного таким образом деривата.

Таблицы 12-14 показывает засвидетельствованные дериваты от всех исчисленных типов инхоативных основ для трех глаголов - якӑ(cb) $\left\{\right.$ jakø\} 'чесаться', хӑвнӑ $(c b)\left\{\mathrm{xøw}^{\circ}\right.$ nø $\}$ 'идти (о дожде)', - а также отыменного инхоатива xodolă $(c b)$ \{xodolø\} 'начинать кашлять' (от хо” $\{\mathrm{xoq}\}$ 'кашель'). Во всех таблицах столбец GFS - общий для вариантов с $-\varnothing^{i}$ и $-(y)$ o.

Как видно из таблиц, по меньшей мере один дериват образуется от каждой из основ, полученных описанным выше методом. Это безусловно доказывает реальность всей серии объектов, традиционно описываемых в терминах ауслаутных чередований. Можно с определенностью говорить о том, что масштаб этого явления был существенно недооценен в предшествующих описаниях. Обобщение А. Ю. Урманчиевой можно, таким образом, уточнить: речь идет не столько об образовании форм аориста, сколько о полноценном деривационном процессе, который дает о себе знать сразу в нескольких частях грамматической системы.

Морфологический материал, которым мы хотели бы поделиться с читателем, на этом исчерпан. Мы готовы подвести скромные итоги обсуждения.

Таблица 12. Дериваты от якӑл- \{jakøl-\} 'начинать чесаться' Table 12. Derivatives of якӑл- \{jakøl-\} 'start itching'

\begin{tabular}{|c|c|c|c|c|c|c|}
\hline & \multirow{2}{*}{$\begin{array}{l}\text { \{jakøla }\} \\
\text { ИO=GFS=CNG } \\
\text { jakıla }\end{array}$} & \multicolumn{2}{|l|}{$\mathrm{jak} ø l O$} & \multirow{2}{*}{ I jaks } & \multicolumn{2}{|l|}{ I $\{$ jakølyo $\}$} \\
\hline & & $\begin{array}{l}\text { ИО }^{11} \\
\text { jak } \Lambda 1 \Lambda\end{array}$ & $\begin{array}{l}\text { CNG } \\
\text { jakılu }\end{array}$ & & $\begin{array}{l}\text { I ИО } \\
\text { I jaks lio }\end{array}$ & $\begin{array}{l}\text { CNG } \\
\text { jakslju }\end{array}$ \\
\hline DUR & jakılambi & jakılbi & & I & I & \\
\hline IPFV & jakslani? & jakslni? & & I jaks lini? & I jaks lioni? & \\
\hline FREQ & jakılor & jakslor & jakslur & i jaknlir & I jak $\Lambda$ ljor & jaks ljur \\
\hline ITER & jakslang $\Lambda$ : & jaks $\operatorname{lng} \mathrm{g}_{\Lambda}$ : & $\operatorname{jak}_{\Lambda} \operatorname{lung} \mathrm{g}_{\Lambda}$ : & I jaksling ${ }_{\Lambda}:$ & $\mathrm{I}$ jaks $\mathrm{l}^{\mathrm{j} o \mathrm{~g} g} \mathrm{~g}$ & jaks $\mathrm{l}^{\mathrm{j} u n g} \mathrm{~g}_{\Lambda}$ : \\
\hline
\end{tabular}

${ }^{11} \mathrm{~B}$ этих формах мы предполагаем редукцию -ø до ${ }^{\circ}:\left\{j a k ø l^{\circ} \mathrm{bi}\right\}$ [jakılbi]. 
Таблица 13. Дериваты от хӑвнӑл- $\left\{\mathrm{xøw}^{\circ} \mathrm{n}\right.$ - $\}$ 'начинать идти (о дожде)'

Table 13. Derivatives of хӑвнӑл- $\left\{{\left.\mathrm{x} ø w^{\circ} n ø l-\right\}}^{-}\right.$'start raining'

\begin{tabular}{|c|c|c|c|c|c|c|}
\hline & \multirow{2}{*}{$\begin{array}{l}\left\{\mathrm{x} ø \mathrm{w}^{\circ} \text { nøla }\right\} \\
\text { ИO=GFS=CNG } \\
\mathrm{x} \Lambda \mathrm{wn} \wedge \mathrm{la}\end{array}$} & \multicolumn{2}{|l|}{ xøw'nølO\} } & I & \multicolumn{2}{|c|}{ I $\left\{\right.$ xøw ${ }^{\circ}$ nølyo $\}$} \\
\hline & & $\begin{array}{l}\text { ИО } \\
\mathrm{x} \Lambda \mathrm{wn} \Lambda 1 \Lambda\end{array}$ & $\begin{array}{l}\text { CNG } \\
\text { x } \Lambda \text { wn } \wedge l u\end{array}$ & 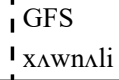 & $\begin{array}{l}\text { ИО } \\
\text { I } \mathrm{x} \Lambda \mathrm{Wn} \wedge \mathrm{lj} \text { o }\end{array}$ & $\begin{array}{l}\mathrm{CNG} \\
\mathrm{x} \Lambda \mathrm{wn} \Lambda \mathrm{j} \mathrm{u}\end{array}$ \\
\hline DUR & & $\mathrm{x} \Lambda \mathrm{wn} \Lambda \mathrm{lbi}$ & & I & I & \\
\hline IPFV & $\mathrm{x} \Lambda \mathrm{wn} \wedge$ lani? & $\mathrm{x} \Lambda \mathrm{wn} \Lambda \ln i ?$ & & I & I & \\
\hline FREQ & $\mathrm{x} \Lambda \mathrm{wn} \Lambda \mathrm{lor}$ & $\mathrm{x} \Lambda \mathrm{Wn} \wedge$ lor & x^wnslur & I x^wnslir & I $\mathrm{x} \Lambda \mathrm{wn} \Lambda \mathrm{l}$ jor & $\mathrm{x} \Lambda \mathrm{wn} \Lambda \mathrm{ljur}$ \\
\hline ITER & $\mathrm{x} \Lambda \mathrm{wn} \wedge \operatorname{lag} \mathrm{g}$ : & $\mathrm{x} \Lambda \mathrm{wn} \Lambda \operatorname{lng} \Lambda$ : & $\mathrm{x} \wedge w n \wedge l u \eta$ & I x $\Lambda$ wn $\Delta$ lin & I & \\
\hline
\end{tabular}

Таблица 14. Дериваты от ходол- \{xodol-\} 'начинать кашлять'

Table 14. Derivatives of ходол- $\{$ xodol- $\}$ 'start caughing'

\begin{tabular}{|c|c|c|c|c|c|c|}
\hline & $\{$ xodola $\}$ & \multicolumn{2}{|c|}{ xodolO } & I & \multicolumn{2}{|l|}{ I $\{$ xodolyo $\}$} \\
\hline & $\begin{array}{l}\text { ИО=GFS=CNG } \\
\text { xodola }\end{array}$ & $\begin{array}{l}\text { ИО } \\
\text { xodolı }\end{array}$ & $\begin{array}{l}\text { CNG } \\
\text { xodolu }\end{array}$ & $\begin{array}{l}\text { GFS } \\
\text { xodoli }\end{array}$ & $\begin{array}{l}\text { ИО } \\
\text { xodoljo }\end{array}$ & $\begin{array}{l}\text { CNG } \\
\text { xodolju }^{\mathrm{j}}\end{array}$ \\
\hline DUR & xodolambi & & & I & I & \\
\hline IPFV & xodolani? & & & I xodolini? & I & \\
\hline FREQ & & & xodolur & I xodolir & I xodoljor & xodoliur \\
\hline ITER & xodolang $\Lambda$ : & & xodolun & I xodoling $\Lambda$ : & I xodoljong $\Lambda$ : & \\
\hline
\end{tabular}

\section{7. Заключение}

Предшествующее обсуждение представляется небесполезным в нескольких отношениях. Во-первых, оно показывает, что варьирование ауслаута — явление значительно более масштабное, чем мы привыкли думать. Многие глаголы, образуемые в рамках четырехчленного противопоставления $-a,-\varnothing^{\wedge},-\varnothing^{i}$ и -y(o), не зарегистрированы в имеющихся материалах по ненецкому языку, даже наиболее полных - [Teрещенко 1965] и [Salminen 1998]. Наличие этого противопоставления у продуктивных дериватов, таких, как инхоатив, каузатив и т. д., осталось и вовсе практически незамеченным. Во-вторых, становится ясно, что это явление невозможно анализировать в терминах (мор)фонологических чередований. Мы имеем дело с продуктивной деривационной морфологией, с помощью которой создаются отдельные лексические 
единицы. В-третьих, характерное для противопоставленных по ауслауту глаголов морфологическое поведение позволяет сделать новые обобщения о роли глагольных основ (исходной, общей финитной и коннегативной) в деривационно-морфологических процессах. Один из основных результатов Раздела 6, в частности, состоит в том, что все эти основы задействованы не только в словоизменении, но и в образовании продуктивных дериватов.

Успех любого проекта, предполагающего выделение в исследуемом языке особого класса морфологических единиц, конечно, в большой степени зависит от того, насколько этим единицам возможно приписать семантическое содержание. Этот сюжет выходит за пределы настоящих заметок и освещается в [Татевосов 2018]. Сжатое содержание этой работы состоит в следующем.

Если предполагать, что событийно-структурные типы предикатов ненецкого языка содержат единицы, относящиеся к классам состояний, деятельностей и свершений, то можно отметить, что альтернирующие и неальтернирующие ауслауты имеют разную дистрибуцию по отношению к этим классам. Неальтернирующие - $a$ и - $\varnothing^{\wedge}$ совместимы с любыми событийно-структурными конфигурациями. В отличие от них, альтернирующие показатели имеют более ограниченную дистрибуцию. Глаголы с -(y)o вычленяют результирующее подсобытие в исходной структуре предиката. Это событие может иметь дескриптивные свойства как состояния, так и деятельности. Глаголы с - $\varnothing^{i}$ также описывают состояние или деятельность, однако в этом случае оно вводится в рассмотрение как непроизводное, не вычленяющееся из более сложной событийной структуры.

\section{Приложение. Глагольная база данных ненецкого языка}

База данных по деривационной морфологии ненецкого языка, содержащая информацию о примерно 2600 лексических единицах, продукт коллективной работы ненецкой лингвистической экспедиции Отделения теоретической и прикладной лингвистики филологического факультета МГУ им. М. В. Ломоносова в 2003-2005 гг. В разные годы над ней работали Екатерина Волович, Николай Воронцов, Филипп Дудчук, Павел Иосад, Наталья Зевахина, Денис Иванов, Михаил Иванов, 
Екатерина Лютикова, Анна Пазельская, Петр Староверов, Сергей Татевосов, Мария Цюрупа, Андрей Шлуинский, Елена Ханина, Ольга Ханина. Разработку и техническую поддержку базы данных проводил Денис Иванов.

Целью проекта было углубленное исследование деривационной морфологии ненецкого языка, предполагающее найти ответ на два основополагающих вопроса.

i. Что происходит с актантной структурой и акциональностью глагола при присоединении деривационных морфем?

ii. Каковы ограничения на присоединение деривационных морфем?

База данных, таким образом, разрабатывалась как инструмент для накопления информации о том, является ли комбинация основы $\mathrm{S}$ и деривационной морфемы D возможной, то есть корректно построенной и интерпретируемой. Для каждой возможной комбинации $\mathrm{S}+\mathrm{D}$ база данных содержит информацию о ее актантной структуре и акциональности.

Практическая работа по наполнению базы данных складывалась из следующих шагов.

1. Создание выборки непроизводных основ, отражающих основные актантные и акциональные типы ненецких глаголов.

2. Для каждой основы - выявление ее актантных и акциональных свойств.

3. Для каждой основы - выявление ее деривационного потенциала, то есть определение набора деривационных морфем, с которыми она способна комбинироваться.

4. Построение всех возможных дериватов от всех основ.

5. Добавление дериватов к выборке.

6. Повторение шагов 2-5 для новых единиц выборки.

О каждом элементе словника база данных содержит следующую информацию: лексический вход, глубина деривационной цепочки, фонологическая запись доступных глагольных основ (в формате Т. Салминена), наличие и акциональный тип каждого из спряжений, примеры с переводом, наличие дериватов каузативной зоны с примерами, наличие дериватов аспектуальной зоны с примерами, комментарии и примечания. Форма, соответствующая лексическому входу базы данных, показана на Рисунке 1. 


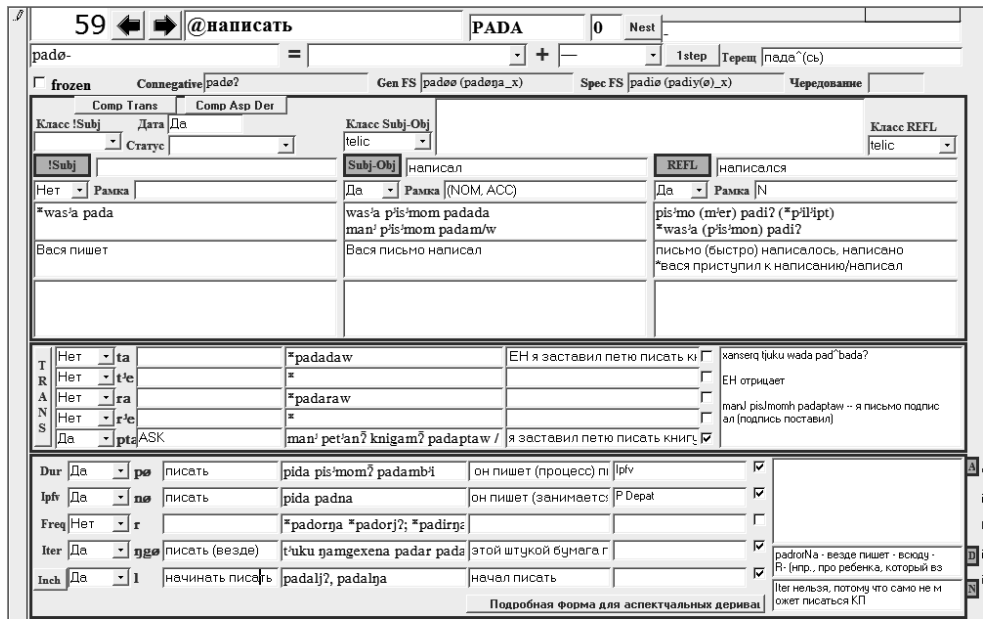

Рисунок 1. Лексический вход базы данных

Fig. 1. Lexical entry of the data base

Кроме того, информация в базе данных допускает представление в виде гнезда, которое иллюстрируется на Рисунке 2. Гнездовая форма содержит все дериваты от одной основы, показывающие для каждого элемента гнезда глубину деривационной цепочки, словообразовательную структуру основы и последний шаг деривации.

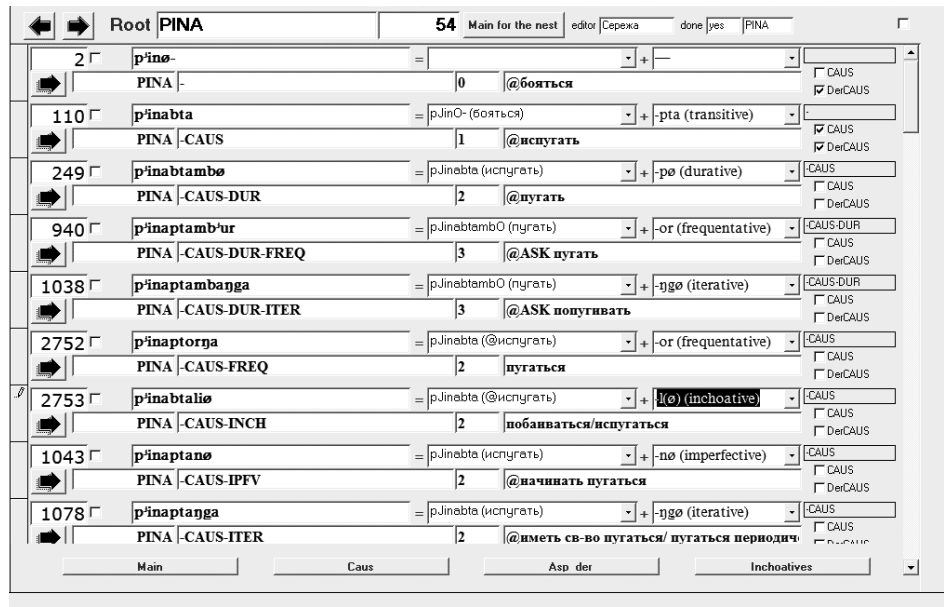

Рисунок 2. Деривационное гнездо

Fig. 2. Derivational cluster 


\section{Список условных сокращений}

1, 2, 3 - 1-е, 2-е, 3-е лицо; ABL — аблатив; ACC - аккузатив; CAUS - каузатив; CNG - коннегатив; DAT — датив; DUR — дуратив; FREQ — фреквентатив; FUT — будущее время; GEN — генитив; GFS - общая финитная основа; нAB - хабитуалис; INCH - инхоатив; IPFV — имперфектив; ITER — итератив; LOC — локатив; M — непродуктивная деривация на - $m$; O - объектное спряжение; PL - множественное число; PST - прошедшее время; R - возвратное спряжение; $\mathrm{s}$ - субъектное спряжение; SFS - специальная финитная основа; SG - единственное число; _V — ocнова с ауслаутом на V.

\section{Литература}

Буркова 2010 - С. И. Буркова. Краткий грамматический очерк восточных говоров тундрового диалекта ненецкого языка // С. И. Буркова, Н. Б. Кошкарева, Р. И. Лаптандер и др. (сост.). Диалектологический словарь ненецкого языка. Тюмень: БАСКО, 2010. С. 179-349.

Гусев 2010 - В. Ю. Гусев. Стативы и декаузативы на *-w в самодийских языках // С. И. Буркова (ред.). Материалы 3-й Международной научной конференции по самодистике. Новосибирск, 26-28 октября 2010. Новосибирск: Любава, 2010. С. 54-65.

Дудчук 2004 - Ф. А. Дудчук. Вопросы глагольного вида в ненецком языке. Технический отчет 2003-04.12. М.: МГУ им. М. В. Ломоносова, 2004.

Татевосов 2016a - С. Г. Татевосов. Структура и интерпретация ненецкого глагола: Актантно-акциональные классы и типы спряжения // Вопросы языкознания. 2016. № 3. С. 81-114.

Татевосов $2016 \mathrm{~b}$ - С. Г. Татевосов. Глагольные классы и межъязыковое варьирование. М.: Языки славянской культуры, 2016.

Татевосов 2017 - С. Г. Татевосов. Структура события и ненецкий глагол: заметки о актантно-акциональных свойствах Итератива // Linguistica Uralica. 2017. Vol. 53. № 3. С. 197-225.

Татевосов 2018 - С. Г. Татевосов. Событийно-структурная морфология в ненецком языке // Rhema. Рема. 2018. № 3. C. 88-118.

Терещенко 1947 - Н. М. Терещенко. Очерк грамматики ненецкого (юрако-самоедского) языка. Л.: Учпедгиз, 1947.

Терещенко 1960 - Н. М. Терещенко. О категории залога в самодийских языках // В. М. Жирмунский (ред.). Вопросы грамматики: Сборник статей к 75-летию академика И. И. Мещанинова. Л.: Изд-во АН СССР, 1960. С. 178-193.

Терещенко 1965 - Н. М. Терещенко (сост.). Ненецко-русский словарь. М.: Советская энциклопедия, 1965.

Терещенко 1973 - Н. М. Терещенко. Синтаксис самодийских языков. Простое предложение. Л.: Наука, 1973. 
Урманчиева 2013 - А. Ю. Урманчиева. Образование форм аориста в самодийских языках // Acta Linguistica Petropolitana. Труды Института лингвистических исследований. 2013. Т. 9. Ч. 2. С. 734-766.

Шлуинский 2004 - А. Б. Шлуинский. Аспектуальные деривации в малоземельском говоре тундрового диалекта ненецкого языка. Технический отчет 200306.22. М.: МГУ имени М. В. Ломоносова, 2004.

Bybee et al. 1994 - J. Bybee, R. Perkins, W. Pagliuca. The Evolution of Grammar. Tense, Aspect, and Modality in the Languages of the World. Chicago; London: University of Chicago Press, 1994.

Dahl 1985 - Ö. Dahl. Tense and Aspect Systems. Oxford: Blackwell, 1985.

Kavitskaya, Staroverov 2010 - D. Kavitskaya, P. Staroverov. When an interaction is both opaque and transparent: the paradox of fed counterfeeding // Phonology. 2010. Vol. 27. P. 1-34.

Körtvély 2005 - É. Körtvély. Verb conjugation in Tundra Nenets (Studia Uralo-Altaica. Vol. 46). Szeged: SZTE Finnugor Tanszék, 2005.

Nikolaeva 2014 - I. A. Nikolaeva. A grammar of Tundra Nenets. Berlin: Mouton de Gruyter, 2014.

Ristinen 1973a - E. K. Ristinen. Some remarks on the function of the subjective and objective conjugations in Samoyedic // Journal de la Société Finno-Ougrienne. 1973. Vol. 72. P. 337-347.

Ristinen 1973b - E. K. Ristinen. Observations on the Functions of the Conjugations in Samoyedic // Uralica. 1973. № 1. P. 11-38.

Salminen 1997 — T. Salminen. Tundra Nenets inflection (Suomalais-Ugrilaisen Seuran Toimituksia. Vol. 227). Helsinki: Suomalais-Ugrilainen Seura, 1997.

Salminen 1998 — T. Salminen. A morphological dictionary of Tundra Nenets (Lexica Societatis Fenno-Ugricae. Vol. 26). Helsinki: Suomalais-Ugrilainen Seura, 1998.

\section{References}

Burkova 2010 - S. I. Burkova. Kratkiy grammaticheskiy ocherk vostochnykh govorov tundrovogo dialekta nenetskogo yazyka [A brief grammar sketch of the Eastern varieties of the Tundra dialect of the Nenets language]. S. I. Burkova, N. B. Koshkareva, R. I. Laptander et al. (comp.). Dialektologicheskiy slovar nenetskogo yazyka [The dialectological dictionary of the Nenets language]. Tyumen: BASKO, 2010. P. 179-349.

Bybee et al. 1994 - J. Bybee, R. Perkins, W. Pagliuca. The Evolution of Grammar. Tense, Aspect, and Modality in the Languages of the World. Chicago; London: University of Chicago Press, 1994.

Dahl 1985 — Ö. Dahl. Tense and Aspect Systems. Oxford: Blackwell, 1985.

Dudchuk 2004 - F. A. Dudchuk. Voprosy glagolnogo vida v nenetskom yazyke. Tekhnicheskiy otchet 2003-04.12 [Aspect in Tundra Nenets. Techincal report 200304.12]. Moscow: Lomonosov Moscow State University, 2004.

Gusev 2010 - V. Yu. Gusev. Stativy i dekauzativy na *-w v samodiyskikh yazykakh [Statives and anticausatives on $*-w$ in Samoyedic languages]. S. I. Burkova (ed.). 
Materialy 3-y Mezhdunarodnoy nauchnoy konferentsii po samodistike. Novosibirsk, 26-28 oktyabrya 2010 [Proceedings of the $3^{\text {rd }}$ international conference on Samoyedic languages. Novosibirsk, 26-28 October 2010]. Novosibirsk: Lyubava, 2010. P. 54-65

Kavitskaya, Staroverov 2010 - D. Kavitskaya, P. Staroverov. When an interaction is both opaque and transparent: the paradox of fed counterfeeding. Phonology. 2010. Vol. 27. P. 1-34.

Körtvély 2005 - É. Körtvély. Verb conjugation in Tundra Nenets (Studia Uralo-Altaica. Vol. 46). Szeged: SZTE Finnugor Tanszék, 2005.

Nikolaeva 2014 - I. A. Nikolaeva. A grammar of Trundra Nenets. Berlin: Mouton de Gruyter, 2014.

Ristinen 1973a - E. K. Ristinen. Some remarks on the function of the subjective and objective conjugations in Samoyedic. Journal de la Société Finno-Ougrienne. 1973. Vol. 72. P. 337-347.

Ristinen 1973b - E. K. Ristinen. Observations on the Functions of the Conjugations in Samoyedic. Uralica. 1973. No. 1. P. 11-38.

Salminen 1997 - T. Salminen. Tundra Nenets inflection (Suomalais-Ugrilaisen Seuran Toimituksia. Vol. 227). Helsinki: Suomalais-Ugrilainen Seura, 1997.

Salminen 1998 - T. Salminen. A morphological dictionary of Tundra Nenets (Lexica Societatis Fenno-Ugricae. Vol. 26). Helsinki: Suomalais-Ugrilainen Seura, 1998.

Shluinskiy 2004 - A. B. Shluinskiy. Aspektualnye derivatsii v malozemelskom govore tundrovogo dialekta nenetskogo yazyka. Tekhnicheskiy otchet 2003-06.22 [Aspectual derivation in Trundra Nenets. Technical report 2003-06.22]. Moscow: Lomonosov Moscow State University, 2004.

Tatevosov 2016a - S. G. Tatevosov. Struktura i interpretatsiya nenetskogo glagola: aktantno-aktsionalnye klassy i tipy spryazheniya [Structure and interpretation of Tundra Nenets verbs: eventuality types and conjugation classes]. Voprosy yazykoznaniya. 2016. No. 3. P. 81-114.

Tatevosov 2016b - S. G. Tatevosov. Glagolnye klassy i mezhyazykovoe varirovanie [Verb classes and cross-linguistic variation] Moscow: Yazyki slavyanskoy kultury, 2016.

Tatevosov 2017 - S. G. Tatevosov. Struktura sobytiya i nenetskiy glagol: zametki o aktantno-aktsionalnykh svoystvakh Iterativa [Event structure and Nenets verb: notes on argument projection and eventuality type of the Iterative]. Linguistica Uralica. 2017. Vol. 53. No. 3. P. 197-225.

Tatevosov 2018 - S. G. Tatevosov. Sobytiyno-strukturnaya morfologiya v nenetskom yazyke [Event-structural morphology in Tundra Nenets]. Rhema. Rema. 2018. No. 3. P. $88-118$.

Tereshchenko 1947 — N. M. Tereshchenko. Ocherk grammatiki nenetskogo (yurakosamoedskogo) yazyka [A sketch of the Nenets (Yurak-Samoyed) grammar]. Leningrad: State Educational and Pedagogical Publishing House, 1947.

Tereshchenko 1960 — N. M. Tereshchenko. O kategorii zaloga v samodiyskikh yazykakh [On the category of voice in Samoyedic languages]. V. M. Zhirmunskiy (red.). Voprosy grammatiki: Sbornik statey $k$ 75-letiyu akademika I. I. Meshchaninova 
[Grammar issues. Collection of papers dedicated to the $75^{\text {th }}$ anniversary of academician I. I. Meshchaninov]. Leningrad: Publishing House of the USSR Academy of Sciences, 1960. P. 178-193.

Tereshchenko 1965 - N. M. Tereshchenko (comp.). Nenetsko-russkiy slovar [Nenets-Russian dictionary]. Moscow: Sovetskaya entsiklopediya, 1965.

Tereshchenko 1973 — N. M. Tereshchenko. Sintaksis samodiyskikh yazykov. Prostoe predlozhenie. [Syntax of Samoyedic languages. Clause structure]. Leningrad: Nauka, 1973.

Urmanchieva 2013 - A. Yu. Urmanchieva. Obrazovanie form aorista v samodiyskikh yazykakh [Aorist formation in Samoyedic languages]. Acta Linguistica Petropolitana. Trudy Instituta lingvisticheskikh issledovaniy. 2013. Vol. 9. Pt. 2. P. 734-766. 


\title{
Деривационная морфология образных глаголов тундрового ненецкого языка
}

\section{А. Ю. Урманчиева}

Институт лингвистических исследований РАН, Санкт-Петербург; urmanna@yandex.ru

Аннотация. В статье рассматривается деривационная морфология образных глаголов тундрового ненецкого языка. Глаголами образной семантики в данной статье считаются такие, которые соответствуют следующему определению В. А. Аврорина: «Образные слова обозначают понятия, наиболее тесно связанные с непосредственными зрительными, слуховыми, осязательными впечатлениями и душевными переживаниями. 〈...> Образное слово представляет собой как бы снимок с реального образа с его разнообразными признаками» [Аврорин 1961: 213]. Интересной чертой ненецкого языка является то, что в нем образные глаголы можно выделить не только с опорой на семантику (такой подход трудно объективировать, и он практически всегда чреват «раздуванием» этого класса, так как границы образной семантики не могут быть очерчены достаточно четко), но прежде всего с опорой на характерные для этих глаголов деривационные суффиксы, противопоставляющие их глаголам «необразной» семантики. Исследование основывается на лексикографическом описании ненецких глаголов в словаре [Терещенко (сост.) 1965]. Основы образной семантики образуют целые деривационные гнезда: большинство из них присоединяет несколько суффиксов из описанных в данной статье, что подкрепляет идею о существовании в ненецком особой подсистемы деривационных суффиксов, характерных только для образных глаголов.

Ключевые слова: ненецкий язык, образные глаголы, деривационная морфология.

\section{Derivational morphology of depictive (onomatopoeic) verbs in Tundra Nenets}

\author{
A. Yu. Urmanchieva \\ Institute for Linguistic Studies, Russian Academy of Sciences, St. Petersburg; \\ urmanna@yandex.ru
}

\footnotetext{
Abstract. The article discusses the derivational morphology of depictive or onomatopoeic verbs in Tundra Nenets. Verbs of depictive semantics correspond to the following definition by V. A. Avrorin: "Figurative words denote concepts that are most
} 
closely related to direct visual, auditory, tactile impressions and emotional experiences. $\langle\ldots\rangle$ The figurative word is like a snapshot of a real image with its various attributes" [Avrorin 1961: 213]. Compare he meanings of several depictive verbs of the Tundra Nenets language: 'speak slurring (for example, from under the covers)', 'walk quickly in wide open clothes', 'stretch out arms palms up', 'stand and watch (smb. eating or working) for a long time', 'swallow smth. poorly chewed or unpleasant in taste'.

An interesting feature of depictive verbs in Nenets is that this class can be identified not only relying on their semantics (such an approach is difficult to objectify, and it is almost always fraught with "bloating" of this class, since the boundaries of depictive semantics cannot be clearly defined), but primarily based on the derivational suffixes characteristic of these verbs.

The study is based on the lexicographic description of Nenets verbs in the dictionary by Tereshchenko [(comp.) 1965]. The derivational suffixes of depictive verbs in Nenets fall into imperfectivizing and perfectivizing morphemes, the former representing a larger class. Within each of the groups, suffixes can express fairly elaborate aspectual meanings. For example, imperfectivizing suffixes distinguish between stative verbs denoting states and stative verbs denoting properties; there are also several multiplicative suffixes denoting different intensity of action. Some suffixes combine with stems with specific lexical meanings; for example, a dyad of a perfective and an imperfective suffixes attach to verbal stems describing either sounds proper or actions accompanied by a loud sound e.g., 'drop smth. with a crash'). There is yet another imperfective suffix that can form new verbs by means of "metaphoric comparison"; for example, it can derive verbs meaning 'slowly sink (about a dying person's eyelids)' or 'barely gasp (for breath)' from the verb meaning 'flicker (like stars)'. Perfectivizing suffixes are represented by inchoatives and semelfactives. Most verbal stems with depictive semantics can combine with several suffixes from among those described in this article, which supports the hypothesis of a special subsystem of derivational suffixes characteristic of only depictive verbs.

Keywords: Nenets language, depictive (ideophonic) verbs, derivational morphology.

\section{1. Введение}

В данной статье рассматривается деривационная морфология образных глаголов тундрового ненецкого языка. Глаголами образной семантики в данной статье считаются такие, которые соответствуют следующему определению В. А. Аврорина: «Образные слова обозначают понятия, наиболее тесно связанные с непосредственными зрительными, слуховыми, осязательными впечатлениями и душевными 
переживаниями. Семантика их по сравнению с другими разрядами знаменательных слов, за исключением, может быть, междометий, обладает наименьшей степенью абстрагированности, обобщенности. Они предназначены для выражения в речи конкретно-образных характеристик предметов и их действий. Образное слово представляет собой как бы снимок с реального образа с его разнообразными признаками. Многие из них рисуют довольно сложную картину, характеризуя предмет или действие одновременно с различных сторон. Они беднее прочих слов в смысле возможности их употребления, поскольку обладают слабой степенью обобщенности, но значительно ярче их по своему внутреннему содержанию» [Аврорин 1961: 213]. Для иллюстрации приведу значения нескольких образных глаголов тундрового ненецкого: 'невнятно говорить (например, из-под одеяла)', 'быстро идти в широко распахивающейся одежде', 'протягивать руки ладонями вверх', 'долго стоять и смотреть (как другой ест или работает)', 'появляться - о проблесках света, мерцать', 'проглотить что-л. плохо разжеванное или неприятное на вкус'.

Важной и интересной чертой образных глаголов тундрового ненецкого (далее, для краткости - ненецкого) является то, что класс этих глаголов можно выделить не только с опорой на семантику (такой подход трудно объективировать, и он практически всегда чреват «раздуванием» этого класса, так как границы образной семантики не могут быть очерчены достаточно четко), но прежде всего с опорой на характерные для этих глаголов деривационные суффиксы, противопоставляющие их глаголам «необразной» семантики. Деривационные суффиксы, характерные для образных глаголов ненецкого языка, выполняют двоякую функцию. С одной стороны, они выделяют глаголы определенной лексической семантики (например, есть деривационные суффиксы, присоединяющиеся к глаголам звучания). С другой стороны, поскольку ненецкому глаголу присуща бинарная категория вида (каждый ненецкий глагол является перфективным либо имперфективным), а также богатый репертуар суффиксов, выражающих значения из сферы глагольных совершаемостей, каждый суффикс образных глаголов также выражает определенное аспектуальное значение.

Деривационные аспектуальные суффиксы ненецкого глагола с точки зрения возможности присоединения к глаголам образной семантики делятся на два класса: а) суффиксы, присоединяющиеся исключительно к глаголам образной семантики (а также примыкающие к ним суффиксы, присоединяющиеся по преимуществу к глаголам 
образной семантики), и б) суффиксы, присоединяющиеся к глаголам любой семантики (о последних см., например, [Буркова 2010: 301303]). Это означает, что в ненецком глагольные основы образной семантики не избирательны в отношении аспектуальных суффиксов (они могут присоединять как собственные уникальные суффиксы, так и «общеязыковые» суффиксы с аспектуальным значением). Однако есть группа аспектуальных суффиксов, избирательных в отношении глагольных основ: функционирование этих суффиксов ограничено глаголами образной семантики.

Соблазнительно было бы считать, что такая асимметрия связана с архаичным характером образной глагольной лексики: в этом случае ситуация выглядела бы так, что деривационный потенциал образных глаголов расширялся за счет присоединения (помимо собственных уникальных суффиксов) наиболее продуктивных общеязыковых глагольных деривационных показателей. Однако эти продуктивные показатели (например, инкомплетив на -трб) являются, по всей видимости, общесамодийскими, тогда как ряд суффиксов ненецких образных глаголов не имеет параллелей в других самодийских языках. Это, впрочем, может объясняться разрушением деривационной подсистемы образных глаголов в других самодийских языках. В целом вопрос о том, являются ли деривационные показатели образных глаголов более архаичными в сравнении с общеязыковыми деривационными показателями, требует дополнительных исследований.

Ниже дается обзор суффиксов, характерных для образных глаголов ненецкого языка. Материалом статьи послужила прежде всего сплошная выборка глаголов с определенными суффиксами из словаря [Salminen 1998]. Словник указанной работы включает словник «Ненецко-русского словаря» [Терещенко (сост.) 1965], по которому в настоящей статье приводятся значения рассматриваемых глаголов (в тех случаях, когда в [Терещенко (сост.) 1965] дается указание на узкодиалектное распространение глагола, соответствующая помета с указанием говора - таймырский, большеземельский, ямальский - воспроизводится также в тексте статьи). В статье учитываются также те глаголы, которые отсутствуют в [Терещенко (сост.) 1965], но представлены в [Salminen 1998] с опорой на другие источники.

Поскольку работа [Salminen 1998] представляет собой морфологический словарь, в статье я опираюсь прежде всего на морфологическую интерпретацию дериватов, предложенную в указанной работе. Вместе с тем в некоторых случаях (что оговаривается специально в каждом 
подразделе) предложены изменения списков дериватов, составленных по [Salminen 1998]. Такое изменение списков может происходить по двум причинам. Во-первых, в ряде глагольных основ-изолятов, на синхронном уровне являющихся непроизводными, можно предполагать наличие соответствующего суффикса в исторической перспективе. Во-вторых, в ряде случаев фонологический облик суффиксальной морфемы может допускать неоднозначную морфологическую интерпретацию: некоторые суффиксы в ненецком имеют омонимичные алломорфы. В таких случаях список может быть модифицирован - как за счет введения отсутствующих в нем глаголов, так и за счет исключения «лишних».

В статье для записи ненецких суффиксов используется следующая нотация: а) кириллическая запись, представляющая транскрипцию, принятую в словаре [Терещенко (сост.) 1965], б) строчные латинские буквы - запись, используемая в словаре [Salminen 1998], в) прописные латинские буквы - запись морфологической модели глагольной основы (также по словарю [Salminen 1998]) ${ }^{1}$. В соответствии с [Salminen 1998] обозначается также класс глагольной основы (после символа V), используются следующие коды:

i — $\quad$ непереходные глаголы, изменяющиеся по субъектному типу спряжения;

t - переходные глаголы;

$\mathrm{r}$ - непереходные глаголы, изменяющиеся по рефлексивному типу спряжения;

t-r - переходные глаголы, которые допускают также спряжение по рефлексивному типу спряжения с изменением семантики от переходной к декаузативной;

c - имперфективные глаголы;

$\mathrm{m}$ - перфективные глаголы.

Материал в статье упорядочен следующим образом: в Разделе 2 рассматривается пара деривационных суффиксов (один с имперфективным, другой с перфективным значением): группы глагольных основ, присоединяющих эти суффиксы, в значительной степени пересекаются, так что их разумно рассматривать параллельно, как словообразовательные

${ }^{1}$ Основные сведения по фонологии тундрового ненецкого и соотношении различных способов записи (транскрипции Т. Салминена, финно-угорской транскрипции и орфографии) приведены в [Salminen 1997: 36-39] и в [Буркова 2010: 224-226]. 
корреляты. В Разделе 3 рассматриваются суффиксы, образующие имперфективные глаголы, в Разделе 4 - суффиксы, образующие перфективные глаголы. В Разделе 5 подводится итог исследования. В каждом разделе приводится максимально полный список глаголов с соответствующим показателем, что позволяет оценить частотность того или иного суффикса, а также дать более или менее исчерпывающее представление о семантике образных глаголов ненецкого языка.

\section{2. Имперфективные глаголы с суффиксом -нӑ /-NØ Vi c и их перфективные корреляты с суффиксом -хадӑ -цядӑ -зядӑ /-XА-ТØ -ХУА-ТØ Vi m}

2.1. Суффикс -нă / -NØ Vi c оформляет имперфективные глаголы класса непредельных процессов, по преимуществу имеющие значение негромкого повторяющегося звука либо мелкого быстрого движения (в том числе предполагающего перемещение): вӑйнӑсь/wøу ${ }^{\circ} \varnothing-$ 'быстро двигать ногами (отбиваясь, защищаясь); семенить'; вӑрнӑсь / wør nø- 'бежать - о небольших животных и птицах'; вывнӑсь / wiw nø'свистеть, завывать - о ветре'; выйнӑсь / wiy nø- 'быстро идти, бежать'; вырнӑсь / wirnø- 'катиться вниз с легким шумом'; вјрнӑсь / wer ${ }^{\circ} \varnothing-$ 'выдергиваться, тянуться - о чем-либо длинном'; ейнӑсь/ уеу ${ }^{\circ} \varnothing-$ 'пищать, визжать'; иднӑсь / yid $\mathrm{n} \varnothing-$ 'пищать'; ирнӑсь / yirº $\varnothing-$ 'скрипеть, хрустеть'; лабнӑсь / lab no- 'сильно дуть - о ветре'; лӑбнӑсь / løb `nø- 'трепаться на ветру'; лӑднӑсь / lød 'nø- 'шуршать - о бумаге';

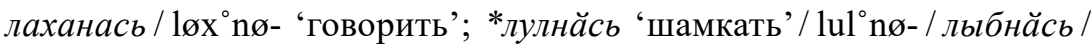
lib nø- 'бушевать о ветре, пурге'; мӑлнӑсь/møl'nø 'щебетать, чирикать'; мӑрнӑсь / mør пøø- 'шуметь, гудеть, скрипеть, хрустеть, трещать'; мирнась / myir nø- 'нестить'; мулнӑсь / mul'nø- 'невнятно говорить (например, из-под одеяла)'; нӑлнӑсь / nøl' пø- 'гнусавить'; нӑрнӑсь / nør ${ }^{\circ} \varnothing-$ 'храпеть'; нёрнӑсь / nyor ${ }^{\circ}$ п- 'литься — например, о слезах на ветру';

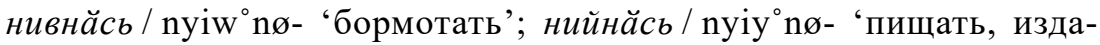
вая надоедливый, непрекращающийся звук'; нуйнӑсь / пuу пø- 'стучать, цокать'; нэрнӑсь / ner'nø- 'хрипеть, сопеть, храпеть'; нюрнӑсь / nyur'nø- 'раздаваться - о сильном глухом шуме, гуле'; няйнӑсь / nyay ${ }^{\circ} ø-$ 'идти длительное время - о дожде'; уарнӑсь / ngør пø- 'рычать'; уаснась/ngøs ำ- 'издавать негромкие звуки, сопеть, часто, прерывисто дыша (о ребенке, собирающемся заплакать)'; уасьнась / 
ngøsy ${ }^{\circ} \varnothing-$ 'производить шум (напр., о волнах, о низвергающейся вниз воде)'; уурнӑсь/ngur nø- 'звенеть'; пӑлнӑсь (ямальский) pøl'nø- 'болтать, точить лясы'; пӑрнӑсь / pør' nø- 'издавать скрип (при движении)'; пийнӑсь / pуіу пø- 'сипеть, издавать свистящие, шипящие звуки (напри-

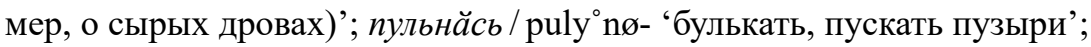
пюрнӑсь / pyur nø- 'быстро и обильно течь, литься'; пярнӑсь / pyar nø'делать что-либо очень быстро'; сейнӑсь/ syey nø- 'громко звенеть, гудеть, греметь'; сеснӑсь / syes `nø- 'шелестеть, шуршать'; сыйнась / siy ${ }^{\circ} ø-$ 'шипеть - например, о раскаленных предметах при соприкосновении с водой'; сю”лнась / syuql 'nø- 'журчать'; сябнӑсь / syab no- 'быстро и жадно есть'; сябнӑсь / syab no- 'шуршать'; ся̆внӑсь / syøw nø- 'лить, непрерывно семенить, трусить'; ся̆йнӑсь / sуøуnø- 'литься ручьем, быстро, свободно двигаться'; ся̆лнӑсь / syøl'nø- 'весело щебетать о птицах'; сярнӑсь / syar nø 'визжать, пронзительно кричать, плакать'; сӑрнӑсь / syør'nø 'шипеть, трещать (об огне или о чем-либо, попавшем в огонь)'; *ся̆”ллнӑсь / syøql ${ }^{\circ} \varnothing-$ 'подаваться, болтаться, быть плохо закрепленным'; тайнӑсь / tay ${ }^{\circ} \varnothing-$ 'звенеть'; тӑрнӑсь / tør nø- 'дребезжать'; *тёрнӑсь / tyor nø- 'кричать'; тирнӑсь = тырнӑсь / tyir пø- 'быть острым, пронизывающим - о ветре, морозе'; турнӑсь / tur'nø- 'быть о резком сухом кашле'; тыднӑсь / tid ${ }^{\circ} \varnothing-$ 'трещать'; хӑвнӑсь / хøw $n \varnothing-$ 'идти, литься - о сильном дожде, ливне'; хӑйнӑсь / хøу двигаться по гладкой поверхности'; хӑрнӑсь / хør пø- 'течь, литься, бежать - о жидкости'; хорнӑсь / xor ${ }^{\circ} ø$ '1) хоркать 2) литься слабой струей - о жидкости 3) хрипеть'; хубнӑсь / хub пø- 'неясно грохотать вдали'; хурнӑсь / xur nø 'литься струей — о жидкости’; хуснӑсь / xus nø'бренчать, звенеть'; хывнӑсь / хіш nø- 'скулить, хныкать'; “хыллнӑсь / xil'nø- 'лежать на животе'; хырнӑсь / xir`nø- 'рокотать'; хыңднаӑсь / xingk ${ }^{\circ} \varnothing-$ 'звучать, звенеть - о порожней закрытой посуде'; хэрнӑсь/ xær nø- 'издавать сильный скрип, скрежетать'; юснӑсь / yus nø- 'бренчать'; йлнӑсь / yøl'nø- 'греметь, громыхать'.

Т. Салминен предполагает наличие этого суффикса также в следующих глаголах: тарарнӑсь / $\operatorname{tar}^{\circ}$ пø 'тянуть, тащить с трудом, с усилием'; mыххйнӑсь / tix ${ }^{\circ} \varnothing-$ 'приходиться трудно, туго, тяжело'; тэтннӑсь / tat ${ }^{\circ}$ п‘быть занятым чем-либо'; хӑлнӑсь / хøl' пø- 'быть жадным, ненасытным’;

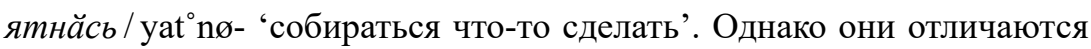
по семантике от перечисленных выше глаголов; кроме того, последние четыре глагола из пяти не имеют других суффиксальных производных из разряда тех, которые характерны для образных основ. С другой стороны, у основ того фонетического класса (основы на гласный), 
которые составляют рассматриваемую группу, имперфектив был бы представлен алломорфом -NØ. Этот алломорф стандартного имперфективного суффикса омонимичен суффиксу образных глаголов -NØ, описываемому в данном разделе. Следует отметить, что аспектуальные характеристики обоих суффиксов также совпадают. Тем самым, можно предполагать, что в этих пяти глаголах -nø представляет собой алломорф имперфективного суффикса.

Кроме этого, можно добавить к данной лексической группе несколько глаголов из тех, которые рассматриваются Т. Салминеном как содержащие имперфективный суффикс: лабцзанась / 1øbc nø- 'ударяться со шлепающим звуком (о тяжелом или мокром предмете)'; тялнӑсь / tyal ${ }^{\circ}$ ø 'плескаться (о воде)'; хӑугӑнӑсь / хøngk nø- 'раздаваться о звуке (барабана, шаманского бубна и т. п.); гореть, разгораться большим пламенем’.

\section{2. Суффикс -хадӑ -цядӑ -зядӑ / -ХА-ТØ -ХуA-TØ Vi m²} образует перфективные (семельфактивные) глаголы, описывающие резкое действие, часто представляющее собой громкий звук либо сопровождающееся громким звуком. Примечательно, что большинство глаголов из этой группы имеют корреляты в рассмотренной выше в разделе 2.1 группе глаголов: вӑриядӑсь/wørcyadø- 'рвануться, дёрнуться' (ср. вӑрнӑсь 'бежать - о небольших животных и птицах'); выркадӑсь / wirkadø- 'выскользнуть, соскользнуть' (ср. вырнӑсь 'катиться вниз с легким шумом'); вэлкадась/welkadø- 'выйти быстро и бесшумно, выскользнуть'; вэркадӑсь/werkadø- 'выдернуться' (ср. вэрнӑсь 'выдергиваться, тянуться — о чем-либо длинном'); иркадӑсь/ yirkadø-'скрипнуть, заскрипеть' (ср. ирнӑсь 'скрипеть, хрустеть'); лабкадась / løbkadø- 'грохнуть, грянуть', (ср. лӑбнӑсь 'трепаться на ветру'); мӑркадӑсь / mørkadø- 'сломаться, разломаться с треском' (ср. мӑрнӑсь 'шуметь, гудеть, скрипеть, хрустеть, трещать'); мириядӑсь / myircyadø- 'удариться обо что-либо, наткнуться на чтолибо, упав сверху', (ср. мирнась 'нестить'); мулкадӑсь / mulkadø- 'булькнуть, нырнуть, произведя при этом бульканье' (ср. мулнӑсь 'невнятно говорить, например, из-под одеяла)'; мялкадась / myalkadø- 'показаться

\footnotetext{
2 Для каузативного варианта этого суффикса -xaд-ma (-xa-d ${ }^{\circ}$-ta) в словаре Т. Салминена предлагается нотация -XА-TØ $\rightarrow($ ()QTA; впрочем, можно считать, что речь идет не об особом каузативном суффиксе -QTA, а о фонетически более «легком» варианте каузативного суффикса -BТА.
} 
на миг и быстро скрыться'; наркадӑсь/narkadø- 'вздрогнуть, ёкнуть (о сердце)'; нӑрияядӑсь / nørcyadø- 'крепко уснуть (моментально)' (ср. нӑрнӑсь 'храпеть'); ууркадӑсь/ngurkadø- 'удариться, стукнуться со звоном' (ср. уурнӑсь 'звенеть') поркадӑсь / porkadø- 'высунуться наружу'; сйлкӑдӑсь/ syølkadø- 'раздаться — о тонком звенящем звуке' (ср. сйлнӑсь 'весело щебетать - о птицах'); сяркадӑсь/syarkadø‘взвизгнуть, запищать' (ср. сярнӑсь 'визжать, пронзительно кричать, плакать'); ся̆ркадӑсь / syørkadø- 'зашипеть, затрещать (об огне, от жире, о клоке шерсти, попавшей в огонь)', (ср. сйрнӑсь 'шипеть, трещать (об огне или о чем-либо, попавшем в огонь)'); тӑлкадӑсь / tølkadø- 'закрыться, захлопнуться с шумом'; тэбкӑдӑсь / tebkadø- 'раздасться, разнестись - о звуке', тялкадась / tyalkadø- 'плеснуть - о звуке воды' (ср. тялнӑсь 'плескаться (о воде)'); хӑмзядӑсь / хømсуаdø- 'упасть с грохотом' (ср. хӑвнӑсь 'идти, литься - о сильном дожде, ливне');

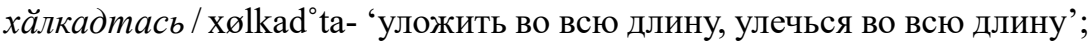
хоркадӑсь / хorkadø- 'оказаться пробитым насквозь, провалиться (напр., в глубокий снег, под лед)'; хубкӑдӑсь / хubkadø- 'упасть тяжело, с шумом, с грохотом' (ср. хубнӑсь 'неясно грохотать вдали'); хулкадӑсь / хulkadø- 'раздаться - о звуке при питье', хуркадтась/ xurkad ta 'выпить залпом' (ср. хурнӑсь 'литься струей — о жидкости'); ялкадась/ yalkadø- 'блеснуть, сверкнуть'; я̆льиядӑсь / yølсуаdø- 'упасть с грохотом' (ср. йлнӑсь 'греметь, громыхать').

Во всех глаголах из приведенного списка элемент -хадӑ -цядӑ -зядӑ легко выделяется на синхронном уровне благодаря тому, что эти глагольные корни имеют другие дериваты. Но можно предполагать наличие этого суффикса (как минимум в качестве «омертвевшего» элемента) еще в некоторых глаголах из следующих списков:

a) основы-«изоляты»: нямгадӑсь / nyamkadø- 'скользнуть, юркнуть'; полкадӑсь / polkadø- 'повалиться спать - о пьяном'; самгадӑсь / samkadø- 'слегка провалиться'; сумгадась / sumkadø'провалиться (в яму, в глубокий снег)' 3; *ся̆бкадась / syøbkadø'раздаться - о скрипе, треске' (однако, возможно, ошибочно syøbkadø- вместо syabkadø-, в этом случае ср. сябнӑсь 'шуршать'); $x \dot{\jmath} к а д а c ь$ / хelkadø- 'утихнуть (на короткий срок — о ветре)';

${ }^{3}$ Интересно сопоставить глаголы сумгадӑсь и сӑмгадась со значением 'провалиться' - можно отметить, что в сфере образной лексики возможна некоторая фонетическая «неустойчивость» основ, ср., например, в тундровом энецком kubo-be-, но в лесном энецком kuga-be- 'быть выпуклым'. 
б) основы, к которым можно найти корреляты без -кадӑ, не связанные, однако, с рассматриваемыми глаголами в рамках полностью регулярных морфологических моделей: вамгадӑсь / wamkadø- 'сердито буркнуть' (ср. вамборцьь 'быть суровым'); вылкадӑсь/ wilkadø- 'выскользнуть (из рук, напр., об аркане, рыбе)' (ср. вылэсь 'двигаться, резвиться (о привязанном к люльке ребенке)'); нӑлкадӑсь / nølkadø- 'быстро и крепко уснуть', также с каузативом нӑлкадтась / nølkad ta 'ударить, задеть (ср. нӑркадӑсь с аналогичным значением 'быстро уснуть'); палкадтась / palkad 'ta- 'быстро проглотить что-либо, не ощущая вкуса' (ср. паларась: сёда палары 'он не может откашляться', палесь 'проглотить что-л. плохо разжеванное или неприятное на вкус'); саркадтась / sarkad ta- 'довести до слез' (ср. сарась '1) лопнуть 2) заслезиться'); сянцадӑсь/ syangadø'кинуться, наброситься, накинуться' (ср. сянэрцьь 'прыгать, играя' и сяныризь 'быстро бежать (о животных)'); тирия̆дӑсь / tyircyadø-'прикоснуться, коснуться, притронуться, налететь' (возможно, связано с глаголом тирнӑсь 'быть острым, пронизывающим - о ветре, морозе' из описанной в 2.1 группы глаголов с суффиксом -NØ); хӑнзедась / хønсуеdø- 'быстро двинуться; потечь' (ср. хӑнёриьь 'легко и свободно двигаться, бежать'); хэндадӑсь / хеngkadø- 'соскользнуть - о нюке, лямке; провалиться’ (ср. хынӑсь “'скользнуть, соскользнуть').

Есть также несколько основ, которые, возможно, образованы по иной, нехарактерной для ненецкого морфонологической модели с выпадением второго согласного корня (для корней вида CVC) или же второго относящегося к корню слога (для корней вида CVCØ). На синхронном уровне элемент -ХА в этом случае, безусловно, не выделяется, однако семантика перечисленных ниже глаголов соответствует семантике рассматриваемых в данном разделе производных. Кроме того, по крайней мере к некоторым из приводимых глагольных основ можно указать возможные корреляты, в которых корень представлен в неусеченном виде: лакадӑсь/lakadø- 'стукнуться, удариться' (ср. лаб ' нась б.-3. и м.-з. 'производить звук, треск, шум'); лӑкадась / løkadø- 'захлопнуться' (ср. лӑбнӑсь 'трепаться на ветру'); тыкӑдӑсь / tikadø- 'треснуть, хрустнуть, раздаться о треске' (ср. тылнӑсь 'трещать'); токадӑсь /

\footnotetext{
${ }^{4}$ Варьирование эं ы в корне возможно.
} 
tokadø- 'стукнуться, удариться' (? ср. тобрё 'стук, топот, цокот копыт'); сакадӑсь/sakadø- 'юркнуть, мелькнуть, вильнуть, быстро спуститься; рвануться, вырваться вперед', сакадтась/sakad ta- 'бросить, забросить что-л. быстрым движением, быстро схватить, поймать; сказать что-л. неожиданно', (? ср. салӑмзь 'показаться на мгновение'); секадтась/syekad 'ta- 'взять, вырвать, выхватить, схватить (мгновенно)'; пикадась / pyikadø- 'удариться, стукнуться, шлепнуться, хлопнуться, упасть плашмя'.

В ряде ненецких глаголов представлен суффикс -тӑ / -TØ Vi m, образующий глаголы образной семантики со значением однократного действия. Я предполагаю, что этот суффикс идентичен второму элементу в составе суффикса -XА-ТØ, описываемого в данном разделе. Обращает на себя внимание то, что все глагольные основы данной группы имеют единый фонологический праязыковой прототип * CV $(\mathrm{C}) \mathrm{KA}$ : caxaдӑсь / saxadø- 'сильно разноголосо зашуметь, загомонить - о птицах'; мяхадӑсь / myaxadø- 'начать тяжело дышать (ср. мяханась тяжело дышать'); тэхэдӑсь / tæxado- 'быстро просочиться, протечь, впитаться'; хэхэдӑсь 'скатиться, провалиться (в снег, под тонкий лед, в прикрытую яму и т. п.)'; ңээхэдӑсь / ngexadø- 'броситься, кинуться, ринуться'; сэंхэдӑсь / sexadø- 'временно прекратиться, прерваться'; вэ்эдӑсь / wexadø- 'устремиться, залезть, высунуться'; лехэдӑсь/lyехаdø- 'разнестись, донестись (о запахе)'; пехэдӑсь / pyexadø- 'широко, быстро распахнуться, раскрыться (напр., о двери)'; пехэдӑсь/ руехаdø- 'плеснуть (о крупной рыбе)'; сехэдӑсь / syexadø- 'хлынуть, вылиться, вытечь; высыпаться, просы́паться (о чем-либо звенящем)'; мащедӑсь / møсуаdø- 'уткнуться, упереться, наткнуться'; мюмзядась / myumсуаdø- 'прошипеть' .

Таким образом, можно предполагать, что в глаголах данного списка имеет место гаплология (стяжение двух фонетически близких или тождественных слогов): первый элемент суффикса опускается, так как он фонетически идентичен последнему слогу глагольной основы.

Весьма вероятно, что к этой группе примыкает также глагол хыңгадmacb/xingkad ${ }^{\circ}$ a- 'вызвать звон, ударив по порожней посуде', cp. хыңцгнӑсь 'звучать, звенеть - о порожней закрытой посуде'. В данном случае суффикс формально выступает в виде -ТØ; следует, однако, обратить внимание, что во втором слоге корня выступает фонетическая последовательность /ka/ (или, возможно, /kø/; подобные фонетические

${ }^{5}$ В двух последних глаголах этого списка последний согласный основы изменился вследствие палатализации: ${ }^{*} k>c$. 
колебания при записи рассматриваемого в данном разделе суффикса то в виде -катӑ, то в виде -кӑтӑ - характерны для словаря [Терещенко (сост.) 1965]). Возможно, отсутствие элемента -ХА в суффиксе в этом глаголе также можно объяснить явлением гаплологии.

Нетривиальным является также морфонологическое поведение глагольных основ и суффиксов, рассмотренных в 2.1 и 2.2. Как можно видеть из сопоставления имперфективных глаголов с суффиксом -NØ и перфективных глаголов с суффиксом -(ХА-)ТØ, в первом случае глагольный корень выступает в виде $\mathrm{C}_{1} \mathrm{VC}_{2} \varnothing$, во втором - в виде $\mathrm{C}_{1} \mathrm{VC}_{2}$ (при этом $\mathrm{C}_{2}$ может быть представлена $/ 1 /, / \mathrm{r} /, / \mathrm{g} /, / \mathrm{b} /$ и /m/.). Такое варьирование типа основы (консонантная вокалическая) для ненецкого несвойственно.

\section{3. Производные с имперфективным значением}

3.1. Стативы с суффиксом -кӑдӑ (и, возможно, также -сӑдӑ, см. ниже), для которых Т. Салминен предлагает нотацию-QXØ-(N )TØ Vi c. Очевидно, что в предложенной Т. Салминеном морфологической записи второй элемент суффикса, -(N )TØ, идентичен показателю имперфектива. Тем не менее такой алломорф имперфективного суффикса может выступать в ненецком после гласного в том случае, если этимологически основа оканчивалась на *-w, образующий стативные глаголы, см. [Гусев 2010], либо на *-ј (или же следует предполагать, что перед нами иной суффикс, вида -ТØ). Таким образом, этот составной суф-

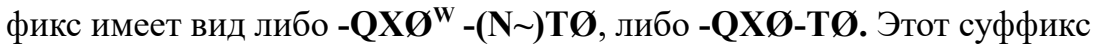
представлен в глаголах, описывающих определенную характерную позу, ср. следующий список: вӑрявкадӑсь/wøryawkødø- 'бежать мелким семенящим шагом'; тёськӑдӑсь / tyosy ํødø- 'быть на корточках'; мӑнзекадась / møncyekødø- 'лежать, свернувшись комочком, клубочком'; тыриекӑдӑсь / tircyekødø- 'быть растрепанным, взъерошенным'; нйлекадӑсь / nyølyekødø- 'быть выпуклым'; на ”лекадӑсь / ngaqlyekødø'быть нахохлившимся (о птице)'; хӑрмекӑдӑсь / хørmyekødø- 'быть аккуратно сидящим - о человеке небольшого роста'; хасекӑдӑсь / xasyekødø- 'быть, находиться без движения'.

Обращает на себя внимание, что в шести из восьми перечисленных глаголов перед суффиксом выступает палатализующий гласный уе, в трех глаголах происходит перегласовка финального гласного основы 
Ø, А > уе, в трех глаголах (хасекӑдӑсь, ңза"лекадӑсь и мӑнзекадась) палатализующий гласный относится к основе 6 .

Есть еще несколько глаголов, которые, возможно, следует рассматривать вместе с только что перечисленными. Они также имеют стативное значение; образованы они с помощью составного суффикса -сӑтӑ. В словаре Т. Салминена этот суффикс имеет нотацию -SØ -(N ) T Ø, однако в соответствии с тем, что было сказано несколькими абзацами ра-

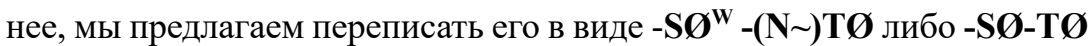
Этот суффикс представлен в следующих глаголах:

хо ”лесӑдӑсь/ xoqlyesødø- 'стоять сгорбившись'; my”лесӑдӑсь/ túqlyesødø- 'белеть, сверкать, блестеть'; нуӑндесӑдӑсь / ngøntyesødø- 'шутить, издеваясь'; вэннысадась/wenesødø- 'гордо стоять на высоких ногах’.

В этом кратком списке в трех первых глаголах перед суффиксом также происходит перегласовка финального гласного основы в палатализующий $y e$, в последнем глаголе - перегласовка в непалатализующий $e$. Таким образом, можно объединить в одну группу стативы, образующиеся по двум близким моделям, а также уточнить морфологическую запись суффикса: -уеQX ${ }^{\mathbf{w}}$-(N )T

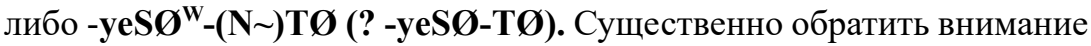
на наличие палатализующих гласных в этих производных со стативным значением, так как следующие две группы производных, представленные в разделах 3.2 и 3.3 , противопоставлены именно наличием / отсутствием палатализующего $y e$.

\section{2. Глаголы с суффиксом -на $\sim$-не $\sim$ aнa /-NA -NyE $\sim$-aNA Vi c} с точки зрения аспектуальной характеристики представляют собой непредельные процессы либо стативы со значением состояния. Они описывают какую-либо яркую внешнюю характеристику субъекта, например, особенности внешнего вида либо поведения.

\footnotetext{
${ }^{6}$ Тем не менее у двух последних глаголов, цуа"лекадӑсь и мӑнзекадась, представлены только такие производные, в которых финальный гласный основы может заменяться на палатализующий уе, так что не исключено, что и в этих глагольных основах можно усматривать чередование финального гласного основы с палатализующим уе, см. ниже. Другой вариант интерпретации - предполагать, что в том случае, когда основа заканчивается на палатализующий уе, при присоединении рассматриваемого суффикса дополнительной перегласовки не происходит.
} 
Алломорф -NA -NyE/ Cуø представлен в следующих глаголах:

nӑднась / pød na- 'потрескивать'; пэкнась pæk na- 'сиять, ярко светить (о луне, месяце)'; няркнась / nyørk na- 'тревожиться, беспокоиться'; лолнась lol na- 'подражать звуку звонка, колокола'; лулнась / lul'na-'шамкать, невнятно говорить'; морнась / mor na-'быть хрустящим, хрустеть на зубах'; лэйнась / leу па'пламенеть, гореть'; юёнась /уúy nа- 'идти вертлявой походкой’; юльия̆несь / уulcy nуе- 'быть сделанным изящно, красиво’; nӑриьнесь / pørсу пуе- 'быть ясно видимым, четко вырисовывающимся'; ляризьнесь / lyarcy nye- 'быть отчетливо видным (о далеком предмете)'; тёсьнесь / tyosynye- 'сидеть на корточках'.

Алломорф -aNA представлен в следующих глаголах:

лӑбанась / løbаnа- 'колыхаться, трепаться с шумом'; сӑбанась / søbana- 'ничего не понимать, быть несмышленым'; лэбанась / lebana- 'то раздуваться, то спадать (например, о парусах при порывистом ветре)'; льбцанась / libcana- 'качаться, шататься, склоняться'; халцанась / хølсапа- 'извиваться'; панзанась / pancana- 'быть живым, подвижным'; ерцанась/yercana- 'находиться в неустойчивом положении, подниматься и опускаться'; тярцанась/tyarcana- 'шлепать по воде, разбрызгивая ее во все стороны, быстро бежать, шурша одеждой’; нэризанась / nercana'делать небрежно'; тылцанась / tircana- 'трястись, скакать верхом'; лурияанась/lurcana- 'трястись (о гриве лошади во время бега)'; саданась / sadana-'шататься из стороны в сторону'; тяданась / tyadana- 'быстро идти в широко распахивающейся одежде'; сӑнзганась / søngkana- 'быть высоко подпоясанным, быть на высоких ножках, подставках’; пэнгӑнась/pængkana- 'качаться, шататься, колебаться'; лэнцӑнась/lengkana- 'находиться в неустойчивом положении'; лоңганась/longkana- 'быть бездеятельным, безучастным'; мунзанась/mubgkana- 'с шумом выходить через какое-либо отверстие, бить ключом'; ня̆ланась / nyølana- 'прощупываться (об округлом предмете)'; нэланась/nelana- 'производить при быстром движении шум рваной одеждой'; силанась / syilana- 'шалить, резвиться'; вы ”ланась/wiqlana- 'выглядывать, высматривать, засматриваться'; хӑлманась/ хølmana- 'шевелиться, виться, извиваться'; сарманась / sarmana- 'бродить, блуждать'; лямбанась / lyampana- 'спускаться, слетать, взмахивая крыльями'; 
лӑсанась / løsana- 'нетвердо держаться, шататься'; лисанась / lyísana- 'протягивать руки ладонями вверх' посанась/posana'долго и сильно дуть - о ветре'; ңээтанась / ngetana- 'неуклюже идти, двигаться (напр., о хромом)'; нитанась / nyítana- 'плести, тащиться'; ня̆мданась/nyømtana- 'ходить взад и вперед'; лэммданась / lemtana- 'быть гибким’; ңзӑнданась/ngøntana- 'быть чересчур широким (о капюшоне)'; хонданась / хоntana- хунданась/ xuntana- 'копаться, медленно делать что-л.'; хылванась / xilwanaхулванась/ хulwana- 'извиваться'; мяханась/myахапа- 'тяжело дышать'; сяханась / syaxana- 'бренчать, звенеть'; тэхэнась / tæxana- 'быть сильно занятым'; сэхэнась/ sexana- 'хрипеть (из-за чересчур тугого воротника)'; вэхэнась / wexana- 'выглядывать, высовываться'; пыхынась/piхапа- 'ворочаться с боку на бок'.

3.3. Глаголы с суффиксом -ена $\sim$-ине /-yeNA -yiNyE с точки зрения аспектуальной характеристики представляют собой стативы со значением свойства. Как и глаголы из предыдущей группы, они описывают какую-либо яркую внешнюю характеристику субъекта, однако в случае стативных глаголов это обычно нетривиальное положение в пространстве либо необычная внешность: ялкэнась/yalkena- 'светиться (беспрерывно)'; тобенась/tobyena- 'быть ярким - о небесных светилах'; хэщенась / хæсуепа- 'быть негнущимся'; лӑбиенась / løbcyena- 'быть плоским, раздавшимся в ширину, расширившимся'; тӑбиенась / tabcyena(таймырский) 'идти, волоча ноги, прерываться - о голосе, песне'; нямзенась/nyamcyena- 'находиться в состоянии покоя - о человеке, не приставать'; мӑнзенась/mønсуеnа- 'лежать, свернувшись в клубок'; хӑриенась / хørсyеnа- 'лежать (о чем-либо большом)'; сариенась / sarcyena- 'торчать, выступать'; яриенась/yarcyena- 'иметь необычный вид, быть одетым в неподходящую одежду, быть выступающим, выдающимся, торчащим'; нэриенась / nercyena- 'лежать небрежно, валяться'; ериенась yercyena- 'торчать в разные стороны'; вӑденась/wødyena- 'быть согнутым, искривленным'; хӑденась / хødyena- 'лежать скорчившись'; ngodyena- / нуоденась 'быть запрокинутой назад, с задранным кверху носом - о голове'; ня̆ленась / nyølyena- 'иметь выпученные глаза'; яленась / yalyena- ‘быть серым, быть светлым'; мӑ”ленась / moqlyena- ‘быть слегка согнувшимся вперед'; хо ”ленась / хоqlyena- 'быть наклоненным вперед'; му”ленась / muqlyena- (таймырский) ‘быть выпуклым'; ту”ленась / túqlyena- 'белеть, сверкать, блестеть'; хуленась / хуlyеnа- 'быть с горбинкой, быть согнутым'; вэं ”мменась weqmyеnа- 'быть вытянутым - о шее'; 
хӑрменась / хørmyеna- ‘быть чересчур изогнутым'; вырменась / wirmyena'быть длиннолицым, с крупными, грубыми чертами лица'; хылтенась/ xiltyena- 'лежать ничком'; ямненась / yamnyena- 'быть скорчившимся, съежившимся от холода'; пӑ”ненась рøqnyena- 'быть острым и коротким’; хӑрненась / хørnyena- 'быть загнутым - о конце чего-либо'; хэрненась / xernyena- 'быть высоко подпоясанным; хумбенась / xumpyena'быть слегка приподнятой - о части гладкой поверхности'; маренась / maryena- 'лететь в дальние страны'; яренась/yaryena- 'быть большим, видным издали'; лыренась/liryena- 'быть с зазубренными краями'; выренась / wiryena- 'долго стоять и смотреть (как другой ест или работает)'; моренась/moryena- 'белеть'; хасенась/хаsyena- 'быть спокойным (в том числе, например, о воде), отдыхать'; лисенась / lyísyena- 'лежать ничком'; носенась/ngosyena- 'глядеть вверх, приподняв голову'; нятенась / nyatena- (ямальский) 'говорить с акцентом'; лябтенась / lyabtyena- 'быть поставленным широко и низко (о чуме)'; нэтенась/ ngetyena- 'выдаваться, выступать'; хумденась/ xumtyena- 'расти из плеч (о голове), быть без отделки'; пынденась / pintyena- 'лежать ничком, лежать вверх дном'; тинденась / tyintyena- 'лежать на животе - о животном'; пӑртенась / pørtyena- ‘быть излишне коротким’; мыртенась / mirtyena- (большеземельский) 'выдаваться вперед (о какой-либо части тела)'; хортенась/ хоrtyena- 'быть насквозь пробитым, быть открытым настежь, широко'; хутенась / хutyena- 'быть негнущимся (от холода)'; тоенась/ toyena- 'быть твердым, жестким'; сэбинесь/sæbyinye'быть упрямым, своевольным'; мюмзинесь mуuтсуіпуе- 'тускло светить, едва виднеться между облаками, быть узким (об отверстии); тӑнзинесь / tøncyinye- 'темнеть, синеть'; мӑдинесь / mødyinye- 'находиться на одном месте, никуда не двигаясь'; вэдинесь/wædyinye- 'вертеться, не сидеть на месте'; ялинесь/yalyinye- 'быть отчетливо видным, белеть'; пӑрминесь / pørmyinye- 'чернеть'; сӑбнинесь / søb nyinye- 'быть излишне глубоким (например, о грубо вырезанной из нароста дерева миске)'; хӑмбинесь / хøтруіnyе- 'вертеться, поворачиваться из стороны в сторону'; лямбинесь / lуатруіпуе- 'быть широким и низким (о чуме)'; сӑсинесь / søsyinye- 'быть говорящим свысока, с гонором, грубовато'.

Заслуживают комментария дериваты, представленные в группах 3.2 и 3.3. В производных глаголах обеих групп используется суффикс -NA, однако в первой группе перед ним в большинстве основ происходит перегласовка финального гласного основы в $a$, а во второй группе во всех основах - перегласовка финального гласного основы в палатализующий уе. В обеих группах представлены непредельные глаголы, первая 
группа состоит из глаголов, относящихся к классу процессов либо стативов со значением состояния, во второй представлены по преимуществу стативные предикаты со значением свойства. Как отмечает В. А. Плунгян, «в целом свойства являются более стабильными, чем состояния: для последних хотя и характерна длительность, но для них также естественно иметь начало и конец» [Плунгян 2011: 112]. С этой точки зрения стативы со значением состояния ближе к непредельным процессам, чем стативы со значением свойства, поэтому естественно их объединение в одной группе, как в 3.2. Различие между двумя типами ситуаций (в 3.2 и 3.3 ) заключается в том, что субъект глаголов из группы 3.2 более активен, чем субъект глаголов из группы 3.3. Есть некоторое количество глагольных основ, которые имеют производные обоих типов, сопоставление семантических различий в этом случае особенно показательно:

Таблица 1. Сопоставление производных с суффиксами -aNA и -yeNA

Table 1. Comparison of verbs derived by means of suffixes -aNA and-yeNA

\begin{tabular}{|c|c|}
\hline $\begin{array}{c}\text { Непредельные процессы либо } \\
\text { состояния, более активный субъект }\end{array}$ & Свойства, менее активный субъект \\
\hline $\begin{array}{l}\text { ңзэтанась 'неуклюже идти, двигаться } \\
\text { (например, о хромом)' }\end{array}$ & ңзэтенась 'выдаваться, выступать' \\
\hline $\begin{array}{l}\text { хӑрияанась 'откидываться, наклоняться } \\
\text { назад, падать навзничь' }\end{array}$ & $\begin{array}{l}\text { хӑриенась 'лежать (о чем-либо } \\
\text { большом)' }\end{array}$ \\
\hline $\begin{array}{l}\text { ня̆ланась 'прощупываться } \\
\text { (об округлом предмете)' }\end{array}$ & ня̆ленась 'иметь выпученные глаза' \\
\hline нэрианась 'делать небрежно’ & $\begin{array}{l}\text { нэрриенась 'лежать небрежно, } \\
\text { валяться' }\end{array}$ \\
\hline $\begin{array}{l}\text { лямбанась 'спускаться, слетать, } \\
\text { взмахивая крыльями' }\end{array}$ & $\begin{array}{l}\text { лямбинесь ‘быть широким и низким } \\
\text { (о чуме)' }\end{array}$ \\
\hline $\begin{array}{l}\text { лисанась 'протягивать руки ладонями } \\
\text { вверх' }\end{array}$ & лисенась 'лежать ничком’ \\
\hline $\begin{array}{l}\text { ерианась 'находиться в неустойчивом } \\
\text { положении, подниматься и опускаться' }\end{array}$ & ериенась 'торчать в разные стороны' \\
\hline
\end{tabular}

3.4. Стативы -ай, в нотации словаря [Salminen 1998] — -ä̈Ø; эти глаголы относятся по морфонологическому поведению к группе так называемых альтернирующих глаголов (для целей данной статьи достаточно указать, что альтернирующие глаголы образуют основную финитную темпоральную форму, так называемый аорист, особым образом, отличным от остальных глаголов). Как показал В. Ю. Гусев 
[Гусев 2010], самодийским языкам свойственны производные стативы (с результативным значением) с суффиксом *-w, именно такое происхождение имеют альтернирующие глаголы ненецкого языка. Соответственно, данный суффикс восходит к праформе ПСС *-ajəw, и для наглядности его можно переписать для ненецкого в виде -ä̈ $\boldsymbol{\emptyset}^{\mathbf{w}}$. Рассматриваемая группа представлена следующими производными: вырая̆сь/wirayø- 'стоять, выстаивать, простаивать'; ляхайсь / lуахауø“стоять, широко расставив ноги, лапы'; мӑ’лайсь / møqlayø- 'быть горбатым, сгорбленным'; нэрицайь / nercayø- 'лежать небрежно'; нйлая̆сь / nyølayø- 'выступать - о каком-либо круглом предмете'; нянцгайсь / nyangkayø- 'быть раскрытым, разинутым’; пындайсь/ pintayø- ‘лежать на груди, приподняв зад’; ся̆лая̆сь / syølayø- 'обильно течь, струиться (о крови - из многих ран)'; тиндая̆сь / tyintayø- 'лежать на животе о животном'; хӑрмайсь / хørmaуø- 'неуклюже сидеть'; хо”’лайсь / хоqlayø'быть согнутым, сгорбленным'; хылтайсь/хіltayø- 'быть мало согнутым; быть откинутым назад’; ярайсь / уанауø- 'лежать на боку'.

Сопоставим эту группу с другими производными со стативным значением. Большинство глаголов с суффиксом -а $\varnothing^{\mathrm{W}}$ имеют корреляты с суффиксом -уeNA, однако регулярных семантических различий между производными с этими двумя суффиксами от одной и той же основы нет, так что в каждом конкретном случае можно говорить скорее о каком-то частном семантическом развитии, об определенной идиоматизации, приводящей к семантической дифференциации двух суффиксальных производных от одной основы, нежели о регулярной семантической оппозиции, см. Таблицу 2 ниже.

Итак, значимых и регулярных семантических различий между двумя группами производных в этом случае обнаружить не удается. Возможно, однако, и иное сопоставление этих двух групп. Дело в том, что они значительно различаются по количеству, и если большинство глаголов с суффиксом -а Ү̈ $\varnothing^{\mathrm{W}}$ имеет параллели в группе производных с суффиксом -уеNA, то обратное неверно: глаголов, образованных по второй модели, существенно больше. Это означает, что можно попытаться сформулировать какие-то лексические ограничения на использование модели с суффиксом -а Ү̈ $\varnothing^{\mathrm{w}}$. Действительно, в эту группу попадают такие стативные ситуации, которые можно рассматривать как результирующую фазу некоторой предшествующей ситуации: ‘лежать' < ‘лечь', ‘быть согнутым, сгорбленным' < 'согнуться, сгорбиться'. В то же время в группе глаголов с суффиксом -уеNA далеко не все стативные глаголы описывают именно результирующую фазу, 
Таблица 2. Сопоставление производных с суффиксами -аҮ̈ $\varnothing^{\mathrm{W}}$ и -уеNA

Table 2. Comparison of verbs derived by means of suffixes -aŸ $\emptyset^{\mathrm{W}}$ and -yeNA

\begin{tabular}{|c|c|}
\hline Глаголы с суффиксом -а Ү̈ ${ }^{w}$ & Глаголы с суффиксом -уеNA \\
\hline 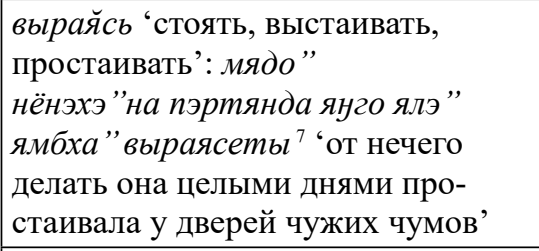 & $\begin{array}{l}\text { выренась 'долго стоять и смотреть } \\
\text { (как другой ест или работает)': } \\
\text { няна” выренананю” ‘уж очень ты } \\
\text { надоедливый (говорят тому, кто стоит, } \\
\text { мешая своим присутствием)'. }\end{array}$ \\
\hline $\begin{array}{l}\text { мӑ’’лая̆сь ‘быть горбатым, } \\
\text { сгорбленным’ }\end{array}$ & $\begin{array}{l}\text { мӑ’’ленась 'быть слегка согнувшимся } \\
\text { вперед' }\end{array}$ \\
\hline $\begin{array}{l}\text { нэрриая̆сь лежать небрежно: } \\
\text { панэияеда хонё’мяххананда нэризаи } \\
\text { ‘на том месте, где она спала, } \\
\text { небрежно лежит одежда’ }\end{array}$ & $\begin{array}{l}\text { нэриенась лежать небрежно, валяться: } \\
\text { пя"я”хханярина нэриена" } \\
\text { “дрова валяются как попало' }\end{array}$ \\
\hline $\begin{array}{l}\text { ня̆лая̆сь 'выступать - о каком-либо } \\
\text { круглом предмете': няк' сэври” нялаи” } \\
\text { 'у нерпы только глаза круглятся’ }\end{array}$ & нйленась 'иметь выпученные глаза' \\
\hline $\begin{array}{l}\text { nьндайсь 'лежать на груди, } \\
\text { приподняв зад’ }\end{array}$ & $\begin{array}{l}\text { пьнденась 'лежать ничком, } \\
\text { лежать вверх дном’ }\end{array}$ \\
\hline $\begin{array}{l}\text { тиндайсь 'лежать на животе - } \\
\text { о животном' }\end{array}$ & $\begin{array}{l}\text { тинденась 'лежать на животе - } \\
\text { о животном' }\end{array}$ \\
\hline $\begin{array}{l}\text { хӑрмайсь 'неуклюже сидеть': } \\
\text { мэта хан 'ниня тэри харман } \\
\text { 'он неуклюже сидит на нарте' }\end{array}$ & $\begin{array}{l}\text { хӑрменась ‘быть чересчур изогнутым } \\
\text { (о конце чего-либо - например, } \\
\text { о полозе нарты, о детской люльке } \\
\text { с дугой); сидеть, ничего не делая’: } \\
\text { уамгэ яле”'мякӑна хармена пэруан } \\
\text { ‘почему ты целыми днями сидишь } \\
\text { в чуме, ничего не делая?' }\end{array}$ \\
\hline $\begin{array}{l}\text { хо’’лая̆сь ‘быть согнутым, } \\
\text { сгорбленным' }\end{array}$ & $\begin{array}{l}\text { хо ”ленась 'быть наклоненным вперед, } \\
\text { сгорбиться' }\end{array}$ \\
\hline $\begin{array}{l}\text { хылтайсь 'быть мало согнутым, } \\
\text { быть откинутым назад’ }\end{array}$ & хылтенась 'лежать ничком’ \\
\hline ярайсь 'лежать на боку' & $\begin{array}{l}\text { яренась 'быть большим, видным } \\
\text { издали (с одной стороны на близком } \\
\text { расстоянии)' }\end{array}$ \\
\hline
\end{tabular}

7 Глагол оформлен суффиксом хабитуалиса. 
ср., например, ялкэнась 'светиться (беспрерывно)' или тобенась 'быть ярким - о небесных светилах'. Такое лексическое ограничение вполне естественно для модели с суффиксом -аҮ̈ ${ }^{\mathrm{w}}$, поскольку, как уже говорилось, этот суффикс содержит этимологический показатель статива-результатива *-(ә)w. В подтверждение этой трактовки следует также отметить, что для ненецкого, как и для других северносамодийских языков, характерно именно такое направление производности в парах типа 'лежать' ‘лечь': глагол 'лежать' является производным по модели статива с результативным значением.

3.5. Небольшая группа имперфективных глаголов с суффиксом -э/-E, описывающих определенные характерные черты субъекта (как одушевленного, так и неодушевленного), как правило, через типичное для него движение или поведение (в эту группу входят как стативы, так и процессуальные предикаты): уӑндэсь / ngønte- 'быть шальным'; тядэсь / tyade- 'свободно развеваться - напр., о концах пояса, упряжи, об украшениях, идти легко и свободно в развевающейся одежде'; моңгэсь/mongke- 'подниматься, клубиться (о дыме, тумане)'; ёнзгэь yongke- 'озираться по сторонам'; вылэсь/ wile- 'двигаться, резвиться (о привязанном к люльке ребенке)'; лулэсь/lule- (ямальский) 'шамкать, невнятно говорить'; палмэсь/palme- 'вести себя легкомысленно, много говорить попусту'; ёмбэсь/уотре- 'шалить с детьми, вести себя по-детски'; ся̆рэсь / syøre- 'быть скрипучим'; явэсь/ yawe'быть накрененным - о котле, чайнике и т. п.'

3.6. Суффикс -ра -ире / RA yiRyE Vi c образует процессуальные глаголы, в основном с мультипликативной семантикой, описывающие хаотичное, часто бестолковое движение: ензарась/yencara- 'тянуться, протягиваться, проникать сквозь, мелькать, виднеться сквозь'; u(“)нрась / yíqn 'ra- 'качаться, раскачиваться из стороны в сторону'; лӑхарась/ løхага- 'быть расшатанным, шататься'; ливрась / lyíw ra- 'колыхаться (о чем-либо пушистом, распушившемся)'; лурирась/lurc 'ra- 'трястись (о гриве лошади во время бега)'; льбцирась / libc ' ra- 'быть шатким'; льмкаирась / limp ' ra- 'быть колеблющимся, неустойчивым (о поверхности земли), быть вязким; прыгать, колотиться, стучать - о сердце'; льнзаирась / linc 'ra- 'быстро двигаться в разных направлениях'; лэйрась/ ley ra- 'жужжать'; лэмдӑрась/lemt ra- 'сгибаться, шататься, качаться, гнуться'; лэнзгарась / lengk ra- 'двигаться не по прямому направлению, петлять'; лябрась/lyab ra- 'медленно опускаться (о веках умирающего), 
едва улавливаться - о дыхании'; мӑнзӑрась / mønc ' ra- 'шевелиться, колебаться, находиться в движении'; мӑнрась / møn ra- 'быть в неустойчивом положении, шататься (о предметах круглой формы)'; мунзгрась / mungk ${ }^{\circ}$ 'быть горячим, вспыльчивым'; мыххырась / mixara- 'кишеть, копошиться'; мяхарась / myахага- 'тяжело дышать'; ну”ўмрась / nuqm ra- ‘быть гордым, высокомерным, важным'; na( ”) нацась / pøqn 'ra- 'непроизвольно двигаться в разные стороны, трястись (напр., о голове)'; nympacb/put 'ra- 'виться, струиться (откуда-либо)'; nухурась / puхаra- 'выходить (о дыме из дымохода, о дыхании)'; nыларась / pidara- nyдарась / pudara- 'высыпа́ться, рассыпа́ться, осыпа́ться'; пэнзрась/pængk ra- 'мелькать перед глазами (мешая что-л. делать)'; сайрась / say a- 'ходить взад и вперед без дела'; сасрась / sas 'ra- 'гнуться, шататься'; сейрась / syеу 'ra- 'бренчать, звенеть (о металлических предметах)'; сибарась / syíb ra- 'обильно литься (о поносе)'; силмрась / syilmra- 'играть, резвиться'; судрась / súd ra- 'трястись во время езды'; ся̆лрась / syøl 'ra- 'быть бренчащим, звенеть, бренчать'; mамрась/tam ra- 'шевелиться, быть беспокойным'; тырмрась/ tirm ra'семенить, идти частыми мелкими шагами'; тырцрась/ tirc 'ra- 'трястись (на спине лошади)'; халмрась / хølm a- 'помахивать, вилять хвостом (неперех.)'; халирась / хølс 'ra- 'извиваться, скользить'; хулврась xulw raхылврась/xilw ra- 'колыхаться, качаться на волнах'; юлмрась yulm ra'быть вертлявым, легкомысленным'; яйрась / уауㅇ- 'вертеться, кокетничать (вообще)'; нуацдацась / ngønt 'ra- 'смеяться без стеснения, с издевкой'; лӑбресь/løb rуе- 'шуметь крыльями, производить шум одеждой'; лабресь lab rуe- 'говорить громко'; ибиьресь / yibcyirye- 'быть ярко окрашенным'; я̆лресь/yølrye- 'создавать шум движением'; nacpecь/pas rye'болтать, нести вздор'; cumpecь / syit rye- 'проворно двигаться, говорить необдуманно, торопливо'; мечресь / mуесу гуе- 'катиться, словно мяч';

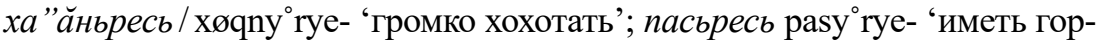
деливую походку'; вэсьресь / wæsу 'rye- 'говорить свободно, без запинки'; нинересь / nyinyerye- 'слегка дуть, веять (о ветре)'; тебтересь / tyebtyerye'протекать, просачиваться сквозь что-л.'; ха ”ересь/хаqӱегуе- 'выходить, подниматься - о дыме, паре, дыхании'; хӑбиресь/хøbyirye'подниматься, выходить легкой струйкой (о дыме, паре, дыхании)'.

Очевидно, что и при рассмотрении этой, достаточно обширной, лексической группы встает вопрос о разнице в значении производных с суффиксом -RA и производных из другой группы со сходным значением, а именно производных с суффиксом -aNA -NyE. Можно и в данном случае составить выборку тех глагольных основ, которые имеют производные обоих типов, она представлена в Таблице 3. 
Таблица 3. Сопоставление производных с суффиксами -RA и -aNA

Table 3. Comparison of verbs derived by means of suffixes -RA and -aNA

\begin{tabular}{|c|c|}
\hline Глаголы с суффиксом -RA & Глаголы с суффиксом -aNA \\
\hline $\begin{array}{l}\text { лэмдӑрась 'сгибаться, шататься, } \\
\text { качаться, гнуться' }\end{array}$ & $\begin{array}{l}\text { лээданась ‘быть гибким, сгибаться, } \\
\text { шататься, качаться, гнуться (под } \\
\text { тяжестью чего-л., от ветра и т.п)’ } \\
\text { [действие более плавное (выделение } \\
\text { мое - А. У.), чем по глаголу } \\
\text { лэмдӑрась] }\end{array}$ \\
\hline $\begin{array}{l}\text { лэңзӑарась '1) двигаться не по прямому } \\
\text { направлению, петлять; 2) менять ранее } \\
\text { принятое решение' }\end{array}$ & $\begin{array}{l}\text { лэздӑнась '1) находиться } \\
\text { в неустойчивом положении: извиваясь, } \\
\text { аргиши двигаются за хребет 2) перен. } \\
\text { идти не по прямой линии, петляя } \\
\text { (напр. о невыдрессированном } \\
\text { упряжном олене, о пьяном' } \\
\text { [характеризует более плавное } \\
\text { движение (выделение мое - } A . \text {. У.), } \\
\text { чем по глаголу лэугӑрась]) }\end{array}$ \\
\hline ибциресь ‘быть ярко окрашенным’ & $\begin{array}{l}\text { ибиььнесь (большеземельский) } \\
\text { ‘пахнуть кислым’ }\end{array}$ \\
\hline $\begin{array}{l}\text { лӑбресь 'шуметь крыльями, } \\
\text { производить шум одеждой’ }\end{array}$ & $\begin{array}{l}\text { лӑбанась '1) колыхаться, трепаться } \\
\text { с шумом (при большом размахе } \\
\text { (от ветра); 2) бушевать (о ветре); } \\
\text { 3) говорить быстро и громко' } \\
\end{array}$ \\
\hline $\begin{array}{l}\text { лурирась '1) трястись (о гриве лошади } \\
\text { во время бега); 2) быть шалуном, } \\
\text { живым, подвижным’ }\end{array}$ & $\begin{array}{l}\text { лурианась '1) трястись (о гриве } \\
\text { лошади во время бега); 2) скакать } \\
\text { на лошади’ }\end{array}$ \\
\hline $\begin{array}{l}\text { лыбцрась '1) быть шатким; 2) быть } \\
\text { расслабленным’ }\end{array}$ & $\begin{array}{l}\text { льбццанась 'качаться, шататься, } \\
\text { склоняться' }\end{array}$ \\
\hline $\begin{array}{l}\text { лябрась 'медленно опускаться (о веках } \\
\text { умирающего), едва улавливаться } \\
\text { (о дыхании)' }\end{array}$ & лябанась 'мерцать (о звездах)' \\
\hline $\begin{array}{l}\text { мяхарась '1) тяжело дышать (напр., } \\
\text { после бега, о больном и т. п.): он едва } \\
\text { дышит (об умирающем); 2) быть } \\
\text { раздутым (о животе, от болезни или } \\
\text { после еды)' }\end{array}$ & $\begin{array}{l}\text { мяханась '1) тяжело дышать (всё } \\
\text { время); 2) колыхаться, подниматься } \\
\text { (напр., о волнах на море без ветра)' }\end{array}$ \\
\hline $\begin{array}{l}\text { пэнъгрась 'мелькать перед глазами } \\
\text { (мешая что-л. делать)' }\end{array}$ & $\begin{array}{l}\text { пэщзгӑнась ‘1) качаться, шататься, } \\
\text { колебаться, раскачиваться из стороны } \\
\text { в сторону (о висящем предмете); } \\
\text { 2) путаться под ногами' }\end{array}$ \\
\hline
\end{tabular}




\begin{tabular}{|c|c|}
\hline Глаголы с суффиксом -RA & Глаголы с суффиксом -aNA \\
\hline $\begin{array}{l}\text { mырирась ‘1) трястись (на спине } \\
\text { лошади); 2) быть неугомонным’ }\end{array}$ & тырияанась 'трястись, скакать верхом' \\
\hline $\begin{array}{l}\text { хӑлмрась '1) помахивать, вилять } \\
\text { хвостом (неперех.)'; 2) ласкаться } \\
\text { (о собаке); 3) подлизываться, } \\
\text { угодничать' }\end{array}$ & $\begin{array}{l}\text { хӑлманась '1) шевелиться (о хвосте } \\
\text { животного), виться, извиваться, } \\
\text { кружить (о дороге, тропинке); } \\
\text { 2) не иметь твердых убеждений, } \\
\text { приноравливаться к чужому мнению; } \\
\text { 3) подлизываться' }\end{array}$ \\
\hline хӑлцрась 'извиваться, скользить' & $\begin{array}{l}\text { хӑлианась '1) извиваться: налим } \\
\text { извивается; 2) увертываться, } \\
\text { ускользать, быстро и свободно } \\
\text { двигаться (о юрком существе); } \\
\text { 3) валяться; 4) отпираться, } \\
\text { отказываться (от своих слов)' }\end{array}$ \\
\hline $\begin{array}{l}\text { хулврась, хылврась 'колыхаться } \\
\text { на волнах, качаться на волнах' }\end{array}$ & $\begin{array}{l}\text { хылванась, хулванась '1) извиваться, } \\
\text { изгибаться; 2) перен. качаться } \\
\text { на волнах; 3) ложиться свободными } \\
\text { складками (об одежде)' }\end{array}$ \\
\hline $\begin{array}{l}\text { ңұӑндӑрась 'смеяться без стеснения, } \\
\text { с издевкой; играть в шумные игры' }\end{array}$ & $\begin{array}{l}\text { нуӑнданась '1) быть чересчур широким } \\
\text { (о капюшоне); 2) чересчур увлекаться } \\
\text { шумной игрой; чересчур громко } \\
\text { говорить, быть горластым’ }\end{array}$ \\
\hline
\end{tabular}

Для двух дериватов (они вынесены в начало списка) в словаре Н. М. Терещенко отмечено различие в интенсивности: указано, что действие, описываемое глаголом с суффиксом -aNA, является более плавным, чем действие, описываемое глаголом с суффиксом -RA. Однако во всех остальных глаголах из представленного списка подобного различия как будто бы нет. Но при этом глаголы с суффиксом -RA отличаются от глаголов с суффиксом -aNA некоторым плохо формализуемым, но при этом достаточно регулярным образом. В частности, имеют место следующие типы семантических соотношений.

a) Глагол с суффиксом -aNA имеет только прямое значение, глагол с суффиксом -RA - прямое и переносное:

лурирась '1) трястись (о гриве лошади во время бега); 2) быть шалуном, живым, подвижным' лурианась '1) трястись (о гриве лошади во время бега) 2) скакать на лошади’; 
льюирась '1) быть шатким, шататься'; 2) быть расслабленным’ льљияанась 'качаться, шататься, склоняться';

тырирась '1) трястись (на спине лошади); 2) быть неугомонным' тырианась 'трястись, скакать верхом'.

б) Глагол с суффиксом -aNA имеет прямое и переносное значение, глагол с суффиксом -RA - только переносное:

лэңгӑрась '1) двигаться не по прямому направлению, петлять; 2) менять ранее принятое решение' лэ่ңзайнась '1) находиться в неустойчивом положении; 2) перен. идти не по прямой линии, петляя (напр. о невыдрессированном упряжном олене, о пьяном' [характеризует более плавное движение, чем по глаголу лэугӑрась]);

пэнъгрась 'мелькать перед глазами (мешая что-л. делать)' пэңцгӑнась '1) качаться, шататься, колебаться, раскачиваться из стороны в сторону (о висящем предмете) 2) путаться под ногами';

хулврась, хылврась 'колыхаться на волнах, качаться на волнах' хылванась, хулванась '1) извиваться, изгибаться; 2) перен. качаться на волнах; 3) ложиться свободными складками (об одежде)';

ңзӑндӑрась 'смеяться без стеснения, с издевкой; играть в шумные игры' ңзӑнданась 'быть чересчур широким (о капюшоне), чересчур увлекаться шумной игрой; чересчур громко говорить, быть горластым'.

Однако самой интересной, как кажется, является третья группа, в которой глагол с суффиксом -RA имеет только производное значение, причем такое, которого не имеет глагол с суффиксом -aNA. Первая пара из этого списка представлена глаголами ибциресь 'быть ярко окрашенным' ибиьнесь 'пахнуть кислым'. На первый взгляд, между этими двумя значениями нет семантической связи (глагол ибизиресь трактуется в словаре [Salminen 1998] как морфологически непроизводный). Однако следует принять во внимание то, что в действительности значение основы уibcyø- является более широким, ср. ибцика 'горький, кислый, чересчур соленый, сладкий'. Таким образом, эта основа обозначает не какой-то один конкретный вкус, а «экстремальный», яркий 
вкус вообще. Переход от такого значения к значению яркого окраса кажется гораздо более естественным: речь идет о впечатлении, «экстремальном» для другого чувства — не вкуса, а зрения.

В следующей паре глаголов: лябрась 'медленно опускаться (о веках умирающего), едва улавливаться (о дыхании)' лябанась 'мерцать (о звездах)' - происходит метафорическое уподобление явления из жизни человека природному явлению.

В третьей паре происходит метафорический перенос с описания части тела животного на описание поведения всего животного: хӑлмрась '1) помахивать, вилять хвостом (неперех.); 2) ласкаться (о собаке); 3) подлизываться, угодничать' хӑлманась '1) шевелиться (о хвосте животного), виться, извиваться, кружить (о дороге, тропинке); 2) не иметь твердых убеждений, приноравливаться к чужому мнению; 3) подлизываться'.

И, наконец, в последней паре происходит также метафорический перенос - поведение живого существа уподобляется движениям предметов, колеблющихся на ветру: лӑбресь 'шуметь крыльями, производить шум одеждой' лӑбанась '1) колыхаться, трепаться с шумом (при большом размахе (от ветра)) 2) бушевать (о ветре); 3 ) говорить быстро и громко'.

Такого же рода семантические различия наблюдаются и в случае других глаголов с суффиксом -RA - они не имеют соотносительных стативов с суффиксом -aNA, однако от соответствующих основ представлены другие производные, которые также демонстрируют более прямое значение - в сравнении с переносным значением у глаголов с суффиксом -RA:

ензарась 'тянуться, протягиваться, проникать сквозь, мелькать, виднеться сквозь' ензориь 'стать прозрачным';

лымбӑрась '1) быть колеблющимся, неустойчивым (о поверхности земли), быть вязким; 2) прыгать, колотиться, стучать (о сердце)' лымбась 'быть болотистым, вязким, зыбким, быть заболоченным, быть болотом';

лэйрась 'жужжать' лэириь '1) разгораться, ярко вспыхивать; 2) пронзительно хоркать (о некастрированных оленях осенью во время гона); 3) громко жужжать';

мӑнзӑрась 'шевелиться, колебаться, находиться в движении; работать, трудиться' мӑнзӑсь 'быть слегка колышущимся'; 
мӑнрась 'быть в неустойчивом положении, шататься (о предметах круглой формы), катиться, бежать (о чем-либо маленьком), неустойчиво, покачиваясь сидеть на чем-либо выпуклом' мантась 'упасть (покатившись кубарем)';

мунзгрась 'быть горячим, вспыльчивым' муңгӑмзь 'хлынуть, брызнуть';

мыхырась 'кишеть, копошиться' мыхқцмзь 'подергавшись, почесать спину об одежду', мыхыбайсь (длительн.) 'чесать';

ну”ўмрась 'быть гордым, высокомерным, важным' ну”ммоmăсь '1) сидеть сложа руки; 2) перен. важничать, задаваться';

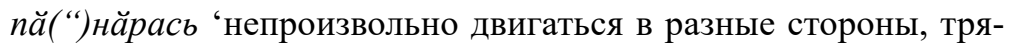
стись (напр., о голове)' пӑнарц̧ь 'возиться, суетиться';

путрась 'виться, струиться (откуда-либо)' путолась 'пробить, пронзить, проткнуть насквозь, нанизать';

nyxypacb 'выходить (о дыме из дымохода, о дыхании)' nухубтась, пухубтэсь 'разлететься, рассыпаться, налететь, нагрянуть'; nыдарась nударась '1) высыпа́ться, рассыпа́ться, осыпа́ться; 2) перен. выходить, выбегать' nудабтась 'насыпать(ся), рассыпать(ся)';

сибӑрась 'обильно литься (о поносе)' сибӑсь 'распутаться, размотаться';

cудрась 'трястись во время езды' судӑмзь 'дрогнуть, качнуться';

ся̆лрась 'быть бренчащим, звенеть, бренчать' ся̆лнӑсь 'весело щебетать - о птицах', сйлкӑдӑсь 'раздаться — о тонком звенящем звуке';

тырмрась 'семенить, идти частыми мелкими шагами' mырмори̧ь, тэрмори̧ь 'стать шероховатым, негладким, неровным' лабресь 'говорить громко' лабнась '1) сильно дуть (о ветре); 2) громко говорить';

я̆лресь 'создавать шум движением' йлнӑсь 'греметь, громыхать, грохотать'. 
Таким образом, глаголы этой группы в некоторых случаях не отличаются по семантике от остальных производных (впрочем, для двух глаголов Н. М. Терещенко специально отметила более интенсивный характер действия), однако в подавляющем большинстве случаев они имеют такое значение, которое образуется от основного значения глагольной основы путем метафорического переноса. В принципе значение уподобления входит в ненецком в сферу грамматических, cp. интраклитику -røxø, образующую от имен формы со значением 'подобный X-у'. Можно предполагать, что подобное значение реализовано в сфере образных глаголов за счет производных с суффиксом -RA. To, что в некоторых случаях глагол с суффиксом -RA a) имеет только прямое значение, свойственное исходной основе и б) сохраняет прямое значение наряду с переносным, вероятно, указывает на то, что значение 'как будто $\mathrm{P}^{\text {' }}{ }^{\text {не }}$ было исконным значением этого суффикса. Однако, вероятно, следует признать, что на данном этапе развития ненецкой глагольной системы это значение свойственно данному суффиксу. Может возникнуть альтернативное предположение - что производные с данным суффиксом являются наиболее «старыми» и при появлении в системе новых суффиксов со сходным значением семантически регулярные производные образуются по новой модели, а конкурирующие с ними старые производные оказываются вытеснены в особые семантические ниши, подвергаясь идиоматизации. Против этой точки зрения, однако, можно привести два аргумента. Во-первых, в системе глагольных производных ненецкого языка производные с суффиксом -RA оказались бы единственной группой, подвергшейся такой массовой идиоматизации. Второй аргумент касается отыменных производных с этим суффиксом: с одной стороны, мы имеем производный от слова тебт 'сок' глагол тебтересь 'протекать, просачиваться сквозь что-л.', т. е. буквально - 'течь, как сок'. С другой стороны, мы имеем дериват мечресь 'катиться, как мяч'; этот глагол, очевидно, довольно «молод», т. к. он относится по крайней мере к периоду знакомства сибирских народов с русским языком. Тем не менее и в данном случае идея уподобления представлена в семантике производного глагола, что, на мой взгляд, доказывает то, что ее следует приписать не идиоматизации производной в целом, а семантическим свойствам собственно суффикса.

\footnotetext{
${ }^{8}$ Следует отметить во избежание неверного прочтения, что речь идет не о притворном действии, а именно о подобии двух ситуаций.
} 
3.7. Суффикс -оc/-oS v i c образует процессуальные глаголы, прежде всего мультипликативы. Отличие мультипликативов из этой группы от мультипликативов с суффиксом -aNA либо -RA заключается в более медленном темпе действия, большем интервале между квантами ${ }^{9}$. Ниже приводится список глаголов с данным суффиксом - сразу с сопоставлением с другими производными от тех же глагольных основ:

лемзоць / lyemcoq- 'торчать, выдаваться, быть неповоротливым, нерасторопным' лемз '1) часть чего-либо пушистого, густого; 2) неповоротливый', лемза 'медлительный', лемзэриь 'быть медлительным', лемзериь, лемзориь 'стать густым, пушистым, распушившимся';

льбциоць / libcoq- 'непроизвольно наклоняться вперед (напр. о дремлющем человеке), идти, еле-еле передвигая ноги, тащиться' лььбцанась 'качаться, шататься, склоняться';

лябоџь / lyaboq- 'тяжело подниматься и опускаться (о веках)' лябанась 'мерцать', лябрась 'медленно опускаться (о веках умирающего)';

лябтоиьь / lyabtoq- 'низко прогибаться под тяжестью чего-либо' лябтенась 'быть поставленным широко и низко (о чуме)';

лямбоць / lyampoq- 'взмахивать крыльями, падать на глаза (о волосах)' лямбанась 'спускаться, слетать, взмахивая крыльями';

нибкоць / nyibkoq- 'никнуть, наклоняться (о голове) и слегка наклоняться (о туловище)';

нитоиьь / nyítoq- 'быть несобранным (о человеке)' нитанась ‘плестись, тащиться’;

нэ்лоць / neloq- 'производить при движении шум одеждой' нэ̇ланась 'производить при быстром движении шум рваной одеждой';

9 Этому обобщению противоречат только два глагола из данной группы тыриоць 'трястись, подпрыгивать (при тряской езде)' и панзоць ‘быстро двигаться в разные стороны, вилять из стороны в сторону’. Однако поскольку все остальные глаголы обозначают либо такие мультипликативные ситуации, которые отчетливо разделены на кванты достаточно значительными промежутками времени, либо такие ситуации, которые осуществляются медленно и с трудом, можно предполагать, что в этих двух случаях мы имеем дело с несовершенством лексикографического описания. 
ня̆лцоць / nyølcoq- 'выскальзывать (о каком-либо предмете)';

панзоць / pancoq- 'быстро двигаться в разные стороны, вилять из стороны в сторону' панзанась 'быть живым, подвижным'

сулоць / suloq- 'прогибаться от тяжести' сулӑмзь 'упасть на переднюю часть';

măбйоць / tabcoq- 'иметь свойство загораться вспышками' тӑбиенась (таймырский) 'идти, волоча ноги, прерываться о голосе, песне';

тӑлмоць / tølmoq- 'то затемняться, то проясняться' тӑлмориь 'стать сумрачным, пасмурным, тёмным, затемнённым, тусклым';

mыриоць / tircoq- 'трястись, подпрыгивать (при тряской езде)' тырцанась 'трястись (на спине лошади)'

хӑлизоць / хølcoq- 'иметь способность изгибаться, гнуться, извиваться' хӑлцанась 'извиваться';

хортоць / xortoq- 'раскрываться, разеваться (о рте, пасти)' хортенась 'быть насквозь пробитым, быть открытым настежь, широко';

ялмоць / yalmoq- 'появляться - о проблесках света, мерцать' ялмориь 'побелеть; посветлеть, просветлеть (о небе); поседеть; выцвести, выгореть' .

3.8. В пп. 3.8 и 3.9 приводятся две лексически ограниченные группы имперфективов, которые включают в свой состав также необразную лексику. Однако в обе эти группы попадает и достаточно много образных глаголов (тех, которые имеют соотносимые производные с суффиксами образных глаголов; выделены в обоих списках полужирным шрифтом).

Глаголы с суффиксом -(a)бăp/-(a)BØR обозначают ситуации, осуществляющиеся редко, замедленно либо неуклюже: ирнабӑрць / yirnøbør- скрипеть (по временам); хэцабӑрць / хæсаbør- 'быть чересчур большим, быть неуклюжим'; *лемзабӑрць / lyemcabør- 'работать лениво'; сабкабӑрць / sabkabør- 'медленно, неуверенно двигаться, брести'; пэңгабӑрць / pængkabør- 'слегка качаться, шататься'; ялабӑрць / yalabør'мигать, сверкать, мерцать (о звёздах)'; вырмабарць/ wirmabør- 'с трудом раскрываться (о глазах)'; тэнабариьь 'тянуться, вытягиваться (напр., при игре, борьбе)'; вэнабӑриь 'быть растягивающимся, быть тягучим’; 
са"набӑрць / saqnabør- 'болтаться, свисать'; сӑрабӑрць / sørabør- 'быть неловким, нерасторопным, неумелым'; сурабӑрць / surabør- 'слегка прихрамывать, хромать'; хӑсабӑриьь 'шептать, шептаться’; сесабӑрць / syesabør- 'шуршать, шелестеть'; есабӑрць / уеsabør- 'блестеть, сверкать'; тӑмдабӑриьь 'извиваться'; тавабӑризь 'быть медлительным, неповоротливым'; сяхабӑрць / syaxabør- 'бренчать, звенеть'; хӑябӑрць / хøуаbør- 'медленно двигаться друг за другом'; лэябарць / leyabør- 'полыхать'; мӑкэбаризь / møkebør- 'слезиться’; юебарцьь / yúyebør- ‘идти неуверенно нетвердой походкой или стесняясь'.

3.9. Стативы -я/-Ү̈У. Эта группа по лексическому наполнению стоит несколько особняком, так как в нее входит значительное количество глаголов, которые с точки зрения их семантики следует определить как качественные. В то же время кажется резонным рассматривать эту группу в рамках данной статьи, так как в нее попадает некоторое количество глагольных основ, принимающих другие суффиксы образных глаголов (такие основы в данной группе выделены полужирным шрифтом) ${ }^{10}$ : в является необходимой принадлежностью (листьев, веток, сучьев о дереве, одежды, обуви - о человеке); быть стройным, хорошо сложенным'; вэръясь 'быть очень белым, молочно-белым (о человеке, животном); быть чистым, безлесным'; иръясь 'быть ровным'; лыра-

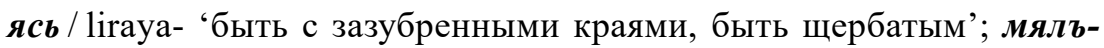

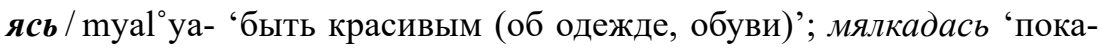
заться на миг и быстро скрыться'; нумъясь / пuqm уa- 'быть важным, держаться гордо, высокомерно'; няльясь / пуøl у уа- 'быть гладкошерстным, упитанным'; ня̆мдъясь/ пуømt уа- 'быть стройным'; няръясь 'быть красным' 11; ня̆угъясь 'быть мягким'; порьясь/ por ${ }^{\circ}$ уа- 'стоять

${ }^{10}$ Из этого списка исключены также отыменные глаголы типа неугъясь 'быть счастливым, удачливым, иметь в изобилии жизненные блага' < неуг 'внутренняя часть невода, загона; круг, образованный нартами во время коллективной охоты на песцов’ (очевидно, удачливым является тот, у кого внутренность этих средств промысла не является пустой, ср. идиоматическое выражение поуганда неңг сава 'у него счастливый невод’, досл. 'внутренность его невода хорошая’) или ёркъясь ‘быть с ровно очерченным полукругом' < ёрка 'изгиб с пространством, которое он описывает; полукруг, полуокружность' или хэвъясь 'выступать (о костях)' < хэв ‘бок, сторона'.

${ }^{11}$ Сама по себе основа няр- 'красный' не входит в группу образных основ; тем не менее есть дериват нярмориь 'стать багряным, багровым', которая образуется по модели, свойственной образным глаголам, см. 4.2 ниже. Т. Салминен в данном 
торчком, казаться в отдалении тонким и длинным'; пудаясь/pudaya'выходить (о паре изо рта, из ноздрей усталых оленей перед ясной по-

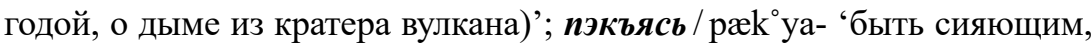
ярко светящим (о луне, месяце)'; салъясь / sal ${ }^{\circ}$ уа- 'блестеть (о гладкой, ровной поверхности)'; сӑръясь / sør ${ }^{\circ}$ уа- 'возвышаться, быть выпуклым'; суръясь / sur 'уа- 'сидя возвышаться на чем-либо'; тёръясь / tyor ${ }^{\circ}$ уа- 'стоять торчком, торчать (о нешироком предмете)'; тэбъясь /

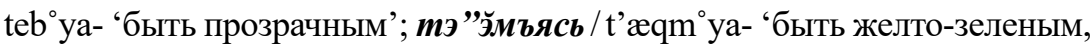
цвета желчи'; хӑльясь / хø1 ${ }^{\circ}$ уа- 'лежать (о длинных, растянутых предметах)'; хӑрвясь / хøг у уа- 'быть красиво стоящим, слегка приподнятым (напр., о меховой опушке), сидеть прямо (напр., о ребенке в люльке)'; хӑсъясь / хøз ${ }^{\circ}$ уа- 'быть проворным'; ууръясь / ngur ${ }^{\circ}$ уа'быть гладким, блестящим (например, о постриженной наголо голове).

\section{4. Производные с перфективным значением}

Теперь перейдем к перфективным производным от соответствующих основ. Одна группа производных, семельфактивы с суффиксом

случае выделяет основу nyar mø-, которая содержит суффикс -mø. В других основах в [Salminen 1998] этот суффикс не выделяется. Тем не менее есть небольшая группа слов сходной семантики, в которых по крайней мере исторически может быть выделен суффикс -тø: помимо нярм 'краснота, красноватая окраска' (ср. няръясь 'быть красным'), это слова ялм 'зарево, проблеск, белизна (в темноте или при световом контрасте), седина' (ср. ялкадӑсь 'блеснуть, сверкнуть'; ? ср. также яля 'день; свет; место, откуда исходит свет, освещенное пространство; светлый, яркий'), холм 'наиболее тёплая часть дня' (? ср. холкась 'растаять'), тӑлм 'облачность, сумрачность; обложенное тучами небо; пасмурный’ (ср. тӑлӑсь 'закрыть(ся)', тӑлкадӑсь 'закрыться, захлопнуться с шумом; причалить вплотную; сгуститься (о тьме)', талкадёй 'очень тёмный'), пӑрм 'тёмное пятно; неясно выступающий вдали или или в темноте силуэт; чернота; величина тени (какого-либо предмета)', (ср. пӑри: уэбт пӑри 'черноволосый’, сэв пӑри 'черноглазый', пӑридесь 'быть черным'), салм 'гладкая, зеркальная поверхность чего-либо; место на воде, которое во время массового хода рыбы словно покрыто жиром’ (ср. салъясь ‘блестеть - о гладкой ровной поверхности'), вэрм 'открытое незаросшее место’ (ср. вэръясь ‘быть очень белым, молочно-белым (о человеке и животном), быть чистым, безлесным’. Возможно, сюда же отно-

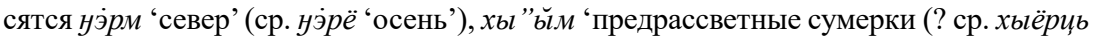
‘стать жёлтым, бурым; выцвести, потерять окраску, выветриться', хылдӑсь 'выгореть, обесцветиться, потерять цвет'), а также тэ ”э̆м ‘бурый, выгоревший (о цвете)'. 
-хада -цяда -зяда / -ХА-ТØ -ХуА-ТØ Vi m, уже была рассмотрена выше, в Разделе 2.2, так как эти производные удобно было рассматривать в сопоставлении с группой соотносимых с ними имперфективных производных. В действительности суффикс -хада -цяда -зяда / ХА-ТØ -ХуА-ТØ является единственным суффиксом с перфективным значением, который присоединяется исключительно к образным основам. В этом состоит принципиальное различие между перфективными и имперфективными производными от образных основ: если среди имперфективных суффиксов легко выделяется группа таких морфем, которые характерны именно для образных основ, среди перфективных суффиксов можно указать те, для которых оформление основ с образной семантикой является сильной тенденцией.

Прежде всего, можно указать на две группы инхоативных производных.

4.1. Первая из инхоативных групп представлена суффиксом -ел / -yeL Vr m. Сам по себе суффикс -L используется в ненецком для образования инхоативных производных от основ с вокалическим исходом, вне зависимости от их семантики (для образования инхоативов от основ с консонантным исходом используется суффикс -LØ). Тем не менее группа инхоативов, в которой присоединение инхоативного суффикса сопровождается заменой финального гласного основы палатализующим -уе представляет собой именно инхоативы от основ образной семантики. Многие инхоативы имеют соотносительные стативы с суффиксом -уеNA (указаны в приводимом ниже списке; если такая соотносимая производная отсутствует и не приводится никаких дополнительных комментариев, это означает, что от этой основы зафиксированы другие производные с суффиксами, характерными для образных глаголов): вӑделц̧ь / wødyel- 'стать крючковатым' (этот глагол естественно трактовать как отыменной - производный от слова вӑда 'крюк'; тем не менее в группе глаголов с этим корнем представлены несколько производных с суффиксами, характерными только для образных глаголов, ср. хотя бы вӑденась 'быть согнутым, искривленным'); ёнделцьь / yontyel- 'стать широко растянутым - о рте' (ср. ёнденась 'шутить, слегка издеваясь, широко растягиваться - о рте'); ензелць / yеncyel- 'стать бесцветным (о глазах)'; понзелизь/poncyel- 'стать слабо закрепленным, стать некрасиво сделанным' (в ненецком эта основа не употребляется без суффикса -yeL); сӑбелцьь / søbyel-'рассесться без дела’ (ср. саибанась 
'ничего не понимать, быть несмышлёным'); сибелць / syibyel- 'стать бледным с землистым оттенком; стать угрюмым’ '2; тӑбелиь / tøbyel'сползти, спуститься, стать несобранным' (в ненецком эта основа не употребляется без суффикса -yeL, но cp. энецкий глагол tobarta'снять одежду, обувь'); тӑнзелиь / tøncyel- 'посинеть, стать синим (о месте ушиба)' (ср. тӑнзинесь 'темнеть, синеть'); тиделць / tyídyel'смеркнуться, наступить - о сумерках'; тыбелць / tybyel- 'стать с тупой короткой мордой - о животном, стать с круглым маленьким лицом - о человеке, стать с изящно отделанной лицевой стороной о пимах' (в ненецком эта основа не употребляется без суффикса -yeL); хӑделць / xødyel- 'съежиться, покоробиться' (ср. хӑденась 'лежать скорчившись'); хумбелць / хuтруеl- 'стать выпуклым' (ср. хумбенась 'быть слегка приподнятым’); хэиелиь / хæсуеl- 'стать скрюченным от холода' (ср. хэценась 'быть негнущимся').

4.2. Следующая группа инхоативов представлена суффиксом -ep/yeR Vr m. Эти инхоативы также образуются от образных основ и также соотносятся со стативами с суффиксом -yeNA (при наличии соответствующей стативной производной она приводится в списке ниже; если такая соотносимая производная отсутствует и не приводится никаких дополнительных комментариев, это означает, что от этой основы зафиксированы другие производные с суффиксами, характерными для образных глаголов) ${ }^{13}$ :

вӑдериъь / wødyer- 'согнуться, скорчиться (о человеке)' (этот глагол естественно трактовать как отыменной - производный от слова вӑда 'крюк'; тем не менее в группе глаголов с этим корнем представлены несколько производных с суффиксами, характерными только для образных глаголов, ср. хотя бы вӑденась 'быть согнутым, искривленным'); вэ ”мериь / weqmyer- 'вытянуть шею - о настороженно прислушивающемся животном, вытянуться - о шее настороженно прислушивающегося животного’ (ср. вэ ” менась ‘быть вытянутым - о шее'); ериериь /

12 Т. Салминен сопоставляет эту основу со словом сибй ‘пыль, мучная пыль' и далее с сиво̆лтӑсь 'иметь перхоть; быть сивым'. Однако, судя по всему, эти основы можно развести как минимум с опорой на нганасанские соответствия, сp. kimora'побледнеть', но симиә 'пепел'.

13 Из списка исключены редкие отыменные производные типа мӑрерць 'стать с распухшими железами' < мӑр 'железа'. 
yercyer- 'откинуться, отклониться назад' (ср. ерценась 'торчать в разные стороны'); лӑбизерu̧ь / løbcyer- 'стать плоским' (ср. лӑбценась 'быть плоским, раздавшимся в ширину, расширившимся'); лемзерцзь / lyemcyer- 'стать густым, пушистым, распушившимся'; лисери̧ь / lyísyer- ‘лечь плашмя’, ср. лисенась 'лежать ничком'; лырериьь/ liryer- 'стать с зазубренными краями, стать щербатым' (ср. льренась 'быть с зазубренными краями'); лэнзеризь / lencyer- 'стать прямым, вытянутым'; мӑдери̧ь / mødyer- 'упереться, заупрямившись', ср. мӑдинесь 'неизменно находиться на одном месте (о громоздком, огромном предмете); находиться на одном месте, никуда не двигаясь'; мӑ”леризь/ møqlyer- 'нагнуться, согнуться, ссутулиться' (ср. мӑ”ленась 'быть слегка согнувшимся вперед'); мӑнзеризь / møncyer- 'лечь, свернувшись в клубок' (ср. мӑнзенась 'лежать, свернувшись в клубок'); морерuуь / moryer- 'побелеть' (ср. моренась 'белеть'); мумдерuзь / mumtyer- 'поджать губы'; nӑртерu̧ь / pørtyer- 'стать слишком коротким' (ср. пӑртенась 'быть излишне коротким'); nосерцьь / posyer- 'вздуться'; пындеризь / pintyer- 'лечь, упасть лицом вниз' (ср. пьлденась 'лежать ничком, лежать вверх дном'); сасериьь / sasyer- 'заторопиться'; сэбериць / sæbyer- 'заупрямиться' (ср. сэбинесь 'быть упрямым, своевольным'); тӑнзеризь / tønсуег- 'потемнеть, посинеть' (ср. тӑнзинесь 'темнеть, синеть'); тоеризь / toyer- 'затвердеть' (ср. тоенась 'быть твердым, жестким'); my 'лерųь / túqlyer- 'стать белеющим' (ср. mу”ленась 'белеть, сверкать, блестеть'); хӑдеризь / хødyer'сжаться, съежиться' (ср. хӑденась 'лежать скорчившись'); хӑрмерияь / хørmyer- 'чересчур изогнуться (о конце чего-либо), искривиться' (ср. хӑрменась 'быть чересчур изогнутым'); хӑрнерцьь / хørnyer- 'стать загнутым' (ср. хӑрненась 'быть загнутым - о конце чего-либо'); хӑриеерuьь / хørcyer- 'откинуться назад’ (ср. хӑриченась 'лежать (о чем-либо большом)’); хасери̧ь / хаsyer- 'утихнуть, успокоиться' (ср. хасенась 'быть спокойным (в том числе, например, о воде), отдыхать'); хо’леризь / xoqlyer'наклониться, нагнуться' (ср. хо ”ленась 'быть наклоненным вперед'); хортеризь / хоrtyer- 'широко открыться' (ср. хортенась 'быть насквозь пробитым, быть открытым настежь, широко'); хулерц̧ь / хulyer- 'стать с горбинкой (о носе, клюве)' (ср. хуленась 'быть с горбинкой, быть согнутым'); хумберизь / хumpyer- 'стать слегка приподнятым’ (ср. хумбенась 'быть слегка приподнятой 
(о части гладкой поверхности)'); хутерцьь / xutyer- 'стать негнущимся (от холода)' (ср. хутенась 'быть негнущимся (от холода)'); хылтеризь / хiltyer- 'лечь ничком' (ср. хылтенась 'лежать ничком'); хэизери̧ь / хæсуег- 'стать очень жестким' (ср. хэценась 'быть негнущимся').

Инхоативов с суффиксом -R в ненецком не так много; как только что было продемонстрировано, вариант суффикса с перегласовкой финального гласного основы в палатализующий уе присоединяется к основам с образной семантикой. Есть еще две группы инхоативов c -R: инхоативы с показателем -оR Vr m r и инхоативы с показателем -оR Vr m r. В списке суффиксов с показателем -oR количество образных и необразных основ примерно равно, приведу список соответствующих производных.

а) Основы, имеющие другие производные с суффиксами, характерными для образных основ: ензоризь/yencor- 'стать прозрачным'; ерu̧ори̧ь / yercor- 'стать торчащим'; лабц̧ори̧ь løbcor- 'расплющиться, раздаться, растянуться, расшириться'; лемзоризь / lyemcor- 'стать густым, пушистым, лохматым'; лисоризь / lyísor- 'лечь, расположиться широко, свободно, раскинуться'; лямбори̧ь / lуатрог- 'растрепаться, взъерошиться, стать длинным, густым (о распущенных волосах, о ветвях деревьев), расположиться, раскинуться широко и удобно'; лярцуорц̧ь / lyarcor- 'распуститься, разветвиться, распушиться'; мадёризь / mødyor'стать неровным, ухабистым'; мороризь / moror- (=морерц̧ь) 'побелеть'; муңгоризь / mungkor- 'стать широко открытыми, вытаращенными'; мырттори̧ь / mirtor- мyртори̧ь / murtor- 'стать с туго зачесанными назад волосами (отчего черты лица выступают более резко)'; нэлоризь/ nelor- 'обтрепаться (об одежде)'; нэризоризь/nercor- 'стать неаккуратным, небрежным; оказаться разбросанным'; пӑдори̧ь / pødor- 'уставиться на кого-либо'; тырморизь / tirmott $\sim$ тэрморизь / termor- 'стать шероховатым, негладким, неровным'; тырц̧оризь / tircor- 'стать растрепанным'; хӑризори̧ь/ хørсor- 'сесть, рассесться, заняв много места'; хӑторизь / хøtor- 'всплыть'.

Приведу также ряд производных от основ, перечисленных в сноске 10: нярморизь / nyarmor- 'стать багряным, багровым'; тӑлморцьь / tølmor- 'стать пасмурным'; mэ ”моризь / tæqmor- 'стать бурым, пожелтевшим'; $x b l$ 'мори̧ь/хіqmor- 'стать бледно окрашенным, потерять цвет'; ялморизь / yalmor- 'побелеть, посветлеть (о небе)'; холмори̧ь / xolmor'стать тепловатым'. 
б) Основы, не имеющие других производных с суффиксами, характерными для образных основ. Среди них выделяются две подгруппы:

А) основы-изоляты, не имеющие других производных: вамбориьь / wampor- 'стать суровым, строгим, нелюдимым, замкнутым'; вырториьь / wirtor- 'стать осунувшимся, унылым'; вэризоризь / wercor- 'лишиться чего-либо необходимого (одежды - о человеке, шерсти - о животном)'; лэсёрцьь / lesyor- 'стать угловатым, неуклюжим'; мерноризь / myernor'стать с большими, выпуклыми глазами, стать с раздувшимися ноздрями'; молориь / molor- 'стать пасмурным'; насорųь / nasor- 'стать шероховатым, бугристым'; сидори̧ь / syidor- 'побледнеть'; сэкоризь / sekor- 'стать одиноким, стать скучным'; танори̧ь / tanor- 'стать прибранным (о помещении)' и

Б) основы, имеющие другие производные, среди которых, однако, не встретилось ни одной такой, которая однозначно определяла бы глагольную основу как образную: латорuзь / lator- 'стать широким (о лице)'; талвори̧ь / talwor- 'стать сплющенным, сдавленным, узким, сплющиться, сузиться'; тарнорияь / tarnor- 'сесть, аккуратно, собранно в позе шьющей'; хӑб 'лоризь / хøblor- 'стать раздутым, раздуться'; хохоризь / хохог- 'распухнуть, раздуться'; хылдориьь / xidor- 'стать выгоревшим'; хыёрu̧ь / хіуоr- 'стать желтым, бурым, выцвести, выветриться'; ясоризь / yasor- 'стать шероховатым, бугристым, с выступами'.

$\mathrm{B}$ списке инхоативных производных с суффиксом -øR соотношение образных и необразных основ примерно такое же, как в списке основ с суффиксом -оR, приведу список соответствующих дериватов:

A) основы, имеющие другие производные с суффиксами, характерными для образных основ: вӑнугӑрu̧ь / wøngkør- 'сжаться, подобраться до предела (чтобы не дать задеть себя или от холода)'; выяризь /

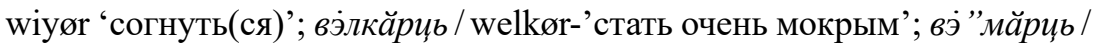
weqmør- 'поднять шею, настороженно прислушиваясь и пугливо озираясь'; вэхэри̧ь/ weхør- 'стать опустошенным, стать лишенным чего-либо необходимого’; ехэри̧ь / уехør- 'вытянувшись, откинуться назад’; лабйӑрuъ / løbcør- 'сплющиться'; ледарu̧ь / lyedør- 'застыть'; ливариьь / lyíwør- 'стать пушистым'; лонугӑрųь / longkør- 'стать выпуклым, шарообразным'; лэбарц̧ь / lebør- 'стать отвисшим, потерявшим форму'; лябтӑри̧ь / lyabtør- 'упасть на живот, заупрямившись'; ляхари̧ь / lyexør'раздвинуть ноги, разъехаться (о ногах)'; нйнзӑриь / пуønсør- 'стать сырым, промокшим, размякшим'; няңгӑрuзь / nyangkør- 'разинуть(ся), раскрыть(ся)'; năyzăрųь/pøngkør- 'закрутить, закрутиться, отвернуться 
в другую сторону'; сӑбӑриьь / søbør- ‘стать глубоким’; хыңцӑриь / xingkør'стать неприлегающим'; уамня̆риь / ngamnyør- 'издать чавкающий звук (при падении чего-либо мокрого)'.

Б) основы, не имеющие других производных с суффиксами, характерными для образных основ. Среди них выделяются

Б1) основы-изоляты, не имеющие других производных: лӑмбариь / løтрør- 'стать с чересчур широкой опушкой (о капюшоне), одеться в слишком широкую одежду'; лӑндаризь / lntør- 'стать студенистым'; хӑтӑриь / хøtør- 'стать белым с большим количеством черных волосков (об олене)'; хулцӑриь / xulcør- 'стать слегка теплым (с любого конца шкалы)' и

Б2) основы, имеющие другие производные, среди которых, однако, не встретилось ни одной такой, которая однозначно определяла бы глагольную основу как образную: вӑндӑриь / wøntør- 'стать сплющенным, помятым'; лусариь / lusør- 'стать искривленным, скрюченным'; мамзӑризь/mamсør- 'свернуться клубком'; хубӑризь/ xubør'слегка приподняться - в результате чего образуется небольшая выпуклость, слегка округлиться'; нюлӑриь / nyulør- 'стать мягким, слегка распаренным'.

Таким образом, в группе инхоативов с суффиксом -R большинство составляют производные от образных основ, однако только вариaнт -yeR присоединяется исключительно к образным основам.

4.3. Еще одна группа перфективных производных, состоящая по преимуществу из основ образной семантики - семельфактивы с суффиксом -м/-M Vr m, образующим глаголы рефлексивного спряжения. Ниже перечислены те основы, которые можно идентифицировать как образные на основании того, что они присоединяют другие суффиксы, характерные для глагольных основ образной семантики: вӑугӑмзь / wøngkøm- 'быстро увернуться, подпрыгнуть'; вӑсӑмзь / wøsøm- 'быстро оглянуться (на зов или на какой-л. звук)'; вэ் 'лӑмзь/ weqløm- 'выглянуть, показаться (высунув голову) и снова скрыться'; вэрриӑмзь/wercøm- 'неожиданно вскочить'; вээхэммз / wехøm- 'вынырнуть'; ёугӑмзь 'оглянуться, обернуться'; есӑмзь 'сверкнуть, вспыхнуть (не загораясь)'; ехэ̆мзь 'быстро откинуться назад'; ехэ̆мзь / уехøт'быстро откинуться назад'; идӑмзь/ уіdøт- 'пискнуть'; лӑбӑмзь / løbøm- 'всколыхнуться'; лӑбцӑмзь / løсøm- 'упасть плашмя'; лӑсӑмзь 'пошатнуться, покачнуться'; лӑхӑмзь / løхøт- 'высвободиться из чеголибо, сняться с чего-либо, отделиться от чего-либо'; ледӑмзь/ 
lyedøm- 'неожиданно, внезапно заспешить, поторопиться'; лэ่наймзь / lengkøm- 'ответвиться, отделиться (от основной части)'; лямбӑмзь 'взмахнуть крыльями, вспорхнуть'; лясӑмзь / lyasøm- 'упасть плашмя'; муңгӑмзь/mungkøm- 'хлынуть, брызнуть'; мыртӑмзь 'неожиданно появиться, показаться'; мыхьймзь / mixøm- 'подергавшись, почесать спину об одежду'; нихймзь / nуіхәт- 'показаться неожиданно, внезапно (о движущемся предмете)'; ныдӑмзь / nidøm- 'дрогнуть, вздрогнуть'; ныкӑмзь 'остановиться на время, передохнуть'; нэрриӑмзь / nercøm- 'лечь, упасть небрежно, как попало, шлёпнуться, плюхнуться'; нюнӑмзь 'пробормотать сердито, проворчать, буркнуть'; няңгӑмзь 'раскрыться, разинуться'; уамня̆мзь 'шлепнуться (о чем-либо мокром)'/ngamnyøm- ; панзӑмзь / pancøm- 'скользнуть, соскользнуть (напр., о топоре, ноже)'; nӑугӑмзь / pøngkøm- 'повернуть, свернуть круто в сторону'; пӑртӑмзь / pørtøm- 'быстро вскочить на ноги'; пыдӑмзь / pidøm- nyдӑмзь / pudøm'вывалиться, высыпаться'; пындӑмзь / pintøm- 'шагнуть, прихрамывая, упасть на грудь'; пырӑмзь 'упасть (о более слабом человеке)'; nэнฺгӑмзь / pængkøm- 'покачнуться, пошатнуться'; салӑмзь / 'выглянуть, появиться на мгновение'; судӑмзь / súdøm- 'дрогнуть, качнуться'; сулӑмзь 'упасть на переднюю часть'; тидӑмзь / tyídøm- 'наступить о сумерках'; тиндӑмзь / tyintøm- 'споткнувшись, слегка наклониться вперед, лечь на живот'; туйлзь / tuyøm- 'закатиться, спуститься за горизонт (о солнце)'; хӑлцӑмзь / хølсøт- 'перевернуться через голову'; хӑрнӑмзь / хørnøm- б.-з. 'сесть прямо'; хӑтӑмзь / хøtøm- 'всплыть'; хортӑмзь / хоrtøm- 'открыться — о рте, пасти'; худӑмзь / xúdøm- 'всколыхнуться, раздуться’; хэртайль / хеrtøm- 'быстро вскочить куда-либо’; юя̆мзь (юёмзь) / уи́уøт- 'вскочить со своего места'; ярӑмзь / yarøm'опрокинуться, лечь на бок'.

Есть, однако, несколько глаголов рефлексивного спряжения с этим же суффиксом, которые не имеют соотносимых производных с суффиксами, характерными для основ образной семантики ${ }^{14}:$ ихйлзь / уіхøт- 'потереться обо что-либо, скользнуть, пройти вскользь по чему-либо'; нотӑмзь 'рассердиться из-за пустяка'; хэдӑмзь 'взглянуть искоса'; я̆цұгӑмзь / yøngkøm- 'отделиться'; мӑямзь / тøуøm- 'обрадоваться (от неожиданности)'; ууя̆мзь / nguyøm- 'ослабиться — о ремне, привязи и т. п.'; хӑя̆мзь / хøуøт- 'прикрыться (о глазах)'.

${ }^{14}$ Не приводятся отыменные производные типа уая̆мзь 'разжиреть, стать жирным' или сидӑмзь 'разделиться надвое'. 


\section{5. Заключение}

В ненецком отчетливо выделяется группа деривационных (аспектуальных) суффиксов, характерных для образных глаголов. Это прежде всего ряд имперфективных суффиксов, но также и несколько суффиксов с перфективной семантикой, образующих семельфактивы либо глаголы с инхоативным значением.

Чтобы более наглядно представить деривационный потенциал образных глаголов, ниже приводятся примеры деривационных гнезд:

лабианась / løbc nø- 'ударяться со шлепающим звуком (о тяжелом или мокром предмете)'; лӑбиенась / фøсуеnа- 'быть плоским, раздавшимся в ширину, расширившимся'; лӑбиӑмзь/løbcøm'упасть плашмя'; лӑбиери̧ь/ løbcyer- 'стать плоским' лабиоризь/ løbcor- 'расплющиться, раздаться, растянуться, расшириться’; ня̆лекадӑсь/ nyølyekødø- 'быть выпуклым'; ня̆ланась / nyølana'прощупываться (об округлом предмете)' ня̆ленась / nyølyena'иметь выпученные глаза'; нйлайсь / nyølayø- 'выступать — о каком-либо круглом предмете';

хортенась / хоrtyena- 'быть насквозь пробитым, быть открытым настежь, широко'; хортӑмзь/ хоrtøm- 'открыться - о рте, пасти'; хортериь / xortyer- 'широко открыться';

хумбенась / хumpyena- 'быть слегка приподнятой - о части гладкой поверхности'; хумбелиь / хuтруеl- 'стать выпуклым'; хумбериь / хumpyer- 'стать слегка приподнятым’;

хылтенась / хiltyena- 'лежать ничком'; хылтая̆сь/ хіltayø- 'быть мало согнутым, быть откинутым назад’; хылтериь / xiltyer- ‘лечь ничком';

юёнась / yúy na- 'идти вертлявой походкой'; юёмзь / уúуøm- 'вскочить со своего места';

яренась/yaryena- 'быть большим, видным издали (с одной стороны на близком расстоянии)'; ярая̆сь / уагауø- 'лежать на боку'; ярӑмзь / yarøm- 'опрокинуться, лечь на бок';

ерцанась/yercana- 'находиться в неустойчивом положении, подниматься и опускаться'; ериенась/yercyena- 'торчать в разные 
стороны'; еризерu̧ь / yercyer- 'откинуться, отклониться назад'; ерцьорць / yercor- 'стать торчащим';

есӑмзь / уеsøm- 'сверкнуть, вспыхнуть (не загораясь)'; есабӑри̧ь / yesabør- 'блестеть, сверкать';

ехэмззь / уехøт- ‘быстро откинуться назад’; ехэри̧ь / уехør- ‘вытянувшись, откинуться назад';

льбцанась / libcana- 'качаться, шататься, склоняться'; льббрась / libc 'ra- 'быть шатким'; льљбуоц̧ь / libcoq- 'непроизвольно наклоняться вперед (напр. о дремлющем человеке), идти, еле-еле передвигая ноги, тащиться';

лэнзгӑрась / lengk ${ }^{\circ}$ - 'Двигаться не по прямому направлению, петлять'; лэнцӑнась / lengkana- 'находиться в неустойчивом положении, двигаться извиваясь'; лэнцаймзь / lengkøm- 'ответвиться, отделиться (от основной части)';

лябтощь / lyabtoq- 'низко прогибаться под тяжестью чего-либо’; лябтенась/lyabtyena- 'быть поставленным широко и низко (о чуме)';

лямбанась / lyampana- 'спускаться, слетать, взмахивая крыльями'; лямбӑмзь / lуатрøт- 'взмахнуть крыльями'; лямбоцьь / lyampoq- 'взмахивать крыльями, падать на глаза (о волосах)'; лямборизь / lyampor- 'растрепаться, взъерошиться (о волосах)';

мыртенась / mirtyena- б.-3. муртанась / murtana- ям. 'выдаваться вперед (о какой-либо части тела)'; мыртаимзь / mirtøm'неожиданно появиться, показаться'; мыртори̧ь / mirtor- б.-3., мурториь / murtor- ям. 'стать с туго зачесанными назад волосами (отчего черты лица выступают более резко)'.

Особенность образных глаголов ненецкого языка состоит в том, что они обладают собственным репертуаром деривационных морфем; тем самым, данная лексическая группа может быть выделена не только с опорой на семантику, но и на формальных основаниях. В Таблицее 4 суммируются данные по группам производных глаголов образной семантики. 
Таблица 4. Деривационные суффиксы образных глаголов тундрового ненецкого (сводная таблица)

Table 4. Derivational suffixes of Tundra Nenets depictive verbs: summary

\begin{tabular}{|c|c|}
\hline Суффикс & $\begin{array}{c}\text { Аспектуальный класс: } \\
\text { лексическое значение производных глаголов }\end{array}$ \\
\hline \multicolumn{2}{|c|}{ Производные глаголы с имперфективным значением } \\
\hline -Hă /-NØ Vi c & $\begin{array}{l}\text { Непредельные проиессы: негромкий повторяющий звук } \\
\text { либо мелкое быстрое движение }\end{array}$ \\
\hline $\begin{array}{l}\text {-(е)кӑдӑ либо -(e) } \\
\text { сӑдӑ)/ -уеQХØ-(N ) } \\
\text { TØ (? -yеQXØ-TØ) } \\
\text { либо -yeSØw-(N )TØ } \\
\text { (? -yeSØ-TØ) }\end{array}$ & $\begin{array}{l}\text { Непредельные проиессы либо } \\
\text { стативы со значением состояния: характерная поза }\end{array}$ \\
\hline $\begin{array}{l}- \text { на } \sim \text {-не } \sim \text { aна } /-\mathrm{NA} \sim \\
\text {-NyE } \sim \text {-aNA Vi c }\end{array}$ & $\begin{array}{l}\text { Непредельные процессы либо стативы со значением } \\
\text { состояния }\end{array}$ \\
\hline $\begin{array}{l}\text {-ена } \sim \text {-ине /-yeNA } \\
\text {-yiNyE }\end{array}$ & Стативы со значением свойства \\
\hline -ай / -ä̈ $\emptyset^{\mathbf{W}}$ & стативы со значением свойства: результативы \\
\hline$-\boldsymbol{-} /-\mathbf{E}$ & $\begin{array}{l}\text { Непредельные проиессы либо стативы: типичное } \\
\text { движение или поведение }\end{array}$ \\
\hline $\begin{array}{l}\text {-pa } \sim \text {-ире / RA } ~ \\
\text { yiRyE Vi c }\end{array}$ & $\begin{array}{l}\text { Henредельные процессы: мультипликтивные ситуации } \\
\text { хаотичного движения (с дополнительным компонентом } \\
\text { метафорического уподобления 'подобно Р') }\end{array}$ \\
\hline$-\mathbf{o c} /-\mathbf{o S} \mathbf{v} \mathbf{i} \mathbf{c}$ & $\begin{array}{l}\text { Hепредельные процессы: мультипликтивные ситуации, } \\
\text { разделенные на кванты значительными промежутками } \\
\text { времени, либо ситуации, осуществляющиеся медленно } \\
\text { и с трудом }\end{array}$ \\
\hline -(a)бăp / -(a)BØR & $\begin{array}{l}\text { Hепредельные процессы: ситуации (часто, } \\
\text { но не обязательно мультипликативные), } \\
\text { осуществляющиеся редко, замедленно либо неуклюже }\end{array}$ \\
\hline Стативы -я /- Ү̈А. & $\begin{array}{l}\text { Стативы со значением свойства: группа глаголов } \\
\text { качественной семантики, в которую входят также } \\
\text { основы образной семантики. }\end{array}$ \\
\hline
\end{tabular}




\begin{tabular}{|c|c|}
\hline Суффикс & $\begin{array}{c}\text { Аспектуальный класс: } \\
\text { лексическое значение производных глаголов }\end{array}$ \\
\hline \multicolumn{2}{|c|}{ Производные глаголы с перфективным значением } \\
\hline $\begin{array}{l}\text {-хадӑ -цядӑ -зядӑ } / \\
\text {-ХА-ТØ -ХуА-ТØ } \\
\text { Vi m }\end{array}$ & $\begin{array}{l}\text { Cобытия: семельфактивы, описывающие резкое } \\
\text { действие - мелкое быстрое движение, громкий звук } \\
\text { или сопровождающееся громким звуком действие }\end{array}$ \\
\hline -ел / -yeL Vr m & События: инхоативы \\
\hline -ep / yeR Vr m & События: инхоативы \\
\hline$-o R$ Vr m r & $\begin{array}{l}\text { События: инхоативы ( } 50 \text { \% инхоативов с этим } \\
\text { суффиксом составляют основы образной семантики) }\end{array}$ \\
\hline$-\boldsymbol{- \sigma R}$ Vr m r & $\begin{array}{l}\text { События: инхоативы ( } 50 \text { \% инхоативов с этим } \\
\text { суффиксом составляют основы образной семантики) }\end{array}$ \\
\hline$-\mathbf{M} /-\mathbf{M ~ V r ~ m ~}$ & События: семельфактивы \\
\hline
\end{tabular}

\section{Литература}

Аврорин 1961 - В. А. Аврорин. Грамматика нанайского языка. Т. 2. М.; Л.: Издво АН СCCP, 1961.

Буркова 2010 - С. И. Буркова. Краткий грамматический очерк восточных говоров тундрового диалекта ненецкого языка // С. И. Буркова, Н. Б. Кошкарева, Р. И. Лаптандер и др. (сост.). Диалектологический словарь ненецкого языка. Тюмень: БАСКО, 2010. С. 179-349.

Гусев 2010 - В. Ю. Гусев. Стативы и декаузативы на *-w в самодийских языках // С. И. Буркова (ред.). Материалы 3-й Международной научной конференции по самодистике. Новосибирск, 26-28 октября 2010. Новосибирск: Любава, 2010. C. 54-65.

Плунгян 2011 - В. А. Плунгян. Введение в грамматическую семантику: грамматические значения и грамматические системы языков мира. М.: РГГУ, 2011.

Терещенко (сост.) 1965 - Н. М. Терещенко (сост.). Ненецко-русский словарь. М.: Советская энциклопедия, 1965.

Salminen 1997 - T. Salminen. Tundra Nenets Inflection (Suomalais-Ugrilaisen Seuran Toimituksia. Vol. 227). Helsinki: Suomalais-Ugrilainen Seura, 1997. 
Salminen 1998 - T. Salminen. A Morphological Dictionary of Tundra Nenets (Lexica Societatis Fenno-Ugricae. Vol. XXVI). Helsinki: Suomalais-Ugrilainen Seura, 1998.

\section{References}

Avrorin 1961 - V. A. Avrorin. Grammatika nanayskogo yazyka [Grammar of the Nanai language]. Vol. 2. Moscow; Leningrad: Publishing House of the USSR Academy of Sciences, 1961.

Burkova 2010 - S. I. Burkova. Kratkiy grammaticheskiy ocherk vostochnykh govorov tundrovogo dialekta nenetskogo yazyka [A brief grammar sketch of the eastern dialects of the Tundra dialect of the Nenets language]. S. I. Burkova, N. B. Koshkareva, R. I. Laptander et al. (comp.). Dialektologicheskiy slovar nenetskogo ya$z y k a$ [The dialectological dictionary of the Nenets language]. Tyumen: BASKO, 2010. P. 179-349.

Gusev 2010 - V. Yu. Gusev. Stativy i dekauzativy na *-w v samodiyskikh yazykakh [Statives and anticausatives on $*_{-} w$ in Samoyedic languages] S. I. Burkova (ed.). Materialy 3-y Mezhdunarodnoy nauchnoy konferentsii po samodistike. Novosibirsk, 26-28 oktyabrya 2010 [Proceedings of the Third international conference on Samoyedic languages. Novosibirsk, 26-28 October 2010]. Novosibirsk: Lyubava, 2010. P. 54-65.

Plungian 2011 - V. A. Plungian. Vvedenie v grammaticheskuyu semantiku: grammaticheskie znacheniya i grammaticheskie sistemy yazykov mira [Introduction to grammatical semantics: Grammatical meaning and grammatical systems of the world's languages]. Moscow: Russian State University for the Humanities Press, 2011.

Salminen 1997 - T. Salminen. Tundra Nenets Inflection (Suomalais-Ugrilaisen Seuran Toimituksia. Vol. 227). Helsinki: Suomalais-Ugrilainen Seura, 1997.

Salminen 1998 - T. Salminen. A Morphological Dictionary of Tundra Nenets (Lexica Societatis Fenno-Ugricae. Vol. XXVI). Helsinki: Suomalais-Ugrilainen Seura, 1998.

Tereshchenko (comp.) 1965 — N. M. Tereshchenko (comp.). Nenetsko-russkiy slovar [Nenets-Russian dictionary]. Moscow: Sovetskaya entsiklopediya, 1965. 


\section{Indo-Iranian loanwords in Finnic - a critical overview*}

\section{S. Holopainen}

University of Helsinki (Finland); sampsa.holopainen@helsinki.fi

Abstract. The article deals with presumed Indo-Iranian loanwords in Finnic languages which have no cognates in other branches of the Uralic language family. A mainstream view, held by nearly all scholars of Uralic etymology, is that the contacts began already at the proto-language level, and that the words with a wide distribution in Uralic languages were borrowed from Proto-Indo-Iranian. Actually, contact is even attributed to before that, from "Pre-Indo-Iranian" which was still retaining the PIE vowel system, while some changes characteristic of Indo-Iranian had already happened in the consonantal system. The article discusses all the etymologies presented in earlier research and assesses their credibility (convincing/unconvincing/unclear). According to the author, the number of Indo-Iranian borrowings restricted to Finnic is in fact very low. In almost half of the cases evaluated in the paper, the words are either of non-Indo-Iranian origin or have cognates in other Uralic languages. If the unclear cases are counted, the number is even greater. Finnic words with a plausible Indo-Iranian etymology clearly reflect several diachronic layers, all of which are shared by some other Uralic branches. This means that Finnic could not have acquired these words as a separate language. Some clearly late Iranian loans such as varsa and vasa have regular cognates in Mordvin [Koivulehto 1999a: 218-219], whereas some more archaic words are confined to Finnic. It is, however, interesting to note that many of the loanwords confined to Finnic manifest clearly Iranian features, and among those that are not demonstrably Iranian, there are no features that force us to consider these borrowings earlier Proto-Indo-Iranian loans; some of the more archaic loans are either problematic (such as verso) or should be rejected (such as herätä).

There are few irregular cases (*waćara, *akštara, *̌̌ukta) which cannot be explained as wrong etymologies or results of undetected sound laws, though. They could either be parallel Indo-Iranian loans or indicate that the respective Indo-Iranian words

* I would like to express my gratitude to Janne Saarikivi, Niklas Metsäranta, Santeri Junttila, Petri Kallio, Juha Kuokkala and the editor of this volume for useful comments and discussions on the topic of this paper and comments of its earlier versions. All the remaining errors are, of course, mine. A large part of the results of this paper has been published in my 2019 dissertation Indo-Iranian borrowings in Uralic: critical overview of sound substitutions and distribution criterion. 
spread through a dialect continuum which consisted of predecessors of Finnic, Saami and Mordvin, at the least. However, at least *waćara and * šukta clearly reflect different layers of Indo-Iranian borrowings (*waćara with *ć from PII *j and *šukta with * ś from PI $* t s$ ). It is therefore unlikely that they were simultaneously diffused through the already differentiated West-Uralic dialects.

Keywords: Finnic languages, Uralic languages, Indo-Iranian languages, etymology, language contact.

\section{Индоиранские заимствования в прибалтийско-финских языках: критический обзор}

\section{С. Холопайнен}

Хельсинкский университет (Финляндия); sampsa.holopainen@helsinki.fi

Аннотация. В статье рассматриваются предполагаемые индоиранские заимствования в прибалтийско-финских языках, не имеющие соответствий в других ветвях уральской языковой семьи. Основная точка зрения, которой придерживаются почти все исследователи уральской этимологии, состоит в том, что контакты начались уже на праязыковом уровне и что слова, широко представленные в уральских языках, были заимствованы из праиндоиранских языков. Более того, есть даже точка зрения, относящая контакт к «доиндоиранской» эпохе, когда сохранялась еще праиндоевропейская система вокализма, а в системе согласных уже произошли некоторые изменения, характерные для индоиранских языков. В статье обсуждаются все этимологии, предложенные в более ранних исследованиях, и оценивается их достоверность (убедительные / неубедительные /неясные). По нашему мнению, количество индоиранских заимствований, ограниченных прибалтийско-финскими языками, на самом деле очень мало. Почти в половине случаев, рассмотренных в статье, слова либо не являются индоиранскими по происхождению, либо имеют соответствия в других уральских языках. Если включить в эти подсчеты и случаи неясных этимологий, число слов, которые нельзя считать заимствованиями из индоиранских в прибалтийско-финские, будет еще больше. Прибалтийско-финские слова, имеющие надежные индоиранские этимологии, без сомнения, отражают несколько диахронических пластов, и при этом они имеют соответствия в других уральских ветвях. Это означает, что праприбалтийскофинский язык не мог заимствовать эти слова сепаратно, как отдельный язык. Некоторые явно поздние иранские заимствования, такие как varsa или vasa, имеют регулярные соответствия в мордовском языке [Koivulehto 1999a: 218-219]. Есть и некоторое количество более архаичных иранских слов, дистрибуция которых ограничивается прибалтийко-финскими. Надо отметить, что многие из таких заимствований явно 
демонстрируют черты, характерные для иранских языков, а те, которые не являются очевидно иранскими, не имеют таких особенностей, которые заставляли бы нас датировать их более ранней доиндоиранской эпохой; наконец, этимология некоторых из таких предполагаемых архаичных заимствований либо проблематична (как в случае verso), либо должна быть отклонена (как в случае herätä).

Есть несколько случаев очевидно верных этимологий, демонстрирующих нерегулярные фонетические соответствия. (*waćara, *akštara, *šukta); их фонетический облик не получается объяснять как результат действия каких-то еще не сформулированных звуковых законов. Можно думать, что в данном случае мы имеем дело либо с параллельным заимствованием индоиранских слов в отдельные языки, либо с распространением индоиранских слов в рамках диалектного континуума, который состоял по крайней мере из прибалтийско-финских, саамских и мордовских языков. Но, как минимум *waćara и * šukta, без сомнения, отражают разные временные слои индоиранских заимствований (*waćara * $^{\prime} c^{\prime}$ из праиндоиранского *j, но *šukta

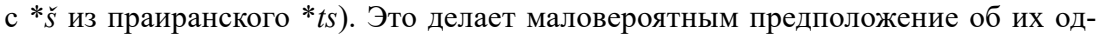
новременном распространении в отдельных западных ветвях уральских языков.

Ключевые слова: прибалтийско-финские языки, уральские языки, индоиранские языки, этимология, языковые контакты.

\section{Introduction}

The study of Indo-Iranian loanwords in Uralic languages has a notable history of more than a hundred years (see [Joki 1973: 3-243] for a comprehensive presentation of early research history). A mainstream view, held by nearly all scholars of Uralic etymology, is that the contacts began already at the proto-language level, and that the words with a wide distribution in Uralic languages were borrowed from Proto-Indo-Iranian. Actually, contact is even attributed to before that, from "Pre-Indo-Iranian", which was still retaining the PIE vowel system, while some changes characteristic of Indo-Iranian had already happened in the consonantal system ${ }^{1}$. Some geographically central branches of the Uralic family, such as Permic or ObUgrian, as well as Hungarian, continued to contact Iranian languages until the late prehistorical period and early Middle Ages, cf. [Korenchy 1972; Joki 1973; Rédei 1986]. However, for reasons relating to the geographical

${ }^{1}$ It is possible that there were contacts already between Proto-Uralic and Proto-Indo-European, cf. [Koivulehto 2001b], but this is beyond the scope of this article. 
location of Proto-Finnic it has been usually assumed that Proto-Finnic did not have any independent contacts with Indo-Iranian languages after its split from Proto-Uralic.

In the late 1990s and early 2000s, Jorma Koivulehto [1999a; 2001a, 2001b], Asko Parpola [1999] and Pekka Sammallahti [1999; 2001] proposed a number of Indo-Iranian etymologies for words that are found only in the Finnic or Saami branches. In this paper, I investigate all the etymologies that have a distribution limited only to Finnic. I try to determine whether it is reasonable to suppose their independent borrowing by Pre-/Proto-Finnic, or whether their cognates were simply lost from other Uralic languages. Indo-Iranian etymologies in Saami were explored in a similar study elsewhere [Holopainen 2018].

The importance of this topic was highlighted e.g. by Saarikivi and Grunthal [2005: 127-129]. The dating of Finnic separation from its nearest neighbouring branches is influenced by the early Indo-European etymologies, which were suggested mainly by Koivulehto. Early Indo-European (incl. Indo-Iranian) loans in Finnic missing from elsewhere have indeed been used as evidence for early dispersal of the Uralic family. The same statement was made about loanwords in Saami, which likewise includes a lot of vocabulary with tentative archaic Indo-European origin. However, Koivulehto himself has expressed the view that the distribution alone is not a well-working criterion in determining the age of Indo-European loans in Uralic [Koivulehto 1999a: 210]. The same view was expressed also by Kallio [2012: 227], and I agree with it. So the very fact that a loanword is present only in Finnic (or Saami, Mordvin, or any other branch of Uralic) tells less of its age than the phonological characteristics.

In this article, I concentrate on linguistic evidence, and leave archaeological and other kinds of considerations aside (some recent archaeological considerations are very briefly summarized below).

\section{The background of the contacts}

\subsection{Taxonomy of Finnic within the Uralic language family}

While the Uralic language family is a clearly defined entity, the exact relations between different branches of Uralic are a matter of discussion, viz. [Itkonen 1997; Salminen 2001; 2002; Häkkinen 2009]. Only the problems 
concerning the taxonomy of Finnic relevant for our topic are shortly presented here ${ }^{2}$.

Although many of the proto-languages postulated between Proto-Uralic and Finnic in earlier research are now considered obsolete by many researchers [Häkkinen 1984; Itkonen 1997; Salminen 2002; Saarikivi 2011: 88-95], it is possible that the Saami and the Mordvin branches of Uralic are genetically the most closely related to Finnic. This has been stated explicitly by Häkkinen [2009: 15-16], who calls the Finno-Saami-Mordvinic proto-language West-Uralic, and some others (e.g. [Aikio 2015b]) have followed his example. However, the exact relationship between these three branches is not clear at all [Zhivlov 2014: 115-117; Saarikivi 2011: 106110; Saarikivi, Grünthal 2005: 114-117, 122]. Traditionally it was assumed that Saami and Finnic are most closely related to each other (see, for instance, [Sammallahti 1999]), but this view is frequently criticized in modern research. Aikio [2012b: 69] states that the relation between Saami and Finnic is verycomplicated due to a long-lasting areal convergence, to the point that the issue "remains so far unsolved, and perhaps insoluble".

The views on when Proto-Finnic or its predecessor started to be spoken around the Baltic Sea vary widely [Aikio 2012b; Saarikivi, Grünthal 2005]. Most recently, Valter Lang [2015; 2016: 32-33] has suggested a new convincing model for the split and dispersal of the Finnic branch. He suggested that the predecessor of Proto-Finnic has spread from the Volga region to the Daugava basin in the Baltic area and from there to its current speaking area in the Late Bronze Age. This idea places the early phases of Finnic more south and east than has often been assumed, perhaps bringing the speakers of Pre-Finnic to closer proximity to speakers of Iranian.

\subsection{Taxonomy and prehistory of Indo-Iranian}

The Proto-Indo-European language was probably spoken in the Pontic steppes, and Proto-Indo-Iranian likely emerged near this area as well

\footnotetext{
${ }^{2}$ A short remark should be made on terms Proto-Uralic and Proto-Finno-Ugric. I am not taking a stance on whether to reconstruct a Proto-Finno-Ugric intermediary stage after the Proto-Uralic one or not. The term Proto-Uralic is used in the paper for the reconstructed proto-language which acquired the earliest Indo-Iranian loans, and also for the reconstruction stage preceding the characteristic, possibly common innovations of Finnic, Saami and Mordvin.
} 
[Mallory 1991; Parpola 2015: 35-50; Kallio 2006]. It can be assumed that after the Proto-Indo-European period, the linguistic ancestors of Indo-Iranians, Armenians and the Greeks occupied the territory of the so-called Yamnaya culture from ca. 3300-2500 BC. These three branches of Indo-European share numerous innovations, so they might go back to the same dialect of Indo-European [Martirosyan 2010]. According to Parpola [2015: 51-54], the Proto-Indo-Iranians lived in the so-called Catacomb Grave culture between Dnepr and Volga from 2500 BC onwards.

Proto-Indo-Iranian and Proto-Iranian obviously were geographically close enough to Proto-Uralic (or at least Proto-Finno-Ugric) for the contacts to occur. This is proven by a large number of early borrowings wide-spread in the Uralic languages (for example, PU *śata 'hundred' $\leftarrow$ PII *ćatá- id., $\mathrm{PU} *$ asVra 'lord' $\leftarrow$ PII *ásura- id.).

In the Uralic languages, even the oldest loanwords consist of several layers. The earliest Indo-Iranian loans were acquired from Pre-Indo-Iranian, and later a large number of loans were acquired from Proto-Indo-Iranian proper. After the split-up of Proto-Uralic, its daughter languages continued to be in contact with Iranian languages, which resulted in different loanword layers in different branches of Uralic. According to Koivulehto [1999a: 220-227; 2001b: 254-299], in the western part of the Uralic family (corresponding to the traditional Finno-Permic affinity) there are loans which are clearly Proto-Iranian; also the Finnic languages include many such cases. The latest loans in Finnic are probably later than the Proto-Iranian stage. They show some phonological innovations characteristic of Ossetic and might therefore be from an early form of Alanian (for example, Fi varsa 'foal' $\leftarrow$ Pre-Ossetic *warsa-, cf. Ossetic wyrs, urs; from PII * wršan[Koivulehto 1999a: 226-229].

Indo-Aryan origin has also been supposed for some Uralic and Finnic words, see [Parpola 1999; Koivulehto 1999a: 219-220, 231-233; Napolskikh 2014], but there is no conclusive evidence to postulate contacts between Uralic and Indo-Aryan. Koivulehto [2007: 254, footnote 4] dropped the idea of Indo-Aryan loans later. Helimski [1997] has also suggested that a part of Indo-Iranian loans in some Uralic languages could be derived from an unattested branch of Indo-Iranian, the so-called Andronovo Aryan. However, this idea has not received general acceptance, and anyway is not so much relevant for the study of loanwords in Finnic (see Zhivlov [2013] in support of Helimski's hypothesis, and Napolskikh [2014: 84-85] for criticism).

The later, recorded history of Indo-Iranian languages in the Near East and Central and South Asia is well-documented and will not be presented here. 


\section{Survey of the etymologies}

I will further discuss all the etymologies presented in earlier research and assess their credibility (convincing/unconvincing/unclear). The etymologies are taken mainly from the following sources: [Aikio 2014; 2015b; Blážek 1990; EES; Joki 1973; Koivulehto 1999a; 2000; 2001a; 2001b; 2003 3; 2005; Parpola 1999; 2010; Rédei 1986; SSA; Uotila 1973], although many of the etymologies stem originally from earlier works, such as [Munkácsi 1901] or [Jacobsohn 1922]. The etymologies presented by Katz [2003] will not be systematically discussed here, because the methods and results of Katz have been not widely accepted within the Uralic linguistics, cf. [Aikio, Kallio 2005] for a detailed criticism of Katz's work. The default forms given here are (standard) Finnish if not mentioned otherwise.

\subsection{Possible Pre-Indo-Iranian etymologies (Pre-II *e retained)}

\subsubsection{Herätä, heräjä- 'to wake up' (has cognates in all Finnic languages)}

$\leftarrow$ Pre-II *Hdžer- > Av perf. jayara 'is awake', OI medium jarase 'he wakes up' ([Cheung 2007] * Hgar- ${ }^{4}$; [EWAIa I 574-575]; [LIV 245-246] s. v. ${ }^{*} h_{1}$ ger-)

([Koivulehto 1999a: 221, 2001b: 291])

Koivulehto assumes that in this very early borrowing the Indo-Ira-

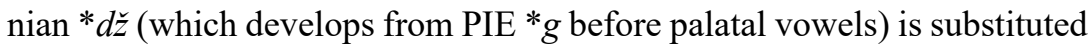
by Pre-Finnic * ${ }^{c}$. The Indo-Iranian root is probably inherited from Indo-Eu-

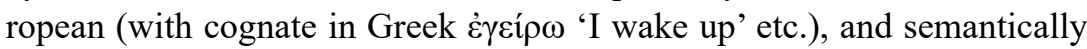
the loan etymology is convincing.

However, Koivulehto's assumption that Finnic $h$ can reflect earlier $*_{\breve{c}}$ is outdated by now. Aikio [2015a: 4-5] has convincingly shown that $*_{\check{c}}$ develops to $t$ in all positions in Finnic, and earlier examples of the development $*_{\breve{c}}>h$ are falsely reconstructed. Thus, the Finnic word has

${ }^{3}$ This work is an unpublished handout of a presentation, but the etymologies have been later published and commented in [EES] and [Häkkinen 2004].

${ }^{4}$ Cheung's notation shows the retained * $g$ - because in certain positions (before back vowels) the velar stop was regularly retained. 
to reflect earlier $*_{s ̌ e r a ̈}$, if the word indeed goes back to an earlier stage than Proto-Finnic. If the etymology is correct, a substitution $* \check{s} \leftarrow * d z ̌$ has to be assumed. This is possible but unlikely, as the affricate $* \check{c}$ would be the expected substitution. PII * $d \check{z}$ was retained in both Proto-Iranian and Proto-Indo-Aryan, so a later Iranian loan into Finnic is also unlikely, and the $e$-vocalism also makes this assumption impossible.

Furthermore, Junttila (manuscript) connects the verb herätä to the adjective herkkä 'sensitive' (= Estonian erk 'watchful'). Also [EES] (s. v. erk) and already [SKES] connect the verb to Finnish herkkä and its cognates. This makes the background of the Finnic word more complicated. Junttila also mentions that the Finnic word has been borrowed from another Indo-European word, from a reflex of the verbal root *ser- 'to keep an eye on, to protect' ([LIV: 534] s. v. *ser-), although Junttila does not specify which Indo-European language would be the most suitable origin for the Finnic verb. LÄGLOS ([I: 98-99], s. v. herätä) notes that earlier Koivulehto [1976] has suggested that an unattested Germanic reflex of this Indo-European verbal root could be the origin of the Finnic word, but [LÄGLOS] finds this very unlikely. According to [LIV] the root *ser-is attested at least in Indo-Iranian (Av ni-šayharatū 'has to watch over') and Greek (Homeric obpovtal 'watch over', 3PL.MED, Mycenean o-ro-me-no 'watching over' ${ }^{5}$ ) and possibly in Anatolian (Lydian sarẽta- 'protector', katared- 'keeps watch'). In an old (Proto-)Indo-European loan a substitution Uralic $* \check{s} \leftarrow$ Indo-European $*_{s}$ might occur, as a similar substitution is known from various Germanic loans [LÄGLOS I: 98-99]. If the explanation revived by Junttila is accepted, the Indo-Iranian etymology can easily be rejected, although here one has to share the criticism by [LÄGLOS]: it would certainly be preferable to be able to point out a convincing donor form from some daughter-language of Proto-Indo-European.

Etymology: unconvincing

\subsubsection{Piimä 'sour milk', Est piim 'milk', also in Karelian',} Ingrian, Votic $<$ ? Pre-Fi * pejmä

$\leftarrow$ Pre-II * peyHmn- (> PII, PI * payHman-) 'thick fluid; milk’> Av paèman'mother's milk'; derived from the PIE root *peyH- 'to be thick; to swell' ([EWAia II: 83-84; Garnier et al. 2017: 300]; [LIV: 464-465] s. v. *peyH-)

5 According to Beekes [2010: 1095-1096], the Greek word is rather from PIE *wer-, although he admits that the absence of the reflexes of $\mathrm{F}_{-}\left(<\mathrm{PIE}^{*} w\right.$ - $)$ in some forms is problematic.

${ }^{6}$ According to [SSA] and [EES], the Karelian word is probably borrowed from Finnish. 
([Munkácsi 1901: 263, 597; Joki 1973: 302]; [SSA II] s. v. piimä; [EES] s. v. piim; [UEW] s. v. *pije- [378] and *pä 'e- [359])

The idea of an Indo-Iranian origin of this Finnic word is old (stemming from Munkácsi), but its acceptance has varied over the years. Joki accepts the etymology with caution. The Indo-Iranian etymology of the Finnic word is also mentioned in a recent article by Garnier et al. [2017: 300]. [SSA] states that because of phonological reasons the Iranian loan etymology is less probable than borrowing from a hypothetical Baltic form *piyimas. The phonological reason is that Finnic $i i$ would be easier to explain from hypothetical Baltic *iy than from Iranian *ay or earlier Indo-European *ey; this would be a cognate of the Iranian word, but this form is only hypothetical and not attested in Baltic (Lithuanian has a verb pýti 'to get milk' which is derived from the same Indo-European root ([LIV] s. v. *peyH-), and there is also Proto-Baltic noun *peinas 'milk' reflected as pienas in Lithuanian and piens in Latvian, but no corresponding noun to Indo-Iranian *payHmanor *payHas- is found in Baltic). The idea stems from Larsson [1984: 12940], and this is supported also by EES, which notes also that the limited distribution of the word within Finnic points to the Baltic origin. Larsson also notes that the Avestan word paeman- reflects earlier diphthong *oy, but this is not correct according to modern research; [Garnier et al. 2017] reconstruct the predecessor of the Iranian word as *peyHmn-.

However, since Aikio [2014: 90-91] has convincingly argued that Finnic long ii can result from Pre-Finnic *ej, cf. also [Kallio 2018: 262-263], the (Indo-)Iranian etymology does not seem improbable; the word could be a borrowing from a Pre-Indo-Iranian form which still retained PIE * $e$ : Pre-II * peyHmn- $\rightarrow$ Pre-Fi * pejmä > piimä. Junttila [2012: 275] in his survey of Baltic borrowings in Finnic casts doubt on the Baltic origin of this word because the exact Baltic source is unattested, so it seems that the Indo-Iranian etymology is clearly the best option. [EES]'s note that the word's distribution is limited within the Finnic branch does not make Baltic origin more probable, as most of the Baltic loans also have a wide distribution, and the word is in any case attested in various Finnic languages on both sides of the gulf of Finland.

[SSA] also mentions that Mo E ṕed'ams, ṕäd'ams, M ṕed'ams 'to sieve; to milk a cow' and $\mathrm{Hu} f e j$ 'to milk a cow' have been considered cognates of this Finnic word in earlier research. If the Finnic word indeed reflects * $e j$, the Hungarian word could be its cognate, as Hungarian ej could regularly reflect PU *ej. However, according to [SSA], Finnic - $m a$ would be a derivational suffix in this case, and the Hungarian form would reflect the underived stem. This seems possible, but the Hungarian word could also be 
an early parallel loan from another Indo-Iranian form derived from the same root, namely *payHas- 'thick fluid' (> Av paiiah- 'milk', OI páyas- id.; cf. [EWAia II: 83-84; Garnier et al. 2017: 301-302]). The Hungarian word could also reflect a later Middle Iranian form, where * $a$ has developed to $* \ddot{a}$. Róna-Tas [2017: 62-63] has recently called into question the Iranian etymology of the Hungarian word because of word-class differences: the Hungarian word is a verb, whereas in Indo-Iranian, the word is only a noun, as a different root is used to denote 'milking'. Even though no verb 'to milk' is derived from this root in (Indo-)Iranian, the Baltic verb pýti mentioned above shows this kind of development from the root originally meaning 'to be thick, swollen'; a parallel semantic development for this root in some Iranian language of the steppe is not impossible to imagine. The Indo-Iranian verbal root * payH-also has attested meanings related to milk, such as Vedic payate 'oozes with milk' and Avestan pipiiuši- 'bringing milk', cited by [LIV], so the semantics of the Hungarian verb should not pose a problem for the etymology. Phonologically, there are no difficulties in connecting the Hungarian and Iranian words, and it is natural to suppose that $f e j$ is a loanword like many other words related to pastoralism and cattle terminology in Hungarian.

The Mordvin word is a more peculiar case: [UEW] reconstructs its predecessor as *pe 'mä and suggests cautiously that it can be cognate to the Hungarian word. On the other hand, [UEW] also reconstructs *peje- (which would be *peji- in our reconstruction) as a possible predecessor of the Finnic and Hungarian forms. The Indo-Iranian origin is mentioned in both entries of [UEW]. The Finnic word obviously cannot be derived from a form with $* \delta$ '. An Indo-Iranian origin for a PU form *pe 'mä would be difficult to suppose. However, it is not at all clear that the Mordvin word reflects this kind of proto-form. If Mordvin - $d$ ' $a$ - is a suffix, it can be postulated that $p e-$ reflects earlier *pej-, and the $-j$ - has been lost before the suffix. This seems to be the case in some other Mordvin words, such as PU *pexi- 'boil'> Mo pije->pi-d'ems [Sammallahti 1988: 539], but the exact development of the Mordvin word needs more research.

Honti [2017: 95-97] has also criticized the Iranian etymology of the Hungarian word, but without providing any detailed arguments. In Honti's view the Mordvin and Hungarian words can be cognates, but the Finnic word cannot be connected with the Hungarian one. Again, no details are given.

To sum up, it can be stated that the Indo-Iranian origin for the Finnic word looks plausible. The Mordvin and Hungarian words probably reflect separate borrowings from Iranian.

Etymology: convincing 
3.1.3. Terni (stem terni-) 'milk of a cow that has recently given birth, colostrum', also Est ternes, ternespiim, Votic terne,

Lv ter-sēmd'a id. < ? PFi *terni

$\leftarrow$ ? Pre-II *teru-no-, PII *taruna- > OI táruna- ‘young, fresh' Av tauruna- 'young; son', Oss toeryn 'son' ([EWAia I: 632])

([Rédei 1986: 61]; [SSA] s. v. terni; [EES] s. v. ternes)

The Indo-Iranian etymology for the Finnic word is an old idea and it is mentioned as a possibility by both [SSA] and [EES]. However, the etymology is not without its problems, and it has been criticized by Jacobsohn [1933: 138-139] already. Jacobsohn notes that it is unlikely that the Finnic disyllabic word could be derived from thrisyllabic Indo-Iranian *taruna-. Also the form tárna- is attested in Old Indic, but this is a later form that shows a Middle Indo-Aryan development, and it is impossible to derive the Finnic word from this kind of form. One could perhaps assume that syncope has occurred in the Finnic side, which would be unlikely, or that the word has simply been borrowed as disyllabic.

According to [EWAia], cognates of the Indo-Iranian word are attested in other Indo-European languages too (cf. Greek $\tau \dot{\varepsilon} \rho \eta v$ 'soft, delicate', $\tau \dot{\varepsilon} \rho v$ 'weak, soft' Latin tener 'soft, delicate', if metathesized, cf. [de Vaan 2008: 613]). [EWAia] considers the connection of táruna- and the adjective turá- 'sick; tender' possible. According to [EWAia], both could be derived from the PIE root *terh ${ }_{3^{-}}$'to grind', turá- reflecting earlier *trh $h_{3} o^{-}$, cf. also [LIV: 634]. Theoretically the Finnic word could be a borrowing from some other archaic branch of Indo-European, although assuming a loan from some other branch of Indo-European would also not solve the phonological problems, and one has to note that the word does not appear in the branches such as Balto-Slavic or Germanic that have had most contact with Finnic, and the meaning 'soft' attested in other branches does not really fit the meaning of the Finnic words. Regarding the vocalism, Finnic * $e$ cannot result from PII * $a$, so it might be a substitute for Ossetic-type $* \alpha$ but there are no parallel cases to such substitution. This would require more research, and the Ossetic word's meaning is very far from the one found in Finnic. Finnic $e$ could be easily derived from Pre-Indo-Iranian $* e$, which would point to a very early borrowing.

Modern Finnic words reflect different forms. Finnish unaltering $i$ stem is likely a result of a secondary derivation, cf. *kota-j $>$ koti 'home'. Estonian form probably continues PFi *terneš (the Estonian $s$ here can be generalized from Sandhi forms, as it is not a regular reflex of $*_{s}$ ). It is 
difficult to judge what was the original stem-vowel in the Proto-Finnic or Pre-Finnic word.

[EES] also tentatively connects the noun to the verb terendama 'shimmer' (Fi terhentää), which has a possible but disputed Baltic etymology (from a hypothetical Baltic form *ster-, postulated on the basis of Latvian stars 'ray' [Vaba 1997b]; see [SSA] s. v. terhentä̈̈; [Junttila 2015: 183-184] for criticism). The etymological connection of *tern $V$ and this verb does not look plausible because of semantic reasons.

Taking into account all the problems mentined above, the Indo-Iranian origin of the Finnic word cannot be considered as certain. The word is probably a loan, and many other Finnic terms connected to cattle breeding are Indo-Iranian loans (see piimä and tiine), so this word would also fit well into this category of borrowings.

Etymology: unclear

\subsubsection{Tiine, Ka tiineh 'pregnant', SEst tiinõh (cognates also in Veps,} Ludic, Votic, Ingrian and Estonian) $<\mathrm{PFi} *$ tiineš $<\mathrm{Pre}-\mathrm{Fi} *$ tejniš

$\leftarrow$ PIE/Pre-II *dheHinu- 'pregnant (of animals)'> OI dhenú- 'cow, milking cow', Av daēnu- 'female animal' ([EWAia I: 797])

([Kalima 1936: 169; Joki 1973: 329]; [SSA III] s. v. tiine; [EES] s. v. tiine; [Aikio 2014: 90-91])

The Indo-Iranian etymology of the Finnic word stems from Kalima [1936: 169]; the possible Baltic origin (from Baltic *deini > Lith. dieni;

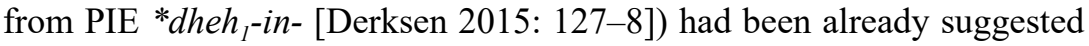
earlier by Lõo [1911: 86]. The possible relationship of the Finnic word to Mari tüž, tüjôž 'pregnant (animal)' [TschWB: 846] is likewise an old idea. Both the Baltic *deini and Indo-Iranian *dhainu- are derived from the PIE root *dheh I- $^{-}$'to suck mother's milk' ([LIV: 138] s. v. dheh ${ }_{1^{-}}$; [Garnier et al. 2017: 296]). [SSA] considers both Baltic and Indo-Iranian origins for the Finnic word possible and is uncertain about the relationship with the Mari word. Joki rejects the Mari cognate and considers the Finnic word either a Baltic or Indo-Iranian loan. Interestingly, Joki tentatively considers *tejni a possible preform of the Finnic word. Both the possible Baltic and Indo-Iranian origins, as well as the possible relation to Mari tüž are also mentioned by [EES]. The Finnic and Mari words are not mentioned in the [UEW].

The uncertainty stems from the unclear background of Finnic ii. Recently Aikio has convincingly shown that the suggested Mari cognate tüz̆, 
tüjâž 'pregnant (animal)' is regular because *ej > ii is a regular development in Finnic (see above Section 3.1.3). Therefore, it is clear that even if this word is an Indo-Iranian loan, it was borrowed into an earlier proto-language and is not part of the words restricted to Finnic only. The Indo-Iranian origin is not at all straightforward, because the word can be also an earlier PIE loan, as it does not manifest the sound change $* e>* a$. The origins of the second syllable vowel and consonants are unclear there are no examples of $*_{s}$ reflecting the PII $*_{s} s$ of the nominative endings. Aikio supports the obvious Indo-European origin of the Finno-Mari word, but leaves the exact donour language (Indo-Iranian or Baltic) open. This requires further study. Many other terms connected to cattle breeding and animal husbandry have been borrowed from Indo-Iranian, and this word would fit well into that group of borrowings. On the other hand, if the word was a Baltic (or Balto-Slavic) loan, it would not have to be so extremely early borrowing, as * $e$ would have been regularly retained there. Semantically the attested Baltic forms (Lith. dieni 'with young') are closer to the Finnic and Mari words than the Indo-Iranian words where the meanings relating to pregnancy are not attested.

It is interesting to note that Liukkonen [1999: 142-4], arguing for a Baltic etymology of the word, had already proposed similar kind of explanation for the development of the Finnic long vowel, which Junttila [2012: 278] nevertheless rejected as impossible. Now it can be stated that Junttila's rejection of Liukkonen's explanation was too hasty, thanks to Aikio's new groundbreaking studies. Also [SSA] mentions that the Indo-European explanation can be correct if the Finnic word reflects earlier *ej diphthong. However, the detailed explanation of the sound law $* e j>i i$ is attributable to Aikio.

Etymology: unclear (certainly an Indo-European loan, but not necessarily Indo-Iranian)

\subsubsection{Verso, Est võrse 'sprout'; verb versoa} (also in Karelian) ${ }^{7}$, Est võrsuma 'to sprout'

$\leftarrow$ PII *varća- (? Pre-II *verćo-) > OI válsá- 'shoot, sprout, twig', Av varasa- 'hair, hair on the head'; or $<\leftarrow$ PII *wrćša- > OI vrkșá- 'tree', varasa- 'a plant' ([EWAia II: 526-527; Lubotsky 2001: 313])

([Parpola 1999: 201]; [SSA] s. v. verso)

\footnotetext{
7 The Karelian verb is possibly borrowed from Finnic ([EES] s. v. võrsuma).
} 
The semantic connection of the Indo-Iranian and Finnic words can hardly be a coincidence, and on the first sight the etymology looks convincing. However, some phonological problems are involved.

The word is either a Pre-II loan where the Finnic initial syllable vowel reflects $* e$ of the donour language, or the root-internal $e$ has to result from a substitute of Indo-Iranian syllabic $*_{r}$ (= the vocalic allophone of the tremulant *r), which is reflected in OI vrkșá-, Av varəsa- (there is no systematic study of the substitutions of syllabic resonants in Indo-Iranian loanwords).

If the Finnic word reflects Pre-II *e, this might be a proof for an early change $* l>* r$ in Indo-Iranian, together with kekri. The Indo-Aryan word with $l$ is probably secondary (see [Mayrhofer 2002] for a discussion of the Indo-Iranian sound-change $* l>* r$ and the apparent exceptions). If the Finnic word is a borrowing from the zero-grade form, *er could be explained simply as a substitution of PII or PI $*_{o}$, and there is no reason to consider this a Pre-II borrowing and the loanword could have been acquired much later.

Kallio [2014: 160-161] has recently suggested that the the vowel correspondence of Estonian $\tilde{o}$ and Finnish $e$ continue Proto-Finnic * $(>$ Est $\tilde{o}$ ), meaning that Estonian $\tilde{o}$ is an archaism and not a late development as was often assumed in recent research. This word could be also reconstructed as *vërs $V$; phonetically the Proto-Finnic vowel $* \ddot{e}$ could be a plausible substitution for PII $* a$ (or $*_{r}$ ), but there are no known cases of inherited words (i.e., older than Proto-Finnic) which would feature this vowel, and this makes the idea of deriving this word from a very old stage of Indo-Iranian problematic [Holopainen et al. 2017: 119].

The second syllable vowel also raises questions, since according to the mainstream view [Sammallahti 1988, 1999; Salminen 2002], *o became possible only in Proto-Finnic (this view has been recently challenged by Aikio [2015b: 37-39], who reconstructs $* o$-stems to Proto-Uralic). Also, words with a front-back vowel combination are usually not very old in Finnic, but if $*_{o}$ is a result of a derivational suffix here, this could explain the vowel combination. The stem-final vowel in Estonian võrse points, however, not at $-o$ but at a different derivative with Proto-Finnic *ek or * $e s$.

Despite certain difficulties with vocalism, the etymology seems convincing enough. Semantically the etymology is plausible, especially because the Indo-Aryan forms match the meaning of the Finnic word well.

Etymology: convincing 


\subsection{Etymologies with *a (<PII, PI *a)}

\subsubsection{Ahnas, ahne 'greedy (for food)'}

(cognates in all Finnic languages) $<$ ? Pre-Fi aćnas

$\leftarrow$ PII *HaćHna- (or PI *HatsHna-) > OI aśna-s 'gluttonous, hungry', root OI $a s^{\prime}$ - 'sich nähren/sättigen, zu sich nehmen, essen' ([EWAia I: 136] s. v. $A S^{I}$; [KEWA I: 60-61] s. v. aśnāti; [RIVELEX I: 595] s. v. áśna)

([Schindler 1963: 205; Koivulehto 1999a: 227]; [SSA] s. v. ahnas)

While the Indo-Iranian etymology is coherent, it is difficult to determine the exact age of this borrowing. Aikio [2015b] has stated that the reflexes of PU sibilants and affricates are hardly distinguishable in certain consonant clusters (cf. also the word *ocra below), and this word does not have to be a specifically Iranian loan although Koivulehto assumes so. Furthermore, the Indo-Iranian root *Háć $H$ - is poorly attested in Iranian [de Vaan 2000: 285].

The second syllable vowels and consonants of the Indo-Iranian loans have not been systematically studied. Here, *as seems to reflect PII masculine ending *as, which was probably still retained by the time of borrowing. The word ahma 'wolverine; greedy for food' is probably a parallel loan, as it neatly matches the Old Indic form aśman- 'eater' ( $<$ PII *Haćman-). Interestingly, ahma has a regular cognate in Saami: SaN vuosmmis 'eager, greedy for food' [Holopainen 2018: 151-152]. Komi adžni 'to gulp down', mentioned in [SSA] as a possible cognate of ahnas, in turn, cannot belong to this cognate set due to its irregular vocalism.

Etymology: convincing

\subsubsection{Aisa 'wagon shaft', Veps (deriv.) aižaz id.}

(cognates in all Finnic languages)

$\leftarrow$ PII or PI *Hayša- > Av aēša- < PIE * $h_{2}{ }_{3}$ oy $(H) s-([E W A i a$ I: 208; Peters 1980: 95])

([Mayrhofer 1964: 185-186]; [SSA] s. v. aisa; [Peters 1980: 95; Koivulehto 1991: 97-98, footnote 53]; [EES] s. v. ais)

Although references to the possible Indo-Iranian origin of the Finnic word can frequently be found in literature (for example, Peters [1980: 95] notes that the Finnic word is borrowed from either Baltic or Iranian, and [SSA] mentions the Indo-Iranian origin as one possible etymology for 
the Finnic word), it is now universally accepted that the word is borrowed from some other Indo-European language, most probably Baltic or Balto-Slavic ([Katz 1983: 118; Junttila 2016]; noted already by Lidén [1897: 60-63]). The Finnic word has to be dissociated from the words with a similar meaning in Mordvin (ažija) and Permic (Ud vajiž, Ko vož), as is noted by Joki [1973: 253-254] already. This view is followed by [EES], but [SSA] is ambiguous about the relationship of the Finnic word and the Mordvin and Permic ones. The latter words can be true Indo-Iranian borrowings from PII or PI *(H)aiša- (> Av aēša- (dual) '(?) both parts of a pole' ${ }^{8}$; [EWAia I: 208]), although the irregular relationship of the Komi and Udmurt forms makes the reconstruction of a common Proto-Permic forms difficult and the etymology more complicated; however, this problem has to be solved elsewhere. In any case, the possible Indo-Iranian origin of the Finnic word has to be rejected, as PII or PI *ayša (reconstructed on the basis of the Avestan word) would have given **aiha in Finnic.

Junttila [2012: 280] has considered also the Baltic borrowing hypothesis as dubious, because the cognate is actually missing from Baltic (it would be *aisā or *aisa according to Junttila), but later [Junttila 2016] has considered the word borrowed from a lost dialect of Balto-Slavic. Junttila [2016: 218-219] reconstructs the Baltic word differently from the earlier research: as *ajes, corresponding to Slavic $s$-stem *oje, and he assumes that the Finnic word is borrowed from the plural/collective *ajes $\bar{a}$ or a neuter form based on it (with regular contraction of $e$ ). Koivulehto [2001a: 362 footnote 3] has considered the Finnic word a possible loan from Slavic *oje(s) (see also the entry ojas below), but because the development *ajesa > aisa the borrowing has to be early (this kind of development had to take place in Middle Proto-Finnic, cf. [Kallio 2014]), it is more plausible to assume that the Finnic word is an earlier borrowing from Balto-Slavic or some lost dialect of Baltic. As there are other specifically Proto-Balto-Slavic borrowings in Finnic (see Section 3.3.3), aisa could well belong to the same layer of loanwords.

${ }^{8}$ The meaning of the scarcely attested Avestan word is uncertain, and also its exact relationship to OI $\bar{i} s \underline{a}-$ 'shaft' ( $\left.<* h_{2} i-H s-a-\right)$ and its Indo-European cognates oin $\xi \xi$ : o' $\bar{\alpha} \xi$ 'Griff des Steuerruders, Steuerruder' and Hittite hišša- 'shaft' has remained unclear [Melchert 2000: 235; Höfler 2017: 3, footnote 2]. For details on the etymology of the Hittite and Greek words, see Kloekhorst [2008: 403] s. v. ${ }^{\mathrm{GIS}} h i \check{s} \check{s} a-$ (c.) and Beekes [2010: 1052] s. v. ő̋ $\xi$. 
Etymology: unconvincing (a borrowing in Finnic but not from Indo-Iranian)

3.2.3. Aivan 'whole, exact' (also in Karelian, Ludic, Votic, Estonian)

$\leftarrow$ PII *aywa- > Av aēva 'one, only, lonely, some, OI evá 'so, just' ([EWAia I: 270] s. v. evá)

([Joki 1973: 247; SSA I: 19])

Phonetically the etymology is plausible, and there are no semantic problems either, if the meaning 'so, just' was present already in Proto-Indo-Iranian. It has to be noted, however, that because of the large semantic scale of the Finnic word it is difficult to reconstruct exact meaning which makes finding a loan etymology more difficult. [SSA] also mentions a possible Germanic etymology: the Finnic word could be a borrowing from PG *aiwina- ( $>$ Gothic aiweins 'eternal'), PG *aiwan ( $>$ ON ey 'always'). From the point of view of phonology, both sources are equally probable. The semantics of the Indo-Iranian word seems to work out better, but from the "statistical" point of view a Germanic origin would be more plausible for a word that is attested only in Finnic. LÄGLOS [I: 18-19] accepts the Germanic etymology.

In Finnish dialects and old written Finnish, there is also a word aiva, which is clearly connected to aivan. [LÄGLOS] refers to Hahmo [1988: 82], who considers the forms without $-n$ back-formations.

Etymology: unclear (can also be from Germanic)

\subsubsection{Apu 'help', auttaa, avittaa 'to help' Est abi}

(has cognates in all Finnic languages)

$\leftarrow$ PII (or PI) *HawHas- 'help', root *HawH- > Av auuah-, OI ávas'help' ([EWAia I: 132, 134])

([Koivulehto 1999a: 228])

This word displays a high level of phonetic variability across cognate Finnic languages. The word apu is explained as a result of the "analogical strong grade" in Finnic according to Koivulehto (a phonetically regular form in modern Finnic languages would be *avV). Also a Germanic etymology has been assumed for the Finnic word ([LÄGLOS I: 31] s. v. apu): PG *auja-/*awi- > ON auja 'luck; divine help, shelter', Goth awi-liudōn 'to thank'; according to [LÄGLOS] the meaning of Runic auja is uncertain, but it is possible that it meant 'help'. However, Koivulehto finds the 
Germanic origin much less convincing on semantic grounds (no meaning 'help' is certainly attested for this root in Germanic; also [LÄGLOS] notes that the meaning of Runic auja is uncertain). In spite of this [LÄGLOS] supports the Germanic etymology (Koivulehto's Indo-Iranian etymology was not yet published at the time when the first part of [LÄGLOS] was published, so this possibility is not commented in the book). The second syllable $u$ in some Finnic words is secondary.

Etymology: convincing (can also be a Germanic loan)

\subsubsection{Hadas, hata, hatu 'germ', Adv. hataalla 'to be embryonic'} (cognates in Karelian and Estonian) $<$ Pre-Fi *šata-

$\leftarrow$ PI *dzaHta- a verbal adjective from the root *dzanH- "to be born, to grow' (*anH- in Cheung's [2007] reconstruction) $<\mathrm{PIE} *$ genen $h^{-}$

([Koivulehto 1999a: 225])

This word is cited among Koivulehto's Proto-Iranian etymologies. According to his "palatal criterion" (see [1999a: 219-220] and [2001b: 252253]), the Proto-Iranian loanwords can be recognized by the substitution of PI $* t$ s and $* d z{ }^{9}$ as affricate $* \check{c}$ in Uralic. Kallio (personal communication) has argued that the substitution in the word-initial position was PI $* t s, * d z>$ PU $* \check{s}$, because the Finnic $h$ can only result from $* \check{s}$, not $* \check{c}$, according to current understanding of Uralic historical phonology (as noted above, [Aikio 2015a: 4-5] has shown that the alleged Uralic examples of the development $* \check{c}>h$ in Finnic can be explained otherwise). If the substitution is accepted, the etymology itself is unproblematic, although also a Germanic etymology for this word has been suggested (see below). There are other words manifesting the same substitution which have cognates in Mordvin or Saami, so it is unlikely that this word was a separate borrowing to pre-Finnic. Probably, its cognates in Mordvin and Saami have simply disappeared (many old agricultural terms have disappeared from Saami because of its geographical location, and this word might have been one of them).

LÄGLOS ([I: 84-85] s. v. hata) cautiously supports a Germanic etymology for the Finnic word family: the Finnic word could have been borrowed from North-West Germanic PG *sāda- (<PG *sēda-) 'sowing, seeding', (cf. ON sað) or *sādi-z (<PG *sēdi-z) 'sowing, seeding' or alternatively from

9 They are reflexes of PIE $* k$ and $* g$ according to many, but not all Iranists: see Mayrhofer [1989: 6], Windfuhr [2009: 21]. 
PG *hazda-z 'hair on the head' (cf. ON haddr; [LÄGLOS] notes that Finnic $t$ would be difficult to explain from this latter form). [LÄGLOS] is also critical of the relationship between the adverb hataalla and the noun hata.

Both the Germanic ( $\leftarrow{ }^{*} s \bar{e} d a$ ) and the Iranian etymology for the Finnic word are convincing, so it is difficult to decide which one is more plausible.

Etymology: convincing

3.2.6. *Iha 'life force, joy', Fi ihana 'wonderful; (dial.) healthy, blooming', dial. and Karelian ihala 'dear', ihastua 'to fall in love;

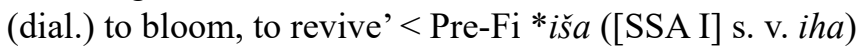

$\leftarrow$ PII or PI *(H)iš- > Av ī̌s- 'force', OI iṣ- 'drunk; refreshment; life force' $<$ PIE *heys- ([EWAia I: 98, 271])

([Tunkelo 1913: 99-100; Koivulehto 2001a: 367-368; Rintala 2003: 306-308])

According to Koivulehto, there are two homonymous words iha in Finnic languages, which have different etymologies (iha discussed here appears in Finnish and Karelian, see below for the other word). [SSA] considers both of them as one word, and so does [EES], but Rintala [2003] in her comprehensive study of the Finnic iha words accepts Koivulehto's conclusions. Koivulehto reconstructs the meaning of this *iha word as 'life force, joy'. The borrowing from a form *Hiš- looks plausible, and also all the semantic variants of the Finnic word can be derived from this. The Finnic $h(<* s)$ reflects either PII or PI $* \check{s}$, a result of the so-called RUKI change $(=s$ becomes $* \check{s}$ after $r, u / w, i / y$ and $k$; [Mayrhofer 1989: 8]).

Rintala has also assumed that ihana could be a separate borrowing from an unattested Indo-Iranian adjective derived *išana from the root $\bar{\imath}$, because it would be difficult to explain the exact derivational process of the Finnic adjective from *iha. As there is no trace of an Indo-Iranian adjective of the type *išana, this explanation has to be rejected as too speculative, even if Rintala is right about the difficulties conserning the history of the Finnic adjective ihana.

Rintala [2003: 296-297] also mention that Moksha Mordvin ežâlgâdâms, ožâlgâdâms 'to rejoice' has been connected etymologically with the Finnic word in earlier research, but the relationship is uncertain because of the phonological irregularity. Further research can show whether the Mordvin word could be a separate borrowing from the Iranian root mentioned above.

Etymology: unconvincing (not a separate borrowing from Iranian, but related to Estonian $i h a$ ) 
3.2.7. Est iha 'yearning, passion (Vorlangen, Begierde)', Finnish ihastua 'take a fancy to something, be overjoyed with something'

$\leftarrow$ ? PII *Histsā- $<$ PII *Hisća - -, cf. OI icchā- id.; root eș- 'suchen; wünschen, begehren', Praes icchá- $<$ PII *Hayš or *Hayš $H^{10}<$ PIE *h $h_{2}$ eys $(H)$; OI root-noun iṣ- 'Labung, Kraft, Opfergruss' < PII *Hiš ([EWAia I: 270271] s. v. $E S^{l}$; [Cheung 2007: 158])

([Tunkelo 1913: 99-100; Koivulehto 2001a: 365-366; Rintala 2003: 306-308])

Koivulehto argues that the word is etymologically different from the North Finnic *iha, and is also borrowed from a different source. [EES] accepts the etymology, and considers this iha word the same as the one mentioned above (also [SSA] considers the two words one, see above).

Koivulehto assumes that this particular word family is borrowed from PI *ists $\bar{a}(=\mathrm{OI} i c c h \bar{a})$ as Pre-Finnic *iča. However, iha can only result from earlier *iša, not *iča. On the other hand, it is unlikely that PI *sts in word-internal position would result in Pre-Finnic * $\kappa^{\prime}$ or $* \check{c}$. Because of this phonological difficulty, it is more likely to consider the Finnic $i h a$ with various meanings as one word and not two, although the semantic differences between the various derivations of the $i h a$ word are admittedly large. [SMS] gives only one headword iha 'lust; wish'.

Etymology: the Indo-Iranian etymology is convincing, but the word is identical with the other iha word

3.2.8. Ihta (dial., obsolete) 'lust, eagerness', ihan, dial. ihran, ihlan $(<*$ ihtan $)$ 'just, quite'

$\leftarrow$ PII/PI *Hišta-, cf. OI iṣta- 'wished, desired' ([EWAia I: 270-271] s. v. $E S^{l}$; [Cheung 2007: 158])

([Koivulehto 2001a: 366-367; Rintala 2003: 396-308])

According to Koivulehto, this Finnic word reflects an Indo-Iranian participle (= verbal adjective) form *Hišta-. The etymology is plausible, although the Finnic word is a simple noun. It is, however, strange that the word is present only in Finnish (and in no other Finnic language). Because of the cluster $h t$, the word cannot be a regular derivation of the Indo-Iranian loanword iha (of which see above), but it is more probable that it is a separate borrowing like Koivulehto assumes.

Etymology: convincing

${ }^{10}$ About the possible set root, see [RIVELEX] s. v. with references. 
3.2.9. Est isu 'appetite' (PFi *iso 'hungry, greedy');

in Ingrian, Finnish attested in the verb isota

$\leftarrow$ Iranian *(H)isa-'to seek, to pursue, to want', cf. Av isəmna- 'seeking', isaite 'he/she pursues', cf. OI iccháti 'seeks, wishes' < PII *Hišśća, root *Hiš ([EWAia I: 270-271])

([Koivulehto 2001a: 359-362])

If this etymology is correct, it is among the latest possible Iranian loanwords in Finnic because $*_{s}$ in the Avestan word reflects PIE $* s k$ or $* s k$ (> PII *ść, see [Kobayashi 2004: 67-74]), and if the word was Proto-Iranian or older, we would expect a different substitution here (in Proto-Iranian the word was probably *istsa-, and this would have likely resulted in Pre-Finnic *iča, not *isa). Therefore, the word can belong to the same loanword layer as other relatively late loans like vasa and varsa [Koivulehto 1999a: 226-227]. The Iranian donour form is etymologically related to the original of iha (see Section 3.2.7 above).

Semantically, the Iranian and Finnic words match well. There is no alternative etymology for this Finnic word, so the Iranian loan hypothesis is a reasonable option. All of the attested Finnic words point to second-syllable $* o$ in Proto-Finnic already, the origin of which remains unexplained. It can result from a later derivation; however, Aikio [2015b: 37-39] suggested that ${ }^{*} o$ would have been possible in the second syllable already in Proto-Uralic, contrary to this general view. As noted by [Holopainen et al. 2017: 117], there is no explanation to why the Iranian $a$ was substituted by $o$ in this word, but in spite of this the etymology can be considered as convincing.

Etymology: convincing

\subsubsection{Isäntä 'master' (cognates in all Finnic languages)}

$\leftarrow$ PII (or PI) *(H)ićāna- > OI İ́śāna- 'ruling, dominating' (medium present participle from the verb ťšs- ; [EWAia I: 207]), Av isāna 'ruling over something'

([Tunkelo 1913; Koivulehto 2001a: 372-371])

Koivulehto attempts to prove isäntä as an Iranian borrowing and not a derivation of Finnic is $\ddot{a}(<\mathrm{PU} * i c \ddot{a}$, which in itself is a PII borrowing from * $(H) i c$ - 'master, lord' according to him). This idea is based on an earlier etymology by Tunkelo (see below). Koivulehto considers *isänä as the original Finnic form, and isäntä would be secondary. He presents other words with $n \sim n t$ variation, such as sarana $\sim$ saranta 'Türangel', sarvena $\sim$ sarventa 
'Hüftbuckel'. Emäntä 'mistress' would have been analogically formed from emä 'mother'. However, the problem is that the word isäntä manifests no $n \sim n t$ variation, so it is dubious to suppose $* * i s \ddot{a} n \ddot{a}$ as an original form.

Koivulehto mentions that Tunkelo [1913: 115-118] had already suggested an Iranian origin for this Finnic word. However, the postulated origin would have been an active present participle *isant- 'besitzend' $<$ PII *ićant, which is unattested in Indo-Iranian languages.

It seems difficult to determine whether this word is a real derivation or an Indo-Iranian loan. Historical derivational processes are not well-studied in Uralic etymology. Therefore, we do not know the processes leading from is ä to isäntä or emä to emäntä well enough to choose between the competing etymologies.

Etymology: uncertain

\subsubsection{Jäädä, jää ‘to stay, remain’ (cognates in all Finnic languages)}

$\leftarrow$ Pre-II *g'eg'heH-, root *ǵheH-, > OI jáhāti ‘leaves, rejects', root $h \bar{a}-$ ([EWAia II: 813-814] s. v. $H \bar{A}$ )

([Koivulehto 1999a: 218-219])

This etymology is almost certainly incorrect. First of all, there are hardly any convincing examples of the substitution $* g h \rightarrow * j$. If Proto-Indo-European $* g h$ was still retained in the language from which the word was supposedly borrowed, there is nothing that would make it Indo-Iranian (note that Koivulehto's "Pre-Indo-Iranian" reconstruction *geg'he is impossible, as Grasmann's law - the desapiration of the first aspirated stop in a word that contains too aspirated stops - could not have operated this early). A possible parallel case is PU *aja- 'to drive' (> Fi ajaa etc.), a loan from PIE * $h_{2} a g$ - 'to drive'.

The vowel substitution is also unexpected, as Koivulehto remarks himself: Koivulehto assumes that *je was impossible in early Uralic, and that this is the reason why the word was borrowed as *jä-; however, recent research has shown that $* j e$ - was in fact possible (see, for example, [Aikio 2015a]).

Etymology: unconvincing

3.2.12. Marras : marta- 'dead' (cognates in Karelian and Estonian)

$\leftarrow$ PII/PI *marta- 'dead'> OI márta- 'mortal, human' (< ? PIE * morto-) ([EWAia II: 318-319, 327]) or 
$\leftarrow$ PII/PI *mrta- > OI mrtá- 'dead', verbal adjective from the root mar'to die' ([EWAia II: 318-319, 327])

([Mikkola 1902: 72; Joki 1973: 280-281; Katz 1983: 174-177; Koivulehto 1999a: 228-229]; [SSA] s. v. marras)

This is a traditionally well-accepted etymology, although there is no consensus on the exact Indo-Iranian donour word of the Finnic word. Koivulehto supports the noun *marta-s as the original, whereas [SSA] mentions only the zero-grade verbal adjective *mrta-. In either case, the explanation is plausible both phonologically and semantically. *martas is derived from the Indo-Iranian root *mar- $(<\mathrm{PIE} *$ mer-) which means 'to die'.

A parallel borrowing from the same source (probably from a zero-grade form *mrta- 'dead' < PIE *mrto- ${ }^{11}$ ) is PU *mertä > Mo miŕd'e, Ko mort, Ud murt 'man' [Koivulehto 1999: 228-229]. The Finnic word could also be a separate loan from this -to- verbal adjective (with a different substitution of syllabic $*_{r}$ ), but it is difficult to prove this. Both *martas and *mrtas could equally well result in Finnic *martas. Also semantically both forms are suitable. In any case, the Indo-Iranian origin of the Finnic word is obvious.

Häkkinen [2009: 23-24] has erroneously considered Finnic * martas and Mordvin mird'e cognates (Häkkinen attempts to establish a group of words in which Finnic $a$ corresponds to Mordvin $i$, but all the examples can be explained otherwise; see the entry vasara below), and parallel borrowings is the only possibility to explain the relationsip of these words.

Etymology: convincing

\subsubsection{Niska 'neck' (cognates in Ka, Lu ńišk[e], Ve nišk, Vo, Lv)}

$\leftarrow$ PIA (?) *niška- > OI niṣká- 'a golden ornament for the neck' ([EWAia II: 48])

([Blážek 1990: 41; Parpola 2005: 47])

This etymology has been suggested separately by Blážek and Parpola. The etymology is one of the weakest in this group. The etymology manifests

\footnotetext{
${ }^{11}$ Koivulehto notes that there is no need to suppose a Pre-II *mérto- as the pre-form of the substantive *márta- to explain the origin of PU *mertä (from which the Mordvin and Permic words); EWAia [II: 327] refers to Katz [1983b], where this kind of explanation is found (cf. also now [Katz 2003: 123]). The PII form *márta-probably reflects

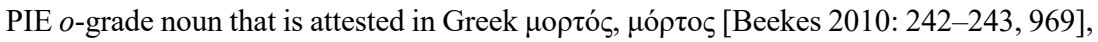
and thus the zero-grade *mrta- is the most probable origin for Uralic *mertä.
} 
both semantic and phonological problems. First of all, the Finnic word should reflect the Indo-Iranian RUKI change $*_{s}>*_{s}$, and this would result in a Finnic word like **nihka. Parpola [2005: 47, footnote 313] also notes that Jorma Koivulehto has rejected the etymology in personal communication because of this phonological problem. The sibilant $\check{s}$ in Veps and Ludic has to be secondary from earlier $*_{s}$.

Also the semantic development is not straightforward. While names for body-parts can be borrowed (cf. Finnic *kakla 'neck' < Baltic *kakla), this word would suggest a word meaning 'necklace' to be borrowed first, and a later metonymical change of the meaning into 'neck'. Blážek suggests that 'neck' might have been the original meaning of the Indo-Aryan word, which is hard to prove. EWAia [II: 48] considers the background of the Indo-Aryan word unclear. Since the word does not have cognates even in Iranian, it is dubious whether this is an Indo-Iranian word at all, or whether the Indo-Aryan word is a loanword from some unknown source. It is best to reject the etymology altogether.

Etymology: unconvincing

\subsubsection{Ohra 'barley', dial. otra, Karelian osra}

(has cognates in all Finnic languages) $<\mathrm{PFi}$ *ocra

$\leftarrow$ PI *(H)atsra- or PII *(H)aćra- 'sharp', from root*(H)ać- 'sharp', cf. OI aśra- id. < PIE * $h_{2} e k$ - 'to be/become/make sharp' ([LIV: 261])

([Kallio 2012: 231, footnote 9])

A Proto-Baltic origin *aštra- has been suggested for this word ([SSA II] s. v. ohra), but Kallio [2012] considers the word Iranian because of phonotactic reasons. A cluster *str would be impossible or at least atypical in Proto-Finnic, and Iranian *atsra- would yield *ocra in Finnic, a more pausible form for Proto-Finnic reconstruction. However, since the development of consonant clusters is poorly known, the dating of the borrowing is difficult. This and the other words reconstructed with * $\mathrm{cr}$ have a lot of variability in different Finnic languages. It is unlikely that the cluster *ćr existed in Pre-Finnic, so this word could also be a loan from PII *aćra-.

If the loanword is indeed Iranian, it shows that the substitution $* \leftarrow * a$ was used in both later Iranian and earlier Proto-Indo-Iranian loans (for the examples of Proto-Indo-Iranian loanwords manifesting this substitution, see [Koivulehto 1999a]).

Etymology: convincing 
3.2.15. Est oide 'grass root', dial. õidad, uit (no cognates in other Finnic languages)

$\leftarrow$ PII *waida- > OI vedá- 'a bunch of grass' ([EWAia II: 581]) or

$\leftarrow$ PII/PI *waita- > OI vetása- 'Calamus Rotang or a similar cane', Av vaēiti- 'willow', Oss wìdag, wedagae 'root' ([EWAia II: 578-579])

([Blážek 1990: 41])

This word is attested only in Estonian and is rare also there (the word is not found in [EES]), which makes its old age unlikely. The vowel relations between the various Estonian dialects are irregular, which further makes it difficult to assume that the word is old. Although there is no good competing etymology for this Estonian word, the Indo-Iranian etymologies supposed by Blážek do not seem convincing. The first Indo-Aryan word is of unclear background according to [EWAia], and it is methodologically suspicious to assume that these isolated words in Estonian and Sanskrit would be etymologically connected, especially because it is impossible to reconstruct a regular Proto-Finnic predecessor for the Estonian word.

The other Indo-Aryan word (vetásah) has also cognates in Iranian and it goes back to PIE *wey $(H)$-t- (from the root *wey $(H)$ - 'to bind, to twist'), which is reflected also by Germanic words for willow, such as German Weide 'willow', Old High German wìda and Old Norse víðir ([EWAia]; [Kluge 2012] s. v. Weide). The more credible Indo-European etymology of this Indo-Aryan word means that the word existed in Proto-Indo-Iranian already, and assuming that this word was borrowed into some early form of Finnic is less troubling. However, because of the phonological difficulties mentioned above, this explanation is also unlikely. Note that the Germanic words reflect zero-grade forms of the IE $\operatorname{root}(\mathrm{PG} *$ wipja/ō, *wippig), making also a loanword from Germanic to Finnic unlikely (the Germanic words are also semantically rather far from the Estonian word).

Etymology: unconvincing

\subsubsection{Oja, ojas 'shaft of plough' (cognates in Ludic and Veps)}

$\leftarrow$ PII ? ([SSA II] s. v. ojas gives a PII reconstruction *ojas, which is impossible)

This Finnic word is probably of Indo-European origin, but more likely not from Indo-Iranian. The reconstructed Proto-Indo-Iranian form *ojas given by [SSA] is impossible: to begin with, there was no $*_{o}$ in PII, and this reconstructed $s$ stem is also formally incorrect and cannot be the preform 
of OI $\bar{l} s \underline{a}$ - nor Av aēsa-; the attested Indo-Aryan form mentioned by SSA, OI $\bar{\imath} s \bar{a}^{-}$- 'shaft', is the same that is treated in connection with aisa above. The reconstruction of the Indo-European word is known to be difficult: the Indo-Iranian word has cognates in Anatolian (Hittite hišša-) and Slavic (see below). Höfler [2017] has recently discussed this Indo-European word in detail. However, regardless of the exact relationship of the Indo-European words, the precursor of the Indo-Iranian forms cannot be the source of the Finnic word.

[SSA] also mentions the Slavic word *oje 'shaft' (which is a cognate of the Indo-Iranian word and actually reflects the form reconstructed by [SSA]: more precisely the Indo-European predecessor of the Slavic word can be reconstructed as $* h_{3} e y H-e / o s-$ [Peters 1980: 95]), and it seems plausible to consider the Finnic word as a Slavic borrowing. Koivulehto [2001a: 362, footnote 3] has also suggested that Finnic aisa could be a borrowing from this same Slavic source (however, he also considers the substitution of Slavic $* o$ by $* a$ as problematic). If ais $a$ is a Baltic or earlier Balto-Slavic loan, ojas could easily reflect the Slavic cognate of the word. According to [SSA], a Russian etymology has been presented for the word earlier, but no details are given. The word is rare in modern Russian, but it is attested in dialects. Because of the limited distribution of the word in Northern Finnic, it seems probable that we are dealing with a relatively late Slavic (Russian) borrowing.

Etymology: unconvincing (not Indo-Iranian)

\subsubsection{Karelian, Veps ola 'flint'}

$\leftarrow$ ? PII *al-, cf. OI așthìla $(? * a l-s-t h \bar{\imath}-)$ 'ball, round stone, flint' ([EWAia III: 19])

([Vilkuna 1933: 160-162; Joki 1973: 294]; [SSA] s. v. ola)

As mentioned by [SSA], this Finnic word has been also connected with Baltic (from Proto-Baltic *ōla, cf. Latvian uola 'a small stone; egg'), and this origin seems more probable. Indo-Iranian loan etymology is unlikely and lacking enough substance for comparison. EWAia [III: 19] only briefly mentions the word așthìla , the background of which is considered unclear. Lidén [1897: 83-85] assumed that the Sanskrit word is an old compound/ derivation from *alsthi -, and the first syllable would correspond to Baltic *ōla. This explanation is not mentioned by [EWAia], but in [KEWA] Mayrhofer considered Liden's explanation unlikely, as is cited by Joki [1973: 294]. 
According to Grünthal [2012: 312-313], Mordvin al 'egg' is also a loan from the same Baltic word. According to Grünthal, the Baltic word could have been borrowed already into a common proto-language of Finnic and Mordvin, but this is unlikely due to the irregular relationship of the two words. The Mordvin word could reflect earlier $* a-a, *_{i-i}$ or $*_{i-a}$ stem, whereas the Finnic word can only reflecft earlier ${ }^{*} o-a$. The Baltic origin of the Mordvin word needs more detailed research. Kildin Saami vue'll is probably borrowed from Karelian, as [SSA] suggests.

Regarding the etymology of the Baltic donour word, it is interesting that Derksen [2015: 481] does not provide any Indo-European cognates for the Baltic word, and seems to doubt even the Proto-Baltic origin of the Lithuanian and Latvian words. The borrowing of the word from Baltic to Finnic and Mordvin would, of course, support its presumed existence in Proto-Baltic, if the Uralic and Baltic words are not parallel borrowings from a third unknown source.

Etymology: unconvincing

\subsubsection{Paksu 'thick'}

(has cognates in Karelian, Veps, Ludic, Votic, Estonian)

$\leftarrow$ PI *badzu- > Av bazuuant-, OI báhu- 'thick, large' ([EWAia II: 220-

([Koivulehto 1999a: 220-221; 2001b: 251])

This etymology is one of the few cases in which Koivulehto assumes a substitution $* d z \rightarrow * k s$. This presumed sound substitution has its problems, as it is supported by very few etymologies only, and some of these etymologies are problematic. However, this particular etymology seems correct, in spite of these questions about the substitution pattern. The semantic correlation is almost exact, and even the Finnic $-u$ seems to reflect the second-syllable $-u$ of the Iranian word. Usually Finnic second-syllable labial vowels are considered late (of the Proto-Finnic stage). If the substitution $* u>* u$ is correct, it would mean that the second-syllable *u was possible already at the time of the contacts with Proto-Iranian. However, since there are no other cases of such substitution, the question of the age of $* u$ has to be left for further research (see [Holopainen et al. 2017] for some more detailed considerations on the development of $* u$ in non-initial syllables).

Etymology: convincing 
3.2.19. Peijas, peijaiset 'a drinking feast, funeral', Karelian peijahat, peijahaiset 'feast in honour of a killed bear', Estonian peied 'funeral', Livonian peijed id. $<\mathrm{PFi}$ *peijas

$\leftarrow$ ? Pre-II * paHiya- > PII *paHiya- 'drink'> OI -pāyya ${ }^{12}$, -peya 'drink', in compounds: pú rva-pắya 'first drink' ([EWAia II: 113] s. v. $P \bar{A}$ )

([Koivulehto 2005: 329-332])

Koivulehto's etymology is plausible. Semantically the attested Indic words match the meaning of the Finnic words well, as the general meaning of feasting can easily be derived from a 'drinking feast'. There are some intriguing questions about vowel substitution though; Koivulehto considers the word as a loan from PII proper, and the Finnic - ei- would reflect the "sporadic" sound change *ai $>* e i$ which has happened in a number of Finnic words. However, here Koivulehto is on the wrong track, as he fails to see that this change is not Proto-Finnic, but affects only certain Finnic languages, viz. every language except for Livonian and South Estonian. Kallio [2014: 159-160] has considered this sound change a "Gulf of Finland Finnic" innovation, meaning that this change happened in the predecessor of all the Finnic languages other than South Estonian and Livonian, which had already branched off at this point. Kallio (p. c.) further remarks that because the change was more precisely $* a i \_a>* e i \_\ddot{a}$, the expected outcome would be *peijäs, not *peijas.

It is thus clear that because this word is found also in Livonian, the $e i$ diphthong has to be original, not the result of the sound change described above. This means that the word could not be borrowed from Indo-Iranian proper, but it has to be either a Pre-Indo-Iranian loan or borrowing from a cognate of the Indic words in some other Indo-European language. Koivulehto notes that Ritter had already before him considered the Finnic word a borrowing from a hypothetical Baltic form *pa(i)yas, but Koivulehto rejects this explanation because this kind of formation is not attested in Baltic. It seems that the Indo-Iranian etymology is clearly the best option, although this means that the borrowing has to be very early. Another option is to consider the Livonian word borrowed from Estonian, which has regularly been affected by the sound change *ai $>* e i$.

Etymology: convincing

12 Koivulehto notes that the Sanskrit form with long $\bar{a}$ is probably secondary and influenced by the long vowel of the verb pāti 'to drink'. 
3.2.20. Perna 'spleen', Est põrn and regular cognates in all the other Finnic languages $<$ PFi * perna

$\leftarrow$ PI *sprdzna- > Av sparazn-, sparəna- 'spleen' (cf. OI plíhan- id.) ([EWAia II: 196-197] s. v. plíhan-)

([Koivulehto 2003]; [EES] s. v. põrn)

This is one of Koivulehto's etymologies which have not been published in print, but this etymology can be found in [EES]. There is no other convincing etymology for this Finnic word: Liukkonen [1999: 104-105] has attempted to derive the word from Baltic *spern $\bar{a}$ 'wing', but this is unconvincing because of the semantics. Semantically Koivulehto's explanation is obviously convincing. Problems with phonology occur mainly because of the $\tilde{o}$ in the southern Finnic languages: as noted above in the case of verso, the vowel correspondence Fi $e$ - Est $\tilde{o}$ derives from PFi $e$.

The precise reconstruction of the Indo-Iranian word is unclear because of the long $\overline{1}$ in Indo-Aryan, but the Avestan word regularly reflects earlier *sprzna- (<*sprdzna-). According to [EWAia] the word has a secure Indo-European etymology, as Latin liēn, Greek $\sigma \pi \lambda \eta \nu$ and Slavic (Serbo-Croatian) slëzena, all with the similar meaning 'spleen'. However, Beekes [2010: 1384-1385] states that no common proto-form for the words in various Indo-European branches can be reconstructed. The $l$ in Indo-Aryan words is probably secondary.

Etymology: convincing

\subsubsection{Sammas : sampa-, Vo sammaz, Est sammas,} arch. sambas $<\mathrm{PFi}$ *sampas 'pillar'

$\leftarrow$ PII *stamb $b^{h}$ as 'pillar' > OI stamb ${ }^{h} a$ - 'pole, pillar', from the root stamb ${ }^{h}$ - 'befestigen, stützen' < PIE * stemb $b^{h} H$ - ([EWAia II: 753-754])

([Kalima 1933: 128; Uotila 1973: 7; Koivulehto 1999a: 230]; [SSA] s. v. sammas; [Parpola 2006])

The etymology is convincing, ${ }^{*} s t>*_{s}$ is a plausible substitution which has parallels in other early Indo-European loans in Finnic [Junttila 2015: 171]. Uotila has also suggested a different Indo-Iranian etymology, *śamba- 'Stange, Keule etc.', but it is no more convincing than the earlier one. Phonologically both suggested Indo-Iranian forms are suitable origins for the Finnic word, but the formation *samba- is attested only in Indo-Aryan and does not have a solid Indo-Iranian etymology, although it probably is derived from Indo-Iranian root *śam- ([EWAia II: 612-613] 
s. v. śamba-, śamy $\bar{a}$-). The Indo-European root ${ }^{*} s t e m b b^{h} H$ - is reflected also in the Iranian branch (Av staßra- 'strong, solid', MP stabr 'strong, big'), although a noun correspinding to OI $\operatorname{stamb} b^{h} a$ - is not found there. Phonologically there is nothing to force us to think that the word is borrowed into Pre-Finnic from Proto-Indo-Iranian already, but its non-attestation in Iranian could point to this kind of conclusion.

Nuutinen ([1987: 55-56]) and following him Koivulehto [1999b] have also considered Baltic *stamba- (> Lithuanian stamba 'stem of a plant') as the source of the Finnic word; in particular, Koivulehto argued that the Baltic word could have had a more general meaning in the prehistoric past. This is possible, but it does not make it preferable to the Indo-Iranian etymology. Later Koivulehto [1999a: 230] himself has also considered the Finnic word as a Baltic borrowing.

The word sampo 'a mythological mill in Finnish folklore' is a derivation from sammas according to [SSA]. SaN cuobbo 'frog' has been connected to this Finnic word, but the resemblance is probably accidental (viz. [Holopainen 2018: 142-146]).

Etymology: convincing

\subsubsection{Sammua 'to be extinguished'}

(also in Karelian, Lydic, Veps, Votic)

$\leftarrow$ *ćamH-> OI śam- 'to be calm, to be exhausted, to be extinguished' ([EWAia II: 610-611])

([Parpola 2010: 313])

Parpola's etymology is plausible, as both the semantics and the phonological correlations are satisfactory. However, according to [Koivulehto, Kallio 2016] the Finnic word could also be derived from Proto-Germanic *stammian- 'to stop, staunch, stem'. Koivulehto and Kallio also remark that Parpola's etymology is likewise credible, but because of the distribution in only Finnic, the Germanic origin would be more likely. Nevertheless, some other convincing Indo-Iranian etymologies involve a similar sound substitution, and because also the semantics fits perfectly, there is no compelling need to reject the Indo-Iranian loan etymology of Parpola, and it is difficult to decide which etymology is better.

Aikio [2014: 88-89] has suggested the same Indo-Iranian origin for the Uralic word *śoma (> Mo E śumoŕd'e-, Mari šuma- 'become tired, languish', Ud śuma- 'be hungry', Hu szomorú 'sad', szomjas 'thirsty' etc.). 
This etymology is convincing, but the Finnic verb cannot be derived from this Proto-Uralic noun.

Etymology: convincing (can also be a Germanic loan)

\subsubsection{Sarajas 'mythological river in the land of the dead'} (only in old folk poetry, not found in other Finnic languages)

$\leftarrow$ Iranian *zraya- (= Proto-Iranian *dzraya-) $>$ Av zraiiah-, OP drayah'sea' ([EWAia I: 606-607] s. v. jráyas-)

([Setälä 1912: 189; Jacobsohn 1922: 122-123; Joki 1973: 151; SSA] s. v. sarajas; [Häkkinen 2009: 22])

The Iranian etymology for this Finnic word is an old idea (first suggested by [Setälä 1912]), which suffers mainly from the fact that the word is a hapax in Finnic poetic language. If the etymology were correct, it should be a relatively late borrowing, because the Finnic $s$ probably reflects the Avestan-type $z$, not PI $* d z$ or PII $* j h(<* g h)$, so the loan would be later than Proto-Iranian (comparable to such cases as iso or vasa). Also semantically only the Iranian words could come to question, as the meaning 'sea' is attested only there. In the Vedic cognate jráyas- the more original meaning 'the edge' has still been retained. The Indo-Iranian word belongs to the root *jray- 'to stretch oneself', which is of unclear origin according to EWAia. The substitution of $*_{z} r$ in Finnic would be interesting because of the epenthetic $-a$ - in the consonant cluster. Usually word-initial consonant cluster is simplified in loans in a way that one of the consonants is dropped.

The word belongs to old mythological vocabulary, so it could have fallen out of use later, and many other words linked to mythology, such as jumala 'god' and taivas 'heaven, sky' also have Indo-Iranian etymology, but because of the very scarce attestation one really cannot say anything certain of this etymology.

Komi sarid'ź 'sea', Udmurt zarid'ź 'sea; a warm (southern) region where birds migrate for winter' are probably true borrowings from this Iranian word (this was established already by [Munkácsi 1851: 382]). Setälä attempted to connect the Finnish word to these, but the relationship of the Permic and Finnic words is irregular and these words cannot be considered as true cognates. Recently Häkkinen has tried to connect the Finnish word to other Permic words, but without offering any new convincing arguments to overcome the phonological irregularities involved: Komi šor and Udmurt šur 'river, brook'. Häkkinen considers all of these words, 
as well as Hungarian ár 'stream' and Khanty * $₫ \bar{a} r$, Mansi *tūra 'lake' (< POUg * $\theta$ ēra [cf. Zhivlov 2006]) loans from PII *saras (< PIE * selos), but this is unlikely: the Komi and Udmurt words are derived from PU *serë, which is also the source of Hungarian ér 'stream'. In no way can Finnish sarajas be regularly related to these words, and Häkkinen mistakenly assumes that Avestan zrayah-is related to this Indo-Iranian word. It remains open whether PU *serä is borrowed from a Pre-Indo-Iranian form *seros. Koivulehto [1999a: 215] has derived the Hungarian and Ob-Ugrian words from PII *saras, and this is a convincing etymology with no phonological problems.

Etymology: unconvincing

\subsubsection{Suoda, suo- 'to grant', Votic (der.) sōvia}

and Est (der.) soovida 'to wish' $<$ PFi *soo-

$\leftarrow$ PII *suw(H)-a-, OI suváti 'to put into motion', sav- 'to drive' ([EWAia II: 715-716]; [LIV: 538] s. v. ${ }^{*}$ sewh $_{1^{-}}$)

([Koivulehto 1999a: 230])

Koivulehto's etymology is semantically possible: the meanings of the Finnic verb ('to grant; to wish') can be derived from meanings that have been attested in Old Indic, but because of the wide-ranging polysemy of the verb, it is very difficult to reconstruct all the meanings of the verb to Proto-Indo-Iranian. It is obvious that the original meaning of the Indo-Iranian root was 'to put into motion', as this meaning is also attested in its Indo-European cognates, and this is reconstructed as the meaning of the PIE root by [LIV].

Morpho-phonologically this tentative loan is an interesting case, since here the Finnic word seems to reflect a zero-grade rather than a full-grade form. Because of Ablauting Indo-Iranian verbs, it is often theoretically possible to derive loanwords from several different forms, which make the loan etymologies less credible. Because not many verbs have been borrowed from Indo-Iranian to Uralic, it is very difficult to evaluate this etymology comparing it to parallel examples. A systematic study of the different Ablaut grades in Indo-European loanwords would be an important task for Uralic etymology.

Here one has to note that the zero-grade ${ }^{*} s u H$ could have been borrowed as such also from some other branch of Indo-European, not necessarily from Indo-Iranian. 
The problem of the background of the Finnic long vowels has been explored since Koivulehto, especially by Aikio [2012a; 2015b]. Koivulehto compares the development of vowels in this word to the word juo- 'to drink' ( $<$ PFi *joo-), but according to Aikio [2015: 65b], the vowel correspondences of juo- and its Uralic cognates are contradictory (it is unclear what the initial-syllable vowel in Proto-Uralic was), so it seems that we do not know precisely what kind of Proto-Uralic stem the Finnic word actually reflects; thus the verb juo- cannot be used as a parallel to the vowel developments in suo-.

In [UEW] and [SSA], Komi sí- 'to promise, to wish' is connected etymologically to the Finnic word, but this is unlikely because the Komi and Finnic vowels cannot be derived regularly from a common PU source.

The verb suvaita (: suvaitse-) 'to tolerate' (in Karelian 'to love') is probably a derivation from the same stem, but the fact does not affect our evaluation of the Indo-Iranian etymology.

Etymology: unclear

\subsubsection{Syte ä 'to hit', syttyä 'to set on fire'}

(cognates in all Finnic languages)

$\leftarrow$ Pre-Iranian *tsewč- ([Cheung 2007] *sauč-), cf. Avestan saoc'to burn' ([EWAia II: 655-656] s. v. ŚOC-)

([Koivulehto 1999a: 223-224])

The same root is manifest in Fi huhta $<*$ šukta $<$ PI tsuxta (see Section 3.3.2). Koivulehto's etymology for syteä and syttyä involves phonological problems. The diphthong *ew cannot be regularly simplified to Finnic * $\ddot{u}$, compare the well-known cases PU *lewli (> Fi löyly) 'spirit, steam' [Sammallahti 1988: 545] and PFi *kewhä (> Fi köyhä, Est kehv) 'poor' ([SSA] s. v. köyhä), where the diphthong is retained. This etymology, therefore, has to be rejected. It is also one of the examples where PI affricate would be reflected as Finnic $s$ in Inlaut. There are very few cases like this, so the whole substitution rule might be wrong.

The Finnic $* \ddot{u}$ could, however, reflect PI $* u$, as there are examples of such substitution in other Indo-European loans. Therefore, the Finnic word could reflect a zero-grade form $\left({ }^{*} s u \check{c}_{-}\right)$in Iranian. In Old Indic there are zero-grade forms such as śuc- 'flame' and śuci- 'gleaming'. If the Finnic word was derived from such a form there would also be no need to suggest a "Pre-Iranian" origin, as the Finnic $s$ could simply reflect later Iranian $s$ and not PI $* t s$ (or theoretically even PII ${ }^{*} c$ ). While there are few examples 
of Iranian $s$ in Finnic loanwords, the prehistoric post-PI steppe languages clearly had $s$ and $z$, like Avestan and the majority of Iranian languages.

Semantically it is problematic that the verb syteä simply means 'to hit', and syttyä looks like a derivation from this verb. It is of course possible that the two verbs are unrelated, and only syttyä is borrowed from Iranian, but it is more probable that syttyä is derived from syteä.

Janne Saarikivi (personal communication) considers the verb syteä and the noun sysi (stem syte-) 'coal' to be of same origin. sysi has a convincing Uralic etymology ([SSA] s. v. sysi), but it remains uncertain whether the verbs syteä and syttyä have anything to do with this noun. Saarikivi also connects Komi sot-, Udmurt sutini 'to aflame' to the Finnic verbs, considering the Permic word as a borrowing from Finnic, but it remains open whether this can be suggested by actual linguistic evidence. The Permic words cannot be direct borrowings from Iranian, as Permic $-t$ cannot reflect earlier affricate $*_{\check{c}}$ (in Finnic $*_{\check{c}}>t$ is a regular development), and it would be very difficult to derive the Permic word from Iranian *suč. Joki [1973: 67] notes that the Komi word has been connected with the Iranian word by R. R. Stackelberg as early as in 1893, but Joki rejects the explanation because of the problem with the affricate.

Etymology: convincing (from Iranian *suč-)

\subsubsection{Taivas 'sky, heaven' (cognates in all Finnic languages)}

$\leftarrow \mathrm{PI}(\mathrm{I}) *$ daywa- > Av daēvō 'demon; god', OI devah 'heavenly, divine; god' ([EWAia I: 742-3] s. v. devá-)

([Joki 1973: 323; Rédei 1986: 60; Koivulehto 1999a: 228, 232]; [SSA II] S. v. taivas)

This is a credible Indo-Iranian etymology, first suggested by Diefenbach [1851: 607]. A Baltic origin (from *deiwas $>$ Lith. dievas) has also been suggested by Thomsen [1869: 73], but the Finnic diphthong ai fits the Indo-Iranian form better (cf. Larsson [1984]; Koivulehto [1999b: 80]). [SSA] notes that also semantically the Indo-Iranian word is better, as the meaning 'heavenly' is not attested in Baltic. Nevertheless, [EES] follows the now outdated view that a Baltic origin is more likely ${ }^{13}$. Although the

13 This question has a long research history, which is referred to by Joki [1973]. Kalima [1936; 1950] has defended the Baltic origin both by assuming that the origin 'heaven' might have been present in Baltic earlier and by considering the origin of the Finnic variation of *ei and *ai diphthongs unclear, assuming that Finnish taivas could continue 
Indo-Iranian etymology is convincing, it is difficult to date the borrowing precisely, as the word can equally well be Iranian or Proto-Indo-Iranian on phonological grounds. Schmid [1979: 268] sees the Iranian origin unlikely because of the negative semantics that are connected to the word *daywa (>Av daēvō) in the Iranian languages. But these negative semantics are clearly the result of Zoroastrian religion, and there is no reason to suppose that in Proto-Iranian the word already had acquired a meaning referring to 'demons'.

Some other terms related to mythology (such as *juma 'god') were borrowed from Iranian at a stage when Finnic, Saami, Mordvin (and Mari?) were still forming a dialect continuum at the least, if not a unitary proto-language. This word might belong to the same era, but has simply been lost from the other languages.

According to Koivulehto [2003], the verb toivoa 'to wish' is borrowed from a reflex of the same Indo-Iranian root (see the Section 3.2.30).

Etymology: convincing

\subsubsection{Takra 'piece of meat (as a bait)' (has cognates} in Karelian, Ludic and Veps)

$\leftarrow$ *daHtra-, from verb *daH- 'to give' > OI dātrá- 'allotted portion, share', Av dāera- 'gift, alms' ([EWAia I: 713-715] s. v. $D \bar{A}$ )

([Koivulehto 1999a: 232])

Here Koivulehto proposed a substitution *tr- $>* k r$-, as no $* t r$ - would have been possible in Pre-Finnic (if the word was borrowed from Proto-Iranian, then probably $* \theta r-\rightarrow * k r-)$. His explanation is satisfactory, and since there is no competing etymology for this Finnic word, the Indo-Iranian etymology can be accepted. Nevertheless, one has to note that the very limited distribution of the word raises questions of its early Indo-Iranian origin, and it would be more convincing if there were parallel cases of this substitution within Indo-Iranian loanwords. Koivulehto does present similar cases among Germanic loans (PFi *nekla 'needle' $\leftarrow$ PG *nēpla-). Semantically the etymology is plausible.

Etymology: convincing

earlier *ei. Koivulehto rightly stats that this view is now outdated, as Finnish *ei can reflect earlier *ai, but not vice versa (see now also [Kallio 2014; 2018] for detailed discussions of the development of these Finnic diphthongs). 
3.2.28. Talas 'shelter' (has cognates in Estonian and Livonian); talo 'house' (derivate; has cognates in all Finnic languages) $<$ ? PU * talas

$\leftarrow$ PII *talHa- > OI tala- 'surface, level (Fläche, Ebene)' ([EWAia I: 637]) ([UEW]; [SSA] s. v. talo; [Korenchy 1972: 74-75])

It is unclear whether the Finnic word has cognates in other branches of Uralic. It is included in the present list because Koivulehto [1999: 227] states that the word occurs only in Finnic. However, Sammallahti [1988: 550] considers Permic and Mansi words (Mansi tul 'pool; shed', Ud tilis 'hut') as regular cognates of the Finnic words. The same comparison is found also in [UEW], although there the Mansi word is accompanied by a question mark. Recently Aikio [2015b: 56] has considered the Finnic and Permic words as regular cognates. The Finnic word has also competing Germanic and Baltic etymologies ([SSA] s. v. talas; [LÄGLOS III: 268$269]$ s. v. talas). ${ }^{*} l$ of the Uralic forms is atypical of Indo-Iranian loans, as they usually reflect the Indo-Iranian sound-change $* l>* r$.

The etymology of the Indo-Iranian word is uncertain according to [EWAia]. IEW [1061] assumed that the word has cognates in several Indo-European languages, such as Slavic *tblo 'ground', Baltic (Lith. pã-talas, Latv. patali [Pl.] 'bed', Old Prussian talus 'floor') Germanic (German Diele 'floorboard') and Latin (tellūs 'earth'), but [EWAia] is less certain of this connection. Derksen [2015: 465] reconstructs the Indo-European root as *tl $h_{2}$ - connects the Baltic words * patalas and *tiles "bottom of a barge, flooring' to the Slavic and Germanic words, but does not mention the Indo-Aryan word.

LÄGLOS notes that Koivulehto (in an unpublished handout) has considered talas as a borrowing from early Proto-Germanic * stāla-s $(>\mathrm{ON}$ stóll 'chair'), and that Hofstra [1985] supposes that the word was borrowed from Germanic (cf. *stalla-z (> Old Norse stallr 'stand; (pagan) altar; stable, manger'). [LÄGLOS] considers both etymologies as plausible, and states that the Finnic word is possibly (but not certainly) a loanword from Germanic.

However, if the set indeed includes Mansi and Permic cognates, the Indo-Iranian source would be more credible, as no Germanic loan has such a distribution within Uralic. If the word indeed is an Indo-Iranian borrowing, Finnic -as has to be a later suffix, as the Indo-Iranian word is a neuter (the nominative form would be *talHam $>$ OI talam) and does not manifest the ending - as that is found in some other loans such as taivas ( $\leftarrow$ PII *daywas). It is also possible that the similarity of the Uralic and the various Indo-European words is simply accidental. 
Also a Baltic origin has been assumed (Proto-Baltic *talas $>$ Lith $p \tilde{a}-t a-$ las 'bed') but according to [LÄGLOS] this is semantically less suitable than the Germanic and Indo-Iranian words. One has to state that semantically the Indo-Iranian etymology is not very good either.

Etymology: unconvincing (can be other Indo-European loan)

3.2.29. Terve 'healthy, whole', Est tere id. and regular cognates in all the other Finnic languages $<$ PFI *terves

$\leftarrow$ PII (or PI) *drva-, *drvā > Av druua- 'healthy', OP duruva- 'solid, firm', New Persian darōd 'health, bloom', OI dhruvá- 'solid, firm, fixed, secure' ([EWAia I: 798-799])

([Setälä 1928: 300; Koivulehto 2003]; [EES] s. v. tere)

Koivulehto's etymology was proposed in a presentation and its handout and has not been published as such, but is referred to by [EES], K. Häkkinen [2004] and [LÄGLOS III: 291] s. v. terve. [LÄGLOS] considers Koivulehto's Indo-Iranian etymology better than the Germanic etymologies that have been suggested: Katz [1990: 14] has derived the Finnic word from PG *trewwas (> ON tryggr 'faithful'), and Hofstra [1992: 59-60], from $\mathrm{PG} *$ derbaz (> ON djarfr 'brave'), but neither is supported by [LÄGLOS]. In [SSA], the relationship of terve to terva 'tar' (originally presented by Kiparsky [1952: 94-99]) is considered the most viable option; terva is originally a Baltic loan from *derva 'tar'.

Both semantically and phonologically, the etymology suggested by Koivulehto is convincing. The vowel $e$ results here from the substitution of the cluster *drv-. The meaning 'healthy' seems to be attested exclusively in the Iranian side, although also the more original meaning of 'solid, firm' is attested in Old Persian. According to [EWAia], the adjective is derived from the root *dhar- 'to keep, maintain'.

Earlier Setälä [1928: 298-308] had presented another Indo-Iranian source for the word terve, namely Pre-II *dhermen- (> PII *dharman- > OI dharman-), but this etymology was rejected by Jacobsohn [1933: 139] already as phonologically impossible.

Also a Slavic etymology for the Finnic word has been suggested earlier (Ahlqvist [1857] derived the word from Russian zdorovyj 'healthy' $<$ PSl *sbdorvb), which is ultimately from the same Indo-European root as the Indo-Iranian word (the Slavic word continues PIE $* h_{l}$ sudhoruo, cf. [Derksen 2009: 478-479] s. v. *sbdòrvъ]). It would be very difficult 
to derive the Finnic vocalism from either the Proto-Slavic or Russian word, and the Indo-Iranian etymology is clearly a better option.

Etymology: convincing

3.2.30. Toivoa 'to hope, wish; to foresee', toivo, toive 'hope, wish', toivio-retki 'pilgrimage', Est tõotama 'to promise, to foresee', cognates in all Finnic languages; Votic toivoa 'to wish' is probably borrowed from Ingrian [SSA] s. v. toivoa; [EES] s. v. tõotama]

$\leftarrow$ PII (or PI) *daywa- or *dāywa-, *dāiwya- > OI devá- 'heavenly, divine; god', daíva-, dáivya- 'divine, belonging to the gods' ([EWAia I: 742743] s. v. devá-)

([Koivulehto 2003]; [EES] s. v. tõotama)

It is uncertain whether the word is restricted to Finnic, as Saami $(\mathrm{N})$ doaivut (with cognates in most Saami languages) is either a cognate of the Finnic word or borrowed from it [Kuokkala 2018: 32]. In [SSA], the words are considered as cognates, [EES] mentions the possibility of Finnish loan to Saami. The relationship of the Saami and Finnic words remains unclear for the time being.

Koivulehto's etymology for this Finnic word family is, in principle, convincing. Koivulehto never published the etymology in print, but it is referred to by [EES]. The Indo-Iranian original is the same word from which the noun taivas (see Section 3.2.26) has been borrowed; the semantic difference between 'to wish' and 'heaven' is rather wide, but both can be derived from the semantics of the Indo-Iranian word, as Koivulehto lists also meanings 'divine will, faith, happiness' among the meanings of the Indic word dáivya-.

The problem is that the vowel substitution is different, and it is difficult to see why PII $* a$ was substituted differently in the same environment in these two words. One possibility is that the words reflect two different layers of borrowing, but it is very difficult to prove this. On the other hand, Koivulehto notes that an old vrddhi formation *dāywa- (PIE *dēywo-) can be reconstructed for the word in question. It is possible that a short $a$ is reflected in taivas, whereas a long $\bar{a}$ is reflected in toivo. Phonetically, this is not compelling, and this solution would be rather speculative. Another hypothetical reason could be a difference in accentuation: in the Vedic vrddhi-forms daívya- 'divine', Fem. daivi-, dáiva- id. (but note also daivá-) the accent is on the first syllable, but on the last syllable on devá-.

Despite the phonological problem mentioned above, the etymology can be accepted. No competing loan explanation for the Finnic word exists.

Etymology: convincing 
3.2.31. viha 'hate', vihata 'to hate' (has cognates in all Finnic languages)

$\leftarrow$ PII *dwišs- > OI dviș- 'to hate' ([EWAia: 770-71] s. v. DVEṣ) ([Parpola 1999: 201-202]; [SSA] s. v. viha)

According to the traditional view that is reflected by [UEW], the words viha 'venom' and viha 'hate' are the same word, which is a borrowing from Indo-Iranian *wiša- 'venom'. This is an established and well-known etymology, and the Finnic word has probable cognates in Permic. Parpola separates the two viha words and considers these as separate borrowings from two different Indo-Iranian sources. It is difficult to determine whether these are separate borrowings or not, since both Indo-Iranian origins (*wišaand $\left.* d w i \check{s}^{-}\right)$are phonologically suitable. In Hungarian, the words for "poison' and 'hate' (méreg and mérges) are clearly etymologically connected ([Bárczi 1941] s. v. méreg; [MszFE] s. v. méreg). Therefore, it seems plausible to suppose that the two Finnic words could reflect the same word, the original meaning of which would have been 'venom, poison'.

Etymology: unclear

\subsection{Indo-Iranian etymologies that have irregular cognates in Finnic and neighbouring branches}

This section deals with Finnic words with proposed Indo-Iranian etymologies, which have irregular cognates in other (Western) Uralic branches. This irregularity indicates that these words might be also Indo-Iranian loans which are reflected solely in Finnic. The irregularity can result from parallel borrowing, undetected sound laws, or false etymologies, and each case has to be treated separately.

\subsubsection{Ahtera 'barren, sterile (of a cow)' (has cognates in Votic,}

Estonian and Livonian); Mo E ekšt'er', jekšt 'er', jakšt'ér M jašt’’́r < ? *äštärä or *äkštärä

$\leftarrow$ PII (or PI) *akšaitra > OI ákșetra- 'destitute of fields, uncultivated' ([Blážek 1990: 40; Aikio 2015b: 44])

This word is present in both Finnic and Mordvin, but Aikio (p. c.) indicated that the words are not regular cognates, so they could be parallel borrowings. A cluster of three consonants is also atypical for the inherited 
Proto-Finnic words. Aikio [2015b] argues that the Finnic word could reflect the originally front-vocalic form *äkštärä. It is interesting that there seem to be no other credible Indo-Iranian etymologies in Finnic, where PII or PI * $a$ would have been substituted by $* \ddot{a}$. If the Finnic and Mordvin words are indeed parallel loans, there is no reason to suppose a front-vocalic reconstruction for the Finnic word, as different substitution patterns could have been used in Pre-Finnic and Pre-Mordvin. The Mordvin word certainly reflects a front-vocalic form *äkštärä.

This word is one of the best examples providing support for the hypothesis that Finnic could have borrowed words from an Indo-Iranian language independently, after its split off from the nearest proto-languages.

Munkácsi [1901: 238-289] had earlier considered the Uralic words as a loan from another Indo-Iranian word, namely *starī- (> OI starî- 'cow that does not give milk', from PIE *sterih $2^{-}$'sterile', [EWAia II: 757]). This explanation looks less likely, because here we would have to assume that a prothetic vowel developed before the word-initial consonant cluster in Uralic. Although this kind of substitution would be a possible way to avoid the Anlaut cluster, there are no parallel examples in the early loanwords, where these kinds of clusters were typically simplified (cf. * sampas $\leftarrow{ }^{*}$ stambhas). Also the substitution of $*_{s}$ by $*_{s}$ would be unexpected. Munkaćsi also connects Hungarian eszter 'infertile, barren' to the Mordvin and Finnic words, but it is impossible to derive the Hungarian, Finnic and Mordvin words from the same Uralic pre-form. The possible Indo-Iranian origin of the Hungarian word has to be left for further study to solve.

The Indo-Iranian etymology suggested by Blážek itself is convincing in principle, but because of various vowel-reductions in this kind of trisyllabic word, it is difficult to establish the precise substitutions. Here one has to also take into account the possibility that the similarity of the Uralic and Sanskrit words might be accidental. Many words relating to agriculture have irregular cognates in Mordvin, Mari and sometimes in Saami, and these could reflect substrate borrowings from some unknown language [Aikio 2015b: 43-47]. The semantics and the irregular relationship of Finnic ahtera and Mordvin ekšt'er mean that these words could belong to this group of words as well.

Etymology: convincing 
3.3.2. Huhta, huuhta 'burned patch in slash-and-burn agriculture' (has cognates in Karelian, Ludic and Estonian); Mordvin E čuvto, M šufta 'tree' < ? West-Uralic * šukta (Koivulehto: čukta)

$\leftarrow$ PI *tsuxta-, verbal adjective from the root *tsawč- > Av upa-suxta 'burned', root saoč- 'to burn' ([Cheung 2007] *sauč-)

([Koivulehto 1999a: 225-226; 2001b: 256-257])

The etymology itself is plausible, as the Finnic and Mordvin words can be regularly derived from Iranian *tsuxta-. Koivulehto [2001b: 257] himself notes that the relationship Fi $u^{14}$ : Mo $u$ is irregular (one would expect Mo $o$ ), but states that this "points to borrowing". However, most of early borrowings display identical reflexes with those observed in the inherited Uralic words. The reason for irregularity can simply be that the word is a parallel loan in Mordvin and Finnic, or that it has penetrated from pre-Mordvin to pre-Finnic. While there is a lot of research about secondary contacts and lexical diffusion between Saami and Finnic, the possibility of post-proto-language convergence between Mordvin and Finnic has been poorly studied. Aikio [2015b: 44-46] noted that in Finnic, Mordvin and Mari (and also in Saami, yet more rarely) there are many irregular words, which could probably result from a substrate language (for example, Fi lehmä 'cow' Mo E lišme 'horse' < ? *lešmä, Fi vehnä 'wheat' Mo E viš, Mari E wiste 'spelt' $<$ ? *wešnä). The latest Iranian borrowings might have been acquired at the time when these substrate words were borrowed.

Koivulehto [1991: 32] had earlier suggested a Baltic etymology for this word, but the postulated Baltic form * šukta- is unattested. It would equally well match the Finnic and Mordvin words, which have to reflect Proto(-West-)Uralic *̌s rather than *̌c; according to Aikio's [2015b: 4-5] views on Uralic sibilants, the word has to be reconstructed as * škta, not *čukta, although the latter form would suit the Iranian reconstruction better. Nevertheless, the etymology is otherwise convincing, and due to the lack of the attested Baltic form, the Iranian borrowing looks more likely.

Etymology: convincing

${ }^{14}$ The long $u u$ in eastern dialects of Finnish and in Karelian is secondary, cf. [Itkonen 1987]. 


\subsubsection{Porsas 'piglet' (has cognates in all Finnic}

languages); Mo E purtsos, M puŔts id.; Ud parś, pariś, Ko porś' 'pig' < Pre-FI/PU *porćas *porśas 'pig'

\section{$\leftarrow$ ? PII *parća- / Pre-II *porćo or $\leftarrow$ PBS1 ? *parśa- < PIE *porḱos}

([Joki 1959: 52; 1973: 303; 1988: 585]; [SSA II] s. v. porsas; [Koivulehto 2001b: 242])

This is an intriguing word, as it is clearly an Indo-European borrowing, but not necessarily an Indo-Iranian one. According to Kallio (ms.) the Finnic word could be a Balto-Slavic borrowing. This possibility has been hinted also by Napolskikh [2002], and already Benveniste [1949: 87] noted the difficulties of deriving the Uralic word(s) from Indo-Iranian, and supported an earlier Indo-European etymology for the word. The second syllable * $o$ was either not possible or at least very rare in PU, cf. [Aikio 2015b], so * as could have been a suitable substitution of PIE *os. Indo-Iranian origin would work too, as Uralic ${ }^{*} o$ is a possible substitution for PII $* a$ (cf. wellknown examples like *ora 'awl' $\leftarrow$ PII *āra- [Koivulehto 2001b: 248]). Whether $* a$ or $*_{o}$ should be reconstructed in the first syllable of the Balto-Slavic word at this point does not matter much, as both could be substituted by Uralic/Pre-Finnic *o. Koivulehto [1991: 24; 2001b: 242] has assumed that the Finnic word could be borrowed from North-West Indo-European, and Uralic $c$ would substitute the retained PIE $* k$ here (as argued already by Joki [1959: 52]), but it is impossible to prove that the word was not borrowed from a later satem language (such as Balto-Slavic). Koivulehto also notes that the ending - as is atypical for the earliest Indo-Iranian loans, but this claim is only partly correct, as it appears in a number of loans, some of which are difficult to date and are not necessarily very late. It seems correct that ending * as is not attested in tentative PIE loans.

As said, Mordvin and Permic (Ud parś, Ko poŕś) forms cannot be regular cognates of the Finnic word, so they are parallel loans, probably from Indo-Iranian, as Koivulehto (2001b: 242) has noted. The problem here is that because of the palatal $s$ in Permic this borrowing, too, must be quite old, but a more detailed treatment of this issue has to be pursued elsewhere. [EES] mentions that the Mordvin words could have been borrowed from Finnic languages, but this could hardly explain the Mordvin affricates.

Hyllested [2014: 84-85] has argued that at least the forms in Mordvin and Permic are borrowed from Turkic *borsuq 'badger' ( $>$ Chuvash porz $\check{s}$ id.). Hyllested assumes that the Indo-European words, too, are ultimately borrowed from this Turkic word, which he considers a "Central Asiatic 
culture word". I find no reason to support Hyllested's arguments. The consonantism of the Udmurt, Komi and Mordvin words can hardly be explained from the Turkic forms: while I admit that the Indo-Iranian origin explains the palatal sibilant of Permic only if the borrowing is very early (not from Iranian *partsa- or *parsa-), the Turkic $s$ or $s$ is not better at all, as it would probably have been substituted by $* s$ in Permic. And although semantically it would not be impossible to derive the 'pig(let)' words from 'badger', the idea that the central Uralic words are simply Indo-Iranian loanwords is more convincing also from this point of view.

Etymology: unclear (certainly from Indo-European, but not necessarily from PII)

\subsubsection{Hyvä 'good' (has cognates in all Finnic languages), SaN savvit} 'to heal a wound' (has cognates in all Saami languages except Akkala and Ter); Mordvin E čiv, M čiva 'hospitable'<? *šivä $\sim$ *čiwä

$\leftarrow$ PI *tsiwa-, cf. OI śiva- 'auspicious, propitious, gracious, favourable, benign, kind, benevolent, friendly, dear'; god's name Śiva- < PII *ćiwa([EWAia II: 640])

([Koivulehto 2009: 85-87])

Koivulehto considers this West-Uralic word as a loan from Proto-Iranian, but this is not necessarily the case. First of all, this word is not even attested in Iranian. It is attested in Indo-Aryan and has an Indo-European etymology (the word is derived from PIE *keywo-, as Koivulehto notes), so the word must have been present in PII, but there are no traces of it in the attested Iranian languages. Of course, it is possible that the word was still present in Iranian, even though it has not been attested (it is well-known that the corpus of Old Iranian texts is much smaller than the huge amount of Old Indo-Aryan material, and this is also mentioned by Koivulehto), but there are other problems with the etymology as well.

Apart from this, the phonological relations between the Finno-Ugric words are irregular: the Saami and Finnic words point at $*$ siw $\ddot{a}^{15}$, whereas the Mordvin words cannot reflect this form. Erzya affricate $c$ is often secondary and reflects regularly earlier (PU) $* s$. Finnic $h$, on the other hand, cannot reflect PU *č according to Aikio [2015a: 4-5]. Koivulehto still assumed

${ }^{15}$ In earlier sources such as [UEW], the word has been reconstructed as *šeyä. Koivulehto convincingly argues that such a reconstruction is impossible because $\mathrm{\eta}$ would have been retained in Mordvin. 
that Finnic $h$ can reflect either $* \check{s}$ or $* \check{c}$. Furthermore, the relation $\mathrm{E} \check{c}: \mathrm{M} \check{c}$ is irregular (in the case of earlier $* \check{s}$, the reflex $\check{s}$ should have been retained in Moksha), and it is difficult even to reconstruct this word to Proto-Mordvin. Koivulehto assumes that the Finnic word could reflect earlier *ciwä, and the Saami word could be a loan from Finnic, but this cannot be the case since the Finnic $h$ must go back to $*_{s}$, not $*_{\breve{c}}$ according to Aikio [2015].

Furthermore, the vowels are also problematic: in * $\ddot{a}$ stems, PU/ PWU $* i$ regularly develops into $e$ in both Mordvin languages [Bereczki 1988: 320], so on the basis of the Mordvin forms an old $i-\ddot{a}$ stem cannot be reconstructed. A form *čewä could be reconstructed for Pre-Mordvin on the basis of the Moksha and Erzya forms. The Saami form could reflect either earlier *e or *i. According to Santeri Junttila (personal communication), the Livonian cognate point to *šiwä. Both the vocalism and the consonantism manifests serious problems and the words cannot be regular cognates.

All these things considered, the etymology is rather to be rejected. Alternatively, parallel loans with different consonant and vowel substitutions in Finnic, Saami and Mordvin could be assumed, but the absence of the word from Iranian makes this unlikely. Probably the Finnic and Saami words are cognates, but they have nothing to do with the Mordvin words.

Etymology: unconvincing

\subsubsection{Suka 'haircomb' (has cognates in all Finnic languages); SaN} čohkut 'to comb' (has cognates in all Saami languages except Akkala); Mo śuva 'husk of grain'; Mari šu 'husk of grain'; Ud śu 'rye; grain'

$\leftarrow$ PII *'cūka- > Av sūkā 'spike, needle', Oss syg 'awn', OI śūka 'awn, stangle ([EWAia III: 494-495]), cf. also Ved. suci- (< ? earlier *'suci) 'needle' or $\leftarrow$ PBSl *śuka 'comb', cf. Lith. pl. šùkos 'comb, woolcomb' ([Frankel 1962-1965: 1031] s. v. šúkos)

([Kallio 2009: 32-33; Junttila 2012]; [SSA] s. v. suka; [Joki 1973: 315316; Redei 1986: 59-60])

The Finnic word has been cautiously connected to the Mordvin and Permic words in earlier research, but Kallio has convincingly shown that the Finnic word and its Saami cognate represent separate loans from Balto-Slavic. It indeed seems to be the case that the Finnic and Saami words should be separated from the Mordvin, Mari and Permic words for semantic reasons. Kallio's Balto-Slavic etymology for the Finnic word is more plausible semantically. Fraenkel ([1962-1965] s. v. šùko) notes that the 
background of the Baltic word is unclear, but the Lithuanian word could regularly reflect Balto-Slavic *śskā.

The words in Mordvin, Mari and Permic might be parallel loans from Indo-Iranian, as the relationship between them is not entirely regular. In Mordvin, earlier * $u-a$ stems should develop $o$ in the initial syllable, compare PU *muna 'egg'> Mordvin mona, PU *kuma- 'face down'> Mordvin koma[Sammallahti 1988: 537-538]. However, the borrowing has to be early in all the languages because Permic and Mordvin clearly show reflexes of PU palatal sibilant, which could not result from later Iranian forms.

Etymology: unconvincing (the Finnic word is not borrowed from Indo-Iranian)

\subsubsection{Syntyä 'to be born' (has cognates in all Finnic} languages); Ko sod-, sud- 'to increase' $<$ ? *sentä-

$\leftarrow$ "Pre-Iranian" *dzenH- ([Cheung 2007] *zanH) $<$ PIE * ǵenh ${ }_{1}$ - 'to be born' ([LIV: 163])

([Koivulehto 1999a: 222-223; 2001b: 254-255])

For this etymology, Koivulehto had to postulate an irregular change $*_{e}>* \ddot{u}(=$ Fi $y)$ in Finnic. There are examples of PU/Pre-FI $* e$ being reflected as Finnic * $\ddot{u}$ (such as *jewä $>* j \ddot{u} w a ̈$ 'grain', also an Indo-Iranian loanword). However, this change is usually caused by phonological factors which are missing from this word. Pystynen [2015] dealt with some of these cases and concluded that $* e$ does not usually labialize even in front of $* w$. Therefore, labialization in this context would be even more unlikely.

The Komi cognate supposed by Koivulehto cannot be a regular cognate of the Finnic word. One possibility to explain the irregular relationship would be to consider the Komi word a loan from Finnic, but this is improbable because the borrowing would have to be extremely old, from the time before the Proto-Permic denasalization (Niklas Metsäranta: personal communication). Thus, for the time being, the etymology of the Komi word remains unclear. The Saami word šaddat 'to grow, to be born' is a well-known loan from Finnic [Sammallahti 1998: 264].

Therefore, this etymology is most probably wrong. It might be possible to derive the Finnic word from a reflex of the PIE root $* g e n h_{1}$ - in some branch of Indo-European, but this requires further study. Koivulehto's Pre-Iranian source is obviously wrong, so this cannot be used as an evidence for a particular substitution pattern of Proto-Iranian affricates.

Etymology: unconvincing 
3.3.6. vasara 'hammer'; SaN veahcir ( $<\mathrm{PSa}$ *veaćēē; cognates in all Saami languages; cf. [Lehtiranta 2001, no. 1367]) id.; Mo E uźer, viźiŕ, M uźaŕ 'axe'<? *waćara

$\leftarrow$ PII *wajra-> Av vazra- 'club', OI vajra- 'thunderbolt, Indra's weapon' ([EWAia II: 492] s. v. vájra-)

\section{([Joki 1973: 339; SSA III: 395])}

This is an established etymology. According to Häkkinen [2009: 23-24], the vowel relations between Finnic, Saami and Mordvin are regular. However, this is not exactly the case: vaski<*wäśkä is irregular, and so it is impossible to reconstruct a unitary form to Proto-Uralic [Aikio 2015]. Also, marras is not a cognate of Mordvin miŕd'e (which reflects earlier *mertä and is a cognate of the Komi mort and Udmurt murt), this has to be a separate loan from the same source as Finnic marras (see also Section 3.2.12). Therefore, there is no explanation for this irregularity other than assuming that the words were acquired separately to Pre-Finnic, Pre-Saami and Pre-Mordvin.

The Indo-Iranian etymology of these words is, therefore, clearly plausible, but it is impossible to reconstruct them into a unitary proto-form. Maybe this word, as a cultural term, has been a Wanderwort that was borrowed into one of the West-Uralic dialects after the split-up of the common proto-language of Finnic, Saami and Mordvin, and diffused between dialects. It can also simply be a parallel borrowing from Indo-Iranian in all these languages (however, the archaic, Proto-Indo-Iranian phonological shape of the word seems to contradict the idea of a late separate borrowing).

Etymology: convincing (the Finnic word is certainly an Indo-Iranian loan)

\section{Conclusions}

The Indo-Iranian loan etymology was rejected for the following words: herätä, jäädä, niska, oide, sarajas, syntyä, talas

The following words are probably loans but rather from other Indo-European languages than Indo-Iranian:

aisa, talas, porsas, oja(s), ola, suka, ? tiine 
The following words have a credible Indo-Iranian etymology but their distribution is not restricted to Finnic, as they have cognates in other branches of the Uralic language family:

tiine (can also be from Baltic), piimä

The following cases remained uncertain:

isäntä (probably a derivation from isä 'father', but the Indo-Iranian etymology cannot be ruled out), sammua (both Germanic and Indo-Iranian etymologies are plausible), perna (a promising etymology, but includes phonological problems with vowel developments), suoda (the vowel reconstruction is complicated which makes it hard to either accept or reject the etymology), terni (phonological and semantic problems), viha (certainly an Indo-Iranian borrowing, but it is difficult to determine whether it is the same word as viha 'venom'), verso (similar problems as with perna)

The following etymologies indeed seem to be Indo-Iranian loans which are found only in Finnic:

ahnas, aivan, apu, hadas, iha ${ }^{16}$, ihta, iso, marras, ohra, paksu, peijaiset, taivas, takra, toivoa, sammas, syttyä, terve, toivoa

Out of the Finnic etymologies with irregular cognates elsewhere in the Uralic family, the following ones are probably of non-Indo-Iranian origin:

hyvä (not an IE loan), suka (probably from Balto-Slavic), syntyä (not an IE loan)

The word porsas can be from either Indo-Iranian or Balto-Slavic.

The rest (ahtera, huhta, vasara) have a credible Indo-Iranian etymology.

Therefore, it seems that the number of Indo-Iranian borrowings restricted to Finnic is in fact very low. In almost half of the cases evaluated here, the words are either of non-Indo-Iranian origin or have cognates in other Uralic languages. If the unclear cases are counted, the number is even greater.

As was mentioned above, distribution is not always a valid criterion in the stratigraphy of Indo-European borrowings in Uralic. Finnic words with a plausible Indo-Iranian etymology clearly reflect several diachronic layers, all of which are shared by some other Uralic branches. This means

${ }^{16}$ But note that here it has been argued that there is no reason to suppose two homonymous iha words, both of which would have been borrowed from Indo-Iranian 
that Finnic could not have acquired these words as a separate language. Some clearly late Iranian loans such as varsa and vasa have regular cognates in Mordvin [Koivulehto 1999a: 218-219], whereas some more archaic words are confined to Finnic. It is, however, interesting to note that many of the loanwords confined to Finnic manifest clearly Iranian features, and among those that are not demonstrably Iranian, there are no features that force us to consider these borrowings earlier Proto-Indo-Iranian loans; some of the more archaic loans are either problematic (such as verso) or should be rejected (such as herätä).

There are few irregular cases (*waćara, *akštara, *šukta) which cannot be explained as wrong etymologies or results of undetected sound laws, though. They could either be parallel Indo-Iranian loans or indicate that the respective Indo-Iranian words spread through a dialect continuum which consisted of predecessors of Finnic, Saami and Mordvin, at the least. However, at least *waćara and * šukta clearly reflect different layers of Indo-Iranian borrowings (*waćara with $*^{*} \dot{c}$ from PII $* j$ and $* \check{s} u k t a$ with $* \check{s}$ from PI $*_{c}$ ). It is therefore unlikely that they were simultaneously diffused through the already differentiated West-Uralic dialects. Further development of historical phonological studies can reveal hitherto unexpected conditioned developments in the history of Finnic and its neighboring branches, which might help us to explain some of these cases.

\section{Abbreviations}

Av - Avestan; Est - Estonian; Ko - Komi; Lv - Livonian; Mo - Mordvin; Mo E - Erzya Mordvin; Mo M - Moksha Mordvin; OI - Old-Indo-Aryan (Sanskrit); PBsl - Proto-Balto-Slavic; PFi — Proto-Finnic; PG — Proto-Germanic; PI — Proto-Iranian; PIE — Proto-Indo-European; PII — Proto-Indo-Iranian; Pre-Fi — Pre-Finnic; Pre-II — Pre-Indo-Iranian; PSa — Proto-Saami; SaN — North Saami; SEst — South Estonian (Võro-Seto); Ud - Udmurt.

\section{References}

Ahlqvist 1857 - A. Ahlqvist. Venäläisiä sanoja suomen kielessä. Suomi. Tidskrift i fosterländska ämnen. 1857. P. 89-99.

Aikio 2012a - A. Aikio. On Finnic long vowels, Samoyed vowel sequences, and Proto-Uralic *x. T. Hyytiäinen, L. Jalava, J. Saarikivi, E. Sandman (eds.). Per Urales ad Orientem. Iter polyphonicum multilingue. Festskrift tillägnad Juha Janhunen på hans sextioårsdag den 12 februari 2012 (Suomalais-Ugrilaisen Seuran Toimituksia. Vol. 264). Helsinki: Suomalais-Ugrilainen Seura, 2012. P. 227-250. 
Aikio 2012b - A. Aikio. An essay on Saami linguistic prehistory. R. Grünthal, P. Kallio (eds.). A Linguistic map of Prehistoric Northern Europe (Suomalais-Ugrilaisen Seuran Toimituksia. Vol. 266). Helsinki: Suomalais-Ugrilainen Seura, 2012. P. 63-117.

Aikio 2014 - A. Aikio. Studies in Uralic etymology III: Mari etymologies. Linguistica Uralica. 2014. Vol. L. No. 2. P. 81-93.

Aikio 2015a -A. Aikio. Studies in Uralic Etymology IV: Ob-Ugric etymologies. Linguistica Uralica. 2015. Vol. LI. No. 1. P. 1-20.

Aikio 2015 b - A. Aikio. The Finnic 'secondary e-stems' and Proto-Uralic vocalism. Suomalais-Ugrilaisen Seuran Aikakauskirja. Journal de la Société Finno-Ougrienne. 2015. No. 95. P. 25-66.

Aikio, Kallio 2005 - A. Aikio, P. Kallio. Zu Hartmut Katz: Studien zu den älteren indoiranischen Lehnwörtern in den uralischen Sprachen. Aus dem Nachlass herausgegeben von Paul Widmer, Anna Widmer und Gerson Klumpp. Die Sprache: Zeitschrift fur Sprachwissenschaft. 2005. Bd. 45. S. 212-222.

Bárczi 1941 — G. Bárczi. Magyar szófejtő szótár. Budapest: Királyi Magyar Egyetemi Nyomda, 1941.

Beekes 2010 - R. Beekes. Etymological dictionary of Greek (Leiden Etymological Dictionary Series. Vol. 10). Leiden; Boston: Brill, 2010.

Benveniste 1949 - E. Benveniste. Noms d'animaux en indo-européen. Bulletin de la Société de linguistique de Paris. 1949. No. 45. P. 74-103.

Bereczki 1988 - G. Bereczki. Geschichte der wolgafinnischen Sprachen. D. Sinor (ed.). The Uralic languages. Description, History and Foreign Influences. Leiden; New York; København; Köln: Brill, 1988. P. 314-350.

Blážek 1990 - V. Blážek. New Fenno-Ugric-Indo-Iranian lexical parallels. Вяч. Вс. Иванов, Т. М. Судник, Е. А. Хелимский (ред.). Uralo-Indogermanica II. Балтославянские языки и проблема урало-индоевропейских связей. Материалы 3-й балто-славянской конференции, 18-22 июня 1990 г. М.: Институт славяноведения и балканистики АН СССР, 1990. C. 40-45 (V. Blážek. New Fenno-Ugric-Indo-Iranian lexical parallels. Vyach. Vs. Ivanov, T. M. Sudnik, E. A. Khelimskiy (eds.). Uralo-Indogermanica II. Balto-slavyanskiye yazyki i problema uralo-indoyevropeyskikh svyazey [Balto-Slavic languages and the problem of Ural-Indo-European relations]. Proceedings of the $3^{\text {rd }}$ Balto-Slavic conference, June 18-22, 1990. Moscow: Institute of Slavic and Balkan Studies of the USSR Academy of Sciences, 1990. P. 40-45).

Cheung 2007 - J. Cheung. Etymological dictionary of the Iranian verb (Leiden Etymological Dictionary Series. Vol. 2). Leiden: Brill, 2009.

de Vaan 2000 - M. de Vaan. The Indo-Iranian animal suffix *āćá-. Indo-Iranian Journal. 2000. Vol. 43. P. 279-293.

Derksen 2009 - R. Derksen. Etymological dictionary of the Slavic inherited lexicon (Leiden Etymological Dictionary Series. Vol. 4). Leiden; Boston: Brill, 2009.

Derksen 2015 - Rick Derksen. Etymological dictionary of the Baltic inherited lexicon. Leiden Etymological Dictionary Series. Vol. 13. Leiden/Boston: Brill, 2015. Diefenbach 1851 — L. Diefenbach. Vergleichendes Wörterbuch der Gothischen Sprache. Bd. II. Frankfurt am Main: Verlag von Joseph Baer, 1851. 
EWAia - M. Mayrhofer. Etymologisches Wörterbuch des Altindoarischen. Heidelberg: Winter, 1986-2001.

Fraenkel 1962-1965 — E. Fraenkel. Litauisches etymologisches Wörterbuch. Heidelberg: Winter, 1962-1965.

Garnier et al. 2017 - R. Garnier, L. Sagart, B. Sagot. Milk and the Indo-Europeans. M. Robbeets, A. Savelyev (eds.). Language Dispersal Beyond Farming. Amsterdam: Benjamins, 2017. P. 291-311.

Grünthal 2012 - R. Grünthal. Baltic loanwords in Mordvin. R. Grünthal, P. Kallio (eds.). A Linguistic map of Prehistoric Northern Europe (Suomalais-Ugrilaisen Seuran Toimituksia. Vol. 266). Helsinki: Suomalais-Ugrilainen Seura, 2012. P. 297-343. Hahmo 1988 - S.-L. Hahmo. Omaa vai lainattua: itämerensuomen germaanisiin lainasanoihin liittyviä kirjoitelmia. Helsinki: Suomalaisen Kirjallisuuden Seura, 1988.

Häkkinen 1984 - K. Häkkinen. Wäre es schon an der Zeit, den Stammbaum zu fallen? Ural-Altaische Jahrbucher, Neue Folge. 1984. Bd. 4. S. 1-24.

Häkkinen 2004 — K. Häkkinen. Nykysuomen etymologinen sanakirja. Juva: WSOY, 2004.

Häkkinen 2009 - J. Häkkinen. Kantauralin ajoitus ja paikannus: perustelut puntarissa. Journal de la Société Finno-Ougrienne. 2009. No. 92. S. 9-56.

Helimski 1997 - Eugene Helimski. The southern neighbours of Finno-Ugrians: Iranians or an extinct branch of Aryans ("Andronovo Aryans")? S.-L. Hahmo, T. Hofstra, L. Honti, P. van Linde, O. Nikkilä (hrsg.). Finnisch-ugrische Sprachen in Kontakt. Vorträge des Symposiums aus Anlaß des 30- jährigen Bestehens der Finnougristik an der Rijksuniversitejt Groningen 21.-23. November 1996. Maastrich: Shaker, 1997. P. 117-125.

Höfler 2017 — S. Höfler. Hittite hǐ̌ša- c. 'thill, shaft (of a cart)' and the feminine gender in Proto-Indo-European. Conference Handout: The Split - Reconstructing Early Indo-European Language and Culture. University of Copenhagen, September 13-15, 2017. Available at: https://www.academia.edu/34569864/Hittite_hišša-_c._thill_shaft_ of_a_cart_and_the_feminine_gender_in_Proto-Indo-European (accessed in July 2018). Hofstra 1985 - T. Hofstra. Ostseefinnisch und Germanisch. Frühe Lehnbeziehungen im nördlichen Ostseeraum im Lichte der Forschung seit 1961. Doctoral thesis. Groningen: Rijksuniversiteit te Groningen, 1985.

Holopainen et al. 2017 - S. Holopainen, S. Junttila, J. Kuokkala. Indoeurópai jövevényszavak és a második szótagi labiális magánhangzók fejlődése az uráli nyelvekben. T. Forgács, M. Németh, B. Sinkovics (szerk.). A nyelvtörténeti kutatások újabb eredményei IX. Szeged: Szegedi Tudományegyetem, 2017. 109-136. o.

Holopainen 2018 - S. Holopainen. Indo-Iranian loans in Saami. S. Holopainen, J. Saarikivi (toim.). Perì orthótētos etýmōn. Uusiutuva uralilainen etymologia (Uralica Helsingiensia. Vol. 11). Helsinki: Suomalais-Ugrilainen Seura, 2018. P. 135-179.

Honti 2017 — L. Honti. A magyar és a nyugati ótörök szókészleti kapcsolatairól. Budapest: Tinta Könvkiadó, 2017.

Hyllested 2014 - A. Hyllested. Word Exchange at the Gates of Europe: Five Millennia of Language Contact. PhD dissertation. Copenhagen: Det Humanistiske Fakultet, Københavns Universitet, 2014.

IEW — J. Pokorny Indogermanisches Etymologisches Wörterbuch. Bern: Francke, 1959-1969. 
Itkonen 1987 — T. Itkonen. Erään vokaalivyyhden selvittelyä. Virittäjä. 1987. Vol. 91. No. 2. S. 164-208.

Itkonen 1997 - T. Itkonen. Reflections on pre-Uralic and the "Saami-Finnic protolanguage”. Finnisch-Ugrische Forschungen. 1997. Bd. 54. P. 229-266.

Jacobsohn 1922 - H. Jacobsohn. Arier und Ugrofinnen. Göttingen: Vandenhoeck and Ruprecht, 1922.

Jacobsohn 1933 - H. Jacobsohn. Zu den ältesten arischen Lehnwörtern in den finnisch-ugrischen Sprachen. Liber semisaecularis Societatis Fenno-Ugricae. (Suomalais-Ugrilaisen Seuran Toimituksia. Vol. 67). Helsinki: Suomalais-Ugrilainen Seura, 1933.

Joki 1973 - A. J. Joki. Uralier und Indogermaner (Suomalais-Ugrilaisen Seuran Toimituksia. Vol. 151). Helsinki: Suomalais-Ugrilainen Seura, 1973.

Joki 1959 - A. J. Joki. Paleolingvistiikkamme ongelmia. P. Virtaranta, T. Itkonen, P. Pulkkinen (toim.). Verba docent. Juhlakirja Lauri Hakulisen 60-vuotispäiväksi. Helsinki: Suomalaisen Kirjallisuuden Seura, 1959. S. 48-67

Junttila (ms.) — S. Junttila. Huomioita itämerensuomen her $V$-sanoista. Unpublished manuscript.

Junttila 2012 - S. Junttila. The prehistoric context of the oldest contacts between Baltic and Finnic languages. R. Grünthal, P. Kallio (eds.). A Linguistic map of Prehistoric Northern Europe (Suomalais-Ugrilaisen Seuran Toimituksia. Vol. 266). Helsinki: Suomalais-Ugrilainen Seura, 2012.

Junttila 2015 - S. Junttila. Tiedon kumuloituminen ja trendit lainasanatutkimuksessa. Kantasuomen balttilaislainojen tutkimushistoria. Doctoral dissertation. Helsinki: Helsingin yliopisto, 2015. P. 261-296.

Junttila 2016 - S. Junttila. Die baltisch-slawische Frage im Lichte der alten baltischen Lehnwörter des ostseefinnischen. Baltistica. 2016. Vol. LI. No. 2. S. 217-238.

Kalima 1933 - J. Kalima. Fi. sammas 'grenzstein'. Finnisch-Ugrische Forschungen. 1933. Bd. 21. S. 128-137.

Kalima 1936 - Jalo Kalima. Itämerensuomalaisten kielten balttilaiset lainasanat. Helsinki: Suomalaisen Kirjallisuuden Seura, 1936.

Kallio (ms.) - The Proto-Balto-Slavic loanword stratum in the Uralic languages. Unpublished manuscript.

Kallio 2009 - P. Kallio. Stratigraphy of Indo-European loanwords in Saami. T. Äikäs (ed.). Mattut - maddagat: The Roots of Saami Ethnicities, Societies and Spaces / Places. Oulu: Giellagas Institute at the University of Oulu, 2009. P. 30-45.

Kallio 2006 - P. Kallio. Suomen kantakielten absoluuttista kronologiaa. Virittäjä. 2006. Vol. 110. No. 1. S. 2-25.

Kallio 2014 - P. Kallio. Diversification of Proto-Finnic. J. Ahola, Frog, C. Tolley (eds.). Fibula, Fabula, Fact. The Viking age in Finland (Studia Fennica Historica. Vol. 18). Helsinki: Suomalaisen Kirjallisuuden Seura, 2014. P. 155-168.

Kallio 2018 - Ensitavun diftongit kantasuomessa. S. Holopainen, J. Saarikivi (toim.). Perì orthótētos etýmōn. Uusiutuva uralilainen etymologia (Uralica Helsingiensia. Vol. 11). Helsinki: Suomalais-Ugrilainen Seura, 2018. S. 251-268.

Katz 1983b - H. Katz. Zu idg. *mrtó-. Die Sprache. 1983. Bd. 29. S. 174-177. 
Katz 2003 - H. Katz. Studien zu den älteren indoiranischen Lehnwörtern in den uralischen Sprachen. Aus dem Nachlas herausgegeben von P. Widmer, A. Widmer und G. Klumpp. Heidelberg: C. Winter, 2003.

Katz 1983a - H. Katz. Hehtitisch hišša - und zubehör. G. Frantz-Szabo (hrsg.). Festschrift Annelies Kammenhuber (Orientalia. Vol. 52. No. 1). Rome: Pontificium Institutum Biblicum, 1983. S. 116-122.

KEWA - M. Mayrhofer. Kurzgefaßtes etymologisches Wörterbuch des Altindischen. Bd. I-IV. Heidelberg: C. Winter, 1956-1980.

Kloekhorst 2008 - A. Kloekhorst. Etymological Dictionary of the Hittite Inherited Lexicon (Leiden Etymological Dictionary Series. Vol. 5). Leiden; Boston: Brill, 2008.

Kluge 2012 - F. Kluge. Etymologisches Wörterbuch der deutschen Sprache. 25. erweiterte Auflage. Bearbeitet von E. Seebold. Berlin; New York: de Gruyter, 2012.

Kobayashi 2004 - M. Kobayashi. Historical phonology of Old Indo-Aryan consonants (Study of Languages and Cultures of Asia and Africa Monograph Series. Vol. 42). Tokyo: Research Institute for Languages and Cultures of Asia and Africa, Tokyo University of Foreign Studies, 2004.

Koivulehto 1991 - J. Koivulehto. Uralische Evidenz für die Laryngaltheorie (Veröffentlichungen der Kommission für Linguistik und Kommunikationsforschung, Heft 24). Wien: Verlag der Österreichischen Akademie der Wissenschaften, 1991.

Koivulehto 1999a - J. Koivulehto. Varhaiset indoeurooppalaiskontaktit: aika ja paikka lainasanojen valossa. P. Fogelberg (toim.). Pohjan poluilla. Suomalaisten juuret nykytutkimuksen mukaan (Bidrag till kannedom Av Finlands natur och folk. Vol. 153). Helsinki: Suomen Tiedeseura, 1999. S. 207-236.

Koivulehto 1999b - J. Koivulehto. Verba mutuata. Quae vestigia antiquissimi cum Germanis aliisque Indo-Europaeis contactus in linguis Fennicis reliquerint (SuomalaisUgrilaisen Seuran Toimituksia. Vol. 237). Helsinki: Suomalais-Ugrilainen Seura, 1999.

Koivulehto 2001a - J. Koivulehto. Zum frühen iranischen und indoiranischen lexikalischen Einfluss auf das Finnisch-Ugrische. K. Karttunen, P. Koskikallio (eds.). Vidyārnavavandanam: essays in honour of Asko Parpola (Studia Orientalia. Vol. 94). Helsinki: Suomen Itämainen Seura, 2001. S. 359-378.

Koivulehto $2001 \mathrm{~b}$ - J. Koivulehto. The earliest contacts between Indo-European and Uralic speakers in the light of lexical loans. Ch. Carpelan, A. Parpola, P. Koskikallio (eds.). Early Contacts between Uralic and Indo-European: linguistic and archaeological considerations (Suomalais-Ugrilaisen Seuran Toimituksia. Vol. 242). Helsinki: Suomalais-Ugrilainen Seura, 2001. P. 235-264.

Koivulehto 2003 - J. Koivulehto. Arjalaisia lainoja. Handout of a presentation held at the meeting of the Finno-Ugrian Society 21.3.2003.

Koivulehto 2005 - J. Koivulehto. Noin jalot vietettiin hevonsuistajan Hektorin peijaat: peijaiset- ja peikko- sanojen alkuperästä. Virittäjä. 2005. Vol. 109. No. 3. S. 322-333. Koivulehto 2007 - J. Koivulehto. Saamen ja suomen 'poro'. J. Ylikoski, A. Aikio (doaim.). Sámit, sánit, sátnehámit. Riepmočála Pekka Sammallahtii miessemánu 21. beaivve 2007 (Suomalais-Ugrilaisen Seuran Toimituksia. Vol. 253). Helsinki: Suomalais-Ugrilainen Seura, 2007. S. 251-258.

Koivulehto 2009 - J. Koivulehto. Etymologisesti hämäriä -(is)tA-johdosverbejä, lainoja ja omapohjaisia. Journal de la Société Finno-Ougrienne. 2009. No. 92. S. 79-102. 
Koivulehto, Kallio 2016 - J. Koivulehto. Lainaetymologioita neljältä vuosikymmeneltä (kirjoittanut P. Kallio). S. Holopainen, P. Kallio, J. Saarikivi (eds.). Verba Vagantur. Jorma Koivulehto in memoriam (Suomalais-Ugrilaisen Seuran Toimituksia. Vol. 272). Helsinki: Suomalais-Ugrilainen Seura, 2016. S. 456-463.

Korenchy 1972 - É. Korenchy. Iranische Lehnwörter in den obugrischen Sprachen. Budapest: Akadémiai Kiadó, 1972.

Lang 2015 - V. Lang. Formation of Proto-Finnic - an archaeological scenario from the Bronze Age/Early Iron Age. H. Mantila, K. Leinonen, S. Brunni, S. Palviainen, J. Sivonen (eds.). Congressus Duodecimus Internationalis Fenno-Ugristarum, Oulu 2015, Plenary papers. Oulu: University of Oulu, 2015. P. 63-84.

Lang 2016 - V. Lang. Early Baltic-Finnic contacts as evidenced by archaeological and linguistic data. ESUKA - JEFUL. 2016. Vol. 7. No. 1. P. 11-38.

Larsson 1984 - L.-G. Larsson. Estnisch piim und finnisch piimä - ein baltisches Lehnwort? Fenno-Ugrica Suecana. 1984. No. 7. P. 129-140.

Lehtiranta 2001 - J. Lehtrianta. Yhteissaamelainen sanasto. Second edition. (SuomalaisUgrilaisen Seuran Toimituksia. Vol. 200). Helsinki: Suomalais-Ugrilainen Seura, 2001.

Lidén 1897 - E. Lidén. Studien zur altindischen und vergleichenden Sprachgeschichte. Uppsala: Almqvist and Wiksells, 1897.

Liukkonen 1999 - K. Liukkonen. Baltisches in finnischen. (Suomalais-Ugrilaisen Seuran Toimituksia. Vol. 235). Helsinki: Suomalais-Ugrilainen Seura, 1999.

LIV - H. Rix. Lexikon der indogermanischen Verben. Die Wurzeln und ihre Primärstammbildungen. Bearbeitet von M. Kümmel, T. Zehnder, R. Lipp und B. Schirmer. Zweite, erweiterte und verbesserte Auflage, bearbeitet von M. Kümmel und H. Rix. Wiesbaden: Dr. Ludvig Reichelt Verlag, 2001.

Lõo 1911 - J. Lõo. Meie koduloomade nimetused. Eesti Kirjandus. 1911. Vol. VI. Ihk. 49-61. P. 81-89.

Lubotsky 2001 - A. Lubotsky. The Indo-Iranian substratum. Ch. Carpelan, A. Parpola, P. Koskikallio (eds.). Early Contacts between Uralic and Indo-European: linguistic and archaeological considerations (Suomalais-Ugrilaisen Seuran Toimituksia. Vol. 242). Helsinki: Suomalais-Ugrilainen Seura, 2001. P. 301-317.

Mallory 1991 - J. Mallory. In search of the Indo-Europeans. Language, Archaeology and Myth. London: Thames and Hudson, 1991.

Martirosyan 2013 - H. Martirosyan. The place of Armenian in the Indo-European language family: the relationship with Greek and Indo-Iranian. Voprosy yazykovogo rodstva. Journal of Language Relationship. 2013. No. 10. P. 85-137.

Mayrhofer 1964 - M. Mayrhofer. "Hethitisch und Indogermanisch". Gedanken zu einem neuen Buche. Die Sprache. 1964. Bd. 10. 174-197.

Mayrhofer 1989 - M. Mayrhofer. Vorgeschichte der iranischen Sprachen; Uriranisch. R. Schmitt (hrsg.). Compendium linguarum iranicarum. Wiesbaden: Dr. Ludwig Reichert Verlag, 1989. S. 4-24.

Mayrhofer 2002 - M. Mayrhofer. Zur Vertretung der indogermanischen Liquiden in den indoiranischen Sprachen. Indologica Taurinensia. 2002. No. 28. S. 149-161. (Published in 2004.) 
Melchert 2000 - C. Melchert. Critical response to the last four papers. R. Drews (ed.). Greater Anatolia and the Indo-Hittite language family. Papers presented at a colloquium hosted by the University of Richmond, March 18-19, 2000 (Journal of Indo-European Studies Monograph Series. Vol. 38). Washington: Institute for the Study of Man, 2000. P. 229-235.

Mikkola 1902 — J. J. Mikkola. Sananselityksiä. 1. Lohikäärme. 2. Marras. Virittäjä. 1902. Vol. 6. S. 70-72.

MSzFE - L. György (fösz.). A magyar szókészlet finnugor elemei. K. I-IV. Budapest: Akadémiai Kiadó, 1967-1981.

Munkácsi 1901 — Bernát Munkácsi. Árja és kaukázusi elemek a finn-magyar nyelvekben. Budapest: Magyar Tudományos Akadémia, 1901.

Napolskich 2002 - W. Napolskich. Beziehungen zwischen Finno-Ugriern und zentraleuropäischen Indogermanen. R. Blokland, C. Hasselblatt (eds.). Finno-Ugrians and Indo-Europeans: linguistic and literary contacts. Proceedings of the Symposium at the University of Groningen, November 22-24, 2001 (Studia Fenno-Ugrica Groningana. Vol. 2). Maastricht: Shaker, 2002. P. 265-271.

Napolskikh 2014 - В. В. Напольских. Проблема начала финно-угорско-иранских контактов. С. В. Кузьминых, А. А. Чижевский (ред.). Ананьинский мир: истоки, развитие, связи, исторические судьбы (Археология евразийских степей. Вып. 20). Казань: Институт археологии РАН, 2014. C. 76-89 (V. V. Napolskikh. Problema nachala finno-ugorsko-iranskikh kontaktov [To the problem of the beginning of Finno-Ugric-Iranian contacts]. S. V. Kuzminykh, A. A. Chizhevskiy (eds.). Ananinskiy mir: istoki, razvitiye, svyazi, istoricheskiye sudby [The Ananino World: origins, development, connections, historical destinies] (Arkheologiya yevraziyskikh stepey [Archeology of the Eurasian steppes]. Iss. 20). Kazan: Institute of archeology RAS Press, 2014. P. 76-89).

Nuutinen 1987 - O. Nuutinen. Balttilaisten lainojen substituutiotapauksia. Virittäjä. 1984. Vol. 91. P. 52-70.

Parpola 1999 - A. Parpola. Varhaisten indoeurooppalaiskontaktien ajoitus ja paikannus kielellisen ja arkeologisen aineiston perusteella. P. Fogelberg (toim.). Pohjan poluilla. Suomalaisten juuret nykytutkimuksen mukaan (Bidrag till kannedom Av Finlands natur och folk. Vol. 153). Helsinki: Suomen Tiedeseura, 1999. S. 179-206.

Parpola 2005 - A. Parpola. The Nāsatyas, the Chariot and Proto-Aryan Religion. Journal of Indological Studies. 2005. Nos. 16; 17. P. 1-63.

Parpola 2010 - A. Parpola. New etymologies for some Finnish words. K. Karttunen (ed.). Anantaì Śāstram. Indological and linguistic studies in honour of Bertil Tikkanen (Studia Orientalia. Vol. 108). Helsinki: Suomen Itämainen Seura, 2010. S. 305-318.

Parpola 2015 - A. Parpola. Roots of Hinduism. Oxford: Oxford University Press, 2015. Peters 1980 - M. Peters. Untersuchungen zur Vertetung der indogermanischen Laryngale im Griechischen (Veröffentlichungen der Kommission für Linguistik und Kommunikationsforschung. Heft 8). Wien: Verlag der Österreichischen Akademie der Wissenschaften, 1980.

Pystynen 2015 - J. Pystynen. Semivowel losses and assimilations. Presentation in CIFU XII, August 19 2016. Oulu. Available at: https://www.academia.edu/15172786/Semivowel_losses_and_assimilations_in_Finnic_and_beyond (accessed in September 2016). 
Rédei 1986 - K. Rédei. Zu den indogermanisch-uralischen Sprachkontakten (Veröffentlichüngen der Kommission für Linguistik und Kommunikationsforschung. Heft 16). Wien: Verlag der Österreichischen Akademie der Wissenschaften, 1986.

Rintala 2003 — P. Rintala. Iha köyhän laihakin. Tutkimus itämerensuomen iha-ikantaisista sanoista. Helsinki: Suomalaisen Kirjallisuuden Seura, 2003.

RIVELEX - T. Krisch et al. RIVELEX. Rigveda Lexikon. Vols. 1-2. Graz: Leykam, 2006-2012.

Róna-Tas 2017 - A. Róna-Tas. Vitás magyar etimológiák. Válasz Honti Lászlónak. Nyelvtudományi közlemények. 2017. K. 113. 37-84. o.

Róna-Tas, Berta 2011 - A. Róna-Tas, Á. Berta (with the assistance of L. Károly). West Old Turkic. Turkic loanwords in Hungarian. Wiesbaden: Harrassowitz, 2011.

Saarikivi 2011 - J. Saarikivi. Saamelaiskielet. Historiaa ja nykypäivää. I. SeurujärviKari, P. Halinen, R. Pulkkinen (toim.). Saamentutkimus tänään (Tietolipas. Vol. 234). Helsinki: Suomalaisen Kirjallisuuden Seura, 2011. S. 77-119.

Saarikivi, Grünthal 2005 - J. Saarikivi, R. Grünthal. Itämerensuomalaisten kielten uralilainen tausta. J. Vaattovaara, T. Suutari, H. Lappalainen, R. Grünthal (toim.). Muuttuva muoto: kirjoituksia Tapani Lehtisen 60-vuotispäivän kunniaksi (Kieli. No. 16). Helsinki: Helsingin yliopiston suomen kielen laitos, 2005.

Salminen 2001 - T. Salminen. The rise of the Finno-Ugric language family. Ch. Carpelan, A. Parpola, P. Koskikallio (eds.). Early Contacts between Uralic and Indo-European: linguistic and archaeological considerations (Suomalais-Ugrilaisen Seuran Toimituksia. Vol. 242). Helsinki: Suomalais-Ugrilainen Seura, 2001. P. 385-396.

Salminen 2002 - T. Salminen. Problems in the taxonomy of the Uralic languages in the light of modern comparative studies. А. Е. Кибрик (ред.), Т. Б. Агранат, О. А. Казакевич (сост.). Лингвистический беспредел: сборник статей к 70-летию А. И. Кузнецовой. М.: Издательство Московского гос. университета, 2002. C. 44-55 (T. Salminen. Problems in the taxonomy of the Uralic languages in the light of modern comparative studies. A. E. Kibrik (ed.), T. B. Agranat, O. A. Kazakevich (comp.). Lingvisticheskiy bespredel: sbornik statey $k$ 70-letiyu A. I. Kuznetsovoy [Linguistic lawlessness: a collection of articles dedicated to the $70^{\text {th }}$ anniversary of A. I. Kuznetsova]. Moscow: Moscow State University Press, 2002. P. 44-55).

Sammallahi 1998 — P. Sammallahti. The Saami languages. An introduction. Kárásjohka: Davvi Girji, 1998.

Sammallahti 1999 - P. Sammallahti. Saamen kielen ja saamelaisten alkuperästä. P. Fogelberg (toim.). Pohjan poluilla. Suomalaisten juuret nykytutkimuksen mukaan (Bidrag till kannedom Av Finlands natur och folk. Vol. 153). Helsinki: Suomen Tiedeseura, 1999. S. 70-90.

Sammallahti 2001 - P. Sammallahti. The Indo-European loanwords in Saami. Ch. Carpelan, A. Parpola, P. Koskikallio (eds.). Early Contacts between Uralic and Indo-European: linguistic and archaeological considerations (Suomalais-Ugrilaisen Seuran Toimituksia. Vol. 242). Helsinki: Suomalais-Ugrilainen Seura, 2001. P. 397-416. Sammallahti 1988 - P. Sammallahti. Historical phonology of the Uralic languages. D. Sinor (ed.). The Uralic languages. Description, History and Foreign Influences. Leiden; New York; København; Köln: Brill, 1988. P. 478-554. 
Schindler 1936 - J. Schindler. Zu einigen Lehnwörtern im Finnischen. Die Sprache. 1936. Bd. 9. S. 203-206.

Schmid 1979 - W. P. Schmid. Zur Frage der Datierung Iranischer Lehnwörter in den Finnisch-Ugrischen Sprachen. C. Gläser, J. Pusztay (hrsg.). Festschrift für Wolfgang Schlachter zum 70. Geburtstag (Veroffentlichungen der Societas Uralo-Altaica. Bd. 12). Wiesbaden: Harrassowitz, 1979. S. 265-270.

Setälä 1912 — E. N. Setälä. Eine arische Bezeichnung des Meeres in der finnischen Volkspoesie. Festschrift Vilhelm Thomsen zur Vollendung des siebzigsten Lebensjahres am 25. Januar 1912 dargebracht von Freunden und Schülern. Leipzig: Harrassowitz, 1912. S. 188-191.

Setälä 1928 - E. N. Setälä. Einige vor- und urarische -er und -r- Wörter in den finnisch-ugrischen Sprachen. Ungarische Jahrbücher. 1928. Bd. VIII. S. 298-308.

SMS - Suomen murteiden sanakirja. Kotimaisten kielten keskuksen verkkojulkaisuja 30. Helsinki: Kotimaisten kielten keskus. 2012. Available at: http://kaino. kotus.fi/sms. Constantly updated. Last update 18.05.2018 (accessed in August 2018).

SSA — E. Itkonen, U.-M. Kulonen (päätoim.). Suomen sanojen alkuperä. Etymologinen sanakirja. T. I-III. Helsinki: Kotimaisten kielten tutkimuskeskus; Suomalaisen Kirjallisuuden Seura, 1992-2000.

TschWB - A. Moisio, S. Saarinen. Tscheremissisches Wörterbuch. Aufgezeichnet von V. Porkka, A. Genetz, Y. Wichmann, M. Räsänen, T. E. Uotila und E. Itkonen (Lexica Societatis Fenno-Ugricae. Vol. XXXII) Helsinki: Suomalais-Ugrilainen Seura; Kotimaisten Kielten tutkimuskeskus, 2008.

Tunkelo 1913 - E. A. Tunkelo. Wortgeschichtliche Beiträge. Finnisch-Ugrische Forschungen. 1913. Bd. 13. 74-119.

UEW - K. Redei et al. Uralisches Etymologisches Wörterbuch. Wiesbaden: Harrassowitz, 1988.

Uotila 1973 - E. Uotila. Zur Etymologie von finn. sampa (Euroasiatica. 2; 4). Napoli: Istituto Universitario Orientale, 1973.

Vilkuna 1933 - K. Vilkuna. Ein frühurarisches lehnwort, fi. ola 'feuerstein, kiesel'. Finnisch-Ugrische Forschungen. 1933. Bd. 21. S. 160-162.

Windfuhr 2009 - G. Windfuhr. Dialectology and topics. G. Windfuhr (ed.). The Iranian Languages. London: Routledge, 2009. P. 5-42.

Zhivlov 2006 - М. А. Живлов. Реконструкция праобско-угорского вокализма. Дисс. ... канд. филол. наук. М.: Институт языкознания РАН, 2006. (М. A. Zhivlov. Rekonstruktsiya praobsko-ugorskogo vokalizma [Reconstruction of Proto-Ob-Ugric vocalism]. Candidate thesis. Moscow: Institute of linguistics, 2006).

Zhivlov 2013 - М. А. Живлов. Андроновский арийский язык. Ю. Б. Коряков, А. А. Кибрик (ред.). Языки мира. Реликтовые индоевропейские языки Передней и Центральной Азии. М.: Academia, 2013. С. 217-220 (М. A. Zhivlov. Andronovskiy ariyskiy yazyk [Andronovo Arian language]. Yu. B. Koryakov, A. A. Kibrik (eds.). Yazyki mira. Reliktovyye indoyevropeyskiye yazyki Peredney $i$ Tsentralnoy Azii [Languages of the world. Relict Indo-European languages of the Anterior and Central Asia]. Moscow: Academia, 2013. P. 217-220).

Zhivlov 2014 - M. Zhivlov. Studies in Uralic vocalism III. Voprosy yazykovogo rodstva. Journal of Language Relationship. 2014. No. 12. P. 113-148. 


\title{
Морфологические особенности нелексических глаголов в энецком языке*
}

\author{
А. Б. Шлуинский \\ Московский государственный университет им. М. В. Ломоносова, \\ Институт языкознания РАН, Москва; ashl@yandex.ru
}

Аннотация. В статье суммируется информация о морфологических особенностях нелексических глаголов в лесном и тундровом диалектах энецкого языка: глагола-связки, отрицательных глаголов, модально-вопросительного глагола и словозаместителя. У глагола-связки в лесном диалекте, в отличие от тундрового, имеются две дополнительно распределенных основы. У основного отрицательного глагола две дополнительно распределенных основы есть в обоих диалектах и представлен ряд иных морфологических особенностей, включая наличие особых форм. Парадигма прочих отрицательных глаголов является дефектной и включает только некоторые формы. У существующего в лесном диалекте модально-вопросительного глагола представлена только форма неопределенного времени субъектнообъектного спряжения. Словозаместитель образует как именные, так и глагольные формы от единой основы.

Ключевые слова: энецкий язык, нелексические глаголы, глагол-связка, отрицательный глагол, вопросительный глагол, словозаместитель.

\section{Morphological pecularities of non-lexical verbs in Enets}

\author{
A. B. Shluinsky \\ Lomonosov Moscow State University, Institute of Linguistics, \\ Russian Academy of Sciences, Moscow; ashl@yandex.ru
}

\begin{abstract}
The article summarizes the information on the morphological features of Forest and Tundra Enets (Northern Samoyedic $<$ Samoyedic $<$ Uralic) non-lexical verbs, namely the copula, negative verbs, the modal-interrogative verb and the placeholder. In Forest Enets, in contrast to Tundra Enets, the copula has two suppletive stems
\end{abstract}

* Работа выполнена в рамках проекта РНФ № 16-18-02081. 
that display an almost complementary distribution, although there are some exceptional uses in the data. The main negative verb has two complementarily distributed stems in both dialects, and their distribution is close to the one of the basic stem and of the indefinite tense stem of regular verbs. The main negative verb has other morphological peculiarities: first, the single imperative form does not distinguish between the subject, subject-object and middle conjugations as other verbs do; second, it has dedicated 'contrastive forms' of the indefinite tense and of the interrogative mood; third, in Forest Enets, it has an irregular form of the interrogative marker. The other negative verbs have defective paradigms: the verb denoting 'not at all' has the indefinite tense and the interrogative mood, the verb denoting 'almost' has the indefinite tense and the inferential mood, while the verb denoting 'of course' has only the indefinite tense. The modal-interrogative verb is only attested in Forest Enets and has only the indefinite tense form of the subject-object conjugation. The placeholder has all nominal and verbal forms built from the same stem. The paper is based on field materials collected and processed with the author's participation: a glossed corpus of spontaneous Enets texts (includes about 25 hours of speech records in the Forest Enets dialect and about 7 hours of speech records in the Tundra Enets dialect), and elicited examples.

Keywords: Enets, Samoyedic, non-lexical verbs, copula, negative verb, interrogative verb, placeholder.

\section{1. Введение}

Задача настоящей статьи состоит в том, чтобы суммировать информацию о морфологических особенностях нелексических (в частности вспомогательных) глаголов в обоих диалектах энецкого языка - лесном (Л) и тундровом (Т).

Термин «нелексические глаголы» мы условно употребляем для обозначения множества словарных глагольных единиц, которые объединены следующими двумя особенностями. Во-первых, все они имеют намного более абстрактные значения, чем бо́льшая часть других глаголов. Эти абстрактные значения не похожи на те случаи, которые принято иметь в виду, говоря о лексической полисемии. Иначе говоря, все рассматриваемые нами глаголы не называют конкретных ситуаций, а имеют другие функции. Во-вторых, все рассматриваемые глаголы имеют нетривиальные морфологические особенности, требующие специального описания, которое и является предметом настоящей статьи. Таким образом, мы используем термин «нелексические глаголы» 
как обобщающий для того класса энецких лексем, описание идиосинкратической морфологии которого необходимо произвести ${ }^{1}$.

К числу энецких нелексических глаголов, требующих специального морфологического описания, относятся следующие:

- глагол-связка Л $\varepsilon$ - ya- / Т $a$ - ${ }^{2}$ 'быть';

- отрицательные глаголы, включая основной $n^{j} e-/ i$ - и прочие: Л bunil-/ Т bon'i- 'ведь не', Л kitfe-/ Т kstje- 'чуть не', Л ine-/ Т iine- 'конечно, как не';

- модально-вопросительный глагол Л sbujta- 'зачем';

- словозаместитель $m u$ - 'это самое'.

Сам факт существования перечисленных глаголов в энецком языке не является новым (они приводятся в словарях), однако ранее не проводилось систематическое описание особенностей их словоизменения.

Основным фактическим материалом послужили данные, полученные и обработанные в рамках проекта «Документация энецкого языка: оцифровка и анализ архивных материалов и полевая работа с последними носителями» (Б. Комри, О. В. Ханина, А. Б. Шлуинский) при финансовой поддержке международного фонда «Программа документации языков, находящихся под угрозой исчезновения» ("Endangered Languages Documentation Programme", ELDP), 2008-2011 гг. ${ }^{3}$ Это, во-первых, глоссированный корпус спонтанных

${ }^{1}$ Отметим, однако, что термин "non-lexical verbs" для множества морфологически нетривиальных глаголов с абстрактным значением уже употреблялся в литературе, например, в [Haumann 2007: 188-193].

${ }^{2}$ В настоящей работе принята следующая практическая транскрипция: для корней записывается наиболее полный вариант произнесения (с восстановлением всех гласных и гортанного смычного согласного, которые в речи часто подвергаются редукции), но для аффиксов записывается наиболее частотный вариант.

3 Автор выражает благодарность всем носителям энецкого языка, с которыми ему посчастливилось работать; Н. М. Стойновой, С. А. Трубецкому и в особенности М. А. Овсянниковой, участвовавшим в сборе и расшифровке энецких текстов; Дудинскому отделению ГТРК «Норильск», Таймырскому Дому народного творчества, Д. С. Болиной, О. Э. Добжанской, И. П. Сорокиной и А. Ю. Урманчиевой, любезно предоставившим архивные аудиозаписи, сделанные в разные годы Д. С. Болиной, Н. Н. Болиной, О. Э. Добжанской, К. И. Лабанаускасом, И. П. Сорокиной, Е. А. Хелимским. Многие аналитические решения при анализе энецкой грамматической системы приняты совместно с О. В. Ханиной, которая сделала замечания и к начальной версии данной статьи. 
энецких текстов, подготовленный автором и О. В. Ханиной (включает около 25 часов речи на лесном диалекте и около 7 часов речи на тундровом диалекте ${ }^{4}$ ), а во-вторых, элицитированные данные. Кроме того, использованы и опубликованные тексты [Сорокина, Болина 2005]. Цитируемые примеры без ссылок на источник взяты из корпуса энецких текстов, а элицитированные примеры сопровождаются пометой (elic.).

\section{2. Глагол-связка}

Глагол-связка в тундровом диалекте ведет себя стандартно, а в лесном диалекте имеет много морфологических особенностей. В тундровом диалекте основа $a$ - у глагола-связки является единственной, не имеет морфологических ограничений и используется для образования всех форм. Так, в (1) представлена форма аориста, в (2) - форма коннегатива, в (3) - форма юссива (императива 3 л.); пример (4) иллюстрирует форму интеррогатива, а пример (5) - форму будущего времени ${ }^{5}$. Как будет показано ниже, в лесном диалекте в аналогичном наборе форм используются разные основы.
(1) tee-zu?
me-kone a-?
T олень-NOM.PL.3PL чум-LOC.SG быть-3PL.S
'Их олени дома'.

(2) galja nes nie a-??

T Галя ребенок NEG.3sG.s быть-CONN

'Не Галин ли ребенок?'

\footnotetext{
${ }^{4}$ Корпус продолжает обновляться, и потому наиболее актуальная его версия может быть получена у автора. Предшествующие версии общедоступны в сети Интернет - в электронном Архиве языков под угрозой исчезновения при Школе восточных и афиканских исследований Лондонского университета http:/elar.soas. ac.uk/deposit/0302, а для лесного диалекта - также в веб-интерфейсе на странице http://larkpie.net/siberianlanguages/recordings/forest-enets.

${ }^{5} \mathrm{~B}$ качестве дополнительного морфологически значимого факта отметим, что в форме будущего времени глагол-связка Т $a$ - / Л $\varepsilon$ - присоединяет /z/-начальный алломорф, который используется с ограниченным количеством глагольных основ (в отличие от /d/-начального алломорфа) и синхронно в целом является лексически заданным.
} 


$\begin{array}{lllll}\text { (3) } & d^{j} a u d j a & \boldsymbol{a} \text {-aba, } & \text { saxar } & \boldsymbol{a} \text {-aba } \\ \text { T } & \text { мука } & \text { быть-3SG.S.IMP } & \text { сахар } & \text { быть-3SG.S.IMP } \\ & \text { 'мука ли, сахар ли' } & & \end{array}$

(4) $n^{j i-d a \quad m i i ? ~ a-b a ? ~}$

T имя-NOM.SG.3Sg что быть-Q.3sG.S

'Как его звали?'

(5) kunadiu kere-nii? kaa-j? a-za?

$\mathrm{T}$ как сам-OBL.SG.1sG товарищ-NOM.SG.1SG быть-FUT.3SG.S

'Как он может быть [= будет] моим родственником?'

Морфология глагола-связки в лесном диалекте устроена намного более сложно и идиосинкратично. Представлены две супплетивных глагольных основы $\varepsilon$ - и $\eta а$-, демонстрирующие распределение, близкое к дополнительному ${ }^{6}$. От основы $\eta a$ - образуются форма аориста (6) и морфологически производная от нее форма прошедшего времени, формы императива (7), юссива (8) и коннегатива (9).

(6) peri? ckon $\boldsymbol{y a - z ?}$

Л всегда этот.LOC быть-1SG.S

'Я всегда здесь нахожусь'.

(7) cke dia-xane-d uи? bemu-d ya-?!

Л этот земля-LOC.SG-OBL.SG.2SG ты глава-2SG.s быть-2SG.S.IMP

'На этой земле ты будь хозяином!'

(8) Jize, mana, bogulia ya-j

Л два сказать.3sg.s медведь быть-3sG.S.IMP

\{Герой сказки выбирает, каких животных ему запрячь.\}

'Пусть, говорит, два медведя будут'.

${ }^{6}$ B [Siegl 2013: 336-340] эти две основы трактуются как независимые друг от друга глаголы-связки, имеющие разные функции. Тем не менее, вопреки прямому утверждению Ф. Сигла о том, что основа $\eta a$ - не имеет морфологических ограничений, фактически приводимые им примеры не противоречат распределению, описываемому нами. Что же касается функционирования этих основ, то скорее следует отметить, что в контекстах аориста и прошедшего времени имена в предикативной позиции употребляются без связки, принимая субъектные лично-числовые показатели. Как следствие, употребление глагола связки в формах аориста и прошедшего времени, с одной стороны, и всех прочих формах, с другой стороны, асимметрично. Однако эта асимметрия оказывается связана не с внешним обликом основы (она представлена и в тундровом диалекте, где основа единая). 
(9) tfike mu, fuzebitfu $n^{i} i \quad$ ya-?.

Л этот PLC сказка NEG.3SG.S быть-CONN

‘Это самое, это не сказка'.

Все остальные формы образуются от основы $\varepsilon$-. Так, пример (10) иллюстрирует форму интеррогатива, пример (11) - форму будущего времени, пример (12) - форму гортатива, примеры (13) и (14) - нефинитные формы (инфинитив и причастие предшествования соответственно).

(10) cke-хол-? sbu te-? $\boldsymbol{\varepsilon}$-sa-??

Л этот-TOP-PL что олень-PL быть-Q-3PL.S

'Эти-то какие олени?'

(11) yo-liu tos noneda $\boldsymbol{\varepsilon}$-za

Л один-RESTR лето он(a).LOC быть-FUT.3SG.S

'Одно лето она с ним будет'.

(12) tori $\boldsymbol{\varepsilon}-\boldsymbol{x u}-\boldsymbol{j} \boldsymbol{j}$, mana

Л так быть-HORT-1DU.s/so SG $_{\text {cказать.3sG.s }}$

'Давай так сделаем, он сказал'.

(13) bodu-n $\quad \varepsilon-\int \quad i$ cke potabu-xon $\varepsilon-\int$

Л тундра-LOC быть-CVв и этот Потапово-LOC.SG быть-CVв

'в тундре ли и здесь ли в Потапово'

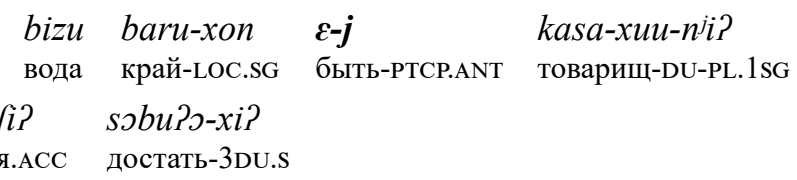

‘Мои товарищи, которые были на берегу, меня вытащили'.

Однако указанное распределение не для всех форм действует без исключений: представлены редкие текстовые примеры, ему противоречащие. Во-первых, в текстах встречаются случаи образования формы причастия предшествования от основы уа- (15), наряду с указанным выше в (14) вариантом от основы $\varepsilon-$. Во-вторых, в речи ныне ушедшего поколения носителей лесного диалекта ${ }^{7}$ представлены примеры

${ }^{7}$ Современные данные, записанные автором и его коллегами в 2005-2016 гг,, получены в основном от носителей 1940-х - 1960-х гг. рождения, архивные данные, записанные другими исследователями в 1969-2002 гг, получены в основном от носителей 1910-х - 1930-х гг. рождения, к 2005 г. уже умерших. В ряде случаев вторые непосредственно являются родителями первых. 
образования коннегатива от основы $\varepsilon$-, как в (16), наряду с его стандартным образованием от основы $\eta a-$, как в (9) ${ }^{8}$. Наконец, в речи наиболее молодых современных носителей представлены примеры образования форм аориста и прошедшего времени от основы $\varepsilon$-, как в (17), наряду с их стандартным образованием от основы уа-, как в (6).
пuzu irugu $\min \boldsymbol{y a - j}$ oburi-z
Л шест нарта в быть-PTCP.ANT вещь-NOM.PL.2SG
'вещи, которые лежали в нарте для шестов'
(16) yo-liu entee? $n^{i} i \quad \varepsilon-?$.
Л один-RESTR человек NEG.3SG.S быть-CONN
'Это не один человек'.
(17) $\varepsilon t f u j-i f \quad$ modina? oka $\boldsymbol{\varepsilon}$-batf tos-noju $Л$ ребенок-TRANSL мы много быть-1PL.S/SO sG. $_{\text {PST }}$ лето-ADV 'Нас, детей, много было летом'.

Помимо наличия двух супплетивных основ и их нетривиального распределения, глагол-связка в лесном диалекте имеет еще одну морфологическую особенность. Только от этого глагола, а именно от его основы $\varepsilon$-, образуется так называемое ирреальное деепричастие ${ }^{9}$, которое употребляется в аналитических формах с лексическими глаголами в форме причастия предшествования (18)-(19).
(18) sbu diru-j
$\varepsilon-b u-z a ?$
Л что поднять-PTCP.ANT быTb-CVB.IRR-NOM.SG.3SG
'Что он поднял?'
(19) fit tolaxa vot tori djazu-mi $\boldsymbol{\varepsilon}$-bu-zu?
Л ты.GEN как вот так идти-PTCP.ANT быть-CVB.IRR-NOM.SG.3PL
entfeu-?
человек-PL
‘Раньше вот, как ты, приезжали люди’.

\footnotetext{
${ }^{8}$ Возможна альтернативная интерпретация таких примеров: в тундровом диалекте - в частности, в [Хелимский, рук.] — отмечается отрицательная глагольная связка $n^{i} i a-$, и речь может идти о реликтах ее употребления в лесном диалекте; имеющийся материал не позволяет установить верную трактовку.

${ }^{9}$ Сама эта форма внешне похожа на форму деепричастия условия с показателем -bu?/-bune-, однако радикально отличается от нее морфонологическим поведением и выбором посессивных показателей прямого vs. косвенного ряда, см. подробнее в [Khanina, Shluinsky 2013].
} 


\section{3. Отрицательные глаголы}

\section{1. Основной отрицательный глагол}

Как известно, в обоих диалектах энецкого языка у основного отрицательного глагола (использующегося собственно для сентенциального отрицания без дополнительных семантических компонентов) представлены две супплетивные основы: $n^{j} e-$ и $i$-. В лесном диалекте в формах 3 лица единственного и множественного (но не двойственного) числа обычно используется алломорф $n^{i} i^{10}(22)$. Отдельные замечания к распределению основ отрицательного глагола сделаны в [Сорокина 2010: 391-392] и [Sieg1 2013: 303-304], но наиболее точное утверждение содержится в [Урманчиева 2006: 95]: основа $n^{j} e$ - соответствует основе лексических глаголов с показателем *-па- (в [Ханина, Шлуинский 2015] названа основой аориста).

Перечислим точный набор форм, образующихся от этой основы. Это формы аориста, как в (20)-(22), и производные от них формы прошедшего времени, в том числе формы аориста 2 л. дв. и мн. ч. в функции императива, как в (23), и формы юссива, имеющие специализированные показатели, как в (24)-(25).

(20) ljalja tfinadii $\boldsymbol{n}^{\boldsymbol{j} e} \quad$ modiera-??

$\mathrm{T}$ Ляля сейчас NEG.3sG.S работать-CONN

'Сейчас Ляля не работает?'

(21) buniki-fuz te $\boldsymbol{n}^{j} \boldsymbol{e}-\boldsymbol{r}, \quad \boldsymbol{n}^{j} \boldsymbol{e}-\boldsymbol{r} \quad$ yoda-d

Л собака-СAR олень NEG-2SG.SO $\mathrm{SO}_{\mathrm{SG}}$ NEG-2SG.SO $\mathrm{SG}_{\mathrm{SG}}$ собрать-FUT.CONN 'Без собаки оленей не соберешь'.

(22) sza oom-a-d nit-? koma-?

Л мясо есть-NMLZ-DAT.SG NEG-3PL.S хотеть-CONN

'Они не хотят мясо есть'.

(23) moga-xan $\boldsymbol{n}^{j} \boldsymbol{e}-\boldsymbol{r a}$ ? nebi-r-?!

л лес-LOC.SG NEG-2PL.S/SO $\mathrm{SO}_{\mathrm{SG}}$ бежать-MULT-CONN

'В лесу не бегайте!'

${ }^{10}$ B [Siegl 2013: 303] этот алломорф указан как основной. 
$\begin{array}{lllll}\text { (24) } & \text { Jizinji? } & a n^{j} \boldsymbol{e} ? & \boldsymbol{n}^{j} \boldsymbol{e}-\boldsymbol{e} \boldsymbol{P} & \text { tubota-? } \\ \mathrm{T} & \text { мы.DU.ACC } & \text { и } & \text { NEG-3PL.S.IMP } & \text { обмануть-CONN }\end{array}$

'Пусть нас не обманывают'.

(25) buuse-xi? tfike ker-tfi? ti-zi?

Л старик-DU этот сам-OBL.SG.3DU олень-NOM.PL.3DU

n'e-gi? pon ir

NEG-3DU.S.IMP делать-CONN

'Эти старики своих оленей пусть не запрягают'.

Все остальные формы образуются от основы $i$-. Примеры (26)(29) иллюстрируют употребление финитных форм: перфекта, интеррогатива, конъюнктива и гортатива соответственно, — a (30)-(32) употребление нефинитных форм: деепричастия условия, инфинитива и причастия предшествования.
(26) mii-gores $\boldsymbol{i}$-bi
teza-?
T чTO-EVEN NEG-PRF.3SG.S принести-CONN

'Он ничего не принес'.

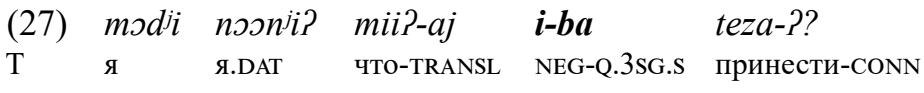

'А почему мне-то не дал?'

(28) fimu-mi entfeu-? ftob i-n ii-zut

Л убежать-PTCP.ANT человек-PL чтоб NEG-CONJ-3PL.SO SG $_{\text {.PST }}$

tuda-?

узнать-CONN

‘... чтобы сбежавшие люди его не узнали'.

(29) yulii i-xu-z? kəjabi-?

Л очень NEG-HORT-1SG.S лгать-CONN

' Я слишком сильно врать не буду'.

$\begin{array}{lllll}\text { (30) } & \boldsymbol{a} & \boldsymbol{i} \text { - } \boldsymbol{b} \boldsymbol{u} \text {-to } & \text { sero-? } & a n^{j} e ? \\ \mathrm{~T} & \text { a } & \text { NEG-CVB.COND-OBL.SG.2SG } & \ldots \\ \text { завязать-CONN } & \text { и } & \end{array}$

'А если не завяжешь...'

(31) antofka kudaxaa, kudaxaa i-f biitur-? man-?

Л Антошка долго долго NEG-CVB думать-CONN сказать-CONN

$n^{j i-u ? \quad \ldots}$

NEG-3SG.S.CONT

'Антошка, недолго думая, сказал...' 


$$
\begin{array}{llll}
\text { teza-ri-xoa } & k u n^{i} i & \text { minxu-da } & \text { sว?-d-e-z? } \\
\text { сейчас-RESTR-TOP } & \text { как } & \text { сразу-OBL.SG.3SG } & \text { прыгнуть-FUT-м-3sG.м }
\end{array}
$$

$\begin{array}{llll}m \varepsilon-k o z o-d a & \boldsymbol{i}-\boldsymbol{j} & b i i s-u j & d^{j} a-d \\ \text { чум-ABL.SG-OBL.SG.3SG } & \text { NEG-PTCP.ANT } & \text { помнить-PTCP.ANT } & \text { земля-DAT.SG }\end{array}$

'Сейчас же, она сразу выскочит из дома в место, о котором и не думала'.

Помимо наличия двух супплетивных основ, у отрицательного глагола представлен целый ряд иных морфологических особенностей.

В императиве 2 л. ед. ч. отрицательный глагол, в отличие от лексических глаголов, не различает субъектную, субъектно-объектную и медиальную (возвратную) согласовательную серии, а имеет для всех контекстов единый показатель императива Л -z / Т -zo. Это показано и в [Siegl 2013: 309-311]; подробнее структура энецкой императивной парадигмы обсуждается в [Ханина, Шлуинский 2015]. Примеры (33a-b) и (34a-b) наглядно показывают это морфологическое различие между лексическими глаголами и отрицательным глаголом. В (33a) и (34a) представлены формы императива 2 л. ед. ч. непереходных глаголов, принимающих показатели субъектной и медиальной серий соответственно, а в (33b) и (34b) - соответствующие им отрицательные императивные формы. В последних отрицательный глагол принимает один и тот же императивный показатель, формально не совпадающий ни с показателем субъектной, ни с показателем медиальной серии. Пример (35) иллюстрирует употребление этой формы в контексте, где ожидается употребление формы субъектно-объектной согласовательной серии для множественного объекта.

a. sira-za ka?a-a-xaz, घu? to-? снег-NOM.SG.3SG спуститься-NMLZ-ABL.SG сюда прийти-2SG.S.IMP 'Когда выпадет снег, приходи сюда' .

b. kiuze $\quad$ ba-xaz $\boldsymbol{i}-\boldsymbol{z} \quad$ to-?! утро голова-ABL.SG NEG-2SG.IMP прийти-CONN 'С утра не приходи!'

a. gen-วu,

neru-z?, tfaj-gu-j?! Гена-ехс встать-2SG.M.IMP пить_чай-HORT-1DU.S/SO ${ }_{\mathrm{SG}}$ 'Гена, вставай, давай пить чай!'

b. $\boldsymbol{i}-\boldsymbol{z}$ neru-?! NEG-2SG.IMP встать-CONN 'Не вставай!' (elic.) 
$\begin{array}{lllll}\text { (35) } & \text { tee- } k u \text {-zo } & a \text {-aba?, } & \boldsymbol{i - z o} & \text { tidara-go-?! } \\ \mathrm{T} & \text { олень-DIM-NOM.PL.2SG } & \text { быть-3PL.S.IMP } & \text { NEG-2SG.IMP } & \text { продать-DUR-CONN }\end{array}$ 'Пусть будут олени, не продавай их!'

Другая яркая морфологическая особенность энецкого основного отрицательного глагола — наличие у него форм аориста с «контрастивными» лично-числовыми показателями. Такие окончания диахронически являются результатом слияния стандартных лично-числовых окончаний с эмфатической клитикой *-u? (см. подробнее в [Шлуинский 2010]). Все глаголы присоединяют «контрастивные» лично-числовые показатели в определенных формах, но возможность такой морфологической комбинации с формой аориста эксклюзивна для отрицательного глагола. Конструкции с отрицательным глаголом в такой форме выражают значение эмфатического утверждения, как в примерах (36а), (37). Сочетание «контрастивного» показателя с формой лексического глагола, как в (36b), неграмматично.

a. poga-xaz-da

ani diri-? $\boldsymbol{n}^{j} \boldsymbol{e}$-bam?. сеть-ABL.SG-OBL.SG.3SG и жить-CONN NEG-1PL.S/SO ${ }_{\mathrm{SG}}$.CONT 'Благодаря сети \{т. е. рыбалке\} мы ведь живем'.

Л $\quad$ мы

b. *modina?

potabu-xon

diiri-bam?.

$$
\text { sira nวग-xoa udja-ku-zo-na? kuno-xoa-zo }
$$

$\mathrm{T}$ снег на-тоР мясо-DIM-DEST.SG-OBL.SG.1PL откуда-TOP-ABL

kวग-obi-?

n'e-bau?.

найти-НАВ-CONN NEG-1PL.S/ $/ \mathrm{SO}_{\mathrm{SG}}$.CONT

'Зимой-то мы ведь находим мясо где-нибудь'.

В лесном диалекте отрицательный глагол имеет аномальную форму интеррогатива. Если стандартным показателем интеррогатива является -sa-, как в (38), то с отрицательным глаголом сочетается идиосинкратический показатель -si- — как в собственно интеррогативной функции с базовыми лично-числовыми показателями (39), так и в невопросительных формах с «контрастивными» лично-числовыми показателями ${ }^{11}$, описанными выше (40).

11 Отметим, что такие формы отрицательного глагола имеют и нестандартное значение. Если форма интеррогатива с «контрастивными» лично-числовыми 
(38) fee-d ke-xon adii-sa-d?

Л кто-OBL.SG.2SG сторона-LOC.SG сидеть-Q-2SG.S

'С кем ты сидел рядом?'

$$
\begin{array}{llll}
\text { sbu-u } & \text { Jijp } & \boldsymbol{i} \text {-si-d } & \text { neru-ta-?? } \\
\text { что-TRANSL } & \text { я.ACC } & \text { NEG-Q-2sG.S } & \text { встаTь-CAUS-CONN }
\end{array}
$$

'Почему ты меня не разбудил?'

(40) d'sxa i-si-m?

mota-?

Л река NEG-Q-3PL.S.CONT отре́зать-CONN

'Они ведь перешли реку'.

У отрицательного глагола, по вполне понятным причинам, отсутствует ряд форм. Во-первых, это форма коннегатива: отрицательный глагол сочетается только с коннегативом от других глаголов. Во-вторых, это форма будущего времени, показатель которой морфологически ведет себя как словообразовательный и поэтому в отрицательной конструкции входит в состав коннегатива лексического глагола (41)(42). Таким же образом в основном употребляется и форма хабитуалиса, ср. (43)-(44). Однако в материале обоих диалектов представлены и маргинальные аномальные примеры, в которых показатель хабитуалиса присоединяется напрямую к отрицательному глаголу (45)-(46).

\section{(41) $\boldsymbol{n}^{j} \boldsymbol{e}$-d \\ $\mathrm{T} \quad$ NEG-2SG.S ectb-FUT-CONN \\ 'Ты есть не будешь?'}

(42) kaza-xaru- $\int$ fit $\boldsymbol{n}^{j} \boldsymbol{e}-\boldsymbol{z}$ ? $\quad k a z a-d$

Л убить-EVEN-CVB tы.ACC NEG-1SG.S убить-FUT.CONN

'Я даже убить тебя не убью'.

эne bare $\boldsymbol{n}^{\boldsymbol{j} \boldsymbol{e}-\boldsymbol{z} \boldsymbol{0}}$ p ponem-obi-?

настоящий песня NEG-1SG.S делать-HAB-CONN

'Свои \{т. е. на своем языке\} песни я не пою'.

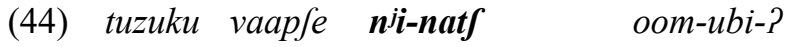
Л гриб вообще NEG-1PL.SO $\mathrm{NSG}_{\mathrm{NG}}$.PST есть-HAB-CONN
'Мы грибы вообще не ели'.

показателями лексического глагола имеет значение предположения, то форма интеррогатива с «контрастивными» лично-числовыми показателями отрицательного глагола намного чаще имеет значение эмфатического утверждения, как в (40). 
(45) oka i-ta-?, i-obi-ta-? a-?

$\mathrm{T}$ много NEG-PROB-3PL.S NEG-HAB-PROB-3PL.S быTь-CONN

'Много, наверное, не было, не бывало'.

(46) sbu diodij-gon kodara-ubi-t-e-zu?,

$Л$ что время-LOC.SG заснуть-HAB-PROB-M-3SG.M.CONT

$\begin{array}{lll}\boldsymbol{i} \text { - } \boldsymbol{u b i} \boldsymbol{i} \boldsymbol{t}-\boldsymbol{e}-\boldsymbol{z} \boldsymbol{u} \boldsymbol{P} & b a ? a-d a & n^{i j i} \\ \text { NEG-HAB-PROB-M-3SG.M.CONT } & \text { постель-OBL.SG.3SG } & \text { на }\end{array}$

'Иногда она, может быть, задремлет, а может быть, и нет, на своей постели'.

\section{2. Прочие отрицательные глаголы}

В энецком языке представлены еще три отрицательных глагола, сочетающиеся с коннегативом и выражающие более сложные значения, связанные с отрицанием. Более подробно они описаны в [Ханина, Шлуинский 2012]. Все эти глаголы имеют дефектную парадигму, включающую только отдельные финитные формы.

Отрицательный глагол Л $b u n^{j} i$ - / Т $b o n^{j} i$ - 'ведь не' в обоих энецких диалектах имеет форму аориста (47)-(48). В лесном диалекте представлена также форма интеррогатива. Последняя, во-первых, образуется при помощи идиосинкратического показателя -si- (как и проиллюстрированная в (39)-(40) форма интеррогатива основного отрицательного глагола), а во-вторых, имеет аномальное значение и выражает не вопрос, а эмфатическое отрицательное утверждение (49).

$\begin{array}{llll}k a i-n^{j} i \text { ? } & \text { Jii? } & \text { bon }^{\mathbf{i} \boldsymbol{i}-\boldsymbol{P}} & \text { peretfo-? } \\ \text { товарищ-PL.1sG } & \text { я.АCC } & \text { ведь_не-3PL.s } & \text { помогать-CONN }\end{array}$

'Мои товарищи ведь мне не помогают'.

$\partial z i-\int$

buni-na?

Л быть_видимым-CVB ведь_не-1PL.SO

'Мы ведь на виду не хороним'.

səjza-an

\section{buni-si-a?}

diriri-?

Л хороший-PROL.SG ведь_не-Q-1PL.s/SO

'Хорошо, конечно, мы не жили'.

Отрицательный глагол Л kitfe-/ Т kstfe- 'чуть не' в обоих диалектах имеет формы аориста (50)-(51) и перфекта (52)-(53). В материалах 
по лесному диалекту также представлена производная от аориста форма прошедшего времени (54).

\begin{tabular}{|c|c|c|c|c|}
\hline (50) & $m \partial d j i$ & neว-j? & kotfi-zo? & diuso-? \\
\hline $\mathrm{T}$ & я & ребенок-NOM.SG.1sG & ЧУТЬ_HE-1SG.S & потерять-CONN \\
\hline & eke & diere & & \\
\hline & этот & день & & \\
\hline
\end{tabular}

'Я чуть не потерял ребенка в этот день'.

(51) neliuku-xiz kitfe-na? o-la-?

Л мошка-DAT.PL чуть_не-1PL.M съесть-PASS-CONN

'Чуть нас мошка не съела'.

(52) kotfe-bi-no djabu-?

$\mathrm{T}$ чуть_не-PRF-1SG.SO NSG $_{\text {догнать-CONN }}$

'Я чуть их не догнал'. [Хелимский, рук.]

(53) turatfeda an'i saloba an'i kitfe-bi-zu? leuza-?

Л Турачеда и лед и чуть_не-PRF-3PL.SO ${ }_{\mathrm{SG}}$ проломить-CONN

'Они чуть не проломили лед (озера) Турачеда'.

(54) vajna-as kitfe-f kan ${ }^{i} i-$ ?

Л война-transl чуть_не-3SG.S.PST уйти-CONN

‘Чуть война не случилась'.

Отрицательный глагол Л ige-/ Т iige- 'конечно, как не' в обоих диалектах имеет только форму аориста (55)-(56).
(55) iige-o
lietobe-?
$\mathrm{T}$ конечно-1SG.SO $\mathrm{SG}_{\mathrm{S}}$ coxранять-CONN
'Я, конечно, сторожу'.
(56) iye-xi? kauzur-?
Л конечно-3DU.s ругаться-CONN
'Конечно, они поругались'.

\section{3. Модально-вопросительный глагол}

Только в лесном диалекте представлен не упоминавшийся ранее в литературе модально-вопросительный глагол sbujta- 'зачем (кому-л.)', который имеет только форму аориста. Этот глагол присоединяет только 
лично-числовые показатели субъектно-объектной согласовательной серии, что также является морфологической аномалией. У стандартных глагольных лексем возможность употребления субъектно-объектных показателей всегда означает возможность употребления в других контекстах и субъектных лично-числовых показателей (см., например, [Сорокина 2010: 310-314]). Глагол sbujta- используется для выражения вопроса со значением цели внутренней необходимости обладания объектом, который выражается прямым дополнением и контролирует объектное согласование.

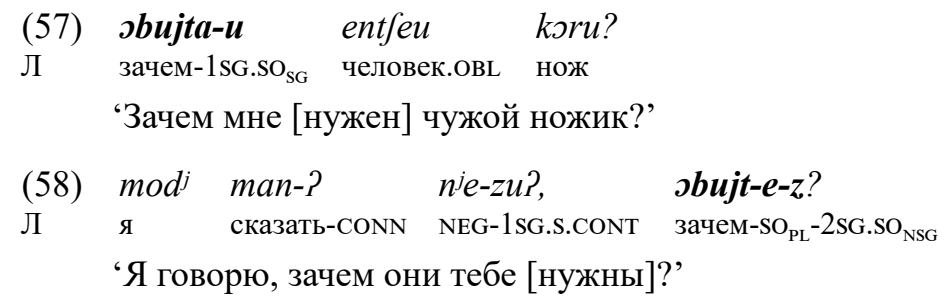

\section{4. Словозаместитель}

Наконец, в ряду энецких нелексических глаголов с нетривиальными морфологическими особенностями следует упомянуть словозаместитель $m u$ - 'это самое'. Это единственная энецкая лексема, имеющая нестандартно широкую морфологию, а именно, одновременно и полный набор именных морфологических возможностей, и полный набор глагольных. Примеры (59)-(60) иллюстрируют именное употребление этой лексемы, а (61)-(62) - глагольное ${ }^{12}$.

\begin{tabular}{|c|c|c|c|}
\hline (59) & $\begin{array}{l}\text { mu-xone } \\
\text { PLC-LOC.SG }\end{array}$ & $\begin{array}{l}\text { mədjera, } \\
\text { работать.3sG.s }\end{array}$ & $\begin{array}{l}\text { balinisa-xane } \\
\text { больница-LOC.SG }\end{array}$ \\
\hline & \multicolumn{3}{|c|}{ ‘В этом самом работает, в больнице'. } \\
\hline & $\begin{array}{l}\boldsymbol{m u}-\boldsymbol{x o}- \\
\text { PLC-DAT. }\end{array}$ & .SG.2SG силс & BL.SG.2SG \\
\hline
\end{tabular}

12 Строго говоря, таким образом, речь идет не о глаголе, а об уникальной лексеме, образующей собственную часть речи. Мы, однако, включили ее в рассмотрение, поскольку в контексте рассмотрения маргиналий глагольной морфологии имеет значение и сама возможность ее сочетания с именной у той же лексемы. 
ker-ta

poga-d-e-z?

cam-OBL.SG.3sG

попасть_в_сеть-FUT-M-3SG.M

'В это самое, в силок она сама попадется'.
(61) kəo
nine peri?
mua-zo?
хребет

на
всегда
PLC-1SG.S
' $Я$ в тундре всегда это самое'.
produkti-ni?
$t \int u k u$
mu-bi-za,
beri-pi-za
Л продукт-PL.1SG весь
PLC-PRF-3SG.SO ${ }_{\text {NSG }}$
разбросать-PRF-3SG.SO $\mathrm{NSG}_{\mathrm{N}}$

‘Он все мои продукты это самое, разбросал'.

\section{5. Заключение}

Таким образом, в энецком языке целый ряд глаголов, лишенных полноценного лексического значения, обнаруживают идиосинкратические морфологические особенности. В настоящей статье было предложено описание, сводящее их воедино.

\section{Список условных сокращений}

1, 2, 3 - 1, 2, 3 лицо; ABL - аблатив; ACC - аккузатив; ADV - показатель адвербиализации; CAR - каритив; CAUS - каузатив; CONJ - конъюнктив; CONN коннегатив; CONT - «контрастивная» серия; CVB - деепричастие / инфинитив; CVB. COND - деепричастие условия; CVB.IRR - ирреальное деепричастие; DAT — датив; DEST - дестинатив; DIM - диминутив; DU - дв. число; DUR - дуратив; EVEN 'даже'; ЕXC — экскламатив; FUT — будущее время; GEN — генитив; HAB — хабитуалис; HORT - гортатив; IMP — серия императива; LOC — локатив; м - медиальная согласовательная серия; MULT - мультипликатив; NEG - отрицательный глагол; NMLZ — номинализация; NOM — номинатив; OBL — косвенный падеж; PASS — пассив; PL - мн. число; PLC - словозаместитель; PRF — перфект; РROB - пробабилитив; PROL - пролатив; PST - серия прошедшего времени; PTCP.ANT - причастие предшествования; Q - интеррогатив; RESTR - рестриктив; $\mathrm{S}$ - субъектная согласовательная серия; $\mathrm{SG}$ - ед. число; $\mathrm{SON}_{\mathrm{SG}}$ - субъектно-объектная согласовательная серия для объекта неед. ч.; $\mathrm{SO}_{\mathrm{SG}}$ - субъектно-объектная согласовательная серия для объекта ед. ч.; $\mathrm{SO}_{\mathrm{PL}}$ - субъектно-объектная согласовательная серия для объекта мн. ч.; TOP — топик; TRANSL — транслатив. 


\section{Литература}

Сорокина 2010 - И. П. Сорокина. Энецкий язык. СПб.: Наука, 2010.

Сорокина, Болина 2005 - И. П. Сорокина, Д. С. Болина. Энецкие тексты. СПб.: Наука, 2005.

Урманчиева 2006 - А. Ю. Урманчиева. Время, вид или модальность? Глагольная система энецкого языка // Вопросы языкознания. 2006. № 4. С. 84-100.

Ханина, Шлуинский 2012 - О. В. Ханина, А. Б. Шлуинский. Эмфатические отрицательные глаголы в энецком языке // Вестник Томского государственного педагогического университета. 2012. № 116 (1). С. 115-121.

Ханина, Шлуинский 2015 - О. В. Ханина, А. Б. Шлуинский. Императивные формы в энецком языке // Acta Linguistica Petropolitana. Труды Института лингвистических исследований. 2015. Т. ХІ. Ч. 2. С. 610-626.

Хелимский, рукопись - Е. А. Хелимский. Материалы к словарю энецкого языка. Рукопись.

Шлуинский 2010 - А. Б. Шлуинский. «Контрастивные» глагольные окончания в лесном диалекте энецкого языка // С. И. Буркова (ред.). Материалы 3-й Международной конференции по самодистике. Новосибирск: Любава, 2010. С. 279-291.

Haumann 2007 - D. Haumann. Adverb licensing and clause structure in English. Amsterdam; Philadelphia: John Benjamins, 2007.

Khanina, Shluinsky 2013 - O. Khanina, A. Shluinsky. Choice of case in cross-reference markers: Forest Enets non-finite forms // Finnisch-Ugrische Mitteilungen. 2013. Bd. 37. S. 31-44.

Siegl 2013 - F. Siegl. Materials on Forest Enets, an indigenous language of Northern Siberia (Suomalais-Ugrilaisen Seuran Toimituksia. Vol. 267). Helsinki: SuomalaisUgrilainen Seura.

\section{References}

Haumann 2007 - D. Haumann. Adverb licensing and clause structure in English. Amsterdam; Philadelphia: John Benjamins, 2007.

Helimsky, Ms. - E. A. Helimsky. Materialy k slovaryu enetskogo yazyka [Materials for the dictionary of the Enets language]. Manuscript.

Khanina, Shluinskiy 2015 - O. V. Khanina, A. B. Shluinskiy. Imperativnye formy $\mathrm{v}$ enetskom yazyke [Imperative forms in the Enets language]. Acta Linguistica Petropolitana. Trudy Instituta lingvisticheskikh issledovaniy. 2015. Vol. XI. Pt. 2. P. 610-626.

Khanina, Shluinskiy 2012 - O. V. Khanina, A. B. Shluinskiy. Emfaticheskie otritsatelnye glagoly $\mathrm{v}$ enetskom yazyke [Emphatic negative verbs in the Enets language]. Vestnik Tomskogo gosudarstvennogo pedagogicheskogo universiteta. 2012. No. 116 (1). P. 115-121. 
Khanina, Shluinsky 2013 - O. Khanina, A. Shluinsky. Choice of case in cross-reference markers: Forest Enets non-finite forms. Finnisch-Ugrische Mitteilungen. 2013. Bd. 37. S. 31-44.

Shluinsky 2010 - A. B. Shluinsky. «Kontrastivnye» glagolnye okonchaniya v lesnom dialekte enetskogo yazyka ["Contrastive" verbal personal inflexions in the Forest Enets]. S. I. Burkova (ed.). Materialy 3-y Mezhdunarodnoy konferentsii po samodistike [Materials of the $3^{\text {rd }}$ International conference on Samoyedology]. Novosibirsk: Lyubava, 2010. P. 279-291.

Siegl 2013 - F. Siegl. Materials on Forest Enets, an indigenous language of Northern Siberia (Suomalais-Ugrilaisen Seuran Toimituksia. Vol. 267). Helsinki: Suomalais-Ugrilainen Seura.

Sorokina 2010 - I. P. Sorokina. Enetskiy yazyk [Enets language]. St. Petersburg: Nauka, 2010.

Sorokina, Bolina 2005 - I. P. Sorokina, D. S. Bolina. Enetskie teksty [Enets texts]. St. Petersburg: Nauka, 2005.

Urmanchieva 2006 - A. Yu. Urmanchieva. Vremya, vid ili modalnost? Glagolnaya sistema enetskogo yazyka [Time, aspect or modality? The system of Enets verb]. Voprosy yazykoznaniya. 2006. No. 4. P. 84-100. 


\section{VARIA}





\section{Рецепция грамматических идей М. В. Ломоносова в русских грамматиках второй половины XVIII в.}

\section{С. В. Власов}

Санкт-Петербургский государственный университет; s.vlasov@spbu.ru

\section{С. С. Волков}

Институт лингвистических исследований РАН, Санкт-Петербург; sergejvolkov2006@yandex.ru

\section{Л. В. Московкин}

Санкт-Петербургский государственный университет; 1.moskovkin@spbu.ru

Аннотация. В статье рассматривается вопрос о влиянии «Российской грамматики» М. В. Ломоносова (1755) на содержание создававшихся во второй половине XVIII в. учебников русского языка как иностранного - учебников для французов Ж.-Б. Ж. Шарпантье и Ф. де Мариньяна, для немцев - Я. М. Родде и учебного пособия Ф. В. Каржавина. Приводятся результаты сравнительного анализа параграфов «Российской грамматики» (имя, глагол, наречие) и соответствующих глав указанных учебников, позволившего выявить влияние ломоносовских идей в области метаязыка, интерпретации грамматических явлений и использования примеров. Установлено, что авторы указанных учебников русского языка как иностранного опирались не только на текст «Российской грамматики», но и на другие источники, главным из которых была грамматика В. Е. Адодурова. Доказано, что грамматические разделы указанных учебников являются не переводами «Российской грамматики», а их авторскими интерпретациями, в которых отразились собственные лингвистические взгляды авторов, их педагогический опыт, учет адресата и т. д.

Ключевые слова: «Российская грамматика», учебники русского языка для иностранцев, М. В. Ломоносов, И. Л. Стафенгаген, Ж-Б. Ж. Шарпантье, Ф. де Мариньян, Я. Родде, Ф. В. Каржавин. 


\section{Adoption of M. Lomonosov's grammar ideas by Russian grammars of the second half of the $18^{\text {th }}$ century}

\section{S. V. Vlasov}

St. Petersburg State University; s.vlasov@spbu.ru

\section{S. S. Volkov}

Institute for Linguistic Studies, Russian Academy of Sciences, St. Petersburg; sergejvolkov2006@yandex.ru

\section{V. Moskovkin}

St. Petersburg State University; 1.moskovkin@spbu.ru

Abstract. The article reviews the influence of M. V. Lomonosov's Rossijskaya grammatika (Russian grammar), St. Petersburg, 1755) on the Russian grammars for foreign students issued in the second half of the $18^{\text {th }}$ century: Élémens de la langue russe ou Méthode courte et facile pour apprendre cette langue conformément à l'usage (St. Petersburg, 1768) by J.-B. J. Charpentier and F. de Marignan, Russische Sprachlehre zum bestem der deutschen Jugend eingerichtet von Jac. Rodde (Riga, 1773), and Remarques sur la langue russienne et sur son alphabet, avec des Pièces relatives à la connoissance de cette Langue (St. Pétersbourg, 1791) by Phéodore Karjavine. The review is subdivided into three paragraphs on Russian nouns and adjectives (gender, declination, case), on the Russian verb tense system, and on Russian adverbs (semantic classes). A comparative analysis of the respective Rossijskaya grammatika's paragraphs and the corresponding chapters of the textbooks for foreign students reveals a strong influence of Lomonosov's concepts on their metalanguage, interpretation of grammatical phenomena, and examples used. Notably, apart from Lomonosov's Rossijskaya grammatika, they also build on some other resources, mostly the Anfangs-Gründe der Russischen Sprache (St. Petersburg, 1731) by V. E. Adodurov. The study shows that the grammatical sections of these textbooks, rather than using direct translations from Rossijskaya grammatika, tend to rethink and enrich Lomonosov's grammatical theory. Such innovations reflect the authors' linguistic ideas, teaching experience, knowledge of their students' needs, etc. The analysis allows to overview and reconstruct the post-Lomonosov period in the history of the $18^{\text {th }}$ century Russian linguistics and linguodidactics. All this shows the importance of a philological study of manuals of the Russian language for foreigners as a source of information for historical phonetics, accentology, grammar, lexicology, and phraseology, especially since the authors of these manuals sought to reflect the Russian speech of their time.

Keywords: M. V. Lomonosov, "Rossiyskaya grammatika”, Russian language textbooks for foreign students, J. L. Stavenhagen, J.-B. J. Charpentier, F. de Marignan, J. Rodde, Ph. Karjavine. 


\section{1. Введение}

Вкладу «Российской грамматики» М. В. Ломоносова в становление русской национальной культуры, ее значению для нормализации русского языка и развития его грамматической системы, связям с европейской филологической традицией и трудами предшественников посвящены исследования А. С. Будиловича [Будилович 1869], И. И. Давыдова [Давыдов 1855], С. П. Обнорского [Обнорский 2010 (1940): 136-150], В. Н. Макеевой [Макеева 1961], В. М. Живова [Живов 2004; Живов 2017], Г. Кайперта [Keipert 1999: 726-779], Б. А. Успенского [Успенский 1994: 140-149], П. А. Клубкова [Клубков 2011], К. А. Филиппова, Н. В. Каревой [Карева, Филиппов 2010: 436-444], Р. Рёнкя [Rönkä 2005], С. Аршембо [Archaimbault 1999b] и др. Однако почти не изучено влияние этой грамматики на содержание создававшихся во второй половине XVIII в. учебников и учебных пособий по русскому языку, предназначенных для иностранцев. Можно назвать ряд работ, посвященных анализу учебников Ж.-Б. Ж. Шарпантье и Ф. де Мариньяна [Archaimbault 1999a: 371-380; Власов, Московкин 2007: 72-80], Я. М. Родде [Bernhagen 1968: 114-121, 395-397; Keipert 2006: 85-110; Сазонова 2008: 173-179; Ершова 2011: 24-30; Ершова 2013; Власов, Московкин 2014: 151-163], Ф. В. Каржавина [Алексеев 1961: 8-36; Долгова 1984; Съедина 1997: 67-89; Siedina 1999: 162-177; Власов, Московкин 2012: 68-72] и некоторых других авторов. При этом лишь в немногих из них рассматривается вопрос о влиянии грамматических идей М. В. Ломоносова на содержание указанных учебников.

Материалом исследования послужили тексты разделов «Имя», «Глагол», «Наречие» из «Российской грамматики» М. В. Ломоносова [Ломоносов 1755; Ломоносов 1952: 389-578], ее немецкого перевода, выполненного И. Л. Стафенгагеном [Lomonossow 1764], учебника «Ocновы русского языка» Ж.-Б. Ж. Шарпантье и Ф. де Мариньяна [Charpentier, Marignan 1768], учебника русского языка Я. Родде [Rodde 1773], учебного пособия «Заметки о русском языке и его алфавите» Ф. В. Каржавина [Karjavine 1791].

Цель данного исследования - рассмотрение влияния грамматических идей М. В. Ломоносова на содержание грамматических разделов названных выше учебников русского языка для иностранцев. Основной задачей исследования являлось установление влияния ломоносовских 
идей в области а) грамматической терминологии, б) интерпретации грамматических явлений, в) использования примеров. Кроме того, в задачи исследования входило установление возможного влияния на содержание указанных учебников других источников, в частности, немецкого перевода «Российской грамматики» М. В. Ломоносова.

Основной метод исследования - сравнительный анализ указанных текстов, выявление сходств и различий интерпретации грамматических явлений, приводимых примеров и используемого метаязыка для определения источников грамматических описаний.

\section{2. Учебники русского языка в XVIII в.}

Анализ постломоносовских учебников русского языка для иностранцев необходимо осуществлять, учитывая контекст российской лингвистики и лингводидактики XVIII в. В частности, следует иметь в виду, что первые учебники русского языка создавали не русские, а иностранцы, у которых была потребность овладеть не столько церковнославянским языком, преподаваемым в русских школах, сколько обиходным общепонятным русским языком. Они не могли создавать учебники русского языка как иностранного на основе учебников русского языка для русской школы, так как таких учебников еще не было. Создавая свои учебники, они записывали факты обиходного русского языка и пытались их осмыслить, опираясь на славянскую грамматику Мелетия Смотрицкого или на грамматики других языков. Тот факт, что первые учебники русского языка как иностранного создавались иностранцами, в значительной степени повлиял не только на их построение, метаязык и интерпретацию явлений русского языка, но и обусловил появление в них ряда неточностей и языковых ошибок.

Первый печатный учебник русского языка для иностранцев был написан на латинском языке Г. В. Лудольфом [Ludolf 1696]. Из рукописных трудов наиболее интересны грамматики для немецких учащихся И. Э. Глюка [Keipert et al. (ed.) 1994], И. В. Паузе [Михальчи 1969; Keipert (ed.) 2016] и М. Шванвица [Compendium 2002]. Деятельность двух последних авторов была связана с Императорской Академией наук, которая с 1720-х гг. стала центром российской научной русистики. 
В первые годы деятельности Академии наук была опубликована на немецком языке грамматика В. Е. Адодурова «Первые основания российского языка» [Адодуров 1731; Волков и др. (ред.) 2014] в качестве приложения к немецко-латинско-русскому словарю, называемому обычно «Вейсманновым лексиконом». На основе ее расширенной версии была создана грамматика русского языка для шведов М. Грёнинга [Успенский 1975].

Важным событием отечественной лингвистики и лингводидактики была публикация в 1757 г. «Российской грамматики» М. В. Ломоносова [Ломоносов 1755; Ломоносов 1952: 389-578;], наиболее авторитетного описания русского языка в XVIII в. На ее основе были созданы учебники русского языка для русских учащихся Н. Г. Курганова, В. Ф. Романова, В. П. Светова, П. И. Соколова, А. А. Барсова, Е. Б. Сырейщикова, для французов - Ж.-Б. Ж. Шарпантье и Ф. де Мариньяна, Ф. В. Каржавина, для немцев - Я. М. Родде, И. А. Гейма, Д. А. В. Таппе, для поляков - М. Любовича, М. Зубаковича, М. Бутовского, И. Дворжецкого-Богдановича.

Первый постломоносовский учебник русского языка для иностранцев «Élémens de la langue russe» («Основы русского языка») составил Жан-Батист Жюд Шарпантье, учитель французского языка Санкт-Петербургской академической гимназии, член комиссии Императорской Академии наук по аттестации иностранных учителей, переводчик с русского и немецкого языков на французский. Этот учебник, выдержавший четыре издания $(1768,1791,1795,1804)$, содержит правила русского произношения, грамматический раздел, упражнения на перевод, диалоги, список русских пословиц, таблицу мер и весов. Как указано в предисловии, создавая грамматический раздел, Шарпантье выполнил перевод «Российской грамматики» Ломоносова на французский язык, однако в дальнейшем от него отказался в пользу более простой версии ломоносовской грамматики, составленной Ф. де Мариньяном [Charpentier, Marignan 1768: VII].

Франсуа де Мариньян в 1757 г. был аттестован в Императорской Академии наук на звание учителя французского и латинского языков и с этого времени служил домашним учителем в Санкт-Петербурге. В 1764-1765 гг. он был гувернером в школе К. Г. Разумовского «Академия Десятой линии» [Шлецер 1875; Васильчиков 1880]. Вероятно, он преподавал и русский язык французам, для чего и разработал собственную версию ломоносовской грамматики. В дальнейшем, говоря о грамматическом разделе учебника Шарпантье, мы будем его называть грамматикой Шарпантье и Мариньяна. 
Второй постломоносовский учебник русского языка для иностранцев «Russische Sprachlehre» («Учебник русского языка») написал Якоб Родде, секретарь и переводчик магистрата г. Риги. Этот учебник, который также несколько раз переиздавался $(1773,1778,1784,1789)$ и пользовался большой популярностью, включает правила русского произношения, грамматический очерк, диалоги, пословицы, исторические и художественные тексты для чтения.

Третью из рассматриваемых в статье учебных книг «Remarques sur la langue russienne et sur son alphabet» («Заметки о русском языке и его алфавите») составил Федор Васильевич Каржавин, полиглот, переводчик, учитель французского языка. Источником этого пособия, по словам его составителя, послужила не дошедшая до нас рукопись его дяди Ерофея Никитича Каржавина, составленная во Франции в 1755 г. и адресованная французским географам и историкам. Этим ученым было необходимо правильно читать и транскрибировать русские географические названия, а также имена разных лиц в справочной и исторической литературе, поэтому более половины объема этого пособия посвящено русской фонетике и орфографии. Судя по опубликованному тексту, Ф. В. Каржавин значительно переработал и дополнил рукопись своего дяди новыми оригинальными материалами, в том числе учебными текстами и кратким очерком русской грамматики, что позволяет нам считать автором «Заметок» самого Ф. В. Каржавина. Сведения по русской грамматике представлены в этом пособии в максимально сжатом виде - на девяти страницах в особом разделе «Diverses Observations Abrégées qui donneront une idée de la Langue et de la Grammaire Russiénnes» [Karjavine 1791: 108-117].

В историографии русского языкознания в XIX в. высказывались мнения о том, что грамматические разделы постломоносовских учебников представляют собой переводы или сокращенные варианты «Российской грамматики» [Давыдов 1855: XIX; Балицкий 1876: XV]. В ходе исследования было установлено, что грамматики Шарпантье и Мариньяна, Родде и Каржавина являются не переводами и не сокращенными вариантами «Российской грамматики», а их авторскими интерпретациями, попытками переосмыслить или дополнить грамматические идеи Ломоносова, в которых отразились собственные лингвистические взгляды авторов, их педагогический опыт, учет адресата и т. д. Покажем это на примерах. 


\section{3. Имя (существительное, прилагательное)}

В «Российской грамматике» сведения об имени содержатся в разных местах: в главе 4 «О знаменательных частях человеческого слова» наставления первого «О человеческом слове вообще», где Ломоносов рассматривает общие вопросы о знаменательных и служебных словах, о именах и глаголах, существительных нарицательных и собственных (§ 48), собирательных (§ 49), существительных и прилагательных (§ 50) и проч. [Ломоносов 1952: 405-413], и в наставлении третьем «О имени», где подробно рассматриваются вопросы о роде, склонениях, степенях сравнения, притяжательных прилагательных, именах увеличительных и уменьшительных, именах числительных (§§ 131263) [Ломоносов 1952: 436-478]. В грамматиках Шарпантье и Мариньяна, Родде и Каржавина все эти сведения приведены в одной главе, посвященной рассмотрению имени, и кроме того, они упрощены и минимизированы. Уже это говорит о том, что грамматические разделы этих учебников не являются переводами «Российской грамматики» Ломоносова.

\section{1. Род}

М. В. Ломоносов выделяет в русском языке четыре рода: мужской, женский, средний и общий. Он выбирает один из двух возможных способов описания категории рода - группирует существительные по абсолютному концу слова (конечной букве) и указывает на принадлежность каждой группы к родовому классу: - $a$ (похвала и др.) - женский род; -е (сердие и др.) - средний род; -й и -ъ (сарай, храмъ и др.) мужской род; -о (слово и др.) - средний род; -ь (добродњтель и др.) женский род; -я (земля и др.) - женский род [Ломоносов 1952: 438439]. В каждой группе выделяются исключения.

А. С. Будилович одним из первых отмечал, что в «Российской грамматике» получил отражение индуктивный метод исследования, характерный для естествознания XVIII в. и включавший следующие приемы работы: сбор материала, его анализ, распределение его по группам и формулирование выводов [Будилович 1869: 71-72]. Вместе с тем, очевидно, что М. В. Ломоносов, хорошо знакомый с европейскими грамматиками, мог выбрать и иное представление языкового 
материала - от обобщений к языковым фактам, что соответствовало бы дедуктивному методу, также распространенному в естественных науках. Нельзя исключать, что при выборе способа описания языкового материала, в данном случае - рода имен существительных, он руководствовался педагогическими соображениями - стремился показать ученикам путь получения обобщенного научного знания.

Педагогическая ценность представленного в «Российской грамматике» способа описания рода очевидна - знание формы слова позволяет учащемуся самостоятельно определить его принадлежность к тому или иному родовому классу. Этот способ введения информации о роде практикуется и в настоящее время на начальном этапе обучения иностранцев русскому языку в условиях, когда использование перевода невозможно или нецелесообразно. Принцип определения грамматической характеристики слов по абсолютному концу слова лежит в основе описания русской грамматики «от формы к значению» в работе И. Г. Милославского [Милославский 1987].

В грамматиках Шарпантье и Мариньяна, Родде и Каржавина прослеживается связь с «Российской грамматикой», однако в них представлено собственное видение категории рода. Так, Шарпантье и Мариньян считают, что в русском языке можно выделить три рода:

(1) En Français nous n'avons que deux genres; en Russe il y en a quatre, le masculin, le féminin, le neutre $\&$ l'epicæne, ou de tout genre: il me parait néanmoins qu'on pourrait avec un peu de courage, et sans inconvenient, les réduire à trois; le dernier n'étant point d'un usage déterminément nécessaire, \& me paraissant au contraire fort inutile [Charpentier, Marignan: 1768: 19];

«Во французском языке у нас всего лишь два рода; в русском же их четыре: мужской, женский, средний и обоюдный, то есть всякий; тем не менее мне кажется, что можно было бы набраться храбрости и без каких-либо неудобств сократить их до трех; последний, не будучи определенно необходимым в употреблении, кажется мне вовсе ненужным» (перевод наш. - Aвт.).

Тем не менее, как и Ломоносов, Шарпантье и Мариньян приводят слова плакса, пьяница, ханжа и указывают на их принадлежность к общему роду. Кроме того, к общему роду они относят слова pluralia tantum (вильl, сани, латы, мощци) [Charpentier, Marignan: 1768: 20-22]. Подобные слова к общему роду относит и Родде (штаны, виль) [Rodde 1773: 14], хотя это и противоречит позиции Ломоносова, который писал: 
(2) «Множественнаго числа имена по большей части суть рода женскаго: вериги, вильl, воробы, голени, сани, латы, мошии» [Ломоносов 1952: 440].

Нет сомнения в том, что авторы первых постломоносовских учебников русского языка для иностранцев опирались не только на «Российскую грамматику» Ломоносова, но и на другой источник - грамматику Адодурова.

В частности, влиянием адодуровской грамматики можно объяснить то, что Шарпантье и Мариньян не приняли предложенный Ломоносовым способ описания категории рода. Хотя они отмечали:

(3) C'est par la terminaison des mots Russes qu'on connoit leur genre: ceci demande beaucoup d'attention [Charpentier, Marignan 1768: 19]; «Именно по окончанию русских слов узнают их род: это требует большого внимания» (перевод наш. - Авт.),

они описывали русский род по принципу «от родового класса к форме», а не «от формы к родовому классу»:

(4) - мужской род - все имена, которые относятся к мужскому полу, а также слова, оканчивающиеся на -й, -ъ, -ь (Петръ, повелитель, сарай, храмъ и др.);

- женский род - имена, оканчивающиеся на - $a,-b,-я$ (похвал $a$, добродътель, земля и др.);

- средний род - имена, оканчивающиеся на -е, -о (сердие, кальияо ${ }^{1}$ и др.) [Charpentier, Marignan 1768: 19-21].

В каждом случае Шарпантье и Мариньян приводят списки исключений.

Такой способ представления рода в целом характерен для обучения иностранному языку с использованием перевода. Он дает учителю возможность сразу же ввести понятие о роде и формальных признаках каждого родового класса, а затем сосредоточиться на примерах.

Нельзя не заметить, что, хотя подход Шарпантье и Мариньяна к представлению информации о роде отличен от ломоносовского, французские авторы используют примеры, в основном, из «Российской грамматики». Родде же, который аналогичным образом излагает сведения о роде, приводит в основных правилах примеры из грамматики Адодурова, а в уточняющих - из грамматики Ломоносова.

\footnotetext{
${ }^{1}$ Везде сохраняется авторская орфография.
} 
О том, что при описании данной грамматической категории Родде опирался главным образом на грамматику Адодурова, свидетельствуют следующие примеры:

Грамматика Адодурова:

(5) «Feminini Generis sind die Nahmen der Frauen, dererselben Bedienungen, der Tugendeln, Laster, Bäume und Landschaften, und alle Wörter, so sich auf a und $\mathbf{я}$ (wenn kein $\mathbf{M}$, vorher gehet) imgleichen auf $\mathbf{b}$ endigen, das in Genitiuo и annimt, als: Елена Helena, повариха die Köchin, любовь, gen. любви die Liebe, гордость, gen. гордости die Hoffarth, береза Birken-Baum, Полша Pohlen, вода das Wasser, земля die Erde, дверь, gen. двери die Thür» [Волков и др. (ред.) 2014: 108];

«К женскому роду относятся имена женщин, названия выполняемых ими работ, добродетелей, пороков, деревьев и ландшафтов, а также все слова, заканчивающиеся на а, я (если этой букве не предшествует м) и $\mathbf{b}$, который превращается в родительном падеже в и: Елена Helena, повариха die Köchin, любовь, род. любви die Liebe, гордость, род. гордости die Hoffarth, береза Birken-Baum, Полша Pohlen, вода das Wasser, земля die Erde, дверь, род. двери die Thür» (перевод Л. Н. Григорьевой) [Волков и др. (ред.) 2014: 109].

Грамматика Родде:

(6) «Fœminina sind die Namen der Frauen und deren Bedienungen; besgleichen der Länder, und alle Wörter, so sich auf $\mathbf{a}$ und $\boldsymbol{я}$ (wenn kein $\mathbf{M}$, vor sich hat) imgleichen auf $\mathbf{b}$, das in Genitiuo $\mathbf{и}$ hat, enden, als: Елена, повариха, Гишпанїя, Россїя, Лифляндїя, Полша, вода, земля» [Rodde 1773: 13-14];

«К женскому роду относятся имена женщин и названия выполняемых ими работ; точно так же названия стран и все слова, которые только заканчиваются на а и я (если перед ним не стоит м), а также на ь, которые в генитиве имеют и, как например: Елена, повариха, Гишпанїя, Россїя, Лифляндїя, Полша, вода, земля» (перевод наш. - Aвт.).

Грамматика Адодурова:

(7) «Neutrius Generis sind die Verba, Aduerbia, und eine jede gantze Rede, so an statt eines Substantiui gebrauchen wird, wie nicht 
weniger die Wörter, so auf е, о und мя, ausgehen, als: поле das Feld, сыно das Heu, имя der Nahme» [Волков и др. (ред.) 2014: 108]; «К среднему роду относятся глаголь, наречия и целые высказывания, которые используются вместо существительных, а также множество слов, заканчивающихся на е, о и мя, как в словах: поле das Feld, сьно das Heu , имя der Nahme» (перевод Л. Н. Григорьевой) [Волков и др. (ред.) 2014: 109].

\section{Грамматика Родде:}

(8) «Neutrius Generis sind die Verba, Adverbia, und eine jede ganze Rede, so an statt eines Substantivi gebrauchen wird; wie nicht weniger die Wörter, so auf e, о und мя, ausgehen, als: поле, сьно, имя» [Rodde 1773: 14];

«Среднего рода глаголы, наречия и всякое высказывание, когда оно только употребляется вместо имени существительного; также все слова, которые только заканчиваются на е, о и мя, как например: поле, сьно, имя» (перевод наш. - Aвm.).

Приведенные фрагменты грамматики Родде были заимствованы им из текста грамматики Адодурова и подверглись сокращениям и незначительной стилистической правке.

Анализ представления категории рода в анализируемых материалах позволяет отчасти ответить и на вопрос, не повлиял ли на содержание постломоносовских грамматик перевод «Российской грамматики» на немецкий язык, выполненный И. Л. Стафенгагеном. Для этого были проведены сравнения фрагментов об именах мужского рода на -ь из «Российской грамматики», ее немецкого перевода и изучаемых нами грамматик.

Как уже было отмечено, имена на -ь Ломоносов относил к женскому роду. При этом он отмечал, что исключениями являются имена, «до мужеского пола надлежащие» (повелитель, избавитель и т. д.) и 57 других (неодушевленных и одушевленных) имен (валдырь, вепрь и др.) [Ломоносов 1952: 439]. Этот же самый текст мы видим и в немецком переводе Стафенгагена, однако количество исключений в нем сокращено до 54-х: отсутствуют слова вязель, ломоть, простень [Lomonossow 1764: 86-87]. В грамматике Шарпантье и Мариньяна количество исключений еще меньше - их 44 [Charpentier, Marignan 1768: 20-21], и если бы французские авторы пользовались не русским оригиналом, а немецким переводом грамматики Ломоносова, то среди этих 44 имен 
не было бы отсутствующих в немецком переводе слов вязель, ломоть и простень. Однако слова ломоть и простень мы видим среди исключений у Шарпантье и Мариньяна. Это убедительно доказывает, что немецким переводом «Российской грамматики» они не пользовались. Что касается Родде и Каржавина, то на материале описания категории рода невозможно сделать вывод о том, опирались они на немецкий перевод грамматики Ломоносова или нет.

В учебном пособии Каржавина за основу берется описание категории рода в «Российской грамматике», при этом указываются только основные случаи, а исключения опускаются. Такой подход приводит к тому, что существительные на -ь относятся Каржавиным только к женскому роду, а многочисленные слова мужского рода на -ь, указанные Ломоносовым как исключения, вообще не упоминаются [Karjavine 1791: 109].

\section{2. Склонение}

В «Российской грамматике» представлены пять склонений: четыре - существительных и одно - прилагательных. Приведем их перечень с примерами имен, которые в тексте грамматики даны в парадигмах:

- первое склонение на $a$, я - имена мужского и женского рода (воевода, изба, рука, княгиня, пустыня);

- второе склонение - имена мужского рода на $b, \check{u}, b$ и среднего рода на $e$, ̈ее, о (соколь, орехъ, поводъ, злодњй, богатырь, рой, якорь, слово, лице или лицо, зданїе, копье);

— третье склонение - имена среднего рода на я (сьмя, жеребя);

— четвертое склонение - имена женского рода на ь (добродътель);

- пятое склонение - имена прилагательные всех трех родов (истинный, прежней, божей) [Ломоносов 1952: 440-455].

Выделяются семь падежей: именительный, родительный, дательный, винительный, звательный, творительный, предложный [Ломоносов 1952: 411-412].

Эта система склонений полностью перенесена в грамматику Шарпантье и Мариньяна, которые творчески отнеслись только к примерам. Например, они добавили в первое склонение слова вода и земля и удалили слова воевода, изба и пустыня. Из 11 примеров второго склонения они оставили только лище (лищо) и копье и добавили 6 новых слов 
(баранъ, якорь, дъло, ученїе, змғй, житье). В третье склонение они добавили слова время, иылпля и дитя, в четвертое - слова лошадь, мать и дочь. В пятом склонении вместо ломоносовской формы именительного падежа прилагательного божей [Ломоносов 1952: 454] Шарпантье и Мариньян дают божій.

В грамматике Родде мы видим иную систему склонений, которая заимствуется не из «Российской грамматики», а из грамматики Адодурова. Родде, как и Адодуров, относит к третьему склонению слова женского рода на -ь (лошадь), которые у Ломоносова и французских авторов принадлежат к четвертому склонению. К четвертому склонению Родде относит слова гвоздь, злодъй, рожденїе, иарь, рой, питїе, которые у Ломоносова и французских авторов отнесены ко второму склонению. Формы прилагательных пятого склонения в учебнике Родде совпадают то с формами, приводимыми Адодуровым (добрый, добрые или добрыя - для всех 3-х родов), то с формами, которые приводит Ломоносов (прежней, божей - ед. ч. м. р.; у Адодурова - божій). Предложный падеж он называет, как и Адодуров, сказательным - Narrativus [Rodde 1773: 17]. Таким образом, в системе склонений, примерах и названиях падежей в грамматике Родде проявляется влияние не столько «Российской грамматики» Ломоносова, сколько грамматики Адодурова.

Сведения об особых правилах склонения русских имен, содержащиеся в «Российской грамматике», отражены в грамматике Шарпантье и Мариньяна, а также в учебнике Родде с сокращениями примеров. Они расположены не в отдельных главах, а там же, где и общие правила склонения. При этом в грамматике Родде также отмечается влияние не только грамматики Ломоносова, но и грамматики Адодурова. Например, § 27 [Rodde 1773: 30] представляет собой творческую переработку соответствующего фрагмента грамматики В. Е. Адодурова [Адодуров 1731: 19] с добавлением примеров из грамматики Ломоносова.

В учебном пособии Каржавина сведения о склонении полностью заимствуются из «Российской грамматики» [Karjavine 1791: 110-111], но парадигмы имен не приводятся.

\section{3. Другие сведения об имени}

В грамматиках Шарпантье и Мариньяна, Родде и Каржавина отражены сведения о степенях сравнения прилагательных, но эти сведения также расположены по-своему, не в том порядке, как в «Российской 
грамматике». М. В. Ломоносов сначала пишет о формах сравнительной и превосходной степени, а затем приводит особые правила образования сравнительной степени отдельных групп прилагательных. В грамматиках Шарпантье и Мариньяна, Родде и Каржавина иная структура: вначале говорится о наличии трех степеней сравнения, а затем рассматриваются способы образования сравнительной и превосходной степени. При этом Шарпантье и Мариньян приводят на русском языке название сравнительной степени - это не «рассудительный степень», как у Ломоносова [Ломоносов 1952: 410, 466], а «уравнительный степень» [Charpentier, Marignan 1768: 46], что лучше передает значение латинского термина Comparativus или французского le Comparatif.

Подход Каржавина к описанию превосходной степени отличается от подходов Шарпантье и Мариньяна, а также Родде - если последние заимствуют у Ломоносова всю информацию о превосходной степени (у Шарпантье и Мариньяна отсутствуют только формы с приставкой наи-: наилутчій), то Каржавин приводит только два способа ее образования: «богатъйший, le plus riche, et весьма богатый, très riche» [Karjavine 1791: 112].

Полностью, но с сокращением примеров воспроизведена у Шарпантье и Мариньяна глава 5 «О произвожденїи притяжательныхъ, отечественныхъ и отеческихъ именъ, и женскихъ отъ мужскихъ» наставления третьего «Российской грамматики». При этом особое внимание уделяется образованию отчеств, отсутствующих во французском языке [Charpentier, Marignan 1768: 46-53]. В грамматиках Родде и Каржавина этих сведений не имеется.

У Шарпантье и Мариньяна, как и у Родде, воспроизводится информация об увеличительных и уменьшительных именах. Французские авторы указывают на богатство этих форм и их частое использование в русском языке в отличие от французского. Также полностью воспроизведены в грамматике Шарпантье и Мариньяна и в учебнике Я. Родде сведения о числительных. В грамматике Каржавина эти сведения отсутствуют.

\section{4. Глагол}

Глагол в «Российской грамматике» сначала рассматривается в общелингвистическом плане в наставлении первом «О человеческом слове вообще», а затем в особом наставлении четвертом 
«О глаголе» - применительно к русскому языку. В грамматике Шарпантье и Мариньяна глаголу посвящена глава $\mathrm{X}$ «О глаголах», в которой объединены сведения о об этой части речи, приводимые Ломоносовым в разных местах его грамматики [Charpentier, Marignan 1768: 72-208].

Несмотря на то, что в предисловии к «Основам русского языка» утверждается, что глава «О глаголах» воспроизводит «нога в ногу» (pied à pied) грамматику М. В. Ломоносова, Шарпантье и Мариньян упрощают сложную систему десяти глагольных времен Ломоносова до восьми, давая некоторым из них другие названия как на французском, так и на русском языке, что особенно интересно с точки зрения метаязыка описания русского глагола в учебниках русского языка. Видовые характеристики прошедших и будущих времен, четко обозначенные Ломоносовым, не учитываются Шарпантье и Мариньяном, которые вводят формально-грамматическое деление ряда прошедших и будущих времен русского глагола по признаку «простое» / «сложное» (составное) время, более привычному для французской грамматики.

Исходя из педагогических соображений простоты изложения и употребительности языковых форм, Шарпантье и Мариньян удаляют из ломоносовской системы времен русского глагола два малоупотребительных давнопрошедших времени - «давнопрошедшее второе» (бывало трясъ, бывало глоталь, бросаль, плескалъ) и «давнопрошедшее третие» (бывало трясывалъ, глатывалъ, брасываль, плескивалъ) [Ломоносов 1952: 480].

«Прошедшее однократное» у Ломоносова (тряхнуль, глотнуль, бросиль, плеснулъ) названо по-русски в грамматике Шарпантье и Мариньяна «прошедшим простым» (Prétérit simple), а «прошедшее совершенное» («написаль от пишу») - «прошедшим сложным» (Prétérit composé) [Charpentier, Marignan 1768: 78]. Соответственно, «будущее однократное» у Ломоносова (тряхну, глотну, брошу, плесну) именуется в «Основах русского языка» «будущим простым» (Futur simple) [Charpentier, Marignan 1768: 78], а «будущее совершенное» (напишу) — «будущим сложным» (Futur composé). Отметим, что в немецком переводе «Российской грамматики» форма напишу получает название не «будущего сложного», а «будущего простого» (Futurum simplex) [Lomonossow 1764: 170], или «будущего совершенного» (Futurum perfectum):

(9) «Die vollkommen zukünftige futurum perfectum, als напишý ich werde (völlig, gewiß) schreiben von писа́ти schreiben» [Lomonossow 1764: 179] 
«Будущее совершенное futurum perfectum от глагола писа́ти 'schreiben' - напишý» (перевод наш. - Aвm.), ср. в «Российской грамматике»: «будущее совершенное - напишу» [Ломоносов 1952: 480].

Это еще раз доказывает независимость грамматических новаций Шарпантье и Мариньяна от немецкого перевода Стафенгагена.

В этих терминологических новациях Шарпантье и Мариньян верно подметили соответствие приставочных («сложных» по их терминологии и «совершенных» по Ломоносову) форм русского глагола по видовому признаку завершенности действия «сложным» (составным) временам французского глагола - Passé (Prétérit) composé и Futur composé (Futur antérieur).

«Прошедшее неопределенное» по Ломоносову (трясъ, глоталъ, бросаль, плескаль) названо Шарпантье и Мариньяном по-русски «прошедшим не совершенным» (по-французски Imparfait) [Charpentier, Marignan 1768: 78], что не только дословно соответствует французскому традиционному названию соответствующего времени, но и отражает видовую характеристику «прошедшего несовершенного» в русском языке. Впрочем, и в немецком переводе И. Л. Стафенгагена «Российской грамматики» Ломоносова, и до этого перевода в доломоносовских грамматиках прошедшее неопределенное получает латинское название Imperfectum:

(10) «Die Rußischen Zeitwörter haben zehen Zeiten ... 2) die unvollkommen vergangene (praeteritum imperfectum), трясь ich schütterte, глоталь ich schluckte, бросалъ ich warf, плескаль ich platschete» [Lomonossow 1764: 169];

«Времен имеют российские глаголы десять: ... 2) прошедшее неопределенное - трясъ, глоталъ, бросалъ, плескалъ» [Ломоносов 1952: 480]

С терминологией Ломоносова совпадают лишь названия трех остальных оставленных Шарпантье и Мариньяном в глагольной системе русского языка времен - Présent «настоящее» (трясу, глотаю, бросаю, плещу), Plus-que-parfait «давно прошедшее» (тряхиваль, глатывваль, брасываль, плескиваль) и Futur indéterminé «будущее неопределенное» (буду трясти; стану глотать, бросать, плескать) [Charpentier, Marignan 1768: 78].

Я. Родде [Rodde 1773: 154-195] в своей грамматике заимствовал из грамматики Шарпантье и Мариньяна, хотя и с рядом изменений 
и дополнений, таблицы спряжения русских неправильных глаголов, что было отмечено уже Х. Л. К. Бакмейстером [Васmeister 1775: 64; см. также: Keipert 2006: 85-110]. Внимание Я. М. Родде к неправильным глаголам отнюдь не случайно. В предисловии к своей грамматике он подчеркивал, что основная трудность изучения русского языка состоит в большом количестве неправильных глаголов, формы которых учащиеся должны выучивать наизусть.

Во всем остальном Я. Родде следует немецкому переводу «Российской грамматики», а не грамматике Шарпантье и Мариньяна. Он приводит десять глагольных времен по Ломоносову, но дает им только латинские названия без перевода на немецкий язык: 1) Praesens (бросаю), 2) Imperfectum (бросаль), 3) Praeteritum singulare unitatis (бросиль), 4) Plusquamperfectum primum (брасывалъ), 5) Plusquamperfectum secundum (бывало бросалъ), 6) Plusquamperfectum tertium (бывало брасывалъ), 7) Futurum Imperfectum (буду бросать), 8) Futurum simplex (брошу), 9) Praeteritum perfectum (написал), 10) Futurum perfectum (напишу) [Rodde 1773: 78-79].

Следует обратить внимание на то, что в латинских названиях русских времен в переводе Стафенгагена уже имплицитно содержится противопоставление по совершенному / несовершенному виду двух времен - Imperfectum (показываль) и Praeteritum perfectum (показаль) [Lomonossow 1764: 135], однако Родде не обращает на это внимания и не развивает идею видового противопоставления.

В грамматическом очерке Каржавина количество времен русского глагола сокращено до восьми, как и у Шарпантье и Мариньяна, но в отличие от своих французских предшественников Каржавин исключает из ломоносовской схемы десяти времен не второе и третье давнопрошедшие времена, а прошедшее и будущее совершенные от «сложенных» глаголов типа написал, напишу [Karjavine 1791: 115]. В этом он следует за русской грамматикой П. И. Соколова, исключившего именно эти формы из состава времен русского глагола, предложенного Ломоносовым [Соколов 1788: 49-50].

Новации Каржавина в метаязыке описания русского глагола довольно многочисленны. Прежде всего в названиях многих оставленных им глагольных времен появляется новое видовое, по сути, противопоставление между прошедшими временами «определенными», которые отсутствуют в «Российской грамматике», и «неопределенными», которые в ней имеются, но без противопоставления «определенным» временам (Ломоносов выделяет «прошедшее неопределенное» типа трясъ и «будущее неопределенное» типа буду трясти). 
Так, Каржавин противопоставляет прошедшее неопределенное (le Prétérit parfait indéfini) я двигаль прошедшему определенному (le Prétérit parfait défini) я двинул. Давнопрошедшее определенное (le Plus-que-parfait défini - давнопрошедшее второе у Ломоносова) я бывало двигаль противопоставляется Каржавиным давнопрошедшему неопределенному (le Plus-que-parfait indéfini - давнопрошедшее третье у Ломоносова) я бывало двигивалъ. Однако два оставленных Каржавиным будущих времени противостоят друг другу по другим признакам как будущее условное (le Futur conditionnel, будущее неопределенное у Ломоносова) буду двигать будущему определенному (le Futur défini, будущее однократное у Ломоносова) я двину, хотя противопоставление по признаку «определенное» / «неопределенное» можно было бы распространить и на будущие времена, к чему подталкивало ломоносовское название «будущее неопределенное».

Еще одна важная терминологическая новация Каржавина - это выделение в русском языке (вероятно, по аналогии с английскими длительными временами) группы глаголов, называемых им verbes persévératifs, т. е. длительных, выражающих «не только действие, но и продолжение этого действия», например, летаю (je suis à voler), таскаю (je suis à tirer), бъгаю (je suis à courir) [Karjavine 1791: 114]. «Длительные» глаголы у Каржавина - это то же, что «учащательные» глаголы в грамматике Ломоносова [Ломоносов 1952: 483], которые ни тот, ни другой в отличие от Мелетия Смотрицкого [Смотрицкий 2000: 287] никак не связывают с глагольными видами. Однако внимание Ломоносова, Мариньяна и Каржавина к видовым оттенкам выделяемых ими глагольных времен подготавливает почву для дальнейших размышлений о соотношении времен и видов русского глагола.

\section{5. Наречие}

В «Российской грамматике» Ломоносова наречие достаточно кратко рассматривается в числе вспомогательных или служебных частей речи - местоимения, причастия, предлога, союза, междометия (наставление 5, глава 3 «О наречии») [Ломоносов 1952: 550-551]. $\S \$ 40-454$ посвящены определению наречия, семантической (идеографической) классификации наречий, степеням сравнения наречий, происходящих от прилагательных (ясно, яснъе, преясно) префиксальным 
компаративам [Сичинава 2013] и суффиксальным образованиям (рановато, раненько), адвербиализации имен (кругомъ, даромъ).

Наречие в «Российской грамматике» — одна из восьми частей речи (partes orationis). Оно служит средством краткого обозначения обстоятельств ${ }^{2}$ : «Наречиями обстоятельства $\langle\ldots\rangle$ кратко представляются. Следовательно, одно речение имеет в себе силу многих, которых разные перемены в оном изобразиться не могут. Того ради ни склонениям, ни спряжениям не подвержены и никаких о том рассуждений не требуют» [Ломоносов 1952: 417]; наречие у Ломоносова, таким образом, неизменяемая часть речи. Кроме того, Ломоносов считает, что «наречия, которые принимают уравнения, суть по большей части имена прилагательные в среднем роде и неправедно к оной части сло́ва (т. е. к наречию. - Авт.) причитаются» [Ломоносов 1952: 417], в чем решительно расходится с В. Е. Адодуровым, который полагал, что

(12) «В русском языке прилагательные часто не образуют сравнительной степени... Так, при сравнении вещей друг с другом, где необходима сравнительная степень, используется наречие в сравнительной степени (Aduerbiorum comparatiue), как в онъ умнъе меня (er is klüger als ich)...» [Волков и др. (ред.) 2014: 113].

Ломоносов подметил прозрачность границы между наречием и предлогом: «Другие предлоги суть купно и наречия, затем что и с падежами сочиняются и без оных вне сложения одне полагаются; сюда принадлежат: прежде, внутри, внғ, блиско, противу, около, подль, чрезъ, сквозь, посль, мимо, кромг и проч., ибо говорим: прежде времени, внутри дома, внғь храма, блиско или близъ ргки, противъ горы, подль берега, черезъ ровъ, сквозь двери, посль бури, мимо дгла, кромг или опричь товарища. Здесь видим силу предлогов. Но в я быль прежде здоровъ, останься внутри или внг, не подходи блиско, вооруженъ противу, обойди около, не стой подль, другъ прошоль мимо, сквозь пробиться, перелесть черезъ, притти посль наречия находим» [Ломоносов 1952: 552]. В заключение укажем, что наречие может «сочиняться», т. е. сочетаться с глаголом, причастием, деепричастием, наречием «для изъяснения или напряжения их знаменования: весьма

2 Термин обстоятельство у Ломоносова, по-видимому, должен рассматриваться более широко, т. е. не с позиций современного синтаксиса (см. [Евтюхин 2009: 501]), а в рамках риторической традиции XVIII века как наименование одного из общих риторических мест. 
прильженъ; читай скоро; просящій неотступно; вопрошая важно; очень рано» [Ломоносов 1952: 570].

Семантическая (идеографическая) классификация наречий, предложенная Ломоносовым [Ломоносов 1952: 550], включает 16 групп (разрядов), 106 примеров:

Таблица 1. Классификация наречий в «Российской грамматике» М. В. Ломоносова

Table 1. Classification of adverbs in M. V. Lomonosov's Russian grammar

\begin{tabular}{|c|c|c|}
\hline № & Наречие & Примеры \\
\hline 1. & Времени & $\begin{array}{l}\text { нынъ, донынъ, отнынъ, понынъ, всегда, доколь, завтре, } \\
\text { рано, поздно, вчера, искони, иногда; }\end{array}$ \\
\hline 2. & Mecma & $\begin{array}{l}\text { гдђ, здъсь, тутъ, вездъ, тамъ [sic!], индъ, внутрь, снаружи, } \\
\text { внъ, далече, блиско, откуду, отсюду, оттуду, отъинуда, } \\
\text { оттуду же, спереди, ззади, куда, сюда, тамъ [sic!], туда, } \\
\text { инуда, вспять. }\end{array}$ \\
\hline 3. & $\begin{array}{l}\text { Качества } \\
\text { и количества }\end{array}$ & $\begin{array}{l}\text { какъ, такъ, хорошо, худо, прямо, нарочно, около, удобно, } \\
\text { всуе, сколько, столько, довольно; }\end{array}$ \\
\hline 4. & Числительные & $\begin{array}{l}\text { однажды, многажды, двожды, трожды; четырежды, } \\
\text { десятью; }\end{array}$ \\
\hline 5. & Порядка & $\begin{array}{l}\text { прежде, пото́мъ, напосльди, даже, паки, снова, вновь, еще, } \\
\text { впервые, вдругіе, посемъ; }\end{array}$ \\
\hline 6. & Уверения & такъ, истинно, ей, весьма, подлинно; \\
\hline 7. & Отрицания & не такъ, никакъ, отнюдъ, ни мало; \\
\hline 8. & Напряжения & очень, весьма; \\
\hline 9. & Уподобления & $\begin{array}{l}\text { какъ, какъ-бы, подобно, подобно какъ; такъ, акибы, коль, } \\
\text { толь; }\end{array}$ \\
\hline 10. & Разности & инако, иначе, разно, различно; \\
\hline 11. & Вопрочения & что, почто, какъ, доколь, отколь; \\
\hline 12. & Сомнения & восьлибо, никакъ \\
\hline 13. & Собрания & вмъстђ, вкупъ, заодно, вдругъ; \\
\hline 14. & Скорости & внезапу, вдругъ, нечаянно; \\
\hline 15. & Указания & вотъ, тутъ; \\
\hline 16. & Отгонения & вонъ, прочь, далъе \\
\hline
\end{tabular}

Данная классификация отражает разные семантические разряды знаменательных и местоименных наречий. Однако, как мы видим, Ломоносов исключает из нее мотивированные прилагательными наречия 
с суффиксом - $u$ и префиксально-суффиксальные наречия с префиксом no- и суффиксом $-u$, хотя их встречается довольно много в текстах его филологических сочинений. Некоторые лексемы, включенные Ломоносовым в классификацию, наречиями не являются. Так, лексическая единица ей в разряде «наречия уверения» все-таки не наречие, а междометие [Сорокин (ред.) 1992: 75].

Немецкий перевод «Российской грамматики» был выполнен переводчиком Академии наук И. Л. Стафенгагеном; работа эта, как известно, заняла 6 лет, поэтому текст «Russische Grammatik», казалось бы, может в какой-то степени служить источником сведений о динамике взглядов М. В. Ломоносова на грамматическую систему русского языка той поры (ср. осуществленное В. Н. Макеевой сопоставление русского и немецкого текстов [Ломоносов 1952: 862-888]), однако раздел о наречиях в немецком переводе представляет собой почти точный перевод исходного текста.

Поскольку немецкий перевод «Российской грамматики» предназначен для иностранцев, изучающих русский язык, во всех примерах поставлены ударения. Так, Стафенгаген (а, следовательно, и Ломоносов, под «смотрением» которого, как известно, осуществлялся перевод) кодифицирует для наречия иногда́ ударение на последнем слоге, хотя «Словарь русского языка XVIII века» фиксирует также выходящий из употребления акцентологический вариант и́ногда [Сорокин (ред.) 1997: 97]. Подобных примеров довольно много. Это еще раз подтверждает уже получившую обоснование в трудах Б. А. Ларина и Б. О. Унбегауна важность тщательного многоаспектного филологического исследования пособий и руководств по изучению русского языка для иностранцев как источника материалов для исторической фонетики, акцентологии, грамматики, лексикологии и фразеологии, тем более что авторы этих пособий стремились отразить живую русскую речь своего времени. Наличие в этих пособиях перевода русских слов, фразеологизмов, предложений и диалогов на иностранные языки считаем важным материалом для подготовки словарей русского языка XVIII в. (ср. немецкие аналоги наречия иногда в «Вейсманновом лексиконе» 1731 г. и у И. Л. Стафенгагена, свидетельствующие об утрате актуальности значения 'некогда, однажды').

Представляет интерес раздел о наречии в грамматике Шарпантье и Мариньяна [Charpentier, Marignan: 1768: 212-217]. Предлагая в начале раздела общую характеристику наречия (Adverbe) как неизменяемой части речи, которая может определять прилагательное, глагол 
и причастие, французские авторы подвергают текст «Российской грамматики» собственной интерпретации. Количество семантических разрядов русских наречий упрощается до 15: исключается разряд наречий напряжения и разряд наречий скорости (у Ломоносова - внезапу, вдруг, нечаянно), но наречия качества и количества рассматриваются как отдельные разряды, в чем, возможно, проявляется влияние грамматики В. Е. Адодурова, в которой эти группы также рассматриваются как раздельные.

В значительной степени обновлен корпус примеров (всего предлагаются 103 примера наречия); возьмем для примера группы наречий времени, количества и качества, объединив для наглядности эти группы.

Таблица 2. Наречия времени в «Российской грамматике» М. В. Ломоносова и в «Élémens de la langue russe» Ж.-Б. Ж. Шарпантье и Ф. де Мариньяна

Table 2. Adverbs of time in M. V. Lomonosov's Russian Grammar and in Élémens de la langue russe by J.-B. J. Charpentier and F. de Marignan

\begin{tabular}{|l|l|l|}
\hline Российская грамматика & \multicolumn{1}{|c|}{ Élémens de la langue russe } \\
\hline $\begin{array}{l}\text { нынъ, донынъ, отнынъ, } \\
\text { понынъ, всегда, доколь, } \\
\text { завтре, рано, поздно, } \\
\text { вчера, искони, иногда; }\end{array}$ & $\begin{array}{l}\text { нынъ, до нынъ, всегда, завтря, рано, позно, вчерась } \\
\text { или вчера, прежде, иногда, тотъ часъ, вскорь, } \\
\text { никогда; }\end{array}$ \\
\hline $\begin{array}{l}\text { Удалено: } \\
\text { доколь, искони, отнынъ, } \\
\text { понынъ }\end{array}$ & $\begin{array}{l}\text { Добавлено: } \\
\text { вчерась, вскорђ, тотъ } \\
\text { часъ, никогда }\end{array}$ \\
\hline
\end{tabular}

Следует указать на варианты доныни - до ныньь, завтре - завтря, поздно - поздо. Варианты вчера и вчерась, последний из которых представляется современным носителям языка устаревшим или диалектным, «Словарь русского языка XVIII века» рассматривает для этого исторического языкового состояния еще как равноценные (см. Таблицу 3, с. 711).

Таким образом, Шарпантье и Мариньян насыщают классификационные рубрики, предложенные Ломоносовым, новым, коммуникативно актуальным и полезным материалом, адаптируя его соответственно задачам преподавания русского языка иностранцам, и избавляются от слов, по их мнению, выходящих за пределы лексического минимума, необходимого для ежедневного общения. В число последних входят славянизмы и устаревшие слова: см. инуда 'в иное, в другое 
Таблица 3. Наречия качества и количества в «Российской грамматике» М. В. Ломоносова и в «Élémens de la langue russe»

Ж.-Б. Ж. Шарпантье и Ф. де Мариньяна

Table 3. Adverbs of quality and quantity in M. V. Lomonosov's Russian Grammar and in Élémens de la langue russe

by J.-B. J. Charpentier and F. de Marignan

\begin{tabular}{|l|l|}
\hline \multicolumn{1}{|c|}{ Российская грамматика } & \multicolumn{1}{c|}{ Élémens de la langue russe } \\
\hline $\begin{array}{l}\text { какъ, такъ, хорошо, худо, } \\
\text { прямо, нарочно, около, } \\
\text { удобно, всуе, сколько, } \\
\text { столько, довольно }\end{array}$ & $\begin{array}{l}\text { какъ, такъ, прямо, худо, хорошо, удобно, } \\
\text { нарочно, всуе, легко, мудрено, благоразумно, } \\
\text { безрассудно; } \\
\text { около, только, сколько, столько, довольно, мало, } \\
\text { много, чрезмърно, почти, пополамъ; }\end{array}$ \\
\hline $\begin{array}{l}\text { Добавлено: безрассудно, благоразумно, легко, } \\
\text { мало, много, мудрено, пополам, почти, только, } \\
\text { чрезмьрно }\end{array}$ \\
\hline
\end{tabular}

место', вдругіе ‘еще раз, вторично', отъинуда 'из другого места' [Петрова (ред.) 2007: 242] и пр.

Новацией грамматики Шарпантье и Мариньяна можно считать небольшой раздел о «нерегулярных» (irréguliers) степенях сравнения: речь идет о наречиях много, мало и хорошо, которые, по их мнению, образуют сравнительную и превосходную степень следующим особым образом: много - болье - очень много; мало - меньие очень немного, хорошо - лутче - очень или весьма хорошо [Charpentier, Marignan: 1768: 216]. Можно сделать вывод о том, что исключение группы наречий напряжения (очень, весьма) из семантической классификации Ломоносова, о чем мы уже упоминали выше, не было случайным и имеет своей целью сохранение этих единиц для использования в качестве средства образования аналитической (сложной) превосходной степени.

Все грамматики русского языка должны считать «Российскую грамматику» М. В. Ломоносова «своей родоначальницею» - писал в 1855 г. академик И. И. Давыдов [Давыдов 1855: с. XIX]. Это правило полностью распространяется на раздел о наречии (§147-148) в грамматике Я. Родде [Rodde 1773: 203-205], который довольно точно передает семантическую классификацию наречий Ломоносова, возможно, 
опираясь на перевод И. Л. Стафенгагена, так как в них совпадают не только разряды наречий и примеры, но и переводы примеров на немецкий язык.

Таблица 4. Наречия времени в «Russische Sprachlehre»

Я. М. Родде и переводе «Российской грамматики»

М. В. Ломоносова на немецкий язык

Table 4. Adverbs of time in Russische Sprachlehre by Jac. Rodde and in translation of M. V. Lomonosov Russian grammar into German

\begin{tabular}{|c|c|}
\hline Russische Sprachlehre & Russische Grammatik \\
\hline $\begin{array}{l}\text { Adverbia temporis, die eine Zeit } \\
\text { bedeuten: ны́нъ jetzt, донь́нъ bishero, } \\
\text { отнь́нъ von nun an, понь́нъ bis jetzo, } \\
\text { всегда́ allezeit, доко́ль bis zu welcher } \\
\text { Zeit, за́втре morgen, ра́но frühe, по́здно } \\
\text { spät, вчеpá gestern, пре́жде vorher, } \\
\text { искони́ von Anbeginn, иногда́ zuweilen } \\
\text { [Rоdde 1773: 203] }\end{array}$ & $\begin{array}{l}\text { Die eine Zeit anzeigen (adv. temporis): } \\
\text { ны́нъ jetzt, дони́нъ bishero, отны́нъ } \\
\text { von nun an, поны́нъ bis jetzo, всегда́ } \\
\text { allezeit, доко́лъ bis zu welcher Zeit, } \\
\text { за́втре morgen, páно frühe, по́здно } \\
\text { spät, вчеpá gestern, пре́жде vorher, } \\
\text { искони́ von Anbeginn, иногда́ zuweilen } \\
\text { [Lomonossow 1764: 316]. }\end{array}$ \\
\hline
\end{tabular}

Семантическая (идеографическая) классификация наречий Ломоносова, мы предполагаем, привлекла внимание Родде потому, что является более современной, полной и детализированной, в отличие от классификации наречий в грамматике Адодурова, включающей только 9 семантических разрядов. Родде, однако, считает нерелевантной для своего пособия информацию о префиксальных компаративах, суффиксальных образованиях, адвербиализации и исключает соответствующие разделы. Укажем на особенности написания некоторых наречий: однажды (Ломоносов) - однажди (Родде), многажды (Ломоносов) - многажди (Родде), восьлибо (Ломоносов) - вослибо (Родде), что обусловлено, по-видимому, тем, что русский язык был неродным для Родде (или наборщиков типографии в Риге).

Каржавин посвятил наречию лишь несколько строк [Karjavine 1791: 116-117], отметив, вслед за Ломоносовым, существование 16 разрядов наречий, как первообразных, так и производных, но без единого примера на тот или иной разряд и перечисления конкретных разрядов. В заключение Каржавин упомянул о том, что «многие наречия имеют три степени сравнения, например, свђтло, свђтлъе, пресвътло, clare, clarius, clarissime». 


\section{6. Метаязык грамматик Шарпантье и Мариньяна, Родде и Каржавина}

Метаязык грамматики Шарпантье и Мариньяна и учебного пособия Каржавина - французский. В них используется французская грамматическая терминология, созданная на основе латинской (nom, genre, déclinaison, verbe и т. д.). Терминология этих двух грамматик во многих случаях совпадает. Несовпадающие термины немногочисленны, например, к ним относится название предложного падежа: у Шарпантье и Мариньяна le prépositif, а у Каржавина - le prépositionel. Кроме того, Каржавин приводит и второе название этого падежа - сказательный падеж (le Narratif) [Karjavine 1791: 110-111]. В использовании этого термина можно усматривать влияние терминологии Адодурова или Родде, но нельзя исключать и влияние терминологии Мелетия Смотрицкого.

Метаязык грамматики Родде - немецкий с включением латинских терминов, которые склоняются по правилам латинского языка, при этом выбор того или иного падежа обусловлен немецким контекстом - правилами немецкого синтаксиса. Например, грамматический термин потеп встречается в форме именительного падежа множественного числа (die lateinischen Nomina propria) [Rodde 1773: 45], родительного падежа множественного числа (das Genus der russischer Nominum) [Rodde 1773: 13], дательного падежа множественного числа (Von den Nominibus) [Rodde 1773: 13] и т. д. Термин verbum встречается в форме именительного падежа множественного числа (Die meiste Schwierigkeit in der Russischen Grammatik machen die Verba) [Rodde 1773: 7], родительного падежа множественного числа (Tabelle der Verborum irregularium) [Rodde 1773: 6], дательного падежа множественного числа (von den Verbis) [Rodde 1773: 5] и т. д.

Склонение латинских терминов в немецком грамматическом тексте по законам латинского языка является еще одним свидетельством преемственной связи грамматики Родде с грамматикой Адодурова, где также имеет место формоизменение латинских терминов (Das Nomen ist zweyerley; alle übrige aber heissen Nomina Apellativa [Волков и др. (ред.) 2014: 9]; Überhaupt hat man auch noch bey einem Nomine zubetrachten [Волков и др. (ред.) 2014: 13] и т. д.).

Это явление, известное как переключение кода (code switching), характерно для целого ряда немецких грамматических текстов XVII- 
XVIII вв. [Дюбо 2001: 52-64]. Оно обнаруживается, например, в немецких грамматиках Ю. Г. Шоттеля и И. Бёдикера [Schottel 1663; Boedikerus 1690]; (подробнее об этом см. [McLelland 2004]), а также в написанной на немецком языке славяно-русской грамматике И. В. Паузе. Все указанные труды могли служить источниками грамматики Адодурова, а затем и грамматики Я. Родде.

В немецком переводе «Российской грамматики», выполненном И. Л. Стафенгагеном, латинские термины также используются (они иногда ставятся в скобки для уточнения соответствующих немецких терминов), но по законам латинского языка они не склоняются. Стафенгаген использует, главным образом, немецкие термины, введенные Шоттелем: вместо nomen - Nennwort, вместо genus - Geschlecht, вместо verbum - Zeitwort и т. д. Некоторые из них встречаются и в грамматике Родде, хотя в целом использование немецких терминов для Родде нехарактерно.

\section{7. Выводы}

1. Ж.-Б. Ж. Шарпантье и Ф. де Мариньян при создании русской грамматики для французов пользовались русским текстом «Российской грамматики» М. В. Ломоносова, а не его немецким переводом, выполненным И. Л. Стафенгагеном. Доказательством этого является отсутствие совпадения ряда примеров в грамматике Шарпантье и Мариньяна и в немецком переводе грамматики М. В. Ломоносова. Дополнительным источником грамматики Шарпантье и Мариньяна была грамматика Адодурова, о чем свидетельствуют заимствованные у Адодурова модели представления сведений о роде и степенях сравнения и отдельные примеры.

2. Источниками русской грамматики Я. М. Родде, адресованной немецким учащимся, также послужили грамматики М. В. Ломоносова и В. Е. Адодурова. В области описания рода, склонения и степеней сравнения Я. Родде использовал адодуровские модели, а из грамматики Ломоносова брал примеры, уточняющие и расширяющие действие основных правил. В области описания глагола и наречия он опирался на грамматику Ломоносова, причем латинские названия глагольных времен и разрядов наречий взяты из ее немецкого перевода. Кроме того, 
Я. Родде использовал и грамматику Шарпантье и Мариньяна, из которой заимствовал таблицы неправильных глаголов.

3. Грамматический очерк в учебном пособии Ф. В. Каржавина, адресованном французским ученым, основан на «Российской грамматике» Ломоносова, однако автор при его написании также пользовался грамматикой П. И. Соколова, и, возможно, грамматиками Адодурова или Смотрицкого. Грамматический раздел в пособии Каржавина не главная, а вспомогательная его часть, именно поэтому он неполный и в некоторых случаях неточный (например, в нем отсутствует указание об отнесении ряда имен существительных на -b к мужскому роду).

4. Русские грамматики Шарпантье и Мариньяна, Родде и Каржавина, предназначенные для иностранцев, представляют собой не переводы «Российской грамматики» Ломоносова, а ее творческие интерпретации. Авторы учебников русского языка для иностранцев минимизировали учебный материал и по-своему компоновали его, стремясь облегчить его понимание и усвоение учащимися. При этом они иногда указывали на трудности, которые могут возникнуть у учащихся при изучении грамматических явлений. Одним из показателей творческого отношения Шарпантье и Мариньяна, Родде и Каржавина к составлению собственных русских грамматик является привлечение дополнительной учебной литературы, среди которой особое место занимает грамматика Адодурова. Результаты исследования показывают, что грамматика Адодурова по крайней мере до 1770-х гг. использовалась в обучении русскому языку как иностранному и была одним из образцов для создания последующих грамматик.

\section{Литература}

Адодуров 1731 - [В. Е. Адодуров]. Anfangs-Gründe der Russischen Sprache // НҺмецко-латинскій и рускій Лексиконъ купно съ первыми началами рускаго языка къ общей пользђ при Імператорской Академіи наукъ печатію изданъ. СПб.: тип. Имп. Академии наук, 1731. С. 3-48 (отд. паг.).

Алексеев 1961 - М. П. Алексеев. Филологические наблюдения Ф. В. Каржавина: Из истории русской филологии в XVIII веке // Ученые записки ЛГУ. 1961. № 299. Серия филологических наук. Вып. 59: Романская филология. Л.: Изд-во Ленинградского государственного университета, 1961. С. 8-36. Балицкий 1876 - И. И. Балицкий. Материалы для истории славянского языкознания. Ч. 1. Киев: тип. Киево-Печерской лавры, 1876.

Будилович 1869 - А. С. Будилович. М. В. Ломоносов как натуралист и филолог. СПб.: тип. В. Головина, 1869. 
Васильчиков 1880 - А. А. Васильчиков. Семейство Разумовских. В 5-ти т. СПб.: тип. М. М. Стасюлевича, 1880-1894.

Власов, Московкин 2007 - С. В. Власов, Л. В. Московкин. Из истории создания учебников русского языка как иностранного в России: «Основы русского языка» Шарпантье и Мариньяна (1768) // Мир русского слова. 2007. № 1-2. С. $72-80$.

Власов, Московкин 2012 - С. В. Власов, Л. В. Московкин. Из истории создания учебников русского языка как иностранного в России: «Заметки о русском языке и его алфавите» Ерофея и Федора Каржавиных $(1789,1791) / /$ Мир русского слова. 2012. № 1. С. 68-72.

Власов, Московкин 2014 - С. В. Власов, Л. В. Московкин. Из истории создания учебников русского языка как иностранного в России: «Russische Sprachlehre» Якоба Родде (1773 г.) // Литературная культура России XVIII века. Вып. 5. Под ред. П. Е. Бухаркина, Е. М. Матвеева. СПб.: Филологический факультет СПбГУ, 2014. С. 151-163.

Волков и др. (ред.) 2014 - С. С. Волков, К. А. Филиппов (ред.). Василий Евдокимович Адодуров. Anfangs-Gründe der Russischen Sprache, или Первые основания российского языка. СПб.: Наука; Нестор-История, 2014.

Давыдов 1855 - И. И. Давыдов. Предисловие к новому изданию Российской Грамматики Михаила Ломоносова // Грамматика русского языка академика М. В. Ломоносова, 1755 года. СПб.: тип. Имп. Академии наук, 1855. C. I-LXXXIII.

Долгова 1984 - С. Р. Долгова. Творческий путь Ф. В. Каржавина. Л.: Наука, 1984.

Дюбо 2001 - Б. А. Дюбо. Рационализм и эмпиризм в немецких грамматических трудах XVI-XVIII вв. СПб.: Изд-во СПбГУ, 2001.

Евтюхин 2009 - В. Б. Евтюхин. Наречие // С. И. Богданов, М. Д. Воейкова, В. Б. Евтюхин, Ю. П. Князев, Ю. В. Рыжова, Ю. Б. Смирнов. Морфология современного русского языка. СПб.: Факультет филологии и искусств СПбГУ, 2009. C. 494-532.

Ершова 2011 - Е. О. Ершова. Грамматическая деятельность Я. М. Родде как фактор распространения русского языка в немецкоязычной аудитории // Вестник Иркутского государственного лингвистического университета. 2011. № 11: Языкознание. С. 24-30.

Ершова 2013 - Е. О. Ершова. Русский язык в немецкоязычном мире XVI-XIX вв.: историко-социолингвистическое исследование учебной литературы разных жанров. Автореф. дис. ... канд. филол. наук. М.: Государственный институт русского языка им. А. С. Пушкина, 2013.

Живов 2004 - В. М. Живов. Очерки исторической морфологии русского языка XVII-XVIII веков. М.: Языки русской культуры, 2004.

Живов 2017 - В. М. Живов. История языка русской письменности: В 2 т. М.: Университет Дмитрия Пожарского, 2017.

Карева 2011 - Н. В. Карева. Становление традиции грамматического описания русского языка (1730-1750-е гг.) // П. Е. Бухаркин, Е. М. Матвеев, А. Ю. Тираспольская (ред.). Литературная культура России XVIII века. Вып. 4. СПб.: Филологический факультет СПбГУ, 2011. С. 90-109. 
Карева, Филиппов 2010 - Н. В. Карева, К. А. Филиппов. К вопросу о классификации временных форм глагола в «Российской грамматике» М. В. Ломоносова и ее переводе на немецкий язык // Индоевропейское языкознание и классическая филология. 2010. T. XIV. С. 436-444.

Клубков 2011 - П. А. Клубков. Формирование петербургской традиции лингвистической русистики (XVIII - начало XIX в.). Историко-лингвистические очерки. СПб.: Изд-во СПбГУ, 2011.

Макеева 1961 - В. Н. Макеева. История создания «Российской грамматики» М. В. Ломоносова. М.; Л.: Изд-во Академии наук СССР, 1961.

Милославский 1987 - И. Г. Милославский. Краткая практическая грамматика русского языка. М.: Русский язык, 1987.

Михальчи 1969 - Д. Е. Михальчи. Славяно-русская грамматика Иоганна Вернера Паузе. Автореф. дис. ... доктора филол. наук. Л.: Ленинградское отделение Института языкознания АН СССР, 1969.

Обнорский 2010 - С. П. Обнорский. Ломоносов и русский литературный язык // С. П. Обнорский. Русский литературный язык: Вехи истории. M.: URSS, 2010. C. $136-150$.

Сазонова 2008 - Л. И. Сазонова. Немецко-русский филолог-переводчик Яков Родде // S. Aloe (Hrsg.). Die slavischen Grenzen Mitteleuropas: Festschrift für S. Bonazza zum 70. Geburtstag (Die Welt der Slaven. Sammelbände. Bd. 34). München: Otto Sagner, 2008. S. 173-179.

Сичинава 2013 - Д. В. Сичинава. Сравнительная степень на по-. Материалы для проекта корпусного описания русской грамматики (http://rusgram.ru). На правах рукописи. М., 2013.

Съедина 1997 - Дж. Съедина. Лексикографическая деятельность Ф. В. Каржавина // Russica Romana. 1997. Vol. IV. P. 67-89.

Успенский 1975 - Б. А. Успенский. Первая русская грамматика на родном языке (доломоносовский период отечественной русистики). М.: Наука, 1975.

Успенский 1994 - Б. А. Успенский. Краткий очерк истории русского литературного языка (XI-XIX вв.). М.: Гнозис, 1994.

Шлецер 1875 - [А. Л. Шлецер]. Общественная и частная жизнь Августа Людвига Шлецера, им самим описанная / Пер. с нем. В. Ф. Кеневича. СПб.: тип. Имп. Академии наук, 1875.

Archaimbault 1999a - S. Archaimbault. Les élémens de la langue russe de Jean-Baptiste Jude Charpentier (1768), ou les Français et l'apprentissage de la langue russe au XVIIIe siècle // G. Hassler, P. Schmitter (eds.). Sprachdiskussion und Beschreibung von Sprachen im 17. und 18. Jahrhundert. Münster: Nodus, 1999. P. 371-380.

Archaimbault 1999b - S. Archaimbault. Préhistoire de l'aspect verbal. L'émergence de la notion dans les grammaires russes. Paris : CNRS éd., 1999.

Bacmeister 1775 - H. L. Ch. Bacmeister. Russische Bibliothek. Des dritten Bandes erstes Stück. St. Petersburg; Riga; Leipzig: bey Johann Friedrich Hartknoch, 1775.

Bernhagen 1968 - W. Bernhagen. Jacob Rodde als Verfasser des Gesprächsbuches «Домашние разговоры» - «Gespräche von Haussachen»// H. Grasshoff, 
U. Lehmann (Hrsg.). Studien zur Geschichte der russischen Literatur des 18. Jahrhunderts. Band II. Berlin: Akademie Verlag, 1968. S. 114-121, 395-397.

Boedikerus 1690 - J. Boedikerus. Grund-Saetze der Deutschen Sprachen im Reden und Schreiben. Cölln an der Spree: Druckts Ulrich Liebpert, 1690.

Keipert 1999 - H. Keipert. Geschichte der russischen Literatursprache // H. Jachnow (Hrsg.). Handbuch der sprachwissenschaftlichen Russistik und ihren Grenzdisziplinen. Wiesbaden: Harrassowitz Verlag, 1999. S. 726-779.

Keipert 2006 - H. Keipert. Das Russisch-Lehrwerk von Jacob Rodde. Zur Kenntnis der russischen Sprache im deutschsprachigen Raum im 18. Jahrhundert // D. Dahlmann (Hrsg.). Die Kenntnis Russlands im deutschsprachigen Raum im 18. Jahrhundert: Wissenschaft und Publizistik über das Russische Reich. Bonn: Bonn University Press, 2006. S. 85-110.

McLelland 2004 - N. McLelland. A historical study of codeswitching in writing: German and Latin in Schottelius' Ausführliche Arbeit von der Teutschen Haubt-Sprache (1663) // International Journal of Bilingualism. 2004. Vol. 8. № 4. P. 499-524.

Rönkä 2005 - Risto Rönkä. У истоков русской и славянской аспектологической мысли (Acta Universitatis Tamperensis. Vol. 1074). Tampere: Tampere University Press, 2005.

Siedina 1999 - G. Siedina. Il plurilinguismo nei Remarques sur la langue russienne et son alphabet di F. V. Karžavin (1791) // M. Ciccarini, K. Żaboklicki (eds.). Plurilinguismo letterario in Ucraina, Polonia e Russia tra XVI e XVIII secolo. Varsavia; Roma: Upowszechnianie Nauki - Oświata, 1999. P. 162-177.

Schottel 1663 - J. G. Schottel. Ausführliche Arbeit von der Teutschen Haubt-Sprache. Braunschweig: gedruckt durch Christoff Zilligern, 1663.

\section{Источники}

Волков и др. (ред.) 2014 - С. С. Волков, К. А. Филиппов (ред.). Василий Евдокимович Адодуров. Anfangs-Gründe der Russischen Sprache, или Первые основания российского языка. СПб.: Наука; Нестор-История, 2014.

Кузьминова 2007 - Е. А. Кузьминова. Грамматика 1648 г. М.: МАКС-Пресс, 2007. Ломоносов 1755 - М. [В.] Ломоносов. Россійская грамматика. СПб.: Типография Императорской Академии наук, 1755.

Ломоносов 1952 - М. В. Ломоносов. Российская грамматика // М. В. Ломоносов. Полное собрание сочинений. Т. 7. Труды по филологии 1739-1758 гг. М.; Л.: Изд-во Академии наук СССР, 1952. С. 389-578.

Петрова (ред.) 2007 - 3. М. Петрова (гл. ред.). Словарь русского языка XVIII века. Вып. 17. СПб.: Наука, 2007.

Соколов 1788 - [П. И. Соколов]. Начальныя основанїя россійской грамматики, въ пользу учащагося въ Гимназїи при Императорской Академїи Наукъ юношества составленныя. СПб.: тип. Имп. Академии наук, 1788.

Сорокин (ред.) 1992 - Ю. С. Сорокин (гл. ред.). Словарь русского языка XVIII века. Вып. 7. СПб.: Наука, 1992. 
Сорокин (ред.) 1997 - Ю. С. Сорокин (гл. ред.). Словарь русского языка XVIII века. Вып. 9. СПб.: Наука, 1997.

Charpentier, Marignan 1768 - [J.-B. J. Charpentier, F. de Marignan]. Élémens de la langue russe ou Méthode courte et facile pour apprendre cette langue conformément à l'usage. St. Pétersbourg: de l'Imprimerie de l'Academie Impériale des Sciences, 1768.

Compendium 2002 - H. Keipert, A. Huterer (Hrsg.). Compendium Grammaticae Russicae (1731). Die erste Akademie-Grammatik der russischen Sprache (Bayerische Akademie der Wissenscaften. Philosophisch-Historische Klasse. Abhandlungen. Neue Folge. Heft 121). München: Verlag der Bayerischen Akademie der Wissenschaften, 2002.

Karjavine 1791 - [Ph. Karjavine]. Remarques sur la langue russienne et sur son alphabet, avec des Pièces relatives à la connoissance de cette Langue. Publiées et augmentées par Phéodore Karjavine, ancien Interprete pour le Roi à la Martinique. St.Pétersbourg : [Тип. Горного училища], 1791.

Keipert (ed.) 2016 - A. Huterer, H. Keipert (hrsg.). Johann Werner Paus. Anweisung zur Erlernung der Slavonisch-Rußischen Sprache. Transkript des Autographs der Akademie-bibliothek St. Petersburg, Handschriftenabteilung, Signatur Q 192/I. Als Manuskript ausgedruckt für Deutsche Forschungsgemeinschaft (Bonn), Biblioteka Akademii nauk, Otdel rukopisej (S.-Peterburg) und Archiv der Franckeschen Stiftungen (Halle/S.). Bonn: S. n., 2016.

Keipert et al. (ed.) 1994 - H. Keipert, B. Uspenskij, V. Živov (Hrsg.). Johann Ernst Glück. Grammatik der russischen Sprache (1704) (Bausteine zur Slavischen Philologie und Kultergeschichte. Reihe B: Editionen. Neue Folge, 5 (20)). Köln; Weimar; Wien: Böhlau Verlag, 1994.

Lomonossow 1764 - M. Lomonossow. Russische Grammatik. Aus dem Russischen übersetzt von Johann Lorenz Stavenhagen. St. Petersburg: gedrukt bey Kayserl. Akademie der Wissenschaften, 1764.

Ludolf 1696 - [H. W. Ludolfi]. Grammatica Russica quae continet non tantum praecipua fundamenta Russicae linguae, verum etiam Manuductionem quandam ad Grammaticam Slavonicam. Oxonii: E Theatro Sheldoniano, 1696.

Rodde 1773 — [J. Rodde]. Russische Sprachlehre zum bestem der deutschen Jugend eingerichtet von Jac. Rodde. Riga: bey Johann Friedrich Hartknoch, 1773.

\section{References}

Adodurov 1731 - [V. E. Adodurov]. Anfangs-Gründe der Russischen Sprache. Nemetsko-latinskiy i ruskiy Leksikon kupno s pervymi nachalami ruskago yazyka k obshchey polze pri Imperatorskoy Akademii nauk pechatiyu izdan. [German-Latin and Russian Dictionary with the basics of the Russian Language. Published to common favor by Imperial Academy of Sciences]. St. Petersburg: The typography of Imperial Academy of Sciences, 1731.

Alekseyev 1961 - M. P. Alekseyev. Filologicheskiye nablyudeniya F. V. Karzhavina: Iz istorii russkoy filologii v XVIII veke [Philological observations of F. V. Karzhavin: 
from the history of Russian philology in the XVIII century]. Proceedings of St. Petersburg State University. 1961. No. 299. Series of philological Sciences. Iss. 59: Roman philology. P. 8-36.

Archaimbault 1999a - S. Archaimbault. Les élémens de la langue russe de Jean-Baptiste Jude Charpentier (1768), ou les Français et l'apprentissage de la langue russe au XVIIIe siècle. G. Hassler, P. Schmitter (eds.). Sprachdiskussion und Beschreibung von Sprachen im 17. und 18. Jahrhundert. Münster: Nodus, 1999. P. 371-380. Archaimbault 1999b - S. Archaimbault. Préhistoire de l'aspect verbal. L'émergence de la notion dans les grammaires russes. Paris : CNRS éd., 1999.

Bacmeister 1775 - H. L. Ch. Bacmeister. Russische Bibliothek. Des dritten Bandes erstes Stück. St. Petersburg; Riga; Leipzig: bey Johann Friedrich Hartknoch, 1775.

Balitskiy 1876 - I. I. Balitskiy. Materialy dlya istorii slavyanskogo yazykoznaniya [Materials for the history of Slavic linguistics]. Pt. 1. Kiev: The typography of the Kiev-Pecherska Lavra, 1876.

Bernhagen 1968 - W. Bernhagen. Jacob Rodde als Verfasser des Gesprächsbuches «Домашние разговоры» — «Gespräche von Haussachen». H. Grasshoff, U. Lehmann (Hrsg.). Studien zur Geschichte der russischen Literatur des 18. Jahrhunderts. Band II. Berlin: Akademie Verlag, 1968. S. 114-121, 395-397.

Boedikerus 1690 - J. Boedikerus. Grund-Saetze der Deutschen Sprachen im Reden und Schreiben. Cölln an der Spree: Druckts Ulrich Liebpert, 1690.

Budilovich 1869 - A. S. Budilovich. M. V. Lomonosov kak naturalist i filolog [M. V. Lomonosov as a naturalist and philologist]. St. Petersburg: The typography of V. Golovin, 1869.

Davydov 1855 - I. I. Davydov. Predisloviye k novomu izdaniyu Rossiyskoy Grammatiki Mikhaila Lomonosova [Preface to the new edition of the Russian Grammar by Mikhail Lomonosov]. Grammatika russkogo yazyka akademika M. V. Lomonosova, 1755 goda [Russian grammar of academician M. V. Lomonosov, 1755]. St. Petersburg: The typography of Imperial Academy of Sciences, 1855. P. ILXXXIII.

Dolgova 1984 - S. R. Dolgova. Tvorcheskiy put F. V. Karzhavina [Career of Ph. V. Karjavine]. Leningrad: Nauka, 1984.

Djubo 2001 - B. A. Djubo. Ratsionalizm i yempirizm v nemetskikh grammaticheski$k h$ trudakh XVI-XVIII vv. [Rationalism and Empiricism in German Grammar treatises of the $16^{\text {th }}-18^{\text {th }}$ centuries]. St. Petersburg: St. Petersburg State University Press, 2001.

Kareva 2011 - N. V. Kareva. Stanovleniye traditsii grammaticheskogo opisaniya russkogo yazyka (1730-1750-e gg.) [Formation of the Russian language grammatical description tradition (1730-1750)]. P. E. Bukharkin, E. M. Matveyev, A. Yu. Tiraspolskaya (eds.). Literaturnaya kultura Rossii XVIII veka [The Russian literary culture of the XVIII century]. Iss. 4. St. Petersburg: Philological Faculty, St. Petersburg State University Press, 2011. P. 90-109.

Kareva, Filippov 2010 - N. V. Kareva, K. A. Filippov. K voprosu o klassifikatsii vremennykh form glagola $\mathrm{v}$ «Rossiyskoy grammatike» M. V. Lomonosova i ee perevode na nemetskiy yazyk [On the classification of tense verb forms 
in M. V. Lomonosov's "Russian Grammar" and its translation into German]. Indoyevropeyskoye yazykoznaniye i klassicheskaya filologiya. 2010. Vol. XIV. P. 436-444. Keipert 1999 - H. Keipert. Geschichte der russischen Literatursprache. H. Jachnow (Hrsg.). Handbuch der sprachwissenschaftlichen Russistik und ihren Grenzdisziplinen. Wiesbaden: Harrassowitz Verlag, 1999. S. 726-779.

Keipert 2006 - H. Keipert. Das Russisch-Lehrwerk von Jacob Rodde. Zur Kenntnis der russischen Sprache im deutschsprachigen Raum im 18. Jahrhundert. D. Dahlmann (Hrsg.). Die Kenntnis Russlands im deutschsprachigen Raum im 18. Jahrhundert: Wissenschaft und Publizistik über das Russische Reich. Bonn: Bonn University Press, 2006. S. 85-110.

Klubkov 2011 - P. A. Klubkov. Formirovaniye peterburgskoy traditsii lingvisticheskoy rusistiki (XVIII - nachalo XIX v.) [Forming of St. Petersburg tradition of the Russian linguistics (XVIII — the early XIX centuries)]. St. Petersburg: St. Petersburg University Press, 2011.

Makeyeva 1961 - V. N. Makeyeva. Istoriya sozdaniya «Rossiyskoy grammatiki» M. V. Lomonosova [M. V. Lomonosov's "Rossiyskaya grammatika" history]. Moscow; Leningrad: Academy of Sciences of USSR Publishing House, 1961.

Miloslavskiy 1987 - I. G. Miloslavskiy. Kratkaya prakticheskaya grammatika russkogo yazyka [Brief practical grammar of the Russian language]. Moscow: Russkiy yazyk, 1987.

Mikhalchi 1969 - D. E. Mikhalchi. Slavyano-russkaya grammatika Ioganna Vernera Pauze [Slavic-Russian grammar of Johann Werner Paus]. Author's abstract of a Doct. of Philology thesis]. Leningrad: Leningrad Branch of the Institute of Linguistics of the USSR Academy of Sciences, 1969.

McLelland 2004 — N. McLelland. A historical study of codeswitching in writing: German and Latin in Schottelius' Ausführliche Arbeit von der Teutschen Haubt-Sprache (1663). International Journal of Bilingualism. 2004. Vol. 8. No. 4. P. 499-524.

Obnorskiy 2010 - S. P. Obnorskiy. Lomonosov i russkiy literaturnyy yazyk [Lomonosov and the Russian literary language]. S. P. Obnorskiy. Russkiy literaturnyy yazyk: Vekhi istorii [Russian literary language: Landmarks of history]. Moscow: URSS, 2010. P. 136-150.

Rönkä 2005 — Risto Rönkä. U istokov russkoy i slavyanskoy aspektologicheskoy mysli [At the root of Russian and Slavic aspectual theory] (Acta Universitatis Tamperensis. Vol. 1074). Tampere: Tampere University Press, 2005.

Sazonova 2008 - L. I. Sazonova. Nemetsko-russkiy filolog-perevodchik Yakov Rodde [German-Russian philologist-translator Jacob Rodde]. S. Aloe (Hrsg.). Die slavischen Grenzen Mitteleuropas: Festschrift für S. Bonazza zum 70. Geburtstag (Die Welt der Slaven. Sammelbände. Bd. 34). München: Otto Sagner 2008. S. $173-179$.

Schottel 1663 - J. G. Schottel. Ausführliche Arbeit von der Teutschen Haubt-Sprache. Braunschweig: gedruckt durch Christoff Zilligern, 1663.

Schlözer 1875 - [A. L. Schlözer]. Obshchestvennaya i chastnaya zhizn Avgusta Lyudviga Shletsera, im samim opisannaya. Perevod s nemetskogo V. F. Kenevicha [The public and private life of August Ludwig Schlözer, described by himself. Translation 
from German by V. F. Kenevich]. St. Petersburg: The typography of Imperial Academy of Sciences, 1875.

Sichinava 2013 - D. V. Sichinava. Sravnitelnaya stepen na po-. Materialy dlya proyekta korpusnogo opisaniya russkoy grammatiki (http://rusgram.ru). Na pravakh rukopisi [Comparative degree with po-. Materials for the project of Russian grammar corpus description (http://rusgram.ru).]. Moscow, 2013.

Siedina 1997 - G. Siedina. Leksikograficheskaya deyatelnost F. V. Karjavina [Lexicographic work of F. V. Karjavin]. Russica Romana. 1997. Vol. IV. P. 67-89.

Siedina 1999 - G. Siedina. Il plurilinguismo nei Remarques sur la langue russienne et son alphabet di F. V. Karžavin (1791). M. Ciccarini, K. Żaboklicki (eds.). Plurilinguismo letterario in Ucraina, Polonia e Russia tra XVI et XVIII secolo. Varsavia; Roma: Upowszechnianie Nauki — Oświata, 1999. P. 162-177.

Uspenskiy 1975 - B. A. Uspenskiy. Pervaya russkaya grammatika na rodnom yazyke (dolomonosovskiy period otechestvennoy rusistiki) [The first Russian grammar in the native language (the pre-Lomonosov period of Russian studies in Russia)]. Moscow: Nauka, 1975.

Uspenskiy 1994 - B. A. Uspenskiy. Kratkiy ocherk istorii russkogo literaturnogo ya$z y k a\left(11-19^{\text {th }} \mathrm{vv}\right.$.) [Short essay on the history of the Russian literary language $\left(11-19^{\text {th }}\right.$ cent.) $]$. Moscow: Gnozis, 1994.

Vasilchikov 1880 - A. A. Vasilchikov. Semeystvo Razumovskikh [The Razumovsky Family]: In 5 vol. St. Petersburg: The typography of M. Stasyulevich, 1880.

Vlasov, Moskovkin 2007 - S. V. Vlasov, L. V. Moskovkin. Iz istorii sozdaniya uchebnikov russkogo yazyka kak inostrannogo v Rossii: «Osnovy russkogo yazyka» Sharpantye i Marinyana (1768) [From the history of the composition of the Russian language textbooks for foreign students in Russia: "The fundamentals of the Russian language" by Charpentier and Marignan (1768)]. Mir russkogo slova. 2007. No. 1-2. P. 72-80.

Vlasov, Moskovkin 2012 - S. V. Vlasov, L. V. Moskovkin. Iz istorii sozdaniya uchebnikov russkogo yazyka kak inostrannogo v Rossii: «Zametki o russkom yazyke i yego alfavite» Yerofeya i Fedora Karzhavinykh $(1789,1791)$ [From the history of the composition of the Russian language textbooks for foreign students in Russia: "Notes on the Russian language and alphabet" by Yerofei and Fedor Karjavine]. Mir russkogo slova. 2012. No. 1. P. 68-72.

Vlasov, Moskovkin 2014 - S. V. Vlasov, L. V. Moskovkin. Iz istorii sozdaniya uchebnikov russkogo yazyka kak inostrannogo v Rossii: «Russische Sprachlehre» Yakoba Rodde $(1773$ g.) [From the history of the composition of the Russian language textbooks for foreign students in Russia: "Russische Sprachlehre" by Jacob Rodde (1773)]. P. E. Bukharkin, E. M. Matveyev (eds.). Literaturnaya kultura Rossii XVIII veka [The Russian literary culture of the XVIII century]. Iss. 5. St. Petersburg: Philological Faculty, St. Petersburg State University Press, 2014. P. 151-163.

Volkov et al. (eds.) 2014 - S. S. Volkov, K. A. Filippov (eds.). Vasiliy Yevdokimovich Adodurov. Anfangs-Gründe der Russischen Sprache, ili Pervyye osnovaniya rossiyskogo yazyka [Vasiliy Yevdokimovich Adodurov. «Anfangs-Gründe der 
Russischen Sprache» or the "Basics of the Russian Language"]. St. Petersburg: Nauka; Nestor-Istoriya, 2014.

Yevtyukhin 2009 - V. B. Yevtyukhin. Narechiye [The Adverb]. S. I. Bogdanov, M. D. Voeykova, V. B. Yevtyukhin, Yu. P. Knyazev, Yu. V. Ryzhova, Yu. B. Smirnov. Morfologiya sovremennogo russkogo yazyka [The morphology of the modern Russian language]. St. Petersburg: Faculty of Philology and Arts, St. Petersburg State University Press, 2009. P. 494-532.

Yershova 2011 - E. O. Yershova. Grammaticheskaya deyatelnost Ya. M. Rodde kak faktor rasprostraneniya russkogo yazyka $\mathrm{v}$ nemetskoyazychnoy auditorii [The grammatical activity of J. M. Rodde as a factor in the spread of the Russian language in a German-speaking audience]. Vestnik Irkutskogo gosudarstvennogo lingvisticheskogo universiteta. 2011. No. 11: Yazykoznaniye. P. 24-30.

Yershova 2013 - E. O. Yershova. Russkiy yazyk v nemetskoyazychnom mire XVI-XIX $v v$.: istoriko-sotsiolingvisticheskoye issledovaniye uchebnoy literatury raznykh zhanrov [Russian language in the German-speaking world of the XVI-XIX centuries: A historical and sociolinguistic study of textbooks of various genres]. Author's abstract of a phil. cand. thesis]. Moscow: Pushkin State Russian Language Institute, 2013.

Zhivov 2004 - V. M. Zhivov. Ocherki istoricheskoy morfologii russkogo yazyka XVII$X V I I I$ vekov [Essays on the historical morphology of the Russian language of the XVII-XVIII centuries]. Moscow: Yazyki slavyanskoy kultury, 2004.

Zhivov 2017 - V. M. Zhivov. Istoriya yazyka russkoy pismennosti [A history of the language of Russian writings]. 2 vol. Moscow: Dmitry Pozharsky University Press, 2017.

\section{Sources}

Charpentier, Marignan 1768 - [J.-B. J. Charpentier, F. de Marignan]. Élémens de la langue russe ou Méthode courte et facile pour apprendre cette langue conformément à l'usage. St. Pétersbourg : de l'Imprimerie de l'Academie Impériale des Sciences, 1768.

Compendium 2002 - H. Keipert, A. Huterer (Hrsg.). Compendium Grammaticae Russicae (1731). Die erste Akademie-Grammatik der russischen Sprache (Bayerische Akademie der Wissenscaften. Philosophisch-Historische Klasse. Abhandlungen. Neue Folge. Heft 121). München: Verlag der Bayerischen Akademie der Wissenschaften, 2002.

Karjavine 1791 - [Ph. Karjavine]. Remarques sur la langue russienne et sur son alphabet, avec des Pièces relatives à la connoissance de cette Langue. Publiées et augmentées par Phéodore Karjavine, ancien Interprete pour le Roi à la Martinique. St. Pétersbourg: [Typography of Mining School], 1791.

Keipert (ed.) 2016 - A. Huterer, H. Keipert (Hrsg.). Johann Werner Paus. Anweisung zur Erlernung der Slavonisch-Rußischen Sprache. Transkript des Autographs der Akademie-bibliothek St. Petersburg, Handschriftenabteilung, Signatur Q 192/I. Als Manuskript ausgedruckt für Deutsche Forschungsgemeinschaft (Bonn), Biblioteka 
Akademii nauk, Otdel rukopisej (S.-Peterburg) und Archiv der Franckeschen Stiftungen (Halle/S.). Bonn: S. n., 2016.

Keipert et al. (ed.) 1994 - H. Keipert, B. Uspenskij, V. Živov (Hrsg.). Johann Ernst Glück. Grammatik der russischen Sprache (1704) (Bausteine zur Slavischen Philologie und Kultergeschichte. Reihe B: Editionen. Neue Folge, 5 (20)). Köln; Weimar; Wien: Böhlau Verlag, 1994.

Kuzminova 2007 - E. A. Kuzminova. Grammatika 1648 g. [Grammar of 1648]. Moscow: MAKS-Press, 2007.

Lomonosov 1755 - M. Lomonosov. Rossiyskaya grammatika [Russian grammar]. St. Petersburg: The typography of Imperial Academy of Sciences, 1755.

Lomonosov 1952 - M. V. Lomonosov. Rossiyskaya grammatika [Russian grammar]. M. V. Lomonosov. Polnoye sobraniye sochineniy. Tom 7. Trudy po filologii 1739$1758 \mathrm{gg}$. [Complete set of works. Vol. 7. Works on philology, 1739-1758]. Moscow; Leningrad: Academy of Sciences of USSR Publishing House, 1952. P. 389-578.

Lomonossow 1764 - M. Lomonossow. Russische Grammatik. Aus dem Russischen übersetzt von Johann Lorenz Stavenhagen. St. Petersburg: gedrukt bey Kayserl. Akademie der Wissenschaften, 1764.

Ludolf 1696 - [H. W. Ludolfi]. Grammatica Russica quae continet non tantum praecipua fundamenta Russicae linguae, verum etiam Manuductionem quandam ad Grammaticam Slavonicam. Oxonii: E Theatro Sheldoniano, 1696.

Petrova (ed.) 2007 — Z. M. Petrova (ed.). Slovar russkogo yazyka XVIII veka [Dictionary of the Russian language of the XVIII ${ }^{\text {th }}$ century]. Vol. 17. St. Petersburg: Nauka, 2007.

Rodde 1773 — [J. Rodde]. Russische Sprachlehre zum bestem der deutschen Jugend eingerichtet von Jac. Rodde. Riga: bey Johann Friedrich Hartcknoch, 1773.

Sorokin (ed.) 1992 - Yu. S. Sorokin (ed.). Slovar russkogo yazyka XVIII veka [Dictionary of the Russian language of the XVIII ${ }^{\text {th }}$ century]. Vol. 7. St. Petersburg: Nauka, 1992.

Sorokin (ed.) 1997 — Yu. S. Sorokin (ed.). Slovar russkogo yazyka XVIII veka [Dictionary of the Russian language of the XVIII ${ }^{\text {th }}$ century]. Vol. 9. St. Petersburg: Nauka, 1997.

Sokolov 1788 - [P. I. Sokolov]. Nachalnyya osnovaniya rossiyskoy grammatiki, v polzu uchashchagosya v Gimnazii pri Imperatorskoy Akademï Nauk yunoshestva sostavlennyya [The beginnings of the Russian grammar, composed in favor of the students of the gymnasium at the Imperial Academy of Sciences]. St. Petersburg: The typography of Imperial Academy of Sciences, 1788.

Volkov et al. (eds.) 2014 - S. S. Volkov, K. A. Filippov (eds.). Vasiliy Yevdokimovich Adodurov. "Anfangs-Gründe der Russischen Sprache» ili «Pervyye osnovaniya rossiyskogo yazyka» [Vasiliy Yevdokimovich Adodurov. "Anfangs-Gründe der Russischen Sprache» or the "Basics of the Russian Language" St. Petersburg: Nauka; Nestor-Istoriya, 2014. 


\section{Трактат Джона Ло «Деньги и купечество»: история русского перевода 1720 г. и текстологический анализ списков}

\section{Т. Д. Коркина}

Институт лингвистических исследований РАН, Санкт-Петербург; TDK2006@bk.ru

Аннотация. В Санкт-Петербурге в фондах БАН и РНБ хранятся три рукописных списка перевода сочинения шотландского банкира Джона Ло, выполненного князем И. А. Щербатовым в 1720 г. При обращении к библиотечным каталогам и литературе возникают вопросы, касающиеся датировки рукописных списков и источников перевода. Противоречивость описания во многом связана с тем, что исследователи до настоящего времени не рассматривали этот источник во всей совокупности его списков.

Цель данной статьи - рассмотреть все известные списки, провести сопоставительный анализ названий глав в списках русского перевода и в двух иностранных изданиях (английском оригинале и его французском переводе), сравнить списки русского перевода между собой. В результате проведенного анализа сделаны выводы о том, что в списке РНБ названия глав в реестре и в основном тексте совпадают; это говорит о том, что они были переведены с английского оригинала и составлены в реестр по образцу французской версии трактата. Кроме того, в результате проделанной работы по сопоставлению разных версий текста трактата Дж. Ло, мы можем реконструировать историю работы князя И. А. Щербатова над русским переводом: изначально он работал с первым изданием трактата на английском языке, выпущенным в свет в 1705 г., на завершающих стадиях работы до отправки в марте 1720 г. в Россию царю он пользовался также французским изданием трактата. Сохранившиеся списки перевода Щербатова можно разделить на две редакции.

Ключевые слова: XVIII в., русский язык XVIII в., Петровская эпоха, переводы Петровской эпохи, Джон Ло, И. А. Щербатов, финансовая терминология. 


\title{
"Money and Trade", a treatise by J. Law: A history of the 1720 Russian translation with a textual analysis
}

\section{T. D. Korkina}

Institute for Linguistic Studies, Russian Academy of Sciences, St. Petersburg; TDK2006@bk.ru

\begin{abstract}
There are three handwritten copies of a Russian translation of the treatise «Money and Trade Considered, with a Proposal for supplying the Nation with Money» by the Scottish economist John Law kept in The Library of the Russian Academy of Sciences and in the Russian National Library in St. Petersburg. This translation was made by Prince I. A. Shcherbatov, one of the supporters of the John Law financial system, in 1720. An analysis of library catalogs and the relevant literature raises questions regarding the dating of both the manuscripts of the Russian translation and its sources. The inconsistencies found in their existing descriptions can be attributed in many respects to the fact that the researchers have failed to review the translated copies in their entirety.

The purpose of this article was to analyze all the known copies by comparing the chapter titles in the Russian translations against those in the English original and in a French translation. The analysis identified three types of discrepancies: textual, lexical, and grammatical. They show that the Russian National Library copy chapter names are the same as in the registry, which suggests that they were translated from the English original but put in the registry in consistence with the French version. Only in one case, the Russian translation still matches the wording in the French version more than the English original. This suggests that at the final stage of work with the translation I. A. Shcherbatov checked the text and made minimal revisions in accordance with the French edition. My comparison of the different versions makes it possible to reconstruct the history of Prince I. A. Shcherbatov's work on the Russian translation. Initially, he started with the first English edition of 1705, while at the final stages, before sending the manuscript to Peter the Great in March 1720, he used the French translation as well. Thus the existing translation copies by I. A. Shcherbatov should be treated as two different versions.
\end{abstract}

Keywords: $18^{\text {th }}$ century, Russian language of the $18^{\text {th }}$ century, the Petrine era, translations of the Petrine era, John Law, I. A. Shcherbatov, financial terms. 


\section{1. Вступление}

В Петровскую эпоху активное усвоение европейских культурных ценностей было возведено в ранг национальной идеи. Ознакомление России с европейскими науками происходило в том числе через посредство русских, учившихся за границей и в большом количестве переводивших на русский язык научные работы. Личный контроль Петра I над отбором иностранных текстов, его «тщательная забота и опека» над процессом их перевода способствовали тому, что «репертуар был жестко подчинен государственной необходимости, и для изящной словесности в нем места не нашлось» [Николаев 1996: 13]. Переводная книга петровской эпохи - это книга, по преимуществу профессиональнотехническая и научная [Биржакова и др. 1972: 53]. Среди первостепенных и самых востребованных в то время отраслей знаний - математика, военное и морское дело, законодательство, медицина [Пекарский 1862: 5; Смирнов 1910: 3; Николаев 1996: 15-16]; появляются переводы произведений «особого жанра наставлений и руководств для правителя с обоснованием идей просвещенного абсолютизма» [Николаев 1996: 17].

В русской лингвистической литературе, посвященной тематическим группам новых заимствований Петровского времени, подробному рассмотрению были подвергнуты морская лексика (кораблестроение и кораблевождение), военный словарь, административная, дипломатическая лексика и словарь международного права, терминология математики и естественных наук, фортификации, медицины, музыки и театра и т. п. (см. лит. в [Биржакова и др. 1972: 17], а также более поздние работы [Сиверина 1972; Алексеев 1974; Бабаева, Запольская 1993; Мольков 2018; Коркина 2019: 66-71] и др.).

Финансовая сфера обычно не выделяется при тематической классификации новых заимствований [Смирнов 1910: 6-11] или представлена в ограниченном объеме [Биржакова и др. 1972: 140-143]. Это связано со сравнительно небольшим количеством переводных сочинений по финансовому делу, выполненных в начале XVIII в. ${ }^{1}$ В этих условиях перевод трактата «Деньги и купечество» Дж. Ло представляет особый интерес.

\footnotetext{
${ }^{1}$ Известны единичные печатные издания этой тематики, вышедшие при Петре I: например, «Книга считания удобнаго ко употреблению всякому хотящему без труда познати цену, или меру какия вещи», впервые опубликованная в Москве в 1682 г. и переизданная в 1714 г. [Быкова и др. 1955: 159-162].
} 
Автор перевода — князь Иван Андреевич Щербатов (1696-1767), оказавшийся в числе тех людей, которые по инициативе Петра I были посланы за границу для обучения языкам и разным наукам. В 1719 г. князь отправился в Англию, жил в Лондоне на собственные средства около трех лет. За это время он «овладел латынью, английским и французскими языками, а также изучил арифметику, геометрию, тригонометрию, астрономию и навигацию» [Троицкий 1970: 94]. В Лондоне Щербатов «всеми силами старался быть $\langle\ldots\rangle$ в практике на военных английских кораблях» (цит. по [Пекарский 1862: 244]), однако пройти стажировку в Британском флоте ему не удалось по причине «ухудшения англо-русских отношений, которое привело к полному разрыву официальных дипломатических связей России и Великобритании в ноябре 1720 г.» [Копелев 2016: 223]. В связи с этими обстоятельствами в 1721 г. И. А. Щербатов возвращается в Россию.

Во время пребывания за границей внимание князя Щербатова привлекла так называемая «система Ло» (фр. système de Law). Эта финансовая система была выстроена во Франции в 1716-1720-х гг. шотландским экономистом Джоном Ло (1671-1729), основавшим в Париже частный Banque Générale. Развал этой системы вверг страну в финансовый кризис, вызвал мировой резонанс и оказал большое влияние на развитие в дальнейшем экономической мысли в Европе и России. В России деятельность Дж. Ло также вызвала интерес у современников, а князь И. А. Щербатов стал одним из активных проводников идей шотландского экономиста в России. Он перевел на русский язык трактат Ло и составил проект о заведении банков и выпуске бумажных денег для распространения коммерции в России [Троицкий 1970: 94].

В научной литературе содержится ряд противоречивых суждений об обстоятельствах перевода и рукописной традиции этого текста. Противоречивость описания во многом связана с тем, что исследователи в разное время пользовались разными списками перевода.

\section{2. История изучения списков и проблема определения источника перевода}

Текст русского перевода сочинения шотландского экономиста Джона Ло, выполненного в первой трети XVIII в. И. А. Щербатовым, под заглавием «Деньги и купечество. Разсуждено с предлогами 


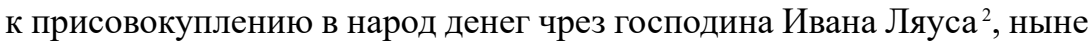
управителя королевского банку в Париже» не был опубликован, сохранился в трех списках из собраний БАН (два списка - черновой автограф и беловой экземпляр) и РНБ (черновой автограф). Как лингвистический источник данный перевод не подвергался отдельному научному освещению ${ }^{3}$ и текстологическому описанию, в связи с чем в отношении его текстологии и языка существует ряд нерешенных вопросов.

Два списка русской версии трактата «Деньги и купечество» впервые рассматривает П. П. Пекарский и публикует из этой рукописи посвящение царю и предисловие. Приведенные Пекарским данные об этих списках [Пекарский 1862: 244] совпадают с описанием рукописей, которые сейчас хранятся в НИОР БАН - черновой автограф И. А. Щербатова П І Б № 91 (Петр. гал. 20) и беловой экземпляр П І Б № 92 (Петр. гал. 21) [Лебедева (сост.) 2003: 207-208].

Через 100 с лишним лет С. М. Троицкий предпринимает попытку «рассмотреть вопрос об отношении в России к „системе“ Джона Ло с привлечением новых документов Москвы и Ленинграда» и дополнить данные Пекарского, поскольку ему «не были известны некоторые документы, в особенности „Мнение“ князя И. А. Щербатова о заведении банков и бумажных денег и развитии коммерции в России, написанное под влиянием идей Ло, и донесения русского посла в Париже барона Шлейница Петру I о финансовых реформах Джона Ло» [Троицкий 1970: 91]. В приложении к статье исследователь публикует «Проект» князя Щербатова.

С. М. Троицкий вместо двух списков, о которых пишет Пекарский, упоминает об одном - хранящемся и сегодня в ОР РНБ (Ф. 885 Эрмитажное собрание, № 120), как о единственном [Троицкий 1970: 96]. На титульном листе после названия помещена надпись: «Перевод

${ }^{2}$ Несмотря на то что имя автора на титульных листах английского издания и его французского перевода указано как J. Law, в основу перевода Щербатова лег другой вариант написания фамилии: «His surname had many natural variants: Lawe, Laws (выделено нами - Прим. Т. К.) and Lawes in England, Las, Lass and Lavv in France, Laur in the United Provinces, Lau and Laus in Italy, Lauu and Labuu in Spain» ('Его фамилия имела много вариантов: Lawe, Laws и Lawes в Англии, Las, Lass и Lavv во Франции, Laur в Объединенных провинциях, Lau и Laus в Италии, Lauu и Labuu в Испании') [Buchan 2018: 41].

3 Лексический материал одного из списков выборочно учтен в КС XVIII и вошел в изданные выпуски СРЯ XVIII. 
с английского на российский язык учинен чрез князь Ивана Щербатово в 1720 -м годе и поправлен им же в $1724-м$ году» ${ }^{4}$. Неточно указано Троицким количество страниц в рукописи - в каталоге Эрмитажного собрания говорится о 116 листах [Опись 1965: 49].

Ошибочные ссылки на отдельные списки перевода встречаются и в новейшей литературе. В частности, Д. Н. Копелев, говоря о «подносном варианте» этого перевода, указывает список РНБ [Копелев 2016: 223; 2017: 452] .

Таким образом, все три сохранившихся списка интересующего нас перевода до сих пор в рамках единого исследования не использовались. На наш взгляд, рассмотрение трех списков в совокупности позволяет восстановить историю работы И. А. Щербатова над переводом.

В научной литературе имеются противоречивые сведения и об источнике перевода. П. П. Пекарский указывает на французский источник: «Щербатов перевел сочинение Дж. Ло „Considérations sur le numéraire et le commerce par J. Law“» [Пекарский 1862: $243]^{6}$. Е. И. Боброва также указывает в качестве источника французскую версию сочинения, но с другим названием - «Considérations sur le commerce et sur l'argent. Trad. de l'anglais. La Haye, 1720» [Боброва (сост.) 1978: 133]. Троицкий, ссылаясь на титульный лист рукописи, пишет, что перевод сделан с английского языка: «Считая крайне важным познакомить русских читателей с взглядами Ло, Щербатов в конце 1719 - начале 1720 г. перевел с английского языка на русский трактат Ло» [Троицкий 1970: 96].

В настоящей статье мы сравним как три списка между собой, так и списки с английским оригиналом (по переизданию 1750 г. [Law 1750]) и французской версией 1720 г.

${ }^{4}$ И. Н. Лебедева, описывая данные рукописи, указывает год создания рукописи - 1724 г., в то время как в черновом автографе и в беловой копии рукой Щербатова написана дата — 27 февраля 1720 г. По всей видимости, исследователь датировал рукопись по филиграни «страсбургская лилия и контрамарка IV, близки к знаку № 1713 у Хивуда (1724 г.)» [Лебедева (сост.) 2003: 207-208].

${ }^{5}$ Кроме того, автор ошибочно указывает шифр Эрмитажного собрания 122б, в действительности представляющий собой список «Мнения кн. И. А. Щербатова о создании в России банка и купеческих компаний» [Опись 1965: 50].

${ }^{6}$ В новейшей литературе также со ссылкой на Пекарского в качестве источника русского перевода указывается французский текст [Копелев 2016: 223; Moser 2020: 68-69, сноска 55]. 
Сочинение Дж. Ло «Money and Trade Considered, with a Proposal for supplying the Nation with Money», посвященное денежному реформированию, было написано на английском языке, впервые опубликовано в 1705 г. в Эдинбурге [Law 1750 (Титул)] и в том же году представлено к рассмотрению в шотландский парламент (см. подробнее о данном проекте [Buchan 2018: 51-59]). Позже проект был переведен на французский язык и опубликован в 1720 г. [Law 1720] ${ }^{7}$, английская версия переиздана в 1750 г. в Глазго [Law 1750] ${ }^{8}$.

\section{3. Сопоставительный анализ структуры и названий глав русского списка перевода трактата Дж. Ло с английским оригиналом и его французским переводом}

Итак, на момент создания И. А. Щербатовым русского перевода существовало два варианта текста сочинения Ло - оригинальное английское издание (1705) и французский перевод (1720). Наиболее вероятным нам представляется, что перевод был сделан с английского оригинала, поскольку был завершен к концу февраля 1720 г. ${ }^{9}$, но не исключено, что Щербатов имел перед собой также французский перевод. Кроме того, на титуле списка, хранящегося в РНБ, указано, что Щербатов вновь обращался к тексту перевода в 1724 г. — текст был «поправлен и ${ }^{\mathrm{M}}$ же в $1724^{\mathrm{M}}$ году».

${ }^{7}$ Интересна оценка Джоном Ло французского перевода собственного сочинения: "Law later said that Money and Trade was "badly enough written", and when it was translated into French and printed in Holland in 1720, he had the French foreign service buy up and destroy all copies it could find" ('Позже Ло сказал, что сочинение «Деньги и торговля» написано достаточно плохо, и когда оно было переведено на французский язык и опубликовано в Голландии в 1720 г., он приказал дипломатической службе Франции выкупить и уничтожить все экземпляры сочинения, которые удастся найти') [Buchan 2018: 52].

${ }^{8}$ Издания [Law 1720] и [Law 1750] мы будем использовать для сравнения с русским переводом.

${ }^{9}$ Согласно документам, на которые ссылается С. М. Троицкий, Петр I получил перевод сочинения Ло и проект Щербатова в сентябре или начале октября 1720 г. [Троицкий 1970: 100, 110]. 
Структура списков БАН идентична: 1) посвящение царю, 2) предисловие «Книжник ко читателю» и 3 ) текст перевода. Структура списка РНБ отличается: 1) посвящение царю, 2) предисловие, 3) реестр глав, 4) текст перевода; 5) дополнительный текст ${ }^{10}$.

Наличие предисловия во всех списках русского перевода и реестра глав только в списке РНБ говорит о том, что Щербатов пользовался французским переводом, поскольку только во французском издании есть предисловие и предшествующий тексту реестр. Наличие в этом предисловии упоминания о смерти Людовика XIV, случившейся в 1715 г., говорит о том, что оно могло быть добавлено не ранее этого года, а следовательно текст предисловия мог быть переведен Щербатовым только из французского издания. В связи с этим возникает вопрос, насколько активно пользовался И. А. Щербатов французским изданием при работе над основным текстом: ограничивалась ли работа заимствованием предисловия и реестра или переводчик пользовался также основным текстом французской версии при создании перевода.

Чтобы ответить на этот вопрос, в данной статье представим показательный результат сравнения названий глав в списках русского перевода с названиями глав в двух иностранных изданиях. По нашим наблюдениям, формулировка названий глав в реестре и в тексте трактата по списку РНБ совпадает. Для удобства сравнения приведем названия глав в Таблице 1 (с. 733), где полужирным выделены текстовые соответствия, а курсивом - противопоставленные им чтения.

10 После перевода Щербатова на л. 77 следует черновик перевода другого экономического сочинения компилятивного характера, снабженного обращением к царю, которое начинается словами: Всемллстив виіи $2^{\tau} \partial p$, По желанию на

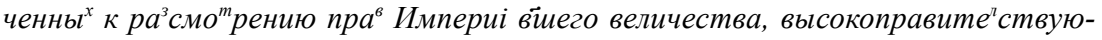

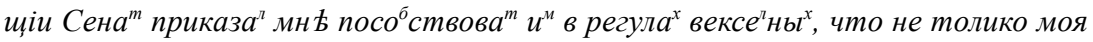
дожность, но с радостию примаю (так!) то сл случа для служения виче ${ }^{\text {иу }}$ импе-

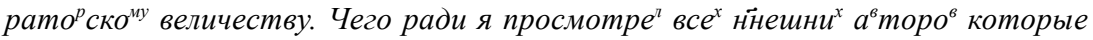

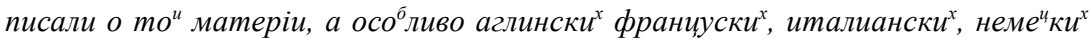

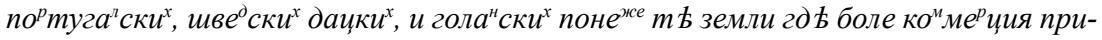
ласкае $e^{m}$ ся (л. 77). На этот дополнительный текст нет указания в описи и каталогах ОР РНБ. 
Таблица 1. Сравнение названий глав русского списка перевода трактата Дж. Ло с английским оригиналом и его французским переводом

Table 1. Comparison of the chapter titles of the Russian copy of the treatise by J. Law with the English original and its French translation

\begin{tabular}{|c|c|c|}
\hline РНБ, Эрм. 120 & $\begin{array}{c}\text { Французское издание } \\
\text { [Law 1720] }\end{array}$ & $\begin{array}{c}\text { Английское издание } \\
\text { [Law 1750] }\end{array}$ \\
\hline 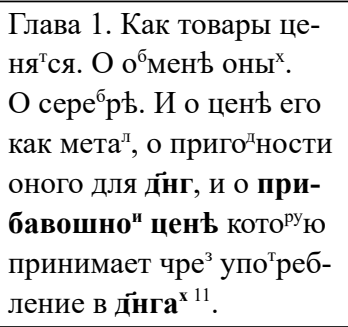 & $\begin{array}{l}\text { Chap. I. Comment les bi- } \\
\text { ens sont évaluez du Troc: } \\
\text { de l'argent \& de la val- } \\
\text { eur entant que métal, ses } \\
\text { qualitez pour le mon- } \\
\text { noyage: Du prix que lui } \\
\text { a donné son monnoyage. }\end{array}$ & $\begin{array}{l}\text { Chap. I. How goods are } \\
\text { valued. of barter. of sil- } \\
\text { ver; its value as a metal; } \\
\text { its qualities fitting it } \\
\text { for money; and of the } \\
\text { additional value it re- } \\
\text { ceived from being used } \\
\text { as money [p. 4] }\end{array}$ \\
\hline $\begin{array}{l}\text { Глава 2. О купечествђ; } \\
\text { и ско много купече- } \\
\text { ство на денга }^{\mathrm{x}} \text { со }^{\mathrm{c}} \text { тои } \\
\text { т }: \\
\text { что при }{ }^{\mathrm{M}} \text { ножение народа } \\
\text { состои }^{\mathrm{T}} \text { на купечествђ. } \\
\text { о менъ. }\end{array}$ & $\begin{array}{l}\text { Chap. II. Du Commerce. } \\
\text { Jusqu'où il dêpend de l'ar- } \\
\text { gent. Que l'augmenta- } \\
\text { tion des Peuples dépend } \\
\text { de l'argent. De l'échange. }\end{array}$ & $\begin{array}{l}\text { Chap. II. Of Trade, } \\
\text { and how far it depends } \\
\text { on money. that the in- } \\
\text { crease of the people de- } \\
\text { pends on Trade. of ex- } \\
\text { change [p. 19]. }\end{array}$ \\
\hline $\begin{array}{l}\text { Глава 3. О } \mathbf{p a}^{3} \mathbf{H ы}^{\mathbf{x}} \text { спосо- } \\
\text { баa }^{\mathbf{x}} \text { которые упо реблены } \\
\text { бывали для сохранения } \\
\text { и прибавки днг: и о бан- } \\
\text { ка }^{\mathbf{x}} \text {. }\end{array}$ & $\begin{array}{l}\text { Chap. III. Des expédiens } \\
\text { dont on s'est servi pour } \\
\text { conserver l'argent dans } \\
\text { le païs, \& pour en aug- } \\
\text { menter la quantité. }\end{array}$ & $\begin{array}{l}\text { Chap. III. Of the different } \\
\text { measures which have } \\
\text { been used to preserve } \\
\text { and increase money. and } \\
\text { of banks [p. 63]. }\end{array}$ \\
\hline 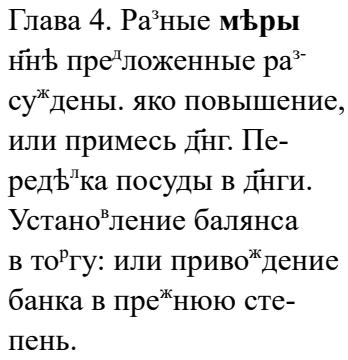 & $\begin{array}{l}\text { Chap. IV. Examen des } \\
\text { divers projets, que } \\
\text { l'on propose au Parlem- } \\
\text { ent. Comme de hausser } \\
\text { les espèces \& de les al- } \\
\text { lier, de monnoyer la Vais- } \\
\text { selle; de régler la bal- } \\
\text { ance du commerce, \& } \\
\text { de rétablir la Banque. }\end{array}$ & $\begin{array}{l}\text { Chap. IV. The several } \\
\text { measures now proposed, } \\
\text { considered. as, raising } \\
\text { or allaying the money. } \\
\text { coyning the plate. regulat- } \\
\text { ing the ballance of trade. } \\
\text { or, re-establishing the bank } \\
\text { [p. } 78] \text {. }\end{array}$ \\
\hline
\end{tabular}

${ }^{11}$ Цитаты из рукописей приводятся в упрощенной графике, сохранено написание $\mathrm{b}$. 


\begin{tabular}{|c|c|c|}
\hline РНБ, Эрм. 120 & $\begin{array}{c}\text { Французское издание } \\
\text { [Law 1720] }\end{array}$ & $\begin{array}{c}\text { Английское издание } \\
\text { [Law 1750] }\end{array}$ \\
\hline 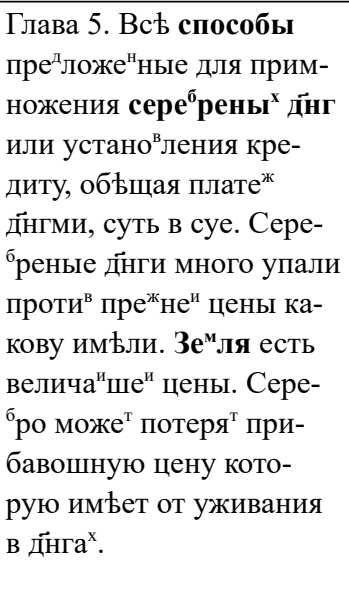 & $\begin{array}{l}\text { Chap. V. Que tous les Pro- } \\
\text { jets qu'on a fait jusqu'ici, } \\
\text { pour l'augmentation des } \\
\text { espèces, ou pour l'étab- } \\
\text { lissement du credit, \&c. } \\
\text { ensorte qu'on promette } \\
\text { de payer en espéces, sont } \\
\text { tous inefficaces. Que l'ar- } \\
\text { gent est beaucoup tombé } \\
\text { de sa premiere valeur. Que } \\
\text { les bien-fonds ont aug- } \\
\text { menté de prix. Que l'ar- } \\
\text { gent peut perdre le haut } \\
\text { prix que lui a donné son } \\
\text { monnoyage. }\end{array}$ & $\begin{array}{l}\text { Chap. V. That any } \\
\text { measures proposed for in- } \\
\text { creasing the silver money } \\
\text { or establishing a credit } \\
\text { promising a payment } \\
\text { of silver money are inef- } \\
\text { fectual. that silver money } \\
\text { has fallen much from the } \\
\text { value it had. that land is } \\
\text { of greater value. that sil- } \\
\text { ver may lose the addi- } \\
\text { tional value it received } \\
\text { from being used as money } \\
\text { [p. } 110 \text { ]. }\end{array}$ \\
\hline $\begin{array}{l}\text { Глава 6. } \mathbf{P a}^{3} \mathbf{c y}^{\text {ж}} \text { дения } \\
\text { о пре } \text { погы каков пода }^{\mathrm{H}} \\
\text { парламенту чре } \text { до }^{\mathrm{x}} \text { тура } \\
\text { Н. С. }\end{array}$ & $\begin{array}{l}\text { Chap. VI. Examen } \\
\text { du projet présenté au Par- } \\
\text { lement par le Docteur } \\
\text { H. C. }\end{array}$ & $\begin{array}{l}\text { Chap. VI. The proposal } \\
\text { given in to Parliament } \\
\text { by Dr. H. C. examined } \\
\text { [p. 147]. }\end{array}$ \\
\hline $\begin{array}{l}\text { Глава 7. Предлог с раз- } \\
\text { суждениями оного. }\end{array}$ & $\begin{array}{l}\text { Chap. VII. Mon projet \& } \\
\text { ses raisons. }\end{array}$ & $\begin{array}{l}\text { Chap. VII. The pro- } \\
\text { posal with reasons for it } \\
\text { [p. 158]. }\end{array}$ \\
\hline 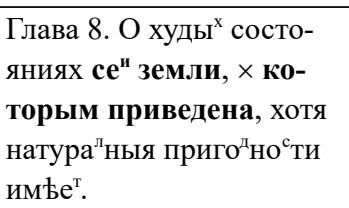 & $\begin{array}{l}\text { Chap. VIII. Du triste état } \\
\text { de l'Écosse, malgré ses } \\
\text { avantages naturels. }\end{array}$ & $\begin{array}{l}\text { Chap. VIII. The low con- } \\
\text { dition this country is } \\
\text { reduced to, notwithstand- } \\
\text { ing its natural advantages } \\
\text { [p. 207]. }\end{array}$ \\
\hline
\end{tabular}

Сравнение названий глав показало, что в списке РНБ по образцу французской версии трактата есть реестр, однако составлен он из названий глав, переведенных с английского оригинала.

Подтверждением этого являются разночтения разного типа, противопоставляющие французский текст английскому и русскому. Можно выделить следующие группы разночтений:

1. Текстологические. Например, текст, отсутствующий во французской версии: and of banks - и о банка ${ }^{x}$ (гл. 3), is reduced to - $x$ которым приведена (гл. 8), или, наоборот, присутствующий только 
во французской версии: местоимение топ 'мой' (гл. 7). Интересно разночтение в названии четвертой главы, которое говорит о том, что французский текст, создававшийся через 15 лет после выхода первого издания оригинала, редактировался: Examen des divers projets, que l'on propose au Parlement 'рассмотрение различных проектов, предлагаемых парламенту' - The several measures now proposed, considered 'несколько мер, предложенных в настоящее время, рассмотрены' (гл. 4). По-видимому, из текста при переводе на французский устранялись реалии 1705 г., уже не актуальные для ситуации в 1720 г.

2. Лексические. Отмечены разночтения, при которых слово в русском переводе является точным соответствием английской лексемы, в то время как во французской версии использовано отличное по семантике слово: денги - топеу 'деньги' - monnoyage 'монетное дело' [ФРЛ ${ }^{1}$ II: 122] (гл. 1), прибавошная иена — additional value 'дополнительная ценность' - prix 'цена' (гл. 1), м қpbl - measures 'меры, способы' - projets 'намерения, предприятия, замыслы, проекты’ [ФРЛ ${ }^{1}$ II: 335] (гл. 4), cnocoбbl - measures 'меры, способы' - projets (гл. 5), cepeбреные денги - silver money 'серебряные деньги' - espèces 'монеты' [ФРЛ ${ }^{1}$ I: 437] (гл. 5), земля - land 'земля' - bien-fonds 'Il se dit Des biens immeubles, comme les terres, les maisons; et on ne l'emploie guère qu'au pluriel” ('обозначает недвижимое имущество, такое как земля, постройки; и используется только во множественном числе') [Dictionnaire 1: 186 ${ }^{12}$ (гл. 5), земля - this country 'эта страна' — l'Écosse 'Шотландия' (гл. 8).

3. Грамматические. К таким разночтениям относятся случаи, когда в русском и английском текстах используется причастие, а во французском - придаточное предложение: предложенные — proposed 'предложенные' - qu'on a fait jusqu'ici 'которые были предложены' (гл. 5).

Большой интерес представляет название шестой главы, т. к. здесь мы встретили единственный случай, когда русский перевод все же больше соответствует формулировке во французской версии, чем английскому оригиналу: Разсуждения о предлоге - Examen du projet 'pacсмотрение проекта' - The proposal 'предложение' (гл. 6). Это говорит о том, что на завершающем этапе работы с переводом И. А. Щербатов сверял текст и вносил минимальную правку в соответствии с французским изданием.

12 Слово bien-fonds появляется только в шестом издании Dictionnaire de L'Académie française. 


\section{4. Сопоставительный анализ названий глав в русских списках перевода трактата Дж. Ло}

При сравнении названий глав в списках русского перевода обнаруживаются незначительные разночтения между версиями БАН и РНБ (названия 7 и 8 глав совпадают), также говорящие о минимальной правке на лексическом уровне (названия глав в обоих списках БАН текстуально полностью совпадают).

Таблица 2. Разночтения в названии глав в списке РНБ и беловой копии БАН

Table 2. Discrepancies in the title of the chapters in the RNL copy and in the LRAS white copy

\begin{tabular}{|c|c|}
\hline РНБ, Эрм. 120 & БАН, П І Б № 92 \\
\hline $\begin{array}{l}\text { Глава 2. О купечествђ; и ско много } \\
\text { купечество на дангах со } \text { с }^{\text {толо }}{ }^{\mathrm{T}}: \text { что при } \\
\text { ножение народа состои }\end{array}$ & $\begin{array}{l}\text { Глава 2. О купечествђ, и сколь много } \\
\text { купечествш на днгах состоит; что } \\
\text { примножение народа состоит на купе- } \\
\text { чествъ. о обменъ. }\end{array}$ \\
\hline 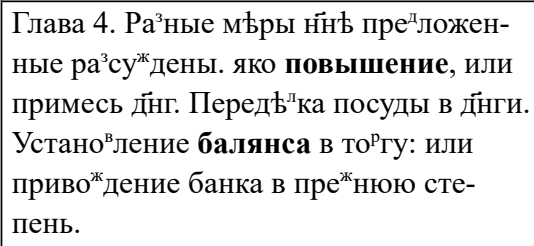 & 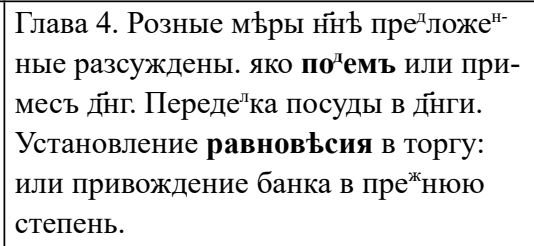 \\
\hline 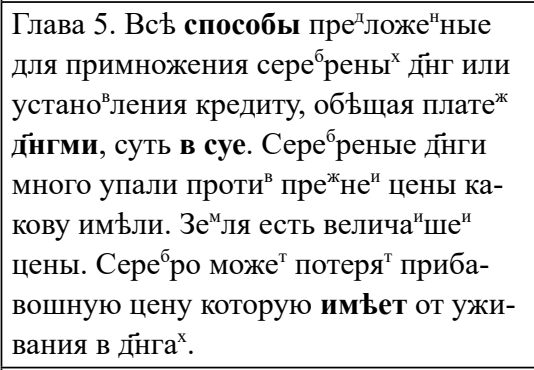 & $\begin{array}{l}\text { Глава 5. Всь мъры пре ложенныя для } \\
\text { примножения серебреных д̈нг или } \\
\text { установления кредиту обещая платеж } \\
\text { серебреными дннги суть без плодны. } \\
\text { Серебреные д̈нги много упали против } \\
\text { прежней цены какову имъли. Земля } \\
\text { есть величайшей цены. Серебро може } \\
\text { потерять прибавошную цену которую } \\
\text { приняло от уживания в дангах. }\end{array}$ \\
\hline 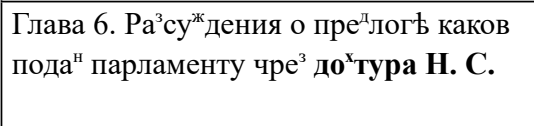 & 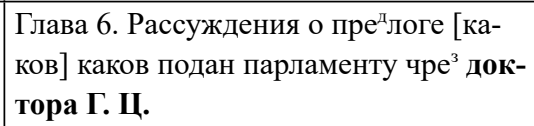 \\
\hline
\end{tabular}

Обращает на себя внимание, что некоторые из исправленных И. А. Щербатовым слов можно отнести к финансовой терминологии: мьна - обмен, повышение - подъем, балянс - равновъсие. Это 
говорит о том, что Щербатов целенаправленно работал над языком своего перевода, уточняя и улучшая словоупотребление. Можно предположить, что списки БАН содержат более позднюю редакцию перевода, т. е. правка вносилась до отправки текста в Россию для Петра I. Об этом позволяет судить одно из разночтений из Таблиц̧ы 2 - правка латинских инициалов «доктора» Н. С. на кириллические Г. Ц. (обратная правка - кириллических букв на латинские - для русского текста маловероятна).

Выборочно просмотренный нами текст списков русского перевода позволяет сделать предварительный вывод о том, что лексическая правка вносилась И. А. Щербатовым последовательно и системно по всему тексту.

О системном характере позволяет говорить тот факт, что разночтения между версиями РНБ и БАН наблюдаются и в основном тексте глав, при этом замене может подвергаться та же лексика, что и отмеченная выше, а также однокоренные слова. Аналогичным образом уточнялось и словоупотребление в тексте оригинальных примечаний И. А. Щербатова к тексту Дж. Ло.

Таблица 3. Разночтения в основном тексте в списке РНБ и беловом списке БАН Table 3. Discrepancies in the main text in the RNL copy and in the LRAS white copy

\begin{tabular}{|c|c|}
\hline РНБ, Эрм. 120 & БАН, П І Б № 92 \\
\hline 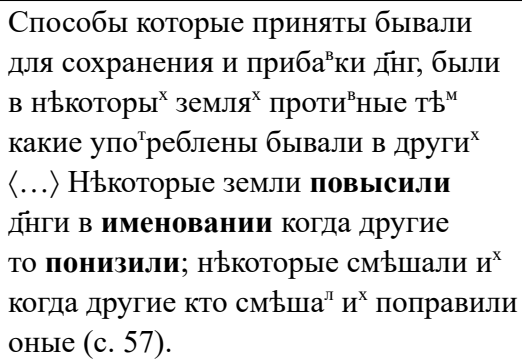 & 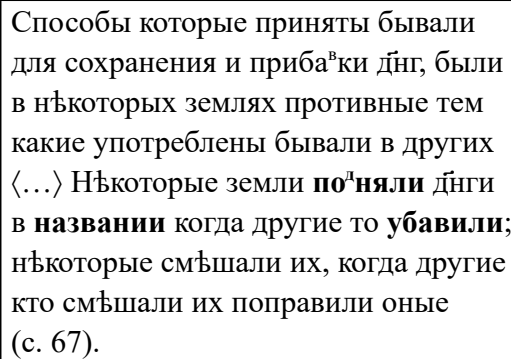 \\
\hline 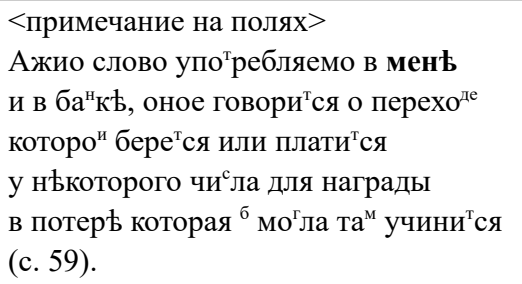 & 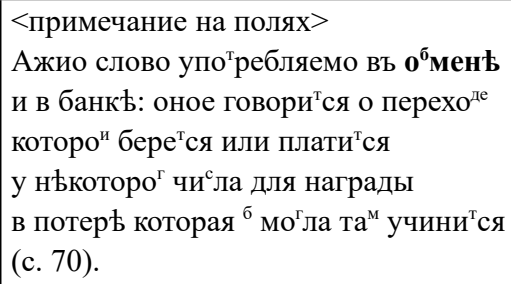 \\
\hline
\end{tabular}




\section{5. Выводы}

В результате проделанной работы по сопоставлению разных версий текста трактата Дж. Ло мы можем реконструировать историю работы И. А. Щербатова над русским переводом. Изначально он работал с первым изданием трактата на английском языке, вышедшим в свет в 1705 г., а на завершающих стадиях работы до отправки в марте 1720 г. имел возможность использовать французский перевод. Именно из французской версии переводчик мог взять предисловие и по ее образцу предпослать основному тексту реестр глав. Еще до отправки белового экземпляра царю И. А. Щербатов правит основной текст своего перевода, улучшая его язык и уточняя некоторые термины. На данном этапе работы мы не можем с уверенностью сказать, чем переводчик руководствовался при редактировании - собственным языковым чутьем, текстом иностранных версий трактата или всем перечисленным в определенном соотношении. Этот вопрос представляется нам задачей дальнейшего исследования, основанного на полных данных о разночтениях в двух обнаруженных нами редакциях русского перевода. Кроме того, нерешенным остается вопрос о нескольких стадиях правки, о наличии которых говорит указание самого переводчика, сохранившееся на титульном листе экземпляра РНБ.

\section{Список условных сокращений}

БАН - Библиотека Российской академии наук, Санкт-Петербург; НИОР БАН - Научно-исследовательский отдел рукописей библиотеки Российской академии наук; РНБ - Российская национальная библиотека, Санкт-Петербург; ОР РНБ - Отдел рукописей Российской национальной библиотеки.

\section{Литература}

Алексеев 1974 - А. А. Алексеев. Из истории общественно-политической лексики Петровской эпохи // Г. П. Макогоненко, Г. Н. Моисеева (ред.). XVIII век. Сб. 9. Л.: Наука, 1974. С. 313-318.

Бабаева, Запольская 1993 - Е. Э. Бабаева, Н. Н. Запольская. Языковой континуум Петровской эпохи: обзор грамматических трактатов первой четверти XVIII в. // Б. А. Успенский, М. Н. Шевелева (отв. ред.). Исследования по славянскому 
историческому языкознанию. М.: Изд-во Московского университета, 1993. С. $188-205$.

Биржакова и др. 1972 - Е. Э. Биржакова, Л. А. Войнова, Л. Л. Кутина. Очерки по исторической лексикологии русского языка XVIII века. Языковые контакты и заимствования. Л.: Наука, 1972.

Боброва (сост.) 1978 - Е. И. Боброва (сост.). Библиотека Петра І. Указатель-справочник. Л.: БАН СССР, 1978.

Быкова и др. 1955 - Т. А. Быкова, М. М. Гуревич. Описание изданий гражданской печати. 1708 - январь 1725 г. М.; Л.: Издательство Академии наук СССР, 1955.

Копелев 2016 - Д. Н. Копелев. Имперская модель князя И. А. Щербатова и ее реализация в 1720-1725 гг. // Н. П. Копанева, М. Ф. Хартанович (ред.). Ломоносовские чтения в Кунсткамере. К 270-летию издания первого «Атласа Российского» (1745) и 250-летию со дня смерти М. В. Ломоносова (1765). СПб.: Музей антропологии и этнографии им. Петра Великого (Кунсткамера) РАН, 2016. С. 221-238.

Копелев 2017 - Д. Н. Копелев. Джон Ло, французские колониальные проекты эпохи Регентства и Петр Великий // В. П. Соломин, Н. О. Верещагина, А. Н. Паранина (отв. ред.). Природное и культурное наследие: междисциплинарные исследования, сохранение и развитие. Коллективная монография по материалам VI Международной научно-практической конференции (25-26 октября 2017 г.). СПб.: РГПУ им. А. И. Герцена, 2017. С. 441-456.

Коркина 2019 - Т. Д. Коркина. Формирование административной лексики в русском языке XVIII века: председатель, президент, презес // В. Н. Калиновская, И. А. Малышева (отв. ред.). Славянская историческая лексикология и лексикография. Вып. 2. СПб.: ИЛИ РАН, 2019. С. 64-78.

Лебедева (автор-сост.) 2003 - И. Н. Лебедева (автор-сост.). Библиотека Петра I. Описание рукописных книг. СПб.: БАН, 2003.

Мольков 2018 - Г. А. Мольков. Терминология трактатов А. П. Ганнибала «Геометрия практика» и «Фортификация» 1725-1726 гг. // С. Д. Шелов, Е Цисун (отв. ред.). Терминология и знание. Материалы VI Международного симпозиума (Москва, 8-10 июня 2018 г.). М.: Институт русского языка им. В. В. Виноградова; Министерство образования КНР, Хэйлундзянский университет, 2018. С. 179-188.

Николаев 1996 - С. И. Николаев. Литературная культура Петровской эпохи. СПб.: Дмитрий Буланин, 1996.

Опись 1965 - Эрмитажное собрание. Опись фонда. Л., 1965.

Пекарский 1862 - П. П. Пекарский. Наука и литература в России при Петре Великом. Т. І. Введение в историю просвещения в России XVIII столетия. СПб.: Издание товарищества «Общественная польза», 1862.

Сиверина 1972 - Е. Г. Сиверина. К истории административно-политической лексики, заимствованной из немецкого языка в Петровскую эпоху // А. А. Дементьев (отв. ред.). Вопросы теории, истории и методики преподавания русского языка. Научные труды. Т. 103. Куйбышев: б. и., 1972. С. 204-211. 
Смирнов $1910-$ Н. А. Смирнов. Западное влияние на русский язык в петровскую эпоху // Сборник Отделения русского языка и словесности Императорской академии наук. Т. 88. № 2. СПб.: Типография Императорской академии наук, 1910.

Троицкий 1970 - С. М. Троицкий. «Система» Джона Ло и ее русские последователи // Ф. Бродель (ред.). Франко-русские экономические связи. М.; Париж: Наука. 1970. С. 90-138.

Buchan 2018 - J. Buchan. John Law. A Scottish Adventurer of the Eighteenth Century. London: Maclehose press, 2018.

Moser 2020 - M. Moser. «Юности честное зерцало» 1717 г. У истоков русского литературного языка (Slavische Sprachgeschichte. Bd. 10). Wien: Lit Verlag, 2020.

\section{Источники}

БАН, П І Б № 91 - Дж. Ло. Деньги и купечество. Черновой автограф. 1720 г. Ркп. БАН, П І Б № 91 (Петр. гал. № 20), 82 л.

БАН, П І Б № 92 - Дж. Ло. Деньги и купечество. Беловая копия. 1720 г. Ркп. БАН, П І Б № 92 (Петр. гал. № 21), 122 л.

РНБ, Эрм. 120 - Дж. Ло. Деньги и купечество. Перевод с английского языка кн. Ивана Андреевича Щербатова «1720 г. и поправлен им же в 1724 г.». Автограф. В картонном переплете. Ф. 885. Эрмитажное собрание, № 120, 116 л.

ФРЛ ${ }^{1}$ - Полной французской и российской лексикон, с последнего издания лексикона Французской академии на российский язык переведенный Собранием ученых людей. СПб.: б. и., 1786. Т. 1-2.

Law 1720 - Considerations sur le Commerce et sur l'Argent. Par Mr. Law. Controlleur Denéral des Finances. Traduit de l'Anglois. A la Haye, Chez Jean Neaulme, 1720.

Law 1750 - Money and Trade considered: with a proposal for supplying the nation with money. By the celebrated John Law, Esq; afterward director to the Missisipi company. Glasgow: printed and sold by R. \& A. Foulis, 1750.

Dictionnaire - Dictionnaire de L'Académie française, $6^{\text {th }}$ Edition (1835) (электронный pecypc). URL: https://portail.atilf.fr/dictionnaires/ACADEMIE/SIXIEME/sixieme. fr.html (дата обращения 5.07.2020).

\section{References}

Alekseyev 1974 - A. A. Alekseyev. Iz istorii obshchestvenno-politicheskoy leksiki Petrovskoy yepokhi [From the history of socio-political vocabulary of the Petrine era]. G. P. Makogonenko, G. N. Moiseyeva (eds.) XVIII vek. [18 $8^{\text {th }}$ century]. Iss. 9. Leningrad: Nauka, 1974. P. 313-318.

Babayeva, Zapolskaya 1993 - E. E. Babayeva, N. N. Zapolskaya. Yazykovoy kontinuum Petrovskoy yepokhi: obzor grammaticheskikh traktatov pervoy chetverti XVIII v. [The language continuum of the Petrine era: a review of grammatical treatises of the first quarter of the $18^{\text {th }}$ century]. B. A. Uspenskiy, M. N. Sheveleva (eds.). 
Issledovaniya po slavyanskomu istoricheskomu yazykoznaniyu [Studies in Slavic historical linguistics]. Moscow: Moscow State University Press, 1993. P. 188-205.

Birzhakova et al. 1972 - E. E. Birzhakova, L. A. Voynova, L. L. Kutina. Ocherki po istoricheskoy leksikologii russkogo yazyka XVIII veka. Yazykovyye kontakty i zaimstvovaniya [Essays on the historical lexicology of the Russian language of the XVIII century. Language contacts and borrowings]. Leningrad: Nauka, 1972.

Bobrova (comp.) 1978 - E. I. Bobrova (comp.). Biblioteka Petra I. Ukazatel-spravoch$n i k$ [Library of Peter the Great. Directory Index]. Leningrad: Library of the Academy of Sciences of the USSR, 1978.

Buchan 2018 - J. Buchan. John Law. A Scottish Adventurer of the Eighteenth Century. London: Maclehose press, 2018.

Bykova et al. 1955 - T. A. Bykova, M. M. Gurevich. Opisanie izdaniy grazhdanskoy pechati. 1708 - yanvar $1725 \mathrm{~g}$. [Description of civil press publications. 1708 January 1725]. Moscow; Leningrad: Publishing House of the Academy of Sciences of the USSR, 1955.

Kopelev 2016 - D. N. Kopelev. Imperskaya model knyazya I. A. Shcherbatova i yeye realizatsiya v 1720-1725 gg. [The imperial model of Prince I. A. Shcherbatova and its implementation in 1720-1725]. N. P. Kopaneva, M. F. Khartanovich (eds.). Lomonosovskiye chteniya v Kunstkamere. K 270-letiyu izdaniya pervogo "Atlasa Rossiyskogo" (1745) i 250-letiyu so dnya smerti M. V. Lomonosova (1765). [Lomonosov readings in the Kunstkamera. On the occasion of the $270^{\text {th }}$ anniversary of the publication of the first "Russian Atlas" (1745) and the $250^{\text {th }}$ anniversary of the death of M. V. Lomonosov (1765)]. St. Petersburg: Peter the Great Museum of Anthropology and Ethnography (the Kunstkamera) Russian Academy of Sciences, 2016. P. 221-238.

Kopelev 2017 - D. N. Kopelev. Dzhon Lo, frantsuzskiye kolonialnyye proyekty yepokhi Regentstva i Petr Velikiy [John Law, French Colonial Regency Projects and Peter the Great]. V. P. Solomin, N. O. Vereshchagina, A. N. Paranina (eds.). Prirodnoye i kulturnoye naslediye: mezhdistsiplinarnyye issledovaniya, sokhraneniye i razvitiye. Kollektivnaya monografiya po materialam VI Mezhdunarodnoy nauchno-prakticheskoy konferentsii (25-26 oktyabrya 2017 g.) [Natural and cultural heritage: interdisciplinary research, preservation and development. Collective monograph based on the materials of the VI International Scientific and Practical Conference (October 25-26, 2017)]. St. Petersburg: Herzen State Pedagogical University of Russia Press, 2017. P. 441-456.

Korkina 2019 - T. D. Korkina. Formirovaniye administrativnoy leksiki v russkom yazyke XVIII veka: predsedatel, prezident, prezes [The formation of administrative vocabulary in the Russian language of the $18^{\text {th }}$ century: predsedatel, president, prezes]. V. N. Kalinovskaya, I. A. Malysheva (eds.). Slavyanskaya istoricheskaya leksikologiya i leksikografiya [Slavic historical lexicology and lexicography]. Iss. 2. St. Petersburg: Institute for Linguistic Studies Press, 2019. P. 64-78.

Lebedeva (comp.) 2003 - I. N. Lebedeva (comp.). Biblioteka Petra I. Opisaniye rukopisnykh knig [Library of Peter I. Description of handwritten books]. St. Petersburg: Library of the Russian Academy of Sciences Press, 2003. 
Molkov 2018 - G. A. Molkov. Terminologiya traktatov A. P. Gannibala "Geometriya praktika" i "Fortifikatsiya" 1725-1726 gg. [The terminology of the treatises of A. P. Hannibal "Practical Geometry" and "Fortification" 1725-1726]. S. D. Shelov, E Tsisun (eds.). Terminologiya i znaniye. Materialy VI Mezhdunarodnogo simpoziuma (Moskva, 8-10 iyunya 2018 g.) [Terminology and knowledge. Materials of the VI International Symposium (Moscow, June 8-10, 2018)]. Moscow: Vinogradov Institute of Russian Language; Ministry of Education of the People's Republic of China, Heilongjiang University, 2018. P. 179-188.

Moser 2020 - M. Moser. "Junosti chestnoe zercalo” 1717 g. U istokov russkogo literaturnogo yazyka ["Junosti chestnoe zercalo" 1717. At the origins of the Russian literary language] (Slavische Sprachgeschichte. Bd. 10). Wien: Lit Verlag, 2020.

Nikolayev 1996 - S. I. Nikolayev. Literaturnaya kultura Petrovskoy yepokhi [Literary culture of the Petrine era]. St. Petersburg: Dmitriy Bulanin, 1996.

Opis' 1965 - Jermitazhnoe sobranie. Opis'fonda [The Hermitage collection. Inventory of the Fund]. Leningrad: The State Public Library named after Saltykov-Shchedrin Press, 1965.

Pekarskiy 1862 - P. P. Pekarskiy. Nauka i literatura v Rossii pri Petre Velikom. Tom I. Vvedeniye $v$ istoriyu prosveshcheniya $v$ Rossii XVIII stoletiya [Science and literature in Russia under Peter the Great. Vol. I. Introduction to the history of education in Russia of the XVIII century]. St. Petersburg: Izdaniye tovarishchestva "Obshchestvennaya polza", 1862.

Siverina 1972 - E. G. Siverina. K istorii administrativno-politicheskoy leksiki, zaimstvovannoy iz nemetskogo yazyka v Petrovskuyu yepokhu [On the history of administrative and political vocabulary borrowed from the German language in the Petrine era]. A. A. Dementyev (ed.). Voprosy teorii, istorii i metodiki prepodavaniya russkogo yazyka. Nauchnyye trudy [Questions of theory, history and methods of teaching the Russian language. Scientific works]. Vol. 103. Kuybyshev: s. n., 1972. P. 204-211.

Smirnov 1910 - N. A. Smirnov. Zapadnoye vliyaniye na russkiy yazyk v petrovskuyu yepokhu [Western influence on the Russian language in the Petrine era]. Sbornik Otdeleniya russkogo yazyka i slovesnosti Imperatorskoy akademii nauk. Vol. 88. No. 2. St. Petersburg: Printing House of the Imperial Academy of Sciences, 1910. Troitskiy 1970 - S. M. Troitskiy. "Sistema" Dzhona Lo i yeye russkiye posledovateli [The "system" of John Law and her Russian followers]. F. Brodel (ed.). Franko-russkiye yekonomicheskiye svyazi [Franco-Russian economic ties]. Moscow; Paris: Nauka. 1970. P. 90-138.

\section{Sources}

BAN, P I B No. 91 - Dzh. Lo. Dengi i kupechestvo. Chernovoy avtograf [Money and trade. Draft autograph]. 1720 g. Rkp. LRAS, P I B No. 91, 82 sheets.

BAN, P I B No. 92 - Dzh. Lo. Dengi i kupechestvo. Belovaya kopiya [Money and trade. White copy]. 1720 g. Rkp. LRAS, P I B No. 92, 122 sheets. 
Dictionnaire - Dictionnaire de L'Académie française, $6^{\text {th }}$ Edition (1835) Available at: URL: https://portail.atilf.fr/dictionnaires/ACADEMIE/SIXIEME/sixieme.fr.html (accessed on 5.07.2020).

FRL $^{1}$ - Polnoy frantsuzskoy i rossiyskoy leksikon, s poslednego izdaniya leksikona Frantsuzskoy akademii na rossiyskiy yazyk perevedennyy Sobraniyem uchenykh lyudey [Complete French and Russian vocabulary, from the latest edition of the vocabulary of the French Academy into Russian translated by the Collective of Scientists]. St. Petersburg: s. n., 1786. Vol. 1-2.

Law 1720 - Considerations sur le Commerce et sur l'Argent. Par Mr. Law. Controlleur Denéral des Finances. Traduit de l'Anglois. A la Haye, Chez Jean Neaulme, 1720.

Law 1750 - Money and Trade considered: with a proposal for supplying the nation with money. By the celebrated John Law, Esq; afterward director to the Missisipi company. Glasgow: printed and sold by R. \& A. Foulis, 1750.

RNB, Erm. 120 - Dzh. Lo. Dengi i kupechestvo. Perevod s angliyskogo yazyka kn. Ivana Andreyevicha Shcherbatova "1720 g. i popravlen im zhe v 1724 g.". Avtograf. V kartonnom pereplete. F. 885. Yermitazhnoye sobraniye, No. 120 [Law, John. Money and trade. Translation from English. Ivan Andreevich Shcherbatov "1720 and corrected by him in 1724". Autograph. In cardboard binding. F. 885. Hermitage collection], 116 sheets. 


\title{
О происхождении самоназваний эвенков
}

\author{
А. М. Певнов \\ Институт лингвистических исследований РАН, Санкт-Петербург; \\ pevnov@gmail.com
}

Аннотация. В статье рассматриваются в этимологическом плане эвенкийские этнонимы илэ, ороче̄н и эвэнкй. Слово илэ '1) человек; 2) эвенк’, вероятно, заимствовано из монгольского, первоначально оно означало 'ясный, очевидный; видимый' (как противоположность невидимым обитателям других миров). Этноним орочён (в русской адаптации орочон) образован от основы оро $(н)-$ 'место, местность' (объяснение, предложенное С. М. Широкогоровым [1944]) при помощи словообразовательного суффикса -чён, оформляющего названия жителей местности, указанной в основе слова; слово означало 'относящийся к (данному) месту, местный' Впрочем, орочоны Забайкалья и Приамурья имели все основания интерпретировать своё самоназвание как 'оленный’ (эвенк. орон ‘домашний олень'). Этноним эвэнкй образован от основы эвэ- 'это место' (сегмент -н восходит к локативному показателю *-ну (поздний пратунгусоманьчжурский язык); суффикс -кй представлен также в эвенкийском $а у н а-\kappa \bar{u}$ 'чужеродец'). Идея о том, что самоназвание эвенов (эвън) включает корень с указательным значением, принадлежит К. А. Новиковой [1960].

Ключевые слова: эвенки, этнонимы, словообразование, локативный показатель, этимология.

\section{On the origin of some Evenki endoethnonyms}

\section{A. M. Pevnov}

Institute for Linguistic Studies, Russian Academy of Sciences, St. Petersburg; pevnov@gmail.com

Abstract. The Evenkis are spread over an extremely vast territory, which may be the reason for the existence of at least 7 endoethnonyms. Most ethnonyms mentioned by G. M. Vasilevich (e.g. ilo, mata, xundisal) are already obsolete.

Considering the etymology of three Evenki endoethnonyms (əwankī, oročēn, and ila) this paper proposes the following conclusions:

1. The word ila '1) man; 2) Evenki' was used by some western Evenki groups. In my opinion, this word was borrowed from Mongolian; initially it meant 'clear, obvious; perceptible, visible' (as opposed to the invisible inhabitants of other worlds). 
2. S. M. Shirokogorov suggested that the Tungus (Evenki) word oročēn 'Orochen' was derived from the Orochen word oro 'place' (cf. Written Mongolian orun 'place in general; territory; dwelling place'). The suffix -čèn is used in some Evenki dialects (Transbaikalia and the Amur Region), in Solon, and Orochen (Oroqen). This suffix has the meaning 'agent noun; an inhabitant of the place indicated in the stem'. The Evenkis of Transbaikalia and the Amur region could interpret the meaning of their endoethnonym as 'those who practise reindeer breeding'. This interpretation is reasonable because the Evenki word oron means 'domestic reindeer'.

3. Most Evenkis call themselves awanki and only one group (the Sym river Evenkis) used the ethnonym awan (which is very close to the Even endoethnonym). The Solon endoethnonym is awayki. The ethnonym awan $(k \hat{\imath})$ was derived from the stem $ə w$ - ' this place' (a very similar idea concerning the ethnonym Even was suggested by K. A. Novikova (1960)). The stem awo- is used in the Evenki words awask ' hither, this way' and awgid̄̄ (from Proto-Evenki *awə-yid̄̄) 'this side'. In my view, the segment - $n$ - was initially a case marker with locative meaning (it is likely that in the Manchu-Tungusic parent language there were three locative markers: *-la $\left./-l \bar{\partial} /-l \bar{o}, *_{-} d \bar{u},{ }^{*}-n u\right)$. The suffix $-k \bar{\imath}$ in the ethnonym awanki is also attached to the Evenki word aynaki 'person of alien tribe'. Apparently, the word awə- $n$ (this.place-LOC) was initially used in collocations like awa- $n$ bi-sì baja- $l$ 'people who live here, in this place' and afterwards it underwent ellipsis (awa-n bi-sī baja-l> awan; awan $+-k \bar{\imath}=$ awank $\vec{\imath})$.

Keywords: Evenkis, ethnonyms, word formation, locative marker, etymology.

\section{1. Введение}

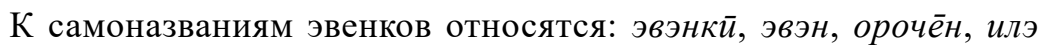
(Г. М. Василевич считает самоназваниями также «мата, хамныган, хундыссал» [Василевич 1969: 10]).

В данной статье предлагаю объяснение происхождения трех этнонимов: илэ, орочён, эвэнкй (эвэн).

\section{2. Этноним илэ}

Этноним илэ, как пишет Г. М. Василевич, применялся в качестве самоназвания эвенками, говорившими на подкаменнотунгусском, непском, ербогачёнском и токминско-верхоленском диалектах [Василевич 1958: 166]. В более поздней работе Глафиры Макарьевны читаем: 
«Самоназвание илэ (человек) было распространено среди эвенков Катангского района, восточной части Эвенкийского национального округа и эвенков с верховьев Лены. Нам представляется возможным связать его происхождение с тюркским словом $и л \sim е л$, употребляемым в значении “народ” уйгурами, чагатайцами, телеутами; “народ”, “племя”, “семья” - алтайцами, лебединцами, телеутами; “чужие люди”, “страна” - крымскими татарами, "родовичи”, “род”, “племя”, “племенной союз”, “народ”, “страна”, "государство" - узбеками; "народ”, “племя", “племенной союз”в древнетюркских памятниках. В тунгусский же язык тюркское слово ил могло попасть от прибайкало-ленских тюрок первых веков н.э. Исчезновение их и объясняется смешиванием с тунгусами, с предками якутов и бурят» [Василевич 1969: 12-13].

Самоназвание эвенков, говорящих (говоривших) на перечисленных выше диалектах, восходит к слову илэ 'человек' (ср. нивхское нивх, айнское аину ('человек'> самоназвание)). Следует отметить семантический параллелизм: эвенк. илэди (П-Т, Н, Е, Ткм, В-Л, С-Б) '1. человеческий;

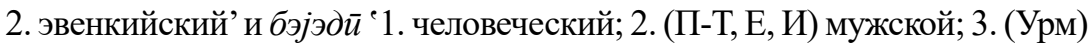
эвенкийский' (диалекты указаны по словарю [Василевич 1958: 73, 167]).

Что касается происхождения эвенк. илэ 'человек', то, по-моему, не исключено заимствование из монгольского, ср. п.-мо. ile 'ясный, очевидный, явный; ощутимый, постижимый (perceptible), видимый' (значения приведены по словарю [MED 1960: 404]). Таким образом, человек для предков некоторых групп эвенков - это человек нашего, видимого мира, среднего мира, а не верхнего и не нижнего. В эвенкийском языке слово илэ с первоначальным значением ('явный, видимый’) не сохранилось, однако соответствующие слова, восходящие к монгольскому, представлены, например, в эвенском и нанайском языках, ср. эвен. ілла́ (К-О) ‘снаружи, на виду’, нан. илэ (Нх, К-У) ‘1) явь; 2) видное место, открытая поверхность', илэлэ (Нх) 'снаружи, сверху, на виду, наяву' [ССТМЯ 1975: 311].

\section{3. Этноним ороче̄н}

Этноним орочён использовался тунгусами (название эвенков до 1931 года), говорившими на витимо-нерчинском, верхне-алданско-зейском 
и учурско-зейском диалектах. Г. М. Василевич дает такое его толкование: «орочен, оленевод (прежнее самоназвание забайкальско-амурской группы оленных эвенков)» (в баргузинском диалекте оричён) [Василевич 1958: 326-327].

Соответствующий этноним srวotfey есть у солонов, которые так называют орочонов Китая. Кроме того, два солонских рода называются srontfey и srontfey haahar [Do Derji 1998: 513-514]). Н. Н. Поппе записал у хайларских солонов иной вариант названия орочонов: orš̌̃ẽ [Поппе 1931: 64].

Сами орочоны называют себя эrstf'eеn (рәјə) [Han, Meng 1993: 30, 58], srotfyen [Whaley, Grenoble, Li 1999: 293].

Словообразовательный суффикс -чён есть в некоторых диалектах эвенков Забайкалья и Приамурья, а также в солонском и орочонском языках.

Г. М. Василевич так характеризует этот суффикс: «-че̄н (-чєн) (3, Алд, Хнг, Чмк) при именной и глагольной основе. 1) Суффикс имени деятеля: гэрбэ- работать — гэрбэче̄н работник; бэюн зверь — бэюче̄н охотник; орон олень - ороче̄н оленевод; $(\ldots\rangle$ 2) при названиях рек. Суффикс, образующий название жителя по реке: Дею Зея - Деючен житель Зеи; Тугур - Тугурчен житель Тугура» [Василевич 1958: 797].

Приведу еще примеры с суффиксом -чён: ламучен 'оседлые прибайкальские эвенки' [Василевич 1969: 71] (от ла̄мy (С, С-Б, Брг, Нрч) название озера Байкал' [Василевич 1958: 233]); гиркучён (мн. ч. гиркучерp) ‘пешие (жители. - А.П.)' (от гирку- 'шагать, ходить'); инэчеен (Тк, Члм) 'оседлые жители' [Мыреева 2004: 140, 251] (ср. инэт- (Учр) ‘жить на одном месте'); мурчен (Нрч, 3, Алд, Учр, Урм) ‘1. конный; 2. коневод' [Василевич 1958: 266] (образовано от мурин 'конь').

Особенностью суффикса -чён является наличие в нем гласного $\bar{e}$, который встречается в эвенкийских словах в первом и в последнем слогах слова, при этом во втором случае наблюдается явная эмфаза, чего нельзя сказать о словообразовательном суффиксе -чён.

По своему употреблению (а также в определенной степени по форме) эвенкийский -че̄н напоминает суффикс -с̌ $i(n)$ в монгольском письменном языке, где он очень продуктивен и обладает весьма широким значением (например: mal 'скот' - mal-čin 'скотовод', temür ‘железо' - temür-с̌іn 'кузнец'). Возможно, эвенкийский суффикс -че̄н когда-то был заимствован из монгольского, но лишь некоторыми диалектами, территориально более или менее близкими к монгольским языкам. В других тунгусо-маньчжурских языках (кроме орочонского 
и солонского, генетически тесно связанных с эвенкийским) этот суффикс соответствий не имеет. Препятствием для сравнения с монгольским является гласный $\bar{e}$ в эвенкийском суффиксе -чён - остается без объяснения, почему не $u$, а $\bar{e}$.

По поводу слова орочён Г. М. Василевич пишет: «Наличие в тунгусских языках слова орон (олень), а также близость суффиксов -чи (обладания) и -чен (по месту жительства, амурские говоры) позволили утвердиться в литературе значению “оленный” за самоназванием орочен орочон» [Василевич 1969: 11-12]. И далее: «Один из средних притоков Амура и весь его бассейн называется по-эвенкийски Оро 〈...〉. Таким образом, слово орочен обозначало жителя местности Оро» [Василевич 1969: 12].

Возможно, это так, однако допускаю, что суффикс -чён был присоединен не к топониму, а к основе оро $(н)$ - 'место, местность', то есть слово орочён означало ‘житель (данного) места, местности’. Эту идею много лет назад высказал С. М. Широкогоров: самоназвание орочонов оро́чен Сергей Михайлович сравнивал с орочонским словом о̆ро 'место; место для сидения; место постоянного проживания; место, занимаемое сидящим' [Shirokogoroff 1944: 210].

Итак, основа оро(н)-, от которой предположительно был образован этноним орочён, могла иметь значение 'место, местность', причем она была связана по происхождению с п.-мо. orun 'место вообще; территория; место постоянного проживания' [MED 1960: 623] (заимствовано маньчжурским языком как орон 'место', из маньчжурского это слово было заимствовано солонским, а из него - орочонским).

В эвенкийских диалектах соответствующего слова нет, поэтому этноним орочён с основой оро (н)- 'место, местность' не мог быть образован в эвенкийском языке - очевидно, он был заимствован.

Есть только два языка, в которых имеется и слово оро $(н)$ 'место, местность', и деривационный суффикс -чён (или его варианты). Такими языками являются солонский и орочонский. В диалектах же тех эвенков России, которые называли себя орочён, есть суффикс -чён, но нет, как только что было сказано, слова орон 'место, местность', так что самоназвание это они могли заимствовать или у солонов, или у орочонов.

Надо сказать, что ни орочоны Китая, ни солоны (они также живут в Китае) оленеводством не занимаются и вряд ли им занимались, так что еще и поэтому самоназвание китайских орочонов не может происходить от названия домашнего оленя. 
В диалектах российских орочонов (тунгусы Забайкалья и Приамурья) есть слово орон 'домашний олень', но нет слова оро (н) 'место, местность'. В орочонском языке все наоборот: есть слово оро 'место' [Shirokogoroff 1944: 210], но нет соответствия слову орон 'домашний олень'. В солонском языке сложнее: во-первых, в нем есть слово эrэn 'место'; во-вторых, олень (по-видимому, любой) в этом языке называется hvmaha, но в солонско-китайском словаре приведено также слово эrэy 'домашний олень; Cervus davidianus; северный олень' [Do Dөrji 1998: 296, 513]. Последнее название оленя, скорее всего, заимствовано солонами у тунгусов-оленеводов - так же, как маньчжурами заимствовано парное слово орон буху «ручной олень, употребляемый ороньчонами в упряжь» [Захаров 1875: 132].

Если забайкальские и приамурские эвенки-орочоны на самом деле заимствовали свое самоназвание ороче̄н, то они могли его переосмыслить в духе народной этимологии, для чего в их языке имелись идеальные предпосылки - домашний олень во всех эвенкийских диалектах называется орон, так что слово орочён вполне могло быть интерпретировано как 'оленевод’ (ср. эвенк. мурчен 'коневод’ - производное от мурин 'конь').

Хотелось бы отметить уникальность формального совпадения производящих основ (сол., орочон. оро(н)- 'место' и эвенк. оро (н)- 'домашний олень'). Как видим, это тот редкий случай, когда народная этимология не противоречит языковым данным - у орочонов Забайкалья и Приамурья слово орочён действительно имеет значение 'оленевод': «орон олень - ороче̄н оленевод» [Василевич 1958: 797].

\section{4. Этноним эвэнкӣ (эвэн)}

Самоназвание эвэнкй Г. М. Василевич отмечает в следующих эвенкийских диалектах: в подкаменнотунгусском, илимпийском, северобайкальском, баргузинском, витимо-нерчинском, учурско-зейском, в урмийском говоре буреинско-урмийско-амгуньского диалекта, а также в сахалинском диалекте [Василевич 1958: 545]. Следует сказать, что солоны называют себя эвэуки (эвэукй).

Сегмент -кй определенно является суффиксом - об этом свидетельствует самоназвание сымских эвенков (эвэн [Василевич 1958: $545]$ ), а также одно из самоназваний эвенов (эвън). Вполне может быть, 
что именно этим суффиксом оформлено эвенкийское слово аунакй 'чужеродец'.

К. А. Новикова предположила, что самоназвание эвенов может быть связано со словом, имеющим корень с указательным значением: «Относительно происхождения самоназвания “эвен” существуют различные предположения. Так, В. И. Цинциус связывает самоназвание “эвен” с глаголом эвдэј ‘спускаться с гор’ (ССТМЯ 1977. — А. П.). По нашему мнению, более вероятным является предположение о близости этого названия к эвенскому слову эвън эвун 'местный', 'здешний'» [Новикова 1960: 11]. Такого эвенского слова в словарях обнаружить не удалось, однако именно эти варианты (эвэ̆н эвун) приведены в работе [Дуткин 1995: 136] со значением 'эвен'.

Обращает на себя внимание то, что среди вариантов самоназвания эвенов имеется вариант эвун (Ол) [ССТМЯ 1977: 436]. Наличие этого варианта подтверждает правильность этимологии, предложенной К. А. Новиковой: ср., с одной стороны, эвен. эвън (Ол, Алл, М, П, Т) ‘эвен' и эвун (Ол) ‘эвен', а с другой, — эвен. эвъски (Б, П) ‘1) сюда; 2) впредь' и эвен. эвуски (Ол, Арм) 1) сюда; 2) впредь'. Такое непозиционное варьирование гласных имеет соответствия в родственных языках, ср. ороч. эвэси 'сюда' и эуки (из праорочского *эву-ки. - А. П.) ‘находящийся на этой стороне' [Аврорин, Лебедева 1978: 255, 259]; нан. эвэнки '1) отсюда; 2) с этих пор, с этого времени' и эуси (из прананайского *эву-си. - А. П.) ‘сюда’ [ССТМЯ 1977: 461-462].

Таким образом, производящей основой этнонима эвэнкй является эвэ- (о сегменте - $н$ см. дальше). Основа эвэ- представлена также в эвен-

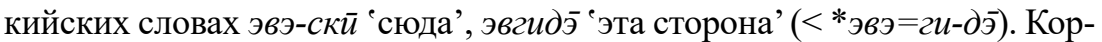
нем этих слов выступает э- ‘этот’ (эр (<*э-рu) ‘этот’, э-ду ‘ здесь', э-лэ 'сюда', э-дук ‘отсюда; с этих пор').

То, что в этнониме эвэнкй производящей основой является эвэ-, можно проиллюстрировать следующими эвенкийскими примерами:

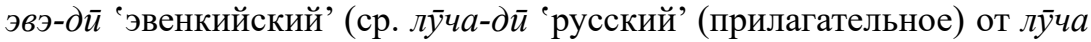

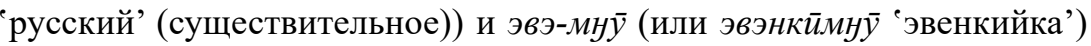

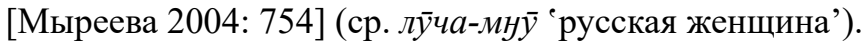

Сегмент -н в эвенском этнониме эвън (эвән) и в эвенкийском эвэнки до сих пор оставался без объяснения. На мой взгляд, этот сегмент когда-то представлял собой показатель местного падежа ${ }^{*}$-ну ${ }^{1}$, рефлексы

1 Здесь и дальше реконструкция данного показателя местного падежа (а также составного аблативного аффикса с этим показателем) относится к состоянию 
которого сохранились в составе наречий некоторых тунгусо-маньчжурских языков. Приведу примеры: эвен. баргин $\left(-н<*_{-}-н\right)$ 'на той сто-

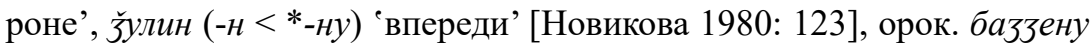
'на том берегу', дулле́ну 'впереди' [Петрова 1967: 82], уд. bagænu ‘на противоположной стороне', зиliənu 'впереди' [Шнейдер 1936: 30, 116].

В эвенском и удэгейском языках в наречиях места сохранился образованный на основе локативного показателя *-ну составной аффикс с аблативным значением (*-ну-ки), ср. эвен. тэуэ-нук 'издалека', да̄ли-нук '1) с близкого расстояния; 2) с недавнего времени', де-нук 'сверху с горы'; уд. yu-ниги (из праудэгейского *uүi-nuki. - A. П.) 'сверху', до-ниги (из праудэгейского *dō-nuki. - A. П.) 'изнутри', го一-ниги (из праудэгейского *goro-nuki. - A. П.) 'издалека' [ССТМЯ 1975: 162, 188, 203, 209, 246; ССТМЯ 1977: 226].

В эвенкийском языке фактически уже в междометии угадывается бывший показатель локатива $-н(<*-н y):$ тулин! ' ${ }^{\circ}$ вон! (так кричат собаке)' [Василевич 1958: 399]; ср. междометное употребление словоформы с современным показателем местного падежа в иенгринском говоре эвенкийского языка: гороло̄! (горо-ло̆ даль-LOC) - так кричат собаке, напр.: Казбек, гороло̄! [Мыреева 2004: 144]. Вероятно, эти междометия являются результатом эллипсиса: Тулин бикэл! > Тулин! 'Снаружи будь!' > 'Вон!'; Гороло̄ бикэл! > Гороло̆! 'Далеко будь!' > 'Пошел (пошла)!'. Возможность эллипсиса в подобных случаях становится очевидной, если привести аналогичный пример без эллипсиса: Дьлн бикэл! 'Будь выше!' (имеется в виду склон горы. - А. П.) [Василевич 1958: 129]. В слове дын (дӣн в транскрипции, принятой в [ССТМЯ 1975, ССТМЯ 1977]) присутствует бывший локативный показатель -н.

Этноним эвэн также мог образоваться в результате эллипсиса:

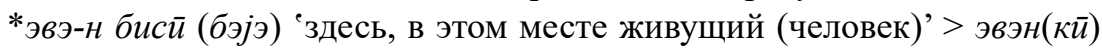
(в данном случае реконструкция относится к праэвенкийскому и к праэвенскому).

Есть еще одно свидетельство того, что в составе этимологизируемого этнонима был показатель местного падежа *-ну: в эвенкийском языке кластер нк представлен вроде бы только в самоназвании эвенков эвэнкй (в то же время в немалом количестве слов встречается кластер $y \kappa)$. Это указывает на то, что между согласными $н$ и $к$ находился

пратунгусоманьчжурского языка после обособления предка чжурчжэньского, маньчжурского и сибинского языков. 
гласный (скорее всего, *y), который был утрачен в соответствии с историко-фонетическим законом редукции и исчезновения кратких узких гласных в исходе корневых и аффиксальных морфем эвенкийского, эвенского, негидальского, солонского, орочонского и хамниганского языков.

\section{Список условных сокращений}

нан. - нанайский язык; орок. - орокский (уильта) язык; ороч. - орочский язык; орочон. — орочонский язык; п.-мо. — монгольский письменный язык; сол. солонский язык; уд. - удэгейский язык; эвен. - эвенский язык; эвенк. - эвенкийский язык

\section{Территориальные варианты нанайского языка:}

Нx — найхинский говор, К-У — кур-урмийский говор (диалект)

Территориальные варианты эвенкийского языка (по [CСТМЯ 1975: XXIV$\mathrm{XXV}$; см. «схему распространения диалектов эвенкийского языка» в словаре [Baсилевич 1958]):

Алд - алданский говор восточного наречия, Брг - баргузинский говор южного наречия, В-Л - верхоленский говор южного наречия, Е - ербогачёнский говор северного наречия, 3 - зейский говор восточного наречия, И - илимпийский говор северного наречия, Н - непский говор южного наречия, Нрч - нерчинский говор восточного наречия, П-Т - подкаменнотунгусские говоры южного наречия, C - сымский говор южного наречия, С-Б - северо-байкальский говор южного наречия, Тк - токкинский говор восточного наречия, Ткм - токминский говор южного наречия, Урм - урмийский говор восточного наречия, Учр - учурский говор восточного наречия, Хнг - хинганский говор восточного наречия, Члм - чульманский говор восточного наречия, Чмк - чумиканский говор восточного наречия

\section{Территориальные варианты эвенского языка:}

Алл - аллайховский говор среднего наречия, Арм - арманский диалект, Б быстринский говор восточного наречия, К-О — колымско-омолонский говор восточного наречия, М — момский говор среднего наречия, Ол - ольский говор восточного наречия, П - пенжинский говор восточного наречия, Т — томпонский говор среднего наречия

\section{Литература}

Аврорин, Лебедева 1978 - В. А. Аврорин, Е. П. Лебедева. Орочские тексты и словарь. Л.: Наука, 1978. 
Василевич 1969 - Г. М. Василевич. Эвенки. Историко-этнографические очерки (XVIII — начало XX в.). Л.: Наука, 1969.

Дуткин 1995 - Х. И. Дуткин. Аллаиховский говор эвенов Якутии. СПб.: Наука, 1995.

Новикова 1960 - К. А. Новикова. Очерки диалектов эвенского языка. Ольский говор. Ч. 1. М.; Л.: Изд-во АН СССР, 1960.

Новикова 1980 - К. А. Новикова. Очерки диалектов эвенского языка. Ольский говор: глагол, служебные слова, тексты, глоссарий. Л.: Наука, 1980.

Петрова 1967 - Т. И. Петрова. Язык ороков (ульта). Л.: Наука, 1967.

Поппе 1931 - Н. Н. Поппе. Материалы по солонскому языку. Л.: Изд-во АН СССР, 1931. Han, Meng 1993 — 韩有峰, 孟淑贤. 鄂伦春语汉语对照读本. 北京: 中央民族学院出 版社出版社, 1993 [Han Youfeng, Meng Shuxian. Elunchunyu hanyu duizhao duben. Beijing: Zhongyang minzu xueyuan chubanshe, 1993. Хань Юфэн, Мэн Шусянь. Сопоставительная хрестоматия орочонского и китайского языков. Пекин: Центральное издательство Института национальностей, 1993].

Whaley, Grenoble, Li 1999 - L. J. Whaley, L. A. Grenoble, F. Li. Revisiting Tungusic Classification from the Bottom up: A Comparison of Evenki and Oroqen // Language. 1999. Vol. 75. № 2. P. 286-321.

\section{Источники}

Василевич 1958 - Г. М. Василевич (сост.). Эвенкийско-русский словарь. М.: Государственное изд-во иностранных и национальных словарей, 1958.

Захаров 1875 - И. Захаров (сост.). Полный маньчжурско-русский словарь, составленный Иваном Захаровым. СПб.: б. и., 1875.

Мыреева 2004 - А. Н. Мыреева. Эвенкийско-русский словарь. Новосибирск: Наука, 2004.

ССТМЯ 1975 - В. И. Цинциус (отв. ред.). Сравнительный словарь тунгусо-маньчжурских языков. Материалы к этимологическому словарю. Т. І. Л.: Наука, 1975.

ССТМЯ 1977 - В. И. Цинциус (отв. ред.). Сравнительный словарь тунгусо-маньчжурских языков. Материалы к этимологическому словарю. Т. ІІ. Л.: Наука, 1977.

Шнейдер 1936 - Е. Р. Шнейдер. Краткий удэйско-русский словарь с приложением грамматического очерка. М.; Л.: Учпедгиз, 1936.

Do Derji 1998 — 杜·道尔基 编著. 鄂汉词典. 海拉尔: 内蒙古文化出版社, 1998 [Du Dao'erji bianzhe. E-Han cidian. Haila'er: Nei Menggu wenhua chubanshe, 1998. До Дорджи (сост.). Солонско-китайский словарь. Хайлар: Культура Внутренней Монголии, 1998].

Shirokogoroff 1944 — S. M. Shirokogoroff. A Tungus Dictionary. Tungus-Russian and Russian-Tungus. Photogravured from the manuscripts. Tokyo: Minzokugaku kyōkai, 1944.

MED 1960 - F. D. Lessing (ed.). Mongolian-English Dictionary. Berkeley; Los Angeles; London: University of California Press; Cambridge University Press, 1960. 


\section{References}

Avrorin, Lebedeva 1978 - V. A. Avrorin, Ye. P. Lebedeva. Orochskiye teksty i slovar [Oroch Texts and Dictionary]. Leningrad: Nauka, 1978.

Dutkin 1995 - Kh. I. Dutkin. Allaikhovskiy govor evenov Yakutii [Allaikha dialect of Evens of Yakutia]. St. Petersburg: Nauka, 1995.

Han, Meng 1993 - 韩有峰, 孟淑贤. 鄂伦春语汉语对照读本. 北京: 中央民族学院 出版社出版社, 1993 [Han Youfeng, Meng Shuxian. Elunchunyu hanyu duizhao duben. Beijing: Zhongyang minzu xueyuan chubanshe, 1993. Han Youfeng, Meng Shuxian. Comparative reading-book of Orochen and Chinese. Beijing: Central Publishing House of the Institute of Nationalities, 1993.

Novikova 1960 - K. A. Novikova. Ocherki dialektov evenskogo yazyka. Olskiy govor [Study of Dialects of the Even Language. Ola Dialect]. Pt. 1. Moscow, Leningrad: Publishing House of the USSR Academy of Sciences, 1960.

Novikova 1980 - K. A. Novikova. Ocherki dialektov evenskogo yazyka. Olskiy govor: glagol, sluzhebnyye slova, teksty, glossariy [Study of Dialects of the Even Language. Ola Dialect: Verb, Function Words, Texts, Glossary]. Leningrad: Nauka, 1980.

Petrova 1967 — T. I. Petrova. Yazyk orokov (ulta) [The Language of the Oroks (Ulta)]. Leningrad: Nauka, 1967.

Poppe 1931 - N. N. Poppe. Materialy po solonskomu yazyku [Materials on the Solon Language]. Leningrad: Publishing House of the USSR Academy of Sciences, 1931.

Vasilevich 1969 - G. M. Vasilevich. Evenki. Istoriko-etnograficheskiye ocherki (XVIIInachalo XX veka) [Evenki. History-Ethnographical Studies (XVIII — the beginning of the XX century)]. Leningrad: Nauka, 1969.

Whaley, Grenoble, Li 1999 — L. J. Whaley, L. A. Grenoble, F. Li. Revisiting Tungusic Classification from the Bottom up: A Comparison of Evenki and Oroqen. Language. 1999. Vol. 75. No. 2. P. 286-321.

\section{Sources}

Do Derji 1998 一 杜·道尔基 编著. 鄂汉词典. 海拉尔: 内蒙古文化出版社. 1998 [Du Dao'erji bianzhe. E-Han cidian. Haila'er: Nei Menggu wenhua chubanshe. 1998. Do Derji (comp.). Solon-Chinese Dictionary. Hailar: Culture of Inner Mongolia, 1998].

MED 1960 - F. D. Lessing (ed.). Mongolian-English Dictionary. Berkeley; Los Angeles; London: University of California Press; Cambridge University Press, 1960.

Myreyeva 2004 - A. N. Myreyeva. Evenkiysko-russkiy slovar [Evenki-Russian Dictionary]. Novosibirsk: Nauka, 2004.

Shirokogoroff 1944 - S. M. Shirokogoroff. A Tungus Dictionary. Tungus-Russian and Russian-Tungus. Photogravured from the manuscripts. Tokyo: Minzokugaku kyōkai, 1944. 
Shneyder 1936 - Ye. R. Shneyder. Kratkiy udeysko-russkiy slovar s prilozheniyem grammaticheskogo ocherka [Concise Ude-Russian Dictionary Supplemented with a Grammatical Sketch]. Moscow; Leningrad: State Educational and Pedagogical Publishing House, 1936.

SSTMYa 1975 - V. I. Tsintsius (ed.). Sravnitelnyy slovar tunguso-manchzhurskikh yazykov. Materialy $k$ etimologicheskomu slovaryu [Comparative Dictionary of Manchu-Tungusic Languages. Materials for the Etymology Dictionary]. Vol. I. Leningrad: Nauka, 1975.

SSTMYa 1977 - V. I. Tsintsius (ed.). Sravnitelnyy slovar tunguso-manchzhurskikh yazykov. Materialy $k$ etimologicheskomu slovaryu [Comparative Dictionary of Manchu-Tungusic Languages. Materials for the Etymology Dictionary]. Vol. II. Leningrad: Nauka, 1977.

Vasilevich 1958 - G. M. Vasilevich (comp.). Evenkiysko-russkiy slovar. [Evenki-Russian Dictionary]. Moscow: State Publishing House of Foreign and National Dictionaries, 1958.

Zakharov 1875 - I. Zakharov (comp.). Polnyy manchzhursko-russkiy slovar, sostavlennyy Ivanom Zakharovym. [Complete Manchu-Russian dictionary compiled by Ivan Zakharov]. St. Petersburg: s. n., 1875. 


\title{
Люди в языковой политике: теория и практика дискурсивного поворота в социолингвистике (на примере России и Западной Европы)
}

\section{Э. В. Хилханова}

Институт языкознания РАН, Москва; erzhen.khilkhanova@iling-ran.ru

Аннотация. Целью статьи является обобщающий и сравнительный анализ теории и практики дискурсивного «поворота к людям» в языковой политике на примере России и стран Западной Европы. Делается вывод о трансформации взглядов на субъектность в языковой политике в сторону большей инклюзивности и отхода от государствоцентричности. Предложена типология акторов языковой политики, обнаружены сходства и различия языкового активизма в России и Западной Европе. Делается вывод о повышении роли этнического самосознания и изменении лингвистических идеологий в сторону большей либеральности и толерантности.

Ключевые слова: языковая политика, миноритарные языки, дискурсивная социолингвистика, субъектность, языковой активизм, «новые говорящие», акторы, свобода действий, лингвистические идеологии, (русский) монолингвизм, Россия, Западная Европа.

\section{People in language policy: Theory and practice of the discursive turn in sociolinguistics (comparing Russia and Western Europe)}

\author{
E. V. Khilkhanova \\ Institute of Linguistics, Russian Academy of Sciences, Moscow; \\ erzhen.khilkhanova@iling-ran.ru
}

\begin{abstract}
The article proposes a general review and comparative analysis of the theory and practices of the "turnaround to people" in the language policy in Russia and Western Europe. It looks into the theoretical and terminological specifics of this process while comparing the "grassroots" actors of respective language policies, the social and political context of their activities, and the linguistic ideologies behind them.
\end{abstract}


The article notes an on-going change in the views on subjectivity in language policies, a turn toward greater inclusiveness, and a departure from state-centered approaches. It proposes a classification of language-policy actors while pointing out the similarities and differences in language activism in Russia and in Western Europe. They are similar in that their language activism is developing in the urban environment; the activists are heterogeneous, predominantly young people actively applying new technologies. Russia differs in that its language activism has had a later start, shows a smaller scale, while the people are less prepared to take personal responsibility for and initiative in minority languages preservation. A comparison of the socio-political context of language activism in Russia and in Western Europe shows that (1) the important factors for minority languages preservation include political autonomy and a developed sense of ethnic identity, and (2) duality and inconsistency of the ethno-linguistic policy are prominent features of Russian state bodies. After a brief review of the interrelated modern linguistic ideology components such as hypertraditionalization, association of language with only the nation's past developments, the ideology of authenticity, purism, and (Russian) monolingualism, the article highlights not only the growing importance of linguistic ideology studies, but also the ideology's unfolding transformation toward greater liberalism and tolerance. In conclusion, the paper notes a significant progress achieved by the sociolinguistic literature in its analyses and theoretical understanding of the ongoing "turnaround to people" process, while more insistent research in this field is still high on the agenda. The article was prepared as a contribution toward better theoretical understanding of these problems from the macro-sociolinguistic perspective.

Keywords: language policy, minority languages, discursive sociolinguistics, subjectivity, language activism, «new speakers», actors, agency, linguistic ideologies, (Russian) monolingualism, Russia, Western Europe.

\section{1. Введение}

До относительно недавнего времени при изучении миноритарных языков ${ }^{1}$ причины их неблагоприятного положения виделись в основном в языковой политике государства, будь то Франция, Германия, бывший

1 Термин «миноритарные языки» (языки меньшинств) используется в отношении всех языков, соответствующих двум критериям: количественному и функциональному, т. е. имеются в виду языки, носители которых представляют демографическое меньшинство в регионе своего проживания, и языки, функции и сфера использования которых ограничены по сравнению с официальными языками / языком данного региона. 
Советский Союз или другие страны. До определенного момента в истории это было оправдано: примерно до середины XX в. большинство стран проводило в той или иной степени дискриминационную политику по отношению к миноритарным языкам (далее - МЯ). В итоге только между 1950 и 2010 гг. из 2500 языков, перечисляемых в Атласе языков, находящихся под угрозой исчезновения, 230 окончательно исчезло [UNESCO Atlas]. Однако с послевоенного времени в западноевропейских странах понемногу рождается осознание: необходимо поддерживать многоязычие и языковое разнообразие [Смокотин 2010: 4]. Принимается ряд документов, начиная со Всеобщей декларации ООН о правах человека (1948 г.), Международного пакта ООН о гражданских и политических правах (1966 г., вступил в силу в 1976 г.), что становится легитимным основанием и точкой отсчета новой идеологической парадигмы, построенной на признании ценностей многоязычного и поликультурного общества.

В результате в последние десятилетия на арене языковой политики (далее - ЯП) появились новые игроки, доселе лишенные права голоса в ее определении; с этого момента «низы» не только пассивно принимают или сопротивляются ЯП, проводимой «верхами», но и сами в той или иной степени делают ее. В этом контексте наиболее ярким воплощением новых идеологий и практик в Западной Европе являются «новые говорящие» (new speakers) - люди, которые освоили МЯ не «естественным» путем - в семье, а сознательно и целенаправленно, через систему образования (школы, языковые курсы и т. д.) или самостоятельно (подробнее об этом см. в Разделах 3, 4 и 5). Понятие «новые говорящие» интерпретируется нами как часть языкового активизма, который представляет собой третью, недооцененную силу в сфере языковой политики (подробнее о языковом активизме см. далее).

Произошедшие изменения отражаются и в научной теории: в социолингвистике и других смежных дисциплинах в последние десятилетия происходит ревизия старых и появление новых концепций и понятий, поскольку только так можно отразить все многообразие изменяющейся многоязычной картины мира как в глобальном, так и региональных масштабах. Меняется и одно из базовых понятий социолингвистики понятие языковой политики, отражая ее нынешний все более многослойный и полифонический характер [Tollefson, Pérez-Milans 2018; Johnson 2009, 2013]. Несмотря на большое количество исследований на тему ЯП, составляющих на сегодня отдельную субдисциплину социолингвистики, само понятие языковой политики относится к числу «интуитивно понятных» и поэтому зачастую используемых по умолчанию. 
Если раньше для большинства как западных, так и российских исследований в этой области «дефолтной» интерпретацией ЯП было понимание ее как процесса, проводимого «сверху», что отмечается во многих публикациях [Tollefson, Pérez-Milans 2018; Мухарямов 2018; Ricento, Hornberger 1996; Canagarajah 2005 и др.]), то в исследованиях современной ЯП подчеркивается ее дискурсивный и многоуровневый характер [Barakos, Unger 2016; Halonen et al. 2015] и приоритетное внимание уделяется тому, как официальная языковая политика, сформированная на правительственном уровне (общегосударственном или региональном), интерпретируется и обсуждается на местах различными социальными субъектами, как носителями, так и не-носителями того или иного идиома [Johnson 2013; McCarty 2011].

Наверное, не будет преувеличением назвать нынешнее внимание к роли отдельных людей в политических процессах дискурсивным поворотом в исследованиях ЯП. При этом здесь очевидно лидерство западной науки, что проявилось и в терминологии (agency, actors, language activism и т. д.), и в появлении новых подходов, таких, как этнография ЯП (подробнее об этом см. в Разделе 2). В отличие от западноевропейских стран, в России мы не можем констатировать массовое появление «новых говорящих», да и языковой активизм в силу ряда причин отстал на несколько десятков лет от аналогичных движений в Западной Европе. Таким образом, как с теоретической, так и с фактической точки зрения проблематика «люди в языковой политике» и ее общественно-политический контекст в России и Западной Европе имеют как сходства, так и существенные отличия. Сопоставление этих двух макрорегионов под таким углом зрения представляется очень интересной задачей, которая позволит:

1) сравнить взгляды на категорию субъектности в российской и западной социолингвистике в теоретическом плане, включая вопросы терминологии и адаптации англоязычных терминов в русскоязычном научном дискурсе;

2) показать, как языковые активисты, включая «новых говорящих», вносят вклад в ревизию и трансформацию как практик, так и теоретических представлений о языковой политике, ее акторах и субъектах в данных макрорегионах;

3) проанализировать роль общественно-политического контекста в деятельности языковых активистов, включая «новых говорящих», в сравнительном аспекте; 
4) исходя из того, что ЯП неизменно основывается на лингвистических идеологиях, рассмотреть некоторые наиболее актуальные лингвистические идеологии, служащие препятствием использованию, освоению и продвижению МЯ.

В отличие от «новых говорящих» в странах Западной Европы, языковой активизм в России еще не становился объектом специального научного исследования, хотя роль языковых активистов как проводников ЯП очень важна: «Путь от языковых прав к языковой политике проложен языковым активизмом, но этот путь все еще плохо понимается с точки зрения законности, прав, обязанностей и политик» ${ }^{2}$ [Combs, Penfield 2012: 474]. Поэтому анализ «низовых» инициатив для сохранения МЯ, их акторов и общественно-политического контекста, наиболее актуальных для России лингвистических идеологий в сопоставлении с языковым активизмом в Западной Европе, как нам представляется, может внести вклад в теоретическое осмысление «дискурсивного поворота» к людям в ЯП в России. Принцип сопоставления призван выявить как общие тенденции, так и специфические для Западной Европы и России конкретные характеристики этого процесса. Поскольку работа носит теоретический характер, материалом послужили преимущественно вторичные источники (опубликованные результаты исследований в области ЯП и социолингвистики в целом), но также были задействованы и первичные источники (тексты официальных документов, статистические сведения, тексты на темы языковой политики и языковой ситуации в России в социальных сетях и на веб-сайтах, данные этнографического наблюдения и полевого исследования автора).

В статье реализован в основном макросоциолингвистический подход. Масштабность географического охвата с очевидностью предполагает некоторое невнимание к деталям, региональным и прочим особенностям. Но работы макросоциолингвистического, обобщающего и сопоставительного плана нужны не меньше, чем микроуровневые исследования, т. к. они позволяют выявить глобальные тренды, их общности и различия как в теоретических подходах, так и в практике (в данном случае языковой политики). Каждая из рассматриваемых категорий, будь то agency, общественно-политический контекст или лингвистические идеологии, так или иначе была объектом отдельных исследований, которые рассматриваются в соответствующих разделах.

\footnotetext{
2 Здесь и далее перевод наш. - Прим. Э. X.
} 
Вместе с тем можно с уверенностью ожидать появления новых интересных работ, проливающих дополнительный свет на действие «человеческого фактора» в языковой политике.

\section{2. Российский и западный взгляд на субъектность в языковой политике}

Содержательный анализ современных российских исследований на тему ЯП обнаруживает, что для большинства, помимо интерпретации ЯП как процесса, проводимого «сверху», характерен макросоциолингвистический взгляд на ЯП. В последнее время, однако, появляется все больше работ, в которых осознается необходимость дискурсивного «поворота к людям» и критикуются недостатки макросоциолингвистического и top-down подхода к ЯП. Например, отмечается, что большинство политиков рассматривают ЯП лишь как законодательную возможность регламентирования употребления языков, не обращая внимания на то, что языковое законодательство должно учитывать реально сложившуюся языковую ситуацию в обществе [Шепелев 2015: 168].

Вопрос, кто может и должен проводить и реализовывать ЯП, рассматривается в России в рамках категории субъектности, т. е. кто является субъектом / субъектами ЯП. Характерный для России государствоцентричный подход проявляется в распространенном взгляде на то, что «в современной России доминирующим субъектом языковой политики является государство», хотя это «внутренне не единый и, в общем-то, не единственный политический субъект» [Борисова 2019: 76]. Помимо государства, упоминаются также негосударственные акторы и агенты «языковой преференциальной политики» в современной России - это, прежде всего, разнообразные, в т. ч. этнические, некоммерческие организации (НКО), образовательные государственные и негосударственные учреждения (прежде всего университеты), деятельность которых разнообразна в различных региональных контекстах. Н. В. Борисова также отмечает, что субъектами языковой политики являются не этнические группы и сообщества, а политические и общественные организации, политические элиты и лидеры, совмещающие и статус субъектов / агентов языковой политики [там же].

Порой проводится принципиальное разграничение между теми, кто может «проводить ЯП», и теми, кто может «оказывать влияние» на нее: 
«Проводить языковую политику могут только государственные органы, обладающие для этого определенными полномочиями, поскольку языковая политика является важнейшим компонентом национальной политики и, соответственно, реализовываться она может только на определенном пространстве. При этом оказывать влияние на языковую политику могут различные общественные организации, движения, партии и другие посредством внесения определенных предложений в соответствующие государственные органы» [Шепелев 2015: 169]. Автор утверждает, что в России языковая политика всегда носила насильственный характер, объясняя это большим количеством проживающих на ее территории народностей со своими языками и, как следствие, необходимостью создания единого языка общения наций и народностей, которым выступал русский язык, вытесняя иные языки [там же: 170-171].

В сборнике экспертных докладов «Языковая политика в современной России: проблемы и перспективы» сказано: «В Российской Федерации субъектами реализации языковой политики являются ее административные и судебные инстанции. Ключевыми учреждениями в этой сфере являются Федеральное агентство по делам национальностей и Министерство образования» [Головко и др. 2018: 16]. При этом авторы сборника заявляют о своем более широком понимании ЯП, перечисляя в списке субъектов ее реализации, помимо государства и его институтов, «множество других субъектов политики, включая региональные политические элиты, различные группы творческой интеллигенции и академической науки, бизнес-элиты, лидеров и активистов различных общественных движений и неправительственных организаций, а также религиозных организаций и различных конфессий, университетских преподавателей и школьных учителей, студентов и школьников и их родителей, издательства, редколлегии газет и журналов, мигрантские сообщества и землячества и т. д.» [там же: 6].

Конечно, государствоцентричный взгляд на субъекты ЯП отражает реалии централизованного и авторитарного государства, каковым Россия была со времен Российской империи, и где люди, действительно, являлись не субъектами, а объектами ЯП. Мы согласны с Л. Гренобль и Н. Булатовой, что, хотя особенности отдельных языковых сообществ различаются в деталях, централизация власти в Российской Федерации, а до нее в Советском Союзе, означает, что общие решения о языковой политике и планировании исходят из Москвы в другие «периферийные» регионы. На примере ЯП в отношении стандартизации языков авторы подчеркивают, что сам вопрос о том, принимали ли коренные 
народы, сопротивлялись или отвергали разработанный для них стандартизированный вариант языка, неверен, поскольку право принимать решения у коренных народов в Советском Союзе ограничивалось только политикой внутри семьи, а их взгляды и идеологии подвергались сильному влиянию языковой и образовательной политики государства [Grenoble, Bulatova 2018: 118-119].

В силу вышесказанного понятно, почему работ по ЯП Советского государства множество, но гораздо меньше пишут о том, как люди реагировали на инициированные «сверху» меры по ЯП, поддерживали они или не поддерживали существующую ЯП, каковы были их мнения и установки. Вообще для советской социолингвистики было характерно более сильное и продолжительное, чем в западных социальных науках, недоверие к субъективным фактам и факторам; социолингвистами исследовались либо внешние, социальные аспекты языковых ситуаций (этноязыковая политика государства, влияние модернизации и глобализации, соотношение между этническим большинством и меньшинством, наличие или отсутствие институциональной поддержки и др.), либо структурные (внутриязыковые) изменения, происходящие с контактирующими языками - как правило, с миноритарными языками в контакте с мажоритарным. Субъективные, «привязанные к человеку» параметры языковой ситуации только упоминались в виде социальных установок [Швейцер 1976: 134] или аксиологического параметра языковых ситуаций [Виноградов 1990: 616-617), но не подвергались специальному изучению. Об этом свидетельствует и отсутствие ряда обозначающих субъектность терминов в «Словаре социолингвистических терминов» 2006 г:: языковые установки (они лексикографированы как социальные установки), agency, актор и т. д. [Михальченко 2006].

Социолингвистика постсоветского периода постепенно начинает обращать внимание на «говорящего человека» (термин Остгофа и Бругмана: [Остгоф, Бругман 1960: 153]). Здесь особо следует отметить работы Н. Б. Вахтина, который включил в набор традиционно рассматриваемых детерминирующих факторов установки и мотивации самих акторов и весьма убедительно рассмотрел их роль в языковом сдвиге на материале языков народов Севера ([Вахтин 1998, 2001]; см. также [Вахтин, Головко 2005]). Из-за становящейся все более очевидной ограниченности эвристических и экспланаторных возможностей традиционного анализа внешних факторов Э. В. Хилхановой предлагается методология дискурсивной соичилингвистики, расширяющая наши представления о социолингвистических явлениях как «вширь», так 
и «вглубь». Первое предполагает интерпретацию данных в широком социокультурном, этнопсихологическом, политическом и других контекстах, второе - изучение того, что происходит «в голове» человека, как индивидуума, так и группы, при использовании и выборе языка: это отношение к языку, мотивации и языковые установки; поведенческие и речевые стереотипы; существующие в обществе и группе социокультурные нормы, а также особенности национального характера, включающие в себя привязанность народа к своей культуре и языковую лояльность коллектива [Хилханова 2009]. Появление таких работ в России в первое десятилетие 2000 -х гг. симптоматично, т. к. это показывает общность мировых тенденций и вектора развития исследований ЯП с учетом человека, а не только системы. Впоследствии таких социолингвистических и междисциплинарных работ появляется такое количество, что мы только ограничимся их перечислением, ни в коей мере не претендующим на полноту: [Баранова 2010; Fedorova, Gavrilova 2010; Хилханова и др. 2016; Иванова 2018; Fedorova, Ваranova 2018; Баранова 2019] и др.

B западной науке учет «низовых» (grassroots) процессов и инициатив и стоящих за ними людей произошел раньше, чем в российской, примерно с конца 1990-х — начала 2000-х гг. [Ricento, Hornberger 1996; Canagarajah 2005]. Сформировалось направление, получившее название этнографии языковой политики [Johnson 2009, 2013; Hornberger, Johnson 2007; McCarty 2011]. До того, как произошел этот поворот, даже устоявшиеся категории ЯП, такие, как корпусное и статусное планирование, были направлены скорее на сам язык, чем на говорящих на этом языке. Для корпусного планирования это естественно, однако и статусное планирование было сосредоточено скорее на самом языке, чем на его носителях, хотя очевидно, что статус языка влияет на его носителей и наоборот - статус говорящих также может влиять на сам идиом [Wiley, Garcia 2016: 49].

Этнография языковой политики (далее - ЭЯП) представляет собой гносеологически и методологически обновленный взгляд на анализ ЯП. Основная идея состоит в том, чтобы включить этнографическую составляющую в изучение процессов и контекстов ЯП. Это не просто механический учет этнографических данных в процессах ЯП - основным принципом ЭЯП является изучение «агентов, контекстов и процессов на нескольких уровнях создания, интерпретации и присвоения языковой политики» [Johnson 2013: 44]. Таким образом, основным достоинством ЭЯП является то, что она может снять противоречия между 
взглядом на ЯП как исключительно на действия властей (макроуровень) и учетом активного творчества отдельных говорящих (микроуровень). Более конкретно, этот подход предполагает взгляд на политику как социокультурный процесс, и тогда в анализ вовлекаются практики, идеологии, установки и механизмы, которые влияют на выбор языка людей повсеместно и повседневно [McCarty 2015: 81]. ЭЯП обладает и практическим потенциалом, т. к. критическое описание и анализ конкретной ЯП, по сути, нацелены на расширение возможностей практиков на местах, чтобы добиться значимых социальных изменений и, возможно, улучшить ситуацию с языковым неравенством [Johnson 2009; McCarty 2015].

Далее мы хотели бы остановиться на некоторых теоретических вопросах терминологии, связанной с обозначением людей как действующих лиц в ЯП, и затронуть некоторые проблемы перевода и адаптации их в русскоязычном научном дискурсе.

Одним из ключевых в рассуждениях на тему ЯП в современной научной литературе является термин agency. Он является вполне устоявшимся в западных исследованиях ЯП, однако в российских социолингвистических работах его нельзя считать прижившимся. Его нет в «Словаре социолингвистических терминов» 2006 г. [Михальченко 2006], и тем более, по очевидным причинам, — в «Лингвистическом энциклопедическом словаре» 1990 г. [Ярцева (гл. ред.) 1990] и его втором издании - Большом энциклопедическом словаре по языкознанию 1998 г. [Ярцева (ред.) 1998]. Термин agency мы находим в диссертации С. В. Кириленко, где он находится в Приложении 5 «Терминологические единицы англоязычной социальной лингвистики (на материале Словаря социолингвистики (A Dictionary of Sociolinguistics (2012))» [Кириленко 2015: 252]. Этот факт наряду с отсутствием данного термина среди основных словарных статей словаря социолингвистических терминов свидетельствует о том, что он воспринимается и подается как новый, пришедший из «англоязычной социальной лингвистики» и еще не интегрировавшийся в российский социолингвистический тезаурус ${ }^{3}$. Помимо словарей, поиск этого термина как на английском языке, так и в переводе на русский (подробнее об этом см. ниже) среди социолингвистических публикаций дал единичные случаи использования

${ }^{3}$ Подчеркнем, что мы не говорим здесь о гораздо более частотном использовании термина agency ('агентивность') в других лингвистических дисциплинах исследованиях функционально-семантического, коммуникативного плана и др. 
данного термина (см. [Баранова 2019b] и [Молодыченко 2017], где он переводится как «агентивность»).

Нам представляется, что такой перевод — это слишком простое решение. Перевод этого термина довольно проблематичен, и это связано с его множественной интерпретацией. Распространенным в социальных науках является понимание agency как свободы действий, т. е. это способность людей действовать независимо и делать свой собственный свободный выбор. В этом значении оно противопоставляется структуре, т. е. таким факторам влияния, как социальный класс, религия, пол, этническая принадлежность, способности, обычаи и т. д. Эти факторы определяют или ограничивают агента и его решения [Barker 2005: 448]. Понятие agency относится к ощущению контроля над действиями и их последствиями и, соответственно, может переводиться как волеизъявление или свобода воли. Как говорят социальные психологи, «когда мы совершаем добровольные действия, мы не склонны чувствовать, что они просто случаются с нами, вместо этого мы чувствуем, что мы отвечаем за них. Ощущение свободы воли означает это чувство нахождения в водительском кресле, когда речь заходит о наших действиях» [Moore 2016: 1]. Л. Ахерн определяет agency как «социокультурно опосредованную способность действовать» [Ahearn 2001: 112].

Отсутствие консенсуса относительно общепринятой дефиниции подытожил В. П. Главеану: «Не[удивительно] для такой сложной концепции, [что] значение слова „agency“ не является однозначным и не существует согласия по поводу его значения». Он выделяет четыре антиномии понятия agency: «(1) agency as complete freedom compared to the absence of freedom; (2) individual agency versus agency of supra-individual agents; (3) agency as expressive versus agency as responsive; and (4) agency as cognitive process versus agency as both a mental and physical reality» [Glăveanu 2015: 247] ${ }^{4}$. И, наконец, касательно перевода понятия agency на русский язык читаем: «У этого слова нет общепринятого перевода, его часто переводят как „,агент“, „,агентность“, „,агентство“, агентивность“, „действие“, „действенность“, „деятельность“. Из-за этого постоянно есть риск спутать "agency" с “agent”, “action", "activity”. При столкновении с некоторыми из теорий на английском языке это станет

${ }^{4}$ «...(1) agency как полная свобода по сравнению с отсутствием свободы; (2) индивидуальное agency по сравнению с agency надындивидуальных агентов; (3) agency как <способ> выражения, а не ответа; и (4) agency как когнитивный процесс, а не как ментальная и физическая реальность». 
особо принципиально, как, например, с теорией морфогенеза М. С. Арчер» [Кучинов 2015].

Минусом перевода термина agency как «агентивность» или «агентность» является и непрозрачность семантики, ассоциирующейся больше с человеческой активностью, чем с его способностью выступать в качестве самостоятельного действующего лица и делать осознанный и свободный выбор, хотя впоследствии именно этот вариант перевода имеет шансы установиться и в социолингвистике, как это произошло, например, в социологии, т. к. однословные переводческие эквиваленты всегда имеют преимущество перед другими вариантами. На данный момент, исходя из вышесказанного, мы не будем останавливаться на каком-то из вариантов перевода, а будем использовать оригинальный английский термин в совокупности тех значений, которые были перечислены выше. Тем не менее переводной термин все же нужен, и задача эта не снимается с повестки дня, поскольку мы предполагаем, что данное направление исследований в социолингвистике будет только шириться.

В 2019 г. вышла в свет книга «Agency in Language Policy and Planning: Critical Inquiries», в которой суммируются теоретические исследования на эту тему и приводятся кейсы из разных регионов мира. Это своего рода промежуточный итог дискурсивного поворота к человеческому фактору в ЯП, и нам хотелось бы привести здесь отрывок из предисловия, звучащий как своего рода манифест нового направления в исследованиях ЯП: «Хотя легко попасть в ловушку рассмотрения языковой политики и планирования как чего-то безликого и абстрактного и сосредоточиться на анализе законов о языке или учебных планов, никогда не следует забывать, что на каждом этапе здесь участвуют люди - от формирования политики до ее реализации на всех уровнях, от наднационального до местного. На всех этапах и на разных уровнях политика обсуждается, интерпретируется и присваивается людьми. Соответственно, современные исследования языковой политики и планирования уделяют особое внимание политическим действиям, предпринимаемым людьми, которые рассматриваются как ключевые политические акторы, агенты или арбитры» [Hult 2018: 1].

В небольшом комментарии, на наш взгляд, нуждается и менее проблемный термин языковой активизм (language activism) и, соответственно, вопрос о том, кого считать языковыми активистами. Языковой активизм определяется как энергичные действия, направленные на использование языка с целью создания, изменения и влияния 
на существующую языковую политику. В этом смысле языковые активисты - это отдельные лица или группы, которые с помощью различных средств активно отстаивают свои права на уважение и свободное использование своих языков в различных, часто публичных областях. Языковой активизм может развиваться как реакция на более масштабные, навязанные государством усилия по подавлению или пресечению использования недоминирующих языков [Combs, Penfield 2012: 462]

В этом принимаемом нами в целом определении языкового активизма есть все же один спорный момент: оно предполагает, что языковые активисты должны «быть шумными, чтобы быть услышанными» [там же: 463]. Несмотря на то, что «шумная» деятельность, безусловно, важна, думается, что более правильным было бы другое, более широкое понимание языкового активизма. Оно фактически представляет собой четвертый из подходов, или отношений к МЯ, различаемых в социолингвистической литературе и включающих в себя: (1) негативную оценку языка; (2) индифферентность, когда у людей нет интереса к языку и, соответственно, к его поддержке; (3) общую позитивную оценку - рассмотрение языка как важного элемента этничности в сочетании с личной неготовностью учить его; (4) личную позитивную оценку — рассмотрение языка как основной культурной ценности и реализация этой позиции на практике [Smolicz, Secomble 1998: 13]. Если человек рассматривает язык как основную культурную ценность и реализует эту позицию на практике, то это означает, что языковой активизм может быть и тихим, личным и практиковаться в более камерной обстановке. Если индивид берет на себя обязательство изучать или учить заново язык своих предков, он практикует своего рода языковой активизм. Если он учит языку своих детей - это тоже языковой активизм. Ключевыми являются действия и результаты, а конечной целью являются дети - носители языка, которые в результате активно говорят на этом языке [Combs, Penfield 2012: 463]. Таким образом, языковым активистом может быть каждый - и тот, кто начал изучать недоминантный язык, будучи уже взрослым, и тот, кто пишет книги и учебники на малых языках, и тот, кто продвигает малые языки в интернете, - список сфер и индивидуальных стратегий языкового активизма может быть бесконечен.

Последним нуждающимся в более подробном освещении термином является, пожалуй, самый популярный и частотный термин $а \kappa-$ тор. Вопрос о том, кого понимать под акторами в сфере ЯП, неизбежно 
выливается в уровнево-типологическое русло. С. Чжао и Р. Бальдауф выделяют следующие четыре типа акторов [Zhao, Baldauf 2012]:

- Люди, обладающие властью (или те, кто занимают государственные должности, осуществляют судебную власть в сфере ЯП)

- Люди, обладающие знаниями (те, кто обладает высоким уровнем экспертных знаний - лингвисты и другие подготовленные эксперты, предоставляющие свои знания для выполнения консультативных функций по вопросам ЯП)

- Люди, обладающие влиянием (ученые, писатели и другие авторитетные члены общества)

- Заинтересованные люди (обычные люди на 'низовом' (grassroots) уровне, кто может участвовать в принятии решений об использовании языка).

И эта, и другие типологии отражают иерархию акторов в сфере ЯП. Наиболее четко эта иерархия видна в другой уровневой классификации, где выделяются супра-макро-, макро-, микро- и инфрамикроуровни. Супра-макроуровень — это уровень государственной ЯП, а инфра-микроуровень - семейной или индивидуальной ЯП [Chua, Baldauf 2011: 940]. В другом варианте типологии акторов Т. Г. Вайли и О. Гарсиа, опираясь на исследования других ученых, проводят различие между (1) акторами на уровне государственного планирования (actors in governmental planning), (2) влиятельными ключевыми лицами, которые обозначаются как «языковые стратеги» (language strategists), (3) de facto planners or arbiters - ключевыми лицами в государственных образовательных учреждениях, школах или университетах, которые помогают формировать образовательную языковую политику или влияют на ее интерпретацию, внедрение или ресурсное обеспечение и (4) заинтересованными лицами (stakeholders), включая семьи и местные сообщества [Wiley, Garcia 2016: 50].

На наш взгляд, в классификации Вайли и Гарсиа несколько искусственным является деление между стратегическим и фактическим типами акторов. В целом нужно иметь в виду и проницаемость уровней, и то, что типология акторов ЯП - это удобный аналитический инструментарий, хотя в действительности их взаимодействие сложнее: «обычные люди» на «низовом» уровне могут стать людьми, обладающими влиянием и т. д., особенно в переломные времена. В странах с сильной централизацией власти, как например в России, решающим моментом в деятельности и позициях акторов на поле ЯП является степень 
их институционализированности, что прямо влияет на наличие или отсутствие у них свободы воли и свободы действий (agency). С учетом этого можно предложить альтернативную типологию акторов ЯП:

1) акторы государственно-законодательного уровня;

2) (институциональные) имплементаторы ЯП в официальных структурах разных уровней - федерального, регионального и муниципального, не обладающие agency;

3) (внеинституциональные) акторы - языковые активисты, члены этнических сообществ, учителя, университетские преподаватели, ученые и т. д., обладающие agency.

Другими словами, если отдельные «игроки» «на поле» ЯП обладают свободой воли и действуют, исходя из собственных представлений (безусловно, неизбежно социокультурно опосредованных) о разных аспектах ЯП, они относятся к третьей категории. Эти игроки могут быть как официальными лицами, членами (региональных) политических и бизнес-элит, лидерами различных организаций и т. д., так и «обычными людьми»: весь вопрос в наличии или отсутствии у них agency. Поэтому слова «институциональные» и «внеинституциональные» в этом списке взяты в скобки: жесткой границы тут нет. Проблема наличия у официальных лиц собственной свободы воли и действий (agency) хорошо иллюстрируется примером из статьи Э. Алос-и-Фонта [Alòs i Font 2019], показывающей, как приоритеты государства «считываются» чиновниками (о механизме этого процесса см. в Разделе 5 «Лингвистические идеологии»). 7 октября 2014 г., за два дня до визита президента Путина в Чебоксары (Чувашия) все таблички с названиями автобусных остановок на центральных улицах между аэропортом и центром города буквально за одну ночь были заменены с двуязычных (чувашско-русских) только на русскоязычные. Автор предполагает, что кто-то в администрации, видимо, был убежден, что президент Путин испытает дискомфорт, увидев на улицах двуязычные вывески, в том числе на региональном языке. Через несколько недель, после серии протестов, вывески опять поменяли, и чувашские названия были на них восстановлены.

И этот, и другие факты, о которых будет сказано в следующих разделах (см., в частности, Раздел 3), свидетельствуют о том, что пока в ЯП российского государства есть противопоставление структуры (системы) и людей, что отражается в теории (в частности, в предлагаемой типологии акторов), но, безусловно, есть также и взаимодействие 
уровней и акторов. Думается, что уменьшение противопоставления и усиление взаимодействия весьма способствовало бы единению и построению более справедливого и демократического общества. Подчеркнем, что при принятой нами широкой интерпретации языкового активизма, которая потенциально может включать любых акторов, проявляющих инициативу и «энергично действующих» для сохранения MЯ, в данной работе акцент делается на «низовом», bottom-up, наименее институционализированном ${ }^{5}$, индивидуализированном уровне ЯП (третья группа в трехуровневой типологии акторов в сфере ЯП).

\section{3. Акторы и agency в языковой политике в России и Западной Европе}

В послевоенной Западной Европе в рамках политики регионализма и защиты прав человека кардинально изменились общественные стандарты. В результате многим национальным меньшинствам - таким, к примеру, как баски или саамы - постепенно удалось достичь значительных успехов в ревитализации своих языков и культур. Так, например, в Стране Басков запрет на обучение на баскском языке был снят в 1960 г., после чего началось возрождение икастол ${ }^{6}$, многие из которых получили покровительство католической церкви. В 1970-х гг. началось изучение баскского языка и обучение на нем в государственных и частных школах, которые посещали в то время, соответственно, $46,4 \%$ и 31,5 \% учащихся Страны басков и Наварры (в икастолы тогда ходили около 22,1\%) [Кожановский 2011: 113].

Как уже упоминалось, наиболее ярко эти изменения видны в появлении в Западной Европе феномена «нового говорящего» (new speaker), в том числе и в Стране Басков. В самом общем плане понятие «новый говорящий» относится к тем социальным акторам, которые используют и претендуют на владение языком, который по самым разным причинам, как правило, не воспринимается как принадлежащий им или «людям вроде них» [Ó Murchadha et al. 2018: 4]. Таким образом, под это

\footnotetext{
${ }^{5}$ Конечно, многие инициативы изначально неинституционального плана впоследствии могут институционализироваться.

${ }^{6}$ Икастолы - школы с преподаванием на эускаре (баскс. эускара — язык басков).
} 
понятие подпадают в том числе мигранты и беженцы, которые, оказавшись в другой стране, осваивают язык этой страны, но не воспринимаются принимающим сообществом как «аутентичные» говорящие, и их аффилиация с языком не воспринимается как естественная.

Но в данной статье мы хотели бы остановиться на этом понятии в контексте миноритарных языков. Хотя в человеческой истории миграции были всегда и автоматически продуцировали «новых говорящих», каковым может считаться любой человек, осваивающий язык, который изначально не был его родным или первым языком, появление «новых говорящих», осваивающих миноритарные, непрестижные, не приносящие дивидендов на современном «лингвистическом рынке» [Бурдьё 2005] языки, - явление новое и беспрецедентное.

Фактически «новые говорящие» идут «против течения», сопротивляясь языковому сдвигу, и есть случаи, когда языки меньшинств обязаны своим существованием только появлению «новых говорящих». Например, хотя было общепризнано, что последний носитель мэнского языка умер в 1974 г., на этом языке сегодня говорят люди, которые усвоили его в основном через образовательные инициативы и благодаря своей личной приверженности языку. Если бы не эти новые говорящие, мэнский язык уже не существовал бы как живой разговорный язык, и в палитре глобального языкового разнообразия стало бы меньше еще одним языком. Таким образом, вклад «новых говорящих» в поддержку языков меньшинств является потенциально серьезной силой для того, чтобы остановить упадок отдельных языков и сыграть роль в остановке более широких процессов языковой гомогенизации во всем мире [Ó Murchadha et al. 2018: 9].

Примеры успешного вмешательства «новых говорящих» в, казалось бы, неизбежные процессы языкового сдвига и исчезновения языков меньшинств не ограничиваются мэнским языком. Говорить о том, что это - тенденция, набирающая силу в европейских странах, позволяют уже довольно многочисленные примеры [см. в: Smith-Christmas et al. 2018; Darquennes, Soler 2019; Puigdevall 2014 и др.]: гэльский язык в Шотландии, уэльский (валлийский) язык в Уэльсе, гернсийский язык / гернсийский диалект нормандского языка ${ }^{7}$, галисийский язык, баскский язык.

7 Остров Гернси находится во владении британской короны, но не является частью Соединенного Королевства. Джулия Саллабанк и Ян Маркиз, авторы статьи о «новых говорящих» на о. Гернси, ссылаясь на предпочтения большинства «новых говорящих», описывают его как язык Giernesiei [’d孔єrnєzjei], а не как диалект [Sallabank, 
В концепте «новые говорящие» следует подчеркнуть их принципиальную разницу со «старыми говорящими». Последние - это люди, которые владеют миноритарным языком просто в силу того, что им довелось родиться в сельской местности в среде, говорящей на этом языке; зачастую формального образования на этом языке у них нет (ср. аббревиатуру NORM [Ó Murchadha et al. 2018: 6], расшифровываемую как «nonmobile, older, rural males» 'немобильные, принадлежащие к старшему поколению, сельские жители, мужчины') — те, кто традиционно считаются носителями миноритарного языка. «Новые» же говорящие противопоставляются «старым» по всем параметрам: это мобильные, молодые городские жители, представители обоих полов. Так, например, в Галиции ${ }^{8}$ термин «неофаланте» 'новые говорящие' стал использоваться и в народе, и в научном сообществе для описания людей, которые выросли, говоря по-испански, но в ключевые моменты своей жизни (как правило, в подростковом или раннем взрослом возрасте) приняли сознательное решение перейти на галисийский язык. Порой это решение включает в себя отказ от говорения на своем первом языке вообще [O’Rourke, Ramallo 2018: 93].

Если в Западной Европе либерализация экономической, политической и социальной жизни после Второй мировой войны повлекла за собой признание ценности многоязычия и культурного разнообразия, то в СССР в это время, напротив, возобладала идеология национального единомыслия и политика продвижения русского языка как языка межнационального общения. На «низовом» уровне, в самих миноритарных сообществах эта политика имела результатом усиление национально-русского двуязычия и русского монолингвизма наряду с падением престижа миноритарных языков. Эти процессы хорошо известны и описаны в огромном количестве работ. С точки зрения нашего исследования здесь примечательно то, что языковой активизм как явление в Советском Союзе отсутствовал. Начало языкового активизма - это, пожалуй, конец 1980-х — начало 1990-х гг, когда в преддверии и после распада Советского Союза на фоне политического и экономического кризиса в стране произошла мобилизация этнического самосознания, всплеск

Marquis 2018: 67-90]. При этом гернсийского языка нет во Всемирной базе языков Ethnologue, что хорошо отражает разницу интерпретаций того, что считать языком и что - диалектом, в зависимости от того, является ли это мнением самого лингвосообщества или взглядом извне, а также от политических и иных факторов.

8 Галисия - историческая область на северо-западе Испании. 
этнонационализма и регионализма. Этот период менее интересен с точки зрения целей нашей статьи в силу того, что, во-первых, инициаторами движений этого периода были национальные элиты [Замятин 2018; Соколовский, Подлесных 2019: 75] и национальная интеллигенция, во-вторых, эти движения шли преимущественно в институциональном поле и вылились, соответственно, в придание статуса государственных языкам национальных республик РФ и принятие законов о языках. Таким образом, как с точки зрения «игроков», так и уровней ЯП это в большей степени макроуровневые действия, и из четырех групп акторов, выделяемых Чжао и Бальдауфом, ЯП формировалась в тот период в первую очередь людьми, обладающими властью, знаниями и влиянием.

Несмотря на то, что инициативы 1990-х гг. — это тоже языковой активизм, нас, как уже было сказано, интересуют современные bottom-up инициативы и «игроки» на этом поле. Но и в синхроническом плане в рамках одной статьи совершенно невозможно описать даже часть такого масштабного явления, как современный российский языковой активизм. Говоря «масштабный», мы имеем в виду не размах самого движения: это не мейнстрим, а скорее тенденция, которая, тем не менее, имеет тот же вектор развития, что и общемировые, в частности, западноевропейские тенденции в сфере многоязычия, описанные выше. Под масштабностью мы имеем в виду размер страны и разнообразие языковых ситуаций с самых разных точек зрения: статуса МЯ в РФ (государственные языки в республиках РФ, официальные языки, языки коренных малочисленных народов и др.), количества говорящих или членов этнической группы, степени сохранности языков, развитости языкового активизма и т. д.

Здесь нам хотелось бы начать с одного полевого социолингвистического исследования, которое автор данной статьи проводила в 20042006 гг. на территории этнической Бурятии ${ }^{9}$ с целью выявления факторов, способствующих сохранению или исчезновению бурятского языка. Одним из выводов исследования было то, что бурятская этническая общность рассматривает язык как важный элемент этничности в сочетании с личной неготовностью изучать его и учить ему

9 Под этнической Бурятией в современной монголистике понимается регион компактного проживания современных бурят на территории Российской Федерации. Этот регион включает в себя Республику Бурятия, бывший Усть-Ордынский Бурятский автономный округ (ныне часть Иркутской области) и Агинский Бурятский автономный округ (ныне часть Забайкальского края). 
своих детей [Хилханова 2009: 336-337]. Это третий из четырех подходов, или отношений, к миноритарным языкам, о которых говорилось в Разделе 2. Другими словами, национально-культурное возрождение в те годы проявлялось в изменении субъективно-детерминированных параметров языковой ситуации, т. е. в изменении ценностных установок и общем позитивном отношении к миноритарным языкам не только бурятской этнической группы, но и многих других миноритарных сообществ России (см., например: [Алпатов 2018; Вахтин 2001; Боргоякова, Гусейнова 2017; Куцаева 2018]). Этот разрыв между символическим и реальным (практическим) уровнями отношения к языку и речевого поведения достаточно типичен и зафиксирован в разных странах мира [Алпатов 2000: 204; Ó Duibhir et al. 2015]. Отношение к языку как к символической ценности без подкрепления реальными действиями может продолжаться довольно долго; особенно показателен здесь пример с ирландским языком, который, несмотря на благоприятные внешние условия - статус первого официального языка, институциональную поддержку, преподавание его в школе, все же очень медленно входит в сферу реального речеупотребления [Mac Giolla 2012].

С момента вышеупомянутого исследования прошло более 10 лет, и мы можем констатировать, что, хотя и сейчас для родителей характерен перенос ответственности за освоение МЯ с себя на систему образования [Бабич 2019], сегодня не только в этнической Бурятии, но и по всей России мы наблюдаем и четвертый подход - рассмотрение языка как основной культурной ценности и реализация этой позиции на практике. По нашим данным и данным других исследователей языков России [Alòs i Font 2019; Хилханова 2019; Репортаж 2020 и др.], растет количество «низовых» инициатив (grassroots initiatives), когда люди начинают учить миноритарные языки и инициировать разные проекты в области их сохранения и продвижения.

Несмотря на обилие сведений, где сообщается о тех или иных проектах и инициативах, подпадающих под определение языкового активизма, анализ его с теоретической точки зрения на российском материале, насколько нам известно, еще не был сделан. Основной причиной этого является, конечно, сама внелингвистическая природа языкового активизма, сразу выводящая его за пределы интереса ученых, занимающихся сугубо языками, их документацией, описанием и анализом (ср.: «процесс, который мы называем возрождением языка, является не языковым, а прежде всего, социальным явлением, которое должно интерпретироваться исходя из интересов языкового сообщества» 
[Марусенко 2014: 147]). Сами же языковые активисты слишком заняты делом - сохранением миноритарных языков. Поэтому в этом разделе приводится данный в первом приближении собирательный «портрет» современного российского языкового активиста, дающий представление об акторах и agency в этом поле.

Во-первых, современный российский активизм имеет городской характер. «Языковым активизмом занимается продвинутая интеллигенция и „городская хипстота“, а говорят на языках в основном сельские люди» [Специальный проект]. Это отмечалось и лингвистами на заседании дискуссионно-аналитического клуба по языковой политике в Институте языкознания РАН 17 марта 2020 г. Как подчеркнула О. А. Казакевич, «видимо, надо, чтобы язык совсем почти умер, чтобы он приехал в город», приведя в качестве примера курсы селькупского в Томске и Абашево, которые пользуются спросом среди местного населения. Аналогичные тенденции, особенно за последние три года, были отмечены А. В. Дыбо в Хакасии, когда «Абакан поднялся и бросился на борьбу за хакасский язык» [Репортаж 2020]. Удивительным образом язык, «выйдя» из деревни, возвращается (напомним, что мы говорим только о начальной тенденции) в этническое сообщество (понятие языковое сообщество не всегда здесь применимо ввиду утери языка многими этническими группами) через его более «продвинутых» горожан.

Следующей чертой является гетерогенность группы языковых активистов, среди которых В. Харитонов и Ф. Алексеев выделяют «внутренних» и «внешних» языковых активистов. Первые являются частью этнического общества и волнуются за судьбу своего языка, а вторые это те, кто вдруг почему-то решил заняться языком народа, к которому изначально не имел отношения [Алексеев, Харитонов 2020]. К «внешним» языковым активистам авторы также относят иностранцев, которые занимаются не (только) научным изучением, но и проектами по поддержке МЯ России как из-за рубежа, так и внутри самой страны. К последним принадлежат такие известные языковые активисты и социолингвисты, как Эктор Алос-и-Фонт, который успешно работает как на научном поле, так и в проектах по сохранению чувашского языка.

И, наконец, необходимо отметить преимущественно молодежный характер современного российского языкового активизма. Зачастую это молодые люди, которым, как и «новым говорящим», миноритарный язык не был передан «естественным» путем, но поиск своей идентичности в глобализованном мире заставляет их к нему обратиться. Новое поколение выбирает и новые стратегии изучения, сохранения 
и продвижения МЯ, делая ставку на интернет-технологии (подробнее об этом см.: [Хилханова 2019; Pischlöger 2010; 2016]).

Все три характеристики воплощаются в одной из наиболее впечатляющих «низовых» инициатив всероссийского масштаба - проекте «Страна языков» (см. группу в социальной сети Vkontakte и вебсайт https://stranayaz.ru). Инициаторы и реализаторы проекта - языковые активисты Василий Харитонов и Федор Алексеев. «Страна языков» объединяет всевозможные материалы, информацию, новости, ссылки на учебные проекты по языкам разных народов России, формулируя свое кредо следующим образом: «Россия богата не только нефтью, классической литературой и достопримечательностями. В нашей стране говорят на огромном количестве уникальных языков, многие из которых находятся под угрозой исчезновения. Страна языков - площадка, где языковые активисты могут обмениваться опытом, идеями и энергией» [Страна языков].

Итак, в этом разделе были рассмотрены «новые говорящие» (в Западной Европе) и языковые активисты (в России). Это не значит, что первые существуют только в Западной Европе, а вторые - в России. «Новые говорящие» также являются языковыми активистами, только ушедшими дальше по некоей шкале континуума Смолича и Секомбле: они рассматривают язык как основную культурную ценность и реализуют эту позицию в своих личных практиках. Языковые активисты это «зонтиковый» термин, включающий в себя и «новых говорящих», но если языковым активистом можно быть, занимаясь только организационной и иной деятельностью на благо МЯ, стать «новым говорящим» можно, лишь самому осваивая МЯ, что тоже является разновидностью языкового активизма. И в том, и в другом случае, конечно, очень важен общественно-политический контекст деятельности языковых активистов. О нем и пойдет речь в следующем разделе.

\section{4. Общественно-политический контекст языкового активизма в России и Западной Европе}

В исследованиях «новых говорящих» и их роли в языковой ревитализации говорится о том, что они были фактически результатом ЯП действующих правительств и соответствующих институциональных мер [Darquennes, Soler 2019]. Действительно, важным моментом 
в решении освоить МЯ, помимо желания (мотивации идентичности), является то, что у этих людей была и такая возможность. Это значит, что МЯ преподавался в школе в том объеме, который позволяет человеку выйти на уровень говорения. Как говорится в [O’Rourke, Ramallo 2018: 94], «новые говорящие» на галисийском — это продукт языковой политики в этом регионе с 1980-х гг. после перехода Испании к демократии и включения галисийского языка в те сферы использования, в которых он раньше отсутствовал, в том числе в сферу образования и государственного управления.

Тем самым феномен «новых говорящих» вносит вклад в дискуссию о роли образования в сохранении и развитии МЯ, несколько подрывая аргументы тех, кто считает, что язык передается только в семье, и если этого не происходит, никакие образовательные меры не помогут. Получается, что нет: языковая политика в сфере образования может что-то изменить, правда, в комплексе с другими мерами, какие принимаются в таких регионах, как Каталония, Страна Басков, Уэльс, Южный Тироль. Там соответствующие языки пользуются политическим приоритетом и поддерживаются общественностью и правительством. Это означает что стороны готовы финансово инвестировать в язык [Gardner 2005]. Уровень самоуправления в этих регионах достаточно высок, следовательно, регион может сам выбирать, куда и как вкладывать налоговые деньги. Там МЯ рассматриваются не просто как часть этнокультурной идентичности, но и как необходимые для должностей в государственном секторе экономики. Например, в Стране Басков знание баскского языка считается важным преимуществом - до такой степени, что это мотивирует испаноговорящих родителей отправлять своих детей в школу с баскским языком обучения, с тем чтобы укрепить будущие позиции своих детей на рынке труда [Van Dongera et al. 2017: 55].

Следует особо отметить, что такая тенденция зафиксирована не повсеместно в западноевропейских странах. Наряду с новыми подходами, продуцирующими «новых говорящих» и демонстрирующими порой удивительные примеры возрождения языков (к примеру, мэнского или инари-саамского), сохраняются также старые подходы и идеологии, когда МЯ слабо представлены в сфере образования и в целом им не уделяется внимание как со стороны властей, так и самих миноритарных сообществ. Пример первого подхода мы наблюдаем в регионах с высоким уровнем (а) политической автономии и (б) регионального (или этнического) самосознания: Каталония, Страна Басков, Галиция, 
кельтские регионы, саамский регион в Финляндии [Пасанен 2011; Gardner 2005; Gorter, Cenoz 2011; Toivanen 2015; Van Dongera et al. 2017]. При отсутствии этих факторов позиции МЯ остаются слабыми, как, например, в случае с фризским языком в Нидерландах или сорбским в ФРГ [Gorter, Cenoz 2011; Toivanen 2015]. Так, во Фрисландии фризский язык используется в основном в ситуациях неформального общения в семье, общения внутри сообщества и в неквалифицированных профессиях. Межпоколенческая передача языка под вопросом, он не идет в табель успеваемости, поэтому не рассматривается как условие социально-экономического успеха и в самом миноритарном сообществе не считается важным [Gorter, Cenoz 2011: 661].

Подчеркнем, что в современных условиях фактор самосознания / идентичности не менее важен, чем политическая автономия. Например, «классической» страной, где поддерживается один официальный язык и традиционно проводится жесткая ЯП по отношению к МЯ, считается Франция [Бичурина 2012; Ле Коадик 2013; Пестей 2013]. Однако сегодня и во Франции происходит повышение статуса региональных и миноритарных языков, который Н. М. Бичурина вслед на П. Бурдье называет «актом социальной магии», основывая свой анализ на изучении «малых романских языков» на юго-востоке Франции: окситанского (провансальского) и франкопровансальского (арпитанского / савойского) [Бичурина 2012: 88]. Снижение давления государства в сфере ЯП, действительно, переносит фокус инициативы на сами миноритарные сообщества, языковых активистов.

Конечно, как в любой стране, языковые ситуации во Франции отличаются от региона к региону: в одних мы можем говорить о появлении «новых говорящих», как в Испании, к другим более применим термин «языковой активизм». В регионе Рона-Альпы, судя по данным, приведенным Н. М. Бичуриной, речь идет скорее о борьбе языковых активистов за большее признание своего идиома, его сохранение или ревитализацию. В отношении бретонского языка французский лингвист Ле Коадик говорит об «эффекте ножниц, который выражается в том, что вот уже на протяжении нескольких десятилетий практическое использование языка сокращается, тогда как интерес к нему постоянно растет» [Ле Коадик 2013: 104]. При этом в другом регионе - на острове Корсика - есть и «новые говорящие» - молодые люди, для которых корсиканский язык не является родным языком, и большинство выучило его в возрасте после 18 лет, будучи активистами корсиканского движения либо просто находясь в поисках идентичности [Пестей 2013]. 
Сегодня корсиканский язык из языка, на котором в начале XX в. говорило население острова, на тот момент в основном сельскохозяйственное и живущее в предгорьях, стал языком населения городов и пригородов, занятого преимущественно в третьем секторе. В целом участники процесса языковой ревитализации считают, что ситуация находится на подъеме, и признают достигнутый прогресс. Они ставят перед собой цель к 2030 г. обеспечить возможность двуязычного обучения во всех школах острова [там же: 137].

Таким образом, в западноевропейских странах и общественнополитический контекст, и движимая мотивацией идентичности деятельность языковых активистов имеют значительно отличающуюся региональную специфику. Но тенденции таковы, что, даже если внешний контекст неблагоприятен, движение в поддержку МЯ ширится, и «новые говорящие» появляются даже в странах, где официальная ЯП не поддерживает миноритарные и региональные языки. О том, что активная деятельность людей, позиция самого миноритарного сообщества становятся все более важными, прекрасно сказал Р. Ле Коадик в статье с говорящим названием «Мы столкнулись с врагом, и он - это мы: бретонский язык вчера, сегодня, завтра»: «У бретонского языка на протяжении его истории было несколько врагов. Внешний враг французское государство, в значительной мере базирующееся на общефранцузском языковом единстве - конечно, сыграл свою роль. Но существует и внутренний враг - сами бретонцы, подчинившиеся государственной идеологии монолингвизма, смирившиеся со своим коллективным положением угнетенного меньшинства и отказавшиеся от своего языка ради социальных выгод. Сегодня государство более не занимает враждебную позицию в отношении региональных языков как таковых. Оно лишь препятствует их возможной институционализации. Что же касается бретонцев, они сами становятся отчасти врагами бретонского языка, когда позволяют себе самоуспокоенность относительно его будущего, проявляют безразличие или недостаток инициативы. Нет спору, язык понес невосполнимые утраты, но еще не все потеряно» [Ле Коадик 2013: 122].

Перейдем теперь к России и посмотрим, насколько инициативы языковых активистов вписываются в общественно-политический контекст современной России, каково соотношение их действий с ЯП государства и ее имплементацией на институциональном уровне. Чтобы ответить на этот вопрос, необходимо рассмотреть нынешний вектор государственной языковой политики и системную (институциональную) реакцию 
на «низовые» инициативы. Говоря об институциональном уровне, мы сосредоточимся на системе образования как наиболее важной для ЯП.

Примерно после 2000-х гг. произошла «корректировка национальной и языковой политики в стране в целом» [Мартынова 2019: 61], или «перезапуск политическим руководством страны государственной этнонациональной политики» [Попков, Костюк 2015]. Наиболее ощутимо эта корректировка проявилась в сфере образования. Сначала из ФГОС в 2007 г. был удален национально-региональный компонент. В 20152016 гг. были утверждены и приняты Примерные основные образовательные программы общего образования [ПрООП]. Из пяти вариантов учебного плана, предлагаемых на ступени основного общего образования, лишь в двух (вариантах 4 и 5) содержится предмет «Родной язык» ${ }^{10}$, при этом вариант 5, который предназначен для школ с родным (нерусским) языком обучения, отпадает для многих национальных регионов ввиду отсутствия там таких школ. Поэтому единственно возможным остается вариант 4, в котором изучение государственного языка субъекта РФ возможно в объеме 3 часов, и это реализуемо лишь в условиях 6-дневной учебной недели. Поэтому многие родители отказываются от изучения родного языка, если это нерусский язык [Боргоякова 2013], дабы не увеличивать нагрузку для детей, да и для школ более желательна 5-дневная учебная неделя как финансово менее затратная.

Если эти изменения прошли относительно незаметно для широкой общественности, не вызывая широкого резонанса, то вопрос об изучении государственных языков в национальных республиках РФ вышел далеко за пределы образовательного пространства, и совокупность дискурсов 2017-2018 гг. вокруг этого уже квалифицировалась как языковой конфликт [Михальченко 2019: 18; Wingender 2018]. Позиция государства была манифестирована в Федеральном законе от 3 августа 2018 г. № 317-Ф3 «О внесении изменений в статьи 11 и 14 Федерального закона „Об образовании в Российской Федерации“», символическое значение ${ }^{11}$ которого оказалось крайне негативным для миноритарных со-

${ }^{10}$ Напомним, что это было до внесения изменений в Федеральный закон «Об образовании в Российской Федерации», когда русский язык также получил статус родного языка. До этого под родными языками имелись в виду только нерусские языки, и в ПрООП отражена именно такая интерпретация.

${ }^{11}$ В фактическом плане, согласно «Методическим рекомендациям органам исполнительной власти субъектов Российской Федерации, осуществляющим государственное управление в сфере образования, по вопросу изучения государственных 
обществ: в регионах осталось стойкое убеждение, что государство четко обозначило свое отношение к МЯ как к дисциплине «второго сорта» ${ }^{12}$, ведь «почему-то никто не требует от родителей заявлений о добровольном обучении математике и биологии, и что подобное требование к школе является нонсенсом» [Якут.]. Общественность, как известно, раскололась на две группы, преимущественно по этническому принципу: русские были в основном против обязательности изучения государственных языков национальных республик, представители других этносов - за (подробнее об этом см., напр., [Мартынова 2019; Соколовский, Подлесных 2019]. Несмотря на небывалую с 1990-х гг. протестную активность общественности в национальных регионах (родительских сообществ, преподавателей, учителей, правозащитников и т. д.), государство провело свою линию, выступив фактически в поддержку русского языка.

Однако у поправок в ФЗ «Об образовании в РФ», помимо того, что они всколыхнули волну языкового активизма и до, и после их принятия, есть и другая, менее заметная, но важная в перспективе сторона. Они делают акцент на инициативе и индивидуальных правах граждан, ведь, чтобы реализовать свое право на изучение родных (в данном случае нерусских) языков, родители должны написать соответствующие заявления. Также они могут консолидироваться, чтобы сформировать группу детей, т. к. право на изучение родного языка осуществляется «в пределах возможностей, предоставляемых системой образования» [ООРФ]. Недостаточное количество желающих как раз может стать

языков республик, находящихся в составе Российской Федерации» [МетРек], изучение родных языков (в том числе русского) в соответствии с новой редакцией ФГОС включено в инвариантную часть учебного плана, и теперь с учетом предмета «государственный язык» часов в учебном плане на изучение родных языков остается столько же, сколько и ранее.

12 Напомним, однако, что эти дискуссии касались только языков, имеющих статус государственных в республиках РФ, и не затрагивали языки с официальным статусом, или официальные языки (например, бурятский язык в Агинском Бурятском округе Забайкальского края, ненецкий язык в Ямало-Ненецком автономном округе, Ненецком, Ханты-Мансийском автономных округах и др.), а также языки коренных малочисленных народов. Поэтому и негативный эффект от понижения статуса государственных языков в виде уменьшения количества учеников, желающих изучать родные (нерусские) языки, был только в этих регионах, но он гораздо менее существенен, чем ЕГЭ по русскому языку, являющийся определяющим фактором выбора языка в школе. 
основанием для отказа в предоставлении данной образовательной услуги. Тем самым закон создает потенциальную платформу для языкового активизма в образовательной сфере, тем более что опыт западноевропейских стран дает достаточно примеров того, как граждане могут объединиться, если они желают, чтобы их дети обучались на МЯ.

Все вышеперечисленные факторы (ПрООП, добровольность изучения родных (нерусских) языков в сочетании с обязательным ЕГЭ по русскому языку) выстраиваются в определенную систему, в которой нерусские языки как бы сами собой «выдавливаются» из образования как институциональной сферы. В. А. Тишков называет это «структурным насилием», понимая под ним действующие правовые и другие нормы, а также институциональные параметры общественно-культурной жизни, которые лишают индивида возможности реализовать свои языковые запросы и потребности, а также и права. В частности, невозможность сдавать аттестационные школьные экзамены на нерусских языках рассматривается им как одна из форм структурного насилия [Тишков, Акбаев 2019: 26].

Описанные выше тенденции в сфере образования происходят параллельно с заметным повышением внимания к роли государственного русского языка, о чем свидетельствует ряд решений на высшем уровне: Правительством РФ утверждена целевая программа «Русский язык» на 2001-2005 гг. (1996), восстановлен ликвидированный в 1997 г. Совет по русскому языку при Правительстве РФ (2005), разработан новый вариант законопроекта «О государственном языке РФ» (2005 г.) [Мартынова 2019: 61-62], принята Федеральная целевая программа «Русский язык» на 2016-2020 гг. с финансированием 7604,5 млн рублей, в том числе за счет средств федерального бюджета - 6767,5 млн рублей [ФЦП]; образован Совет по русскому языку при Президенте РФ (2014), утвержден новый состав Совета по русскому языку при Президенте РФ по русскому языку (2019) и т. д.

Этот поворот в национальной и языковой политике страны представляет, по сути, вступление России на новый виток нациестроительства, где в укреплении государственного единства важная роль отводится русскому языку [Стратегия 2012] и русскому этносу, что эксплицитно отражено и в поправках в Конституцию РФ, где появляется понятие «государствообразующего народа» [Полный текст]. При этом государство пытается сохранить межнациональное согласие и межъязыковой баланс, что зафиксировано и в новой редакции Конституции (см. статью 68, п. 3 и статью 69, п. 2) [там же], и в таких мерах, как 
учреждение Фонда сохранения и изучения родных языков народов РФ, Института родных языков, премии за вклад в сохранение и возрождение языков коренных народов и за освещение событий года языков коренных народов в СМИ и т. д.

Двойственность такой позиции явственно отражена и в поправках в Конституцию РФ, где «государствообразующий народ» входит «в многонациональный союз равноправных народов Российской Федерации», что многими рассматривается как противоречие (см., например: [Гавриленко и др. 2020]). Противоречивость официальной ЯП РФ подчеркивается и в заключении Консультативного комитета рамочной конвенции по защите национальных меньшинств в Российской Федерации, принятой 20 февраля 2018 г.: «Russian society continues overall to be characterised by a climate of appreciation for ethnic diversity. The Russian Federation has maintained a flexible and pragmatic attitude to the scope of application of the Framework Convention. The country's immense variety of ethnic groups, languages and religions is still largely perceived as an asset and multiple identities as natural. However, official minority policies are framed in a way that appears to emphasise the significance of the Russian ethnicity and language as the core of an overarching all-Russian national identity» ${ }^{13}$ [Advisory Committee 2018]. Такие же противоречия эксперты видят и в Стратегии государственной национальной политики РФ на период до 2025 г. (далее - Стратегия) [Попков 2016].

В целом, как говорил В. А. Тишков, прямого насилия (запрет на пользование языком, языковые инспекции и наказания и т. п.) в Российской Федерации не существует, но структурное насилие существует [Тишков, Акбаев 2019: 26]. Ученый и языковой активист по сохранению вепсского языка 3. И. Строгальщикова формулирует это следующим образом: «Большая часть решений властей являлась ответом, часто запоздалым и малоэффективным, на инициативы вепсской общественности» [Строгальщикова 2016: 166], отмечая в целом отсутствие постоянного взаимодействия между органами власти регионов проживания

13 «Российское общество в целом по-прежнему характеризуется атмосферой признания этнического разнообразия. В области применения Рамочной конвенции Российская Федерация придерживалась гибкой и прагматичной политики. Множество этнических групп, языков и религий страны продолжает в значительной мере восприниматься как преимущество, а разнообразие идентичностей — как естественный факт. Тем не менее официальная политика в отношении меньшинств подчеркивает, как представляется, значение русской этнической принадлежности и русского языка как основы общероссийской национальной идентичности». 
вепсов и игнорирование властями данных проблем. Ею же подчеркивается, что «с институциональной точки зрения часть из программы вепсского возрождения удалось реализовать, но в основном за счет усилий общественности. По отношению к вепсам пока действует известный принцип: права меньшинств возникают, когда они востребованы» (курсив мой - Прим. Э. Х.) [там же].

В этом смысле ситуация с вепсским языком типична для МЯ России, поэтому нет смысла множить примеры, иллюстрирующие взаимодействие «власти и народа» в области ЯП. Думается, что приведенных фактов и аргументов достаточно, чтобы сделать вывод о том, что государственная ЯП РФ, пусть и не сформированная в виде доктринального документа, по-прежнему недружелюбна интересам миноритарных сообществ и их языков, хотя в основополагающих государственных документах заявлены цели «сохранения и развития этнокультурного многообразия народов России, их этнокультурной самобытности» [Стратегия]. Государство, опасаясь этнического сепаратизма, проводит политику централизации и поддержки (обще)государственного русского языка. Миноритарные языки и сообщества не совсем вписываются в эту парадигму, что создает системно-обусловленное противопоставление системы и agency и описанные выше трудности в действиях «низовых» акторов — языковых активистов.

Но ситуация с миноритарными языками в России схожа с ситуацией в странах с жесткой языковой политикой, таких как Франция, где государство препятствует институционализации данных языков, но запретить усилия своих граждан по сохранению МЯ не может. В таких условиях более серьезным препятствием становится не внешний, а «внутренний враг» (по выражению Р. Ле Коадика) - находящиеся в головах у людей лингвистические идеологии, являющиеся «концепциями $\langle.$. коммуникативного поведения, реализующими коллективное предписание» [Gal, Woolard 1995: 30]. О них и пойдет речь в следующем разделе.

\section{5. Лингвистические идеологии}

Лингвистические идеологии - системы убеждений, установок и идей, которые носители имеют о языке/языках и их связи с социальными ценностями [Woolard 2003; Kroskrity 2000: 5] Они имеют аффективное измерение и связаны с тем, что Дж. Кавано называет 
«социальной эстетикой языка» [Cavanaugh 2009: 194-195]. Лингвистические идеологии также определяются как образы социально желательных форм использования языка и идеального социального языкового ландшафта, которые сами являются частью и/или производными от более крупных, часто исторически укоренившихся социально-политических идеологий [Blommaert 2006: 244].

Лингвистами выделяется много идеологий, служащих препятствием использованию, освоению и продвижению МЯ. Это и фольклоризация, и гипертрадиционализация (см., напр., [Sallabank, Marquis 2018]), и ассоциация языка только с прошлым и стариной (см., напр., [Боргоякова, Гусейнова 2017; Хилханова 2009]). Многие идеологии вращаются вокруг понятий легитимности и «владения» языком, аутентичности, причем последняя идет рука об руку с пуризмом [Pischlöger 2010, 2016]. В реальной жизни эти идеологии переплетены друг с другом и действие их осуществляется комплексно; нередко противоречивые идеологии сосуществуют в головах одних и тех же людей. Очевидно, что теоретическая статья сравнительного макросоциолингвистического характера не предполагает подробный анализ данных идеологий, однако и теоретический анализ будет неполон, если не показать, как лингвистические идеологии могут выступать в качестве внутреннего регулятора поведения людей в вопросах, связанных с языками. Попытка примирения макро- и микроуровня делается в данном разделе посредством ограничения и фокусации: говоря о Западной Европе, мы ограничимся одним регионом, говоря о России - одной идеологией.

Лингвистическим идеологиям, действующим в отношении гернсийского языка на о. Гернси, посвящена работа Д. Саллабанк и Я. Маркиза под названием «,Мы так не говорим“: Право собственности на язык и (де)легитимация новых говорящих». Авторы изучают эти идеологии в контексте появления «новых говорящих» и языковых активистов, пытающихся учить гернсийский язык и способствовать его ревитализации. Их исследование показало, что для жителей острова, особенно традиционалистов, чья привязанность к своему языку связана с ностальгической идеализацией, изменения языка воспринимаются как пагубные и ведущие к дегенерации. Д. Саллабанк и Я. Маркизом был выявлен целый ряд преимущественно негативных реакций на вариации и изменения в гернсийском, главным образом среди «старых» говорящих, но также интернализованных новыми говорящими и теми, кто еще только учит гернсийский язык. Эти представления отражают опасения утраты права собственности (ownership) на язык: что новые 
говорящие могут «взять его, убежать с ним и сделать его своим собственным» [Sallabank, Marquis 2018: 75]. Это усиливает представления о том, что (гернсийский) язык принадлежит только тем, для кого он является «родным» (native speakers), т. е. «традиционным» говорящим, которые считают себя «хранителями» гернсийского языка, но в большинстве своем не передали его своим детям и используют его все реже и реже [там же: 74-75]. Несмотря на это противоречие, в глазах многих «традиционных» говорящих, обладающих престижем в сообществе, только они являются легитимными «владельцами» (гернсийского) языка, и на этом основании они играют демотивирующую роль в ревитализации гернсийского языка. Когда «новые говорящие», изучающие язык, пытаются говорить со старшим поколением, они часто получают в ответ реакцию в виде гиперкоррекции: «мы так не говорим» или «вы никогда не произнесете это так, как это делаем мы». Отсутствие толерантности к ошибкам и изменениям в языке, неизбежно привносимым «новыми говорящими», ведет к тому, что некоторые отказываются от изучения гернсийского языка. Таким образом, в исследовании Саллабанк и Маркиза хорошо показано, как идеологии переплетаются друг с другом: идеологии «владения языком» и «языка прошлого» названы «идеологиями-близнецами» (twin ideologies); они, в свою очередь, связаны с широко распространенными идеологиями аутентичности и «правильности». При этом авторы видят некий парадокс в том, что люди настаивают на «правильности» в языке, который не является стандартизированным и даже полностью описанным.

Такие же идеологии, как правило, действуют во многих миноритарных сообществах, и российские не являются исключением. Но, поскольку эта тема относительно нова для российской социолингвистики, публикаций отечественных ученых о лингвистических идеологиях в России мало (см., напр., [Баранова 2010; Баранова, Федорова 2018; Соколовский, Филиппова 2019; Харитонов, Степина 2020], большинство принадлежит западным ученым (см. [Ferguson 2016a, 2016b; Graber 2017 и др.]). Среди идеологий, препятствующих развитию гражданских инициатив, включая языковой активизм, следует в первую очередь упомянуть особенности массового сознания россиян - унаследованное с советских и более ранних исторических времен восприятие государства как патерналистской силы, «гражданско-политический инфантилизм, который до сих пор сковывает многих россиян по рукам и ногам» [Баталов 1995: 63], ощущение, что «от людей ничего не зависит». Однако, если по мере увеличения временно́й дистанции, отделяющей 
нас от советского периода, и с появлением молодого поколения гражданская пассивность постепенно уходит в прошлое, то другие идеологии продолжают определять отношение к МЯ и их носителям и сейчас.

Как уже говорилось, мы вынуждены остановиться на одной лингвистической идеологии, являющейся наиболее существенным препятствием многоязычию - это, на наш взгляд, укорененная в массовом сознании «одноязычная идеология», которая в России выглядит как русский монолингвизм. Как писал А. А. Бурыкин: «Билингвизм в целом не характерен для русской языковой ментальности. На уровне обыденного сознания владение и пользование языками иных этносов носителями данной ментальности не поощряется и не приветствуется» [Бурыкин 2004a] (см. также [Zamyatin 2015: 286]). Тому есть и статистическое подтверждение: только 0,6 \% из этнических русских говорили на региональных языках или языках коренных народов России, и тенденция русских оставаться одноязычными продолжается и даже усиливается [Mikhalchenko, Trushkova 2003]. То, что говорить на родном (нерусском) языке в присутствии русскоговорящих считалось «неприличным» почти во всех регионах бывшего СССР [Бурыкин 2004b: 27], также является проявлением «одноязычной идеологии» на уровне коммуникативного поведения. В упоминавшемся выше полевом исследовании Э. В. Хилхановой информанты не раз говорили о том, что в советские годы в городе людям делались замечания или давались пейоративные оценки из-за того, что они говорили на бурятском языке в общественных местах (об аналогичных случаях в Якутии см. [Ferguson 2016b: 99]).

Касательно современного периода исследователи также пишут о «жесткой монолингвальной установке и неприятии иных языков для части российского общества» [Баранова, Федорова 2018: 44] в статье, посвященной российскому городскому многоязычию. Следствием такой установки является то, что в современном российском обществе владение русским языком (а не каким-либо еще из языков, распространенных в отдельных регионах России) является нормативным и ожидаемым для мигрантов, а представления о нормах русского языка рассматриваются как крайне жесткие и обязательные, в том числе и для не-носителей. В то же время в статье отмечены и трансформации, происходящие в поведении русскоязычных жителей больших городов, постепенно приходящее осознание реально существующего в городе многоязычия. В Заключении авторы выражают надежду на возможность постепенного изменения отношения к многоязычию [там же: passim]. 
В [Харитонов, Степина 2020] для обозначения монолингвальных установок используется термин монолингвальный габитус, под которым авторы понимают «общественные установки и практики, при которых монолингвальность считывается как дефолтное, «нормальное» качество социума, в то время как многоязычие проблематизируется. При этом таким монолингвальным установкам противостоит фактическое многоязычие т. н. «слышимых» меньшинств, которое может быть скрытым в силу стигматизации и социальной исключенности. Эксплицитное проявление негативных установок в отношении многоязычия мы называем глоттофобией» [там же: 93]. Выводы авторов базируются на анализе текстов на темы языковой политики и языковой ситуации в России, комментариев к ним, интервью и данных тематического опроса в социальных сетях.

В социальной сети Facebook 7 марта 2020 г. был размещен пост о том, что некий гражданин обратился в прокуратуру с заявлением против нерусского названия детского этнокультурного центра дополнительного образования в Ханты-Мансийске. Центр назывался «Лылынг союм» (в переводе на русский «Живой ручеек»), «а теперь никак не называется, т. к. прокуратура заставила центр снять вывеску с этим названием. Прокуроры объяснили, что мы живем в России и таких названий быть не должно» [Бульбинская 2020]. В данном случае действия этого написавшего заявление гражданина были продиктованы не чем иным, как нормативным «коллективным предписанием» - идеологией (русского) монолингвизма. Это, безусловно, далеко не единичный пример того, как лингвистические идеологии, укоренившиеся в массовом сознании, управляют поведением людей.

Итак, в этом разделе было показано, как лингвистические идеологии оказывают влияние на ЯП, обусловливая принятие разных решений языкового характера на индивидуальном и семейном уровнях: изучать или не изучать МЯ, говорить или не говорить на нем на публике и т. д. В конечном итоге совокупность этих решений выливается в кардинальный вопрос: жить или не жить миноритарному языку, поэтому важность вскрытия лингвистических идеологий трудно переоценить. Хорошей новостью здесь является то, что лингвистические идеологии, как и идеологии в целом, изменчивы, и мы являемся свидетелями того, как они постепенно меняются в сторону большей либеральности и толерантности. Думаем, многие разделяют впечатление, высказанное А. Б. Шлуинским о том, что «общественный менталитет меняется. Когда я 15 лет назад говорил, что еду в экспедицию изучать 
никому не известный малый язык, то люди, не связанные профессионально с лингвистикой, смотрели на меня как на сумасшедшего. Сейчас все откуда-то знают, что это очень важное дело. Это стало витать в воздухе» [Киселева 2020].

\section{6. Выводы и заключение}

Настоящая статья, целью которой является сравнительный анализ теории и практики «поворота к людям» в языковой политике на примере России и стран Западной Европы, сама написана в жанре дискурсивной социолингвистики ${ }^{14}$. Как в случае с лингвистическими идеологиями, которые влияют на социальную и политическую реальность и, в свою очередь, формируются под влиянием ситуационных, институциональных и социальных контекстов, языковая политика также формирует социальную практику, а в последнее время и все больше формируется ею. Поэтому, помимо отдельного раздела, посвященного теоретическим и терминологическим вопросам (Раздел 2), сравнительный анализ был обращен на: новые социальные практики в сфере ЯП и реализующих их людей («новых говорящих» и языковых активистов) (Раздел 3); внешний общественно-политический контекст их деятельности в исследуемых макрорегионах (Раздел 4); внутренний контекст - лингвистические идеологии, существующие в головах людей и влияющие на социальную реальность в данной сфере (Раздел 5).

В Разделе 2 прослежен взгляд на субъектность в советской и российской социолингвистике в сопоставлении с западными исследованиями. Российский взгляд на субъектность в языковой политике обнаруживает некое переходное состояние от интерпретации ЯП как сферы ответственности государства как единственного или главного субъекта ЯП, юридически регламентирующего этот процесс, до включения в субъекты ЯП разнообразных агентов, от региональных политических и бизнес-элит, групп творческой интеллигенции и академической науки до студентов, школьников, родителей, мигрантских сообществ и т. д. Новый, более инклюзивный взгляд на ЯП вполне соответствует и принятой в статье широкой интерпретации языкового

14 Как по исходному посылу, так и его имплементации статья может быть отнесена и к направлению этнографии языковой политики. 
активизма, где акцент делается на личную позицию и практические действия, так что языковыми активистами могут считаться и те, кто говорит со своими детьми на МЯ, и те, кто инициирует акции в поддержку МЯ, и «новые говорящие».

Лидерство западной науки в разработке новых антропоцентрических направлений изучения ЯП и соответствующей терминологии повлекло за собой необходимость освещения дискуссий вокруг терминов agency, language activism, actors / agents, включая проблемы их перевода на русский язык. Понятие agency закладывается в качестве типологизирующего критерия в предлагаемой трехуровневой типологии акторов ЯП, более приспособленной к российским реалиям. Помимо государства и устанавливаемых им законов в сфере ЯП, выделяются обладающие и не обладающие agency акторы, что, в свою очередь, зависит от их институционализированности (являются ли они официальными лицами), хотя границы между этими категориями проницаемы. В России structure и agency, т. е. система и свободное волеизъявление людей все еще противопоставлены. В связи с этим заметим, что в западных теоретических работах противопоставление structure и agency, характерное для более ранних работ [Carter, Sealey 2000], сменяется аргументацией в пользу интеграции этих понятий [Bouchard, Glasgow (eds.) 2018]. Теоретически, безусловно, это так, и интеграция - это идеал, к которому нужно стремиться, но в реальности она зависит от того, насколько сама система (structure) позволяет свободу действий и волеизъявлений людей (agency).

Сравнение языкового активизма в России и Западной Европе обнаруживает определенные сходства и различия. Общность проявляется в городском характере языкового активизма, гетерогенности самих акторов, молодежном характере и связанном с последним активном применении новых технологий. Сами эти характеристики знаменуют тенденцию к либерализации общественного климата в данных макрорегионах. Если раньше МЯ давался автоматически, «по наследству», и имел «деревенское происхождение», то возврат его либо в структуру персональной идентичности или просто в палитру языкового многообразия - это сознательный выбор, диалектически связанный с изменением ЯП и общественных идеологий. Различия заключаются не только в более позднем начале российского языкового активизма и его меньшем масштабе; они связаны и с более существенным фактором - тем, что меньшее количество людей, чем в Западной Европе, готово принять на себя личную ответственность и проявить инициативу, идущую 
порой вразрез с официальной ЯП и идеологией. Перенос ответственности с себя на других (как правило, на школу или государство) проявляется и в том, что в России «новые говорящие» еще не стали столь заметным явлением общественной жизни и объектом интереса социолингвистов, как в Западной Европе. При этом именно «новые говорящие» воплощают в себе языковой активизм, ушедший дальше по пути индивидуализации поведенческих стратегий и «присвоения» недоминирующих и в подавляющем большинстве не приносящих дивидендов на «лингвистическом рынке» миноритарных языков.

Сравнительный анализ общественно-политического контекста в России и странах Западной Европы позволяет прийти к следующим выводам: (1) о важности двух основных факторов в ревитализации МЯ - (a) политической автономии и (б) развитого регионального (или этнического) самосознания при все более повышающейся роли второго даже в странах с жесткой ЯП; (2) о двойственности и противоречивости ЯП российского государства, опасающегося этнического сепаратизма и вступившего на новый виток нациестроительства, в котором русскому языку и русскому этносу отводится важная роль по укреплению государственного единства, но в то же время государство пытается сохранить межнациональное согласие и межъязыковой баланс. В современных условиях, на фоне общемировых процессов регионализации, смены европоцентристской парадигмы на признание ценности всех языков и культур, борьбы за языковые права как часть прав человека, давление государства может иметь парадоксальный эффект. Пример тому - дискуссионные поправки в ФЗ «Об образовании в РФ» 2018 г., вызвавшие волну языкового активизма: люди в регионах (Дагестане, Татарстане, Башкирии, Удмуртии, Сибири и т. д.) активизировали деятельность по развитию и сохранению языков и стали развивать институты общественного управления системой образования (см. об этом также в [Мартынова 2019]) — полагаем, что во многом на протестной волне.

В современных условиях возрастает значимость лингвистических идеологий и, соответственно, их анализа. На основе материалов полевого исследования, данных социальных сетей и анализа литературы в Разделе 5 был кратко рассмотрен комплекс взаимосвязанных идеологий, препятствующих использованию и освоению гернсийского языка и миноритарных языков в целом, включая идеологию (русского) монолингвизма. Делается вывод о том, что лингвистические идеологии, как и идеологии в целом, являются не статичным, а динамичным 
образованием. Механизм их формирования и функционирования реципрокальный: с одной стороны, описанная в Разделе 5 регуляция ими социального поведения индивида и группы является проекцией идеологий как ментальных образований вовне, на окружающий мир, но, с другой стороны, сами идеологии являются продуктом сложных когнитивных процессов переработки информации извне и создания личностного смысла в сознании индивида. Если меняется социальная и политическая реальность, как мы это наблюдаем в языковой сфере в разных странах, лингвистические идеологии тоже постепенно меняются - в сторону большей либеральности и толерантности.

В заключение скажем, что появление обобщающих публикаций [Bouchard, Glasgow (eds.) 2018; Barakos, Unger 2016; Lane et al. 2018 и др.], качество и количество научных исследований и событий в сфере ЯП, в которых значимость и активность «человеческого фактора» только повышается - показатель того, что степень отражения и теоретического осмысления данных событий в социолингвистической литературе достигли определенного уровня. Пока еще рано говорить о построении теории, способной интегрировать подходы, фокусирующиеся на «внешних» (структурных) и «внутренних» («человеческих») факторах в ЯП. Пока стоит задача научной разработки, условно говоря, второго подхода - «людей в языковой политике». Мы надеемся, что данная статья в какой-то степени будет способствовать решению этой задачи.

\section{Литература}

Алпатов 2018 - В. М. Алпатов. Языковая политика в современном мире // А. Н. Биткеева, М. А. Горячева (отв. ред.). Языковое единство и языковое разнообразие в полиэтническом государстве: Международная конференция (Москва, 14-17 ноября 2018): Доклады и сообщения. Институт языкознания РАН, Научно-исследовательский центр по национально-языковым отношениям. М.: Языки народов мира, 2018. С. 24-33.

Алпатов 2000 - В. М. Алпатов. Зарубежная социолингвистика о проблемах двуязычия и языков национальных меньшинств // Л. П. Крысин (ред.). Речевое общение в условиях языковой неоднородности. М.: Едиториал УРСС, 2000. C. $192-209$.

Бабич 2019 - И. Л. Бабич. Современные языковые процессы как фактор национальной идентичности причерноморских адыгов-шапсугов // Е. И. Филиппова, С. В. Соколовский (отв. ред.). Смерть языка - смерть народа? Языковые ситуации и языковые права в России и сопредельных государствах. М.: Горячая линия - Телеком, 2019. С. 137-159. 
Баранова 2019 - В. В. Баранова. Калмыцкий онлайн: ревитализация, особенности языка и эффективность коммуникации // А. А. Кибрик, В. Ю. Гусев, А. Б. Шлуинский (ред.). Международная конференция «Лингвистический форум-2019: коренные языки России и мира». 4-6 апреля 2019 г. Институт языкознания РАН, Москва: Тезисы докладов. М.: Б. и., 2019. С. 91.

Баранова 2010 - В. В. Баранова. Каждый калмык должен знать родной язык? Языковая лояльность сообщества в диахронии // А. Байбурин, Е. Головко (ред.). Nomen est omen: Сб. статей к 60-летию Николая Борисовича Вахтина (от непослушных учеников). Вып. 7. СПб.: Европейский университет в Санкт-Петербурге, 2010. С. 15-23.

Баранова, Федорова 2018 - В. В. Баранова, К. С. Федорова. Многоязычие в городе: языковая политика, дискурсы и практика // Acta Linguistica Petropolitana. Труды Института лингвистических исследований. 2018. Т. XIV. Ч. 3. С. 38-56. DOI 10.30842/alp2306573714303

Баталов 1995 - Э. Я. Баталов. Советская политическая культура (к исследованию распадающейся парадигмы) // Общественные науки и современность. 1995. № 3. С. 60-70.

Бичурина 2012 - Н. М. Бичурина. «Малые романские языки»: металингвистический дискурс и языковая политика Франции (на примере окситанского / провансальского и арпитанского / савойского) // Вопросы языкознания. 2012. № 1. C. $88-98$.

Боргоякова 2013 - Т. Г. Боргоякова. Развитие билингвизма в Республиках Тыва и Хакасия (электронный документ) // Филологические науки. Вопросы теории и практики. 2013. № 7(25): в 2-х ч. Ч. 1. С. 36-39. URL: http://gramota.net/ editions/2html (дата обращения 01.10.2019).

Боргоякова, Гусейнова 2017 - Т. Г. Боргоякова, А. В. Гусейнова. Статус и функционирование тюркских языков Южной Сибири. Абакан: Изд-во ФГБОУ ВО «Хакасский государственный университет им. Н. Ф. Катанова», 2017.

Борисова 2019 - Н. В. Борисова. Агентские факторы языковой политики в современной России // О. В. Гаман-Голутвина, Л. В. Сморгунов, Л. Н. Тимофеева (ред.). Траектории политического развития России: Институты, проекты, акторы: материалы Всероссийской научной конференции РАПН, г. Москва, МПГУ, 6-7 декабря 2019 г. М.: МПГУ, 2019. С. 76.

Бурдьё 2005 - П. Бурдьё. О производстве и воспроизводстве легитимного языка. Отечественные записки. 2005. № 2. URL: https://magazines.gorky.media/ oz/2005/2/o-proizvodstve-i-vosproizvodstve-legitimnogo-yazyka.html (дата обращения 12.09.2019).

Бурыкин 2004a - А. А. Бурыкин. Язык меньшинства как «тайный язык» в отечественном социокультурном контексте (электронный ресурс). 2004. URL: https:// www.km.ru/referats/BD7FDF83F8E4453D8804C216C325E380 (дата обращения 18.04.2020).

Бурыкин 2004b - А. А. Бурыкин. Язык малочисленного народа в его письменной форме (на материале эвенского языка). СПб.: Петербургское востоковедение, 2004. 
Вахтин 1998 - Н. Б. Вахтин. Исчезновение языка и языковая трансформация: заметки о метафоре «языковой смерти» // Н. А. Козинцева, А. К. Оглоблин (ред.). Типология. Грамматика. Семантика. К 65-летию В. С. Храковского. СПб.: Наука, 1998. С. 115-128.

Вахтин 2001 - Н. Б. Вахтин. Языки народов Севера в XX веке. Очерки языкового сдвига. СПб.: Дмитрий Буланин, 2001.

Вахтин, Головко 2005 - Н. Б. Вахтин, Е. В. Головко. Исчезающие языки и задачи лингвистов-североведов // А. Е. Кибрик (отв. ред.). Малые языки и традиции: существование на грани. Вып. 1: Лингвистические проблемы сохранения малых языков. М.: Новое издательство, 2005. С. 40-51.

Виноградов 1990 - В. А. Виноградов. Языковая ситуация // В. Н. Ярцева (гл. ред.). Лингвистический энциклопедический словарь. М.: Советская энциклопедия, 1990. С. 616-617.

Головко и др. 2018 - Е. В. Головко, С. В. Соколовский, А. Б. Шлуинский. Языковая политика в контексте реализации Стратегии государственной национальной политики Российской Федерации на период до 2025 г. // М. А. Омаров (отв. ред.). Языковая политика в современной России: проблемы и перспективы. М.: Изд-во РГГУ, 2018. С. 4-60.

Замятин 2018 - К. Замятин. Формирование языковой политики в республиках России в постсоветский период: анализ политического цикла // А. Н. Биткеева, М. А. Горячева (отв. ред.). Языковое единство и языковое разнообразие в полиэтническом государстве: Международная конференция (Москва, 14-17 ноября 2018 г.): Доклады и сообщения. Институт языкознания РАН, Научно-исследовательский центр по национально-языковым отношениям. М.: Языки народов мира, 2018. С. 193-203.

Иванова 2018 - Н. И. Иванова. Языковые установки саха в сфере образования в контексте современных экстралингвистических реалий (по материалам опросов в г. Якутске) (Электронный ресурс) // Новые исследования Тувы. 2018. № 1. URL: https://nit.tuva.asia/nit/article/view/750 (дата обращения 01.03.2019). DOI: $10.25178 /$ nit.2018.1.13.

Кириленко 2015 - С. В. Кириленко. Процессы формирования понятийного аппарата социолингвистики. Дис. ... канд. филол. наук. М.: Институт языкознания РАН, 2015.

Кожановский 2011 - А. Н. Кожановский. «Баскский вопрос»: Этнический или территориальный? // Общественные науки и современность. 2011. № 6. С. 110-122.

Кучинов 2015 - А. М. Кучинов. Современные теории structure-agency и русская социология // Гуманитарные научные исследования. 2015. № 4. Ч. 3 (Электронный pecypc). URL: http://human.snauka.ru/2015/04/9598 (дата обращения 26.03.2019).

Куцаева 2018 - М. В. Куцаева. Чувашская диаспора в Московском регионе: социолингвистический портрет // А. Н. Биткеева, М. А. Горячева (отв. ред.). Языковое единство и языковое разнообразие в полиэтническом государстве: Международная конференция (Москва, 14-17 ноября 2018): Доклады и сообщения. Институт языкознания РАН, Научно-исследовательский центр по национально-языковым отношениям. М.: Языки народов мира, 2018. С. 655-661. 
Ле Коадик 2013 - Р. Ле Коадик. Мы столкнулись с врагом, и он - это мы: бретонский язык вчера, сегодня, завтра // Е. Филиппова (отв. ред.). Языки меньшинств: Юридический статус и повседневные практики. Российско-французский диалог. М.: ФГНХ «Росинформагротех», 2013. С. 104-124.

Мартынова 2019 - М. Ю. Мартынова. Язык и школьное образование. Российский опыт // Е. И. Филиппова, С. В. Соколовский (отв. ред.). Смерть языка - смерть народа? Языковые ситуации и языковые права в России и сопредельных государствах. М.: Горячая линия - Телеком, 2019. С. 40-74.

Марусенко 2014 - М. А. Марусенко. Языковая идеология и борьба за возрождение языков // Древняя и Новая Романия. 2014. Вып. 14. С. 145-161.

Михальченко 2019 - В. Ю. Михальченко. Динамика языковой ситуации в Российской Федерации // М. Вингендер, А. Н. Биткеева, Э. В. Хилханова (отв. ред.). Перспективы и вызовы языковой политики и языковой ситуации в Крыму. Международный круглый стол (Москва, 5-6 ноября 2019 г.): Доклады и сообщения. Институт языкознания РАН, Научный центр «Восточная Европа» (GiZo) Гиссенского университета им. Юстуса Либига. М.: Б. и., 2019. С. 8-24.

Молодыченко 2017 - Е. Н. Молодыченко. Идентичность и дискурс: от социальной теории к практике лингвистического анализа // Научно-технические ведомости СПбГПУ. Гуманитарные и общественные науки. 2017. Т. 8. № 3. С. $122-$ 133. DOI: $10.18721 / \mathrm{JHSS} .8312$

Мухарямов 2018 - Н. М. Мухарямов. Языковая политика и нациестроительство в меняющихся контекстах // М. А. Омаров (отв. ред.). Нациестроительство: состояние, проблемы, перспективы. Материалы Всероссийской научной конференции. М.: Изд-во РГГУ, 2018. С. 68-75.

Остгоф и Бругман 1960 - Г. Остгоф, К. Бругман. Предисловие к книге «Морфологические исследования в области индоевропейских языков» // В. А. Звегинцев. История языкознания XIX и XX веков в очерках и извлечениях. М.: Б. и., 1960. С. $153-164$.

Пестей 2013 - Ф. Пестей. Официальное признание двуязычия на Корсике: итоги и перспективы // Е. Филиппова (отв. ред.). Языки меньшинств: Юридический статус и повседневные практики. Российско-французский диалог. М.: ФГНХ «Росинформагротех», 2013. С. 125-144.

Попков 2016 - Ю. В. Попков. Концептуальные вопросы этнонациональной политики России // Культурное наследие России. 2016. № 3. С. 13-19.

Попков, Костюк 2015 - Ю. В. Попков, В. Г. Костюк. 2015. Проблемное поле национальной политики в современной России // Вестник Новосибирского государственного университета. Серия: Философия. Т. 13. № 3. С. 71-80.

Смокотин 2010 - В. М. Смокотин. Европейское многоязычие: от государств-наций к многоязычной и поликультурной Европе. Томск: Изд-во Томского университета, 2010.

Соколовский, Подлесных 2019 - С. В. Соколовский, О. Н. Подлесных. Язык и политика в сфере образования в Татарстане // Е. И. Филиппова, С. В. Соколовский (отв. ред.). Смерть языка - смерть народа? Языковые ситуации 
и языковые права в России и сопредельных государствах. М.: Горячая линия Телеком, 2019. С. 75-98.

Соколовский и Филиппова 2019 - С. В. Соколовский, Е. И. Филиппова. Законы и идеологии: политика и управление языковыми ситуациями // Е. И. Филиппова, С. В. Соколовский (отв. ред.). Смерть языка - смерть народа? Языковые ситуации и языковые права в России и сопредельных государствах. М.: Горячая линия - Телеком, 2019. С. 5-18.

Строгальщикова 2016 - 3. И. Строгальщикова. Вепсы в этнокультурном пространстве европейского Севера. Петрозаводск: Периодика, 2016.

Тишков, Акбаев 2019 - В. А. Тишков, Х. М. Акбаев. «Народ не умирает с языком» или «Язык не живет без народа»? Диалог ученых о конфликте вокруг родного языка // Е. И. Филиппова, С. В. Соколовский (отв. ред.). Смерть языка смерть народа? Языковые ситуации и языковые права в России и сопредельных государствах М.: Горячая линия - Телеком, 2019. С. 19-39.

Харитонов, Степина 2020 - В. Харитонов, Д. Степина. Монолингвальный габитус в многоязычном обществе: как и что говорят о языках в России // Антропология. Фольклористика. Социолингвистика. Конференция молодых ученых. Сб. тезисов. Санкт-Петербург: Б. и., 2020. С. 92-94.

Хилханова 2009 - Э. В. Хилханова. Факторы языкового сдвига и сохранения миноритарных языков: дискурсный и социолингвистический анализ (на примере языковой ситуации в этнической Бурятии). Дис. ... д-ра филол. наук. Барнаул: Алтайский государственный университет, 2009.

Хилханова 2019 — Э. В. Хилханова. Интернет и миноритарные языки России: символическое присутствие или инструмент ревитализации? (на примере бурятского языка) // Монголоведение. 2019. Т. 11. № 4. С. 967-988. URL: https://doi. org/10.22162/2500-1523-2019-4-967-988 (дата обращения 26.03.2020)

Хилханова и др. 2016 - Э. В. Хилханова, Г. А. Дырхеева, Л. М. Любимова, Д. Б. Сундуева. Языковое сознание и языковые установки жителей приграничных регионов востока России (на примере Республики Бурятия и Забайкальского края). Восточно-Сибирский государственный институт культуры; Институт монголоведения, буддологии и тибетологии СО РАН. М.: Наука; Издательская фирма «Восточная литература» PAH, 2016. URL: https://doi.org/10.22162/25001523-2019-4-967-988 (дата обращения 26.03.2020)

Швейцер 1976 - А. Д. Швейцер. Современная социолингвистика. Теория, проблемы, методы. М.: Наука, 1976.

Шепелев 2015 - А. Н. Шепелев. Роль языковой политики в современной России // Вестник Тамбовского университета. Серия: гуманитарные науки. 2015. № 10 (150). C. 168-172.

Ahearn 2001 - L. Ahearn. Language and Agency. Annual Review of Anthropology. 2001. Vol. 30. P. 109-137.

Alòs i Font 2019 - H. Alòs i Font. Russian, Chuvash and English: minority-language activism, tourism promotion and the evolution of municipal advertisements in Shupashkar/Cheboksary (2015-2018) // A. Nikunlassi, E. Protassova (eds.). 
Slavica Helsingiensia. Vol. 52. Russian Language on the Multilingual World. Helsinki: University of Helsinki, 2019.

Barakos, Unger 2016 - E. Barakos, J. Unger. Discursive approaches to language policy. Basingstoke: Palgrave Macmillan, 2016.

Barker 2005 - C. Barker. Cultural Studies: Theory and Practice. London: Sage, 2005.

Blommaert 2006 - J. Blommaert. Language policy and national identity // T. Ricento (ed.). An introduction to language policy: Theory and method. Oxford: Wiley Blackwell, 2006. P. 238-254.

Bouchard, Glasgow (eds.) 2018 - J. Bouchard, G. P. Glasgow (eds.). Agency in Language Policy and Planning: Critical Inquiries. New York; London: Routledge, 2018.

Canagarajah 2005 - A. S. Canagarajah (ed.). Reclaiming the Local in Language Policy and Practice. Mahwah, New Jersey: Lawrence Erlbaum, 2005.

Carter, Sealey 2000 - B. Carter, A. Sealey. Language, structure and agency: What can realist social theory offer to scoiolinguistics? // Journal of Sociolinguistics. 2000. Vol. 4. Iss. 1. P. 3-20.

Cavanaugh 2009 - J. R. Cavanaugh. Living Memory: The Social Aesthetics of Language in a Northern Italian Town. Oxford: Wiley Blackwell, 2009.

Chua, Baldauf 2011 - S. K. C. Chua, R. B. Jr. Baldauf. Micro Language Planning // E. Hinkel (ed.). Handbook of Research in Second Language Learning and Teaching. Vol. 2. New York: Routledge, 2011. P. 936-951.

Combs, Penfield 2012 - M. C. Combs, S. D. Penfield. Language activism and language policy // B. Spolsky (ed.). The Cambridge Handbook of Language Policy (Cambridge Handbooks in Language and Linguistics. Pt. I). Cambridge: Cambridge University Press, 2012.

Darquennes, Soler 2019 - J. Darquennes, J. Soler. 'New speakers' and language policy research: thematic and theoretical contributions to the field // Language policy. 2019. Vol. 18. Iss. 4. P. 475-491. URL: https://doi.org/10.1007/s10993-018-9506-2 (дата обращения 26.03.2020).

Fedorova, Baranova 2018 - K. Fedorova, V. Baranova. Moscow: diversity in disguise // P. Heinrich, D. Smakman (eds.). Urban sociolinguistics: the city as a linguistic process and experience. London: Routledge, 2018. P. 221-237.

Fedorova, Gavrilova 2010 - K. Fedorova, T. Gavrilova. Native speakers of Russian in interethnic communication: sociolinguistic situations and linguistic strategies // A. Mustajoki, E. Protassova, N. Vakhtin (eds.). Slavica Helsingiensia. Vol. 40. Instrumentarium of Linguistics. Sociolinguistic Approaches to Non-Standard Russian. Helsinki, 2010. P. 50-64.

Ferguson 2016a - J. K. Ferguson. Code-mixing among Sakha-Russian bilinguals in Iakutsk: A spectrum of features and shifting indexical fields // Journal of Linguistic Anthropology. 2016. Vol. 26. Iss. 2. P. 141-161.

Ferguson 2016b - J. K. Ferguson. Language has a spirit: Sakha (Iakut) language ideologies and aesthetics of sustenance // Arctic Anthropology. 2016. Vol. 53. № 1. P. 95-111.

Gal, Woolard 1995 - S. Gal, K. Woolard. Constructing Languages and Publics: Authority and Representation // Pragmatics. 1995. Vol. 5. Iss. 2. P. 129-138. 
Gardner 2005 - N. Gardner. The Basque language in education in Spain (2 ${ }^{\text {nd }}$ Edition). Leeuwarden / Ljouwert: Mercator Research Centre on Multilingualism and Language Learning, 2005. URL: https:/www.euskadi.eus/contenidos/informacion/ dia6/en_2027/adjuntos/publications_in_english/basque_language_in_education_ in_spain_2005_en.pdf (дата обращения 10.09.2019).

Glăveanu 2015 - V. P. Glăveanu. From individual agency to co-agency // C. W. Gruber, M. G. Clark, S. H. Klempe, J. Valsiner (eds.). Constraints of agency: Explorations of theory in everyday life. Cham, Switzerland: Springer, 2015. P. 245266.

Gorter, Cenoz 2011 - D. Gorter, J. Cenoz. Multilingual education for European minority languages: The Basque Country and Friesland // International Review of Education. 2011. № 57. P. 651-666.

Graber 2017 - K. E. Graber. The kitchen, the cat, and the table: Domestic affairs in minority-language politics // Journal of Linguistic Anthropology. 2017. Vol. 27. Iss. 2. P. 151-170.

Grenoble, Bulatova 2018 - L. A. Grenoble, N. Ja. Bulatova. Language standardization in the aftermath of the Soviet Language Empire // P. Lane, J. Costa, H. De Korne (eds.). Standardizing Minority Languages: Competing Ideologies of Authority and Authenticity in the Global Periphery. New York: Routledge, 2018. P. 118-134.

Halonen et al. 2015 - M. Halonen, P. Ihalainen, T. Saarinen (eds.). Language policies in Finland and Sweden: Interdisciplinary and multi-sited comparisons. Bristol: Multilingual Matters, 2015.

Hornberger, Johnson 2007 - N. Hornberger, D. Johnson. Slicing the onion ethnographically: Layers and spaces in multilingual language education policy and practice // TESOL Quarterly. 2007. Vol. 41. № 3. P. 509-532.

Hult 2018 - F. M. Hult. Foreword // J. Bouchard, G. P. Glasgow (eds.). Agency in Language Policy and Planning: Critical Inquiries. New York; London: Routledge, 2018.

Johnson 2009 - D. Johnson. Ethnography of language policy // Language Policy. 2009. Vol. 8. Iss. 2. P. 139-159.

Johnson 2013 - D. Johnson. Language policy. Basingstoke: Palgrave Macmillan, 2013.

Kroskrity 2000 - P. V. Kroskrity. Regimenting Languages: Language Ideological Perspectives // P. V. Kroskrity (ed.). Regimes of Language: Ideologies, Polities, and Identities. Santa Fe: School of American Research Press, 2000. P. 1-34.

Lane et al. 2018 - P. Lane, J. Costa, H. De Korne (eds.). Standardizing Minority Languages: Competing Ideologies of Authority and Authenticity in the Global Periphery. New York: Routledge, 2018.

Mac-Giolla 2012 - C. D. Mac-Giolla. Jailtacht: The Irish Language, Symbolic Power and Political Violence in Northern Ireland, 1972-2008. Cardiff: University of Wales Press, 2012.

McCarty 2011 - T. McCarty (ed.). Ethnography and language policy. New York; London: Routledge, 2011.

McCarty 2015 - T. McCarty. Ethnography in language planning and policy research // F. Hult, D. Johnson (eds.). Research methods in language policy and planning: A practical guide. Oxford: Wiley Blackwell, 2015. P. 81-93. 
Mikhalchenko, Trushkova 2003 - V. Yu. Mikhalchenko, J. Trushkova. Russian in the modern world // J. Maurais, M. A. Morris (eds.). Languages in a globalizing world. Cambridge; New York: Cambridge University Press, 2003. P. 260-290.

Moore 2016 - J. W. Moore. What Is the Sense of Agency and Why Does it Matter? // Frontiers in Psychology. 2016. 29 August. URL: https:/www.frontiersin.org/articles/10.3389/fpsyg.2016.01272/full (дата обращения 10.09.2019)

Ó Duibhir et al. 2015 - P. Ó Duibhir, N. Ní Chuaig, L. Ní Thuairisg, C. Ó Brolcháin. Educational Provision through Minority Languages: Review of International Research // Commissioned Research Report: An Chomhairle um Oideachas Gaeltachta agus Gaelscolaíochta (COGG). Dublin: Dep. Educ. Skills, 2015.

Ó Murchadha et al. 2018 — N. P. Ó Murchadha, M. Hornsby, C. Smith-Christmas, M. Moriarty. New Speakers, Familiar Concepts? // C. Smith-Christmas, M. Hornsby, M. Moriarty, N. Ó Murchadha (eds.). New Speakers of Minority Languages: Linguistic Ideologies and Practices. Basingstoke: Palgrave McMillan, 2018. P. 1-22. O'Rourke, Ramallo 2018 - B. O'Rourke, F. Ramallo. Identities and New Speakers of Minority Languages: A Focus on Galician // C. Smith-Christmas, M. Hornsby, M. Moriarty, N. Ó Murchadha (eds.). New Speakers of Minority Languages: Linguistic Ideologies and Practices. Basingstoke: Palgrave McMillan, 2018. P. 91-109.

Pischlöger 2010 - C. Pischlöger. Udmurtness in Web 2.0: Urban Udmurts Resisting Language Shift // Finnisch-Ugrische Mitteilungen. 2010. Band 38. P. 143-161.

Pischlöger 2016 - C. Pischlöger. Udmurt on Social Network Sites: A Comparison with the Welsh Case // R. Toivanen, J. Saarikivi (eds.). Linguistic Genocide Or Superdiversity? New and Old Language Diversities. Bristol; Buffalo: Multilingual Matters, 2016. P. 108-132.

Puigdevall 2014 - M. Puigdevall. Introduction. "New Speakers of Minority Languages: Belonging and Legitimacy” [online dossier] // Digithum. 2014. Iss. 16. P. 44-46. URL: https://www.raco.cat/index.php/Digithum/article/view/n16-puigdevall/394155 (дата обращения 26.03.2020).

Ricento, Hornberger 1996 - T. K. Ricento, N. H. Hornberger. Unpeeling the Onion: Language Planning and Policy and the ELT Profession // TESOL Quarterly. 1996. Vol. 30. № 3. P. 401-427.

Sallabank, Marquis 2018 - J. Sallabank, Y. Marquis. 'We Don't Say It Like That': Language Ownership and (De)Legitimising the New Speaker // C. Smith-Christmas, M. Hornsby, M. Moriarty, N. Ó Murchadha (eds.). New Speakers of Minority Languages: Linguistic Ideologies and Practices. Basingstoke: Palgrave McMillan, 2018. P. 67-90.

Smith-Christmas et al. 2018 - C. Smith-Christmas, M. Hornsby, M. Moriarty, N. Ó Murchadha (eds.). New Speakers of Minority Languages: Linguistic Ideologies and Practices. Basingstoke: Palgrave McMillan, 2018.

Smolicz, Secomble 1998 - J. Smolicz, M. Secomble. Community languages, core values and cultural maintenance: the Australian experience with special reference to Greek, Latvian and Polish groups // M. Clyne (ed.). Australia, Meeting Place of Languages. Canberra, Australia: Australian National University, Pacific Linguistics, 1988. P. 11-38. 
Toivanen 2015 - R. Toivanen. Obstacles and successes Comparing Minority Language Activism Among the Sorbs in Germany and the Sámi in Finland // H. F. Marten, M. Riessler, J. Saarikivi, R. Toivanen (eds.). Cultural and Linguistic Minorities in the Russian Federation and the European Union. Comparative Studies on Equality and Diversity. Series Multilingual Education. Vol. 13. London: Springer International Publishing, 2015. P. 83-105. DOI 10.1007/978-3-319-10455-3_4.

Tollefson, Pérez-Milans 2018 - J. W. Tollefson, M. Pérez-Milans (eds.). The Oxford Handbook of Language Policy and Planning. Oxford: Oxford University Press, 2018.

Van Dongera et al. 2017 - R. van Dongera, C. van der Meer, R. Sterk. Research for CULT Committee Minority Languages and Education: Best Practices and Pitfalls // Policy Department for Structural and Cohesion Policies. Culture and Education. Brussels: Policy Dep. Struct. Cohes. Policies Eur. Parliament, 2017.

Wiley, Garcia 2016 - T. G. Wiley, O. Garcia. Language policy and planning in language education: Legacies, consequences, and possibilities // Modern Language Journal. 2016. Vol. 100. Suppl. 1. P. 48-63. URL: https://doi.org/10.1111/modl.12303 (дата обращения 26.03.2020).

Wingender 2018 - M. Wingender. Diskursive Konstruktion von Sprachenvielfalt und Sprachenkonflikten in Russland - Sprachenpolitik im Kontext von nationaler Sicherheit // S. Kempgen, M. Wingender, L. Udolph (eds.). Deutsche Beiträge zum 16. Internationalen Slavistenkongress. Wiesbaden: Harrasowitz, 2018. P. 353-364.

Woolard 2003 - K. Woolard. We Don't Speak Catalan Because We Are Marginalized: Ethnic and Class Connotations of Language in Barcelona // R. K. Blot (ed.). Language and Social Identity. Westport, CT: Praeger Publishers, 2003. P. 85-103.

Zamyatin 2015 - K. Zamyatin. The Evolution of Language Ideology in Post-Soviet Russia // H. F. Marten, M. Riessler, J. Saarikivi, R. Toivanen (eds.). Cultural and Linguistic Minorities in the Russian Federation and the European Union. Comparative Studies on Equality and Diversity. (Series Multilingual Education). Vol. 13. London: Springer International Publishing, 2015. P. 279-314.

Zhao, Baldauf 2012 - S. Zhao, R. B. Baldauf. Individual agency in language planning: Chinese script reform as a case study. Language Problems and Language Planning. 2012. Vol. 36. Iss. 1. P. 1-24. URL: http://doi.org/10.1075/lplp.36.1.01zha (дата обращения 26.03.2020).

\section{Источники}

Алексеев, Харитонов 2020 - Ф. Г. Алексеев, В. С. Харитонов. Российский языковой активизм. Кто спасает алеутский, нивхский, эвенкийский и другие языки России (электронный ресурс). URL: https://zapovednik.space/material/ rossijskij-jazykovoj-aktivizm?fbclid=IwAR2SQ5TYBBEnWsi4aRQZTYKC7YQqCUOabtJ3KH-7OboZdkqZdvWVYHUuIZc (дата обращения 19.04.2020).

Баранова 2019b - В. В. Баранова. Сохранение малых языков самими носителями: кто и как возрождает калмыцкий? (электронный ресурс). URL: https://eusp.org/ 
news/sokhranenie-malykh-yazykov-samimi-nositelyami-kto-i-kak-vozrozhdaet-kalmytskij (дата обращения 15.03.2020).

Бульбинская 2020 - O. Бульбинская. SOS! Дискриминация хантыйского языка в Ханты-Мансийске!? (электронный ресурс). URL: https://www.facebook.com/ denis.tokmashev/posts/3111880362190723 (дата обращения 15.04.2020).

Гавриленко и др. 2020 - А. Гавриленко, А. Хаиров, А. Городнова, Л. Фархутдинов. Этой формулировкой Путин точно закладывает мину. Кто такие русские? 4 марта 2020: (электронный ресурс). URL: https://www.business-gazeta.ru/article/459939 (дата обращения 07.04.2020).

Киселева 2020 - Языки народов России: кому они родные и почему мы хотим их сохранить. 21.02.2020 (электронный ресурc). URL: https://растимдетей. pф/articles/yazyki-narodov-rossii-komu-oni-rodnye (дата обращения 15.03. 2020).

МетРек - Методические рекомендации органам исполнительной власти субъектов Российской Федерации, осуществляющим государственное управление в сфере образования, по вопросу изучения государственных языков республик, находящихся в составе Российской Федерации // Консорциум Кодекс (электронный ресурс). URL: http://docs.cntd.ru/document/550918049 (дата обращения 10.11.2019).

Михальченко 2006 - В. Ю. Михальченко (ред.). Словарь социолингвистических терминов. М.: Институт языкознания РАН, 2006.

ООРФ — Федеральный закон от 29 дек. 2012 г. № 273-Ф3 «Об образовании в Российской Федерации» (электронный ресурс). URL: http://static.kremlin.ru/ media/acts/files/0001201212300007.pdf (дата обращения 8.10.2019).

Пасанен 2011 - А. Пасанен. «Языковые гнезда» для саамов Финляндии работают и в школах, этот опыт необходимо применить в России (электронный ресурс)/ Информационный центр финно-угорских народов. 2011. URL: http://finugor.ru/ node/21489 (дата обращения 20.04.2019).

Полный текст - Полный текст поправок в Конституцию: за что мы голосуем? (электронный ресурc). URL: http://duma.gov.ru/news/48045 (дата обращения 20.04.2020).

ПрООП - Примерная основная образовательная программа основного общего образования (электронный ресурс). URL: https://fgosreestr.ru (дата обращения 18.02.2020).

Репортаж 2020 - Репортаж о 1-м заседании Дискуссионно-аналитического клуба по вопросам языковой политики (электронный ресурс). URL: https://iling-ran. ru/web/ru/news/200324_daclp (дата обращения 30.04.2020).

Специальный проект - Специальный проект «Языковая среда». В бой идет хипстота. Что могут сделать простые горожане для сохранения языков народов РФ (электронный ресурс). URL: https://nazaccent.ru/content/29636-v-boj-idet-hipstota.html (дата обращения 20.04.2020).

Страна языков - Страна языков. Площадка для обмена опытом, идеями и энергией для оживления языков (электронный ресурс). URL: http://stranayaz.ru (дата обращения 19.06.2019). 
Стратегия - Стратегия государственной национальной политики Российской Федерации на период до 2025 г. (электронный ресурс). URL: http://base.consultant.ru/cons/cgi/online.cgi?req=doc;base=LAW;n=139350 (дата обращения 28.01.2013).

ФЦП — Федеральная целевая программа «Русский язык» на 2016-2020 гг. (электронный ресурс). URL: http://static.government.ru/media/files/UdArRuNmg2Hdm3MwRUwmdE9N3ohepzpQ.pdf (дата обращения 06.04.2020).

Якут. - Якутия: мы же не требуем согласия родителей на изучение математики или биологии, 28 сентября 2017: (электронный ресурс). URL: https:/ru.wikinews.org/wiki/Якутия:_Мы_же_не_требуем_согласия_родителей_на_изучение_ математики_или_биологии (дата обращения 22.11.2019).

Ярцева (гл. ред.) 1990 - В. Н. Ярцева (гл. ред.). Лингвистический энциклопедический словарь. М.: Советская энциклопедия, 1990.

Ярцева (ред.) 1998 - В. Н. Ярцева (ред.). Языкознание: большой энциклопедический словарь. 2-е изд. Репр. воспроизведение изд. «Лингвистического энциклопедического словаря» 1990 г. М.: Большая Российская Энциклопедия, 1998.

Advisory Committee 2018 - Advisory Committee on the Framework Convention for the Protection of National Minorities on the Russian Federation. Fourth Opinion on the Russian Federation — adopted on 20 February 2018. (электронный документ). URL: https://rm.coe.int/4 ${ }^{\text {th }}$-advisory-committee-opinion-on-the-russian-federation-english-langu/1680908982 (дата обращения 19.01.2019).

UNESCO Atlas — UNESCO Atlas of the World's Languages in Danger (электронный документ). URL: http://www.unesco.org/new/en/culture/themes/endangered-languages/atlas-of-languages-in-danger/ (дата обращения 09.09.2019).

\section{References}

Ahearn 2001 - L. Ahearn. Language and Agency. Annual Review of Anthropology. 2001. Vol. 30. P. 109-137.

Alòs i Font 2019 - H. Alòs i Font. Russian, Chuvash and English: minority-language activism, tourism promotion and the evolution of municipal advertisements in Shupashkar/Cheboksary (2015-2018). A. Nikunlassi, E. Protassova (eds.). Slavica Helsingiensia. Vol. 52. Russian Language on the Multilingual World. Helsinki: University of Helsinki, 2019.

Alpatov 2000 - V. M. Alpatov. Zarubezhnaya sotsiolingvistika o problemakh dvuyazychiya i yazykov natsionalnykh menshinstv [Foreign sociolinguistics on the problems of bilingualism and languages of national minorities]. L. P. Krysin (ed.). Rechevoe obshchenie v usloviyakh yazykovoy neodnorodnosti [Speech communication in the conditions of linguistic heterogeneity]. Moscow: Editorial URSS, 2000. P. 192-209.

Alpatov 2018 - V. M. Alpatov. Yazykovaya politika v sovremennom mire [Language policy in the modern world]. A. N. Bitkeeva, M. A. Goryacheva (eds.). Yazykovoe edinstvo i yazykovoe raznoobrazie v polietnicheskom gosudarstve: Mezhdunarodnaya 
konferentsiya (Moskva, 14-17 noyabrya 2018): Doklady i soobshcheniya [Linguistic unity and linguistic diversity in a multi-ethnic state: International conference (Moscow, November 14-17, 2018): Reports and presentations]. Institute of Linguistics of the RAS, Research Center on Ethnic and Language Relations. Moscow: Yazyki narodov mira, 2018. P. 24-33.

Babich 2019 - I. L. Babich. Sovremennye yazykovye protsessy kak faktor natsionalnoy identichnosti prichernomorskikh adygov-shapsugov. E. I. Filippova, S. V. Sokolovskiy (eds.). Smert yazyka - smert naroda? Yazykovye situatsii i yazykovye prava $v$ Rossii i sopredelnykh gosudarstvakh [The death of the language - the death of the people? Language situations and language rights in Russia and neighboring countries]. Moscow: Goryachaya liniya - Telekom, 2019. P. 137-159.

Barakos, Unger 2016 - E. Barakos, J. Unger. Discursive approaches to language policy. Basingstoke: Palgrave Macmillan, 2016.

Baranova 2010 - V. V. Baranova. Kazhdyy kalmyk dolzhen znat rodnoy yazyk? Yazykovaya loyalnost soobshchestva v diakhronii. A. Bayburin, Ye. Golovko (eds.). Nomen est omen: Sbornik statey k 60-letiyu Nikolaya Borisovicha Vakhtina (ot neposlushnykh uchenikov). Iss. 7. St. Petersburg: European University in St. Petersburg, 2010. P. 1523.

Baranova 2019 - V. V. Baranova. Kalmytskiy onlayn: revitalizatsiya, osobennosti yazyka i effektivnost kommunikatsii [Kalmyk online: revitalization, language features and communication efficiency]. A. A. Kibrik, V. Yu. Gusev, A. B. Shluinskii (eds.). Mezhdunarodnaya konferentsiya "Lingvisticheskiy forum-2019: korennye yazyki Rossii i mira». 4-6 aprelya 2019 g. Institut yazykoznaniya RAN, Moskva: Tezisy dokladov [International Conference "Linguistic Forum-2019: Indigenous Languages of Russia and beyond". April 4-6, 2019. Institute of Linguistics of the RAS, Moscow: Abstracts]. Moscow: S. n., 2019. P. 91.

Baranova, Fedorova 2018 - V. V. Baranova, K. S. Fedorova. Mnogoyazychie v gorode: yazykovaya politika, diskursy i praktika [Multilingualism in the city: language policy, discourses and practice]. Acta Linguistica Petropolitana. Trudy Instituta lingvisticheskikh issledovaniy. 2018. Vol. XIV. Pt. 3. P. 38-56. DOI 10.30842/ alp2306573714303.

Barker 2005 - C. Barker. Cultural Studies: Theory and Practice. London: Sage, 2005.

Batalov 1995 - E. Ya. Batalov. Sovetskaya politicheskaya kultura (k issledovaniyu raspadayushcheysya paradigmy) [The Soviet political culture (towards the study of a disintegrating paradigm)]. Obshchestvennye nauki i sovremennost. 1995. No. 3. P. 60-70.

Bichurina 2012 - N. M. Bichurina. «Malye romanskie yazyki»: metalingvisticheskiy diskurs i yazykovaya politika Frantsii (na primere oksitanskogo/provansalskogo i arpitanskogo / savoyskogo) [«Small romance languages»: metalinguistic discourse and language policy of France (on the example of Occitan / Provencal and Arpitan/ Savoy)]. Voprosy yazykoznaniya. 2012. No. 1. P. 88-98.

Blommaert 2006 - J. Blommaert. Language policy and national identity. T. Ricento (ed.). An introduction to language policy: Theory and method. Oxford: Wiley Blackwell, 2006. P. 238-254. 
Borgoyakova 2013 - T. G. Borgoyakova. Razvitie bilingvizma v Respublikakh Tyva i Khakasiya [The development of bilingualism in the Republics of Tuva and Khakassia]. Filologicheskie nauki. Voprosy teorii i praktiki. 2013. No. 7 (25): in 2 parts. Pt. 1. P. 36-39. Available at: http://gramota.net/editions/2html (accessed on 01.10.2019).

Borgoyakova, Guseynova 2017 - T. G. Borgoyakova, A. V. Guseynova. Status i funktsionirovanie tyurkskikh yazykov Yuzhnoy Sibiri [Status and functioning of the Turkic languages of southern Siberia]. Abakan: N. F. Katanov Khakass State University Press, 2017.

Borisova 2019 - N. V. Borisova. Agentskie faktory yazykovoy politiki v sovremennoy Rossii. O. V. Gaman-Golutvina, L. V. Smorgunov, L. N. Timofeeva (eds.). Traektorii politicheskogo razvitiya Rossii: Instituty, proekty, aktory: materialy Vserossiyskoy nauchnoy konferentsii Rossiyskoy Akademii pedagogicheskikh nauk. Moskva, Moskovskiy gorodskoy pedagogicheskiy universitet, 6-7 dekabrya 2019 [Trajectories of Russia's political development: Institutes, projects, actors: materials of the all-Russian scientific conference RAPS. Moscow, Moscow State Pedagogical University, 6-7 December 2019]. Moscow: Moscow State Pedagogical University Press, 2019. P. 76.

Bouchard, Glasgow (eds.) 2018 - J. Bouchard, G. P. Glasgow (eds.). Agency in Language Policy and Planning: Critical Inquiries. New York; London: Routledge, 2018.

Bourdieu 2005 - P. Bourdieu. O proizvodstve i vosproizvodstve legitimnogo yazy$\mathrm{ka}$ [On the production and reproduction of a legitimate language. Otechestvennye zapiski. 2005. No. 2. Available at: https://magazines.gorky.media/oz/2005/2/o-proizvodstve-i-vosproizvodstve-legitimnogo-yazyka.html (accessed on 12.09.2019).

Burykin 2004a - A. A. Burykin. Yazyk menshinstva kak «taynyy yazyk» v otechestvennom sotsiokulturnom kontekste [Minority language as a «secret language» in the Russian socio-cultural context]. 2004. Available at: https:/www.km.ru/referats/ BD7FDF83F8E4453D8804C216C325E380 (accessed on 18.04.2020).

Burykin 2004b - A. A. Burykin. Yazyk malochislennogo naroda v ego pismennoy forme (na materiale evenskogo yazyka) [The language of a small people in its written form (based on the material of the Even language)]. St. Petersburg: St. Petersburg Oriental studies, 2004.

Canagarajah 2005 - A. S. Canagarajah (ed.). Reclaiming the Local in Language Policy and Practice. Mahwah, New Jersey: Lawrence Erlbaum, 2005.

Carter, Sealey 2000 - B. Carter, A. Sealey. Language, structure and agency: What can realist social theory offer to scoiolinguistics? Journal of Sociolinguistics. 2000. Vol. 4. Iss. 1. P. 3-20.

Cavanaugh 2009 - J. R. Cavanaugh. Living Memory: The Social Aesthetics of Language in a Northern Italian Town. Oxford: Wiley Blackwell, 2009.

Chua, Baldauf 2011 - S. K. C. Chua, R. B. Jr. Baldauf. Micro Language Planning. E. Hinkel (ed.). Handbook of Research in Second Language Learning and Teaching. Vol. 2. New York: Routledge, 2011. P. 936-951.

Combs, Penfield 2012 - M. C. Combs, S. D. Penfield. Language activism and language policy. B. Spolsky (ed.). The Cambridge Handbook of Language Policy. 
Cambridge Handbooks in Language and Linguistics. P. I. Cambridge: Cambridge University Press, 2012.

Darquennes, Soler 2019 - J. Darquennes, J. Soler. 'New speakers' and language policy research: thematic and theoretical contributions to the field. Language policy. 2019. Vol. 18. Iss. 4. P. 475-491. Available at: https://doi.org/10.1007/s10993-0189506-2 (accessed on 18.04.2020).

Fedorova, Baranova 2018 - K. Fedorova, V. Baranova. Moscow: diversity in disguise. P. Heinrich, D. Smakman (eds.). Urban sociolinguistics: the city as a linguistic process and experience. London: Routledge, 2018. P. 221-237.

Fedorova, Gavrilova 2010 - K. Fedorova, T. Gavrilova. Native speakers of Russian in interethnic communication: sociolinguistic situations and linguistic strategies. A. Mustajoki, E. Protassova, N. Vakhtin (eds.). Slavica Helsingiensia. Vol. 40. Instrumentarium of Linguistics. Sociolinguistic Approaches to Non-Standard Russian. Helsinki, 2010. P. 50-64.

Ferguson 2016a - J. K. Ferguson. Code-mixing among Sakha-Russian bilinguals in Iakutsk: A spectrum of features and shifting indexical fields. Journal of Linguistic Anthropology. 2016. Vol. 26. Iss. 2. P. 141-161.

Ferguson 2016b - J. K. Ferguson. Language has a spirit: Sakha (Yakut) language ideologies and aesthetics of sustenance. Arctic Anthropology. 2016. Vol. 53. No. 1. P. 95-111.

Gal, Woolard 1995 - S. Gal, K. Woolard. Constructing Languages and Publics: Authority and Representation. Pragmatics. 1995. Vol. 5. Iss. 2. P. 129-138.

Gardner 2005 - N. Gardner. The Basque language in education in Spain ( $2^{\text {nd }}$ Edition). Leeuwarden/Ljouwert: Mercator Research Centre on Multilingualism and Language Learning. 2005. Available at: https://www.euskadi.eus/contenidos/informacion/dia6/en_2027/adjuntos/publications_in_english/basque_language_in_education_in_spain_2005_en.pdf (accessed on 10.09.2019).

Glăveanu 2015 - V. P. Glăveanu. From individual agency to co-agency. C. W. Gruber, M. G. Clark, S. H. Klempe, J. Valsiner (eds.). Constraints of agency: Explorations of theory in everyday life. Cham, Switzerland: Springer, 2015. P. 245-266.

Golovko et al. 2018 - Ye. V. Golovko, S. V. Sokolovskiy, A. B. Shluinskiy. Yazykovaya politika v kontekste realizatsii Strategii gosudarstvennoy natsionalnoy politiki Rossiyskoy Federatsii na period do 2025 goda [Language policy in the context of implementing the Strategy of the state national policy of the Russian Federation for the period up to 2025]. M. A. Omarov (ed.). Yazykovaya politika v sovremennoy Rossii: problemy i perspektivy [Language policy in modern Russia: problems and prospects]. Moscow: Russian State University for the Humanities Press, 2018. P. 4-60.

Gorter, Cenoz 2011 - D. Gorter, J. Cenoz. Multilingual education for European minority languages: The Basque Country and Friesland. International Review of Education. 2011. No. 57. P. 651-666.

Graber 2017 - K. E. Graber. The kitchen, the cat, and the table: Domestic affairs in minority-language politics. Journal of Linguistic Anthropology. 2017. Vol. 27. Iss. 2. P. 151-170.

Grenoble, Bulatova 2018 - L. A. Grenoble, N. Ja. Bulatova. Language standardization in the aftermath of the Soviet Language Empire. P. Lane, J. Costa, H. De Korne 
(eds.). Standardizing Minority Languages: Competing Ideologies of Authority and Authenticity in the Global Periphery. New York: Routledge, 2018. P. 118-134.

Halonen et al. 2015 - M. Halonen, P. Ihalainen, T. Saarinen (eds.). Language policies in Finland and Sweden: Interdisciplinary and multi-sited comparisons. Bristol: Multilingual Matters, 2015.

Hornberger, Johnson 2007 - N. Hornberger, D. Johnson. Slicing the onion ethnographically: Layers and spaces in multilingual language education policy and practice. TESOL Quarterly. 2007. Vol. 41. No 3. P. 509-532.

Hult 2018 - F. M. Hult. Foreword. J. Bouchard, G. P. Glasgow (eds.). Agency in Language Policy and Planning: Critical Inquiries. New York; London: Routledge, 2018.

Ivanova 2018 - N. I. Ivanova. Yazykovye ustanovki sakha v sfere obrazovaniya v kontekste sovremennykh ekstralingvisticheskikh realiy (po materialam oprosov v g. Yakutske) [Sakha language attitudes in the field of education in the context of modern extralinguistic realities (based on surveys in Yakutsk)]. Novye issledovaniya Tuvy [The New Research of Tuva]. 2018. No. 1. Available at: https:/nit.tuva.asia/nit/article/view/750 (accessed on 01.03.2019.). DOI: 10.25178/nit.2018.1.13.

Johnson 2009 - D. Johnson. Ethnography of language policy. Language Policy. 2009. Vol. 8. Iss. 2. P. 139-159.

Johnson 2013 - D. Johnson. Language policy. Basingstoke: Palgrave Macmillan, 2013.

Kharitonov, Stepina 2020 - V. Kharitonov, D. Stepina. Monolingvalnyy gabitus v mnogoyazychnom obshchestve: kak i chto govoryat o yazykakh v Rossii [Monolingual habitus in a multilingual society: how and what people say about languages in Russia]. Antropologiya. Folkloristika. Sotsiolingvistika. Konferentsiya molodykh uchenykh. Sbornik tezisov [Anthropology. Folkloristics. Sociolinguistics. Conference of young scientists. Book of abstracts]. St. Petersburg: S. n., 2020. P. 92-94.

Khilkhanova 2009 - E. V. Khilkhanova. Faktory yazykovogo sdviga i sokhraneniya minoritarnykh yazykov: diskursnyy i sotsiolingvisticheskiy analiz (na primere yazykovoy situatsii v etnicheskoy Buryatii) [Factors of language shift and minority languages maintenance: discourse and sociolinguistic analysis (on the example of language situation in ethnic Buryatia]. Doctoral thesis. Barnaul: Altay State University, 2009.

Khilkhanova 2019 - E. V. Khilkhanova. Internet i minoritarnye yazyki Rossii: simvolicheskoe prisutstvie ili instrument revitalizatsii? (na primere buryatskogo yazyka) [The Internet and minority languages of Russia: a symbolic presence or a tool for revitalization? (The Buryat case)]. Mongolovedenie [Mongolian Studies]. 2019. Vol. 11. No. 4. P. 967-988. Available at: https://doi.org/10.22162/2500-1523-20194-967-988 (accessed on 01.10.2019).

Khilkhanova et al. 2016 - E. V. Khilkhanova, G. A. Dyrkheeva, L. M. Lyubimova, D. B. Sundueva. Yazykovoe soznanie i yazykovye ustanovki zhiteley prigranichnykh regionov vostoka Rossii (na primere Respubliki Buryatiya i Zabaykalskogo kraya) [Linguistic Consciousness and Language Attitudes of Residents of the Border Areas of the East of Russia (the Case of the Republic of Buryatia and the Transbaikal Region)]. East Siberian State Institute of Culture; Institute of Mongolian, Buddhist and Tibetan Studies of the Siberian branch of the RAS. Moscow: Nauka; Izdatelskaya firma "Vostochnaya literature", 2016. 
Kirilenko 2015 - S. V. Kirilenko. Protsessy formirovaniya ponyatiynogo apparata sotsiolingvistiki [Processes of formation of the conceptual apparatus of sociolinguistics]. Candidate thesis. Moskva: Institute of Linguistics of the RAS, 2015.

Kozhanovskiy 2011 - A. N. Kozhanovskiy. «Baskskiy vopros»: Etnicheskiy ili territorialnyy? [«The Basque Question»: Ethnic or Territorial?]. Obshchestvennye nauki i sovremennost. 2011. No 6. P. 110-122.

Kroskrity 2000 - P. V. Kroskrity. Regimenting Languages: Language Ideological Perspectives. P. V. Kroskrity (ed.). Regimes of Language: Ideologies, Polities, and Identities. Santa Fe: School of American Research Press, 2000. P. 1-34.

Kuchinov 2015 - A. M. Kuchinov. Sovremennye teorii structure-agency i russkaya sotsiologiya [Modern theories of structure-agency and Russian sociology]. Gumanitarnye nauchnye issledovaniya. 2015. No 4. Ch. 3. Available at: http://human.snauka.ru/2015/04/9598 (accessed on 26.03.2019).

Kutsaeva 2018 - M. V. Kutsaeva. Chuvashskaya diaspora v moskovskom regione: sotsiolingvisticheskiy portret [The Chuvash Diaspora in the Moscow region: a sociolinguistic portrait]. A. N. Bitkeeva, M. A. Goryacheva (eds.). Yazykovoe edinstvo i yazykovoe raznoobrazie v polietnicheskom gosudarstve: Mezhdunarodnaya konferentsiya (Moskva, 14-17 noyabrya 2018): Doklady i soobshcheniya [Linguistic unity and linguistic diversity in a multi-ethnic state: International conference (Moscow, November 14-17, 2018): Reports and presentations. Institute of Linguistics of the RAS, Research Center on Ethnic and Language Relations. Moscow: Yazyki narodov mira, 2018. P. 655-661.

Lane et al. 2018 - P. Lane, J. Costa, H. De Korne (eds.). Standardizing Minority Languages: Competing Ideologies of Authority and Authenticity in the Global Periphery. New York: Routledge, 2018.

Le Koadik - R. Le Koadik. My stolknulis s vragom, i on - eto my: bretonskiy yazyk vchera, segodnya, zavtra [We have met the enemy and he is us: the Breton language yesterday, today, tomorrow]. E. Filippova (ed.). Yazyki menshinstv: yuridicheskiy status i povsednevnye praktiki. Rossiysko-frantsuzskiy dialog [Minority languages: legal status and everyday practices. Russian-French dialogue]. Moscow: Rosinformagrotekh, 2013. P. 104-124.

Mac Giolla 2012 - C. D. Mac Giolla. Jailtacht: The Irish Language, Symbolic Power and Political Violence in Northern Ireland, 1972-2008. Cardiff: University of Wales Press, 2012.

Martynova 2019 - M. Yu. Martynova. Yazyk i shkolnoe obrazovanie. Rossiyskiy opyt [Language and school education. Russian experience]. E. I. Filippova, S. V. Sokolovskiy (eds.). Smert yazyka - smert naroda? Yazykovye situatsii i yazykovye prava $v$ Rossii i sopredelnykh gosudarstvakh [The death of the language - the death of the people? Language situations and language rights in Russia and neighboring countries]. Moscow: Goryachaya liniya - Telekom, 2019. P. 40-74.

Marusenko 2014 - M. A. Marusenko. Yazykovaya ideologiya i borba za vozrozhdenie yazykov [Language ideology and the struggle for the revival of languages]. Drevnyaya i Novaya Romaniya. 2014. Iss. 14. P. 145-161. 
McCarty 2011 — T. McCarty (ed.). Ethnography and language policy. New York, London: Routledge, 2011.

McCarty 2015 - T. McCarty. T. Ethnography in language planning and policy research. F. Hult, D. Johnson (eds.). Research methods in language policy and planning: A practical guide. Oxford: Wiley Blackwell, 2015. P. 81-93.

Mikhalchenko 2019 - V. Yu. Mikhalchenko. Dinamika yazykovoy situatsii v Rossiyskoy Federatsii [Dynamics of the language situation in the Russian Federation]. M. Wingender, A. N. Bitkeeva, E. V. Khilkhanova (eds.). Perspektivy i vyzovy yazykovoy politiki i yazykovoy situatsii v Krymu. Mezhdunarodnyy kruglyy stol (Moskva, 05-06 noyabrya 2019 g.): Doklady i soobshcheniya [Prospects and challenges of language policy and language situation in the Crimea. International round table (Moscow, 05-06 November 2019): Reports and presentations]; Institute of Linguistics of the RAS, the Giessen Centre for Eastern European Studies (GiZo) of the Justus Liebig University Giessen. Moscow: S. n., 2019. P. 8-24.

Mikhalchenko, Trushkova 2003 - V. Yu. Mikhalchenko, J. Trushkova. Russian in the modern world. J. Maurais, M. A. Morris (eds.). Languages in a globalizing world. Cambridge; New York: Cambridge University Press, 2003. P. 260-290.

Molodychenko 2017 - Ye. N. Molodychenko. Identichnost i diskurs: ot sotsialnoy teorii k praktike lingvisticheskogo analiza [Identity and discourse: from social theory to the practice of linguistic analysis]. Nauchno-tekhnicheskie vedomosti Sankt-Peterburgskogo gosudarstvennogo Politekhnicheskogo universiteta. Gumanitarnye i obshchestvennye nauki. 2017. Vol. 8. No. 3. P. 122-133. DOI: 10.18721/JHSS .8312.

Moore 2016 - J. W. Moore. What Is the Sense of Agency and Why Does it Matter? Frontiers in Psychology. 2016. 29 August. Available at: https://www.frontiersin.org/ articles/10.3389/fpsyg.2016.01272/full (accessed on 18.04.2020).

Mukharyamov 2018 - N. M. Mukharyamov. Yazykovaya politika i natsiestroitelstvo $\mathrm{v}$ menyayushchikhsya kontekstakh [Language policy and nation-building in changing contexts]. M. A. Omarov (ed.). Natsiestroitelstvo: sostoyanie, problemy, perspektivy. Materialy Vserossiyskoy nauchnoy konferentsii [Nation-building: state, problems, prospects. Materials of the all-Russian scientific conference]. Moscow: Russian State University for the Humanities Press, 2018. P. 68-75.

Ó Duibhir 2015 et al. 2015 - P. Ó Duibhir, N. Ní Chuaig, L. Ní Thuairisg, C. Ó Brolcháin. Educational Provision through Minority Languages: Review of International Research. Commissioned Research Report: An Chomhairle um Oideachas Gaeltachta agus Gaelscolaiochta (COGG). Dublin: Dep. Educ. Skills, 2015.

Ó Murchadha et al. 2018 - N. P. Ó Murchadha, M. Hornsby, C. Smith-Christmas, M. Moriarty. New Speakers, Familiar Concepts? C. Smith-Christmas, M. Hornsby, M. Moriarty, N. Ó Murchadha (eds.). New Speakers of Minority Languages: Linguistic Ideologies and Practices. Basingstoke: Palgrave McMillan, 2018. P. 1-22.

O'Rourke, Ramallo 2018 - B. O'Rourke, F. Ramallo. Identities and New Speakers of Minority Languages: A Focus on Galician. C. Smith-Christmas, M. Hornsby, M. Moriarty, N. Ó Murchadha (eds.). New Speakers of Minority Languages: Linguistic Ideologies and Practices. Basingstoke: Palgrave McMillan, 2018. P. 91-109. 
Ostgof, Brugman 1960 - G. Ostgof, K. Brugman. Predislovie k knige «Morfologicheskie issledovaniya v oblasti indoevropeyskikh yazykov» [Preface to the book «Morphological research in the field of Indo-European languages»]. V. A. Zvegintsev. Istoriya yazykoznaniya XIX i XX vekov v ocherkakh i izvlecheniyakh [History of linguistics of the XIX and XX centuries in essays and extracts]. Moscow: S. n., 1960. P. 153-164.

Pestey 2013 - F. Pestey. Ofitsialnoe priznanie dvuyazychiya na Korsike: itogi i perspektivy [Official recognition of bilingualism in Corsica: results and prospects]. E. Filippova (ed.). Yazyki menshinstv: Yuridicheskiy status i povsednevnye praktiki. Rossiysko-frantsuzskiy dialog [Minority languages: Legal status and everyday practices. Russian-French dialogue]. Moscow: Rosinformagrotekh, 2013. P. 125-144.

Pischlöger 2010 - C. Pischlöger. Udmurtness in Web 2.0: Urban Udmurts Resisting Language Shift. Finnisch-Ugrische Mitteilungen. 2010. Band 38. P. 143-161.

Pischlöger 2016 - C. Pischlöger. Udmurt on Social Network Sites: A Comparison with the Welsh Case. Linguistic Genocide Or Superdiversity? New and Old Language Diversities. 2016. Vol. 14. P. 108-132.

Popkov 2016 - Yu. V. Popkov. Kontseptualnye voprosy etnonatsionalnoy politiki Rossii [Conceptual issues of ethno-national policy of Russia]. Kulturnoe nasledie Rossii. 2016. No. 3. P. 13-19.

Popkov, Kostyuk 2015 - Yu. V. Popkov, V. G. Kostyuk. Problemnoe pole natsionalnoy politiki v sovremennoy Rossii [The problem field of national politics in modern Russia]. Vestnik Novosibirskogo gosudarstvennogo universiteta. Seriya: Filosofiya. 2015. Vol. 13. No. 3. P. 71-80.

Puigdevall 2014 - M. Puigdevall. Introduction. "New Speakers of Minority Languages: Belonging and Legitimacy" [online dossier]. Digithum. 2014. Iss. 16. P. 44-46. Available at: https://www.raco.cat/index.php/Digithum/article/view/n16-puigdevall/394155 (accessed on 26.03.2020).

Ricento, Hornberger 1996 - T. K. Ricento, N. H. Hornberger. Unpeeling the Onion: Language Planning and Policy and the ELT Profession. TESOL Quarterly. 1996. Vol. 30. No. 3. P. 401-427. DOI: http://dx.doi.org/10.2307/3587691.

Sallabank, Marquis 2018 - J. Sallabank, Y. Marquis. 'We Don't Say It Like That': Language Ownership and (De)Legitimising the New Speaker. C. Smith-Christmas, M. Hornsby, M. Moriarty, N. Ó Murchadha (eds.). New Speakers of Minority Languages: Linguistic Ideologies and Practices. Basingstoke: Palgrave McMillan, 2018. P. 67-90.

Shepelev 2015 - A. N. Shepelev. Rol yazykovoy politiki v sovremennoy Rossii [The role of language policy in modern Russia]. Vestnik Tambovskogo universiteta. Seriya: gumanitarnye nauki. 2015. No. 10 (150). P. 168-172.

Shveytser 1976 - A. D. Shveytser. Sovremennaya sotsiolingvistika. Teoriya, problemy, metody [Modern sociolinguistics. Theory, problems, methods]. M.: Moscow: S. n., 1976.

Smith-Christmas et al. 2018 - C. Smith-Christmas, M. Hornsby, M. Moriarty, N. Ó Murchadha (eds.). New Speakers of Minority Languages: Linguistic Ideologies and Practices. Basingstoke: Palgrave McMillan, 2018.

Smokotin 2010 - V. M. Smokotin. Evropeyskoe mnogoyazychie: ot gosudarstv-natsiy $k$ mnogoyazychnoy i polikulturnoy Evrope [European multilingualism: from 
nation-states to a multilingual and multicultural Europe]. Tomsk: Tomsk State University Press, 2010.

Smolicz, Secomble 1998 - J. Smolicz, M. Secomble. Community languages, core values and cultural maintenance: the Australian experience with special reference to Greek, Latvian and Polish groups. M. Clyne (ed.). Australia, Meeting Place of Languages. Canberra, Australia: Australian National University, Pacific Linguistics, 1988. P. 11-38.

Sokolovskiy, Filippova 2019 - S. V. Sokolovskiy, E. I. Filippova. Zakony i ideologii: politika i upravlenie yazykovymi situatsiyami [Laws and ideologies: policy and management of language situations]. E. I. Filippova, S. V. Sokolovskiy (eds.). Smert yazyka - smert naroda? Yazykovye situatsii i yazykovye prava $v$ Rossii i sopredelnykh gosudarstvakh [The death of the language — the death of the people? Language situations and language rights in Russia and neighboring countries]. Moscow: Goryachaya liniya - Telekom, 2019. P. 5-18.

Sokolovskiy, Podlesnykh 2019 - S. V. Sokolovskiy, O. N. Podlesnykh. Yazyk i politika $\mathrm{v}$ sfere obrazovaniya $\mathrm{v}$ Tatarstane [Language and education policy in Tatarstan]. E. I. Filippova, S. V. Sokolovskiy (eds.). Smert yazyka - smert naroda? Yazykovye situatsii i yazykovye prava $v$ Rossii $i$ sopredelnykh gosudarstvakh [The death of the language — the death of the people? Language situations and language rights in Russia and neighboring countries]. Moscow: Goryachaya liniya - Telekom, 2019. P. 75-98.

Strogalshchikova 2016 - Z. I. Strogalshchikova. Vepsy v etnokulturnom prostranstve evropeyskogo Severa [Vepsians in the ethnocultural space of the European North]. Karelian Scientific Center of the RAS, Institute of Language, Literature and History. Petrozavodsk: Periodika, 2016.

Tishkov, Akbaev 2019 - V. A. Tishkov, Kh. M. Akbaev. «Narod ne umiraet s yazykom» ili «Yazyk ne zhivet bez naroda»? Dialog uchenykh o konflikte vokrug rodnogo yazyka [«The people do not die with the language» or «the Language does not live without the people»? Dialogue of scientists about the conflict over the native language]. E. I. Filippova, S. V. Sokolovskiy (eds.). Smert yazyka - smert naroda? Yazykovye situatsii i yazykovye prava $v$ Rossii $i$ sopredelnykh gosudarstvakh [The death of the language - the death of the people? Language situations and language rights in Russia and neighboring countries]. Moscow: Goryachaya liniya - Telekom, 2019. P. 19-39.

Toivanen 2015 - R. Toivanen. Obstacles and successes Comparing Minority Language Activism Among the Sorbs in Germany and the Sámi in Finland. H. F. Marten, M. Riessler, J. Saarikivi, R. Toivanen (eds.). Cultural and Linguistic Minorities in the Russian Federation and the European Union. Comparative Studies on Equality and Diversity. Series Multilingual Education. Vol. 13. London: Springer International Publishing, 2015. P. 83-105. DOI 10.1007/978-3-319-10455-3_4.

Tollefson, Pérez-Milans 2018 - J. W. Tollefson, M. Pérez-Milans (eds.). The Oxford Handbook of Language Policy and Planning. Oxford: Oxford University Press, 2018. Vakhtin 1998 - N. B. Vakhtin. Ischeznovenie yazyka i yazykovaya transformatsiya: zametki o metafore «yazykovoy smerti» [Language disappearance and language 
transformation: notes on the metaphor of «language death»]. N. A. Kozintseva, A. K. Ogloblin (eds.). Tipologiya. Grammatika. Semantika. K 65-letiyu V. S. Khrakovskogo [Typology. Grammar. Semantics. To the $65^{\text {th }}$ anniversary of V. S. Khrakovsky]. St. Petersburg: Nauka, 1998. P. 115-128.

Vakhtin 2001 - N. B. Vakhtin. Yazyki narodov Severa v XX veke. Ocherki yazykovogo sdviga [Languages of the peoples of the North in the twentieth century. Essays on the language shift]. St. Petersburg: Dmitriy Bulanin, 2001.

Vakhtin, Golovko 2005 - N. B. Vakhtin, Ye. V. Golovko. Ischezayushchie yazyki i zadachi lingvistov-severovedov [Vanishing languages and tasks of Northern linguists]. A. Ye. Kibrik (ed.). Malye yazyki i traditsii: sushchestvovanie na grani. Vyp. 1: Lingvisticheskie problemy sokhraneniya malykh yazykov [Small languages and traditions: existence on the edge. Iss. 1: Linguistic problems of preserving small languages]. Moscow: Novoe izdatelstvo, 2005. P. 40-51.

Van Dongera et al. 2017 - R. van Dongera, C. van der Meer, R. Sterk. Research for CULT Committee - Minority Languages and Education: Best Practices and Pitfalls. Policy Department for Structural and Cohesion Policies, Culture and Education. Brussels: Policy Dep. Struct. Cohes. Policies Eur. Parliament, 2017.

Vinogradov 1990 - V. A. Vinogradov. Yazykovaya situatsiya [Language situation]. V. N. Yartseva (ed.). Lingvisticheskiy entsiklopedicheskiy slovar [Linguistic encyclopedic dictionary]. Moscow: Sovetskaya entsiklopediya, 1990. P. 616-617.

Wiley, Garcia 2016 - T. G. Wiley, O. Garcia. Language policy and planning in language education: Legacies, consequences, and possibilities. Modern Language Journal. 2016. Vol. 100. Suppl. 1. P. 48-63. Available at: http://doi.org/10.1111/modl.12303 (accessed on 26.03.2020).

Wingender 2018 - M. Wingender. Diskursive Konstruktion von Sprachenvielfalt und Sprachenkonflikten in Russland - Sprachenpolitik im Kontext von nationaler Sicherheit. S. Kempgen, M. Wingender, L. Udolph (eds.). Deutsche Beiträge zum 16. Internationalen Slavistenkongress. Wiesbaden: Harrasowitz, 2018. P. 353-364.

Woolard 2003 - K. Woolard. We Don't Speak Catalan Because We Are Marginalized: Ethnic and Class Connotations of Language in Barcelona. R. K. Blot (ed.). Language and Social Identity. Westport, CT: Praeger Publishers, 2003. P. 85-103.

Zamyatin 2015 - K. Zamyatin. The Evolution of Language Ideology in Post-Soviet Russia. H. F. Marten, M. Riessler, J. Saarikivi, R. Toivanen (eds.). Cultural and Linguistic Minorities in the Russian Federation and the European Union. Comparative Studies on Equality and Diversity. Series Multilingual Education. Vol. 13. London: Springer International Publishing, 2015. P. 279-314.

Zamyatin 2018 - K. Zamyatin. Formirovanie yazykovoy politiki v respublikakh Rossii $\mathrm{v}$ postsovetskiy period: analiz politicheskogo tsikla [Formation of language policy in the Russian republics in the post-Soviet period: analysis of the political cycle]. A. N. Bitkeeva, M. A. Goryacheva (eds.). Yazykovoe edinstvo i yazykovoe raznoobrazie v polietnicheskom gosudarstve: Mezhdunarodnaya konferentsiya (Moskva, 1417 noyabrya 2018): Doklady i soobshcheniya [Linguistic unity and linguistic diversity in a multi-ethnic state: International conference (Moscow, November 14-17, 2018): Reports and presentations]. Moscow: Yazyki narodov mira, 2018. P. 193-203. 
Zhao, Baldauf 2012 - S. Zhao, R. B. Baldauf. Individual agency in language planning: Chinese script reform as a case study. Language Problems and Language Planning. 2012. Vol. 36. Iss. 1. P. 1-24. Available at: http://doi.org/10.1075/lplp.36.1.01zha (accessed on 26.03.2020).

\section{Sources}

Advisory Committee 2018 - Advisory Committee on the Framework Convention for the Protection of National Minorities on the Russian Federation. Fourth Opinion on the Russian Federation - adopted on 20 February 2018. Available at: https:// $\mathrm{rm}$.coe.int $/ 4^{\text {th }}$-advisory-committee-opinion-on-the-russian-federation-english-lan$\mathrm{gu} / 1680908982$ (accessed on 19.01.2019).

Alekseyev, Kharitonov 2020 - F. G. Alekseyev, V. S. Kharitonov. Rossiyskiy yazykovoy aktivizm. Kto spasayet aleutskiy, nivkhskiy, evenkiyskiy i drugiye yazyki Rossii [Russian language activism. Who saves Aleutian, Nivkh, Evenk and other languages of Russia]. Available at: https://zapovednik.space/material/rossijskij-jazykovoj-aktivizm?fbclid=IwAR2SQ5TYBBEnWsi4aRQZTYKC7YQqCUOabtJ3KH-7OboZdkqZdvWVYHUuIZc (accessed on 19.04.2020).

Baranova 2019b - V. V. Baranova. Sokhraneniye malykh yazykov samimi nositelyami: kto i kak vozrozhdayet kalmytskiy? [Preservation of small languages by native speakers themselves: who is reviving Kalmyk and how?]. Available at: https://eusp.org/news/sokhraneniye-malykh-yazykov-samimi-nositelyami-kto-i-kak-vozrozhdayet-kalmytskij (accessed on 15.03.2020).

Bulbinskaya 2020 - O. Bulbinskaya. SOS! Diskriminatsiya khantyyskogo yazyka v Khanty-Mansiyske!? [SOS! Discrimination of the Khanty language in Khanty-Mansiysk!?]. Available at: https:/www.facebook.com/denis.tokmashev/ posts/3111880362190723 (accessed on 15.04.2020).

FTSP — Federalnaya tselevaya programma «Russkiy yazyk» na 2016-2020 gg. [Federal target program «Russian language» for 2016-2020]. Available at: http://static.government.ru/media/files/UdArRuNmg2Hdm3MwRUwmdE9N3ohepzpQ.pdf (accessed on 06.04.2020).

Gavrilenko et al. 2020 - A. Gavrilenko, A. Khairov, A. Gorodnova, L. Farkhutdinov. Etoy formulirovkoy Putin tochno zakladyvayet minu. Kto takiye russkiye? 4 marta 2020 [With this wording, Putin is definitely laying a mine. Who are the Russians? March 4, 2020]. Available at: https:/www.business-gazeta.ru/article/459939 (accessed on 07.04.2020).

Kiseleva 2020 - K. L. Kiseleva. Yazyki narodov Rossii: komu oni rodnyye i pochemu my khotim ikh sokhranit [Languages of the peoples of Russia: for whom they are native languages and why we want to preserve them]. Available at: https://rastimdetey.rf/articles/yazyki-narodov-rossii-komu-oni-rodnyye (accessed on 15.03.2020).

MetRek - Metodicheskiye rekomendatsii organam ispolnitelnoy vlasti subyektov Rossiyskoy Federatsii, osushchestvlyayushchim gosudarstvennoye upravleniye $v$ sfere obrazovaniya, po voprosu izucheniya gosudarstvennykh yazykov respublik, 
nakhodyashchikhsya v sostave Rossiyskoy Federatsii [Methodological recommendations to Executive authorities of the Russian Federation's constituent entities that exercise state administration in the field of education, on the issue of studying the state languages of the republics that are part of the Russian Federation]. Konsortsium Kodeks. Available at: http://docs.cntd.ru/document/550918049 (accessed on 10.11.2019).

Mikhalchenko 2006 - V. Yu. Mikhalchenko (ed.). Slovar sotsiolingvisticheskikh terminov [Dictionary of sociolinguistic terms]. Moscow: Institute of Linguistics of RAS Press, 2006.

OORF - Federalnyy zakon ot 29 dek. 2012 g. № 273-FZ «Ob obrazovanii v Rossiyskoy Federatsii» [Federal law of 29 Dec. 2012 No. 273-FZ «On education in the Russian Federation»]. Available at: http://static.kremlin.ru/media/acts/ files/0001201212300007.pdf (accessed on 8.10.2019).

Pasanen 2011 — A. Pasanen. «Yazykovyye gnezda» dlya saamov Finlyandii rabotayut $i v$ shkolakh, etot opyt neobkhodimo primenit v Rossii [«Language nests» for the Finnish Sami also work in schools, and this experience should be applied in Russia]. The Finno-Ugric media center. 2011. Available at: http://finugor.ru/node/21489 (accessed on 20.04.2019).

Polnyy tekst - Polnyy tekst popravok v Konstitutsiyu: za chto my golosuyem? [Full text of amendments to the Constitution: what do we vote for?]. Available at: http:// duma.gov.ru/news/48045/ (accessed on 20.04.2020)

PrOOP - Primernaya osnovnaya obrazovatelnaya programma osnovnogo obshchego obrazovaniya [Approximate basic educational program of basic general education]. Available at: https://fgosreyestr.ru (accessed on 18.02.2020)

Reportazh 2020 - Reportazh o 1-m zasedanii Diskussionno-analiticheskogo kluba po voprosam yazykovoy politiki [Report on the $1^{\text {st }}$ meeting of the Discussion-analytical club on language policy]. Available at: https://iling-ran.ru/web/ru/news/200324 daclp (accessed on 30.04.2020)

Spetsialnyy proyekt - Spetsialnyy proyekt «Yazykovaya sreda». V boy idet khipstota. Chto mogut sdelat prostyye gorozhane dlya sokhraneniya yazykov narodov $R F$ [Special project «Linguistic environment». Hipsters go into battle. What can ordinary citizens do to preserve the languages of the peoples of the Russian Federation]. Available at: https://nazaccent.ru/content/29636-v-boj-idet-hipstota.html (accessed on 20.04.2020).

Strana yazykov - Strana yazykov. Ploshchadka dlya obmena opytom, ideyami i yenergiyey dlya ozhivleniya yazykov [Country of languages. A platform for the exchange of experience, ideas and energy for the revival of languages]. Available at: http:// stranayaz.ru (accessed on 19.06.2019).

Strategiya - Strategiya gosudarstvennoy natsionalnoy politiki Rossiyskoy Federatsii na period do 2025 goda [Strategy of the state national policy of the Russian Federation for the period up to 2025]. Available at: http://base.consultant.ru/cons/cgi/online.cgi?req=doc; base $=\mathrm{LAW} ; \mathrm{n}=139350$ (accessed on 28.01.2013).

UNESCO Atlas - UNESCO Atlas of the World's Languages in Danger. Available at: http://www.unesco.org/new/en/culture/themes/endangered-languages/atlas-of-languages-in-danger/ (accessed on 09.09.2019). 
Yakut. — Yakutiya: my zhe ne trebuyem soglasiya roditeley na izucheniye matematiki ili biologii. 28 sentyabrya 2017. [Yakutia: we do not require parental consent to study mathematics or biology. September 28, 2017]. Available at: https://ru.wikinews.org/ wiki/Yakutiya:_My_zhe_ne_trebuyem_soglasiya_roditeley_na_izucheniye_matematiki_ili_biologii (accessed on 22.11.2019).

Yartseva (ed.) 1990 - V. N. Yartseva (ed.). Lingvisticheskiy entsiklopedicheskiy slovar [Linguistic encyclopedic dictionary]. Moscow: Sovetskaya entsiklopediya, 1990.

Yartseva (ed.) 1998 - V. N. Yartseva (ed.). Yazykoznaniye: bolshoy yentsiklopedicheskiy slovar. 2-e izd. Repr. vosproizvedeniye izd. «Lingvisticheskogo yentsiklopedicheskogo slovarya» 1990 goda [Linguistics: a large encyclopedic dictionary. $2^{\text {nd }}$ ed. Reprint of the ed. «Linguistic encyclopedic dictionary»]. Moscow: Bolshaya Rossiyskaya Entsiklopediya, 1998. 


\section{Восторг в поэтическом языке М. В. Ломоносова и в Четьих Минеях Димитрия Ростовского (к вопросу о церковнославянском субстрате одического восторга)}

\section{М. Г. Шарихина}

Институт лингвистических исследований РАН, Санкт-Петербург; justmilya@yandex.ru

Аннотация. Статья посвящена исследованию лингвостилистической преемственности одического восторга в поэзии М. В. Ломоносова по отношению к языку церковнославянской литературы предшествующего периода (в частности, минейного собрания Димитрия Ростовского). Сравнительно-сопоставительный анализ между понятиями одического восторга и мистического экстаза, а также лингвостилистическими способами их выражения в сопоставляемых текстах позволил выявить их общие черты на лексико-семантическом и фразеологическом уровнях.

Ключевые слова: Ломоносов, одическая поэзия, одический восторг, мистический экстаз, Четьи Минеи Димитрия Ростовского, furor poeticus, историческая лексикология, фразеология.

\section{Rapture in the poetic language of $M$. V. Lomonosov and in Menology of Dimitri Rostovsky (to the question of the Church Slavonic substrate of the odic rapture)}

\section{G. Sharikhina}

Institute for Linguistic Studies, Russian Academy of Sciences, St. Petersburg; justmilya@yandex.ru

Abstract. The article presents a study of the linguistic and stylistic continuity of odic rapture in M. V. Lomonosov's poetry relative to the Church Slavonic literature of earlier periods (in particular, the Menologion by Dimitry Rostovsky). 
The analysis compares the concepts of odic rapture and mystic ecstasy to reveal similarity of their conceptual content and investigate the relationships between the various linguistic ways of expressing these concepts in comparable texts. In particular, the article examined the words vostorg 'rapture', voskhitit' (voskhishchat') 'bewilder', voskhitit'sya (voskhishchat'sya) 'be bewildered' and fixed word combinations (for example, voskhishchennyj umom 'bewildered mind', um voskhishchayetsya '[my] mind is bewildered', or umnyje, myslennyje ochi 'mind's eyes', umom zrit' '[s/he] sees with [his/ her] mind'). In the texts analyzed, these linguistic units have common semantic and stylistic features. They are used to express a special emotional state that is usually accompanied by visions. In this state, the heroes of the Lives and the lyrical hero of odic poetry obtains the ability to see what is hidden from the ordinary eye. Thus, the lexical units analyzed are involved in the expression of oppositions between the sensual and the spiritual, the external and the internal, the visible and the invisible. The Church Slavonic origins of the lexicon of odic delight are emphasized by the fact that M. V. Lomonosov's non-poetic works use it in meanings characteristic of Church Slavonic together with bright Church slavicisms.

In addition, it was found that a state of mystic ecstasy in the Menologion by Dimitry Rostovsky is generally characteristic of the lives of ascetics. Therefore, the similarity of the linguistic means to express a special emotional state in Lomonosov's odic poetry and in Dimitri Rostovsky's Menology raises the question of a connection between the odic style and the ascetic direction in hagiography.

Keywords: Lomonosov, odic poetry, odic rapture, mystic ecstasy, Menologion of Dimitry Rostovsky, furor poeticus, historical lexicology, phraseology.

\section{1. Одический восторг в контексте церковнославянской литературной традиции (литература вопроса)}

Поэтический восторг (или furor poeticus) является основой смысловой организации панегирической оды, «постоянным признаком одического жанра и - в результате экстраполяции - конститутивным элементом высокого стиля» [Живов 1994: 72-73]. Учение о furor poeticus как необходимом условии для постижения идеальной сущности предмета ${ }^{1}$ восходит к неоплатонизму, оказавшему большое влияние

1 Принцип отражения действительности в одическом жанре также восходит к идеям неоплатоников: «В панегирической оде предмет... предстает не в своей реальности, а преображенным, идеально увиденным» [Алексеева 2005: 190]. 
на новоевропейскую лирику и, в частности, на становление пиндарической оды: «...уучение о божественном вдохновении, о поэтическом восторге, о священном исступлении (безумии) поэта опирается на понятие

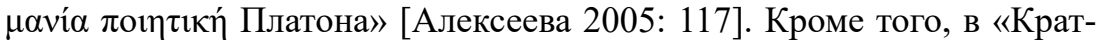
ком руководстве к красноречию» М. В. Ломоносова фигура восхищение, генетически связанная с поэтическим восторгом ${ }^{2}$, иллюстрируется цитатами из «Метаморфоз» Овидия и «Оды на взятие Намюра» Н. Буало [Ломоносов, VII: 285]. Таким образом устанавливается преемственность одического восторга по отношению к западноевропейской поэтической традиции.

Вопрос о связи русской оды с барочной поэтикой и предшествующей литературной традицией ${ }^{3}$ был рассмотрен В. М. Живовым. Он указал на два источника влияния на стилистику торжественной оды: торжественную силлабическую поэзию и торжественную проповедь, «фразеология и стилистика силлабического панегирика восходили, с одной стороны, к фразеологии и стилистике барочной проповеди, а с другой - к фразеологии и стилистике славянской Псалтыри. Эти связи переносятся теперь и на одическую поэзию» [Живов 1994: 66]. При этом исследователь подчеркивает, что эта преемственность более всего отражается именно в категории furor poeticus: «Барочная поэтика, а отсюда и связь с предшествующей литературной традицией, оказывается нормативной, она выступает как свидетельство профетической одаренности поэта» [Там же: 71]. С вопросом об истоках одического восторга непосредственно связан отдельный экскурс, который В. М. Живов посвятил сочетанию трезвое пианство ${ }^{4}$ в сочинении В. К. Тредиаковского и sainte ivresse у Буало. Объясняя второй случай влиянием учения Филона Александрийского и трактата

\footnotetext{
2 Фигура «восхищение» обычно рассматривается исследователями поэтического творчества М. В. Ломоносова в контексте теории «лирического восторга» [Серман 1966: 136-137; Серман 2002: 343; Живов 1994: 71-72; Алексеева 2005: 191].

${ }^{3}$ Источники одического стиля Ломоносова, в частности Св. Писание и богослужебные тексты, являются предметом исследования в статьях В. Дороватовской и И. И. Солосина [Дороватовская 1911; Солосин 1913]. Вопросу функционирования библейских и богослужебных заимствований в разножанровых сочинениях Ломоносова посвящено исследование Е. М. Матвеева [Матвеев 2017].

4 Это сочетание, так же как и бодрая дремота и явный сон у Ломоносова используются для обозначения поэтического восторга [Живов 1994: 72].
} 
Псевдо-Лонгина «О возвышенном», В. М. Живов возводит сочетание, использованное Тредиаковским, к патристической традиции (Оригену, Евсевию, Григорию Нисскому и Симеону Новому Богослову): «В данной традиции это выражение может означать как экстатическое состояние аскета, так и состояние верующих вообще, обоженных причастием и соединяющихся с Божеством» [Там же: 79].

Идеи Живова получили развитие в исследованиях М. Левитта. Он устанавливает влияние на оды Ломоносова православной литературы богословско-мистического направления (Григория Паламы и его предшественников - Климента Александрийского, Дионисия Ареопагита, Симеона Нового Богослова и Евагрия Понтийского) [Левитт 2015: 122 126]. По мнению исследователя, «характерные жанровые маркеры оды, такие как поэтический „экстаз“, „жар“ и „восхищение“, соответствуют православному эсхатологическому дискурсу, описывающему особое состояние души в момент приобщения к Божественному» [Там же: 140]. Одическое «восхищение» М. Левитт возводит к библейскому контексту, посвященному восхищению апостола Павла (2 Кор. 12:4): «Палама описывает „сладостное зрелище, которое восхитило ум“" святого Павла: он созерцал это божественное зрелище, „весь сделавшись зрением“. Экстатическое видение в одах, безусловно, принадлежит к этому же типу откровения» [Там же: 140-141].

Итак, в научной литературе в качестве вероятных источников одического восторга было обозначено два направления церковнославянской литературы: патристическая традиция (В. М. Живов) и православная литература богословско-мистического направления (М. Левитт).

Идейное сходство между поэзией Ломоносова и указанными направлениями церковнославянской литературы не свидетельствует о непосредственном влиянии - доказательств знакомства ученого с произведениями перечисленных выше представителей греческой и латинской патристики ${ }^{5}$, а также мистического богословия у нас нет. Безусловно, знания Ломоносовым в сфере церковнославянской литературы нельзя ограничивать объемом процитированных им текстов или рукописей и изданий, которые сохранили его рабочие пометы. Интерес к церковно-религиозной литературе проявился у него еще в ранние годы жизни

${ }_{5}^{5}$ В сочинениях Ломоносова присутствуют ссылки на труды Василия Великого, Иоанна Златоуста и Иоанна Дамаскина, они перечислены в монографии Г. М. Коровина [Коровин 1961: 346-348]. 
на Севере [Морозов 1962: 88-99]. К этому времени относится знакомство ученого с Библией, богослужебной литературой и четьими сборниками. Во время обучения в Славяно-греко-латинской академии знания Ломоносова в этой области естественным образом расширялись.

В настоящей статье предпринимается сравнительно-сопоставительный анализ исследуемых понятий на языковом (точнее, на лексическом) уровне. Но прежде чем приступить к лексико-семантическому исследованию, мы рассмотрим основные структурно-смысловые компоненты, которые формируют содержание религиозного экстаза и одического восторга. Выделение тех или иных конститутивных элементов в содержании категории является в определенной мере условным, так как во многом зависит от базовых параметров, на которых оно основано. В данном случае такое описание является рабочим, так как служит для того, чтобы в дальнейшем дать адекватную оценку языковым фактам.

\section{2. Содержание понятия одический восторг сквозь призму религиозного дискурса}

Одический восторг обычно рассматривается исследователями как особое эмоциональное состояние лирического героя оды и как способ ви́дения окружающих предметов. Выделенные смысловые компоненты одического восторга обнаруживают связь с понятием мистического экстаза. В истории христианской религии оно устойчиво ассоциируется с аскетизмом, или подвижничеством ${ }^{6}$. В богословской литературе религиозные основы мистического опыта описаны в трудах представителей двух направлений - абстрактно-спекулятивного (сочинения Климента Александрийского, Дионисия Ареопагита и Григория Нисского) и нравственно-практического (сочинения Оригена, Макария Египетского и Симеона Нового Богослова) [Минин 2015: 494-532]. Целью духовной жизни для обоих направлений является обожение, «венец

${ }^{6}$ «Христ[ианский] а[скетизм], или подвижничество, есть ревность и сила пребывать в деятельном, путем подвигов (постничества, девства, отшельничества и др.), общении с Богом, по вере в Господа нашего Иисуса Христа, при помощи благодати Божией, для обретения истинно христ. настроенности как залога к участию в Царствии Небесном» [Литвинова 2001: 593]. 
мистического подвига и там, и здесь ekstasis. Но в первом случае экстаз представляет восхищение или „исступление“ ума, во втором - восхищение или восторг чувства» [Там же: 495-496]. Кроме двух указанных направлений выделяется также этико-гностическое (примирительное), которое объединяет в себе их характерные особенности. Его основные принципы отражены в трудах Исаака Сирина и Максима Исповедника [Там же: 532-543].

\section{1. Одический восторг как особое эмоциональное состояние}

Специфика эмоционального состояния, которое обозначается понятием одический восторг, состоит в том, что оно не имеет качественной характеристики: «может быть „радостный восторг“, может быть восторг ужаса» [Алексеева 2005: 191]. Обычно его сближают с эмоцией удивления [Там же]. В «Кратком руководстве к красноречию» Ломоносов дает следующее определение фигуры восхищение:

(1) «Восхищуение есть когда сочинитель представляет себя как изумленна в мечтании, происходящем от весьма великого, нечаянного или страшного и чрезъестественного дела. Сия фигура совокупляется почти всегда с вымыслом и больше употребительна у стихотвориеев». [Ломоносов, VII: 284-285].

Здесь это эмоциональное состояние характеризуется с помощью слова изумленныци, которое в XVIII в. сохраняло значение 'лишенный ума, безумный', однако употреблялось и в значении 'сильно удивленный, пораженный’ [СлРЯ XVIII 9: 66]. Это подтверждает справедливость сближения одического восторга и удивления. Другая особенность furor poeticus отражена в описании этого состояния в «Рассуждении о оде во обще» (1734 г.) В. К. Тредиаковского:

(2) Они (Пиндар и Гораций. - Прим. М. Ш.) только одни умели писать так чудесно, когда, чтоб изъявить разум свой, как бы вне себя быть, прерывали с умысла последование своея речи и, чтоб лучше войти в разум, выходили, буде позволено так сказать после Боало, из самого разума, удаляясь с великим старанием от того порядка методического и исправного связания сенса, который имел бы отнять всю соль, весь сок или, лучше, самую душу у лирическия поэзии [Тредиаковский 2009: 157]. 
В приведенном фрагменте Тредиаковский описывает восторг с помощью сочетаний как бы вне себя быть, войти в разум, выходили из разума. Выход за пределы чувственного мира является необходимой стороной furor poeticus и в платоновской концепции поэзии, ставшей философской основой для учения о поэтическом восторге в новоевропейской лирике [Алексеева 2005: 117].

Эта сторона одического состояния, как нам представляется, более всего сближает его с мистическим экстазом. Характеризуя последний, М. Левитт подчеркивал эту его особенность: «этот особый тип опытного познания подразумевает одновременно „утрату себя“ и достижение более высокого рефлективного уровня сознания через „выход за пределы“ самого себя (на это наводит буквальное значение гре-

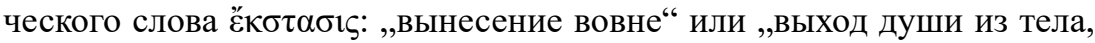
мистический и пророческий транс“)» [Левитт 2015: 138]. Переход в состояние религиозного экстаза сопровождается утратой физических ощущений, что достигается путем «преодоления „феноменальной““ стороны своего бытия» [Минин 2015: 491]. В истории христианской мистики такое состояние обозначается понятием спекулятивный экстаз, оно характерно, например, для мистики Григория Нисского [Там же: 511].

\section{2. Одический восторг как способ ви́дения}

Понятие одического восторга тесно связано с воображением, фантазией. На это, в частности, указывает определение фигуры восхищение в «Кратком руководстве к красноречию» М. В. Ломоносова (см. пример (1)). Вероятно, эта связь обусловлена более широким взаимодействием понятия одического восторга и особым взглядом на окружающую действительность, характером ви́дения и, как следствие, отражением реальности в пиндарической оде, которое обычно рассматривается как влияние неоплатонизма. Исследователи нередко обращались к визуальным метафорам для описания одического восторга: «восторг, или восхищение, есть умственное созерцание предмета, рассмотрение его умными очами», «в этом состоянии поэт видит „умными очами“, „мысленным взором“ недоступное простому глазу» [Алексеева 2005: 191-192]. Зрительное восприятие в данном случае является не физическим, а духовным, оно является результатом умственной или, шире, духовной деятельности: «Мысленный образ всегда отличен 
от реального, реальность, увиденная внутренним взором, преображается, очищается от случайного, наносного, временного, несовершенного. Отсюда в эстетике Нового времени мысленный взор, умные очи становятся своего рода категорией» [Там же: 194]. Указывая на распространенное в русской поэзии XVIII в. противопоставление двух видов зрения (физического и духовного, внешнего и внутреннего), М. Левитт присваивает такую особенность и одам Ломоносова, в которых он выделяет «три практически взаимозаменяемых источника зрения: ум, дух и мысль» [Левитт 2015: 132]. Фразеология од Ломоносова ярко иллюстрирует это положение, так как для нее характерны сочетания лексем зрительного восприятия (зреть, видеть, смотреть, очи, взор) и лексем, обозначающих интеллектуальную деятельность: представить в уме, мысленно взирать, умные очи, мысленные очи, мысленный взор [Там же: 132-133].

Такое умственное созерцание предмета находится в близком родстве с «божественным видением» православных мистиков. С одной стороны, постижение идеальной сущности вещей и окружающей действительности благодаря духовному созерцанию имеет много общих черт с категорией гносиса, которая была описана в трудах Климента Александрийского: «гносис есть неизменное созерцание, интуитивное проникновение в сущность познаваемого, высшая функция человеческого духа и единственное средство приблизиться к Божеству и приобщиться Его совершенствам» [Минин 2015: 497]. Эта категория, которая была разработана в противовес еретическому гностицизму греческой философии, «заимствует аргументы и соображения из греческой философии - платоновской, стоической» [Там же: 497].

С другой стороны, взгляд на окружающую действительность в одическом пространстве нередко обусловливается особым состоянием поэта, парением: «Восторгаясь духом в наднебесье, он (поэт. - Прим. М. Ш.) парит и смотрит на все с идеальной высоты 〈...〉 Пространство в оде изображается с идеальной высоты» [Алексеева 2005: 192]. В этом аспекте, как нам представляется, было бы более корректно использовать понятие восхищение. Здесь оно сближается с восхищением, которое описано во Втором послании к Коринфянам апостола Павла:

(3) Знаю человека во Христе, который назад тому четырнадияать лет (в теле ли - не знаю, вне ли тела - не знаю: Бог знает) восхищен был до третьего неба. И знаю о таком человеке 
(только не знаю - в теле или вне тела: Бог знает), что он был восхищен в рай и слышал неизреченные слова, которых человеку нельзя пересказать (2 Кор. 12:4) [Библия 2004: 1237$1238]$.

Вероятно, под влиянием этого текста в сочинениях христианских авторов слово восхищение развило новое значение 'духовное исступление, возвышение' [Петров 2004: 331].

Итак, в содержательном плане одический восторг может быть поставлен в связь с мистическим экстазом, который является важным понятием в христианском богословии аскетического направления. Между тем, как отмечает П. М. Минин, описания проявлений религиозного экстаза нередко встречаются в житиях подвижников, составленных Руфином, Палладием и Иоанном Мосхом [Минин 2015: 514]. Несколько примеров описания духовного восторга, взятых из житий христианских монахов-аскетов, приводится и в статье П. Флоренского [Флоренский 1996]. Указанные обстоятельства делают актуальным исследование житийного материала для выявления церковнославянских источников одического восторга.

Исследователи творчества Ломоносова обходили вниманием большой корпус церковнославянской агиографии. Между тем известно, что ученый еще в юности проявлял интерес к житиям святых, преимущественно в составе богослужебных и четьих сборников [Морозов 1961: 77]. Сохранилась и рукопись Ломоносова со списком «Жития и службы» Димитрия Солунского [Моисеева 1971: 30, 33 ].

Агиографические сочинения Димитрия Ростовского (в составе «Книги житий святых») стали материалом настоящего исследования, ввиду их широкого распространения и популярности в XVIII в. Свидетельством внимания и уважения Ломоносова к митрополиту и его сочинениям является надпись, составленная для раки Димитрия Ростовского, которая приписывается ученому [Ломоносов, VIII, 1959: 646, 1088-1089].

Описания состояния мистического экстаза в минейном сборнике являются топосом именно житий монахов-аскетов, в других типах житий они встречаются редко. Это во многом связано со спецификой этого состояния, которое обычно является результатом многодневного монашеского (чаще молитвенного) подвига. Такая религиозная активность сопровождается многодневным постом и физическим изнурением, а момент духовного восторга нередко становится высшей точкой духовного напряжения. 


\section{3. Лингвостилистические способы выражения одического восторга в поэзии М. В. Ломоносова в сопоставлении с языком житий сборника Димитрия Ростовского}

\section{1. Способы обозначения особого эмоционального состояния}

В языке Ломоносова эмоциональный план лирического восторга чаще всего реализуется с помощью лексемы восторг, например:

(4) Восторг внезапный ум пленил, / Ведет на верьх горы высокой [Ломоносов, VIII: 16];

(5) Всего народа весел шум, / Как глас вод многих, в верьх восходит, / И мой отрады полныгй ум, / Восхитив тем, в восторг приводит [Там же: 60];

(6) Мой дух течет к пределам света, / Охотой храбрых дел пленен, / В восторге зрит грядущи лета / И грозный древних вид времен [Там же: 107].

Единичны случаи употребления других лексем, обозначающих эмоцию:

(7) Священный ужас мысль объемлет! [Там же: 84];

(8) Какую радость ощущаю? / Куда я ныне восхищен? / Небесну пищу я вкушаю, / На верьх Олимпа вознесен! [Там же: 394].

$\mathrm{B}$ «Книге житий святых» Димитрия Ростовского слово восторг также является наиболее частотной лексемой, которая используется для описания состояния мистического экстаза (всего обнаружено 16 словоупотреблений). Приведем примеры:

(9) Единою стоя на молитве преподобный Пахомий, бысть в восторзе, и виде [Димитрий, 3: 458 об.];

(10) Паки некогда по молитве святый бысть в восторзе, и виде [Димитрий, 2: 173 об.-174];

(11) И бысть аки в восторзе, и виде одежду белую и пресветлую свыше сошедшую, и покрывшую Лукиана [Димитрий, 3: 421]. 
Другие лексические варианты встречаются реже, они включают лексемы сон (тонок) и исступление. Приведем примеры:

(12) Видения некая Божественная яве видяше <монах>, овая спя, овая же бодрствуя. Сон же его бе зело мал и тонок, яко едва возможно бе нарещи сном [Димитрий, 3: 162];

(13) Тако святая молящися, от многия печали воздремася, и тонким сном усну. И се в видении сонном предста ей един от свяmых оных мучеников [Димитрий, 4: 572];

(14) Единою посреде братий седя и делая, во изступлении бысть, и прилежно взирая на небо воздыхаме, и со умилением прекланяме колене на землю [Димитрий, 2: 341 об.];

(15) По шести же днех бысть аки во изступлении в день седмый намедшу на него святому Духу, и нача литургисати [Димитрий, 2: 244].

Значение 'духовное исступление, экстаз' закрепилось за словом восторг, вероятно, уже в ранних церковнославянских текстах. Так, например, в исторических словарях древнейшим памятником, в котором фиксируется рассматриваемое слово в указанном значении, является «Синайский патерик» (ранний список датируется XI в.) [СлРЯ XI-XVII: 61]. В старославянских текстах данное значение выражалось с помощью лексемы ужас. Кроме того, в словаре старославянского языка также фиксируется словосочетание ум ужасен в том же значении [SJS: 616-617]. В «Словаре древнерусского языка XI-XIV вв.» отмечено 4 употребления слова восторг в составе устойчивого сочетания быти (в) възтързе 'о состоянии религиозного экстаза, видений' [СлДРЯ: 134].

Рассматриваемое значение устойчиво закрепляется за словом восторг в церковнославянском языке. Об этом могут свидетельствовать данные «Большого словаря церковнославянского языка Нового времени», где выделяется значение слова ('состояние духовного просветления, иногда сопровождающееся видениями') и устойчивого сочетания быти въ восторзе ('пребывать в состоянии духовного просветления') [БСЦСЯ: 399].

Вероятно, только в XVIII в. слово восторг проникает в поэтическую сферу. Об этом свидетельствует значение 'поэтическое вдохновение', которое фиксируется в «Словаре русского языка XVIII века» и отсутствует в словарях предшествующих периодов [Там же]. Возможно, 
появление нового значения было вызвано формированием категории восторга в сфере поэзии. В «Картотеке Словаря русского языка XVIII в.» первое употребление этого значения отмечено у Ф. Прокоповича в «Слове похвальном о флоте российском» (1720). Однако именно благодаря М. В. Ломоносову слово восторг стало устойчивым маркером высокой поэзии.

\section{2. Употребление глаголов восхитить (восхищцать) и восхититься (восхищаться) при описании восторга и мистического экстаза}

Лексема восхищение, которую Ломоносов использовал для обозначения фигуры в «Кратком руководстве к красноречию», в его поэзии не встречается. Вместо существительного, в метафорических контекстах, обозначающих одический восторг, употребляются глаголы восхитить (восхищуать) и восхититься (восхищзаться) в значении 'поднять на высоту, вознести к небу’ (см. выразительный случай такого употребления глагола восхитить в примере (8)).

Наречие куда подчеркивает сему направленного движения в значении причастия восхищен. В этом примере, с одной стороны, появление античного мифологического топонима Олимп лишает весь контекст тех сакральных смыслов, которые обычно сопровождают значение причастия восхищеенный в церковнославянском языке, о чем свидетельствуют словарные иллюстрации к рассматриваемому значению глагола [СлДРЯ: 143, 145; СлРЯ XI-XVII: 66, 67]. С другой стороны, «следы» церковнославянского употребления обнаруживаются в контексте, где присутствуют слова и сочетания, которые являются церковнославянизмами и/или обычно используются в языке церковно-религиозных текстов, такие как небесная пищуа, вкушать, вознесенный. В связи с этим примечателен следующий пример непоэтического употребления глагола восхищзаться в рассматриваемом значении:

(16) Но кто притом представляет еще всесильного строителя и начальника натуры, взирает просвещченным и проницающим оком в сокровенные внутренности многообразных тварей, видит взаимным союзом соединенные и стройным чином расположенные их части, таинства иным несведомые, в которых непостижимая зиждителева премудрость тем великолепнее является, чем 
тончае есть оных строение, тот не токмо легкими крилами благоговения к небу восхищается, но и сам якобы в некое обожсене приходит [Ломоносов, I: 535].

Приведенная цитата относится к «Программе» к курсу лекций по экспериментальной физике, который Ломоносов читал в 1746 г. В смысловом плане она связана с религиозным дискурсом, что отражено в ее стилистике: здесь широко используется церковнославянская лексика и фразеология (всесильный строитель и начальник натуры, взирать просвещенным и проницающим оком, взаимныл союзом соединенные и стройным чином расположенные части, таинства иным несведомые, непостижимая зиждителева премудрость, легкие крила благоговения, к небу восхищаться). Кроме того, в этом фрагменте встречается единственный пример употребления в языке Ломоносова слова обожение, обозначающего одно из центральных христианскобогословских понятий ${ }^{7}$. Как нам представляется, приведенные примеры иллюстрируют не только отношение глагола восхитить в значении 'поднять на высоту, вознести к небу' к церковно-религиозной сфере, но и актуальность религиозного понимания категории восторга для создания поэтического образа. В этой связи агиографические описания мистического экстаза представляют собой уникальный материал, который описывает разнообразные проявления этого феномена.

В целом, для описания лирического восторга движение вверх является важным композиционным и смысловым элементом, а также необходимым условием для обретения особой, сверхъестественной способности видеть то, что недоступно чувственному зрению. Поэтому изображение одического восторга нередко передается с помощью лексики, обозначающей движение вверх или реализующей оппозицию верх - низ, земля - небо (см. примеры (4), (5)).

$\mathrm{B}$ «Книге житий святых» Димитрия Ростовского глаголы восхитить (восхищуать) и восхититься (восхищуаться) нередко употребляются в значении 'вознестись (быть поднятым) к небесам' в контекстах, семантически близких к описанию восхищения апостола Павла, причем

7 Это понятие тесно связано с мистическим направлением богословия: «Основная идея греко-восточного богословия — идея „обожения“ (theosis), 〈...〉 в большей части своего содержания, если не всецело, - опытно-мистического происхождения. Для отцов Церкви „обожение“- - не идея, не теория, не догма, а прежде всего и более всего - факт их внутренней жизни» [Минин 2015: 490]. 
в ряде случаев его имя упоминается в сравнительных конструкциях. Приведем примеры:

(17) В видении же соннем зряшеся быти восхищена в высоту небесную [Димитрий, 4: 241];

(18) Блаженный Симеон бысть в восторзе, и виде себе восхищценна были в выссоту (Димитрий, 3: 500);

(19) Тако святый Андрей подобне святому Павлу восхищен быв, виде то, еже око бренное не виде, и сльиша то, еже ухо мертвенное не сльшиа [Димитрий, 1: 171].

При этом духовное движение вверх не всегда передается с помощью этих глаголов, но обычно сопровождает состояние мистического экстаза. Приведем примеры:

(20) Аз же мнехся не яко на земли, но яко на небеси быти, и от великия радости духовныл бых яко в восторзе [Димитрий, 4: 93 об.];

(21) Ум горе имея, нощуи уже глубоцей сущуей, бысть в восторзе, и виде [Димитрий, 2: 355].

Так же, как и лирический герой торжественных од, святой, наблюдая за происходящим с высоты, получает возможность видеть истинные сущности вещей.

Другая особенность употребления глаголов восхитить (восхищуать) и восхититься (восхищуаться) в одической поэзии Ломоносова состоит в том, что они используются в сочетании с существительными ум и мыссль, например:

(22) Какие представляет виды / Отрадой восхищенный ум? [Ломоносов, VIII: 796];

(23) Каким необычайным треском, / Каким молниевидным блеском / Восхитился внезапно ум? [Там же: 501];

(24) Какую чувствует премену / Желанием вперенный дух? / Се мысль, внезапно возхищенну, / Весельй ободряет слух! [Там же: 139] ${ }^{8}$.

В церковнославянском языке устойчивые словосочетания со словом yм, обозначающие мистический экстаз, появляются уже в ранних памятниках. В n. 3.1 было приведено словосочетание ум ужасен со значением 'экстаз', характерное для старославянского языка. В более 
поздних текстах (XV-XVI вв.) фиксируется сочетание восхищенный умом в значении 'в религиозном экстазе (?)' [СлРЯ XI-XVII: 67]. Кроме этого, к глаголу восхищатися в значении 'увлекаться, находиться в приподнятом состоянии, приходить в экстаз’ в «Словаре русского языка XI-XVII вB.» приведен пример с грамматической трансформацией этой конструкции, хотя ее устойчивость не указана:

(25) Во время молитвы восхищается ум вне хотениа, в мысли бесплотных, во яже убо не повелена быша чювства сказати. Нил. Сор. Устав, 28. XV-XVI вв. [СлРЯ ХІ-XVII: 68].

Устойчивость таких сочетаний может подтверждаться данными [БСЦСЯ], в котором приводится как предикативный фразеологизм ум восхищается 'приходит в восторженное состояние, экстаз', так и субстантивное словосочетание восхищение ума 'особое, экстатическое состояние ума; духовное просветление' [БСЦСЯ: 407]. При этом для слова восторг такая сочетаемость не характерна - в исторических словарях соответствующего материала нет.

В минейном сборнике Димитрия Ростовского встречаются сочетания восхищение ума и восхищенный умом, которые используются в рассматриваемом значении. Приведем примеры:

(26) Углубляшеся в Богомыслии даже до восхищения ума [Димитрий, 3: 126 об.];

(27) Непрестанно бяме в восхищении к Богу ума своего [Димитрий, 2: 357];

(28) Восхищен бысть умом, и виде [Димитрий, 1: 362 об.].

\section{3. Языковые средства, используемые для передачи особого зрительного восприятия}

Как и состояние одического восторга, мистический экстаз нередко сопровождается видениями. На это, в частности, указывает формула бысть (аки) в восторзе и виде, характерная для описаний этого состояния в житийных произведениях Димитрия Ростовского. Примеры: 
(29) Блаженный Симеон на особном своем месте седя, бысть в восторзе, и виде [Димитрий, 4: 376 об.];

(30) Бысть и блаженный Иоанн в восторзе, и виде [Димитрий, 4: 377];

(31) Бысть бо Иоанн аки в восторзе, и виде [Димитрий, 4: 145]9․

Видения, которые наблюдают монахи в религиозном экстазе, особого свойства, они являются результатом чрезвычайного духовного и ментального напряжения. В этом состоянии герой жития обретает способность видеть то, что скрыто от обыденного взгляда (чувственного ока). В языке житий эта способность может передаваться с помощью словосочетания умные очи:

(32) (Иоанн. - М. Ш.) восхищен бысть умом в святый Вифлеем, и виде ... То блаженный Иоанн умными видев очесы, абие воста [Димитрий, 2: 15 об.].

Однако необходимо отметить, что дар прозрения, которым могут обладать герои житий, обычно проявляется не в особом экстатическом состоянии, а при обычных условиях. В контекстах, посвященных таким видениям, весьма часто употребляются словосочетания, в которых одним из компонентов является лексика зрительного восприятия, а другим - слова, обозначающие умственную деятельность человека: умные, мысленные, сердечные, душевные, духовные очи; умом зрить, смотреть. Приведем примеры:

(33) Егоже аще и не виде чувственными очесы, духовными же того издалече усмотрел [Димитрий, 4: 143];

(34) Толико же блаженный Нифонт име умныя просвещены очи, яко ведати ему тайная сердец человеческих, со аггель же яко с други своими беседоваме яве, и зряме бесов очевидно [Димитрий, 2: 174];

(35) Иже далняя яко ближняя мысленными зряше очесы [Димитрий, 2: 363];

(36) Все же жития его течение бе молитва непрестанная, и к Богу желание несытно: того бо, нощию и днем в светлейшем душевныя

\footnotetext{
${ }^{9}$ См. также примеры (9)-(11), (18).
} 
чистоты зерцале умом зря, насытитися не можаше [Димитрий, 3: 169 об.].

В таких контекстах реализуются противопоставления чувственного и духовного, внешнего и внутреннего, видимого и невидимого.

Такие словосочетания являются не только важным стилистическим элементом одического восторга и, как следствие, одической поэзии Ломоносова (см. n. 2.2), но и значимой смысловой категорией в его идиостиле. В качестве примера приведем фрагмент из его «Слова о явлениях воздушных»:

(37) Должно ли тех почитать дерзостными и богопротивнылми, которые, для общей безопасности, к прославлению божия величества и премудрости величия дел его в натуре молнии и грома следуют? Никак! Мне кажется, что они ещзе особливою его щуедротою пользуются, получая пребогатое за труды свои мздовоздаяние, то есть толь великих естественных чудес откровение. Отворено видим его святилище по открытии электрических действий в воздухе, и мановением натуры во внутренние входы призываемся! Еще ли стоять будем у порога и прекословием неосновательного предуверения удержимся? Никоею мерою; но, напротив того, сколько нам дано и позволено, далее простираться не престанем, осматривая все, к чему умное око проникнуть может [Ломоносов, III: 71]

\section{4. Выводы}

В настоящей статье было выявлено сходство лингвостилистических средств выражения одического восторга в поэзии М. В. Ломоносова с языком житийной литературы, в частности минейного собрания Димитрия Ростовского. Кроме того, внимание было уделено и соответствию выражаемых общими для сопоставляемых текстов лексическими и фразеологическими единицами понятий и категорий. На этом материале мы попытались показать связь одического стиля М. В. Ломоносова с аскетическим направлением церковнославянской литературы вообще и агиографии в частности. Эта проблема, безусловно, требует дальнейших исследований, однако, как нам представляется, уже на данном этапе можно сделать вывод о ее актуальности и перспективности. 


\section{Литература}

Алексеева 2005 - Н. Ю. Алексеева. Русская ода: Развитие одической формы в XVII-XVIII веках. СПб.: Наука, 2005.

Дороватовская 1911 - В. Дороватовская. О заимствованиях Ломоносова из Библии // В. В. Сиповский (ред.). М. В. Ломоносов. 1711-1911. Сборник статей. СПб.: Я. Башмаков и К, 1911. С. 33-65.

Живов 1994 - В. М. Живов. Церковнославянская литературная традиция в русской литературе XVIII в. и рецепция спора «древних» и «новых» // Л. А. Софронова (отв. ред.). История культуры и поэтика. М.: Наука, 1994. С. 62-82.

Коровин 1961 - Г. М. Коровин. Библиотека Ломоносова. М.; Л.: Изд-во Академии наук СССР, 1961.

Левитт 2015 - М. Левитт. Визуальная доминанта в России XVIII века. М.: Новое литературное обозрение, 2015.

Литвинова 2001 - Л. В. Литвинова. Аскетизм // Православная энциклопедия. Т. 3: Анфимий - Афанасий. М.: Церковно-науч. центр «Православная энциклопедия», 2001. С. 593-608.

Матвеев 2017 - Е. М. Матвеев. К вопросу о библейских и богослужебных заимствованиях у М. В. Ломоносова // Slověne. 2017. № 1. С. 393-412.

Минин 2015 - П. М. Минин. Главные направления древнецерковной мистики // В. Н. Лосский. Очерк мистического богословия Восточной Церкви. Догматическое богословие. М.: Академический проект; Парадигма, 2015. С. 490-543.

Моисеева 1971 - Г. Моисеева. Ломоносов и древнерусская литература. Л.: Наука, 1971.

Морозов 1962 - А. А. Морозов. М. В. Ломоносов: Путь к зрелости. 1711-1741. М.; Л.: Изд-во Академии наук СССР, 1962.

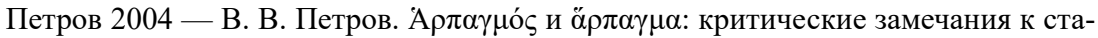
тье о. Павла Флоренского «Не восхищение непщева (Флп. 2:6-8)» // Диалог со временем. 2004. № 13. С. 327-334.

Серман 1966 - И. З. Серман. Поэтический стиль Ломоносова. М.; Л.: Наука, 1966.

Серман 2002 - И. 3. Серман. Неизданный конспект М. В. Ломоносова «Трактата о возвышенном» Псевдо-Лонгина в переводе Н. Буало // Н. Д. Кочеткова (отв. ред.). XVIII век. Сб. 22. СПб.: Наука, 2002. С. 333-346.

Солосин 1913 - И. И. Солосин. Отражение языка и образов Св. Писания и книг богослужебных в стихотворениях Ломоносова // Известия Отделения русского языка и словесности Академии наук. 1913. T. XVIII. Кн. 2. С. 238-293.

Флоренский 1996 - П. Флоренский. «Не восхищение непщева» // П. Флоренский. Сочинения в 4 тт. Т. 2. М.: Мысль, 1996. С. 143-188.

\section{Источники}

Библия 2004 - Библия. Книги Священного Писания Ветхого и Нового Завета. М.: Российское библейское общество, 2004. 
БСЦСЯ - А. Г. Кравецкий, А. А. Плетнева (ред.). Большой словарь церковнославянского языка Нового времени. Т. ІІ. М.: Родное слово, 2019.

Димитрий, 1 - Димитрий Ростовский. Книга житий святых, 1-я четверть: Сентябрь - ноябрь. Киев: Тип. Киево-Печерской лавры, 1764.

Димитрий, 2 - Димитрий Ростовский. Книга житий святых, 2-я четверть: Декабрь - февраль. Киев: Тип. Киево-Печерской лавры, 1764.

Димитрий, 3 - Димитрий Ростовский. Книга житий святых, 3-я четверть: Март май. Киев: Тип. Киево-Печерской лавры, 1764.

Димитрий, 4 - Димитрий Ростовский. Книга житий святых, 4-я четверть: Июнь август. Киев: Тип. Киево-Печерской лавры, 1764.

Ломоносов - М. В. Ломоносов. Полное собрание сочинений: в 11 тт. М.; Л.: Издво Академии наук СССР, 1950-1983.

СлДРЯ - Р. И. Аванесов (гл. ред.). Словарь древнерусского языка (XI-XIV вв.): В 10 т. Т. II. М.: Русский язык, 1989.

СлРЯ XI-XVII - С. Г. Бархударов (гл. ред.). Словарь русского языка XI-XVII вв. Вып. 3. М.: Наука, 1976.

СлРЯ XVIII - Ю. С. Сорокин (гл. ред.). Словарь русского языка XVIII века. Вып. 1-6. Л.: Наука, 1984-1991; Вып. 7-... СПб.: Наука, 1992-...

Тредиаковский 2009 - В. К. Тредиаковский. Сочинения и переводы как стихами, так и прозою. СПб.: Наука, 2009.

SJS - J. Kurz (hl. red.). Slovník jazyka staroslověnského. Lexicon linguae palaeoslovenicae. T. 42. Praha: Academia, nakladatelství Československé akademie věd, 1989.

\section{References}

Alekseeva 2005 - N. Yu. Alekseeva. Russkaya oda: Razvitie odicheskoy formy v XVIIXVIII vekah [Russian ode: The development of the odic form in the XVII-XVIII centuries]. St. Petersburg: Nauka, 2005.

Dorovatovskaya 1911 - V. Dorovatovskaya. O zaimstvovaniyah Lomonosova iz Biblii [On the borrowings of Lomonosov from the Bible]. V. V. Sipovskiy (ed.). M. V. Lomonosov. 1711-1911. Sbornik statey [M. V. Lomonosov. 1711-1911. Digest of articles]. St. Petersburg: Ya. Bashmakov i K, 1911. P. 33-65.

Florenskij 1996 - P. Florenskiy. «Ne voskhishchenie nepshcheva» ["Who Did Not Consider It Rapture"]. P. Florenskiy. Sochineniya v chetyrekh tomah [Works in four volumes]. Vol. 2. Moscow: Mysl, 1996. P. 143-188.

Korovin 1961 - G. M. Korovin. Biblioteka Lomonosova [Lomonosov's library]. Moscow; Leningrad: USSR Academy of Sciences Publishing House, 1961.

Levitt 2015 - M. Levitt. Vizual'naya dominanta v Rossii XVIII veka [The Visual Dominant in Eighteenth-Centry Russia]. Moscow: Novoe literaturnoe obozrenie, 2015.

Litvinova 2001 - L. V. Litvinova. Asketizm [Asceticism]. Pravoslavnaya enciklopediya [Orthodox Encyclopedia]. Vol. III. Moscow: Church science Centre «Pravoslavnaya enciklopediya», 2001. P. 593-608. 
Matveev 2017 - E. M. Matveev. K voprosu o bibleyskih i bogosluzhebnyh zaimstvovaniyah u M. V. Lomonosova [On the issue of biblical and liturgical borrowings from M. V. Lomonosov]. Slověne. 2017. No. 1. P. 393-412.

Minin 2015 - P. M. Minin. Glavnye napravleniya drevnecerkovnoy mistiki [The main directions of ancient church mysticism]. V. N. Losskiy. Ocherk misticheskogo bogosloviya Vostochnoy Cerkvi. Dogmaticheskoe bogoslovie [Essay on the mystical theology of the Eastern Church. Dogmatic theology]. Moscow: Akademicheskiy proekt; Paradigma, 2015. P. 490-543.

Moiseeva 1971 - G. N. Moiseeva. Lomonosov i drevnerusskaya literatura [Lomonosov and Old Russian literature]. Leningrad: Nauka, 1971.

Morozov 1962 - A. A. Morozov. M. V. Lomonosov: Put k zrelosti. 1711-1741 [M. V. Lomonosov: The path to maturity. 1711-1741]. Moscow; Leningrad: USSR Academy of Sciences Publishing House, 1962.

Petrov 2004 - V. V. Petrov. A $\rho \alpha \gamma \mu$ ó i $\alpha \rho \pi \alpha \gamma \mu \alpha$ : kriticheskie zamechaniya k state o. Pavla Florenskogo "Ne voskhishchenie nepshcheva (Flp 2:6-8)" [«A and $\alpha \rho \pi \alpha \gamma \mu \alpha$ : Critical Comments to Fr. Pavel Florensky's Article "Who Did Not Consider It Rapture (Phil 2:6-8)"']. Dialog so vremenem. No. 13. 2004. P. 327-334.

Serman 1966 - I. Z. Serman. Poeticheskiy stil' Lomonosova [The poetic style of Lomonosov]. Moscow; Leningrad: Nauka, 1966.

Serman 2002 - I. Z. Serman. Neizdannyy konspekt M. V. Lomonosova «Traktata o vozvyshennom» Psevdo-Longina v perevode N. Bualo [Unpublished compendium of M. V. Lomonosov's "Treatise on the Sublime" Pseudo-Longin translated by N. Boileau]. N. D. Kochetkova (ex. ed.). XVIII vek [XVIII century]. Misc. 22. St. Petersburg: Nauka, 2002. P. 333-346.

Solosin 1913 - I. I. Solosin. Otrazhenie yazyka i obrazov Sv. Pisaniya i knig bogosluzhebnyh $\mathrm{v}$ stihotvoreniyah Lomonosova [The reflection of the language and images of Holy Scripture and the books of the liturgical in Lomonosov's poems]. Izvestiya Otdeleniya russkogo yazyka i slovesnosti Akademii nauk. 1913. Vol. XVIII. Misc. 2. P. 238-293.

Zhivov 1994 - V. M. Zhivov. Tserkovnoslavyanskaya literaturnaya traditsiya v russkoy literature XVIII v. i retseptsiya spora «drevnikh» $\mathrm{i}$ «novykh» [Church Slavonic literary tradition in Russian literature of the XVIII century and the reception of the dispute of the "ancient" and "new"]. L. A. Sofronova (ex. ed.). Istoriya kultury i poetika [History of Culture and Poetics]. Moscow: Nauka, 1994. P. 62-82.

\section{Sources}

Bibliya 2004 - Bibliya. Knigi Svyashchennogo Pisaniya Vethogo i Novogo Zaveta [Bible. Scriptures of the Old and New Testaments]. Moscow: Rossiyskoe bibleyskoe obshchestvo, 2004.

BSCSYA - A. G. Kraveckiy, A. A. Pletneva (eds.). Bolshoy slovar tserkovnoslavyanskogo yazyka Novogo vremeni [Large dictionary of Church Slavonic language of New time]. Vol. II. Moscow: Rodnoe slovo, 2019. 
Dimitrij, 1 - Dimitrij Rostovskiy. Kniga zhitiy svyatyh, 1-ya chetvert: Sentyabr - noy$a b r$ [Book of the Lives of the Saints, $1^{\text {st }}$ quarter: September - November]. Kiev: Printing House of the Kiev-Pechersk Lavra, 1764.

Dimitriy, 2 - Dimitriy Rostovskiy. Kniga zhitiy svyatyh, 2-ya chetvert: Dekabr - fevral [Book of Lives of the Saints, $2^{\text {nd }}$ quarter: December - February]. Kiev: Printing House of the Kiev-Pechersk Lavra, 1764.

Dimitriy, 3 - Dimitrij Rostovskiy. Kniga zhitiy svyatyh, 3-ya chetvert: Mart - may [Book of Lives of the Saints, $3^{\text {rd }}$ quarter: March - May]. Kiev: Printing House of the Kiev-Pechersk Lavra, 1764.

Dimitriy, 4 - Dimitriy Rostovskiy. Kniga zhitiy svyatyh, 4-ya chetvert: Iyun - avgust [Book of Lives of the Saints, $4^{\text {th }}$ quarter: June - August]. Kiev: Printing House of the Kiev-Pechersk Lavra, 1764.

Lomonosov - M. V. Lomonosov. Polnoe sobranie sochineniy: v $11 \mathrm{tt}$. [Complete works in 11 volumes]. Moscow; Leningrad: USSR Academy of Sciences Publishing House, 1950-1983.

SJS - J. Kurz (hl. red.). Slovník jazyka staroslověnského. Lexicon linguae palaeoslovenicae. T. 42. Praha: Academia, nakladatelství Československé akademie věd, 1989.

SIDRYA - R. I. Avanesov (ed.-in-chief). Slovar drevnerusskogo yazyka (XI-XIV vv.): $V 10 t$. [Dictionary of the Old Russian Language (XI-XIV centuries): In 10 vol.] Vol. II. Moscow: Russkiy yazyk, 1989.

SIRYA XI-XVII - S. G. Barhudarov (ed.-in-chief). Slovar russkogo yazyka XI-XVII vv. [Dictionary of the Russian language of the $11^{\text {th }}-17^{\text {th }}$ centuries]. Edit. 3. Moscow: Nauka, 1976.

SIRYA XVIII - Yu. S. Sorokin (ed.-in-chief.). Slovar russkogo yazyka XVIII veka [Dictionary of the Russian language of the XVIII century]. Edit. 1-6. Leningrad: Nauka, 1984-1991; edit. 7-... St. Petersburg: Nauka, 1992-... (continued edition). Trediakovskiy 2009 - V. K. Trediakovskiy. Sochineniya i perevody kak stihami, tak i prozoyu [Compositions and translations as poems and prose]. St. Petersburg: Nauka, 2009. 


\title{
Изменение валентности английских глаголов
}

\author{
Н. М. Юликова \\ Санкт-Петербургский государственный университет \\ аэрокосмического приборостроения; n-yulikova@mail.ru
}

Аннотация. Анализируются причины и результаты изменения валентности английских глаголов, характеризующиеся низкой частотой встречаемости. На основе теоретических положений структурного и функционального синтаксиса рассматриваются изменения валентности английских глаголов (синтаксические сдвиги), в результате действия которых в зависимой позиции при глаголах, не обладающих локативной валентностью, реализуются синтаксемы и синтагмы из ряда локативных. Показана роль синтаксической категории локативности в формировании текста.

Ключевые слова: валентность, дискурс, локативность, синтаксема, синтаксические категории, синтаксические сдвиги, структурный и функциональный синтаксис, уровни языка.

\section{Valency change of English verbs}

\section{N. M. Yulikova}

St. Petersburg State University of Aerospace Instrumentation; n-yulikova@mail.ru

\begin{abstract}
Many valency studies focus on typical valency configurations, because they rely on dictionaries as their main data source. This paper focuses on both texts and dictionaries, with the former chosen as the main information resource. This paper builds on the theory of structural and functional syntax and views valency as a syntactic property of verbs disclosed in sentences through basic syntactic units or syntaxemes demonstrating specific syntactic meanings and a range of distinctive features. Thus, the syntactic locative category embraces syntaxemes of two of the three functional classes with substantive and qualificative properties that, in their turn, represent syntactic categories as well. Therefore, one can say that the syntactic locative category interacts with the syntactic categories of substantiality and qualificativity.Verbs with the same locative valencies and common lexical semantics can combine in valency groups. There are valency groups comprising verbs with varying valency properties such as verbs of motion, speech, etc. The cases of use of certain syntaxemes with verbs can be either frequent or have low frequency of occurrence. Such occasional changes in verbs' valency,
\end{abstract}


i.e. in their syntactic properties, can be described as "syntactic shifts". These valency changes of verbs play the role of structural signals, acting in some cases as formal indicators of the text's discreteness, and in some cases as its integrators. Syntactic shifts can be markers of the beginning of a paragraph and the end of a paragraph (indicators of discreteness), and also occur in the middle of a paragraph, playing the role of semantic peaks (acting as integrators). The article shows that low-frequency elements considered peripheral can play an important role in text formation. The specific method of analysis applied in this paper reveals instances of discursive use of the syntactic locative category.

Keywords: discourse, language levels, locativity, syntaxeme, syntactic categories, structural and functional syntax, syntactic shifts, valency.

\section{1. Введение}

Изменение глагольной валентности встречается в произведениях английских и американских авторов. Под изменением глагольной валентности в данной работе мы будем иметь в виду, во-первых, изменение в современном состоянии языка (current change) и, во-вторых, такое изменение глагольного окружения, которое не является обычным или повторяющимся или встречающимся у других авторов. Это такое употребление глагола, которое фактически противостоит всей остальной массе примеров с данным глаголом. При исследовании изменения глагольной валентности в таком понимании возникают следующие вопросы: 1) что является обычным употреблением или нормой для данного языка; 2) как определить, что является отклонением от нормы; 3) какова причина отклонения от нормы.

Материалом исследования послужили примеры из литературных произведений английских и американских авторов первой половины XX века. Для справок и уточнений использовались данные двух корпусов: Британского национального корпуса (BNC) и Корпуса современного американского языка (COCA).

Поскольку в произведениях англо-американских авторов подобные случаи изменения валентности глаголов встречаются довольно часто в предложениях с локативными элементами, в данной статье будут рассматриваться такие изменения валентности английских глаголов, в результате которых глаголы, не обладающие локативной валентностью, приобретают ее или, если она была им свойственна, получают измененную локативную валентность. 


\section{2. О понятии валентности}

Валентность рассматривается рядом исследователей как продукт континентальной, то есть небританской, лингвистики [Herbst 1999], особо отмечается вклад немецких лингвистов [Herbst, Götz-Votteler 2007]. Считается, что понятие «валентность» начало разрабатываться в европейских университетах: во Франции на материале французского языка [Tesnière 1953, 1959], в Германии на материале немецкого [Helbig 1992] и французского [Busse 1974], а также английского языка [Emons 1974, Herbst 1983]. Изучение литературы показывает, что британские лингвисты также уделяли достаточно много внимания проблеме валентности [Leech 1974, Somers 1984, Matthews 2007].

Общим для исследований данного этапа является различение семантической и синтаксической валентности, при этом основным уровнем валентности считается семантический. В соответствии с семантическим подходом валентностные свойства глагола оказываются жестко обусловленными лексической семантикой последнего, что дает основание говорить о «семантическом детерминизме» - semantic determination of syntactic properties [Levin 1993: 13].

Наряду с достижениями западноевропейских исследователей некоторые авторы также признают вклад, внесенный в развитие теории валентности российскими лингвистами. Так, Дж. Лайонз отмечает широкое применение понятия валентности при изучении типологических особенностей различных языковых систем в работах А. А. Холодовича и Ю. Д. Апресяна [Lyons 1977: 486], а само понятие валентности valency metaphor, по справедливому замечанию А. Пржепиорковски, было предложено С. Д. Кацнельсоном [Кацнельсон 1948], причем на год раньше, чем оно было сформулировано А. де Гроотом [Groot 1949], а затем Ч. Хоккетом [Hockett 1958] и Л. Теньером [Tesnière 1953, 1959] [Przepiórkowski 2018].

Существенным, однако, является не только то, что С. Д. Кацнельсон первым из ученых середины прошлого века использовал термин «валентность», но также и то, что предложенная им трактовка данного понятия заметно отличается от выдвинутых в названный период. Отличие заключается в том, что, по мнению С. Д. Кацнельсона, валентность имеет синтаксический характер: «Свойство слова определенным образом реализовываться в предложении и вступать в определенные комбинации с другими словами можно было бы назвать его синтаксической 
валентностью» [Кацнельсон 1948: 132]. Трактовка валентности с этих позиций оказала определенное влияние на целый ряд лингвистов, которые рассматривают валентность как понятие по большей части синтаксическое [Уздинская 1972; Сильницкий 1974; Helbig 1992].

Похожий взгляд несколько позже был представлен в работе Д. Кристала, по мнению которого валентность связана с синтаксической способностью глагола вступать в комбинации:«〈...〉 valency refers to a verb syntactic 'combining capacity'»[Crystal 2008: 507].

В синтаксическом направлении шли исследования валентности и в работах А. М. Мухина, при этом отличительной особенностью его валентностной теории стало применение понятия синтаксемы для описания глагольного окружения.

Подход к рассмотрению валентности, о котором пойдет речь далее, выполнен на основе теории и методов исследования, предложенных А. М. Мухиным. Центральным в теории функционального синтаксиса, разработанной А. М. Мухиным [Мухин 1960, Мухин 1964, Мухин 1980], является понятие синтаксемы. Синтаксема не отождествляется ни со словом, ни с членом предложения. Синтаксема - это «синтаксическая единица-инвариант, представленная в языке системой вариантов, которые могут быть выражены как отдельными лексемами, относящимися к той или иной части речи, так и синтаксически неделимыми сочетаниями лексем со служебными элементами; ее содержание составляет синтаксическая семантика, или, точнее, дифференциальные синтаксико-семантические (синсемантические) признаки, которые находят свое проявление в специфической для данной синтаксемы системе вариантов и в ее дистрибутивных особенностях (сочетаемости, позиционных возможностях и местоположении)» [Мухин 1999b: 12]. Приводим это определение полностью, чтобы показать отличие от точки зрения на синтаксему других авторов, которые также использовали данный термин ${ }^{1}$. Важная особенность трактовки А. М. Мухина заключается том, что содержательная сторона синтаксемы формулируется как кластер дифференциальных признаков. Это имеет большое практическое значение, так как дает возможность максимально полно описать содержание каждого синтаксического элемента, например, at the table - это

${ }^{1}$ Ср.: Г. А. Золотова использовала термин «синтаксема» с 1980 г. вместо предложенного ранее термина «синтаксическая форма слова». Синтаксема в трактовке Г. А. Золотовой - это минимальная единица русского языка, которая образована от слова [Золотова 1988: 4]. 
не просто «локатив», а элемент, наделенный двумя синсемантическими признаками - субстанциальности и локативности, - субстанциальная локативная синтаксема.

Между дифференциальными синсемантическими признаками существуют сложные системные отношения. Наверху иерархии находятся три основных признака: субстанциональности, процессуальности и квалификативности, образующие три функциональных класса синтаксем (ФКС) - субстанциональные, процессуальные и квалификативные, охватывающие наибольшее число синтаксем. Вторым уровнем организации оказываются синтаксические категории (СК), объединяющие элементарные синтаксические единицы, относящиеся к разным функциональным классам, но объединенные общим для них синсемантическим признаком [Мухин 1995: 31]. Так, синтаксическая категория локативности объединяет синтаксемы двух из трех функциональных классов - наделенных признаками субстанциальности и квалификативности, которые, впрочем, также представляют собой синтаксические категории. Поэтому можно сказать, что синтаксическая категория локативности взаимодействует с синтаксическими категориями субстанциальности и квалификативности. Отметим, что все рассматриваемые в данной работе локативные синтаксемы относятся к субстанциальному ряду, за исключением квалификативной локативной синтаксемы в примере (2).

Понятие синтаксемы сыграло важную роль при разработке теории валентности. Именно с применением понятия синтаксемы связана особенность, о которой упоминалось выше. Валентность рассматривается в предложении, причем в отличие от сочетаемости, где речь идет о взаимодействии единиц одного уровня языка, валентность описывает взаимодействие единиц разных уровней.

Валентность рассматривается как «синтаксическое свойство глаголов, которое раскрывается в предложениях по отношению к элементарным синтаксическим единицам, обладающим синтаксической семантикой» [Мухин 1987a: 60]. Если мы говорим о глагольной валентности, то здесь речь идет о взаимодействии глагольных лексем (элементарных единиц лексического уровня языка) и синтаксем (элементарных единиц синтаксического уровня языка) в предложении (конструктивной единице синтаксического уровня языка), то есть изучается взаимодействие элементарных единиц двух уровней языка - лексического и синтаксического.

Возвращаясь к теме локативной валентности английских глаголов, можно сказать, что она реализуется в виде синтаксем в зависимой 
позиции при тех или иных глаголах. Однако описание картины было бы неполным, если бы здесь не было уделено внимание одному существенному обстоятельству. Оказалось, что среди единиц синтаксического уровня языка, с которыми в границах предложения взаимодействует глагол, встречаются локативные элементы разного состава, не только элементарные единицы - синтаксемы, но также и конструктивные единицы. Речь идет о синтагмах. Синтагмы - простые или сложные синтаксические единицы, которые представляют собой образованные из синтаксем конструкции. Среди конструкций с локативными синтаксемами обнаружены подлежащные, сказуемные и косвенно-объектные синтагмы. Поскольку в данном случае нас интересуют синтаксемы в приглагольной позиции, основное внимание будет уделено сказуемным синтагмам.

\section{3. Локативные синтаксемы и локативные синтагмы}

В отличие от тех исследователей, которые считали, что валентность глагола определяется только числом актантов [Tesnière 1953, 1959], ряд ученых обращает внимание на тип или качественный состав синтаксических элементов, образующих глагольное окружение [Matthews 2007; Herbst 2015]. Применительно к рассматриваемому материалу это означает, что для более детального описания глагольного окружения необходимо отметить, что в зависимой позиции при глаголе встречаются не только синтаксемы из ряда локативных, но также и разнообразные локативные синтагмы. В числе таковых оказались локативные аллативные, локативные аблативные и локативные дистрибутивные синтаксемы и синтагмы. Поскольку перечисленные синтаксемы уже рассматривались в целом ряде исследований, остановимся более подробно на синтагмах.

Локативная аллативная синтагма (LcAll), например:

(1) Afterwards they went around to Dick's room and he read some poems out loud.

'После этого они пошли в комнату Дика, и он стал читать стихотворения вслух’ [Dos Passos 1979: 106]

Признак аллативности определяется как связанный с обозначением цели движения. To Dick's room - локативная аллативная синтагма, 
состоящая из двух синтаксем, локативной аллативной to... room и посессивной Dick's.

Локативная аблативная синтагма (LcAbl), например:

(2) Then suddenly the living painter himself appeared from the garden door.

'Затем внезапно сам художник появился из дверей сада' [Fowles 1980: 47]

Признак аблативности связан с обозначением удаления от кого-либо / чего-либо. From the garden door - локативная аблативная синтагма, состоящая из локативной аблативной синтаксемы from the ... door и квалификативной локативной garden.

Локативная дистрибутивная синтагма (LcDtr). Признак дистрибутивности (распределительности) обнаруживается в примере (3):

(3) $\langle\ldots\rangle$ drivers stopped at all the wineshops along the sunny roads.

'〈...〉 водители останавливались у всех винных лавок вдоль залитых солнцем дорог’ [Dos Passos 1979: 202]

At all the wineshops along the sunny roads - сложная локативная дистрибутивная синтагма, выраженная локативной дистрибутивной синтаксемой at the ... wineshops, коллективной all, локативной дистрибутивной along the ... roads и квалитативной sunny.

В данном разделе были рассмотрены три синтагмы из числа локативных. Еще раз отметим, что в зависимой позиции при глаголе встречаются как синтаксемы из ряда локативных, так и синтагмы, имеющие в своем составе элементы с семантикой локативности. Представляется, что учет наличия при глаголах как первых, так и вторых создает условия для исследования особенностей локативной валентности английских глаголов.

\section{4. Моделирование как метод исследования валентности глаголов}

Л. Теньер разделил элементы глагольного окружения на более важные и менее важные. Исследуя структуры, образующие предложения, Л. Теньер пришел к выводу, что глагол является главным элементом в предложении. В окружении глагола, в свою очередь, он также 
выделил в качестве главных элементов актанты, а в качестве второстепенных элементов - сирконстанты. Далее оказалось возможным описать свойства глаголов исходя из количества актантов, которыми они управляют, что привело к делению глаголов на одновалентные, двухвалентные и трехвалентные. Обстоятельствам (сирконстантам или, иначе, адъюнктам) в традиционной теории валентности редко уделялось внимание, поскольку они, как считалось, не отражают глагольных свойств.

Иной сюжет мы получаем при исследовании валентности с опорой на теорию и методы структурного и функционального синтаксиса. На вопрос, следует ли рассматривать только элементы первого ранга актанты или необходимо также учитывать сирконстанты, здесь можно получить следующий ответ. Лингвистический анализ предложения следует начинать с изучения структурных особенностей предложения, чем занимается структурный синтаксис. На основе полученных данных можно переходить к анализу функционирующих в рассматриваемых структурах синтаксем, что изучается в функциональном синтаксисе.

Структурный синтаксис охватывает изучение структурных особенностей предложений - их внутренних синтаксических связей и компонентов (членов) предложения. Предложение рассматривается как конструкция, в которой на основе синтаксических связей выделяются компоненты (члены) предложения (подлежащее, сказуемое, зависимый компонент и др.). В отличие от структурного синтаксиса, функциональный синтаксис исследует синтаксемы и синтагмы - функциональные синтаксические единицы, находящиеся в позиции того или иного компонента (члена предложения), выделенного в первой части анализа.

Позиция сказуемого рассматривается как центральная синтаксическая позиция [Мухин 1999b: 173]. Синтаксическое окружение глагола образуют синтаксемы / синтагмы, находящиеся в зависимой позиции при глаголе-сказуемом на основе субординативной связи независимо от их «ранга». Глагольное окружение включает все элементы, традиционно разделяемые на первостепенные и второстепенные. В разграничении их нет необходимости, поскольку изучение глаголов в синтаксическом аспекте позволяет принимать во внимание данные об элементах разного уровня.

Пояснения, вероятно, требует термин «зависимый компонент». В традиционной грамматике термин «члены предложения» включает два главных - подлежащее, сказуемое и три второстепенных - дополнение, определение и обстоятельство, выделяемых на основе трех типов связи - согласования, управления и примыкания. В структурном синтаксисе А. М. Мухина обосновывается наличие двух основных 
типов связи - предикативной и субординативной. На основе предикативной связи выделяются подлежащее и сказуемое, а на основе субординативной связи вместо трех второстепенных членов выделяется один компонент предложения, называемый зависимым компонентом. Рассмотрим это на следующем примере:

(4) I fetched Her Excellency an extra rug from my compartment.

'Я принес ее превосходительству еще один плед из своего купе'. [Christie 1975: 116]

А. М. Мухин в своей монографии «Эксперимент и моделирование в лингвистике: Структурный синтаксис предложения» [Мухин 2004] с опорой на традиционное грамматическое учение о главных и второстепенных членах предложения обосновывает правомерность выделения ядерных и неядерных компонентов предложения, в позиции которых встречаются те или иные синтаксемы. Разработанный А. М. Мухиным метод моделирования помогает наглядно представить всю сложность организации предложения. Основу предложения образует компонентная структура, состоящая из ядерных (nuclear) компонентов - ядерного предицируемого (nuclear predicated) и ядерного предицирующего (nuclear predicating) - подлежащего и сказуемого, которые сокращенно обозначаются NP1 и NP2, и неядерных компонентов (dependent), обозначенных значком D. Компонентная структура предложения примера (4) может быть отражена в следующей модели:

Компонентная модель предложения примера (4)

$$
\mathrm{NP} 1 \cdot \mathrm{NP} 2 \cdot \mathrm{D} 1 \cdot \mathrm{D} 2 \cdot \mathrm{D} 3
$$

Следующим этапом будет изучение связей между компонентами предложения, которые находят отражение в юнкционной модели:

Юнкционная модель предложения примера (4)

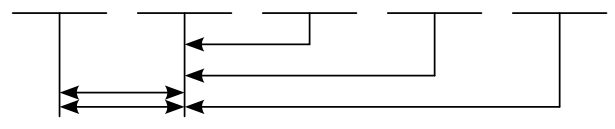

В модели $\longleftrightarrow$ обозначает двусторонне направленную предикативную связь, а бординативную связь. 
Совместив эти две модели, получаем следующую модель, которую здесь будем называть юнкционно-компонентной. Юнкционно-компонентной структуре принадлежит центральная роль в предложении, так как именно она образует структурную основу предложения.

Юнкционно-компонентная модель предложения (4)

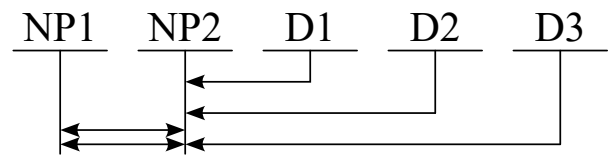

Далее мы переходим к изучению функциональных синтаксических единиц - синтаксем, которые определяются в парадигматическом и синтагматическом планах языка и характеризуются синсемантическими признаками.

А. М. Мухин в своем исследовании «Функциональный синтаксис» указывает: «В отличие от синтаксических признаков компонентов предложения, которые составляют их синтаксическое содержание, признаки этого рода в совокупности образуют синтаксико-семантическое (синсемантическое) содержание синтаксем или, иначе, их с ин такси че скую с еман т и ку» [Мухин 1999b: 6]. Метод моделирования позволяет построить модель предложения, отражающую синтаксическую семантику предложения, которая для примера (4) будет иметь следующий вид.

Синтаксемная модель предложения примера (4)

$\mathrm{SbAg} \cdot \operatorname{PrAc} \cdot \mathrm{SbØb} \cdot \mathrm{SbOb} \cdot \mathrm{SbLcAb}$

В данной модели использованы следующие сокращения: $\mathrm{SbAg}-$ субстанциальная агентивная, $\operatorname{PrAc}$ - процессуальная акциональная, $\mathrm{SbØb}$ - субстанциальная косвенно-объектная, $\mathrm{SbOb}$ - субстанциальная объектная и SbLcAbl - субстанциальная локативная аблативная семантика.

Совместив все три модели, получаем следующую модель:

Объединенная модель предложения (ОМП) примера (4):

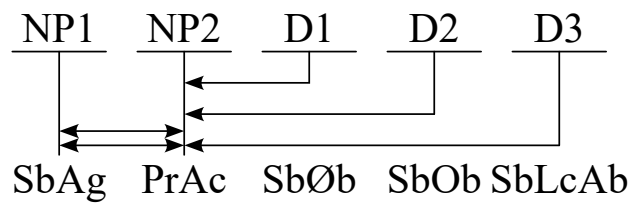


Отметим, что юнкционно-компонентная модель данного предложения (которое относится к числу двухъядерных ${ }^{2}$ ) является базовой для описываемого в данной статье множества примеров. Все многообразие синтаксемного состава в цитируемых примерах функционирует на «платформе» одной и той же юнкционно-компонентной модели предложения. Предложения, которые встретились и встретятся далее в данной статье, соответствуют указанной модели, различие между ними чисто количественное. Так, имеются предложения с одним зависимым компонентом (пример (7)), с двумя (пример (10)) и с тремя (пример (4)). Юнкционно-компонентная модель относится к языку, но в речи, заполняясь элементарными единицами синтаксического уровня языка (синтаксемами), она образует конструктивную единицу синтаксического уровня языка - предложение, поэтому в речи юнкционно-компонентная и синтаксемная модели неотделимы.

Построенная объединенная модель предложения (ОМП) позволяет визуально представить тот факт, что зависимый компонент D1, в позиции которого находится субстанциальная косвенно-объектная синтагма, выраженная словосочетанием Her Excellency, зависимый компонент D2, в позиции которого находится объектная синтагма an extra $r u g$, и зависимый компонент D3, в позиции которого находится локативная аблативная синтагма from my compartment, находятся в равном положении по отношению к глаголу, поскольку все три зависимых компонента находятся в зависимой позиции при глаголе-сказуемом на основе субординативной связи. Таким образом, синтагмы, находящиеся в позиции трех зависимых компонентов при глаголе-сказуемом, образуют синтаксическое окружение глагола fetch, которому свойственны три валентности, а именно косвенно-объектная, объектная и локативная аблативная. Данная модель показывает, что все элементы, находящиеся в зависимой позиции при глаголе, равнозначны, поэтому нет оснований различать среди них (как это принято в традиционной теории валентности) актанты и сирконстанты.

\footnotetext{
2 По мнению А. М. Мухина, предложения служат исходными единицами для функционального синтаксиса, как единицы языка и речи. «Как единицы языка они распадаются на два основных структурных типа - двухъядерные и одноядерные предложения, которые формируются по определенным правилам и законам, в принципе не зависящим от воли или произвола носителей языка. В речи же (или тексте) они являются теми необходимыми звеньями, которые обеспечивают ее смысловую связность или целостность...» [Мухин 1999b: 4].
} 
Из приведенной объединенной модели предложения (ОМП) можно выделить валентностную модель глагола (ВМ). Валентность глагола fetch может быть представлена в виде следующей модели:

$$
\mathrm{V}+\mathrm{S} \emptyset \mathrm{b} / \mathrm{SOb} / \mathrm{LcAbl} \text {, }
$$

отражающей межуровневое взаимодействие глагольной лексемы и синтагм, реализующихся в зависимой позиции при глаголе. В ходе дальнейшего изложения нам понадобятся обе модели, сначала будет использоваться валентностная модель (BM), а затем мы вновь обратимся к объединенной модели предложения (ОМП).

Глаголы, обладающие теми или иными локативными валентностями и общей лексической семантикой, объединяются в валентностные группы. В ряде работ высказываются сомнения в правильности и целесообразности изучения глаголов в виде групп. В некоторых случаях предпочтение отдается индивидуальному изучению глаголов (valency of particular lexical units) [Cruse 1986: 49; Herbst 2015: 5]. Изучение собранного материала показало, что имеются глаголы, образующие четкие группы, и глаголы, которые обладают индивидуальными особенностями и не вполне соответствуют характеристикам каких-либо групп. Кроме того, в некоторых валентностных группах обнаруживаются отдельные глаголы с изменяющейся валентностью, к числу которых относятся, например, глаголы движения, перемещения, речевой деятельности, а также дистрибутивные глаголы. Представляется целесообразным объединить, где это необходимо, изучение глаголов в виде групп с индивидуальным подходом.

Глаголам движения - самой многочисленной группе: come, crawl, creep, cross over, drift, drive, float, flow, fly, go, move, pass, return, run, ride, steel, tiptoe, trot, walk, whirl, etc. - свойственны два вида локативной валентности, а именно локативная аллативная и локативная аблативная. Например:

(5) They drove in silence until Mason came to the parking lot.

'Они ехали молча, пока Мейсон не подъехал к стоянке' [Gardner 1974: 50]

(6) The murderer comes from his own compartment $\langle\ldots\rangle$

'Убийца выходит из своего собственного купе $\langle. .$.$\rangle ' [Christie$ 1975: 84] 
Названные валентности реализуются в приведенных примерах в виде локативных синтагм: локативной аллативной (пример (5)) и локативной аблативной (пример (6)). Синтаксическое окружение глаголов данной группы может быть представлено в виде валентностной модели (BM):

$$
\mathrm{V}+\mathrm{LcAll} / \mathrm{LcAbl}
$$

В модели отражено взаимодействие единиц двух уровней языка лексического и синтаксического: свойства глаголов - единиц лексического уровня языка - определяются через исследование валентности в виде синтаксического окружения - единиц синтаксического уровня языка, в данном случае - синтагм, обладающих двумя видами локативной синтаксической семантики.

Однако группа глаголов движения оказалась не однородной по своему составу. Имеется большое стабильное ядро, характеризующееся семантической близостью глагольных лексем и относительно более высокой частотой встречаемости ${ }^{3}$ глаголов данной группы в указанном синтаксическом окружении. К числу таких случаев относятся вышеприведенные примеры (5) и (6). Вместе с тем в составе данной группы обнаружен ряд глаголов, отличающихся по своему значению и относящихся к другим валентностным группам. Например, глагол pedal, имеющий, по данным словарей, значение 'крутить педали', которому свойственна объектная валентность $(\mathrm{Ob})$, встретился нам в примере:

(7) One day he would get up at six o'clock and pedal away to Kenilworth $\langle\ldots\rangle$

'Однажды он встанет в шесть часов и укатит к Кенилворту $\langle\ldots\rangle$ ' [Huxley 1979: 37]

в локативном аллативном окружении. Глагол pedal, для которого из всех рассматриваемых типов окружения наиболее вероятным является объектная валентность $(\mathrm{Ob})$, что может быть отражено в модели $\mathrm{V}+\mathrm{Ob}$, в имеющемся примере употреблен в локативном аллативном окружении (модель V+LcAll), при этом значение глагола претерпело некоторые изменения, в результате чего глагол pedal получил новое

3 Термин Б. А. Успенского [Успенский 1970] используется здесь, чтобы подчеркнуть отличие данной работы от исследований, выполненных с применением квантитативных методов [Андреев 2002; Bod 1995], в которых встречается термин «частотность». 
значение 'ехать на велосипеде'. Использовав модель синтаксического окружения, свойственную глаголам движения, глагол pedal сам превратился в глагол движения:

BM примера (7): pedal 1 [V+Ob] $\rightarrow$ pedal 2 [V+ LcAll].

Случаи употребления тех или иных синтаксем/ синтагм при глаголах могут обладать как высокой частотой встречаемости, так и низкой. Пример (6) можно отнести к случаям с высокой частотой встречаемости, в противоположность ему пример (7) представляет собой пример с низкой частотой встречаемости. Для таких случаев окказиональных изменений валентности глаголов, то есть их синтаксических свойств, можно также использовать название «синтаксические сдвиги» (syntactic shifts). Отметим, что одновременно с изменением валентности глагола pedal изменилась и его семантика, что отражено в модели 7 цифрами 1 и 2 - pedal 1 и pedal 2.

Аналогичным образом глагол marry присоединяется к валентностной группе глаголов движения:

(8) $\langle\ldots\rangle$ after she was free, they were to go back to Louisville and be married from her house - just as if it were five years ago.

' $\ldots$.$\rangle когда она освободится, они вернутся в Луисвилль, и он за-$ берет ее из дома родителей [они поженятся из ее дома] 一 как будто это было пять лет назад' [Fitzgerald 1974: 117]

Локативная валентность глаголу marry не свойственна. По данным словарей для глагола marry типичным окружением является marry somebody - модель marry $(\mathrm{V}+\mathrm{Ob})$ с объектной синтаксемой. В примере (8) глагол marry с помощью реализации при нем локативной аблативной синтагмы (LcAbl) from her house присоединяется к глаголам движения. То, что здесь речь идет о пространственных отношениях, подчеркивается использованным ранее глаголом движения go back 'вернуться' в сочетании с локативной аллативной синтаксемой to Louisville.

Здесь также имеет место синтаксический сдвиг окружения глагола marry, что отражено в следующей схеме:

$\mathrm{BM}$ примера (8): marry $[\mathrm{V}+\mathrm{Ob}] \rightarrow \operatorname{marry}[\mathrm{V}+\mathrm{LcAbl}]$.

В отличие от примера (7) значение глагола marry не меняется, что обозначено в схеме отсутствием цифр 1 и 2 после слова marry как в первом, так и во втором случае. 
Второй группой глаголов с изменяющейся валентностью является группа перемещения кого-либо, чего-либо (bring, carry, drive, deliver, draw, fetch, get, move, remove). Данной глагольной группе также свойственны локативная аллативная (пример (9)) и локативная аблативная (пример (10)) валентности:

(9) Your valises have been moved $\langle\ldots\rangle$ to the compartment No1.

'Ваши чемоданы перенесены 〈...> в купе № 1' [Christie 1975: 23]

(10) Soames drew the forged cheque from his pocket.

'Сомс вытащил фальшивый чек из кармана' [Galsworthy 1976: 210]

(9) и (10) являются типичными случаями с высокой частотой встречаемости. Сравним предложения (9) и (10) с примерами (11) и (12):

(11) Your baggage shall be changed at once to another compartment. 'Ваш багаж должен быть немедленно перенесен в другое купе' [Christie 1975: 128]

Глагол change 1, имеющий основное значение 'менять(ся)' (ORD), c появлением в зависимой позиции при нем локативной аллативной синтагмы в примере (11) приближается по своему значению к глаголу move 'перенести', таким образом, глагол change, меняя свое значение на change 2 'перенести', примыкает к глаголам перемещения, превращается в случай с низкой частотой встречаемости употребления данного глагола, что и отражено в схеме:

BM примера (11): change $1[\mathrm{~V}] \rightarrow$ change $2[\mathrm{~V}+\mathrm{Ob}+\mathrm{LcAll}]$

Аналогичное изменение происходит с глаголом compel в случае peализации локативной аблативной валентности в примере (12):

(12) $\langle\ldots\rangle$ wedging his tense arm imperatively under mine, Tom Buchanan compelled me from the room $\langle\ldots\rangle$

' $\langle\ldots\rangle$ просунув свою напряженную руку под мою, Том Бьюкенен заставил меня [выйти] из комнаты 〈...〉’ [Fitzgerald 1974:17]

Значение глагола compel также меняется при изменении синтаксического окружения. Чаще всего compel означает 'заставлять, принуждать' (ORD). В примере (12) глагол compel получает значение 'заставить выйти, вывести насильно, вытащить'. Ср. с примером (10), в котором глагол draw 'вытащить (из кармана)' в типичном для него локативном 
аблативном окружении оказывается близким по значению к compel 'заставить выйти, вытащить (из комнаты)', при этом оба глагола оказываются в группе глаголов перемещения. Здесь также происходит синтаксический сдвиг, сопровождающийся изменением семантики глагола.

BM примера (12): compel $1[\mathrm{~V}+\mathrm{Ob}] \rightarrow$ compel $2[\mathrm{~V}+\mathrm{Ob}+\mathrm{LcAbl}]$

Интересной деталью является то, что глагол compel относится к группе каузативных глаголов, которым локативная валентность вообще не свойственна, что и отражено в первой части схемы. «Теоретически» можно «заставить кого-то сделать что-то где-то», однако среди множества имеющихся у нас примеров встретился только один пример - (12), в котором при каузативном глаголе используется синтаксема из ряда локативных. Итог: данный пример является редким, необычным, его появление требует каких-то объяснений.

Третьей интересной группой являются глаголы речевой деятельности, из которых только два глагола - call 'позвать' и yell (out) 'выкрикнуть' - регулярно встречаются в локативном окружении, а именно в локативном аблативном, например:

(13) From the darkness Lenny called, "George - you asleep?"

'Из темноты Ленни позвал: «Джордж, ты спишь?»' [Steinbeck 1972: 17]

Локативная аблативная валентность является типичной только для глаголов call и yell. Вместе с тем зафиксированы случаи, в которых другие глаголы речевой деятельности (explain, enquire, plead, say, talk, tell) присоединяются к названным двум, попадая под действие не свойственной им модели, как, например, глагол say в примере (14):

(14) From his bedroom door Jon said to his sister $\langle\ldots\rangle$

'От двери своей спальни Джон сказал своей сестре $\langle. .$.$\rangle ' [Gals-$ worthy 1976: 38],

что может быть представлено в виде следующей схемы:

$$
\text { ВМ примера (14): say [V + C] } \rightarrow \text { say [V+C+ LcAbl], }
$$

где в первой и второй частях модели значение глагола say не меняется, несмотря на появление нового для него окружения. Изменение валентности глагола (синтаксический сдвиг) происходит, но не сопровождается изменением значения глагола. Перечисленные пять глаголов — pedal, change, compel, say и marry, — присоединяясь к новым 
группам, в одних случаях частично меняют свое лексическое значение, в других же их значение не подвергается изменению. Во всех случаях валентностные группы глаголов, к которым они присоединяются, становятся менее однородными, связь между лексическим значением и синтаксическим окружением несколько ослабляется на фоне сохранения действия синтаксической модели, которая остается неизменной. Образуется основное ядро глагольной группы, обладающее сходной семантикой и высокой частотой встречаемости в данном синтаксическом окружении, и периферия. Эта новая периферия является следствием того, что ряд лексических единиц попадает под действие моделей, которые им были до того не свойственны. Привлекают внимание примеры, в которых относительная частота встречаемости таких употреблений низка. Наиболее часто это происходит с глаголами, которые присоединились к глаголам движения и перемещения, а также говорения. Из локативных синтаксем / синтагм наиболее часто встречающимися в рассмотренных случаях оказываются локативная аблативная и локативная аллативная.

Реже нечто подобное происходит также и с другими синтаксемами / синтагмами из локативного ряда - локативными дистрибутивными синтаксемами / синтагмами ${ }^{4}$. Наиболее распространенной из ряда дистрибутивных является дистрибутивная локативная аллативная, которая чаще всего встречается в зависимой позиции при глаголах, имеющих дистрибутивное значение (disperse, distribute, dispatch, scatter), ср.:

\section{(15) These treasures were being scattered to the corners of the galaxy} as trinkets.

'Эти сокровища разбрасывались по всем углам галактики как безделушки' [Silverberg 1979: 162]

Однако не всегда лексическая семантика глагола соответствует синтаксической семантике глагольного окружения. В противоположность примеру (15), в примерах (16) и (17) локативные дистрибутивные элементы, выраженные локативной дистрибутивной синтаксемой in cafes в примере (16) и локативной дистрибутивной синтагмой in all the capitals of Europe в примере (17), реализуются в зависимой позиции при глаголах, не обладающих дистрибутивной семантикой:

${ }^{4}$ Дистрибутивная локативная, дистрибутивная локативная аллативная, дистрибутивная локативная директивная, дистрибутивная локативная медиативная, дистрибутивная локативная экстериорная [Юликова 1996]. 
(16) The accordions were playing in the cafes.

'Аккордеоны играли в [по] кафе' [Fleming 1964: 162],

что может быть отражено в схеме:

$\mathrm{BM}$ примера (16): play $[\mathrm{V}+\mathrm{C}] \rightarrow$ play $[\mathrm{V}+\mathrm{LcDtr}]$,

(17) After that I lived like a young rajah in all the capitals of Europe $\langle\ldots\rangle$ 'После этого я жил, как молодой раджа, во всех столицах Европы [по всем столицам Европы] 〈...〉’ [Fitzgerald 1974: 71], что может быть отражено в схеме:

$\mathrm{BM}$ примера (17): live $[\mathrm{V}+\mathrm{Lc}] \rightarrow$ live $[\mathrm{V}+\mathrm{LcDtr}]$

Получается, что глаголы play и live также присоединяются к дистрибутивным глаголам и тем самым образуют периферию дистрибутивных глаголов. Особо следует отметить низкую частоту встречаемости таких употреблений. Таким образом, наметился ряд примеров изменения валентности глаголов, которые пока еще не имеют объяснения. Попытаемся его найти.

\section{5. Причины изменения валентности глаголов}

Существует точка зрения, согласно которой редкие необычные явления, являясь периферийными, не представляют большого интереса для изучения языков [Croft 2003: 12].

В начале нашей работы над локативной валентностью английских глаголов рассматривались наиболее типичные примеры. В результате в остатке оказались примеры, которые нельзя было по выбранным критериям (наличие общей лексической семантики и синтаксического окружения) отнести к выделенным группам. Изучение особенностей этих периферийных примеров показало, что чем ниже их относительная частота встречаемости, тем больше внимания читателя они привлекают, в результате чего возрастает значимость таких употреблений в тексте. Согласно имеющимся данным, можно описать как характеризующееся относительно низкой частотой встречаемости локативное аллативное окружение глагола pedal, который присоединяется к валентностной группе глаголов движения (пример (7)), локативное аблативное 
окружение глагола marry (пример (8)), который также присоединяется к группе глаголов движения, а также локативное аллативное окружение глагола change (пример (11)), локативное аблативное окружение глагола compel (пример (12)), которые присоединяются к глаголам перемещения, локативное аблативное окружение глагола say (пример (14)) и локативное дистрибутивное окружение глаголов play и live в примерах (16) и (17).

Но чем вызвано изменение валентности глаголов - синтаксические сдвиги, подобные описанным выше?

Чтобы понять причину возникновения таких изменений, границ предложения оказалось недостаточно. Пришлось обратиться к текстам, в которых названные примеры были обнаружены.

Текст 1

He left his luggage to be called for later, and pushed off on his bicycle. He always took his bicycle when he went into the country. It was part of his theory of exercise. One day he would get up at six o'clock and pedal away to Kenilworth, or Stratford-on-Avon - anywhere. And within a radius of twenty miles there were always Norman churches and Tudor mansions to be seen in the course of an afternoon's excursion. Somehow they never did get seen, but all the same it was nice to feel that the bicycle was there, and one fine morning one might really get up at six.

[A. Huxley. Crome Yellow. P. 37.]

Текст 2

The conductor looked into the carriage. "The American lady is coming back".

Dr. Constantine looked rather guilty. He had, he felt, treated Mrs. Hubbard rather cavalierly. But she had no reproaches for him. Her energies were concentrated on another matter.

"I'm going to say one thing out right," she said breathlessly as she arrived at the door. "I'm not going on any longer in this compartment! Why, I wouldn't sleep in it to-night if you paid me a million dollars."

"But, Madam -“

"I know what you are going to say..."

Poirot interrupted firmly.

"You misunderstand, Madam. Your demand is most reasonable. Your baggage shall be changed at once to another compartment.

[A. Christie. Murder on the Orient Express. P. 128.] 


\section{Текст 3}

I looked at Miss Baker, wondering what it was she "had done".

"You live in West Egg", she remarked contemptuously. "I know somebody there."

"I don't know a single -"

"You must know Gatsby."

"Gatsby?" demanded Daisy. "What Gatsby?"

Before I could reply that he was my neighbour dinner was announced; wedging his tense arm imperatively under mine, Tom Buchanan compelled me from the room as though he were moving a checker to another square.

[F. S. Fitzgerald. The Great Gatsby. P. 17.]

Текст 4

And there was silence at thirty miles an hour.

From his bedroom door Jon said to his sister:

"They say Fleur runs this canteen. Is she really so old now?"

"Fleur has a very clear head, my dear. She saw you there. No second go of measles, Jon."

Jon laughed.

[J. Galsworthy. Swan Song. P. 38.]

Текст 5

They were now weaving expertly through the traffic down the famous Canebière and Marius needed all his breath to insult the other drivers. Bond could smell the sea. The accordions were playing in the cafes. He remembered that it was rather fun, this time, being on the side of the evil. [I. Fleming. On her Majesty’s Secret Service. P. 162.]

Текст 6

"My family all died and I came into a good deal of money."

His voice was solemn, as if the memory of that sudden extinction of a clan still haunted him. For a moment I expected that he was pulling my leg, but a glance at him convinced me otherwise.

"After that I lived like a young rajah in all the capitals of Europe - Paris, Venice, Rome - collecting jewels, chiefly rubies, hunting big game, painting a little, things for myself only, and trying to forget something very sad that happened to me long ago." [F. S. Fitzgerald. The Great Gatsby. P. 71.] 
Текст 7

He wanted nothing less of Daisy than that she should go to Tom and say: "I never loved you". After she had obliterated four years with that sentence they could decide upon more practical measures to be taken. One of them was that, after she was free, they were to go back to Louisville and be married from her house - just as if it were five years ago.

"And she doesn't understand," he said. He broke off ...

"I wouldn't ask too much of her," I ventured. "You can't repeat the past."

"Can't repeat the past?" he cried incredulously. "Why of course you can!"

[F. S. Fitzgerald. The Great Gatsby. P. 117.]

Итак, чем вызваны изменения валентности глаголов в приведенных выше текстах?

Выделенные случаи изменения валентности глаголов (синтаксические сдвиги) являются результатом действия дискурсивного фактора. Изучение текстового материала показало, что синтаксические сдвиги могут совпадать с началом абзаца (Teксm 4) и с концом абзаца (Текст 2 , Teкст 3), где они выступают как средство делимитации смысловых отрезков, а также в середине абзаца как в Текстах 1, 5, 6 и $7^{5}$. Так, например, в Тексте 1 интересующий нас пример занимает не начальную / конечную позицию, а находится в середине абзаца. Выделенное таким образом предложение выполняет более важную функцию - выражает основную мысль абзаца, в котором речь идет о мечте одного из участников описываемых событий встать пораньше и pedal away 'укатить на велосипеде' все равно куда. Синтаксический сдвиг используется автором как средство выделения главного, с его точки зрения, предложения. То же самое можно сказать и о Текстах 5,6 и 7, где синтаксические сдвиги служат знаками, привлекающими внимание читателя к основной идее абзаца. В Тексте 7 выделенное автором с помощью синтаксического сдвига предложение, как и в предыдущих случаях, выражает основную мысль абзаца ${ }^{6}$, но, кроме того, та же мысль оказывается

5 Появление синтаксических сдвигов в разных частях абзаца может рассматриваться как дистрибутивная особенность локативных синтаксем.

${ }^{6}$ Автор выделяет эту мысль в качестве главной. Напрашивается аналогия с тем, что в американских и британских университетских учебниках называется topic 
одновременно важной и для всего текста известного произведения Ф. С. Фицджеральда, герой которого хотел совершить невозможное вернуться в прошлое и исправить его.

Исследования в области лингвистики текста, а также дискурса, показывают, что тексту как единице коммуникации свойственны две такие противоположные характеристики, как целостность и дискретность [Колшанский 1984], проявляющиеся как содержательно, так и формально. В содержательном плане целостность и дискретность заключаются в том, что текст, объединенный общей темой, разделяется на ряд подтем. Такое членение находит свое отражение в наборе разнообразных признаков формального характера, именуемых коннекторами [Дресслер 1978: 122], средствами текстовой когезии [Гальперин 1981: 73], сигналами смысловой и структурной связи [Москальская 1981: 26], языковыми и контекстуальными сигналами [Гончарова, Шишкина 2005: 8], средствами выражения специфических дискурсивных отношений, в том числе для обозначения фрагментов структуры дискурса [Плунгян 2008: 11].

Описанию средств делимитации текста и его структурных единиц в литературе уделено немало внимания. Тем не менее список формальных текстоформирующих средств, вероятно, нельзя считать закрытым. На наш взгляд, изменение валентности глаголов (синтаксические сдвиги) можно отнести к числу структурных сигналов. В качестве таковых они функционально обусловлены, но в одних случаях они играют роль формальных показателей дискретности текста, а в других выступают как его интеграторы. Так, синтаксический сдвиг в Тексте 4 является маркером начала абзаца, синтаксические сдвиги в Текстах 2 и 3 - показателем завершения высказывания (показатели дискретности), в то время как в Тексmax 1, 5, 6 и 7 синтаксические сдвиги играют роль смысловых пиков (т. е. выполняют функцию интеграторов). Следует отметить, что рассматриваемый механизм маркирования начала, конца и главной мысли абзаца (или текста), скорее всего, не является эксплицитным сигналом для большинства читателей.

Исследователями дискурса отмечаются случаи дискурсивного употребления грамматических категорий [Плунгян 2008]. В контексте дискурсивных исследований можно говорить не только о дискурсивном употреблении грамматических категорий, но также, поскольку локативность представляет собой синтаксическую категорию (см. Раздел 2), и о дискурсивном употреблении синтаксических категорий.

sentence: https://literaryterms.net/topic-sentence (дата обращения: 11.10.2020). 
Что касается мнения У. Крофта о периферийных явлениях, то невозможно согласиться с тем, что они не представляют никакого интереса. В границах одного языка как элементы с низкой частотой встречаемости, так и высокочастотные оказываются равнозначными, поскольку и те и другие образуют вместе единую систему. Для создания целостной картины целесообразно изучать всю совокупность примеров в их противопоставлении.

\section{6. О семантической и синтаксической валентности}

В Разделах 1-5, посвященных изучению валентности как синтаксического понятия, валентность рассматривалась как синтаксическое свойство глагольных лексем. В следующей части статьи будет сделана попытка дополнить предложенный подход рассмотрением проблемы изменения валентности английских глаголов с несколько иных позиций, а именно, на основе исследований, в которых разграничивается семантическая и синтаксическая валентность. Если раньше нас интересовало синтаксическое окружение, то теперь мы сконцентрируемся на семантике глагола, на разных случаях изменения семантики глаголов.

Не беря на себя задачу обзора сложных теоретических положений, изложенных в монографиях и статьях создателей данного направления лингвистики, остановимся лишь на двух идеях, имеющих значение для выбранной темы.

Во-первых, многие авторы, в работах которых разграничивается семантическая и синтаксическая валентность, считают, что существует неразрывная связь между лексическим значением глагола и его семантическими и синтаксическими валентностями. «Классы глаголов, обладающих разной валентностью, всегда отличаются друг от друга и семантикой» [Храковский 2014: 28]. По мнению Ю. Д. Апресяна, «семантические и синтаксические актанты глагольных лексем находятся в отношении взаимно-однозначного соответствия» [Апресян 2006: 15]. Актантная рамка, однако, не всегда оказывается столь жесткой, особенно, если речь идет об изучении английского языка ${ }^{7}$

${ }^{7}$ Ср.: С. В. Шустова и Е. А. Смирнова, исследуя соотношение семантических и синтаксических актантов в валентностной структуре английских 
Во-вторых, общим для рассматриваемого направления является отношение к локативу как второстепенному элементу — сирконстанту, при этом все же следует отметить, что в последнее время локативности придается несколько большее значение. В. А. Плунгян считает локативные элементы при глаголах перемещения локативными аргументами [Плунгян 2011: 329], Я. Г. Тестелец выделяет особый вид зависимых - адъекты, к которым относит обстоятельства места и времени, занимающие положение между актантами и сирконстантами [Тестелец 2001:189], В. С. Храковский отмечает, что «хотя сирконстанты являются необязательными элементами конструкции, многие из них играют определяющую роль при акциональной интерпретации конструкции» [Храковский 2014: 27].

Принимая во внимание все указанные теоретические положения, перейдем к практике. Рассмотрим соотношение между лексическим значением глаголов и семантическими и синтаксическими валентностями глаголов в примерах, отобранных в первой части данной статьи. Тот факт, что локативным элементам в настоящее время придается большее, чем раньше, значение, послужил основанием для включения локатива в число рассматриваемых элементов наравне с актантами.

Валентность является универсальным понятием для всех языков, но ее реализация в конкретных языках может не совпадать. Далее на примере собранного материала будет показано, что семантическая валентность английских глаголов регулярно совпадает с синтаксической только в примерах с относительно высокой частотой встречаемости. Словосочетаниям с низкой частотой встречаемости свойственна большая вариативность элементов, образующих глагольную валентность. В английском языке в низкочастотных примерах встречаются разнообразные варианты изменения валентности: 1) изменение синтаксической валентности глагола может сопровождаться изменением значения глагола, 2) изменение синтаксической валентности глагола может не сопровождаться изменением значения глагола, 3) возможна замена одного глагола другим в уже существующих конструкциях. Рассмотрим это на конкретных примерах из литературных произведений.

Для сравнения вначале приведем примеры с высокой частотой встречаемости, в которых имеются глаголы, относящиеся к рассмотренным

метеорологических глаголов, обнаружили, что синтаксическая валентность анализируемых в работе названных авторов глаголов шире семантической [Шустова, Смирнова 2015]. 
выше трем валентностным группам: глаголам движения, перемещения и речевой деятельности.

BM примеров (5) и (6): come [V + LcAll/ LcAbl] 'приходить'

BM примера (9): move [V+ LcAll] 'передвигать'

BM примера (13): call [V + LcAbl] 'звать'

Валентностные свойства глаголов в высокочастотных моделях (примеры (5), (6), (9) и (13)) отражены в Таблице 1.

Таблица 1. Примеры с высокой частотой встречаемости

Table 1. High frequency of occurrence examples

\begin{tabular}{|c|c|c|c|}
\hline Валентностные группы & $\begin{array}{c}\text { Глаголы } \\
\text { движения }\end{array}$ & $\begin{array}{c}\text { Глаголы } \\
\text { перемещения }\end{array}$ & $\begin{array}{c}\text { Глаголы речевой } \\
\text { деятельности }\end{array}$ \\
\hline Пример & 5 и 6 & 9 & 13 \\
\hline $\begin{array}{l}\text { Актант / } \\
\text { Сирконстант }\end{array}$ & $\begin{array}{c}\text { come } \\
\text { 'приходить' }\end{array}$ & $\begin{array}{c}\text { move } \\
\text { 'передвигать' }\end{array}$ & $\begin{array}{c}\text { call } \\
\text { 'звать' }\end{array}$ \\
\hline 1 актант & сем+синт & сем+синт & сем+синт \\
\hline 2 актант & сем+синт & сем+синт & сем+синт \\
\hline Локатив & сем+синт & сем+синт & сем+синт \\
\hline
\end{tabular}

Как показано в таблице, лексическое значение глаголов соответствует своим валентностным группам, семантические и синтаксические валентности совпадают. Такие примеры являются типичными, в них наблюдается полное совпадение семантической и синтаксической валентности.

Высокочастотным типичным примерам противопоставлены функционально примеры с низкой частотой встречаемости, представляющие в данном случае основной интерес как выполнившие роль дискурсивных сигналов. Итак, первый вариант изменения валентностных свойств глаголов в низкочастотных примерах — изменение синтаксической валентности глагола, сопровождающееся изменением значения глагола. В качестве примера возьмем изменение значения двух глаголов:

ВМ примера (11) change 1: 'менять' [V +Ob] $\rightarrow$ change 2 'перенести' [V+Ob + LcAll]

ВМ примера (12): compel 1 'заставить' [V +Ob] $\rightarrow$ compel 2 'заставить выйти' [V+Ob + LcAbl]. 
В Таблище 2 представлено соотношение семантических и синтаксических актантов / сирконстантов данных глаголов. В первой и третьей графах приведены переводы основного значения change - 'менять(ся)'; compel — 'заставить кого-то сделать что-то'(ORD), во второй и четвертой графах приведены производные значения тех же глаголов, встречающиеся в примерах с низкой частотой встречаемости. В низкочастотных примерах (11) и (12) (см. графы 2 и 4) происходит синтаксический сдвиг, лексическое значение глаголов меняется, глаголы присоединяются к новым валентностным группам, при этом семантическая валентность данных глаголов приходит в соответствие с синтаксической.

Таблица 2. Примеры с низкой частотой встречаемости (Семантическая валентность глаголов меняется одновременно с синтаксической валентностью)

Table 2. Low frequency of occurrence examples (Semantic valency changes simultaneously with syntactic valency)

\begin{tabular}{|c|c|c|c|c|}
\hline $\begin{array}{l}\text { Валентност- } \\
\text { ная группа }\end{array}$ & & $\begin{array}{c}\text { Глаголы } \\
\text { перемещения }\end{array}$ & & $\begin{array}{c}\text { Глаголы } \\
\text { перемещения }\end{array}$ \\
\hline & $\begin{array}{c}\text { Исходное } \\
\text { значение }\end{array}$ & $\begin{array}{c}\text { Производное } \\
\text { значение } \\
\text { Пример (11) }\end{array}$ & $\begin{array}{l}\text { Исходное } \\
\text { значение }\end{array}$ & $\begin{array}{c}\text { Производное } \\
\text { значение } \\
\text { Пример (12) }\end{array}$ \\
\hline Глагол & $\begin{array}{l}\text { Change } 1 \\
\text { 'менять' }\end{array}$ & $\begin{array}{l}\text { Change } 2 \\
\text { 'перенести' }\end{array}$ & $\begin{array}{c}\text { Compel } 1 \\
\text { 'заставить' } \\
\text { (кого-то } \\
\text { сделать } \\
\text { что-то) }\end{array}$ & $\begin{array}{c}\text { Compel } 2 \\
\text { 'заставить } \\
\text { выйти' }\end{array}$ \\
\hline 1 актант & сем+синт & & сем+синт & сем + синт \\
\hline 2 актант & сем+синт & сем+синт & сем+синт & сем+синт \\
\hline локатив & & синт & & синт \\
\hline
\end{tabular}

Как показано в таблице, синтаксическая валентность глагола compel 2 шире семантической в примере (12), но является более узкой у глагола change 2 в примере (11). Особенность таких глаголов обусловлена тем, что одновременно с изменением синтаксической валентности меняется и лексическое значение глагола, в результате чего глаголы change 2 и compel 2 присоединяются к группе глаголов перемещения.

Вторым вариантом изменения валентности может быть изменение синтаксической валентности глагола, не сопровождающееся 
изменением его значения. Данный вариант характеризуется еще более низкой частотой встречаемости, чем первый. Сравним построенные ранее модели примеров (8) и (14) с теми данными, которые представлены в Таблице 3:

$$
\begin{gathered}
\text { ВМ примера (8): marry }[\mathrm{V}+\mathrm{Ob}] \rightarrow \\
\text { marry }[\mathrm{V}+\mathrm{LcAbl}], \text { 'жениться / выйти замуж’ }
\end{gathered}
$$

ВМ примера (14): say [V + C] $\rightarrow$ say [V+C+ LcAbl], 'сказать'.

В первой графе Таблищьы 3 приведен перевод глагола marry - 'жениться / выйти замуж'; say - 'сказать кому-то что-то'. Здесь нельзя говорить об исходных и производных значениях, поскольку значения глаголов, реализующихся в данных примерах с низкой частотой встречаемости (в отличие от примеров в Таблице 2), не меняются. В $\mathrm{Ta}$ блице 3 представлено соотношение семантических и синтаксических актантов / сирконстантов в приведенных низкочастотных примерах.

Таблица 3. Примеры с низкой частотой встречаемости (Изменение синтаксической валентности глагола не сопровождается изменением значения глагола)

Table 3. Low frequency of occurrence examples

\begin{tabular}{|c|c|c|c|c|}
\hline Пример & $\begin{array}{c}\text { Словарное } \\
\text { толкование } \\
\text { глагола }\end{array}$ & Пример (8) & $\begin{array}{c}\text { Словарное } \\
\text { толкование } \\
\text { глагола }\end{array}$ & Пример (14) \\
\hline $\begin{array}{l}\text { Актант/ } \\
\text { Сирконстант }\end{array}$ & $\begin{array}{l}\text { Marry } \\
\text { 'жениться / } \\
\text { выйти } \\
\text { замуж’ }\end{array}$ & $\begin{array}{l}\text { Marry } \\
\text { 'жениться / } \\
\text { выйти } \\
\text { замуж' }\end{array}$ & $\begin{array}{l}\text { Say } \\
\text { 'сказать } \\
\text { кому-то } \\
\text { что-то' }\end{array}$ & $\begin{array}{l}\text { Sау } \\
\text { ‘сказать } \\
\text { кому-то } \\
\text { что-то' }\end{array}$ \\
\hline 1 актант & сем+синт & & сем+синт & сем+синт \\
\hline 2 актант & сем+синт & сем+синт & сем+синт & сем+синт \\
\hline локатив & & синт & & синт \\
\hline
\end{tabular}
(Syntactic valency shift is not accompanied by the change of verb meaning)

Итак, в примерах с низкой частотой встречаемости синтаксические валентности глаголов меняются, но их значение не претерпевает изменений, что довольно необычно. В ряде случаев синтаксическая валентность оказывается шире, в ряде случаев - уже, но значение глаголов нигде не меняется. Изменение валентности глаголов приводит к образованию оригинальных, нигде больше не встречающихся, тем не менее 
грамматически правильных, с точки зрения английского языка, словосочетаний: (8) be married from her house, (14) say from his bedroom door.

При переводе на русский язык таких предложений, как (8) *выйти замуж из своего дома, (14) *сказать от двери, возникает необходимость внесения определенных изменений ${ }^{8}$.

И наконец, третий вариант изменения валентности - замена одного глагола другим в готовых конструкциях. Такие замены встретились нам в дистрибутивных конструкциях. В дистрибутивных конструкциях чаще всего используются дистрибутивные глаголы. Однако в единичных примерах встречаются другие случаи. Так, в «типичном» примере (15) These treasures were being scattered to the corners of the galaxy $\langle\ldots\rangle$ 'Сокровища были разбросаны по разным уголкам галактики $\langle. .$.$\rangle ':$

${ }^{8}$ Несовпадение синтаксических сдвигов в английском и русском языках создает определенные проблемы для переводчиков. Сравним пример (8) 〈...〉 $\underline{\text { be married }}$ from her house $\langle\ldots\rangle$ с примером из перевода Е. Д. Калашниковой: 〈... сыграть свадьбу в ее доме [Фицджеральд 2014а] (В других вариантах - отпраздновать свадьбу). Е. Д. Калашникова прибегает к лексической замене с одновременной синтаксической трансформацией замены локативной аблативной синтаксемы на локативную интериорную (8): V1 + LcAbl $\rightarrow$ V2 + LcInt.

Пытаясь подчеркнуть значимость словосочетания from her house..., другой автор перевода, С. Таск, для усиления эффекта удваивает количество локативных синтаксем: 〈...〉 они вернутся в Луисвилль и там, в ее доме, поженятся, как это должно было произойти пять лет назад [Фицджеральд 2014b]. В результате ни первый, ни второй варианты не передают в той же мере идею невозможности называемого события, как локативная аблативная синтагма from her house в английском оригинале.

Другой пример - (14) From his bedroom door Jon said to his sister 〈...〉 обычно переводят, используя лексическую замену: с порога своей комнаты. Например, перевод Е. Д. Калашниковой:

С порога своей комнаты Джон сказал сестре:

- Я слымшал, столовую устроила Флер. Неужели она так постарела?

- У Флер очень умная головка, милый. Она тебя видела. Смотри, Джон, не заболей корью во второй раз!

Дюжон засмеялся. [Голсуорси 2009]

Пытаясь найти замену недопустимому в РЯ 'сказать от двери', Е. Д. Калашникова (как и другие переводчики) 'дверь' door заменяет словом 'порог’ - 'сказал с порога своей комнаты', что как бы решает проблему, но при этом делает происходящее не совсем понятным для читателя, поскольку в РЯ 'сказать с порога' означает 'сказать в начале встречи', в то время как в оригинале Джон обращается к своей сестре в конце встречи, уходя. 
BM примера (15): scatter [V+ LcDtr] 'разбрасывать', значение глагола scatter 'разбрасывать' соответствует своему окружению в виде дистрибутивной конструкции.

$\mathrm{B}$ «нетипичных» примерах с низкой частотой встречаемости (16) и (17) произошло изменение валентности глаголов:

BM примера (16): play $[\mathrm{V}+\mathrm{C}] \rightarrow$ play [V+ LcDtr] 'играть'

$\mathrm{BM}$ примера (17): live [V + Lc] $\rightarrow$ live [V+ LcDtr] 'жить'

Глаголы play и live реализуются в дистрибутивных конструкциях, однако сами при этом не являются дистрибутивными. Обращение к словарям показывает, что глаголы play и live обычно встречаются с локативными словосочетаниями, например Children were playing about in the garden (ORD), I live in No 17 (ORD), но нигде не встречаются в дистрибутивных конструкциях. Также и в собранном материале данные два глагола нигде не встречаются в дистрибутивном окружении за исключением рассматриваемых двух случаев. Можно предположить, что реализация глаголов play и live в локативных дистрибутивных конструкциях в примерах (16) и (17) представляет собой новое явление.

Таблица 4. Примеры с низкой частотой встречаемости (Использование глаголов в локативных дистрибутивных конструкциях)

Table 4. Low frequency of occurrence examples (Verbs used in locative distributive constructions)

\begin{tabular}{|c|c|c|c|c|}
\hline $\begin{array}{l}\text { Валентност- } \\
\text { ные групाы }\end{array}$ & $\begin{array}{c}\text { Глаголы } \\
\text { деятельности }\end{array}$ & $\begin{array}{c}\text { Глаголы } \\
\text { деятельности }\end{array}$ & $\begin{array}{c}\text { Глаголы } \\
\text { пребывания }\end{array}$ & $\begin{array}{c}\text { Глаголы } \\
\text { пребывания }\end{array}$ \\
\hline Пример & $\begin{array}{l}\text { Словарное } \\
\text { толкование } \\
\text { глагола }\end{array}$ & (16) & $\begin{array}{l}\text { Словарное } \\
\text { толкование } \\
\text { глагола }\end{array}$ & (17) \\
\hline $\begin{array}{l}\text { Актант / } \\
\text { сирконстант }\end{array}$ & $\begin{array}{l}\text { Play 'играть } \\
\text { (в саду)' }\end{array}$ & $\begin{array}{l}\text { Play 'играть } \\
\text { (в разных } \\
\text { кафе)' }\end{array}$ & $\begin{array}{l}\text { live 'жить } \\
\text { (доме, } \\
\text { в квартире)' }\end{array}$ & $\begin{array}{l}\text { live } \\
\text { 'жить } \\
\text { (в столицах)' }\end{array}$ \\
\hline 1 актант & сем+синт & сем+синт & сем+синт & сем+синт \\
\hline \multicolumn{5}{|l|}{2 актант } \\
\hline локатив & сем+ синт & сем+синт & сем+синт & сем+синт \\
\hline $\begin{array}{l}\text { Дистрибутив- } \\
\text { ная } \\
\text { конструкция }\end{array}$ & - & + & - & + \\
\hline
\end{tabular}


Локативная дистрибутивная конструкция нетипична для глаголов деятельности и пребывания, но встречается в примерах с низкой частотой встречаемости: пример (16) с глаголом play 'играть' и (17) с глаголом live 'жить'. Показательно, что перевод типичного примера примера (15) These treasures were being scattered to the corners of the galaxy $\langle\ldots\rangle$ 'сокровища были разбросаны по разным уголкам галактики $\langle\ldots\rangle$ ' не представляет труда, в то время как при переводе на русский язык примеров с низкой частотой встречаемости (16) The accordions were playing in cafes, (17) I lived $\langle\ldots\rangle$ in all the capitals of Europe возникают очевидные затруднения: (16)*аккордеоны играли по кафе, $(17)^{*}$ я жил $\langle\ldots\rangle$ по всем столицам Европы. Простые и допустимые в английском языке, эти словосочетания создают проблемы при переводе на русский язык.

По мнению целого ряда исследователей [Щерба 1958, Успенский 1997, Croft 2003], межъязыковые сопоставления являются показательными. Сопоставление изменения валентности в английском языке с примерами в русском языке в данном случае помогает подчеркнуть значимость сравниваемых изменений, а также периферийность рассматриваемых случаев в системе английского языка.

Сравним этот случай с английскими примерами, приведенными Бет Левин. В английском языке имеются глаголы, такие как whistle 'свистеть' и roar 'грохотать', регулярно принимающие дополнительные значения, которые могут использоваться глаголами направленного движения, описывающими движущийся объект, одновременно издающими какой-либо звук, например: The bullet whistled through the window и The car roared up the driveway [Levin 1993: 4]. В русском языке аналогичные предложения Пуля просвистела и Машина прогрохотала вдоль дороги также возможны и довольно часто встречаются. Первоначально, вероятно, данные предложения также возникли в результате изменения валентности глаголов, но затем по разным причинам они вошли в норму. Наличие аналогичных конструкций в сравниваемых языках может рассматриваться как косвенное свидетельство того, что ни в том, ни в другом языке они не являются ни периферийными, ни окказиональными.

Приведенные ранее низкочастотные примеры - совершенно иного рода. Не стали общеупотребительными He compelled me from the room, Your luggage shall be changed to another compartment. Данные фразы через много лет так и остались единичными примерами, не встречающимися ни в разговорной речи, ни в каких-то литературных произведениях. 
Рассматривая понятие «семантический шаблон конструкции», В. С. Храковский приходит к выводу, «что конкретный глагол как бы встраивается в готовый шаблон, который может даже перестроить семантику глагола, если она не соответствует семантике шаблона». По мнению В. С. Храковского, «в семантический шаблон могут встраиваться глаголы иной семантики, но, чтобы адаптироваться к данному шаблону, они должны изменить свою исходную семантику» [Храковский 2014: 36].

Данная норма, однако, относится в большей степени к русскому языку, чем, например к английскому. Если в русском языке наблюдается соответствие семантики глагола и синтаксиса (семантический детерминизм), то обнаруженные выше особенности английского языка свидетельствуют о том, что глагольное окружение не так уж сильно связано с его значением (см. Таблицы 3,4 ).

Возможность такого рассогласования, вероятно, ощущается англоязычными исследователями валентности, что нашло отражение в целом ряде высказываний. Неслучайно еще в середине прошлого века Ч. Хоккет высказывал мысль о том, что валентности могут быть нереализованными: «Valencies may be left unsaturated or have to reach into the non-speech context» [Hocket 1958: 252] ${ }^{9}$.

Бет Левин отмечает, что поведение глагола в большой степени (т. е. не полностью) детерминировано его значением: «The behavior of a verb, particularly with respect to the expression and interpretation of its arguments, is to a large extent determined by its meaning» [Levin 1993: 1] ${ }^{10}$.

Еще менее однозначным это соотношение кажется М. Хаспельмату и Т. Мюллер-Бардею: «Verb valency patterns are not completely predictable on the basis of the semantic roles they fulfill, thus it is quite common to consider valency as a syntactic notion» [Haspelmath, MüllerBardey 2004: 1131] ${ }^{11}$, что возвращает нас к синтаксической валентности - круг замыкается.

А Т. Лондаль приходит к полному отрицанию исходных положений теории, заявляя, что глаголы вообще не несут информации о числе

9 Валентности могут остаться незаполненными или выходить за рамки речевого контекста.

10 Поведение глагола, особенно в отношении выражения и интерпретации его аргументов, в значительной степени определяется его значением.

11 Валентностные модели глагола не полностью предсказуемы на основе реализуемых ими семантических ролей, поэтому довольно часто валентность рассматривается как понятие синтаксическое. 
и типе аргументов, с которыми они сочетаются: «〈...〉 verbs do not have any information about the number of arguments they take or what kind of arguments they take» [Lohndal 2014:148] ${ }^{12}$.

Сравнение высказываний, рассмотренных в начале и конце данного раздела, с фактическим материалом, приведенным выше, заставляет предполагать, что связь между семантикой и синтаксисом может быть разной в разных языках. Так, в английском языке связь между семантикой глагола и синтаксическим окружением слабее, чем в русском языке. Но это, однако, не означает, как могло бы показаться, что в английском языке - полный хаос. Синтаксические сдвиги охватывают лишь периферию, при этом четкость структурного сигнала в виде изменений валентности глаголов, возникающих под действием дискурсивного фактора, базируется на четком функционировании системы в основном корпусе.

Рассмотренные в настоящей статье изменения валентности глаголов, возникшие под действием дискурсивного фактора, регулярно встречаются в текстах английских и американских авторов, но в силу своей низкой индивидуальной повторяемости они не влияют на постоянные (исходные) валентностные характеристики английских глаголов. Обращение к словарям, а также к данным Британского национального корпуса и Корпуса современного американского языка подтверждает отсутствие возрастающей частоты использования рассмотренных в данной статье примеров с низкой частотой встречаемости.

\section{7. Валентность в предложении и тексте}

Изменения валентности английских глаголов, рассмотренные в настоящей статье, имеют важные причины. На примере семи текстов показаны механизмы перехода от нормы к отклонению от нормы - изменению глагольной валентности (синтаксическому сдвигу). Во всех приведенных случаях глаголы получили локативную валентность, которая не была им свойственна ранее. Рассмотренные глаголы относятся к разным семантическим группам. Глаголы по воле авторов литературных произведений регулярно подвергаются подобным изменениям, а сами изменения действуют не только по отношению

$12\langle\ldots\rangle$ глаголы не несут никакой информации о количестве аргументов, которые они принимают, или о том, какие аргументы они принимают. 
к глаголам, наделенным локативной валентностью, но, вероятно, охватывают и другие виды валентности.

В зависимой позиции при рассматриваемых глаголах реализуются синтаксемы и синтагмы с разной относительной частотой встречаемости. Низкочастотные варианты локативных синтаксем / синтагм в приглагольной позиции - это не что иное, как маркированные члены оппозиций.

Фонологический и синтаксический уровни языка довольно часто подвергаются сравнению. Сравнение дистрибутивных особенностей фонологических и синтаксических единиц приводит ряд авторов к общему выводу о том, что как в фонологии, так в синтаксисе немаркированные члены оппозиций обладают более широкими дистрибутивными возможностями, чем маркированные [Gundel et al. 1986: 121].

Аналогично тому, как на фонологическом уровне противопоставляются фонологически существенные признаки фонем, так и на синтаксическом уровне противопоставляются синсемантические признаки, образующие содержание синтаксем и синтагм. Поясним это на примере. Для наглядности вернемся к объединенной модели предложения (ОМП) уже упомянутой фразы из Оксфордского словаря, представляющей собой высокочастотное (типичное) употребление глагола live: I live in No 17 (ORD).

ОМП модель такого предложения будет иметь вид:

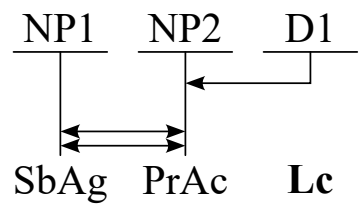

Сравним ее с ОМП моделью низкочастотного примера (17) I lived ... in all the capitals of Europe:

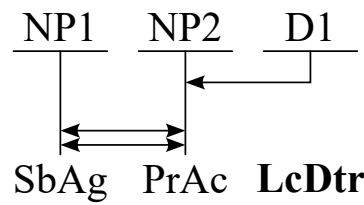

В примере (17) в содержании локативного элемента, выраженного синтагмой из ряда локативных, появляется дополнительный признак дистрибутивности (Dtr). Как замечает Б. А. Успенский, обычно 
немаркированный элемент характеризуется относительно более высокой частотой встречаемости, нежели соответствующий маркированный [Успенский 1970: 28]. Именно такую картину мы наблюдаем при сравнении валентностных моделей (BM), отражающих взаимодействие единиц лексического и синтаксического уровней языка, live [V + Lc] live in No 17 и live [V + Lc Dtr] live in all the capitals of Europe (пример (17)). В примере (17) в результате изменения валентности добавляется один синсемантический признак - дистрибутивности, появление которого в содержании локативной дистрибутивной синтагмы in all the capitals of Europe (обладающей низкой относительной частотой встречаемости) превращает ее в маркированный член оппозиции.

Рассмотренные изменения валентности глаголов (синтаксические сдвиги) не являются случайными, но возникли в результате действия дискурсивного фактора, выполняют дискурсивную функцию. Появление даже одного нового признака в содержании синтаксемы играет роль на следующем уровне анализа, придавая новый смысл предложению и тексту. Как отмечал Э. Бенвенист, между элементами одного уровня существуют дистрибутивные отношения, между элементами разных уровней - интегративные. «Единица признается различительной для данного уровня, если она может быть идентифицирована как «составная часть» единицы высшего уровня, интегрантом которого она становится» [Бенвенист 1974: 135].

В данной статье была сделана попытка определить причину / одну из причин изменения валентности английских глаголов, был описан механизм синтаксических сдвигов, в результате действия которого синсемантические признаки могут оказываться в роли «интегрантов».

\section{Список условных сокращений}

NP1 - подлежащее, ядерный предицируемый компонент (nuclear predicated); NP2 - сказуемое, ядерный предицирующий компонент (nuclear predicating); D1 первый зависимый компонент; D2 - второй зависимый компонент; D3 - третий зависимый компонент; V - глагол, ВМ - валентностная модель, ОМП - объединенная модель предложения.

Синсемантические признаки

$\mathrm{Abl}$ - аблативный; Ac - активный; Ag — агентивный; All - аллативный; $\mathrm{Dtr}$ - дистрибутивный; Lc — локативный; Ob - объектный; Øb - косвенно-объектный; $\mathrm{Pr}$ - процессуальный; $\mathrm{Sb}$ - субстанциальный. 


\section{Литература}

Андреев 2002 - С. Н. Андреев. Сопоставительный анализ текстов методом дискриминантного анализа // С. Н. Андреев (отв. ред.), Л. А. Кузьмин (ред.). Многомерный анализ в лингвистике. Смоленск: Смоленский гос. пед. ун-т, 2002. С. 27-36. Апресян 2006 - Ю. Д. Апресян. Типы соответствия семантических и синтаксических актантов // В. С. Храковский, С. Ю. Дмитренко, Н. М. Заика (ред.). Проблемы типологии и общей лингвистики. СПб.: Нестор-История, 2006. С. 15-27.

Бенвенист 1974 - Э. Бенвенист. Общая лингвистика. М.: Прогресс, 1974.

Гак 1996 - В. Г. Гак. Функционально-семантическое поле предикатов локализации // А. В. Бондарко (отв. ред.). Теория функциональной грамматики. Локативность. Бытийность. Посессивность. Обусловленность. СПб.: Наука, 1996. С. 6-26.

Гальперин 1981 - И. Р. Гальперин. Текст как объект лингвистического исследования. М.: Наука, 1981.

Гончарова, Шишкина 2005 - Е. А. Гончарова, И. П. Шишкина. Интерпретация текста. Немецкий язык. М.: Высшая школа, 2005.

Дресслер 1978 - В. Дресслер. Синтаксис текста // Т. М. Николаева (отв. ред.). Новое в зарубежной лингвистике. Вып. 8. М.: Прогресс, 1978. С. 111-137.

Золотова 1988 - Г. А. Золотова. Синтаксический словарь. Репертуар элементарных единиц русского синтаксиса. М.: Наука, 1988.

Касевич 1988 - В. Б. Касевич. Семантика. Синтаксис. Морфология. М.: Наука, 1988.

Касевич 2014 - В. Б. Касевич. Эллипсис и pro-drop // Acta Linguistica Petropolitana. Труды Института лингвистических исследований. 2014. Т. Х. Ч. 3. С. 315-323.

Кацнельсон 1948 - С. Д. Кацнельсон. О грамматической категории // Вестник ЛГУ. 1948. № 2. С. 114-134.

Колшанский $1984-$ Г. В. Колшанский. Коммуникативная функция и структура языка. М.: Наука, 1984.

Москальская 1981 - О. И. Москальская. Грамматика текста. М.: Высшая школа, 1981.

Мухин 1960 - А. М. Мухин. Метод структурного анализа синтаксических явлений // Тезисы докладов на совещании языковедов вузовских и академических учреждений по теоретическим вопросам синтаксиса / Отд-ние литературы и языка АН СССР. Филол. фак-т МГУ им. М. В. Ломоносова. М.: Б. и., 1960. С. 10 .

Мухин 1964 - А. М. Мухин. Функциональный анализ синтаксических элементов (на материале древнеанглийского языка). М.; Л.: Наука, 1964.

Мухин 1980 - А. М. Мухин. Синтаксемный анализ и проблема уровней языка. Л.: Наука, 1980.

Мухин 1987a - А. М. Мухин. Валентность и сочетаемость глаголов // Вопросы языкознания. 1987. № 6. С. 52-64.

Мухин $1987 \mathrm{~b}$ - А. М. Мухин. Системные отношения переходных глагольных лексем (на материале английского и русского языка). Л.: Наука, 1987. 
Мухин 1995 - А. М. Мухин. Вариантность синтаксических единиц. СПб.: Наука, 1995.

Мухин 1999a - А. М. Мухин. Структурный и функциональный синтаксис предложения // А. П. Сытов (отв. ред.). Лингвистические исследования 1998. СПб.: Институт лингвистических исследований РАН, 1999. С. 110-117.

Мухин1999b - А. М. Мухин. Функциональный синтаксис. СПб.: Наука, 1999.

Мухин 2004 - А. М. Мухин. Эксперимент и моделирование в лингвистике: Структурный синтаксис предложения. СПб.: Наука, 2004.

Плунгян 2008 - В. А. Плунгян. Дискурс и грамматика // В. А. Плунгян (отв. ред.), В. Ю. Гусев, А. Ю. Урманчиева (ред.). Исследования по теории грамматики. Вып. 4: Грамматические категории в дискурсе. М.: Гнозис, 2008. С. 7-31.

Плунгян 2011 - В. А. Плунгян. Введение в грамматическую семантику: грамматические значения и грамматические системы языков мира. М.: Российский государственный гуманитарный университет, 2011.

Сильницкий 1974 - Г. Г. Сильницкий. Семантические и валентностные классы английских каузативных глаголов: Автореф. дис. ... докт. филол. наук. Л.: АН СССР. Ленинградское отделение Института языкознания, 1974.

Тестелец 2001 - Я. Г. Тестелец. Введение в общий синтаксис. М.: Российский государственный гуманитарный университет, 2001.

Трубецкой 2000 - Н. С. Трубецкой. Основы фонологии. М.: Аспект-Прогресс, 2000.

Уздинская 1972 - Е. Н. Уздинская. Синтаксическая валентность глаголов современного английского языка: Автореф. дис. ... канд. филол. наук. Калинин: Калининский государственный университет, 1972.

Успенский 1970 - Б. А. Успенский. Проблема универсалий в языкознании // Б. А. Успенский (отв. ред.). Новое в лингвистике. Вып. 5 (Языковые универсалии). М.: Прогресс, 1970.

Успенский 1997 - Б. А. Успенский. Отношения подсистем в языке и связанные с ним универсалии // Б. А. Успенский. Избранные труды. Т. III. М.: Школа «Языки русской культуры», 1997. С. 34-57.

Храковский 1974 - В. С. Храковский. Пассивные конструкции // А. А. Холодович (отв. ред.). Типология пассивных конструкций. Л.: Наука, 1974. С. 5-45.

Храковский 2012 - В. С. Храковский. Вербоцентрический подход к конструкциям и (или) грамматика конструкций // Ю. Д. Апресян, И. М. Богуславский, Л. Ваннер, Л. Л. Иомдин, Я. Миличевич, М.-К. Л. Омм, А. Польгер (ред.). Смыслы, тексты и другие захватывающие сюжеты. Сб. статей в честь 80-летия Игоря Александровича Мельчука. М.: Языки славянских культур, 2012. С. 288-300.

Храковский 2014 - В. С. Храковский. Два подхода к анализу синтаксических конструкций: «лексико-семантический» и «конструкционный» (опыт сопоставления) // Acta Linguistica Petropolitana. Труды Института лингвистических исследований. 2014. Т. Х. Ч. 2. С. 25-40.

Шустова, Смирнова 2015 - С. В. Шустова, Е. А. Смирнова. Глагольная валентность как семантико-грамматическая категория. Вестник Пермского университета. 2015. Вып. 4. С. 21-29. 
Щерба 2002 - Л. В. Щерба. О второстепенных членах предложения // М. И Матусевич (ред.). Избранные работы по языкознанию и фонетике. СПб.: Изд-во Санкт-Петербургского государственного университета, 1958. С. 92-103.

Юликова 1996 - Н. М. Юликова. О дистрибутивных синтаксемах в английском языке // А. П. Сытов (отв. ред.). Лексикология, лексикография, грамматика. Лингвистические исследования 1995. СПб.: Институт лингвистических исследований РАН, 1996. С. 149-153.

Bod 1995 - R. Bod. Enriching Linguistics with Statistics: Performance Models of Natural Language. PhD thesis. Amsterdam: Institute for Logic, Language and Computation, Universiteit van Amsterdam, 1995. P. 146-162.

Busse 1974 - W. Busse. Klasse, Transitivität, Valenz. München: Finck, 1974.

Croft 2003 - W. Croft. Typology and Universals. Cambridge: Cambridge University Press, 2003.

Croft 2007 - W. Croft. Construction grammar // D. Geeraerts, H. Cuyckens (eds.). Handbook of Cognitive Linguistics. Oxford: Oxford University Press, 2007. P. 463508.

Cruse 1986 - D. A. Cruse. Lexical semantics (Cambridge textbooks in linguistics). Cambridge: Cambridge University Press, 1986.

Crystal 2008 - D. Crystal. A Dictionary of Linguistics and Phonetics. $6^{\text {th }}$ ed. Oxford: Blackwell, 2008.

Emons 1974 - R. Emons. Valenzen englischer Prädikatsverben. Tubingen: Max Niemeyer Verlag, 1974.

Goldberg 1995 - A. E. Goldberg. Constructions. A Construction Grammar Approach to Argument Structure. Chicago: The University of Chicago Press, 1995.

Goldberg 2006 - A. E. Goldberg. Constructions at work: The nature of generalization in language. Oxford: Oxford University Press, 2006.

Groot 1949 - A. W. de Groot. Structurele syntaxis. Den Haag: Servire, 1949.

Gundel et al. 1986 - J. K. Gundel, K. Houlihan, G. A. Sanders. Markedness and Distribution in Phonology and Syntax // F. R. Eckman, E. A. Moravcsik, J. R. Wirth (eds.). Markedness. Boston, MA: Springer, 1986.

Haspelmath, Müller-Bardey 2004 - M. Haspelmath, T. Müller-Bardey. Valency change // G. Booij, Ch. Lehmann, Jo. Mugdan (eds.). Morphology: A Handbook on Inflection and Word Formation. Vol. 2 (Handbücher zur Sprach und Kommunikationswissenschaft). Berlin: Mouton de Gruyter, 2004. P. 1130-1145.

Helbig 1992 - G. Helbig. Probleme der Valenz- und Kausustheorie. Tübingen: Max Niemeyer Verlag, 1992.

Herbst 1983 - T. Herbst. Untersuchungen zur Valenz englischer Adjektive und ihrer Nominalisierungen. Tübingen: Narr, 1983.

Herbst 1999 - T. Herbst. English Valency Structures: A First Sketch // Erfurt Electronic Studies in English. 1999. URL: http://webdoc.sub.gwdg.de/edoc/ia/eese/rahmen22. html (дата обращения 24.08.2020).

Herbst 2015 - T. Herbst. Why Construction Grammar Catches the Worm and Corpus Data can Drive you Crazy: Accounting for Idiomatic and Non-Idiomatic Idiomaticity // Journal of Social Sciences. 2015. Vol. 11. Iss. 3. P. 91-110. 
Herbst, Götz-Votteler 2007 - T. Herbst, K. Götz-Votteler (eds.). Valency: Theoretical, Descriptive and Cognitive Issues (Trends in Linguistics. Studies and Monographs 187). Berlin; New York: Mouton de Gruyter, 2007.

Hocket 1958 - Ch. F. Hocket. A Course in Modern Linguistics. New York: Macmillan, 1958.

Leech 1974 - G. Leech. Semantics. Harmondsworth, England: Penguin Books, 1974.

Levin 1993 - B. Levin. English Verb Classes and Alternations. A Preliminary investigation. Chicago: University of Chicago Press, 1993.

Lohndal 2014 - T. Lohndal. Phrase structure and argument structure: A case study of the syntax-semantics interface (Oxford Studies in Theoretical Linguistics 49). Oxford: Oxford University Press, 2014.

Lyons 1977 - J. Lyons. Semantics. Vol. 2. Cambridge: Cambridge University Press, 1977. Matthews 2007 - P. Matthews. The scope of valency in grammar // T. Herbst, K. Götz-Votteler (eds.). Valency: Theoretical, Descriptive and Cognitive Issues (Trends in Linguistics. Studies and Monographs 187). Berlin; New York: Mouton de Gruyter, 2007.

Przepiórkowski 2018 - A. Przepiórkowski. The origin of the valency metaphor in linguistics // Lingvisticæ Investigationes. Vol. 41. Iss. 1. P. 152-159.

Somers $1984-$ H. L. Somers. On the validity of the complement-adjunct distinction in valency grammar // Linguistics. 1984. Vol. 22. Iss. 4. P. 507-530.

Tesnière 1953 - L. Tesnière. Esquisse d'une Syntaxe Structurale. Paris : Klincksieck, 1953.

Tesnière 1959 — L. Tesnière. Éléments de Syntaxe Structurale. Paris : Klincksieck, 1959.

\section{Источники}

Голсуорси 2009 - Дж. Голсуорси. Лебединая песня. Пер. Е. А. Калашниковой. M.: ACT, 2009.

Фицджеральд $2014 \mathrm{~b}$ - Ф. С. Фицджеральд. Великий Гэтсби. Пер. С. Таска. М.: Азбука; Азбука-Аттикус, 2014.

Фицджеральд 2014a - Ф. С. Фицджеральд. Великий Гэтсби. Перевод Е. А. Калашниковой. СПб.: Лениздат, 2014.

BNC - British National Corpus. URL: https://www.english-corpora.org/bnc/ (дата обращения 24.08.2020).

Christie 1975 - A. Christie. Murder on the Orient Express. New York: Pocket Books, 1975.

COCA - Corpus of Contemporary American English. URL: https://www.english-corpora.org/coca/ (дата обращения 24.08.2020).

Dos Passos 1979 - J. Dos Passos. Nineteen Nineteen. New York: Signet Books, 1979.

Fitzgerald 1974 — F. S. Fitzgerald. The Great Gatsby. Harmondsworth: Penguin Books, 1974.

Fleming 1964 — I. Fleming. On Her Majesty's Secret Service. New York: Signet Books, 1964.

Fowles 1980 - J. Fowles. The Ebony Tower. Eliduc. The Enigma. Moscow: Progress, 1980. 
Galsworthy 1976 - J. Galsworthy. Swan Song. Moscow: Progress, 1976.

Gardner 1974 -E. S. Gardner. The Case of the Nervous Accomplice. New York: Pocket books, 1974.

Huxley 1979 - A. Huxley. Crome Yellow. Moscow: Progress, 1979.

ORD - M. Wheeler, B. Unbegaun, P. Falla, D. Thompson (eds.). Oxford Russian Dictionary. $4^{\text {th }}$ ed. Imprint: Oxford; New York: Oxford University Press, 2007.

Silverberg 1979 - R. Silverberg. The Artifact Business // Science Fiction. English and American Short Stories. Moscow: Progress, 1979. P. 159-170.

Steinbeck 1972 - J. Steinbeck. Of Mice and Men. New York: Bantam Books, 1972.

T. Herbst, D. Heath, I. Roe, D. Götz. A Valency Dictionary of English. A Corpus-Based Analysis of the Complementation Patterns Of English Verbs, Nouns and Adjectives (Topics in English Linguistics. Vol. 40). Berlin; New York: Mouton de Gruyter, 2004.

\section{References}

Andreyev 2002 - S. N. Andreyev. Sopostavitelnyy analiz tekstov metodom diskriminantnogo analiza [Benchmarking texts by the method of discriminant analysis]. S. N. Andreyev, L. A. Kuzmin (eds.). Mnogomernyy analiz v lingvistike [Multidimensional Analysis in Linguistics]. Smolensk: Smolensk State Pedagogical University Press, 2002. P. 27-36.

Apresyan 2006 - Yu. D. Apresyan. Tipy sootvetstviya semanticheskikh i sintaksicheskikh aktantov [Types of correspondence of semantic and syntactic actants]. V. S. Khrakovskiy, S. Yu. Dmitrenko, N. M. Zaika (eds.). Problemy tipologii i obshchey lingvistiki [Problems of typology and general linguistics]. St. Petersburg: Nestor-Istoriya, 2006. P. 15-27.

Benveniste 1974 - É. Benveniste. Obshchaya lingvistika. [Problems in general linguistics]. Moscow: Progress, 1974.

Bod 1995 - R. Bod. Enriching Linguistics with Statistics: Performance Models of Natural Language. PhD thesis. Amsterdam: Institute for Logic, Language and Computation, Universiteit van Amsterdam, 1995. P. 146-162.

Busse 1974 - W. Busse. Klasse, Transitivität, Valenz. München: Finck, 1974.

Croft 2003 - W. Croft. Typology and Universals. Cambridge: Cambridge University Press, 2003.

Croft 2007 - W. Croft. Construction grammar. D. Geeraerts, H. Cuyckens (eds.). Handbook of Cognitive Linguistics. Oxford: Oxford University Press, 2007. P. 463-508.

Cruse 1986 - D. A. Cruse. Lexical semantics (Cambridge textbooks in linguistics). Cambridge: Cambridge University Press, 1986.

Crystal 2008 - D. Crystal. A Dictionary of Linguistics and Phonetics. $6^{\text {th }}$ ed. Oxford: Blackwell, 2008.

Dressler 1978 - W. Dressler. Sintaksis teksta [Textsyntax]. T. M. Nikolayeva (ed.) Novoe $v$ zarubezhnoy lingvistike [New in foreign linguistics]. Iss. 8. Moscow: Progress, 1978. P. 111-137. 
Emons 1974 — R. Emons. Valenzen englischer Prädikatsverben. Tubingen: Max Niemeyer Verlag, 1974.

Gak 1996 - V. G. Gak. Funktsionalno-semanticheskoye pole predikatov lokalizatsii [Functional-semantic field of localization predicates]. A. V. Bondarko (ed.). Teoriya funktsionalnoy grammatiki. Lokativnost. Bytiynost. Posessivnost. Obuslovlennost [The theory of functional grammar. Lokativity. Beingness. Possession. Conditionality]. St. Petersburg: Nauka, 1996. P. 6-26.

Galperin 1981 - I. R. Galperin. Tekst kak obyekt lingvisticheskogo issledovaniya [Text as an object of linguistic study]. Moscow: Nauka, 1981.

Goldberg 1995 - A. E. Goldberg. Constructions. A Construction Grammar Approach to Argument Structure. Chicago: The University of Chicago Press, 1995.

Goldberg 2006 - A. E. Goldberg. Constructions at work: The nature of generalization in language. Oxford: Oxford University Press, 2006.

Goncharova, Shishkina 2005 - E. A. Goncharova, I. P. Shishkina. Interpretatsiya teksta. Nemetskiy yazyk [Interpreting the text. German]. Moscow: Vysshaya shkola, 2005.

Groot 1949 - A. W. de Groot. Structurele syntaxis. Den Haag: Servire, 1949.

Gundel et al. 1986 - J. K. Gundel, K. Houlihan, G. A. Sanders. Markedness and Distribution in Phonology and Syntax. F. R. Eckman, E. A. Moravcsik, J. R. Wirth (eds.). Markedness. Boston, MA: Springer, 1986.

Haspelmath, Müller-Bardey 2004 - M. Haspelmath, T. Müller-Bardey. Valency change. G. Booij, Ch. Lehmann, Jo. Mugdan (eds.). Morphology: A Handbook on Inflection and Word Formation. Vol. 2 (Handbücher zur Sprach und Kommunikationswissenschaft). Berlin: Mouton de Gruyter, 2004. P. 1130-1145.

Helbig 1992 — G. Helbig. Probleme der Valenz- und Kausustheorie. Tübingen: Max Niemeyer Verlag, 1992.

Herbst 1983 - T. Herbst. Untersuchungen zur Valenz englischer Adjektive und ihrer Nominalisierungen. Tübingen: Narr, 1983.

Herbst 1999 - T. Herbst. English Valency Structures: A First Sketch. Erfurt Electronic Studies in English. 1999. Available at: http:/webdoc.sub.gwdg.de/edoc/ia/eese/ rahmen22.html (accessed on 24.08.2020).

Herbst 2015 - T. Herbst. Why Construction Grammar Catches the Worm and Corpus Data can Drive you Crazy: Accounting for Idiomatic and Non-Idiomatic Idiomaticity. Journal of Social Sciences. 2015. Vol. 11. Iss. 3. P. 91-110.

Herbst, Götz-Votteler 2007 - T. Herbst, K. Götz-Votteler (eds.). Valency: Theoretical, Descriptive and Cognitive Issues (Trends in Linguistics. Studies and Monographs 187). Berlin, New York: Mouton de Gruyter, 2007.

Hocket 1958 - Ch. F. Hocket. A Course in Modern Linguistics. New York: Macmillan, 1958.

Kasevich 1988 - V. B. Kasevich. Semantika. Sintaksis. Morfologiya. [Semantics. Syntax. Morphology]. Moscow: Nauka, 1988.

Kasevich 2014 - V. B. Kasevich. Yellipsis i pro-drop [Ellipsis and pro-drop]. Acta Linguistica Petropolitana. Trudy Instituta lingvisticheskikh issledovaniy. 2014. Vol. X. Pt. 3. P. 315-323. 
Katsnelson 1948 - S. D. Katsnelson. O grammaticheskoy kategorii [On the grammatical category]. Vestnik Leningradskogo gosudarstvennogo universiteta. 1948. No. 2. P. 114-134.

Khrakovskiy 1974 - V. S. Khrakovskiy. Passivnyye konstruktsii [Passive constructions]. A. A. Kholodovich (ed.). Tipologiya passivnykh konstruktsiy [Typology of passive contructions]. Leningrad: Nauka, 1974. P. 5-45.

Khrakovskiy 2012 - V. S. Khrakovskiy. Verbotsentricheskiy podkhod k konstruktsiyam i (ili) grammatika konstruktsiy [Verbotcentric approach to structures and (or) the grammar of constructions]. Yu. D. Apresyan, I. M. Boguslavskiy, L. Vanner, L. L. Iomdin, Ya. Milichevich, M.-K. L. Omm, A. Polger (eds.). Smysly, teksty i drugiye zakhvatyvayushchiye syuzhety. Sbornik statey $v$ chest 80-letiya Igorya Aleksandrovicha Melchuka [Senses, texts and other captivating plots. Collection of articles in honor of the $80^{\text {th }}$ anniversary of Igor Alexandrovich Melchuk]. Moscow: Yazyki slavyanskikh kultur, 2012. P. 288-300.

Khrakovskiy 2014 - V. S. Khrakovskiy. Dva podkhoda k analizu sintaksicheskikh konstruktsiy: «leksiko-semanticheskiy» i «konstruktsionnyy» (opyt sopostavleniya) [Two approaches to the analysis of syntactic constructions: "lexical semantic" and "constructional" (an essay in comparison)]. Acta Linguistica Petropolitana. Trudy Instituta lingvisticheskikh issledovaniy. 2014. Vol. X. Pt. 2. P. 25-40.

Kolshanskiy 1984 - G. V. Kolshanskiy. Kommunikativnaya funktsiya i struktura yazyka [Communicative function and the structure of the language]. Moscow: Nauka, 1984 Leech 1974 - G. Leech. Semantics. Harmondsworth, England: Penguin Books, 1974.

Levin 1993 - B. Levin. English Verb Classes and Alternations. A Preliminary Investigation. Chicago: University of Chicago Press, 1993.

Lohndal 2014 — T. Lohndal. Phrase structure and argument structure: A case study of the syntax-semantics interface (Oxford Studies in Theoretical Linguistics 49). Oxford: Oxford University Press, 2014.

Lyons 1977 - J. Lyons. Semantics. Vol. 2. Cambridge: Cambridge University Press, 1977. Matthews 2007 - P. Matthews. The scope of valency in grammar. T. Herbst, K. GötzVotteler (eds.). Valency: Theoretical, Descriptive and Cognitive Issues (Trends in Linguistics. Studies and Monographs 187). Berlin; New York: Mouton de Gruyter, 2007.

Moskalskaya 1981 - O. I. Moskalskaya. Grammatika teksta [Text Grammar]. Moscow: Vysshaya shkola, 1981.

Mukhin 1960 - A. M. Mukhin. Metod strukturnogo analiza sintaksicheskikh yavleniy [The method of structural analysis of syntactical phenomena]. Tezisy dokladov na soveshchanii yazykovedov vuzovskikh i akademicheskikh uchrezhdeniy po teoreticheskim voprosam sintaksisa [Abstracts of reports at the meeting of linguists of university and academic institutions on theoretical issues of syntax]. Moscow: S. n., 1960. P. 10.

Mukhin 1964 - A. M. Mukhin. Funktsionalnyy analiz sintaksicheskikh yelementov (na materiale drevneangliyskogo yazyka) [Functional analysis of syntactic elements (on the material of the Old English language)]. Moscow; Leningrad: Nauka, 1964.

Mukhin 1980 - A. M. Mukhin. Sintaksemnyy analiz i problema urovney yazyka [Syntaxeme analysis and the problem of language levels]. Leningrad: Nauka, 1980. 
Mukhin 1987a - A. M. Mukhin. Valentnost i sochetayemost glagolov [Valency and compatibility of verbs]. Voprosy yazykoznaniya. 1987. No. 6. P. 52-64.

Mukhin 1987b - A. M. Mukhin. Sistemnyye otnosheniya perekhodnykh glagolnykh leksem (Na materiale angliyskogo i russkogo yazyka) [System relationships of transitive verbal lexemes (On the material of English and Russian)]. Leningrad: Nauka, 1987.

Mukhin 1995 - A. M. Mukhin. Variantnost sintaksicheskikh yedinits [Variation of syntactic units]. St. Petersburg: Nauka, 1980.

Mukhin 1999a - A. M. Mukhin. Strukturnyy i funktsionalnyy sintaksis predlozheniya [Structural and functional sentence syntax]. Lingvisticheskiye issledovaniya 1998 [Linguistic research 1998]. St. Petersburg: Institute for Linguistic Studies, 1999. P. 110-117.

Mukhin 1999b - A. M. Mukhin. Funktsionalnyy sintaksis [Functional syntax]. St. Petersburg: Nauka, 1999.

Mukhin 2004 - A. M. Mukhin. Yeksperiment i modelirovaniye v lingvistike: Strukturnyy sintaksis predlozheniya [Experiment and modeling in linguistics: Structural syntax of a sentence]. St. Petersburg: Nauka, 2004.

Plungyan 2008 - V. A. Plungyan. Diskurs i grammatika [Discourse and grammar]. V. A. Plungyan, V. Yu. Gusev, A. Yu. Urmanchiyeva (eds.). Issledovaniya po teorii grammatiki. Vyp. 4: Grammaticheskiye kategorii v diskurse [Reseach in the theory of grammar. Iss. 4. Grammatical categories in discourse]. Moscow: Gnozis, 2008. P. 7-31.

Plungyan 2011 - V. A. Plungyan. Vvedeniye v grammaticheskuyu semantiku: grammaticheskiye znacheniya i grammaticheskiye sistemy yazykov mira [Introduction into grammatical semantics: grammatical meanings and grammatical systems of the languages of the world.] Moscow: Russian State University for the Humanities Press, 2011.

Przepiórkowski 2018 - A. Przepiórkowski. The origin of the valency metaphor in linguistics. Lingvistica Investigationes. 2018. Vol. 41. Iss. 1. P. 152-159.

Shcherba 2002 - L. V. Shcherba. O vtorostepennykh chlenakh predlozheniya [On the secondary parts of speech]. M. I. Matusevich (ed.). Izbrannyye raboty po yazykoznaniyu i fonetike [Selected papers on linguistics and phonetics]. St. Petersburg State University Publishing House, 1958. P. 92-103.

Shustova, Smirnova 2015 - S. V. Shustova, E. A. Smirnova. Glagolnaya valentnost kak semantiko-grammaticheskaya kategoriya [Verb valence as semantic-grammar category]. Vestnik Permskogo universiteta. 2015. Iss. 4. P. 2-29.

Silnitskiy 1974 - G. G. Silnitskiy. Semanticheskiye $i$ valentnostnyye klassy angliyskikh kauzativnykh glagolov [Semantic and Valence classes of English causative verbs]. Author's abstract of phil. doct. diss. Leningrad: Institute of Linguistics of the Academy of Sciences of USSR, 1974.

Somers $1984-$ H. L. Somers. On the validity of the complement-adjunct distinction in valency grammar. Linguistics. 1984. Vol. 22. Iss. 4. P. 507-530.

Tesnière 1953 - L. Tesnière. Esquisse d'une Syntaxe Structurale. Paris : Klincksieck, 1953. Tesnière 1959 — L. Tesnière. Éléments de Syntaxe Structurale. Paris : Klincksieck, 1959. 
Testelets 2001 - Ya. G. Testelets. Vvedeniye v obshchiy sintaksis. [Introduction into general syntax]. Moscow: Russian State University for the Humanities Press, 2001.

Trubetzkoy 2000 - N. S. Trubetzkoy. Osnovy fonologii [Principles of Phonology]. Moscow: Aspekt-Progress, 2000.

Uspenskiy 1970 - B. A. Uspenskiy. Problema universaliy v yazykoznanii [The problem of universals in linguistics]. B. A. Uspenskiy (ed.). Novoye v lingvistike. Vyp. 5. (Yazykovyye universalii) [New in linguistics. Iss. 5. (Language universals)]. Moscow: Progress, 1970.

Uspenskiy 1997- B. A. Uspenskiy. Otnosheniya podsistem v yazyke i svyazannyye s nim universalii [The relationship of the subsystems in the language and the associated universals]. B. A. Uspenskiy. Izbrannyye trudy [Selected works]. Vol. 3. Moscow: Shkola "Yazyki russkoy kultury", 1997. P. 34-57.

Uzdinskaya 1972 - E. N. Uzdinskaya. Sintaksicheskaya valentnost glagolov sovremennogo angliyskogo yazyka [Syntactic valency of modern English verbs]: Author's abstract of phil. cand. diss. Kalinin: Kalinin State University, 1972.

Yulikova 1996 - N. M. Yulikova. O distributivnykh sintaksemakh v angliyskom yazyke [Distributive syntaxemes in English]. A. P. Sytov (ed.). Leksikologiya, leksikografiya, grammatika. Lingvisticheskiye issledovaniya 1995 [Lexicology, lexicography, grammar. Linguistic research 1995]. St. Petersburg: Institute for Linguistic Studies, 1996. P. 149-153.

Zolotova 1988 - G. A. Zolotova. Sintaksicheskiy slovar slovar. Repertuar yelementarnykh yedinits russkogo sintaksisa [The syntaxeme dictionary. The repertoire of elementary units of Russian syntax]. Moscow: Nauka, 1988.

\section{Sources}

BNC - British National Corpus. Available at: https:/www.english-corpora.org/bnc/ (accessed on 24.08.2020).

Christie 1975 - A. Christie. Murder on the Orient Express. New York: Pocket Books, 1975.

COCA - Corpus of Contemporary American English. Available at: https://www.english-corpora.org/coca/ (accessed on 24.08.2020).

Dos Passos 1979 - J. Dos Passos. Nineteen Nineteen. New York: Signet Books, 1979.

Fitzgerald 1974 - F. S. Fitzgerald. The Great Gatsby. Harmondsworth: Penguin Books, 1974.

Fitzgerald 2014b - F. S. Fitzgerald. Velikiy Getsbi. Perevod S. Taska [The Great Gatsby. Translation by S. Tusk]. Moscow: Azbuka, Azbuka-Attikus, 2014.

Fitzgerald 2014a - F. S. Fitzgerald. Velikiy Getsbi. Perevod E. A. Kalashnikovoy [The Great Gatsby. Translation by E. A. Kalashnikova]. St. Petersburg: Lenizdat, 2014.

Fleming 1964 - I. Fleming. On Her Majesty's Secret Service. New York: Signet Books, 1964.

Fowles 1980 - J. Fowles. The Ebony Tower. Eliduc. The Enigma. Moscow: Progress, 1980. 
Galsworthy 1976 - J. Galsworthy. Swan Song. Moscow: Progress, 1976.

Galsworthy 2009 - J. Galsworthy. Lebedinaya pesnya. Perevod E. A. Kalashnikovoy [Swan song. Translated by E. A. Kalashnikova]. Moscow: AST, 2009.

Gardner 1974 — E. S. Gardner. The Case of the Nervous Accomplice. New York: Pocket books, 1974.

Huxley1979 - A. Huxley. Crome Yellow. Moscow: Progress, 1979.

ORD - M. Wheeler, B. Unbegaun, P. Falla, D. Thompson (eds.). Oxford Russian Dictionary. $4^{\text {th }}$ ed. Imprint: Oxford; New York: Oxford University Press, 2007.

Silverberg 1979 - R. Silverberg. The Artifact Business. Science Fiction. English and American Short Stories. Moscow: Progress, 1979. P. 159-170.

Steinbeck 1972 - J. Steinbeck. Of Mice and Men. New York: Bantam Books, 1972.

T. Herbst, D. Heath, I. Roe, D. Götz. A Valency Dictionary of English. A Corpus-Based Analysis of the Complementation Patterns Of English Verbs, Nouns and Adjectives (Topics in English Linguistics. Vol. 40). Berlin; New York: De Gruyter Mouton, 2004. Available at: https://www.english-corpora.org/bnc/ (accessed on 24.08.2020). 


\section{Сведения об авторах}

Афанасьева Анастасия Алексеевна - старший преподаватель, Петрозаводский государственный университет, Петрозаводск. Электронная почта: anastasia20085@mail.ru.

Буркова Светлана Игоревна - кандидат филологических наук, доцент, Новосибирский государственный технический университет. Электронная почта: burkova_s@mail.ru.

Власов Сергей Васильевич - кандидат филологических наук, доцент кафедры французского языка факультета иностранных языков Санкт-Петербургского государственного университета. Электронная почта: s.vlasov@spbu.ru.

Волков Сергей Святославович - кандидат филологических наук, доцент, заведующий отделом «Словарь языка М. В. Ломоносова» Института лингвистических исследований РАН, Санкт-Петербург. Электронная почта: sergejvolkov2006@yandex.ru.

Гусев Валентин Юрьевич - кандидат филологических наук, старший научный сотрудник, Институт языкознания РАН, Москва. Электронная почта: vgoussev@yandex.ru.

Егорова Анастасия Дмитриевна - аспирант, Московский государственный университет имени М. В. Ломоносова, Москва. Электронная почта: astya28@mail.ru.

Зайщева Нина Григорьевна - доктор филологических наук, ведущий научный сотрудник, Институт языка, литературы и истории КарНЦ РАН, ФИЦ «Карельский научный центр РАН», Петрозаводск. Электронная почта: zng@ro.ru.

Кашкин Егор Владимирович - кандидат филологических наук, научный сотрудник Института русского языка им. В. В. Виноградова РАН, Москва; старший научный сотрудник Томского государственного университета. Электронная почта: egorka1988@gmail.com. 
Ким Чондо - докторант, Хельсинкский университет, Хельсинки, Финляндия. Электронная почта: jeongdo.kim@helsinki.fi.

Колпакова Наталья Николаевна - кандидат филологических наук, доцент, заведующий кафедрой финно-угорской филологии, Санкт-Петербургский государственный университет, Санкт-Петербург. Электронная почта: nnkolp@mail.ru.

Коркина Татьяна Дмитриевна - кандидат филологических наук, научный сотрудник Отдела русской исторической лексикологии и лексикографии, группы «Словарь русского языка XVIII века»; Институт лингвистических исследований РАН, Санкт-Петербург. Электронная почта: TDK2006@bk.ru

Коряков Юрий Борисович - кандидат филологических наук, старший научный сотрудник, Институт языкознания РАН, Москва. Электронная почта: ybkoryakov@gmail.com.

Кузнецова Наталья Викторовна - кандидат филологических наук, старший научный сотрудник, Институт лингвистических исследований РАН, Санкт-Петербург. Электронная почта: nkuzn@yandex.ru.

Кузьмин Денис Викторович - кандидат филологических наук, старший научный сотрудник, Институт языка, литературы и истории КарНЦ РАН, ФИЦ «Карельский научный центр РАН», Петрозаводск. Электронная почта: kusmiccu@hotmail.com.

Макарова Анна Андреевна - кандидат филологических наук, старший научный сотрудник Топонимической лаборатории, Уральский федеральный университет, Екатеринбург; старший научный сотрудник, Институт русского языка им. В. В. Виноградова РАН, Москва. Электронная почта: toponimist@yandex.ru.

Маркус Елена Борисовна - кандидат филологических наук, старший научный сотрудник, Институт языкознания РАН, Москва; старший научный сотрудник, Тартуский университет, Тарту, Эстония. Электронная почта: helenmarkus@yahoo.com.

Московкин Леонид Викторович - доктор педагогических наук, профессор кафедры русского языка как иностранного и методики его преподавания филологического факультета Санкт-Петербургского государственного университета. Электронная почта: 1.moskovkin@, spbu.ru. 
Муллонен Ирма Ивановна - член-корреспондент РАН, доктор филологических наук, профессор, главный научный сотрудник, Институт языка, литературы и истории Карельского научного центра РАН, ФИЦ «Карельский научный центр РАН», Петрозаводск. Электронная почта: mullonen@sampo.ru.

Муравьев Никита Алексеевич - кандидат филологических наук, старший преподаватель, Национальный исследовательский университет «Высшая школа экономики», Москва. Электронная почта: nikita. muraviev@gmail.com.

Муслимов Мехмет Закирович - кандидат филологических наук, старший научный сотрудник, Институт лингвистических исследований РАН, Санкт-Петербург. Электронная почта: mehmet@yandex.ru.

Некрасова Галина Александровна - кандидат филологических наук, доцент, ведущий научный сотрудник, Институт языка, литературы и истории Коми научного центра УрО РАН, Сыктывкар. Электронная почта: komilang@gmail.com.

Певнов Александр Михайлович - доктор филологических наук, главный научный сотрудник; Институт лингвистических исследований РАН, Санкт-Петербург. Электронная почта: pevnov@gmail.com.

Плешак Полина Сергеевна - аспирант, кафедра лингвистики в универитете Мэриленда, Колледж Парк, США. Электронная почта: ppleshak@umd.edu.

Рожанский Федор Иванович - кандидат филологических наук, старший научный сотрудник, Институт лингвистических исследований РАН, Санкт-Петербург; старший научный сотрудник, Тартуский университет, Тарту, Эстония. Электронная почта: handarey@yandex.ru.

Сердобольская Наталья Вадимовна - кандидат филологических наук, старший научный сотрудник, Институт языкознания РАН, Москва; преподаватель, Государственный институт русского языка им. А. С. Пушкина, Москва. Электронная почта: serdobolskaya@gmail.com.

Татевосов Сергей Георгиевич - доктор филологических наук, профессор, заведующий кафедрой теоретической и прикладной лингвистики филологического факультета; Московский государственный университет им. М. В. Ломоносова. Электронная почта: tatevosov@ gmail.com. 
Урманчиева Анна Юрьевна - кандидат филологических наук, старший научный сотрудник, Институт лингвистических исследований РАН, Санкт-Петербург. Электронная почта: urmanna@yandex.ru.

Хилханова Эржен Владимировна - доктор филологических наук, ведущий научный сотрудник Научно-исследовательского центра по национально-языковым отношениям Института языкознания РАН, Москва; ведущий научный сотрудник многопрофильного центра экспертиз Бурятского государственного университета им. Д. Банзарова. Электронная почта: erzhen.khilkhanova@iling-ran.ru.

Холопайнен Сампса - докторант, Хельсинкский университет, Хельсинки, Финляндия. Электронная почта: sampsa.holopainen@helsinki.fi.

Шарихина Миляуша Габдрауфовна - кандидат филологических наук, научный сотрудник отдела «Словарь языка М. В. Ломоносова» Института лингвистических исследований РАН, Санкт-Петербург. Электронная почта: justmilya@yandex.ru.

Шлуинский Андрей Болеславович - кандидат филологических наук, заместитель директора Института языкознания РАН, Москва; член научного коллектива проекта по гранту РНФ № 16-18-02081, выполнявшегося на филологическом факультете, Московский государственный университет им. М. В. Ломоносова. Электронная почта: ashl@yandex.ru.

Юликова Наталия Михайловна - кандидат филологических наук, доцент кафедры иностранных языков гуманитарного факультета Санкт-Петербургского государственного университета аэрокосмического приборостроения (ГУАП), Санкт-Петербург. Электронная почта: n-yulikova@mail.ru. 


\section{Contributors}

Afanasyeva Anastasiya A. - Assistant Professor, Department of Baltic and Finnish Studies, Petrozavodsk State University, Petrozavodsk. E-mail: anastasia20085@mail.ru.

Burkova Svetlana I. - Cand. Sc. in Philology, Associate Professor, Department of Philology, Novosibirsk State Technical University. E-mail: burkova_s@mail.ru.

Egorova Anastasiya D. - Postgraduate Student, Department of Theoretical and Applied Linguistics, Lomonosov Moscow State University; Moscow.E-mail: astya28@mail.ru

Gusev Valentin Yu. - Cand. Sc. in Philology, Senior Researcher, Institute of Linguistics, Russian Academy of Sciences, Moscow. E-mail: vgoussev@yandex.ru.

Holopainen Sampsa - MA, doctoral student, University of Helsinki, Finland. E-mail: sampsa.holopainen@helsinki.fi.

Kashkin Egor V. - Cand. Sc. in Philology, Researcher, V. V. Vinogradov Russian Language Institute, Russian Academy of Sciences, Moscow. E-mail: egorka1988@gmail.com.

Khilkhanova Erzhen Vl. - Doct. Sc. in Philology, Leading Researcher of the Research Center on Language and Ethnic Relations, Institute of Linguistics, Russian Academy of Sciences, Moscow; Leading Researcher of the Multidisciplinary Expertise Center, D. Banzarov Buryat State University. E-mail: erzhen.khilkhanova@iling-ran.ru

Kim Jeongdo - MA, Doctoral Student, University of Helsinki, Finland. E-Mail: jeongdo.kim@helsinki.fi.

Kolpakova Natalya N. - Cand. Sc. in Philology, Associate Professor, Head of Department of Finno-Ugric Phililogy, St. Petersburg State University, St. Petersburg. E-mail: nnkolp@mail.ru.

Korkina Tatiana D. - Cand. Sc. in Philology, Researcher of the Department of Russian historical Lexicology and Lexicography, Institute for 
Linguistic Studies, Russian Academy of Sciences, St. Petersburg. E-mail: TDK2006@bk.ru

Koryakov Yury B. - Cand. Sc. in Philology, Senior Researcher, Institute of Linguistics, Russian Academy of Sciences, Moscow. E-mail: ybkoryakov@gmail.com.

Kuzmin Denis V. - Cand. Sc. in Philology, Senior Researcher, Institute of Language, Literature and History, Karelian Scientific Center, Russian Academy of Sciences, Petrozavodsk. E-mail: kusmiccu@hotmail.com.

Kuznetsova Natalia V. - Cand. Sc. in Philology, Senior Researcher, Institute for Linguistic Studies, Russian Academy of Sciences, St. Petersburg. E-mail:nkuzn@yandex.ru.

Makarova Anna A. - Cand. Sc. in Philology, Senior Researcher of Toponimic Laboratory, Ural Federal University, Yekaterinburg; Senior Researcher, V. V. Vinogradov Russian Language Institute, Russian Academy of Sciences, Moscow. E-mail: toponimist@yandex.ru.

Markus Elena B. - Cand. Sc. in Philology, Senior Researcher, Institute of Linguistics, Russian Academy of Sciences, Moscow; Senior Researcher, Tartu University, Tartu, Estonia. E-mail: helenmarkus@yahoo.com.

Moskovkin Leonid V. - Doct. Sc. in Philology, professor of the Department of Russian as a Foreign Language and its teaching methods of the Philological Faculty, St. Petersburg State University. E-mail: 1.moskovkin@ spbu.ru.

Mullonen Irma I. - Corresponding Member of the Russian Academy of Sciences, Dr. Sc. in Philology, Full Professor, Chief Researcher, Institute of Language, Literature and History, Karelian Scientific Center, Russian Academy of Sciences, Petrozavodsk. E-mail: mullonen@sampo.ru.

Muravyev Nikita A. - Cand. Sc. in Philology, Assistant Professor, National Research University Higher School of Economics, Moscow. E-mail: nikita.muraviev@gmail.com

Muslimov Mehmet Z. - Cand. Sc. in Philology, Senior Researcher, Institute for Linguistic Studies, Russian Academy of Sciences, St. Petersburg. E-mail:mehmet@yandex.ru.

Nekrasova Galina A. - Cand. Sc. in Philology, Associate Professor, Leading Researcher, Institute of Language, Literature and History of the Komi 
Scientific Center, Ural Branch of the Russian Academy of Sciences, Syktyvkar. E-mail: komilang@gmail.com.

Pevnov Aleksandr M. - Dr. Sc. in Philology, Chief Researcher of the Institute for Linguistic Studies, Russian Academy of Sciences, St. Petersburg. E-mail:pevnov@gmail.com.

Pleshak Polina S. - Postgraduate Student, University of Maryland, College Park, USA. E-mail: ppleshak@umd.edu.

Rozhansky Fedor I. - Cand. Sc. in Philology, Senior Researcher, Institute for Linguistic Studies, Russian Academy of Sciences, St. Petersburg; Senior Researcher, Tartu University, Tartu, Estonia. E-mail: handarey@, yandex.ru.

Serdobolskaya Natalya V. - Cand. Sc. in Philology, Senior Researcher, Institute of Linguistics, Russian Academy of Sciences, Moscow; Lecturer, Pushkin State Russian Language Institute, Moscow. E-mail: serdobolskaya@gmail.com.

Sharikhina Milyausha G. - Cand. Sc. in Philology, Researcher of the Institute for Linguistic Studies, Russian Academy of Sciences, St. Petersburg. E-mail: justmilya@yandex.ru.

Shluinsky Andrei B. - Cand. Sc. in Philology, Deputy Director, Institute of Linguistics, Russian Academy of Sciences, Moscow; member of the research team of the project supported by Russian Science Foundation (grant No. 16-18-02081), carried out at the Faculty of Philology, Lomonosov Moscow State University; Moscow. E-mail: ash1@yandex.ru.

Tatevosov Sergei G. - Dr. Sc. in Philology, Full Professor, Head of Department of Theoretical and Applied Linguistics, Lomonosov Moscow State University; Moscow. E-mail: tatevosov@gmail.com.

Urmanchieva Anna Yu. - Cand. Sc. in Philology, Senior Researcher, Institute for Linguistic Studies, Russian Academy of Sciences, St. Petersburg. E-mail: urmanna@yandex.ru.

Vlasov Sergey V. - Cand. Sc. in Philology, Associate Professor of French Language Department, Faculty of Foreign Languages, St. Petersburg State University. E-mail: s.vlasov@spbu.ru. 
Volkov Sergey S. - Cand. Sc. in Philology, Associate Professor, Head of the Department of the Dictionary of the of M. V. Lomonosov's idiolect, Institute for Linguistic Studies, Russian Academy of Sciences, St. Petersburg. E-mail: sergejvolkov2006@yandex.ru.

Yulikova Natalia M. - Cand. Sc. in Philology, Docent of the Department of Foreign Languages, Faculty of Humanities, St. Petersburg State University of Aerospace Instrumentation (SUAI), St. Petersburg. E-mail: n-yulikova@mail.ru.

Zaitseva Nina G. - Dr. Sc. in Philology, Leading Researcher, Institute of Language, Literature and History, Karelian Scientific Center, Russian Academy of Sciences, Petrozavodsk. E-mail: zng@ro.ru. 


\section{Этические требования}

\section{1. Этика научных публикаций}

Международный журнал «Acta Linguistica Petropolitana. Труды Института лингвистических исследований» - научное периодическое издание, не имеющее политической, идеологической, религиозной или иной направленности; деятельность журнала связана исключительно с академической наукой. Все участники редакционного и издательского процесса (авторы, рецензенты, редакторы и члены редакционной коллегии) обязаны учитывать это и следовать указанным ниже этическим стандартам, основанным на рекомендациях Комитета по этике научных публикаций (СOPE).

\section{2. Авторство работы}

Автор гарантирует, что рукопись, подаваемая для публикации в журнале «Acta Linguistica Petropolitana. Труды Института лингвистических исследований» является оригинальным текстом, и подтверждает свои исключительные авторские права на эту публикацию. В случае совместной работы материалы для публикации может подать один из авторов, указав всех соавторов и предоставив необходимую и достоверную информацию о них.

Автору следует указать организации и учреждения, предоставившие финансовую поддержку или оказавшие содействие в создании рукописи, при наличии таковых.

Автор обязан в полном объеме указать все источники информации, используемые в работе, включая источники (опубликованные и неопубликованные), исследовательскую литературу (в том числе собственные ранее опубликованные работы) и данные информантов (при публикации результатов полевых исследований). Автор обязан соответствующим образом оформить ссылки на использованные в работе 
труды или утверждения других авторов. Любая форма плагиата неприемлема. Автоплагиат, т. е. попытка повторной публикации собственной ранее опубликованной работы без существенных изменений, также неприемлем. Подача рукописи работы одновременно более чем в один журнал для публикации недопустима. Научный архив автора, на котором основано исследование и работа, должен быть при необходимости доступен к рассмотрению на период не менее двух лет.

В случае нарушения любого из перечисленных выше правил редакционная коллегия может отказать в публикации рукописи в любое время, в том числе на этапе предварительного рассмотрения, без привлечения рецензентов, а также отказать автору в публикации его работ в течение трех последующих лет.

Внесение автором любых изменений в текст, прошедший этап рецензирования и принятый к публикации, допустимо только с согласия редакционной коллегии. Автор может отозвать принятую рукопись до того, как материалы будут отправлены для редактирования. В случае если автор отзывает рукопись по завершении процесса редактирования, редакционная коллегия вправе отказать в публикации его работ в течение трех последующих лет.

Автор обязуется не размещать в открытом доступе любые принятые к публикации, но еще не опубликованные материалы. В случае нарушения этого правила редакционная коллегия вправе снять рукопись с публикации, а также отказать автору в публикации его работ в течение трех последующих лет.

\section{3. Авторское право и открытый доступ}

В соответствии с Будапештской инициативой по открытому доступу к научным публикациям (Budapest Open Access Initiative, BOAI) журнал «Acta Linguistica Petropolitana. Труды Института лингвистических исследований» обеспечивает свободный доступ к опубликованным материалам, руководствуясь принципом поддержки глобального обмена знаниями. Какие-либо сборы за публикацию в журнале «Acta Linguistica Petropolitana. Труды Института лингвистических исследований» с авторов не взимаются.

При отправке материалов для публикации в журнале «Acta Linguistica Petropolitana. Труды Института лингвистических исследований» автор выражает согласие с тем, что принятие этих материалов 
к публикации подразумевает их дальнейшее распространение в соответствии с лицензией Creative Commons | Attribution-NoDerivatives, допускающей распространение материалов в коммерческих и некоммерческих целях, если оно осуществляется без каких-либо изменений текста и с указанием авторства. Вместе с тем за автором в полном объеме сохраняются авторские права на опубликованную работу.

\section{4. Достоверность информации}

Представляя рукописи для публикации в журнале «Acta Linguistica Petropolitana. Труды Института лингвистических исследований», авторы несут ответственность за тщательную проверку информации, содержащейся в их работе, во избежание неточных ссылок или отсутствия необходимых ссылок на источники. Если в процессе редактирования материалов, принятых к публикации, автор обнаруживает ошибки или неточности, он должен незамедлительно уведомить редактора и доработать статью или, при наличии существенных ошибок, требующих полной ревизии текста, отозвать рукопись.

В журнале «Acta Linguistica Petropolitana. Труды Института лингвистических исследований» не допускается клевета. Автор должен избегать личных нападок, пренебрежительных замечаний и обвинений в адрес других ученых.

Авторы несут ответственность за достоверность всех данных, опубликованных в журнале «Acta Linguistica Petropolitana. Труды Института лингвистических исследований». Если после публикации обнаружено нарушение вышеуказанных правил, редакционная коллегия имеет право опубликовать опровержение в следующем выпуске, а также отказать автору в публикации его работ в течение трех последующих лет.

\section{5. Процесс рецензирования}

Представленные рукописи оцениваются по принципу двойного анонимного рецензирования; это означает, что все материалы направляются рецензентам в анонимной форме (файлы и метаданные не содержат информации об авторах). 
Члены редакционной коллегии или другие участники процесса публикации не имеют права сообщать рецензентам имен авторов до принятия окончательного решения относительно публикации представленных рукописей.

Если рецензент узнает автора рассматриваемой статьи и обнаруживает конфликт интересов, он должен сообщить об этом редактору и отказаться от рецензирования. Контакты между рецензентом и автором, поддерживаемые за пределами сферы ответственности редакционной коллегии, не являются достаточным основанием для смены рецензента.

Имя рецензента может быть раскрыто автору редакционной коллегией только по просьбе самого рецензента и только после принятия окончательного решения относительно публикации представленной рукописи.

Рецензия должна быть объективной и беспристрастной, личная критика в адрес автора не допускается. Все комментарии и рекомендации по улучшению работы должны быть высказаны в корректной форме, а замечания аргументированы. Рецензенты могут рекомендовать автору проработать дополнительную литературу, касающуюся темы представленной рукописи и отсутствующую в списке использованной литературы. Рецензент обязан обратить внимание редакционной коллегии на любые признаки плагиата.

Рецензирование работы должно быть завершено в установленный журналом срок; в ряде случаев публикация работы может быть перенесена на следующий год.

\section{6. Обязанности членов редакционной коллегии}

На всех этапах редакционного и издательского процесса редакционная коллегия журнала обеспечивает следующее:

- предварительное рассмотрение рукописей авторов;

- выбор рецензентов для экспертизы в соответствии с их научными интересами;

- соблюдение конфиденциальности в процессе двойного анонимного рецензирования;

- решение о принятии, отказе в публикации или назначении дополнительной экспертизы в зависимости от заключения рецензента; 
- все члены редакционной коллегии должны быть в курсе содержания текущего выпуска;

- члены редакционной коллегии могут оказывать посильную помощь авторам в вычитке статей;

— корректуру выпуска перед публикацией в бумажном формате и в сети Интернет.

Главный редактор координирует работу редакционной коллегии и принимает решения по ключевым вопросам, а также дает разрешение на печать выпуска и его публикацию в сети Интернет. Входя в состав редакционной коллегии, главный редактор гарантирует строгое соблюдение всех этических стандартов, изложенных в настоящем документе.

Редакторы не вправе злоупотреблять служебным положением и должны соблюдать беспристрастность и объективность по отношению ко всем участникам редакционного и издательского процесса вне зависимости от расы, пола, сексуальной ориентации, религиозных убеждений, этнической принадлежности, гражданства или политических предпочтений. Материалы, представленные для публикации в журнале «Acta Linguistica Petropolitana. Труды Института лингвистических исследований», рассматриваются исключительно с точки зрения их научной ценности с соблюдением принципа двойного анонимного рецензирования.

Конфликт интересов редакторов и авторов предоставляемых для публикации рукописей недопустим. В случае возникновения конфликта интересов работы авторов должны быть направлены на рассмотрение другому редактору.

Редакционная коллегия гарантирует высокий научный уровень материалов, публикуемых в журнале «Acta Linguistica Petropolitana. Труды Института лингвистических исследований», и, при необходимости, обязана публиковать исправления, разъяснения и извинения.

\section{7. Редакционная коллегия}

Международная редакционная коллегия журнала «Acta Linguistica Petropolitana. Труды Института лингвистических исследований» является высшим руководящим и контролирующим органом журнала. Члены редакционной коллегии имеют право принятием коллективного 
решения приостановить или отклонить публикацию материалов, прошедших процедуру двойного анонимного рецензирования. Рукописи членов редакционной коллегии, представленные для публикации в журнале «Acta Linguistica Petropolitana. Труды Института лингвистических исследований», рассматриваются на общих основаниях, вне зависимости от вхождения автора в состав редакционной коллегии.

Благодаря научному авторитету, географическому охвату и принципу коллегиальности международная редакционная коллегия журнала «Acta Linguistica Petropolitana. Труды Института лингвистических исследований» гарантирует соответствие опубликованных материалов международным стандартам научной и редакционной этики. Все конфликты, возникающие между участниками редакционного и издательского процесса, должны решаться при непосредственном вмешательстве редакционной коллегии.

\section{8. Язык публикаций}

Журнал «Acta Linguistica Petropolitana. Труды Института лингвистических исследований» принимает рукописи статей на русском, английском, французском и немецком языках. Если язык статьи не является для автора родным, рекомендуется, во избежание возможных недоразумений, проконсультироваться с компетентным носителем соответствующего языка.

Все метаданные статей представлены на веб-сайте журнала на русском и английском языках. 


\section{Publication ethics and publication malpractice statement}

\section{Publication ethics}

The international journal "Acta Linguistica Petropolitana" is an academic periodical with no political, ideological, confessional, or other agendas; therefore the journal's activities are solely for the sake of scholarship. All participants in the editorial and publishing process (Authors, Reviewers, Editors, and Editorial Board Members) should keep this in mind and follow the ethical standards outlined below, which are based on the recommendations of the Committee on Publication Ethics (COPE).

\section{Authorship issues}

When submitting a paper to publish in "Acta Linguistica Petropolitana", the Author thereby confirms his or her authorship. In the case of a collaborative work, one of the Authors may submit material for publication provided that all coauthors are listed with all necessary and correct information about them.

If there are agencies or other entities that contributed to the content or provided funding or support for the work submitted, the Author should clearly identify them. If necessary, the Author should express gratitude to colleagues who have made a contribution to the submitted work.

The Authors must present in full all sources of information used in the work, including lists of sources (both published and unpublished), research literature (including the Authors' own previously published works), and informants (when publishing the results of field studies). The Authors should ensure that if they have used the work and/or words of others, this has been appropriately cited or quoted. Any form of plagiarism is unacceptable. 
Self-plagiarism, i.e., the attempt to republish one's own previously published work without significant changes to it, is similarly unacceptable. Concurrent submission of the same work to "Acta Linguistica Petropolitana" and to any other publication is prohibited. The research archive used by the Author should be accessible upon request for the period of at least two years.

In case of violation of any of the rules listed above, the Editorial Team is entitled to refuse to publish the materials at any time, including during preliminary consideration, without involving reviewers, and also not to proceed with the publication of any work from the Author for a period of three years.

Any changes added by the Author to a text that has been peer-reviewed and accepted for publication can be made only in coordination with the Editorial Team. An Author can withdraw an accepted work only before the materials have been sent out for editing. If the Author absolutely wishes to withdraw the material from publication after the editorial work has been done, the Editorial Team is entitled to refuse to consider publication of any work submitted by this Author for a period of three years.

It is unacceptable for an Author to place into the public domain any materials that have been accepted for publication and sent for editing but which have not yet been published. If this rule is violated, the Editorial Team is entitled to withdraw these materials and to refuse to consider publication of any work by the Author for a period of three years.

\section{Copyright and open access}

The journal "Acta Linguistica Petropolitana" has agreed to the Budapest Open Access Initiative and therefore provides immediate open access to its content on the principle that making research freely available to the public supports a greater global exchange of knowledge. At the same time, the Authors are not charged any fees for publication in "Acta Linguistica Petropolitana".

When sending materials for consideration by the journal "Acta Linguistica Petropolitana", the Authors agree that the acceptance of these materials for publication ensures their redistribution in accordance with the license Creative Commons | Attribution-NoDerivatives (this allows for 
redistribution, commercial and non-commercial, as long as it is passed along unchanged and in its entirety, with attribution). At the same time, copyright remains in full with the Authors.

\section{Accuracy of information}

The Authors of the papers submitted to the journal "Acta Linguistica Petropolitana" are responsible for detailed verification of all the information contained in their work in order to avoid inaccurate references to sources or the omission of necessary references. If, in the process of editing the materials accepted for publication, the Author discovers mistakes or inaccuracies, he or she must notify the Editor as soon as possible and either withdraw the publication (in the case of significant errors requiring a complete revision of the text) or correct it.

The Author must avoid personal attacks, disparaging remarks, and accusations against other scholars. Defamation is not allowed in the journal "Acta Linguistica Petropolitana".

The Authors are responsible for the accuracy of all data published in the journal "Acta Linguistica Petropolitana". If a violation of the above rules is discovered after publication, the Editorial Team is entitled to publish a refutation in the next issue and also not to proceed with any work from the defaulting Author for a period of three years.

\section{Review process}

All submitted papers are evaluated on the principle of double-blind peer review, which means that all materials are sent to the Reviewers in anonymized form (the files contain no information about the Authors and information is also deleted from the metadata of the submitted files).

None of the members of the Editorial Team or any other participants in the publication process is allowed to disclose the Authors' names to Reviewers before the final decision regarding the publication of the submitted papers.

If a Reviewer recognizes the Author of the article being reviewed and discovers a conflict of interest, he or she is to inform the Editor of this and 
recuse himself or herself. Contacts between the Reviewer and the Author maintained outside of the Editorial Team's responsibilities are not sufficient grounds for disqualification of the Reviewer.

The Reviewer's name can be disclosed to the Author by the Editorial Team only at the request of the Reviewer and only after the final decision regarding the publication of the submitted materials.

The review should be objective and impartial and must not contain personal attacks against the Author. All comments and suggestions for improving the work should be made in polite form, and all criticism should be justified. Reviewers are encouraged to recommend additional publications relating to the submitted work for which there are no references. The Reviewer should also draw the attention of the Editorial Team to any evidence of plagiarism.

The review should be completed within the time frame established by the journal; the appointment of reviewers, reviewing, acceptance, editing and publication can take over 12 months.

\section{Duties of the Editorial Team members}

Managing / Academic Editors provide for all stages of the editorial and publishing process:

- preliminary consideration of the Authors' submissions;

- selecting the Reviewers in accordance with their research interests;

- maintaining confidentiality during the double-blind review process;

- deciding on acceptance, rejection, or submission to additional peer review, depending on the Reviewers' reports;

- notifying members of the Editorial Board of the current issue data;

— sending the edited materials to the Layout Editor and facilitating the Authors' proofreading of the galleys;

- control proofreading (reconciliation) of the issue before its publication online and in hard copy.

The Editor-in-Chief coordinates all the work of the Editorial Team and makes decisions on key issues; he or she also releases issues for printing and gives permission for publication on the website. Also, as a member of the 
Editorial Team and the Editorial Board, the Editor-in-Chief fully guarantees strict compliance with all ethical standards set forth herein.

All Editors must be careful not to abuse their official position and they are to maintain their impartiality and objectivity toward all participants in the editorial and publishing process regardless of race, gender, sexual orientation, religious belief, ethnic origin, nationality, or political opinion. The materials submitted by the Editors for publication in the journal "Acta Linguistica Petropolitana" are considered solely on their scholarly merit and with the observance of the principle of double-blind peer review.

There must be no conflict of interest between the Editors and the Authors of the materials accepted or rejected for publication. In case such conflict occurs, the Authors' materials are to be sent to another Editor.

The Editorial Team ensures the high academic quality of the materials published in the journal "Acta Linguistica Petropolitana" and, if necessary, is obliged to publish corrections, clarifications, and apologies.

\section{Editorial Board}

The international Editorial Board of the journal "Acta Linguistica Petropolitana" is the supreme governing and controlling body of the periodical. The Editorial Board members, by means of collective decision, have the right to suspend or reject the publication of materials that have gone through double-blind peer review. Papers written by members of the Editorial Board that are submitted for publication in the journal "Acta Linguistica Petropolitana" are considered on their own merit, without regard for their Author's position on the Board.

Due to its academic authority, geographical coverage, and the principle of collegiality, the international Editorial Board of the journal "Acta Linguistica Petropolitana" guarantees that the published content meets international standards of scholarly and editorial ethics. All conflicts arising between the participants of the editorial and publishing process are to be resolved through the direct involvement of the Editorial Board. 


\section{Our languages}

The journal "Acta Linguistica Petropolitana" accepts papers in Russian, English, French or German. If the paper is written in a non-native language, the Authors are advised to consult a qualified native-speaking editor in order to avoid possible misunderstanding.

All metadata of the papers are reflected on the website of the journal in Russian and English. 


\section{Содержание}

\section{Uralistica Petropolitana}

А. А. Афанасьева, И. И. Муллонен

Карело-вепсский диалог на карте южной Карелии . . . . . . . . . . 9

С. И. Буркова

О дискурсивных функциях энклитик $=m a$ и $=m$ ?

в тундровом ненецком языке . . . . . . . . . . . . . . . . . . . . . . . 29

В. Ю. Гусев

'Разве он дороги не знает': к грамматикализации

риторических вопросов в северносамодийских языках . . . . . 53

Н. Г. Зайц̧ева

К генезису маркеров вепсских диалектных ареалов . . . . . . . 95

Е. В. Кашкин, Н. А. Муравьев

'На столе сидит чашка': о контактных изменениях

в коми-ижемских говорах Ямало-Ненецкого АО . . . . . . . . . . 118

Jeongdo Kim

Variations in Uralic words:

The case of the Uralic * $t V r$-stem with a meaning 'trembling' $\ldots 146$

Н. Н. Колпакова

У истоков отечественной унгаристики: опыт первого

научного русскоязычного описания венгерского языка . . . . . . . 159

Ю. Б. Коряков

Картографирование уральских языков . . . . . . . . . . . . . . . . . . 169

Н. В. Кузнецова

Рукописи Н. Д. Пыдера на нижнелужском диалекте

ижорского языка (р. Россонь) с комментариями. . . . . . . . . . . . . 184 
Д. В. Кузьмин

Межэтническое контактирование в Карелии в свете данных карелоязычной географической терминологии. . . . . . 289

A. А. Макарова

К интерпретации некоторых калек в топонимии Белозерья:

виды калькирования и способы верификации . . . . . . . 308

М. 3. Муслимов

Об идиоме дер. Куровицы (Kukkõsi / Kukkuzi) . . . . . . . . . 330

Г. А. Некрасова

Конкуренция иллатива и послелогов

в коми-зырянском языке . . . . . . . . . . . . . . . . . . . . . 377

П. С. Плешак

Посессивные конструкции в самбургском коми. . . . . . . . . . 407

Ф. И. Рожанский, Е. Б. Маркус

О фонологическом статусе аффрикаты $t s$

в сойкинском диалекте ижорского языка. . . . . . . . . . . . . . . 440

Н. В. Сердобольская, А. Д. Егорова

Грамматический статус показателей субъектно-объектного согласования в конструкциях с сентенциальными актантами (мокша-мордовский язык) . . . . . . . . . . . 480

С. Г. Татевосов

Несколько наблюдений над основами ненецкого глагола . . . . . 533

А. Ю. Урманчиева

Деривационная морфология образных глаголов тундрового ненецкого языка . . . . . . . . . . . . . . . . . . 570

S. Holopainen

Indo-Iranian loanwords in Finnic - a critical overview. . . . . . 613

А. Б. Шлуинский

Морфологические особенности нелексических глаголов

в энецком языке . . . . . . . . . . . . . . . . . . . . . . . . . . . 669 


\section{Varia}

С. В. Власов, С. С. Волков, Л. В. Московкин

Рецепция грамматических идей М. В. Ломоносова

в русских грамматиках второй половины XVIII в. . . . . . . . 689

\section{Т. Д. Коркина}

Трактат Джона Ло «Деньги и купечество»:

история русского перевода 1720 г.

и текстологический анализ списков . . . . . . . . . . . . . . . 725

А. М. Певнов

О происхождении самоназваний эвенков . . . . . . . . 744

Э. В. Хилханова

Люди в языковой политике: теория и практика

дискурсивного поворота в социолингвистике

(на примере России и Западной Европы) . . . . . . . . . . 756

М. Г. Шарихина

Восторг в поэтическом языке М. В. Ломоносова

и в Четьих Минеях Димитрия Ростовского (к вопросу

о церковнославянском субстрате одического восторга). . . . . 816

Н. М. Юликова

Изменение валентности английских глаголов $\ldots \ldots \ldots \ldots . . .837$

Сведения об авторах $\ldots \ldots \ldots \ldots \ldots \ldots \ldots \ldots \ldots \ldots \ldots . \ldots \ldots$

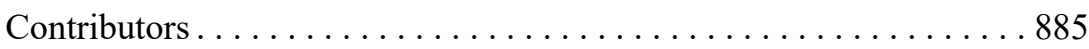

Этические требования . . . . . . . . . . . . . . . . . . . . 889

Publication ethics and publication malpractice statement . . . . . . 895 


\title{
Contents
}

\section{Uralistica Petropolitana}

\author{
A. A. Afanasjeva, I. I. Mullonen
}

A Karelian-Veps dialogue on the map of southern Karelia . . . . . 9

\section{S. I. Burkova}

On the discourse functions of the enclitics $=m a$ and $=m$ ?

in Tundra Nenets . . . . . . . . . . . . . . . . . . . . . . 29

\section{Yu. Gusev}

'Does not he really know the way': On grammaticalization

of rhetoric questions in North Samoyed languages .......... 53

N. G. Zaitseva

On the genesis of markers of Veps dialectal areas......... 95

E. V. Kashkin, N. A. Muravyev

'A cup is sitting on the table': On the contact-induced change in the subdialects of Izhma Komi spoken in the Yamalo-Nenets Autonomous District . . . . . . . 118

Jeongdo Kim

Variations in Uralic words:

The case of the Uralic *tVr-stem with a meaning 'trembling' $\ldots 146$

N. N. Kolpakova

The dawn of Russian ungaristics: The experience of the first scientific Russian-language description of Hungarian . . . . . . . 159

Yu. B. Koryakov

Mapping of Uralic languages. . . . . . . . . . . . . . . . 169

N. V. Kuznetsova

Manuscripts by N. D. Põder in the Lower Luga dialect of Ingrian (Rosona river) with comments . . . . . . . . . . . 184 
D. V. Kuzmin

Transethnic Contacts in Karelia

as Revealed by Karelian Toponymy Evidence . . . . . . . . . . . 289

A. A. Makarova

Towards interpretation of some calques in the Belozerye

toponymy: Loan translation types and verification methods. . . . . 308

M. Z. Muslimov

On Kurovitsy (Kukkõsi / Kukkuzi) linguistic variety . . . . . . . 330

G. A. Nekrasova

The illative vs. postpositions in Komi-Zyryan . . . . . . . . . 377

P. S. Pleshak

Possessive constructions of Samburg Komi

F. I. Rozhansky, E. B. Markus

On the phonological status of the affricate $t s$

in Soikkola Ingrian

N. V. Serdobolskaya, A. D. Egorova

Subject-object agreement markers in Moksha-Mordvin

complement clauses. . . . . . . . . . . . . . . . . . . 480

S. G. Tatevosov

Notes on the structure of the verb stem in Tundra Nenets. . . . . . 533

A. Yu. Urmanchieva

Derivational morphology of depictive (onomatopoeic) verbs

in Tundra Nenets . . . . . . . . . . . . . . . . . . . . . 570

S. Holopainen

Indo-Iranian loanwords in Finnic - a critical overview. . . . . . . 613

A. B. Shluinsky

Morphological pecularities of non-lexical verbs in Enets . . . . . . 669 


\section{Varia}

S. V. Vlasov, S. S. Volkov, L. V. Moskovkin

Adoption of M. Lomonosov's grammar ideas

by Russian grammars of the second half of the $18^{\text {th }}$ century . . . . 689

T. D. Korkina

"Money and Trade", a treatise by J. Law: A history of the 1720

Russian translation with a textual analysis . . . . . . . 725

A. M. Pevnov

On the origin of some Evenki endoethnonyms . . . . . . . . 744

E. V. Khilkhanova

People in language policy: Theory and practice of the

discursive turn in sociolinguistics (comparing Russia and

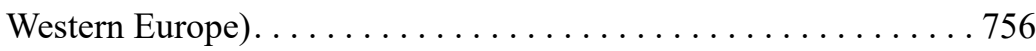

M. G. Sharikhina

Rapture in the poetic language of M. V. Lomonosov

and in Menology of Dimitri Rostovsky (to the question

of the Church Slavonic substrate of the odic rapture) $\ldots \ldots \ldots 816$

N. M. Yulikova

Valency change of English verbs . . . . . . . . . . . . 837

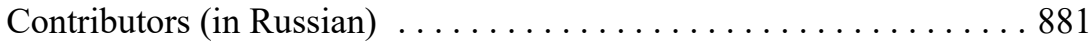

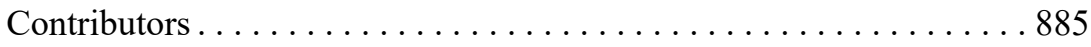

Publication ethics and publication malpractice statement

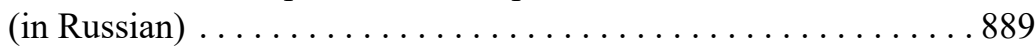

Publication ethics and publication malpractice statement . . . . . . 895 


\section{Научное издание}

Acta Linguistica Petropolitana. Труды Института лингвистических исследований. 2020. - T. XVI. Ч. 3. — 912 с.

Подписано к печати 01.10.2020

Формат $60 \times 901 / 16$

Усл. печ. л. 57. Тираж 500 экз.

Институт лингвистических исследований РАН

199053, Санкт-Петербург, Тучков переулок, 9

info@iling.spb.ru

https://iling.spb.ru

Печатается с оригинал-макета, изготовленного в ИЛИ РАН

Оригинал-макет подготовил С. С. Белоусов

Корректор - Е. В. Артемьева

Издательство РХГА

191011, Санкт-Петербург, наб. р. Фонтанки, д. 15

Тел.: +7 812 310-79-29, +7 981 699-65-95

E-mail: rhgapublisher@gmail.com

http://irhga.ru

Материалы выпуска доступны в электронном виде по ссылке:

https://alp.iling.spb.ru/ru/issues.html 




